\title{
TOMASZ KŁYS
}

\section{OD MABUSEGO DO GOEBBELSA}

Weimarskie filmy Fritza Langa i kino niemieckie do roku 1945

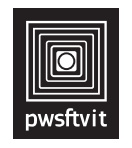


Tomasz Kłys - Zakład Historii i Teorii Filmu

Katedra Mediów i Kultury Audiowizualnej, Instytut Kultury Współczesnej Wydział Filologiczny, Uniwersytet Łódzki, e-mail: augpatom@uni.lodz.pl

\author{
RECENZENT \\ Ewelina Nurczyńska-Fidelska \\ REDAKTOR WYDAWNICTWA UŁ \\ Dorota Stępień \\ SKŁAD I ŁAMANIE \\ ESUS - Agnieszka Buszewska \\ OKŁADKĘ PROJEKTOWAŁA \\ Barbara Grzejszczak \\ Indeksy sporządzone przez Autora
}

(C) Copyright by Uniwersytet Łódzki - Wydawnictwo Uniwersytetu Łódzkiego, Łódź 2013

(C) Copyright for this edition by Wydawnictwo Biblioteki PWSFTviT, Łódź 2013

Zdjęcie na okładce z filmu Doktor Mabuse, gracz

(C) Copyright by Friedrich-Wilhelm-Murnau-Stiftung, Wiesbaden

Wydane przez Wydawnictwo Uniwersytetu Łódzkiego

i Wydawnictwo Biblioteki PWSFTviT

Wydanie I. 5076

Wstęp i rozdziały 1-6 z części II: Od Mabusego do Goebbelsa: Weimarskie filmy Fritza Langa niniejszej publikacji stanowią uaktualnioną wersję monografii T. Kłysa Dekada doktora Mabuse: Nieme filmy Fritza Langa (Wydawnictwo Uniwersytetu Łódzkiego, Łódź 2006)

ISBN Wydawnictwa Uniwersytetu Łódzkiego 978-83-7525-759-5

e-ISBN 978-83-7969-909-4

ISBN Wydawnictwa Biblioteki PWSFTviT 978-83-8787-060-7

\footnotetext{
Wydrukowano na papierze One Matt $80 \mathrm{~g}$

Wydawnictwo Uniwersytetu Łódzkiego

90-131 Łódź, ul. Lindleya 8

www.wydawnictwo.uni.lodz.pl

e-mail: ksiegarnia@uni.lodz.pl

tel. (42) 66558 63, faks (42) 6655862
} 


\section{SPIS TREŚCI}

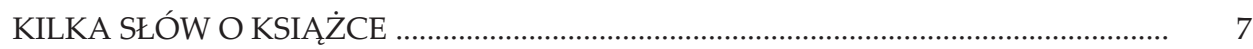

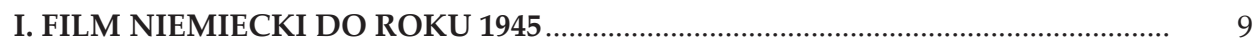

Rozdział 1

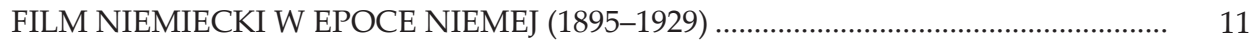

Kanoniczne ujęcie historii kina niemieckiego: Kracauer i Eisner ........................... 11

Kino wilhelmińskie ..................................................................................... 12

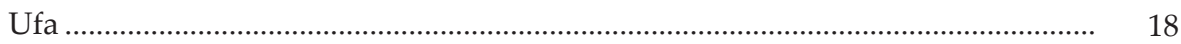

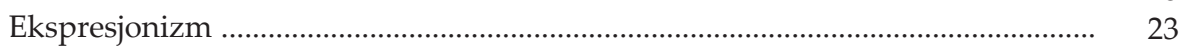

Kino niemieckie doby Nowej Rzeczowości ........................................................ 36

Gatunki kina weimarskiego ................................................................................... 41

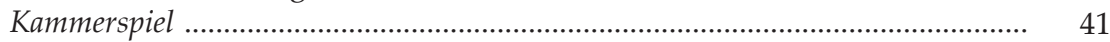

Inne gatunki ....................................................................................... 45

Weimarska krytyka i kultura filmowa …….......................................................... 56

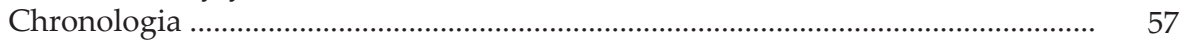

Propozycje lektur ................................................................................................. 62

Rozdział 2

NIEMIECKI FILM FABULARNY OD PRZEŁOMU DŹWIĘKOWEGO

DO UPADKU TRZECIEJ RZESZY (1929-1945) …………............................................. 65

Między Weimarem a Trzecią Rzeszą - przepaść czy ciągłość? ............................... 65

Kino schyłku Republiki .......................................................................................... $\quad 72$

Kino niemieckie w okresie nazistowskim .............................................................. 95

Struktura przemysłu filmowego Trzeciej Rzeszy .......................................... 95

Filmy fabularne w zaprzęgu ideologii i propagandy .................................... 102

Kino popularne w Trzeciej Rzeszy i jego gwiazdy ........................................ 118

Kino artystyczne Trzeciej Rzeszy ............................................................ 133

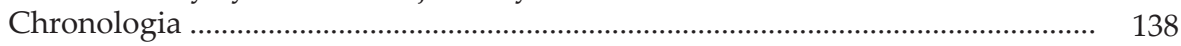

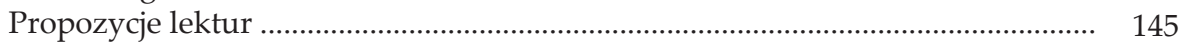

II. OD MABUSEGO DO GOEBBELSA: WEIMARSKIE FILMY

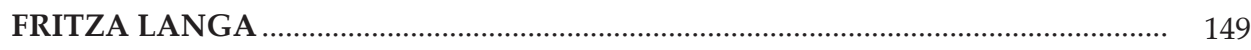

Wstęp

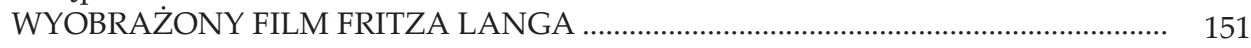

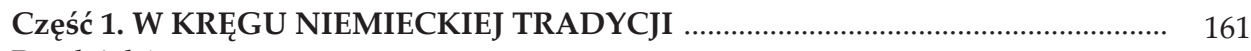

Rozdział 1

MIĘDZY USTAMI A BRZEGIEM PUCHARU: ZMĘCZONA ŚMIERĆ .......................... 163

Ósmy film, pierwsze arcydzieło i dwie śmierci ..................................................... 163

Märchenfilm w sześciu aktach, bez trzech wierszy .............................................. 171 
Rahmenhandlung $\mathrm{i}$ „Historie trzech świec" .............................................................. 174

Bycie-ku-miłości czy bycie-ku-śmierci? ............................................................ 183

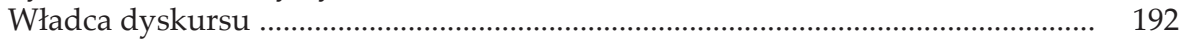

Czkawka czasu i to, co pomiędzy ............................................................................. 199

Alegoryczność …....................................................................................................... 205

Rozdział 2

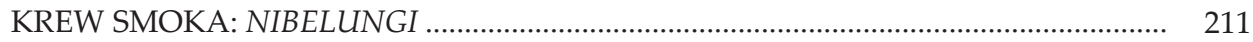

Supergigant ery inflacji .................................................................................... 213

Der Nibelungen-Film: głosy krytyki ..................................................................... 222

Ein deutsches Heldenlied in 14 Gesänge ................................................................... 229

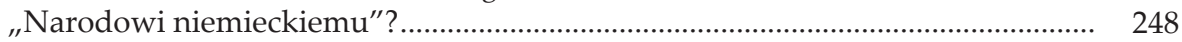

Smocze plemię .................................................................................................. 254

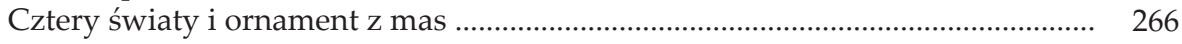

Część 2. ZEITSPIEGEL: BURZLIWE LATA DWUDZIESTE ….................................. 273

Rozdział 3

DZIKOŚĆ LWA I JAD WĘŻA: DOKTOR MABUSE, GRACZ …................................... 275

Kampania multimedialna .................................................................................. 276

Ein Bild der Zeit, Menschen der Zeit ...................................................................... 281

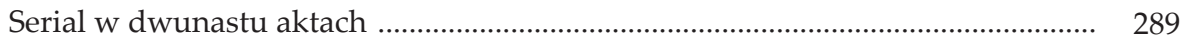

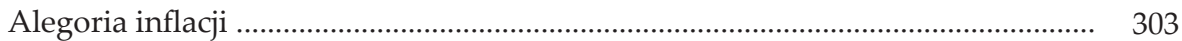

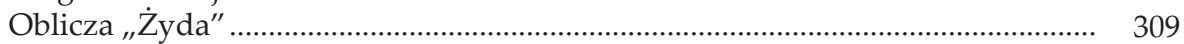

Pan i niewolnicy …................................................................................... 315

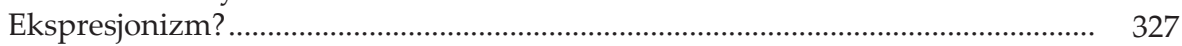

Rozdział 4

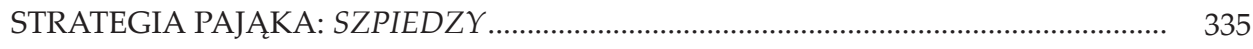

Pierwszy i przedostatni film spółki Fritz Lang Film GmbH ................................ 335

Referencje: sowiecka agentura („gdzieś w Europie”) i pułkownik Redl............. 342

Eliptyczny sjużet, paralelizmy i synekdochiczne kadry ....................................... 349

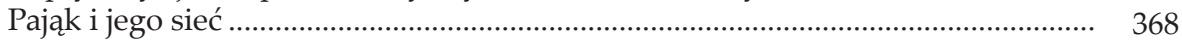

Neue Sachlichkeit ......................................................................................... 378

Część 3. KSZTAŁT RZECZY, KTÓRE NADEJDĄ ..................................................... 383

Rozdział 5

CZAS APOKALIPSY: METROPOLIS ………............................................................ 385

Paradygmatyczny film Ufy ................................................................................ 386

Recepcja: między potęgą (obrazu) i absurdem (fabuły) ......................................... 395

W poszukiwaniu pierwotnego tekstu: wciąż-odbudowywana-ruina .................. 403

Antyutopia i jej referencje .................................................................................... 417

Genesis, Ewangelia, Apokalipsa (według Thei von Harbou) ................................ 429

Efekty specjalne. Megapolis czy Mikropolis? .......................................................... 436

Rozdział 6

NA ZŁOTYM GLOBIE: KOBIETA NA KSIĘŻYCU ……............................................... 441

Pożegnanie z Ufą i z filmem niemym .............................................................. 441

Weltraumfahrt .......................................................................................... 448

Niebo gwiaździste i moralny nieład ................................................................... 453

Wrażenie (nie)realności ......................................................................................... 468 
Część 4. KOMISARZ LOHMANN PROWADZI ŚLEDZTWO 475

Rozdział 7

CAŁE MIASTO O TYM MÓWI ALBO KRYMINAŁ ZA TRZY GROSZE:

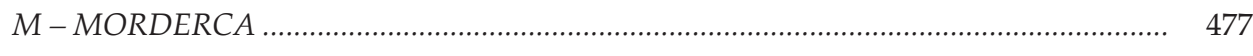

Pochwała pewnego widza ............................................................................ 477

Mordercy są wśród nas .................................................................................... 478

Społeczeństwo masowe ........................................................................................ 486

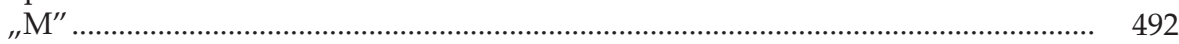

Rozdział 8

SZEPCZĄCE ŚCIANY ALBO AWATAR: TESTAMENT DOKTORA MABUSE ............ 499

Historia z mrocznej epoki, gdy rządzili naziści/Żydzi (niepotrzebne skreślić) ... 499

Komisarz Lohmann kontra awatar doktora Mabuse ........................................... 504

Niby-kryminał o narracji pełnej „rymów” ............................................................... 514

Od gabinetu doktora Caligari do kliniki profesora Bauma .................................. 526

Podsumowanie

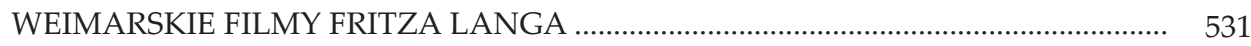

Bibliografia

OD MABUSEGO DO GOEBBELSA: WEIMARSKIE FILMY FRITZA LANGA ............ 535

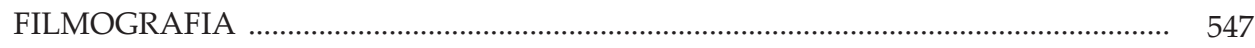

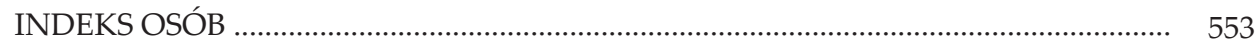

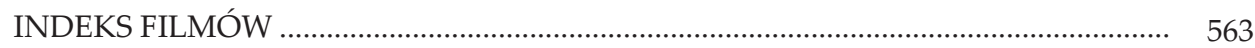





\section{KILKA SŁÓW O KSIĄŻCE}

W niniejszej książce postanowiłem zebrać teksty o klasycznym kinie niemieckim napisane przeze mnie w latach 2005-2011. Jest więc tu w całości tekst mojej książki habilitacyjnej Dekada doktora Mabuse: Nieme filmy Fritza Langa (Wydawnictwo Uniwersytetu Łódzkiego, Łódź 2006) poszerzony o dwa rozdziały poświęcone ostatnim dwóm weimarskim filmom Langa, już dźwiękowym: $M$ - morderca i Testament doktora Mabuse, a także pełna, autorska wersja dwóch obszernych tekstów o kinie niemieckim w okresie niemym i w latach 1929-1945. Dwa ostatnie powstały jako rozdziały do kolejnych dwóch tomów nowej Historii kina (Kino nieme i Kino klasyczne) pod redakcją Tadeusza Lubelskiego, Iwony Sowińskiej i Rafała Syski. $\mathrm{Z}$ wersji tych tekstów, opublikowanych w Historii kina, nie byłem w pełni usatysfakcjonowany, gdyż z racji nieodzownych z powodów objętościowych skrótów zostały one - zwłaszcza drugi, o filmie dźwiękowym - dość mocno okrojone przez redaktorów.

Ten brak satysfakcji i chęć opublikowania ich w integralnej wersji autorskiej oraz fakt napisania kolejnych dwóch analiz weimarskich filmów Fritza Langa przyczyniły się zatem do tego, iż ośmielam się Państwu przedstawić książkę Od Mabusego do Goebbelsa. Jej tytuł w sposób oczywisty nawiązuje do tytułu znanej pracy Siegfrieda Kracauera Od Caligariego do Hitlera-książki omawiającej filmy niemieckie z dwudziestolecia 1913-1933 pod kątem „przeczucia” w nich (czy też nieświadomego „wyrazu”) nazizmu. Tytuł ten jest jednak nie tylko, może nieskromnym, nawiązaniem do Kracauera, ale i trochę polemiką z nim. Proponuję bowiem jako dwie figury reprezentatywne dla kina niemieckiego w okresie weimarskim i nazistowskim (czyli tym, który omawiał także Kracauer) nie demonicznego lekarza z filmu Roberta Wiene, lecz superprzestępcę z filmów Langa, i nie Führera, lecz jego ministra. Wybór drugiego na taką reprezentatywną figurę łatwo uzasadnić - to nie Hitler, ale właśnie Goebbels bezpośrednio zarządzał kinematografią niemiecką w latach 1933-1945. Minister propagandy zdołał zreszta, często wbrew intencjom czy skłonnościom Hitlera, przeforsować jako dominujący w Trzeciej Rzeszy własny model kina jako przede wszystkim eskapistycznej rozrywki i to na wysokim, profesjonalnym (a nierzadko i artystycznym) poziomie. Caligari z kolei o tyle nie nadaje się na „patrona” kina weimarskiego, o ile ekspresjonistyczny trend, 
który film Roberta Wiene uosabia, choć ważny dla powstania światowego kina artystycznego, w kinie niemieckim tego okresu jest ilościowo zupełnie marginalny. Znacznie lepiej jako figura modelowa dla kina weimarskiego wypada Mabuse: jako superprzestępca to także figura prenazistowskiego „tyrana” jak Caligari. W dwuznaczny sposób Mabuse wyraża jednak także i to, co nazizm wściekle zaatakuje - „,żydostwo". Mabuse, który pojawił się $\mathrm{w}$ kinie niemieckim $\mathrm{w}$ apogeum inflacji początku lat 20., powróci pod koniec Weimaru i u progu Trzeciej Rzeszy z wszystkimi tymi ambiwalentnymi konotacjami. A filmy Langa o doktorze Mabuse też znacznie lepiej uosabiają kino weimarskie niż Gabinet doktora Caligari. Ten ostatni to przykład wyrafinowanego formalnie, hermetycznego kina artystycznego dla dość elitarnej publiczności, wcale w Republice Weimarskiej nieczęstego. Filmy o Mabusem są zaś reprezentatywne dla strategii Ufy - i kina weimarskiego w ogólności - by atrakcyjną dla masowej widowni rozrywkę łączyć z wysokim artystycznym poziomem, na który składały się profesjonalne, warsztatowe mistrzostwo i oryginalność formy, pełnej eksperymentalnych, często wręcz awangardowych, chwytów i rozwiązań.

Pragnę w tym miejscu wyrazić podziękowanie Panu Profesorowi Tadeuszowi Lubelskiemu, bo jego zaproszenie do opracowania kolejnych dwóch rozdziałów o filmie niemieckim we współredagowanej przez niego Historii kina zmobilizowało mnie do gruntowniejszego wniknięcia w kino niemieckie przed rokiem 1945 i tym samym, pośrednio, przyczyniło się do powstania sporej partii tej książki. Pragnę też gorąco podziękować Panu Michałowi Dondzikowi - bez jego pomocy nie dotarłbym zapewne do wielu trudno dostępnych filmów, a moja znajomość klasycznego kina niemieckiego byłaby znacznie uboższa. 


\section{I}

FILM NIEMIECKI DO ROKU 1945 



\section{Rozdział 1}

\section{FILM NIEMIECKI W EPOCE NIEMEJ (1895-1929)}

\section{Kanoniczne ujęcie historii kina niemieckiego: Kracauer i Eisner}

Pisane wcześniej historie kina ujmowały film niemiecki w okresie niemym na ogół przez pryzmat ekspresjonizmu, w którym upatrywano dominującego trendu stylistycznego, nawet jeśli nie bardzo to potwierdzała estetyka samych filmów, dość rzadko przylegających do kanonicznego wzorca filmu ekspresjonistycznego, którym był Gabinet doktora Caligari (Das Cabinet des Dr. Caligari, 1919, Robert Wiene). Trzeba jednak pamiętać, iż „ekspresjonizm” ujmowano nie tylko na poziomie stylu obrazu filmowego (do czego będzie nawoływał Barry Salt, chcąc precyzyjnie ująć szeroką i rozmytą co do zakresu kategorię), ale także w aspekcie tematyczno-znaczeniowym. Filmy określane raczej swobodnie jako „ekspresjonistyczne” cechowała na ogół dość szczególna tematyka, o rodowodzie sięgającym niemieckiego romantyzmu (rozdwojenie jaźni, szaleństwo, eksploracja mrocznych głębin duszy), fabuły zaś ex post, z perspektywy znajomości późniejszej historii, odczytywano jako kasandryczną zapowiedź nazizmu. Oczywiście, na taką lekturę wpływ miała sugestywna i powszechnie znana książka Siegfrieda Kracauera Od Caligariego do Hitlera: Z psychologii filmu niemieckiego (1947) ${ }^{1}$. Wewnętrznie rozdwojonych, szalonych, zbrodniczych czy słabych i podatnych na zło bohaterów filmów niemieckich ujął on w duchu społecznej psychoanalizy à la Erich Fromm (zresztą jego kolega ze szkoły frankfurckiej), widząc w nich typową dla Niemców "osobowość autorytarną z kompleksem sado-masochistycznym", żądną władzy i pragnącą podporządkować sobie innych, ale zarazem uległą wobec „autorytetu”, za jaki mógł dla niej uchodzić charyzmatyczny tyran. To Kracauerowskie czytanie filmów niemieckich z lat 1913-1933 jako symbolicznej czy alegorycznej prefiguracji nazizmu jest też obecne $\mathrm{w}$ drugiej, niesłychanie wpływowej książce,

1 Siegfried Kracauer, Od Caligariego do Hitlera: Z psychologii filmu niemieckiego, przeł. W. Wertenstein, E. Skrzywanowa, Filmowa Agencja Wydawnicza, Warszawa 1958. 
późniejszym o kilka lat Ekranie demonicznym (1952) Lotte H. Eisner ${ }^{2}$, choć samą autorkę bardziej zdaje się interesować romantyczny rodowód niemieckich demonów i ich wyraz w poprzedzającej i inspirującej film ekspresjonistyczny sztuce - malarstwie, literaturze, teatrze. Thomas Elsaesser w swych tekstach, rewidujących zarówno kategorię ekspresjonizmu, jak i uznawanie prac Kracauera i Eisner za monografie tego nurtu, obie te książki nazywa "proroctwami Kasandry après coup" ${ }^{3}$ i proponuje, by posługiwać się $\mathrm{w}$ odniesieniu do analizowanych w nich filmów, znacznie mniej dyskusyjną za to owocniejszą, bo sytuującą kino w kontekście historyczno-politycznym i społeczno-kulturowym, kategorią „kina weimarskiego” (ewentualnie: „kina Republiki Weimarskiej”). Analogicznie, w odniesieniu do filmów niemieckich do roku 1918, proponuje stosować - powszechnie już przyjętą w światowej literaturze nazwę „kina epoki wilhelmińskiej”.

\section{Kino wilhelmińskie}

Kinematografia niemiecka, w odróżnieniu od amerykańskiej, francuskiej, włoskiej czy duńskiej, wkroczyła na światowy rynek filmowy z pewnym opóźnieniem i to pomimo faktu, iż berliński pokaz Bioskopu braci Maxa i Emila Skladanowskich w Wintergarten (1 listopada 1895) o prawie dwa miesiące wyprzedził pierwszy seans braci Lumière w paryskiej Grand Café. Kino bardzo długo nie mogło uzyskać w Niemczech prestiżu - już w roku 1901 wpływowy estetyk Konrad Lange w rozprawie Das Wesen der Kunst (Istota sztuki) zaatakował je jako „nieartystyczne” z racji m.in. jego mechanicznego, reprodukcyjnego charakteru. Aż gdzieś do roku 1912 postrzegano je jako wulgarną rozrywkę dla niewykształconego pospólstwa (opinię taką podtrzymywały magazyny poświęcone sztukom pięknym i teatrowi). I rzeczywiście, etap "kina jarmarcznego" (Jahrmarktkino) czy też, w dzisiejszej nomenklaturze, ",kina atrakcji” trwał tam dłużej niż w innych krajach Europy Zachodniej. Jak wskazuje Thomas Elsaesser, nie więcej niż 14\% filmów pokazywanych w Cesarstwie Niemieckim przed I wojną światową było rodzimej produkcji - lwia część pochodziła z importu. Wśród ocalałych niemieckich materiałów z pierwszej dekady kina dominują aktualności

${ }^{2}$ Lotte H. Eisner, Ekran demoniczny, przeł. Konrad Eberhardt, Wydawnictwa Artystyczne i Filmowe, Warszawa 1974.

${ }^{3}$ Thomas Elsaesser, Weimar Cinema and After: Germany's Historical Imaginary, Routledge, London-New York 2000, s. 35. Por. także: Thomas Elsaesser, Weimar Cinema, Mobile Selves and Anxious Males: Kracauer and Eisner Revisited, [w:] Expressionist Cinema: New Perspectives, ed. Dietrich Scheunemann, Camden House, Rochester-Woodbridge 2003. Jeśli nie zaznaczono inaczej - tłumaczenia cytatów są moje - T. K. 
(berlińskie scenki uliczne, obrazki parad wojskowych czy cesarza dokonującego przeglądu wojsk), zapisy numerów wodewilowych czy cyrkowych albo pokazów mody, filmiki erotyczne, a nawet jawnie pornograficzne, filmy trickowe, a także scenki komediowe w stylu produkcji braci Pathét.

Stosunkowo nieliczne we wczesnym kinie niemieckim filmy „zintegrowane fabularnie" - by posłużyć się sformułowaniem Toma Gunninga - były reprezentowane przez melodramaty na tle społecznym (ze służącymi, guwernantkami albo pannami sklepowymi jako bohaterkami), dramaty małżeńskie, dramaty z trójkątem miłosnym albo Bergfilme („filmy górskie"), które w okresie weimarskim staną się niemiecką specjalnością. "Generalnie - pisze Thomas Elsaesser - ich tytuły wskazują na ideologicznie konserwatywne społeczeństwo, konwencjonalne w swojej moralności, filistyńskie $\mathrm{w}$ smaku, ale przede wszystkim nastawione na rodzinę" ${ }^{\prime \prime}$. Nawet jednak w tych schematycznych i przewidywalnych filmach Elsaesser odnotowuje staranność wizualnej mise-en-scène.

Ważną postacią kina epoki wilhelmińskiej jest Oskar Messter (1866-1943), wynalazca, producent, filmowiec, jakby niemiecki odpowiednik Edisona. Udoskonalił on, obowiązujący praktycznie do dziś, system projekcji filmów w oparciu o tzw. krzyż maltański, a był też jednym z najważniejszych pionierów filmu dźwiękowego, eksperymentującym z zastosowaniem sprzężonego z projektorem fonografu dla kreacji zsynchronizowanych z dźwiękiem obrazów. Już około 1903 r. stosował w swych filmach plany bliskie (nieco później niż Brightończycy, ale zdecydowanie wyprzedzając Griffitha, w sławetnej autoreklamie przypisującego sobie wynalazek close up - zbliżenia). Jako jeden z pierwszych filmowców Messter stosował na planie sztuczne oświetlenie. Swoje studio filmowe na słynnej później z przemysłu rozrywkowego berlińskiej Friedrichstraße, gdzie realizował krótkie filmiki fabularne i aktualności, założył już w roku 1897. Od roku 1909 zajął się produkcją filmów o dłuższym metrażu (reżyserowanych przez innych), a jego spółka prosperowała aż do roku 1917, po którym kontrolę nad nią przejął nowo powołany przez koła rządowe koncern - Ufa. To właśnie w filmach produkowanych przez Messtera zadebiutowały późniejsze wielkie gwiazdy niemieckiego kina: Emil Jannings, Lil Dagover, Conrad Veidt i Henny Porten - nordycka blond-piękność, którą rozsławiły melodramaty reżyserowane przez Adolfa Gärtnera, takie jak: Zu späte Reue! (Spóźniona skrucha, 1911), Der Müller und sein Kind (Młynarz i jego dziecko, 1911),

4 Thomas Elsaesser, Germany: The Weimar Years, [w:] The Oxford History of World Cinema, ed. Geoffrey Nowell-Smith, Oxford University Press, Oxford-New York 1997, s. 137.

${ }^{5}$ Ibidem. 
Im Glück vergessen (Zapomniana w szczęściu, 1911), Tragödie eines Streiks (Tragedia pewnego strajku, 1911) $^{6}$.

Ważnym konkurentem Messtera wśród producentów był ukierunkowany głównie na rozrywkę Paul Davidson, twórca „pionowo zintegrowanej” kompanii PAGU. „W roku 1909 - pisze Elsasesser - otworzył w Berlinie na Alexanderplatz kino na 1200 miejsc i zainicjował produkcję filmów, by uzupełnić dystrybuowany przez siebie zapas filmów sprowadzonych z zagranicznych wytwórni, zwłaszcza Pathé w Paryżu i kopenhaskiego Nordisku"7. To właśnie on sprowadził do Niemiec i zakontraktował duńską amantkę, Astę Nielsen, a także jej męża, reżysera Urbana Gada. Nielsen - piękna brunetka o płomiennych oczach i egzotycznym typie urody - była główną konkurentką rodzimej w typie Porten. Paradoksalnie, to właśnie niemieckie filmy rozsławiły duńską gwiazdę, która w ciągu całej dekady lat 10. zagrała w ojczyźnie jedynie w czterech filmach!

Mimo złej reputacji, kino cieszyło się w Niemczech przed rokiem 1912 sporą popularnościa, odbierając publiczność teatrowi. Organizacja zrzeszająca autorów, reżyserów i aktorów teatralnych wezwała w maju 1912 r. do bojkotu kina, który zakończył się pół roku później, kiedy producenci filmowi zaczęli rywalizować o podpisanie z ludźmi teatru wyłącznych kontraktów. Proklamowano wówczas Autorenfilm, który można uznać za niemiecki odpowiednik film d'art we Francji. Słowo ",autor" w nazwie tego nurtu nie odnosiło się jednak do reżysera (takie windowanie pozycji reżysera filmowego nie wchodziło jeszcze w grę), lecz do renomowanego współczesnego pisarza, którego pierwowzór literacki był podstawą adaptacji lub który napisał, co odpowiednio nagłaśniała prasa, oryginalny scenariusz filmu. Wśród pisarzy, dzięki udziałowi których pewne dzieła reklamowano jako Autorenfilme, byli całkiem dziś zapomniani (Paul Lindau, Hanns Heinz Ewers, Heinrich Lautensack) oraz klasycy, których utwory przetrwały próbę czasu (Gerhard Hauptmann, Arthur Schnitzler, Hugo von Hofmannstahl). Prestiż Autorenfilm miał także uzyskać za sprawą uczestnictwa w realizacji czołowych postaci teatru - zarówno aktorów, jak i reżyserów teatralnych. Bojkot kina przez to środowisko został przerwany właśnie udziałem teatralnego gwiazdora, Alberta Bassermanna w filmie Inny (Der Andere, 1913, Max Mack), będącym adaptacją sztuki renomowanego dramaturga Paula Lindaua. Film ten zawierał (zdaniem Kracauera, paradygmatyczny dla kina niemieckiego) motyw rozdwojenia jaźni: pewien mieszczuch, wskutek wypadku, doznaje rozpadu osobowości na kogoś w rodzaju Jekylla i Hyde'a ${ }^{8}$.

${ }^{6}$ David A. Cook, A History of Narrative Film, 4th ed., W. W. Norton \& Company, New York-London 2003, s. 87-88.

7 T. Elsaesser, Germany: The Weimar Years, s. 137.

8 Por.: T. Elsaesser, Germany: The Weimar Years, s. 138-139; Kristin Thompson, David Bordwell, Film History: An Introduction, McGraw-Hill, Inc., New York 1993, s. 56-57. 
Innego przyjęto $\mathrm{z}$ aplauzem i Lindau wkrótce napisał oryginalny scenariusz do kolejnego wybitnego dzieła, dziś uznanego za jeden $\mathrm{z}$ najciekawszych pośród Autorenfilme - Wiejska droga (Die Landstraße, 1913, Paul von Woringen). Znowu jest to opowieść o mrokach natury ludzkiej: zbiegły skazaniec popełnia $\mathrm{w}$ małej osadzie morderstwo, lecz o zbrodnię tę zostaje obwiniony przypadkowy żebrak, dopiero w finale oczyszczony z zarzutów dzięki wyznaniu prawdziwego sprawcy. Kristin Thompson upatruje w powolnej, kontemplacyjnej narracji filmu, starannym komponowaniu kadru w głąb i precyzyjnie prowadzonym montażu paralelnym, zestawiającym losy żebraka i zbiega, typowej dla rodzącego się w Europie przed I wojną światową kina artystycznego "nowej ekspresywności”, polegającej na autonomii i autoteliczności rozwiązań formalnych, ich braku funkcjonalności wobec linii fabularnej, która jest podstawą narracji w klasycznym kinie hollywoodzkim? .

Max Reinhardt, wybitny reżyser teatralny, z którego zespołu wywodzi się wiele gwiazd kina niemieckiego, podpisał kontrakt z Davidsonem, dla którego wyreżyserował dwa filmy: Wenecka noc (Eine venezianische Nacht, 1913) i Wyspa błogosławionych (Insel der Seligen, 1913), „pełne mitologicznych i baśniowych motywów, swobodnie zaczerpniętych z komedii Szekspira i fin-de-sièclowych sztuk niemieckich"10.

Najwybitniejszym pośród Autorenfilme był jednak, uznany ex post za film (pre)ekspresjonistyczny, Student z Pragi (Der Student von Prag, 1913). Jego scenariusz napisał Hanns Heinz Ewers, popularny wówczas pisarz fantastyczny, w latach I wojny światowej uwikłany w szpiegostwo na rzecz Niemiec i internowany w USA, później aktywny stronnik Hitlera i autor biografii nazistowskiego „męczennika”, Horsta Wessela ${ }^{11}$. Film, formalnie wyreżyserowany przez Duńczyka Stellana Rye, uchodzi za autorskie dzieło Paula Wegenera, znanego reżysera i aktora teatralnego, który w przyszłości, jako producent, reżyser i aktor, będzie jedną z czołowych postaci kina niemieckiego. Jest to opowieść - znowu, zdaniem Kracauera, modelowa - o człowieku, który w zamian za bogactwo odstępuje diabłu własne odbicie w lustrze. Ów zwierciadlany wizerunek prześladuje bohatera i prowokuje w końcu feralny pojedynek, w którym student, strzelając

9 Por.: K. Thompson, D. Bordwell, op. cit., s. 57; Kristin Thompson, The International Exploration of Cinematic Expressivity, [w:] Film and the First World War, ed. Karel Dibbets, Bert Hogenkamp, Amsterdam University Press, Amsterdam 1995, s. 65-84.

${ }_{10}$ T. Elsaesser, Germany: The Weimar Years, s. 139. Por. także: Sabine Hake, German National Cinema, Routledge, London-New York 2002, s. 21.

${ }^{11}$ W oparciu o tę książkę i scenariusz Ewersa powstał film Franza Wenzlera Hans Westmar: jeden z wielu (Hans Westmar: Einer von Vielen), jeden z trzech „brunatnych” filmów z roku 1933. Nazwisko głównej postaci i tym samym tytuł filmu zostały zmienione na żądanie Goebbelsa. 
do własnego odbicia, zabija samego siebie. Niezależnie od romantycznej z ducha, à la E. T. A. Hoffmann, Faustopodobnej anegdoty i jej symbolicznej wymowy, film był wybitnym osiągnięciem technicznym - podziw budziły zwłaszcza sceny, w których student i jego sobowtór, obaj grani przez Paula Wegenera, stoją naprzeciw siebie w jednym kadrze. Oczywiście, osiągnięto to za pomocą wynalezionej przez Mélièsa techniki oddzielnego eksponowania różnych fragmentów tego samego kadru (tzw. podwójna ekspozycja). Twórcą tych znakomitych zdjęć był Guido Seeber, zarazem autor rozlicznych tekstów o sztuce operatorskiej, oświetleniu i efektach specjalnych, w których Thomas Elsaesser upatruje klucz do rozumienia niemieckiego stylu wizualnego lat $20 .^{12}$

Student z Pragi, niezależnie od swego statusu jako Autorenfilm, jest $\mathrm{w}$ historii filmu przełomowy także $\mathrm{z}$ tej racji, iż zapoczątkowuje $\mathrm{w}$ kinie niemieckim potężny pod koniec okresu wilhelmińskiego i potem w okresie weimarskim nurt fantastyki o romantycznej proweniencji. Jego popularność nie świadczy może wcale o predylekcji „niemieckiej duszy” do niesamowitego, das Unheimliche, jak chcieliby Kracauer i Eisner, lecz wynika po prostu, jak sądzi Elsaesser, z trojakich powodów. Po pierwsze, fantastyka dała sposobność do eksplorowania rozmaitych technik filmowych, takich jak podwójna ekspozycja, szczególne oświetlenie czy różne efekty specjalne, co pomogło zabłysnąć talentowi i inwencji znakomitych niemieckich operatorów-wynalazców (jak Guido Seeber, Günther Rittau, Carl Hoffmann, Karl Freund czy Fritz Arno Wagner). Po drugie, sięgnięcie do romantycznej, gotyckiej czy ludowej tradycji niemieckiej było, podobnie jak Autorenpolitik, legitymizacją estetyczną kina, jego nobilitacją jako „kultury”. Po trzecie, postawienie na rodzimą tradycję pozwoliło wyodrębnić film niemiecki jako kinematografię narodową i było definitywnym zerwaniem $\mathrm{z}$ quasi-uniwersalnym charakterem kina $\mathrm{w}$ jego pierwszych dwu dekadach (w zakresie tematów i gatunków) ${ }^{13}$.

Student z Pragi jest pierwszym z tzw. Märchenfilme - filmów opartych o baśnie, podania ludowe czy fantastyczne opowieści ze skarbca niemieckiego romantyzmu, powstałych głównie między 1913 a $1918 \mathrm{r}$. Czołowym ich twórcą był właśnie Paul Wegener, a do najbardziej znanych należą zrealizowane przezeń Golem (1915), Jogin (1916), Wesele króla gór (Rübezahls Hochzeit, 1916), Golem i tancerka (Der Golem und die Tänzerin, 1917), Szczurołap z Hameln (Der Rattenfänger von Hameln, 1918), Obcy ksiaże (Der fremde Fürst, 1918), a z filmów innych twórców - Opowieści Hoffmanna (Hoffmanns Erzählungen, 1916) Richarda Oswalda czy se-

\footnotetext{
12 T. Elsaesser, Germany: The Weimar Years, s. 141.

13 Ibidem.
} 
rial Ottona Ripperta Homunculus (1916) ${ }^{14}$. Druga, nieco skromniejszą ilościowo, za to potężną artystycznie, falę tych filmów z lat 20. reprezentują m.in.: Golem (1920) - remake Paula Wegenera i Carla Boese, Zmęczona Śmierć (Der müde Tod, 1921) Fritza Langa, Kopciuszek (Der verlorene Schuh, 1923) Ludwiga Bergera, Kronika z Grieshuus (Zur Chronik von Grieshuss, 1925) Arthura von Gerlacha, druga wersja Studenta z Pragi (1926) Henrika Galeena, wreszcie Faust (1926) Friedricha Wilhelma Murnaua. Ten ostatni jest zdecydowanie bliższy baśni bądź legendzie niż dramatowi Goethego, o czym dodatkowo świadczy podtytuł: Eine deutsche Volkssaga (Niemieckie podanie ludowe).

Potężnym graczem na niemieckim rynku filmowym przed I wojną światową była duńska kompania Nordisk, która wyprodukowała najkosztowniejszy i obok Studenta z Pragi najwybitniejszy Autorenfilm - Atlantyda (Atlantis, August Blom, 1913) ${ }^{15}$. Film ten, choć formalnie to produkcja duńska, przeznaczony był głównie na rynek niemiecki, co nie dziwi, zważywszy, iż była to adaptacja powieści niemieckiego pisarza, Gerharta Hauptmanna, który zaledwie rok wcześniej, w 1912, otrzymał literacką Nagrodę Nobla. Z tej racji, a także dlatego iż centralnym wydarzeniem fabularnym filmu było - rok po katastrofie Titanica - zatonięcie luksusowego transatlantyku, towarzyszyło tej adaptacji autentyczne zainteresowanie publiczności, niezależne od włączenia jej w kampanię promującą Autorenfilm. Atlantis realizowano zresztą częściowo w Berlinie i najciekawsze sekwencje filmu zawierają fascynujące zdjęcia niemieckiej stolicy doby fin-de-siècle'u.

Oczywiście, kino wilhelmińskie przed I wojną światową to nie tylko - i nie przede wszystkim - Autorenfilm, ambitna próba „uartystycznienia” kina i zdobycia dlań prestiżu. Thomas Elsaesser zwraca uwagę, iż gros produkcji to były filmy czysto rozrywkowe - zwłaszcza sensacyjne, naśladujące francuskie seriale kinowe, $\mathrm{z}$ detektywami o obowiązkowo angielskich nazwiskach, toczącymi zacięte pojedynki z superprzestępcami wzorowanymi na Fantomasie. Filmy te epatowały modernizmem, eksplorując urok wielkomiejskiej scenerii oraz ujawniając fascynację widowni i twórców nowoczesnymi środkami komunikacji, takimi jak telefon czy pędzące $\mathrm{w}$ szalonym tempie (w obowiązkowych sekwencjach pościgów) samochody i pociagi. Harry Piel, gwiazda tych filmów, znacznie ponoć przewyższał popularnością czołowe amantki, Henny Porten i Astę Nielsen.

${ }^{14}$ Nt. Märchenfilme zob.: S. Hake, op. cit., s. 20; T. Elsaesser, Weimar Cinema, Mobile Selves, and Anxious Males: Kracauer and Eisner Revisited, s. 47-48; L. H. Eisner, op. cit., s. 50-54, 60-63.

15 Do Autorenfilme zalicza Atlantis Bloma Thomas Elsaesser (Germany: The Weimar Years, s. 139). 
Gatunkiem, stopniowo odkrywanym ostatnimi laty w kinie niemieckim tamtego okresu, jest też komedia - późniejsze arcydzieła Lubitscha były poprzedzone przez utwory Franza Hofera. Okołu roku 1913 ustabilizował się metraż standardowego filmu - na poziomie trzech do pięciu rolek ${ }^{16}$.

I wojna światowa, która $\mathrm{w}$ znacznym stopniu załamała produkcję filmową w krajach sąsiednich (Francja, Dania), miała raczej stymulujący wpływ na kinematografię niemiecką. Wydany w roku 1916 i obowiązujący do końca 1920 r. zakaz importu filmów był potężnym bodźcem do ekspansji rodzimych kompanii produkcyjnych - nie tylko nie miały konkurencji spółek zagranicznych na rynku wewnętrznym, ale mogły też skorzystać na konfiskacie ich majątku. Tak np. Erich Pommer, reprezentant francuskich wytwórni Gaumont i Éclair, uformował wytwórnię Decla (Deutsche Éclair), która miała na progu Republiki Weimarskiej zostać czołowym producentem ambitnego kina artystycznego (wchłonięta potem przez Ufę zachowała jednak pewną autonomię i pod szyldem Decla-Bioskop wyprodukowała szereg arcydzieł kina weimarskiego). Liczba kompanii produkcyjnych wzrosła z $25 \mathrm{w}$ roku 1914 aż do $130 \mathrm{w}$ roku $1918^{17}$.

\section{Ufa $^{18}$}

Najważniejszym jednak dla przyszłości kina niemieckiego wydarzeniem lat wojny było utworzenie koncernu filmowego Universum Film Aktiengeselschaft (UFA), zwanego Ufą. Został on powołany rozkazem głównodowodzącego niemieckich sił zbrojnych, generała Ericha Ludendorffa, z 18 grudnia 1917 r., w celu produkcji i marketingu wysokiej jakości filmów propagujących pozytywny obraz Niemiec w kraju i za granicą (co w latach wojny byłoby odpowiedzią na antyniemiecką propagandę Ententy). Na Ufę złożyły się najważniejsze niemieckie spółki produkujące filmy (jak Messter, PAGU, Joe May Film, niemiecka filia Nordisku), skupione początkowo wokół pierwotnego rdzenia, jakim była BUFA (Bild und Film Amt) - propagandowa jednostka Pruskiego Ministerstwa Wojny, subsydiowana przez konsorcjum firm reprezentujących przemysł chemiczny, elektryczny i stoczniowy pod zarządem Deutsche Bank. Państwo dostarczyło funduszy, by wykupić niektórych właścicieli, innym

16 T. Elsaesser, Germany: The Weimar Years, s. 138.

17 Ibidem, s. 139. Por. także: K. Thompson, D. Bordwell, op. cit., s. 58, 105-106.

${ }_{18}$ Podstawowym źródłem informacji nt. Ufy jest w literaturze światowej znakomita monografia: Klaus Kreimeier, Die Ufa-Story: Geschichte eines Filmkonzerns, Carl Hansen Verlag, München-Wien 1992 (wyd. angielskie: K. Kreimeier, The Ufa Story: A History of Germany's Greatest Film Company, 1918-1945, transl. Robert and Rita Kimber, University of California Press, Berkeley-Los Angeles-London 1999). 
zaś oferowano udziały w nowym koncernie (pierwszym szefem produkcji został Paul Davidson). Utworzenie takiego zintegrowanego poziomo (rozmaite podmioty) i pionowo (produkcja, dystrybucja, sieć kin) giganta sprawiło, że mniejsze spółki filmowe stały się stopniowo coraz bardziej zależne od niego jako głównego krajowego eksploatatora i dystrybutora eksportu filmów. Wyeliminowany został też główny konkurent o podobnych ambicjach politycznych - zrzeszający szereg drobnych spółek filmowych koncern Deulig, zarządzany przez powiązanego z kołami nacjonalistycznymi i przemysłowymi Alfreda Hugenberga, i jego prawą rękę, Ludwiga Klitzscha. Ale, jak na ironię, to właśnie ci przegrani na jakiś czas rywale wezmą odwet, gdy Ufa znajdzie się w tarapatach i przejmą w roku 1927 zarząd nad koncernem ${ }^{19}$.

Gdy wojna skończyła się kapitulacją Niemiec w listopadzie 1918 r., rząd sprzedał swe udziały w Ufie potężnym koncernom (Krupp, I. G. Farben) iDeutsche Bankowi, a Ufę przekształcono w prywatną spółkę, której kapitał podstawowy czynił ją największym niemieckim kartelem. Ufa stworzyła ogromny nowoczesny kompleks studiów w Poczdamie-Neubabelsbergu, rozbudowując ateliers przejęte po wchłonięciu wytwórni Decla-Bioskop, posiadała też tereny i wielkie studio w Berlinie-Tempelhofie, nabyte od Messtera i kompanii Union. Dysponowała również siecią luksusowych kin w całych Niemczech oraz biurowcem w centrum Berlina. Po zakończeniu wojny i wycofaniu się udziałowca rządowego przestały mieć rację bytu propagandowe zadania stawiane koncernowi $\mathrm{u}$ jego narodzin (choć jego polityką nadal rządziła ukryta, acz nie zawsze konsekwentnie realizowana, ideologia o nacjonalistycznym posmaku). Ufa dbała jednak głównie o drugi postawiony przez jej fundatorów cel: podniesienie jakości produkcji i eksploatacji (kina), usprawnienie dystrybucji i promocję eksportu. Toteż zgromadziła zespół najwybitniejszych filmowców, techników, aktorów i producentów. Nieustanne inwestycje w ateliers i technikę filmową (możliwe w dobie hiperinflacji z lat 1919-1923) uczyniły koncern największą wytwórnią w Europie do II wojny światowej, jedyną porównywalną rozmiarami i zapleczem do studiów amerykańskich. W polityce repertuarowej Ufa nastawiona była na kino popularne, ale zarazem dbała o wysoki poziom artystyczny, pozwalając swym czołowym reżyserom Murnauowi, Langowi - na eksperymenty formalne i kosztowne ekstrawagancje, nawet za cenę ryzyka finansowego (casus Fausta i Metropolis, dwóch superprodukcji, które przyczyniły się do tarapatów giganta w drugiej połowie lat 20.). Wbrew wrażeniu, które można odnieść czytając dotychczasowe historie kina, Ufa nie zmonopolizowała niemieckiej

19 Por.: K. Kreimeier, The Ufa Story, s. 29-33; D. A. Cook, op. cit., s. 90-91; T. Elsaesser, Germany: The Weimar Years, s. 141-142. 
produkcji filmowej w latach weimarskich - tylko w 1921 (rok wielkiej inflacji) istniało na terenie Niemiec około 300 filmowych spółek! Ufa nigdy nie przekroczyła w okresie weimarskim $18 \%$ udziału w ogólnoniemieckiej produkcji, a udział ten w skali roku procentowo był zwykle liczbą jednocyfrową. Ufa służyła mniejszym wytwórniom głównie jako dystrybutor, a niektóre z nich - monachijska Emelka czy Nero - utrzymywały własną sieć kin i zawierały umowy dystrybucyjne bezpośrednio z firmami amerykańskimi czy brytyjskimi ${ }^{20}$.

Okresem prosperity zarówno Ufy, jak i całego niemieckiego przemysłu filmowego tuż po I wojnie światowej jest, paradoksalnie, trwająca od końca wojny do końca 1923 r. inflacja. Była ona m.in. rezultatem nałożonych na Niemcy przez aliantów ogromnych odszkodowań, tzw. reparacji wojennych, których ciężaru młoda Republika Weimarska (zmagająca się w dodatku z próbami komunistycznych przewrotów i nacjonalistyczno-ancienregimowych puczów) nigdy nie była w stanie udźwignąć. Konieczność spłaty regularnych rat w złocie, węglu, stali, ciężkim sprzęcie, okrętach itd. spowodowała gwałtowny wzrost cen i niedobór wszelkich dóbr na rynku, a podsycała ją polityka monetarna państwa, które nie chcąc dopuścić do bezrobocia, zwłaszcza w dobie wkroczenia na rynek pracy zdemobilizowanych weteranów, wolało utrzymywać wysoki poziom zatrudnienia, a pracowników opłacać drukowanym pieniądzem bez pokrycia. Rezultaty tej polityki były fatalne, gdy w roku 1914 kurs dolara do marki wynosił $1: 4$, to na początku 1923 r. $-1: 50$ 000, a pod koniec tego roku - 1:4,2 biliona (bilion to jedynka z dwunastoma zerami!). Ta największa w dziejach świata hiperinflacja miała katastrofalne skutki nie tylko ekonomiczne, ale także moralne, psychologiczne i polityczne, wzbudzając wzrost nastrojów antysemickich (skoro to "Żydzi” rządzą międzynarodowym kapitałem, wysysającym Niemcy z wszelkich dóbr) i nadzieję na charyzmatycznego lidera-wybawcę (znaczna część społeczeństwa dekadę później ujrzy go w Hitlerze). Choć ogromna rzesza Niemców popadła w dotkliwą biedę (deklasacja dosięgła zwłaszcza inteligencję i ludzi wolnych zawodów), to jednak istnieli też doraźni beneficjenci inflacji. Należeli do nich np. wzbogaceni na wymianie barterowej ze zbiedniałymi gwałtownie mieszkańcami miast rolnicy czy zwłaszcza przemysłowi magnaci, którzy dzięki zaciągnięciu nierewaloryzowanych kredytów szybko zamienianych na twardą walutę skupili w swym ręku olbrzymi kapitał i władzę (np. Hugo Stinnes, którego kryptoportretami są postacie z filmów Fritza Langa - tytułowy bohater Doktora Mabuse, gracza, 1922 i Joh Fredersen, władca miasta z Metropolis, 1926) ${ }^{21}$.

${ }^{20}$ Por.: K. Kreimeier, The Ufa Story, s. 38-157; D. A. Cook, op. cit., s. 90-91, 95; T. Elsaesser, Germany: The Weimar Years, s. 144.

${ }^{21}$ Por.: Bernd Widdig, Culture and Inflation in Weimar Germany, University of California Press, Berkeley-Los Angeles-London 2001, passim. 
Do beneficjentów należał też przemysł filmowy. $\mathrm{W}$ okresie inflacji znacznie wzrosła frekwencja w kinach - pracownicy etatowi wydawali zarobek, póki był jeszcze cokolwiek wart, a zresztą na rozrywkę nie żal było inflacyjnych pieniędzy. W tym czasie zbudowano wiele kin, a wytwórnie - w tym przede wszystkim Ufa - inwestowały w technikę, ateliers, kosztowne dekoracje, rzesze statystów dla realizacji wielkich scen masowych w takich filmach, jak historyczne widowiska Lubitscha (Madame DuBarry, 1919; Anna Boleyn, 1920) czy narodowy epos Langa (Nibelungi, 1924). W tej właśnie epoce grupa inwestorów przekształciła hangar w berlińskiej dzielnicy Staaken, w którym w latach wojny trzymano zeppeliny, w największą na świecie halę zdjęciową do realizacji scen atelierowych. Studio Staaken wynajmowano wytwórniom, które potrzebowały hal dla olbrzymich dekoracji (tu nakręcono szereg scen z Metropolis Langa). Inflacja zniechęcała do sprowadzania filmów zagranicznych, co nawet po zniesieniu zakazu importu filmów w styczniu 1921 r. w dalszym ciągu promowało rodzimą produkcję (przy porównywalnych walorach widowiskowych kilkunastokrotnie tańszą niż np. w Hollywood), tym samym - jej eksport na rynki zagraniczne po cenach dumpingowych ${ }^{22}$.

Strategia promowania eksportu przez realizację filmów widowiskowych, atrakcyjnych dla masowej widowni (dzięki czemu miano nadzieję konkurować z Hollywoodem i wkroczyć na ogromny rynek amerykański), a zarazem stojących na wysokim poziomie artystycznym (dzięki czemu można było odnieść prestiżowy sukces w Europie, w tworzącym się właśnie obiegu art cinema) była w Ufie lansowana przez szefa produkcji trzech zrzeszonych w koncernie spółek, Ericha Pommera. Była ona skuteczna właśnie w latach inflacji, gdyż dzięki deprecjacji rodzimej waluty szybko amortyzował się koszt produkcji filmu: sprzedaż na choćby jeden rynek zagraniczny (np. Szwajcarii) gwarantowała ilość twardej waluty wystarczającą na sfinansowanie produkcji kolejnego filmu; sprzedaż na więcej rynków była już czystym zyskiem ${ }^{23}$.

Po zdławieniu inflacji i wprowadzeniu nowej twardej waluty gwarantowanej przez państwo, tzw. Reichsmarki, co było możliwe m.in. dzięki wspomagającemu niemiecką gospodarkę tzw. Planowi Dawesa, wszystko to uległo zmianie. Filmy niemieckie przestały być konkurencyjne cenowo na światowym rynku, coraz trudniejsza sprzedaż zagraniczna nie była już w stanie amortyzować kosztów tak szybko ani tym bardziej finansować nowych produkcji. Pomiędzy 1924 a 1926 r. wiele małych spółek musiało

${ }^{22}$ Por.: K. Kreimeier, The Ufa Story, s. 76-84; K. Thompson, D. Bordwell, op. cit., s. $106-108$.

${ }^{23}$ T. Elsaesser, Germany: The Weimar Years, s. 144-145; K. Kreimeier, The Ufa Story, s. $121-122$. 
wycofać się z interesu. Wysokobudżetowe filmy stały się rzadsze niż w latach inflacji, wielkie studia nie były w pełni wykorzystywane. Ufa, która usiłowała kontynuować poprzednią politykę, o mało nie splajtowała pod koniec 1925 r. Budżet koncernu, niesłychanie nadwątlony uprzednim przeinwestowaniem, dodatkowo pogrążały przedłużające się i znacznie przekraczające pierwotnie planowane koszty realizacje Fausta Murnaua i Metropolis Langa, prestiżowe przedsięwzięcia dwóch najbardziej renomowanych reżyserów (gdy już oba filmy weszły na ekrany w sezonie 1926/27, nie mogły choćby częściowo zwrócić kosztów - zwłaszcza, że Ameryka, gdy sensacją dnia i przyszłością kina stał się film dźwiękowy, nie była już zainteresowana nawet najbardziej wyrafinowanymi artystycznie i widowiskowymi filmami z Europy).

Z dwuznaczną pomocą przyszły Ufie dwa amerykańskie studia - MGM i Paramount, oferując na 7,5\% pożyczkę 4 mln dolarów (suma wówczas olbrzymia!) na spłatę długu koncernu wobec Deutsche Bank. Warunkiem jej uzyskania były prawa do korzystania z personelu i ateliers Ufy, a także zarezerwowanie $\mathrm{w}$ sieci kin Ufy $1 / 3$ premier dla filmów obu pożyczkodawców. Umowa ta, z grudnia 1925 r., powołała także firmę dystrybucyjną Parufamet, w której Ufa była właścicielem połowy udziałów, zaś Paramount i MGM po 1/4. Firma ta miała dystrybuować po 20 tytułów rocznie każdej z członkowskich kompanii. Oczywiście, był to zysk dla hollywoodzkich potentatów, którzy w ten sposób wdzierali się na największy w Europie rynek filmowy. Kierownictwo Ufy po zawarciu tej umowy zmusiło Ericha Pommera do rezygnacji. Pommer wyjechał do USA i tam pracował jako producent dla Paramountu. Skłócony jednak z kierownictwem studia wrócił pod koniec roku 1927 do Ufy, gdzie jednak nigdy nie odzyskał rangi naczelnego producenta, stając się tylko jednym $\mathrm{z}$ wielu podrzędnych ${ }^{24}$.

Pommer jednak nie był jedynym spośród ludzi Ufy, którzy wyemigrowali po umowie Parufamet za ocean (co dla kina niemieckiego było może najbardziej dotkliwym jej skutkiem). Do znajdujących się w Hollywood od roku 1922 reżyserów Ernsta Lubitscha i Dymitra Buchowieckiego, w latach 1926-1927 dołączyli reżyserzy Friedrich Wilhelm Murnau, Ewald André Dupont, Paul Leni, Ludwig Berger, Mihály Kertész (tak naprawdę nazywał się przyszły reżyser Casablanki, Michael Curtiz), operator Karl Freund, scenarzysta Carl Mayer, scenografowie Rochus Gliese i Walter Reimann, aktorzy Greta Garbo, Lya de Putti, Emil Jannings i Conrad Veidt (dwaj ostatni powrócą do Niemiec w roku 1929)25.

${ }^{24}$ K. Kreimeier, The Ufa Story, s. 126-130; D. A. Cook, op. cit., s. 105-106; K. Thompson, D. Bordwell, op. cit., s. 119-120.

${ }^{25}$ D. A. Cook, op. cit., s. 106-107; K. Thompson, D. Bordwell, op. cit., s. 121. 
Ani jednak amerykański „desant” na Niemcy nie okazał się czymś trwałym, ani Ufa nie uzyskała finansowej stabilizacji. Z olbrzymimi stratami finansowymi 12 mln dolarów na początku roku 1927 musiała najpierw sprzedać swój biurowiec, a później szukać pożyczki u dawnego konkurenta Alfreda Hugenberga, niegdyś dyrektora u Kruppa, a później magnata prasowego. W marcu 1927 Hugenberg wykupił amerykańskie udziały, spłacił długi i przejął pakiet kontrolny nad Ufa, zostając szefem rady nadzorczej koncernu. Dyrektorem generalnym mianował Ludwiga Klitzscha, który, dzięki rozsądnej polityce i rezygnacji zarówno z artystycznych ambicji, jak i gigantomanii produkcynej poprzedniego zarządu, przywrócił kompanii ekonomiczną stabilność. Dzięki tej stabilności Ufa zostanie za kilka lat rdzeniem coraz bardziej scentralizowanego i kontrolowanego przez nazistów przemysłu filmowego Trzeciej Rzeszy. I choć nie można stwierdzić, iż profil produkcyjny Ufy jakoś radykalnie się zmienił z dnia na dzień, to stopniowo, zwłaszcza już w okresie dźwiękowym, coraz wyraźniejszy stawał się nacjonalistyczny podtekst wielu realizacji - widoczny np. w Bergfilme, filmach "fryderycjańskich” albo w ilości miejsca, poświęcanego nazistowskim Parteitagom w kronikach Ufy. Co, rzecz jasna, odzwierciedlało polityczne predylekcje Hugenberga ${ }^{26}$.

\section{Ekspresjonizm}

Omówienia estetyki kina weimarskiego nie sposób nie zaczać od Gabinetu doktora Caligari Roberta Wiene. Paradoksalnie jednak film ten nie jest ani bezdyskusyjnym arcydziełem sztuki filmowej, ani utworem stylistycznie szczególnie miarodajnym dla kina niemieckiego tej epoki. Wagę pozaartystyczną nadała mu interpretacja Siegfrieda Kracauera, który poprzez umieszczenie tytułowej postaci filmu w efektownym tytule swej książki Od Caligariego do Hitlera podkreślił, iż zapoczątkowuje ona w kinie niemieckim swoisty „pochód tyranów”, który jest wyrazem zbiorowej nieświadomości społeczeństwa weimarskiego i przeczuciem mającego niedługo zawładnąć Niemcami nazizmu. W aspekcie estetycznym film Roberta Wiene jest ważniejszy raczej z perspektywy kina światowego niż niemieckiego. Datę jego premiery - Berlin, 26 lutego 1920 - wypada bowiem uznać bardziej niż jakąkolwiek inną za narodziny światowego kina artystycznego, adresowanego nie do masowej, lecz elitarnej publiczności, może trochę snobistycznej, za to zorientowanej w estetycznych modach i intelektualnych trendach, nastawionej nie na rozrywkę, lecz na kontemplację sztuki. s. 150.

${ }^{26}$ K. Kreimeier, The Ufa Story, s. 158-172; T. Elsaesser, Germany: The Weimar Years, 
Tak zreszta, jako narodziny kina artystycznego, powitali ten film krytycy - najpierw francuscy, potem, już po sukcesie we Francji, niemieccy, co zbiegło się z rozmaitymi inicjatywami promującymi kino jako sztukę i tworzącymi alternatywny do komercyjnego obieg kina artystycznego (przedsięwzięcia Louis Delluca, Ricciotta Canudo, Jeana Tedesco, magazyny i pisma poświęcone filmowi artystycznemu, kina $\mathrm{z}$ artystycznym repertuarem, ekspozycje filmowe na wystawach poświęconych sztuce, np. na paryskim Salonie Jesiennym w latach 1921-1923 albo berlińskiej „Kipho”- Kino und Photo Ausstellung - w roku 1925).

Gabinet doktora Caligari jest filmem intrygującym fabularnie i kompozycyjnie. Młody człowiek, Francis, snuje w nim opowieść o serii zbrodni w miasteczku Holstenwall - w jednej z nich zginął Allan, jego przyjaciel i zarazem rywal w miłości do pięknej Jane. Francis, prowadząc dochodzenie, odkrywa, iż są one dziełem szarlatana mieniącego się "doktorem" Caligarim, a popełnił je on przy pomocy medium - somnambulika Cezara, pokazywanego jako osobliwość na miejscowym jarmarku. Historia ta w finale filmu okazuje się opowieścią wariata. Caligari, zdemaskowany przez Francisa jako faktyczny inspirator zbrodni, ostatecznie okazuje się istotnie doktorem (i to psychiatrii), Francis zaś pacjentem szpitala psychiatrycznego, w którym Caligari jest dyrektorem! Zgodnie z jednowymiarowa, alegoryczną lekturą filmu, proponowaną przez Siegfrieda Kracauera, Caligari posługujący się bezwzględnie mu posłusznym medium miał być figurą tyrana, posyłającego swych bezwolnych poddanych, by zabijali jak cesarz Wilhelm II Niemców podczas I wojny światowej. Wbrew licznym, ale dość powierzchownym interpretacjom inspirowanym książką Kracauera ${ }^{27}$, rama narracyjna nie neutralizuje zamierzonej przez scenarzystów, Carla Mayera i Hansa Janowitza, ostrej wymowy politycznej, lecz wprowadza intrygującą dwuznaczność i raczej potęguje niż osłabia „antytyrańskie" ostrze. Czy rzeczywiście bowiem przerażający i odstręczający Caligari jest naukowym autorytetem, który wie, jak wyleczyć Francisa (o czym zapewnia nas $\mathrm{w}$ finale)? Widzowi, choćby $\mathrm{z}$ racji identyfikacji emocjonalnej z narracją Francisa, trudno to zaakceptować. Czy może raczej nieszczęsny Francis został „zneutralizowany” i wraz z innymi bohaterami opowieści - Cezarem, Jane - wtrącony w drodze jakichś mrocznych machinacji do domu wariatów? Zaniepokojony widz skłonny jest raczej podejrzewać drugą ewentualność, którą w kontekście znajomości niedalekiej przyszłości Niemiec trzeba uznać za przerażająco prawdziwe rozpoznanie, iż demony nie zostały pokonane...

Swą kompozycją Gabinet doktora Caligari zapoczątkował w kinie weimarskim modę na Rahmenhandlung - ramę narracyjną. Posiadają ją i inne

27 Por.: S. Kracauer, op. cit., s. 56-69. 
ważne filmy niemieckie z tych lat: Zmęczona Śmierć (1921) i Metropolis (1926) Fritza Langa, Cienie (Schatten, 1923) Arthura Robisona, Gabinet figur woskowych (Das Wachsfigurenkabinett, 1924) Paula Leniego. W ramowej opowieści Zmęczonej Śmierci Dziewczyna, której Śmierć zabrała ukochanego, stara się przedostać do krainy umarłych, aby się z nim połączyć. Historie wewnątrzramowe $\mathrm{w}$ tym filmie - dzieje nieszczęśliwych kochanków, których rozdzieliła Śmierć, rozgrywające się kolejno w świecie arabskim, renesansowej Wenecji i dość umownych Chinach - obrazują "trzy szanse" na ocalenie ukochanego, jakie dała bohaterce Śmierć (rzecz jasna - niewykorzystane). W Cieniach wędrowny kuglarz demonstruje zgromadzonemu na zamku wykwintnemu towarzystwu teatr cieni, a później, hipnotyzując zgromadzonych i usuwając ich cienie, powoduje, iż zahipnotyzowani przenoszą się za swymi cieniami w krainę własnej podświadomości. Tragedia, która w tym widmowym świecie się rozegra, umożliwia rozładowanie prawdziwych napięć postaci i gdy w finale akcja wraca do ramy realnej rzeczywistości, bohaterowie są „wyleczeni”. W ramie Gabinetu figur woskowych ubogi poeta zyskuje szansę zarobku, polegającą na wymyśleniu "reklamowych” historii o trzech mrocznych postaciach (Harun al-Raszid, Iwan Groźny, Kuba Rozpruwacz) wystawionych jako woskowe figury na jarmarku; opowieści wewnątrzramowe to właśnie rezultat wyobraźni poety. Zwłaszcza zaś chyba dla Friedricha Wilhelma Murnaua rama narracyjna stała się ulubionym zabiegiem kompozycyjnym, ogarniającym całość dzieł: Satanas (1919), Fantom (Phantom, 1922), Nosferatu, symfonia grozy (Nosferatu, eine Symphonie des Grauens, 1922), Świętoszek (Tartüff, 1925). W zaginionym filmie Satanas, zastanawiająco podobnym do powstałych niemal równolegle Kartek z Księgi Szatana (Blade af Satans Bog, 1920) Carla Theodora Dreyera, tytułowa postać objawia się jako uwodziciel i zdrajca w trzech epokach historycznych (starożytny Egipt, renesansowe Włochy, Niemcy 1918). W Fantomie, według powieści Gerharta Hauptmanna, bohater spisuje po latach burzliwą historię swej młodości, kiedy owładnięty ambicjami i pożądaniem, uganiając się za "fantomem" idealnej kobiety o wysokiej pozycji społecznej, przegapił prawdziwą miłość, zmarnował talent literacki i wkroczył na drogę przestępczą. Nosferatu to mimo zmienionych imion postaci wierna, choć nielegalna adaptacja powieści Brama Stokera Dracula ${ }^{28}$. Historia agenta nieruchomości Huttera, transylwańskiego hrabiego Orloka, a faktycznie

${ }^{28}$ Wytoczony przez wdowę po pisarzu proces o naruszenie praw autorskich zakończył się przegraną producenta filmu i wyrokiem nie tylko zakazującym rozpowszechniania filmu Murnaua, ale też żądającym zniszczenia negatywu i wszystkich kopii. Film szczęśliwie ocalał do naszych czasów dzięki kopii w Cinémathèque Française, ale skutkiem wyroku był mało znany niemieckiej publiczności w latach 20. 
- wampira Nosferatu, który do północnoniemieckiego miasta sprowadza dżumę i śmierć, oraz Ellen, żony Huttera, która dzięki swemu poświęceniu ratuje miasto od zagłady, jest w skomplikowany, szufladkowy sposób zapośredniczona w narracji przez rozmaite źródła pisane: kronikę wielkiego moru w Wisborgu z roku 1838, księgę o wampirach, listy z podróży pisane przez Huttera do Ellen oraz dziennik pokładowy statku, którym wampir podróżuje z Rumunii do Niemiec. W Świętoszku mamy z kolei współczesną ramę i „film w filmie”, którego akcja oparta jest o uproszczoną fabułę komedii Moliera.

Funkcje ramy narracyjnej mogły być rozmaite: od prostego zaznaczenia, że akcja wewnątrzramowa jest definitywnie minioną przeszłością (Fantom, Nosferatu), przez odzwierciedlanie wewnątrz ramy rzeczywistości zarówno obramowującej, jak i pozatekstowej („film w filmie” w Świętoszku, teatr cieni w Cieniach), po zawarcie w obramowanej opowieści swoistej ideologicznej wykładni dzieła (Legenda o Wieży Babel w Metropolis). Najbardziej intrygująca jest niepewność widza co do ontologicznego statusu pewnych partii filmu, wytwarzająca frapującą dialektykę między tym, co obramowujące a tym, co obramowane. Co jest prawdą w Caligarim: zawartość opowieści Francisa czy status jego jako wariata, a Caligariego jako psychiatrycznego autorytetu? Czy Dziewczyna w Zmęczonej Śmierci naprawdę po wypiciu trucizny przeniosła się w zaświaty, gdzie otrzymała od Śmierci „trzy szanse” na ocalenie ukochanego, czy raczej wszystko było projekcją jej rozgorączkowanej jaźni, czy też może „czas dostał czkawki i cofnął się jak zacięta płyta”? Czy w Gabinecie figur woskowych poeta śni lub wymyśla trzecią z historii, o Kubie Rozpruwaczu, czy też figura seryjnego mordercy ożyła i ściga bohatera z ukochaną - jak nam się przez jakiś czas zdaje - w realnej rzeczywistości? ${ }^{29}$

Gabinet doktora Caligari jest jednak powszechnie postrzegany przede wszystkim jako początek filmowego ekspresjonizmu. Tendencja ekspresjonistyczna, polegająca na wyrazistej deformacji tego, co przedstawione, dla wyrażenia dramatycznych uczuć artysty i silnego emocjonalnego działania na odbiorcę, istniała w sztuce od dawna, w zasadzie już od rzeźby hellenistycznej (vide: Grupa Laokoona). Jednak sam termin ek s p r e sj on i z m (Expressionismus) został ukuty i upowszechniony przez Herwartha Waldena, wydawcę berlińskiego periodyku „Der Sturm” (1910-1932), dla określenia antyrealistycznej i antyimpresjonistycznej stylistyki w malarstwie. Przejawy ekspresjonizmu znalazły wyraz w twórczości artystów z różnych krajów w ostatniej dekadzie XIX w. (np. Edvarda Muncha, Vincenta van Gogha, Jamesa Ensora, Henri de Toulouse-Lautreca), ale

${ }^{29} \mathrm{Nt}$. ramy narracyjnej w filmach weimarskich zob.: T. Elsaesser, Weimar Cinema and After, s. 82-83. 
trend ten wiążemy przede wszystkim ze sztuką niemiecką zwłaszcza zaś z działalnością drezdeńskiej grupy „Die Brücke” [Most] (1905-1913), berlińskiego środowiska artystycznego wokół powiązanej z pismem Waldena „Galerie Der Sturm” (1912-1924), oraz monachijskiego ugrupowania „Der Blaue Reiter" [Błękitny Jeździec] (1911-1914). Ze środowiskami tymi byli związani artyści, dziś uznawani za czołowych przedstawicieli ekspresjonizmu: Ernst Ludwig Kirchner, Erich Heckel, Emil Nolde („Die Brücke”), Oskar Kokoschka („Der Sturm”), Franz Marc, Wassily Kandinsky, Alfred Kubin, August Macke („Der Blaue Reiter”). Wspólnym rysem ekspresjonistycznego malarstwa było unikanie subtelnych odcieni i kolorów, które obrazom realistycznym nadają głębię, a przedstawionym na nim obiektom bryłowatość. Przeciwnie, postacie i przedmioty z ekspresjonistycznych obrazów wydają się płaskie, namalowane zaś są jaskrawymi, nierealistycznymi kolorami (np. zielone twarze portretowanych osób, niebieskie konie z obrazów Marca) i często obwiedzione ciemnym konturem, niczym postacie z kreskówek. Sylwetki ludzi często były wydłużone, a ich twarze groteskowo zdeformowane. Oczywiście, w malarstwie tym nie obowiązywały zasady renesansowej perspektywy (przeczyło im np. nierealistyczne przechylenie budynków i zanegowanie zasady znikającego punktu). Wzorcem ekspresjonistycznego teatru - był on bardziej bezpośrednim źródłem stylu Gabinetu doktora Caligari niż malarstwo - stała się natomiast inscenizacja w roku 1908 sztuki Oskara Kokoschki prowokacyjnie zatytułowanej Morderca, nadzieja kobiet (Mörder, Hoffnung der Frauen). Styl tego widowiska podchwycono w niemieckim teatrze lat 10. Dekoracje, deformujące realizm scenerii, przypominały estetyką ekspresjonistyczne malarstwo. Aktorzy wrzeszczeli, wyraziście gestykulowali i poruszali się w choreograficznie wystylizowany sposób w równie wystylizowanej scenografii. Celem tego wszystkiego była ek s p re sja - zarówno stanów wewnętrznych postaci, "duszy” autora, jak i pewnych idei czy ideologii tak, aby jak najsilniej oddziałały na publiczność (np. wystawiano lewicowe sztuki protestujące przeciwko wojnie lub „kapitalistycznemu wyzyskowi"). Tuż po I wojnie światowej - jak konstatują Kristin Thompson i David Bordwell - ekspresjonizm dawno już przestał być radykalnym artystycznym eksperymentem, stając się stylem szeroko akceptowanym i wręcz modnym ${ }^{30}$.

Transponowanie do filmu w Gabinecie doktora Caligari estetyki rodem z teatralnego i malarskiego ekspresjonizmu było tak naprawdę kolejna, po film d'art i Autorenfilm, próbą nobilitacji filmu jako kultury wysokiej. Niemiecki ekspresjonizm filmowy, za którego narodziny uznaje się film Roberta Wiene, to „kino scenografów” (warto zapamiętać nazwiska

${ }^{30}$ Por.: K. Thompson, D. Bordwell, op. cit., s. 109. 
trzech dekoratorów Caligariego, bo powrócą one jeszcze w innych wybitnych filmach: Walter Röhrig, Walter Reimann i Hermann Warm) ${ }^{31}$. W filmie tym cały świat przedstawiony został stworzony $\mathrm{w}$ atelier za pomoca ostentacyjnie nierealistycznych, wystylizowanych dekoracji, reprezentujących nie tylko wnętrza, ale i plenery - ulice miasteczka Holstenwall i jego najbliższą okolicę. Kamera ani razu nie wychodzi w prawdziwy plener, co w połączeniu z jej statycznością i frontalnością kadrowania rodzi $\mathrm{w}$ widzu wrażenie umowności przedstawionego świata i teatralności stylu (gdy w USA około 1917 r. ostatecznie ukształtował się już styl klasyczny, a szkoła szwedzka zachwyciła świat niesłychaną „filmowością" naturalnych plenerów, estetyka taka mogła wydawać się wręcz krokiem wstecz, powrotem do rozwiązań w stylu film d'art czy Mélièsa). To wrażenie zostaje jeszcze pogłębione przez nierealistyczne oświetlenie - w filmie brak światła naturalnego, a cienie nie tylko są rzucane na ścianę przez zasłaniające źródło światła postacie, lecz też namalowane na płótnie i jako takie na stałe związane z obiektami. Dekoracje zrywają radykalnie z iluzjonizmem renesansowej perspektywy - pełne zygzaków i ostrych kątów krzywe, wyznaczające przebieg ulic czy zarys budynków, z pewnością nie zbiegają się na horyzoncie. Co więcej, wygląd malowanych na płótnie obiektów wydaje się negować prawo ciążenia, zaś dziwaczna ekspresywność niektórych elementów scenografii (np. groteskowo wysokich stołków, na których siedzą magistraccy urzędnicy, albo kształt okien i wysokość, na jakiej się one znajdują) ewidentnie góruje nad ich funkcjonalnością czy jakąkolwiek motywacją realistyczną. Z brakiem realizmu scenerii koresponduje wystylizowane aktorstwo - gdyż nie tylko Werner Krauss w roli tytułowej i Conrad Veidt jako somnambulik Cezar, ale i inni aktorzy poruszają się jak w transie czy półśnie, a ich sylwetki stapiają się z dekoracjami (zastygły w dziwnej pozie Cezar przypomina stojące nieopodal drzewo).

Ta nierealistyczna, "trudna” estetyka (Caligari jest filmem percepcyjnie dość męczącym) zwabiła jednak do kin „wyrobioną” publiczność, która $\mathrm{z}$ satysfakcją odnalazła $\mathrm{w}$ obrazie filmowym modny w owym czasie w malarstwie i w teatrze styl artystyczny, należący do sztuki wysokiej, ale zarazem na tyle „oswojony”, że stał się częścią zbiorowej świadomości i trafił do wzornictwa przemysłowego ${ }^{32}$. Wraz z wkroczeniem do filmu ekspresjonizmu „,kino artystyczne” stało się faktem.

${ }^{31}$ Do tych trzech warto dorzucić jeszcze nazwiska kilku innych wybitnych scenografów kina weimarskiego, takich jak: Otto Hunte, Erich Kettelhut, Robert Herlth czy Rochus Gliese.

32 Tak z grubsza ujmuje triumf Gabinetu doktora Caligari i pojawienie się w filmie ekspresjonistycznego designu Thomas Elsaesser (Weimar Cinema and After, s. 69-71). 
Trzeba jednak pamiętać, że dzieł tak wprost przenoszących do filmu ekspresjonistyczną estetykę malarstwa i teatru, a ściśle rzecz biorąc - design scenografii z ekspresjonistycznych przedstawień, jest niewiele. Brytyjski historyk stylu i techniki filmowej, Barry Salt, prócz Caligariego wymienia zaledwie kilka filmów: Genuine (1920, Robert Wiene), Od poranka do pótnocy (Von Morgens bis Mitternachts, 1920, Karlheinz Martin), Torgus (1920, Hanns Kobe), Raskolnikow (1923, Robert Wiene), a także Gabinet figur woskowych (1924) i, z pewnym wahaniem, Metropolis (1926) ${ }^{33}$. Osobiście dodałbym takie filmy, jak Nerwy (Nerven, 1919, Robert Reinert), Lalka (Die Puppe, 1919, Ernst Lubitsch), Golem (1920, Paul Wegener i Carl Boese), Zmęczona Śmierć (1921), Doktor Mabuse, gracz (1922) i Nibelungi (Die Nibelungen, 1924) - wszystkie trzy w reżyserii Fritza Langa, Fantom (1922) i Faust (1926) - oba w reżyserii F. W. Murnaua, Tajemnice duszy (Geheimnisse einer Seele, 1926, Georg Wilhelm Pabst), wreszcie sowiecki film Aelita (1924, Jakow Protazanow). Rozszerzenie tej listy jest jednak dość problematyczne. Aelita na przykład to film powstały ewidentnie z inspiracji ,caligaryczną" estetyka, niebędący jednak dziełem kultury niemieckiej. Z kolei Nerwy i Lalka są wcześniejsze od Caligariego, w powszechnym mniemaniu „pierwszego" ekspresjonistycznego filmu, co więcej, film Lubitscha jest jawną parodią ekspresjonistycznego designu, w czym można dostrzec satyrę na ówczesną modę nań, w odniesieniu do filmu właściwie profetyczną. Doktor Mabuse wydaje się też raczej pastiszem ekspresjonizmu, skoro ostentacyjnie ekspresjonistyczny design w niektórych fragmentach tego generalnie dość realistycznego filmu wzięty jest w rozmaite cudzysłowy: ramę obrazu malarskiego, scenografię kabaretowego show, wystrój knajpy albo kasyna, ostentacyjność plastycznego cytatu. Dzieje się tak zgodnie z cyniczną odpowiedzia, jakiej Mabuse (w pewnych aspektach porte-parole samego Langa) udziela w filmie hrabiemu Toldowi, kolekcjonerowi dzieł sztuki nowoczesnej, głównie ekspresjonistycznych, na pytanie - czym jest ekspresjonizm: "Expressionismus ist Spielerei. Aber warum auch nicht? Alle ist heute Spielerei!” („Ekspresjonizm to gra. Ale właściwie, czemu nie? Dziś wszystko jest grą!"). W Nerwach, Fantomie i Tajemnicach duszy, podobnie jak Doktor Mabuse filmach zasadniczo realistycznych w stylu, za ekspresjonistyczne można uznać jedynie pewne sekwencje (w Nerwach są to ekstradiegetyczna, alegoryczna sekwencja wstępna i partie ukazujące roztargane "nerwy" bohatera, w Fantomie - znakomita sekwencja "dnia chwiania się w posadach", kiedy na bohatera, który zdefraudował pieniądze swej ciotki, wydaje się walić cały świat, zaś w Tajemnicach duszy

${ }^{33}$ Barry Salt, From Caligari to Who?, "Sight \& Sound”, Spring 1992, vol. 48, no. 2, s. 119-123; Barry Salt, Styl $i$ technologia filmu. Historia $i$ analiza, przeł. Alicja Helman, PWSFTviT, Łódź 2003, t. 2, s. 130-131. 
oniryczne partie ukazujące we Freudowskim kluczu symbolicznym koszmary psychoanalitycznie leczonego bohatera). Efekt ekspresjonistycznego designu obrazu został tam osiągnięty - bardziej zresztą niż na poziomie scenografii - technikami à la francuski impresjonizm: zdjęciami nakładanymi, montażem i pracą kamery. Wreszcie w Golemie, Zmęczonej Śmierci i Nibelungach charakter dekoracji czy zasada stylizacyjna płaszczyzn, sprawiająca, że postać wtapia się $w$ tło o tej samej fakturze czy ornamencie, wywodzą się mniej z ekspresjonizmu niż np. z praskiej, wiedeńskiej albo monachijskiej secesji (Jugendstil) ${ }^{34}$, gotyku, romantyzmu albo ornamentyki Orientu.

Najbardziej chyba modelowym obok Caligariego filmem ekspresjonizmu jest Od poranka do pótnocy, zrealizowana przez teatralnego reżysera Karlheinza Martina ekranizacja sztuki Georga Kaisera - też zresztą paradygmatycznej dla ekspresjonistycznego teatru. Martin historię kasjera, który ucieka ze skradzioną z banku wielką gotówką ${ }^{35}$, opowiedział, sytuując aktorów w scenografii ostentacyjnie dwuwymiarowej i umownej (pod tym względem to film może radykalniejszy nawet od Caligariego): wszystkie „plenery zewnętrzne” (ulica przed bankiem, wejście do hotelu, dom bohatera, dworzec etc.) są naszkicowane kilkoma oślepiająco białymi liniami, wręcz rozmyślnie unikającymi wiarygodnej sugestii głębi. Scenerię tę spowija czerń atelierowej przestrzeni, z której wyłaniają się i w której znikają postacie, z ich nierealistycznym, ekspresyjnym makijażem też jawiące się bardziej widmami niż ludźmi. Czerń ta tworzy oślepiający kontrast z białymi konturami miejsc i przedmiotów w scenografii i zdaje się korespondować z mrokiem (moralnym) przedstawionego świata. Plastyczną konsekwencję filmu Martina rozbija nieco słynna, omawiana przez Lotte Eisner w Ekranie demonicznym, sekwencja "Sześciodniowego wyścigu". Mordercze zmagania kolarzy o ufundowaną ze skradzionych pieniędzy wielką nagrodę zostały sfilmowane przy pomocy interesujących trików optycznych, dających ekspresjonistyczny efekt "pędu” zawodników poprzez „rozciąganie” i „ścieśnianie” obrazu. Aktorstwo, a szczególnie nerwowa, nadekspresyjna gra Ernsta Deutscha w roli kasjera-defraudanta, wydaje się kwintesencją aktorstwa ekspresjonistycznego w może jeszcze większym stopniu niż kreacje Kraussa i Veidta w Caligarim. Ten znakomity, od Caligariego artystycznie znacznie ciekawszy, film pozostaje jednak

${ }^{34}$ Thomas Elsaesser właśnie z secesją (Jugendstil), a nie z ekspresjonizmem, wiąże $\mathrm{w}$ dużej mierze rodowód estetyki obrazu w filmach Fritza Langa (por.: T. Elsaesser, Weimar Cinema and After, s. 187).

${ }^{35}$ Marzenie o szybko zdobytej wielkiej forsie jest charakterystyczne dla lat inflacji vide: inne niemieckie filmy tych lat, jak: Doktor Mabuse, gracz Langa, Fantom Murnaua czy Zatracona uliczka Pabsta. 
niezasłużenie mało znany. Wpływ na to miał fakt, iż w epoce swego powstania nie znalazł on w Niemczech dystrybutora. Cieszył się jednak powodzeniem... w Japonii, gdzie też ocalała jedyna kopia, która stała się bazą współczesnej cyfrowej rekonstrukcji i znakomitej edycji DVD, przygotowanej przez Filmmuseum w Monachium ${ }^{36}$.

Barry Salt słusznie zauważa, że $\mathrm{w}$ historiach filmu za stylistyczne wyróżniki filmowego ekspresjonizmu uznano - prócz istotnie przejętych z ekspresjonistycznego malarstwa i teatru - także środki wyrazu wypracowane przez kino w różnych kinematografiach (amerykańskiej, francuskiej, duńskiej, niemieckiej) przed Caligarim i będące „powszechną" własnością światowego kina: zdjęcia w niskim kluczu, szczególne ustawienia kamery pod „ekspresywnymi” kątami, zastosowanie „groźnych” cieni, podwójną ekspozycję, czyli tzw. zdjęcia nakładane. Takie środki stylistyczne można jednak było stosować $w$ dziełach sfilmowanych i rozgrywających się w zwykłej, naturalistycznie pojętej scenerii, zupełnie pozbawionej cech ekspresjonistycznego designu. Nie najmniej ważnym atrybutem niewłaściwie, zdaniem Salta, pojętego ekspresjonizmu filmowego była nadprzyrodzona, fantastyczna tematyka o gotycystyczno-romantycznych korzeniach (co umożliwiło uznanie za ekspresjonistyczne - wcześniejszych od Caligariego - Märchenfilme ze Studentem z Pragi na czele). Tym samym kryteria stylistyczne, wzięte istotnie $\mathrm{z}$ ekspresjonizmu w sztukach pięknych $\mathrm{i}$ teatrze, zostały przemieszane z nieswoistymi dla tego stylu (dla tych, jak zdjęcia w niskim kluczu, cienie, ustawienia kamery etc., Salt proponuje nazwę „ekspresywizmu”), a co gorsza, także z kryteriami zupełnie nieformalnymi, o charakterze tematycznym ${ }^{37}$.

Trzeba przyznać, że pojęciowy rygoryzm Salta, choć może wydawać się dogmatyczny, porządkuje refleksję nad kinem weimarskim, w której pojęcie „ekspresjonizmu” zaczęło się znaczeniowo rozmywać, a jego mechaniczne stosowanie uniewrażliwiało widzów, krytyków i filmoznawców na fakt, iż nie jest zasadne określanie jednym słowem tak kompletnie odmiennych stylistycznie filmów, jak z jednej strony całkowicie atelierowy, ostentacyjnie sztuczny i plastycznie wymyślny Caligari, a z drugiej zrealizowany wyłącznie $w$ plenerze i realistycznie pojętych wnętrzach, operujący przede wszystkim światłem, a nie dekoracją Nosferatu. Nosferatu Murnaua z całą pewnością nie ma nic wspólnego na poziomie plastyki kadru z ekspresjonistycznym designem filmów Roberta Wiene bądź stylistyką znaną nam z obrazów Kokoschki, Kirchnera czy Noldego.

${ }^{36}$ Karlheinz Martin, Von Morgens bis Mitternachts, Seria Edition Filmmuseum, No. 55, Filmmuseum München-National Film Center Tokyo-Goethe-Institut München-Bonner Kinemathek Bonn 2010.

37 B. Salt, From Caligari to Who?, passim; B. Salt, Styl i technologia filmu, t. 2, s. 129-133. 
Oczywiście, „ekspresjonizm” można pojmować mniej lub bardziej szeroko. Salt proponuje stosowanie tego pojęcia wąsko, w odniesieniu do zjawiska, które wypadałoby nazwać „ekspresjonizmem sensu stricto", a które można by też określić jako „ekspresjonizm caligaryczny” czy też "caligaryzm". Pierwszym filmem tak pojętego ekspresjonizmu byłby oczywiście Caligari, ostatnim - Gabinet figur woskowych lub, ewentualnie, Metropolis. Ramami czasowymi kierunku byłyby lata 1919-1924 (w przypadku uznania za film ekspresjonistyczny Metropolis, 1919-1926). Jeśli rozszerzyć pojęcie „niemieckiego ekspresjonizmu filmowego" na filmy także z fantastyczno-niesamowitą tematyka, o romantycznym rodowodzie, ewentualnie realistyczne w temacie, ale posługujące się „,ekspresywistycznymi" w sensie Saltowskim środkami stylistycznymi (głównie cieniami i zdjęciami w niskim kluczu), okres panowania nurtu w kinie niemieckim wydłużyłby się na całe dwudziestolecie 1913-1933. Pierwszym filmem tak szeroko pojętego kierunku byłby Student z Pragi, ostatnim - chyba Testament doktora Mabuse (Das Testament des Dr. Mabuse, 1933, Fritz Lang). Rzecz jasna, to ogólniejsze rozumienie ekspresjonizmu kazałoby włączyć w jego obręb także np. filmy zaliczane do Neue Sachlichkeit. Oczywiście, ekspresywistyczne atrybuty stylistyczne przestają być cechami filmów wyłącznie niemieckich, toteż historycy kina nierzadko mówią o „ekspresjonistycznym stylu", np. horrorów Universalu z lat 20. i 30. albo dzieł należących do film noir (co można by usprawiedliwić wkładem w te zjawiska emigrantów z Niemiec). Jeszcze dalej jednak ekspresywistyczne środki stylistyczne odnajdziemy po II wojnie światowej, m.in. w filmach Carola Reeda czy wczesnych filmach Andrzeja Wajdy, których styl także określano jako „ekspresjonizm”. Kategoria ekspresjonizmu tym samym zdaje się na dobre oddzielać od ściśle określonego nurtu w historii sztuki, zwłaszcza niemieckiej, panującego mniej więcej w latach 1905-1924, który w latach 1919-1924 zamanifestował się także w filmie fabularnym szczególnym designem dekoracji. Ekspresjonizm tak szeroko pojęty jest już tym, co Alicja Helman określiła jako kategorię „multiperiodycznie powracającą", czymś w ogóle nieswoistym dla sztuki (filmu) pewnego okresu w kulturze Niemiec.

Przyznam, że sam, wraz z rosnącą znajomością kina weimarskiego, dzięki licznym odrestaurowanym kopiom i płytowym edycjom filmów, jestem zwolennikiem stosowania raczej wąskiego zakresu pojęcia „ekspresjonizm”, choć rozszerzyłbym listę filmów uznanych przez Salta za ekspresjonistyczne o te, które podałem wyżej. Dodać można jeszcze filmy wymienione przez Kristin Thompson i Davida Bordwella w ich popularnym podręczniku Film History: An Introduction (podają oni ok. 25 tytułów, zajmując stanowisko „pośrednie” pomiędzy Saltowskim a „panekspresjonistyczną" postawą takich autorów, jak Lotte H. Eisner czy John 
D. Barlow $)^{38}$. Para amerykańskich neoformalistów uznaje za reprezentujące ekspresjonizm niemiecki także takie filmy, jak: Algol (1920, Hans Werckmeister), Dom na Księżycu (Das Haus zum Mond, 1921, Karlheinz Martin), Skarb (Der Schatz, 1923, Georg Wilhelm Pabst), Duch ziemi (Erdgeist, 1922, Leopold Jessner), Kamienny jeździec (Der steinerne Reiter, 1922, Fritz Wendhausen), Kronika z Grieshuus (Die Chronik von Grieshuus, 1925, Arthur von Gerlach) ${ }^{39}$.

Cechy stylistyczne, określające differentia specifica niemieckiego ekspresjonizmu filmowego, znajdują się przede wszystkim w obrębie mise-en-scène, podczas gdy atrybutów stanowiących o specyfice szkoły sowieckiej i francuskiego impresjonizmu należy upatrywać w obszarze montażu, a w przypadku impresjonizmu - także pracy kamery. Zgodnie ze zdaniem wypowiedzianym przez współscenografa Caligariego, Hermanna Warma, a przytoczonym przez Rudolfa Kurtza w pierwszej monografii kierunku: „Obraz filmowy ma być przede wszystkim sztuką graficzną" 40 - filmy ekspresjonistyczne dbały szczególnie o kompozycję pojedynczego kadru. Budowano więc kadr jako autonomiczny, plastycznie wyrafinowany i kompozycyjnie zamknięty obraz, niespecjalnie troszcząc się ani o jego narracyjną funkcjonalność wobec fabuły, ani o wiarygodność diegezy na poziomie fizykalnym (fundamentalne atrybuty stylu klasycznego). Postacie w takich filmach, jak Caligari, Od poranka do pótnocy czy Faust żyją i poruszają się nie w jakimś wiarygodnym, trójwymiarowym świecie przedstawionym, ale jakby pośród dziwacznej, teatralnej dekoracji, ograniczającej trajektorie ich ruchów (Cezar uchodzi z porwaną Jane, Caligari ucieka przed Francisem, a Faust z Mefistem umykają po zabójstwie Walentego tą właśnie, a nie inną ścieżką, bo scenografia nie daje im innej szansy: reszta świata i „dróg ucieczki” namalowana jest na płótnie, zresztą w sposób wyłącznie „ekspresyjny”, nie kreując wiarygodnej iluzji perspektywy). Film fabularny - a filmy ekspresjonistyczne to przecież filmy fabularne - nie może być jednak sztuką wyłącznie malarską, choćby z racji swej procesualności i progresji akcji fabularnej. Toteż w miarę tej progresji i ruchu aktorów w kadrze - zauważają Thompson i Bordwell-kompozycje graficzne rozpadają się. Akcja przebiega w nagłych „,zrywach” i „zatrzymaniach”, a opowieść jakby "przystaje” czy toczy się wolniej w chwilach, kiedy mise-en-scène zastyga w przykuwające oko kompozycje. Nie oznacza to, że owe kompozycje muszą być statyczne. Wręcz przeciwnie, pewna dynamika aktorstwa, często przestylizowanego w gestach i choreografii

${ }^{38}$ L. H. Eisner, Ekran demoniczny; John D. Barlow, German Expressionist Film, Twayne Publishers, Boston 1982.

${ }^{39}$ K. Thompson, D. Bordwell, op. cit., s. 109-115.

40 Rudolf Kurtz, Expressionismus und Film, Hans Rohr, Zürich 1965, s. 66 [prwdr. 1926]. 
ruchu, może dynamizować kadr, współgrając z „ekspresyjną” dynamiką zygzaków, linii krzywych i ukośnych, charakterystycznych dla ekspresjonistycznego designu. Inna sprawa, że na dzisiejszym widzu aktorstwo to może sprawiać wrażenie nieznośnie teatralnego ${ }^{41}$.

Charakterystyczne dla ekspresjonizmu jest stopienie aktorów ze scenografia, wskutek czego dochodzi zarazem do swoistej animizacji dekoracji (domy zdają się mieć oczy, drzewa jawią się jako złowrogie istoty) i urzeczowienia bohaterów w dekoracjach, ich "zamierania”. Postacie i sceneria mogą mieć np. taką samą fakturę - i ożywiony w Golemie przez rabiego Löwe potwór, i domy średniowiecznego praskiego getta zdają się tak samo ulepione z gliny. Postacie zlewają się z tłem np. wskutek tego, iż ich kostium pokrywają takie same wzory geometryczne, jak otaczającą je scenerię: Jane w Caligarim ma na sukience takie same zakrzywione linie jak deseń ścian wokół niej, a w Nibelungach w sekwencjach przedstawiających stolicę państwa Burgundów, Wormację, stroje, tarcze, obiekty (statek Guntera, szkatułka Krymhildy) mają takie same geometryczne desenie, jak architektura wnętrz - romby, zygzaki, łamane linie, ostre kąty ${ }^{42}$. W tymże filmie, w słynnej scenie kłótni królowych na stopniach katedry, one same i ich orszaki przypominają figury szachowe: białe (orszak Krymhildy) i czarne (orszak Brunhildy). Postacie - szczególnie w filmach Fritza Langa - tworzą nierzadko "ornament z mas", efektownie skomponowane z ludzkich tłumów, fascynujące plastycznie abstrakcyjne układy sfilmowane w planach ogólnych. Nie jest to, zdaniem Kracauera i Eisner, niewinne znaczeniowo, bo degraduje ludzi do przedmiotów ${ }^{43}$ (przywołajmy choćby "żywy most pontonowy" z trzymających tarcze nad głowami i stojących po pas w wodzie rycerzy, po którym schodzą ze statku na ląd Brunhilda i Gunter w Nibelungach). Tworzenie "ornamentu z mas" świadczyć ma o ambiwalencji wymowy filmów niemieckich, zdając się potwierdzać tezę Kracauera o niemieckiej „osobowości autorytarnej z kompleksem sado-masochistycznym”. Najlepiej unaocznia to pamiętna scena z Metropolis: podczas powodzi w Mieście Robotników postacie (głównie dzieci) biegną nie w górę, jak nakazywałaby logika ucieczki przed zalewającą woda, ale w dól, by skupić się wokół walącej w gong charyzmatycznej wybawczyni, Marii, i stworzyć wraz z nią kompozycję tym bardziej malownicza, że zalewa je wzburzona woda. Dopiero gdy kamera pokontempluje tę grupę, wyrażającą pragnienie masy podporządkowania się autorytetowi i jej

${ }^{41}$ Por.: K. Thompson, D. Bordwell, op. cit., s. 111-112.

${ }^{42}$ Ibidem, s. 112-113.

${ }^{43}$ Por.: S. Kracauer, op. cit., s. 84; Lotte H. Eisner, Fritz Lang, Da Capo Press, New York 1986, s. 70, 73. 
bezradność w stanie chaosu, który dopiero autorytet zorganizuje, postacie rzucają się do ucieczki w górę, ratując się przed wzbierającą wodą.

Obiegowe sądy o ekspresjonizmie filmowym dopatrują się w zabiegach prestylizacyjnych (termin Erwina Panofsky'ego), wpływających na deformację świata przedstawionego, zasadniczej cechy kierunku - subiektywizacji świata, odzwierciedlania przez diegezę „ekspresji duszy”. Takie postrzeganie kierunku ma uzasadnienie w etymologii nazwy oraz $\mathrm{w}$ tradycji literackiego i malarskiego ekspresjonizmu, gdzie istotnie celem była często ekspresja rozmaitych podmiotów - autora, narratora, postaci przedstawionych. Zdaje się też je wspierać wypowiedź Conrada Veidta, odtwórcy roli Cezara w Caligarim i Iwana Groźnego w Gabinecie figur woskowych: "Jeśli dekorację pojęto jako posiadająca ten sam stan duchowy, jak ten, który rządzi umysłem postaci, aktor odnajdzie $\mathrm{w}$ tej dekoracji wartościową pomoc w skomponowaniu i przeżyciu swej roli. Stopi się on z przedstawionym otoczeniem i oboje poruszać się będą $\mathrm{w}$ tym samym rytmie" $^{\prime 4}$. Sądzę jednak, iż nie jest uzasadnione uznawanie subiektywizacji za zasadniczy powód ekspresjonistycznej deformacji w filmie niemieckim (na subiektywizację, w aspekcie oddawania zarówno podmiotowej percepcji, jak i świata wewnętrznego postaci, nastawiony był francuski impresjonizm filmowy). Nawet w Gabinecie doktora Caligari fakt, iż wewnątrzramowa historia jest "opowieścią wariata”, jest zbyt słabą motywacją dla totalnego zniekształcenia diegezy - tym bardziej, że podobna stylistycznie deformacja rządzi dekoracją w ramie zewnętrznej, gdzie "władcą dyskursu" nie jest już Francis-wariat, lecz Caligari-naukowy autorytet (lub autor). Zresztą inne filmy ekspresjonistyczne nie mają już takiego pretekstu konstrukcyjnego, jak film Roberta Wiene. Motywacją dla ekspresjonistycznego designu (ale także dla ekspresywistycznych rozwiązań, takich jak oświetlenie, cienie, niskie lub wysokie albo pod dziwnymi kątami ustawienia kamery) może być po prostu kreacja tego, co Niemcy nazywają Stimmung: aury, nastroju, niesamowitej atmosfery. Stąd np. predylekcja do pokazywania w filmach klatek schodowych, przestrzeni pośredniej, niebezpiecznej, na zewnątrz mieszkania, gdzie może czaić się das Unheimliche - i gdzie układ schodów, efekt światłocienia i „ekspresywnie” usytuowana kamera mogą tworzyć sugestywne efekty. Pretekstem dla ekspresjonistycznego designu i/lub ekspresywnych środków wyrazu bywały też w filmach weimarskich tematyka fantastyczna (Algol, Metropolis, Kobieta na Księżycu, 1929, Fritz Lang), aura grozy (Genuine, Nosferatu), usytuowanie świata w odległej przeszłości, na ogół dość nieokreślonej lub zmitologizowanej (Golem, rama narracyjna i nowela wenecka w Zmęczonej Śmierci, Nibelungi, Skarb), wreszcie egzotyczne tło akcji (Dzika kotka, Die

${ }^{44}$ Cyt. za: K. Thompson, D. Bordwell, op. cit., s. 111-112. 
Bergkatze, 1921, Ernst Lubitsch; nowele arabska i chińska w Zmęczonej Śmierci, nowele arabska i rosyjska w Gabinecie figur woskowych). Wreszcie ekspresjonistyczny design, o czym już była mowa, mógł być zastosowany parodystycznie lub pastiszowo (Lalka, Dzika kotka, Doktor Mabuse, gracz). Wszystko to jednak nie ma nic wspólnego z subiektywizacją - jakoby główną motywacją ekspresjonistycznej stylistyki.

Owszem, zdarza się, iż w weimarskich filmach z pierwszej połowy lat 20. motywacją do ekspresjonistycznych efektów jest intencja oddania subiektywnych stanów postaci, jak ma to miejsce w przywołanych wyżej sekwencjach filmów Nerwy i Fantom. Sam jednak fakt, że posługują się one repertuarem rozwiązań wyrazowych nieswoistych dla ekspresjonizmu, typowych raczej dla stylistyki impresjonistycznej (zdjęcia nakładane, kalejdoskopowy montaż, ruchliwa kamera), świadczy, iż są raczej wyjątkiem niż regułą. Ich charakter gwałtownych sekwencji montażowych służy zresztą nie tylko subiektywizacji, ale i efektowi „wielkomiejskiej gorączki", nerwowego rytmu nowoczesnej epoki, oszołomienia człowieka wciągającą jak wir mechaniczną cywilizacją. Co czyni te sekwencje przejawem czegoś w rodzaju Nowej Rzeczowości avant la lettre.

\section{Kino niemieckie doby Nowej Rzeczowości}

Gdy już około roku 1924 ekspresjonizm zaczynał dogasać, w sztuce niemieckiej (w tym i w filmie) zapanowała aż do roku 1933 Neue Sachlichkeit. Termin ten, który najtrafniej oddaje po polsku nazwa „Nowa Rzeczowość”, został ukuty przez Gustawa Hartlauba, dyrektora Kunsthalle w Mannheim, na określenie stylu obrazów, charakteryzujących się „dotykalną rzeczywistością" i przedstawionych na tak zatytułowanej wystawie w połowie $1925 \mathrm{r}^{45}$ Fraza szybko się przyjęła jako nazwa nowego postekspresjonistycznego trendu. „Była to fraza, która zdawała się zawierać w pigułce ducha czasu, przywołując zarówno Gegenständlichkeit (przedmiotowość) berlińskich dadaistów, jak i Sachlichkeit (rzeczowość) przedwojennego Werkbundu, tę samą Sachlichkeit, którą wskazywano jako probierz dobrego dziennikarstwa Egona Erwina Kischa" ${ }^{46}$. Kracauer cytuje list Hartlauba, dookreślający pojęcie: „Wiązało się ono z powszechnym wówczas w Niemczech poczuciem rezygnacji i cynizmu po okresie wybujałych nadziei, które znalazły ujście w ekspresjonizmie. Cynizm i rezygnacja to negatywna strona Neue

${ }^{45}$ Por.: John Willett, Art E Politics in the Weimar Period: The New Sobriety 1917-1933, Pantheon Books, New York 1978, s. 111. Siegfried Kracauer (Od Caligariego do Hitlera, s. 140) umieszcza utworzenie terminu Neue Sachlichkeit w roku 1924.

${ }^{46}$ J. Willett, op. cit., s. 111. 
Sachlichkeit; pozytywna wyraża się w entuzjazmie dla bezpośredniej rzeczywistości wskutek pragnienia traktowania rzeczy całkowicie obiektywnie, na podstawie materialnej, bez obdarzania ich zaraz idealnymi implikacjami" ${ }^{47}$.

Charakterystyczne dla Neue Sachlichkeit są zwłaszcza tematy - pejzaż miejski, z jego ruchem, gorączkową krzątanina, ludźmi na tle architektury; portret i akt, ale nie naturalistyczne, tylko jakby "spotworniałe” w wyrazie, graniczące np. u Ottona Dixa, Georga Grosza czy Rudolfa Schlichtera z karykatura, albo niepokojąco udziwnione przez hiperrealistyczną "namacalność" czy "fotograficzność", jak u Christiana Schada czy Ottona Griebla; obrazy półświatka - knajp, kabaretów, tingel-tangli, domów publicznych; sport i rozmaite rozrywki. Technika i styl sztuki Nowej Rzeczowości były rozmaite-od olejów zbliżonych kolorytem, faktura, linią do ekspresjonizmu, przez delikatne akwarele, wyrafinowane technicznie hiperrealistyczne oleje, po kolaże i fotomontaże. W literaturze manifestem Nowej Rzeczowości stała się powieść Alfreda Döblina Berlin Alexanderplatz (1929), sfilmowana w roku 1931 przez lewicowego reżysera Piela Jutziego. Wyróżnikiem tej sztuki jest też dystans emocjonalny, chłodna, beznamiętna obserwacja, czasem coś w rodzaju ironii wobec niewątpliwej brzydoty czy ohydy obiektu, a nawet odczucie samobójczej Schadenfreude z apokaliptycznej wizji „,ducha czasu". Obrazy tego nurtu byłyby idealnymi ilustracjami Witkacowskiego Pożegnania jesieni czy Nienasycenia.

W drugiej połowie lat 20. Nowa Rzeczowość znalazła wyraz także w kinie niemieckim. Kracauer, opierając się na atrybutach wskazanych przez Hartlauba, skrytykował jakąś fundamentalną dwuznaczność tej estetyki, na pozór bezstronnej i obiektywnej: „Innymi słowy, Nowa Rzeczowość oznacza stan paraliżu. Cynizm, rezygnacja, pozbawienie złudzeń: tendencje te wskazują na mentalność nieskłonną do zaangażowania w jakimkolwiek kierunku. Główną cechą Nowej Rzeczowości jest niechęć do zadawania pytań, do zajmowania stanowiska. Rzeczywistość portretowano nie tak, by fakty ujawniały swe implikacje, ale by utopić wszystkie implikacje w oceanie faktów, jak w Kulturfilme Ufy" ${ }^{48}$.

Wzmiankowane tu Kulturfilme to realizowane przez Ufe od roku 1924 dokumentalne, zarówno krótko-, jak i pełnometrażowe filmy, których zadaniem była popularyzacja wiedzy czy propagowanie pewnych idei (można więc powiedzieć, że Ufa była jednym z pierwszych w świecie producentów filmu oświatowego). Cieszyły się one powodzeniem w kraju i na świecie, będąc istotnym towarem eksportowym kina niemieckie$\mathrm{go}^{49}$. Do najsłynniejszych należą pełnometrażowe dokumenty Drogi do siły

\footnotetext{
${ }^{47}$ S. Kracauer, op. cit., s. 140 (przekład zmieniony po konfrontacji z oryginałem).

${ }^{48}$ Ibidem, s. 140-141 (przekład zmieniony po konfrontacji z oryginałem).

${ }^{49}$ Nt. Kulturfilme zob. np.: S. Kracauer, op. cit., s. 121-122.
} 
i piękna (Wege zu Kraft und Schönheit - Ein Film über moderne Körperkultur, 1925, Wilhelm Prager) i Cud stworzenia (Wunder der Schöpfung, 1925, Hanns Walter Kornblum). Pierwszy z nich propaguje sport i ćwiczenia fizyczne, lansując antyczny model piękna, co zresztą stwarza pretekst do licznych kadrów z nagimi modelami i atletami, ucieleśniającymi pogańskie ideały (odwoła się do nich kult tężyzny fizycznej w estetyce Trzeciej Rzeszy, vide: prologi do obu części Olimpiady, 1938, Leni Riefenstahl). Drugi próbuje przedstawić w atrakcyjnej formie (podróży poprzez Mleczną Drogę statku kosmicznego) całość naukowej wiedzy z lat 20. o miejscu człowieka we wszechświecie. W realizację tego projektu, kombinującego specjalnie nakręcone materiały dokumentalne, dokumenty historyczne, elementy fikcjonalne, scenki animowane i oświatowy tekst, zaanagażowanych było czterech uniwersyteckich uczonych, piętnastu ekspertów od efektów specjalnych i dziewięciu operatorów. Ciekawe skądinąd, że wydźwięk tego edukacyjnego filmu wcale nie był optymistyczny - zapowiadał w apokaliptycznej tonacji zagładę rodzaju ludzkiego, wynikłą z praw fizyki $\mathrm{i}$ astronomii.

Kulturfilm mógł mieć także postać filmu fabularnego, jak słynne Tajemnice duszy (1926) Georga Wilhelma Pabsta. Dzieło to powstało przy współpracy Karla Abrahama i Hannsa Sachsa, uczniów Freuda, do których zwrócił się Hans Neumann, odpowiedzialny w Ufie za Kulturfilme, z prośbą o przedstawienie procesu psychoanalitycznej terapii, ujawniającej nieświadomość marzeń sennych pacjenta. Werner Krauss wcielił się tu w mężczyznę dręczonego przez irracjonalny lęk przed nożem i przymus zabicia żony. Doprowadzony na krawędź obłędu przez senne koszmary (zwizualizowane przez dekoracje Ernö Metznera i zdjęcia Guido Seebera, w fascynującym wizualnie stopie estetyk ekspresjonizmu i surrealizmu) zostaje w końcu wyleczony przez psychoanalityka.

Formułą gatunkowa bardziej niż Kulturfilm odpowiednią dla ",topienia znaczeń w oceanie faktów", okazał się f i l m m on t a ż o w y, ukazujący świat w szybko zmieniających się przed oczami widza kalejdoskopowych obrazach. Filmem fabularnym, bliskim takiej formule filmu „przekrojowego", są Przygody dziesięciomarkowego banknotu (K 13513: Die Abenteuer eines Zehnmarkscheines, 1927) Bertholda Viertla, historia wędrującego z rąk do rąk pieniądza, a paradygmatyczny jest tu Berlin, symfonia wielkiego miasta (Berlin, die Sinfonie der Großstadt, 1927) Waltera Ruttmanna, efektowny film montażowy, przedstawiający jeden syntetyczny dzień z życia niemieckiej stolicy. Strategia ta odzwierciedliła się także w filmach fabularnych o luźnej strukturze dramaturgicznej, choć niewolnych (wbrew opiniom Kracauera) od np. ambicji socjologicznych. Przykładem są Ludzie w niedziele (Menschen am Sonntag, 1929, Robert Siodmak i Edgar Ulmer), zrealizowana $\mathrm{w}$ paradokumentalnym stylu, z lekka tylko fabularyzowana 
opowieść o niedzieli czworga młodych berlińczyków, czy, z okresu już dźwiękowego, znakomity od strony estetycznej, ale irytujący marksistowską deklaratywnością ideologiczną film według scenariusza Bertolta Brechta Kuhle Wampe, albo do kogo należy świat? (Kuhle Wampe, oder: Wem gehört die Welt?, 1932, Slatan Dudow). Odpowiednikiem zaś filmowym tematyki wielkomiejskiej, ulicznej, półświatkowej, obecnej w malarstwie Neue Sachlichkeit, stały się Straßenfilme - „filmy uliczne”, zapoczątkowane przez słynną Ulice (Die Straße, 1923) Karla Grune. Opowiadała ona o eskapadzie "na miasto” znudzonego codzienną egzystencją mieszczucha, której niewiele brakowało, by skończyła się źle: bohater, wrobiony przez półświatkowych zbirów w morderstwo, będące ich dziełem, zostaje aresztowany i o mało nie popełnia samobójstwa.

Najwybitniejszym twórcą "filmów ulicznych" w latach 20. był Georg Wilhelm Pabst, twórca takich utworów, jak Zatracona uliczka (Die freudlose Gasse, 1925), Miłość Joanny Ney (Die Liebe der Jeanne Ney, 1927), Kryzys (Abwege, 1928), Puszka Pandory (Die Büchse der Pandora, 1929), Dziennik upadłej dziewczyny (Tagebuch einer Verlorenen, 1929). Szczególnie ciekawa jest Zatracona uliczka, posępny obraz Wiednia lat inflacji (dotknęła ona także Austrię). Królem tytułowej uliczki jest rzeźnik, żądający od głodnych zdesperowanych kobiet seksualnych gratyfikacji w zamian za mięso, po które nieustannie ustawia się kolejka (to, iż głodowe kolejki stoją nie po chleb, a właśnie po mięso, podkreśla drapieżność ludzi w latach inflacji). Ojciec Grety, jednej z bohaterek, traci rentę, ulokowawszy ją w chybionej spekulacji giełdowej, a ona sama o mało nie zostaje prostytutka, wpadając w szpony sąsiadki rzekomo prowadzącej salon mody, a faktycznie - dom publiczny. Na tak zarysowanym tle społecznym rozgrywała się prócz tego melodramatyczno-kryminalna historia Marii - mści się ona na swoim kochanku, rzucając nań podejrzenie o zbrodnię, którą sama popełniła: zabójstwo kobiety, z którą miał schadzkę. Znakomite kreacje stworzyły w tym mrocznym filmie skandynawskie gwiazdy, Greta Garbo i Asta Nielsen, a demonicznego rzeźnika zagrał Werner Krauss, aktor wszechstronny i o zadziwiającej zdolności fizycznej metamorfozy - tu zupełnie nie przypominał ani Caligariego, ani Natana Mędrca z filmu Manfreda Noa, ani Orgona z Murnauowskiego Świętoszka. Pabst miał w ogóle szczęśliwą rękę do aktorów - Brigitte Helm, znana z podwójnej roli prawdziwej i fałszywej Marii w Metropolis Langa, stworzyła w Kryzysie doskonałą kreację niespełnionej w życiu małżeńskim kobiety, która za namową przyjaciółki najpierw rzuca się w wir szalonego nocnego Berlina lat 20., później zaś zamierza porzucić przyziemnego męża, ale wybranek, z którym miała rozpocząć nowe życie, nie stawia się na pociąg, jaki miał ich wywieźć za granicę... Największym jednak aktorskim odkryciem Pabsta jest Amerykanka Louise Brooks, pełna seksapilu i wdzięku, obcięta krótko „na 
chłopczycę" dziewczyna epoki charlestona. Zagrała ona przynoszącą pecha kochającym ją osobom (nie tylko mężczyznom) Lulu z Puszki Pandory, mistrzowskiej adaptacji dyptyku dramatycznego Franka Wedekinda, oraz uwiedzioną jako nieletnia, skazaną na poprawczak, skąd zbiegła, rzuconą przez los do domu publicznego i szczęśliwie z niego wydobytą przez bogatego arystokratę, Thymian z Dziennika upadłej dziewczyny.

Louise Brooks nie była jedyną Amerykanka, która zabłysła w niemieckich "filmach ulicznych" tamtej epoki. Gwiazdą Asfaltu (Asphalt, 1929), filmu dziś na nowo odkrytego jako jedno z arcydzieł kina weimarskiego, jest Betty Amann. Wcieliła się w nim w ponętną utrzymankę uwikłanego $\mathrm{w}$ podejrzane interesy dyplomaty. Złapana na kradzieży brylantu w sklepie jubilerskim unika aresztowania, usidlając eskortującego ją policjanta (Gustav Fröhlich) tak, iż ten traci dla niej głowę i zabija w bójce rywala... Asfalt to melodramat, kryminał i komedia zarazem, a jednocześnie pełna celnych obserwacji refleksja nad autorytetem władzy i kultem munduru (tu: policjanta) w niemieckim społeczeństwie. Najbardziej pamiętną partią filmu jest kilkunastominutowy początek, kiedy bohaterem wydaje się tytułowy asfalt - nawierzchnia, po której pędzą w rozmaite strony sznury samochodów, którą depczą niezliczeni przechodnie, na której po deszczu odbijają się w kałużach światła pojazdów i neony reklam. Sekwencję tę, wizualnie efektowną i dynamiczna, zrealizowaną całkowicie w studio, a nie $\mathrm{w}$ rzeczywistym plenerze, można uznać za swego rodzaju kwintesencję estetyki Neue Sachlichkeit.

Fenomenem charakterystycznym dla tego okresu są też Zillefilme, „filmy Zille'owski e”, zwane tak od nazwiska Heinricha Zille, artysty, który w swych rysunkach, grafikach i obrazach portretował proletariacki Berlin, z jego brzydkimi, ale malowniczymi ulicami i zaułkami, nędza, charakterystycznymi typami ludzkimi. Jak dzieła Zillego, filmy te pokazywały stolicę Niemiec "od podszewki”, a ich fabuły opowiadały o dolach i niedolach berlińskiej biedoty ${ }^{50}$. Powstawały one od około 1925 r., a ich estetykę - oczywiście z przesunięciem akcentów ideowych - kontynuowano nawet w okresie Trzeciej Rzeszy (np. w osławionym, ale skądinąd artystycznie interesującym filmie Hansa Steinhoffa Hitlerjunge Quex, 1933). W okresie niemym najwybitniejszy w tej grupie jest powstały w oparciu o fabularny pomysł Zillego film Podróż Matki Krause do szczęścia (Mutter Krausens Fahrt ins Glück, 1929, Piel Jutzi), brutalnie naturalistyczny w opisie degeneracji proletariatu przez biedę i przestępczość, i iście antyczny w wymiarze tragicznym (bohaterka, głowa robotniczej rodziny, wyrusza w tytułową podróż, tj. popełnia samobójstwo, gdy scalany przez nią świat rodziny ostatecznie rozpada się).

${ }^{50}$ Nt. Zillefilme zob. np.: S. Kracauer, op. cit., s. 123-124, 167-168. 
Jak modelowym dziełem ekspresjonizmu jest Gabinet doktora Caligari, za film emblematyczny dla Nowej Rzeczowości uznałbym Szpiegów (Spione, 1928) Fritza Langa ${ }^{51}$. Jest to w twórczości tego reżysera kolejny, po Doktorze Mabuse, graczu (1922), film o superprzestępcy dezorganizującym współczesne życie (tym razem nie w Niemczech, a w nieokreślonym kraju Europy Zachodniej, noszącym znamiona zarówno Niemiec, jak Francji i Wielkiej Brytanii). Walkę z Haghim - tak zwie się ów superłotr - prowadzą zarówno "tubylcze" służby specjalne, jak i wywiad japoński, a sensacyjną intrygę komplikuje pełen dramatycznych zwrotów wątek miłości tajnego agenta Nr 326 (tylko tyle wiemy o jego tożsamości) i „nawróconej” eks-agentki Haghiego, Soni. Haghi i służby specjalne walczą ze sobą i inwigilują się nawzajem przy pomocy rozmaitych mediów i środków łączności (telefon, telegraf, mikrofony podsłuchowe, interkom, radio), wykorzystują nowoczesną technikę (daktyloskopia), a podstawową ich zdobyczą zdaje się informacja, uzyskiwana dzięki sieci wszechobecnych agentów, podsłuchom, kontroli rozmaitych instytucji (hotele, biura podróży) i pieczołowicie gromadzona w archiwach. Szpiegowska centrala Haghiego, której legalną fasadą jest jego bank, samym wystrojem architektonicznym wciela w życie rozsławiony przez Michela Foucault w książce Nadzorować i karać Benthamowski pomysł Panoptikonu, choć wizja panoptycznego nadzoru nad społeczeństwem wynika w tym filmie głównie z inwigilacyjnego użycia techniki i mediów (co antycypuje wizję George'a Orwella z Roku 1984). Narzędziami walki skonfliktowanych stron są też w filmie Langa pojazdy - motocykl, samochód, pociąg, samolot. Estetyczny kult maszyn i mediów czyni ze Szpiegów dzieło typowe dla zafascynowanej modernizmem Nowej Rzeczowości. Trzeba też dodać, że styl wielu partii filmu (często zestawiający ze sobą szybko montowane ujęcia, w których efektowne detale metonimicznie czy synekdochicznie określają ogólne stany rzeczy) ewokuje inną modernistyczną estetykę, która musiała go zainspirować - sowiecką szkołę montażu.

\section{Gatunki kina weimarskiego}

\section{Kammerspiel}

Niezależnie od swej estetyki, stricte ekspresjonistycznej bądź jedynie „ekspresywistycznej", ani Märchenfilme, ani opowieści niesamowite à la Caligari czy Nosferatu, romantyczno-gotycystycznej proweniencji, nie stanowiły zasadniczego genre'u kina weimarskiego. Za jeden z najważniejszych

51 Szczegółową analizę Szpiegów przedstawiam w rozdziale 4. Strategia pająka: „Szpiedzy", s. 335. 
artystycznie gatunków - ale też tylko za gatunek, a nie za jakąś odrębną tendencję stylistyczną przeciwstawną ekspresjonizmowi - wypada uznać Ka m mer s p i e $l^{52}$. Jego nazwa, którą można by przełożyć jako „dramat kameralny" (ewentualnie, biorąc pod uwagę wieloznaczność niemieckiego słowa Spiel jako „film kameralny"), z jednej strony wywodzi się od teatru Kammerspiele, otwartego w roku 1906 przez Maxa Reinhardta dla wystawiania kameralnych, intymnych sztuk dla niewielkiej widowni, z drugiej zaś odzwierciedla strukturę samych Kammerspielfilme. Są to bowiem utwory z niewielką liczbą postaci, rozgrywające się w ograniczonej przestrzeni (z przewagą akcji w jednym, co najwyżej dwóch miejscach), w dość ograniczonym odcinku czasu - choć nie realizują ściśle klasycystycznej zasady trzech jedności, to mocno się do niej zbliżają. Scenarzystą większości filmów, które są do dziś wymieniane jako czołowe osiągnięcia gatunku, jest Carl Mayer. Współtwórca Gabinetu doktora Caligari napisał scenariusze do takich dzieł, jak Arthura von Gerlacha Vanina (1922), Leopolda Jessnera Schody kuchenne (Hintertreppe, 1921) i Duch ziemi (Erdgeist, 1923), Lupu Picka Szyny (Scherben, 1921) i Sylwester (Sylvester, 1922) czy wreszcie Friedricha Wilhelma Murnaua Zamek Vogelöd (Schloß Vogelöd: Die Enthüllung eines Geheimnisses, 1921), Portier z hotelu Atlantic (Der letzte Mann, 1924) i Świętoszek (1925). Co ciekawe, filmy ze scenariuszami Mayera są niespotykanym $\mathrm{w}$ całej historii kina triumfem narracji czysto wizualnej, obywającej się bez słowa - w większości z nich napisy są dość oszczędne, a Sylwester, Szyny i Portier z hotelu Atlantic nie posiadają ich niemal wcale. Thompson i Bordwell za wybitne osiągnięcie Kammerspielu uznają też zrealizowany dla spółki Decla-Bioskop, a faktycznie dla Ufy, film duńskiego mistrza Carla Theodora Dreyera Michael (1924) ${ }^{53}$. Współautorką jego scenariusza (wraz z reżyserem) jest Thea von Harbou - obok Mayera z pewnością najwybitniejszy scenarzysta kina weimarskiego, m.in. większości weimarskich filmów Fritza Langa.

Kammerspielfilm przedstawia zazwyczaj kilka postaci o znamionach raczej "typu” niż „charakteru”, a zatem o cechach reprezentatywnych dla pewnej klasy osób czy też związanych z ich funkcją - rodzinna, społeczna, zawodową i, rzecz jasna, dramaturgiczną. W niektórych filmach (Schody kuchenne, Szyny, Sylwester, Portier z hotelu Atlantic) postaci nie mają imion, gdyż ważne jest tylko, że to dziewczyna, narzeczony, cichy

52 Najciekawsza, choć kontrowersyjną analizę Kammerspielfilme przedstawia Kracauer (Od Caligariego do Hitlera, s. 84-93). Nazywa on je "filmami o instynktach", a za faktycznego ich twórcę uważa scenarzystę, Carla Mayera - podobnie zresztą jak Elsaesser, który nieco rozszerza kanon gatunku o takie filmy, jak Genuine czy Vanina, omawiane jednak przez Kracauera w innych kontekstach niż Kammerspiel.

${ }^{53}$ K. Thompson, D. Bordwell, op. cit., s. 11-116. 
wielbiciel (Schody kuchenne), mąż, żona, matka (Sylwester), ojciec, córka, gość-uwodziciel (Szyny), stary portier, jego rodzina, sąsiedzi, przełożeni, koledzy z pracy i hotelowi goście (Portier z hotelu Atlantic). W innych filmach, które jak Vanina, Michael czy Świętoszek, są adaptacjami literatury, bohaterowie noszą wprawdzie zgodne z pierwowzorami imiona, ale i tak liczy się głównie ich funkcja w pełnym napięć układzie relacji: między ojcem-tyranem, córką i jej kochankiem-rewolucjonistą (Vanina), między żoną mężem i gościem (Świętoszek), między dziadkiem, wnukiem i dybiącą na majątek dziadka gospodynią (dodana przez Mayera współczesna rama narracyjna w Świętoszku) czy też między starym mistrzem (malarzem), jego uczniem (zarazem przybranym synem i być może kochankiem) a kochanką ucznia, rosyjską księżną (Michael).

W zamkniętym układzie kilku postaci wyłania się nagle sytuacja kryzysu: $w$ tytułową noc napięcie między - nienawidzącymi się i zadrosnymi o bohatera - żoną i matką sięga zenitu (Sylwester). Zazdrosny i impulsywny narzeczony wraca po dłuższej nieobecności, akurat kiedy bohaterka udała się z wizytą do mieszkającego w suterenie tego samego podwórka listonosza, nic zresztą nie wiedząc, iż jest on jej wielbicielem (Schody kuchenne). Dróżnik kolejowy dowiaduje się o uwiedzeniu swej córki przez gościa - będącego jego przełożonym inspektora (Szyny). Stary mistrz stopniowo odkrywa kolejne zdrady, które wobec niego popełnił hołubiony uczeń/syn/ukochany (Michael). Ku przerażeniu żony i rozsądnej służącej pan domu po powrocie z podróży wpada w dewocję, a co gorsza, szasta pieniędzmi pod wpływem przybierającego świątobliwe pozy cwanego oszusta (Świętoszek). W rezydencji, do której pewien arystokrata zaprosił gości na polowanie, gęstnieje atmosfera, gdy okazuje się, iż pod jednym dachem mają się znaleźć wdowa po zamordowanym niedawno człowieku (wraz z nowym mężem) i jej eks-szwagier, brat ofiary, któremu mimo braku dowodów opinia publiczna przypisuje ową zbrodnię (Zamek Vogelöd). Rozwiązanie kryzysu rzadko było pomyślne, a gdy nawet się zdarzało (jak w Świętoszku czy Zamku Vogelöd), to nie niwelowało mrocznej aury całości. W Świętoszku zresztą nie mogło być inne - wymyślił je przecież Molier, a poza tym zdemaskowanie Tartuffe'a wobec Orgona przez Elmirę zdarza się wewnątrz ramy narracyjnej, w "filmie w filmie”, który wnuk-aktor wyświetla swemu dziadkowi po to, by otworzyć mu oczy na obłudę i chciwość jego gospodyni. Rzecz jasna po takiej nauce oczy dziadka otwierają się, toteż i we współczesnej ramie następuje happy end. Z kolei w Zamku Vogelöd happy end można uzasadnić genologicznie - ta ponura psychodrama okazuje się na koniec kryminałem detektywistycznym à la Conan Doyle, a zdemaskowanie prawdziwego mordercy i wyjaśnienie zagadki jest typowym dla detective stories triumfem logiki i racjonalności. Dla mrocznej aury Kammerspielfilme naturalną konsekwencją wydają 
się jednak rozwiązania tragiczne. Zdesperowany pełną napięć atmosferą bohater Sylwestra popełnia samobójstwo o północy, akurat kiedy w lokalach i na ulicach ludzie świętują Nowy Rok, co tworzy gorzko-ironiczny kontrapunkt dla jego desperackiego czynu (podobnie jak przestrzeń rozbawionego miasta kontrastuje z klaustrofobicznym mieszkaniem). W Schodach kuchennych po krótkiej i gwałtownej walce listonosz zabija rywala, a zrozpaczona bohaterka rzuca się ze szczytu kamienicy w czeluść podwórka-studni, którego przestrzeni akcja nigdy nie opuszcza. Dróżnik w Szynach dusi uwodziciela, a po popełnieniu zbrodni nastawia semafor tak, by zatrzymać ekspres i oddaje się w ręce policji - z urwiska córka patrzy z obłędem w oczach na uwożący ojca pociąg. W Vaninie, według opowiadania z Kronik włoskich Stendhala, ojciec-tyran (domowy i polityczny) uniemożliwia ucieczkę córki z ukochanym-rebeliantem, a potem skazuje tego ostatniego na szubienicę. U jej stóp pada też martwa bohaterka, nie mogąc przeżyć śmierci kochanka. Wreszcie załamany zdradami, nielojalnością i cynizmem ukochanego Michaela mistrz w filmie Dreyera umiera, zapomniany i opuszczony, podczas gdy "syn" zabawia się z kochanka, na którą zresztą trwoni pieniądze ze sprzedaży przywłaszczonych sobie dzieł mistrza...

Wydaje się, iż zarówno „wyrobiona” widownia kina artystycznego, jak i niemiecka krytyka lat 20., miały predylekcję do tragicznych zakończeń, podobnie jak filmowa publiczność w przedrewolucyjnej Rosji w epoce królowania w filmie rosyjskim „,chanżonkowszczyzny”. Niekoniecznie jednak gust taki musiała podzielać widownia masowa. Toteż Portier $z$ hotelu Atlantic Murnaua, jeden z ostatnich, a zarazem najwybitniejszy Kammerspielfilm, posiada narzucony Mayerowi przez producenta, Ericha Pommera, happy end. Opowieść o starym portierze z luksusowego hotelu, zdegradowanego „z racji podeszłego wieku”, jak głosi uzasadnienie tej decyzji przez dyrekcję, do funkcji posługiwacza w toalecie, nie kończy się zatem rozpaczą i totalną apatią bliskiego śmierci bohatera. Wydawać się one mogły jedynym logicznym rozwiązaniem, gdy portier nie tylko utracił świetną $\mathrm{w}$ jego mniemaniu posadę i związany z nią uniform, ale także został zdemaskowany i skompromitowany jako nikt w oczach rodziny i sąsiadów, choć do tej pory jawił się im kimś (mundur portiera jest bowiem czymś w rodzaju Gombrowiczowskiej formy, jego „jaźnią odzwierciedloną", sposobem, w jaki widzi sam siebie w oczach innych). Napis wprowadzający do epilogu dystansuje jednak odbiorcę do "szczęśliwości” zakończenia („historia taka w prawdziwym życiu, niestety, się nie zdarza"), a sama jego zawartość, nieprawdopodobna fabularnie, po pierwsze, wydaje się parodią happy endu, po drugie, tym dotkliwiej unaocznia faktyczny tragizm i bezwyjściowość poprzedniego położenia bohatera. Zresztą jeśliby nawet epilog zamierzono w tonacji serio, po refleksji 
nie można uznać jego zawartości za „szczęśliwy koniec”. Szastający w restauracji "swego" hotelu odziedziczonymi w niespodziewanym spadku pieniędzmi eks-portier (czy też, co gorsza, eks-dziadek klozetowy), dla dyrekcji, pracowników i bogatej klienteli nadal jest n ik i m jako nieokrzesany parweniusz; tyle tylko, że dyrektor i przyjmujący sute napiwki kelnerzy traktują go teraz z ostentacyjną uniżonością, na ironiczne uśmieszki pozwalając sobie za jego plecami.

Film Murnaua okazał się przebojem, zwłaszcza eksportowym, podbijając, o dziwo, rynek amerykański - to właśnie po jego sukcesie Fox ściągnął do Hollywood Murnaua, a za ocean wyemigrował też jego genialny operator, Karl Freund. Z pewnością wpływ na ten sukces miał jednak nie rzekomy happy end, ale przejmująca, dzięki wielkiej roli Emila Janningsa, psychologiczna i socjologiczna prawda filmu oraz jego niezwykła forma (to może najwybitniejszy niemiecki film lat 20., obfitujących przecież $w$ arcydzieła). Nie ma tu wprawdzie designu rodem $z$ ekspresjonistycznego malarstwa, ale zdjęcia w niskim kluczu, rzucane na ściany klatki schodowej niepokojące cienie i udramatyzowane poprzez sugestywny ruch przedmioty (obrotowe drzwi hotelu, wahadłowe drzwi u wejścia w czeluść toalety) czynią z filmu Murnaua emblematyczne arcydzieło estetyki „ekspresywnej”. Ruchliwa, „wyzwolona” (entfesselte) kamera, poruszająca się w fantastycznych jazdach po hotelowym hallu czy wokół murów kamienicy, albo wirująca w pijackim zawrocie głowy (narracja próbująca oddać subiektywne stany upojonego alkoholem bohatera w zakresie zarówno percepcji, jak i jego marzeń) zachwyciła świat, podobnie jak znakomite efekty specjalne, łączące $w$ jednym kadrze zastawki oraz miniaturowe modele ludzi i pojazdów z dekoracjami naturalnej wielkości i zdjęciami aktorskimi. Zresztą to właśnie dzięki tym efektom ulica przed hotelem i wielkomiejska zabudowa wydają się bardziej monumentalne i "metropolitalne” niż gdyby sfilmowano po prostu berlińską ulicę. W zabiegach takich widać modernistyczne urzeczenie twórców wielkomiejską gorączką i ruchem, a zarazem zapowiedź zafascynowanej ulicą i wyrażonej w Straßenfilme estetyki Nowej Rzeczowości.

\section{Inne gatunki}

W pierwszej połowie lat 20., gdy inflacja umożliwiała szybką amortyzację kosztów filmów, ich eksport po konkurencyjnych cenach i wynajmowanie niemal za bezcen wielkich rzesz statystów dla kręcenia scen masowych w nowo wybudowanych i świetnie technicznie wyposażonych studiach, ważnym gatunkiem kina weimarskiego był fil m his to r y c zn y. 
Jednym z największych produkcyjnie przedsięwzięć genre'u, do czasu Metropolis Langa najwystawniejszym filmem Ufy, jest inne dzieło tego reżysera - Nibelungi (1924). Monumentalna, pięciogodzinna adaptacja Pieśni o Nibelungach, starogermańskiego eposu spisanego w średniowieczu i spopularyzowanego w epoce romantycznej, podzielona była na dwie dość autonomiczne fabularnie i zupełnie do siebie stylistycznie niepodobne części, wyświetlane na osobnych seansach: Zygfryd (Siegfried) i Zemsta Krymhildy (Kriemhilds Rache). Obiegowa opinia, rozpowszechniona przez krytyczną wobec Langa książkę Kracauera, głosi, iż film ten jest manifestacją niemieckiego nacjonalizmu, a co więcej, poprzez urzeczowienie postaci w ekspresyjnych dekoracjach, kreacje "ornamentu z mas", wykazuje on tendencję totalitarną i antycypuje masowe inscenizacje epoki nazistowskiej - np. w Triumfie woli (Triumph des Willens, 1934, Leni Riefenstahl $)^{54}$. Opinia ta wydaje się jednak niesprawiedliwa - epos Langa można uznać nie za wyraz, ale za demaskację totalitarnego systemu urzeczowiającego jednostkę. Bardziej zaś niż manifestacją nacjonalizmu (można by dopatrywać się go ewentualnie w afirmacji Treue, więzi plemiennej Burgundów-Nibelungów w Zemście Krymhildy) wydaje się on analizą opisanych przez René Girarda mechanizmów przemocy u podłoża wszelkich kultur (Zygfryd jako „kozioł ofiarny”, przechodzący z rąk do rąk skarb jako przyczyna powodującej kryzys rywalizacji) oraz wyrazem katastroficznych nastrojów epoki (zagłada germańskiego państwa przez hordy dzikich Hunów koresponduje z apokaliptyczną wizją Oswalda Spenglera w Zmierzchu Zachodu) $)^{55}$.

Nibelungi to jednak kulminacja i łabędzi śpiew weimarskiego filmu historycznego - premiera Zygfryda w lutym 1924 r. zbiegła się z zahamowaniem inflacji, wprowadzeniem twardej waluty i niemożnością dalszej realizacji tak wystawnych filmów. Nurt historycznych spektakli poprzedzających epos Langa jest jednak całkiem obfity, a wśród jego najwybitniejszych osiągnięć należy wymienić filmy emigranta z Rosji, Dymitra Buchowieckiego - Danton (1920), Otello (Othello, 1922) i Piotr Wielki (Peter der Große, 1923), wszystkie z Emilem Janningsem w rolach tytułowych, czy też Richarda Oswalda Lady Hamilton (1921), Lukrecja Borgia (Lucrezia Borgia, 1922), Don Carlos i Elżbieta (Carlos und Elisabeth, 1924).

Prawdziwą rewelacją jest odkrycie $w$ ostatnich latach $w$ archiwach moskiewskiego Gosfilmfondu kopii filmu Manfreda Noa Natan Mędrzec (Nathan der Weise, 1922), zrealizowanego dla spółki Bavaria-Filmhaus, wchodzącej w skład monachijskiego koncernu filmowego Emelka (MLK - Münchner Lichtspielkunst), kierowanej przez polskiego Żyda, Ericha

\footnotetext{
${ }^{54}$ Por.: S. Kracauer, op. cit., s. 81-84.

55 Odsyłam do analizy Nibelungów w rozdziale 2. Krew smoka: „Nibelungi”, s. 211.
} 
Wagowskiego. Film ten, odrestaurowany i wypuszczony w znakomitej edycji DVD przez monachijskie Filmmuseum, unaocznia, iż także poza Ufą i Berlinem powstawały filmy o niezwykłym rozmachu produkcyjnym i wysokim poziomie artystycznym. Swobodna i skomplikowana konstrukcyjnie (z retrospekcjami, symultanicznymi wątkami etc.) adaptacja dramatu Lessinga rozgrywa się na Bliskim Wschodzie w czasach krzyżowców i sułtana Saladyna, a tytułowa postać, zaznawszy w życiu wielu krzywd ze strony innowierców, jest mimo wszystko apostołem wzajemnej tolerancji i pokojowego współżycia wyznawców trzech wielkich religii: judaizmu, chrześcijaństwa i islamu. Film, entuzjastycznie przyjęty przez lewicowe i liberalne kręgi intelektualne w Berlinie, nie mógł być wyświetlany $\mathrm{w}$ miejscu swego powstania - Monachium, $\mathrm{z}$ racji protestów potężnych w Bawarii kręgów nacjonalistycznych, które uznały go za „prożydowską" propagandę (ciekawe, że z podobnych powodów nie dopuściła do jego pokazów także cenzura w... Warszawie). Tytułową rolę zagrał, jak zawsze znakomity i nie do poznania, Werner Krauss (nb. także Robespierre i Jago w filmach Buchowieckiego), a fakt, że wcielił się $\mathrm{w}$ żydowskiego mędrca w tej ponoć pro-semickiej propagandzie, nie przeszkodził mu później zagrać jednej z głównych ról w osławionym antysemickim filmie Veita Harlana Żyd Süss (1940). Manfred Noa zrealizował jeszcze dla Bavaria-Filmhaus dwuczęściową superprodukcję, która była najdroższym niemieckim filmem lat inflacji, wystawnością przewyższającym nawet Nibelungi: Helenę Trojańska (Helena, 1924). Mimo znakomitej recepcji po premierze i świetnych recenzji w USA (wpływowy magazyn „Variety” ocenił go wyżej niż eposy Griffitha), Helena Trojańska nie mogła z powodu utrudniającej eksport twardej Reichsmarki zwrócić ogromnych kosztów produkcji i przyczyniła się do plajty Bavaria-Filmhaus, spółki tak zasłużonej dla kinematografii weimarskiej ${ }^{56}$.

Na ideologicznych antypodach Natana Mędrca znajdują się wyprodukowane przez Ufę, prestiżowe i kosztowne, wypełniające powierzoną koncernowi u jego narodzin misję proniemieckiej propagandy, filmy "fryderycjańskie" - biograficzne filmy historyczne, będące peanami na cześć króla Prus, Fryderyka Wielkiego, np. Tancerka Barberina (Die Tänzerin Barberina, 1920, Carl Boese) czy Fridericus Rex (1925, Arzén von Cserépy). Stanowiły one apoteozę rządów silnej ręki i charyzmatycznego władcy, co z jednej strony przedłużało „politykę historyczną” okresu

${ }^{56}$ Nt. Manfreda Noa, spółki Bavaria-Filmhaus, a także filmów Natan Mędrzec i Helena Trojańska odsyłam do arcyciekawego artykułu Stefana Drösslera Der Fall "Nathan der Weise", zamieszczonego w książeczce dołączonej do edycji DVD: Manfred Noa, Nathan der Weise, Seria Edition Filmmuseum, No. 10, Filmmuseum München-Goethe-Institut München 2006. 
wilhelmińskiego, z drugiej - przygotowywało grunt pod nazizm i apoteozę Hitlera. Nie przypadkiem seria fryderycjańska wybuchnie ponownie po przełomie dźwiękowym, u schyłku okresu weimarskiego, i będzie kontynuowana w Trzeciej Rzeszy. Etatowym odtwórcą roli pruskiego króla zarówno $\mathrm{w}$ wymienionych, jak i w późniejszych realizacjach, był Otto Gebühr ${ }^{57}$.

Najsłynniejszym jednak twórcą spektakli historycznych jest Ernst Lubitsch. Jego Madame DuBarry (1919) z Polą Negri w roli tytułowej i Emilem Janningsem jako Ludwikiem XV była pierwszym wielkim sukcesem eksportowym kina niemieckiego po I wojnie światowej (koszt tego wystawnego filmu, zrealizowanego za inflacyjny ekwiwalent 40 tysięcy dolarów, amerykańscy eksperci ocenili 12,5 raza wyżej - na pół miliona). Za tym sukcesem przyszedł kolejny - Anna Boleyn (1920), z Henny Porten w roli tytułowej i znowu Janningsem jako Henrykiem VIII. Filmy Lubitscha zwracały uwage ruchliwością kamery i nierzadko oryginalnymi jej ustawieniami, a także ciekawym operowaniem tłumami w scenach masowych, przejętym z teatru Maxa Reinhardta, którego zespołu Lubitsch był niegdyś aktorem; zresztą później także grywał mniejsze role w filmach, ostatnią we własnym filmie Sumurun (1920). Bohaterki obu przebojów Lubitscha kończyły na szafocie, nie rozumiejąc tego, co się wokół nich dzieje i w co zostały uwikłane, i były przeciwstawione tłumom - tłuszczy szalejącej podczas rewolucji na ulicach Paryża, londyńskiej gawiedzi wiwatującej najpierw na cześć Anny, a potem wznoszącej okrzyki przeciwko niej. Tłumy zresztą w wielkiej ekscytacji oczekiwały egzekucji bohaterek jak wielkiego teatralnego widowiska (nb. oszczędzonego widzowi). Kracauer, niesprawiedliwy wobec historycznych widowisk Lubitscha, wiąże obecny w nich lęk przed tłumem z antydemokratycznymi tendencjami kina weimarskiego ${ }^{58}$. Jak najniesłuszniej - lęk taki jest raczej objawem zdrowego rozsądku i instynktownego rozpoznania w postawach tłumnych objawów totalitaryzmu (vide: zafascynowana estetyką tłumów i ornamentem z mas propaganda nazistowska i komunistyczna).

Lubitsch realizował jednak nie tylko filmy historyczne sensu stricto, ale i kostiumowe filmy egzotyczne, osadzone w dość nieokreślonej czy umownej przeszłości, w egzotycznej scenerii, o sensacyjno-melodramatycznej linii fabularnej. Wymienić tu można takie filmy, jak Oczy mumii Mâ (Die Augen der Mumie Mâ, 1918), Carmen (1918), Sumurun (1920), Dzika kotka (Die Bergkatze, 1921), Żona faraona (Das Weib des Pharao, 1922) ten ostatni, z Emilem Janningsem w roli faraona, to efektowne widowisko

57 Analizę filmów „fryderycjańskich” proponuje S. Kracauer, Od Caligariego do Hitlera, s. 100-103, 227-229.

${ }^{58}$ Ibidem, s. 45-52. 
z 6 tysiącami statystów i monumentalnymi dekoracjami. W czterech pierwszych zagrała Pola Negri, wielkie "odkrycie” Lubitscha, która jak i on po swych niemieckich sukcesach wyruszyła na podbój Hollywood; o ile jednak jemu udał się on jako reżyserowi, to jej jako aktorce znacznie mniej. Cechą charakterystyczną i historycznych, i egzotycznych filmów Lubitscha jest cynizm postaci (zwłaszcza bohaterek granych przez Polę Negri) i erotyczny libertynizm, którego śmiałość koresponduje z okresowym zniesieniem cenzury zaraz po I wojnie światowej (przywrócona ustawą z maja 1920, została dodatkowo zaostrzona w roku 1922, choć aby zachować wolność wypowiedzi, dodano klauzulę mającą chronić filmy o wysokim poziomie artystycznym albo doniosłym przesłaniu).

Ważnym twórcą zarówno dla gatunku historycznego, jak i egzotycznego, jest Joe May. Moda w kinie weimarskim na wystawne Kostümfilme, z pewnością nie bez wpływu włoskiej epiki historycznej, została zainaugurowana właśnie przez monumentalny film Maya Veritas vincit (1918). Film ten, powstały także z niewątpliwej inspiracji Nietolerancja (1916) Griffitha, odwoływał się do teorii metempsychozy, aby przedstawić historię miłosną ciągnącą się na przestrzeni trzech, z rozmachem ukazanych, stuleci (konstrukcja ta inspirowała z kolei takie "trans-epokowe" filmy, jak Satanas Murnaua i Zmęczona Śmierć Langa). May zrealizował także jeden z cieszących się największym powodzeniem weimarskich filmów egzotycznych, dwuczęściowy Indyjski grobowiec (Das indische Grabmal, 1921), z Conradem Veidtem w roli demonicznego maharadży. Film ten, powstały według scenariusza Thei von Harbou i Fritza Langa, pierwotnie miał realizować właśnie Lang. Ostatecznie Lang wyreżyseruje drugi remake Indyjskiego grobowca (1958) dopiero po II wojnie światowej, gdy wróci do Niemiec z Hollywood, ale rezultat - ostentacyjnie kiczowata i anachroniczna produkcja klasy B, jest artystycznie słabszy od stylowego i zrealizowanego z produkcyjnym rozmachem filmu Maya. Do genre'u egzotycznego należy też wystawny 8-odcinkowy serial kinowy Joe Maya, z jego żoną Mią May jako gwiazda, zatytułowany Władczyni świata (Die Herrin der Welt, 1919-1920), prawdopodobnie najdroższy projekt kinematografii niemieckiej tuż po I wojnie światowej. W siedmiu epizodach bohaterka doświadcza niezwykłych przygód w Chinach, Ameryce Środkowej i Afryce, a ósmy jest autotematyczny, przedstawiając realizację sensacyjnego filmu o jej przygodach.

Ważnym gatunkiem ery weimarskiej $\mathrm{w}$ kinie niemieckim jest se $\mathrm{n}$ sacyjny film o superprzestępcach. Oczywiście, takie inspirowane trzeciorzędną literaturą czy francuskimi serialami w rodzaju Fantomasa i Wampirów Feuillade'a filmy powstawały w Niemczech jeszcze przed wojna, ale na wyżyny artystyczne wprowadził ten genre Fritz Lang. Jego nieukończony serial Pajaki (Die Spinnen, 1919) przedstawia walkę 
prywatnego detektywa, Kay Hooga, sportsmena i dżentelmena, z tajemniczą przestępczą organizacją Pająków, którą dowodzi kobieta-wamp, Lio Sha. Jest to film o ewidentnie "feuilladowskim” charakterze, z komiksowymi postaciami i dość zawiła, nie całkiem zrozumiałą akcją. Z czterech planowanych odcinków powstały zaledwie dwa - Złote Jezioro (Der Goldene See) i Brylantowy statek (Das Brillantenschiff) - i trzeba powiedzieć, że nie zapowiadały jeszcze poziomu, na jaki Lang wzniesie się trzy lata później, realizując na podstawie popularnej powieści w odcinkach, autorstwa Norberta Jacques'a, dwuczęściowy, czteroipółgodzinny film Doktor Mabuse, gracz (1922). Arcydzieło Langa jest nieocenionym portretem Niemiec epoki inflacji, z szaleństwem hazardu i spekulacji giełdowych, echami rewolucyjnego wrzenia i estetycznych dyskusji o ekspresjonizmie, obrazującym dekadenckie lokale o awangardowym wystroju, z których słynął Berlin, jak i modę na psychoanalizę. W tytułowej postaci - prezentującej się światu jako doktor psychoanalizy, a faktycznie kierującym niebezpieczną organizacją i posługującym się telepatią superprzestępcy - kumulują się rozmaite i często sprzeczne znaczenia: to Kracauerowska figura "tyrana”, antycypująca nazizm, lecz zarazem alegoria "Żyda”, obcego, winnego inflacji, gospodarczemu kryzysowi, hazardowej gorączce, spekulacjom, nieokiełznanemu libertynizmowi epoki... Doktor Mabuse to także rezultat starannie przemyślanej strategii marketingowej i wzorowo przeprowadzonej, w aspekcie zarówno nagłośnienia, jak i synchronizacji, kampanii multimedialnej, w której publikowana w odcinkach powieść i film nawzajem się promowały. Ostatnie odcinki, z lutego 1922, zawierały fotosy z realizowanego właśnie filmu, pobudzając apetyt czytelników na wersję filmową - która w kwietniu trafiwszy na ekrany, istotnie okazała się przebojem. Strategię takiego wzajemnego promowania książki oraz filmu Lang i Thea von Harbou skutecznie powtórzyli przy swych następnych superprodukcjach z lat 20.: Nibelungach, Metropolis, Szpiegach ${ }^{59}$. Ten ostatni film, wyżej już omówiony, jest jeszcze jednym, artystycznie równie wybitnym jak utwór o Mabusem, sensacyjnym filmem Langa o superprzestępcy, przekonująco wyrażającym ducha epoki.

Modernistyczne fascynacje Republiki Weimarskiej znalazły też wyraz w filmach fantastycznonaukowych ${ }^{60}$. Co prawda najwcze-

59 Odsyłam do analizy filmu w rozdziale 3. Dzikość lwa i jad węża: "Doktor Mabuse, gracz", s. 275. Por. także: B. Widdig, op. cit., s. 113-133; Tom Gunning, The Films of Fritz Lang: Allegories of Vision and Modernity, BFI Publishing, London 2000, s. 87-116; David Kalat, The Strange Case of Dr. Mabuse: A Study of the Twelve Films and Five Novels, McFarland \& Company, Inc., Publishers, Jefferson, NC-London 2001, s. 9-60.

${ }^{60}$ Nt. weimarskich filmów science-fiction, zob.: Peter S. Fisher, Fantasy and Politics: Visions of the Future in the Weimar Republic, University of Wisconsin Press, Madison 1991; Krzysztof Loska, Kino i technika: Niemiecki film fantastycznonaukowy w latach 1918-1939, [w:] Kino niemiec- 
śniejszy z nich, Algol (Algol - Tragödie der Macht, 1920, Hans Werckmeister), jest zrealizowanym $\mathrm{w}$ dekoracjach o stricte ekspresjonistycznym designie jeszcze jednym wariantem odwiecznego niemieckiego mitu o pakcie z diabłem - bo taką funcję pełni tytułowa "odległa planeta", obdarzając bohatera, zwykłego górnika (Emil Jannings), nadludzką mocą. Znacznie nowocześniejsza wydaje się superprodukcja Ufy, Metropolis (1926) Fritza Langa, choć futurystyczna antyutopia, obrazująca supermiasto przyszłości za około sto lat, skażona jest anachronicznymi motywami romantyczno-gotycystycznego chowu, pseudoreligijnymi konceptami zawłaszczającymi chrześcijańską symbolikę i podejrzanym politycznie przesłaniem, w którym późniejsza krytyka dopatrywała się nie bez racji apologii nazizmu (avant la lettre). Do dziś jednak robią wrażenie choreografia tłumów (znów rodem z teatru Reinhardta) i fascynująca plastycznie scenografia. W niektórych sekwencjach filmu (np. w obrazach metropolii z napowietrznymi ciągami komunikacyjnymi i samolotami latającymi wśród drapaczy chmur) zastosowano żmudne filmowanie planów klatka po klatce jak w filmie lalkowym. W innych zaś użyto "tricków Schüfftanowskich" (zwanych tak od nazwiska ich wynalazcy, Eugena Schüfftana), polegających na kombinowaniu małych modeli wielkich obiektów z żywą akcją. Przed kamerą umieszczano lustro, aby odbijało obiekty znajdujące się za nią albo obok niej, np. modele budynków czy krajobrazu. Lustro to było albo na wpół przejrzyste, albo umieszczone przed kamerą pod pewnym kątem, który umożliwiał jednoczesne filmowanie owych modeli i aktorów. Głównym operatorem filmu był Karl Freund (autor zdjęć do podobnie technicznie wymyślnego Portiera z hotelu Atlantic), choć za zdjęcia $\mathrm{z}$ animacją i efektami specjalnymi odpowiadał inny wielki mistrz obrazu w kinie niemieckim tamtych lat - Günther Rittau ${ }^{61}$.

Artystycznie mniej udanym, za to bliższym nowoczesnemu kanonowi kina science-fiction, jest drugi film fantastyczny Langa - Kobieta na Księżycu (Frau im Mond, 1929). Dzięki współpracy eksperta od budowy rakiet, Hermanna Obertha, sugestywne są tam sekwencje startu i podróży załogowego statku kosmicznego, choć powolne tempo narracji oraz obfitość pseudonaukowych szczegółów czynią go dość nużącym w odbiorze. Gorzej wypadła też finałowa sekwencja z nawiązującą do ekspresjonizmu scenografią, ukazującą powierzchnię Księżyca, który z racji

kie w dialogu pokoleń i kultur, red. Andrzej Gwóźdź, Rabid, Kraków 2004, s. 21-29.

${ }^{61} \mathrm{Nt}$. Metropolis istnieje olbrzymia literatura. Zob. np. rozdział 5. w niniejszej książce Czas Apokalipsy: "Metropolis", s. 385; Agnieszka Ćwikiel, "Metropolis" albo z archiwum filmowej ikonografii, [w:] Kino niemieckie w dialogu pokoleń i kultur, red. Andrzej Gwóźdź, Rabid, Kraków 2004, s. 159-169; T. Gunning, op. cit., s. 52-83; Thomas Elsaesser, Metropolis, BFI Publishing, London 2003; Fritz Lang's "Metropolis": Cinematic Visions of Technology and Fear, ed. Michael Minden, Holger Bachmann, Camden House, Rochester-Woodbridge 2000. 
rzekomych pokładów złota okazuje się raczej złotym niż srebrnym globem $^{62}$.

Strukturę melod ra matu znaleźć można w wielu weimarskich filmach, reprezentujących formalnie inne gatunki, np. w Märchenfilme (Faust), Kammerspielfilme (Vanina, Michael), Straßenfilme (Miłość Joanny Ney, Asfalt), $\mathrm{w}$ filmach historycznych (Anna Boleyn) czy science-fiction (Kobieta na Księżycu). Wśród wybitnych, niewymienionych dotąd dzieł, które można zasadniczo uznać za melodramaty, warto z pewnością wymienić Tragedie ulicznej dziewczyny (Dirnentragödie, 1927, Bruno Rahn), jeden z modelowych "filmów ulicznych", z paradygmatycznymi wedle Kracauera motywami mieszczańskiego buntu (chłopak z dobrego domu ucieka zeń i trafia na ulicę) oraz „prostytutki i młodzieńca” (wątek znany także z filmów Pabsta czy Asfaltu). Kolejną wielką rolę tragiczna, podstarzałej prostytutki, która źle ulokowała swe uczucia w niedojrzałym i nielojalnym chłopaku, zagrała tam Asta Nielsen. Za melodramat wypada uznać także Variété (1925, Ewald André Dupont), opowiedzianą w ciągu retrospekcji i rozgrywającą się w środowisku artystów trapezu historię miłosnego trójkąta, w której zazdrość o partnerkę doprowadza głównego bohatera (znowu Emil Jannings) do zabójstwa rywala. To kolejny z niemieckich filmów lat 20., który podbił Amerykę, a miała na to wpływ nie tylko atrakcyjna, emocjonująca fabuła, ale i rewelacyjna forma - zwłaszcza zaś ruchliwość i niezwykłe ustawienia „wyzwolonej kamery” Karla Freunda. Ciekawostką jest sfilmowany w tym filmie występ sławnego zespołu choreograficznego Tiller Girls, któremu znany esej poświęcił Siegfried Kracauer.

Gatunkiem specyficznym dla kina niemieckiego są Bergfilme, „filmy górskie”. W latach 20. czołowym ich realizatorem był Arnold Fanck, sportsmen i operator-samouk, który karierę filmową zaczął od realizacji niefabularnego filmu Cuda narciarskich szusów (Das Wunder des Schneeschuhs, 1919), mającego ukazać publiczności piękno wyczynowego narciarstwa sfilmowanego $\mathrm{w}$ naturalnych alpejskich plenerach. Wynajął w tym celu wybitnego operatora i narciarza w jednej osobie, Seppa Allgeiera oraz sławnego w swoim czasie narciarza Hannesa Schneidera. Mimo problemów z dystrybucją film okazał się sukcesem i Fanck wkrótce przystąpił do realizacji utworów, w których stopniowo do zdjęć górskich o niezwykłych walorach estetycznych i dokumentalnych zaczął wprowadzać elementy fabularyzowane. Jego piąty film, Góra przeznaczenia (Der Berg des Schicksals, 1924), stricte już fabularny, zwrócił uwagę Leni Riefenstahl, która skłoniła reżysera do zaangażowania jej w następnej produkcji, Świętej górze (Der heilige Berg, 1926). Zagrała w niej razem z Luisem Trenkerem, alpinista, aktorem i filmowcem; później, w okresie

${ }^{62}$ Odsyłam do analizy filmu w rozdziale 6. Na Złotym Globie: „Kobieta na Księżycu”, s. 441. 
dźwiękowym, oboje samodzielnie wyreżyserują ważne filmy należące do tego genre'u. Riefenstahl zagrała w sumie w sześciu filmach Fancka, a najlepsze z nich to dwa z okresu niemego: Święta góra i Białe piekło na Piz Palü (Die Weiße Hölle vom Piz Palü, 1929, współreż. G. W. Pabst) ${ }^{63}$. Filmy Fancka są wspaniałe formalnie: zachwycają kadrami przedstawiającymi majestat ośnieżonych gór, zdumiewają dynamiką jazd kamery prowadzonej przez świetnych operatorów-narciarzy (Sepp Allgeier, Hans Schneeberger), budzą podziw fenomenalnymi zdjęciami lotniczymi i nocnymi, które obrazują górskie akcje ratunkowe $\mathrm{w}$ świetle pochodni (zwłaszcza w drugim z filmów). Mistrzowsko też operują suspensem, trzymając widza w napięciu niemal od pierwszej do ostatniej minuty. Jednocześnie irytują pretensjonalnym melodramatyzmem akcji i bynajmniej nie niewinną ideologicznie mistyka, bliską neopogańskiemu panteizmowi, który od niemieckiego romantyzmu poprzez ruch volkistowski wiedzie wprost do nazistowskiego kultu "ziemi i krwi”. W mrocznych fabułach demoniczna i majestatyczna góra wzywa bohatera "ku przeznaczeniu”, a właściwie na pewną śmierć. Afirmowana w nich męska przyjaźń ma podobny posmak co opiewana w Nibelungach, cesarstwie wilhelmińskim czy Trzeciej Rzeszy Treue - wierność do ostatka, wzajemna lojalność, wynikająca z więzów krwi czy ideowej wspólnoty, żądająca ofiary z własnego życia. Posmak ideologiczny ma też $w$ tych filmach kult sportu i tężyzny fizycznej - nie przypadkiem zarówno Fanck, jak Riefenstahl i Trenker należeć będą do najbardziej prominentnych filmowców niemieckich w okresie hitlerowskim.

Ko media to gatunek rzadziej kojarzony z kinem weimarskim, ale miała ona swój złoty okres pod koniec I wojny światowej i tuż po niej, kiedy komedie kręcił w Berlinie Ernst Lubitsch (to nie film historyczny, ale właśnie ten genre ze sławetnym „Lubitsch touch” stanie się jego główną specjalnością, gdy w roku 1922 wyemigruje do Hollywood). W najlepszych komediach Lubitscha z okresu niemieckiego główne role grała Ossi Oswalda, aktorka niezbyt ładna, ale obdarzona niesłychaną vis comica i perwersyjnym seksapilem. W Nie chce być mężczyzna (Ich möchte kein Mann sein, 1918) gra ona dziewczynę-chłopczycę, która przebiera się w męski strój i wyrusza na nocną eskapadę na miasto; dopiero w tym przebraniu zdobywa „kumplowskie zaufanie”, a potem miłość swego domowego nauczyciela, który zupełnie nie zauważał jej jako kobiety. W arcyzabawnej Lalce (1919) gra córkę wytwórcy człowiekopodobnych automatów; wskutek qui pro quo trafia jako kobieta-automat do domu pewnego

${ }^{63}$ Sylwetkę Arnolda Fancka i historię jego współpracy z Leni Riefenstahl przedstawia artykuł Douga Cummingsa, "The Holy Mountain": A Film by Arnold Fanck, w broszurze dołączonej do edycji DVD: The Holy Mountain. A Film by Arnold Fanck, Seria „Masters of Cinema", \# 2, Eureka Video, London 2002. 
fajtłapy-mizogina, który by nie zostać wydziedziczonym, musi ożenić się w określonym terminie. I odkrywa przed nim - nieświadomym, że ma do czynienia z prawdziwą kobieta, a nie "lalką" - uroki seksu. W Księżniczce ostryg (Die Austernprinzessin, 1919) wciela się w córkę amerykańskiego potentata finansowego (,króla ostryg”) pragnącą poślubić europejskiego arystokratę. Biedny jak mysz kościelna polski książę (sic!) podstawia do ołtarza swego szkaradnego służącego, który ma ochotę skonsumować zawarte per procura małżeństwo przed swym chlebodawcą... Komedie Lubitscha skrzą się dowcipem cynicznym i libertyńskim, a ich podteksty są nie tylko dosadne, ale też skandaliczne (sugerują np. niekoniecznie standardową orientację seksualną postaci albo ich upodobania niekoniecznie zgodne z ich pozycją społeczną - vide: lubieżni zakonnicy w Lalce, prostactwo „króla” i „,księżniczki ostryg"). Komedie Lubitscha są ciekawym Zeitspiegel, zwierciadłem epoki: Lalka mistrzowsko parodiuje w scenografii modę na ekspresjonizm; Nie chcę być mężczyzna i Księżniczka ostryg ukazują nowoczesny świat, w którym wyzwolone kobiety stylizują się na „chłopczycę”, a na parkietach króluje fokstrot (niewiarygodnie śmieszna i choreograficznie zadziwiająca scena „epidemii fokstrota” w Księżniczce ostryg to jedna z najoryginalniejszych scen komediowych w całej historii kina).

Komedię, i to w iście Lubitschowskim stylu, ma też w swym dorobku Friedrich Wilhelm Murnau. Jego Finanse wielkiego księcia (Die Finanzen des Großherzogs, 1924) według scenariusza Thei von Harbou to pogmatwana fabularnie i farsowa w stylu historia władcy fantastycznego państewka Abacco, którego plany wydobycia się z finansowych tarapatów i uniknięcia krachu państwa przez małżeństwo z rosyjską księżniczką krzyżują intrygi wierzycieli oraz zamach stanu przeprowadzony przez złowrogich, ale i niepoważnych rewolucyjnych konspiratorów. Zrealizowane częściowo w skalistych plenerach chorwackiego wybrzeża Finanse zupełnie nie przypominają w obrazie innych filmów Murnaua o mrocznej i „ekspresywnej" estetyce, z którymi na ogół bywa kojarzony. Antycypują za to w fabule i groteskowo-fantastycznej tonacji Ostatniego miliardera (1934) René Claira, dla którego, kto wie, czy nie były inspiracją. W tytułową rolę wcielił się popularny aktor komediowy, Harry Liedtke.

Specyficznie niemiecki genre filmowy powstał w latach I wojny światowej, ugruntował się u progu Republiki Weimarskiej, gdy zniesiono cenzurę, i wkrótce osłabł (choć nie zanikł całkowicie), gdy instytucję cenzury przywrócono. Mowa o tzw. Sittenfilme czy też Aufklärungsfilme, "filmach uświadamiających"64. Były to realizacje mające teore-

\footnotetext{
${ }^{64}$ Trudno ten genre zgrabnie nazwać po polsku - nie są to bowiem ani „filmy obyczajowe”, ani „edukacyjne” czy „oświatowe”, co sugerowałyby obie ich nazwy niemieckie. Z pewnością niezgrabne jest nazywanie ich „filmami seksualnymi”, jak to ma miejsce
} 
tycznie przybliżać rozmaite negatywne obyczajowo, moralnie i zdrowotnie zjawiska, o zazwyczaj seksualnym charakterze i kryminalnych aspektach, takie jak choroby weneryczne, prostytucja, domy publiczne, pokątne aborcje, homoseksualizm, narkomania, alkoholizm. Zasadniczo były to filmy bynajmniej nie dokumentalne, lecz fabularne, z tym że anegdota miała wyraźnie uświadamiający, "poglądowy” charakter i przeplatana była ekstradiegetycznymi elementami odnoszącymi ją do problemów pozafilmowej rzeczywistości społecznej (np. wykładami autorytetów medycznych). Taka konstrukcja nie sprzyjała poziomowi artystycznemu tych filmów, a ich „edukacyjny” charakter schodził na drugi plan wobec sensacyjności tematów, którymi wabiły publiczność do kin. Ich czołowym realizatorem (jako reżyser i/lub producent czy scenarzysta) był Richard Oswald, który już w roku 1917 zrealizował pod auspicjami Towarzystwa dla Zwalczania Chorób Wenerycznych film o negatywnych skutkach kiły Niech się stanie światłość! (Es werde Licht!), po którym nastąpiło około 30 dalszych. Najsłynniejszym z nich jest rozsławiony dziś przez środowiska gejowskie, a skądinąd nudny i statyczny w sposobie narracji film Inaczej niż inni (Anders als die Andern, 1919), opowiadający tragiczną historię młodego człowieka (Conrad Veidt), odkrywającego późno, z racji społecznego tabu i wewnętrznego wyparcia, swą homoseksualną orientację. W filmie tym, jak i w kilku innych, jako naukowy autorytet wystąpił psycholog dr Magnus Hirschfeld, który zainicjował kampanię zmierzającą do zniesienia penalizacji homoseksualizmu i uznania go za naturalną skłonność mniejszości populacji.

Prócz realizacji Oswalda pośród innych ważnych Sittenfilme warto wymienić Opium (1919, Robert Reinert), Alkohol (1919, E. A. Dupont), Wolna miłość (Freie Liebe, 1919, Max Mack). Genre nie zanikł całkowicie po ponownym wprowadzeniu cenzury, o czym świadczą filmy zrealizowane już po roku 1920, jak dwuczęściowy Ze wspomnień ginekologa (Aus den Erinnerungen eines Frauenarztes, 1922, Gerhard Lamprecht i Lupu Pick), Dusze dzieci oskarżaja was (Kinderseelen klagen euch an, 1927, Kurt Bernhardt) - zrealizowany na zamówienie Kościoła katolickiego film antyaborcyjny czy głośna Płeć w kajdanach (Geschlecht in Fesseln, 1928, Wilhelm Dieterle), obrazująca stłumienie seksualności ludzi odsiadujących wyroki i nawołująca o reformę więziennictwa. W dobie Neue Sachlichkeit gatunek rozkwitł na nowo, choć mniej intensywnie niż zaraz po I wojnie światowej ${ }^{65}$.

\footnotetext{
w polskim przekładzie książki Kracauera. Określenie „filmy uświadamiające” wydaje mi się ich najzręczniejszym określeniem, choć można by też mówić o „filmach edukujących seksualnie".

${ }^{65}$ Najpełniejsze omówienie Sittenfilme można znaleźć w książce: Siegbert Salomon Prawer, Between Two Worlds: The Jewish Presence in German and Austrian Films, 1910-1933,
} 
Na koniec nie sposób nie wspomnieć, iż to w Republice Weimarskiej powstał pierwszy w świecie pełnometrażowy animowany film f a bu la rn y. Za taki trzeba uznać Przygody księcia Achmeda (Die Abenteuer des Prinzen Achmed, 1926), zrealizowane przez Lotte Reiniger przy współpracy męża, Carla Kocha, i Waltera Ruttmanna, mistrza abstrakcyjnej animacji, a później znanego dokumentalisty. Historię zaczerpniętą z Księgi 1001 nocy, o skomplikowanej szkatułkowej konstrukcji, autorka opowiedziała metodą animacji wycinanych sylwetek o delikatnych, finezyjnych kształtach. Tę technikę „filmu sylwetkowego" kontynuowała w swych artystycznie wyrafinowanych realizacjach niemal aż do swej śmierci w $1981 \mathrm{r}$.

\section{Weimarska krytyka i kultura filmowa}

Skutecznie przeprowadzona dzięki kampaniom lansującym Autorenfilm i ekspresjonizm nobilitacja filmu zaowocowała uzyskaniem przezeń nie tylko statusu sztuki, ale też istotnego miejsca w kulturze Niemiec jako czynnika kształtującego - podobnie jak literatura - narodową tożsamość i wyrażającego Zeitgeist, ducha czasów. Na łamach gazet codziennych, magazynów ilustrowanych albo pism kulturalnych snuto refleksje nad specyfiką filmu jako medium i formy artystycznej, albo toczono gorące debaty nad relacjami filmu (bądź konkretnych filmów) do społeczeństwa, polityki, rozmaitych idei. Specjalistyczne magazyny branżowe, jak „Lichtbild-Bühne” czy „Der Kinematograph”, reprezentowały punkt widzenia przemysłu filmowego i jego rozmaitych gałęzi. Z kolei na łamach założonego w roku 1919 „Film-Kuriera” (pierwszego pisma filmowego, wydawanego jako dziennik) żywa wymiana myśli na takie tematy, jak odpowiedzialność krytyki czy możliwość pogodzenia przez kino ekonomicznej i artystycznej perspektywy, miała miejsce między takimi krytykami, jak Willy Haas, Hans Siemsen, Rudolf Kurtz (ten ostatni to także autor pierwszej monografii niemieckiego kina ekspresjonistycznego Expressionismus und Film, 1926) ${ }^{66}$.

W licznych artykułach i recenzjach na łamach „Frankfurter Zeitung” Siegfried Kracauer, przyszły autor Teorii filmu oraz Od Caligariego do Hitlera, rozważał społeczne i ekonomiczne procesy, które przeobraziły paradygmat kulturowy poprzez wytworzenie kultury popularnej i nowe jakościowo, bezprecedensowe doświadczenie nowoczesności w zurbanizowanym, stechnicyzowanym świecie ${ }^{67}$. Z kolei Béla Balázs uznał film za

Berghahn Books, New York-Oxford 2007, s. 72-81. Por. także: S. Kracauer, op. cit., s. 41-44, 124; S. Hake, op. cit., s. 31.

66 S. Hake, op. cit., s. 48.

${ }^{67}$ Dwa słynne artykuły, reprezentatywne dla pisarstwa Kracauera na łamach „Frankfurter Zeitung”, można znaleźć w polskim przekładzie w tomie Rekonfiguracje 
pierwsze demokratyczne mass medium, a w jego roli „,nowoczesnego folkloru" dostrzegał niemal rewolucyjny potencjał. Wydarzeniem roku 1924 była jego książka Der sichtbare Mensch (Człowiek widzialny); rozważając rolę filmowych środków wyrazu, takich jak zbliżenie czy zmienne plany, odsłaniała zarazem uniwersalny, niewerbalny język ludzkiego ciała. Sześć lat później pod wpływem przełomu dźwiękowego Balázs zmodyfikował nieco swe koncepty w książce Der Geist des Films (Duch filmu, 1930), zawierającej do dziś inspirujące rozważania na temat ontycznego statusu i estetyki dźwięku w kinie. Natomiast Rudolf Arnheim w wydanej pod koniec ery weimarskiej, już w okresie panowania dźwięku w filmie, książce Film jako sztuka (Film als Kunst, 1932) estetycznej kwintesencji kina dopatrzył się w definitywnie już wypartym modelu kina niemego (i czarno-białego). Może zresztą nic w tym dziwnego, zważywszy, iż ów wybitny psycholog krytyką filmową aktywnie parał się głównie w latach 20. na łamach takich periodyków, jak „Das Stachelschwein” czy „Die Weltbühne”68.

Nie można też chyba pominąć w tym miejscu tak wybitnych krytyków, jak Kurt Pinthus (pisujący na łamach „Das Tage-Buch”), Roland Schacht („Der Kunstwart”, „B. Z. am Mittag”), Herbert Thering („Berliner Börsen-Courier"), Paul Ickes („Die Filmwoche”), Willy Haas („Die Literarische Welt”) czy Axel Eggebrecht („Die Weltbühne”). Jakość ich recenzji, ich zdolność syntezy i analityczna wnikliwość, w niemałym stopniu przyczyniły się do wysokiego statusu kina w kulturze całego okresu weimarskiego.

\section{Chronologia}

\section{5}

- 1 listopada - pierwszy publiczny pokaz w Berlinie Bioskopu braci Maxa i Emila Skladanowskich.

\section{7}

- Oskar Messter zakłada studio filmowe na Friedrichstraße w Berlinie.

modernizmu. Nowoczesność i kultura popularna, red. Tomasz Majewski, Wydawnictwa Akademickie i Profesjonalne, Warszawa 2009 (S. Kracauer, Kult dystrakcji: O berlińskich kinoteatrach, przeł. Magdalena Karkowska, s. 207-213; idem, Panny sklepowe ida do kina, przeł. M. Karkowska, s. 267-282).

${ }^{68}$ Por.: S. Hake, op. cit., s. 48. Sabine Hake kulturze i krytyce filmowej w okresie zarówno wilhelmińskim, jak i weimarskim, poświęciła swą książkę: The Cinema's Third Machine: Writing on Film in Germany, 1907-1933, University of Nebraska Press, LincolnLondon 1993. 


\section{5}

- powstanie drezdeńskiej grupy artystycznej „Die Brücke”.

\section{8}

- narodziny ekspresjonistycznego teatru (Morderca, nadzieja kobiet Oskara Kokoschki).

\section{9}

- Paul Davidson tworzy „pionowo zintegrowaną” kompanię PAGU i otwiera wielkie kino na Alexanderplatz.

\section{0}

- założenie pisma „Der Sturm”; jego wydawca, Herwarth Walden, lansuje termin „ekspresjonizm”.

\section{1}

- powstanie w Monachium grupy artystycznej „Der Blaue Reiter”.

\section{2}

- bojkot kina przez środowisko autorów, reżyserów i aktorów teatralnych.

\section{3}

- zostaje proklamowany Autorenfilm; premiery ważnych Autorenfilme: Inny Maxa Macka, Wiejska droga Paula von Woringena, Atlantis Augusta Bloma, Student z Pragi Stellana Rye;

- Student z Pragi początkiem filmowej kariery Paula Wegenera i pierwszym z fali Märchenfilme (1913-1926), opartych na tradycjach niemieckiego romantyzmu.

\section{6}

- zakaz importu filmów (obowiązujący do końca 1920 r.) potężnym bodźcem do ekspansji kinematografii rodzimej.

\section{7}

- 18 grudnia - rozkaz gen. Ericha Ludendorffa powołujący do istnienia Ufę. 
1918

- 9 listopada - abdykacja cesarza Wilhelma II;

- 11 listopada - kapitulacja Niemiec;

- prywatyzacja Ufy;

- pierwsze filmy Ernsta Lubitscha z Polą Negri (Oczy mumii Mâ, Carmen).

\section{9}

- 6 lutego - w Weimarze pierwsze posiedzenie Zgromadzenia Narodowego Republiki;

- 11 sierpnia - podpisanie Konstytucji Republiki Weimarskiej;

- wielkie sukcesy Ernsta Lubitscha (Lalka, Księżniczka ostryg, Madame DuBarry);

- fala Sittenfilme (Aufklärungsfilme) - „filmów uświadamiających” - po zniesieniu cenzury (do maja 1920); m.in. Inaczej niż inni Richarda Oswalda, Opium Roberta Reinerta;

- preekspresjonistyczny film Roberta Reinerta Nerwy;

- seriale kinowe Joe Maya (Władczyni świata) i Fritza Langa (Pająki);

- założenie „Film-Kuriera” - pierwszego pisma filmowego, wydawanego jako dziennik.

\section{0}

- 26 lutego - berlińska premiera Gabinetu doktora Caligari Roberta Wiene; „oficjalny” początek niemieckiego ekspresjonizmu filmowego;

- kolejne filmy ekspresjonistyczne: Algol Hansa Werckmeistra, Golem Paula Wegenera i Carla Boese, Genuine Roberta Wiene, Od poranka do pótnocy Karlheinza Martina, Torgus Hannsa Kobe;

- kolejne przeboje Lubitscha: Anna Boleyn, Sumurun.

1921

- listopad - Ufa wchłania wytwórnię Decla-Bioscop, która pozostaje samodzielną jednostką produkcyjną pod kierownictwem Ericha Pommera;

- kolejne filmy ekspresjonistyczne: Zmęczona Śmierć Fritza Langa, Dom na Księżycu Karlheinza Martina;

- Dzika kotka Ernsta Lubitscha (pastisz ekspresjonizmu);

- wielki przebój Joe Maya Indyjski grobowiec;

- Kammerspielfilme: Schody kuchenne Leopolda Jessnera, Szyny Lupu Picka, Zamek Vogelöd Friedricha Wilhelma Murnaua. 


\section{2}

- Doktor Mabuse, gracz Fritza Langa „zwierciadłem epoki”; wielki sukces u publiczności i krytyki;

Fantom);

- arcydzieła Friedricha Wilhelma Murnaua (Nosferatu, symfonia grozy,

- kolejne Kammerspielfilme: Sylwester Lupu Picka, Vanina Arthura von Gerlacha;

- fala wielkich filmów historycznych: Żona faraona Ernsta Lubitscha, Natan Mędrzec Manfreda Noa, Otello Dymitra Buchowieckiego, Lukrecja Borgia Richarda Oswalda;

- wyjazd do Hollywood Ernsta Lubitscha, Poli Negri, Dymitra Buchowieckiego.

\section{3}

- apogeum hiperinflacji - pieniądze o astronomicznych nominałach rosnących z dnia na dzień i znikomej wartości;

- kolejne filmy ekspresjonistyczne: Cienie Arthura Robisona, Raskolnikow Roberta Wiene, Skarb Georga Wilhelma Pabsta, Duch ziemi Leopolda Jessnera, Kamienny jeździec Fritza Wendhausena;

- pierwszy Straßenfilm - „film uliczny”: Ulica Karla Grune.

\section{4}

- wprowadzenie nowej stabilnej waluty (Reichsmark) i zahamowanie inflacji; początek kryzysu przemysłu filmowego;

- premiery gigantów historycznych, wyprodukowanych pod koniec inflacji: Nibelungi Fritza Langa, Helena Trojańska Manfreda Noa;

- Kammerspiel w zenicie: Portier z hotelu Atlantic F. W. Murnaua, Michael Carla Theodora Dreyera;

- schyłkowe arcydzieło ekspresjonizmu - Gabinet figur woskowych Paula Leniego;

- komedia Murnaua Finanse wielkiego księcia;

- teoretycznofilmowa książka Béli Balázsa Der sichtbare Mensch (Człowiek widzialny).

\section{5}

- grudzień - umowa Ufy z MGM i Paramountem; powstanie spółki Parufamet i chwilowe uratowanie Ufy od bankructwa przez amerykańską pożyczkę;

- wystawa w Mannheim i proklamowanie Nowej Rzeczowości (Neue Sachlichkeit) w sztuce niemieckiej; 
- przebojowe Kulturfilme Ufy: Drogi do sity i piękna Wilhelma Pragera, Cud stworzenia Hannsa Waltera Kornbluma;

- Zatracona uliczka - artystyczny portret niedawnej inflacji w pierwszym mistrzowskim „filmie ulicznym" G. W. Pabsta;

- schyłkowe arcydzieło Kammerspiel - Świętoszek F. W. Murnaua;

- eksportowy przebój - Variété E. A. Duponta, melodramat z „wyzwoloną kamerą".

\section{6}

- luty - kierownictwo Ufy zmusza do rezygnacji Ericha Pommera; Pommer wyjeżdża do USA;

- początek dużej fali (1926-1927) emigracji za ocean wybitnych postaci kina niemieckiego (m.in.: F. W. Murnaua, Paula Leniego, E. A. Duponta, Karla Freunda, Carla Mayera, Waltera Reimanna, Rochusa Gliese, Grety Garbo, Conrada Veidta, Emila Janningsa, Lyi de Putti);

- sfinalizowanie z trudem superprodukcji Ufy, ostatnich osiągnięć scenograficznego ekspresjonizmu: Fausta Murnaua (premiera: wrzesień) i Metropolis Langa (premiera: styczeń 1927);

- pierwszy w historii kina pełnometrażowy animowany film fabularny - Przygody księcia Achmeda Lotte Reiniger;

- Kulturfilm propagujący psychoanalizę - Tajemnice duszy G. W. Pabsta;

- pierwszy mistrzowski Bergfilm i początek współpracy Arnolda Fancka z Leni Riefenstahl - Święta góra;

- pierwsza książkowa monografia niemieckiego kina ekspresjonistycznego - Expressionismus und Film Rudolfa Kurtza.

\section{7}

- marzec - Alfred Hugenberg przejmuje kontrolę nad Ufą i jej dyrektorem generalnym mianuje Ludwiga Klitzscha;

- powrót z USA do Ufy Ericha Pommera (ale na drugorzędne stanowisko);

- "przekrojowe” filmy Ufy: Berlin, symfonia wielkiego miasta Waltera Ruttmanna, Przygody dziesięciomarkowego banknotu Bertholda Viertla;

- mistrzowskie melodramaty "uliczne”: Miłość Joanny Ney G. W. Pabsta, Tragedia ulicznej dziewczyny Bruno Rahna.

\section{8}

- Szpiedzy Fritza Langa - paradygmatyczny film Nowej Rzeczowości;

- Płeć w kajdanach Wilhelma Dieterle - reprezentant drugiej fali "filmów uświadamiających". 


\section{9}

- ostatnie arcydzieła niemieckiego kina niemego: Puszka Pandory i Dziennik upadłej dziewczyny G. W. Pabsta, Asfalt Joe Maya, Podróż Matki Krause do szczęścia Piela Jutziego, Białe piekło na Piz Palü Arnolda Fancka i G. W. Pabsta;

- pierwszy nowoczesny film science-fiction i jego spektakularna klęska: Kobieta na Księżycu Fritza Langa.

\section{Propozycje lektur}

W języku polskim szczęśliwie są dostępne dwie fundamentalne w literaturze światowej prace na temat kina wilhelmińskiego i weimarskiego w okresie niemym: Siegfrieda Kracauera Od Caligariego do Hitlera: Z psychologii filmu niemieckiego, przeł. Wanda Wertenstein, Eugenia Skrzywanowa, Filmowa Agencja Wydawnicza, Warszawa 1958, oraz Lotte H. Eisner Ekran demoniczny, przeł. Konrad Eberhardt, Wydawnictwa Artystyczne i Filmowe, 1974. Obie pozycje zostały niedawno wznowione przez gdańskie wydawnictwo słowo/obraz terytoria (Kracauer - 2010; Eisner - 2011); niestety, w starych, niewolnych od błędów przekładach. Nieodzowny wydaje się też możliwie szybki przekład książki Thomasa Elsaessera Weimar Cinema and After: Germany's Historical Imaginary (Routledge, London-New York 2000), która pośród pozycji o kinie niemieckim z pewnością obok dwóch wymienionych ma już status "trzeciej w kanonie” - zresztą w sposób niezwykle twórczy i ciekawy rewiduje ich lekturę filmów weimarskich w duchu „krytyki symptomatycznej”, proponując nowoczesną perspektywę kulturoznawczą.

Literatura w języku polskim na temat tego okresu w kinie niemieckim nie jest, niestety, zbyt bogata. Prócz książek Kracauera i Eisner najważniejszą pozycją wydaje się tom zbiorowy Niemiecki ekspresjonizm filmowy pod redakcją Alicji Helman i Aliny Madej (Uniwersytet Śląski, Katowice 1985), a w nim zwłaszcza syntetyczne teksty Alicji Helman, Ernesta Wildego i Jolanty Kłyszcz oraz monograficzne artykuły Marka Hendrykowskiego i Andrzeja Kołodyńskiego poświęcone, odpowiednio, twórczości Langa i Murnaua. Ciekawe artykuły o kinie weimarskim można znaleźć także w tomie zbiorowym (poświęconym nie tylko interesującemu nas tu okresowi) Kino niemieckie $w$ dialogu pokoleń $i$ kultur: Studia i szkice pod redakcją Andrzeja Gwoździa (Rabid, Kraków 2004). Godnym polecenia tomem artykułów jest także Niemiecki ekspresjonizm filmowy, wydany przez Petera C. Seela i Bogusława Zmudzińskiego (Akademickie Centrum Kultury 
„Rotunda" - Goethe Institut, Kraków 1995), choć to w zasadzie katalog wydany z okazji przeglądu filmów. Podobny charakter wydawnictw okazjonalnych, lecz wobec szczupłości opracowań w języku polskim wartych odnotowania, mają wydane wspólnie przez Filmotekę Narodową w Warszawie i Goethe Institut monograficzne tomy pod redakcją Renaty Prokurat i Grażyny M. Grabowskiej, poświęcone wybitnym weimarskim reżyserom: Fritz Lang (1993), G. W. Pabst (1995) i Friedrich Wilhelm Murnau (1998). Trzeba wreszcie polecić przekład jednego z najważniejszych w światowym filmoznawstwie tekstów o kanonicznym dla ekspresjonizmu filmie Roberta Wiene: Mike Budd, Odsłony "Gabinetu doktora Caligari", przeł. Iwona Kurz, [w:] Film i historia: Antologia, red. Iwona Kurz, Wydawnictwo Uniwersytetu Warszawskiego, Warszawa 2009, s. 189-241.

Jedynym reżyserem okresu weimarskiego, który doczekał się książkowej monografii w języku polskim, jest Fritz Lang. Jego twórczości w latach 20. poświęcona jest książka Tomasza Kłysa Dekada doktora Mabuse: Nieme filmy Fritza Langa (Wydawnictwo Uniwersytetu Łódzkiego, Łódź 2006).

Dostępne $\mathrm{w}$ języku polskim teoretycznofilmowe prace $\mathrm{z}$ okresu weimarskiego to zwłaszcza Wybór pism Béli Balázsa (przeł. Raoul Porges, Karol Jung, Wydawnictwa Artystyczne i Filmowe, Warszawa 1987) oraz Rudolfa Arnheima Film jako sztuka (przeł. Wanda Wertenstein, Wydawnictwa Artystyczne i Filmowe, Warszawa 1961).

Dla poznania artystycznego kontekstu kina niemieckiego tych lat celowe wydaje się też zapoznanie z monograficznymi tomami w serii „Style - Kierunki - Tendencje", takimi jak Gillian Naylor Bauhaus (przeł. Ewa M. Biegańska, Wydawnictwa Artystyczne i Filmowe, Warszawa 1988) i John Willett Ekspresjonizm (przeł. Maria Kluk, Wydawnictwa Artystyczne i Filmowe, Warszawa 1976). Godna polecenia jest zwłaszcza druga z pozycji, autorstwa jednego z najwybitniejszych w świecie znawców ekspresjonizmu i w ogóle sztuki weimarskiej.

Wreszcie dla poznania kontekstu politycznego, kulturowego i filozoficznego Republiki Weimarskiej rekomendowałbym dwie książki, szczęśliwie dostępne już w języku polskim: Detlev J. K. Peukert, Republika Weimarska: Lata kryzysu klasycznego modernizmu (przeł. Barbara Ostrowska, Wiedza Powszechna, Warszawa 2005) i Peter Sloterdijk Krytyka cynicznego rozumu (przeł. Piotr Dehnel, Wydawnictwo Naukowe Dolnośląskiej Szkoły Wyższej, Wrocław 2008). 



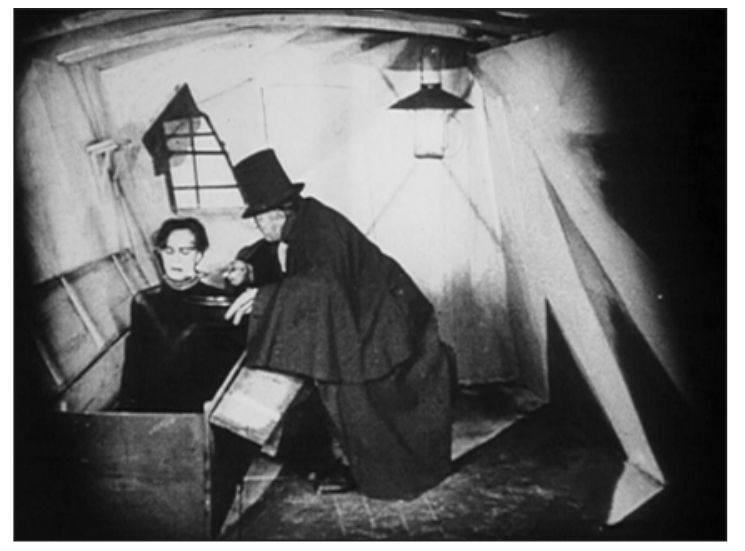

1. Gabinet doktora Caligari (1919, reż. Robert Wiene). Caligari i jego medium, Cezar. Modelowy film ekspresjonizmu

2. Nerwy (1919, reż. Robert Reinert). Impresjonistyczne techniki dla ekspresji chorej niemieckiej duszy
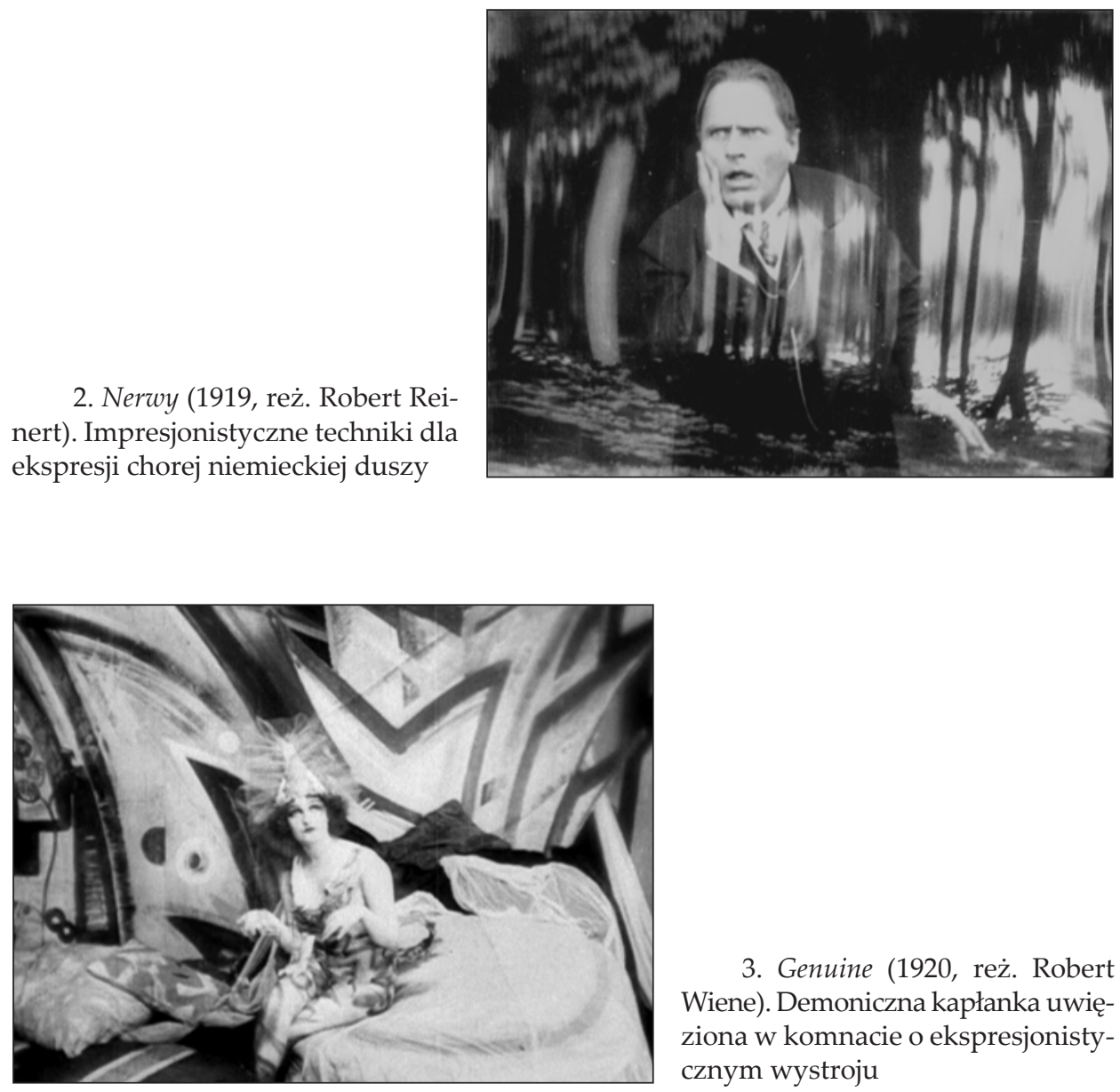

3. Genuine (1920, reż. Robert Wiene). Demoniczna kapłanka uwięziona w komnacie o ekspresjonistycznym wystroju 


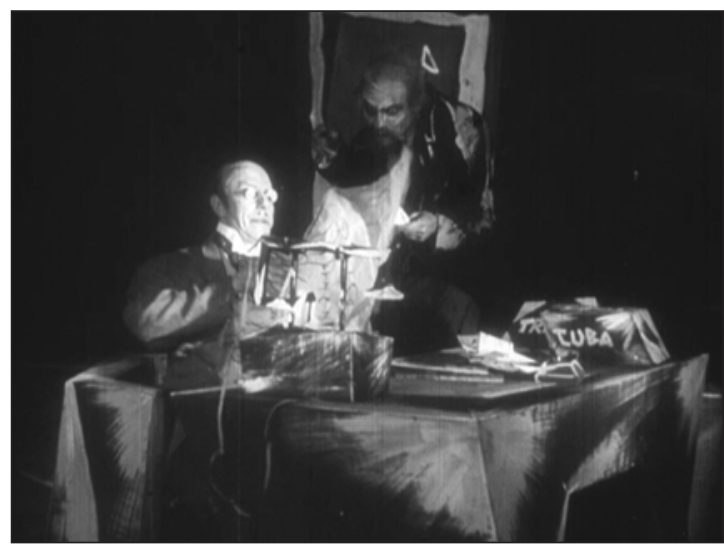

4. Od poranka do pótnocy (1920, reż. Karlheinz Martin). Postacie wtopione w abstrakcyjna, czarną przestrzeń i umowne, rozbielone dekoracje o ekspresjonistycznym designie

5. Faust (1926, reż. Friedrich Wilhelm Murnau). W ekspresjonistycznej scenografii bywa tylko jedna droga dla aktora
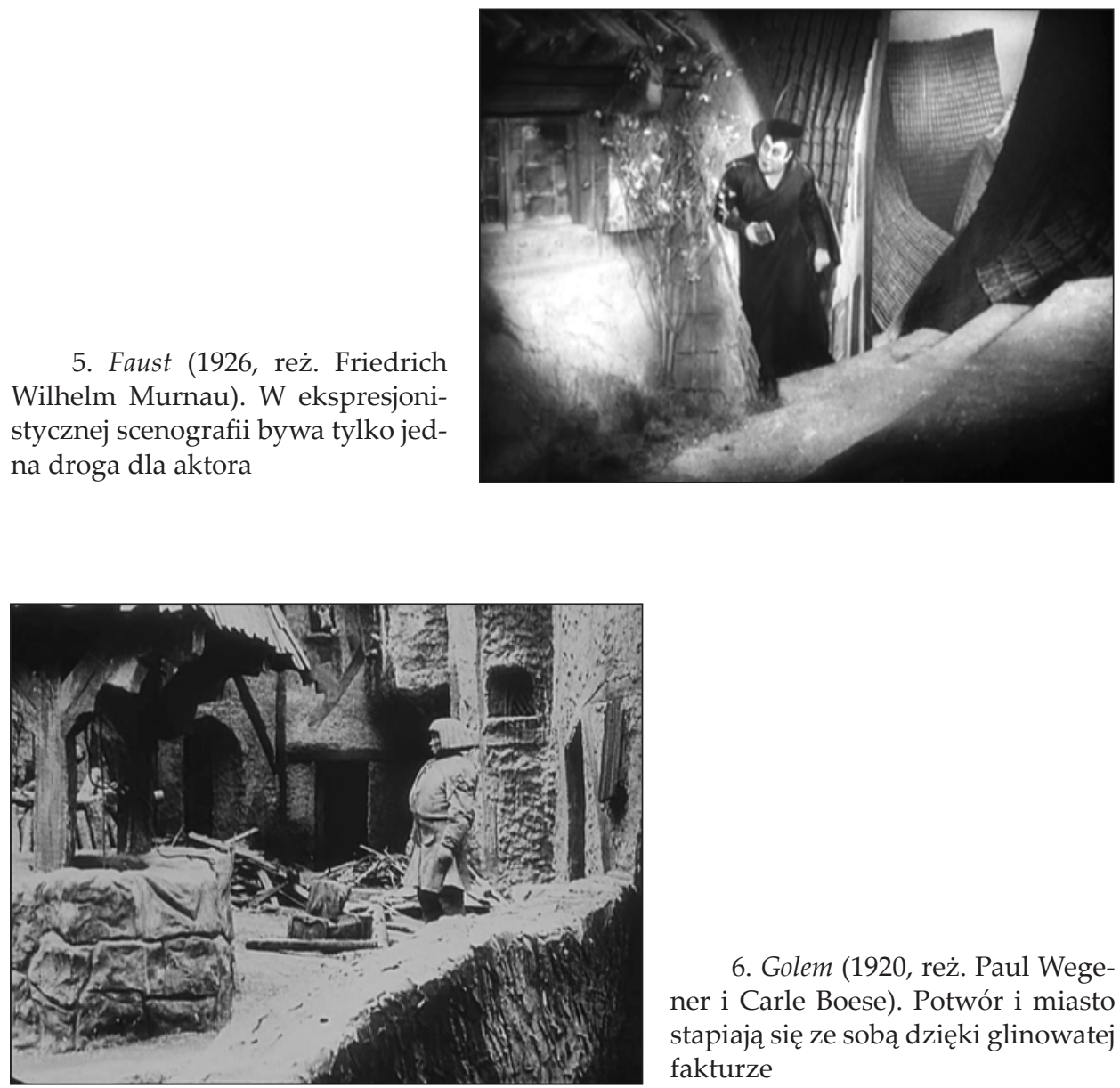

6. Golem (1920, reż. Paul Wegener i Carle Boese). Potwór i miasto stapiają się ze sobą dzięki glinowatej fakturze 


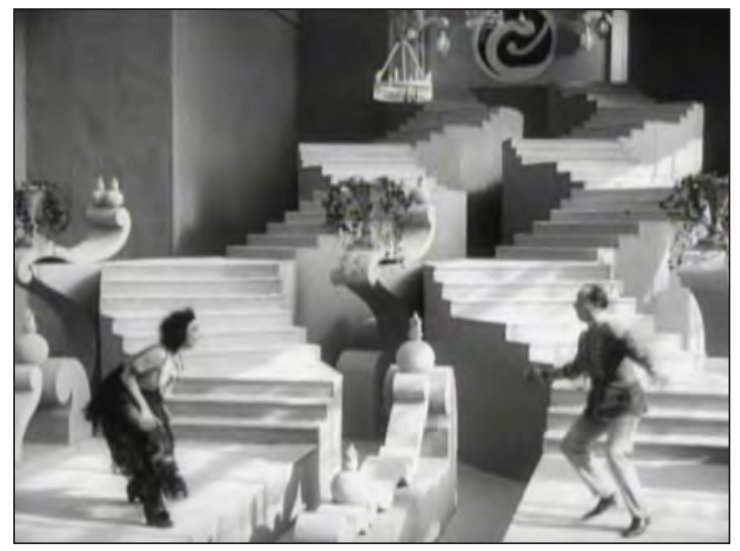

7. Dzika kotka (1921, reż. Ernst Lubitsch). Pastisz ekspresjonistycznej dekoracji (w wariancie egzotycznym)

8. Drogi do sity i piękna (1925, reż. Wilhelm Prager). Wskrzeszanie antycznego ideału czy prenazistowski kult ciała i sportu?
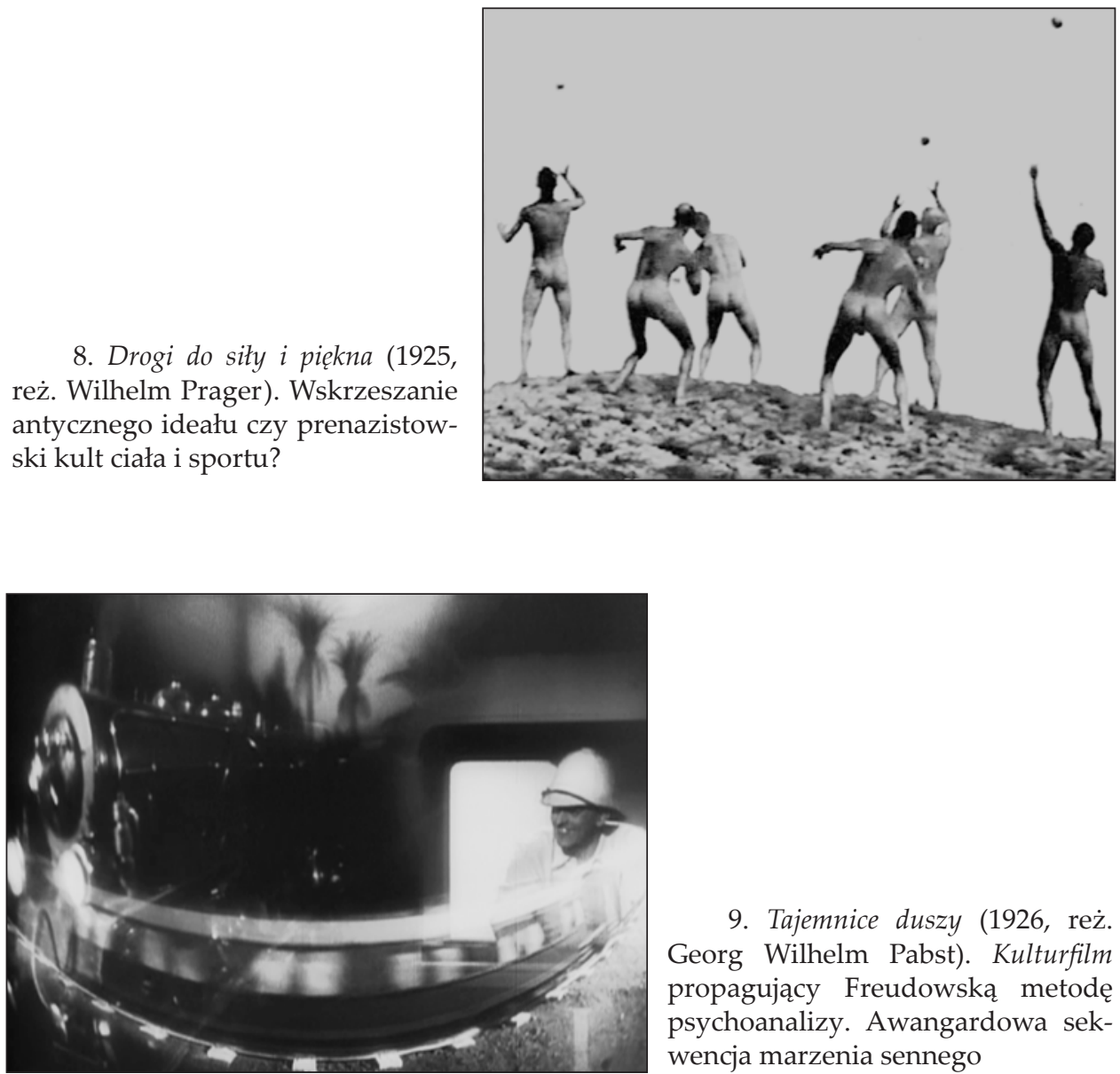

9. Tajemnice duszy (1926, reż. Georg Wilhelm Pabst). Kulturfilm propagujący Freudowską metodę psychoanalizy. Awangardowa sekwencja marzenia sennego 


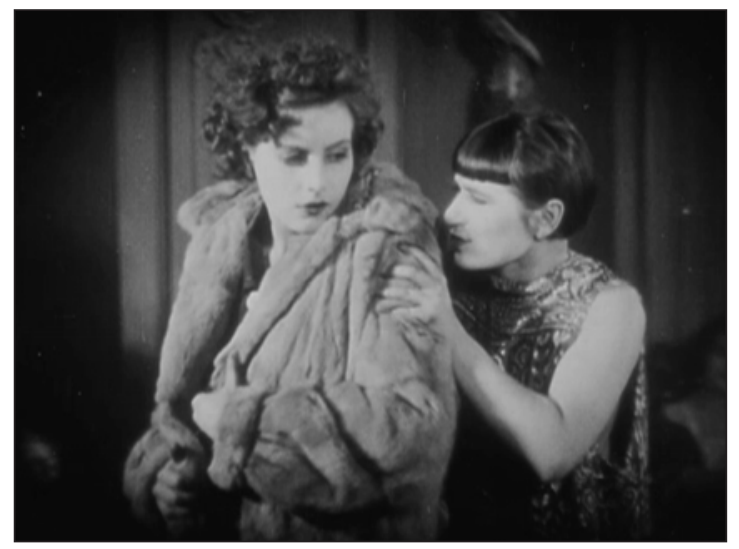

10. Zatracona uliczka (1925, reż. Georg Wilhelm Pabst). Greta i Frau Greifer, stręczycielka (Greta Garbo i Valeska Gert)

11. Puszka Pandory (1929, reż. Georg Wilhelm Pabst). Louise Brooks jako piękna i feralna Lulu
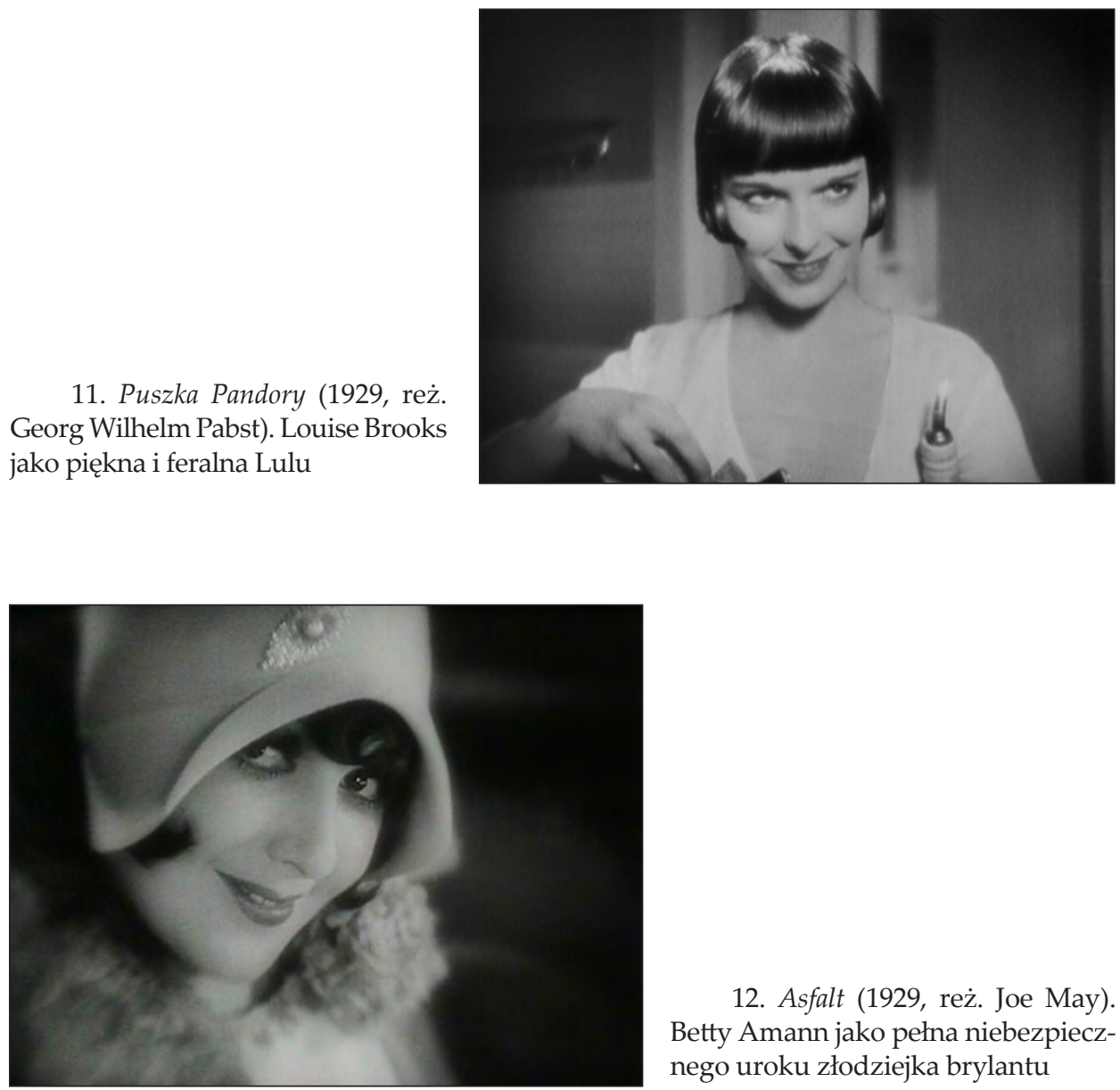

12. Asfalt (1929, reż. Joe May). Betty Amann jako pełna niebezpiecznego uroku złodziejka brylantu 


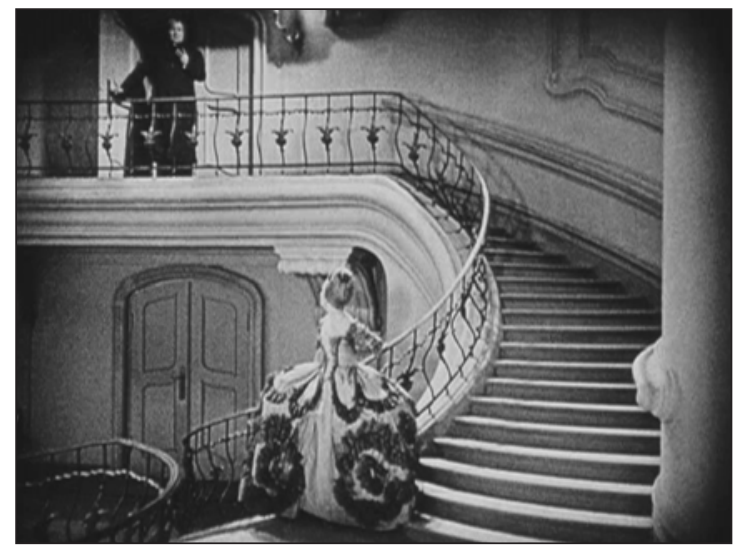

13. Świętoszek (1925, reż. Friedrich Wilhelm Murnau). Kammerspiel w rokokowej scenerii

14. Michael (1924, reż. Carl Theodor Dreyer). Kammerspielfilm na ogół kończy się źle
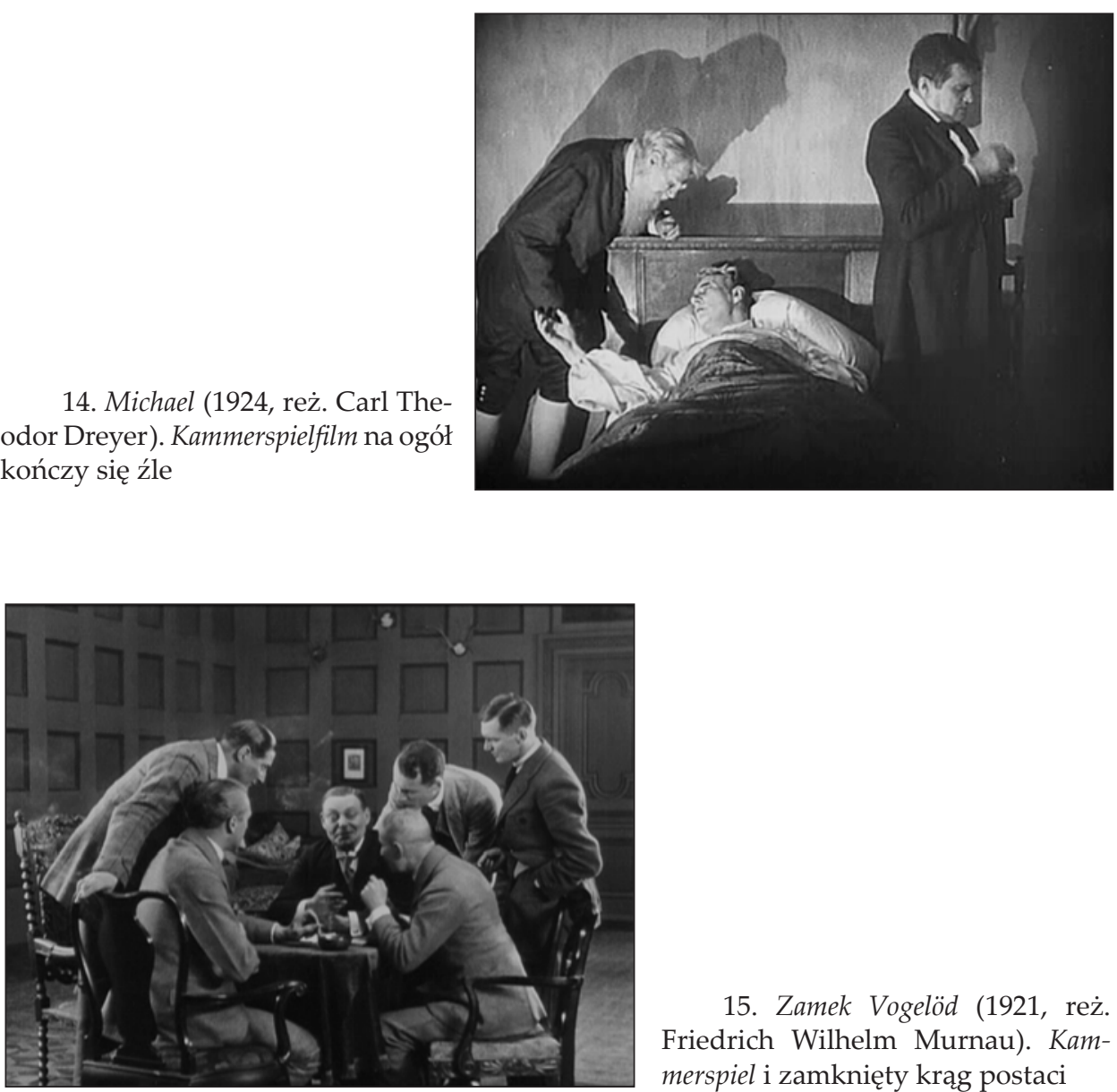

15. Zamek Vogelöd (1921, reż. Friedrich Wilhelm Murnau). Kammerspiel i zamknięty krąg postaci 


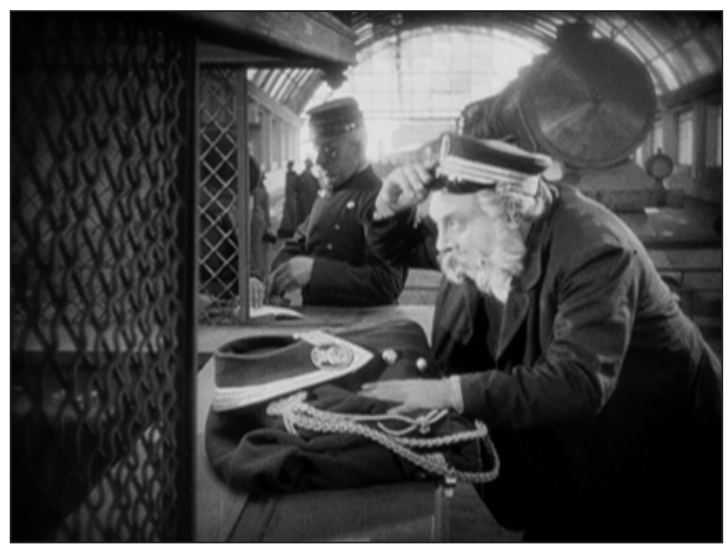

16. Portier $z$ hotelu Atlantic (1924, reż. Friedrich Wilhelm Murnau). Dramat starości i kult munduru

17. Natan Mędrzec (1922, reż. Manfred Noa). Wołanie o rasowa i religijną tolerancję, a zarazem przeczucie Holokaustu. W roli tytułowej Werner Krauss
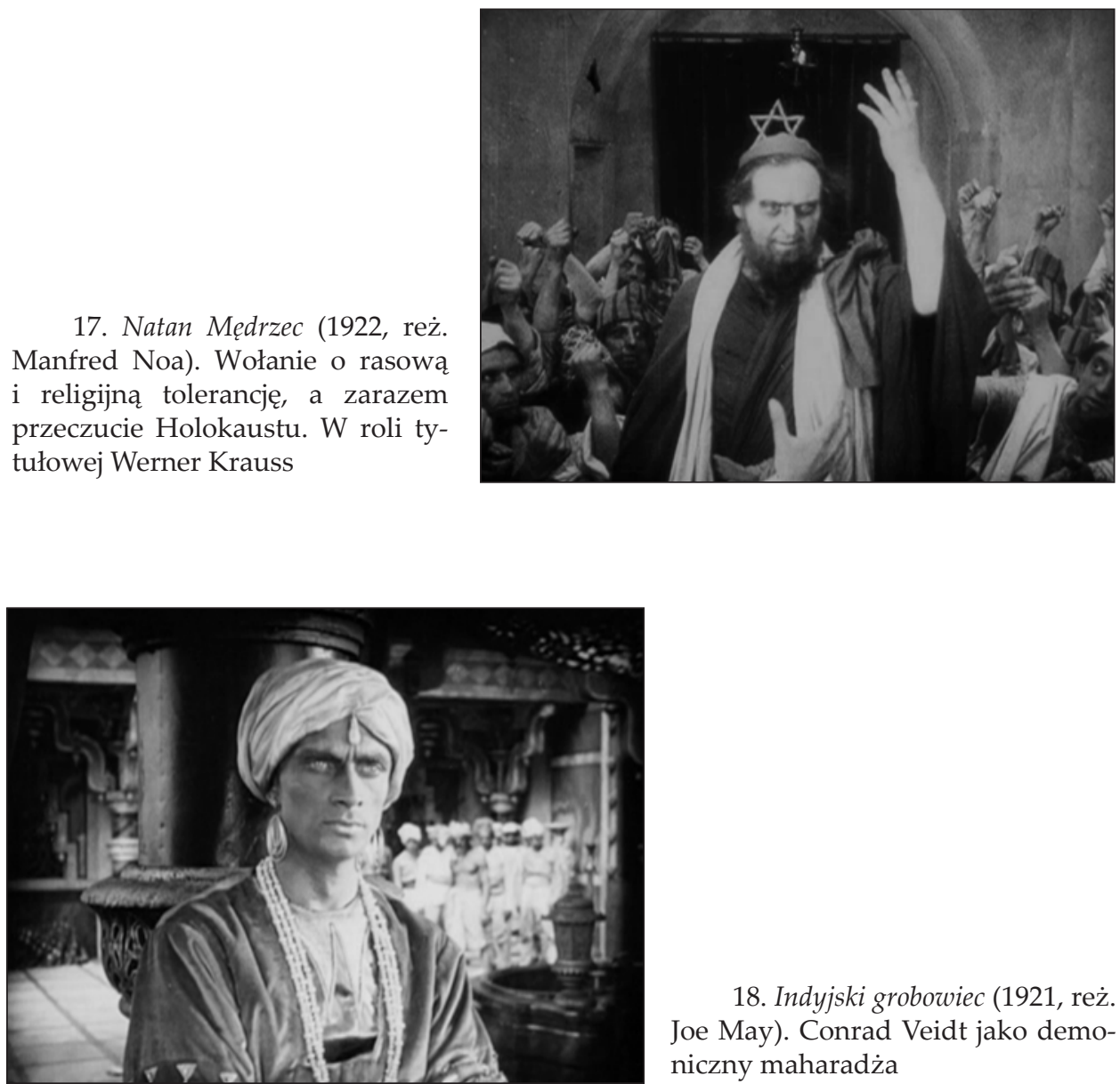

18. Indyjski grobowiec (1921, reż. Joe May). Conrad Veidt jako demoniczny maharadża 


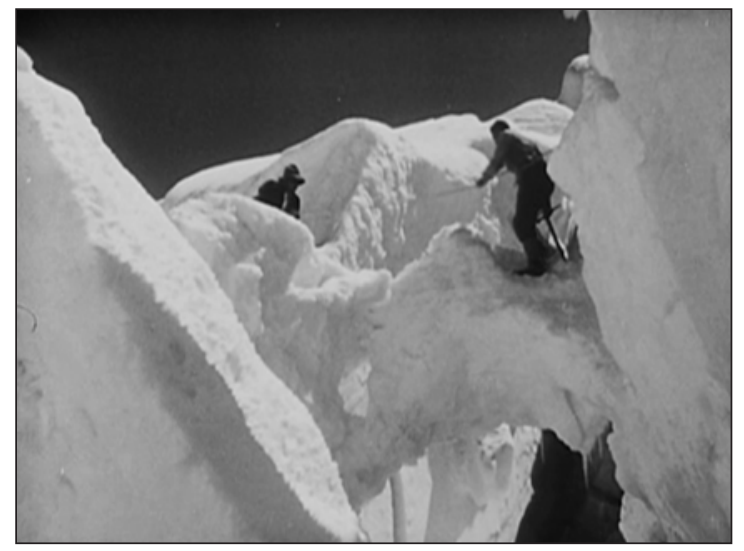

19. Białe piekło na Piz Palü (1929, reż. Arnold Fanck i Georg Wilhelm Pabst). Groźna sceneria górskiego lodowca

20. Nie chcę być mężczyzna (1918, reż. Ernst Lubitsch). Dwuznaczny seksualnie podtekst
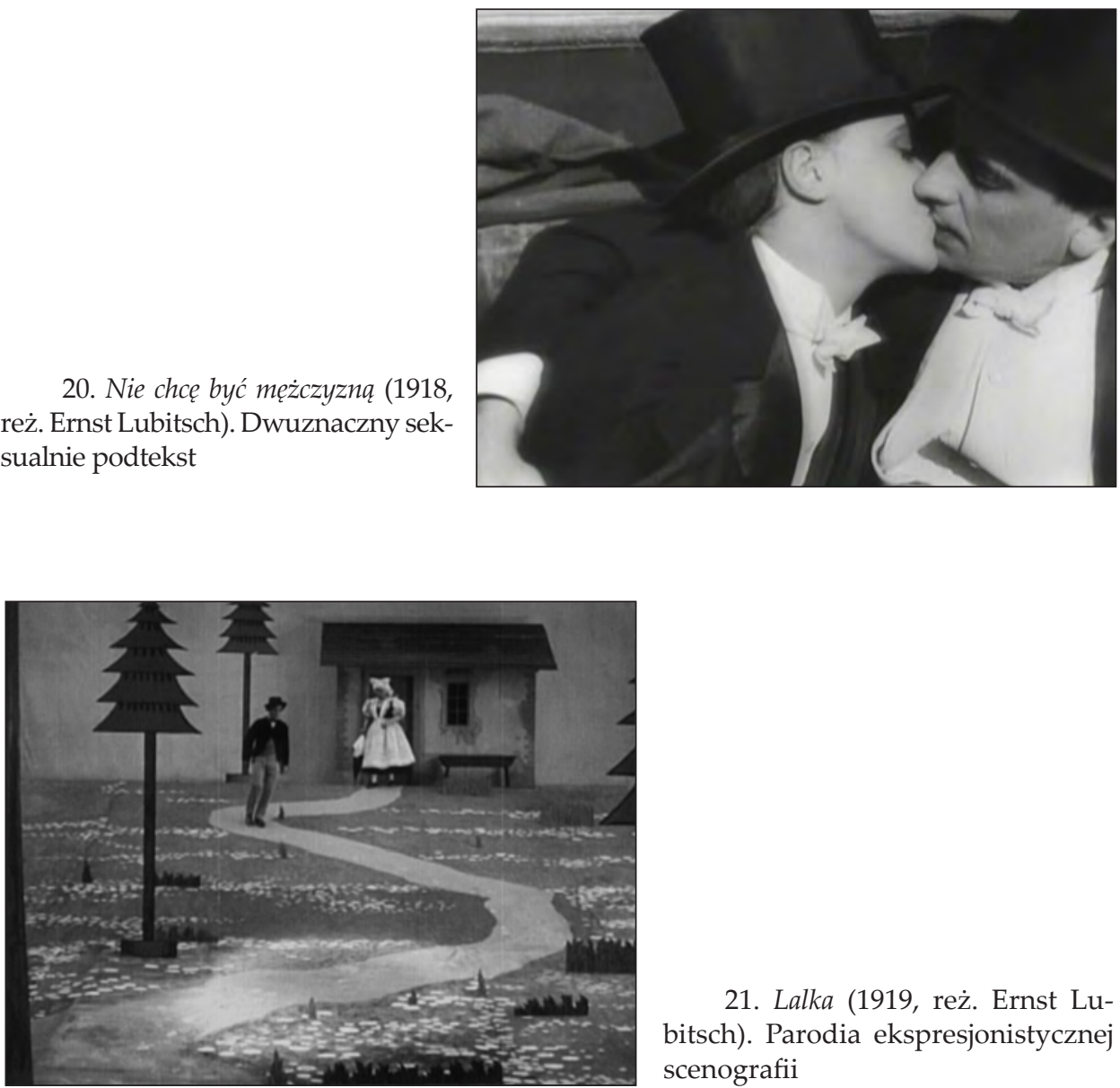

21. Lalka (1919, reż. Ernst Lubitsch). Parodia ekspresjonistycznej scenografii 


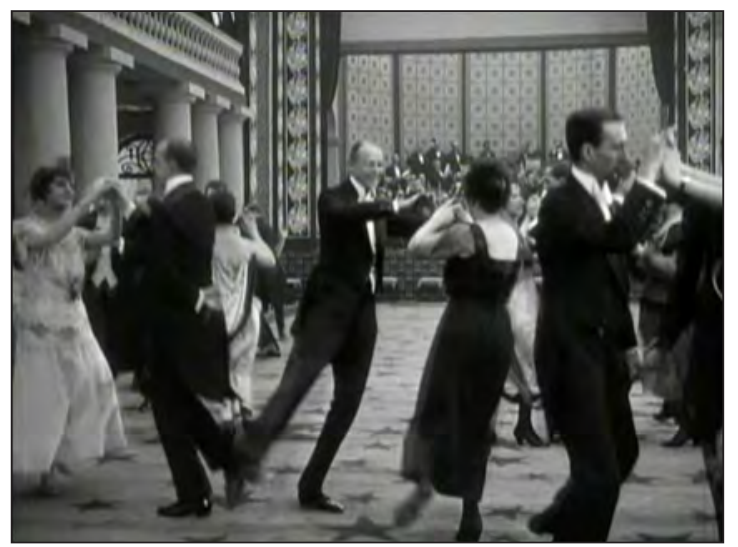

22. Księżniczka ostryg (1919, reż. Ernst Lubitsch). Niewiarygodnie śmieszny fokstrot

23. Inaczej niż inni (1919, reż. Richard Oswald). Zabawa taneczna homoseksualistów w jednym z najgłośniejszych filmów uświadamiających
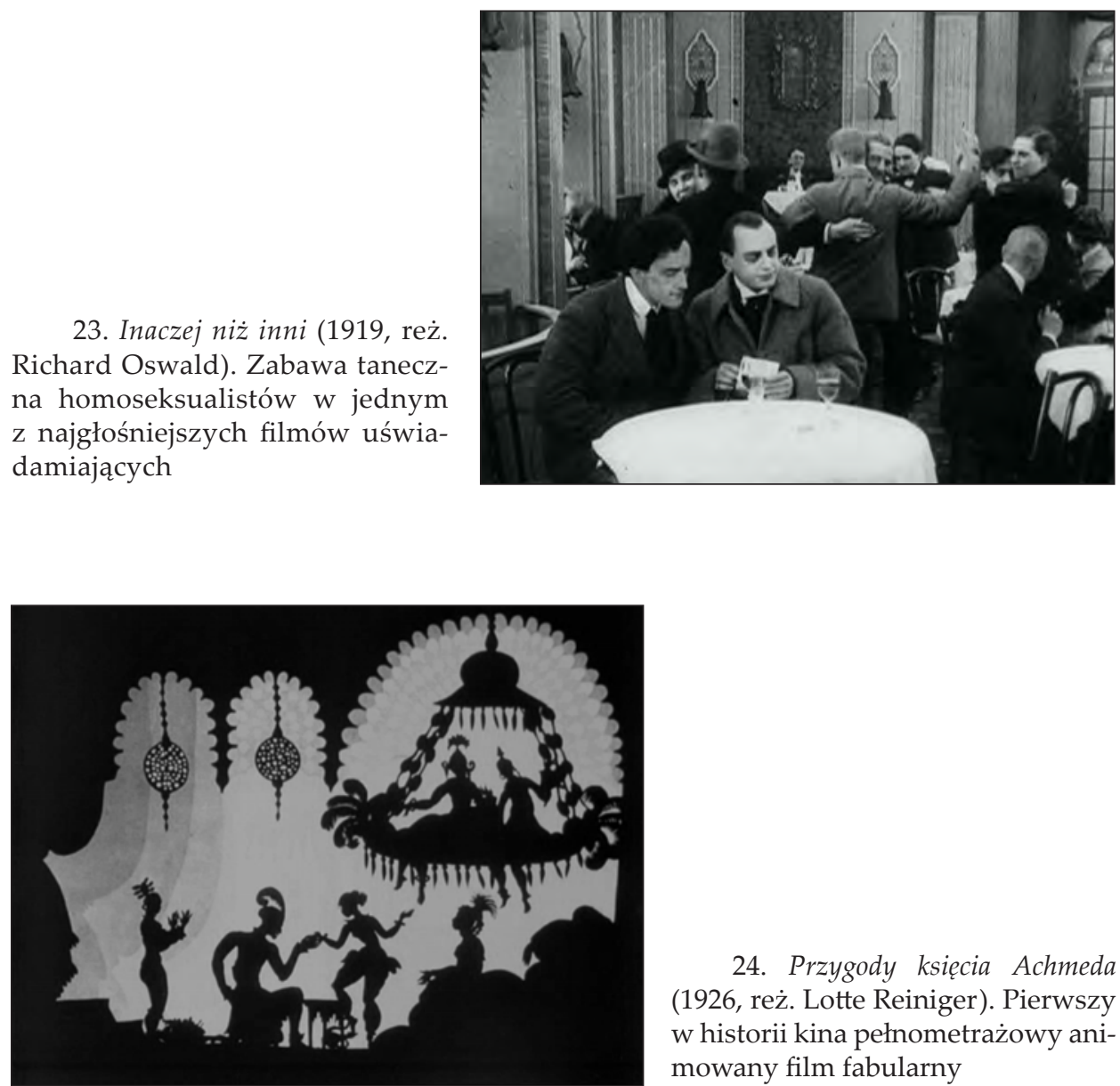

24. Przygody księcia Achmeda (1926, reż. Lotte Reiniger). Pierwszy w historii kina pełnometrażowy animowany film fabularny 


\section{Rozdział 2}

\section{NIEMIECKI FILM FABULARNY OD PRZEŁOMU DŹWIĘKOWEGO DO UPADKU TRZECIEJ RZESZY (1929-1945)}

\section{Między Weimarem a Trzecią Rzeszą - przepaść czy ciągłość?}

Dnia 30 stycznia 1933 r. prezydent Hindenburg, po częstych w poprzedzających kilku latach wyborach parlamentarnych ${ }^{1}$ i jeszcze częstszych kryzysach gabinetowych, mianował kanclerzem swego niedawnego rywala z wyborów prezydenckich ${ }^{2}$, przywódcę narodowych socjalistów Adolfa Hitlera. Data owa, jak wiemy z dalszej historii Niemiec i świata, oznaczała definitywny kres Republiki Weimarskiej powołanej do istnienia w roku 1919 na gruzach cesarstwa wilhelmińskiego, a tym samym - kres na długie lata chwiejnej niemieckiej demokracji, którą zastąpiła totalitarna dyktatura narodowych socjalistów (oficjalnie Trzecią Rzeszę powołała do istnienia tzw. proklamacja poczdamska z 15 marca 1933). Cezura polityczna 1933 r. jest czymś tak oczywistym, iż nie wymaga ona uzasadnienia także $\mathrm{w}$ pisanych historiach filmu. Trzeba jednak powiedzieć, iż postrzeganie historii kina niemieckiego tylko poprzez tę cezurę, odzielającą niczym jakaś ogromna szczelina tektoniczna obfitujące $\mathrm{w}$ artystyczne dokonania i formalne eksperymenty kino weimarskie od serwującego zasadniczo nazistowską propagandę i kiczowatą rozrywkę kina Trzeciej Rzeszy, jest kreowaniem obrazu nie tylko uproszczonego, ale i generalnie fałszującego faktyczny stan rzeczy³. 1932.

${ }^{1}$ Wybory parlamentarne miały miejsce: 14 września 1930, 31 lipca 1932 i 6 listopada

${ }^{2}$ Wybory odbyły się w dwóch turach: 13 marca i 10 kwietnia 1932.

3 Taki upraszczający obraz przynoszą m.in. odpowiednie rozdziały w Historii sztuki filmowej Jerzego Toeplitza (t. 4: 1934-1939, Wydawnictwa Artystyczne i Filmowe, Warszawa 1969, rozdział V: Film pod znakiem swastyki, s. 261-300; t. 5: 1939-1945, Warszawa 1970, rozdział V: Film Trzeciej Rzeszy w czasie wojny, s. 222-258) czy skądinąd cenna faktograficznie książka Bogusława Drewniaka Teatr i film Trzeciej Rzeszy, Wydawnictwo Morskie, Gdańsk 1972, s. 160-309 (nb. wycofana przez cenzurę PRL już z księgarń; część nakładu zdołano jednak przedtem sprzedać). 
Po pierwsze zatem, zaledwie jedna szósta z ok. 1100 niemieckich filmów fabularnych zrealizowanych między 1933 r. a kapitulacją Trzeciej Rzeszy 8 maja $1945^{4}$ (czyli ok. 16-17\%) to filmy o jawnie propagandowej zawartości, z nieskrywanym przesłaniem politycznym. Zamówione przez państwo tzw. Staatsauftragsfilme, finansowane przez Wydział Filmowy Ministerstwa Oświecenia Publicznego i Propagandy zarządzanego przez Josepha Goebbelsa, to zaledwie 96 tytułów z ogólnej produkcji ${ }^{5}$. Takie proporcje wynikają z przyjętej przez Goebbelsa strategii ${ }^{6}$, by dostarczać publiczności przede wszystkim atrakcyjnej rozrywki. „Większość filmów wyprodukowanych w państwie Hitlera oferowała radosne doznania, antidotum przeciwko propagandzie i polityce, rozładowanie emocjonalnych napięć, uciechę z codziennych małych przyjemności poza dramatami walki i śmierci w realnym życiu" - pisze historyk Ufy, Klaus Kreimeier ${ }^{7}$. Owe wyabstrahowane z bieżącego kontekstu politycznego, oferujące przyjemności komedie, melodramaty i musicale (bo one zdominowały niemiecką produkcję w latach 1933-1945) lansowały też pewien konsumpcjonistyczny styl życia, związany z nowoczesna, zurbanizowaną kultura, masową produkcją przemysłową dóbr będących obiektem pożądania (samochód, odbiornik radiowy, gadżety kuchenne), z mediami i środkami komunikacji (samolot, auto, pociąg, jacht, metro, tramwaj). Z jednej strony przedłużało to trwanie w niemieckim kinie estetyki Nowej Rzeczowości, zapoczątkowanej w połowie lat 20. (choć już bez jej uprzedniego krytycyzmu i sarkazmu), z drugiej - utwierdzało widownię w przekonaniu (pośrednio, nie wprost), że nowoczesne, narodowo-socjalistyczne państwo rozwijające produkcję przemysłową (nie tylko czołgów, ale i dóbr konsumpcyjnych) oraz budujące autostrady i gęstą sieć kolei jest gwarantem takiego

${ }^{4}$ Por. David Welch, Propaganda and the German Cinema 1933-1945, I. B. Tauris \& Co. Ltd., London-New York 2006, s. 36. Welch podaje liczbę 1097 filmów fabularnych „wyprodukowanych w Trzeciej Rzeszy", Eric Rentschler (The Ministry of Illusion: Nazi Cinema and Its Afterlife, Harvard University Press, Cambridge, Mass.-London 1996, s. 225) 1094 filmy niemieckie, które miały swą publiczną premierę po 30 stycznia 1933 a przed 7 maja 1945 - nawet jeśli po kilku pokazach zostały zakazane. Liczba 1094 nie obejmuje jednak 26 filmów zatrzymanych przez cenzurę i niedopuszczonych na ekrany, 67 koprodukcji z innymi kinematografiami, filmów firmowanych przez Austrię przed Anschlussem oraz filmów zakazanych w Niemczech, za to mających swe premiery w innych krajach. Uwzględniając owe filmy niedopuszczone, pokazywane tylko za granicą czy koprodukcje, możemy „przypisać” Trzeciej Rzeszy w sumie około 1200 filmów fabularnych.

${ }^{5}$ D. Welch, op. cit., s. 36.

${ }^{6}$ Kontestowanej przez niektórych wpływowych członków NSDAP, np. Alfreda Rosenberga.

${ }^{7}$ Klaus Kreimeier, The Ufa Story: A History of Germany's Greatest Film Company, 1918-1945, transl. Robert and Rita Kimber, University of California Press, Berkeley-Los Angeles-London 1999, s. 216. 
„idyllicznego" status quo ${ }^{8}$. Kreimeier zauważa jednak, iż cel narodowych socjalistów był dwojaki: prócz wzbudzenia w społeczeństwie poczucia „normalności” stworzonego przez nich systemu, musieli też zainwestować niemałe środki, kreując szczególną „aurę" niepowtarzalnej „narodowej rewolucji", przekształcającej wszystkie aspekty życia społecznego, jednocześnie „przedstawiając siebie jako półbogów wybranych przez Przeznaczenie i spowitych $\mathrm{w}$ tragiczne chmury bitewne ${ }^{\prime \prime}$. Oczywiście, tę funkcję pełniły przede wszystkim rozmaite publiczne ceremonie realizowane $\mathrm{z}$ wielką pompa, będące teatrem na żywo i zawierające przewidziany z góry potencjał medialny, np. transmitowane na żywo przez wszystkie niemieckie rozgłośnie radiowe obchody Narodowego Dnia Pracy (1 maja 1933), norymberskie Parteitagi [jak ten ukazany w Triumfie woli (Triumph des Willens, 1934) Leni Riefenstahl] czy Igrzyska Olimpijskie $1936 \mathrm{w}$ Berlinie [również uwiecznione w dokumentalnym dyptyku montażowym Leni Riefenstahl Olimpiada (Olympia, 1938)]. Nośnikiem hitlerowskiej propagandy i nazistowskiej ideologii były zatem zasadniczo filmy niefabularne: dokumenty, Kulturfilme i kroniki, zwłaszcza osławiony Wochenschau. Rola propagandowego filmu niefabularnego wzrosła, rzecz jasna, wraz z wybuchem wojny.

Po drugie, kiedy ogląda się w jednym ciągu filmy weimarskie i filmy powstałe w Trzeciej Rzeszy (a przygotowując niniejszy rozdział, obejrzałem 35 filmów ze schyłkowego okresu Weimaru 1929-1933 i ok. 120 filmów z epoki nazistowskiej, łącznie ok. 155 tytułów), uderza ich podobnie wysoki poziom warsztatowo-techniczny, kontynuowanie w Trzeciej Rzeszy weimarskich trendów stylistycznych i konwencji gatunkowych, wreszcie podobna ambiwalencja sensów ideowych i to zarówno wtedy, gdy analizuje się „intencjonalne” przesłanie „tekstów”, jak i ich „nieświadomość". Już książka Kracauera Od Caligariego do Hitlera unaocznia, iż weimarskie filmy - przy całej klasie artystycznej wielu z nich - nie były bynajmniej takie niewinne ideowo. Można się bowiem często zastanawiać, czy były tylko „przeczuciem” nazizmu, czy może jednak mniej lub bardziej (nie)świadomym w y r a z em jakichś prenazistowskich postaw i ciągot; ta niepewność dotyczy tak wybitnych dzieł, jak prawie wszystkie filmy Fritza Langa z lat 1921-1933 czy uznawane zasadniczo za wyraz tendencji demokratycznych arcydzieła późnego Weimaru: Błękitny Anioł (Der Blaue Engel/The Blue Angel, 1930) Josefa von Sternberga, Dziewczęta w mundurkach (Mädchen in Uniform, 1931) Leontine Sagan i Carla Froelicha czy Berlin Alexanderplatz (Berlin-Alexanderplatz: Die Geschichte Franz Biberkopfs, 1931)

8 Por. Thomas Elsaesser, Weimar Cinema and After: Germany's Historical Imaginary, Routledge, London-New York 2000, s. 383-415.

${ }_{9}$ K. Kreimeier, op. cit., s. 215. 
Piela Jutziego. Z kolei w filmach fabularnych Trzeciej Rzeszy uderza dominujący w nich eskapizm, totalne abstrahowanie od bieżącego kontekstu (zwłaszcza w filmach z lat wojny, co jest szokujące dla dzisiejszego widza). Nierzadko można się w nich, nie bez podstaw, dopatrzyć "subwersywności" (modne dziś słowo), aspektów wręcz wywrotowych czy kontestacyjnych wobec nazistowskiego porządku - i to nie tylko u kontynuującego libertyńską tradycję Lubitscha, mistrza zwariowanych komedii Reinholda Schünzla (tylko do czasu tolerowanego w Rzeszy) ${ }^{10}$ czy mistrza nastrojowego melodramatu - Rolfa Hansena, ale i przynajmniej w niektórych filmach reżyserów hołubionych przez hitlerowski reżim: Karla Rittera [Urlop na słowo honoru (Urlaub auf Ehrenwort, 1938); Capriccio, 1938], Carla Froelicha [Byłem Jackiem Mortimerem (Ich war Jack Mortimer, 1935); Traumulus (1936); Kręte drogi pięknego Karola (Die Umwege des schönen Karl, 1938); Inkasent (Der Gasmann, 1941)] czy Veita Harlana [Zatarte ślady (Verwehte Spuren, 1938), a nawet osławione Żyd Süss (Jud Süß, 1940) czy Kolberg (1945)].

Po trzecie, jako argument na rzecz zerwania, przepaści nie do zasypania między kinem weimarskim a kinem okresu nazistowskiego, jest na ogół przytaczany fakt, iż po przejęciu władzy przez Hitlera wyemigrowała z Niemiec wielka rzesza ludzi związanych z branżą filmową (głównie pochodzenia żydowskiego, lecz nie tylko - także tych związanych z polityczną lewica). Istotnie, lista ta obejmuje ponad 1500 osób, rozmaitych kinematograficznych profesji: producentów (Erich Pommer, Seymour Nebenzahl, Gregor Rabinowitsch, Alexander Korda, Arnold Pressburger, Friedrich Zelnik), scenarzystów (Carl Mayer, Billie Wilder), reżyserów (Fritz Lang, Robert Siodmak, Anatol Litvak, Joe May, Erik Charell, Wilhelm Thiele, Ludwig Berger, Edgar Ulmer, Kurt Bernhardt, Max Ophüls, Georg Wilhelm Pabst, Richard Oswald, Slatan Dudow, Fiodor Ocep, Hanns Schwarz), aktorów (Elisabeth Bergner, Marlena Dietrich ${ }^{11}$, Rosa Valetti, Lucie Mannheim, Fritzi Massary, Conrad Veidt, Peter Lorre, Albert Bassermann, Ernst Deutsch, Richard Tauber, Fritz Kortner, Max Hansen,

10 Schünzel, aktor i reżyser, mimo swego żydowskiego pochodzenia był tolerowany przez Goebbelsa jako twórca niezwykle dochodowy. Do emigracji skłoniły go dopiero kłopoty z cenzura, jakie miał jego ostatni niemiecki film, komedia Kraina miłości (Land der Liebe, 1937). Wzbudziła ona furię Goebbelsa, który w swym dzienniku określił ją jako „typowo żydowskie brednie” (zob. K. Kreimeier, op. cit., s. 284-285). Ciekawy portret Schünzla kreśli też Thomas Elsaesser (Weimar Cinema and After, s. 295-310).

11 Marlena już wcześniej wyjechała do Hollywood ze Sternbergiem, po sukcesie Błękitnego Anioła w 1930 r. Nakłaniana wielokrotnie przez reżim oparła się jednak pokusom astronomicznych honorariów i bycia największą gwiazdą Trzeciej Rzeszy i do Niemiec nie wróciła (czego nigdy nie mogła jej wybaczyć znaczna część niemieckiej publiczności jeszcze wiele lat po wojnie). 
Siegfried Arno, Otto Wallburg ${ }^{12}$, Kurt Gerron ${ }^{13}$ ), operatorów (Eugen Schüfftan, Rudolph Maté), kompozytorów muzyki filmowej (Friedrich Holländer, Paul Dessau, Erich Wolfgang Korngold). Oczywiście, strata tak wielu wybitnych postaci była potężnym ciosem dla kina niemieckiego, znacznie dotkliwszym niż pierwsza emigracja do Hollywood w latach 20. Warto też wymienić nazwiska tych, którzy pozostali w Niemczech lub zastąpili mistrzów-emigrantów jako nowa generacja. Jest to całkiem imponujący zestaw postaci, a wielu z nich trzeba przyznać pierwszorzędną rangę artystyczną. Wśród twórców, którzy wystartowali w kinie niemieckim lub austriackim jeszcze przed rokiem 1933, w Trzeciej Rzeszy pracowali: Walter Ruttmann, Paul Wegener, Carl Boese, Carl Froelich, Willy Forst, Hans Steinhoff, Leni Riefenstahl, Arnold Fanck, Luis Trenker, Gerhard Lamprecht, Gustav Ucicky, Karl Hartl, Georg Wilhelm Pabst ${ }^{14}$, Piel Jutzi, Curt Goetz (do 1939), Reinhold Schünzel (do 1937), Géza von Bolváry, Georg Jacoby, Thea von Harbou, Erich Engel, Herbert Selpin, Erich Waschneck. Najwybitniejszymi debiutantami Trzeciej Rzeszy spośród reżyserów byli: Veit Harlan, Karl Ritter, Detlef Sierck ${ }^{15}$, Wolfgang Staudte, Helmut Käutner, Wolfgang Liebeneiner, Rolf Hansen, Herbert Maisch, Eduard von Borsody, Josef von Báky. A Wiktor Turżański, rosyjski biały emigrant, trafił do kina Rzeszy z kinematografii francuskiej. Równie imponujący jest zestaw aktorów - w Trzeciej Rzeszy kontynuują swe kariery takie gwiazdy sprzed 1933 r., jak: Emil Jannings, Heinrich George, Werner Krauss, Willy Fritsch, Heinz Rühmann, Hans Albers, Mathias Wieman, Otto Wernicke, Gustaf Gründgens, Gustav Fröhlich,

12 Wallburg, który nie wyemigrował do Ameryki, został w roku 1944 aresztowany przez gestapo w Holandii i deportowany do Auschwitz, gdzie zginął w komorze gazowej (K. Kreimeier, op. cit., s. 213).

${ }^{13}$ Historia Kurta Gerrona jest bardzo podobna do tej Wallburga. Również nie wyemigrował za ocean, również w Holandii został aresztowany w latach wojny i również zginął w Auschwitz (28 października 1944) - jak na gorzką ironię, w ostatnim gazowaniu, jakie miało tam miejsce. Przedtem jednak został zmuszony przez hitlerowców do zrealizowania propagandowego filmu o „dobrodziejstwach” getta-obozu w Terezinie pt. Theresienstadt (Theresienstadt. Ein Dokumentarfilm aus dem jüdischen Siedlungsgebiet, 1944).

${ }^{14}$ Po wyjeździe z Niemiec w 1933 Pabst pracował we Francji i w USA. Tuż przed wojną powrócił jednak do rodzinnej Austrii, która tymczasem po Anschlussie znalazła się w granicach Rzeszy. Tam zastał go wybuch wojny. Dla hitlerowskiej kinematografii zrealizował dwa, zresztą bardzo ciekawe artystycznie, filmy: Komedianci (Komödianten, 1941) i Paracelsus (1943).

${ }_{15}$ Po 1937 na emigracji, Detlef Sierck zasłynął w Hollywood jako Douglas Sirk. Jego niemieckie melodramaty (zresztą formalnie znakomite) nie są bynajmniej ideologicznie niewinne i „eskapistyczne”, lansując skąpaną w nazistowskim sosie ideę nordyckiej ojczyzny (Heimat), za którą bohaterki tęsknią na obczyźnie - Ostatni akord (Schlußakkord, 1936), La Habanera (1937). 
Gustav Diessl, Theodor Loos, Hans Moser, Rudolf Klein-Rogge, Paul Hörbiger, Fritz Rasp, Rudolf Forster, Viktor de Kowa, Adolf Wohlbrück ${ }^{16}$, Friedrich Kayßler, Theo Lingen, Harry Liedtke, Paul Hartmann [nie zapominajmy o reżyserach-aktorach, w owym okresie z pewnością bardziej popularnych jako aktorzy: Paul Wegener, Willi (Willy) Forst ${ }^{17}$, Luis Trenker $]^{18}$. Do tych dołączyli aktorzy debiutujący już w Trzeciej Rzeszy: Ferdinand Marian, Carl Raddatz, Viktor Staal, Willy Birgel, Joachim Gottschalk ${ }^{19}$. Spośród aktorek okresu weimarskiego w filmach Trzeciej Rzeszy występowały: Lilian Harvey, Olga Czechowa, Sybille Schmitz, Renate Müller, Lil Dagover, Henny Porten, Brigitte Helm (do 1935), Pola Negri, Brigitte Horney, Magda Schneider, Jenny Jugo, Adele Sandrock, Hilde Hildebrand, Margarete Kupfer, Frida Richard, Käthe von Nagy, Hertha Thiele ${ }^{20}$, Marta Eggerth ${ }^{21}$. Nowymi twarzami Rzeszy były przede wszystkim cudzoziemki: Szwedki ${ }^{22}$-Zarah Leander i Kristina Söderbaum, Czeszka - Lída Baarová, roztańczona Węgierka - Marika Rökk, choć równie popularne i nie mniej utalentowane były odkrycia rodzime (Marianne Hoppe, Ilse Werner, Carsta Löck, Ursula Herking) i „wiedenki” (Paula Wessely, Luise Ullrich, Käthe Gold, Heidemarie Hatheyer). W kinie Trzeciej Rzeszy kontynuuje karierę zawodową czołówka weimarskich operatorów filmowych ${ }^{23}$ (Fritz Arno Wagner, Carl Hoffmann, Günther Rittau, Sepp Allgeier, Richard Angst, Hans Schneeberger, Guido Seeber, Willy Hameister) oraz scenografów (Otto Hunte, Erich Kettelhut, Robert

16 Adolf Wohlbrück po 1936 przebywał na emigracji. W filmach angielskich i francuskich występował jako Anton Walbrook.

${ }_{17}$ W czołówkach filmów Forst na przemian figuruje jako Willi lub Willy.

18 Także spośród filmowców nowej generacji niektórzy, zanim ostatecznie nie wybrali kariery reżyserskiej, zagrali sporo ról filmowych - Wolfgang Liebeneiner, Veit Harlan, Wolfgang Staudte.

19 Gottschalk to postać tragiczna. Nie chcąc rozwieść się z żoną Żydówką, do czego był nakłaniany przez Goebbelsa, w 1941 uprzedził planowany cios (wysłanie jego na front, a żony do obozu w Theresienstadt) - zabił żonę i trzyletniego syna, po czym sam popełnił samobójstwo.

${ }^{20}$ Pełna uroku gwiazda Kuhle Wampe i Dziewczat w mundurkach opuściła Niemcy dopiero w roku 1937.

${ }^{21}$ Także jej przyszły mąż (od 1936), nasz rodak - Jan Kiepura, zagrał w czterech ukończonych w Trzeciej Rzeszy filmach [tylko o udział w pierwszym z nich, Pieśn dla ciebie (Ein Lied für dich), zrealizowanym w 1933 przez Joe Maya jeszcze przed jego emigracja, nie można by mieć do niego pretensji o co najmniej polityczną lekkomyślność].

22 Jeden wypad do Berlina Ingrid Bergman, by w roku 1938 zagrać w (bardzo zresztą dobrym) filmie Carla Froelicha Spótka czterech (Die vier Gesellen), nie uczynił z niej, jak z rodaczek, gwiazdy Rzeszy.

${ }^{23}$ Z wyjątkiem przebywającego w Hollywood Karla Freunda oraz raczej kosmopolitycznego niż ściśle związanego z kinem niemieckim Rudolpha Maté (operatora m.in. filmów Dreyera - Michael, Męczeństwo Joanny d'Arc, Wampir). 
Herlth, Walter Reimann, Walter Röhrig, Hermann Warm, Rochus Gliese) - to właśnie dzięki nim filmy zrealizowane w Trzeciej Rzeszy zachowują plastyczne wyrafinowanie obrazu i inscenizacyjny rozmach, którego nie powstydziłby się Hollywood, oraz stylistyczną ciągłość z kinem weimarskim. Wyliczanka tych wszystkich nazwisk może się wydawać przydługa, ale pokazuje, iż mimo exodusu filmowców po dojściu nazistów do władzy potencjał kadrowy kina niemieckiego po roku 1933 nadal był ogromny.

Po czwarte wreszcie, argument na rzecz nieciągłości między kinem Weimaru a Trzeciej Rzeszy w postaci stwierdzenia, iż kino weimarskie było w znacznej mierze "artystyczne", a w okresie nazistowskim serwowało prócz propagandy jedynie prymitywną rozrywkę, jest o tyle nietrafiony, iż po przełomie dźwiękowym nastąpiło zasadnicze „urozrywkowienie” większości kinematografii i zanik na jakiś czas wyrazistych trendów kina artystycznego. Już w schyłkowym okresie Republiki Weimarskiej, po roku 1930, kino niemieckie zostało zdominowane przez filmy muzyczne, komedie i melodramaty. Oczywiście nazistowska cenzura i polityka Goebbelsa promująca rozrywkę i eskapizm utrwaliły tę przemianę. Nie znaczy to jednak, iż kino artystyczne na bardzo wysokim poziomie nie było w Trzeciej Rzeszy możliwe. Przeczą temu, nieliczne co prawda i niewolne też czasem od serwitutów ideologicznych, ale naprawdę wybitne, "poważne" filmy, takie jak: Jeździec na siwym koniu (Der Schimmelreiter, 1933) Hansa Deppe i Curta Oertla, Przewoźnik Maria (Fährmann Maria, 1936) Franka Wysbara, Władca (Der Herrscher, 1937) Veita Harlana, Poczmistrz (Der Postmeister, 1940) Gustava Ucicky'ego, Rembrandt (1942) Hansa Steinhoffa, Romanca w moll ${ }^{24}$ (Romanze in Moll, 1943) Helmuta Käutnera czy Paracelsus (1943) Georga Wilhelma Pabsta.

Reasumując, ponad polityczną przepaścią między Republiką Weimarską a Trzecią Rzeszą istnieje ciągłość kina niemieckiego objawiająca się $\mathrm{w}$ ciągłości personalnej, kontynuacji pewnych trendów stylistycznych i konwencji gatunkowych, w znaczeniowej i ideologicznej ambiwalencji, w ekonomicznym protekcjonalizmie wobec własnego rynku i imperialnych zapędach ekonomicznych wobec rynków ościennych oraz - last but not least - profesjonalizmie i wysokim poziomie technicznym i artystycznym, które niezależnie od agresywnej polityki państwa niemieckiego $\mathrm{w}$ obu okresach tę ekspansję kina niemieckiego na świat czyniły całkiem realną.

${ }^{24}$ W Historii sztuki filmowej Toeplitza film ten jest omawiany pt. Melodia miłości. Jeśli nawet był on dystrybuowany w Polsce pod takim tytułem, to nie jest ów tytuł tak zadomowiony w naszym filmoznawstwie, jak np. równie niewierne wobec tytułów oryginalnych Towarzysze broni czy Portier z hotelu Atlantic. Ponieważ może nasuwać konotacje z jakimiś błahymi melodramatami, najlepszym rozwiązaniem wydaje się po prostu przekład tytułu oryginalnego. 


\section{Kino schyłku Republiki}

Ostatnie trzy lata Republiki to raptowne zawieszenie wszystkich pożyczek zagranicznych dla Niemiec po nowojorskim krachu z października 1929, drastyczny spadek produkcji, gwałtowny wzrost bezrobocia, brutalne kampanie agitacyjne przed każdymi kolejnymi wyborami, których sekwencję rozpoczął kryzys gabinetowy z marca 1930 r., zamieszki i walki uliczne między zwalczającymi się stronnictwami, zwłaszcza między nazistami i komunistami, podczas których zdarzały się nierzadko ofiary śmiertelne. Szczególnie dramatyczny był rok 1932, kiedy wiosną miały miejsce dwie tury wyborów prezydenckich, w których Hitler przegrał z Hindenburgiem, oraz dwukrotnie, latem i jesienia, wybory do Reichstagu.

Jak w swej historii kina niemieckiego odnotowuje Sabine Hake, na kino ostatnich lat Weimaru decydujący wpływ wywarły trzy, początkowo niezależne, procesy, których wzajemny splot ostatecznie przyniósł dość ponure konsekwencje: przełom dźwiękowy, światowy kryzys gospodarczy i odmalowane powyżej jego reperkusje w Niemczech oraz stopniowy wzrost w siłę i polityczne znaczenie narodowego socjalizmu ${ }^{25}$.

„Ogromne koszta związane z przejściem na dźwięk i prawne batalie o patenty dźwiękowe zmusiły przemysł filmowy do ujednolicenia swych poczynań. Ufa, Terra i Emelka, największe wytwórnie owego czasu, skonsolidowały swe działania, przedefiniowały swój profil artystyczny i poszukiwały wielce potrzebnego dopływu inwestycyjnego kapitału. W tych okolicznościach ściślejszy związek z państwem, które samo mieniło się protektorem niemieckiej kultury i przemysłu, wydawał się pożądaną alternatywą dla zdominowania przez wielkie kompanie amerykańskie"26. W takim duchu została już wcześniej rozpoczęta restrukturyzacja Ufy przez Alfreda Hugenberga po spłacie przezeń jej zadłużenia wobec hollywoodzkich wytwórni i przejęciu w roku 1927 pakietu kontrolnego nad kompanią przy jednoczesnym mianowaniu jej dyrektorem generalnym Ludwiga Klitzscha. Dalszym etapem tego procesu był lansowany w Ufie przez podstawionych ludzi Hugenberga tzw. Plan SPIO (Spitzenorganisation der Deutschen Filmindustrie) z 1932 r. Przewidywał on daleko posuniętą centralizację kinematografii, priorytet produkcji nad dystrybucją i kłócącą się z wolną konkurencją ekonomię opartą o państwowy zarząd. Plan ten uprzywilejowywał też wielkie kina premierowe $\mathrm{w}$ posiadaniu dużych kompanii, szykanując z kolei drobnych

\footnotetext{
${ }^{25}$ Sabine Hake, German National Cinema, Routledge, London-New York 2002, s. 49.

${ }^{26}$ Ibidem.
} 
kiniarzy zmuszanych przez praktykę block booking (sprzedaży wiązanej) do kupowania filmów w ciemno, nawet, gdy nie były jeszcze ukończone. Plan rekomendował rezygnację $\mathrm{z}$ wewnętrznej demokracji $\mathrm{w}$ rozmaitych związkach i organizacjach branżowych oraz lansował potrzebę powołania "ministerstwa do spraw filmu” - co się niedługo ziściło, kiedy Goebbels utworzył Reichsfilmkammer, Izbę Filmową Rzeszy. Plan ten - jak zauważa Klaus Kreimeier - był pierwszym krokiem do przejęcia przez nieliczne pozostałe na rynku wytwórnie wyłącznej kontroli nad środkami produkcji filmów, ich dystrybucją i eksploatacją kinową wedle wytycznych dyktowanych z centrali. Funkcje tradycyjnych branżowych organizacji miałyby się sprowadzać do kontroli ich członków, czy aby przestrzegają odgórnych wytycznych, oraz do eliminowania z branży nieposłusznych producentów, dystrybutorów i kiniarzy ${ }^{27}$. W świetle forsowania przez Hugenberga takiej polityki w zarządzanej przez niego największej niemieckiej kompanii filmowej nie może dziwić otwarte już jego poparcie dla Hitlera i NSDAP, jakiego udzielił im w ramach tzw. Frontu Harzburskiego w roku 1931. Hugenberg, wpływowa figura w DNVP (Deutschnationale Volkspartei - Narodowo Niemiecka Partia Ludowa), wszedł $\mathrm{w}$ ten sposób $\mathrm{w}$ koalicję z NSDAP, by kontestować poczynania rządu kanclerza Brüninga i przyspieszyć jego upadek.

Ufa, choć w latach 1929-1932 nadal była największą wytwórnią na niemieckim rynku filmowym (i pozostała nią do 1945 r.), miała jednak poważnego konkurenta w postaci koncernu Tobis-Klangfilm. Mimo że nigdy nie osiągnął on takiego poziomu produkcji filmów jak Ufa, to po Umowie Paryskiej z 22 lipca 1930 był praktycznie monopolistą w zakresie patentów dźwiękowych i sprzedaży sprzętu dźwiękowego na większości obszaru Europy. W roku 1929 Tobis uprzedził niezdecydowaną pośród chaosu wywołanego techniczną rewolucją Ufę i to właśnie on wyprodukował pierwsze niemieckie filmy dźwiękowe - chociaż niepełnometrażowe.

Kwestia "pierwszego niemieckiego filmu dźwiękowego" - podobnie jak kwestie "pierwszego filmu” czy "pierwszego filmu barwnego" - jest mocno dyskusyjna. Dnia 17 stycznia 1929 w Tauentzien-Palast w Berlinie odbył się pamiętny seans. Najpierw pokazano dwie niemieckie krótkometrażówki, Ramona i Ostatnia pieśń (Das letzte Lied), wyprodukowane w 1928 r. przy użyciu systemu dźwiękowego Tobis. Po nich nastąpiło clou programu: film Roberta Landa Całuję twoja dłoń, madame (Ich küsse ihre Hand, Madame, 1928). Ta miłosna komedia, gdzie Marlena Dietrich grała, jak to ona, wampa, a Harry Liedtke zubożałego rosyjskiego hrabiego-emigranta pracującego jako kelner w paryskiej restauracji, była praktycznie filmem

27 K. Kreimeier, op. cit., s. 194. 
niemym. Zachwycała plenerowymi zdjęciami Paryża, scenerią eleganckich lokali i jedną scena, w której Liedtke (dość kiepsko zsynchronizowanym z jego gra głosem Richarda Taubera) wyśpiewywał Marlenie wyznanie miłosne słowami tytułowej piosenki, będącej zresztą światowym szlagierem. W marcu miała miejsce premiera wyprodukowanego przez Tobis montażowego filmu Waltera Ruttmanna Melodia świata (Melodie der Welt, 1929). Ten kalejdoskopowy opis obyczajów i rozmaitych osiągnięć ludzkiej cywilizacji w różnych kulturach (a zarazem reklama towarzystwa żeglugowego „Hamburg-America Line”, które udostępniło footage) niesłusznie rozmaite źródła wymieniają jako „pierwszy pełnometrażowy niemiecki film dźwiękowy". Po pierwsze, to tylko film średniometrażowy (niespełna 50 minut), po drugie - w ścieżce dźwiękowej w zasadzie nie ma wypowiadanych słów ${ }^{28}$ (nawet komentarz do obrazów dany jest tylko na planszach zapowiadających zawartość kolejnych aktów, tak jak w filmie niemym), są jedynie efekty akustyczne i muzyka Wolfganga Zellera. David Bordwell i Kristin Thompson jako first German talkie - "pierwszy niemiecki film mówiony" - wymieniają Ziemie bez kobiet (Das Land ohne Frauen/The Land without Women), epos z Conradem Veidtem o osadnikach w Australii, wśród których kobiety były cenniejsze niż złoto. Ten film, zrealizowany w Niemczech dla spółki F.P.S.-Film GmbH przez włoskiego reżysera Carmine Gallone jeszcze w 1928 r., to typowy dla epoki multilingual film, posiadający niemiecką i angielską wersję językową (premiera wersji niemieckiej odbyła się w Berlinie 30 września 1929). Może właśnie z racji tej „międzynarodowości” Klaus Kreimeier nie uznaje pierwszeństwa filmu Gallone i jako pierwszy "stuprocentowy film mówiony" powstały w Niemczech wymienia Ciebie tylko kochałem (Dich hab' ich geliebt, 1929) Rudolfa Walthera-Feina, melodramat wyprodukowany dla wytwórni Aafa-Film, choć jego premiera (30 listopada 1929) jest o dwa miesiące późniejsza. Przed tym ostatnim filmem na ekranach Niemiec pojawiły się jeszcze dwa inne filmy mówione po niemiecku - w październiku Atlantic (1929) Ewalda André Duponta, a 21 listopada Loża królewska (Königslogel The Royal Box, 1929) Bryana Foy. Oba to jednak tylko niemieckie wersje filmów „wielojęzycznych" - pierwszy został wyprodukowany w Anglii, drugi - w USA dla Warner Bros.

Ufa swój pierwszy niefabularny film dźwiękowy wypuściła na ekrany 2 sierpnia 1929. Był to Kulturfilm zatytułowany Szklane cud-zwierzaki (Gläserne Wundertiere). Dopiero 16 grudnia 1929 wszedł na ekrany

${ }^{28}$ Wyjątkiem jest krótki fragment sekwencji Sprachen der Welt (Języki świata), w którym jednak mamy do czynienia z mową zsynchronizowaną z obrazem; przeplata on w montażu naprzemiennym mówiącego coś do kamery Japończyka z autoprezentacją przed kamerą George'a Bernarda Shawa. 
pierwszy "stuprocentowo" mówiony film fabularny Ufy, Melodia serc (Melodie des Herzens, 1929) Hannsa Schwarza - rozgrywający się w węgierskich realiach melodramat z tragicznym zakończeniem, o miłości żołnierza i wiejskiej dziewczyny, przybyłej do Budapesztu, by pracować jako służąca, z Ditą Parlo i Willy Fritschem w rolach głównych. Film nie tylko bardzo poruszał emocjonalnie, ale i zachwycał zdjęciami fantastycznie sfilmowanego Budapesztu, w całej krasie objawiającego swój metropolitalny urok. Był także „wielojęzyczny”, aż w czterech wersjach językowych (prócz niemieckiej - w angielskiej, francuskiej i węgierskiej), choć nieufna wobec „nowinki” dźwięku Ufa na wszelki wypadek wypuściła film również w wersji niemejej.

Melodia serc, jako pierwszy dźwiękowy film fabularny Ufy, była sygnałem dla całej branży filmowej, iż nastała era filmu dźwiękowego ${ }^{30}$. Jej producentem był Erich Pommer, kierujący w Ufie zespołem odpowiedzialnym za produkcję dźwiękową. I to on właśnie uzgodnił z przybyłym do Berlina po amerykańskich sukcesach Emilem Janningsem (pierwszy Oscar dla najlepszego aktora!), że wystawny, prestiżowy dla Ufy i całego kina niemieckiego talkie wyreżyseruje Josef von Sternberg specjalnie ściągnięty z Hollywood. Tym filmem jest Błękitny Anioł, adaptacja powieści Henryka Manna Profesor Unrat (1905), może najbardziej znany niemiecki film omawianego okresu, z emblematycznym obrazem Marleny Dietrich jako kabaretowej śpiewaczki Loli-Loli, gdy w cylindrze na głowie, w prowokacyjnej pozie usytuowana na... beczce, śpiewa swym niskim głosem: Ich bin von Kopf bis Fuß auf Liebe eingestellt („,Od stóp do głów jestem stworzona do miłości”) $)^{31}$. Śpiew to, zaiste, syreni, gdyż skłania nobliwego profesora Ratha (Jannings), nauczyciela angielskiego w prowincjonalnym gimnazjum, do rzucenia posady i sprowadza go na manowce małżeństwa z dużo młodszą "szansonistką". Poruszająca historia społecznej deklasacji inteligenckiego mieszczucha jest zarazem, na co słusznie wskazuje Kracauer, wieloaspektowym studium niemieckiego sado-masochizmu, tej „ucieczki od wolności”, która niezadługo w pozatekstowej rzeczywistości wyrazi się w niemal dobrowolnym poddaniu całego społeczeństwa narodowo-socjalistycznej tyranii ${ }^{32}$. Świat Błękitnego Anioła odpycha widza,

${ }^{29}$ Por.: K. Kreimeier, op. cit., s. 181-182; K. Thompson, D. Bordwell, Film History: An Introduction, McGraw-Hill, New York 1993, s. 221, 229.

${ }^{30} \mathrm{~K}$. Kreimeier, op. cit., s. 182.

31 Tekst tej piosenki w równolegle zrealizowanej angielskiej wersji filmu (Falling in love again - can't help it!) ani nie jest tak dobrze zgrany z muzyką Friedricha Holländra, jak w wersji niemieckiej, ani nie posiada w takim stopniu jej cynizmu i perwersyjności.

${ }_{32}$ Por. Siegfried Kracauer, Od Caligariego do Hitlera: Z psychologii filmu niemieckiego, przeł. W. Wertenstein, E. Skrzywanowa, Filmowa Agencja Wydawnicza, Warszawa 1958, s. $183-185$. 
frustrując go niemożliwością identyfikacji z kimkolwiek czy choćby wytworzenia się cienia sympatii dla kogokolwiek: antypatyczny jest profesor $\mathrm{w}$ jego sadyzmie podczas lekcji i nadgorliwym tropieniu młodzieńczych wykroczeń, za którym kryją się niezdrowa ciekawość i pożądanie; przerażają uczniowie, bo ich zemsta na nielubianym nauczycielu to nie uczniowski psikus, ale brutalny lincz, obnażający mechanizmy kozła ofiarnego w społeczeństwie; odpycha Lola-Lola, gdy starego, bezradnego męża drażni ostentacyjnym prowadzaniem się z modelowo nordyckim Mazeppą (Hans Albers); przeraża postępowanie służącej z martwym szczygłem $^{33}$ profesora, kiedy niedawno jeszcze żywe stworzenie wrzuca od niechcenia, niczym jakiś śmieć, d o pi e c a (każdemu widzowi tego filmu po 1945 r. przychodzi do głowy przerażająca konotacja, przez scenarzystów zapewne nieprzewidziana...). Film Sternberga - paradoksalnie, jedyny niemiecki film reżysera w zasadzie amerykańskiego - wydaje się jakąś kwintesencją i syntezą weimarskiej estetyki z różnych jej faz: dekadencka, mroczna aura kabaretowego półświatka oraz cynizm dialogów i piosenek Marleny ewokują Nową Rzeczowość, z którą kłóci się jednak ostentacyjnie sztuczny, malarsko-teatralny design scenografii (szczególnie ulicy wiodącej do kabaretu), przywodzący na myśl wcześniejszy „caligaryczny" ekspresjonizm à la Robert Wiene. Te eklektyczne, plastycznie fascynujące dekoracje zaprojektował prawdziwy geniusz wśród niemieckich scenografów, Otto Hunte, a ich teatralno-filmową urodę wydobył swymi zdjęciami inny Meister - Günther Rittau.

Błękitny Anioł odniósł wielki sukces u krytyki i publiczności. Nawet Hugenberg, niechętny adaptowaniu powieści autora uznawanego za jednoznacznie lewicowego, oświadczył na łamach „Nachtausgabe”, iż Ufie „udało się stworzyć dzieło sztuki z nędznej książki Henryka Manna”. $\mathrm{Na}$ ten świadomy nietakt Pommer odpowiedział na łamach „Berliner Tageblatt”, iż „,nie tylko podczas przygotowywania scenariusza, ale i podczas realizacji filmu miały miejsce stałe konsultacje z Henrykiem Mannem [...], dla którego mam najwyższy podziw"34. I niezależnie od tego, że Błękitny Aniot to dość posępny film na "poważny” temat, jest to też „film z piosenkami". Co, rzecz jasna, było kolejną (obok amerykańskich wzorów) wytyczna, jakie filmy należy tworzyć, by w dobie rozszalałego znienacka kryzysu ściągnąć publiczność do kin.

${ }^{33}$ Ptak ten często jest błędnie identyfikowany jako kanarek. To nie egzotyczny kanarek, ale rodzimy szczygieł, co nie jest bez znaczenia. Niemcy często łapali ptaki ze swego najbliższego otoczenia, by trzymać je w klatkach. Być może nie bez znaczenia jest tu też konotacja szczygła w dawnej sztuce jako ptaka Chrystusowego (vide: Madonna ze szczygłem Rafaela).

${ }_{34}$ O tym „dwugłosie” na temat Henryka Manna pisze Kreimeier (op. cit., s. 191). 
Rozśpiewało się więc, roztańczyło i w ogóle rozmuzykowało kino niemieckie ${ }^{35}$ aż do 1945 r., co przejawi się na rozmaite sposoby - nie tylko w dużej liczbie filmów stricte muzycznych, ale i w obecności piosenek, numerów taneczno-wodewilowych czy sporych fragmentów muzyki klasycznej w filmach zasadniczo niemuzycznych. I tak np. piosenki (przynajmniej jakiś jeden hit) staną się niemal obowiązkowe w komediach $^{36}$, a bohaterami licznych melodramatów będą pieśniarka ${ }^{37}$ bądź kompozytor/dyrygent ${ }^{38}$. Nawet w historycznym filmie Carla Froelicha Serce królowej (Das Herz der Königin, 1940) oczekująca szafotu Maria Stuart wyśpiewuje swój ból niskim głosem Zarah Leander, zaś w lotniczym dramacie Karla Rittera Stukas (1941) oficerowie Luftwaffe między akcjami bojowymi grywają na pianinie, a rannemu lotnikowi przywraca chęć do życia i dalszego zrzucania bomb na Europę pogrążenie się w Bayreuth w muzyce Wagnera... Tak to muzyka stała się w niemieckojęzycznych filmach z lat 1930-1945 dziedziną par excellence niemiecką (czy też niemiecko-austriacką).

U schyłku okresu weimarskiego w kinie niemieckim pojawiła się konwencja wi ed eńs ki ej o pe retki, od 1933 r. aż do lat powojennych wspólny gatunek Austriaków i Niemców. Filmy tego genre'u kreowały wyobrażony świat epoki romantycznej, połowy XIX w. albo belle époque (Wiedeń bądź jakieś konkretne czy nieokreślone księstwo), zaludniony przez piękne dziewczyny, przystojnych oficerów, zdolnych kompozytorów i szarmanckich arystokratów, sycąc oczy bajecznymi kostiumami i wystawną scenografia, uszy staromodnymi ariami i dominującymi w ścieżce muzycznej walcami, budząc tęsknotę za "starymi dobrymi czasami” monarchii austro-węgierskiej albo beztroską i blichtrem operetkowych

${ }^{35}$ Wraz z austriackim. Wskutek jednak braku bariery językowej, pracy całej rzeszy reżyserów i aktorów rodem z Austrii w Niemczech i niemieckich w Austrii, ,,wiedeńskich” czy austriackich tematów i gatunku operetki w kinie niemieckim oraz wchłonięcia Austrii przez Niemcy w 1938, trudno rozdzielić definitywnie obie kinematografie i przyznawać jakąś jednoznaczną tożsamość państwową wielu filmom, takim jak np. filmy Gustava Ucicky'ego czy Willi Forsta.

${ }_{36}$ W sposób umotywowany, np. przeniesieniem się akcji na estradę [Viktor $i$ Viktoria (Viktor und Viktoria, 1933) Reinholda Schünzla], albo i bez żadnej motywacji fabularnej, np. w Szczęściarzach (Glückskinder, 1936) Paula Martina nonsensowna piosenka Chciał(a)bym być kura (Ich wollt' ich wär' ein Huhn), brawurowo wykonana przez Lilian Harvey, Willy Fritscha, Paula Kempa i Oskara Simę.

${ }^{37} \mathrm{Na}$ przykład bohaterki grane przez Zarah Leander w takich filmach, jak Heimat (1938) Carla Froelicha czy Wielka miłość (Die große Liebe, 1942) Rolfa Hansena.

38 Zarówno historyczny, np. Schubert [Niedokończona symfonia (Leise flehen meine Lieder/Unfinished Symphony, 1933) Willy Forsta] czy Czajkowski [Romanse Czajkowskiego (Es war eine rauschende Ballnacht, 1939) Carla Froelicha], jak i fikcyjny [Ostatni akord Detlefa Siercka czy Immensee (1943) Veita Harlana]. 
państewek ${ }^{39}$. Niewątpliwymi sukcesami pośród operetek okazały się Walc miłości (Liebeswalzer, 1930) Wilhelma Thiele ${ }^{40}$, z Lilian Harvey i Willy Fritschem, Bomby na Monte Carlo (Bomben auf Monte Carlo, 1931) Hannsa Schwarza, z Hansem Albersem, Anną Sten i Heinzem Rühmannem, oraz Wojna walców (Walzerkrieg, 1933) Ludwiga Bergera ${ }^{41}$, z Renate Müller i Willy Fritschem. Prawdziwą rewelacją jest jednak Kongres tańczy (Der Kongreß tanzt, 1931) Erika Charella ${ }^{42}$, nie tylko najwybitniejsze osiągnięcie gatun$\mathrm{ku}$, ale i arcydzieło sztuki filmowej. Ufa nie żałowała środków ani na imponujące dekoracje rekonstruujące $\mathrm{w}$ ateliers Wiedeń $1815 \mathrm{r}$. (znakomita scenografia Roberta Herltha i Waltera Röhriga), ani na rzesze statystów tworzących tłum roztańczonych na ulicach miasta wiedeńczyków, ani na gaże gwiazd (Lilian Harvey jako wiedeńska kwiaciarka wplątana trochę z własnej winy, a trochę mimo woli, w polityczne intrygi i w romans z carem, Willy Fritsch w podwójnej roli przystojnego cara Aleksandra I i jego głupawego sobowtóra, Conrad Veidt jako Metternich, austriacki kanclerz-intrygant, pragnący odsunąc władcę Rosji od decyzji politycznych przez podsunięcie mu pięknej wiedenki). Polityczno-miłosna intryga poprowadzona jest $\mathrm{z}$ lekkością i wdziękiem, aktorzy grają $\mathrm{z}$ werwa, ale i z ironicznym dystansem wobec dość umownych i operetkowych postaci. Numery taneczno-wodewilowe przekształcają historię Europy w roztańczony i rozśpiewany spektakl, który porywa widza rozmachem i tempem, w czym także zasługa wyrafinowanej mise-en-scène, gdzie efektowna choreografia rzesz statystów jest wspaniale zgrana z kunsztownymi jazdami kamery w bardzo długich ujęciach (zdjęcia Carla Hoffmanna).

Prócz operetek kostiumowych powstawały także „operetki” współczesne czy raczej komedie muzyczne z akcją osadzoną "dzisiaj”, choć niekoniecznie w „realiach” dnia bieżącego. Znany widzom aż za dobrze kryzys jest $\mathrm{w}$ tym przypadku fabularnym punktem wyjścia. Później bohaterowie, trochę dzięki własnej zaradności, przede wszystkim jednak przy pomocy szczęśliwego trafu i rozmaitych chwytów na zasadzie deus ex machina, zdobywają pieniądze, dobrą pracę, wysoki status społeczny i wymarzonego ukochanego/wymarzoną ukochaną. Modelowym filmem tego nurtu są wyprodukowani w Ufie przez Pommera Trzej ze stacji

39 Por. S. Hake, op. cit., s. 52.

40 Angielskojęzyczną wersję The Love Waltz wyreżyserował Carl Winston.

${ }^{41}$ Film ten, do którego scenariusz powstał w okresie weimarskim, zrealizowano już w Trzeciej Rzeszy. Po prostu nie zerwano umowy z Bergerem (był $̇$ ydem) przed finalizacją projektu, który już pochłonął spore koszta. Berger wyjechał po realizacji tego filmu, ale w Niemczech z czołówki usunięto jego nazwisko. Por. K. Kreimeier, op. cit., s. 212-213. Wersję francuską La guerre des valses współreżyserował Raoul Ploquin.

${ }_{42} \mathrm{~W}$ angielskiej i francuskiej wersji filmu (The Congress Dances/Le Congrés s'amuse) Henri Garat zastąpił Willy Fritscha. Wersję francuską współreżyserował Jean Boyer. 
benzynowej (Die Drei von der Tankstelle, 1930) Wilhelma Thiele, z Lilian Harvey, Willy Fritschem, Oskarem Karlweisem i Heinzem Rühmannem ${ }^{43}$. To bodaj pierwszy w kinie światowym tak udany artystycznie musical zintegrowany fabularnie, wzór dla przyszłych muzycznych filmów amerykańskich (choć bezpośrednio po premierze nie odniósł spektakularnego sukcesu za oceanem), a zarazem jeden z najlepszych filmów w całej historii niemieckiego kina popularnego. Komornik rekwiruje dom i meble trzem przyjaciołom, których dotknął kryzys i splajtowali. Chcąc się odkuć, za ocalały samochód kupują stację benzynową. Idzie im dość marnie, aż zjawia się ona - Lilian, córka dyplomaty. Flirtując jednocześnie z wszystkimi trzema (przy czym każdy z nich myśli, że jest tym jedynym), musi się w końcu zdecydować na jednego z nich (rzecz jasna, wybrankiem Harvey jest Willy Fritsch) - co o mało nie doprowadza do rozbicia więzów przyjaźni. Wszystko jednak kończy się dobrze, zwłaszcza gdy "przegranym” kumplom przynoszą pociechę intratne posady... Czegóż nie załatwi tatuś dyplomata? Chociaż elementy fabuły wyrażają pochwałę przedsiębiorczości, recepta na wyjście z kryzysu jest iluzoryczna - codzienna praca bohaterów na stacji przynosi im raczej marny grosz, ale czy to ważne, widzu, gdy może cię zauważyć i pokochać piękna dziedziczka niemałej fortuny? Aż nazbyt optymistyczna muzyczna komedia Wilhelma Thiele sprawia jednak czysto filmową frajdę: numery wokalno-choreograficzne nie stanowią interludium, lecz współtworzą zasadniczą część akcji fabularnej (co było wówczas prawdziwym novum), czołowa czwórka jest znakomita aktorsko, tanecznie i wokalnie, a doskonałe piosenki, Przyjaciel, dobry przyjaciel (Ein Freund, ein guter Freund) czy Kochany panie komorniku (Lieber, guter Herr Gerichtsvollzieher), wpadają w ucho i nie dziw, że w swoim czasie były dużymi przebojami - zwłaszcza, iż spopularyzowali je rewelacyjni Comedian Harmonists ${ }^{44}$.

Harvey i Fritsch pojawili się w jeszcze jednej współczesnej komedii muzycznej - Jasnowłosy sen (Ein blonder Traum, 1932) Paula Martina (a towarzyszył im na dokładkę inny wielki gwiazdor niemieckojęzycznych filmów muzycznych, Willy Forst - zarówno świetny aktor, jak i reżyser $)^{45}$. Willy i Willy, zarabiający na życie zmywaniem okien, rywalizują o względy cyrkówki Jou-Jou i ścielą z nią sobie rozkoszne gniazdko

${ }^{43}$ Francuska wersja filmu nosi tytuł Droga do raju (Le Chemin du paradis). Jej współreżyserem jest Max de Vaucorbeil, a partnerami Lilian Harvey - Henri Garat, René Lefèvre i Jacques Maury. Ta właśnie wersja był wyświetlana w Polsce.

${ }^{44}$ Popularny sekstet pojawił się w filmie w roli tragarzy wynoszących meble, tworząc muzyczny dialog z trójką bohaterów oraz komornikiem podczas piosenki Kochany panie komorniku (znanej także jako Kukutka - Kuckuck].

${ }^{45}$ We francuskiej wersji tego filmu, Un Rêve blond (1932), partnerami Harvey byli Henri Garat i Pierre Brasseur, a współreżyserem Paula Martina - André Daven. 
w porzuconych wagonach kolejowych, gdzieś na pustkowiu. We śnie bohaterki ich domy-wagony tworzą pociąg, który przekracza Atlantyk i zabiera ją do wyśnionego przez nią Hollywood... Ale marzenia, tak czy inaczej, się spełnią: jeden Willy (Fritsch) zdobędzie Jou-Jou, a drugi (Forst) pojedzie zamiast niej do Ameryki robić karierę - choć w ubogiej bieżącej rzeczywistości bohaterowie mogą na razie pocieszać się tylko tym, że za mieszkanie w kolejowym eks-wagonie nie płaci się czynszu (a ta radość jest przez obu Willych, rzecz jasna, wyśpiewana $)^{46}$.

Do innych bajkowo optymistycznych komedii tych lat kryzysu należą również Osobista sekretarka (Die Privatsekretärin, 1931) ${ }^{47}$ Wilhelma Thiele z Renate Müller w roli tytułowej czy Hrabina Monte Christo (Die Gräfin von Monte Christo, 1932) Karla Hartla, z Brigitte Helm. W pierwszym filmie skromną urzędniczkę banku spotyka nagroda za zostanie w pracy po godzinach - dyrektor banku wyciagnnie ją stamtąd na randkę, a potem, zapewne, na szczyt drabiny społecznej. W drugim - skromna statystka z filmu wskutek qui pro quo zostaje wzięta za arystokratkę. Wchodzi w tę rolę, korzystając bezprawnie z życia na takim poziomie, o jakim mogła tylko śnić. Kiedy zostaje zdemaskowana, nie spotyka jej kara, tylko... nagroda w postaci kontraktu z dbałą o publicity wytwórnia, o jakim nie śmiała nawet marzyć. „Jest to oczywiście dostatecznym dowodem, że życie jest bajką - co wszystkie te filmowe narkotyki miały za zadanie wykazać" podsumowuje pointę tej i innych nierealistycznie optymistycznych komedii lat kryzysu Siegfried Kracauer ${ }^{48}$.

Wśród innych komedii tych lat, patrzących na świat wbrew ponurym niemieckim realiom przez różowe okulary, należy wymienić jeszcze: Ja w dzień, a ty noca (Ich bei Tag und du bei Nacht, 1932) Ludwiga Bergera, z Käthe von Nagy i Willy Fritschem, Pieniadz leży na ulicy (Geld auf der Straße, 1930) Georga Jacoby'ego, Niedługo znowu będzie lepiej (Es wird schon wieder besser, 1931) Kurta Gerrona, z Dolly Haas i Heinzem Rühmannem czy Forsy nie trzeba (Man braucht kein Geld, 1932) z Heinzem Rühmannem i Hansem Moserem. Tytuły trzech ostatnich mówią same za siebie. Emblematyczna jest fabuła ostatniej - rodzina bez grosza i upadły bank, odgrywając komedię z „,bogatym wujaszkiem z Ameryki” (ten też oczywiście jest bez grosza), nie tylko sami się bogaca, ale przynoszą prosperity lokalnej społeczności.

Szczególny typ komedii pod koniec okresu weimarskiego stanowiły farsy kos zarowe, cieszące się sporym wzięciem wśród publiczności.

\footnotetext{
${ }^{46}$ Zwracam uwage na bezsensowne streszczenie tego filmu w polskim przekładzie książki Kracauera (S. Kracauer, op. cit., s. 180).

${ }^{47}$ Angielskojęzyczną wersję Sunshine Susie (1931), także z udziałem Renate Müller, wyreżyserował Victor Saville.

${ }^{48}$ S. Kracauer, op. cit., s. 181.
} 
W latach 1930-1932 ukazywało się ich po kilkanaście w roku. Do najbardziej popularnych należały te zrealizowane przez Carla Boesego: Trzy dni paki (Drei Tage Mittelarrest, 1930), Cud w koszarach (Kasernenzauber, 1931), Postrach garnizonu (Der Schrecken der Garnison, 1931), Stużba to stużba (Dienst ist Dienst, 1931), Trzej z kawalerii (Drei von der Kavallerie, 1932). Naziści po dojściu do władzy w roku 1933 zakazali tych filmów, uważając, że poprzez wyśmiewanie armii i kpiny ze służby wojskowej odzwierciedlają tendencję liberalną, nie do pogodzenia z promilitarystyczną polityką hitleryzmu ${ }^{49}$. Ich obawy nie były bezpodstawne, sądząc $w$ oparciu o jedyny weimarski film tego genre'u, do którego udało mi się dotrzeć - bardzo fabularnie pomysłową i rzeczywiście arcyzabawna, a także znakomitą od strony formalnej farsę Freda Sauera Duma trzeciej kompanii (Der Stolz der 3. Kompanie, 1932). Ta zwariowana komedia, z doskonałym Heinzem Rühmannem w roli głównej, wyśmiewając militaryzm epoki wilhelmińskiej, musiała być wywrotowa wobec każdego systemu politycznego stawiającego w swym centrum armię i gloryfikującego ją.

Melodramat, w przeciwieństwie do musicalu i komedii, ze swej natury nie jest gatunkiem optymistycznym. Dźwiękowe melodramaty schyłku Weimaru, podobnie jak te z lat 20. (filmy uliczne, Variété, 1925, E. A. Duponta), kreowały duszną, posępną aurę, przygniatającą widza i postacie poczuciem melancholii i bezwyjściowości sytuacji. Arcydziełem tego gatunku jest przedostatni z niemieckich filmów Maxa Ophülsa Miłostki (Liebelei, 1933) - oparty o sztukę Arthura Schnitzlera, $\mathrm{w}$ sposób przewrotny wykorzystuje scenerię Wiednia $\mathrm{z}$ belle époque. Znany z operetek beztroski na pozór świat balów i operowych spektakli, gdzie zdawałoby się czymś normalnym jest flirt przystojnego oficera z zamężną damą z wyższych sfer, okazuje się nagle dziedziną niemal totalitarnego dyktatu formy, który - nieproporcjonalnie do winy - żąda krwi niefortunnego amanta w imię honoru męża i wątpliwej „czci” damy. Młody porucznik (Wolfgang Liebeneiner), który w końcu naprawdę zakocha się w córce kapelmistrza (Magda Schneider), nie zdoła wywikłać się z fatalnego romansu z piękną i zaborczą baronową (Olga Czechowa) - pewny swej ręki nieugięty baron (Gustaf Gründgens) zabija go w pojedynku, a zrozpaczona narzeczona popełnia samobójstwo. Demaskujące formę społeczną Miłostki same są wybitnym osiągnięciem formy filmowej: stylistyka osaczających postacie kunsztownych jazd kamery $\mathrm{w}$ długich ujęciach pośród precyzyjnie przemyślanej scenografii świetnie współgra z coraz bardziej powikłaną fabułą i atmosferą gęstniejącą wokół bohatera. Wyrafinowane travellingi w długich ujęciach

49 Por. J. Toeplitz, Historia sztuki filmowej, t. 3: 1928-1933, Filmowa Agencja Wydawnicza, Warszawa 1959, s. 219. 
niedługo staną się zresztą rozpoznawalnym od razu idiomem Ophülsa, z pewnością jednego z największych stylistów kina.

Niewątpliwymi osiągnięciami wśród dźwiękowych melodramatów weimarskich są te zrealizowane przez Paula Czinnera z udziałem jego przyszłej żony, Elisabeth Bergner: Ariana (Ariane, 1931) ${ }^{50}$ i Rozmarzone usta (Der träumende Mund, 1932) ${ }^{51}$. W obu partnerem Bergner był Rudolf Forster, pamiętny Mackie Messer z niemieckojęzycznej wersji Pabstowskiej Opery za trzy grosze (Die 3-Groschen-Oper, 1931). Szczególnie ciekawy jest pierwszy z filmów - historia pełnego wzajemnego przyciagania i odpychania, porywów namiętności i nagłego chłodu, szalonego romansu bogatego utracjusza w średnim wieku i rosyjskiej studentki w Berlinie, Ariany Kuzniecowej. Ariana, pozująca na kobietę wyzwoloną i „,z przeszłością”, czym początkowo zdobywa kochanka, ostatecznie przywiąże go do siebie nie tylko siłą swej miłości, ale i odkrytą przezeń ze zdumieniem niewinnością. Intensywna, jakby nieco neurotyczna emocjonalność aktorstwa Bergner (zadziwiająca kreacja) w połączeniu z męskim cynizmem i brutalnością Forstera oraz nieobliczalne meandry klaustrofobicznej fabuły, skupionej na dwóch postaciach, czynią z filmu Czinnera coś w rodzaju Ostatniego tanga w Paryżu epoki weimarskiej.

Za melodramat wypada też chyba uznać Dziewczęta w mundurkach (Mädchen in Uniform, 1931) Leontine Sagan i Carla Froelicha. Krytyka pruskiego drylu w poczdamskiej szkole $\mathrm{z}$ internatem dla córek oficerów $\mathrm{z}$ arystokratycznych rodzin wydaje się jednak drugoplanowa w porównaniu z fascynująco poprowadzonym wątkiem miłości nowo przybyłej do internatu pięknej i zdolnej, lecz nadwrażliwej Manueli (ujmująca subtelną urodą i młodzieńczością Hertha Thiele) do nauczycielki, panny von Bernburg (Dorothea Wieck) ${ }^{52}$. Lesbijski aspekt tego uczucia nie pozostawia cienia wątpliwości, choć ",artystyczne kierownictwo" Froelicha dużo bardziej stonowało dosadny pod tym względem teatralny pierwozór, sztukę

${ }^{50}$ Ariane to był multilingual film, mający trzy wersje językowe, wszystkie wyreżyserowane przez Czinnera. Bergner i Forster zagrali także w wersji angielskiej The Loves of Ariane (1931), natomiast w wersji francuskiej Ariane, jeune fille russe (1932) zastąpili ich Gaby Morlay i Victor Francen.

51 We francuskiej wersji tego filmu zatytułowanej Mélo (1932) znowu Gaby Morley i Victor Francen zastąpili niemiecki duet Bergner - Forster. Wersja angielskojęzyczna Dreaming Lips (1937) powstała dużo później w Wielkiej Brytanii, kiedy Czinner z żoną byli na emigracji. Partnerem Bergner był w niej Raymond Massey.

${ }^{52}$ Hertha Thiele i Dorothea Wieck zagrały razem jeszcze raz $\mathrm{w}$ filmie $\mathrm{z}$ lesbijskim, choć z mniej ostentacyjnym podtekstem, w dramacie Anna i Elżbieta (Anna und Elisabeth, 1933, Frank Wysbar). Domniemana uzdrowicielka Anna (Thiele) staje się obiektem pragnienia - i chyba nie tylko pragnienia uleczenia - sparaliżowanej arystokratki Elżbiety (Wieck). Film wszedł na ekrany już w Trzeciej Rzeszy 12 kwietnia 1933. 
Christy Winsloe Wczoraj i dziś (Gestern und heute). Tak czy inaczej, w obsadzie tego filmu znajdują się wyłącznie kobiety, a o obecności mężczyzn gdzieś w zewnętrznym świecie świadczy jedynie dobiegający w ścieżce dźwiękowej głos trąbki ze znajdującego się nieopodal szkoły garnizonu... Głos ten jest także pointą filmu i to wielce dwuznaczną - jak słusznie zauważa Kracauer ${ }^{53}$. Upewnia strzegącą w szkole „pruskiego ducha” dyrektorkę, że mimo pozornej porażki nie musi ustąpić wobec liberalnych dążeń uczennic, bo tuż obok znajduje się realny gwarant dotychczasowego porządku - armia. Jak chcą feministki i krytyka genderowa, dla których to dziś kultowy film, ten finał świadczy nie tylko o stłumieniu demokracji, ale i o permanentnej przemocy patriarchalnego, męskiego porządku wobec świata kobiet i ich dążeń rozsadzających ten porządek. W kontekście tego zakończenia nie dziwi, że Froelich należał do najbardziej hołubionych filmowców Trzeciej Rzeszy - w 1937 otrzymał artystyczną profesurę, a w 1939 został prezesem Reichsfilmkammer i pełnił tę funkcję do końca wojny. Choć z drugiej strony Dziewczęta w mundurkach powszechnie uważa się za film prodemokratyczny, o antytotalitarnej wymowie, o czym może świadczyć fakt, iż był to jedyny film niemiecki niezdjęty z ekranów nowojorskich na początku roku 1933, gdy Hitler doszedł do władzy ${ }^{54}$. A poza wszystkim jest to majstersztyk formy, dzieło świetnie sfotografowane, zmontowane i zagrane $-\mathrm{w}$ Niemczech uznane za najlepszy film roku, a w Ameryce przyjęte entuzjastycznie i cieszące się wzrastającą $\mathrm{z}$ upływem lat sławą.

Choć w większości źródeł tylko Leontine Sagan wymieniana jest jako reżyser filmu, to za jego kształt artystyczny odpowiada w znacznej mierze Carl Froelich. W czołówce widnieje: Regie - Leontine Sagan, Künstlerische Leitung - Carl Froelich, co zdaje się sugerować dominującą jednak pozycję Froelicha, twórcy o ustalonej już renomie (zresztą w czołówkach wielu filmów niemieckich słowo Spielleitung funkcjonuje wymiennie ze słowem Regie). To „kierownictwo artystyczne” równało się w praktyce współreżyserii - kontrolowaniu mise-en-scène, aktorstwa i strony warsztatowo-technicznej (światło, praca kamery), gdyż Leontine Sagan, aktorka teatralna, miała dość nikłe pojęcie o warsztatowej stronie realizacji filmu. O roli Froelicha jako faktycznego współreżysera wypowiadała się m.in. odtwórczyni roli Manueli, Hertha Thiele. Sagan, prócz tego filmu, zrealizowała jeszcze tylko dwa: Men of Tomorrow (1932) i Gaiety George (1946), za każdym razem mając doświadczonego filmowca o ustalonej reputacji jako współreżysera (przy pierwszym z filmów - Zoltana Kordę, przy

53 S. Kracauer, op. cit., s. 194.

${ }_{54}$ Por. K. Thompson, Narodziny i schyłek "filmowej Europy", przeł. T. Kłys, [w:] Kino Europy, red. P. Sitarski, Rabid, Kraków 2001, s. 43. 
drugim - George'a Kinga). Dziewczęta w mundurkach świetnie zresztą wpisują się tematycznie i stylistycznie w serię zrealizowanych później przez Froelicha, już w Trzeciej Rzeszy, bardzo ciekawych artystycznie filmów poświęconych młodzieży i środowiskom szkolnym: U progu dojrzałości (Reifende Jugend, 1933), Traumulus (1936), Spótka czterech (Die vier Gesellen, 1938). Spośród tych filmów należy jednak wyłączyć rozgrywający się na obozie dla dziewcząt film o Arbeitsdienst, hitlerowskiej Służbie Pracy, Ja tobie, ty mnie (Ich für dich - du für mich, 1934), zrealizowany na zamówienie NSDAP.

Kilka interesujących artystycznie filmów późnoweimarskich sytuowało się na pograniczu melodramatu i filmu kryminalnego - miłość (czy może raczej namiętność) sąsiaduje w nich ze zbrodnią, choć struktura fabuły nie pozwala przypisać ich jednemu bądź drugiemu gatunkowi. Tytułowym bohaterem filmu Kurta Bernhardta Człowiek, który popetnit morderstwo (Der Mann, der den Mord beging, 1931) jest francuski dyplomata w Stambule (Conrad Veidt) zakochany w żonie angielskiego lorda, adorowanej z kolei przez rosyjskiego arystokratę (Grigorij Chmara). Bohater „wyzwala” wybrankę serca terroryzowaną przez brutalnego męża, zabijając go, po czym usuwa się w cień, a życzliwy mu przedstawiciel tureckich władz tuszuje sprawę. W Burzach namiętności (Stürme der Leidenschaft, 1932) Roberta Siodmaka bandyta, który właśnie wyszedł z więzienia (Emil Jannings), odkrywszy niewierność swej dziewczyny, zabija jej nowego kochanka ${ }^{55}$. Wreszcie może najciekawszy z tych filmów to Morderca Dymitr Karamazow (Der Mörder Dimitri Karamasoff/Les Frères Karamazoff, 1931) Fiodora Ocepa ${ }^{56}$, pomysłowa adaptacja powieści Dostojewskiego pokazująca noc zabójstwa Fiodora Pawłowicza Karamazowa z perspektywy jego hulaszczego syna Dymitra (wielką kreację w tej roli stworzył Fritz Kortner). Wszytkie te filmy charakteryzuje moralna ambiwalencja: w pierwszym morderstwo zostaje rozgrzeszone "sprawiedliwością losu”, jaki dosięga ofiarę i „szlachetnością" sprawcy, w drugim - porywem namiętności, w trzecim - zbrodnicza intencja Dymitra wyrosła z niepohamowanej namiętności (choć to nie on, a Smierdiakow, ostatecznie zabił ojca) zostaje odkupiona dobrowolnym pokutnym przyjęciem prawnie niezasłużonej kary katorgi.

Robert Siodmak, reżyser Burz namiętności, zabłysnął jeszcze wcześniej świetnymi filmami kryminalnymi (gatunek ten okaże się

55 We francuskojęzycznej wersji tego filmu, zatytułowanej Tumultes (także reżyserowanej przez Siodmaka), Janningsa zastąpił francuski gwiazdor - Charles Boyer. Udało mi się dotrzeć jedynie do tej właśnie wersji. Wersja niemiecka uchodzi za zaginioną.

${ }^{56} \mathrm{~W}$ niemieckiej transkrypcji nazwisko rosyjskiego reżysera figuruje w czołówce jako Fedor Ocep. 
zresztą jego specjalnością gdy znajdzie się niedługo na emigracji za oceanem). Kryminałem sensu stricto i w tonacji serio jest pasjonujące Śledztwo (Voruntersuchung, 1931). Gustav Fröhlich gra tu studenta oskarżonego o zamordowanie dziewczyny lekkich obyczajów. Dochodzenie w tej sprawie prowadzi prokurator (Albert Bassermann), będący ojcem bliskiego kolegi delikwenta. Śledczy zaczyna sobie coraz bardziej uświadamiać bliską zażyłość syna z oskarżonym i fakt, że może niekoniecznie ten ostatni popełnił zbrodnię... Rozwiązanie zagadki zbrodni, w typie deus ex machina, strąca prokuratorowi kamień z serca (to nie jego syn zabił) i jednocześnie uniewinnia studenta - ale $\mathrm{w}$ pamięci widza pozostaje duszna atmosfera, poczucie bezwyjściowości sytuacji i dwuznaczna moralnie taktyka śledczego, gdy odkrywa on możliwość popełnienia zbrodni przez własnego syna. Z kolei Człowiek, który szuka swego mordercy (Der Mann, der seinen Mörder sucht, 1931) jest raczej parodią filmu kryminalnego niż kryminałem serio. Pewien mężczyzna, który chce skończyć z życiem, zawiera kontrakt z płatnym zabójca, że ten zabije go do południa dnia następnego. Delikwent jednak zdążył się rozmyślić i chce żyć, a po uniknięciu wielu zamachów swego kontrahenta ostatecznie dowiaduje się od niego, iż ów "odsprzedał" swe zadanie prawdziwemu profesjonaliście, który nigdy nie chybia... Absurdalna anegdota nie wyklucza autentycznego suspensu i film Siodmaka trzyma w napięciu do samego końca, niesamowicie przy tym śmiesząc - nic w tym dziwnego skoro współscenarzystą był Billie Wilder, a główną rolę zagrał czołowy niemiecki komik schyłku Weimaru i całego okresu Trzeciej Rzeszy, Heinz Rühmann. Film Siodmaka w scenografii eksploruje ekspresjonistyczną (czy też jakby chciał Barry Salt ekspresywistyczną) stylistykę, podobnie jak czynić to będą należące do film noir jego amerykańskie filmy. Autorami tych rewelacyjnych dekoracji byli mistrzowie ekspresjonistycznego sztafażu - Robert Herlth i Walter Röhrig.

Kryminałem, choć to tylko kryminał dla dzieci, jest znakomita adaptacja popularnej książki Ericha Kästnera Emil i detektywi (Emil und die Detektive, 1931), dokonana przez Gerharda Lamprechta (reżyseria) i Billiego Wildera (scenariusz). Opowieść o przygodzie dwunastolatka z prowincji, okradzionego w pociągu przez demonicznego "pana w meloniku" (świetny Fritz Rasp) z pieniędzy, które wiózł dla babki w Berlinie, i o tym, jak z pomocą całej chmary swych berlińskich rówieśników nie tylko pieniądze odzyskał, ale i pomógł policji schwytać groźnego przestępcę, zachwyca nie tylko prostota, ale i bezpretensjonalnością historii, która musi się podobać i dzieciom, i dorosłym. Rewelacyjna jest forma tego filmu: świetne dialogi, znakomity rytm scen, kreujący zarazem zabawę i suspens, fantastycznie sfotografowane plenery berlińskich ulic, gdzie rozgrywa się gros akcji, kontrastujące $\mathrm{z}$ „ekspresjonistyczną" tonacją 
sekwencji hotelowej, w niskim kluczu i z groźnymi cieniami, gdy Emil zakrada się do pokoju śledzonego zbira. Kracauer w „prawdziwie niemieckim talencie organizacyjnym" nieletnich detektywów (tworzą nie tylko sieć ",agentów” śledzących złodzieja, ale i „,centralę telefoniczną”, poprzez którą wymieniają informacje) dopatruje się wyrazu tendencji demokratycznej i pochwały demokratycznych instytucji. To jednak nie wydaje się takie oczywiste: pochwała kolektywizmu w opowiadających o młodzieży filmach z okresu Trzeciej Rzeszy [vide: Hitlerjunge Quex albo Ja tobie, ty mnie (Ich für dich, du für mich, 1934), film Carla Froelicha o dziewczęcym hufcu Służby Pracy] będzie zarazem afirmacją rezygnacji z ",ja” na rzecz totalitarnej organizacji. Niezależny wobec policji kolektyw „Emil i detektywi" przypomina też chyba trochę alternatywny wobec porządku prawnego świat podziemia z Opery za trzy grosze i $M$ - mordercy, choć trzeba przyznać, iż w dziecięcym kryminale jest on wobec instytucji demokratycznych nie tyle alternatywny, ile raczej komplementarny.

Ostatnie dwa filmy Fritza Langa przed jego wyjazdem z Niemiec w lipcu 1933 to może najsłynniejsze weimarskie kryminały. $M-$ morderca $(M, 1931)$ to właściwie - by użyć hollywoodzkiej nomenklatury genologicznej - topical film, podejmujący temat z pierwszych stron gazet. Inspiracją dla niego były niesłychanie bulwersujące opinię publiczną w całym okresie weimarskim sprawy seryjnych zabójców: Grossmanna, Denkego, Haarmanna, a zwłaszcza Petera Kürtena, zwanego „wampirem z Düsseldorfu" (wyrok w niej zapadł zaledwie 3 tygodnie przed premierą filmu w dniu 11 maja 1931, zaś egzekucja Kürtena miała miejsce już po premierze, 2 lipca 1931). Film Langa opowiada o społecznej psychozie, jaką wywołują zbrodnie seryjnego dzieciobójcy (w tej roli - sugestywny Peter Lorre) w niemieckiej metropolii. Psychozę tę rodzą nie tylko strach i plotka, ale i podsycające ją media: szczególnie zaś prasa publikująca listy mordercy i obwieszczenia rozwieszane na słupach ogłoszeniowych. Sam morderca - psychicznie chory, infantylny i niewątpliwie niekontrolujący swych poczynań - żyje swą , jaźnią odzwierciedloną". "Zapośrednicza” własne zbrodnie przez informacje o nich w środkach przekazu, co alienuje odeń i „obiektywizuje" sprawcę, zapewniając mu sławę (gdy on sam pozostaje anonimowy) i umożliwiając delektowanie się nią przy lekturze prasy i obwieszczeń. Ale $M-$ morderca to jednocześnie film o niemożności bycia anonimowym w społeczeństwie masowym, pełnym archiwów, kartotek, licznych źródeł informacji oraz rozmaitych technik inwigilacji i namiaru (jak chociażby tak eksponowana w filmie daktyloskopia). Owszem, policja pozwala się wyprzedzić światu przestępczemu w namierzeniu i schwytaniu sprawcy - warto jednak zauważyć, że świat prawa i bezprawia posługują się tymi samymi metodami: zbieraniem informacji, inwigilacja, szpiegowaniem osób, gromadzeniem „baz danych”; przestępcy 
organizują nawet "sąd" naśladujący zewnętrzną formą bo już nie istota, procedury prawne demokratycznego państwa. $W$ tym obrazie dwuwładzy w społeczeństwie - istnienia państwa oficjalnego z jego rozmaitymi, nie zawsze skutecznymi służbami, i nieformalnej organizacji o charakterze przestępczym, kontrolującej znaczne obszary życia publicznego - inspiracją dla scenariusza Langa i Thei von Harbou była niewątpliwie Brechtowska Opera za trzy grosze, bodaj najsłynniejszy utwór dramatyczny Republiki Weimarskiej57.

Wymowa tego filmu jest niejednoznaczna: mimo ostatecznego triumfu w fabule legalnych instytucji (policja ratuje mordercę przed samosądem podziemia, a państwowy sąd wydaje wyrok w jego sprawie), widzowi bardziej zapada w pamięć ",ludowa praworządność", która chcąc natychmiast wyegzekwować „sprawiedliwość", nie waha się przed linczem, uzasadnianym wręcz nazistowską $w$ charakterze retoryką i argumentacją... Nic zatem dziwnego, że jednym z największych entuzjastów filmu po premierze był przyszły minister propagandy, Joseph Goebbels, o czym świadczą komplementy dla twórcy w jego dzienniku: „Fantastyczne! Przeciwko humanitarnej czułostkowości! Za karą śmierci! Dobrze zrobione. Lang będzie kiedyś naszym reżyserem" ${ }^{25}$. Lang wprawdzie nie został „ich” reżyserem, jak pokazała nieodległa przyszłość, ale w jednym Goebbels miał rację: $M$ to „dobrze zrobiony” film. Budzi podziw zarówno nowatorskie wykorzystanie dźwięku, błyskotliwe sekwencje montażowe kondensujące dłuższe okresy bądź permanentne stany rzeczy, jak i perfekcyjny montaż naprzemienny, efektownie zestawiający poczynania policji i podziemia (ma on charakter montażu symultanicznego i zarazem paralelnego ideowego). Świetne zdjęcia Fritza Arno Wagnera, w tonacji monochromatycznej szarości, eksplorujące miejski plener i realistyczne wnętrza komisariatów, biurowca, czynszowych mieszkań, należą do czołowych osiągnięć estetyki Nowej Rzeczowości (jednak w przeciwieństwie np. do Emila i detektywów czy Berlin Alexanderplatz miasto Langa zostało stworzone całkowicie w atelier, co nie kreuje typowego dla tamtych filmów „strumienia życia”, stwarza natomiast poczucie klaustrofobicznego osaczenia: wpierw społeczeństwa przez mordercę, później - ściganego mordercy przez społeczeństwo). Zwraca też uwagę nowatorskie posłużenie się elipsą i metonimią dla zasygnalizowania tragicznej śmierci Elsie Beckmann. Potworny akt nie zostaje

57 Odsyłam do omówienia rozmaitych kontekstów i aspektów tego filmu w rozdziale Całe miasto o tym mówi, albo kryminat za trzy grosze: "M - morderca”. Por. także: A. Kaes, M, BFI Publishing, London 2001.

58 Die Tagebücher von Joseph Goebbbels: Sämtliche Fragmente, vol. 1, 1924-1941, München 1987 (zapisek z dnia 21 V 1931); cyt. za: Fritz Lang. Leben und Werke. Bilder und Dokumente, red. R. Aurich, W. Jacobsen, C. Schnauber, Filmmuseum Berlin - Deutsche Kinemathek und jovis Verlag, Berlin 2001, s. 169. 
unaoczniony. Widzimy tylko jego metonimiczne reprezentacje $\mathrm{w}$ postaci zaczepionego o druty balonika i toczącej się w krzaki piłki, które należały do ofiary. Obserwujemy także puste miejsce przy stole w mieszkaniu Elsie, gdzie na próżno oczekuje jej matka.

Jowialny komisarz Lohmann (Otto Wernicke), jeden z głównych bohaterów $M$, wraca w następnym filmie Langa Testament doktora Mabuse (Das Testament des Dr. Mabuse/Le Testament du Dr. Mabuse, 1933), gdzie tym razem musi się zmierzyć nie z terroryzującym miasto dzieciobójca, a z zagadnieniem wręcz metafizycznym, jakim jest „wędrująca świadomość" zbrodniarza, w dniach swej świetności mieniącego się nadczłowiekiem. Doktor Mabuse to tytułowa postać genialnego dzieła Langa z roku 1922. Pod koniec tamtego filmu został ujęty przez prokuratora von Wenka, uprzednio postradawszy zmysły. Osadzony w klinice psychiatrycznej profesora Bauma, niekontaktujący się ze światem, bezwolny i bezbronny, zapisuje na pozór bezsensownymi gryzmołami niezliczone kartki. Okazują się one jego zbrodniczym "testamentem”, planem sterroryzowania społeczeństwa, zasiania w nim zamętu i anarchii. Mabuse gdzieś w połowie filmu umiera, ale jego ego i zbrodnicza myśl „wcielają się" (dosłownie) w profesora Bauma, który jako Mabuse (czy też raczej kolejny jego „awatar”) kieruje grupa niebezpiecznych przestępców - do czasu, kiedy, zdemaskowany i pokonany przez komisarza Lohmanna, sam wpada w szaleństwo, jak jego eks-pacjent i mentor. „Oddzielenie” się fizyczne (i metafizyczne) zbrodniczej świadomości Mabusego od jego osoby umożliwi Langowi w roku 1960 powrót do tego superprzestępcy w Tysiacu oczu doktora Mabuse (Die 1000 Augen des Dr. Mabuse), a producentowi tamtego filmu, Arturowi Braunerowi, kontynuację serii, gdy Lang wyrazi już désintéressment kolejnymi realizacjami tego tematu. Niedopuszczenie przez nazistów do rozpowszechniania tego filmu zrodziło, przy pomocy snutych przez samego Langa opowieści oraz jego manipulacji napisami i ścieżką dźwiękową (gdy w roku 1943 francuska, a w roku 1952 niemiecką wersję filmu wprowadzano na amerykańskie ekrany), legendę o odważnej, antyhitlerowskiej wymowie tego filmu. Nie znajduje ona zupełnie potwierdzenia, gdy ogląda się oryginalną niemiecką wersję z roku 1933, co każe przypuszczać, iż powodem zatrzymania filmu była nie jego wymowa, ale żydowskie pochodzenie reżysera ${ }^{59}$.

Seymour Nebenzahl, związany z lewicą właściciel wytwórni Nero Film, w której powstały owe dwa filmy Langa, wyprodukował także trzy ostatnie weimarskie filmy Georga Wilhelma Pabsta. Pierwszy z nich to Front zachodni 1918 (Westfront 1918, 1930), może niezbyt udany artystycznie,

59 Analiza filmu i omówienie rozmaitych jego kontekstów znajduje się w rozdziale 8. Szepczace ściany albo awatar: „Testament doktora Mabuse”, s. 499. 
ale symptomatyczny dla fali filmowych rozrachunków z I wojną światowa która na przełomie lat 20. i 30. pojawiła się w kinie światowym. Może najsłynniejszy z nich, Na Zachodzie bez zmian (All Quiet on the Western Front, 1930) Lewisa Milestone'a, hollywoodzką adaptację pacyfistycznej powieści Remarque’a, spotkało zdjęcie z niemieckich ekranów wymuszone przez hałaśliwy bojkot nazistów. Film Pabsta borykał się wprawdzie z Filmprüfstelle, czyli cenzura, ale do momentu przejęcia władzy przez Hitlera pozostał na ekranach. Kracauer zwraca uwagę na jego w gruncie rzeczy dość niejasną wymowę: obecny w nim obraz trudu żołnierskiego życia we frontowych okopach wcale nie musi implikować pacyfistycznej intencji, gdyż powtarza się w filmach zrobionych z przeciwnych pozycji politycznych, jak np. w sponsorowanym przez nazistów i zrealizowanym z udziałem prawdziwych weteranów I wojny światowej filmie Hansa Zöberleina Oddział szturmowy 1917 (Stoßtrupp 1917, 1934)60.

Pozostałe dwa filmy Pabsta dla Nebenzahla to już prawdziwe arcydzieła. Mistrzowska adaptacja Opery za trzy grosze (Die 3-Groschen-Oper, 1931) dość bezceremonialnie tasuje i skraca materiał fabularny teatralnego pierwozoru, wskutek czego zresztą Brecht będzie się procesować z producentem i Pabstem o naruszenie praw autorskich. Trzeba przyznać, że właśnie dzięki skrótom i kondensacji drapieżna satyra społeczna wybrzmiewa w filmie Pabsta nie słabiej (a kto wie, czy nie mocniej) niż w oryginale ${ }^{61}$. Film zachwyca mistrzowskim ufilmowieniem atelierowej, teatralnej

60 S. Kracauer, op. cit., s. 197-200. Osobliwym fenomenem przełomu lat 20. i 30. są interesujące zarówno z powodów historycznych, jak i genologicznych, filmowe rekonstrukcje działań wojennych i bitew I wojny światowej. Wspomniany przez Kracauera film Hansa Zöberleina Oddział szturmowy 1917 należy do tego szczególnego genre'u. Filmy te miały bardzo wątłą linię fabularną - charakteryzowała je raczej naturalistyczna opisowość w przedstawieniu życia w okopach oraz podkreślana na rozmaite sposoby (przez komentarz, napisy, mapy) pedanteria $\mathrm{w}$ odtworzeniu batalistyki. Występowali $\mathrm{w}$ nich, co skrupulatnie podkreślano, weterani wojenni, choć, rzecz jasna, także aktorzy zawodowi znajdowali się w obsadzie. W Niemczech weimarskich w filmach tych wyspecjalizował się Heinz Paul: Somma (Die Somme, 1930), Douaumont - piekło pod Verdun (Douaumont - Die Hölle von Verdun, 1931), Tannenberg (1932). Analogiczne filmy powstawały we Francji, np. dyptyk Léona Poirier o Verdun: Verdun, obrazy historii (Verdun, visions d'histoire, 1928) i Verdun, pamiatki historii (Verdun, souvenirs d'histoire, 1931). Oczywiście, naturalizm w zobrazowaniu „okropności wojny" można by uznać za przejaw pacyfizmu, jednak w filmach obu nacji obecna jest też nuta patriotyczna oraz - co spożytkują w propagandzie naziści - kombatanckie sentymenty.

${ }^{61}$ Dotyczy to jednak tylko niemieckiej wersji filmu, ze świetnymi kreacjami Rudolfa Forstera (Mackie Messer) i Fritza Raspa (Peachum), w której songi Weilla brzmią szczególnie drapieżnie i szyderczo. We francuskiej wersji L'Opéra de quat'sous obsada, z Albertem Préjean jako Mackiem na czele, sprawia, iż odnosimy wrażenie jakby przeniesienia się w świat „populistycznych” filmów René Claira, w rodzaju Pod dachami Paryża (Sous le toits de Paris, 1929) czy 14 lipca (Quatorze juillet, 1932). A po francusku songi Weilla i Brechta zupełnie „nie brzmią". 
scenerii poprzez brawurowe travellingi i interesujące umieszczenie $\mathrm{w}$ dekoracjach rozmaitych szyb, luster, szklanych przepierzeń, komplikujących nasze odczuwanie przestrzeni i przekształcających ją wskutek tej „refleksywności" w istny labirynt. Do estetyki tej nawiąże po latach w swych filmach Rainer Werner Fassbinder.

Z kolei Braterstwo (Kameradschaft, 1931) wydaje się z dzisiejszej perspektywy manifestacją neorealizmu avant la lettre. Rekonstrukcja wydarzenia sprzed lat, gdy po tąpnięciu w przygranicznej kopalni francuskim górnikom pospieszyli na ratunek górnicy niemieccy, zachwyca Kracauerowskim „strumieniem życia”, z którego wyłaniają się i w którym na powrót nikną rozmaite "wątki znalezione", oraz niesłychanym realizmem rzeczywistości przed kamerą. Choć nie jest to, trzeba podkreślić, prawda w sensie ontycznego statusu profilmowego świata - prawdziwe jest górnicze miasteczko, ale już kopalnia wyglądająca niesłychanie wiarygodnie to mistrzowska dekoracja zbudowana w atelier. Jak stwierdził jej twórca, Ernö Metzner, zdjęcia prawdziwej katastrofy w kopalni nie wyglądałyby równie przekonująco ${ }^{62}$. A będący nadrzędną ideą tego filmu temat klasowej, ale przede wszystkim ogólnoludzkiej, solidarności ponad podziałami narodowymi antycypuje późniejsze o kilka lat inne ważne dzieło, zrealizowane po drugiej stronie granicy - Towarzyszy broni ( $L a$ Grande illusion, 1937) Jeana Renoira. Pabst zdawał sobie sprawę z tego, że w dobie wzrastających w obu krajach, a zwłaszcza w Niemczech, nacjonalistycznych nastrojów temat taki był bardzo nie w porę. Świadczy o tym pełna gorzkiej ironii jedna z finałowych scen: usuniętą przez górników żelazną kratę oddzielającą niemiecką części kopalni od francuskiej, dzięki czemu Niemcy mogli pospieszyć na ratunek francuskim kolegom, oficjele obu państw z pompą na powrót instalują przywracając granicę między państwami także głęboko pod ziemią.

Braterstwo możemy zaliczyć do programowych filmów lewicy w schyłkowym okresie Weimaru, podobnie jak Kuhle Wampe, albo do kogo należy świat (Kuhle Wampe, oder: Wem gehört die Welt?,1932) Slatana Dudowa i Berlin Alexanderplatz (Berlin-Alexanderplatz: Die Geschichte Franz Biberkopfs, 1931) Piela Jutziego. Ciekawe, że wszystkie te filmy charakteryzuje realistyczna, poniekąd nawet naturalistyczna estetyka, niestroniąca od akcentowania brzydoty świata oraz brzydoty fizycznej i psychologicznej postaci.

Film Kuhle Wampe powstał z olbrzymimi kłopotami. Jego produkcję zainicjowała w sierpniu 1931 spółka Prometheus ${ }^{63}$, która upadła i zosta-

62 S. Kracauer, op. cit., s. 204-205.

63 Prometheusa założyła w roku 1924 niemiecka grupa komunistyczna IAH (Die Internationale Arbeitershilfe) w celu zarówno dystrybuowania sowieckich filmów w Niemczech, jak i produkcji lewicowych filmów, realizowanych tak przez niemieckich, jak 
ła rozwiązana w lutym 1932. Ostatecznie produkcję ukończyła spółka Praesens, z pomocą finansową Lazara Wechslera w marcu 1932. Premiera odbyła się w maju 1932. W realizacji tego przedsięwzięcia uczestniczył kolektyw. Formalnie reżyserem całości był Bułgar, Slatan Dudow, ale finałową sekwencję dyskusji o kawie w powracającym do centrum Berlina pociagu S-Bahnu zrealizował sam Bertolt Brecht, który wespół z Ernstem Ottwaldem napisał scenariusz. Znakomitą muzykę skomponował znany z lewicowych poglądów Hanns Eisler, a w licznych scenach masowych wystąpiły rzesze członków rozmaitych lewicowych organizacji (Fichte Sportklub, Zespół Teatru Robotniczego, Robotniczy Chór Wielkiego Berlina). Film składa się z trzech, dość luźno powiązanych, części. Pierwsza obrazuje kryzys początku lat 30., bezskuteczne poszukiwanie pracy przez bezrobotnych i samobójstwo jednego z nich; druga - tytułowe Kuhle Wampe, barakowe osiedle dla bezdomnych na przedmieściach Berlina, dokąd rodzina samobójcy musiała się przenieść ze śródmieścia; trzecia - działalność lewicowej organizacji, w którą angażuje się główna bohaterka, Anni (siostra samobójcy), jej koleżanka i narzeczony. Kuhle Wampe to film "brechtowski” i to nie tylko z racji współudziału dramatopisarza $\mathrm{w}$ jego realizacji. Pokawałkowaną fabułę (co już samo w sobie „dystansuje" nas od przedstawionego świata) kontrapunktują ideologiczne songi, a polityczne dyskusje czy komentarze bohaterów nieustannie przerywają tok wydarzeń, które powinny być bardziej zajmujące dla widza (jak niechciana ciąża bohaterki czy jej zerwanie z narzeczonym). Kuhle Wampe to niewątpliwie autoportret weimarskiej lewicy, a ściślej weimarskich komunistów. Zwraca uwagę, iż w swych formach działania (imprezy masowe, sport, rozmaite przemarsze i pochody) ogromnie przypominają nazistów, ",anektując" jednostkę i roztapiając ją w euforycznym tłumie. Ciekawe, że obraz proletariatu jest w tym filmie dość niepochlebny. Swobodę seksualną i pijaństwo (naturalistyczna scena zaręczynowego bankietu) zaakcentowane $\mathrm{w}$ fabule wykorzystają do sportretowania nie tyle proletariuszy, co komunistów, trzy „brunatne” filmy z roku 1933: SA-Mann Brand, Hitlerjunge Quex i Hans Westmar.

Piel Jutzi, który zabłysnął zille'owskim filmem Podróż Matki Krause do szczęścia (Mutter Krausens Fahrt ins Glück, 1929), zrealizował adaptację powieści Alfreda Döblina Berlin Alexanderplatz. Jak pierwowzór powieściowy w literaturze, tak i w filmie jego ekranizacja przez Jutziego należy do

\footnotetext{
i rosyjskich reżyserów. W latach 1925-1931 spółka ta wyprodukowała kilka filmów, a wśród nich Żywego trupa (Żywoj trup/Der lebende Leichnam, 1928) Fiodora Ocepa czy Podróż Matki Krause do szczęścia (Mutter Krausens Fahrt ins Glück, 1929) Piela Jutziego. Szerzej na temat Prometheusa, jego historii i ideologii, zob.: Bruce Murray, Film and the German Left in the Weimar Republic: From „Caligari” to „Kuhle Wampe”, University of Texas Press, Austin 1990.
} 
najświetniejszych osiągnięć Nowej Rzeczowości. Musi się podobać strona wizualna, eksponująca wielkomiejski plener, a zwłaszcza szalenie efektowna początkowa sekwencja, ukazująca jak zwolniony właśnie z więzienia po odsiedzeniu wyroku za zabójstwo kochanki Franz Biberkopf jedzie tramwajem z przedmieść Berlina do jego centrum, coraz bardziej oszołomiony gwarem, ruchem i gorączkową krzątaniną metropolii. Bohater usiłuje powrócić do uczciwego życia, ale powrót ten komplikuje mu bandyta Reinhold. Wplątuje go w przestępczą działalność, wyrzucając z auta, powoduje jego kalectwo (Biberkopf traci rękę), aż w końcu zabija jego nową dziewczynę... Po tych wszystkich ciosach bohater zdoła jednak wrócić do w miarę uczciwego życia. W finale sprzedaje na Alexanderplatz zabawki typu „wańka-wstańka”, tak je zachwalając: „Ta laleczka zawsze wstaje na nowo. Dlaczego? Bo ma kawałek metalu we właściwym miejscu". Kracauer, komentując ideowy indyferentyzm czy wręcz cynizm tego zakończenia, nie odnosi go jednak do ideowego wyboru jego twórców, o co znajomość dalszych losów tych realnych „waniek-wstaniek” aż się prosi. Piel Jutzi, niepomny swego niegdysiejszego członkostwa w partii komunistycznej, w roku 1933 wstępuje do NSDAP i w Trzeciej Rzeszy zrealizuje wiele filmów (choć głównie krótkometrażowych, gdyż z racji swej politycznej przeszłości zostanie odsunięty od pełnometrażowych, wysokobudżetowych produkcji). Heinrich George, genialny odtwórca roli Biberkopfa, a zarazem komunista i słynny aktor Brechta oraz Piscatora, po opublikowaniu w roku 1933 na łamach berlińskiej prasy deklaracji lojalności wobec nazistów, stanie się czołową gwiazdą niemieckiego kina i stworzy w nim wiele wspaniałych kreacji - i to nie tylko we względnie neutralnych filmach, jak Wróg ludu (Ein Volksfeind, 1937) Hansa Steinhoffa czy Poczmistrz (1940) Gustava Ucicky'ego, ale też w osławionych filmach Harlana Żyd Süss i Kolberg64.

Twórcy filmów górskich, Bergfilme czy teżfilmów historycznych z serii "fryderycjańskiej”, po 1933 nie musieli wykonywać takich ideowych wolt, bo na podstawie rozmaitych przesłanek już wcześniej można było przypuszczać, że do nazistów nie będzie im specjalnie daleko.

Bergfilm w okresie dźwiękowym u schyłku Republiki nie wydał arcydzieł gatunku na miarę Świętej góry (Der heilige Berg, 1926, Arnold Fanck) czy Białego piekła na Piz Palü (Die weiße Hölle vom Piz Palü, 1929, Arnold Fanck i Georg Wilhelm Pabst). Ostatnie weimarskie filmy Fancka - Burza

${ }^{64}$ Jest jakaś głęboka ironia losu w fakcie, iż Heinrich George 26 września 1946 r. umrze w założonym przez n a z i s tó w obozie Sachsenhausen w Oranienburgu, umieszczony tam przez k o m u n is tó w (okupacyjne władze sowieckie), jakby płacąc za polityczne wybory swego życia. 
nad Mont Blanc (Stürme über dem Montblanc, 1930) i Białe szaleństwo (Der weiße Rausch - Neue Wunder des Schneeschuhs, 1931) - są znacznie poniżej poziomu tamtych filmów, mimo że oba oferują widzowi rozmaite atrakcje: piękne zdjęcia ośnieżonych gór, zapierające dech wyczyny narciarskie i niezwykle sprawna, choć w filmie dźwiękowym jeszcze mniej aktorsko przekonującą Leni Riefenstahl. W pierwszym z filmów dochodzi do tego jeszcze dramatyczna fabuła z suspensem i lotnicze wyczyny pamiętnego z Białego piekła Ernsta Udeta, a w drugim - generalnie relaksowa tonacja sportowej komedii. Leni Riefenstahl, skłócona z Fanckiem, sama w końcu spróbowała swych sił jako reżyser, realizując Niebieskie światło (Das blaue Licht, 1932). Fabularnie to najbardziej melodramatyczny pośród Bergfilme i chyba też najmocniej skąpany w metafizycznym sosie volkistowskiej mistyki. Monte Christallo, góra w Dolomitach, w noce pełni księżyca lśni tajemniczą błękitną poświatą która, kusząc śmiałków do ryzykownej wspinaczki, powoduje ich śmierć. Tajemnicę „niebieskiego światła" zna Junta, dziewczyna ze wsi, uważana przez wszystkich za wiedźmę. Zakochany w niej malarz z miasta potajemnie podąża za nią w górę i odkrywa przyczynę światła - emituje je złoże górskich kryształów. Zdradza on ów sekret wiosce, która bogaci się na jego odkryciu. Ale ogołocona z kryszałów grota nie emituje już niebieskiego blasku - pozbawiona jego przewodnictwa Junta spada w przepaść... Konflikt „kultury” (czy raczej cywilizacji) i "natury”, uosobionej przez niemal alegoryczną postać Junty (w fatalnym aktorskim wykonaniu Riefenstahl), jest aż nazbyt oczywisty. Rzecz jasna to „natura” jest tu uwzniośloną i zmitologizowaną kategoria, chociaż zostanie ona poświęcona na ołtarzu „postępu” i „dobrobytu”... Ten pretensjonalny i kiczowaty film nie zebrał najlepszych recenzji, spodobał się jednak Hitlerowi, co zaowocowało w okresie nazistowskim kuszącymi propozycjami dla reżyserki, z których ta skwapliwie skorzystała.

$\mathrm{Na}$ inne jeszcze tory skierował gatunek filmu górskiego gwiazdor Świętej góry, Luis Trenker. Historisch Bergfilm - tak chyba można by nazwać zaproponowaną przezeń formułę. Góry w płomieniach (Berge in Flammen, współreż. Karl Hartl, 1932) ${ }^{65}$ rozgrywają się w realiach I wojny światowej w Tyrolu, będącym areną walk austriacko-włoskich. Ufortyfikowanym na jednym ze szczytów Austriakom grozi wysadzenie w powietrze przez drążących podkop Włochów. Brawurowy zwiad granego przez Trenkera głównego bohatera (w cywilu - przewodnika górskiego) udaremnia sukces poczynań przeciwnika. Austriakom udaje się

${ }^{65}$ Góry w płomieniach jako multilingual film mają również francuską i angielską wersję językową: Les Monts en flammes (1931, współreż. Joë Hamman) oraz Doomed Batalion (1932, reżyseria angielskojęzycznych dokrętek Cyril Gardner). 
w porę ewakuować. Prolog (osadzony w przededniu wybuchu wojny) i epilog (rozgrywający się wiele lat po wojnie) pokazują męską przyjaźń Austriaka i Włocha, scementowaną przez wspólne wspinaczki - choć w latach wojny, w mundurach swych armii, toczyli bezwzględną walkę na śmierć i życie. Nie jest to jednak afirmacja więzi ponad narodowymi podziałami (jak w Braterstwie Pabsta czy Towarzyszach broni Renoira), ale volkistowska z ducha apoteoza natury i tężyzny fizycznej oraz bliska zarówno nazistom, jak i włoskim faszystom, afirmacja kombatanctwa. Z kolei następny film Trenkera, Buntownik (Der Rebell, 1932, współreż. Kurt Bernhardt), którego premiera odbyła się 17 stycznia 1933, na 2 tygodnie przez objęciem władzy przez Hitlera, osadzony jest w epoce napoleońskiej. Student z Tyrolu (w tej roli oczywiście Trenker), zastawszy rodzinną wieś spalona, a matkę i siostrę zamordowane przez Francuzów, staje się nieprzejednanym wrogiem okupanta, organizując przeciw niemu ruch oporu. W kulminacyjnej scenie filmu przygotowana przezeń zasadzka w górskim wąwozie przynosi zagładę francuskim oddziałom, ale on sam przypłaca to życiem. Nie tylko przygodowa i wizualna atrakcyjność (zdjęcia Seppa Allgeiera) sprawiły, że 28 marca 1933 r. Goebbels, na spotkaniu z pracownikami kinematografii niemieckiej $\mathrm{w}$ Hotelu Kaiserhoff, wymienił Buntownika jako wzór dla przyszłego narodowosocjalistycznego filmu. Zasadniczym powodem tej rekomendacji wydaje się pełen resentymentu nacjonalizm oraz afirmacja samobójczego wręcz heroizmu, gotowego zawsze do poświęcenia na ołtarzu sprawy (zwłaszcza odwetowej $)^{66}$.

Schyłek Republiki Weimarskiej zaowocował reaktywacją serii historycznych filmów o Fryderyku Wielkim. Rolę króla Prus grał w nich słynny z podobieństwa do „starego Fritza” Otto Gebühr. Rzecz jasna, filmowe apoteozy władcy, który rządami silnej ręki i militarnymi sukcesami uczynił z Prus mocarstwo, antycypowały "politykę historyczną" (i estetyczną) Trzeciej Rzeszy, poprzez panegiryki na cześć „silnych ludzi” w rodzaju Fryderyka czy Bismarcka afirmującej jedynowładztwo Führera ${ }^{67}$. Paradoksalnie, jeden z tych filmów - Tancerka z Sans-Souci (Die Tänzerin von Sanssouci, 1932) - został wyprodukowany i wyreżyserowany przez Żyda, Friedricha Zelnika, który w 1933 opuści na stałe Niemcy. Jednak inne z tych filmów wyreżyserują prominentni twórcy okresu hitlerowskiego - Gustav

${ }^{66}$ Chyba nie przypadkiem Buntownik nie posiada francuskiej wersji językowej, choć miały ją Góry w płomieniach. Posiada jednak wersję angielskojęzyczną The Rebel (1933, współreż. Edwin H. Knopf).

${ }^{67}$ Warto zwrócić uwagę na interesującą zbieżność z kryptoapoteozami Stalina w sowieckich filmach historycznych z okresu socrealistycznego, o wielkich władcach czy dowódcach. 
Ucicky [Koncert na flet z Sans-Souci (Das Flötenkonzert von Sanssouci, 1930)] czy Carl Froelich [Chorat pod Leuthen (Der Choral von Leuthen, 1933), współreż. Arzén von Cserépy].

Gustav Ucicky, pochodzący z Austrii i skądinąd naprawdę utalentowany filmowiec, wyreżyseruje też film, który, w towarzystwie m.in. Hugenberga i eks-kanclerza Papena na berlińskiej premierze 2 lutego 1933, obejrzy świeżo mianowany przez prezydenta kanclerz - Adolf Hitler. Filmem tym jest dość zresztą przeciętna artystycznie, za to pełna patosu Jutrzenka (Morgenrot, 1933). Ta historia niemieckiej łodzi podwodnej z lat I wojny światowej, storpedowanej przez Anglików, afirmuje kombatancką więź i samobójczy heroizm marynarzy, którzy odbierając sobie życie, umożliwiają ratunek kolegom. Bohater, który przeżył, mówi w rozmowie z matką: „,Możliwe, że my Niemcy nie umiemy żyć, ale umiemy umierać niewiarygodnie dobrze". Właśnie owa zrealizowana jeszcze w Republice, lecz wypuszczona już u zarania Trzeciej Rzeszy, i to przy takiej publiczności, apoteoza heroicznej śmierci, jest w sposób symboliczny tranzytywnym filmem między okresem weimarskim a hitlerowskim. Chyba nieprzypadkowo to ostatni film, jaki w swej książce Od Caligariego do Hitlera omawia Kracauer ${ }^{68}$.

\section{Kino niemieckie w okresie nazistowskim}

\section{Struktura przemysłu filmowego Trzeciej Rzeszy}

Dnia 11 marca 1933 r. naziści ustanowili Ministerstwo Oświecenia Publicznego i Propagandy (RMVP - Reichsministerium für Volksaufklärung und Propaganda). Zgodnie z prezydenckim dekretem 13 marca na jego czele stanął Joseph Goebbels. Jak ujął to w czerwcu 1933 Hitler, nowy minister miał być odpowiedzialny za „wszystkie zadania związane z duchowym kierownictwem dla narodu" ${ }^{\prime \prime 9}$ - co W praktyce równało się temu, iż szef resortu sprawował kontrolę nad wszystkimi mediami i sztukami. Pisarze, dziennikarze i artyści musieli przynależeć organizacyjnie do utworzonej 22 września 1933 Izby Kultury Rzeszy (RKK - Reichskulturkammer), zrzeszającej siedem Izb (Kammern), z których każda kontrolowała jedną z siedmiu dziedzin: prasę, radio, film, teatr, muzykę, literaturę i sztuki plastyczne. Co ciekawe, Izba Filmowa Rzeszy (Reichsfilmkammer - RFK) powstała najwcześniej, 14 lipca 1933, dwa miesiące przed powołaniem nadrzędnej Izby Kultury - co dobitnie świadczy o randze, jaką naziści przyznawali filmowi

\footnotetext{
68 S. Kracauer, op. cit., s. 229-230.

${ }^{69}$ Cyt. za: D. Welch, op. cit., s. 9.
} 
w ich propagandzie i polityce kulturalnej. Członkami Izby Filmowej (jak i sześciu pozostałych) mogli być wyłącznie obywatele niemieccy o aryjskim pochodzeniu, co umożliwiło usunięcie z przemysłu filmowego prominentnych w kinematografii weimarskiej Żydów (przyspieszyło to, rzecz jasna, ich exodus). Szczególnie intensywne „odżydzanie” (Entjudung) kultury niemieckiej nastąpiło w roku 1935, gdy nad zadaniem tym zaczął sprawować pieczę desygnowany doń przez Goebbelsa Hans Hinkel ${ }^{70}$. Swoistej czystce poddano też... historię filmu niemieckiego. Przy okazji konieczności odnowienia licencji dla wszystkich filmów powstałych przed rokiem 1933 wielu z nich licencji tej nie przedłużono albo usunięto z czołówek nazwiska żydowskich współtwórców (szczególnie reżyserów). Wszczynano też hałaśliwe polityczne nagonki na filmy, w których grali żydowscy aktorzy. Przedmiotem ataków byli również „artyści zdegenerowani” (entartete Künstler), o niepożądanych w Trzeciej Rzeszy poglądach politycznych i/lub kreujący zbyt nowatorskie (,zdegenerowane”) formy. Oczywiście, nie mogli oni być zrzeszeni w poszczególnych Kammern, a w przypadku znanych twórców-emigrantów dzieła ich nie mogły być wydawane, wyświetlane, wystawiane czy eksponowane w muzeach i galeriach ${ }^{71}$.

Powołanie Izby Filmowej było kolejnym etapem coraz wyraźniej postępującej instytucjonalnej centralizacji przemysłu filmowego, zapoczątkowanej kilka lat wcześniej restrukturyzacją Ufy przez Hugenberga, Planem SPIO i uzależnieniem największych wytwórni, które pozostały na rynku (Ufa, Tobis, Bavaria, Terra), od upolitycznionego państwowego mecenatu. Ta integracja niemieckiej kinematografii, wymuszona rozmaitymi sposobami (ustawodawstwo i administracyjny przymus, zakulisowe działania, system pośredniego i bezpośredniego finansowania produkcji filmowej), w literaturze przedmiotu jest określana niemieckim terminem Gleichschaltung ${ }^{72}$. Podstawą prawną tego procesu stała się Ustawa Filmowa Rzeszy (Reichlichtspielgesetz) z 16 lutego 1934. Istotną jej innowacją było wprowadzenie cenzury prewencyjnej, sprawowanej przez urzędnika nazwanego "dramaturgiem filmowym Rzeszy” (Reichsfilmdramaturg). Zanim można było rozpocząć etap zdjęciowy, należało mu przedstawiać do zatwierdzenia zarówno zarys scenariusza (synopsis), jak i po jego

${ }^{70}$ Czy aby przypadkiem wystylizowany na Hitlera bohater Chaplinowskiego Dyktatora (The Great Dictator, 1941) nazywa się Hynkel?

${ }^{71}$ Powszechnie znana jest zainicjowana przez Niemieckie Zrzeszenie Studentów (Deutsche Studentenschaft) akcja z 10 marca 1933 (znacznie wyprzedzająca omawiane tu rozwiązania instytucjonalne). Polegała ona na usunięciu z niemieckich bibliotek i publicznym spaleniu książek skierowanych „przeciw duchowi niemieckiemu” (wider den Deutschen Geist). Objęła ona większość niemieckich miast akademickich, a prócz sprzyjających nazistom studentów w akcji uczestniczyli też profesorowie i rektorzy.

72 Por. np.: S. Hake, op. cit., s. 61-67; D. Welch, op. cit., s. 8-29. 
akceptacji gotowy scenariusz. Nowelizacja z grudnia 1934 stanowiła co prawda, że przedstawienie do akceptacji gotowego scenariusza nie było obligatoryjne, pozostał jednak obowiązek przedkładania do oceny jego zarysu dramaturgowi. „Jeżeli uznał on film za «wart wsparcia», przedkładano mu gotowy scenariusz, i mógł wówczas poczynić kroki, by film został sfinansowany przez Filmkreditbank"73. Dramaturg miał zresztą prawo nadzorować każdy etap produkcji filmu i na dowolnym z nich ją zatrzymać. Jego polecenia czy zmiany sugerowane na poziomie scenariusza bądź realizacji były dla filmowców obligatoryjne ${ }^{74}$. Tajemnicą poliszynela było jednak, iż faktyczną ostateczną instancją w kwestiach produkcji filmu był nie Reichsfilmdramaturg, a sam minister Oświecenia Publicznego i Propagandy, którego prawdziwym „oczkiem w głowie” był przemysł filmowy (dramaturgowie się zmieniali, a Goebbels nieprzerwanie pełnił funkcję szefa resortu do samego końca Trzeciej Rzeszy).

Goebbels był de facto (choć nie de iure) nie tylko naczelnym "dramaturgiem" Rzeszy, ale i naczelnym cenzorem. Cenzura represyjna, powołana w roku 1920 w Republice Weimarskiej, nie została zniesiona powołaniem cenzury prewencyjnej, ale zreorganizowana. Ustawa Filmowa z roku 1934 zastąpiła dwa uprzednio istniejące biura cenzorskie w Berlinie i Monachium centralnym urzędem kontroli filmów (Filmprüffstelle), wcielonym do Wydziału Filmowego Ministerstwa Oświecenia i Propagandy. W Republice Weimarskiej decyzje cenzorskie były podejmowane większością głosów, a od decyzji filmowcy mogli się odwoływać do Najwyższego Urzędu Cenzury, Oberprüffstelle. W świetle nowej ustawy decyzje podejmował jednoosobowo przewodniczący Filmprüffstelle, a instancją odwoławczą od jego decyzji stała się Filmoberprüffstelle, nominalnie nadzorowana przez kierownika Wydziału Filmowego w ministerstwie, faktycznie zaś przez niemal wszechwładnego szefa resortu ${ }^{75}$. Tak pomyślany system cenzury rodził przede wszystkim wynikłą z lęku przed skutkami politycznej nieprawomyślności autocenzurę samych filmowców. Toteż w Trzeciej Rzeszy stosunkowo niewiele filmów padło ofiarą cenzury. Monografiści tematu, Kraft Wetzel i Peter A. Hagemann, wymieniają tylko dwadzieścia siedem filmów w ogóle niedopuszczonych na ekrany ${ }^{76}$.

${ }^{73}$ D. Welch, op. cit., s. 14.

${ }^{74}$ Ibidem, s. 13-14; B. Drewniak, op. cit., s. 162-163.

75 Por. D. Welch, op. cit., s. 14-15; B. Drewniak, op. cit., s. 163.

${ }^{76}$ Kraft Wetzel, Peter A. Hagemann, Zensur: Verbotene deutsche Filme 1933-1945, Volker Spiess, Berlin 1982, passim. Biorąc pod uwagę filmy wyświetlane w kinach Trzeciej Rzeszy, ale z rozmaitych powodów (zmieniona sytuacja polityczna, osoba twórcy stała się tymczasem persona non grata) zakazane po jakimś okresie eksploatacji i zdjęte z ekranów, byłoby to niespełna pięćdziesiąt tytułów. Pouczający wykaz wszystkich tych filmów (zakazanych w ogóle lub po jakimś czasie), z rozpisaniem na poszczególne lata, można znaleźć też 
„Większość z nich miała za reżysera lub w obsadzie kogoś, kto stał się persona non grata. Kilku filmów zakazano pomimo, albo właśnie z powodu, ich narodowo-socjalistycznej gorliwości. W innych przypadkach cenzorzy uznali pewne przedstawienia (np. obrazy zbombardowanych miast) za zbyt demoralizujące dla publiczności lat wojny"77.

W Trzeciej Rzeszy nastąpiło zdławienie bujnie rozkwitłej w okresie weimarskim i stojącej na bardzo wysokim poziomie intelektualnym krytyki filmowej. Nastąpiło to w dwóch etapach. Po pierwsze, jesienią $1933 \mathrm{r}$. dziennikarzy poddano kontroli resortu Goebbelsa, a etatowych pracowników prasy zrównano $\mathrm{w}$ prawach i obowiązkach z urzędnikami państwowymi. Jako urzędnik krytyk przestawał mieć prawo do wyrażania własnych, subiektywnych sądów, lecz miał realizować oficjalną linię państwa. Gdy jednak samodzielność sądów artystycznych w krytyce wciąż się utrzymywała, 27 listopada 1936 r. Goebbels po prostu krytyki zakazał. Recenzentom wolno było wprawdzie opisywać dzieła sztuki, ale zabroniono im wydawania sądów wartościujących. Niezależnie od takich zakazów, Ministerstwo przed każdym ważniejszym filmem rozsyłało do redakcji instrukcje - jak i o czym można i trzeba pisać ${ }^{78}$.

W Republice Weimarskiej istniał system kwalifikacji filmów, którego ustalenia (np. to, że dany film jest „,artystyczny”, , oświatowy” albo „ważny dla edukacji narodu") miały charakter prestiżowy bądź pozwalały uzyskać redukcję „podatku od rozrywki”. Ustawa Filmowa z 1934 rozbudowała ten system, ale nadawane odtąd przez Filmprüffstelle kwalifikacje (tzw. Prädikate) były obligatoryjne, aby film w ogóle mógł być dopuszczony na ekrany. W Trzeciej Rzeszy obowiązywały następujące kategorie określające film (data oznacza rok ich wprowadzenia):
a) „szczególnie wartościowy politycznie i artystycznie”, 1933,
b) „szczególnie wartościowy politycznie”, 1933,
c) „szczególnie wartościowy artystycznie”, 1933,
d) „wartościowy politycznie”, 1933,
e) „wartościowy artystycznie”, 1933,
f) „wartościowy kulturowo”, 1933,
g) „wartościowy dla młodzieży”, 1938,
h) „wartościowy dla narodu”, 1939,

\footnotetext{
w znakomitym aneksie (Appendix A) książki Erica Rentschlera The Ministry of Illusion: Nazi Cinema and Its Afterlife (s. 225-271). Ale pamiętajmy też o ingerencjach na etapie produkcji lub montażu - uwzględniając je, za ofiary cenzury trzeba by uznać jednak większą liczbę filmów, w tym np. prestiżowe i ideologicznie zaangażowane produkcje reżimu, jak Złote miasto czy Kolberg Harlana (wskutek ingerencji Goebbelsa w pierwszym zmieniono zakończenie, drugi - przemontowano i pozbawiono całych zrealizowanych już sekwencji).

77 S. Hake, op. cit., s. 62-63.

${ }^{78}$ J. Toeplitz, Historia sztuki filmowej, t. 4, s. 269.
} 
i) „Film Narodu”, 1939,

j) „oświatowy”, 1920,

k) „wartościowy dla edukacji narodu”, 1924.

Najwyższa z kategorii - (a) - całkowicie zwalniała film z podatku, niższe - pozwalały na jego mniejszą lub większą redukcję. Ulgi tej nie dawała wprawdzie kwalifikacja filmu jako „wartościowego dla młodzieży” (Jugendwert) ani prestiżowe miano „Filmu Narodu”, połączone z wręczaniem filmowcom złotego pierścienia ${ }^{79}$; tak jednak uhonorowane filmy miały zapewnioną dystrybucję w szkołach i wśród członków Hitlerjugend, a po roku 1938 żaden kiniarz nie ośmieliłby się odrzucić filmu z taką szczególną państwową kwalifikacją ${ }^{80}$.

Dnia 1 czerwca 1933 został powołany do istnienia Bank Kredytu Filmowego-Filmkreditbank. Przyjąłon formęprywatnej spółki zo.o., utworzonej przez Towarzystwo Kredytowe Rzeszy (Reichskreditgesellschaft), SPIO (firmę będącą przykrywką dla Reichsfilmkammer), Commerzbank, Deutsche Bank (ze znacznymi udziałami w Ufie) i Dresdner Bank (z udziałami w Tobisie). Dość szybko jednak banki przeniosły swe udziały do Izby Filmowej Rzeszy, a jej przewodniczący - z inicjatywy Goebbelsa - został prezesem Filmkreditbank ${ }^{81}$. Bank ów miał dostarczać kredytu i wsparcia finansowego przemysłowi filmowemu dotkniętemu kryzysem. Ci przedstawiciele przemysłu filmowego, którzy nie szykowali się już do emigracji (jak Żydzi czy twórcy jednoznacznie utożsamiani z politycznymi przeciwnikami nazistów), a wciąż byli nieufni wobec nowej władzy, przywitali z entuzjazmem zarówno powołanie instytucji pomagającej finansować produkcję filmowa, jak i obniżenie podatku od rozrywki z 11,5 do 8\% od średnich przychodów filmu. Tymczasem Filmkreditbank był kolejnym - obok cenzury, systemu kwalifikacji i obligatoryjnej przynależności do Izby Filmowej - przejawem coraz większej zależności kinematografii od totalitarnej władzy. „Bank, działając z ramienia rządu, mógł odmówić jakiegokolwiek kredytu na etapie pre-produkcji, aż film zacząłby zadowalać życzenia nowego reżimu. Znaczące, iż nie ma dowodów świadczących, że przemysł filmowy niechętnie przyjął tę formę autocenzury" ${ }^{\prime 22}$. Do 1936 r. bank ten finansował już 73\%

79 Od ustanowienia kategorii „Filmu Narodu” (Film der Nation) w roku 1939 do końca Trzeciej Rzeszy zaledwie cztery filmy otrzymały ów Prädikat: Wuj Krüger (Ohm Krüger, 1941, Hans Steinhoff), Powrót (Heimkehr, 1941, Gustav Ucicky), Wielki król (Der große König, 1942, Veit Harlan) i Dymisja (Die Entlassung, 1942, Wolfgang Liebeneiner).

${ }^{80}$ D. Welch, op. cit., s. 15-16. System Prädikate podaję za Welchem, gdyż w jego książce jest on zaprezentowany trochę klarowniej (i z nieco innymi kategoriami) niż w pracy Bogusława Drewniaka (op. cit., s. 163-164).

${ }^{81}$ D. Welch, op. cit., s. 10-11.

82 Ibidem, s. 11. 
niemieckich filmów fabularnych, prowadząc interesy wyłącznie z dystrybutorami, gwarantującymi ogólnokrajowe rozpowszechnianie filmu. Niezależni mali producenci, dla których wsparcia instytucję tę formalnie powołano, zostali stopniowo zupełnie wyparci z rynku, a proces centralizacji kinematografii nabrał tempa.

Mimo kredytów i coraz większej frekwencji na niemieckich filmach na rodzimym rynku filmowym, w roku 1936 największe wytwórnie znalazły się w kryzysie finansowym. Powodem tego był drastyczny spadek eksportu (niemieckie filmy były bojkotowane w wielu krajach, m.in. w USA) oraz gwałtownie rosnące koszty produkcji. Tarapaty te stały się sposobnością dla władz, by dokonać przejęcia czołowych kompanii filmowych, doprowadzając $w$ praktyce do nacjonalizacji kinematografii. Proceder przejmowania przebiegał po kryjomu przez podstawionego człowieka, Maxa Winklera, który, stojąc na czele Funduszu Powierniczego Kautio (Kautio Treuhand $\mathrm{GmbH}$ ), nabywał większościowe udziały poszczególnych kompanii, a tym samym zyskiwał prawo zarządzania nimi jako „powiernik” państwa. Dzięki figuranctwu Winklera państwo jawiło się opinii publicznej raczej jako sprawujące kontrolę nad spółkami filmowymi w dobie kryzysu niż jako faktycznie przejmujące je na własność. Pierwszą ofiarą tej polityki padł człowiek, który w kinematografii utorował nazistom drogę - Alfred Hugenberg. Jego medialne imperium, na które składały się Ufa i koncern wydawniczy Scherl Verlag, zostało przejęte przez Kautio w marcu 1937 (dokładnie 10 lat po przejęciu przezeń zadłużonej u Amerykanów Ufy). Niedługo później Winkler zdecydował o rozbiciu zbyt potężnego koncernu Tobis Tonbild Syndikat. Jego trzon produkcyjny został przekształcony w nową spółkę Tobis Filmkunst GmbH (grudzień 1937), a jego przedsiębiorstwo dystrybucyjne Tobis Rota wraz z będącą uprzednio filią Ufy wytwórnią Terra Film AG stopiono w jedną kompanię produkcyjną Terrakunst $\mathrm{GmbH}$ (sierpień 1937). Wkrótce potem trust Winklera wykupił także udziały w największej poza Berlinem spółce filmowej - holdingu Bavaria Film, przekształconym 11 lutego 1938 w Bavaria Filmkunst $\mathrm{GmbH}$. Kolejne zdobycze Funduszu Kautio były już wynikiem terytorialnej ekspansji Trzeciej Rzeszy. Po aneksji Austrii i inwazji na Czechy pod jego jurysdykcją (czyli de facto - w posiadaniu przez niemieckie państwo) znalazły się kompanie Wien Film GmbH i Prag Film AG, utworzone po zawłaszczeniu i reorganizacji, odpowiednio, austriackiego i czechosłowackiego przemysłu filmowego ${ }^{83}$.

Wraz ze zmianą struktury własnościowej musiał zmienić się system finansowania kinematografii. Powołano nową spółkę zwaną FiFi (Film Finanz $\mathrm{GmbH}$ ). O udzielaniu kredytów na realizację decydowała rada

${ }^{83}$ Por.: D. Welch, op. cit., s. 23-26; S. Hake, op. cit., s. 64-66. 
nadzorcza, w której zasiadali przedstawiciele Ministerstwa Oświecenia i Propagandy, Ministerstwa Finansów, Towarzystwa Kredytu Rzeszy, Funduszu Powierniczego Kautio i nowo powstałych, kontrolowanych przez państwo, kompanii filmowych. Pierwsze zebranie tego gremium odbyło się w listopadzie 1937, a podczas niego 22 miliony marek rozdysponowano między Tobis, Ufę i Terrę ${ }^{84}$. Ludzie branży filmowej, choć wywłaszczeni i ubezwłasnowolnieni, zyskali ekonomiczną rękojmię. Tak ten mechanizm przejęcia przez państwo przemysłu filmowego wyjaśnia David Welch: „Winkler w istocie przekonał Goebbelsa, że najlepszym sposobem uzyskania ideologicznie zaangażowanych filmów, jakich on żądał, jest nie zmuszanie ludzi filmu, by zostali narodowymi socjalistami, lecz raczej zapewnienie im finansowej stabilizacji. W ten sposób sektory zarówno produkcji, jak i dystrybucji przyciągane byłyby do nazistowskiego światopoglądu bez uświadamiania sobie, że coraz bardziej stają się politycznymi instrumentami Ministerstwa Propagandy" ${ }^{\prime 25}$.

W roku $193960 \%$ niemieckich filmów fabularnych powstało w wielkich wytwórniach przejętych przez Kautio, w roku 1941 - już 70\%. Kulminacją stopniowej centralizacji i nacjonalizacji kinematografii niemieckiej w Trzeciej Rzeszy było utworzenie gigantycznej kompanii Ufa-Film GmbH (dla odróżnienia od dawnej Ufy często zwanej Ufi), działającej jako holding z jedenastoma spółkami podrzędnymi. Na czele tego nowego tworu stał Reichsfilmintendant, odpowiedzialny za koordynację wszystkich aspektów produkcji i dystrybucji z oficjalną polityką państwa. Został nim Fritz Hippler, twórca niesławnego antysemickiego „dokumentu” Wieczny Żyd (Der ewige Jude, 1940). Na oficjalnie już „posiadany" (a nie tylko, jak dotąd, "zarządzany") przez państwo koncern składało się jedenaście spółek, m.in.: Ufa-Filmkunst, Terra-Filmkunst, Tobis-Filmkunst, Bavaria-Filmkunst, Wien-Film, Prag-Film, Berlin-Film i Continental-Film. Jak zauważa Sabine Hake, monopolizacja produkcji filmowej umożliwiła bardziej skuteczny podział zadań w kinematografii wedle wymagań, z jednej strony - propagandy i ideologii, z drugiej - rozrywki. Po kilku latach (od wybuchu wojny) agresywnego upolitycznienia kina, Ministerstwo powróciło do przedwojennej strategii produkowania kilku wysokobudżetowych filmów propagandowych i całej masy filmów konwencjonalnego kina gatunków, o dużych walorach rozrywkowych. 1943 - kulminacyjny rok wojny - dla branży filmowej okazał się wielce zyskowny. W porównaniu z rokiem 1939 publiczność w niemieckich kinach podwoiła się i osiągnęła zawrotną liczbę 1 mld 117 mln widzów. Ale nic dziwnego - z 8600 kinami w kraju i na

${ }^{84}$ D. Welch, op. cit., s. 25.

85 Ibidem. 
terytoriach okupowanych Niemcy ustępowały liczbą kin jedynie Stanom Zjednoczonym, filmowemu mocarstwu $\mathrm{nr} 1^{86}$.

Swe dwudziestopięciolecie $\mathrm{w}$ roku 1943 Ufa uczciła premierą Münchhausena w reżyserii Josefa von Báky, widowiskowej superproducji $\mathrm{z}$ arcynordyckim i arcypopularnym Hansem Albersem w roli tytułowej, zrealizowanej w kolorze w rodzimym i konkurencyjnym wobec amerykańskiego Technicoloru systemie Agfakolor za niebywałą wówczas sumę 6,5 miliona marek. Gdy uwzględni się moment powstania - rok 1943 i stalingradzkie przesilenie - był to film bezwstydnie eskapistyczny. Cieszył się jednak wielkim powodzeniem i do dziś telewizja niemiecka z lubością pokazuje go w okolicach Bożego Narodzenia i Nowego Roku.

Wkrótce jednak realizacja filmów w niemieckich miastach bombardowanych przez aliantów stała się bardzo utrudniona. Ulubionym miejscem niemieckich filmowców w 1944 i 1945 r. stało się względnie bezpieczne praskie studio w Barrandovie. „Aż do samego końca niektórzy oficjele kinematografii pozostali jednak przekonani o niemieckim zwycięstwie jeśli nie na polu walki, to $\mathrm{w}$ jakiejś wyobrażonej kinematografii przyszłości" ${ }^{\prime \prime 7}$.

\section{Filmy fabularne $\mathrm{w}$ zaprzęgu ideologii i propagandy}

W roku 1933 na ekranach Rzeszy pojawiły się trzy filmy, od których tradycyjnie już rozpoczyna się omawianie filmowej propagandy okresu hitlerowskiego: SA-Mann Brand Franza Seitza, Hitlerjunge Quex Hansa Steinhoffa i Hans Westmar: jeden z wielu (Hans Westmar: Einer von Vielen) Franza Wenzlera. Akcją fabularną przenoszą się one w nieodległą przeszłość, do schyłkowego okresu Republiki Weimarskiej, kiedy w brutalnych kampaniach przed kolejnymi wyborami padały ofiary śmiertelne. Propaganda nazistów, mistyfikując ów okres, przypisywała rolę ofiar jedynie ich własnym zwolennikom - choć to właśnie bojówki SA prowokowały przemoc i uliczne starcia. Jako modelowy męczennik nazistowskiej sprawy został wykreowany Horst Wessel - autor słów do oficjalnego hymnu NSDAP, znanego później jako Horst Wessel Lied. Scenarzysta Studenta z Pragi, Hanns Heinz Ewers, w roku 1932 opublikował jego książkową biografię, a właściwie „hagiografię”, w oparciu o którą sam zresztą przygotował scenariusz trzeciego z wymienionych filmów.

Te trzy filmy są do siebie dość podobne fabularnie: opisują proletariackich bohaterów, którzy deklarując akces do sprawy nazistów, muszą

\footnotetext{
${ }^{86}$ S. Hake, op. cit., s. 66-67.

87 Ibidem, s. 67.
} 
zmagać się z wrogością i ostracyzmem rodziny, sąsiadów, przełożonych z pracy. Ideowe oddanie i heroizm prowadzą Quexa, 15-latka, który wbrew woli ojca-socjalisty wstąpił do Hiterjugend, i Hansa Westmara, zaangażowanego w polityczną agitację członka SA, do „męczeńskiej” śmierci z ręki bezwzględnego wroga - komunistów. SA-Mann Brand, tytułowy bohater pierwszego z filmów, sam wprawdzie nie ginie, ale jako męczennik nazistowskiej sprawy ponosi śmierć jego nieletni podopieczny (syn sąsiadki, z którą się przyjaźnił) - strzałem z ukrycia komuniści zabijają chłopca, gdy ten paradował ulicą w sprezentowanym mu przez matkę mundurze Hitlerjugend, o którym zawsze marzył. Wspólne wyznaczniki tych filmów to: zobrazowanie "heroicznego okresu” zmagań nazistów z komunistami pod koniec Weimaru, motyw męczeńskiej „śmierci dla sprawy" i patos finałów, zrodzony z kreowania żałobno-ofiarniczej aury wokół zabitych poprzez nazistowską ikonografię (umundurowane tłumy na pogrzebach, powiewające flagi ze swastyką) i ścieżkę dźwiękową (Horst Wessel Lied, okrzyki Sieg heil!). Te filmy różnią się jednak stylistyką i poziomem artystycznym. Zrealizowany pośpiesznie i byle jak dla Bavaria-Film SA-Mann Brand, z jego papierowymi postaciami i pompatycznymi dialogami, to właściwie nazistowski odpowiednik jak najgorszego socrealizmu. Ale już powstały w Ufie Hitlerjunge Quex, mimo swej propagandowej wymowy, to film bardzo ciekawy artystycznie. Znakomicie imituje (a może kontynuuje?) estetykę proletariackich filmów ery weimarskiej: sztandarowego dzieła serii Zille'owskiej Podróż Matki Krause do szczęścia (w naturalistycznym opisie ponurej egzystencji proletariackiej rodziny, której kobieca głowa, jak Matka Krause, kończy samobójstwem przez odkręcenie gazu) i „brechtowskiego" Kuhle Wampe (w bezpruderyjnym zobrazowaniu obyczajowej swobody środowiska komunistycznego). „Proletariackośćc filmu Steinhoffa zostaje dodatkowo uwiarygodniona udziałem czołowego aktora weimarskiej lewicy, Heinricha George, w roli ojca bohatera - zaciekłego socjalisty, którego postawa syna skłania do zastanowienia się nad własnym wyborem ideowym. Także Hans Westmar to film interesujący artystycznie. Niewątpliwie odwołuje się do estetyki filmów weimarskich, zarówno w opisie ogarniętego kryzysem Berlina przełomu lat 20. i 30. [widoki kolejek głodowych i tłumów bezrobotnych ewokują Zatracona uliczke (Die freudlose Gasse) Pabsta i Kuhle Wampe], jak i w sekwencjach obrazujących kosmopolityczne, dekadenckie lokale ery weimarskiej [niczym w filmach Langa z lat 20. albo w Kryzysie (Abwege, 1928) Pabsta]. Ukazując ponury - skądinąd wiadomo, iż niewydumany obraz niemieckich komunistów jako manipulowanych przez moskiewską centralę, film Wenzlera ustawia się niczym zaniepokojony „obrońca demokracji”, którą to taktykę miał jedynie domniemanie antysowiecki, alegoryczny thriller Langa Szpiedzy (Spione, 1928) i którą ponownie zastosuje 
szpiegowski antysowiecki thriller Karla Rittera GPU (1942). Świetna, demoniczną kreację $\mathrm{w}$ roli przywódcy berlińskich komunistów stworzył wystylizowany nieco na Lenina i wyglądający bardzo „z azjatycka” Paul Wegener.

Wbrew temu, czego można było oczekiwać, po tych trzech brunatnych „eposach heroicznych" nie nastąpiły kolejne. Z poziomu artystycznego Goebbels był zadowolony jedynie w przypadku filmu Steinhoffa, zaś jeśli chodzi o film Wenzlera, to - ku zdumieniu środowiska filmowego i partyjnych notabli, którzy już zobaczyli film Horst Wessel (bo taki był pierwotny jego tytuł) na pokazie specjalnym 3 października 1933 - cenzura pod naciskiem ministra propagandy nie dopuściła do wyznaczonej na 9 października premiery filmu. Przemontowany i pod zmienionym tytułem Hans Westmar, pozbawiony jednoznacznych odniesień do realnego Wessela, wszedł na ekrany dopiero 13 grudnia. Goebbels wykorzystał (skutecznie) sprawę tego filmu dla przeforsowania własnej wizji propagandy w filmie. Nie było w niej miejsca na zniechęcenie społeczeństwa do nazistów serwowaniem ich widoku na ekranie w filmach fabularnych. O tym, iż obrazowanie na ekranie NSDAP i powiązanych z nimi organizacji (jak SA) jest niepożądane, minister ostrzegł już w przemówieniu skierowanym 19 maja 1933 do pronazistowskich związków zawodowych NSBO (Nationalsozialistische Betriebszellen Organisation) i Związku Walki o Kulturę Niemiecką KdfK (Kampfbund für deutsche Kultur): „Właściwe miejsce SA jest na ulicach, a nie na ekranie" ${ }^{\prime 88}$. Usprawiedliwiając się z zatrzymania filmu Horst Wessel na łamach branżowego magazynu "LichtBild-Bühne”, Goebbels użył bardzo podobnych słów: „My, narodowi socjaliści, nie dostrzegamy niczego wartościowego w tym, że nasze oddziały SA maszerują na scenie czy na ekranie; ich miejsce jest na ulicy"89. Rozgrywka Goebbelsa o jego własną wizję przemysłu filmowego była dla niego dość niebezpieczna, gdyż miał potężnego przeciwnika: czołowego ideologa, Alfreda Rosenberga; a i sam Hitler nie był chyba jednak stuprocentowym zwolennikiem jego koncepcji, o czym świadczą fawory, jakie Führer czynić będzie niecierpianej przez Goebbelsa Leni Riefenstahl, której dokumenty wprowadziły na ekrany nieprzeliczone rzesze umundurowanych nazistów.

Widok setek i tysięcy postaci w uniformach SA, SS czy Hitlerjugend, a także $\mathrm{w}$ mundurach Wehrmachtu, maszerujących i tworzących zgeometryzowane szeregi, zawarty $\mathrm{w}$ Triumfie woli, nazistowskich dokumentach i kronikach, a zwłaszcza w osławionym Przegladzie Tygodniowym (Wochenschau), dodatkowo upowszechniony przez rozmaite filmy

\footnotetext{
${ }^{88}$ Ibidem, s. 62.

89 „Licht-Bild-Bühne”, 13 Oktober 1933 (cyt. za: D. Welch, op. cit., s. 63).
} 
montażowe wykorzystujące wzięty $\mathrm{z}$ wymienionych footage [jak seria Franka Capry Dlaczego walczymy (Why We Fight, 1942-1945) czy Zwyczajny faszyzm (Obyknowiennyj faszyzm, 1965) Michaiła Romma], wytworzył w świadomości zbiorowej obraz filmu Trzeciej Rzeszy jako niemal wyłącznie propagandy militaryzmu i hitlerowskiego paramilitaryzmu. Tymczasem $\mathrm{w}$ odniesieniu do filmu $\mathrm{f}$ a b u la r $\mathrm{n}$ e g o jest to obraz najzupełniej niemający pokrycia w rzeczywistości. Po zwycięskiej rozgrywce Goebbelsa z Horstem Wesselem nawet Staatsauftragsfilme (zamówione przez Wydział Filmowy Ministerstwa Oświecenia Publicznego i Propagandy) pod warunkiem, że fabularne i fikcjonalne - nie miały za głównych bohaterów „brunatnych herosów” z SA czy Hitlerjugend. Częściej pojawiały się $\mathrm{w}$ filmie fabularnym postacie w mundurach Wehrmachtu czy Luftwaffe. Pamiętajmy jednak, że dla ówczesnej publiczności niemieckiej żołnierze czy lotnicy, "nasi chłopcy”, nie mieli konotacji narodowych socjalistów. Ich obecność na ekranie nasiliła się zresztą dopiero po wybuchu wojny $\mathrm{i}$ wtedy była zrozumiała jako signum temporis nawet $\mathrm{w}$ takim gatunku, jak melodramat - vide: Koncert życzeń (Wunschkonzert, 1940, Eduard von Borsody) czy Wielka miłość (Die große Liebe, 1942, Rolf Hansen); przed wojną zaś wyróżniała taki szczególny genre, jak kontynuujące tradycje weimarskich fars koszarowych (tyle, że bez ich antymilitarnej satyry, a wręcz promilitarystyczne) komedie żołnierskie. Najbardziej pośród nich znane to Czterej muszkieterowie (Die vier Musketiere, 1934, Heinz Paul), Żotnierze kamraci (Soldaten-Kameraden, 1936, Toni Huppertz) czy Muszkieter Meier III (Musketier Meier III, 1938, Joe Stöckel).

Twórca, którego można uznać za propagandzistę militaryzmu w „poważnym" filmie fabularnym, jest Karl Ritter. Jego Pour le Mérite (1938) to odyseja bohaterskiego niemieckiego lotnika, który po klęsce wilhelmińskich Niemiec w 1918 r. nie może odnaleźć dla siebie miejsca w słabej, rozsadzanej działalnością Żydów i komunistów Republice Weimarskiej, aż wreszcie tę „wielką smutę" w jego życiu przerywa łamiąca wersalskie ustalenia decyzja Hitlera z roku 1935 o remilitaryzacji Niemiec. Dzięki niej przyjęty do Luftwaffe bohater odnajduje wreszcie sens życia. Film Rittera obsypany państwowymi zaszczytami wzbudził entuzjazm samego Hitlera. W latach wojny Ritter zrealizuje kolejne filmy o środowisku lotników: Stukas (1941), o asach Luftwaffe zrzucających w roku 1940 bomby na Francję, i Załoga "Dory" (Besatzung Dora, 1943), o akcjach bojowych eskadry lotniczej na różnych frontach. Wskutek jednak zmieniającego się szybko kontekstu działań wojennych ten drugi film w ogóle nie wszedł na ekrany, a pierwszy został zakazany już w czerwcu 1944 r. Najlepszym artystycznie filmem Rittera, i co ciekawe, dość niejednoznacznym w wymowie, jest Urlop na słowo honoru (Urlaub auf Ehrenwort, 1937). To opowieść z października 1918 r. o kilkunastu żołnierzach-berlińczykach, którym 
przełożony udzielił kilkugodzinnego nieregulaminowego „urlopu na słowo honoru", gdy przerzucani z frontu na front mieli spędzić krótki czas między przesiadkami $\mathrm{w}$ rodzinnym mieście. $\mathrm{W}$ finale, choć bezsensowna wojna prawie dobiega końca, wszyscy oni z powrotem stawiają się do jednostki, co oczywiście dobrze świadczy o morale niemieckiego żołnierza, którego pochwała wydaje się zasadniczą intencją filmu. W pamięci pozostaje jednak przede wszystkim dość poruszający, realistyczny obraz zabiedzonej, głodującej metropolii, wcale niebudujący morale widowni w przededniu planowanej wojny.

Filmy nawet z eksplicytnym ideologicznym, pronazistowskim przesłaniem (np. takim, iż najwyższa, niemal religijna, wartością w życiu Niemca jest idea ojczyzny jako rodzimej ziemi, Heimat, lub wspólnoty krwi, Vaterland, którą dobrze też wyrażało hasło Blut und Boden - „krew i ziemia") musiały być dla widza atrakcyjną rozrywką. Tę wytyczną Goebbelsa, w zakresie opiewania idei Heimat i Vaterland, realizuje m.in. szereg sensacyjnych filmów, opowiadających o dzielnych Niemcach, którzy w latach I wojny światowej znaleźli się w różnych egzotycznych miejscach i ogarnięci patriotyczną gorączką albo starali się za wszelką cenę dotrzeć do ojczyzny, by stawić się pod jej sztandary [jak nieustępliwy inżynier dążący do Niemiec z Ameryki Południowej w filmie Paula Wegenera Do Niemiec! (Ein Mann will nach Deutschland, 1934)], albo gdzieś „,W pustyni i w puszczy" toczyli zacięte walki z wrogiem, głównie z Anglikami [Jeźdźcy z Niemieckiej Afryki Wschodniej (Die Reiter von Deutsch-Ostafrika, 1934), Herbert Selpin; Awantura w Damaszku (Aufruhr in Damaskus, 1939), Gustav Ucicky]. Bliski wymienionym jest też np. film Karla Rittera Patrioci (Patrioten, 1937), z Martinem Wiemanem i Lídą Baarova, o perypetiach niemieckiego lotnika zestrzelonego nad Francją który dzięki znajomości języka szczęśliwie ukryje się przed nieprzyjacielskimi władzami w trupie teatralnej, a później zorganizuje ucieczkę niemieckich jeńców wojennych.

Dość podobną grupę stanowią filmy o niedoli Niemców w krajach, gdzie byli oni mniejszością. Zaznawszy od przeważających "tubylców" licznych prześladowań i zniewag, podejmują walkę albo/i dążą za wszelką cenę do odległej ojczyzny. Ow schemat realizują takie filmy, jak: Uchodźcy (Flüchtlinge, 1933, Gustav Ucicky)90, Niedola Fryzów (Friesennot, 1935, Peter Hagen) i jeden z najbardziej niesławnych filmów Trzeciej Rzeszy - Powrót (Heimkehr, 1941) znowuż Ucicky'ego. Uchodźcy opowiadają o odysei grupy nadwołżańskich Niemców, którzy z ogarniętej rewolucją i wojną domową Rosji przedzierają się przez międzynarodową strefę pograniczną w Mandżurii do nieopanowanych jeszcze przez komunistów

90 To pierwszy film fabularny wyróżniony Państwową Nagrodą Filmową (Staatspreisfilm) przez nazistów po ich dojściu do władzy - zob. D. Welch, op. cit., s. 108. 
Chin, by stamtąd wyruszyć do odległej ojczyzny; brawurową ucieczką uprowadzonym pociągiem kieruje nordycki heros ucieleśniony przez Hansa Albersa - najlepiej zarabiającego aktora filmowego Trzeciej Rzeszy. W Niedoli Fryzów zamieszkujący od dwóch stuleci Rosję Niemcy nadwołżańscy doznają prześladowań ze strony sowieckich komisarzy w czasie bolszewickiej rewolucji, ale nie pozostają bierni, podejmują bezwzględną walkę na śmierć i życie. Zrealizowany już po wybuchu wojny Powrót obrazuje szykany, jakich w 1939 r. na polskich kresach wschodnich miała rzekomo doznawać mniejszość niemiecka od władz Rzeczypospolitej: odebranie Niemcom szkoły, by przekształcić je na koszary żandarmerii polskiej; publiczne palenie niemieckich książek na rynku; lincz na grupce Niemców w kinie, gdy nie dołączają do nacjonalistycznie uniesionych Polaków w odśpiewaniu polskiego hymnu; nieprzyjmowanie niemieckich petentów $\mathrm{w}$ polskich urzędach ani niemieckich rannych $\mathrm{w}$ polskich szpitalach (przez co pobity w kinie bohater umiera na ulicy); fizyczna przemoc polskich hord wobec Bogu ducha winnych, spokojnych niemieckich obywateli RP (jeden z bohaterów traci oko, giną dwie kobiety); wreszcie brutalna łapanka i wywózka wszystkich osób narodowości niemieckiej do jakichś kazamatów, by zmasakrować ich tam seriami z ckm-u... Na szczęście dla niemieckiej mniejszości Trzecia Rzesza rozprawia się jednak $\mathrm{z}$ „wersalskim bękartem”: bomby Luftwaffe, spadając na Polskę, uwalniają bohaterów z kazamatów. Bohaterowie jednak tak oswobodzeni, nie zostają w swej rodzinnej ziemi (Heimat), dążąc za wszelką cenę do niemieckiej macierzy (Vaterland). Czemuż właściwie? - film nie dopowiada, ale dla ówczesnej publiczności było to oczywiste: polskie kresy po Pakcie Ribbentrop-Mołotow znalazły się po stronie sowieckiej, stąd takie wzruszenie bohaterów, gdy w finale osiągają graniczne słupy Rzeszy (zapewne gdzieś na linii Bugu, czego film już nie konkretyzuje). A swoją droga jak na ironię, oparte o podobny schemat dwa wyżej wymienione filmy, Uchodźcy i Niedola Fryzów, po wrześniu 1939 trafiły na półki - zawarty w nich bardzo negatywny obraz Sowietów w kontekście traktatu z 23 sierpnia 1939 był dla strony niemieckiej ambarasujący. Jednak po 22 czerwca 1941 znów zostały dopuszczone na ekrany, co dobrze unaocznia, iż o decyzjach nazistowskiej cenzury decydowała polityczna koniunktura.

Powrót Ucicky'ego (retrospektywnie propagandowo uzasadniający konieczność inwazji na Polskę we wrześniu 1939) jest reprezentatywny dla taktyki, jaką filmy fabularne Trzeciej Rzeszy stosowały, by wykreować obraz wroga. Polega ona na rzutowaniu na przeciwnika własnych win i zbrodni oraz zaprezentowaniu strony niemieckiej jako niewinnej ofiary. Właśnie w kontekście wiedzy o zbrodniach, jakich Niemcy dopuszczali się w latach II wojny światowej na ludności cywilnej w Polsce, taktyka Powrotu wydać się musi - szczególnie polskiemu widzowi - wyjątkowo 
cyniczna i odrażająca. Podobnej projekcji własnych zbrodni na wroga dla jego zohydzenia dokonywało też kino niemieckie w filmach antybrytyjskich i antysowieckich/antyrosyjskich (co prawda, czasem nie bez faktycznych podstaw $)^{91}$.

Biorąc pod uwagę zasadniczo wrogą (wyjąwszy interludium 1939-1941) politykę Trzeciej Rzeszy wobec Związku Sowieckiego, w sumie bardzo niewiele filmów fabularnych z tego okresu ma wyraźne antybolszewickie

${ }^{91}$ Powrót Ucicky'ego nie jest jedynym filmem Rzeszy o antypolskiej wymowie, jaki pojawił się po wybuchu wojny. Trzeba tu też wspomnieć o filmie Veita Harlana Podróż do Tylży (Die Reise nach Tilsit, 1939), tendencyjnej ekranizacji znanego opowiadania Hermanna Sudermanna, w 1927 r. zaadaptowanego w USA przez Murnaua jako Wschód słońca (Sunrise). W wersji Harlana szczęśliwe (niemieckie) małżeństwo usiłuje rozbić nie alegoryczna Kobieta z Miasta (jak w filmie Murnaua), ale niemoralna i ucieleśniająca rozmaite możliwe występki Polka, w końcu przykładnie ukarana publiczną chłostą. Z kolei podobny w propagandowym zamyśle do Powrotu film Wiktora Turżańskiego Wrogowie (Feinde, 1940) ukazuje niedolę bardzo statecznych, spokojnych i pracowitych Volksdeutschów w przygranicznej miejscowości przedwojennej Polski, prześladowanych przez Polaków, ukazanych jako ksenofobi, pijacy, obiboki i podpalacze. Ratując życie, Niemcy muszą salwować się ucieczką do pobliskiej Rzeszy. W filmach Ucicky'ego i Turżańskiego zwraca uwagę wielki kwantyfikator - to nie jakieś polskie indywidua są złe, ale szowinistyczny, obskurancki, cywilizacyjnie zapóźniony naród polski en globe.

W kontekście tych paskudnych paszkwili mogą zaskakiwać zrealizowane w okresie przedwojennym takie filmy, jak Chopin, piewca wolności (Abschiedswalzer, 1934), August Mocny (August der Starke, 1936), Ku wolności (Ritt in die Freiheit, 1936) i Cytadela warszawska (Die Warschauer Zitadelle, 1937). Pierwszy z nich to biografia kompozytora, eksponująca przede wszystkim jego romanse, ale akcentująca też powstanie listopadowe jako inspirację dla jego muzyki będącej ekspresją ducha wolności. Film ten wyreżyserował Géza von Bolváry, spec od musicali, a główne role zagrali: Chopina - Wolfgang Liebeneiner (wsławiony już kreacją w Miłostkach Maxa Ophülsa), a George Sand - Sybille Schmitz. Drugi film to będąca koprodukcją niemiecko-polską i zrealizowana w dwóch wersjach językowych, z częściowo różną obsadą i z innym opracowaniem muzycznym, biografia niemieckiego władcy, który, będąc dziedzicznym królem Saksonii, został także królem-elektem Polski. Wersję niemiecką filmu reżyserował Paul Wegener, polską - Stanisław Wasylewski. Trzeci z filmów, w reżyserii Karla Hartla, powstał przy współpracy Warszawskiej Kinematograficznej Spółki Akcyjnej, będącej kryptofilią Ufy w Polsce. Mimo że nie była to formalna koprodukcja, władze polskie oddały pułk ułanów do dyspozycji niemieckich filmowców, a zdjęcia plenerowe realizowano koło Ostrołęki. Film opowiada o bohaterskich polskich ułanach w Grodnie, którzy na wieść o wybuchu powstania listopadowego rzucają służbę w rosyjskiej armii, usiłując przedostać się ku walczącym powstańcom. Powstanie zarówno tego zaskakująco propolskiego filmu, z patosem całkiem serio afirmującego polskie dążenia do niepodległości i romantyczny kult polskiego ułana, jak i Cytadeli warszawskiej w reżyserii Fritza Petera Bucha, adaptacji antyrosyjskiego dramatu Gabrieli Zapolskiej Tamten, tłumaczyć się jednak może w kontekście politycznym - antyrosyjskość polityki Rzeszy po Pakcie Antykominternowskim, a przed Paktem Ribbentrop-Mołotow, była chwilowo zbieżna z naturalną w II Rzeczypospolitej antyrosyjską „polityką historyczną". 
ostrze. Prócz Hansa Westmara, Uchodźców i Niedoli Fryzów wymienić tu trzeba film O prawa człowieka (Um das Menschenrecht, 1934, Hans Zöberlein i Ludwig Schmid-Wildy), z akcją rozgrywającą się w 1918 r. na tle próby wywołania w Niemczech bolszewickiej rewolucji, dramat Biali niewolnicy (Weiße Sklaven, 1936, Karl Anton), o niedoli „białych” w ogarniętej rewolucją Rosji, szpiegowski thriller Złoty pajak (Die goldene Spinne, 1943, Erich Engels), o próbach wykradzenia przez parę sowieckich agentów tajnych planów nowego niemieckiego czołgu, i przede wszystkim GPU (1942, Karl Ritter). Ten ostatni film to znakomicie zrealizowany szpiegowski thriller, ukazujący jak pajęczą siecią agentów, zbrodni, szantażu i zamachów osławiona sowiecka służba bezpieczeństwa oplata przedwrześniową Europę. Akcja tego filmu przerzucająca się do coraz to innych europejskich miast (Ryga, Kowno, Göteborg, Helsinki, Rotterdam, Paryż - i wreszcie sama Moskwa, siedziba złowrogiej organizacji) ukazuje niemożność ucieczki przed wszechpotężną sowiecką bezpieką, której parawanem są rozmaite międzynarodowe organizacje w rodzaju Ligi Kobiet. Korzystający z gatunkowych archetypów i inscenizacyjnoformalnych rozwiązań w obrazowaniu totalitarnego zagrożenia ustanowionych przez Langa w znakomitych Szpiegach, niewatpliwie tu ewokowanych, film Rittera można by uznać za "głos w obronie zagrożonej demokracji", gdyby nie: po pierwsze, kontekst polityczny (film powstał po ataku na Związek Sowiecki 22 czerwca 1941), po drugie, groteskowy finał, w którym zrzucone przez Luftwaffe na Rotterdam bomby uwalniają parę amantów z holenderskich kazamatów GPU i przynoszą jakoby Europie „pokój i wolność”.

Akcenty już nie tyle antysowieckie, ile w ogóle antyrosyjskie, prócz propolskich filmów Ku wolności i Cytadela warszawska, zawierają także wojenno-szpiegowski film o wschodnim froncie I wojny światowej Trzynastu ludzi i jedno działo (Dreizehn Mann und eine Kanone, 1938, Johannes Meyer) oraz historyczny dramat Kadeci (Kadetten, 1941, Karl Ritter), opowiadający o niedoli, w jakiej znaleźli się pruscy kadeci po inwazji Rosjan na Berlin w roku 1760, podczas wojny siedmioletniej. „Kontrastując «azjatyckie» rysy «pod-ludzi»-Rosjan z twarzami Aryjczyków, film przedstawiał najeźdźców nie tyle jako groźbę ideologiczna, co raczej jako zagrożenie skazą rasową" - pisał o tym filmie David Welch ${ }^{92}$.

Wrogiem propagandy Goebbelsa byli, czy też raczej bywali, w zależności od politycznej koniunktury, Anglicy. Wśród filmów, gdzie akcenty antyangielskie są sprawą raczej uboczną niż zasadniczym celem filmu, wymienić trzeba szpiegowski thriller Karla Rittera Zdrajca (Verräter, 1936), o wkradnięciu się angielskiej agentury w tajniki niemieckiego

${ }^{92}$ Ibidem, s. 213. 
przemysłu lotniczego, historyczne dramaty Dziewica Joanna (Das Mädchen Johanna, 1935) Gustava Ucicky'ego i Serce królowej (1940) Carla Froelicha (w historiach Joanny d'Arc i Marii Stuart nietrudno było o negatywny obraz Anglików) czy wreszcie katastroficzny Titanic (1943, Herbert Selpin i Werner Klingler), gdzie winą za tragedię transatlantyku można było obciążyć angielskiego kapitana i armatora.

Antyangielskie ostrze było zasadniczym celem tych Staatsauftragsfilme, które powstały w latach 1940-1941, w okresie szczególnie nasilonej antybrytyjskiej kampanii wojennej. Max W. Kimmich (nb. szwagier Goebbelsa) zrealizował dwa "proirlandzkie” dramaty z historii walk Irlandczyków o niepodległość: Lis z Glenarvon (Der Fuchs von Glenarvon, 1940) i Moje życie dla Irlandii (Mein Leben für Irland, 1941). Oczywiście, oba zawierają wyjątkowo odstręczające przedstawienie Anglików jako podstępnych, bezdusznych i cynicznych prześladowców dzielnego i owładniętego patriotycznym uniesieniem narodu irlandzkiego. Cel takiej retoryki był zresztą dwojaki: prócz zdyskredytowania Anglików, chodziło też o umizgi wobec Republiki Irlandzkiej prowadzącej w latach wojny dość dwuznaczną politykę. Jeszcze inną antyangielską tematykę podjęły filmy przedstawiające w wielce czarnych barwach angielski kolonializm w Afryce: Carl Peters (1941, Herbert Selpin) i Germanin (1943, Max W. Kimmich) - w obu przeciwstawiony jest mu zresztą jako wzór pozytywny... kolonializm niemiecki, rywalizujący z angielskim o wpływy w Afryce równikowej.

Najwybitniejszym od strony artystycznej, ale i najperfidniejszym propagandowo spośród antyangielskich filmów, był jednak osławiony $W u j$ Krüger (1941) Hansa Steinhoffa, pierwszy z czterech „Filmów Narodu”. Znakomita dramaturgia, mistrzowskie sterowanie emocjami widza, wielka kreacja Emila Janningsa w tytułowej roli politycznego przywódcy Burów i świetne zdjęcia Fritza Arno Wagnera, oraz - co tu dużo gadać - wyciągnięcie z historii istotnie dość paskudnej karty w dziejach Anglii (wojna burska z początków XX w.), sprawiaja, że trudno się oprzeć perswazyjnej sile tego filmu. A jednak oprzeć się trzeba: mimo wszystko „wynalezione” wówczas przez Anglików obozy koncentracyjne, w których więzili kobiety i dzieci walczących z nimi Burów, były raczej doraźnym, przyjętym ad hoc brutalnym rozwiązaniem wobec niepoddającego się przeciwnika, a nie wyrachowanym, starannie przemyślanym ludobójstwem jak niemieckie obozy zagłady tworzone właśnie w dniach realizacji filmu. Jedna z finałowych scen tego poruszającego obrazu, gdy Anglicy masakrują seriami z karabinów bezbronne kobiety i dzieci, to przykład rzutowania na wroga własnych zbrodni Niemców, świadczący o wyjątkowym tupecie i cynizmie nazistowskiej propagandy.

Zrealizowani w roku 1940 Rotszyldowie (Die Rothschilds: Aktien auf Waterloo, Erich Waschneck) to film zarazem antybrytyjski i antysemicki. 
Ukazując, jak sławny bankierski ród doszedł do swej potęgi dzięki intrygom, tajnym układom biznesowym i bezwzględnemu czerpaniu zysków z paneuropejskiej wojny, z jednej strony bazuje na powszechnym stereotypie Żydów jako finansowych potentatów i mistrzów zakulisowej spekulacji, z drugiej - portretuje Anglię epoki napoleońskiej jako dekadenckie społeczeństwo zdominowane przez Żydów, a zarazem zasługujące na obrabowanie przez nich. „Brytyjczycy w tym filmie, szczególnie bankierzy, politycy i generałowie są tak sportretowani, iż zdaje się to dobitnie uzasadniać stwierdzenie Goebbelsa, iż «Anglicy to Żydzi między Aryjczykami»" ${ }^{\prime \prime}$. W finałowej scenie Natan Rotszyld, twórca potęgi rodu, robiąc odniesienie do mapy Europy, zaznacza na kartce siedziby Banku Rotszyldów - kropki, oznaczające filie w Wiedniu, Londynie i Neapolu, gdy je połączyć, tworzą trójkąt, który wraz z analogicznie utworzonym trójkątem (wyznaczonym przez Frankfurt, Gibraltar i Jerozolimę) formuje gwiazdę Dawida. Obraz płonącej gwiazdy nałożonej na mapę Wielkiej Brytanii zamyka film, a towarzyszy mu ekstradiegetyczny napis: „Gdy ten film był na ukończeniu, ostatni członkowie rodu Rotszyldów opuszczali Europę jako uchodźcy, uciekając do swych sojuszników w Anglii. Walka przeciwko brytyjskiej plutokracji trwa!"

Antysemickie filmy fabularne pojawiły się w Trzeciej Rzeszy dość późno, dopiero w roku 1939. Pierwszym z dwóch tytułów była komedia muzyczna Robert i Bertram (Robert und Bertram, Hans H. Zerlett), oparta na zupełnie pozbawionej antysemickiej wymowy teatralnej farsie Gustava Raedera z roku 1856 (sama miała akcję osadzoną w roku 1839). Tytułowa para włóczęgów usiłuje pomóc swej przyjaciółce. Interesowi jej rodziców grozi ruina ze strony ich wierzyciela, Żyda Biedermeiera, którą może powstrzymać zgoda ich córki na ślub z nim. Robert i Bertram, kradnąc portfel Biedermeiera, odkrywaja, iż jest on zadłużony u berlińskiego bankiera Ipelmeiera (oczywiście też Żyda). Okradając tego z kolei z jego klejnotów, pomagają rozwiązać problem przyjaciółki i jej rodziców, a sami umykają prawu ulatującym ku niebu balonem. Niewinna na pozór komedia utwierdzała stereotyp Żyda - bezwzględnego wierzyciela, unaoczniała łańcuch zadłużenia wynikły z żydowskiej chciwości i sugerowała groźbę „rasowej skazy” ze strony semickiego nuworysza niewolącego materialnie Aryjczyków (pożąda nie tylko ich dóbr, ale też córki). W zasadzie te same punkty zasadnicze wyznaczają ideologię drugiego z filmów z roku 1939, Płótno z Irlandii (Leinen aus Irland, Heinz Helbig). Kuhn, żydowski sekretarz fabrykanta z Pragi, pragnie stać się światowym „królem płótna". Chcąc tego dopiąć, namawia swego mocodawcę, by zalać rodzimy rynek materiałem sprowadzanym z Irlandii, niepomny, że zniszczy to

93 Ibidem, s. 225. 
miejscową produkcję i rynek pracy. Pożąda też aryjskiej dziewczyny, córki swego pryncypała. Rzecz jasna, jego plany biznesowe i matrymonialne spełzną na niczym, za to aryjska publiczność otrzyma kolejne ostrzeżenie o materialnym i seksualnym zagrożeniu ze strony Żydów.

Osławiony Żyd Süss (1940) Veita Harlana na powierzchownym poziomie fabularnym ${ }^{94} \mathrm{~W}$ gruncie rzeczy powiela ten schemat. Bankier Süss-Oppenheimer (Ferdinand Marian), nakładając drakońskie podatki, ograbia niemieckie księstwo, gdzie wdarł się dzięki lichwiarskiej pożyczce udzielonej władcy, ale jego największą zbrodnią jest „los gorszy niż śmierć”, który zgotował modelowo nordyckiej szlachciance, Dorothei Sturm (Kristina Söderbaum) - zniewolona przez Żyda, do którego udała się, by ratować uwięzionego męża, może się już tylko utopić... Jej śmierć przepełnia czarę goryczy. Lud Wirtembergii wznieca bunt, książę Karl-Alexander (Heinrich George), protektor Oppenheimera, dostaje apopleksji i umiera, a pozbawiony jego ochrony Żyd zostaje uwięziony i w okrutny sposób publicznie stracony na rynku w Stuttgarcie. Rzecz jasna, intencja tego filmu jest w oczywisty sposób antysemicka, a motyw "rasowej skazy” jako seksualnej groźby dla Aryjczyków - jawnie rasistowski. A jednak, gdy ogląda się dziś film Harlana, nie sposób uznać go jednoznacznie za „podżeganie do ludobójstwa", a dwukrotny wyrok, wydany przez sąd zachodnioniemiecki (w 1949 i 1950 r.), uniewinniający z tego zarzutu reżysera, nie da się, jak sądzę, zlekceważyć jedynie stronniczością sądu. Intencja ministerstwa, które zamówiło film i zapewne zaprojektowało go jako dyskursywne uzasadnienie zbrodniczego planu Endlösung, nie oznacza jednak jednoznacznego spełnienia tego zadania przez gotowy tekst. Wręcz przeciwnie - pewne aspekty filmu wydają się wręcz subwersywne wobec tego projektu.

Po pierwsze zatem, Süss-Oppenheimer w charyzmatycznej interpretacji Ferdinanda Mariana, góruje nad aryjskim otoczeniem inteligencja, kulturalną ogłada, autentyczną przedsiębiorczością. Na jego tle najbardziej zajadli aryjscy antysemici - radca Sturm, ojciec Dorothei, i jego zięć (w wyjątkowo antypatycznych, chyba dla publiczności wszystkich epok, aktorskich wcieleniach Eugena Klöpfera i Malte Jaegera) - wydają się wręcz prymitywnymi barbarzyńcami. Po drugie, niezależnie od obrazów „ucisku” ludu Wirtembergii przez system podatkowy Oppenheimera, jego rozwiązania jawią się jednak jak jakiś pomysł gospodarczy dla zadłużonego państwa, gdy tymczasem zupełnie pozbawiony zmysłu ekonomicznego

94 Akcja filmu jest oparta na autentycznej historii, która w latach 1733-1738 rozegrała się w księstwie Wirtembergii. W oparciu o nią Wilhelm Hauff napisał nowelę (1827), a Lion Feuchtwanger ostrzegającą przed antysemityzmem powieść (1925) - obie pod tym samym tytułem Jud Süss. Książka Feuchtwangera została zaadaptowana w Wielkiej Brytanii w roku 1934. Reżyserem filmu wyprodukowanego dla Michaela Balcona był Lothar Mendes, a główną rolę zagrał Conrad Veidt. 
władca szasta pieniędzmi na rozrywki. Po trzecie, Süss jest naprawdę kimś $\mathrm{w}$ porównaniu z prymitywnym, zmysłowym, grubiańskim księciem (w świetnej interpretacji Heinricha George, który mógłby wydobyć inne aspekty tej postaci, gdyby inna była jej koncepcja). Po czwarte, reakcja Dorothei na pierwsze awanse Żyda wydaje się po prostu groteskowa (podobnie zreszta, jak jej uprzednia „zgroza”, gdy odkrywa, że szarmancki podróżnik jest Zydem). Sceny te sprawiają dziś wrażenie mimowolnej (albo i niemimowolnej) „dekonstrukcji” czy demaskacji apriorycznego antysemityzmu. Na koniec wreszcie nie sposób nie współczuć Süssowi, gdy z pętlą na szyi, przerażony, zamknięty w zawieszonej kilkanaście metrów nad ziemią klatce, której zapadnia za chwilę usunie się spod jego stóp... prosi o ułaskawienie. Traumatyczny finał chyba żadnej w i ę k s z o ś c i o w e j publiczności (nawet niemieckiej w latach wojny) nie może (nie mógł) wydawać się triumfem sprawiedliwości. Sprawia raczej wrażenie jeszcze jednego, przerażającego przykładu dla zilustrowania Girardowskiego wykładu o rozwiązaniu kryzysu społecznego przez mechanizm kozła ofiarnego, a postawienie takiego przykładu przed oczy w dziele artystycznym raczej ten mechanizm demaskuje i obezwładnia niż wzmacnia ${ }^{95}$.

Generalnie, podsumowując wątek zrealizowanych w Trzeciej Rzeszy fabularnych Staatsauftragsfilme o tematyce antysemickiej, to jest ich zaskakująco mało, gdy uwzględni się wprowadzane od roku 1933 prawodawstwo i realizowany w latach 40. plan "ostatecznego rozwiązania”. Oczywiście, w rozmaitych filmach pojawiały się od czasu do czasu sceny czy drugoplanowe wątki z antysemickimi podtekstami, ale omówione powyżej filmy to właściwie wszystkie, w których antysemickie przesłanie było pierwszoplanową, propagandową intencją rządowego zamówienia.

Rasizm nazistowskiego państwa wyraził się nie tylko w antysemityzmie, ale i w "społecznym darwinizmie”, który dla wyhodowania ",czystej” i „,zdrowej” rasy aryjskiej żądał eliminacji osób „niepełnowartościowych”.

${ }^{95}$ Nie zamierzam tu $\mathrm{w}$ żadnym razie bronić filmu Harlana ani znajdować jakichkolwiek usprawiedliwień dla jego powstania, jednak moje wrażenia podczas jego kilkukrotnego oglądu były kompletnie inne niż to, czego oczekiwałem po zbudowanej przez rozmaite teksty jego złej sławie jako prymitywnej antysemickiej propagandy (taką jest niewątpliwie Der ewige Jude Hipplera - jednoznaczny, prymitywny retorycznie film kompilacyjny, będący istotnie nawoływaniem do „ostatecznego rozwiązania” kwestii prymitywnych, brudnych, zawszonych i podstępnych podludzi). Sądzę, że polityka kulturalna Republiki Federalnej Niemiec, ukrywająca skrzętnie w archiwach filmy takie, jak: Żyd Süss, Powrót, Kolberg czy Wuj Krüger, jest błędna, by nie rzec - fałszywa. Powinny być one wydane na legalnych płytach i o g ól n i e d o s tę p n e, oczywiście wraz z naukowymi opracowaniami, zawierającymi co najmniej opis historycznego kontekstu. Pod pretekstem „uniemożliwienia propagowania nazizmu” polityka ta tak naprawdę uniemożliwia spojrzenie prawdzie w oczy i autentyczne rozliczenie się kultury niemieckiej z urzędowo zapieczętowaną traumatyczną przeszłością. 
Od 1 stycznia 1934 dopuszczalna (a w ponurej praktyce często obligatoryjna) była sterylizacja $w$ takich przypadkach, jak dziedziczny imbecylizm, schizofrenia, dziedziczna głuchota, dziedziczna padaczka, depresja maniakalna, pląsawica Huntingtona i skrajna fizyczna deformacja. Wraz z wybuchem wojny Hitler rozwinął politykę eutanazyjną - choć może „eutanazja” to dość eufemistyczne określenie na proceder obligatoryjnego uśmiercania nieuleczalnie chorych (ponad 50 tys. takich osób pozbawiono życia w ośrodkach eutanazyjnych pomiędzy grudniem 1939 a 24 sierpnia 1941, kiedy proceder ten powstrzymano ${ }^{96}$. Właśnie w sierpniu 1941 pojawił się na ekranach Staatsauftragsfilm, który miał być artystycznym uzasadnieniem eutanazji, a zarazem emocjonalnym argumentem na jej rzecz dla nieprzekonanej opinii publicznej. Filmem tym jest Oskarżam (Ich klage an, 1941) Wolfganga Liebeneinera, opowieść o profesorze medycyny, który cierpienia swej młodej i pięknej żony, umierającej na galopujące stwardnienie rozsiane, skraca na jej własną prośbę „miłosiernym” zastrzykiem. Kolega-lekarz oskarża go o zabójstwo, a proces jest pretekstem do rozpatrzenia rozmaitych argumentów za i przeciw eutanazji, ale tak poprowadzonego, by widz nie miał wątpliwości, iż słuszne są jedynie pierwsze. $\mathrm{Z}$ racji niezłego poziomu artystycznego (świetne kreacje aktorskie, poruszająca emocjonalnie aura) film mógł być perswazyjnie skuteczny - choć przekonani zwolennicy eutanazji mogli nie wiedzieć, iż w nazistowskich ośrodkach nie odbywała się ona w tak podniosłej i czułej atmosferze, jak $\mathrm{w}$ filmie Liebeneinera, tylko $\mathrm{w}$ udających łazienki komorach gazowych (co antycypowało rozwiązania z obozów zagłady).

Znaczna liczba filmów fabularnych spośród zamówionych przez Ministerstwo Propagandy i Oświecenia Publicznego to filmy historyczno-biograficzne. Były to zazwyczaj realizacje bardzo wystawne, reżyserowane przez czołowych filmowców i z najwybitniejszymi aktorami w głównych rolach, co na ogół gwarantowało ich dość wysoki poziom artystyczny, jeśli tylko ideologiczny przekaz, zwłaszcza w dialogach, nie był zbyt natarczywy. Oczywiście, nie mogło zabraknąć kolejnych filmów o Fryderyku Wielkim. W Trzeciej Rzeszy zrealizowano kolejne trzy filmy z serii "fryderycjańskiej”: Stary i młody król (Der alte und der junge König, 1935) Hansa Steinhoffa, Fridericus (1936), Johannesa Meyera i Wielki król (Der große König, 1942) Veita Harlana. W pierwszym Emil Jannings wcielił się we Fryderyka Wilhelma I, ojca przyszłego Fryderyka Wielkiego. Stary król, uniemożliwiwszy młodemu księciu (Werner Hinz) zdradę stanu i ucieczkę do Francji, zamyka go w cytadeli i każe asystować w egzekucji organizatora ucieczki, jego przyjaciela, porucznika Katte. Finał filmu unaocznia, iż ta twarda lekcja przemienia lekkoducha i utracjusza

96 Por. ibidem, s. 100-102. 
w prawdziwego państwowca, twórcę przyszłej potęgi Prus. Biorąc pod uwagę moment realizacji filmu, Jerzy Toeplitz dopatruje się $w$ tym finale usprawiedliwienia niedawnej rozprawy Hitlera $z$ Röhmem i jego świtą z SA podczas "nocy długich noży” (29/30 czerwca 1934) ${ }^{97}$. W pozostałych dwóch filmach "starego Fritza” zagrał już oczywiście Otto Gebühr. Fridericus to biografia króla do wybuchu wojny siedmioletniej, zaś zrealizowany na półmetku II wojny światowej Wielki król przedstawia zwrotny moment wojny siedmioletniej, kiedy po klęsce pod Kunersdorfem w 1759 król potrafił jednak zmobilizować armię pruską do przełamania złej passy i na powrót zwyciężania. Toeplitz uznaje film Harlana za ciężki, pompatyczny i najsłabszy z całej serii filmów fryderycjańskich ${ }^{98}$, ale jest wręcz przeciwnie - to najlepszy obraz spośród nich. $Z$ racji umiejętnego przeplatania wielkiej historii z losami zwykłych ludzi (historia pięknej młynarki i feldfebla Treskowa) film bardzo angażuje emocjonalnie, do czego przyczynia się również świetne aktorstwo w tych rolach Kristiny Söderbaum i Gutava Fröhlicha. Zachwyca też plastyczna uroda, realizm i rozmach scen batalistycznych (nic dziwnego - władze delegowały do nich licznych policjantów, a wojsko wypożyczyło 5 tys. koni) ${ }^{99}$, którym dorównają dopiero zrealizowane z jeszcze większym rozmachem i przy jeszcze większym zaangażowaniu czynników oficjalnych sceny w innym wielkim historycznym eposie Harlana Kolberg (1945). Wielki król dorównuje, jak sądzę, mistrzostwem filmowej formy analogicznym eposom Eisensteina o wielkich władcach (Aleksander Newski, 1938; Iwan Groźny, 1944), a w pewnym aspekcie (mniej natrętna perswazyjność dialogów) zdecydowanie je nawet przewyższa.

Rzeczjasna, w Trzeciej Rzeszy nie mogło zabraknąć filmów o Bismarcku, skoro to przecież „żelazny kanclerz” był twórcą zjednoczonego państwa niemieckiego i orędownikiem nacjonalistycznej polityki. Dyptyk o nim zrealizował dla Tobisu Wolfgang Liebeneiner, choć w sumie musi dziwić, iż mimo ciągłości fabularnej między Bismarckiem (1940) a Dymisja (Die Entlassung, 1942) w każdym z filmów kanclerza odtwarzał inny aktor: w pierwszym - Paul Hartmann, w drugim - Emil Jannings. Wcześniej Jannings zagrał (zresztą jak to on - znakomicie) słynnego niemieckiego uczonego, współtwórcę nowoczesnej bakteriologii, w filmie Hansa Steinhoffa Robert Koch, zwycięzca śmierci (Robert Koch, der Bekämpfer des Todes, 1939). Koch, z jego apostolstwem higieny i hartowania ciała $\mathrm{w}$ przeciaggach, jawi się $\mathrm{w}$ tym filmie nie tylko jako wielki lekarz, ale i prekursor higieniczno-sanitarnych obsesji nazistów. W wielkiej finałowej scenie debaty przed cesarzem upokarza

\footnotetext{
97 J. Toeplitz, Historia sztuki filmowej, t. 4, s. 275.

98 Ibidem, t. 5, s. 236.

99 B. Drewniak, op. cit., s. 254.
} 
on swego naukowego polemistę, radcę Virchowa (świetny Werner Krauss), który zresztą jako demokrata i przeciwnik Bismarcka ponosi zasłużoną porażkę polityczną. Dość $\mathrm{w}$ gruncie rzeczy podobny w wymowie, choć osadzony parę stuleci wcześniej, jest Paracelsus (1943) Georga Wilhelma Pabsta, z doskonałą (jak zwykle) kreacją Wernera Kraussa w roli tytułowej. Paracelsus, tak jak Koch, prowadzi naukowe dysputy z uporczywie trzymającymi się starożytnych autorytetów adwersarzami, a sprzeciwiając się rozmaitym partykularnym interesom, otacza Bazyleę sanitarnym kordonem, mającym zapobiec zawleczeniu dżumy do miasta. Niestety, do miasta przekrada się wędrowny akrobata, "człowiek-mucha”. W niesłychanie ekspresywnej scenie wciaga on zgromadzonych w gospodzie mieszczan we frenetyczny taniec, co jest metaforą zarazy, gdyż jest on nosicielem choroby. Ten fantastyczny filmowo moment dzieła, gdy jeszcze uwzględni się konotacje dżumy jako paraboli nazizmu, zarazy ogarniającej cały naród, można odczytać w Trzeciej Rzeszy jako wręcz wywrotowy - choć inne aspekty filmu, gnostycko-okultystyczne i volkistowskie z ducha, wydają się raczej zgodne z nazistowską ideologią. Paracelsus, z jego odtworzeniem średniowiecznego miasta w atelierowej scenografii, świetną choreografią tłumów i ekspresywistyczną fotografią w niskim kluczu, wydaje się z jednej strony ewokować estetykę weimarskich filmów lat 20., a z drugiej zapowiadać Siódma pieczęć (Det sjunde inseglet, 1957) Bergmana, dla której, kto wie, czy nie był inspiracją (zwłaszcza w scenach tańca "człowieka-muchy” i procesji flagellantów).

Niemały nurt wśród tych filmów historyczno-biograficznych to biografie artystów, najlepiej niemieckich, ewentualnie z germańskiego kręgu kulturowego ${ }^{100}$ [stąd np. zrealizowany w okupowanej Holandii, artystycznie znakomity, plastycznie wyrafinowany Rembrandt (1942) Hansa Steinhoffa, ze świetnym Ewaldem Balserem w roli malarza]. Silne akcenty nacjonalistyczne zawarte są zwłaszcza w dwóch filmowych eposach Herberta Maischa poświęconych twórcom niemieckim: narodowemu poecie w okresie, gdy napisał Zbójców - Fryderyk Schiller (Friedrich Schiller: Der Triumph eines Genies, 1940), z Horstem Casparem w roli tytułowej, i rzeźbiarzowi, którego twórczość towarzyszyła powstawaniu potęgi państwa pruskiego - Andreas Schlüter (1942) z Heinrichem George w roli artysty. Dość niezwykły film to Taniec na wulkanie (Tanz auf dem Vulkan, 1938) Hansa Steinhoffa, opowieść o tym, jak słynny francuski mim, Baptysta Debureau, wystąpił przeciw królowi Karolowi X, satyrycznie

${ }^{100}$ Bywały od tego wyjątki - jak np. wspomniany już film o Chopinie (Chopin, piewca wolności, 1934) czy Romanse Czajkowskiego Carla Froelicha (1940). Oba to zresztą raczej melodramaty niż filmy stricte biograficzne. A film biorący za temat rosyjskiego kompozytora tłumaczyć można chwilową koniunkturą polityczną - powstał po Pakcie RibbentropMołotow, w krótkim interludium w permanentnej sowiecko-nazistowskiej wrogości. 
go portretując. Aresztowano go i o mało nie został stracony, ale powiódł w końcu lud Paryża na barykady rewolucji lipcowej 1830 r., przyczyniając się do obalenia monarchii Burbonów. Gdy zna się romantyczny wizerunek Debureau z Komediantów (Les Enfants du paradis, 1945) Marcela Carné w genialnej interpretacji Jeana-Louisa Barrault, trudno zaakceptować w tej roli brutalnego, wrzeszczącego po niemiecku Gustafa Gründgensa. Film Steinhoffa - reżysera naprawdę utalentowanego - zręcznie jednak odtwarza epokę; posiada też wysmakowane plastycznie zdjęcia i imponującą scenografię autorstwa Rochusa Gliese.

Oczywiście musiały powstać filmowe biografie licznych w kręgu kultury niemieckiej kompozytorów. Dwóch filmów doczekali się Mozart [Eine kleine Nachtmusik (1938) Leopold Hainisch i Kogo bogowie kochaja (Wen die Götter lieben, 1942) Karl Hartl] ${ }^{101}$ i Schubert [Niedokończona symfonia (1933) Willy Forst' ${ }^{102}$ i Trzy panny wokót Schuberta (Drei Mäderl um Schubert, 1936) E. W. Emo], po jednym - Weber [Zaproszenie do tańca (Aufforderung zum Tanz, 1934) Rudolf van der Noss], Schumann [Marzenie (Träumerei, 1944) Harald Braun] i najstarszy syn Jana Sebastiana Bacha (Friedemann Bach, 1941, Traugott Müller). Rekordzistą jest jednak „król walca”, Johann Strauss - nie tylko filmowano jego popularne operetki, ale jako postać pierwszoplanowa pojawił się $\mathrm{w}$ czterech filmach [Petersburskie noce (Petersburger Nächte, 1934) E. W. Emo, Róże z południa (Rosen aus dem Süden, 1934) Walter Janssen, Opowieści Lasku Wiedeńskiego (G'schichten aus dem Wienerwald, 1934) Georg Jacoby ${ }^{103}$ i Nieśmiertelny walc (Unsterblicher Walzer, 1939) E. W. Emo], a jako drugoplanowa w wiedeńskim filmie Willy Forsta Wiedeńska krew (Wiener Blut, 1942) i w operetce Ludwiga Bergera Wojna walców (1933). Z pewnością filmom o Straussie czy Schubercie przesadą byłoby przypisywać jakieś mocno propagandowe intencje - choć niewątpliwie przejawem ideologicznej strategii nazistowskiego państwa jest ich uderzająco eskapistyczny w Trzeciej Rzeszy charakter.

Najsłynniejszy film historyczny Trzeciej Rzeszy - widowiskowy epos w Agfakolorze o obronie Kołobrzegu przed wojskami napoleońskimi

${ }^{101}$ Bogusław Drewniak (op. cit., s. 300) wymienia trzeci film o Mozarcie Nocne spotkanie (Nächtliche Begegnung), pochodzący ponoć także z roku 1942 (ma on opowiadać o spotkaniu Mozarta z młodym Beethovenem). Drewniak nie wymienia nazwiska reżysera tego filmu. Nie znalazłem ani jednej informacji w Internecie na jego temat - ani w IMDB, ani na stronie poświęconej filmom fabularnym o Mozarcie. Nb. autor podaje błędnie tytuł filmu Karla Hartla jako Kiedy bogowie kochaja (Wenn die Götter lieben).

102 To austriacko-niemiecka koprodukcja zrealizowana w Wiedniu.

103 To film austriacki, ale dopuszczony na ekrany Rzeszy w przeciwieństwie do (dlatego tu nieuwzględnionego) filmu Paula Fejosa Wiosenny nastrój (Frühlingsstimmen, 1934), również poświęconego Johannowi Straussowi. Cenzura niemiecka zakazała go z powodu niearyjskiej ekipy. Por. B. Drewniak, op. cit., s. 304. 
w latach 1806-1807 - to zarazem ostatnie na taką skalę przedsięwzięcie propagandowe Goebbelsa. W jego realizacji uczestniczyło co najmniej kilkanaście tysięcy statystów, głównie żołnierzy Wehrmachtu i marynarzy Kriegsmarine oraz 6 tys. koni. Sceny batalistyczne filmowano z sześciu kamer, w tym $z$ jednej znajdującej się w balonie na uwięzi. Obsada była iście gwiazdorska, główne role grali: Heinrich George, Kristina Söderbaum, Paul Wegener, Gustav Diessl, Otto Wernicke, Kurt Meisel i wsławiony rolą Fryderyka Schillera Horst Caspar. Realizację Kolbergu powierzono chyba najwybitniejszemu filmowcowi Trzeciej Rzeszy, jakim był Veit Harlan. Kolberg, do którego zdjęcia ukończono z wielkim trudem w grudniu 1944 r., w styczniu 1945 został jeszcze na życzenie Goebbelsa pocięty i przemontowany (usunięto sceny zbyt drastycznie, zdaniem ministra, unaoczniające cierpienia cywilnej ludności w bombardowanym mieście, zmieniono finał i śpiewany w ramie narracyjnej hymn, bo nasuwał niepożądane konotacje $\mathrm{z}$ audycjami BBC). Wszystko na nic - Kolberg i po tych zmianach nie zdołał wykrzesać patriotycznego zapału w oblężonym ze wszystkich stron i coraz bardziej kurczącym się nazistowskim imperium (a taka właśnie, mobilizująca do walki, miała być jego propagandowa funkcja). Zresztą po 30 stycznia 1945 (zaplanowana data premiery) nie było go już gdzie oglądać. Większość kin w niemieckich miastach, w tym i w samym Berlinie, dawno legła w gruzach. Kolberg oglądany dziś, gdy abstrahować od kontekstu jego powstania i zamierzonej funkcji, wcale nie jawi się jako szczególnie nasączony jadem hitlerowskiej propagandy. Poziom nacjonalistycznego patosu wydaje się w nim standardowy dla filmu historycznego wielu krajów, dlatego decyzja władz RFN, by nadal skrzętnie ukrywać go w archiwach i by wszelkie jego pokazy odbywały się pod kontrolą władz, jest zupełnie niezrozumiała ${ }^{104}$.

\section{Kino popularne w Trzeciej Rzeszy i jego gwiazdy}

Skoro filmy na zamówienie Ministerstwa Propagandy, jak większość $\mathrm{z}$ omawianych $\mathrm{w}$ poprzednim podrozdziale, to tylko $1 / 6$ ogółu niemieckich filmów fabularnych z lat 1933-1945, nie jest bezzasadne posłużenie się metaforą góry lodowej. Osławione filmy propagandowe, skupiające na sobie uwage $\mathrm{z}$ racji ich bezpośredniej instrumentalizacji $\mathrm{w}$ machinie

104 Tym bardziej ona dziwi, że wręcz rasistowski w wymowie melodramat Harlana Złote miasto (1942) bez problemu doczekał się w Niemczech legalnej edycji DVD. Kolberg pokazano ze szczególnymi środkami bezpieczeństwa jako specjalną atrakcję konferencji „Konstelacja Szczecin”, w której uczestniczyłem w listopadzie 2010 r. Kopię przywiózł i odwiózł do Niemiec specjalny kurier, a projekcji musiała towarzyszyć prelekcja historyka; nad prelegentem „opiekę" sprawowało niemieckie MSZ. 
ideologicznej totalitarnego państwa, sąjak część tej góry ponad powierzchnią morza. Zapominanie o pozostałych $83-84 \%$ produkcji musi wytworzyć jednostronny i nieprawdziwy obraz kina Trzeciej Rzeszy. Zatem powtórzmy jeszcze raz - jest to kino przede wszystkim rozrywkowe, eskapistyczne, stwarzające ówczesnej publiczności niemieckiej poczucie normalności świata, w którym żyła, choć nie był to świat normalny. Publiczności międzynarodowej, przynajmniej do wybuchu wojny, kino to prezentowało hitlerowskie Niemcy jako nowoczesny, funkcjonalny kraj, o całkiem wysokiej stopie życiowej, otwarty, z którego można w każdej chwili wyjechać, ale za którym tęsknota skłania, by doń prędzej czy później wrócić. Rodzimej widowni kino to jawiło się głównie poprzez twarze popularnych, wysoko opłacanych gwiazd. Obecność w filmie danej gwiazdy gwarantowała wysoki poziom rozrywki, a zarazem z grubsza definiowała genre, jakiego należało oczekiwać. Nie od rzeczy wydaje się więc ujęcie kina popularnego Trzeciej Rzeszy poprzez wskazanie jego emblematycznych twarzy i omówienie ich profilu.

Twarzą numer jeden komedii filmowej tamtych lat był Heinz R ühman n, który wystąpił w trzydziestu czterech filmach zrealizowanych w Trzeciej Rzeszy. Niski, żwawy, o pogodnej twarzy, na której nieustannie błąkał się filuterny uśmieszek, bawił samym swym wyglądem, jednocześnie zjednując natychmiast sympatię widza. Błysnął pod koniec okresu weimarskiego, kiedy kino przechodziło na dźwięk. Był jednym $\mathrm{z}$ "trzech ze stacji benzynowej" w arcymusicalu Wilhelma Thiele (tym, który u Lilian Harvey z pewnością miał najmniej szans); znerwicowanym klientem płatnego zabójcy w Człowieku, który szuka swego mordercy Roberta Siodmaka; pomiatanym przez kaprala szeregowcem, z tupetem wcielającym się w rolę następcy tronu, czyli „dumą 3. kompanii” w koszarowej farsie Freda Sauera; pomysłowym urzędnikiem zrujnowanego banku, który wpada na genialny pomyst, jak z niczego wydobyć wielkie pieniądze w "kryzysowej” komedii Carla Boese Forsy nie trzeba... Ostatnim zrealizowanym w Republice Weimarskiej filmem Rühmanna była komedia, na poły tylko romantyczna, Roześmiani spadkobiercy (Lachende Erben, 1933), która weszła na ekrany już w Trzeciej Rzeszy i długo na nich miejsca nie zagrzała jako ostatni film niemiecki Maxa Ophülsa. Rühmann zagrał potencjalnego spadkobiercę wielkiej fortuny producenta win reńskich, który otrzyma spadek, pod warunkiem, iż przez określony czas nie tknie najmniejszej kropli alkoholu - co oczywiście było źródłem suspensu (bohater wytrzyma czy nie?) i powodem rozmaitych zamachów na jego abstynencję ze strony innych potencjalnych spadkobierców. Na tym tle rozgrywała się jeszcze pełna rozmaitych qui pro quo miłosna „,komedia omyłek”, wzajemnych podchodów bohatera i jego pięknej sąsiadki (Lien Deyers), córki innego potentata branży winnej. 
W Trzeciej Rzeszy Rühmannowi udało się nie zagrać w kompromitująco propagandowych filmach, dzięki czemu jego kariera będzie mogła trwać jeszcze wiele lat po wojnie. Zresztą to właśnie $\mathrm{w}$ filmach $\mathrm{z}$ okresu nazistowskiego najpełniej zademonstrował swój komediowy talent. Wydawał się stworzony do ról postaci à la Nikodem Dyzma - szaraczków czy przeciętniaków, wskutek splotu okoliczności, tupetu czy cwaniactwa bohatera oraz ślepoty otoczenia wziętych za ważne figury (wedle takiego wzorca fabularnego była skonstruowana Duma 3. kompanii, ale i w paru późniejszych filmach wzór ten się powtórzył). W Szczęśliwym powrocie w rodzinne strony (Heimkehr ins Glück, 1933, Carl Boese) gra wędrownego magika, "artystę" dość podejrzanej konduity wziętego za przemysłowego potentata, który wraca w rodzinne strony. W Krętych drogach pięknego Karola (Die Umwege des Schönen Karl, 1938, Carl Froelich) wciela się w kelnera z małej nadbałtyckiej mieściny marzącego o karierze w wielkim świecie Berlina. Wyjechawszy do stolicy, przez przypadek trafia w wielki świat polityki i podejrzanych interesów, a ludzie z towarzystwa namaszczają go na posła do Reichstagu... Akcja tego filmu rozgrywa się w latach weimarskich i zawiera niemało elementów nazistowskiej propagandy w satyrycznym ukazaniu Republiki, a ostrze tej satyry mierzy w lewo i w prawo, w komunistów i wielki kapitał jednocześnie. To może najbardziej propagandowy z wszystkich filmów Rühmanna (nie dziwne to, gdy zważyć, iż film reżyserował przyszły prezes Reichsfilmkammer), ale mimo wszystko nieodparcie śmieszny. W stylowej, plastycznie wyrafinowanej adaptacji powieści Gottfrieda Kellera Jak cię widza, tak cię piszą (Kleider machen Leute, 1940, Helmut Käutner) gra z kolei marzącego o bogactwie i wyrwaniu się ze swego stanu krawca. W surducie uszytym dla klienta zostaje wzięty w obcym mieście za arystokratę. W tym temacie fałszywej tożsamości było coś wywrotowego wobec polityki zbiurokratyzowanego i zmilitaryzowanego państwa, coś niemal "żydowskiego", jak cwaniactwo bohaterów Chaplina, co może sprawiało, że Rühmann, tolerowany przez władze, był zarazem tak popularny. Jedna z jego komedii ponoć jednak rozsierdziła Goebbelsa - Inkasent (Der Gasmann, 1941, Carl Froelich). Zagrał tam inkasenta gazowego, który pewnego razu podczas podróży pociagiem dokonał dziwnej transakcji - odstąpił swe ubranie pewnemu pasażerowi w tarapatach, otrzymując w zamian bardzo dużą, jak na owe czasy, sumę pieniędzy (przez co zresztą sam musiał w bieliźnie dostać się z dworca do domu). Początkowo nieufny wobec tych pieniędzy zaczyna stopniowo coraz chętniej z nich korzystać, podobnie jego żona, która swym nagłym obnoszeniem się z bogactwem zaczyna kłuć w oczy sąsiadów, a także... smutnych panów z pewnego urzędu, dociekających intensywnie, skąd małżonkowie wytrzasnęli tak duże sumy. Sytuacja bohatera zaczyna się robić niewesoła, a film niespodziewanie nabiera cech złośliwej satyry na państwo, przed 
którym obywatelowi nie sposób się ukryć. Rühmann, z jego drobną posturą i miną "człowieka pełnego dobrej woli”, wydaje się tutaj jakby komediowym wcieleniem Józefa K. Ale Goebbelsa rozsierdziła ponoć spora w tym filmie liczba pozdrowień „,Heil Hitler!”, wzrastająca w miarę, jak urzędnicza machina coraz bardziej brała bohatera w obroty (a tak nie było wolno się pozdrawiać w k o m e d i a c h okresu nazistowskiego).

Największym jednak sukcesem Rühmanna okazała się jedna z jego ostatnich produkcji w Trzeciej Rzeszy, komedia nostalgiczna Poncz (Die Feuerzangenbowle, 1944, Helmut Weiss). Znany pisarz Johannes Pfeiffer, zazdroszcząc swym znajomym, z którymi spotkał się przy konsumpcji tytułowego ponczu, iż nie zaznał, jak oni, lat szkolnych, gdyż edukację przeszedł $\mathrm{w}$ domu, zostaje przez nich wysłany do szkoły średniej. $Z$ racji młodzieńczego wyglądu (i w ogóle typu urody) 42-letniego wówczas aktora cała ta maskarada wydaje się całkiem wiarygodna, a gagi, dialogi i komediowe sytuacje, gdy dorosły pisarz dla hecy zasiada w szkolnej ławie, są naprawdę inteligentne i zabawne ${ }^{105}$. Całkowity eskapizm od realiów Trzeciej Rzeszy 1944 r. jest zdumiewający, ale powojennych widzów urzekła staroświecka aura i fabularny absurd tego filmu. Telewizja niemiecka pokazuje go niemal co roku w okolicach Bożego Narodzenia i Sylwestra, a w kręgach akademickich Niemiec jest to film równie kultowy, jak nasz Rejs.

Kobiecą gwiazdą komedii filmowych zarówno w dźwiękowym okresie kina weimarskiego, jak i w Trzeciej Rzeszy, była Renate Müller. Z lat Republiki może najbardziej pamiętną jej rolą jest „osobista sekretarka" w omawianej wyżej optymistycznej komedii Wilhelma Thiele. Od 1933 zagrała jedynie w ośmiu filmach, gdyż świetnie przebiegającą karierę przerwała jej niespodziewana śmierć w roku 1937; zmarła, mając zaledwie 31 lat $^{106}$. Filmy te były wielkimi przebojami i należą do czołowych osiągnięć kina popularnego Trzeciej Rzeszy, jak np. jeden ze „Straussowskich” filmów, operetka Ludwiga Bergera Wojna walców (1933), czy uwspółcześ-

105 Die Feuerzangenbowle to adaptacja powieści Heinricha Spoerla pod tym samym tytułem. Rühmann zagrał także Hansa Pfeiffera w jej wcześniejszej adaptacji z roku 1934 zatytułowanej $A$ to cham! (So ein Flegel) w reżyserii Roberta Adolfa Stemmle; nie odniosła ona jednak takiego sukcesu, jak film o 10 lat późniejszy. Może dlatego, że aktor był jeszcze... zbyt młody, by film ten był naprawdę absurdalny?

106 Niejasne są okoliczności tej śmierci. Można dziś odrzucić pierwotną oficjalną wersję, iż jej przyczyną była choroba (epilepsja). Ujawnione później okoliczności - wypadnięcie z okna - mogą sugerować zarówno samobójstwo, jak i zabójstwo; jedno i drugie niewykluczone w sytuacji, w jakiej znalazła się aktorka. Wskutek przelotnej znajomości z Hitlerem była inwigilowana przez Gestapo. Mimo wzorcowo nordyckiej urody miała romans z Żydem i wciąż odmawiała udziału w jawnie propagandowych filmach. Pod koniec życia przechodziła rozstrój nerwowy, a podobno - choć być może to pogłoski rozsiewane po jej śmierci przez nazistów dla jej uzasadnienia - była też uzależnioną morfinistką. Śmierć spotkała ją prawdopodobnie w klinice, w której się leczyła. 
niona trawestacja Goetheańskiego romansu Herman $i$ Dorota, zrealizowana w roku 1935 przez Ericha Waschnecka pt. Zakochani (Liebesleute) - Dorotą była oczywiście Renate Müller, a Hermanem Gustav Fröhlich. Najbardziej pamiętne role Renate Müller pochodzą z filmów Reinholda Schünzla, Żyda (!), któremu, o dziwo, udało się aż do roku 1937 kontynuować w nazistowskim państwie tradycję libertyńskich, prowokacyjnych obyczajowo i społecznie komedii w stylu Ernsta Lubitscha. Müller stworzyła w nich typ nowoczesnej, zaradnej, wyemancypowanej dziewczyny, swą spontanicznością i bezpośredniością rozsadzającej skostniałe formy otoczenia, w którym się znalazła. Może bardziej konwencjonalna jest "egzotyczna komedia z wyższych sfer" Sezon w Kairze (Saison in Kairo, 1933), w której jej partnerem, podobnie jak i w Wojnie walców, był Willy Fritsch ${ }^{107}$. Ale już iście Lubitschowski pazur, ze sporą dawką przewrotności i pikantnych podtekstów, posiadają doskonałe komedie Viktor i Viktoria (Viktor und Viktoria, 1933) oraz Małżeństwo po angielsku (Die englische Heirat, 1934). Pierwsza to, podobnie jak Nie chce być mężczyzna (Ich möchte kein Mann sein, 1918) Lubitscha, komedia "przebierankowa”, ale jeszcze bardziej pokrętna fabularnie i dwuznaczna. Müller gra bezrobotną aktorkę, która $\mathrm{w}$ podrzędnym kabarecie zastępuje Viktora, aktora wcielającego się w kobiece role. Udając mężczyznę, który odgrywa kobietę, wzbudza na scenie aplauz jako... mężczyzna udający kobietę (a przecież kobietą jest). Jest to początkiem pełnego sukcesów tournée, które zaprowadza ją i trochę zazdrosnego o jej triumfy Viktora do Londynu, gdzie „młody aktor" (czyli ona sama) stanie się obiektem pożądania dwóch innych kobiet, a sam(a) zakocha się w przystojnym Angliku. To wszystko jest źródłem niesłychanie dwuznacznej erotycznie, perwersyjnej atmosfery i znakomitych gagów. Ich bodaj największe natężenie następuje w arcyzabawnej scenie, gdy bohaterka wciągnięta przez ukochanego do męskiego zakładu fryzjerskiego zostaje poddana serii komicznie sadystycznych zabiegów, zadających istne tortury jej prawdziwej kobiecej tożsamości. $\mathrm{Z}$ kolei w Matżeństwie po angielsku gra wyemancypowana, pełną temperamentu i odważną młodą Niemkę poślubiającą angielskiego arystokratę. W Anglii, dokąd po podróży z Berlina samochodem przybywa poznać rodzinę męża, okazuje się, iż pan młody jest nieprawdopodobnym, niemęskim fajtłapa który nie chce przyznać się do „mezaliansu”, poślubienia zwykłej współczesnej dziewczyny bez „błękitnej krwi” w żyłach, i przed snobistyczną rodziną na wszelkie sposoby ukrywa jej status jako żony. Skłania ją to do zerwania i znalezienia właściwego partnera w osobie...

107 Powstała też francuska wersja tego filmu Idylle au Caire (1933), której współreżyserem, obok Schünela, był Claude Heymann, zaś jako partner Renate Müller wystąpił w niej zamiast Fritscha George Rigaud. 
adwokata rodziny męża. Małżeństwo po angielsku skrzy się złośliwym, a zarazem błyskotliwym antybrytyjskim dowcipem à la Monty Python i chyba zapowiada serię powstałych $\mathrm{w}$ Rzeszy filmów $\mathrm{z}$ antyangielskimi akcentami. Tę doskonałą komedię, żonglującą kulturowymi stereotypami na temat angielskich snobizmów, form i przysłowiowej "flegmy”, trudno jednak uznać za film propagandowy sensu stricto.

Jednym z ostatnich filmów z udziałem Renate Müller była znakomita Allotria (1936), na planie której spotkała się z Heinzem Rühmannem, Jenny Jugo, Hilde Hildebrand i - po raz kolejny - z Adolfem Wohlbrückiem („,najprzystojniejszym amantem Ufy"), który był jej partnerem także w Viktorze $i$ Viktorii oraz Małżeństwie po angielsku. Jest to błyskotliwa „komedia omyłek", w której po wielu qui pro quo, wynikłych z rozmaitych koincydencji i odgrywania przez postaci przybranych tożsamości, w finale dochodzi do ukonstytuowania się trzech szczęśliwych par, wspólnie śpiewających absurdalna, autotematyczną piosenkę Allotria! Reżyserem tego filmu jest Willy (Willi) Forst, austriacki aktor i reżyser, w latach 30. i 40. jedna z największych osobowości kina popularnego zarówno Austrii, jak i Niemiec. Forst, zanim w roku 1933 zajął się reżyserią zabłysnął w wielu filmach jako utalentowany aktor. Ze swą aparycją dżentelmena i elegancją manier nie dziw, iż często grywał arystokratów [np. księcia Modeny w historycznym melodramacie z czasów napoleońskich Tak kończy się miłość (So endete eine Liebe, 1934, Karl Hartl), w którym partnerowała mu Paula Wessely], a dzięki fizycznej sprawności i wokalno-tanecznym talentom mógł być gwiazdą filmów muzycznych lub wykonawcą "numerów” w muzyczno-wodewilowych partiach filmów należących do innych gatunków [jak w przywołanym wyżej, jeszcze weimarskim Jasnowłosym śnie (1932) Paula Martina, gdzie „wepchnął się” między Lilian Harvey i Willy Fritscha]. Wesołe spojrzenie i filuterny uśmiech błąkający się na jego wargach predestynowały go także do ról postaci "dyzmowatych" - sympatycznych oszustów, na których nieodparty wdzięk nabierały się zwłaszcza kobiety, np. Marlena Dietrich w formalnie austriackim, ale zrealizowanym w „berlińskiej” estetyce Nowej Rzeczowości Café Elektric ${ }^{108}$ (1929) Gustava Ucicky'ego, albo Olga Czechowa, Ilse Werner i Hilde Hildebrand w stylowej wizualnie, zrealizowanej w konwencji belle-epokowego musicalu, jego własnej adaptacji powieści Maupassanta Bel Ami (1939).

Jako reżyser Forst zadebiutował w roku 1933 austriacko-niemiecką koprodukcją Niedokończona symfonia (Leise flehen meine Lieder), która rok później doczekała się także angielskojęzycznej wersji Unfinished Symphony, współreżyserowanej przez Anthony'ego Asquitha. Ta romantyczna i pełna muzyki filmowa biografia Schuberta wyznaczyła typ filmu,

108 Polski tytuł ekranowy - Giełda miłości. 
którego Forst okaże się mistrzem - rozgrywającego się w środowiskach artystycznej bohemy (muzyków, ludzi teatru, malarzy) kostiumowego romansu, przeplatającego melodramatyczną i komediową tonację, pełnego filmowo zapierających dech widowiskowych scen wielkich bali, koncertów i spektakli, na tle których rozgrywają się rozmaite intrygi i miłosne dramaty. Arcydziełami tej „wiedeńskiej melo-operetki”, specyficznie Forstowskiego genre'u, są zwłaszcza zrealizowane (jeszcze) w Austrii dwa filmy: nawiązująca cynizmem i dekadencką aurą do Miłostek Ophülsa Maskarada (Maskerade, 1934), z doskonałą Paulą Wessely w roli głównej, oraz melancholijny Teatr Miejski (Burgtheater, 1936), z wielką rolą Wernera Kraussa. Tę formułę kontynuują z powodzeniem jego filmy wyprodukowane już w Trzeciej Rzeszy: Serenada (Serenade, 1937), wspomniany już musicalowo-komediowy Bel Ami i powstała w latach wojny "trylogia wiedeńska" - Operetka (Operette, 1940), Wiedeńska krew (Wiener Blut, 1942) i Wiedeńskie dziewczęta (Wiener Mädeln, 1949) ${ }^{109}$. Jednak jeden z najlepszych filmów Forsta zrealizowanych w Trzeciej Rzeszy to pasjonujący fabularnie, konstrukcyjnie bardzo złożony melodramat i kryminał sądowy zarazem - Mazurek (Mazurka, 1935), z wielką rolą Poli Negri jako kobiety, która zabijając uwodzicielskiego muzyka, mści własną krzywdę i jednocześnie chroni córkę przed jego niebezpiecznym wpływem.

Jak Forst-aktor męska, tak Węgierka Marika Rökk była największą kobiecą gwiazdą muzycznych filmów w hitlerowskich Niemczech. Grała w nich począwszy od 1935 aż do 1944 r., najczęściej zresztą pojawiając się w filmach własnego męża, Georga Jacoby'ego: Goraca krew (Heißes Blut, 1936), Student żebrak (Der Bettelstudent, 1936), I ty pojedziesz, mój skarbie (Und du, mein Schatz, fährst mit, 1936), Gasparone (1937), Noc majowa (Eine Nacht im Mai, 1938), Kora Terry (1940), Lepszymi dyplomatami sa jednak kobiety (Frauen sind doch bessere Diplomaten, 1941), Kobieta moich marzeń (Die Frau meiner Träume, 1944). Filmy Jacoby'ego z jego żoną nie dorównywały artystycznym poziomem wysublimowanym majstersztykom Forsta. Miały jednak żywe tempo, pełną meandrów akcję z miłosnymi powikłaniami i to, co było clou programu - sekwencje muzyczne, w których pełna temperamentu Marika Rökk (nie bez racji porównywana z Ginger Rogers) dawała popis swych niezwykłych umiejętności tanecznych. Najlepsze filmy z jej udziałem zrealizował jednak nie mąż, lecz inni reżyserzy. Błyskotliwą paryską farsę Hallo Janine (1939), z odwiecznym tematem przybierania w miłosnych grach fałszywej tożsamości, wyreżyserował spec od komedii, Carl Boese, zaś melodramatyczną biografię rosyjskiego kompozytora

109 Ów trzeci z filmów w „,trylogii wiedeńskiej” (zdjęcia doń powstawały w roku 1944 i 1945) należy do tzw. "filmów-dezerterów” (Überläufer-Filme), zrealizowanych w Trzeciej Rzeszy, ale mających premiery już po wojnie. 
Romanse Czajkowskiego (Es war eine rauschende Ballnacht, 1939), w którym jej rywalkę grała sama Zarah Leander, doświadczony majster, Carl Froelich (nb. ówczesny prezes Reichsfilmkammer).

Temperamentem i umiejętnościami tanecznymi Marice Rökk nie ustępowała pół Niemka, pół Angielka Lilian Harvey, wsławiona $\mathrm{w}$ okresie weimarskim udziałem $\mathrm{w}$ takich przebojach, jak Trzej ze stacji benzynowej i Walc mitości Wilhelma Thiele, Kongres tańczy Erika Charella czy Jasnowłosy sen Paula Martina (we wszystkich czterech jej partnerem był popularny amant Willy Fritsch, z którym zdawała się tworzyć duet idealny). W Trzeciej Rzeszy spotkali się na planie jeszcze czterokrotnie, za każdym razem w filmie Paula Martina: w szpiegowskim dramacie Czarne róże (Schwarze Rosen, 1935) ${ }^{110}$ oraz w trzech komediach: Szczéściarze (Glückskinder, 1936), Siedmiokrotny policzek (Sieben Ohrfeigen, 1937) i Kobieta za kótkiem (Frau am Steuer, 1939). Prawdziwym arcydziełem są Szczęściarze, mistrzowska odpowiedź na Ich noce (It Happened One Night, 1934) Franka Capry, rozgrywająca się zresztą w Nowym Jorku w środowisku dziennikarskim i będąca wyrazem niemieckich fascynacji samą Ameryką i amerykańskim kinem. W tej historii dziewczyny sądzonej za włóczęgostwo i trzech dziennikarzy wyrzuconych na bruk jest luźno nawiązujący do Ich nocy wątek tropienia zaginionej dziedziczki wielkiej fortuny, ale przede wszystkim pomysłowa, tocząca się w zawrotnym tempie i pełna zaskakujących zwrotów (także miłosnych) akcja oraz nieco satyryczny obraz Ameryki lat kryzysu, co czyni ze Szczęściarzy prawdziwą screwball comedy. Duetowi Harvey - Fritsch sekundują znakomici Paul Kemp i Oskar Sima, a cała czwórka daje prawdziwy popis w dwóch brawurowych numerach choreograficzno-wokalnych: Panna Nikt (Fräulein Niemand) i Chciał(a)bym być kura (Ich wollt' ich wär' ein Huhn). Aura beztroskiej zabawy (choć wcale nie taka wyjątkowa w pełnym rozrywki kinie Trzeciej Rzeszy) tu jawi się jednak wyjątkowo wiarygodnie - może z racji amerykańskiego tła akcji, a może dlatego, iż w roku berlińskich Igrzysk niemiecki film pełen takiego luzu promował nazistowskie państwo jako normalny, przyjazny i pełen swobód kraj.

Żaden z zaledwie sześciu filmów Harvey zrealizowanych w Trzeciej Rzeszy nie był sukcesem na miarę tej świetnej komedii, choć trzeba by jeszcze wspomnieć Capriccio (1938), farsę kostiumową w sztafażu „płaszcza i szpady", w której wcieliła się w Madelone, wychowaną po męsku córkę XVIII-wiecznego szlachcica. W męskim przebraniu (jako „Don Juan”!) umyka ona prześladowcom i wywalcza sprawiedliwość, przeżywając rozliczne przygody, z racji przebieranki niewolne od dwuznacznych

110 Spotkali się tylko w wersji niemieckiej. W wersji angielskiej Black Roses Fritscha zastąpił Esmond Knight, a we francuskiej Roses noires (współreż. Jean Boyer) - Edmond Beauchamp. 
erotycznie podtekstów. Zapewne ten aspekt i osobista antypatia Goebbelsa do aktorki sprawiły, że film rozsierdził ministra i to pomimo faktu, iż wyreżyserował go pupil reżimu, Karl Ritter. W 1939 Harvey opuści Niemcy na dobre, szybko zakończy aktorską karierę, a Trzecia Rzesza pozbawi ją swego obywatelstwa.

Willy Fritsch zagrał w okresie hitlerowskim w aż trzydziestu czterech filmach, ale, poza Wojna walców, Szczęściarzami i może jeszcze Wiedeńska krwia Willy Forsta, nie były to artystyczne sukcesy na miarę jego weimarskich przebojów, wśród których prócz muzycznych komedii trzeba też wymienić np. filmy Fritza Langa: Szpiedzy (Spione, 1928) i Kobieta na Księżycu (Frau im Mond, 1929). Ten urodzony amant najlepiej wypadał w filmach z akcją osadzoną współcześnie, no i oczywiście rozśpiewanych (jak Trzej ze stacji benzynowej, Jasnowłosy sen czy Szczęściarze). Mniej swobodnie czuł się w historycznym kostiumie (choć dobrze poprowadzony, też wypadał znakomicie, np. w Kongres tańczy), a już zupełnie nie pasowały doń role wojskowych, w których obsadzano go w latach 30. i 40. Z żadną z ekranowych partnerek nie stworzył również tak pamiętnego i harmonijnego duetu, jak z Lilian Harvey - ani z Renate Müller (Sezon w Kairze, Wojna walców), ani z Käthe von Nagy [Księżniczka Turandot (Prinzessin Turandot, 1934, Gerhard Lamprecht)], ani z Käthe Gold [Amfitrion (Amphitryon, 1935, Reinhold Schünzel)]. Te dwa ostatnie filmy to komedie kostiumowe na powszechnie znane $\mathrm{w}$ kulturze światowej tematy, zaczerpnięte $\mathrm{z}$ opery Pucciniego (Księżniczka Turandot) czy komedii Plauta i Moliera (Amfitrion). Mimo inscenizacyjnego rozmachu, świetnej obsady i znakomitych reżyserów, są to filmy nieśmieszne, przyciężkie i bez wdzięku, uderzające dzisiejszego widza jakąś totalitarną aurą i militaryzmem choreografii (choć, co prawda, np. Sabine Hake dopatruje się w Amfitrionie weimarskiej z ducha satyry na hitlerowskie Niemcy) ${ }^{111}$. W każdym razie Willy Fritsch wypada w nich znacznie poniżej swych znanych skądinąd możliwości.

Najlepiej jednak opłacanym aktorem Trzeciej Rzeszy był nie najmłodszy już u jej progu (rocznik 1891) Han s Albers. Modelowo "aryjski” blondyn o wyrazistych niebieskich oczach już od lat I wojny światowej grywa w filmach, ale niemiecka i międzynarodowa widownia dostrzega go dopiero w niewielkiej, lecz pamiętnej roli Mazeppy, cynicznego lowelasa, z którym w Błękitnym Aniele Lola-Lola zdradza i upokarza swego starego męża. Pod koniec okresu weimarskiego zagrał też w sensacyjno-fantastycznym filmie Karla Hartla FP 1 nie odpowiada (F.P. 1 antwortet nicht, 1932) i ta rola (dzielnego pilota, rozprawiającego się z sabotażystami, którzy zaatakowali pływające niemieckie lotnisko na Atlantyku - sic!) wyznaczyła poniekąd jego zasadnicze emploi w Trzeciej Rzeszy. Odtąd gra przede

111 Por. S. Hake, op. cit., s. 71. 
wszystkim ludzi czynu, gładko pokonujących rozmaite przeszkody i rozprawiających się z przeciwnikami. Filmy z udziałem Albersa nie są wolne od ideologicznych serwitutów - jak np. przywołani wyżej Uchodźcy (1933) Gustava Ucicky'ego czy Carl Peters (1941) Herberta Selpina - ale urok nordyckiego macho i wartka, sensacyjna akcja w egzotycznej scenerii (Chiny, równikowa Afryka) sprawiaja że ich propagandowy wymiar wydaje się mniej istotny niż suspens, widowiskowość i inne, czysto rozrywkowe walory. Wśród tego typu sensacyjno-przygodowych filmów Albersa należy wymienić: Złoto (Gold, 1934, Karl Hartl), Pod goracym niebem (Unter heißem Himmel, 1936, Gustav Ucicky), Żótta flage (Die gelbe Flagge, 1937, Gerhard Lamprecht), Sierżanta Berry (Sergeant Berry, 1938, Herbert Selpin) czy Wode dla Canitogi (Wasser für Canitoga, 1939, Herbert Selpin).

Trzy najbardziej jednak pamiętne filmy z Albersem z tego okresu nie ukazują nam gwiazdora jako herosa ani nie realizują modelu filmu sensacyjno-przygodowego, a nawet z jednym i drugim jakby się polemicznie przekomarzają. Człowiek, który był Sherlockiem Holmesem (Der Mann, der Sherlock Holmes war, 1937, Karl Hartl) to zwariowana komedia kryminalna. Widz długo nie jest pewien, czy jej dwaj bohaterowie wystylizowani na Sherlocka Holmesa (Albers) i doktora Watsona (Rühmann) to istotnie detektywi dążący do rozwiązania kryminalnej zagadki, czy oszuści spod ciemnej gwiazdy, tyle że sympatyczni. Pełna absurdalnego humoru i zaskakujących zwrotów akcji komedia nieustannie zbija widza z tropu, a z powodu swej taktyki narracyjnej i ostentacyjnej intertekstualności wydaje się prekursorska wobec późniejszego o pół wieku popularnego kina doby postmodernizmu. Wspomniany już jubileuszowy film Ufy, Münchhausen (1943), pozwolił nie najmłodszemu już aktorowi na ironiczny dystans do swego image'u herosa, sam jawiąc się nie tylko jako hiperbolizacja, ale i parodia gatunku sensacyjno-przygodowego. Wreszcie w swym zdecydowanie najlepszym filmie z okresu Trzeciej Rzeszy, kolorowym, nostalgicznym melodramacie Helmuta Käutnera Große Freiheit Nr. 7 (1944), Albers stworzył wspaniała, bogatą psychologicznie postać starego marynarza, zakochanego w młodej dziewczynie (Ilse Werner) i boleśnie zranionego uświadomieniem sobie, że ona kocha kogoś innego, młodszego. Znakomity artystycznie film Käutnera nie doczekał się już w Rzeszy premiery ${ }^{112}$. Został odłożony na półki zapewne ze względu na swą melancholijną, dekadencką aurę, ale i dlatego że przedstawiał świat, jakiego już nie było - Hamburg sprzed alianckich bombardowań.

Za głównego konkurenta Albersa do miana emblematycznego macho nazistowskiej kinematografii można chyba uznać Luisa Trenkera.

112 Był jednak wyświetlany w Protektoracie Czech i Moraw, praska premiera miała miejsce 15 grudnia 1945. 
Ten świetny wspinacz i narciarz błysnął jako gwiazda filmu górskiego w Świętej górze (1926) i Wielkim skoku (Der große Sprung, 1927) Arnolda Fancka, a następnie pod koniec okresu weimarskiego zrealizował dwa historyczne Bergfilme, których sam był gwiazdą: Góry w płomieniach i Buntownika. W okresie nazistowskim, gdy Fanck po sfilmowaniu w plenerach Grenlandii polarnej odysei SOS Eisberg (1934) w zasadzie zarzucił produkcję fabularnych filmów górskich, pałeczkę po nim przejął właśnie Trenker. Klasykiem gatunku jest Góra wzywa (Der Berg ruft, 1937)113, pasjonująca historia XIX-wiecznego wyścigu różnych nacji o pierwszeństwo w wejściu na Matterhorn, zakończona tragedią - pierwsi zdobywcy szczytu zginęli podczas zejścia. Film ten posiada niebywałej urody zdjęcia gór (autorstwa m.in. Seppa Allgeiera) i od początku do końca trzyma w napięciu. Może jednak irytować (przynajmniej w znanej mi niemieckiej wersji) akcentami nacjonalistycznymi i antyangielską wymową - tragedii winien jest angielski organizator wyprawy, Whymper. Lżejszego kalibru, w poetyce sportowej komedii nawiązujące do Białego szaleństwa (1931) Fancka, są Listy miłosne z Engadyny (Liebesbriefe aus dem Engadin, 1938).

Najbardziej symptomatyczne dla image'u Trenkera jako „autochtonicznego herosa" (zawsze podkreślającego "góralskość", "tyrolskość" i bycie „swoim chłopakiem” przez niego samego i przez jego postaci) oraz dla jego związków z bliską nazistom, volkistowską ideologią Blut und Boden, są jego dwa filmy „amerykańskie”: Syn marnotrawny (Der verlorene Sohn, 1934) i Kalifornijski cesarz (Der Kaiser von Kalifornien, 1936). Akcją osadzone w Ameryce i istotnie częściowo sfilmowane w amerykańskich plenerach są z jednej strony wyrazem typowej dla Niemców w dwudziestoleciu międzywojennym fascynacji Ameryka, z drugiej zaś kreują negatywny jej obraz jako kraju bezwzględnej walki o byt i permanentnego kryzysu wynikającego z kultu pieniądza niszczącego moralność i ład społeczny. Na antypodach, aksjologicznych i geograficznych, tego Babilonu znajduje się Heimat - ojczysta ziemia germańskiego bohatera, będąca nie tylko krajem rodzinnym, ale i ostoją wszelkich prawdziwych wartości. Opozycja ta jest szczególnie wyraźna w Synu marnotrawnym. Młody góral z Tyrolu, skuszony mirażem Nowego Świata jako ziemi obiecanej i ufny $\mathrm{w}$ mit self-made-mana udaje się za ocean, by znaleźć się tam na samym dnie i zaznać całej nędzy amerykańskiej rzeczywistości lat 30.: bezrobocia, bezdomności, głodu. Oczywiście jako tytułowy "syn marnotrawny" wraca w rodzinne strony, a oznaką jego ponownego zjednoczenia z rodzimą ziemią jest udział w pierwotnym, pogańskim rytuale Rauhnacht: efektownym, ale niepokojąco orgiastycznym celebrowaniu przez góralską społeczność zimowego solstycjum (najdłuższej nocy w roku). Opozycja

113 Angielską wersję filmu, The Challenge (1938), współreżyserował Milton Rosmer. 
„obczyzna-ojczyzna”, ,kosmopolityczne-rodzime”, ,złudnie nowoczesne-tradycyjne", zostaje zresztą rozpisana nie tylko na przeciwstawienie "Ameryka-Heimat", ale i na wybór serca. Po swojej lekcji za oceanem bohater odtrąca wyemancypowana, nowoczesną córkę amerykańskiego potentata na rzecz zakochanej $\mathrm{w}$ nim dziewczyny $\mathrm{z}$ rodzinnej wioski. Z kolei Kalifornijski cesarz, będący właściwie westernem, ze znaczącymi ideologicznie przekłamaniami odtwarza historię Johna Suttera (w filmie $\mathrm{z}$ premedytacją nazywanego pierwotnym niemieckim nazwiskiem Johann Suter), szwajcarskiego emigranta w Ameryce. Znalezienie w roku 1848 na jego działce kruszcu zapoczątkowało wielką kalifornijską gorączkę złota, co, jak ukazuje film, przynosi Suterowi tylko straty i cierpienia (giną jego dzieci, traci majątek), a pośród osadników powoduje rozpętanie żądzy zysku, rozpad więzi społecznych i zanik międzyludzkiej solidarności. Chciwości, spekulacjom i nadziejom rozgorączkowanych poszukiwaczy złota na szybkie wzbogacenie się przeciwstawiony jest wiodący do indywidualnego bogactwa ciężki, codzienny wysiłek bohatera, typowo niemiecka cnota pracowitości i gospodarności. Owoce tej pracy zostająjednak w wyniku gorączki złota zniszczone. Ambiwalentny jest finał tego filmu stary, zubożały Suter, wywłaszczony z ciężko zapracowanego majątku, na schodach Kapitolu w Waszyngtonie ma wizję przyszłej Ameryki jako kraju drapaczy chmur i wielkiego przemysłu, po czym umiera. Trenker, zafascynowany potęgą USA, swego ideologicznego przeciwnika, atakuje go i jednocześnie składa mu hołd. Niezależnie od tej ideologii filmy Trenkera były atrakcyjnymi widowiskami, cieszącymi się (do dziś zresztą) dużym powodzeniem u niemieckiej publiczności.

Kiedy Marlena Dietrich kategorycznie odmawiała powrotu do Niemiec i opierała się nadzwyczaj atrakcyjnym warunkom angażu, pilną potrzebą kina niemieckiego stało się wykreowanie międzynarodowej gwiazdy podobnej rangi. Aż wreszcie znaleziono aktorkę posągowo piękna, o regularnych rysach jak Greta Garbo, i jak Marlena obdarzoną niskim, zmysłowym głosem, za to o większych niż głos Marleny możliwościach. Odkryciem tym była Szwedka Z a r a h L e a n d e r, niewątpliwie najpiękniejsza, największa kobieca gwiazda w kinie Trzeciej Rzeszy. Pomiędzy 1937 a 1943 r. pojawiła się w dziesięciu ukończonych filmach fabularnych. Pierwszym z nich był melodramat Detlefa Siercka (przyszłego Douglasa Sirka) Ku nowym brzegom (Zu neuen Ufern, 1937), w którym zagrała XIX-wieczną angielską piosenkarkę poświęcającą się dla ukochanego mężczyzny (Willy Birgel). Przyjmując na siebie jego winę, zostaje deportowana do Australii. Tam, wydobyta z kolonii karnej na targu małżeńskim przez przystojnego farmera (Viktor Staal), porzuca nowe stabilne życie, gdy tylko na horyzoncie pojawia się dawny ukochany, dla którego niegdyś poświęciła wszystko... Drugi z melodramatów Siercka 
z jej udziałem, La Habanera (1937), znowu rzuca kreowaną przez nią postać w egzotyczną scenerię. Leander gra Szwedkę, która zauroczona tytułową melodią i latynoskim seksapilem bogatego Portorykańczyka postanawia nie wracać do kraju i zostaje żoną atrakcyjnego adoratora. Za swój wybór płaci jednak wysoką cenę. Zniewoloną przez męża w kulturze, gdzie kobieta nie ma wiele do powiedzenia, zmęczoną zabójczym, tropikalnym klimatem, bohaterkę ogarnia Heimat-Nostalgie, którą można będzie jednak zaspokoić dzięki temu, że na ratunek przybędą jej nordyccy przybysze z Europy, a męża tyrana zasłużenie dosięgnie deus ex machina w postaci śmiercionośnej choroby rozprzestrzeniającej się wskutek jego sanitarnych zaniedbań. Błyskotliwie zrealizowany i świetny aktorsko melodramat Siercka jest nie tylko bliski lansowanej w filmach Trenkera ideologii Blut und Boden, ale dodatkowo wydaje się, że nosi jeszcze nieprzyjemny rasistowski podtekst - związek nordyckiej piękności i latynoskiego macho ma dla bohaterki charakter "rasowej skazy”, choć nie była ona (jak w Żydzie Süssie) wynikiem gwałtu, ale jej świadomej, dobrowolnej decyzji. Dzisiejszemu widzowi trudno jednak uniknąć takich skojarzeń, zwłaszcza iż latynoskiego męża gra odtwórca roli Süssa-Oppenheimera, Ferdinand Marian.

Melodramaty z Zarah Leander nie były wolne od różnych serwitutów ideologicznych. Bliski wymową La Habanerze jest film Carla Froelicha Heimat (1938), w Polsce przedwojennej zatytułowany zresztą wielce stosownie do fabuły Marnotrawna córka. Opowiada on o powrocie do rodzinnego miasteczka w Niemczech wielkiej pieśniarki, która zrobiła karierę w Ameryce pod amerykańskim nazwiskiem. Choć niegdyś uciekła z rodzinnego domu jako miejsca opresji i zaściankowej nietolerancji, to pod wpływem Heimat-Nostalgie i odarcia ze złudzeń co do wielkiego świata, gdzie zrobiła karierę, godzi się z ojcem-despotą (Heinrich George), który niegdyś jej się wyrzekł, a teraz przyjmuje na łono rodziny nie tylko ją ale i owoc jej niewybaczalnego niegdyś grzechu - nieślubną córkę. Z kolei historyczny melodramat Froelicha Serce królowej (1940), w którym zagrała Marię Stuart, pełen jest akcentów antyangielskich, co biorąc pod uwagę moment historyczny - zmasowaną kampanię wojenną przeciwko Wielkiej Brytanii - wcale nie dziwi, a z racji przedstawionych wypadków historycznych jest dość uzasadnione. Natomiast w jednym z najbardziej kasowych niemieckich filmów lat wojny, melodramacie Rolfa Hansena Wielka mitość (1942), gra żonę lotnika (Viktor Staal). Z powodu patriotycznego obowiązku męża, zrzucania bomb na kolejne kraje europejskie, długo nie będzie jej dane zaznać szczęścia pożycia małżeńskiego. Niezależnie od tej propagandowej skazy, melodramaty z Zarah Leander do dziś wywołują ogromne wrażenie, nie tylko ze względu na emanującą z ekranu wielką urodę Szwedki, ale i na jej naprawdę niezwykłe, charyzmatyczne 
aktorstwo. Klasą dla siebie są obowiązkowe we wszystkich jej niemieckich filmach sceny, gdy śpiewając swym głębokim, niskim głosem, oczarowuje zarówno wewnątrzdiegetycznych słuchaczy, jak i kinową publiczność.

Inna importowana ze Szwecji gwiazda nazistowskiej kinematografii, która w latach 1936-1945 wystąpiła w jedenastu niemieckich filmach (dziesięć z nich reżyserował jej mąż, Veit Harlan), była zupełnym przeciwieństwem swej śpiewającej rodaczki. Kristina Söderbaum to nie wielka dama przytłaczająca otoczenie pięknością i królewską dystynkcją jak Leander, ale swojska, raczej plebejska niebieskooka blondynka, o urodzie trochę dziewczęcia z makatki. Nic więc dziwnego, że parokrotnie w filmach Harlana zagrała takie ładne, prostoduszne prowincjuszki, mimo że czasem były to naiwne, bezbronne istoty, jakie łatwo skrzywdzić, zwłaszcza kiedy znalazły się w obcym im świecie miasta [jak w Zatartych śladach (Verwehte Spuren, 1938), Podróży do Tylży (Reise nach Tilsit, 1940) czy Złotym mieście (Die goldene Stadt, 1942)], a czasem, jak w historycznych dramatach, to pełne energii, woli czynu i zimnej krwi niemieckie patriotki (dzielna młynarka w Wielkim królu czy siostrzenica burmistrza Nettelbecka w Kolbergu). Kristina Söderbaum była całkiem niezłą aktorką, o dużej skali środków wyrazu, toteż jedne i drugie postacie mogła grać równie przekonywająco. Jedyną zupełnie nieudaną jej rolą z tego okresu jest, zapewne $\mathrm{z}$ racji propagandowej jednowymiarowości postaci, Dorothea w Żydzie Süssie.

Do najciekawszych filmów Harlana z jej udziałem należą z pewnością Zatarte ślady, gdzie gra kanadyjską prowincjuszkę, przybyłą wraz z matką do Paryża na Wystawę Światową w 1867 r. Po nocy, którą spędziły w różnych hotelach, matka znika bez śladu, a wszyscy dokoła - obsługa hotelowa, policja, a nawet przystojny adorator - nie tylko nie chcą pomóc w jej w odszukaniu, ale wręcz negują fakt jej istnienia, zostawiając bohaterkę w jakimś koszmarnym poczuciu zmowy przeciw niej całego świata. Ostatecznie okazuje się, że powodem tego wszystkiego była obawa przed wywołaniem paniki w metropolii pełnej gości ze świata, gdyż matka zmarła na dżumę. Kristina Söderbaum świetnie zagrała zagubienie, samotność i bezbronność bohaterki we wrogiej dżungli Paryża, a sam film - z jego tematem sanitarnego kordonu i zacierania śladów o drastycznej prawdzie $\mathrm{w}$ obawie przed opinią publiczną - poprzez unaocznienie totalitarnych praktyk państwa w Trzeciej Rzeszy wydaje się wręcz wywrotowy.

Podróż do Tylży i Złote miasto to świetne melodramaty, z poważną jednak skazą antypolskiej (w pierwszym z filmów) i antyczeskiej (w drugim) propagandy. W adaptacji opowiadania Hermanna Sudermanna (sfilmowanego także przez Murnaua) właśnie na dobroduszna, prosta, modelowo nordycką żonę, graną przez Söderbaum, czyha złowroga Polka. W Złotym mieście Anna, grana przez nią bohaterka, jest córką Czeszki i sudeckiego 
Niemca. Ogarnięta marzeniami o Pradze, wskutek opowieści inżyniera osuszającego w jej wsi bagna, wbrew woli ojca rusza do „złotego miasta”. Tam zostaje uwiedziona przez czeskiego kuzyna i pozostawiona $\mathrm{w}$ ciąży na pastwę losu. Po powrocie do rodzinnej wsi odtrącona przez ojca, topi się w tym samym bagnie, które niegdyś pochłonęło jej czeską matkę. W finałowym ujęciu grobu jej i matki nie otacza już bagno, tylko falujące łany zbóż, jakie wyrosły na miejscu osuszonego niemiecką gospodarnością mokradła. Złote miasto to film w oczywisty sposób propagandowy, bliski ideologii Blut und Boden, a zarazem cywilizacyjną i rasową wyższością Niemców uzasadniający prawo ich, a nie Czechów, do Sudetów jako Heimatu. Praga jawi się jako niemoralny Babilon, w otchłaniach którego musi zginąć naiwne, niemieckie dziewczę (a raczej musi zginąć ta "dobra", niemiecka strona jej natury - bo przecież bohaterka jest w połowie Czeszką; zew tej "gorszej”, słowiańskiej strony - rezultat „skazy rasowej” związku Niemca z Czeszką - gubi ją tak, jak niegdyś czeska „rozwiązłość" zgubiła jej matkę). Wszyscy Czesi są ukazani negatywnie, szczególnie ciotka bohaterki, chciwa stręczycielka, i jej syn, kuzyn-uwodziciel - nicpoń i obibok. Film ten jest tym bardziej ideologicznie perfidny, że propaganda sączy się w nim mimochodem, na kanwie fabuły klasycznego melodramatu o „uwiedzionej i porzuconej pannie-matce”. Natomiast dzięki znakomitej mise-en-scène, barwnym kadrom o dużej urodzie plastycznej kompozycji, świetnej muzyce i doskonałemu aktorstwu Kristiny Söderbaum jest naprawdę estetycznie porywającym i przejmującym emocjonalnie spektaklem.

Veit Harlan był naprawdę znakomitym filmowcem, co pokazują jego dwa ostatnie melodramaty z lat Rzeszy, podobnie jak Złote miasto zrealizowane w Agfakolorze, ale szczęśliwie nieobciążone podobną ideologią. W obu z nich Kristina Söderbaum gra postaci zupełnie inne niż dotychczas - już nie prostoduszne, naiwne dziewczęta, ale kobiety dojrzałe, „po przejściach", świadome swej kobiecości. W opartym o prozę Theodora Storma Immensee (1943) poznajemy ujętą w ramę narracyjną historię niespełnionej miłości Elisabeth do muzyka (Carl Raddatz), który po latach stał się słynnym kompozytorem; jak to bywa, bohaterka wyszła za kogoś innego... Bardziej złożonym, intrygującym filmem jest Poświęcenie (Opfergang, 1944). Arystokratyczni małżonkowie, Albrecht (Carl Raddatz) i Octavia (lodowato piękna Irene von Meyendorff), mieszkają w ustronnej rezydencji na przedmieściach Hamburga. Ich sąsiadką okazuje się ekscentryczna Szwedka Äls (Kristina Söderbaum), pływająca nago w jeziorze, jeżdżąca konno po plaży. Albrecht, typ sportsmena, już nieco zmęczony chłodną i przewidywalną żoną, zaczyna coraz bardziej interesować się atrakcyjną i zagadkową sąsiadką, co nie uchodzi uwadze Octavii... Fascynacja bohatera piękną cudzoziemką stopniowo przeradza się w miłość, która 
nie zazna jednak spełnienia. Nad bohaterką ciąży widmo śmierci, jest nieuleczalnie chora, dlatego coraz intensywniejsze wzajemne uczucie skazane jest z góry na klęskę. Oba melodramaty Harlana, wysmakowane plastycznie i świetnie zagrane, są utworami dużej filmowej urody. Ich fabuły wydają się co prawda ostentacyjnie abstrahujące od bieżącego kontekstu, ale spowijająca je melancholia, a w Poświęceniu także dominująca aura t chn i en ia śm i e r ci, z kontekstem tym jakoś nie wprost korespondują. Być może trzeba je uznać za - co prawda w Trzeciej Rzeszy nieliczne - przejawy kina artystycznego, wolnego od ideologicznych serwitutów.

\section{Kino artystyczne Trzeciej Rzeszy}

Jak pokazuje rozkwit szkoły montażu w Związku Sowieckim, konieczność afirmowania obowiązującej ideologii nie wykluczała zaistnienia $\mathrm{w}$ totalitarnym państwie kina na wysokim poziomie artystycznym. W Trzeciej Rzeszy możliwość ta była o tyle bardziej prawdopodobna, o ile Goebbelsowska polityka kinematografii eskapistycznej łatwiej niż w Rosji pozwalała na całkowite stronienie od propagandy. Zgodnie z tym, co wspominałem, także prestiżowe filmy na państwowe zamówienie, Staatsauftragsfilme, często stały na bardzo wysokim poziomie, co zresztą nie powinno dziwić w świetle tego, że nie szczędzono na nie żadnych środków. Realizowane były przez najwybitniejszych twórców (takich jak: Steinhoff, Harlan, Ucicky, Liebeneiner czy Ritter) i grali w nich naprawdę doskonali aktorzy (Jannings, George, Krauss, Marian, Söderbaum). Dla filmowców najlepszym sposobem na zapewnienie sobie, nigdy całkowitej, często jednak zaskakująco znacznej, autonomii artystycznej było ekranizowanie literatury. Wśród literackich adaptacji z okresu Rzeszy są utwory naprawdę wybitne, należące do wyróżniających się osiągnięć kina niemieckiego w całej jego historii.

Arcydziełem jest dokonana przez Hansa Deppe i Curta Oertla adaptacja opowiadania mistrza niemieckiej nowelistyki, Theodora Storma, Jeździec na siwym koniu (Der Schimmelreiter, 1933). Historia ta rozgrywa się gdzieś na fryzyjskim wybrzeżu Morza Północnego. Młody człowiek, Hauke Heian (świetna rola Martina Wiemana), rzuca wyzwanie miejscowej społeczności i naturze, mobilizując krajan do wydarcia morzu wielkich połaci lądu poprzez budowę systemu grobli i kanałów. Mimo iż przedsięwzięcie wydaje się początkowo triumfem inżynierskiej myśli i cywilizacyjnej misji bohatera, ostatecznie ponosi on spektakularną klęskę. Ginie wraz z żoną w odmętach wzburzonego morza, które niszcząc jego dzieło, wdarło się w ląd, by upomnieć się o swoje. Choć może w afirmacji upartego, walczącego z naturą ludu Jeździec... bliski jest ideom 
volkistowskim, to jednak w zobrazowaniu klęski w starciu z naturą pełnego hybris cywilizacyjnego projektu, trudno uznać go za wyraz nazistowskiej ideologii. Film zachwyca świetnym aktorstwem, pięknymi obrazami bezkresnego krajobrazu w długich, kontemplacyjnych ujęciach i niepokoi zestawieniem naturalistycznej prezentacji bytowania nadmorskiego ludu z przejętym z tradycji romantycznej i kina niemego trybem alegorycznym (figura białego rumaka, którego dosiada bohater, jako wcielenia Śmierci; animizacja i symbolika natury, niczym w szkole szwedzkiej).

Adaptując klasyków dramatu, w roku 1937 trzy znakomite filmy zrealizowali czołowi reżyserzy reżimu: Hans Steinhoff, Veit Harlan i Gustav Ucicky. Oparty o dramat Ibsena Wróg ludu (Ein Volksfeind) Steinhoffa przenosi co prawda akcję z XIX-wiecznej Norwegii do współczesnych Niemiec, skutkiem czego walka bohatera, doktora Hansa Stockmanna, o niewygodną dla notabli z nadmorskiego kurortu prawdę o szkodliwości pobytu w nim dla kuracjuszy, przekształca się w apoteozę hitlerowskiego państwa, które w finale, niczym deus ex machina, rozwiązuje problem i rehabilituje zaszczutego przez miejscową społeczność lekarza. Przy okazji tej fabuły otrzymujemy również dodatek do literackiego pierwowzoru w postaci stanowiącej nazistowską idée fixe propagandy higieny oraz sportowego trybu życia hartującego ducha i ciało. Niezależnie od tych naddatków Wróg ludu Steinhoffa jest pasjonującym, wciągającym dramatem z doskonałą rolą Heinricha George.

Dokonana przez Veita Harlana adaptacja dramatu Gerharda Hauptmanna Przed zachodem słońca, zatytułowana Władca (Der Herrscher), to w ogóle jeden z najciekawszych artystycznie filmów Trzeciej Rzeszy. Emil Jannings (kto wie, czy nie w najlepszej spośród swych licznych znakomitych ról) gra niemłodego, owdowiałego przemysłowca, który zakochuje się w młodej sekretarce. Musi stoczyć pasjonującą dla widza rozgrywkę z rodziną sprzeciwiającą się temu związkowi - rzekomo w imię zbrukanej pamięci śp. żony, faktycznie w obawie przed utratą spadku. Na inicjatywę rodziny, mającą na celu ubezwłasnowolnienie bohatera w obliczu jego rzekomej niepoczytalności, ten w zwycięskiej rozgrywce odpowiada przekazaniem $\mathrm{w}$ testamencie całego swego majątku państwu. Rzecz jasna, ten finał (wymuszony zresztą sugestiami Ministerstwa Oświecenia Publicznego i Propagandy) ma jawnie propagandowy charakter, ale poza nim Władca to doskonałe psychologiczne studium charakterów, film znakomity wasztatowo i aktorsko, co zresztą w swej recenzji w „Wiadomościach Literackich" wysoko oceniła Stefania Zahorska ${ }^{114}$.

114 „Wiadomości Literackie”, 3 października 1937, nr 41. Przytaczający Zahorską Toeplitz, doceniając klasę artystyczną filmu Harlana, ocenia go krytycznie: „Władca mógł służyć za przykład subtelnej roboty propagandowej. Bez sztandarów ze swastykami, bez 
Jannings zagrał również $\mathrm{w}$ dokonanej przez Gustava Ucicky'ego ekranizacji dramatu Heinricha von Kleista Rozbity dzban (Der zerbrochene Krug). Sam wybór tej akurat sztuki o skorumpowanym i lubieżnym sędzi, w realiach zbiurokratyzowanej Trzeciej Rzeszy miał posmak czegoś „dywersyjnego" i aluzyjnego, tym bardziej, że doskonale odtwarzający sędziego Adama Jannings kulał, co odczytywano jako referencję do samego Goebbelsa. Przyczyniło się to ponoć do czasowego niedopuszczenia filmu na ekrany. ,Jeśli nawet tak było - konkluduje Bogusław Drewniak - to jest jednak faktem, iż cenzura przyznała temu dziełu wysoką ocenę, określając je jako film politycznie i artystycznie wartościowy"115.

W krótkim okresie niemiecko-sowieckiej idylli po Pakcie RibbentropMołotow Gustav Ucicky sfilmował też jedną z Puszkinowskich Opowieści Biełkina, słynnego Poczmistrza (Der Postmeister, 1940). Jest to, jak sądzę, do dziś jedna z najlepszych adaptacji literatury rosyjskiej w kinie światowym. Udało się zachować zarówno liryzm, jak i intensywną emocjonalność pierwowzoru, a także niezwykle wiarygodnie - co w świecie kultury zachodniej w ogóle jest rzadkie - oddać zarówno rosyjskie realia, jak i sportretować pełną sprzeczności „rosyjską duszę”. Zasługa w tym niemała nie tylko starannej mise-en-scène i wysmakowanych plastycznie zdjęć, ale i genialnego Heinricha George. W roli tytułowej stworzył on wstrząsającą kreację, pokazując zarazem grubiaństwo i wrażliwość, śmieszność i tragizm, wielkość i nędzę ojca uwiedzionej dziewczyny.

Dwa arcyciekawe artystycznie filmy zrealizował Frank Wysbar (Wisbar), który w roku 1938 wyjedzie z Niemiec do USA. Pierwszy z nich, Anna i Elżbieta (Anna und Elisabeth), to film właściwie jeszcze weimarski, choć premierę miał już w Trzeciej Rzeszy, 13 kwietnia 1933 r. Koincydencja (albo i niekoincydencja?) sprawia, że Anna (piękna jak zwykle Hertha Thiele) zostaje uznana przez lokalną społeczność za tę, która przywróciła do życia swego umarłego brata. Wzrastająca sława dziewczyny jako uzdrowicielki - a zdają się to potwierdzać kolejne zdarzenia - dla niej samej staje się brzemieniem coraz cięższym do udźwignięcia. Opinia ta dociera do sparaliżowanej arystokratki Elżbiety (Dorothea Wieck) zaczynającej pożądać nieustannej obecności Anny nie tylko jako uzdrowicielki... Hertha Thiele i Dorothea Wieck niedługo po Dziewczętach w mundurkach znów fascynująco odgrywają dramat wzajemnego przyciągania się i odpychania dwóch kobiet. Lesbijski podtekst został jednak zarysowany bardzo subtelnie, a film jest przede wszystkim fascynująco opowiedzianą historią zbiorowej histerii, której ofiarą pada Anna - wykreowana przez

wznoszenia rąk do góry i bez portretów Führera - był to jednak klasyczny film narodowosocjalistyczny" (zob. J. Toeplitz, Historia sztuki filmowej, t. 4, s. 279).

115 B. Drewniak, op. cit., s. 242. 
swych fanatycznych wyznawców na „świętą", wbrew woli Kościoła i niej samej.

Drugie z arcydzieł Wysbara, Przewoźnik Maria (Fährmann Maria, 1936), ewokuje alegoryczny tryb kina weimarskiego z okresu niemego, świadomie nawiązując do takich filmów, jak Zmęczona Śmierć (Der müde Tod, 1921) Langa czy Nosferatu, symfonia grozy (Nosferatu, eine Symfonie des Grauens, 1922) Murnaua. Film opowiada historię dziewczyny, która $\mathrm{w}$ wiosce pośród bagien podejmuje po ojcu pracę przewoźnika promowego, pomagającego przeprawić się pasażerom przez rzekę (ojca Marii uprowadziła wcześniej upersonifikowana Śmierć). Któregoś dnia Maria ratuje przed tajemniczymi jeźdźcami w czerni nieznajomego z drugiego brzegu i ukrywa go w swej chacie, gdzie ten powraca do zdrowia. W wiosce zjawia się jednak Śmierć upominająca się o uciekiniera. Przeczuwając tożsamość posępnej postaci i drżąc o swego podopiecznego, którego zdążyła pokochać, bohaterka zwodzi ją na rozmaite sposoby, aż wreszcie zaprowadza na mokradła, ryzykując własne życie. Tam Śmierć, pokonana potęgą miłości, pogrąża się w bagnie, Maria zaś zwyciężywszy ja przechodzi trzęsawisko suchą stopą i dociera do szczęśliwie ocalonego ukochanego. Fabuła ta - znakomicie zresztą opowiedziana w powolnym, dostojnym tempie, umożliwiającym kontemplację ekspresywnych, plastycznie wyrafinowanych kadrów - w przeciwieństwie do Zmęczonej Śmierci wydaje się mieć optymistyczne zakończenie, ale po refleksji trzeba je uznać raczej za dwuznaczne. Maria z ocalonym ukochanym przeprawiają się promem na drugi brzeg rzeki, czyli tam, gdzie wcześniej grasowali niesamowici jeźdźcy, a Śmierć uprowadziła ojca bohaterki, na miejsce, które widz kojarzył w zasadzie w niejasny, alegoryczny sposób z „zaświatami”. Czy zatem ceną odniesionego przez miłość zwycięstwa nad Śmiercią nie była jednak śmierć obu postaci?

Z lat wojny pochodzą wybitne osiągnięcia kina artystycznego w Trzeciej Rzeszy, zrealizowane przez twórców, których zasadnicza kariera przebiegać będzie w latach powojennych. Co więcej, to właśnie Wolfgang Staudte i Helmut Käutner, bo o nich mowa, uoasabiać będą nowe, powojenne, przeciwstawiane „nazistowskiemu” kino niemieckie, sami mając reputację twórców raczej „nieskażonych” przez Trzecią Rzeszę ${ }^{116}$, choć przecież $\mathrm{w}$ machinie jej upaństwowionej kinematografii nakręcili swoje wczesne filmy. Staudte w roku 1943 zrealizował zaskakujący w wojennym i nazistowskim kontekście film Akrobat sch-ö-ö-ö-n..., smutno-śmieszną

116 To „nieskażenie” nie jest do końca prawdą w przypadku Käutnera, którego jeden film, popularna komedia Do widzenia, Franciszko! (Auf Wiedersehn, Franziska!, 1941), o żonie niemogącej się nigdy doczekać dłuższego pobytu w domu swego męża, wojennego reportera, jest nośnikiem dosyć nachalnej, prowojennej propagandy nazistów. 
liryczną opowieść o codziennej egzystencji klowna zdradzonego przez swą przyjaciółkę i partnerkę. Główną rolę w tym intrygującym filmie z bardzo skapymi dialogami zagrał klown Charlie Rivel, mim-akrobata budzący podziw swym opanowaniem ciała i maestrią rozbudowanych przestrzennie i narracyjnie gagów, noszący owo imię na cześć Chaplina, którego przed laty naśladował, występując w popularnym trio akrobatów-mimów Andreu-Rivel ${ }^{117}$. W nazistowskich Niemczech już samo tylko imienne odniesienie do postaci Chaplina (i to po Dyktatorze!), trzeba uznać za zuchwałość. A przecież Chaplin przywoływany jest w tym filmie i przez brak słów, i przez choreografię gagów, i przez semantykę postaci klowna z filmu Staudtego - jak i Charlie-Tramp ignorowanego, zepchniętego na margines, pomiatanego małego człowieczka. Dopuszczenie do realizacji tego filmu w Trzeciej Rzeszy A. D. 1943 dziś wydaje się czymś zupełnie niepojętym.

Käutner, który już w roku 1940 zabłysnął wizualnie stylową i dzięki Heinzowi Rühmannowi bardzo zabawną adaptacją powieści Gottfrieda Kellera Jak cie widza, tak cie pisza, swe prawdziwe arcydzieło zrealizował w roku 1943. Jest nim Romanza w moll (1943), swobodna adaptacja noweli Maupassanta, o kunsztownej kompozycji z ramą narracyjną, wewnątrz której seria retrospekcji stopniowo odsłania prowadzącą do tragedii historię uwiedzenia pięknej żony nieciekawego urzędnika (w tej roli Marianne Hoppe) przez czarującego światowca, słynnego kompozytora (Ferdinand Marian po raz kolejny w roli feralnego uwodziciela). Findesieclową sceneria, sugerującą jakąś nieokreślona, niezbyt odległa, ale definitywnie zamkniętą przeszłość, dekadenckim klimatem, wydobytym przez fatalistyczną konstrukcję oraz styl aktorstwa i fotografii, film ten bardzo przypomina posępne arcydzieła Maxa Ophülsa (Miłostki) i Willy Forsta (Maskarada, Teatr Miejski). Koresponduje też z równolegle powstałymi, podobnie wyestetyzowanymi i fabularnie "bezczasowymi" melodramatami Harlana (Immensee, Poświęcenie). Jednak w przeciwieństwie do tych ostatnich w samych Niemczech nie cieszył się powodzeniem. Popularny za to w Szwecji i jako pierwszy film Trzeciej Rzeszy wyróżniony tam nagrodą krytyki ${ }^{118}$ wpłynął być może na estetykę np. wczesnych filmów Ingmara Bergmana.

Po tym doskonałym, posępnym melodramacie Käutner zdołał jeszcze zrealizować w Trzeciej Rzeszy dwa świetne filmy: omówiony już barwny

117 Nt. zapomnianej postaci Charliego Rivela i jego relacji do Chaplina odsyłam do arcyciekawego eseju Tomasza Majewskiego Chaplin w Niemczech: podwójne ciało mima, [w:] T. Majewski, Dialektyczne feerie: Szkoła frankfurcka i kultura popularna, Wydawnictwo Officyna, Łódź 2011, s. 137-139.

118 Por. J. Toeplitz, Historia sztuki filmowej, t. 5, s. 245. 
melodramat z Hansem Albersem i Ilse Werner Große Freiheit Nr. 7 (1944) oraz Pod mostami (Unter den Brücken, 1945), realistyczną i poetycką zarazem opowieść o śródlądowych marynarzach pływających barką po Szprewie, Haweli i berlińskich kanałach, zakochanych w jednej dziewczynie. Stylem i klimatem ten ostatni film zdaje się nawiązywać do kina francuskiego, zwłaszcza Atalanty (L'Atalante, 1934) Jeana Vigo i Panny wodnej (La Fille de l'eau, 1925) Jeana Renoira. Jest to też jeden z najciekawszych wizualnie filmów o Berlinie - z poziomu rzek i kanałów ukazuje miasto, którego niedługo miało nie być w ówczesnym kształcie. Już w trakcie realizacji było mocno zbombardowane, dlatego operatorzy musieli dokonywać rozmaitych ekwilibristycznych sztuczek, by w kadrze nie ukazać ruin... Film Käutnera nie doczekał się zresztą premiery w Trzeciej Rzeszy, wraz z kilkunastoma innymi "filmami-dezerterami" został wypuszczony na ekrany długo po jej upadku (w RFN w roku 1950, a w NRD pokazany dopiero w telewizji w roku 1987, na dwa lata przed upadkiem tego państwa!). Niepotrzebnie, jak się okazało, unikał filmowania ruin. $W$ realizowanych w Niemczech po wojnie Trümmerfilme były one podstawowym składnikiem wizualnym przedstawionego świata.

\section{Chronologia ${ }^{119}$}

\section{9}

- 24 października - krach na giełdzie nowojorskiej; początek światowego kryzysu, który dotkliwie dotyka Republikę Weimarską (w styczniu 1933 bezrobocie osiągnie $6 \mathrm{mln}$ osób).

\section{0}

- 14 września - wybory parlamentarne po długotrwałym kryzysie rządowym (naziści z 18,3\% poparcia są drugą siłą w Reichstagu).

\section{1}

- 11 października - utworzenie Frontu Harzburskiego, antyrepublikańskiej, nacjonalistycznej koalicji z udziałem m.in. NSDAP i DNVP partii Alfreda Hugenberga;

- 16 grudnia - utworzenie Frontu Żelaznego (Die Eiserne Front), koalicji partii i organizacji prorepublikańskich i prodemokratycznych;

${ }^{119}$ W jej opracowaniu korzystałem z pomocy kalendarium Trzeciej Rzeszy zamieszczonego w aneksie książki Erica Rentschlera The Ministry of Illusion (s. 225-271). 
w wyborach 1932 poprze on Hindenburga przeciw Hitlerowi; zlikwidowany 2 maja 1933 z chwilą likwidacji niezależnego ruchu związkowego.

\section{2}

- 13 marcai12kwietnia-wybory prezydenckiewygrane przez Hindenburga (w II turze jego kontrkandydatem był Hitler);

- 31 lipca i 6 listopada - wybory do Reichstagu (naziści uzyskuja, odpowiednio, 37 i $33 \%$ głosów).

\section{3}

- 30 stycznia - prezydent Hindenburg mianuje kanclerzem Adolfa Hitlera;

- 27 lutego - pożar Reichstagu (pretekst do przyznania nazajutrz Hitlerowi przez prezydenta nadzwyczajnych uprawnień „dla ochrony Narodu i Państwa");

- 11 marca - powołanie Ministerstwa Oświecenia Publicznego i Propagandy;

- 13 marca - Joseph Goebbels desygnowany szefem resortu;

- 15 marca - w Poczdamie Hitler proklamuje powstanie Trzeciej Rzeszy;

- 28 marca - spotkanie Goebbelsa z przedstawicielami przemysłu filmowego w Hotelu Kaiserhof w Berlinie. Wytyczne ministra dla prawdziwie niemieckiego kina.

- 4 maja - utworzenie Gestapo, tajnej policji politycznej;

- 1 czerwca - powołanie Banku Kredytu Filmowego (Filmkreditbank);

- 30 czerwca - tzw. „klauzula aryjska” (Arierparagraph) zabrania Żydom pracy w przemyśle filmowym;

- 14 lipca - powołanie Izby Filmowej Rzeszy (Reichsfilmkammer);

- 22 września - utworzenie Izby Kultury Rzeszy (Reichskulturkammer). Izbę Filmową włączono w jej strukturę obok izb prasy, radia, teatru, literatury, muzyki i sztuk pięknych;

- 14 października - Niemcy występują z Ligi Narodów.

\section{4}

- 3 lutego - Willi Krause wyznaczony przez Goebbelsa pierwszym Dramaturgiem Filmowym Rzeszy (Reichsfilmdramaturg); będzie sprawować ten urząd tylko do marca 1935;

- 16lutego-uchwalenieUstawy Filmowej Rzeszy (Reichlichtspielgesetz), która 1 marca wchodzi w życie. Ustanawia ona cenzurę prewencyjną i system Prädikate; 
- 30marca-założenieArchiwum FilmowegoRzeszy (Reichsfilmarchive);

- 29 czerwca-2 lipca - czystka w SA zapoczątkowana „nocą długich noży" (29/30 czerwca); Hitler pozbywa się wpływowego przywódcy SA, Ernsta Röhma. Wśród wielu ofiar było stu siedemdziesięciu znaczących nazistów;

- 2 sierpnia - śmierć Hindenburga, po której Hitler łączy urzędy prezydenta i kanclerza. Armia przysięga Hitlerowi lojalność;

- 19 sierpnia - Hitler obwołuje się Führerem, przywódcą narodu;

- 6-9 września - doroczny VI Kongres Partii Narodowo-Socjalistycznej w Norymberdze, uwieczniony w filmie Leni Riefenstahl Triumf woli;

- 20 września - w Monachium pierwsze z corocznych spotkań Reichsfilmkammer. Wytyczną dla kina niemieckiego są na nim „filmy artystyczne z międzynarodowym odzewem".

\section{5}

- 16 marca - odrzucenie przez Niemcy klauzuli rozbrojeniowych traktatu wersalskiego i przywrócenie powszechnego poboru;

- 22 marca - Poczta Rzeszy (Reichspost) rozpoczyna regularne emisje telewizyjne (początkowo 90 minut każdego wieczoru, trzy razy w tygodniu);

- 25 kwietnia-3 maja - Międzynarodowy Kongres Filmowy w Berlinie z udziałem przedstawicieli 20 kinematografii. 27 kwietnia w Babelsbergu oficjele Ufy witają 1800 gości;

- 26 czerwca - ustawa o przymusowej pracy dla Rzeszy (Reichsarbeitgesetz) dla młodych mężczyzn między 18. a 25. rokiem życia;

- 15 września - ustawy norymberskie („o obywatelstwie Rzeszy” $\mathrm{i}$ „o ochronie niemieckiej krwi i niemieckiej czci”) odmawiają Żydom obywatelstwa i praw cywilnych; małżeństwa i stosunki seksualne między Niemcami a Żydami stają się przestępstwami ściganymi prawem; ograniczenia praw spotykają też Cyganów i przedstawicieli rasy czarnej.

\section{6}

- 7 marca - oddziały niemieckie wkraczają do Nadrenii, której odzyskanie legalizuje plebiscyt z 29 marca (akcja ta uzyskała w nim 99\% poparcia);

- lipiec - pierwsza grupa Cyganów trafia do obozu koncentracyjnego w Dachau;

- 1 sierpnia - otwarcie Igrzysk Olimpijskich w Berlinie;

- 4 sierpnia - premiera pierwszego niemieckiego filmu barwnego, Piękny zakątek (Das Schönheitsfleckchen, 1936, Rolf Hansen), półgodzinnej adaptacji opowiadania Alfreda de Musseta, z Lil Dagover w roli markizy de Pompadour;

- 25 października - traktat niemiecko-włoski powołujący oś BerlinRzym; 
- 25 listopada - Pakt Antykominternowski między Niemcami a Japonią;

- 27 listopada - Goebbels zakazuje krytyki filmowej.

\section{7}

- 18 marca - przez podstawionego człowieka, Maxa Winklera, stojącego na czele Funduszu Powierniczego Kautio (Kautio Treuhand GmbH), rząd wykupuje pakiet kontrolny nad Ufa, płacąc Alfredowi Hugenbergowi pełną wartość rynkową za jego udziały. Kautio przejmie wkrótce na rzecz rządu Rzeszy także wytwórnie Tobis, Terra i Bavaria;

- 4 kwietnia - „New York Times” donosi o wycofaniu się wytwórni amerykańskich z niemieckiego rynku filmowego;

- 12 lipca - regulacje dotyczące wyświetlania w Niemczech filmów zagranicznych; ich dystrybutorzy muszą zarejestrować filmy w Kontingentstelle Berlin, organie Izby Filmowej. Wstępna aprobata zagranicznych filmów przez Ministerstwo Oświecenia Publicznego i Propagandy warunkiem w ogóle dopuszczenia filmu przed gremium cenzorskie;

- 18 lipca - Hitler otwiera Dom Sztuki Niemieckiej w Monachium;

- 19 lipca - otwarcie w Monachium wystawy „sztuki zdegenerowanej" (entartete Kunst);

- 7 października - niewyjaśniona śmierć Renate Müller;

- 1 grudnia - przejęcie przez rząd kontroli nad koncernem Tobis Film.

\section{8}

- 11 lutego - utworzenie w Monachium wytwórni Bavaria Filmkunst $\mathrm{GmbH}$ na gruzach zbankrutowanej prywatnej spółki Bavaria AG;

- 4 marca - na terenach Ufy w Poczdamie-Babelsbergu Goebbels otwiera Akademię Filmu Niemieckiego. Na czele Wydziału Sztuki Filmowej stoi Wolfgang Liebeneiner;

- 12-13 marca - oddziały niemieckie wkraczają do Austrii; jej włączenie do Rzeszy Niemieckiej (Anschluß) zatwierdza plebiscyt z 10 kwietnia;

- 20 kwietnia - berlińska premiera Olimpiady Leni Riefenstahl, filmu chyba najmocniej obsypanego nagrodami Trzeciej Rzeszy;

- 14 maja - dekret Ministerstwa Oświecenia Publicznego i Propagandy stanowiący, iż niemieccy aktorzy mogą występować w filmach zagranicznych tylko za zgodą Izby Kultury Rzeszy;

- 30 września - układ monachijski (zawarty między Francją Wielką Brytanią, Włochami i Niemcami) przyznający Niemcom Sudety;

- 1 października - oddziały niemieckie zajmują Sudety na terytorium Czechosłowacji;

- 3 listopada - wezwanie do bojkotu Olimpiady skierowane przez środowiska żydowskie do amerykańskich dystrybutorów i kiniarzy; 
klęska amerykańskiego tournée Leni Riefenstahl promującego dokument o igrzyskach;

- 9 listopada - fala antyżydowskiej przemocy w całych Niemczech podczas tzw. ",kryształowej nocy”; zabito wówczas dziewięćdziesiąt jeden osób, zniszczono sto dziewięćdziesiąt jeden synagog i sprofanowano wiele żydowskich cmentarzy. Winą za rozruchy obarczono... samych Żydów, wielu z nich aresztując i nakładając na nich miliard marek odszkodowań;

- 16 grudnia - utworzenie na bazie zawłaszczonego austriackiego przemysłu filmowego kompanii Wien-Film, piątej co do wielkości wytwórni Rzeszy.

\section{9}

- 15 marca - zajęcie przez niemieckie wojska Czechosłowacji; utworzenie niemieckiego Protektoratu Czech i Moraw na terenie Czech umożliwia zawłaszczenie majątku praskiego studia filmowego w Barrandovie;

- 25 marca - członkostwo w Hitlerjugend staje się obowiązkowe dla chłopców między 10. a 18. rokiem życia;

- 30 czerwca - reżyser Carl Froelich zostaje prezesem Reichsfilmkammer;

- 23 sierpnia - niemiecko-sowiecki pakt o nieagresji, znany jako Pakt Ribbentrop-Mołotow; tajne klauzule określają m.in. warunki rozbioru Polski;

- 27 sierpnia - początki racjonowania żywności w Niemczech;

- 1 września - inwazja na Polskę; początek II wojny światowej. Hitler legalizuje eutanazję;

- 8 listopada - nieudany zamach bombowy na Hitlera w monachijskiej piwiarni;

- domniemany sprawca, Johann Georg Elser, aresztowany na granicy i osadzony w obozie koncentracyjnym; zabity 9 kwietnia 1945 w Dachau.

\section{0}

- 30 stycznia - przemówienie Hitlera w berlińskim Pałacu Sportu sugerujące możliwość niemiecko-sowieckiej przyjaźni;

- 2-13 lutego - pierwsze deportacje Żydów;

- 9 kwietnia - inwazja na Norwegię i Danię;

- 27 kwietnia - rozkaz Himmlera o założeniu obozu koncentracyjnego w Auschwitz;

- 10 maja - wkroczenie Niemców do Holandii, Belgii i Luksemburga bez oficjalnego wypowiedzenia wojny;

- 22 czerwca - francusko-niemieckie zawieszenie broni;

- 13 sierpnia - intensywne niemieckie bombardowania rozpoczynają „bitwę o Anglię"; 
- 12 grudnia - Hitler podpisuje tajny rozkaz ataku na Związek Sowiecki (Fall Barbarossa).

\section{1}

- 3 kwietnia - Ministerstwo Goebbelsa obwieszcza utworzenie najwyższego wyróżnienia dla filmu, kategorii „Filmu Narodu” (Film der Nation); pierwszym laureatem jest Wuj Krüger Hansa Steinhoffa;

- maj - z rozkazu Izby Prasy Rzeszy zamknięto pięćset pięćdziesiąt tytułów prasowych;

- 22 czerwca - inwazja na Związek Sowiecki łamiąca Pakt RibbentropMołotow; za armią podążają specjednostki policyjne likwidujące komunistów, Żydów i Cyganów;

- 2 września - powołanie spółki Berlin-Film GmbH zrzeszającej nielicznych pozostałych niezależnych producentów;

- 14 października - początek masowych deportacji niemieckich Żydów; zostają osadzeni w gettach Łodzi, Kowna, Mińska i Rygi;

- 31 października - premiera pierwszego niemieckiego pełnometrażowego filmu w kolorze (w systemie Agfakolor) - komedii muzycznej Georga Jacoby'ego Lepszymi dyplomatami sa jednak kobiety, z Mariką Rökk i Willy Fritschem;

- 7 listopada - tragiczna śmierć aktora Joachima Gottschalka, jego żony i dziecka;

- 21 listopada - utworzenie kompanii Prag-Film AG;

- 5 grudnia - początek wielkiej sowieckiej kontrofensywy;

- 7 grudnia - atak Japończyków na Pearl Harbor;

- 8 grudnia - USA i Wielka Brytania wypowiadają wojnę Japonii;

- 11 grudnia - Niemcy i Włochy wypowiadają wojnę Stanom Zjednoczonym.

\section{2}

- 10 stycznia - utworzenie koncernu Ufa-Film GmbH (Ufi), obejmującego m.in. siedem największych wytwórni: Ufa, Tobis, Terra, Bavaria, Wien-Film, Berlin-Film, Prag-Film;

- 20 stycznia - tajna konferencja w Wannsee (rekreacyjne przedmieście Berlina) przesądza o „ostatecznym rozwiązaniu” (Endlösung) - likwidacji europejskich Żydów;

- luty - pierwsze deportacje Żydów do obozów zagłady;

- 30-31 maja - zmasowane bombardowanie Kolonii przez lotnictwo brytyjskie; stadt;

- 2 czerwca - początek deportacji niemieckich Żydów do Theresien- 
- 23 czerwca - rozpoczęcie systematycznych gazowań Żydów w Auschwitz KL;

- 1 sierpnia - śmierć w berlińskim areszcie reżysera Herberta Selpina, aresztowanego przez Gestapo za obraźliwe uwagi o niemieckiej armii na planie Titanica;

- 9 września - wbrew rekomendacji resortu Goebbelsa Hitler odmawia przyznania Zarah Leander tytułu „,aktorki państwowej” (Staatsschauspielerin);

- 19 listopada - początek sowieckiej kontrofensywy pod Stalingradem; w ciaggu 4 dni VI Niemiecka Armia otoczona przez Rosjan wpada w pułapkę.

\section{3}

- 31 stycznia-2 lutego - kapitulacja VI Armii gen. von Paulusa pod Stalingradem;

- 18 lutego - w słynnej przemowie w berlińskim Pałacu Sportu Goebbels wielce emocjonalnym tonem nawołuje do „wojny totalnej”;

- 22 lutego - egzekucja Sophie i Hansa Schollów, członków antyreżimowej organizacji Biała Róża;

- 3 marca - premiera Münchhausena w Ufa-Palast am Zoo, na jubileusz 25-lecia Ufy;

- 13 i 21marca - nieudane próby zamachów na Hitlera;

- kwiecień - Wolfgang Liebeneiner szefem produkcji w Ufa Filmkunst $\mathrm{GmbH}$;

- 20 kwietnia - zagłada getta w Warszawie;

- 19 maja - ogłoszenie Berlina „wolnym od Żydów”;

- 24-30 lipca - zmasowane naloty aliantów na Hamburg (ginie ponad 30 tys. cywili);

- 28 listopada-1 grudnia - Roosevelt, Churchill i Stalin deliberują o przyszłości Niemiec podczas konferencji w Teheranie.

\section{4}

- marzec - Hans Hinkel z SS zostaje wyznaczony przez Goebbelsa jako Reichsfilmintendant; był to vacat po Fritzu Hipplerze zdymisjonowanym w marcu 1943 z tego stanowiska (z racji rozbieżności opinii z Goebbelsem);

- 6 czerwca - lądowanie aliantów w Normandii;

- 20 czerwca - nieudany zamach płk von Stauffenberga na życie Hitlera w jego kwaterze głównej w Prusach Wschodnich; udaremnione próby zamachu stanu w Paryżu i Berlinie;

- 1 sierpnia-2 października - powstanie warszawskie;

- 1 września - zamknięcie wszystkich teatrów, oper, kabaretów i nocnych klubów w całej Rzeszy; głównym źródłem rozrywki stają się radio i kino; 
- 11 września - oddziały amerykańskie wkraczają na terytorium Niemiec;

- koniec października - resort Goebbelsa nakazuje ponowne wypuszczenie na ekrany trzydziestu dziewięciu filmów „o szczególnym znaczeniu dla armii i narodu"; większość to Staatsauftragsfilme zrealizowane po wybuchu wojny, tylko jedenaście z nich to filmy z lat 1933-1939;

- 27 listopada - Himmler zaprzestaje gazowań w Auschwitz i nakazuje zniszczenie krematoriów;

- 16-24 grudnia - niemiecka kontrofensywa w Ardenach.

\section{5}

- 4-11 lutego - konferencja jałtańska;

- 13-14 lutego - naloty dywanowe aliantów z użyciem bomb zapalających obracają w perzynę Drezno;

- 17 kwietnia - specjalnym pokazem filmu Kolberg Goebbels próbuje podbudować morale swego personelu;

- 20 kwietnia - oddziały sowieckie docierają do Berlina; reżyser Hans Steinhoff ginie w zestrzelonym przez Sowietów samolocie, którym usiłował opuścić Niemcy;

- 25 kwietnia - oddziały amerykańskie i sowieckie spotykają się na linii Łaby;

- 30 kwietnia - samobójstwo Hitlera i Ewy Braun w bunkrze Kancelarii Rzeszy;

- 1 maja - niemieckie radio informuje o śmierci Führera. Goebbels, uśmierciwszy z żoną szóstkę własnych dzieci, popełnia wraz z nią samobójstwo;

- 8 maja - bezwarunkowa kapitulacja Niemiec; koniec wojny w Europie.

\section{Propozycje lektur}

Najciekawsze w literaturze światowej opracowanie kina schyłku Republiki Weimarskiej, zawarte w czwartej części książki Siegfrieda Kracauera Od Caligariego do Hitlera: Z psychologii filmu niemieckiego [Okres przedhitlerowski (1930-1933)], jest dostępne po polsku. Pozycja ta doczekała się u nas dwóch wydań (wyd. I - Filmowa Agencja Wydawnicza, Warszawa 1958; wyd. II - słowo/obraz terytoria, Gdańsk 2010). Niestety, II wydanie nie jest nowym tłumaczeniem, ale wznowieniem starego przekładu Wandy Wertenstein i Eugenii Skrzywanowej zawierającego rozmaite błędy. 
Na temat kina Trzeciej Rzeszy w języku polskim najwartościowszą pracą jest solidna faktograficznie książka Bogusława Drewniaka Teatr i film Trzeciej Rzeszy (Wydawnictwo Morskie, Gdańsk 1972). Była ona wycofana z księgarń przez cenzurę PRL, ale część nakładu zdążono sprzedać. Niedawno ukazało się drugie jej wydanie (słowo/obraz terytoria, Gdańsk 2011). Godne polecenia są także odpowiednie rozdziały w Historii sztuki filmowej Jerzego Toeplitza - $\mathrm{w}$ tomie 4 rozdział V: Film pod znakiem swastyki (Wydawnictwa Artystyczne i Filmowe, Warszawa 1969) i w tomie 5 rozdział V: Film Trzeciej Rzeszy w czasie wojny (Wydawnictwa Artystyczne i Filmowe, Warszawa 1970). Warto również sięgnąć do monograficznego numeru miesięcznika Polskiej Federacji DKF „Film na Świecie” (1983, październik-listopad, nr 298-299) poświęconego kinu w hitlerowskich Niemczech i faszystowskich Włoszech. Znajdziemy w nim syntetyczny artykuł Philippe'a J. Maarka Kinematografie faszystowskie (przeł. Joanna Galewska), dwa fragmenty klasycznej pracy Erwina Leisera Nazi Cinema (London 1974) w przekładzie Lecha Niedzielskiego (zatytułowane Program Goebbelsa i Zmierzch bogów) oraz tekst Rogera Manvella i Heinricha Fraenkla Film w Niemczech nazistowskich (tłum. Zbigniew Batko) będący przekładem rozdziału ich książki o historii kina niemieckiego German Cinema (Praeger, London 1976).

Niestety, wadą wszystkich tych pozycji jest ich jednostronność skupienie się głównie na propagandowym wymiarze kina okresu hitlerowskiego i niedostrzeganie ani tego, że było to kino przede wszystkim popularne, ani jego ciągłości z okresem weimarskim i z powojennym kinem niemieckim. Wszystkie one zdecydowanie umniejszają też niewątpliwe walory estetyczne filmów Trzeciej Rzeszy - co szczególnie musi razić zwłaszcza w kontekście stawiania z kolei wysokich ocen (np. przez Toeplitza) znacznie bardziej nasyconemu propagandą i ideologią kinu sowieckiemu, moim zdaniem znacznie en globe słabszemu artystycznie. Trzeba więc odesłać czytelnika do lektur obcojęzycznych.

$\mathrm{Z}$ ogólnych historii kina niemieckiego polecam zbiorowy tom Geschichte des deutschen Films pod redakcją Wolfganga Jacobsena, Antona Kaesa i Hansa Helmuta Prinzlera (J. B. Metzler Verlag, Stuttgart-Weimar 2004) oraz autorskie opracowania Stephena Brockmana A Critical History of German Film (Camden House, Rochester-New York 2010) i Sabine Hake German National Cinema (Routledge, London-New York 2002). Lekturą pasjonującą i bezcenną faktograficznie jest monografia największej niemieckiej wytwórni: Klaus Kreimeier, Die Ufa-Story: Geschichte eines Filmkonzerns, Carl Hansen Verlag, München-Wien 1992 (wyd. angielskie: K. Kreimeier, The Ufa Story: A History of Germany's Greatest Film Company, 1918-1945, transl. Robert and Rita Kimber, University of California Press, 
Berkeley-Los Angeles-London 1999). Oczywiście, powyższe prace rekomenduję jako lekturę zarówno do tematu "film Trzeciej Rzeszy”, jak i do zagadnienia ",kino schyłku Republiki Weimarskiej”; podobnie zresztą jak III i IV część świetnej książki Thomasa Elsaessera Weimar Cinema and After: Germany's Historical Imaginary, Routledge, London-New York 2000.

Najlepsze ujęcie propagandowego wymiaru kina okresu nazistowskiego prezentuje książka Davida Welcha z roku 1983. Korzystałem z jej poprawionego wydania: David Welch, Propaganda and the German Cinema 1933-1945, I. B. Tauris \& Co. Ltd., London-New York 2006. Jest to jednak pozycja tradycyjnie skupiająca się na propagandowych Staatsauftragsfilme - podobnie do innych, nowszych od niej prac: Susan Tegel, Nazis and the Cinema, Hambledon Continuum, London 2008; Rolf Giesen, Nazi Propaganda Films: A History and Filmography, Jefferson, NC 2008; Richard Taylor, Film Propaganda: Soviet Russia and Nazi Germany, I. B. Tauris, London-New York 1998.

Nowsza metodologicznie literatura na temat kina Trzeciej Rzeszy, nie zaniedbując jego ideologicznego wymiaru, skupia się przede wszystkim na kinie popularnym. Najciekawsza jest książka Erica Rentschlera The Ministry of Illusion: Nazi Cinema and Its Afterlife, Harvard University Press, Cambridge, Mass.-London 1995. Zawiera ona - prócz doskonałych analiz najbardziej reprezentatywnych i najwybitniejszych filmów kina popularnego tego okresu - doskonałe pod względem informacyjnym aneksy. Tę nową orientację, analizy ideologicznej kina nazistowskiego poprzez "dekonstrukcję" raczej jego kina popularnego niż omawianie Staatsauftragsfilme, prezentują następujące pozycje: Sabine Hake, Popular Cinema of the Third Reich, University of Texas Press, Austin 2002; Linda Schulte-Sasse, Entertaining the Third Reich: Illusions of Wholeness in Nazi Cinema, Duke University Press, Durham-London 1996; Mary-Elizabeth O'Brien, Nazi Cinema as Enchantment: The Politics of Entertainment in the Third Reich, Camden House, Rochester, New York-Woodbridge 2006; Antje Ascheid, Hitler's Heroines: Stardom and Womanhood in Nazi Cinema, Temple University Press, Philadelphia 2003; Jana Francesca Bruns, Nazi Cinema's New Women, Cambridge University Press, Cambridge 2009. Najnowszą pozycją reprezentującą tę orientację jest zbiór artykułów Pleasure and Power in Nazi Germany, ed. Pamela E. Swett, Corey Ross, Fabrice d'Almeida, Palgrave Macmillan, Basingstoke-New York 2011. 



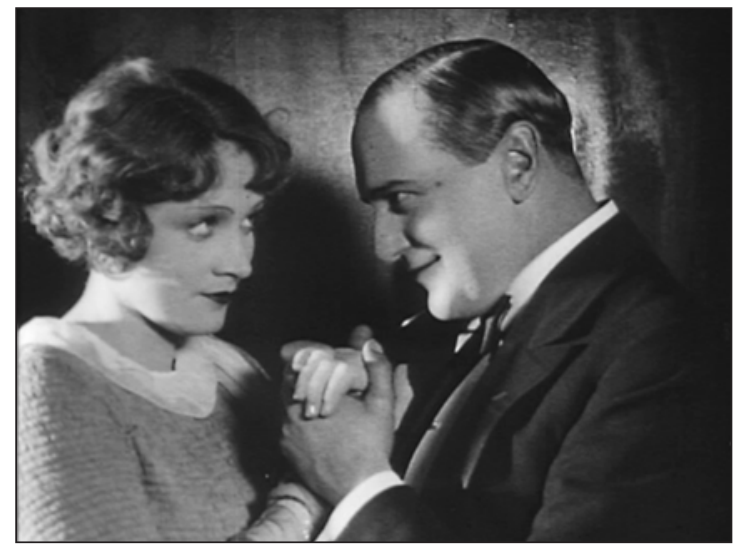

1. Całuje twoja dłoń, madame (1928, reż. Robert Land). Wamp i kelner-hrabia, czyli Marlena Dietrich i Harry Liedtke

2. Kongres tańczy (1931, reż. Erik Charrell). Lilian Harvey na tle bawiącego się Wiednia
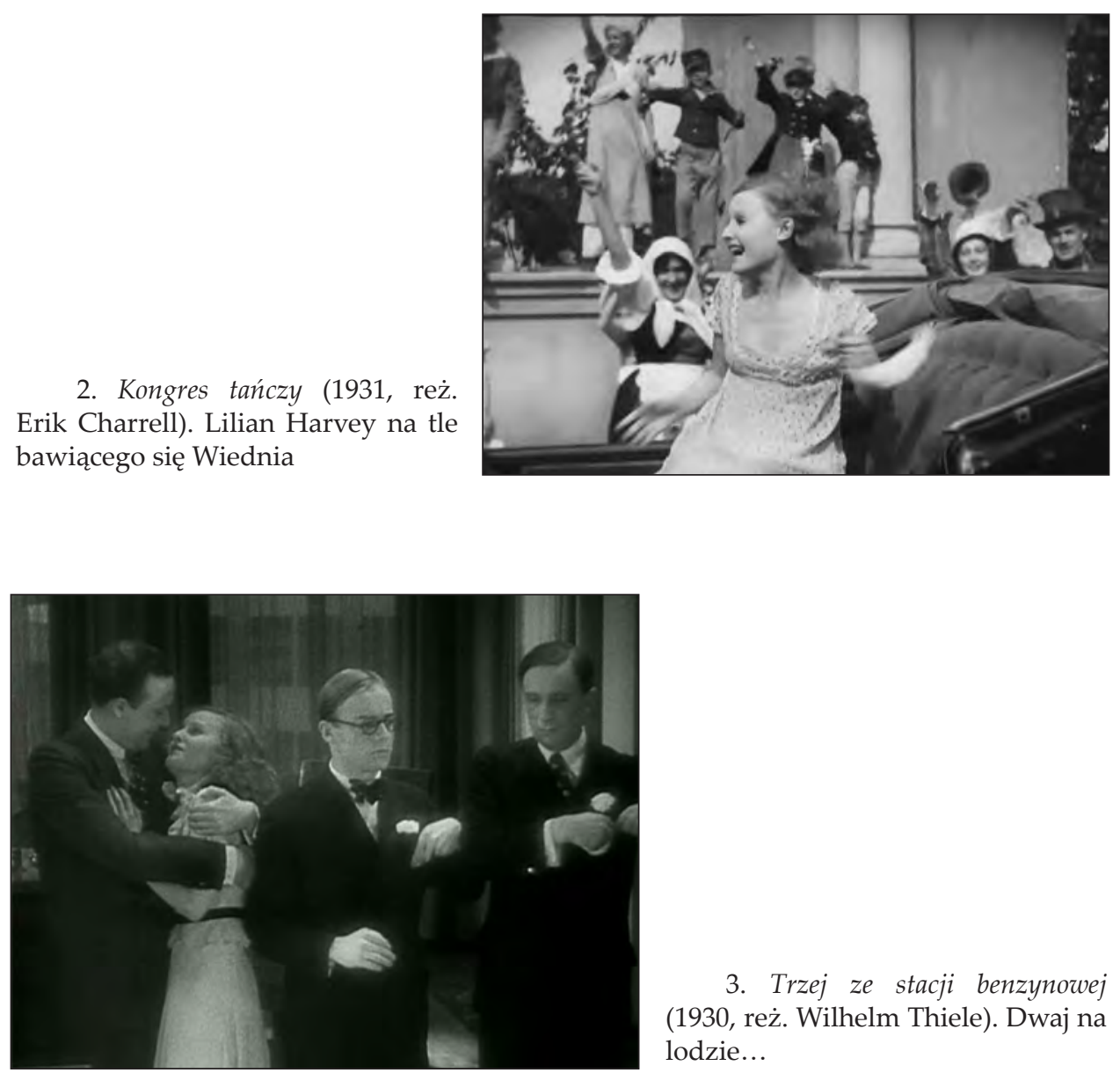

3. Trzej ze stacji benzynowej (1930, reż. Wilhelm Thiele). Dwaj na lodzie... 


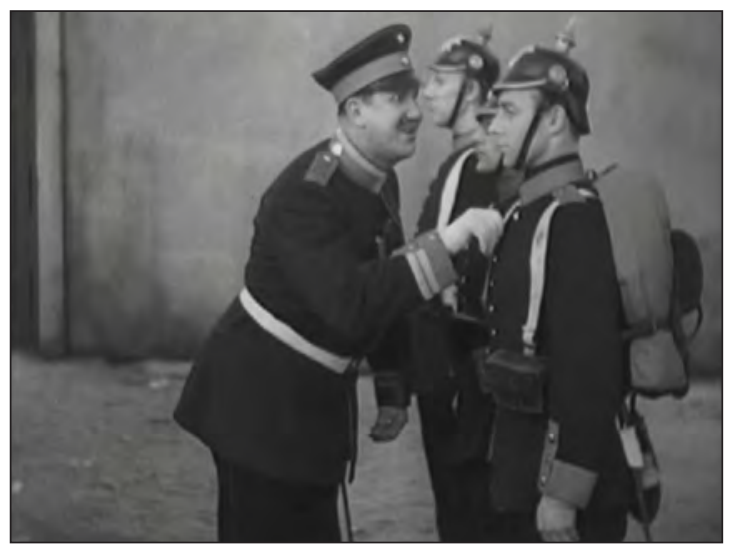

4. Duma trzeciej kompanii (1932, reż. Fred Sauer). Absurdy militaryzmu w koszarowej farsie

5. Dziewczęta w mundurkach (1931, reż. Leontine Sagan i Carl Froelich). Pruski dryl w żeńskiej szkole
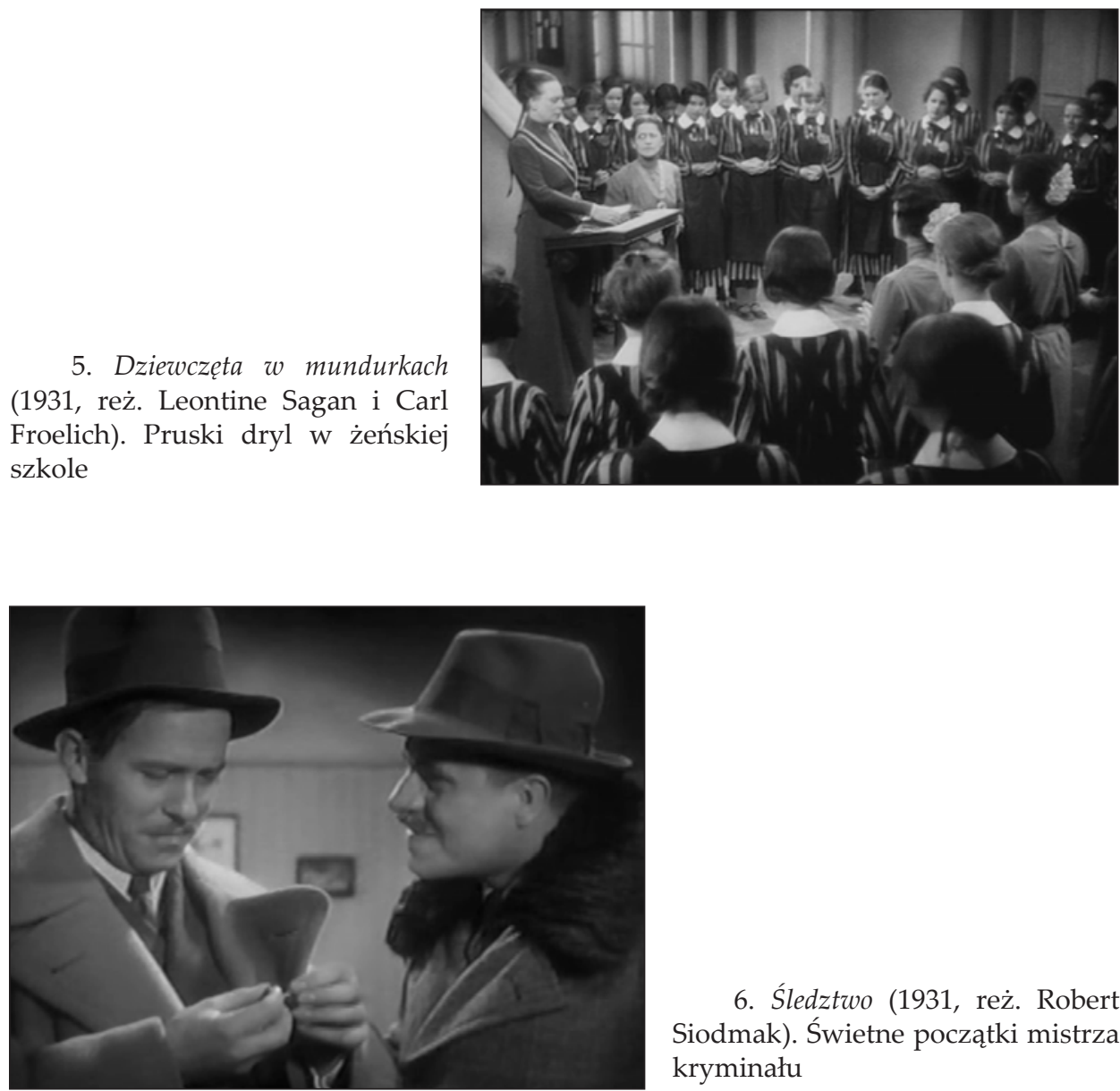

6. Śledztwo (1931, reż. Robert Siodmak). Świetne początki mistrza kryminału 


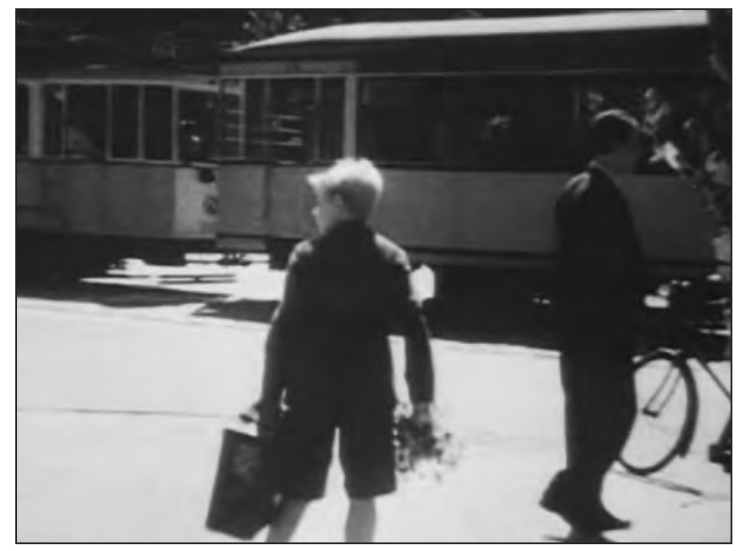

7. Emil idetektywi (1931, reż. Gerhardt Lamprecht). Chłopiec z prowincji w dżungli Berlina

8. Kuhle Wampe (1932, reż. Slatan Dudow). Na komunistycznym festynie
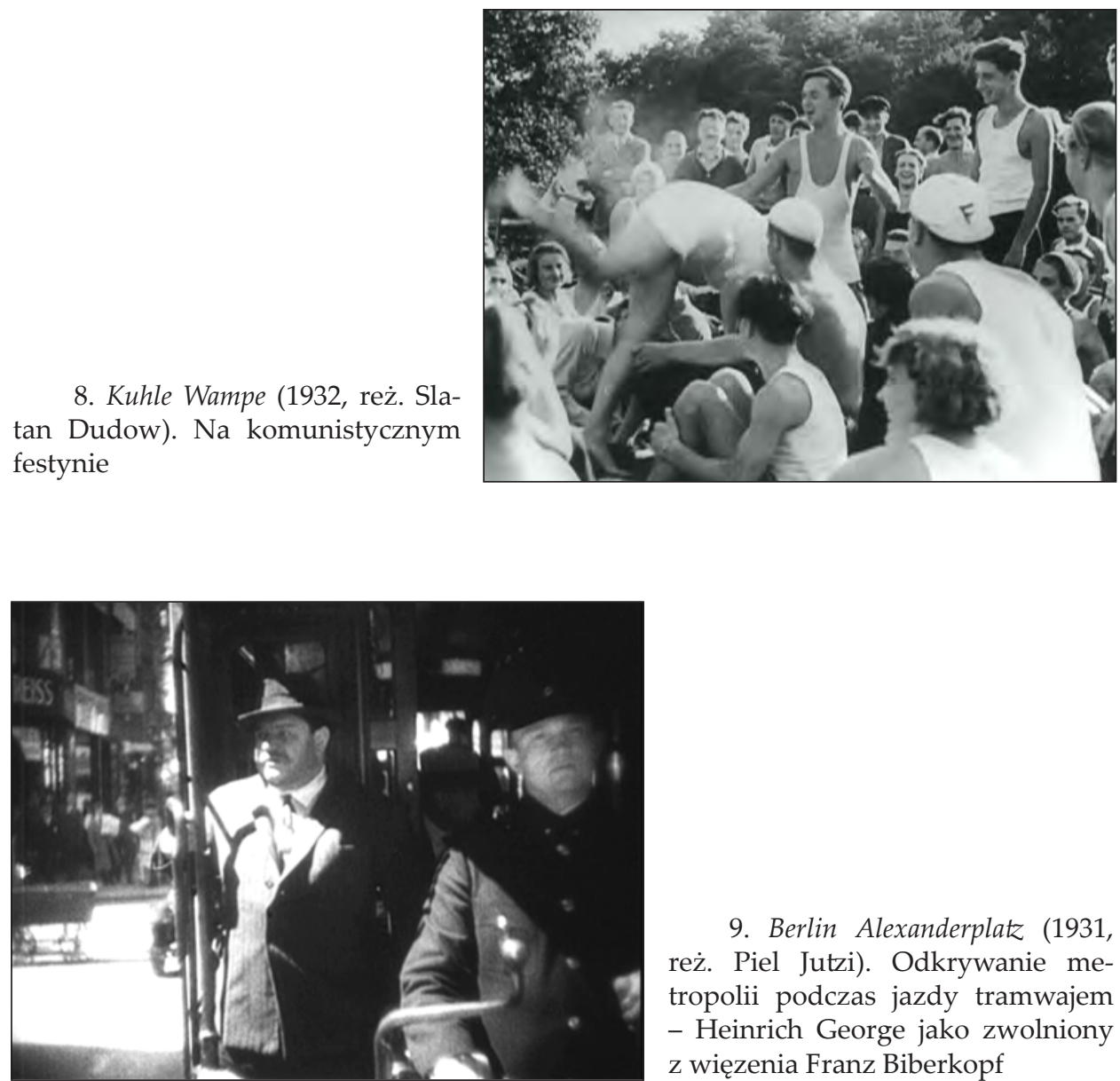

9. Berlin Alexanderplatz (1931, reż. Piel Jutzi). Odkrywanie metropolii podczas jazdy tramwajem - Heinrich George jako zwolniony z więzenia Franz Biberkopf 


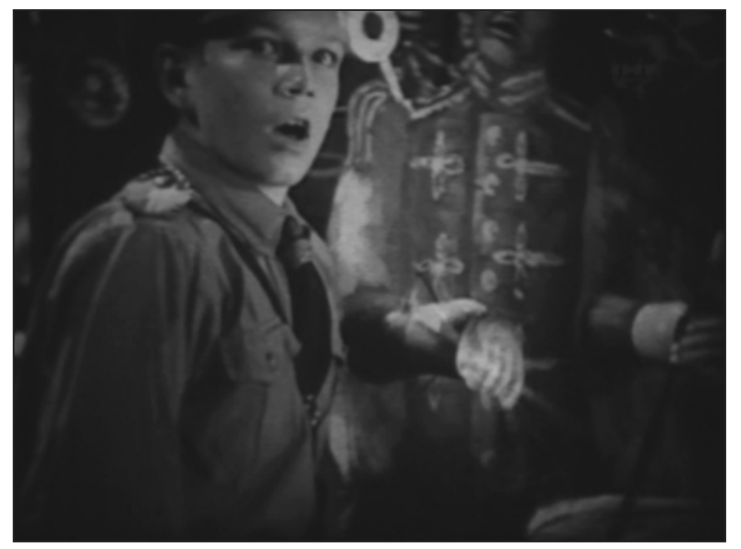

10. Hitlerjunge Quex (1933, reż. Hans Steinhoff). Jeden z pierwszych nazistowskich męczenników

11. Żyd Süss (1940, reż. Veit Harlan). Żyd i zniewolona Aryjka (Ferdinand Marian i Kristina Söderbaum)
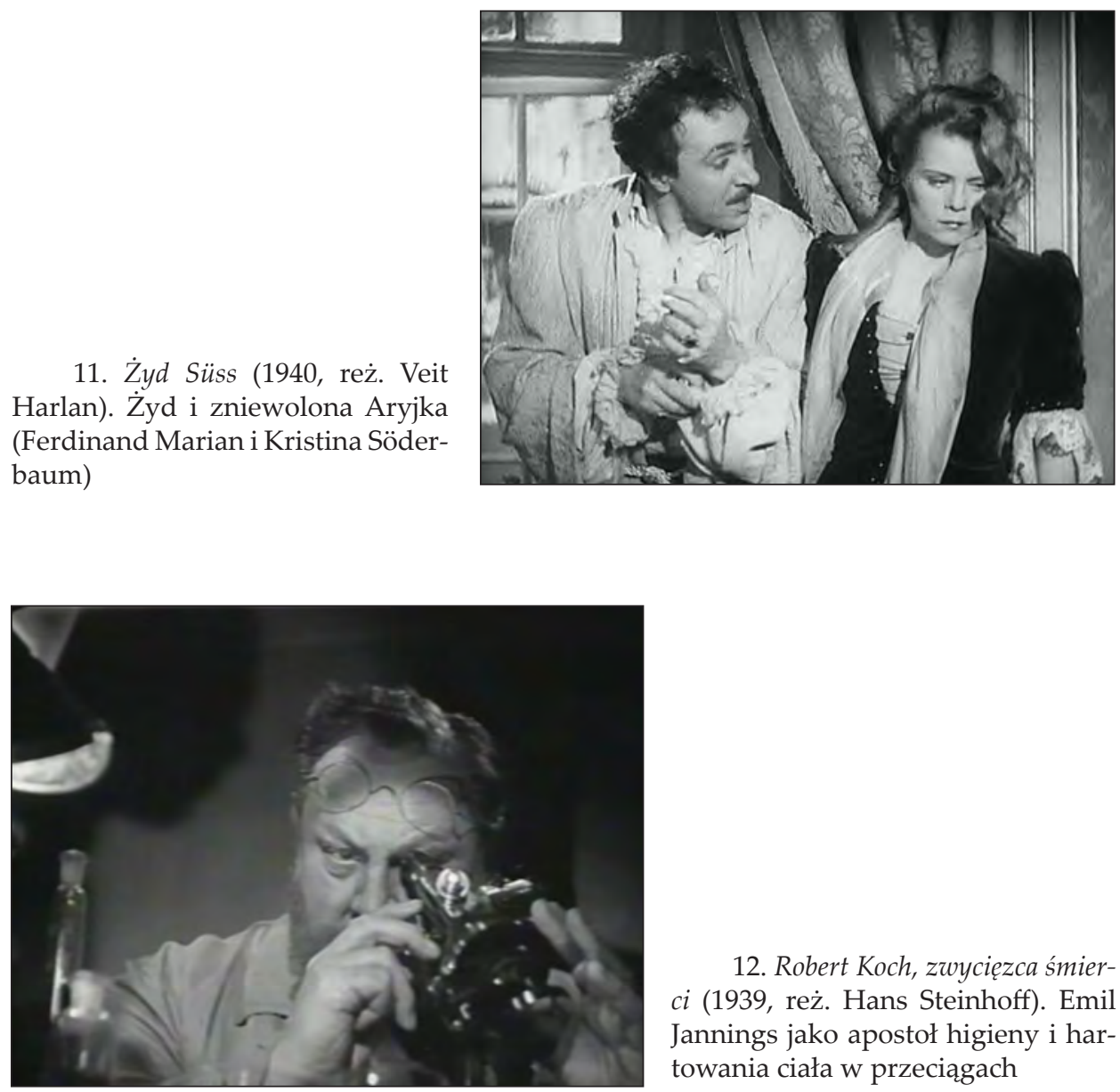

12. Robert Koch, zwycięzca śmierci (1939, reż. Hans Steinhoff). Emil Jannings jako apostoł higieny i hartowania ciała w przeciagach 


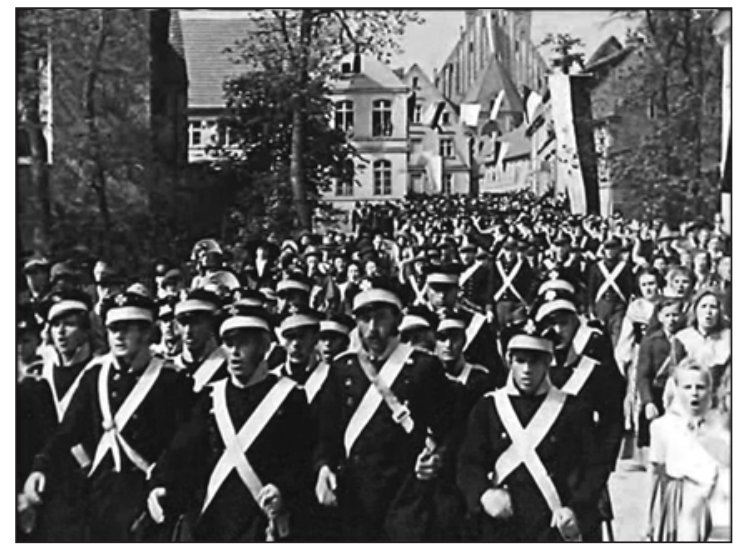

13. Kolberg (1945, reż. Veit Harlan). Wrocławska manifestacja niemieckiej jedności w roku 1813

14. Viktor i Viktoria (1933, reż. Reinhold Schünzel). Renate Müller torturowana przez męskiego fryzjera
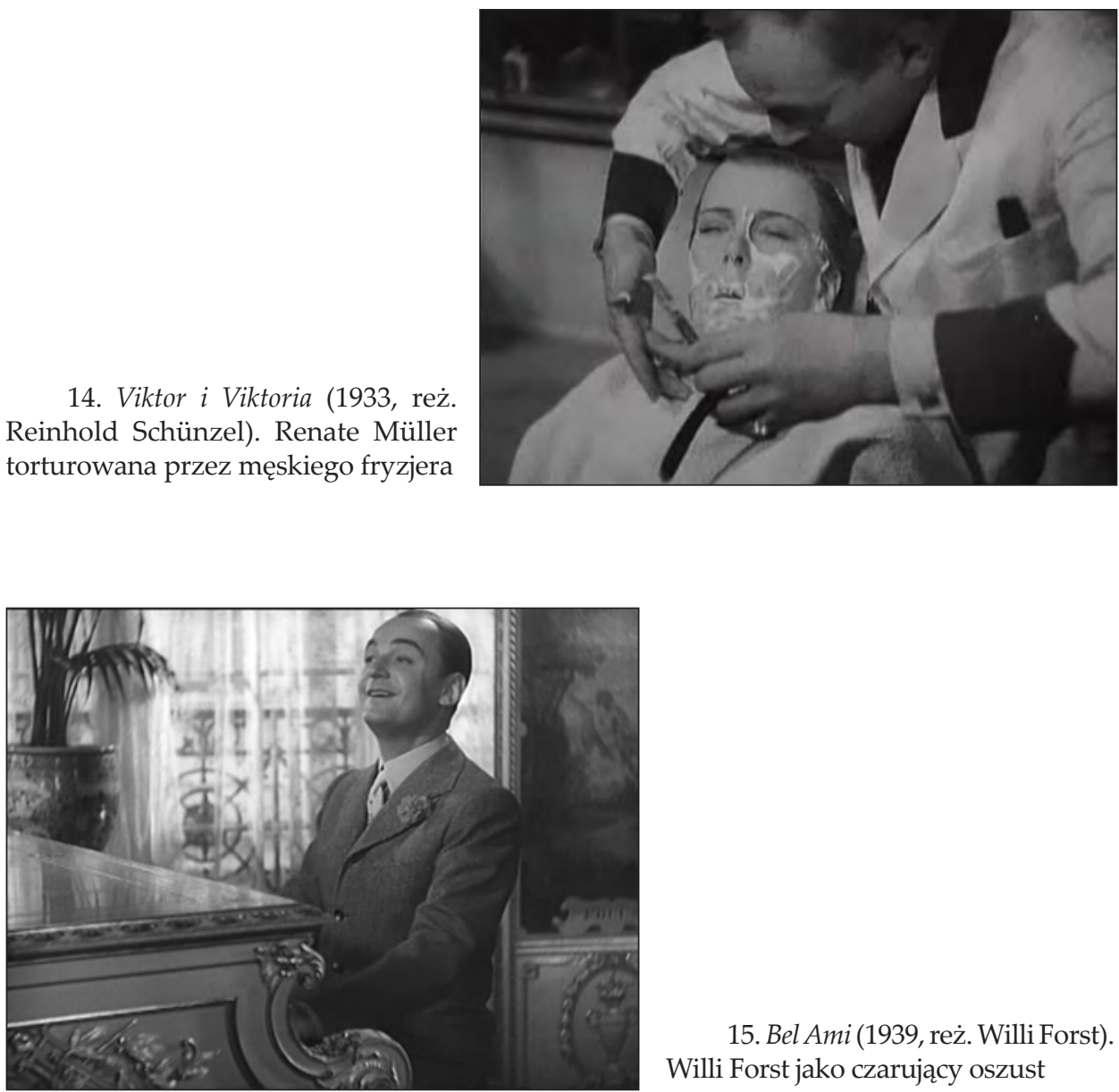

15. Bel Ami (1939, reż. Willi Forst). Willi Forst jako czarujący oszust 


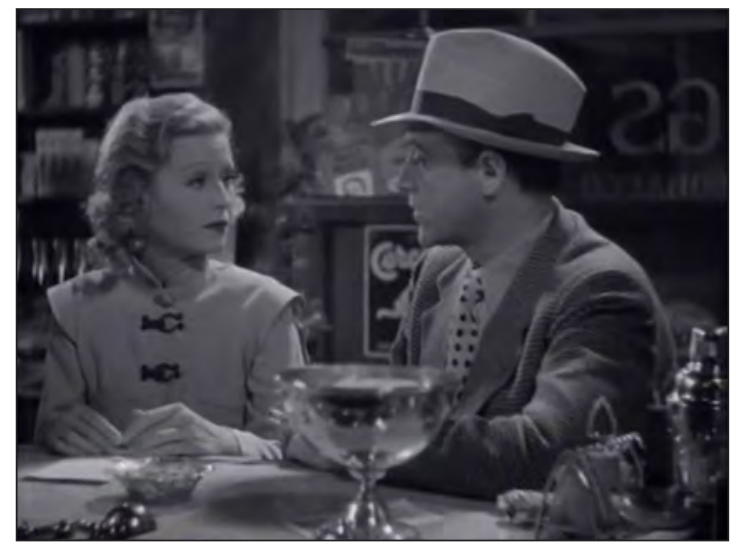

16. Szczęściarze (1936, reż. Paul Martin). Lilian Harvey i Willy Fritsch $\mathrm{w}$ screwball comedy po niemiecku

17. Große Freiheit Nr. 7 (1944, reż. Helmut Käutner). Hans Albers jako podstarzały marynarz w nostalgicznym melodramacie
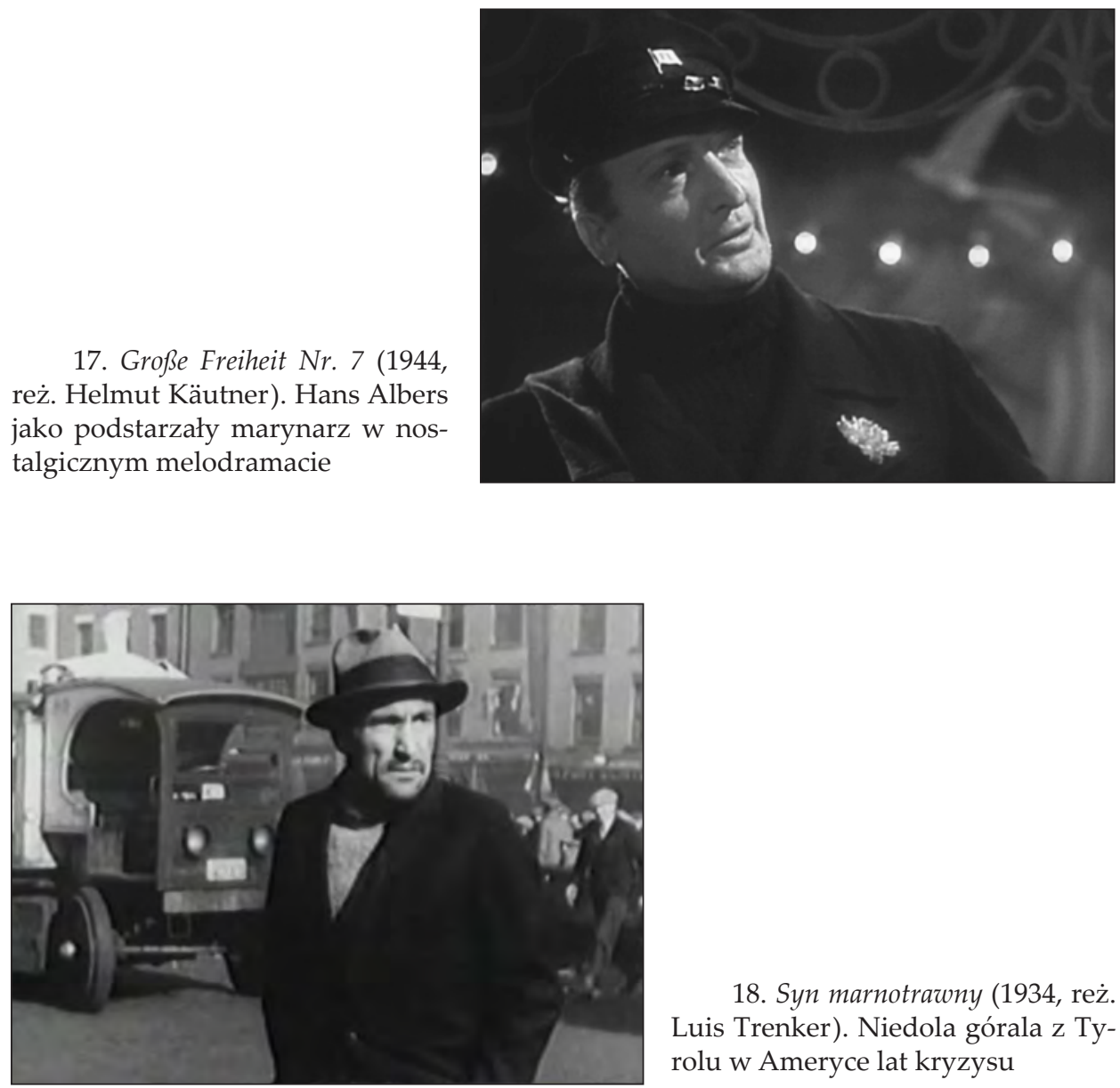

18. Syn marnotrawny (1934, reż. Luis Trenker). Niedola górala z Tyrolu w Ameryce lat kryzysu 


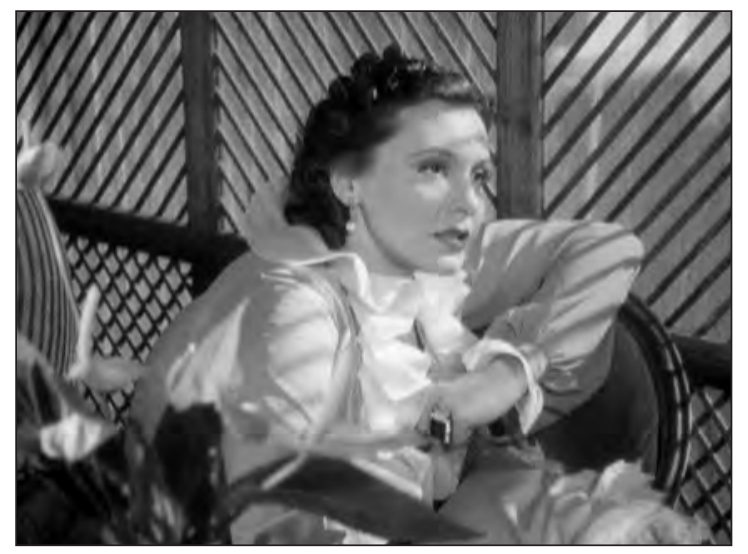

19. La Habanera (1937, reż. Detlef Sierck). Zarah Leander jako nordycka piękność w egzotycznej klatce

20. Wielka miłość (1942, reż. Rolf Hansen). Dole i niedole żony oficera Luftwaffe
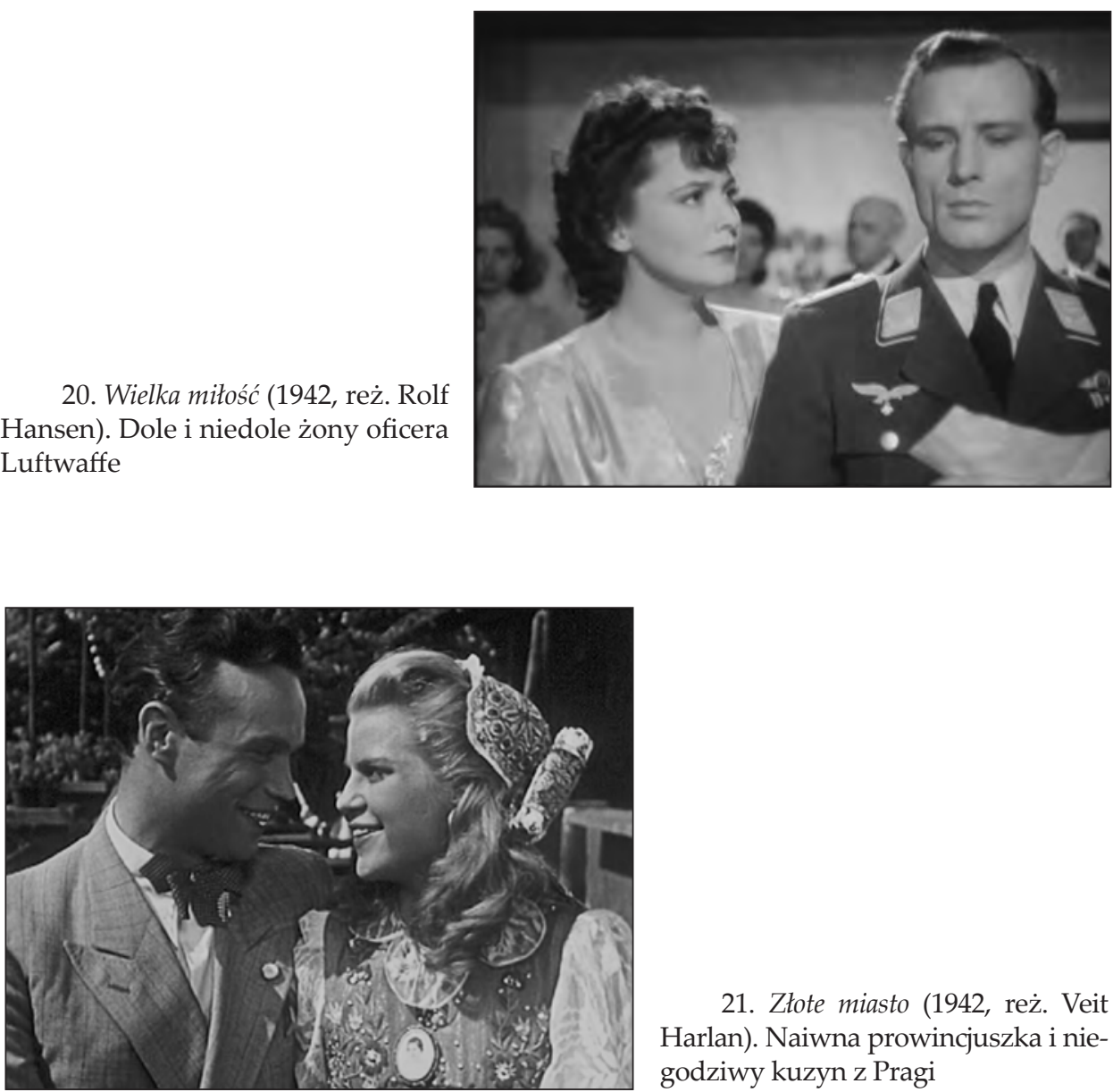

21. Złote miasto (1942, reż. Veit Harlan). Naiwna prowincjuszka i niegodziwy kuzyn z Pragi 


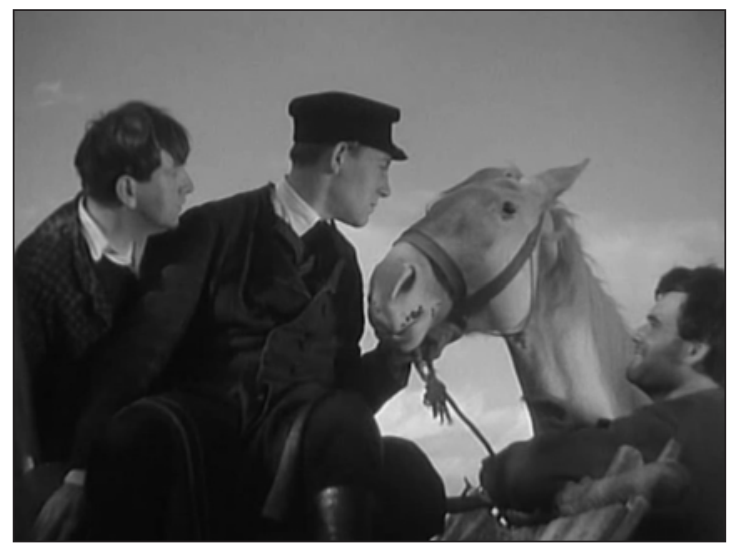

22. Jeździec na siwym koniu (1934, reż. Hans Deppe i Curt Oertl). Alegoryczny tryb kina weimarskiego w Trzeciej Rzeszy

23. Poczmistrz (1940, reż. Gustav Ucicky). Heinrich George (w środku) w doskonałej adaptacji opowiadania Puszkina
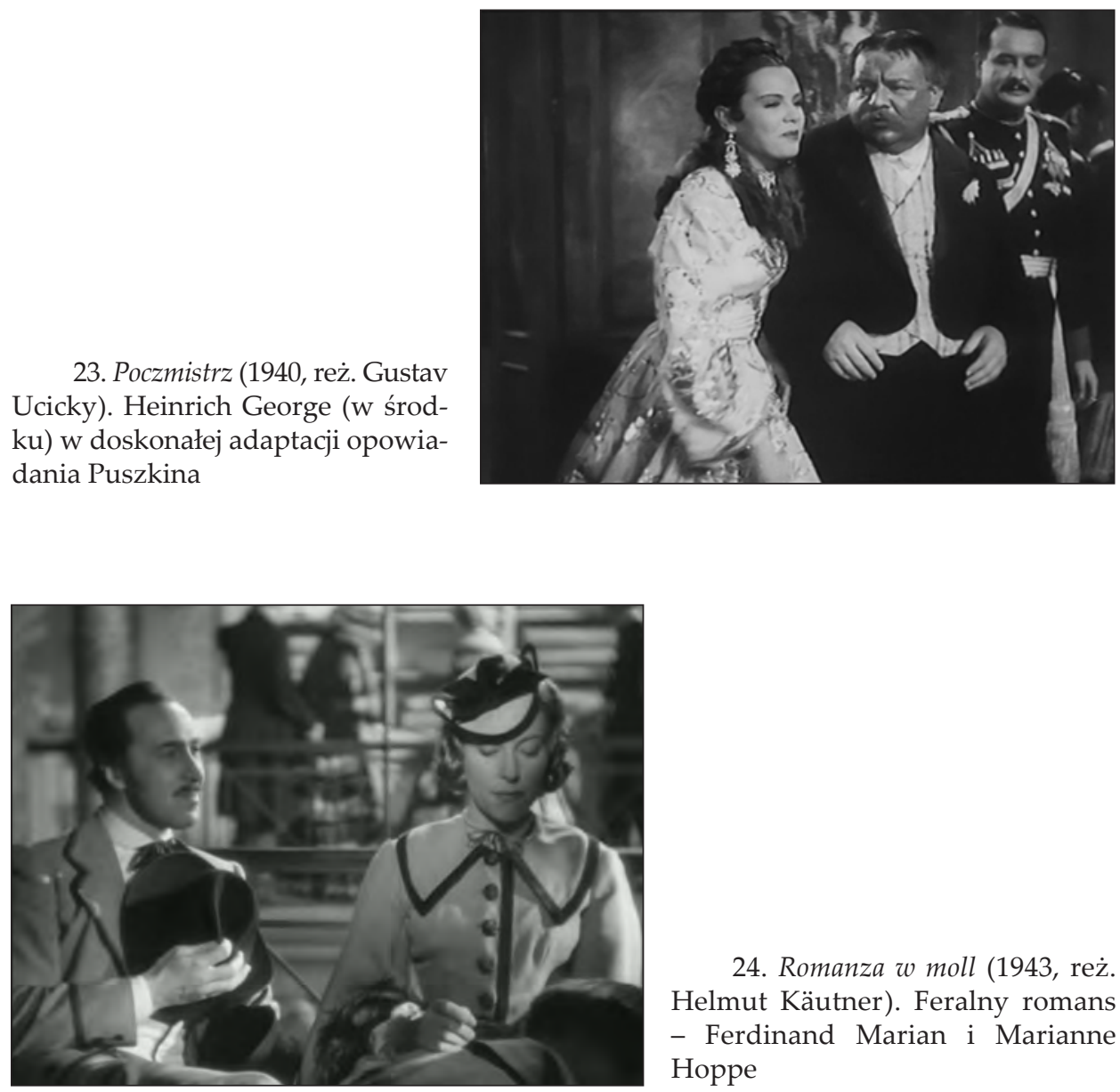

24. Romanza w moll (1943, reż. Helmut Käutner). Feralny romans - Ferdinand Marian i Marianne Hoppe 


\section{II}

OD MABUSEGO DO GOEBBELSA: WEIMARSKIE FILMY FRITZA LANGA 



\section{Wstęp \\ WYOBRAŻONY FILM FRITZA LANGA}

Fritz Lang był najbardziej prominentnym filmowcem Republiki Weimarskiej. „Niemal nie sposób sobie wyobrazić, jaką magię miało wtedy w Niemczech to nazwisko. Pierwszy pokaz filmu Fritza Langa to było coś, co jako społeczne wydarzenie nigdzie nie miało odpowiednika. Publiczność - a było niepisana, ale sztywną regułą przychodzić na premierę w pełnym stroju wieczorowym, a nie w zwykłym codziennym ubraniu - składała się dosłownie wyłącznie ze znakomitości w dziedzinie sztuki i literatury, dodatkowo okraszona osobistościami ze sfer rządowych. Nie ma przesady w stwierdzeniu, że nagłe zawalenie się budynku kina podczas premiery filmu Fritza Langa pozbawiłoby Niemcy za jednym zamachem większość intelektualnej elity, pozostawiając przy życiu tylko nieobecnych, którzy z takich czy innych powodów nie mogli uczestniczyć w wydarzeniu" ${ }^{1}$. Autor tych słów to Willy Ley, naukowiec, specjalista w dziedzinie rakiet i lotów kosmicznych, który był konsultantem Langa przy jego ostatnim niemym filmie Kobieta na Księżycu (Frau im Mond). Pompa i blichtr premiery tego właśnie filmu - zresztą mniej udanego artystycznie od wcześniejszych i późniejszych arcydzieł reżysera - są poniekąd apogeum kariery Langa. Ale to właśnie 15 października 1929 r. niemieckie stacje radiowe po raz pierwszy przeprowadziły transmisję radiową na żywo z ważnego wydarzenia - a wydarzeniem tym była premiera w berlińskim kinie Ufa-Palast am Zoo Kobiety na Księżycu. Oto zapis tamtej sytuacji: „Rozpoczyna się parada kreacji, a kulminacją rewii jest chwila, kiedy mikrofon wędruje do pomieszczenia dla artystów, by wypowiedzieli się przed nim aktorzy filmu, pasażerowie rakiety, reżyser i scenarzystka. I oto mikrofon wkracza do lóż..."2A na fasadzie kina Ufa-Palast świetlista rakieta-zaprojektowana

${ }^{1}$ Willy Ley, Rockets, Missiles and Space Travel, New York 1952; cyt. za: Paul M. Jensen, The Cinema of Fritz Lang, Barnes \& Co.-Zwemmer Ltd., New York-London 1969, s. 79. Ten sam ustęp z Leya przywołuje też: Frederick W. Ott, The Films of Fritz Lang, The Citadell Press, Secaucus, N. J., 1979, s. 8.

2 „Funk-Stunde” 1929, nr 44 (25 X); cyt. za: Fritz Lang. Leben und Werke. Bilder und Dokumente, red. Rolf Aurich, Wolfgang Jacobsen, Cornelius Schnauber, Filmmuseum Berlin-Deutsche Kinemathek und jovis Verlag, Berlin 2001, s. 134. 
przez Rudiego Felda, kierownika działu reklamy w Ufie - wydawała się startować ku Księżycowi... ${ }^{3}$

Niewiele czasu miało upłynąć od pamiętnej premiery do krachu na Wall Street w „czarny wtorek" (29 X 1929). "Złote lata dwudzieste” miały się ku końcowi, zarówno dla całego zachodniego świata, jak i dla Republiki Weimarskiej w szczególności. W kinie Ufa-Palast am Zoo będzie mieć miejsce jeszcze tylko jedna premiera filmu Langa, słynnego filmu kryminalnego $M-$ morderca $(M)^{4}$, przez wielu (a i przez samego reżysera) często wskazywanego jako jego najlepszy film ${ }^{5}$. Zapowiedziana na koniec marca 1933 r. berlińska premiera Testamentu doktora Mabuse (Das Testament des Dr. Mabuse) nie odbyła się: 29 marca 1933 znajdujący się już u władzy naziści wydali zakaz rozpowszechniania filmu ${ }^{6}$. Swój następny film, Liliom, Lang zrealizuje w 1934 r. już na emigracji we Francji.

Lang w licznych swych wypowiedziach prezentował - zresztą w rozmaitych, zastanawiająco odmiennych albo zawierających coraz to nowe szczegóły wariantach - historię swej ucieczki z hitlerowskich Niemiec, przedsięwziętej natychmiast po spotkaniu z Goebbelsem, do którego miało dojść pod koniec marca lub na początku kwietnia 1933 w gmachu ministerstwa na specjalne wezwanie nowo kreowanego ministra propagandy.

3 Ibidem, s. 136.

${ }^{4}$ Premiera ta odbyła się 11 V 1931 (E. Ann Kaplan, Fritz Lang: A Guide to References and Resources, G.K. Hall \& Co., Boston 1981, s. 61).

${ }^{5}$ Taka jest np. opinia Patricka McGilligana, autora świetnie udokumentowanej, choć niechętnej Langowi jego biografii Fritz Lang: The Nature of the Beast (St. Martin's Press, New York 1997). Por.: ibidem, s. 156. Co do opinii samego Langa, por.: Fritz Lang, Interviews, ed. Barry Keith Grant, University Press of Mississippi, Jackson 2003, s. 14, 17.

${ }^{6}$ Ściślej - zakaz ten wydał niemiecki urząd cenzury filmowej, Filmprüfstelle, któremu przewodniczył niejaki radca Zimmermann (Gösta Werner, Fritz Lang and Goebbels: Myth and Facts, „Film Quarterly” 1990, Spring, s. 25). W kwietniu 1933 na paryskie ekrany wchodzi francuska wersja filmu, Le Testament du Dr. Mabuse (por. E. Ann Kaplan, op. cit., s. 66). Było to możliwe, gdyż Testament... powstawał jako film mający dwie „oryginalne" wersje językowe, realizowane równolegle i obie reżyserowane przez samego Langa [praktyka to zresztą nierzadka w tym wczesnym okresie kina dźwiękowego, vide: Atlantic Ewalda André Duponta czy Błękitny Aniot (Der Blaue Engel/The Blue Angel) Josefa von Sternberga]. Negatyw francuskiej wersji został dość wcześnie, jeszcze bodaj w marcu, wywieziony przez jej montażystę, Lothara Wolffa, co przeczy anegdocie o późniejszej „konspiracyjnej” wywózce filmu z Niemiec. Zakaz nazistowskiej cenzury dotyczył jednak tylko Niemiec; niemiecka wersja filmu była sprzedawana do innych krajów, mających silne związki z niemieckim rynkiem filmowym - np. na Węgry (premiera w Budapeszcie - 21 IV 1933), do Szwecji, gdzie pod koniec kwietnia rodzimi cenzorzy, niezależnie od cenzury niemieckiej, nie dopuścili filmu na ekrany, czy do Austrii, gdzie premiera filmu miała miejsce 12 V 1933 (zob. Gösta Werner, op. cit., s. 25; David Kalat, The Strange Case of Dr. Mabuse: A Study of the Twelve Films and Five Novels, Mc Farland \& Company, Inc., Publishers, Jefferson, NCLondon 2001, s. 70-72). 
Historia ta jako pochodząca z samego źródła, „,z pierwszej ręki”, nie była (do czasu) kwestionowana i przytaczają ją poważne monografie reżysera. Klasyczną już monografię Lotte Eisner otwiera „autobiografia” Langa, w której odnaleźć można następujący passus: „Gdy już naziści doszli do władzy, mój antynazistowski film, Testament doktora Mabuse, w którym nazistowskie slogany włożyłem w usta patologicznego przestępcy, został oczywiście zakazany. Wezwano mnie do Goebbelsa, nie po to by, jak się obawiałem, tłumaczyć się z filmu, ale by ku memu zaskoczeniu usłyszeć, jak Reichspropagandaminister informuje mnie, iż w rozmowie $\mathrm{z}$ nim Hitler wyraził życzenie, bym objął kierownicze stanowisko w niemieckim przemyśle filmowym. «Führer widział pański film Metropolis i powiedział: „Oto człowiek do realizacji narodowo-socjalistycznego filmu!"”

Tego samego wieczoru wyjechałem z Niemiec. «Wywiad» dla Goebbelsa trwał od południa do wpół do trzeciej po południu; do tego czasu zamknięto już banki i nie mogłem wyciągnąć żadnych pieniędzy z konta. W domu miałem akurat tyle pieniędzy, że starczyło na bilet do Paryża i praktycznie bez grosza wysiadłem na Gare du Nord"7.

Ta wersja wydarzeń, zawierająca jako węzłowe punkty: wezwanie obawy - zaskakującą propozycję - ucieczkę, jest stosunkowo lakoniczna. Inne wypowiedzi reżysera dorzucają coraz to nowe elementy: opis długich, wysadzanych kamiennymi płytami korytarzy ministerstwa, gdzie kroki odbijały się głośnym echem; kolejne biurka, przed którymi trzeba było przejść jak przez kolejne bramki, nim zostało się dopuszczonym do Reichsministra; fakt, iż Goebbels podczas całej długiej rozmowy był nadspodziewanie uprzejmy, wręcz "czarujący"; pot, który podczas tego „wywiadu” cały czas oblewał reżysera i śledzenie przezeń wolno, ale nieubłaganie się przesuwających wskazówek wielkiego zegara na wieży gdzieś za oknem, przy jednoczesnym zastanawianiu się, czy zdąży podjąć pieniądze; usprawiedliwianie się Goebbelsa z powodów zatrzymania filmu - winne miało być zakończenie, w którym ani przestępca nie został przykładnie ukarany, co groziło wywróceniem na opak porządku społecznego, ani nie pojawił się (a powinien!) Führer, pokonujący Mabusego i przywracający prawdziwe ideały; informacja o komplementach Hitlera nie tylko dla Metropolis, ale i dla Nibelungów; uszczegółowienie „propozycji nie do odrzucenia" jako objęcia szefostwa Reichsfilmkammer - nowej, nazistowskiej agencji rządowej, nadzorującej produkcję filmów w Rzeszy; przyznanie się Langa do żydowskiego pochodzenia ze strony matki, konwertytki na katolicyzm, i zlekceważenie przez Goebbelsa tego faktu jako przeszkody dla przyjęcia „propozycji nie do odrzucenia” następującymi

${ }^{7}$ Fritz Lang, Autobiography, [w:] Lotte H. Eisner, Fritz Lang, Da Capo Press, New York 1986, s. 14-15. 
słowami: „Panie Lang, to my decydujemy, kto jest Żydem!”; 24 godziny udzielone reżyserowi do namysłu; wobec zamknięcia banków desperackie gromadzenie wszelkiej dostępnej gotówki i możliwych do wywiezienia nielicznych kosztowności oraz emocje związane z ukrywaniem ich w pociagu i przekraczaniem granicy ${ }^{8}$.

Dziś już wiadomo, w świetle danych z niemieckiego paszportu Langa z roku 1933, odsprzedanego Deutsche Kinemathek w Berlinie po śmierci reżysera w 1976 przez Lily Latté, jego wieloletnią towarzyszkę życia, że historia o "natychmiastowej ucieczce” pod koniec marca lub na początku kwietnia 1933 jest fikcją. Co najmniej do 23 czerwca Lang nie opuszczał granic Niemiec, zaś po tej dacie, a przed 20 lipca, odbywał podróże (m.in. lotnicze) do Belgii i Wielkiej Brytanii, skąd z pewnością do Berlina powracał. Definitywnie opuścił Niemcy dopiero pod koniec lipca 1933. A czy w ogóle spotkał się z Goebbelsem? Choć jest to niewykluczone, to jednak mało prawdopodobne w świetle faktu, iż w opublikowanych dziennikach Goebbelsa, zazwyczaj pedantycznego i skrupulatnego w odnotowywaniu rozmaitych spotkań, rozmów, spraw urzędowych, o widzeniu z Langiem w marcu lub kwietniu (ani w ogóle w 1933 r.) nie ma ani słowa ${ }^{10}$. Co o tyle jest ciekawe, iż Goebbels był entuzjastycznym widzem poprzedniego filmu Langa, $M-$ mordercy, o czym świadczy zapisek w jego dzienniku pod datą 21 maja 1931: „Fantastyczne! Przeciwko humanitarnej czułostkowości. Za karą śmierci. Dobrze zrobione. Lang będzie naszym reżyserem któregoś dnia"11.

Tom Gunning słusznie zauważa, iż dokonana przez Langa konfabulacja stawia przed nami liczne biograficzne zagadki. „Czy skrywa ona bardziej dwuznaczne stanowisko względem nazistów i Goebbelsa niż wyraża to sama opowieść? Co z detalem, czasami w niej obecnym, dyskusją o żydowskim pochodzeniu Langa, który to aspekt swej tożsamości rzadko wspominał i, jak się zdaje, niechętnie zgłębiał? Czy Lang, nieustannie

${ }^{8}$ Konfrontację i syntezę rozmaitych wersji opowieści Langa o spotkaniu z Goebbelsem i ucieczce z Niemiec, zawierają: P. McGilligan, op. cit., s. 174-181; Tom Gunning, The Films of Fritz Lang: Allegories of Vision and Modernity, BFI Publishing, London 2000, s. 8-10; D. Kalat, op. cit., s. 68-74. Por. także: F. Lang, Interviews, s. 78-79 (wywiad z 1967 dla Alexandra Walkera z BBC); Fritz Lang. Leben und Werk..., s. 215-218.

${ }^{9}$ Choć i teraz jeszcze jest rozbieżność co do daty: Gösta Werner (op. cit., s. 29) po zbadaniu paszportu i innych dostępnych dziś dokumentów podaje jako datę ostatecznego wyjazdu Langa z Niemiec 31 lipca 1933, zaś monumentalny tom Deutsche Kinemathek pod red. Rolfa Auricha (Fritz Lang. Leben und Werk..., s. 217) - 21 lipca. Zamieszczona w tym drugim wydawnictwie na s. 216 fotografia paszportu Langa rozstrzyga wątpliwość na korzyść tej wcześniejszej daty (21 lipca). W każdym razie Lang wiosną i latem 1933 mógł dość swobodnie podróżować (i podróżował) za granicę.

10 P. McGilligan, op. cit., s. 178; T. Gunning, op. cit., s. 9; D. Kalat, op. cit., s. 70.

11 Die Tagebücher von Joseph Goebbels: Sämtliche Fragmente, vol. 1: 1924-1941, Red. Elke Fröhlich, Saur, München 1987 (cyt. za: P. McGilligan, op. cit., s. 157). 
powtarzając tę historię, w końcu sam w nią nie uwierzył?"12 Gunning, nie podejmując nawet próby odpowiedzi w tych intrygujących, ale chyba dziś już niemożliwych do rozstrzygnięcia kwestiach, wskazuje zarazem, iż historia spotkania z Goebbelsem i ucieczki jest „,archetypowym Langowskim scenariuszem z suspensem, podstępem i groźbą dla czyjejś tożsamości, tu zaprezentowaną jako opowieść autobiograficzna"13. Opowieść Langa $\mathrm{o}$ „ucieczce z Niemiec" to jego „wyobrażony film” (his imaginary film) ${ }^{14}$, pełen formalnych i dramaturgicznych rozwiązań rodem ze stałego repertuaru Langowskich chwytów: człowiek osaczony w monumentalnej, nieprzyjaznej przestrzeni; upływający nieubłaganie czas, odmierzany przez eksponowany w kadrze zegar aż do jakiegoś z góry określonego momentu, kiedy ma nastąpić dramatyczne rozstrzygnięcie (zegary, nieraz bardzo dziwne, są natrętnie narzucającymi się elementami scenografii wielu filmów Langa); schwytanie postaci w "machinę Przeznaczenia” (Destiny-machine) - tu składającej się z dwóch nieubłaganych mechanizmów: jednego, odliczającego fizyczny i społeczny czas (aż do zamknięcia banków, aż do odjazdu „ostatniego" pociągu, kiedy już będzie trudno o ratunek), i drugiego, ideologicznego, przedkładającego do wyboru groźbę lub pokusę $^{15}$. Zreszta, trudno też nie dostrzec $\mathrm{w}$ takiej dramaturgii reminiscencji z paradygmatycznego dla kultury niemieckiej dzieła, jakim jest Faust i węzłowa w nim scena kuszenia przez Mefista.

Gunning powstrzymał się od biograficznych konstatacji, choćby dlatego, że to już poczynił (może zbyt odważnie, a w każdym razie z dużą dozą niechęci wobec swego bohatera) Patrick McGilligan, autor obszernej i naprawdę rzetelnie udokumentowanej biografii reżysera, o znaczącym jednak podtytule: The Nature of the Beast. Fascynująca monografia autorstwa Gunninga - przynosząca intelektualnie najciekawsze ze znanych mi interpretacje filmów Langa - jest inna w formule niż tradycyjne monografie historyczne poświęcone Langowi, autorstwa Francisa Courtade'a ${ }^{16}$, Luca Moulleta $^{17}$, Paula M. Jensena ${ }^{18}$, Lotte H. Eisner ${ }^{19}$, Friedy Grafe ${ }^{20}$, Roberta

12 T. Gunning, op. cit., s. 9.

13 Ibidem.

14 Określenia tego, podchwyconego przez Gunninga, użył Jorge Dana w komentarzu filmu dokumentalnego o niemieckich filmach Langa (zob. T. Gunning, op. cit., s. 9).

15 T. Gunning, op. cit., s. 10.

${ }_{16}$ Francis Courtade, Fritz Lang, Le Terrain Vague, Paris 1963.

17 Luc Moullet, Fritz Lang, Seghers, Paris 1963.

18 Zob. przypis 1.

19 Zob. przypis 7 (1 wyd. tej książki: Lotte H. Eisner, Fritz Lang, Secker \& Wartburg, London 1976).

${ }^{20}$ Frieda Grafe, Enno Patalas, Hans Helmut Prinzler, Fritz Lang, Hanser, München 1976. 
A. Armoura ${ }^{21}$, Fredericka W. Otta ${ }^{22}$. Można by ją nazwać „monografią analityczną", której centrum jest analiza tekstualna dzieł, uwzględniająca zarazem szeroki kontekst historii politycznej, historii kultury, poetyki historycznej kina i rozmaitych hermeneutyk, w zależności od typu analizowanego tekstu mniej lub bardziej stosownych jako narzędzie. Gunning, pomny obwieszczonej niegdyś „śmierci autora” nie popada w „naiwny biografizm" (vide: niepodejmowanie nawet prób jakichś definitywnych odpowiedzi na przytoczone powyżej dramatyczne pytania natury biograficznej), ale zarazem unika przedziwnej jałowości znaczeniowej podejścia "czysto tekstualnego", której przykładem mogą być rozprawy publikowane niegdyś na łamach "Cahiers du Cinéma” i zamieszczone później w zbiorze pod red. Stephena Jenkinsa, wydanym przez $\mathrm{BFI}^{23}$. W wydaniu Gunninga analiza tekstu jest zarazem lekturowo ekscytującą i poznawczo odkrywczą analizą kontekstu - i nie ukrywam, iż jako taka jest wzorem dla przedsięwziętej przeze mnie „monografii analitycznej”: przedstawienia takich analiz i interpretacji niemych filmów Fritza Langa, które będąc close readings, ogarną zarazem i powiążą z tekstem istotne konteksty.

Ale wróćmy do opowieści Langa o jego „ucieczce”; nie popadając w biografizm, spróbujmy przyjrzeć się jej jako te k s to w i, który ma pewien istotny $\mathrm{k}$ o n te k s t, w związku z czym ujawniają się jego rozmaite p od t e k s t y. Opowieść ta pojawiła się po raz pierwszy w 1943 r. w materiałach reklamowych z okazji wejścia na amerykańskie ekrany dwóch filmów Langa: jawnie antynazistowskiego amerykańskiego filmu Kaci także umieraja (Hangmen Also Die), przy którego scenariuszu Lang współpracował z Bertoltem Brechtem, oraz francuskojęzycznej wersji jego ostatniego weimarskiego filmu Testament doktora Mabuse ${ }^{24}$. W kontekście takim zrozumiała jest dominująca zarówno w aurze, jak i w dramaturgii opowieści autoprezentacja Langa jako antynazisty, czującego taką odrazę do nowego reżimu i jego karesów, a zarazem tak pełnego obaw i najgorszych przeczuć, że nie pozostaje mu nic innego, jak tylko w dniu złożenia mu przez Goebbelsa propozycji opuścić Niemcy. Trzeba pamiętać, że w roku 1943 wiedziano już o ogromie zbrodni popełnianych przez hitlerowców w Europie (o tym zresztą traktował najnowszy film reżysera) i po prostu nie można było w takim kontekście przedstawiać samego siebie jako kogoś politycznie niezdecydowanego lub po prostu jeszcze nieświadomego. Ale postawa zaangażowanego i świadomego antynazisty została w opowieści rzutowana ex post na rok 1933 nie tylko poprzez przedstawienie jako

\footnotetext{
${ }^{21}$ Robert A. Armour, Fritz Lang, Twayne Publishers, Boston 1978.

${ }^{22}$ Zob. przypis 1.

${ }^{23}$ Fritz Lang: The Image and the Look, ed. Stephen Jenkins, BFI Publishing, London 1981.

${ }^{24}$ Zob.: T. Gunning, op. cit., s. 8.
} 
nagłego, desperackiego aktu woli (decyzja o natychmiastowej ucieczce), czegoś, co - jak wynika z dostępnych dokumentów - było poprzedzone co najmniej trzymiesięcznym namysłem czy przygotowaniami. Ta polityczna świadomość, co więcej, wręcz polityczne zaangażowanie, została przypisana także filmowi Testament doktora Mabuse, który - dość szczęśliwie dla politycznej reputacji Langa - został przez nazistów zakazany. Owszem, można odczytywać figurę i idee Mabusego jako metaforę rozmaitych zagrożeń demokracji, ale z pewnością nie jest to jawny, expressis verbis atak na nazistów: gdyby tak było, Goebbels wcale nie musiałby się tłumaczyć z jego niedopuszczenia na ekrany (o ile do spotkania w ogóle doszło), a niemiecka kinematografia nie sprzedawałaby filmu na ościenne rynki (co faktycznie miało miejsce)!

Co istotne, mimo rzutowania ex post antynazizmu na polityczną świadomość jej bohatera, opowieść Langa zawiera niepokojące szczegóły. Dlaczego w rozmaitych wersjach tej historii akcentowany jest fakt, iż Goebbels okazał się nadspodziewanie sympatyczny, niemal „czarujący"? Dlaczego do przytaczanej przez Goebbelsa pozytywnej opinii Hitlera o Langu jako filmowcu na podstawie Metropolis, kiedy indziej dorzucane są jeszcze jako jej powód Nibelungi? A jeżeli do spotkania w cztery oczy $\mathrm{z}$ ministrem propagandy - co wielce prawdopodobne - nie doszło, to o czym świadczy p r o je k cja uznania nazistów dla własnej twórczości, kumulującego w wy obrażo nej pozycji szefa niemieckiej kinematografii? ${ }^{25}$ I znowu wypada, jak Gunning, powstrzymać się od odpowiedzi (od „biografizmu” tak czy inaczej nie ma ucieczki, jeżeli analiza tekstualna ma być zarazem rzetelnie kontekstowa). Prezentacja oferty ministra jako „propozycji nie do odrzucenia”, jako szantażu potężnego przestępcy, i związany z tym suspens (jak zdoła umknąć osaczony człowiek?), niedostatecznie jednak, jak się wydaje, tłumią dwuznaczność oszołomienia z powodu nazistowskiego uznania. Pomijana przez Langa w innych kontekstach, a tym razem osobiście przywołana sprawa jego żydowskich korzeni (on sam zazwyczaj akcentował raczej swą "niemieckość”, "katolicyzm”, ewentualnie - rodowód „wiedeński”), tu służy jako jednoznaczne

${ }^{25}$ Może opowieść Langa jest rodzajem projekcji czy „wyciągnięcia logicznych wniosków” po wieczorze, który Goebbels zorganizował dla czołowych postaci kinematografii w Hotelu Kaiserhof 28 marca 1933 (a więc w przeddzień wydania zakazu wyświetlania Testamentu doktora Mabuse przez Niemiecką Radę Cenzorów Filmowych). Nie jest pewne, ale jest bardzo prawdopodobne, że Lang w tym wieczorze uczestniczył. W wystąpieniu Goebbelsa jako pozytywne wzory dla niemieckich filmowców wymienione zostały cztery filmy: Anna Karenina (1927) Edmunda Gouldinga z Gretą Garbo, Pancernik Potiomkin (1925) Siergieja Eisensteina, Buntownik (1932) Luisa Trenkera i Kurta Bernhardta oraz... Nibelungi (1924) Fritza Langa. Por.: P. McGilligan, op. cit., s. 171-173; G. Werner, op. cit., s. 26; Fritz Lang. Leben und Werke..., s. 216. 
odcięcie się od nazizmu i wytłumienie skandalicznej satysfakcji z hitlerowskich komplementów.

„Wyobrażony film" Langa jest tekstem równie dwuznacznym i niepokojącym, jak jego filmy zrealizowane w okresie Republiki Weimarskiej. Siegfried Kracauer, rzutując ex post wiedzę o faktycznym obliczu i skutkach nazizmu na analizę niemieckich filmów z lat 1913-1933, upatruje w tych ostatnich a to "przeczucie totalitaryzmu”, a to „wyraz tendencji totalitarnych" ${ }^{\prime 26}$. Oczywiście, metoda Kracauera będąca skrajnie redukcyjnym wariantem „krytyki symptomatycznej” 27 jest też wielce dyskusyjna z racji sterującego interpretacją finalizmu (Thomas Elsaesser nazywa książkę Kracauera oraz Ekran demoniczny Lotte Eisner ${ }^{28}$ - dwie klasyczne pozycje o kinie niemieckim - „proroctwami Kassandry aprés coup" ${ }^{29}$ ). Lang, pytany o ocenę pracy Kracauera, za każdym razem wypowiadał się o niej z niechęcią i lekceważeniem ${ }^{30}$, choć przypisywanie przez reżysera eksplicytnej antynazistowskiej wymowy swemu ostatniemu weimarskiemu filmowi tak naprawdę jest zadziwiająco zgodne z „duchem” Od Caligariego do Hitlera ${ }^{31}$. Rzecz w tym, że nawet przeciwnikom Kracauera, a raczej jego redukcyjnej i finalistycznej metody, trudno uwolnić się od wrażenia, iż "coś jest na rzeczy" (i to coś bardzo istotnego) w jego konstatacjach o związku kina niemieckiego ze społeczno-polityczną rzeczywistością Republiki Weimarskiej. Czy to znaczy, że Kracauer ma rację, a niemieckie filmy tego okresu istotnie są „przeczuciem”, albo, co gorsza, „wyrazem" tendencji totalitarnych?

Zdaniem Thomasa Elsaessera, autora książki Weimar Cinema and After: Germany's Historical Imaginary, która ma chyba szansę stać się trzecią kanoniczną pozycją na temat kina niemieckiego obok książek Kracauera i Eisner, Od Caligariego do Hitlera i Ekran demoniczny przyczyniły się do skonstruowania/odkrycia (niepotrzebne skreślić) „,wyobrażonej tożsamości historycznej”

${ }^{26}$ Siegfried Kracauer, Od Caligariego do Hitlera: Z psychologii filmu niemieckiego, przeł. Eugenia Skrzywanowa, Wanda Wertenstein, Filmowa Agencja Wydawnicza, Warszawa 1958.

${ }^{27}$ Metody „krytyki symptomatycznej” poddał drobiazgowej analizie i gruntownej krytyce amerykański neoformalista, David Bordwell [zob.: Making Meaning: Inference and Rhetoric in the Interpretation of Cinema, Harvard University Press, Cambridge (Mass.)London 1989].

${ }^{28}$ Lotte H. Eisner, Ekran demoniczny, przeł. Konrad Eberhardt, Wydawnictwa Artystyczne i Filmowe, Warszawa 1974.

${ }_{29}$ Thomas Elsaesser, Weimar Cinema and After: Germany's Historical Imaginary, Routledge, London-New York 2000, s. 35.

30 Zob.: F. Lang, Interviews, s. 23, 36, 85, 179.

31 A swoją droga, jak na ironię, w analizie Testamentu doktora Mabuse, Kracauer powołuje się na Langowską opowieść o spotkaniu z Goebbelsem (zob.: S. Kracauer, op. cit., s. 211). 
Niemców (historical imaginary, imaginary identity). Pozwolę sobie tu na nieco dłuższy cytat z tej fascynującej, ale trochę „proteuszowo nieuchwytnej”, jeśliby poszukiwać jednoznacznych konstatacji, książki - także dlatego, iż cytat najlepiej wyrazi trudną do zreferowania dialektykę relacji między niepojętą i straszną historia, jej obrazem w filmach, obrazem tego obrazu w omawianych książkach i skonstruowanym przez te ostatnie „wyobrażonym”: „Ogrom cierpień spowodowanych przez Niemców wśród milionów ludzi w całej Europie w ciągu sześciu lat działań wojennych, ludobójstwa i niszczycielstwa był tak niewyobrażalny, iż jakby domagał się - może nawet bardziej niż argumentacji czy relacji - «obrazów», «symboli», «metafor», które, zdawało się, Eisner i Kracauer znaleźli w filmach powstałych dwadzieścia lat wcześniej. Ponieważ sama historia żądała w tym wypadku in(ter)wencji wyobrażonego, aby stać się ponownie zrozumiała, choć wcale nie mniej niepojęta, filmy $\mathrm{w}$ jakiś sposób stały się cieniem, który pozwolił niewyrażalnemu wkroczyć w porządek czasowości i dyskursu, jakkolwiek nieadekwatnego i banalnego. W pewnym sensie kino stało się podwojeniem tej historii: namacalnym, widzialnym, możliwym do wglądu zwierciadłem czegoś, na co, niczym na Meduzę, nie można (albo tak się przynajmniej zdawało) spoglądać czy w jeszcze inny sposób to zbadać. Nieprzedstawialna historia znalazła nie tyle jej «obiektywny korelat», co raczej jej negatywny obraz, i tym samym iluzję ukrytej prawdy, doświadczanej tym mocniej, iż nie podejrzewanej przez wszystkich zainteresowanych: świadome motywy filmowców, odbiór przez publiczność epoki, eksplicytne opinie ówczesnych krytyków, liczyły się niewiele w obliczu symptomatologii tak doskonale czytelnej - z wnikliwością poniewczasie" ${ }^{\prime 32}$.

A jednak, jak konkluduje Elsaesser, nie da się zaniechać symptomatycznego czytania rozmaitych "tekstów" Republiki Weimarskiej, w tym oczywiście filmów, także filmów Fritza Langa. Są one bowiem wyrazem, sądzi Elsaesser, "oświeconej fałszywej świadomości” czy też "cynicznego rozumu": kategorie te, ukute przez Petera Sloterdijka, zostały przez autora Kritik der zynischen Vernunft (Krytyki cynicznego rozumu) zastosowane do opisu Republiki Weimarskiej ${ }^{33}$ jako „najbardziej rozbudzonej epoki w (niemieckiej) historii, epoki wysoce refleksyjnej i zadumanej, pełnej wyobraźni i niesamowicie zdolnej, przeoranej autoironią i autoanaliza" ${ }^{\prime 34}$. Ale przy tych wszystkich pozytywnych atrybutach „cyniczny rozum” albo „oświecona fałszywa świadomość", choć przeszła z sukcesem (zdobywszy samoświadomość) lekcję oświecenia - to zarazem uczyniła to na próżno.

32 T. Elsaesser, op. cit., s. 35.

33 Zob.: Peter Sloterdijk, Critique of Cynical Reason, transl. Michael Eldred, University of Minnesota Press, Minneapolis-London 2001, s. 384-533.

34 Ibidem, s. 389. 
Autoironiczna, autoanalityczna, samozwrotna świadomość Weimaru niezdolna jest bowiem do działania. W sferze politycznej wyraża się to niemożliwością rozeznania pośród wielu partii politycznych klarownej polaryzacji między siłami pro- i antydemokratycznymi, w pluralistycznej sferze publicznej - zawrotną różnorodnością grup interesów, zwalczających się nawzajem w ramach prawa, jak i poza nim, wreszcie w życiu codziennym - konfliktem między tradycyjną etyką oszczędzania, produkcji i pracy, a wyłaniającą się kulturą konsumpcji, ruchu i zapośredniczenia ${ }^{35}$.

Elsaesser zwraca też uwagę na odnotowane przez Sloterdijka dwa aspekty weimarskiego życia kulturalnego, które, jak się wydaje, występują we wszystkich jego dziedzinach: radykalną de(kon)strukcję (Abbau) metafizyki i mieszczańskiego idealizmu oraz wszechobecną teatralizację zarówno sztuki, jak i działań politycznych ${ }^{36}$. Tak pisze o tym Sloterdijk: „Teatralność wydaje się wspólnym mianownikiem wszystkich przejawów życia - od ekspresjonizmu po widowiskowe nogi Marleny Dietrich w Błękitnym Aniele, od krwawej komedii puczu Hitlera w roku 1923 po Brechtowską Opere za trzy grosze, od okazałego pogrzebu Rathenaua ${ }^{37}$ po skalkulowany bandytyzm pożaru Reichstagu w 1933. Permanentny kryzys, o którym wszyscy mówili, okazał się wspaniałym metteur-en-scène, który wiedział, jak reżyserować, by osiągnąć parę pamiętnych efektów"38.

Sloterdijk w swej obszernej analizie "cynicznego rozumu” Republiki Weimarskiej w zasadzie nie poświęcił uwagi kinu - tak przecież ważnemu aspektowi życia kulturalnego Niemiec w tej intrygującej, ale pełnej ambiwalencji epoce. Zadania zastosowania jego niełatwych konceptów i kategorii do filmu podjął się Elsaesser, który właśnie Langa uznał za emblematyczny wręcz przykład „oświeconej fałszywej świadomości”. A że reżyser to znamienity, który osiągnął w swych filmach bardzo wiele pamiętnych efektów, warto twórczości Langa w jej zenicie - w szalonych latach 20. przyjrzeć się z bliska.

${ }^{35}$ Por.: T. Elsaesser, op. cit., s. 9.

${ }^{36}$ Ibidem.

37 Walther Rathenau, minister spraw zagranicznych Republiki Weimarskiej, zamordowany 24 czerwca 1922 r. przez nacjonalistycznych bojówkarzy (Rathenau był Żydem). Warto tu przytoczyć wnikliwego monografistę kultury weimarskiej, Petera Gaya: „Podczas ucieczki przed policją jeden z zabójców został zabity, drugi sam się zabił, trzeci otrzymał wyrok 15 lat, ale spędził z nich w więzieniu tylko 7 - Republika zawsze była łaskawa dla jej wrogów" (Peter Gay, Weimar Culture: The Outsider as Insider, W. W. Norton \& Company, New York-London 2001, s. 153). To w kategoriach Sloterdijka także przykład niezdolnej do działania, rozdartej „oświeconej fałszywej świadomości”.

${ }^{38}$ P. Sloterdijk, Critique of Cynical Reason, s. 387-388 [ale cytat przekładam za Elsaesserem (op. cit., s. 9), który dał własną angielską wersję odnośnego miejsca z niemieckiego pierwodruku (Peter Sloterdijk, Kritik der zynischen Vernunft, Suhrkamp, Frankfurt/M 1985, Bd. 2, s. 705); przekład Elsaessera jest wyrazistszy niż ten z angielskiego wydania]. 
Część 1

W KRĘGU NIEMIECKIEJ TRADYCJI 



\section{Rozdział 1}

\section{MIĘDZY USTAMI A BRZEGIEM PUCHARU: ZMĘCZONA ŚMIERĆ}

O bóstwa, co podziemne zarządzacie państwa, Którym śmiertelny haracz opłaca poddaństwa, Nie myślcie, że zstąpiłem do tych strasznych ciemnic, Ciekawy docieczenia Erebu tajemnic. [...] Przyjścia powodem żona. Ten kwiat wśród rozkwicia Szpetna żmija swym jadem pozbawiła życia.

Chciałem znieść moją stratę, miłość zwyciężyła. [...]

Na okropność tych pieczar, ten zamęt głęboki,

$\mathrm{Na}$ to państwo milczenia i wiecznej pomroki, Błagam was, Eurydykę wróćcie mi kochaną, Zwiążcie przędzę jej życia za wcześnie zerwaną. [...] Tu jest dom nasz ostatni; wszystkich los ten czeka, Urodzenie dług śmierci wkłada na człowieka. I ona wróci całe ukończywszy życie, Za dobrodziejstwo przyjmiem kilku chwil użycie. Lecz gdybym nieszczęśliwy nie miał widzieć żony, Żyć nie chcę; tak choć śmiercią będę z nią złączony¹.

Owidiusz, Orfeusz i Eurydyka (Przemiany, X, 17-40)

\section{Ósmy film, pierwsze arcydzieło i dwie śmierci}

Mimo iż Zmęczona Śmierć (Der müde Tod, 1921) jest ósmym filmem wyreżyserowanym przez Langa, w świadomości nawet niezłych znawców historii kina dopiero od tego właśnie dzieła rozpoczyna się twórczość niemieckiego mistrza. Przyczyn takiego stanu świadomości jest kilka, ale do najważniejszych należą dostępność filmów i przyznawany im status. Dwa najwcześniejsze filmy w reżyserii Langa, Halbblut (1919) i Władca miłości (Der Herr der Liebe, 1919), zaginęły. Trzeci, Złote Jezioro (Der Goldene See, 1919), i piąty, Brylantowy statek (Das Brillantenschiff, 1920), wprawdzie zachowały

${ }^{1}$ Owidiusz, Przemiany, przeł. Bruno Kiciński, Unia Wydawnicza „Verum”, Warszawa 1995, s. 208-209. 
się, ale jako dwa odcinki sensacyjnego serialu Pająki (Die Spinnen), w zamyśle czysto rozrywkowego i w dodatku nigdy nieukończonego, nie były ani przez historyków kina, ani przez samego Langa, a w konsekwencji - również przez monografistów reżysera, poważnie traktowane (choć są one oczywiście ważnym świadectwem kultury popularnej przełomu lat dziesiątych i dwudziestych XX w. jako przykład popularnej wówczas formy serialu kinowego, to, istotnie, nie dają jeszcze wyobrażenia o mającym wybuchnąć wkrótce z wielką mocą artystycznym geniuszu Langa). Natomiast filmy czwarty, szósty i siódmy, tj. Harakiri (1919), Wędrujacy obraz (Das wandernde Bild, 1920) i Walczace serca (Kämpfende Herzen, 1920), które długo uchodziły za zaginione, po ich odnalezieniu i odrestaurowaniu w latach 80. są do dziś zazdrośnie strzeżone przez filmoteki i tylko od czasu do czasu pokazywane publicznie przy okazji rozmaitych retrospektyw twórczości Langa². Nieobecne aż do listopada 2012 w światowym obiegu płyt DVD i Blu-ray, a wcześniej kaset VHS, nigdy nie wyemitowane w telewizji, nie były w stanie zmienić przekonania, iż pierwszym (przynajmniej - pierwszym naprawdę znaczącym) filmem Langa jest właśnie Zmęczona Śmierć.

Film ten jest z pewnością pierwszym wielkim sukcesem reżysera u krytyki, dziełem, dzięki któremu jego nazwisko uzyskało międzynarodową renomę. Było też, jak to określa Klaus Kreimeier, „triumfalnym zwieńczeniem" ery niezależnej produkcji wytwórni Decla-Bioskop przed jej fuzją z Ufą, świadcząc zarazem o "posagu”" , jaki Decla wnosiła potężnemu partnerowi $\mathrm{w}$ postaci rzutkiego producenta (Erich Pommer), wytrawnego filmowca (Lang) i utalentowanej scenarzystki (Thea von Harbou). Premiera miała miejsce 7 października 1921 równocześnie w dwóch luksusowych przybytkach Berlina: kinie Ufa-Theater na Kurfürstendamm i w Mozartsaal na Nollendorfplatz; w tym drugim miejscu towarzyszyła projekcji muzyka orkiestralna, skomponowana

${ }^{2}$ Np. w Warszawie i w Krakowie w roku 1993, czego materialnym śladem pozostał katalog tamtego przeglądu: Fritz Lang, red. Renata Prokurat, Grażyna M. Grabowska, Filmoteka Narodowa-Goethe Institut, Warszawa 1993. Najcenniejszymi pozycjami tego wydawnictwa są biograficzno-monograficzny artykuł Jerzego Toeplitza Portret Fritza Langa oraz fragmenty rozmaitych wypowiedzi tak reżysera, jak i innych osób o nim. Wydawnictwo to niewolne jest od poważnych błędów - prof. Toeplitz, w skadinąd znakomitym artykule, niepotrzebnie zawierzył już wówczas zdyskredytowanej historii Langa o jego "ucieczce z Niemiec", natomiast po prostu niedbalstwem redakcji jest niedorzeczne streszczenie filmu Das wandernde Bild, przejęte bez zmian ze starszych źródeł, pochodzących z czasów, kiedy film jeszcze uchodził za zaginiony.

${ }^{3}$ Por.: Klaus Kreimeier, The Ufa Story: A History of Germany's Greatest Film Company, 1918-1945, transl. Robert and Rita Kimber, University of California Press, Berkeley-Los Angeles-London 1999, s. 73. 
przez Giuseppe Becce, autora muzyki do wielu prestiżowych filmów niemieckich w latach $20 .^{4}$

Początkowo jednak nic sukcesu nie zapowiadało - mimo pozytywnych, a nawet entuzjastycznych recenzji ${ }^{5}$, na ekranach kin berlińskich Zmęczona Śmierć była obecna tylko przez dwa tygodnie. Zresztą nie wszystkie recenzje były przychylne - recenzent „Berliner Zeitung” złośliwie strawestował tytuł filmu, pisząc o „Męczącej (w domyśle - dla widza) Śmierci" ${ }^{\prime}$. Wróciła jednak triumfalnie do Niemiec po entuzjastycznym przyjęciu we Francji w 1922 r., gdzie wyświetlano ją pod tytułem Les Trois Lumières (Trzy światła) ${ }^{7}$, i gdzie jeden z recenzentów pisał: „Oto Niemcy, jakie kochamy, świat Dürera i Grünewalda, przemawiają do nas w tym filmie" ${ }^{\prime \prime}$. W Wielkiej Brytanii pojawiła się dopiero w lutym $1924 \mathrm{r}$. jako jeden z pierwszych niemieckich filmów po I wojnie światowej, wyprzedzając nawet wcześniejszy i bardziej wpływowy w historii kina Gabinet doktora Caligari (1919) Roberta Wiene9. Krytyk londyńskiego „Spectatora”, który był na brytyjskiej premierze w Polytechnic Hall - Bertram Higgins, pisał, iż „Destiny jest jednym z najoryginalniejszych i najbardziej sugestywnych filmów, jakie kiedykolwiek zrealizowano"10.

Dość zawiłe są amerykańskie losy Zmęczonej Śmierci. Pierwotnie prawa do filmu na rynek amerykański wykupił - za niezbyt dziś imponującą kwotę 5000 \$-Douglas Fairbanks, jeden z czterech głównych udziałowców United Artists, która to spółka miała film dystrybuować. Fairbanks wcale jednak nie zamierzał rozpowszechniać filmu, lecz chciał wnikliwie przestudiować inscenizacyjne i techniczne rozwiązania, zwłaszcza z epizodu chińskiego, by je naśladować i udoskonalić w swym Złodzieju z Bagdadu (dysponując większymi pieniędzmi, bez trudu osiągnął bardziej atrakcyjne i wymyślne technicznie tricki) ${ }^{11}$. Inna, znacznie mniejsza niż United Artists, firma dys-

${ }^{4}$ Ibidem. Por. także: Patrick McGilligan, Fritz Lang: The Nature of the Beast, St. Martin's Press, New York 1997, s. 74.

${ }^{5}$ Np. H. W., "Der müde Tod”: Ein deutsches Volkslied in 6 Versen, „Lichtbildbühne” (Berlin) 1921, 8 Oktober; Frederick W. Ott w książce The Films of Fritz Lang (The Citadell Press, Seacaucus, NJ, 1979, s. 89-93) przytacza fragmenty innych pozytywnych recenzji, opublikowanych w: „Film Kurier” 1921, 7 Oktober; „Berliner Börser-Zeitung” 1921, 9 Oktober; „Der Kinematograph” (Düsseldorf), 1921, nr 765 (16 Oktober).

${ }^{6}$ Zob.: P. McGilligan, op. cit., s. 74-75; Paul M. Jensen, The Cinema of Fritz Lang, A. S. Barnes \& Co-A. Zwemmer Ltd., New York-London 1969, s. 23.

7 Zob.: P. McGilligan, op. cit., s. 75.

${ }^{8}$ Cyt. za: ibidem.

9 Zob.: P. M. Jensen, op. cit., s. 23.

${ }^{10}$ Bertram Higgins, "Destiny at the Polytechnic Hall”, "The Spectator" 1924, 23 February, s. 284-285. Destiny (Przeznaczenie) - taki był brytyjski tytuł Zmęczonej Śmierci.

11 Nt. postępowania Fairbanksa względem filmu Langa, zob.: P. McGilligan, op. cit., s. 89; P. M. Jensen, op. cit., s. 23-24; Fritz Lang, Interviews, ed. Barry Keith Grant, University of Mississippi Press, Jackson 2003, s. 178. 
trybucyjna przejęła prawa do Zmęczonej Śmierci i w lipcu 1924 rozpowszechniała ją w kinach Nowego Jorku, drastycznie skróconą i przemontowaną. Zmieniony nie do poznania i niespójny film był też wyświetlany pod zmienionym tytułem - Between Worlds lub też Between Two Worlds (Pomiędzy dwoma światami). W $1928 \mathrm{r}$. wprowadzono go ponownie na ekrany w USA, tym razem pod tytułem Beyond the Wall (Za murem) ${ }^{12}$. Amerykańskie perypetie pierwszego Langowskiego arcydzieła są wręcz emblematyczne dla recepcji niemieckich filmów reżysera za oceanem $\mathrm{w}$ ",szalonych latach dwudziestych": podobny los spotkał Doktora Mabuse, gracza, Nibelungi, Metropolis, Kobiete na Księżycu. Okrojone, przemontowane, niekomunikatywne i pod zmienionymi tytułami nie mogły zapracować w Ameryce na renomę, jaką Lang cieszył się w Europie. Ale to miało ujawnić swe skutki dopiero w połowie lat 30., gdy Lang znalazł się za oceanem na emigracji.

Zmęczona Śmierć była czwartym scenariuszem, przy którym wspólnie pracowali Lang i Thea von Harbou, jeden z najciekawszych artystycznie, ale i najbardziej kontrowersyjnych ideologicznie duetów reżysersko-scenariopisarskich w historii kina [poprzednie trzy scenariusze to Das wandernde Bild, Kämpfende Herzen oraz Das indische Grabmal (Indyjski grobowiec, 1921) - film, który początkowo miał reżyserować Lang, a który ostatecznie podpisał Joe May]. W świetle dzisiejszej wiedzy o Langu, a zwłaszcza o kluczowym w jego życiorysie roku 1933, należy wystrzegać się uproszczeń przypisujących w scenariuszach wyłącznie jemu pierwiastki „demokratyczne" i „,humanitarne”, wyłącznie zaś jej akcenty „reakcyjne”, „(pre) nazistowskie” czy „nacjonalistyczne”. Sam fakt emigracji Langa po 1933 i pozostania Thei von Harbou w Trzeciej Rzeszy, co więcej - jej dość aktywnej roli w ówczesnej kinematografii niemieckiej ${ }^{13}$, nie jest jednak wystarczającym dowodem, by optować za takimi uproszczeniami; dialektyka wkładu obojga w scenariusze filmów Langa jest jednak bardziej złożona i dziś chyba nie do rozwikłania ${ }^{14}$.

12 Por.: P. M. Jensen, op. cit., s. 24; P. McGilligan, op. cit., s. 90.

${ }^{13} \mathrm{Na}$ ten temat zob. zwłaszcza: P. McGilligan, op. cit., s. 157-158, 163-164, 184-185. W okresie nazistowskim Thea von Harbou próbowała samodzielnie reżyserii (Hanneles Himmelfahrt - Hanusia, 1934), a ,,jej nazwisko jako scenarzystki widnieje w bodaj 26 filmach; musiała mieć także nieudokumentowany w czołówkach wkład do niezliczonych innych filmów - włączając w to garść tytułów z bezdyskusyjnie nazistowskim stygmatem" (ibidem, s. 185).

${ }^{14}$ Tom Gunning w swej analizie Metropolis z ironią pisze o tendencji interpretacyjnej, by ideową niespójność tego filmu przypisywać współpracy Lang/Harbou - „co dobre, to od Langa, a co złe, to od «tej nazistowskiej dziwki» («that Nazi bitch»)" (T. Gunning, The Films of Fritz Lang: Allegories of Vision and Modernity, BFI Publishing, London 2000, s. 53). Zob. też: Reinhold Keiner, Thea von Harbou und der deutsche Film bis 1933, Olms, Hildesheim 1991, passim; K. Kreimeier, op. cit., s. 140-142. 
Wśród pierwiastków, które von Harbou wniosła do wspólnych scenariuszy, Klaus Kreimeier wymienia z jednej strony wyniesioną przez nią z dzieciństwa niemal religijną miłość do natury, uwielbienie dla Karola Maya (które Lang podzielał), a z drugiej - otwartość na nowoczesną technikę, która w typowo niemiecki sposób technikę tę zarazem gloryfikowała i demonizowała. Jej urzeczenie egzotycznymi sceneriami gładko łączyło się z ideologią aktywnego kolonializmu ${ }^{15}$, co zresztą można chyba odczuć w scenariuszu Indyjskiego grobowca, będącego adaptacją jej własnej powieści. A jeszcze inaczej widzi wkład obojga do filmów Langa Eric Rhode: „Lang miał dryg do kompozycji potężnych obrazów i kreowania sardonicznych efektów, podczas gdy jego żona Thea von Harbou [...] miała dar wymyślania w sekwencji jedna po drugiej dziwacznych sytuacji. Razem tworzyli duet dobrze dobrany do tworzenia filmów fantastyczno-przygodowych czy kryminalnych"16.

Nie zapominajmy jednak i o tym, że przed poznaniem Langa Thea von Harbou była pisarką, może wprawdzie drugorzędną, ale o pokaźnym dorobku i ustalonej reputacji. Gdy współpraca z Langiem uświadomiła jej własny talent scenariopisarski, nie zaprzestała pisania powieści, ale podporządkowała swe książki kreacji „wrzawy medialnej” wokół filmu, czyli po prostu wzajemnej reklamie filmu i książki, co jest w sposób oczywisty prekursorskie wobec dzisiejszych strategii marketingowych. Jej Das Nibelungenbuch (Księga Nibelungów), ilustrowana fotosami z filmu, podobnie jak powieści Metropolis i Szpiedzy, powstawały równocześnie z jej własnymi scenariuszami i mniej więcej równolegle do premiery filmów Langa trafiły do księgarń. Wyjątkiem była powieść Kobieta na Księżycu, opublikowana w roku 1928, zanim rozpoczęła pracę nad scenariuszem (film trafił na ekrany rok później) ${ }^{17}$. Nie można też zapewne odmówić Thei von Harbou oczytania i rozległej kultury literackiej, plonem których jest chociażby niemała liczba literackich odniesień czy trawestacji znanych skądinąd wątków w Zmęczonej Śmierci. Znajdziemy tu Pieśń nad Pieśniami, Nowy Testament, Homerową Odyseję, tragedię Eurypidesa Alkestis, Georgiki Wergiliusza i Przemiany Owidiusza (mit o Orfeuszu i Eurydyce), Księge tysiaca i jednej nocy, Dekameron Boccaccia, baśń braci Grimm Kuma Śmierć (Der Gevatter Tod) czy mało znaną baśń Andersena Opowiadanie o matce ${ }^{18}$.

15 Zob.: K. Kreimeier, op. cit., s. 141.

16 Eric Rhode, A History of Cinema from Its Origins to 1970, Penguin Books, LondonNew York 1978, s. 172.

17 Zob.: ibidem, s. 140.

18 Jako istotne inspiracje Zmęczonej Śmierci wymienione baśnie Grimmów i Andersena wskazuje Lotte H. Eisner (Fritz Lang, Da Capo Press, New York 1986, s. 43-45). 
Wśród okoliczności „tłumaczących” poniekąd genezę filmu, Lotte Eisner, a za nią Patrick McGilligan ${ }^{19}$, przywołują sen, o którym reżyser zdał relację w wypowiedzi dla gazety „Berliner Tageblatt” z dnia 1 stycznia $1927 \mathrm{r}$. Myślę, że warto przytoczyć tu in extenso tę opowieść Langa, opatrzoną tytułem O dobroczynnej Śmierci: „Sen z dzieciństwa, który najbardziej wpłynął na moje życie i twórczość, nie dotyczył ani przyjaźni, ani miłości. Obudził jednak we mnie uczucie lęku, urastające do miłości o takiej sile, że nigdy nie byłem w stanie uwolnić się od jej niemal mistycznej potęgi.

Chorowałem, na progu między byciem chłopcem a młodzieńcem, i przydarzyło się to którejś nocy, kiedy byłem bardzo blisko spełnienia porzekadła, że kogo bogowie kochają ten umiera młodo. Odczuwałem bliskość śmierci z rodzajem sennej jasności, byłem jednak zbyt zmożony gorączką żeby przeciwstawić się zbliżaniu się mrocznego obcego. Wymykałem się wraz z mym ledwo odczuwalnym oddechem, który słabł coraz bardziej, a załzawiona twarz uwielbianej przeze mnie mej matki znikała sprzed mych oczu.

Spałem i śniło mi się - a może nie spałem? Z niezamglonym spojrzeniem, niemal aż nadto wyraźnie, widziałem znany mi pokój, w którym leżałem. Okiennice były na wpół otwarte - i poświata księżycowa wlewała się do pokoju. Widziałem samego siebie twarzą w twarz ze, wcale nie przerażająca, ale niemożliwą do pomylenia z czymkolwiek innym, Śmiercią. Tworzyły ją czerń i biel, światło i cień, klatka żeber, nagie kości. Na górze była głowa, ledwo rozpoznawalna, ocieniona przez kapelusz o szerokim rondzie.

Śmierć i ja wpatrywaliśmy się w siebie nawzajem. Nie wiem, czy uczucie, którego wówczas doznawałem, można nazwać strachem. Była w tym groza, ale bez paniki. Ale nawet groza ustąpiła czemuś w rodzaju mistycznej ekstazy, która dała mi, choć wciąż byłem chłopcem, pełne zrozumienie ekstazy, z jaką w objęcia śmierci rzucali się męczennicy i święci.

Podniosłem się, by pójść za nią. W mym osłabieniu upadłem. Przyszli ludzie i podnieśli mnie. Śmierć zniknęła.

Szybko wyzdrowiałem. Ale miłość śmierci, na którą składały się groza i uczucie, [śmierci] obrazowanej przez gotyckich mistrzów, pozostała ze mną i stała się częścią mych filmów [w przedstawieniach śmierci]: uczłowieczonej w Zmęczonej Śmierci, symbolicznej w Nibelungach, ożywionej gotyckiej figury w Metropolis"20.

Trudno powiedzieć, czy Langowi istotnie przyśnił się w młodości sen o „dobroczynnej Śmierci”. Jak pokazuje opowieść o „ucieczce z Niemiec”

19 Zob.: P. McGilligan, op. cit., s. 70.

${ }^{20}$ Fritz Lang, On Benevolent Death, [w:] L. H. Eisner, op. cit., s. 55-56. Prwdr.: „Berliner Tageblatt" 1927, 1 Januar. 
- ale bynajmniej nie ona jedna - reżyser nie był wiarygodnym narratorem własnego życia i należy być nieufnym wobec wszelkich faktów, których jedynym świadkiem był on sam ${ }^{21}$. Ale jeśli nawet nie jest to opowieść prawdziwa, jest tym samym może nawet bardziej interesująca jako jeszcze jeden „wyobrażony film”, jeszcze jedna konfabulacja, w której znalazły wyraz charakterystyczne cechy poetyki filmów Langa: narracja z perspektywy postaci znajdującej się $\mathrm{w}$ poważnym niebezpieczeństwie, obecność alegorii, dwuznaczność ontycznego statusu rzeczywistości przedstawionej oscylującego między snem a realnością, wkroczenie w codzienność elementu metafizycznego, wreszcie - ambiwalencja uczuć, w których lęk przed tym, co jest das Unheimliche, przed elementem niesamowitym i nieoswojonym, stapia się z fascynacją tym elementem, a nawet jego pożądaniem. Zwraca też uwagę w relacji Langa obecność metapoziomu, pewnego przeniesienia uwagi z samego wydarzenia na jego artystyczne opracowanie; patrząc z tej "metadiegetycznej” płaszczyzny, chłopiec śniący o „dobroczynnej Śmierci” przestaje być tylko bohaterem uwikłanym w jakąś sytuację, a staje się figurą artysty zakochanego w temacie śmierci. Obecność takiego metapoziomu, a zarazem rozmaitych portes-paroles artysty jest również wspólną i bardzo strukturalnie istotną cechą niemieckich filmów Langa, a Zmęczonej Śmierci w stopniu szczególnie znaczącym. Innym jeszcze aspektem zwrotności referencji (czy mówiąc bardziej popularnie, lecz na mniejszym poziomie ogólności - autotematyzmu $)^{22}$ jest ujęcie zdarzeń w ramę snu, przez co zostaje podkreślony ich nie tylko oniryczny, ale i fil m o w y charakter. W Zmęczonej Śmierci historie "trzech świec" to jakby trzy "filmy w filmie", prezentowane przez Śmierć Dziewczynie, i to w dodatku o niejasnym i migotliwym statusie snu, filmu i rzeczywistości realnej zarazem. Równie intrygujące „ramy” $\mathrm{w}$ rozmaitych aspektach tej kategorii - jako ramy narracji (otaczające wewnątrzramową opowieść) albo ramy obrazu (otaczające wewnątrzekranowy ekran) - pojawiają się w innych niemieckich filmach Langa, do czego oczywiście powrócimy podczas kolejnych analiz.

Jedną z postaci snu Langa, choć tylko jakby mimochodem obecna, jest „uwielbiana” przezeń matka, której „załzawiona twarz” „znikała sprzed

${ }^{21}$ Wielokrotnie ten sceptycyzm zaleca Patrick McGilligan w swej biografii - także odnośnie przytoczonego snu (op. cit., s. 70). Prawdopodobnie innym jeszcze autobiograficznym mitem jest rzekoma podróż na Daleki Wschód, jaką Lang miał odbyć ok. 1910-1911.

${ }^{22}$ W swej książce Film fikcji $i$ jego dominanty (Wydawnictwo Naukowe Semper, Warszawa 1999) zaproponowałem, by zamiast "autotematyzmu" stosować termin „zwrotność" jako odpowiednik angielskiego reflexivity czy francuskiego reflexivité (por.: ibidem, s. 200-201). Jest on bardziej ogólny niż "autotematyzm”, a zarazem ma uzasadnienie $\mathrm{w}$ terminologii logiki czy językoznawstwa (wypowiedzi zwrotne, zaimki zwrotne, relacja zwrotności etc.). 
jego oczu". Matka reżysera, Paula Schlesinger Lang, zmarła 7 lipca 1920 r. w wieku 55 lat, w okresie bezpośrednio poprzedzającym projekt i realizację Zmęczonej Śmierci23. W kontekście takiej sekwencji zdarzeń i emblematycznej obecności matki we „śnie” Langa, nie dziwi chyba sugestia biografa reżysera, iż „przeniknięta zadumą i współczuciem medytacja nad śmiertelnością", jaką jest Zmęczona Śmierć, wiąże się z tamtą utratą ${ }^{24}$.

A nie była to $\mathrm{w}$ tym okresie jedyna śmierć osoby bardzo blisko z Langiem związanej. 25 września 1920 r. zginęła od kuli, wystrzelonej z rewolweru, który reżyser trzymał w swym biurku, Elisabeth Rosenthal, pierwsza żona reżysera. Było to samobójstwo, nieszczęśliwy wypadek podczas dramatycznej małżeńskiej sprzeczki czy może... morderstwo? O to ostatnie posądzały Langa i Theę von Harbou pogłoski, niedziwne w świetle nie tylko ich coraz ściślejszej artystycznej współpracy, ale i ich coraz bardziej głośnego romansu oraz faktu, że to właśnie Thea dziwnym zbiegiem okoliczności przebywała w mieszkaniu Langów podczas zajścia i była jedynym obok Langa świadkiem. Sprawa ta, pełna niejasności i wskazujących w rozmaitą stronę poszlak, nie stała się jednak przedmiotem policyjnego śledztwa, reżyserowi ani Thei von Harbou nie postawiono żadnych zarzutów, a akt zgonu, podpisany przez wezwanego lekarza, dr. F. Perlsa, stwierdzał jako przyczynę śmierci „strzał w klatkę piersiową; wypadek" 25 . Tak czy inaczej, Lang nie był bez winy - przynajmniej moralnej. I choć może dopatrywanie się, jak czyni to Patrick McGilligan, w późniejszych filmach reżysera ech sprawy Elisabeth Rosenthal ${ }^{26}$ (w postaci tematu samobójstwa, zabójstwa upozowanego na samobójstwo lub nieszczęśliwy wypadek, słusznych bądź niesłusznych posądzeń kogoś o winę czy wreszcie spisków na czyjeś życie) jest zbyt daleko idącym „biografizmem”, to, z drugiej strony, tematy te są w twórczości Langa stale i intensywnie obecne. Także w powstałym niedługo po tych wydarzeniach traumatycznym scenariuszu Zmęczonej Śmierci, wspólnym dziele Fritza Langa i jego d r u g i e j żony ${ }^{27}$.

${ }^{23}$ Zob.: P. McGilligan, op. cit., s. 67.

${ }^{24}$ Ibidem, s. 70.

${ }^{25}$ Okoliczności śmierci pierwszej żony Langa w najpełniej udokumentowany faktograficznie sposób relacjonuje wydawnictwo: Fritz Lang. Leben und Werk. Bilder und Dokumente, red. Rolf Aurich, Wolfgang Jacobsen, Cornelius Schnauber, Filmmuseum Berlin-Deutsche Kinemathek und jovis Verlag, Gmbh, Berlin 2001, s. 59-64. Nieco inaczej okoliczności te referuje Patrick McGilligan (op. cit., s. 76-80).

${ }_{26}$ Zob.: P. McGilligan, op. cit., s. 79-80.

${ }^{27}$ Lang i Thea von Harbou pobrali się 26 sierpnia 1922, niecałe dwa lata po śmierci Elisabeth Rosenthal (P. McGilligan, op. cit., s. 87-88) i po rozwodzie scenarzystki z aktorem Rudolfem Klein-Rogge, znakomitym odtwórcą ról negatywnych, czy wręcz demonicznych, postaci w filmach Langa: Mabusego, Rotwanga, Haghiego. W Zmęczonej Śmierci 


\section{Märchenfilm w sześciu aktach, bez trzech wierszy}

Pełny tytuł filmu brzmi: Der müde Tod: Ein deutsches Volkslied in 6 Versen ${ }^{28}$ (Zmęczona Śmierć: Niemiecka pieśń ludowa w sześciu wierszach). Oczywiście, gdy uwzględnimy, iż jest to film, a nie utwór literacki, określenie „Volkslied” („pieśń ludowa”) uznać trzeba za jedynie metaforyczną kwalifikację genologiczną. Ale określenie to wskazuje zarazem pokrewieństwo dzieła Langa $\mathrm{z}$ ważnym trendem kina niemieckiego drugiej dekady $X X_{\text {w., jaki stanowiły }}$ Märchenfilme czy może nawet przynależność do niego. Chodzi o filmy oparte na baśniach, legendach, podaniach ludowych czy fantastycznych opowieściach z bogatego skarbca niemieckiego romantyzmu, powstałe głównie między 1913 a 1918 r. Czołowym ich twórcą był utalentowany aktor, reżyser i producent $w$ jednej osobie - Paul Wegener, a do najbardziej znanych tytułów należą właśnie filmy Wegenera Student z Pragi (Der Student von Prag, 1913) ${ }^{29}$, Golem (1915) ${ }^{30}$, Jogin (1916), Wesele króla gór (Rübezahls Hochzeit, 1916), Golem i tancerka (Der Golem und die Tänzerin, 1917), Szczurołap z Hameln (Der Rattenfünger von Hameln, 1918), Obcy ksiażę (Der fremde Fürst, 1918), a spośród filmów innych twórców - Opowieści Hoffmanna (Hoffmanns Erzählungen, 1916) Richarda Oswalda czy Homunculus (1916) Ottona Ripperta ${ }^{31}$. Zmęczona Śmierć byłaby zatem reprezentantem drugiej, nieco słabszej fali Märchenfilme z lat 20., wraz z takimi późniejszymi od niej tytułami, jak Kopciuszek (Der verlorene Schuh, 1923) Ludwiga Bergera, Kronika z Grieshuus (Zur Chronik von Grieshuus, 1925) Arthura von Gerlacha, druga wersja Studenta z Pragi (1926) Henrika Galeena czy wreszcie Faust (1926) Friedricha Wilhelma Murnaua, zdecydowanie bliższy baśni bądź legendzie niż dramatowi Goethego, o czym dodatkowo zresztą świadczy jego podtytuł: Eine deutsche Volkssaga - Niemieckie podanie ludowe.

zagrał 2 role: derwisza-donosiciela w epizodzie arabskim i Girolama w epizodzie weneckim.

${ }^{28}$ Na kopii, którą analizowałem, w czołówce filmu nie ma podtytułu. Podaje go jednak wiele źródeł, w tym najbardziej miarodajne, jeśli chodzi o filmografię Langa: E. Ann Kaplan, Fritz Lang: A Guide to References and Resources, G. K. Hall \& Co., Boston 1981, s. 31.

${ }^{29}$ Formalnie reżyserem tego filmu jest Duńczyk Stellan Rye, ale historycy kina zgodnie podkreślają decydujący wpływ na kształt tego dzieła jako faktycznego współreżysera, producenta, pomysłodawcy i odtwórcy roli tytułowej - właśnie Paula Wegenera.

30 Źródłem scenariusza Golema była nie tylko powieść Gustava Meyrinka, ale i żydowska legenda.

${ }^{31}$ Nt. Märchenfilme zob.: Sabine Hake, German National Cinema, Routlegde, London-New York 2002, s. 20; T. Elsaesser, Weimar Cinema, Mobile Selves, and Anxious Males: Kracauer and Eisner Revisited, [w:] Expressionist Films: New Perspectives, ed. Dietrich Scheunemann, Camden House, Rochester-Woodbridge 2003, s. 47-48; Lotte H. Eisner, Ekran demoniczny, przeł. Konrad Eberhardt, Wydawnictwa Artystyczne i Filmowe, Warszawa 1974, s. 50-54, 60-63. 
Tom Gunning uważa, iż pod względem filmowego rzemiosła jest Zmęczona Śmierćjednym znajlepszych filmów okresu Republiki Weimarskiej, a pośród Märchenfilme bodaj najpiękniejszym. „Sześć wierszy” z podtytułu odpowiadać ma sześciu aktom jako rolkom filmu, a zarazem jako jego całostkom dramaturgicznym: pierwsze dwa „wiersze” (akty) oraz ostatni odpowiadałyby ramie narracyjnej filmu (historia Dziewczyny i Chłopca), natomiast trzeci, czwarty i piąty - opowieściom wewnątrzramowym, czyli „historiom trzech świec". Cezurą między „wierszem” (aktem) pierwszym i drugim byłoby zniknięcie ukochanego i wyruszenie Dziewczyny na jego poszukiwanie ${ }^{32}$. To wyjaśnienie z pewnością może tłumaczyć odczucie przez widza kompozycji filmu Langa jako niezwykle harmonijnej i zrównoważonej; kto wie, czy zbadanie filmu metodami ilościowymi nie ujawniłoby czegoś w rodzaju sectio aurea (,złotego podziału”) i „,budowy organicznej" - kategorii, które Siergiej Eisenstein zastosował do analizy Pancernika Potiomkina, by dość nieskromnie wykazać jego „arcydzielność"33. Wydaje mi się nawet, iż fakt, że moment kluczowy i o największym napięciu dramaturgicznym - zbliżenie przez Dziewczynę kieliszka z trucizną do ust wypada gdzieś w okolicy dwóch piątych czy jednej trzeciej czasu projekcji, świadczyć może o przystawaniu Zmęczonej Śmierci (przynajmniej w tym aspekcie) do Eisensteinowskiej koncepcji „,organicznej budowy utworu”.

Określenie „wiersze" z podtytułu filmu mogło mieć też jednak i bardziej dosłowny sens. Lotte Eisner powołuje się na uzyskane od Langa (czy aby wiarygodne?) informacje, dotyczące napisów w filmie. W zachowanych kopiach z niemieckimi napisami wszystkie napisy ekspozycyjne są prozą, ale Lang twierdził, iż pierwotnie wśród napisów ekspozycyjnych znajdowały się trzy teksty poetyckie, trzy „,wiersze”. Pierwszy z nich miał brzmieć następująco:

Jest gdzieś małe miasteczko

Uśpione w dolinie.

Mieszkało tam i kochało się wzajemnie

Dwoje młodych ludzi, pełnych życia;

Ale z wszystkich drzew

Opadają złote liście

W krwawym blasku zmierzchu.

Na skrzyżowaniu dróg,

Które wiele już widziało

Zaczajona czeka na nich

Samotnie

Śmierć ${ }^{34}$.

32 T. Gunning, op. cit., s. 16-17.

${ }^{33}$ Por.: Siergiej Eisenstein, Nieobojętna przyroda, przeł. Mieczysław Kumorek, Wydawnictwa Artystyczne i Filmowe 1975, s. 21-35.

${ }^{34}$ Por.: L. H. Eisner, Fritz Lang, s. 53-54. Przytaczam wiersze we własnym przekładzie. 
Ponieważ zawartością fabularną tekst wiersza wyraźnie odpowiada początkowi filmu, można zakładać, że jeżeli faktycznie pierwotnie był on zamieszczony w filmie, to tuż po czołówce, a nie w miejscu, w którym znajduje się dziś pierwszy w ogóle napis filmu: Eine kleine Stadt, verloren in der Vergangenheit (,Małe miasteczko, zagubione w przeszłości”) ${ }^{35}$. Drugi z niezachowanych wierszy miał się, według reżysera, pojawić po scenie, gdy Dziewczyna po powrocie z kuchni do stołu w gospodzie odkrywa zniknięcie Chłopca:

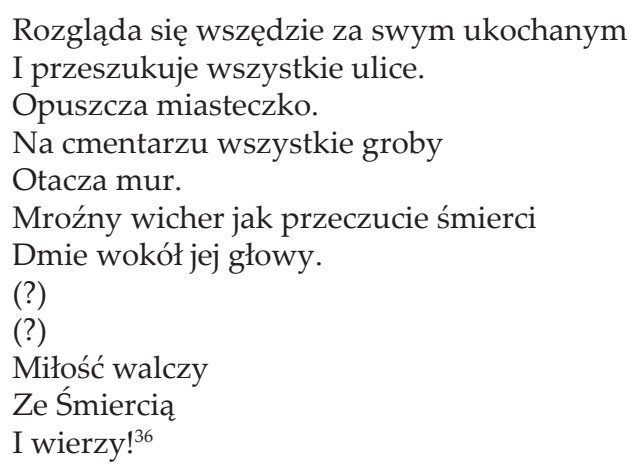

Lang nie przytoczył tekstu trzeciego z wierszy, ale miał być on zlokalizowany po "historii trzech świec”. Jego początkowe wersy podał natomiast monografistce Langa miłośnik kina, Albin Pötzsch ze szkoły filmowej w Miśni:

Śmierć ponownie odniosła triumf w walce.

Ale $\mathrm{z}$ uśmiechem

Składa los

$\mathrm{W}$ ręce cierpiącej

Jeszcze jeden $\mathrm{raz}^{37}$.

Gdyby traktować dość dosłownie podtytuł filmu, nie zgadzałaby się liczba wierszy - trzy zamiast sześciu. Uwzględniając jednak fakt, iż prócz napisów ekspozycyjnych, są także w filmie napisy "diegetyczne" (tzn. przekazujące słowa wypowiadane przez postaci bądź teksty przez nie czytane), byłoby tych wierszy rzeczywiście sześć. Tekstami wierszowanymi są bowiem ustęp z Pieśni nad Pieśniami, odczytywany przez Dziewczynę,

${ }^{35}$ Napis ten następuje po scence $\mathrm{w}$ dyliżansie, przed ujęciem $\mathrm{w}$ planie ogólnym rynku miasteczka, które poprzedza prezentację gospody „Pod Jednorożcem” i jej bywalców - notabli.

${ }^{36}$ Cyt. za: ibidem, s. 54.

37 Ibidem. 
oraz obwieszczenie przez miejskiego herolda godziny jedenastej i dwunastej (co prawda, godzina jedenasta obwieszczana jest w sjużecie ${ }^{38}$ dwukrotnie, ale za to tym samym „wierszem”).

Chociaż świadectwo Albina Pötzscha uwiarygodniło wersję Langa o pierwotnym istnieniu w filmie „wierszy” o charakterze napisów ekspozycyjnych, to wydaje mi się, że ich nieobecność w zachowanych kopiach jest nieprzypadkowa. Może ona bowiem świadczyć nie tyle o ich "zaginięciu" (jeżeli rzeczywiście się tam znajdowały), co raczej o świadomym usunięciu w wyniku przemyślanej artystycznej decyzji jako elementu estetycznie zbędnego. Wiersze te bowiem, po pierwsze, pozbawiają fabułę suspensu, pleonastycznie zapowiadając zdarzenia i miejsca akcji, po drugie, odzierają zarówno obrazy filmu, jak i sens zdarzeń (tak dla widza, jak i dla postaci), z aury tajemnicy, niejednoznaczności, niepokojącego niedookreślenia. Pracy rozwiązania traumatycznych zagadek, jakie stawiają przed odbiorcą i przed Dziewczyną jako reprezentantem widza w tekście alegoryczne zdarzenia i alegoryczne obrazy, nie może bowiem za nich wykonać zbyt jednoznaczny narracyjny komentarz - choćby i poetycki w formie.

\section{Rahmenhandlung i „Historie trzech świec”}

Jak przystało na filmową baśń, fabuła Zmęczonej Śmierci nie wydaje się trudna do zrozumienia i jawi się na pierwszy rzut oka, po pierwszym obejrzeniu, jako raczej łatwa do opowiedzenia, i to pomimo dość skomplikowanej kompozycji. W kompozycji tej rama narracyjna (chwyt znany po niemiecku jako Rahmenhandlung) otacza trzy wewnątrzramowe historie, prosto - jak się zdaje - wobec tej ramy sfunkcjonalizowane jako typowe dla struktury baśniowej "trzy szanse, trzy próby czy trzy życzenia" ${ }^{39}$, dane głównej postaci w trakcie jej dążenia do jakiegoś szczególnie trudnego do osiągnięcia celu. Ale czy istotnie wewnątrzramowe historie w filmie Langa mają taką prostą, baśniową funkcję? Dialektyka ich relacji do ramy, jak zobaczymy dalej, jest jednak bardziej złożona.

Ramowe konstrukcje opowieści w kinie Republiki Weimarskiej nie są niczym niezwykłym - wręcz przeciwnie, wydaje się, iż panowała na

38 Odwołuję się tu do formalistycznego rozróżnienia na „sjużet” (układ fabuły w tekście, tak jak dana jest ona odbiorcy) i „fabułę" („idealny” układ zdarzeń fabularnych, nigdy w pełni odbiorcy niedany, a tylko domniemywany).

39 To podobieństwo filmu Langa (a także będącego jego parodią filmu Paula Leniego Gabinet figur woskowych [Das Wachsfigurenkabinett, 1924]) do baśni o podobnej strukturze, odnotowuje Thomas Elsaesser. Zob.: idem, Weimar Cinema and After: Germany's Historical Imaginary, Routledge, London-New York 2000, s. 84. 
nie nawet swoista moda (np. Thomas Elsaesser uznaje je za najbardziej wyrazistą cechę narracji filmów weimarskich ${ }^{40}$ ). Co więcej, jest to chwyt znany już od stuleci w literaturze pięknej, co najmniej od czasów Homera: przecież historia podróży Odyseusza i jego przygód, zawarta w księgach IX-XII Odysei, jest zapośredniczona przez jego relację o nich na dworze króla Feaków Alkinoosa. Nadrzędna rama narracyjna dla wielu rozmaitych opowieści stała się zasadniczym zabiegiem kompozycyjnym w wielkich dziełach literatury średniowiecznej - Boskiej komedii Dantego, Dekameronie Boccaccia, Opowieściach kanterberyjskich Chaucera czy Księdze tysiaca $i$ jednej nocy (nie przypadkiem adaptacje tych trzech ostatnich dzieł tworzą trylogię Pasoliniego - ich wspólnym mianownikem jest nie tylko "erotyka w średniowieczu”, ale i kompozycja ramowa). Wydaje się też, iż Dekameron i Księga tysiaca i jednej nocy były jedną z inspiracji scenariusza Zmęczonej Śmierci. Poza samym chwytem Rahmenhandlung świadczy o tym orientalny koloryt opowieści arabskiej i chińskiej, baśniowa fantastyka epizodu chińskiego oraz to, iż zarówno każda z "Historii trzech świec", jak i opowieść ramowa, przynosi nam jakiś wariant opowieści o „kochankach, których miłość nieszczęśliwy kres znalazła” - zupełnie tak samo, jak w „Dniu Czwartym” Dekameronu, swą żałosną i melancholijną aurą wyraźnie odmiennego od rubasznej tonacji „Dni” pozostałych.

Ale wpływ na konstrukcję filmu Langa, i to bardziej bezpośredni, miało też kino. Eric Rhode epizodyczną budowę Zmęczonej Śmierci uznaje za "analogiczną do formy serialu" ${ }^{41}$, co można motywować uprzednim doświadczeniem reżysera (Lang wcześniej zrealizował dwa odcinki serialu Pająi), jego związkami z Joe Mayem (w kinematografii niemieckiej jako twórca seriali May pełnił podobną rolę jak we francuskiej Louis Feuillade), wreszcie predylekcjami i typem wyobraźni Thei von Harbou. Bardziej jednak nobliwym, a poza tym zdecydowanie bezdyskusyjnym modelem dla Zmęczonej Śmierci, również wskazanym przez Rhode’a, jest Nietolerancja (Intolerance, 1916) Davida W. Griffitha - ambitny projekt, by poprzez przeplatanie ujętych $\mathrm{w}$ ramę narracyjną czterech historii $\mathrm{z}$ czterech różnych epok w dziejach, ukazać w filmie fabularnym „zmagania miłości na przestrzeni wieków z nienawiścią i nietolerancją".

Konstrukcja Nietolerancji wpłynęła na dwa europejskie filmy bezpośrednio poprzedzające Zmęczona Śmierć: zaginiony dziś film Friedricha Wilhelma Murnaua Satanas (1919) i jedno z wczesnych arcydzieł duńskiego mistrza Carla Theodora Dreyera Kartki z Księgi Szatana (Blade af Satans Bog, 1920). Oba te filmy były opowieściami o złu i zdradzie (w rozumieniu

40 Zob.: ibidem, s. 82-83. Paradygmatyczny jest tu oczywiście najsłynniejszy z weimarskich filmów - Gabinet doktora Caligari (Das Cabinet des Dr. Caligari, 1919) Roberta Wiene.

${ }^{41}$ Zob.: E. Rhode, op. cit., s. 172. 
metafizycznym i moralnym), obecnych $\mathrm{w}$ rozmaitych momentach historii ludzkości. W filmie Murnaua (ze scenariuszem Roberta Wiene) Satanas, uwodziciel i zdrajca, objawiał się w starożytnym Egipcie, w renesansowych Włoszech i w Niemczech podczas stłumionego powstania Związku Spartakusa w 1918 roku. W filmie Dreyera - artystycznie znakomitym, ale wyraźnie konceptualnie wobec dzieła Murnaua wtórnym - zdrady szatana miały miejsce w epoce Jezusa, w czasach hiszpańskiej inkwizycji, podczas rewolucji francuskiej i w trakcie wojny bolszewicko-fińskiej w $1918 \mathrm{r}$. I żeby nie było żadnych wątpliwości co do ideowej orientacji i aksjologii obu dzieł: w ostatnim epizodzie każdego z nich szatan pojawiał się jako fanatyczny rosyjski bolszewik ${ }^{42}$.

Między Zmęczona Śmiercia a wymienionymi filmami, z racji ramy i wewnątrzramowych historii z różnych epok nieodparcie nasuwającymi się jako jej inspiracja, zachodzą jednak istotne różnice. Po pierwsze, gdy w tamtych dziełach centrum sjużetu i punkt ciężkości narracji stanowią opowieści wewnątrzramowe, w filmie Langa zdecydowanym centrum pozostaje opowieść obramowująca. Po drugie, relacje między "nowelami” a ramą są w Zmęczonej Śmierci i bardziej zawiłe, i bardziej niejednoznaczne - epizody, jak się wydaje, nie „ilustrują" jednak pewnej ogólnej kategorii, jaką w tamtych filmach były "zło" czy "nietolerancja”, ale pozostają $\mathrm{w}$ dialektycznej relacji do psychologii i zachowania postaci z historii ramowej. Brak tu też (jeśli nie całkowicie, to przynajmniej w tym samym stopniu, co tam) „przesłania”: czy to klarownie wynikającego z zestawienia i przebiegu fabularnego poszczególnych historii, czy też expressis verbis formułowanego. A jeśli nawet uznać za takowe finałową sentencję: „Kto odda swoje życie - zyska je", to po refleksji osadzonej w materii filmu, trzeba stwierdzić, iż jest to fałszywy trop ${ }^{43}$, a może też - wyraz „fałszy-

${ }^{42}$ Informacje nt. filmu Murnaua znalazłem w: T. Elsaesser, Weimar Cinema and After..., s. 224-225; Casper Tybjerg, Red Satan: Carl Theodor Dreyer and the Bolshevik Threat, [w:] Nordic Explorations: Film Before 1930, eds. John Fullerton and Jan Olsson, John Libbey \& Company Pty Ltd., Sydney 1999, s. 35. Tybjerg wskazuje też (ibidem, s. 20-21) jeszcze jedno możliwe źródło obu filmów, bardziej bezpośrednie niż Nietolerancja: zaginiony dziś film włoski Satana (1912) w reż. Luigiego Maggiego, opisujący działalność szatana w czterech momentach - w Ogrodzie Eden, podczas wydania na śmierć Jezusa, w średniowieczu, gdy pewien mnich wynalazł mocny trunek i współcześnie, kiedy on jest socjalistycznym (sic!) podżegaczem do walki klasowej między robotnikami a kapitalistami. Kto wie, czy film ten nie wpłynął i na Nietolerancję (wiadomo, iż Griffith inspirował się kinem włoskim). We wszystkich wymienionych filmach „ramowych” zwraca uwagę obecność wymiaru religijnego i ich polityczny konserwatyzm.

${ }^{43} \mathrm{Na}$ ten fałszywy trop - narzuconą przez ów aforyzm filmowi, a zwłaszcza jego finałowi, interpretację w duchu „chrześcijańskiego poświęcenia” i „humanizmu” - dali się nabrać nie tylko Adam Garbicz i Jacek Klinowski (Kino, wehikuł magiczny: Przewodnik osiagnięć filmu fabularnego. Podróż pierwsza 1913-1949, Wydawnictwo Literackie, Kraków 
wej świadomości" scenariusza, który w swej istotnej w y mo w i e wcale do tej chrześcijańskiej konkluzji nie wiedzie (w odróżnieniu od tamtych filmów brak bowiem Zmęczonej Śmierci obecności religii jako wyrazistego horyzontu aksjologicznego). Po trzecie wreszcie - podstawowym problemem widza tego filmu jest trudność określenia granic między ramą a tym co obramowane oraz sprzeczność wskazówek tekstualnych odnoszących do tego, c o naprawdę zaszło w świecie przedstawionym, a także kiedy i gdzie (w trakcie odbioru nie ma się problemu ze zrozumieniem; sprzeczności - i to liczne - ujawnia refleksja analityczna). Rezultat jest wprawdzie artystycznie intrygujący, ale zarazem zacieraniem granic między jawą i snem, projekcją i rzeczywistościa, historycznością i wiecznością, Zmęczona Śmierć zaciera też granice między miłością a egoizmem, samobójstwem a poświęceniem, życiem a śmiercią. A to doprawdy nie jest ideowo niewinne.

Spróbujmy zatem zaprezentować możliwie klarownie układ zdarzeń fabularnych: dyliżans, którym podróżują Dziewczyna i Chłopiec (nie znamy ich imion), zatrzymuje tajemniczy nieznajomy w czarnym płaszczu i kapeluszu z szerokim rondem. Podróżująca dyliżansem stara kobieta z gęsią w koszyku pospiesznie opuszcza pojazd. Wejście nieznajomego budzi lęk młodych i sprawia, że przestają radośnie oddawać się pieszczotom, jak czynili to przedtem. Narracja dość arbitralnie przenosi nas z dyliżansu na rynek "miasteczka zagubionego w przeszłości” (najprawdopodobniej, sądząc po strojach i rozmaitych szczegółach, w epoce romantycznej, gdzieś na początku XIX w.). W gospodzie „Pod Jednorożcem” przebywaja, jak co wieczór, miejscowi notable: burmistrz, pastor, lekarz, notariusz i nauczyciel. Tematem ich dyskusji jest przybyły niedawno do miasteczka tajemniczy nieznajomy, którego znamy już jako pasażera dyliżansu. Retrospekcja (to właśnie pierwsza, na ogół niepamiętana przez streszczających film, komplikacja narracyjna historii ramowej) ukazuje, jak nieznajomego jako pierwszy ujrzał na cmentarzu grabarz, jak nieznajomy hojnie sypnął złotem radzie miejskiej, chcąc nabyć teren koło cmentarza („,aby założyć tam ogród, gdyż jest zmęczony i pragnie odpocząć”) i jak przeraził miejscowych notabli fakt, że nieznajomy otoczył nowo nabytą posiadłość bezkresnym murem, w którym nie można było znaleźć żadnej furtki, bramy czy innego wejścia.

Na rynek miasteczka przybywa dyliżans. Dziewczyna i Chłopiec, a za nimi nieznajomy, udają się do gospody. Nieznajomy dosiada się do ich

1981, s. 60), ale także tacy wytrawni tropiciele fałszywej świadomości i znaczeń symptomatycznych, jak Siegfried Kracauer (Od Caligariego do Hitlera: Z psychologii filmu niemieckiego, przeł. Wanda Wertenstein i Eugenia Skrzywanowa, Warszawa 1958, s. 80) czy Lotte H. Eisner (Fritz Lang, s. 51). 
stolika. Oberżystka nakazuje zakochanym wspólne napicie się z „pucharu miłości”. Próba „na sucho” nie bardzo im się udaje, a gdy próbują drugi raz, już z czarami napełnionymi winem, Dziewczyna tłucze puchar (przeraziła się swą wizją, w której należąca do nieznajomego szklanka piwa zmieniła się w klepsydrę, a główka jego laski rzuciła na stół cień kościotrupa). Dziewczyna, pod pretekstem zmycia plamy po rozlanym winie, udaje się do kuchni, gdzie bawi się pieskiem i kotami. Pod jej nieobecność nieznajomy badawczo patrzy na Chłopca, który czuje się nieswojo pod tym wzrokiem. Wydaje się, że nieznajomy swą szklanką („,klepsydralną") wznosi zań toast. Gdy Dziewczyna, z pieskiem w ręku i kotem na ramieniu, wraca do stolika, nikogo już przy nim nie ma. Od notabli przy drugim stole dowiaduje się, że jej ukochany wyszedł z nieznajomym. Rozgorączkowana wybiega z gospody na rynek, a następnie „poza miastem, w świetle księżyca, błąka się w poszukiwaniu ukochanego" (tak głosi napis; obraz ukazuje nam ja, jak obserwowana przez puszczyka, idzie niepewnie wzdłuż cmentarnego muru).

W tym samym czasie herold obwieszcza kolejną godzinę (zdaje się, dziesiątą) ${ }^{44}$, gospodę opuszczają pijani notable, a aptekarz szuka „pewnych ziół, które muszą być zbierane w świetle księżyca". U stóp nieskończonego muru, którym otoczył swą posiadłość nieznajomy, Dziewczyna zaznaje wizji: pochód widmowych osób przenika przez ścianę. Dziewczyna uświadamia sobie ze zgrozą (widzimy jej rozszerzone z przestrachu oczy), że to zmarli, a za nieprzeniknionym dla żywych murem rozpościera się dziedzina Śmierci. Wśród zmarłych jest też widmo jej ukochanego Dziewczyna na próżno wyciąga doń ręce, klęka: po krótkim zatrzymaniu się widmo wraz z innymi przenika za mur. Dziewczyna pada zemdlona. Odnajduje ją aptekarz (właśnie znalazł mandragorę) i zabiera do swego niesamowitego domu, gdzie prócz rozmaitych szpargałów i specyfików jest też wypchany puszczyk, szkielet i siedzący na jego czaszce kruk ${ }^{45}$. Gdy aptekarz z krukiem na ramieniu przygotowuje jej w kuchni „kojący napój", Dziewczyna otwiera leżącą przed nią Biblię, czyta i wyrywa z kontekstu słowa z Pieśni nad Pieśniami (8, 6): Miłość jest silna jak śmierć. Zainspirowana, sięga po flakon z trucizną. Gdy naczynie ze śmiercionośnym specyfikiem zbliża do ust, ujęcie zegara i okrzyk miejskiego herolda na rynku obwieszczają godzinę jedenastą.

${ }^{44}$ Wnioskuję z przebiegu akcji i z rozmaitych kontekstów, iż wybija dziesiąta. Tym razem ani zegar, ani tekst herolda (jak trzykrotnie później), nie informuje widza o godzinie.

45 Ze względu na alegoryczne (symboliczne) konotacje określam ptaka aptekarza jako kruka (Corous corax), choć wydaje się on zdecydowanie za mały. Zdaje się, iż podczas realizacji kruka zagrał bardzo do niego podobny, ale znacznie mniejszy czarnowron (wrona czarna, Corvus corone). Jako kruka (raven) określa ptaka także Tom Gunning (op. cit., s. 26). 
Po przenikaniu Dziewczyna znajduje się w dziedzinie Śmierci (jest to przenikanie w podwójnym sensie tego słowa - jako chwyt filmowy i jako bezproblemowe, nietrafiające na materialne przeszkody znalezienie się w jakimś miejscu). W połowie monumentalnych schodów czeka na nią nieznajomy, którego tożsamość jest ostatecznie zdefiniowana: to Śmierć. Dziewczyna pyta ją o powód zabrania ukochanego. "Jego godzina nadeszła" - odpowiada Śmierć i prowadzi ją do komnaty pełnej płonących świec. „To są żywoty ludzkie: płoną krótko i gasną gdy taka jest wola Boga" - objaśnia Dziewczynie Śmierć i demonstruje to na przykładzie: płomień świecy zmienia się w rękach Śmierci w nagie niemowlę, a obraz "skądinąd", z jakiejś innej, ziemskiej przestrzeni, ukazuje Dziewczynie rozpaczającą nad ciałem dziecka matkę. Śmierć zwierza się ze swego zmęczenia wypełnianiem przykrego obowiązku, ale sugeruje konieczność swego posłuszeństwa wyższej instancji. „Czy nie ma żadnej możliwości pokonania ciebie, Śmierci? Nauczono nas, że miłość jest sil ni ejs z a niż śmierć" - pyta Dziewczyna, w swym życzeniowym myśleniu przekręcając tekst biblijny. Świadoma tego Śmierć, traktuje słowa dziewczyny jako wyzwanie i proponuje targ: „Spójrz na te trzy dogasające świece. Jeżeli potrafisz choć jedną z nich uratować, oddam ci twojego ukochanego". Następują teraz trzy historie, z których każda osadzona jest "gdzie indziej” i chyba też „kiedy indziej”.

"Historia pierwszej świecy” rozgrywa się w świecie muzułmańskim w trakcie Ramadanu. W meczecie nieopodal gwarnego rynku stolicy kalifatu trwają modły: „Nie ma boga prócz Allaha, a Mahomet jest jego prorokiem" - woła mułła, a derwisze pogrążeni są w ekstatycznym tańcu. Siostra kalifa, Zobaida, z przerażeniem konstatuje, że jej ukochany, Frankończyk, wkradł się w przebraniu do świątyni, co w razie odkrycia - jako iż jest on "niewierny” - grozi obojgu zgubą. Jeden z derwiszów zauważa go, wykrada się z sali modłów i zaczajony na wychodzącego Frankończyka, zdziera z niego przebranie, demaskując go. Denuncjator zwołuje tłum wiernych, którego napór udaje się ukochanemu Zobaidy przez jakiś czas powstrzymać. Ucieczkę umożliwia mu jednak bohaterska interwencja Zobaidy, która własną osobą zagrodziła na krótko drogę ścigającym: "Cofnąć się! Nie splamicie tego świętego miejsca krwią niewiernego!" Derwisz-donosiciel powiadamia o zajściu kalifa i nakłania go do podstępu wobec siostry, by odkryć kryjówkę niewiernego. Zobaida udaje wobec kalifa obojętność na los uciekiniera, na co kalif obwieszcza, iż jego ludzie są już na tropie niewiernego. Po odejściu brata Zobaida wysyła swą sługę, Ayeshę, do kryjówki Frankończyka, by ściągnąć go wieczorem do pałacu, jedynego - jak sądzi - bezpiecznego miejsca. Ale to właśnie gubi ukochanego, gdyż Ayesha jest śledzona. Gdy Ayesha wymykała się z misją ogrodnik El Mot kopał coś w ogrodzie. Kalif rozkazuje otoczyć 
wieczorem pałac, tak by każdy mógł doń wejść, nikt zaś opuścić. Po wejściu na dach pałacu przy pomocy Ayeshy, Frankończyk udaje się do komnat Zobaidy, ale zaraz musi uciekać. Zostaje schwytany przez ludzi kalifa (broniąc się, zabił z rewolweru kilku napastników). Władca zaprasza siostrę na dach, ta zaniepokojona jest odgłosami kopania nocą w ogrodzie. Z pełną sadyzmu ironią kalif mówi siostrze, iż "ogrodnik El Mot przygotował dla niej niespodziankę". Przerażona Zobaida zbiega na dół i odkrywa iż jej ukochany został żywcem zakopany w grobie, który wykopał dlań El Mot. Oparty na szpadlu ogrodnik zmienia się (po przenikaniu) w znaną już nam Śmierć. Pierwsza ze świec dogasła.

„Historia drugiej świecy" osadzona jest w renesansowej Wenecji podczas karnawału. Monna Fiametta wydaje się w upojeniu i zachwycie obserwować ze swego balkonu karnawałowe bachanalia - błazeńskiego króla o fallicznym nosie, triumf bachantki z obnażoną piersia, radosne korowody roztańczonych postaci. Fiametta wyjmuje zza gorsu różę, czule ją wącha i upuszcza. Kwiat chwyta stojący u stóp balkonu jej ukochany, Messer Giovanfrancesco. Na balkon przybywa Girolamo - członek władz Wenecji, człowiek kochający ją ale przez nią znienawidzony. Jego powitanie Fiametta przyjmuje ze wstrętem. Dotknięty Girolamo daje do zrozumienia, iż życie jego rywala nie będzie trwalsze niż podarowana mu róża: Giovanfrancesco wzbudził podejrzenia Rady Czternastu i nie przeżyje najbliższego wschodu słońca. „Jestem najlepszym szermierzem w całej Radzie, a w karnawale tak łatwo wszcząć kłótnię. Wiem, że mnie nienawidzisz, Monno Fiametto. Ale mam nadzieję, że po naszym weselu będziesz posyłać uśmiechy i róże mnie, a nie jemu, który już wtedy będzie martwy i pogrzebany" - mówi na odchodne Girolamo. Zdesperowana Fiametta knuje intrygę. Wręcza posłańcowi dwa listy: jeden do Girolama, wyznaczający mu schadzkę o dziesiątej wieczorem, drugi do ukochanego, ostrzegający go o wyroku Rady i informujący, że zastawiła na Girolama śmiertelną pułapkę (treść obu listów poznajemy dopiero poźniej razem z Girolamem). Fiametta wzywa przez swą sługę Maura, którego odrywa od pasjonujących go walk kogutów. Girolamo, nie bardzo wierząc w szczerość pozdrowień Fiametty i podejrzewając w schadzce podstęp, pyta posłańca, czy nie ma jeszcze innego listu. Gdy ten zaprzecza, Girolamo wysyła za posłańcem swych zbirów. Fiametta w tym czasie instruuje Maura, jak ten, ukryty w miejscu schadzki za kotara, ma ugodzić zatrutym ostrzem sztyletu jej wroga. Zbiry Girolama zabijają posłańca Fiametty, a Girolamo poznawszy treść przechwyconego listu do rywala, postanawia go zgubić, posyłając mu ten, który jego samego miał zwabić w pułapkę. List ten, a także karnawałowe przebranie człowiek Girolama wręcza Messerowi Giovanfrancesco koło fontanny (chwilę wcześniej rozpadła się ukochanemu Fiametty doglądana 
przezeń z troską róża). O dziesiątej w miejscu schadzki przebrana i zamaskowana Fiametta wyzywa na szpady przebranego i zamaskowanego Giovanfrancesca, myśląc, iż to zwabiony w zasadzkę Girolamo. Podprowadza go pod zatrute ostrze Maura i dopiero gdy ukochany wydaje śmiertelny okrzyk, uświadamia sobie tragiczne qui pro quo. Zrywając maskę, rzuca się na osuwające się ciało Giovanfrancesca. Po przenikaniu Maur-zabójca zmienia się w znaną już nam figurę Śmierci. Druga z trzech świec dogasła.

"Historia trzeciej świecy" rozgrywa się w Chinach, całkowicie fantastycznych, nieewokujących jakiejś konkretnej epoki historycznej. Czarnoksiężnika A Hai niepokoi list od cesarza, żądający w prezencie urodzinowym nieoglądanych dotąd magicznych sztuczek i grożący śmiercia, gdyby tej zachcianki nie udało się mu spełnić. Para młodych asystentów czarodzieja, Tiao Tsien i Liang, pogrążona w swych miłosnych rytuałach, nie słyszy wezwań mistrza i z długim ociąganiem stawia się, by spełnić jego polecenie dostarczenia mu jego najlepszej różdżki z jadeitu. A Hai, pokrzepiony posiadaniem różdżki, z niekłamaną satysfakcją „uwalnia się od przyczyny swych zgryzot” (jak głosi napis), wysyłając długi zwój cesarskiego listu gdzieś w przestworza. Z parą swych młodych pomocników czarodziej przybywa na dwór cesarza na latającym dywanie. Nawet bijąc przed groźnym władcą korne pokłony, Tiao Tsien i Liang ukradkowo wymieniają pocałunek. Prezentem dla cesarza (postaci obrzydliwej i karykaturalnej) jest wyczarowana przez A Hai miniaturowa armia - cesarz łaskawie chwali dar, ale żąda też wręczającej mu dar Tiao, która ze wstrętem przyjmuje pieszczotę jego długich szponów. Zafrasowany A Hai proponuje cesarzowi w zamian drugi prezent, czarodziejskiego rumaka - władca łaskawie i ten dar przyjmuje, nie rezygnując jednak z dziewczyny i wymownie wskazując znajdującego się na dziedzińcu kata z olbrzymim mieczem, gdyby A Hai dalej się upierał, że Tiao Tsien jest mu niezbędna jako asystentka. „Synu Niebios, twoja sztuka perswazji jest niepokonana” - z westchnieniem ulega czarodziej. Nie poddaje się jednak Liang, który odważa się porwać ukochaną. Szybko pojmanego Lianga cesarz rozkazuje uwięzić w najwyższej pagodzie, a nazajutrz ściąć. Cesarz odwiedza trzymaną pod strażą Tiao Tsien, lecz ta ponownie odtrąca jego umizgi, zamierzając się nań szpilką od włosów. Upartą dziewczynę odwiedza również z namowy cesarza A Hai. Gdy odmawia on swej pomocy w uwolnieniu Lianga, Tiao Tsien kradnie mu różdżkę z jadeitu. Dzięki mocy różdżki zamienia ona A Hai w kaktus, strzegących ją strażników w świnie, a pagodę z uwięzionym Liangiem w słonia, którym razem uciekają i który budzi popłoch wśród straży. Ludzie cesarza wyruszają za nimi w pościg. Wkrótce kochankowie muszą zrezygnować z jazdy na słoniu, gdyż 
górska ścieżka stała się zbyt wąska (Tiao czarami powoduje zniknięcie słonia). Dziewczyna zauważa, że różdżka z każdym jej użyciem stopniowo zanika, stając się coraz mniejsza. Gdy pościg jest już bardzo blisko, Tiao Tsien wzywa na pomoc demony ognia, które ścigającym zagradzają drogę płomieniami. Cesarz rozkazuje swemu łucznikowi wyruszyć na otrzymanym od A Hai czarodziejskim rumaku i sprowadzić uciekinierów żywych lub martwych. Kiedy kochankowie zauważają nadciągającego rumaka, ostatnim czarem niknącej różdżki Tiao zamienia siebie w posąg wieloramiennej bogini, a Lianga w spoczywającego u jego stóp tygrysa. Niezwiedziony łucznik (o znanym nam obliczu Śmierci) strzela do tygrysa, a strzała przeszywa Lianga, w którego na powrót zmieniło się zwierzę. Po twarzy posągu spływa łza. I trzecia świeca dopaliła się, jak dwie poprzednie.

Komnata świec. Dziewczyna, jakby po przebudzeniu z letargu, nie słucha polecenia Śmierci: „Wracaj do żywych - i żyj!”, lecz błaga ponownie Śmierć o oddanie jej ukochanego. Śmierć daje jej ostatnią szansę: jeżeli w ciągu godziny dostarczy ona w zamian za Chłopca jakieś inne życie, z nieprzeżytymi jeszcze latami lub choćby godzinami, dostanie ukochanego z powrotem. Na zegarze wybija godzina jedenasta, herold obwieszcza ją swym wołaniem mieszkańcom miasteczka. Wracający z kuchni z „,kojącym napojem" aptekarz odtrąca od ust Dziewczyny kieliszek ze śmiercionośnym specyfikiem. Dziewczyna zwierza się, że chciała pójść za ukochanym, którego zabrała jej śmierć. Nagle, jakby olśniona swą myślą, zwraca się do aptekarza: „Starcze, rozkoszowałeś się życiem wystarczająco długo. Co może ci ono jeszcze zaofiarować? Daj mi swe życie! Daj mi te kilka dni, które jeszcze ci zostały - pomóż mi ocalić życie mojego ukochanego!" Przerażony aptekarz woła: „Ani dnia, ani godziny, ani jednego oddechu” i wyrzuca Dziewczynę z domu. Do godziny dwunastej pozostaje coraz mniej czasu. Tę samą odpowiedź Dziewczyna słyszy jeszcze dwukrotnie: gdy prosi o oddanie życia za życie jej ukochanego spotkanego na ulicy żebraka i staruszkę w przytułku-szpitalu. Żebrak jednak, który z nadzieją potakiwał, gdy Dziewczyna pytała go o chęć "skrócenia jego niedoli”, szczuje ją psem, uświadomiwszy sobie, że miała na myśli śmierć. Dla staruszki natomiast biadolenie, iż ,jest zmęczona życiem, a śmierć po nią nie chce przyjśćc było tylko retoryką zwyczajowego utyskiwania, a nie faktyczną gotowością poniesienia dla kogoś ofiary ze swego życia. Starzy ludzie w przytułku, widząc w Dziewczynie „wysłannika śmierci”, z popłochem przed nią uciekają po schodach na piętro. Jedna ze staruszek potyka się i gubi ogarek, od którego wkrótce cały przytułek staje w ogniu.

Dziewczyna wraz z innymi mieszkańcami miasta uczestniczy w akcji ratunkowej (pomaga wyjść jakiejś starszej osobie) i w gaszeniu pożaru, który mimo zaangażowania tłumu wydaje się wzmagać. Kobieta 
wyprowadzona jako ostatnia krzyczy, iż w płonącym domu pozostało jej dziecko. Dziewczyna, w kolejnym olśnieniu, upatruje w tym dla siebie następnej szansy. Wbiega na ogarnięte ogniem piętro, odnajduje dziecko, by je przekazać Śmierci, ale gdy ta wyciąga już po nie ramiona, Dziewczyna zmienia zdanie, powraca do okna i związawszy firanki, opuszcza dziecko na dół, przekazując je uszczęśliwionej matce. „Takiej ceny nie mogłam zapłacić. A teraz weź w zamian moje życie, ponieważ be z m oje g o u k ochanego nic ono dla mnie nie znaczy". Śmierć prowadzi ją do miejsca, gdzie leży ciało Chłopca. Dziewczyna kładzie głowę na jego ciele, pada na nie - po dotknięciu Śmierci już nieżywa. „Kto odda swoje życie, zyska je" (następujący teraz ów napis to tekst Śmierci czy aforyzm narracji?). $Z$ zewnątrz budynku widać, jak wali się płonący dach. Tłum przyklęka, rozumiejąc iż Dziewczyna zginęła. Śmierć z ciał Dziewczyny i Chłopca „wydobywa ich widma”, które wędrują za nią w jakąś rozświetloną pustą przestrzeń przypominającą łąkę. Godzina dwunasta na zegarze. Zwyczajowymi słowami obwieszcza kolejną nocną godzinę herold: „Słuchajcie ludzie, i pozwólcie sobie powiedzieć / Nasz dzwon wybił dwunastą / Strzeżcie ognia i świec, aby naszemu miastu / nie przydarzyło się żadne nieszczęście". W kontekście tego, co właśnie się w miasteczku stało, oraz faktu, iż obwieszczają godzinę wyznaczoną Dziewczynie przez Śmierć jako ostateczny termin (deadline), słowa te jawią się jako szczególnie gorzka ironia.

\section{Bycie-ku-miłości czy bycie-ku-śmierci?}

Echo Odysei w filmie Langa zaznacza się nie tylko wtedy, gdy Dziewczyna, niczym Odyseusz w Pieśni XI Homerowego eposu, odwiedza świat zmarłych, gdy Tiao Tsien, niczym Kirke, która rzuca czar na towarzyszy Odysa, zmienia w świnie strzegących jej więzienia wartowników, ale też w dwukrotnym ewokowaniu - dosłownie - objawionej w wierszu 8 Pieśni XXII przerażającej możliwości, że długa, a nawet nigdy nieprzebyta, może być droga "między ustami a brzegiem pucharu"46. A poza dwukrotnym dosłownie unaocznionym nam exemplum sławnej sentencji, Zmęczona Śmierć stawia nam jeszcze parokrotnie przed oczy inne sytuacje, których wymowa jest w gruncie rzeczy taka sama - daremne mogą być ludzkie projekty i przedsięwzięcia (vide: działania kochanków w „Historiach trzech świec”), gdy na ich drodze stanie Los. W ogóle koncepcja Losu w filmach Langa,

${ }^{46}$ W Odysei prawda ta odnosi się do Antinoosa, którego śmiertelnie ugodziła strzała Odysa właśnie wtedy, gdy podnosił do ust czarę z winem. Wydarzenie to rozpoczyna rzeź zalotników. 
ale w tym w szczególności, wydaje się antytezą koncepcji Opatrzności $n p . w$ utworach Dickensa (czy innych „naiwnych” powieściopisarzy lub dramaturgów), której przejawem w świecie przedstawionym są s z c z ę śli we (przynajmniej w długofalowej perspektywie) k o in c y d e n cje. W Zmęczonej Śmierci koincydencje wydają się tylko feralne, a Opatrzność (?) musi być chyba złośliwa i ponura, bo urzeczywistniają się jedynie intrygi osób zawistnych i złych, obmyślających czyjąś zgubę.

Pierwsze „wychylanie pucharu” ma miejsce w gospodzie „Pod Jednorożcem". Gdy oberżystka nakłania przybyłych właśnie Dziewczynę i Chłopca do wspólnego wypicia z pucharu miłości, „bo tak nakazuje tutejszy obyczaj", to mamy niewątpliwie do czynienia z metaforą aktu seksualnego. Młodzi przybyli do gospody wieczorem, prawdopodobnie tuż przed dziesiąta, i zapewne nie tylko na kolację. Oberżystka to choćby $\mathrm{z}$ racji swego zajęcia tradycyjna w literaturze figura rajfurki. $\mathrm{O}$ intencjach pary świadczy też, jak się zdaje, prolog w dyliżansie, tuż przed zabraniem do pojazdu Śmierci. Dziewczyna i Chłopiec siedzieli obok siebie z uszczęśliwionymi minami, roześmiani, ich dłonie były splecione. Patrzyli na gęś w koszyku, należącą do starszej pasażerki na przeciwległym siedzeniu. Gdy Śmierć zatrzymała dyliżans, właścicielka gęsi pośpiesznie go opuściła - nie wiadomo, wystraszona, z własnej inicjatywy, czy wyrzucona przez przerażającego pasażera (analiza kadrów, w których pasażerka wysiada, Śmierć wsiada, dopuszcza obie interpretacje). W każdym razie jej obecność była nie do pogodzenia z obecnością Śmierci - vis à vis młodych mogło się znajdować tylko jedno z nich. Ale zanim wysiadła, młodzi zupełnie nie przejmowali się jej obecnością (chyba drzemała), zwracając uwagę tylko na gęś. Zabierając się do całowania Dziewczyny, Chłopiec zarzucił ptakowi chustkę na głowę. W kontekście „alegorycznego" czy też „figuratywnego" stylu filmu (o którym - nieco dalej), gdzie elementy obrazu i fabuły na ogół są czymś więcej niż są per se, przy uwzględnieniu ich kulturowych konotacji (rozmaitej zresztą proweniencji), gest Chłopca zapewne jest też czymś więcej niż żartobliwym usunięciem powodów zawstydzenia Dziewczyny przez „pozbycie się” świadka amorów. Obecnością właścicielki ptaka Dziewczyna się nie przejmuje i Chłopiec może ją teraz całować bez oporu.

Ta krótka scenka wyrasta jednak ponad bycie zaledwie komiczną scenką rodzajową i wydaje się wielce znacząca, gdy zastosujemy symbolikę gęsi w kulturze chińskiej (pamiętajmy, że zarówno Lang, jak i Thea von Harbou, mocno interesowali się Orientem). Gęś - zazwyczaj kojarzona z symbolem małżeńskiej wierności, co w wypadku zakochanych też nie jest bez znaczenia - służyła w Chinach jako emblemat, który prezentowany przez młodego mężczyznę wybranej dziewczynie miał za zada- 
nie obniżyć jej obronność, defensywne taktyki seksualnej skromności ${ }^{47}$. W kontekście przełamania oporów Dziewczyny i jako prolog do „wspólnego wychylenia pucharu miłości", wyjaśnienie to istotnie usensownia banalny z pozoru, ale jednak eksponowany w narracji szczegó $1^{48}$.

Jak wiemy, do wychylenia pucharu w pełn i nie doszło. Gdy młodzi próbowali sztuki „na sucho”, byli bardzo nieporadni, a gdy już napełnili czarki winem, zręcznie skoordynowali dwustronne naczynie z własnymi ustami i co nieco nawet upili - przeszkodą okazała się wizja bohaterki. „Między ustami a brzegiem pucharu” dojrzała Dziewczyna atrybuty Śmierci. Kościotrup jest oczywistym emblematem Śmierci, zwraca jednak uwage przemiana w klepsydrę - szklanki piwa, przedmiotu banalnego i oferującego przyjemność, konsumpcję, upojenie (tak samo jak „puchar miłości"). I warto zauważyć, że klepsydra jest przecież rodzajem zegara - pierwszym "dziwnym” zegarem z wielu dziwnych czasomierzy w filmach Langa, prawdziwego obsesjonata czasu (zresztą tym dziwniejszym, że tą szklanką-klepsydrą po odejściu Dziewczyny "przepija” do Chłopca Śmierć).

Tom Gunning uważa momenty wizji, których doświadczają bohaterowie filmów Langa, za punkty zwrotne w ich intrydze. „Zazwyczaj są to momenty, kiedy postać przeziera przez powierzchnię rzeczy i osiagga wizję machiny Przeznaczenia (Destiny-machine) pulsującej pod spodem [...] Obrazy te nie są po prostu wizualizacją halucynacji czy fantazji. W filmach Langa są pierwszym momentem uświadomienia i interpretacji, lektury znaków, w trakcie której postać dostrzega prawdziwy mechanizm kontrolujący rzeczywistość. Ta lektura przeczy zwyczajnemu postrzeganiu rzeczy i zdumiewa postacie doświadczające wizji. Najczęściej wizje te alienują postać od jej poprzedniego odczuwania egzystencji" ${ }^{49}$. Ujęcie ukazujące wizję Dziewczyny jest subiektywne, zachowuje jej fizyczny punkt widzenia (figura „POV” - point-of-view shot). Jest ono bardzo krótkie, niemal na krawędzi percepcji, ale bliski plan i kulturowa oczywistość emblematów klepsydry i kościotrupa z kosą nie pozwalają mieć najmniejszej wątpliwości, że tym, co zarówno widz, jak i bohaterka, odczytali w wizyjnym „rebusie”, jest obecność Śmierci.

Dziewczyna opuszcza Chłopca, by „zmyć plamę”. Jest to pretekst, gdyby chodziło tylko o plamę na sukni po rozlanym winie, ale zarazem po-

47 Por.: Jean Chevalier and Alain Gheerbrant, A Dictionary of Symbols, transl. John Buchanan-Brown, Penguin Books, London-New York 1996, s. 445.

48 Thomas Elsaesser widzi w zakryciu głowy i szyi gęsi (,aż nazbyt fallicznych") oznakę odczuwania przez Dziewczynę winy z powodu wykroczenia, seksualnej transgresji (zob.: Weimar Cinema and After..., s. 85).

${ }_{49}$ T. Gunning, op. cit., s. 22. Gunning ważność wizji w filmach Langa i ich alegoryczny charakter uwypuklił podtytułem swej książki: Allegories of Vision and Modernity. 
wód prawdziwy, jeśli uwzględnimy konotacje "plamy" i zmieszanie Dziewczyny. Doświadczenie aktu seksualnego, „picia z pucharu miłości”, rodzi poczucie winy z powodu transgresji (jeśli nie jest to akt legalny, ale schadzka w gospodzie), na dodatek zaś przynosi traumę: objawienie przemijalności istnienia (klepsydra!), lęk przed rozłąka, a zarazem poczucie jej nieuchronności. Peter Sloterdijk zwraca uwagę na obecny w literaturze i sztuce Republiki Weimarskiej "postkoitalny smutek”, aurę melancholii, brak nadziei i odczuwanie wspólnej przyszłości jako niepewnej, gdy kochankowie są już „po" ${ }^{50}$. Rzecz jasna, w Zmęczonej Śmierci mamy do czynienia jedynie $\mathrm{z}$ alegoryczną reprezentacją aktu miłosnego, ale aura ujęcia w planie ogólnym, w którym Dziewczyna tłumacząc się, odchodzi od stołu do kuchni, jest posępna, melancholijna i typowo „weimarska” (knajpa!). Co prawda pamiętajmy i o tym, że akt miał miejsce i nie miał zarazem. Jego świadectwem jest plama, jego niespełnieniem czy też nieudaniem - rozbicie pucharu, a jego obecnościa/nieobecnością w tekście - figuratywna prezentacja. Logika arystotelesowska wydaje się jednak nie obowiązywać przedstawień alegorycznych, o czym jeszcze dobitniej świadczy moment, gdy Dziewczyna niezadługo zbliży do swych ust inny "puchar".

W kuchni Dziewczyna bawi się zwierzętami - są to piesek, mały kociak i duży kot, prawdopodobnie jego matka. W cieple i puszystości zwierząt Gunning upatruje swego rodzaju fetyszystycznej obrony przed chłodnym powiewem Śmierci ${ }^{51}$, ale wydaje mi się, że można też ujrzeć w tym remedium na uprzednią traumę Dziewczyny w postaci alegorycznej wizji macierzyństwa, któremu Dziewczyna oddaje się z radością. W każdym razie to z wielką kotką na karku - matką jak ona in spe - wraca do stolika, by zaprezentować się ukochanemu w nowej, choć na razie tylko hipotetycznej roli. Sądzę, że ta interpretacja jest tym bardziej uprawniona, że w całym filmie rozsiane są sygnały, które każą widzieć jako symboliczną referencję Dziewczyny właśnie figurę zrozpaczonej Matki, a nie tylko Kochanki. Lotte Eisner wskazuje na podobieństwo jej poszukiwania Chłopca w świecie i zaświatach do fabuły baśni Andersena Opowiadanie o matce ${ }^{52}$. W komnacie świec, metaforycznie reprezentujących ludzkie istnienia (to z kolei obraz przejęty przez Langa i Theę von Harbou z innej baśni - Kuma Śmierć braci Grimm) ${ }^{53}$, Śmierć unaocznia Dziewczynie swą władzę, zabierając

${ }^{50}$ Peter Sloterdijk, Critique of Cynical Reason, transl. Michael Eldred, University of Minnesota Press, Minneapolis-London 2001, s. 515-520.

51 Por.: T. Gunning, op. cit., s. 25.

${ }_{52}$ Hans Christian Andersen, Opowiadanie o matce, [w:] idem, Baśnie, przeł. Stefania Beylin, Jarosław Iwaszkiewicz, Państwowy Instytut Wydawniczy, Warszawa 1959, t. 1, s. 418-423. Por.: L. H. Eisner, Fritz Lang, s. 43-44.

${ }^{53}$ Kuma Śmierć, [w:] Baśnie domowe i dziecięce, zebrane przez braci Grimm, przeł. Emilia Bielicka i Marceli Tarnowski, Ludowa Spółdzielnia Wydawnicza, Warszawa 1987, t. 1, s. 209-213. 
dziecko matce, co wydaje się szczególnie ją poruszać. Wreszcie w finale, mając już w rękach znalezione w płonącym budynku niemowlę, nie decyduje się dobić swego targu ze Śmiercią i przekazuje dziecko matce. Momenty te pokazuja, iż macierzyńska struna w duszy Dziewczyny, choć matką (jeszcze) nie jest, okazuje się jakoś szczególnie tkliwa.

Dziewczyna, tak nieomylna w rozwiązaniu alegorycznych emblematów śmierci, nie potrafi zrozumieć jej realistycznej reprezentacji w postaci znanej każdemu z własnego doświadczenia n i e o b e c n o ś c i osoby zmarłej, pustego miejsca po niej. Puste miejsce przy stoliku, które zajmował ukochany, wydaje się czymś nie do pojęcia i nie do ogarnięcia. Śmierć jako a bs en cja, jako pus te mi ej s ce, znajdzie jeszcze raz w dziele Langa przejmujący wyraz w $M-$ mordercy: w bardzo podobnym obrazie miejsca przy stole $n$ i e z a j ę t e g o przez zamordowaną Elsie Beckmann ${ }^{54}$ oraz we wcześniejszej metonimicznej reprezentacji samej zbrodni poprzez obraz toczącej się w trawie piłki i zaplątanego w przewody balonika, należącego do ofiary. Dojmujące uczucie b r a k u, doznawane przez osobę pogrążoną w żałobie, powinno zostać przezwyciężone po dokonaniu tzw. pracy żałoby, której zwieńczeniem $\mathrm{w}$ wypadku osoby normalnej jest zwycięstwo zasady rzeczywistości i powrót do normalnego życia bez osoby utraconej ${ }^{55}$.

Zygmunt Freud w artykule Żałoba i melancholia (Trauer und Melancholie) tak opisuje pracę żałoby (Trauerarbeit): „Badanie rzeczywistości wykazało, że ukochanego obiektu już nie ma i narzuca oto wymóg wycofania całego libido z powiązań z nim. Przeciwko temu rodzi się zrozumiały opór - można powszechnie zauważyć, że człowiek niechętnie opuszcza daną pozycję libido, nawet jeśli jawi mu się możliwość jej zastąpienia. Opór ten może być tak intensywny, że zachodzi odwrócenie od rzeczywistości i zatrzymanie obiektu przez halucynacyjną psychozę życzeniową. Normą jest zwycięstwo uznania rzeczywistości. Ale zadanie to nie może zostać spełnione natychmiast. Wykonywane jest ono w poszczególnych wypadkach dużym nakładem czasu i energii, a w tym okresie trwa psychiczna egzystencja utraconego obiektu. Każde ze wspomnień i oczekiwań, w których z obiektem wiązane było libido, zostaje zatrzymane, podlega superkateksji i libido zostaje z niego uwolnione. [...] bolesna przykrość [tego procesu - T. K.] wydaje się oczywista. W istocie jednak po dokonaniu pracy żałoby Ja staje się znów wolne i nieskrępowane" 56 .

${ }^{54}$ Podobieństwo to wskazuje Tom Gunning (op. cit., s. 25).

55 „Utratą", którą trzeba przepracować podczas żałoby, nie musi być śmierć; może to być też np. odejście niewiernego partnera, z którym też trzeba się pogodzić. Por.: Antoni Kępiński, Melancholia, Państwowy Zakład Wydawnictw Lekarskich, Warszawa 1974, s. 51-57.

${ }_{56}$ Zygmunt Freud, Żałoba $i$ melancholia, przeł. Barbara Kocowska, [w:] Kazimierz Pospiszyl, Zygmunt Freud - człowiek i dzieło, Ossolineum, Wrocław-Warszawa-Kraków 1991, s. 296. 
Wydaje się, iż bohaterka ramowej opowieści Zmęczonej Śmierci podobnej pracy nie dokonała, a co więcej, klęska jej Trauerarbeit zepchnęła ją w stan w psychiatrii zwany depresja, zaś przez Freuda, w ślad za wielowiekową tradycją - m e l a n ch ol i ą. Podążam tu za - trafną jak sądzę - interpretacją Gunninga. Tak diagnozując przypadek Dziewczyny, odradzał on jednocześnie traktowanie jej w interpretacji jako w pełni złożonej psychicznej osobowości, gdyż ani baśń (Märchen), ani forma alegoryczna (a film Langa jest jednym i drugim) nie konstruuje postaci w taki sposób. „Dla Freuda - zauważa Gunning - żałoba popada w melancholię, gdy żałobnik wobec osoby utraconej odczuwa pewną ambiwalencję, nierozwiązany psychologiczny konflikt". Ale z racji alegorycznego i baśniowego charakteru postaci i sytuacji nie warto stosować Freuda "do końca” i kusić się o próbę odpowiedzi, jaka to ambiwalencja bohaterki wobec ukochanego uniemożliwia jej skuteczną pracę żałoby ${ }^{57}$. Chociaż generalnie zgadzam się i z tą konkluzja, to chcę też zauważyć, iż objawem pewnej ambiwalencji Dziewczyny wobec Chłopca jest fakt, iż rozpoznawszy atrybuty Śmierci (a zatem mając „czarne przeczucie”), pozostawia go jednak sam na sam przy stoliku z posępnym nieznajomym: kochanka prawdziwie zatroskana (o ukochanego), a nie tylko zatrwożona (o siebie), tak by nie postąpiła.

Mitycznym wcieleniem żałoby nieutulonej w swym żalu, który znajduje ekspresję w m ela n ch oli j n ej poezji, jest Orfeusz. W literaturze klasycznej artystycznie ujęły rozpacz trackiego poety po utracie ukochanej żony Eurydyki dwa teksty: Owidiuszowe Przemiany (X, 1-86; XI, 1-84) i Wergiliuszowe Georgiki (IV, 455-509). Jako motto do prezentowanego tekstu o Zmęczonej Śmierci wybrałem właśnie fragment z Owidiusza, zawierający przemowę Orfeusza do bóstw podziemia, gdy zstąpił tam, by swymi skargami wyprosić oddanie Eurydyki. Tekst ten niemal modelowo ukazuje popadnięcie w melancholię wdowca, który nie dokonał swej Trauerarbeit i gotów jest popełnić samobójstwo, a może nawet już próbował targnąć się na życie (bo zreszta, czy nie tak w figuratywnych kategoriach należałoby traktować jego zstąpienie do piekieł?). Jego słowa, wieńczące przemowę do władców Hadesu:

Lecz gdybym nieszczęśliwy nie miał widzieć żony

Żyć nie chcę; tak choć śmiercią będę z nią złączony ${ }^{58}$.

- jako żywo przypominają słowa wypowiedziane przez Dziewczynę do Śmierci: „A teraz weź w zamian moje życie, ponieważ bez mojego ukochanego nic ono dla mnie nie znaczy".

\footnotetext{
57 Zob.: T. Gunning, op. cit., s. 27-28. Cytat ze s. 28.

58 Owidiusz, Przemiany, X, 39-40 (op. cit., s. 209).
} 
Podobieństwo ramowej opowieści w filmie Langa do Owidiuszowej wersji mitu o Orfeuszu zawiera się w fakcie zstąpienia żałobnika w krainę śmierci (czytaj: udaremnionej próbie samobójczej), szansie danej przez „władcę” tej krainy (niewykorzystanej) i krótkim, posępnym życiu po tym „piekłowstąpieniu”, które znajduje wreszcie upragniony kres. Kres ten i u Owidiusza, i w filmie Langa następuje w dość gwałtownych, apokaliptycznych okolicznościach: Orfeusza rozszarpują bachantki, mszcząc się za elegijną tonację jego pozbawionej witalności poezji, Dziewczyna ginie w pożarze, ale wcale nie "poświęcając swe życie za życie dziecka” (jak sądzi tłum na zewnątrz płonącego domu i nieuważni odbiorcy), a popełniając s a m o b ój s t w o. Zakończenie Orfeuszowej historii w Przemianach nieodparcie przywodzi obraz w finale filmu, Dziewczyny i Chłopca zaślubionych sobie przez Śmierć:

\footnotetext{
Orfej schodzi pod ziemię i poznaje strony

Widziane w owym czasie, gdy swej szukał żony.

Znajduje Eurydykę w schronieniu szczęśliwych

I sam jest już szczęśliwym w jej uściskach tkliwych.

Zostaje z nią na zawsze; tak z sobą złączeni

Przechodzą się oboje w zamieszkaniu cieni.

Ani srogie zakazy serca im nie ranią;

Może nie zagrożony oglądać się za nią ${ }^{59}$.
}

Historie Orfeusza, artysty, którego od melancholijnej depresji po utracie żony nie ocaliła nawet twórczość, i Dziewczyny z filmu Langa, której żałoba po ukochanym przerodziła się w samobójczą melancholię, klarownie podsumowuje następujący passus z traktatu Antoniego Kępińskiego, dotyczący „miłości utraconej”: "Człowiek, który stracił przedmiot miłości lub nigdy go posiąść nie zdołał, jest z reguły człowiekiem smutnym («kto nie kocha, tkwi w śmierci»); nie pomoże mu wyładowanie postawy twórczej. Postawy uczuciowe («do» $\mathrm{i}$ «od») są bowiem ważniejsze od postawy twórczej («nad») pod względem swego wpływu na poziom nastroju. Nierzadko ze stratą przedmiotu miłości życie traci też swój sens, staje się szare i puste. Takie przerwanie więzi emocjonalnej z tym, co nadaje koloryt życiu, może być przyczyną samobójstwa" ${ }^{60}$.

Dość niebezpieczna ideowo w filmie Langa wydaje mi się taktyka narracji, która rozmaitymi tekstualnymi wskazówkami (a raczej - zwodniczymi aluzjami, kreującymi nieprecyzyjną znaczeniowo „aurę") sugeruje "chrześcijańską wymowę" zarówno finalnego czynu Dziewczyny, jak i uprzednich jej gorączkowych poszukiwań Chłopca. Odkrycie przez

59 Owidiusz, Przemiany, XI, 59-66 (op. cit., s. 229).

${ }^{60}$ A. Kępiński, op. cit., s. 51. 
bohaterkę pustego miejsca przy stole, zapytanie notabli przy drugim stole $\mathrm{o}$ „ukochanego" (mein Liebster), wybiegnięcie na rynek i zapytanie żebraka o ukochanego, wędrówka w świetle księżyca, w porze kiedy nocną godzinę obwieszczał herold - wszystko to rozmaitymi szczegółami, zdarzeniami, kolorytem, odsyła do ustępu Pieśni nad Pieśniami (3, 1-3), w którym Oblubienica szuka Oblubieńca. Warto może tu fragment ten przytoczyć:

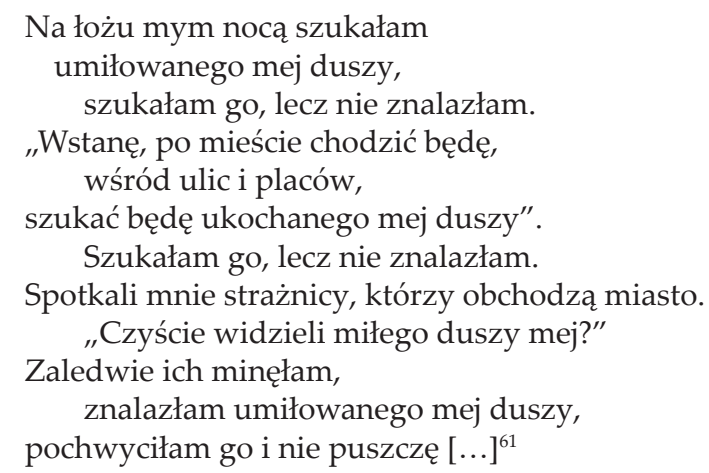

Dziewczyna także zaraz znajduje ukochanego - choć tylko jako widmo w korowodzie zmarłych, przenikające bezkresny mur dziedziny Śmierci. I choć w przeciwieństwie do biblijnej Oblubienicy nie mogła ukochanego "pochwycić", to "nie puszcza” go w tym sensie, iż tak przylgnie do uporczywej odmowy rozłąki z nim, że zakończy się to jej samobójstwem. Odnalezienie podobieństwa sekwencji wędrówki Dziewczyny do odnośnego ustępu biblijnego poematu nie jest jakąś nadinterpretacją. Naprowadza na nie dalszy ciąg, w którym Dziewczyna sięga po flakon z trucizną zainspirowana wyrwanym z kontekstu wersetem z Pieśni nad Pieśniami $(8,6)$ : „Miłość jest silna jak śmierć" ${ }^{\prime \prime}$. W dodatku trucizną tą - co nie jest pewne, ale co narracja wykreowała pełną aluzyjnych szczegółów aurą - jest mandragora, roślina w swych pozytywnych aspektach także wzmiankowana w Pieśni nad Pieśniami $(7,14)^{63}$. W takim kontekście

${ }^{61}$ Cyt. za: Pismo Święte Starego i Nowego Testamentu w przekładzie z języków oryginalnych (Biblia Tysiaclecia, wyd. 3 poprawione), Wydawnictwo Pallotinum, Poznań-Warszawa 1980, s. 749-750.

${ }^{62}$ W Biblii Tysiaclecia, z której korzystam, werset ten brzmi: „bo jak śmierć potężna jest miłość" (op. cit., s. 756).

63 „Mandragory sieją woń" - mówi Oblubienica Oblubieńcowi w odnośnym miejscu Pieśni nad Pieśniami. Bo mandragora, wedle wierzeń, to znany lubczyk (zapewnia miłość), afrodyzjak (zwiększa popęd płciowy) i środek koncepcyjny (zapewnia płodność, gwarantuje kobiecie poczęcie). Aby jednak działać magicznie i/lub leczniczo, musi być odpowiednio i pod kontrolą dawkowana - w przeciwnym razie jest silną trucizną działa nasennie i odurzająco (por.: Władysław Kopaliński, Słownik mitów i tradycji kultury, Państwowy 
stylizacja rozłąki bohaterów filmu na rozłąkę Oblubieńców z Pieśni nad Pieśniami, poematu, w którym miłość ma wymiar nie patologiczny, lecz teologiczny, jest po prostu nadużyciem, uzurpacją nieadekwatnego w danym kontekście sensu.

Interpretacja w duchu „samobójstwa po nieprzepracowanej żałobie przekształconej w melancholię" dużo sensowniej uspójnia przebieg zdarzeń fabularnych niż finałowa sentencja: „Kto odda swe życie - zyska je". Zdanie owo sugeruje "poświęcenie" Dziewczyny, co ona sama także nieco wcześniej podkreśla, mówiąc Śmierci po uratowaniu dziecka z płonącego domu: „Takiej ceny nie mogłam zapłacić. A teraz we ź w z a mian moje życie, ponieważ bez mojego ukochanego nic ono dla mnie nie znaczy". Ale w zamian z a k o g o? Smierć nie żądała dziecka, to Dziewczyna sama wpadła na pomysł ubicia z nią targu w taki sposób; zatem bohaterka nie musi uiszczać się Śmierci własnym życiem za uratowanie dziecka i oddanie go matce (swoją droga, jest to jeden $z$ dwóch, obok udziału w akcji ratunkowej, czynów Dziewczyny po zniknięciu Chłopca godny rzeczywiście pochwały i przywracający ją na chwilę zasadzie rzeczywistości). Gdyby zaś to jej życie miało być „wykupem” za ukochanego - na co z pewnością zdobyłaby się prawdziwa miłość, chrześcijańska caritas - to Śmierć zabrałaby ja przywracając życiu Chłopca. Tak jak to się dzieje w tragedii Eurypidesa Alkestis, gdy tytułowa bohaterka oddaje bóstwom podziemia własne życie za życie pozostawionego na ziemi męża, Admeta.

Mit o Alkestis jest w filmie Langa ewokowany przez trzykrotną odmowę innych osób (aptekarza, żebraka, staruszki z przytułku) oddania „w zamian” swego życia, choć jest ono u swego schyłku, jako że są to ludzie starzy i „bez przyszłości”. Podobnie u Eurypidesa - odmówili oddania swego życia za życie syna starzy rodzice Admeta ${ }^{64}$. Alkestis jednak, która nie odzyskuje męża, ale po prostu bezinteresownie ginie za niego, można chyba rzeczywiście uznać za uosobienie chrześcijańskiej caritas. W filmie Langa Dziewczyna słowami „w zamian” tak naprawdę uzurpuje sobie analogię swego samobójstwa do czynu bohaterki Eurypidesa,

Instytut Wydawniczy, Warszawa 1987, s. 646-647; J. Chevalier, A. Gheerbrant, A Dictionary of Symbols, s. 634). Użycie przez Dziewczynę właśnie mandragory w jej pierwszej próbie samobójczej wydaje się wielce prawdopodobne z racji jej podwójnego działania i podwójnej konotacji - Dziewczyna dąży do ukochanego poprzez śmierć. Na roślinę tę naprowadza widza również fakt, iż aptekarz tuż przed znalezieniem zemdlonej bohaterki znalazł mandragorę (widzimy jej nieomylny niby-ludzki kształt w dłoni aptekarza) i że szukał „pewnych ziół w świetle księżyca”. O tej porze, jako rośliny magicznej, pochodzącej rzekomo z nasienia wisielca, szuka się właśnie mandragory.

${ }^{64}$ Eurypides, Alkestis, 466-470 (zob. Eurypides, Tragedie, t. 1, przeł. Jerzy Łanowski, Państwowy Instytut Wydawniczy, Warszawa 1967, s. 85). 
a narracja ponownie "aurą" kreowaną niejasno przez rozproszone, niespójne z główną akcją szczegóły, uzurpację tę ułatwia - i to pomimo faktu, że jeszcze przed chwilą Dziewczyna była kimś w rodzaju „wysłannika śmierci", przed którym starzy ludzie uciekali w popłochu (melancholia, wynikła z nieprzepracowanej żałoby, może obrócić się nie tylko w popęd samobójczy, ale i w agresję wobec innych, co alegorycznie obrazują natarczywe prośby Dziewczyny o życie innych, a co wprost unaoczni żądza odwetu innej wdowy - Krymhildy w Nibelungach ${ }^{65}$. Przebrane za „bycie-ku-miłości” działania Dziewczyny są bowiem tak naprawdę „byciem-ku-śmierci", a nawet, jak pokazuje finałowa sekwencja ramy narracyjnej - „dla-śmierci".

\section{Władca dyskursu}

„Kto odda swoje życie - zyska je”. Nie bardzo wiadomo, komu przypisać wypowiedzenie tego zdania: Śmierci, która za chwilę „udzieli ślubu” parze umarłych bohaterów? Nadrzędnej instancji narracyjnej, podsumowującej w ten sposób wymowę całości? Być może zresztą odpowiedź jest prosta, jeśli, jak chce Gunning, „władcą dyskursu” jest w tym filmie śmierć. I to "śmierć" pisana małą litera już nie alegoryczna osoba, ale pesymistyczna i wszechogarniająca idea rządząca tym tekstem - i światem. "Aktywność lektury i interpretacji przywodzi [zarówno widza, jak i będącą jego "reprezentantem” w tekście Dziewczynę - T. K.] nie do w pełni obecnego autora, ale do pustego miejsca, którego imię jest śmierć, zmęczona śmierć" ${ }^{\prime 6}$.

Ta pesymistyczna konkluzja współbrzmi z posępnymi doświadczeniami zarówno autora (śmierć matki i żony), jak i z traumą narodu, który przegrał wojnę, czy wreszcie całego kontynentu, któremu dopiero co zakończona wojna zabrała miliony istnień (sam Lang, oficer armii austro-węgierskiej, był dwukrotnie poważnie ranny podczas działań wojennych $)^{67}$. Ale wydaje się, iż nawet takie doświadczenia nie motywują "pantanatyzmu” tego filmu w takim stopniu, jak jego odniesienie do rok wcześniej opublikowanej rozprawy Freuda Poza zasada przyjemności (Jenseits des Lustprinzips, 1920). O zainteresowaniu Langa i Thei von Harbou Freudem świadczy wyraźnie ich następny po Zmęczonej Śmierci film - Doktor Mabuse, gracz (1922), w którym tematyka psychoanalizy została podjęta wprost, choć może w parodystycznej formie. Tym bardziej

\footnotetext{
65 Por.: A. Kępiński, op. cit., passim.

${ }^{66}$ T. Gunning, op. cit., s. 33.

${ }^{67}$ Zob. na ten temat: Fritz Lang. Leben und Werke. Bilder und Dokumente, s. 22-26.
} 
można zakładać, że głośna i kontrowersyjna rozprawa z 1920 r. nie uszła ich uwadze.

Freud w tekście tej rozprawy sam wydaje się tak zaskoczony i niemal przerażony swymi tezami, iż formułuje je w sposób bardzo ostrożny, hipotetyczny, z licznymi zastrzeżeniami. Niemniej - tezy te zdumiały i zaszokowały świat. Otóż u podstaw generalnej ekonomii wszelkiego biologicznego istnienia jest popęd śmierci, dążenie do swoistej „homeostazy śmierci", pozbawionego napięć i nierównowagi spoczynku, który charakteryzuje stan materii nieożywionej i któremu na imię śmierć. Nie jest tak, wedle tez Freuda, iż przeciwwagą tego potężnego dążenia - nazwijemy je Thanatosem - jest Eros, popęd seksualny, wysublimowany przez poetów w miłość; jest on bowiem "popędem życia” tylko na poziomie genotypu, w aspekcie jego dążenia do oszukania popędu śmierci poprzez reprodukcję. Na poziomie zaś osobniczym zasada przyjemności rządząca libido, jak i w ogóle popędami ego, „zdaje się w ogóle pozostawać w służbie popędów śmierci" 68 .

W tekście Freuda, jako uczonego o pozytywistycznej w gruncie rzeczy proweniencji, brak horyzontu metafizycznego, choć konsekwencje własnych konkluzji wydają mu się niepokojące tym bardziej, że w znacznej mierze podważają jego wcześniejszą teorię. W filmie Langa popęd śmierci znajduje wyraz w historii Dziewczyny, która z "bycia-ku-miłości” przechodzi niepostrzeżenie w uporczywe, maniakalne "bycie-ku-śmierci”, oraz w ustanowieniu figury Śmierci „władcą dyskursu”.

Można powiedzieć, iż narracja filmu Langa zaczyna się wraz ze Śmiercią (postacią) i ze śmiercią (bohaterki) się kończy. Pierwsze trzy ujęcia filmu - zanim znajdziemy się wewnątrz dyliżansu naprzeciw oddanej amorom pary - przedstawiają zjawienie się ponurego osobnika w czarnym płaszczu i w kapeluszu z szerokim rondem w posępnym, chyba jesiennym krajobrazie, gdzie prócz bezlistnego drzewa stoją dwa krzyże. Nieznajomy wydaje się patrzeć na pojawiający się w ujęciu $3 \mathrm{w}$ planie ogólnym dyliżans, przekraczający most (jak wiemy, wkrótce zatrzyma on dyliżans i doń wsiądzie). W kontekście znajomości całego filmu dwa krzyże wydają się zapowiedzią dwóch śmierci, przekraczanie mostu - ewokuje przekraczanie granicy, sam zaś wygląd dyliżansu przywodzi na myśl raczej karawan.

Metafizyczny status nieznajomego podpowiada nam jego sposób zjawienia się w krajobrazie - pojawił się „znikąd”, po „mélièsowskim” tricku zatrzymania i ponownego uruchomienia kamery w tym samym miejscu

68 Zygmunt Freud, Poza zasada przyjemności, [w:] idem, Poza zasadą przyjemności, przeł. Jerzy Prokopiuk, Państwowe Wydawnictwo Naukowe, Warszawa 1975, s. 21-89 (cytowane słowa ze s. 88). 
- w tym czasie nastąpiła podmiana filmowanego obiektu ${ }^{69}$. Od tego momentu "nadzwyczajne" rozwiązania montażowe - tricki „mélièsowskie”, przenikania, podwójna ekspozycja (tzw. zdjęcia nakładane) - będą w narracji wyłącznym atrybutem i przywilejem Śmierci bądź oznaką „przynależności” innych postaci do jej dziedziny. W „mélièsowski” sposób w alegoryczną figurę w czarnym płaszczu zmieniają się El Mot i Maur - zabójcy „ukochanych” w historii pierwszej i drugiej świecy. Dziewczyna trafia do dziedziny Śmierci choć nie wiadomo, czy istotnie po zażyciu trucizny, to z pewnością po przenikaniu. Kombinacja zdjęć nakładanych i tricku „mélièsowskiego" unaocznia nam i Dziewczynie oderwanie przez Śmierć od świecy jej płomienia, a następnie jego przemianę w jej rękach w nagie niemowlę, które Śmierć zabiera jakiejś matce $\mathrm{w}$,jjakiejś innej przestrzeni". Widmowość postaci przechodzących przez nieprzekraczalny dla innych mur, osiągnięta za pomocą podwójnej ekspozycji, świadczy o ich statusie jako zmarłych, z czego zdaje sobie sprawę i widz, i jego reprezentant w tekście - przerażona ową wizją Dziewczyna (jest to drugi, po wizji w gospodzie, moment wizyjny, w którym bohaterka odkrywa przerażającą prawdę). Z martwych ciał Dziewczyny i Chłopca w finale Śmierć wydobywa ich „,widma”, by te wiodły wieczną egzystencję w jej zaświatowym królestwie - co unaocznia nam mistrzowska podwójna ekspozycja.

Przywilej Śmierci związany z "panowaniem” w narracji filmu nad tymi niezwykłymi rozwiązaniami wyrazowymi zostaje zakłócony w opowieści chińskiej, gdy A Hai i Tiao Tsien dzięki jadeitowej różdżce jakby uzurpowali sobie nad nimi władzę. Fabularny pretekst ich czarów jest okazją do obecności w narracji scen o niezwykłej, budzącej do dziś podziw inwencji technicznej, tych właśnie, które chciał przestudiować i prześcignąć zawistny Douglas Fairbanks. Niezwykle skomplikowany wariant tricku „mélièsowskiego", z kilkusetkrotnym (!), precyzyjnym ustawianiem na planie obiektu i filmowaniem go klatka po klatce, połączony z podwójną ekspozycja, zrodził pierwszy fascynujący czar różdżki A Hai - odesłanie w przestworza cesarskiego listu ${ }^{70}$. Dzięki podwójnej ekspozycji, a w innym ujęciu - monumentalnej scenografii, wyczarowana została miniaturowa armia, podarowana przez A Hai cesarzowi. Metamorfozy dokonywane przez Tiao Tsien (przemiana czarodzieja w kaktus, wartowników

${ }^{69}$ Trick jest „Mélièsowski”, gdyż wedle przytaczanej w rozmaitych historiach kina legendy, to właśnie „czarodziej ekranu” miał go odkryć, kiedy podczas filmowania paryskiej ulicy zacięła mu się kamera. Rezultatem miał być film, na którym autobus w cudowny sposób zmieniał się w karawan.

${ }_{70}$ Szczegóły techniczne tego skomplikowanego tricku i udręki, jakie przy tej okazji sprawił ekipie osławiony perfekcjonizm Langa, opisuje w swych wspomnieniach jeden z trzech scenografów Zmęczonej Smierci - Robert Herlth. Przytacza go Lotte Eisner (Fritz Lang, s. 51-52). 
w świnie, pagody w słonia, ukochanego w tygrysa, a siebie samej w posag) dokonują się od strony filmowej dzięki trickom „mélièsowskim”, na ogół skombinowanym z przenikaniem. Pod koniec opowieści chińskiej Śmierć odzyskuje jednak swoje narracyjne prerogatywy: nieostrożna Tiao Tsien zamieniła bezpowrotnie, bo różdżka z ostatnim czarem zanikła, oboje uzurpatorów w obiekty w zasadzie martwe (kaktus, posag), co trzeba uznać za faktyczną zemstę Śmierci na nich ${ }^{71}$. Poza tym to jej wcielenie w „Historii trzeciej świecy”, łucznik, dosiada czarodziejskiego rumaka, daremnego okupu A Hai dawanego cesarzowi za swą podopieczna, a napowietrzna podróż rumakiem w pogoni za uciekinierami jest pretekstem do serii zdjęć nakładanych. Gdy łucznik-Śmierć wypuszcza ku tygrysowi swą strzałę, ta - po cięciu montażowym - dosięga Lianga w jego ludzkiej postaci. Bo Śmierć włada nie tylko nad „trickami” w tym filmie, ale i nad montażem w ogólności.

Panowanie nad montażem oznacza panowanie nad czasem i przestrzenią świata przedstawionego filmu. Z punktu widzenia kompozycji dramaturgicznej może wydawać się niezręcznościa, że Śmierć przybywa do miasteczka dwa razy: w retrospekcji (zatem „w przeszłości”) i dyliżansem z parą młodych (zatem „w teraźniejszości”). Ale unaocznia to, iż Śmierć za każdym razem zaskakuje tych, przed którymi się pojawia, za każdym razem zjawia się ona "po raz pierwszy” i za każdym razem jest kimś obcym, kogo naprawdę się instynktownie poznaje, ale kogo nie chce się nazwać. Choć Śmierć powinna być już znana mieszkańcom miasteczka jako ich „współobywatel”, co więcej - jest tematem rozmów w gospodzie miejscowych notabli, którzy, co więcej, jako miejscy rajcy odstąpili jej grunta przy cmentarzu i spisali z nią umowę dzierżawną na 99 lat (czyli umowę w i e c z y s t ą), to jednak jej osoba zadziwia, przeraża, zbija z tropu i zniechęca do określenia jej tożsamości, zupełnie tak samo, jak wtedy, gdy widziana była pierwszy raz. Dziedziną Śmierci jest bowiem nieustanna teraźniejszość, a ściślej - „k a ż d y m om e $\mathrm{t}^{\prime \prime}, \mathrm{w}$ którym znienacka może się ona pojawić.

Dziedziną tą (i to dziedziną zawłaszczoną) jest też wie c zność, o czym świadczą zarazem pewne szczegóły w filmie, jak i jego całościowa konstrukcja. W retrospekcji Śmierć, usytuowana na tle bezkresnego muru swej posiadłości, kreśli na piasku końcem swej podróżnej laski krzyż, a po jego bokach - Alfę i Omegę. Pierwsza i ostatnia litera greckiego alfabetu, oznaczając z racji swego umiejscowienia początek i koniec, są w ostatniej, eschatologicznej księdze Nowego Testamentu symbolami Boga jako

${ }^{71}$ Wieloramienna bogini, wyobrażona przez posag, to chyba Kali, bogini śmierci, co tym bardziej podkreślałoby triumf Śmierci. Co prawda hinduska bogini w chińskim kontekście nie jest zbyt na miejscu, ale nie pierwsza to „niestosowność" filmu. 
praprzyczyny i ostatecznego celu wszystkich rzeczy, ich początku i kresu. Krzyż z kolei to oczywisty znak chrześcijaństwa, a usytuowany między Alfą i Omegą - emblemat Chrystusa. Apokalipsa trzykrotnie wskazuje tożsamość Alfy i Omegi z Bogiem, a w ostatnim miejscu, dzięki kontekstowi - ściśle z Chrystusem. Warto może te fragmenty przytoczyć: „Jam jest Alfa i Omega, mówi Pan Bóg, Który jest, Który był i Który przychodzi, Wszechmogący" $(1,8)^{72}$; „Jam jest Alfa i Omega, Początek i Koniec. Ja pragnącemu dam darmo pić ze źródła wody życia" $(21,6)^{73}$; „Jam Alfa i Omega, Pierwszy i Ostatni, Początek i Koniec" $(22,13)^{74}$. Śmierć można uznać za „początek i koniec wszystkich rzeczy” tylko w materialistycznej i przygnębiającej wizji świata, jaką sugeruje np. rozprawa Freuda. Choć w tym sensie "Alfa i Omega” mogłyby się wydawać uprawnionym jej godłem, to jednak o zawłaszczeniu świadczą słowa drugiego z fragmentów o związku Alfy i Omegi z „wodą życia”: Śmierci z tym aspektem kojarzyć nie sposób. Ale Śmierć jest pokrętna, niejasna, tak jak podporządkowana jej władztwu narracja filmu - Śmierć zawłaszcza słowa Jezusa wyrwane $\mathrm{z}$ kontekstu Jego wypowiedzi i Jego nauczania ${ }^{75}$, i umieszczając je w zupełnie niestosownym miejscu fabuły (po wystylizowanym na poświęcenie samobójstwie), obiecuje wł a s n ą wieczność, która tak naprawdę jest smętną pustką; vide: obraz ogołoconej, nieponętnej niczym pola elizejskie przestrzeni, w którą wstępują zaprowadzone tam przez Śmierć, połączone już teraz ze sobą na wieki „,widma” Dziewczyny i Chłopca.

Śmierć uzurpuje nie tylko sentencję, ale i gest Jezusa, gest pisania palcem na piasku, w Ewangelii demonstrowany oskarżającym

72 Pismo Święte... (Biblia Tysiąclecia), s. 1397.

${ }^{73}$ Ibidem, s. 1415.

${ }^{74}$ Ibidem, s. 1416.

75 Sentencja w filmie („Kto odda swoje życie - zyska je”) jest tylko „echem” słów Jezusa, przytaczanych przez Ewangelie synoptyczne, co zresztą jeszcze raz potwierdza taktykę narracji filmu Langa, kreującej pewną nieprecyzyjną znaczeniowo aurę, która po wnikliwszej analizie okazuje się zawłaszczać sensy, przejęte z nieadekwatnych w danym kontekście paradygmatów. Porównajmy to zdanie z tekstami ewangelicznymi: „Kto chce znaleźć swe życie, straci je, a kto straci swe życie z mego powodu, znajdzie je" (Mt 10, 39; Pismo Święte..., s. 1135); „Bo kto chce zachować swoje życie, straci je; a kto straci swe życie z powodu Mnie i Ewangelii, zachowa je” (Mk 8, 35; Pismo Święte..., s. 1168); „Bo kto chce zachować swoje życie, straci je, a kto straci swe życie z mego powodu, ten je zachowa" (Łk 9, 24; Pismo Święte..., s. 1193). Zwraca uwage wyeliminowanie w narracji filmu powodu straty swego życia (nie może być nim z pewnością samobójstwo, choćby i po uprzednim kogoś uratowaniu) oraz pierwszego członu, który w dialektyce sentencji Jezusa jest poważnym ostrzeżeniem: uporczywe dostrzeganie jedynie cielesnego, biologicznego wymiaru życia (w postaci np. hedonizmu czy uznania życia za bezsensowne po utracie bliskiej osoby) jest drogą do śmierci. Ten człon wypowiedzi Jezusa został nieprzypadkowo wyeliminowany w narracji, bo uzmysłowiłby wprost widzowi, iż postawa Dziewczyny mimo znamion caritas (uratowanie dziecka), w swej istocie chrześcijańska nie jest. 
jawnogrzesznicę faryzeuszom (J 8, 6-8). Śmierć kreśli krzyż, Alfę i Omegę $\mathrm{w}$ chwili, kiedy podchodzą ku niej przerażeni pozbawionym furtki nieskończonym murem miejscy notable. Słowa Śmierci: „Tylko ja znam wejście", wydają się w kreującej niejasną aurę semantyczną narracji kolejnym „podobieństwem” jej figury do Jezusa, w istocie ewokując Jego odpowiedź na pytanie, które zadał Mu Tomasz: „Panie, nie wiemy, dokąd idziesz. Jak więc możemy znać drogę?” Odpowiedział mu Jezus: „Ja jestem drogą i prawda, i życiem. Nikt nie przychodzi do Ojca inaczej, jak tylko przeze $\mathrm{mnie}^{\prime \prime 76}$. Ale podobieństwo jest pozorne - to kolejna uzurpacja atrybutów i prerogatyw Boga, bowiem wejście, które zna „nieznajomy”, nie wiedzie do życia, ale do dziedziny śmierci.

Centrum tej dziedziny wydaje się komnata świec, do której Śmierć wprowadza Dziewczynę. Demonstrując jej związek płomieni z ludzkim istnieniem, Śmierć wolą Boga uzasadnia czas płonięcia i gaśnięcia świecy, tj. życia konkretnego człowieka. Wyznaje zatem swą podległość wyższej instancji (choć kiedy indziej uzurpuje sobie jej atrybuty), jednocześnie zwalniając siebie z odpowiedzialności za cierpienia ludzkie spowodowane śmiercią kochanych osób - matki, której na oczach Dziewczyny zabrała dziecko, samej Dziewczyny, której ukochanego „uprowadziła”. „Uwierz mi, moje zadanie jest trudne. Jestem zmęczony oglądaniem ludzkiego cierpienia i nienawidzę mojego obowiązku, a mimo to jestem posłuszny"77 - zwierza się bohaterce "zmęczona" Śmierć. Czyż to wyznanie nie jest zarazem o ska rż e n i e m Boga o istnienie w świecie zła i śmierci? A jako oskarżyciel, sam zwalniający się z odpowiedzialności, jawi się Śmierć $\mathrm{w}$ istocie jako szatan ${ }^{78}$. Aktywna rola egzekutora ${ }^{79} \mathrm{w}$ intrygach „na zgubę ukochanego" w każdej z trzech „historii świec”, jaką za każdym razem pełni wewnątrzramowe „wcielenie” Śmierci - El Mot, Maur i łucznik, jest podobna do roli, jaką wcielenia szatana pełnią w nowelach filmów Murnaua i Dreyera, urzeczywistniając w świecie zło (co zresztą potwierdzałoby hipotezę o ich wpływie na film Langa). Doprawdy, jeśli Śmierć w filmie Langa jest posłuszna jakiejś wyższej instancji, to nie Bogu w rozumieniu chrześcijaństwa, ale jakiejś złośliwej Ananke.

Tom Gunning przyrównuje komnatę świec do czegoś w rodzaju konsoli czy tablicy rozdzielczej (switchboard) ${ }^{80}$, gdzie Śmierć jest swoistym „dyspozytorem” ludzkich istnień, gasząc „kiedy trzeba” płomień

76 J 14, 5-6 (cyt. za: Pismo Święte..., s. 1233).

77 Śmierć jest w jęz. niemieckim rodzaju męskiego (der Tod), toteż jej upostaciowaniem w filmie Langa czy w inspirującej go baśni braci Grimm jest mężczyzna.

78 "Oskarżyciel" to jedno ze znaczeń hebrajskiego słowa sathan.

79 Aż chciałoby się powiedzieć „terminatora”, gdyby nie konotacje z jednak całkiem innym kinem.

${ }^{80}$ T. Gunning, op. cit., s. 21. 
czyjegoś żywota (jak w wypadku odebranego matce dziecka). Zwróćmy uwagę, że świece, odmierzając czas ziemskiej egzystencji, tak naprawdę są dość szczególnymi z e g a r a mi, jeszcze jednymi zrodzonymi w iście „saturnicznej” ${ }^{\prime 1}$ wyobraźni zafascynowanego czasomierzami Langa. W swej „dyspozytorni" Smierć synchronizuje precyzyjnie spalanie się płomienia z ziemskimi zegarami, odmierzającymi fizyczny czas, co dobitnie unaoczniają przebiegi fabularne każdej z trzech historii: Frankończyk, Giovanfrancesco i Liang nie przeżywają terminu wyznaczonego na ich śmierć przez tyranów (kalifa, Girolama, cesarza), a co więcej, niefortunne działania ich kochanek (Zobaidy, Fiametty, Tiao Tsien) zgubę tę jeszcze przyspieszają. Takich jak Śmierć „dyspozytorów”, precyzyjnie synchronizujących działania na czyjąś zgubę za swymi "konsolami”, zobaczymy w następnych filmach Langa - w chyba jeszcze sugestywniejszych wcieleniach Mabusego (Doktor Mabuse, gracz), Haghiego (Szpiedzy) czy Corneliusa/Jordana (Tysiac oczu doktora Mabuse).

Ciekawe jest zwłaszcza porównanie Śmierci z tym ostatnim, definitywnie ostatnim „wielkim przestępcą” w twórczości Langa. Jordan śledzi innych ze swego pełnego telewizyjnych monitorów „centrum szpiegowskiego", usytuowanego w naszpikowanym podglądającymi kamerami hotelu, co ułatwia mu planowanie i wykonywanie swych zbrodni. Zarazem w drugim swym wcieleniu - niemetafizycznym, po prostu przebrany za jasnowidza Corneliusa - udaje, iż zna przyszłość, zapowiadając to, co sam wykona czy komuś zleci. Jordan wydaje się w swym monitorowym centrum bardzo podobny do Śmierci w jej komnacie świec, tak jak on włączającej swoisty "ekran”, przekazujący obraz „skąd indziej”, by w odpowiednim momencie „zdmuchnąć” płomień jakiegoś toczącego się „gdzie indziej" życia. Ale gdy władza Jordana/Corneliusa ogranicza się do jednego miejsca i jednego momentu historycznego, władztwo Śmierci wydaje się nie mieć granic ani w przestrzeni, ani w czasie.

„Historie trzech świec" toczą się bowiem nie tylko "gdzie indziej”, ale i „kiedy indziej”. W stosunku do opowieści ramowej rozgrywającej się, powiedzmy, na początku XIX stulecia, opowieść wenecka zdecydowanie jawi się jako przeszłość (epoka renesansu), chińska jako bytująca właściwie

${ }^{81}$ Saturn (Kronos) jest upersonifikowaniem czasu jako m.in. „pożeracz” istnień. W ezoteryce jest też emblematem melancholii i planetą patronującą ludziom o usposobieniu melancholijnym, ogarniętym acedią. Por.: Walter Benjamin, The Origin of German Tragic Drama, transl. John Osborne, Verso, London-New York 2003, s. 148-157. Odnośny fragment książki Benjamina został przetłumaczony na język polski i można go znaleźć w poświęconym melancholii monograficznym numerze „Literatury na Świecie” 1995, nr 3 (284) [W. Benjamin, Dramat tragiczny i tragedia, przeł. Małgorzata Sugiera, s. 104-114]. W tymże numerze zob. także: Daniel Birnbaum, Anders Olsson, Czarna żótć. Melancholia klasyczna, przeł. Jan Balbierz, s. 154-160. 
poza kalendarzem (czasy legendarne), zaś arabska jest być może przyszłością. Kilkoro autorów, analizujących i opisujących Zmęczona Śmierć, zwiedzionych być może podobieństwem "Historii pierwszej świecy” do fabuł z Księgi tysiaca i jednej nocy, myli się, sytuując ją w Bagdadzie IX w. ${ }^{82}$ Nowoczesny, wielostrzałowy rewolwer Frankończyka i wcale nie takie „średniowieczne” stroje tańczących derwiszów wskazują iż w aspekcie usytuowania w czasie historycznym nowela arabska może właściwie rozgrywać się później niż rama ${ }^{83}$ (w takim razie komplikującym sprawę anachronizmem jest określenie „wcielenia” ukochanego w tej opowieści jako „Frankończyka” - der Franke - zamiast np. jako Niemca, Francuza czy po prostu „niewiernego"). Tak czy inaczej, w bezczasowej dziedzinie Smierci nie liczy się czas historyczny, skoro mogą w niej współistnieć (a nie zdarzać się „po kolei”) różne epoki. Co nie znaczy, że gdy „wejdzie się" z komnaty świec $\mathrm{w}$ daną historię, czas znowu nie płynie „po ziemsku", linearnie, $\mathrm{w}$ jedną stronę.

\section{Czkawka czasu i to, co pomiędzy}

Kryteria logiki arystotelesowej i prawa fizyki zawodza, gdyby chcieć precyzyjnie określić czas, przestrzeń i relacje między postaciami. Narracja filmu Langa (chyba jednak nie we wszystkim podporządkowana strategii Śmierci) nie przejmuje się potrzebą klarownego rozumienia przez widza wydarzeń, co widać zwłaszcza w dwóch aspektach: wykluczających się hipotezach, co do tego, czy Dziewczyna istotnie wypiła truciznę, oraz kwestii relacji bohaterów opowieści ramowej do postaci z „Historii trzech świec".

Dziewczyna - tak nam się przynajmniej wydaje podczas pierwszego, czyli n a t u r a ln e g o odbioru filmu - musiała wypić truciznę i umrzeć, albo przynajmniej ulec bliskiemu śmierci odurzeniu, aby móc przekroczyć próg dziedziny Śmierci. To, iż znajduje się tam tak ",tatwo", "po przenikaniu" (w podwójnym sensie chwytu filmowego i cudownej zdolności), świadczy, iż nabyła uprawnień, jakie mają tylko zmarli. Śmierć traktuje ją jednak jako nieproszonego gościa, intruza w swej dziedzinie. Po tym, gdy Dziewczyna „nie sprostała” rzuconemu przez Śmierć wyzwaniu i trzy świece dopaliły się, Śmierć rozkazuje jej powrót między żywych. I okazuje się, że choć zgasło kilka żywotów (nie tylko trzy - pamiętajmy też o ofiarach strzałów Frankończyka, posłańcu Fiametty zamordowanym

${ }^{82}$ Np.: E. Ann Kaplan, op. cit., s. 22; P. M. Jensen, op. cit., s. 25; P. McGilligan, op. cit., s. 71. Zresztą wcale nie jest powiedziane, iż miejscem akcji jest Bagdad.

83 Spostrzega to Gunning (op. cit., s. 19). 
przez zbirów Girolama i zaczarowanych bezpowrotnie osobach w opowieści chińskiej), oraz że upłynęło ponad pół filmu, odmierzając czas życia widza, Dziewczyna dopiero trzyma przy ustach naczynie z trucizna, a łyknąć jej już nie zdąży, bo „puchar" odtrąci jej od ust zatroskany aptekarz. Zegar i herold - po ponad połowie czasu projekcji - znowu obwieszczają w sjużecie godzinę jedenastą w dokładnie tych samych ujęciach, co przedtem. Czy rzeczywiście czas świata przedstawionego stanął w miejs$\mathrm{cu}$, a chwyt Langa po prostu wyraziście unaocznia subtelne dystynkcje amerykańskiego neoformalizmu między czasem fabuły, czasem sjużetu i czasem ekranowym? ${ }^{84}$

Sprawa jednak nie jest taka prosta. Wydaje się raczej, iż, jak to ujął Tom Gunning, "czas dostał czkawki i nieznacznie cofnął się jak zacięta płyta" ${ }^{85}$. Jest to możliwe dzięki cięciom montażowym. Te na ujęcia zegara i herolda, przerywając samobójczą próbę Dziewczyny, sytuują akcję w fizycznym, ziemskim, ludzkim czasie. Przenikanie przenosi ją poza czas, w „wieczną" czy bezczasową dziedzinę Śmierci. Ponowne przenikanie, już po daniu Dziewczynie „czwartej szansy”, przenosi wi d z a z obrazu Dziewczyny podnoszonej przez Śmierć na obraz zegara z godziną jedenastą. Później cięciami przechodzimy, kolejno, na obraz herolda oraz Dziewczyny z trucizną przy ustach. Jeżeli zatem samobójstwo nie dokonało się - doprawdy, długa jest droga „między ustami a brzegiem pucharu” - to może powrót do godziny jedenastej jest powrotem na "narracyjne rozdroże", a my oglądaliśmy tylko hipotetyczny wariant wydarzeń (niczym w Przypadku Krzysztofa Kieślowskiego, Zapomnianej melodii na flet Eldara Riazanowa czy Biegnij Lola, biegnij Toma Tykwera)? Jednak taka hipoteza kłóci się z faktem, iż „czwarta szansa” dana przez Śmierć bohaterce w ewentualnie "hipotetycznej" narracji, steruje jej poczynaniami, w alternatywnej, „realnej” narracji, a między zdarzeniami prezentowanymi przez jedną i drugą istnieje logiczna ciągłość. Trzeba zatem pogodzić się $\mathrm{z}$ - nie jedyną przecież $\mathrm{w}$ tym filmie - ontologiczną sprzecznością w prezentacji sytuacji "między ustami a brzegiem pucharu”, w której po raz drugi Dziewczyna zaznała niespełnienia swego pragnienia (za tym drugim razem - pragnienia samobójczego).

${ }^{84}$ Por.: David Bordwell, Narration in the Fiction Film, University of Wisconsin Press, Madison 1985, s. 74-97 (Chapter 6: Narration and Time). Przykład Zmęczonej Śmierci pokazuje, iż subtelne i skądinąd bardzo funkcjonalne w analizie filmu narzędzia Bordwella są niewystarczające. W kategoriach tam proponowanych powrót do tej samej godziny w czasie fabuły jest przykładem wstawki, dzięki której czas sjużetu i czas ekranowy są rozleglejsze od czasu fabuły. Ale co zrobić z samą komplikacją struktury czasu we „wstawce" i z tym, że powrót do godziny 11 niczego nie załatwia w aspekcie konstatacji widza o zdarzeniu fabularnym: wypiła Dziewczyna truciznę czy nie?

${ }^{85}$ T. Gunning, op. cit., s. 21. 
A na czym właściwie polegają „trzy szanse” dane przez Śmierć Dziewczynie podczas jej pobytu w zaświatach? Ocalić płomień choć jednej z trzech świec - no dobrze, ale właściwie jak? Czy Dziewczyna i „warunkowo żywy" Chłopiec wcielają się w postacie "skądinąd" i z jakiejś innej epoki, mając za przeciwnika w szczególnej rozgrywce Śmierć, również w jednej z ról w tych trzech "tragediach kostiumowych"? Taki sens wydaje się sugerowany przez obsadę - Zobaidę, Fiamettę i Tiao Tsien gra Lil Dagover, zaś Frankończyka, Giovanfrancesca i Lianga Walter Janssen, odtwórcy ról Dziewczyny i Chłopca w opowieści ramowej. Zakłóca trochę tę hipotezę fakt, iż odtwórca roli Śmierci, Bernhard Goetzke, choć zagrał El Mota i cesarskiego łucznika, nie wcielił się w środkowego z egzekutorów wyroku na „ukochanym” - Maura w opowieści weneckiej ${ }^{86}$. Dopiero w finale noweli, już po zabójczym ciosie, grający Maura Lewis Brody zmienia się po przenikaniu w Bernharda Goetzke.

A może historia każdej z trzech świec przedstawia po prostu analogiczne do historii Dziewczyny i Chłopca historie jakichś innych par kochanków, których szczęście przerwała gwałtowna śmierć ukochanego? Byłyby zatem historie każdej ze świec zwierciadłem sytuacji, w której Dziewczyna mogłaby i powinna się przejrzeć, by rozeznać własną sytuację. Wydaje się wręcz, że Dziewczyna, reprezentant widza w tekście, ogląda na ekranie komnaty świec trzy filmy, wyświetlane jej przez władcę narracji, wielkiego dysponenta obrazów, jakim jest Śmierć. Byłaby zatem Śmierć, jak potem Mabuse, Volker czy Haghi, jedną z figur artysty w twórczości Langa. Tylko gdzie tu miejsce na "szansę” Dziewczyny, na jej interwencje, aktywny udział w zdarzeniach, grę ze Śmiercią?

Kwestia "trzech szans" wydaje się równie problematyczna, jak sama bytność Dziewczyny w zaświatach i żadną interpretacyjną decyzją nie można przesądzić, że wyzwanie rzucone Dziewczynie przez Śmierć polegało na tym bądź owym. Trzeba po prostu uznać owe niedookreślone co do sposobu realizacji "trzy szanse" za chwyt narracji, mający upodobnić historię Dziewczyny do baśni z tym dość pospolitym w baśniach motywem. Co nie znaczy, iż rozmaite szczegóły każdej z trzech historii czy ich punkty wspólne nie rzucają ciekawego światła na historię ramową i nie dookreślają nam nieco - choćby z racji ich większej konkretności niż bardziej abstrakcyjna rama - istoty sytuacji jej bohaterów. Zgrabnie to ujął Thomas Elsaesser w odniesieniu zarówno do Zmęczonej Śmierci, jak i do

\footnotetext{
${ }^{86}$ Może dlatego, że inaczej niż w opowieściach arabskiej i chińskiej, gdzie zabójca był sługą tyrana (kalifa, cesarza), Maur w opowieści weneckiej jest sługą zatrwożonej kochanki, potencjalnym zabójcą „tyrana” (Girolama) w uknutej przez nią kontrintrydze. Fakt, iż sługa Fiametty zabija jej ukochanego na jej własny rozkaz, czyni opowieść wenecką szczególnie gorzko-ironiczną.
} 
naśladującego, a zarazem parodiującego jej konstrukcję Gabinetu figur woskowych (1924) Paula Leniego: „W obu filmach mamy do czynienia nie tylko z chwytem ramy, lecz $\mathrm{w}$ dodatku $\mathrm{z}$ opowiadaniem, które wiąże trzy epizody: epizody, które co do epoki, scenerii i nastroju wydają się bardzo od siebie różnić, ale które posiadają wspólne elementy, funkcjonujące zarazem iteratywnie, jako p o w tó r z e n i e, i kumulatywnie, jako in te n s y fik a cj a" 87 [podkr. - T. K.].

Trzeba zatem, po pierwsze, stwierdzić, że dominującym rysem pary bohaterów w każdej z trzech nowel jest ich „zakochanie się”, wyrażające się w miłosnych rytuałach, ignorujące zewnętrzne okoliczności, nakazujące im ekspresję uczucia nawet przy narażeniu się na niebezpieczeństwo. Najbardziej zrytualizowane - może ze względu na kulturę epoki renesansu, w której przyszło im żyć - są zachowania Fiametty i Giovanfrancesca: Fiametta zrzuca z balkonu różę, ukochany przez cały dzień wydaje się ją pielęgnować (troskliwie polewa ją wodą z fontanny), dopóki nie rozpadnie mu się w rękach, gdy potrącą go jakieś rozbawione karnawałem kobiety. W ogóle oboje kochankowie wydają się ludźmi karnawału, ignorującymi sferę publiczna, pozostawioną tak niesympatycznym figurom, jak Girolamo, członek Rady Czternastu. Zresztą właśnie dzięki takiemu „karnawałowemu” przeżywaniu rzeczywistości aż nazbyt dobrze udaje się Fiametcie jej pułapka: Giovanfrancesco w maskaradowym stroju z ochotą podejmuje podczas schadzki szermierczy pojedynek "na niby" z ukochana, co przyczynia się do jego zguby. Z kolei bardzo zabawny miłosny rytuał seryjnych pocałunków Tiao i Lianga (Thei i Langa?) całkowicie wyłącza młodych z rzeczywistości, przez co zaniedbują swe obowiązki wobec A Hai. Na ukradkowy pocałunek ważą się nawet, składając cesarzowi hołd, co jest właściwie zbrodnią obrazy majestatu - nawet tak ohydnego majestatu jak tłusty i szponiasty cesarz. Frankończyk natomiast zdobywa się na szaleństwo - wtargnięcie podczas ramadanowych modłów do meczetu, w fanatyczny muzułmański tłum, tylko po to, by zamienić kilka słów z Zobaidą. A noca, gdy Ayesha wprowadza go do komnat ukochanej, która ma przecież zapewnić mu bezpieczną kryjówkę, nie myśli o czyhającym zagrożeniu, tylko porywa kochankę $\mathrm{w}$ ramiona jakby jego jedynym celem była romantyczna randka, której niebezpieczne okoliczności dodają tylko trochę pieprzyku.

Te zachowania kochanków z trzech nowel są istotnie, jak chce Elsaesser, repetycją i intensyfikacją tego, czego dowiedzieliśmy się o parze z opowieści ramowej: właściwie wszystko, co o Chłopcu i Dziewczynie wiemy, to fakt, iż są ze sobą szczęśliwi, oddając się amorom w dyliżansie i „wychylaniu pucharu miłości” w gospodzie. Jak zwłaszcza Fiametta

${ }_{87}$ T. Elsaesser, Weimar Cinema and After..., s. 84-85. 
i Giovanfrancesco, żyją oni w "przestrzeni uciechy", a sensem ich życia jest rozkosz. Wszystkie c zte ry pary wydają się też nierozłączne. Frankończyk i Liang są impulsywni, ryzykując dla ukochanych życiem (dwukrotne wtargnięcie "niewiernego" do jaskini lwa, uprowadzenie Tiao Tsien przez Lianga sprzed nosa samego cesarza); Giovanfrancesco i Chłopiec jawią się z kolei jako trochę zniewieściali sybaryci, zdecydowanie bardziej bierni i mniej energiczni niż ich odpowiednicy z nowel orientalnych. We wszystkich trzech nowelach inicjatywa akcji ratunkowej wychodzi ze strony kochanek, które wydają się w ogóle bardziej przedsiębiorcze i pomysłowe niż ich ukochani (choć, paradoksalnie, właśnie ta inicjatywa jest zgubna). W opowieści ramowej Dziewczyna również wykazuje się dużą inicjatywą - choć tylko ją samą ona gubi, bo kochanek już nie żyje.

Po drugie, we wszystkich trzech historiach wewnątrzramowych młodzi popełniają jakieś wykroczenie przeciw panującemu porządkowi. Peter Gay w swej znakomitej monografii kultury okresu weimarskiego wskazuje na konstytutywny dla ideowej aury wczesnego okresu Republiki Weimarskiej, obecny $\mathrm{w}$ ekspresjonistycznej literaturze, teatrze i filmie „bunt synów" ${ }^{88}$. Thomas Elsaesser z kolei zauważa obecność w wielu filmach weimarskich (w tym i w Zmęczonej Śmierci) fabuł realizujących "edypalny" scenariusz walki młodszego i starszego mężczyzny („ojca”, choć oczywiście często ojca symbolicznego - reprezentanta władzy czy strażnika patriarchalnego porządku) o młodą kobietę. W ramowej opowieści filmu Langa takim fantazmatycznym „ojcem” jest Śmierć ${ }^{89}$. Z kolei w trzech nowelach na straży "prawa ojca” stoją ludzie władzy: kalif (choć nie jest ani rywalem Frankończyka, ani ojcem Zobaidy, tylko jej bratem), Girolamo (rywal Giovanfrancesca, a zarazem członek władz Wenecji), cesarz (bezceremonialnie $\mathrm{z}$ racji swej władzy uznający Tiao Tsien za należną mu własność). Warto zwrócić uwagę, iż w noweli chińskiej figurą ojca (dobrotliwego) jest również A Hai - choć wcale nie jest powiedziane, iż Tiao to rzeczywiście jego córka, jak chcieliby niektórzy interpretato$\mathrm{rzy}^{90}$. W każdym razie, gdy zaszantażowany przez cesarza sprzymierza się z nim i próbuje nakłonić swą asystentkę do akceptacji woli władcy Tiao buntuje się, kradnie różdżkę i symbolicznie zabija, przemieniając go w kaktus. Kwiatek, który swą kolejną magiczną sztuczką wyczarowuje ona na kaktusie-A-Hai, jest oznaką zarazem jej złośliwości, jak i czułości wobec czarodzieja-opiekuna.

${ }^{88}$ Peter Gay, Weimar Culture: The Outsider as Insider, W. W. Norton \& Company, New York-London 2001, s. 102-118 (Chapter V: The Revolt of the Sons: Expressionist Years).

${ }^{89}$ Por.: T. Elsaesser, Weimar Cinema and After..., s. 74-75.

${ }^{0}$ Np. E. Ann Kaplan (op. cit., s. 33) czy Paul M. Jensen (op. cit., s. 25). 
Złamaniu panującego prawa winni są szczególnie partnerzy nieszczęśliwych kochanek. Liang porywa własność cesarza, co jest nie tylko zbrodnią obrazy majestatu, ale i profanacja, skoro obleśny tyran to „Syn Niebios". Giovanfrancesco za jakieś nienazwane w narracji winy wobec republiki zostaje zaocznie skazany na śmierć przez Radę Czternastu (i nie wydaje się to tylko intrygą zazdrosnego Girolama). Frankończyk winien zaś jest szczególnie, profanacją meczetu i wdarciem się do komnat muzułmanki, łamiąc tabu religijne i kulturowe. Czy te sytuacje nie sugerują choć trochę dość niejasno zarysowanej sytuacji Dziewczyny i Chłopca jako również „,transgresyjnej” (prawdopodobnie chodzi o przybycie młodej, niezaślubionej sobie pary nocą do gospody i "picie tam z pucharu miłości", co, gdy uwzględnimy jego sens alegoryczny, jest oczywiście przekroczeniem norm obyczajowych i moralnych). Tak czy inaczej, każda z czterech par winna jest w jakiś sposób naruszenia panującego ładu prawnego.

Jednak, po trzecie, na kochankach w każdej z historii spoczywa też wina moralna. Ich namiętność jest egotyczna, co powoduje nieliczenie się z nikim ani z niczym, gdy stoi to na przeszkodzie ich miłości. Frankończyk z a bi ja ze swego rewolweru bodaj trzech ze ścigających go ludzi kalifa. Fiametta swą kontrintrygą planuje po prostu morderstw o i wpada we własne sidła. Tiao Tsien z jakąś złośli wą i mści wą ra dości ą przemienia innych w rzeczy i zwierzęta - nawet kochającego ją i opiekuńczego A Hai. A Dziewczyna, w imię swej miłości i swego ewentualnego szczęścia z „wykupionym” od Śmierci Chłopcem, rości sobie prawo do wyrokowania, czyje życie jest jeszcze cokolwiek warte, składając swą haniebną propozycję aptekarzowi, żebrakowi i staruszce (względem aptekarza, który znalazł ją zemdlona, ugościł i wyrwał ze szpon śmierci, żądanie życia jest szczególnie odpychające). To nie Alkestis, to raczej złowroga podobizna egoistycznego Admeta, bez skrupułów, mimo swego lamentu, korzystającego z ofiarności żony. A nie zapominajmy i tego, że w najbardziej chwalebny czyn Dziewczyny - ocalenie dziecka, przerodziło się poniechane $\mathrm{w}$ ostatniej chwili dzięki wyrzutom sumienia m o r d e r s tw o. Wielką moralną winą Dziewczyny jest również, rzecz jasna, dwukrotne targnięcie się na własne życie - wyraz boleści, zrodzonej w gruncie rzeczy z niezaspokojonego i niepohamowanego e g o ty z m u.

Tak zatem trzy historie $\mathrm{z}$ trzech różnych kultur i trzech różnych epok w dziejach, zagadkowo zawarte dzięki "czkawce czasu” między ustami (Dziewczyny) a brzegiem "pucharu” (prawdopodobnie z odurzającą mandragorą), rzucają choć trochę moralnego światła na lakonicznie zaprezentowaną i w dodatku pełną alegorii opowieść ramową. 


\section{Alegoryczność}

Na czym polega wielekroć już wzmiankowany alegoryczny styl filmu Langa? Istota jego, jak sądzę, ujawnia się, gdy przywołamy Jakobsonowską dystynkcję między metonimicznym a metaforycznym sposobem budowania wszelkich wypowiedzi, także tekstów artystycznych. W sposobie m e t o n i m i c z n y m elementy wypowiedzi wiążą się między sobą poprzez zasadę p r z y le g ł o śc i, dominują między nimi relacje p r e d y k a t y w n e, a rodzajem tekstów najlepiej go unaoczniającym są teksty fabularne, z wyrazistym układem zdarzeń powiązanych często stosunkiem przyczynowo-skutkowym. W sposobie metaforycznym elementy wypowiedzi wiąże ze sobą zasada p o d o b i eń s t w a, przeważają między nimi relacje $\mathrm{s} u \mathrm{~b}$ s t y t u t y w n e, typem zaś tekstów wyraziście go reprezentującym są utwory poetyckie, obfitujące w figury stylistyczne, jak metafory, porównania etc. ${ }^{11}$ Rozróżnienie Jakobsona stosowne jest nie tylko dla typologii czy charakterystyki wypowiedzi (tekstów) językowych, równie dobrze sprawdza się bowiem w analityce filmu. Sam Jakobson wskazał w przywoływanym tu słynnym artykule możliwość stosowania jego kategorii do filmu, choć akurat jego własne, przedstawione tam przykłady nie były najszczęśliwsze ${ }^{92}$. Natomiast znakomicie wykazali użyteczność zastosowania Jakobsonowskich narzędzi do filmu Rick Altman, analizując film Griffitha Samotna willa jako przykład wyobraźni metaforycznej ${ }^{93}$, oraz Vincente J. Benet Ferrando, analizując właśnie Zmęczona Śmierć ${ }^{94}$.

Tradycyjny, czyli tzw. klasyczny film fabularny, ukształtowany na dobre ok. 1917 r., oparty jest na środkach wyrazu sfunkcjonalizowanych wobec zrozumiałego opowiedzenia pewnej historii, prezentacji powiązanych ze sobą zdarzeń w klarownych relacjach przestrzennych. Najlepiej służą temu system montażu ciągłego (continuity editing system), z jego regułami nieprzekraczania osi montażowej i zachowania kierunku

91 Por.: Roman Jakobson, Dwa aspekty języka $i$ dwa typy zakłóceń afatycznych, przeł. Leon Zawadowski, [w:] idem, W poszukiwaniu istoty języka: Wybór pism, red. Maria Renata Mayenowa, t. 1, Państwowy Instytut Wydawniczy, Warszawa 1989, s. 169-175.

${ }_{92}$ Nie budzi sprzeciwu przykład montażu analitycznego u Griffitha jako wyobraźni metonimicznej (choć np. Rick Altman zaakcentuje akurat również obecny w twórczości Griffitha "styl paradygmatyczny", który jest przykładem raczej metaforycznego sposobu konstruowania tekstu). Za to nietrafny wydaje się przykład Chaplina jako twórcy „nowomodnego montażu metaforycznego" [sic!]. Por.: R. Jakobson, op. cit., s. 171-172.

93 Rick Altman, "The Lonely Villa" and Griffith's Paradigmatic Style, "Quarterly Review of Film Studies" 1981, vol. 6, no. 2.

94 Vincente J. Benet Ferrando, Symbole, metaphore et stabilité narrative dans „Der müde Tod", [w:] Fritz Lang: La mise en scène, ed. Bernard Eisenschitz, Paolo Beretto, Cinématheque Française, Paris 1993. 
ruchu ekranowego, oraz montaż analityczny, z jego zmiennością planów. Opierają się owe środki wyrazu o metonimiczną przyległość w czasie i przestrzeni, a ich kombinacja wzdłuż osi narracyjnej służy postępowi opowiadania. Zdaniem Beneta Ferrando, w Zmęczonej Śmierci dochodzi do zakłócenia osi narracyjnej (metonimicznej) poprzez pochodzące z osi poetyckiej obrazy metaforyczne: zatrzymują one płynność opowiadanej historii wskutek swego dość natarczywego kontrapunktowania akcji (wydają się ją przerywać i komentować). Absorbują uwagę widza samym faktem swej nieruchomości, prezentują bowiem detale architektoniczne lub przedmioty nieożywione. Domagają się interpretacji, która może wydawać się nietrudna, gdyż wiele z nich to emblematy o konotacjach dość powszechnie znanych jako tako wykształconemu odbiorcy. Ich kumulacja w miarę toku filmu czyni jednak jego percepcję (ja zaś dodałbym, iż zwłaszcza analizę) raczej niełatwą. Przykładem interferencji między osią metonimiczną i metaforyczna, narracyjną i poetycka, jest tytułowa figura Śmierci: jako postać jest aktantem, spiritus movens akcji, ale jednocześnie nie sposób uciec od jej znaczenia symbolicznego, które wydaje się w ogóle przeważać nad jej fabularną funkcją aktanta ${ }^{95}$.

Nietrudne wydaje się odczytanie choćby wizji, która po raz pierwszy wytrąciła Dziewczynie puchar z rąk: kościotrup i klepsydra to powszechnie znane emblematy śmierci. Ale już np. rozpoznanie jako mandragory, i to z uwzględnieniem jej rozmaitych sensów symbolicznych, rośliny, którą zbliżenie pokazuje nam w dłoni aptekarza, będzie udziałem znacznie mniejszej liczby widzów. Inne z kolei emblematyczne przedmioty da się odczytywać „piętrowo” - znajdując jeden sens, można nie zauważyć istotnego w kontekście całości filmu drugiego. Przykładem niech będzie rzeźba Wodnika, której zbliżenie pod koniec filmu kontrapunktuje ujęcia pokazujące akcję gaszenia pożaru przez mieszkańców miasteczka. Gunning - rozpoznawszy alegoryczną postać - uważa tę wstawkę za zabawną gdyż upozowana na "aktywnie gaszącą pożar” kamienna figura niezdolna jest do żadnej akcji ${ }^{96}$. Oczywiście, jedną z funkcji owej wstawki jest ten "gag" (zwróćmy uwagę, że takie odczytanie Wodnika właściwie przenosi go z osi metaforycznej na metonimiczna, gdyż w interpretacji "gagowej" najważniejsza jest jego przyległość do pożaru). Na nieco wyższy poziom - choć bardzo bliski poprzedniemu - przenosi nas dostrzeżenie w „bezradności” czy faktycznej „bezczynności” Wodnika ironicznego komentarza do gorączkowej, lecz nieefektywnej akcji gaśniczej. W tej interpretacji wydaje się, że oś metonimiczna i metaforyczna, choć chyba jednak z przewagą metonimicznej interferują. Gdy jednak opuścimy już oś

\footnotetext{
${ }^{95}$ Ibidem, s. 99-109.

${ }_{96}$ Zob.: T. Gunning, op. cit., s. 26.
} 
metonimiczną i przywołamy symboliczne konotacje Wodnika (oś metaforyczna), objawi się jego związek z patronującą temu znakowi w astrologii planetą - Saturnem, a tym samym ujawni się on jako kulminacyjny znak aury melancholii, jaką kreuje narracja: melancholii wiodącej bohaterkę do samobójstwa.

Wiele emblematycznych przedmiotów czy obiektów w filmie Langa w kulturowych konotacjach niesie z sobą ambiwalencję sensów, którą trudno jednak zauważyć w normalnym, nieanalitycznym odbiorze; zazwyczaj odbierze się jeden, bardziej oczywisty aspekt. Przykładem niech będą ptaki w izbie aptekarza - kruk i wypchany puszczyk. Oba ptaki wydają się złowróżbne - żywy puszczyk zresztą "śledził" Dziewczynę podczas jej wędrówki wzdłuż cmentarnego muru (okrzyk puszczyka, często wykorzystywany $\mathrm{w}$ filmach, bywa zapowiedzią nieszczęścia, np. śmierci bohaterów $)^{97}$. Jak sowy w ogólności, puszczyk jest emblematem wtajemniczenia, mądrości, ale też śmierci jako ptak nocy. Nic zatem dziwnego, iż gdy Dziewczyna zbliża do ust truciznę, widzimy w kadrze za nią wypchanego puszczyka. Kruk wydaje się mieć podobne konotacje jako ptak czarny i padlinożerca: nie przypadkiem siedział na szkielecie, gdy Dziewczyna wchodziła do izby aptekarza. Niemniej, kruk jest ptakiem dziennym, to ptak Słońca. I ten jego aspekt ujawnia się, gdy siada na aptekarzu, który przygotowuje Dziewczynie „kojący napój”, a potem odtrąca od jej ust śmiercionośny specyfik ${ }^{98}$.

Symboliczne konotacje niesie z sobą scenografia. Oczywiście, najsłynniejszym przykładem, wielekroć opisywanym, jest niemający w kadrze żadnych granic (prócz podstawy) ani żadnych wejść gigantyczny mur posiadłości Śmierci. Langowi udało się w tak prosty, ale jednocześnie niesłychanie sugestywny sposób, wyrazić nieskończoność i wieczność zaświatowej dziedziny, a zarazem absolutność granicy oddzielającej świat żywych i umarłych - choć przecież nie jej „nieprzenikalność”, o czym świadczy „przenikający” mur (w podwójnej ekspozycji) pochód zmarłych. Nie tak może efektownym, ale sięgającym do podświadomości widza chwytem, jest skojarzenie obecności Śmierci z kształtem ostrołuku, bardzo rozmaicie zresztą wkomponowanego w otoczenie (a to jako cmentarna furtka, a to jako łuk między przęsłami mostu w epizodzie weneckim). Można być niemal pewnym, że tam, gdzie jest ten kształt, prędzej czy później zjawi się Śmierć.

97 Tak jest choćby w Źródle Ingmara Bergmana (poprzedza masakrę pasterzy-zabójców) czy w Pasji Mela Gibsona (rozlega się w Ogrodzie Oliwnym). Ale pamiętajmy, że Zmęczona Smierć to film niemy.

98 Interpretując symbolikę ptaków, skorzystałem ze słownika Chevaliera i Gheerbranta (op. cit.): hasła owl (s. 729-730) i raven (s. 789-791). 
Naszpikowana obrazami z osi metaforycznej jest zwłaszcza opowieść ramowa. W opowieściach orientalnych dominuje zdecydowanie oś narracyjna, a bardzo sprawne stosowanie w tych partiach filmu montażu analitycznego i montażu ciągłego czyni akcję wartką i angażującą widza w suspens (szczególnie w opowieści arabskiej, z jej żywym tempem, gonitwami, pojedynkami). Pokazuje to też, iż Lang miał znakomicie opanowany „styl klasyczny”, a „przyciężkie” tempo, kontemplacyjność i opisowość starannie zakomponowanych kadrów (szczególnie w opowieści ramowej i weneckiej) były nie niezręcznością, a świadomym stylistycznym wyborem ${ }^{99}$.

Gunning, powołując się na odkrytą na nowo po latach rozprawę Benjamina z 1928 r. ${ }^{100}$, zauważa podobieństwo wielu wybitnych zjawisk kina artystycznego w epoce niemej do analizowanego w tej rozprawie fenomenu niemieckiej tragedii barokowej, tzw. Trauerspiel. Podstawowym środkiem wyrazu i tu, i tam jest alegoria, a zafascynowanie nią obu epok wynikało z pewnego nieporozumienia: potraktowania hieroglificznego pisma egipskiego jako alegorii, co zrodziło pragnienie wykreowania poprzez alegorię uniwersalnego języka obrazów, stworzenia nowych uniwersalnych "hieroglifów” (niedziwne pragnienie w dobie wielkich nadziei związanych $z$, ,językiem filmu” ${ }^{101}$. „WW filmach Griffitha, wczesnych filmach DeMille'a, dziełach Gance'a, Dulac, Epsteina, w złożonych retorycznych eksperymentach Sowietów, i w większości filmów weimarskich, zauważamy «niezdarność ciężkiej ręki», którą Benjamin postrzega jako zasadniczą dla alegorii. Dzieła te usiłują wykreować obrazy, które będą zarazem intensywne i (w przeciwieństwie do romantycznego symbolu oraz gustu większości nowoczesnych krytyków) czytelne; obrazy, które aspirują do pisania obrazami, schlebiając sztuczności, która stawia znaczenie ponad obrazowaniem"102.

Rzecz jasna, alegoryczność tak pojęta jest szczególnie wyrazistym przykładem dominacji w dziełach osi metaforycznej nad metonimicz-

99 Zapewne duży wpływ na stylistykę tych partii filmu miał fakt, iż scenografem opowieści ramowej był Walter Röhrig, a opowieści weneckiej i rynku w ramie narracyjnej (zresztą także noweli arabskiej i pałacu cesarza) - Hermann Warm, dekoratorzy Gabinetu doktora Caligari; stąd też "ekspresjonistyczna” tonacja tych sekwencji. Ale sam Lang odżegnywał się od związków z ekspresjonizmem. Epizod chiński, ze scenografią Roberta Herltha i epizod arabski (Warm) mają zupełnie inną tonację.

100 Ursprung des deutschen Trauerspiels. Korzystam z angielskiego przekładu, zob. przypis 80.

101 T. Gunning, op. cit., s. 26. Ideą filmu jako nowego „hieroglificznego języka” był szczególnie opętany Vachel Lindsay w swej książce z 1915 r. The Art of the Moving Picture (wznowienie: Liveright Publishing Company, New York 1970).

102 Ibidem, s. 26-27. 
ną, poetyckiej nad narracyjną. A Zmęczona Śmierć jawi się jako jeden z najbardziej alegorycznych filmów w historii kina niemego choćby z tej racji, iż melancholijną aurą niesłychanie przypomina modelowe alegoryczne tragedie analizowane przez Benjamina. Jak i w Trauerspiele, są w filmie Langa tyrani, skrytobójcy, zmagania miłości ze śmiercia, sentencje wypowiadane przez postaci, egzotyczne scenerie, symultaniczna prezentacja rozmaitych wątków, wzajemne się ich naświetlanie, rama kompozycyjna, nieregularny rytm gwałtownych przyspieszeń czy zmian kierunku akcji na przemian z pauzami i zastygnięciami, i nade wszystko pesymistyczna wizja zarówno historii, jak i ludzkiej duszy ${ }^{103}$. Tak pesymistyczna, że być może jedynym możliwym do akceptacji jej artystycznym wyrazem jest alegoria.

${ }^{103}$ Charakterystyka Trauerspiel jest wyciągiem z: W. Benjamin, The Origin of German Tragic Drama, s. 159-235, szczególnie zaś s. 189-197. 



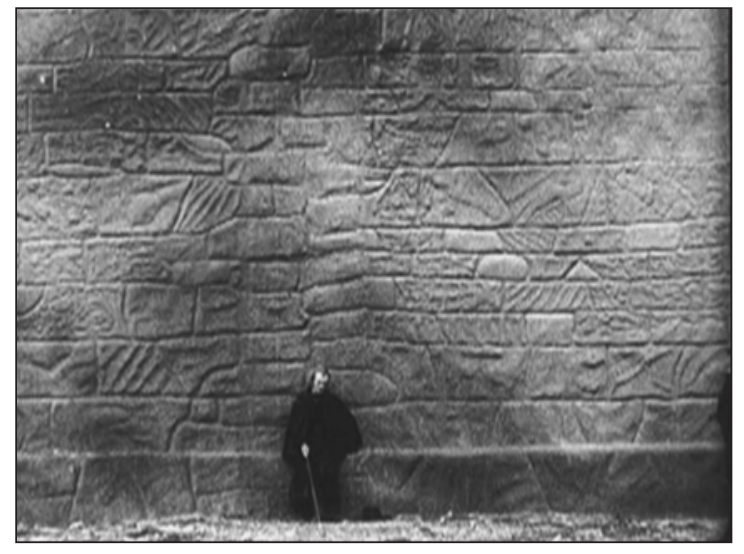

1. Zmęczona Śmierć (1921, reż. Fritz Lang). Na tle nieskończonego muru nieznajomy kreśli na piasku Alfę i Omegę
2. Zmęczona Śmierć (1921, reż. Fritz Lang). Ponury nieznajomy, młodzi i oberżystka z pucharem miłości

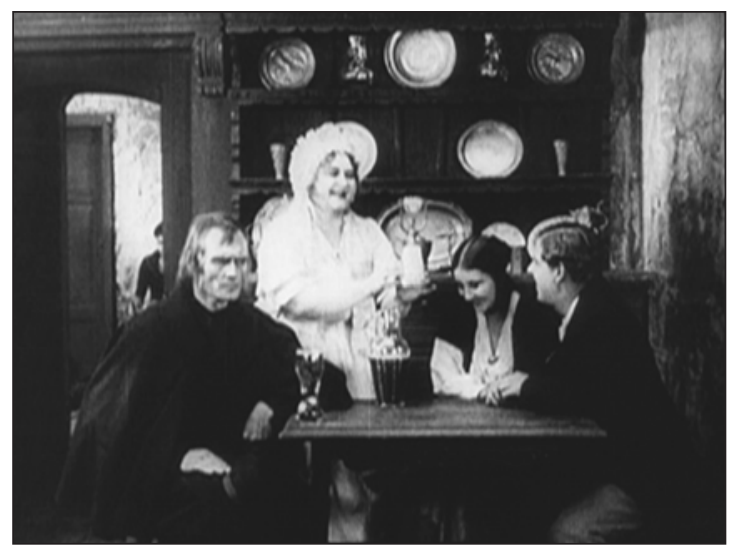

3. Zmęczona Śmierć (1921, reż. Fritz Lang). Młodzi piją z pucharu miłości 


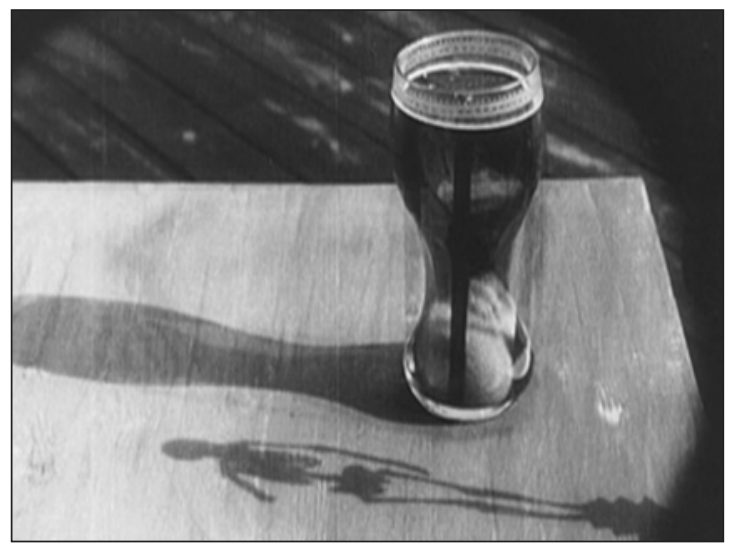

4. Zmęczona Śmierć (1921, reż. Fritz Lang). Wizja Dziewczyny - cień kościotrupa i przemiana szklanki piwa w klepsydrę

5. Zmęczona Śmierć (1921, reż. Fritz Lang). Między ustami a brzegiem pucharu. W tle - puszczyk, ptak śmierci
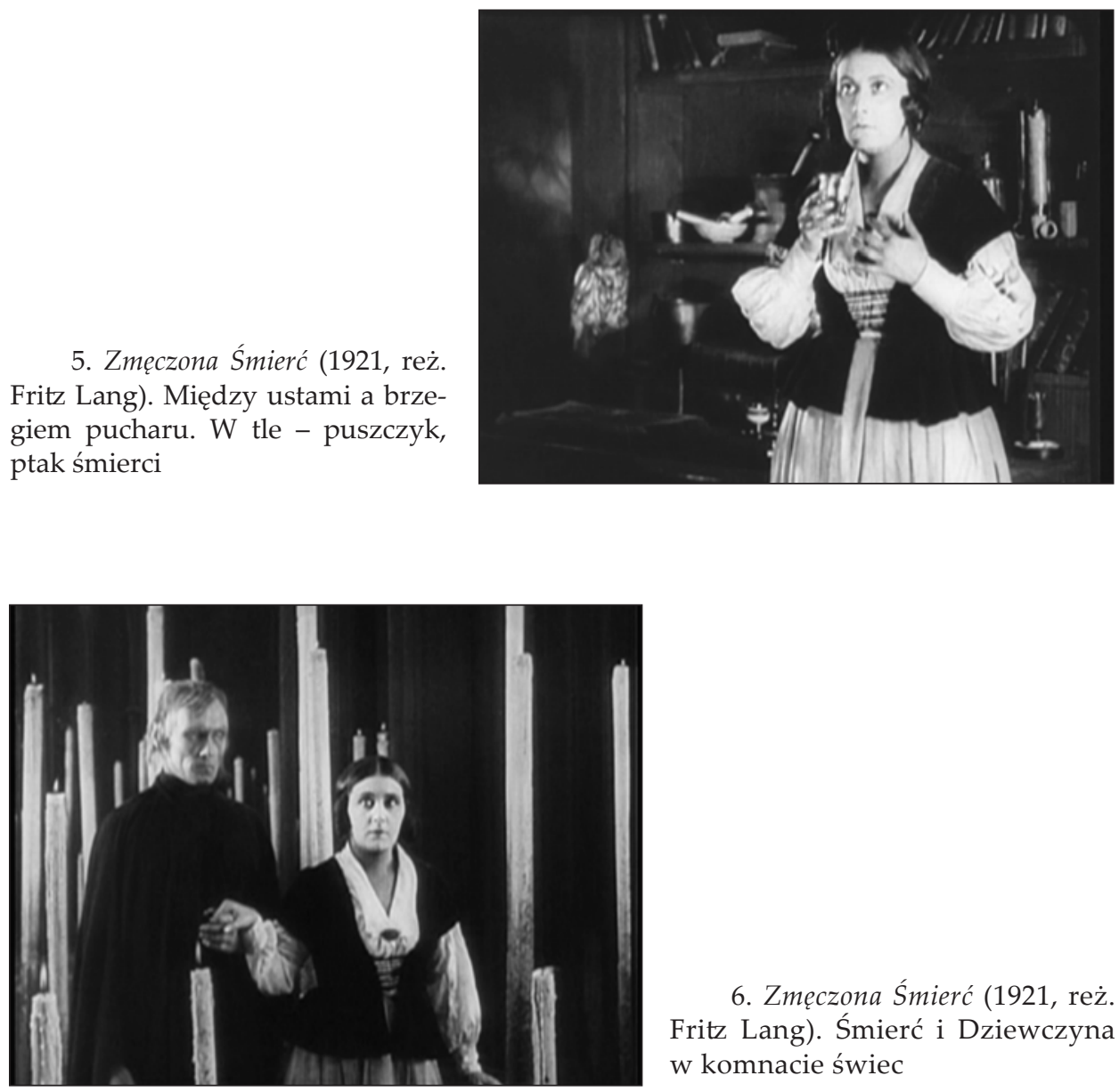

6. Zmęczona Śmierć (1921, reż. Fritz Lang). Śmierć i Dziewczyna w komnacie świec 


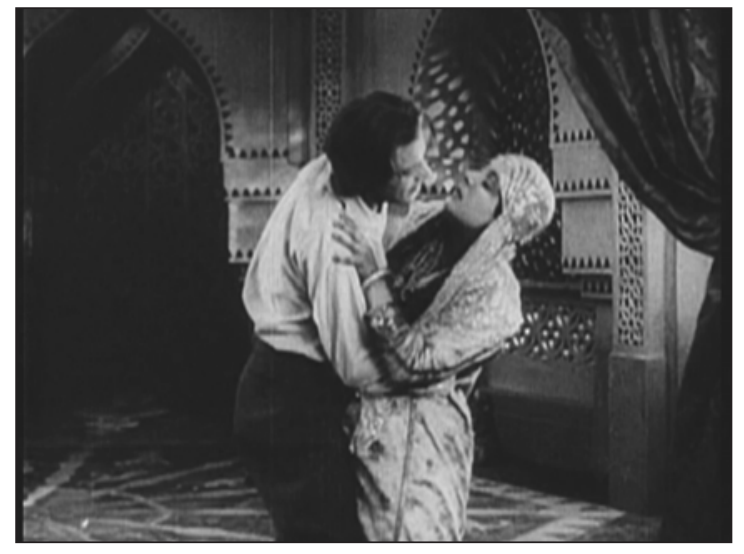

7. Zmęczona Śmierć (1921, reż. Fritz Lang). Frankończyk i Zobaida - nieszczęśni kochankowie z noweli arabskiej

8. Zmęczona Śmierć (1921, reż. Fritz Lang). Bachanalia na weneckim moście z ewokującymi Śmierć ostrołukami
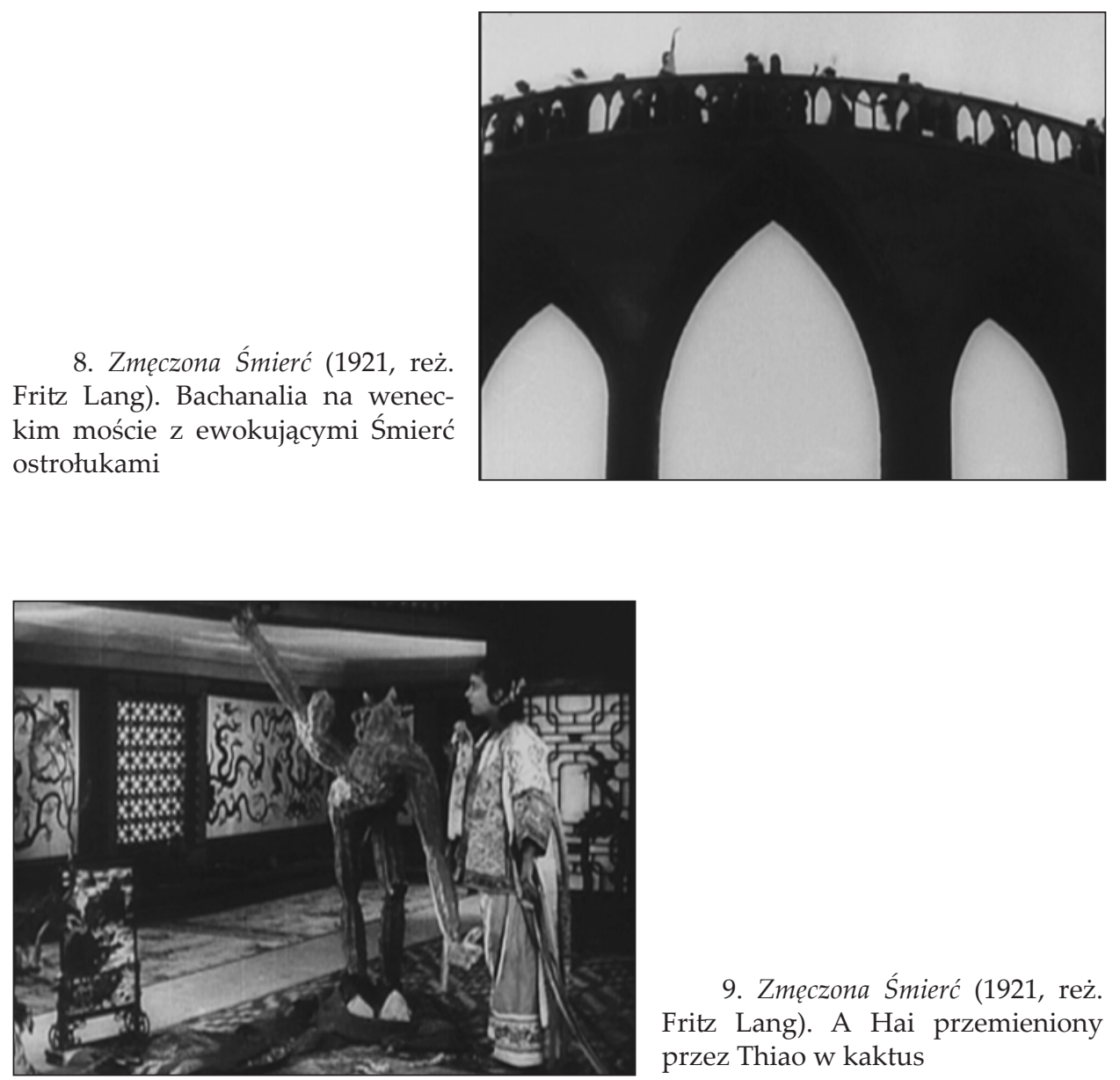

9. Zmęczona Śmierć (1921, reż. Fritz Lang). A Hai przemieniony przez Thiao w kaktus 


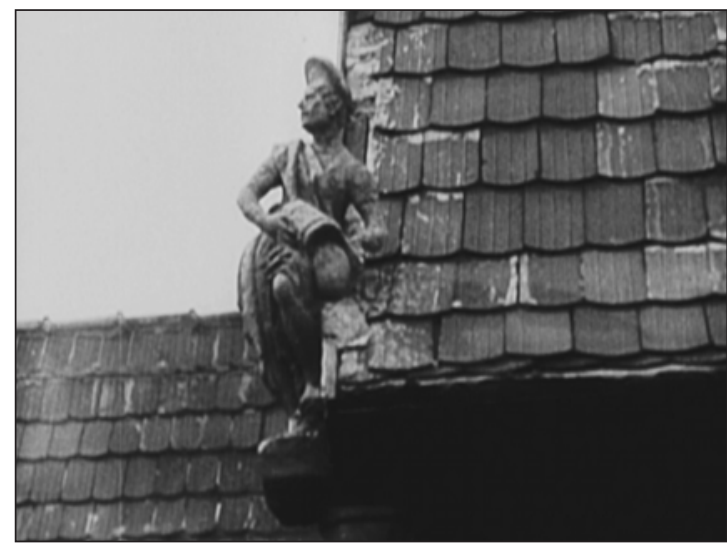

10. Zmęczona Śmierć (1921, reż. Fritz Lang). Alegoryczna figura Wodnika
11. Zmęczona Śmierć (1921, reż. Fritz Lang). Dziewczyna zmienia decyzję i nie oddaje dziecka Śmierci

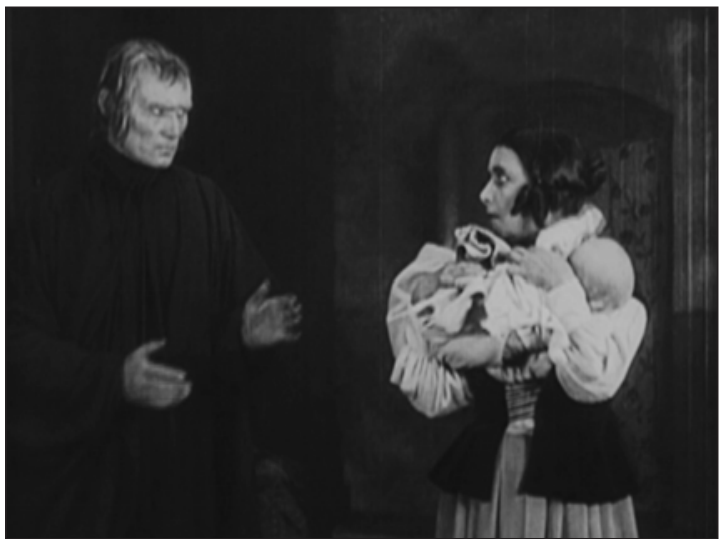

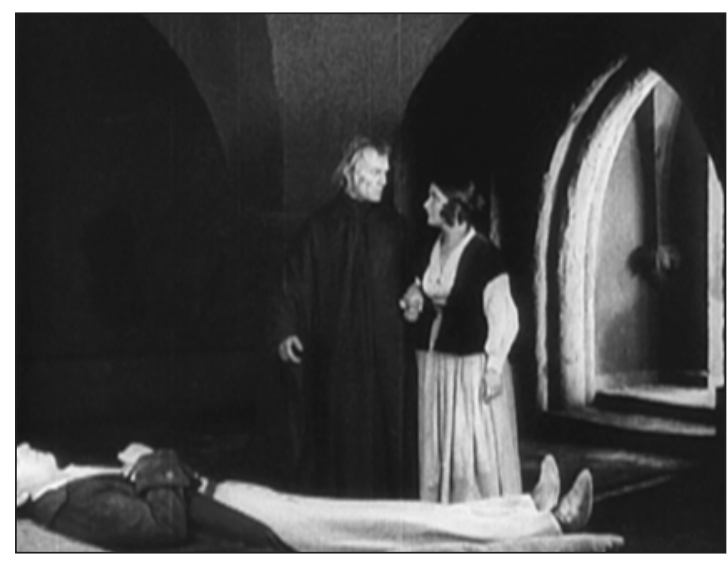

12. Zmęczona Śmierć (1921, reż. Fritz Lang). Śmierć za chwilę połączy Dziewczynę z ukochanym 


\section{Rozdział 2}

\section{KREW SMOKA: NIBELUNGI}

Nie tykany siekierą wznosił się las stary, W nim jaskinia gęstymi zakryta konary, W niski łuk zasklepiona szczupły miała otwór, A przy nim wód obfitość; lecz okropny potwór, Smok Marsa, miał tu swoje zwyczajne schronienie. Błyszczą mu się złociste na głowie grzebienie, Trucizna go rozdyma, ogniem skrzą się oczy I potrójnym językiem jad z paszczęki toczy. [...] ... Kadmus głaz dźwiga, siły swe natęża I z ogromnym zamachem ciska go na węża. [...] Twarda łuska jak tarcza ochrania przed głazem, Niczym jednak jej siła przed ostrym żelazem.

Wdziera się silny pocisk wśród gibkich pierścieni, Wnętrze smoka przeszywa i krwią go rumieni. Obraca się w tył potwór bólem rozsrożony Widzi ranę i kąsa pocisk w niej utkwiony. [...] Aż mu Kadmus w paszczękę zadał cios niemylny I po samą rękojeść utkwił oręż silny. [...] Wielkość zwyciężonego, gdy zwycięzca zważa, Nagle głos niewidomy duszę mu przeraża: „Czego patrzysz na smoka przerażonym okiem Potomku Agenora? I ty będziesz smokiem!" [...] A wtem Pallas, będąca rycerza obrona, Schodzi z nieba i każe w ziemię poruszoną Na rozkrzewienie ludu ciskać zęby smocze. Kadmus do pługu woły zakłada robocze I ciska w grunt zorany pokoleń nasiona. Wtem zaczęła się wzdymać skiba poruszona. I z początku, o cuda, przez grunt jeszcze ścisły, Przedarły się oszczepy, dalej hełmy błysły. Wreszcie barki i piersi, i ramiona zbrojne, I wielki łan rycerzy gotowych na wojnę. [...] Widząc, iż nowi z ziemi powstają rycerze, Zlękły syn Agenora do broni się bierze.

Wtem jeden z synów ziemi rzekł mu: „Bądź spokojny, Tylko nam do domowej nie mieszaj się wojny!" Rzekł i utkwił miecz w sercu jednego z współbraci, 
Lecz sam z trzeciego ręki strzałą życie traci.

I ten, co pocisk rzucił, bratnią dłonią pchnięty,

Poległ, i oddał żywot dopiero co wzięty.

Wszyscy za wzorem pierwszych podobnie szaleją

I nagle giną bracia wzajemną koleją ${ }^{1}$.

Owidiusz, Kadmus (Przemiany, III, 29-126)

Niegdyś w Burgundii śliczne dorastało dziecię Krwi królewskiej, - Krymhilda. Żadna jej na świecie Nie dorówna uroda, co z latami rosła -

A potem mężom tylu zagładę przyniosła. [...]

Trzech ją braci chowało: króle możni, sławni, Gunter i Gernot, obaj wojownicy sprawni, I Giselher, młodzieniec pełen męskiej cnoty; Miała w nich i opiekę, i siostry pieszczoty.

Ród to zacny, wysoki, a serca wspaniałe, Sił wszelakich dostatek, męstwo też wspaniałe, Królowali w burgundzkiej ziemi, a stoczyli Cudowne potem boje w krainie Attyli.

W Wormacji stał nad Renem zamek ich potężny Z lennych włości rycerzy garnął się huf mężny. Do grobu wiernie służąc męże dumni, butni.

- Zginęli potem marnie dla dwóch kobiet kłótni. - [...]

Śniło się raz Krymhildzie, iż jej ulubiony

Sokół, ptak śliczny, dziki, morderczemi szpony

Dwóch orłów padł zabity, rozdarty boleśnie:

Pierwsza to boleść w życiu spotkała ją we śnie.

W trwodze do matki bieży, pyta, co to znaczy?

A matka sen złowieszczy ze smutkiem tłumaczy:

„Twój sokół to małżonek przyszły, córko luba,

Lecz go - niech Bóg odwróci! wczesna czeka zguba!" [...]

Jak sen proroczo wieścił, sokół to był żwawy!

Straciła go, lecz pomsty podjęła się krwawej

Na zabójcach, na własnej mściła go rodzinie:

Za jego krew - strumieniem krew rycerska płynie ${ }^{2}$.

Niedola Nibelungów, Przygoda I, strofy 2-19

\footnotetext{
${ }^{1}$ Owidiusz, Przemiany, przeł. Bruno Kiciński, Unia Wydawnicza „Verum”, Warszawa 1995, s. 64-66.

2 Niedola Nibelungów, przeł. Ludomił German, nakł. Wilhelma Zukerkandla, Złoczów 1894, s. 16-18.
} 


\section{Supergigant ery inflacji}

Niemiecka inflacja okresu po I wojnie światowej, a zwłaszcza jej hiperinflacyjne apogeum, czy też raczej dno, z lat 1922-1923, miała dla społeczeństwa Republiki Weimarskiej katastrofalne skutki nie tylko ekonomiczne, ale przede wszystkim moralne, psychologiczne i polityczne (o czym nieco szerzej traktuje rozdział poświęcony filmowi Doktor Mabuse, gracz, s. 275). Istnieli jednak doraźni beneficjenci inflacji - przemysłowi magnaci, którzy dzięki zaciągnięciu nierewaloryzowanych kredytów skupili w swym ręku olbrzymi kapitał i władzę (jak Hugo Stinnes) ${ }^{3}$, wzbogaceni na wymianie barterowej ze zbiedniałymi gwałtownie mieszkańcami miast rolnicy $^{4}$, wreszcie - przemysł filmowy. W okresie inflacji wzrosła znacznie frekwencja w kinach - pracownicy etatowi wydawali zarobek, kiedy był jeszcze cokolwiek wart, a zresztą na rozrywkę nie żal było inflacyjnych pieniędzy. W tym czasie zbudowano wiele kin, sama zaś inflacja zniechęcała do importu filmów, co promowało rodzimą produkcję (przy porównywalnych walorach widowiskowych filmów, kilkunastokrotnie nawet tańszą niż np. w Hollywood ${ }^{5}$ ), a tym samym - jej eksport na rynki zagraniczne po cenach dumpingowych ${ }^{6}$.

Produktem właśnie hiperinflacji są Nibelungi (Die Nibelungen) Fritza Langa, do czasu Metropolis najbardziej wystawny i zakrojony na największą skalę produkcyjną film w historii kina niemieckiego. Produkcja (wliczając $w$ to etap przygotowania scenariusza) zajęła prawie dwa lata, zaś zaplanowane na 31 tygodni zdjęcia kręcono głównie w roku 1923, pod którego koniec katastrofalny spadek niemieckiej waluty sprawił, iż za 4,2 biliona marek można było w zamian otrzymać zaledwie 1 dolara! ${ }^{7} \mathrm{~W}$ warunkach hiperinflacyjnego niedoboru dóbr istniały rozmaite trudności w zaopatrzeniu planu we wszystko, co było niezbędne - np. aby zdobyć

${ }^{3}$ Nt. jego postaci, zob.: Bernd Widdig, Culture and Inflation in Weimar Germany, University of California Press, Berkeley-Los Angeles-London 2001, s. 134-165.

${ }^{4}$ Zob.: ibidem, s. 86-87, 208-211.

5 Madame DuBarry (1919) Ernsta Lubitscha kosztowała w inflacyjnych markach ekwiwalent około 40000 ówczesnych dolarów. Gdy w roku 1921 film ten z sukcesem trafił na ekrany amerykańskie, eksperci ocenili, że wyprodukowanie w Hollywood filmu o podobnym rozmachu kosztowałoby około 12,5-krotnie więcej - 500000 \$ (sumę na owe lata olbrzymia, jak na budżet pełnometrażowego filmu). Zob.: Kristin Thompson, David Bordwell, Film History: An Introduction, McGraw-Hill, Inc., New York 1993, s. 108.

${ }^{6}$ Zob.: K. Thompson, D. Bordwell, op. cit., s. 106-107.

7 Por.: Jan-Christoph Horak, Die Nibelungen, broszura dołączona do edycji dwupłytowego albumu Die Nibelungen, Kino on Video, New York 2002, s. 3. Album ten zawiera wersję filmu odrestaurowaną przez monachijskie Filmmuseum przy współudziale Murnau-Stiftung, z oryginalną ścieżką muzyczną autorstwa Gottfrieda Huppertza. 
gwoździe nieodzowne dla skonstruowania scenografii, studio wynajęło gromadę emerytów i wojennych weteranów-inwalidów, którzy przeszukiwali tereny wytwórni w Neubabelsbergu, zbierając gwoździe pozostałe po rozebranych dekoracjach ${ }^{8}$. Lang, jak zwykle, żądał od zespołu całkowitego poświęcenia się realizacji. „W tej epoce nie było żadnych nadgodzin. Obsada i ekipa realizatorska pracowały po dziesięć, dwanaście, czternaście godzin dziennie, czasem bez przerwy. Ludzie podczas zdjęć do Nibelungów zmuszeni byli pracować tak długo, że nie zawsze udawało się im dotrzeć na czas do sklepów, by kupić codzienny chleb, który i tak dla ogółu ludności był rzadkim rarytasem. Ceny żywności rosły tak szybko, że studio samo podjęło się zakupu artykułów spożywczych na początku tygodnia i sprzedawania ich przy wypłacie zatrudnionym przy realizacji po cenach z początku tygodnia. Uświadomiwszy sobie, że rozpaczliwe warunki życia wciąż się pogarszały, Thea von Harbou ofiarowała się z przygotowywaniem dla wszystkich regularnych ciepłych posiłków"19w zorganizowanej nieopodal planu kantynie.

Ale z drugiej strony, materiały i praca były tanie, a z inflacyjnym, niewaloryzowanym pieniądzem można było się nie liczyć, mając całkiem realną perspektywę zysku w obcej walucie o ogromnej w Niemczech sile nabywczej; toteż rozmach inscenizacyjny Nibelungów - rozmiary dekoracji, liczba statystów - do dziś musi widzom imponować. Pod dużym wrażeniem był też nieznany jeszcze szerzej młody angielski filmowiec, który tak zapamiętał dekorację w Neubabelsbergu, przedstawiającą olbrzymi las: „Mieli tam ogromny plan pod gołym niebem, długi na czterysta stóp, szeroki na dwieście na poziomie ziemi, a wszystkie boczne ściany miały rusztowania prowadzące do platform długich na sto, głębokich na dwanaście stóp. $Z$ tyłu znajdowała się panoramiczna zastawka, długa na dwieście stóp, ogromna rzecz. I na jej tle zbudowali las Nibelungów... Była to piękna robota"10. Filmowcem tym, podziwiającym na planie niemieckiego kolegę po fachu, któremu powierzono tak olbrzymią realizację, był, o ironio, Alfred Hitchcock, który za oceanem uzyska niebawem status mistrza mogącego pozwalać sobie na rozmaite ekstrawagancje realizacji, podczas gdy Lang spadnie tam do pozycji rzemieślnika, nieufnie traktowanego przez hollywoodzkich potentatów i stale zmagającego się z olbrzymimi problemami, by choć po części zrealizować swe artystyczne wizje...

${ }^{8}$ Zob.: Patrick McGilligan, Fritz Lang: The Nature of the Beast, St. Martin's Press, New York 1997, s. 96.

9 Ibidem, s. 96-97.

${ }^{10}$ Cyt. za: Frederick W. Ott, The Films of Fritz Lang, The Citadell Press, Seacaucus 1979, s. 107. 
Olbrzymie niczym sekwoje pnie drzew wykonano z drewna, gipsu i betonu, a współtworzyła efekt owego fantastycznego lasu, przez który przejeżdża Zygfryd, mieszanka prawdziwego światła słonecznego, sączącego się przez szklany dach ponad planem, oraz oświetlenia sztucznego. Pomiędzy pniami na podłodze studia rozrzucono całe wozy soli dla stworzenia efektu, iż jest to las skamieniały, „zamrożony”. Dla efektu realistycznego eksponowane $\mathrm{w}$ kadrze korzenie wielkich drzew pokryto warstwą mchu, a pomiędzy nimi nasypano prawdziwej ziemi ${ }^{11}$. Inne monumentalne dekoracje filmu to katedra w Wormacji, z niebotycznym frontonem i olbrzymimi schodami wejściowymi, na których dochodzi do brzemiennej w skutki kłótni Krymhildy i Brunhildy, zamek Brunhildy w jej rodzinnej Islandii, wreszcie - miasto-obozowisko Hunów z płonącym w finale pałacem króla Etzela, w którego sali bankietowej znajdują zagładę Burgundowie-Nibelungowie.

Największą jednak atrakcją dla ówczesnej publiczności był 20-metrowy smok, którego zabija Zygfryd, dzieło inżynierskiej inwencji jednego ze świetnych scenografów Langa - Karla Vollbrechta. „Łuskowatą «skórę» miał wykonaną z gipsu pokrytego wulkanizowanym kauczukiem. Siedemnastu techników, którzy ukryci wewnątrz smoka kierowali jego ruchami, przeszło kilkumiesięczny trening. Siedmiu innych operowało z ukrytej pod smokiem studni, otrzymując instrukcje przez telefon. Po tygodniach prób i błędów opanowali przyrządy, które umożliwiały smokowi pełzać w lesie, pić wodę ze stawu czy zionąć dymem i ogniem $\mathrm{w}$ stosownym momencie. Dym i płomienie były wytworzone przez miechy, a specjalne urządzenie pompowało «krew», kiedy skórę smoka przebił miecz Zygfryda. Załoga śledziła kierunek swych ruchów przez małe okienka umieszczone z przodu w kolczastych naroślach. By uczynić smoka realistycznym, jego szczęki i zęby zwilżono płynem, co sugerowało ślinienie się bestii"12.

Nie da się ukryć, że gipsowo-kauczukowy smok, manipulowany przez taki sztab ludzi, wydaje się dziś raczej zabawny niż imponujący - jest zresztą bardzo ociężały, niepewny w ruchach i ograniczony w ich trajektorii. Właściwie nie można się dziwić, że Zygfryd tak łatwo go pokonał. Ale nie oceniajmy ambitnego technicznie A. D. 1923 przedsięwzięcia z perspektywy dzisiejszych możliwości animacji komputerowej - tą samą w zasadzie techniką modeli naturalnej wielkości posłużył się przecież Steven Spielberg, i to nie tylko w pamiętnych Szczękach (1975), lecz jeszcze też w powstałym w 1993 pierwszym z filmów z cyklu Jurassic Park.

11 Zob.: P. McGilligan, op. cit., s. 97.

${ }^{12}$ F. W. Ott, op. cit., s. 108. Por. także: P. McGilligan, op. cit., s. 98. McGilligan podaje trochę inne dane - 10 techników wewnątrz smoka i „,kilku” innych w studni. 
W każdym razie na pamiętnej berlińskiej wystawie filmowej „Kipho” (skrót od „Kino und Photo Ausstellung”), która była wielkim wydarzeniem 1925 r., smok z Nibelungów należał do największych atrakcji13.

Lang, który w sposób mechaniczny kontrolował ruchy smoka, chciał podobnie zapanować nad ruchami i gestami aktorów, co zresztą było poniekąd uzasadnione koniecznością dostarczenia precyzyjnych wskazówek szczególnie w scenach masowych, z udziałem licznych statystów. Erich Kettelhut, jeszcze jeden wybitny przedstawiciel zespołu scenografów Langa, którego szefem był Otto Hunte, tak zapamiętał dyrektywy dawane na planie członkom obsady: „,Brzmiało to tak: «Słuchajcie, na raz-dwa-trzy lekko pochylacie górę ciała do przodu - obracacie głowę ku mnie; na cztery-pięć-sześć-siedem wolno podnosicie do góry lewe ramię. Rozwieracie zaciśniętą pięść, trzymając ją na wysokości głowy. Wasze twarze przybierają wyraz zdumienia, wasze usta nieznacznie się rozchylają; na dziesięć, wyrzucacie do przodu oba ramiona, rozczapierzacie palce, odskakujecie do tyłu, wrzeszczycie». Liczby mogły dochodzić do pięćdziesięciu, w zależności od sceny i od tego, jak zróżnicowane były ruchy. Różni aktorzy na te same numery mogli wykonywać różne ruchy. Bywało, że czasem całe grupy, a czasem wszyscy statyści musieli poruszać się wedle serii liczbowych dyrektyw" ${ }^{\prime 14}$.

Biograf reżysera zauważa, że ten aż nazbyt precyzyjny i arogancki sposób wydawania aktorom poleceń prowadził ich do swego rodzaju zahamowań - próbując możliwie ściśle nadążać za wskazówkami, nieuchronnie sztywnieli na ekranie. Cierpiało z tego powodu człowieczeństwo postaci, a widz doznawał wrażenia nie tylko ich "chłodu"15, ale i ich uprzedmiotowienia, tworzenia z układów ludzkich „ornamentu z mas”16. Do zagadnienia tego, w aspekcie już nie tylko aktorstwa, ale estetyki, w której zdaniem Siegfrieda Kracauera znajduje wyraz tendencja totalitarna, jeszcze powrócimy.

Producentem Nibelungów był, jak i w wypadku Zmęczonej Śmierci i Doktora Mabuse, gracza, Erich Pommer. Wytwórnia Decla-Bioscop, na czele której stał Pommer, faktycznie już wchłonięta przez Ufę, formalnie jednak była osobnym podmiotem i „partnerem” kolosa. Toteż w czołówce Nibelungów widnieje zarówno logo spółki Decla-Bioscop, jak i logo Ufy choć film ten, podobnie jak Metropolis, wydaje się reprezentatywny przede

\footnotetext{
13 Por.: K. Thompson, D. Bordwell, op. cit., s. 190.

${ }^{14}$ Wypowiedź Kettelhuta przytacza P. McGilligan (op. cit., s. 98).

15 Zob.: P. McGilligan, op. cit., s. 98.

16 Por.: Siegfried Kracauer, Od Caligariego do Hitlera: Z psychologii filmu niemieckiego, przeł. Wanda Wertenstein, Eugenia Skrzywanowa, Filmowa Agencja Wydawnicza, Warszawa 1958, s. 83-84.
} 
wszystkim dla monumentalnego stylu drugiej z kompanii. Pommer, choć pokładał w Langu niemal nieograniczone zaufanie i wielokrotnie godził się na przekraczanie i tak napiętych budżetów, zaoponował, gdy Lang zażądał kilkuset statystów i koni dla sceny dzikiej, szalonej jazdy Hunów na czele Etzela zdążających spod Rzymu ku przebywającej w Etzelnburgu ${ }^{17}$ Krymhildzie, która uszczęśliwiła króla potomkiem. Gdy Lang wyraził już gotowość rezygnacji ze swej kosztownej wizji, Pommer jednak niespodziewanie ustąpił. I choć może nie "kilkuset”, to z pewnością dobrze ponad setka jeźdźców wzięła udział w ekscytującej do dziś szalonym tempem i efektownymi planami ogólnymi sekwencji huńskiego galopu „spod Rzymu ku Krymhildzie". Kręcono ją na początku lata 1923 w Rehberge, na bezludnych, pokrytych wzgórzami obrzeżach Berlina, a wedle (przesadnego) opisu z epoki "ziemia drżała od tętentu tysiąca kopyt" ${ }^{18}$.

Patrick McGilligan w swej biografii nazywa Langa „najbardziej zagorzałym piromanem kina” (the cinema's most dedicated pyromaniac). „Był to niemal chłopięcy impuls - kochał fajerwerki i kulminacje z big-bangiem. Nikt nie obmyślał eksplozji czy nie rozpalał ogniska z większą uciechą"19. Istotnie, w kilku filmach Langa mamy do czynienia ze scenami, gdzie pożar stanowi dramatyczną kulminację - vide: pożar przytułku-szpitala w finale Zmęczonej Śmierci, stos, na którym płonie fałszywa Maria w Metropolis, pożar zakładów chemicznych i zawalenie się olbrzymiego komina w finale Testamentu doktora Mabuse, wreszcie - centralna scena jego pierwszego amerykańskiego filmu Jestem niewinny (Fury), w której dokonujący linczu mieszkańcy miasteczka podpalają areszt $\mathrm{z}$ uwięzionym $\mathrm{w}$ nim bohaterem. Najbardziej jednak apokaliptyczną z tych „piromańskich” scen jest finał Nibelungów: podpalenie przez Hunów na rozkaz Krymhildy pałacu króla Etzela, w którego sali bankietowej uwięzieni są Burgundowie. „Opuszczoną fabrykę w Spandau odnowiono za niemałe pieniądze tylko po to, by obrócić ją w zgliszcza w scenie, która była filmowana jednocześnie przez jakieś szesnaście kamer. Oczywiście Lang zdecydował się samemu zażec finalny ogieńn ${ }^{20}$. Tak wspomina realizację tej dramatycznej

17 Tak w eposie Das Nibelungenlied nazywa się stolica króla Hunów Etzela (Attyli), identyfikowana $\mathrm{z}$ węgierskim miastem Esztergom. W filmie nie pada nazwa stolicy państwa Etzela, ale dla wygody można ją tak nazywać.

${ }^{18}$ Cyt. za: F. W. Ott, op. cit., s. 110. Ott w ogóle błędnie określa tę sekwencję jako „bitwę" i „atak” Hunów (s. 108), McGilligan z kolei podaje, że chodzi o scenę szalonej jazdy Hunów po wypatrzeniu przez nich orszaku zdążającej do Etzela Krymhildy (op. cit., s. 99). Owszem, ta znacznie krótsza scena też wymagała pewnej liczby konnych statystów - i zapewne kręcono ją tego samego dnia w Rehberge. Ale tłum jeźdźców niezbędny był głównie w sekwencji odwrotu Hunów spod Rzymu.

19 P. McGilligan, op. cit., s. 74.

${ }^{20}$ Ibidem, s. 99. 
sceny Erich Kettelhut: „Fritz Lang, stojąc poza zasięgiem kamery, wyciągnął łuk i wypuścił strzałę z prochem magnezjowym w grocie. Zatoczyła wysoki łuk nad jednym z narożników dachu. Płomienie rozprzestrzeniały się jak kręgi na wodzie od rzuconego w nią kamienia. Wielkie płomienie niewiarygodnie szybko ogarnęły budynek. Grzyb dymu rósł coraz bardziej, sięgając ku niebu. Dach zawalił się. Robiło się coraz goręcej. Zewnętrzne ściany pałacu Etzela, zmoczone wcześniej woda, by zapobiec ich zapaleniu się, zaczęły dymić. Lang dał znak, że ujęcie skończone. Cała rzecz zajęła około dziesięciu minut. Ludzie stali naokoło w całkowitej ciszy, głęboko poruszeni"21. I trzeba przyznać, że nie tylko na świadkach jej realizacji scena pożaru pałacu Etzela robi niesłychane wrażenie: nie tylko dlatego, że jest porażającą emocjonalnie, katartyczną kulminacją fabularną, ale także z racji jej przygniatającej, apokaliptycznej widowiskowości.

Ale wiele budzących podziw efektów w Nibelungach osiągnięto znacznie mniejszym nakładem środków niż smoka czy pamiętny finał i znacznie prostszymi sposobami. Gęsta mgła w scenie, kiedy karzeł Alberyk ubrany w Tarnhelm (czapkę-niewidkę) napada Zygfryda, który zmaga się z niewidzialnym przeciwnikiem, została wyprodukowana przez gaśnice przeciwpożarowe. Promienie słoneczne przedzierające się z trudem przez szklane ściany i dach studia w Neubabelsbergu (a był to gorący wiosenny dzień) nadały wiszącym, gęstym oparom niezwykły atmosferyczny efekt, którego jednak Langowi nie udało się później powtórzyć - następnym razem mgła po prostu rozproszyła się po atelier ${ }^{22}$. W świecie przedstawionym wykuty przez Zygfryda w kuźni kowala Mime miecz jest tak ostry, że rozcina na pół rzucone $\mathrm{w}$ powietrzu piórko. W rzeczywistości profilmowej rzucono jednak po prostu dwa piórka, tyle tylko, że do filmu włączono nagranie od końca, w ruchu odwróconym ${ }^{23}$.

Lang zamarzył sobie również ujęcie przedstawiające krajobraz z tęczą, co wzbudziło protesty operatora, Carla Hoffmanna, wiedzącego, iż tęczy nie da się sfilmować. Rozwiązanie znalazł drugi operator, odpowiedzialny za zdjęcia specjalne Günther Rittau, po prostu nakładając w podwójnej ekspozycji na obraz zbudowanej w studio góry wykonany kredą na czarnym kartonie rysunek tęczy ${ }^{24}$. Natomiast zorzę polarna, rozświetlającą niebo wokół islandzkiego zamku Brunhildy, Rittau osiągnął za pomocą reflektorów i ruchomego lustra ${ }^{25}$.

\footnotetext{
${ }^{21}$ Cyt. za: ibidem, s. 100.

${ }^{22}$ Zob.: Lotte H. Eisner, Fritz Lang, Da Capo Press, New York 1986, s. 75; P. McGilligan, op. cit., s. 97.

${ }^{23}$ Zob.: P. McGilligan, op. cit., s. 97.

${ }_{24}$ Zob.: L. H. Eisner, op. cit., s. 75; P. McGilligan, op. cit., s. 97.

${ }_{25}$ Zob.: L. H. Eisner, op. cit., s. 97.
} 
Kto wie, czy nie największym osiągnięciem wizualnym Rittaua w eposie Langa, nie jest scena stopniowego obracania się w kamień karłów podtrzymujących w grocie Alberyka gigantyczną misę ze skarbem Nibelungów. Twarze karłów są jeszcze żywe i pełne przerażenia, gdy dół ich ciał już zastygł w głaz pod wpływem klątwy Alberyka. Ale i te oblicza stopniowo ulegają petryfikacji, która uwiecznia strach i grymas bólu ofiar. Rittau osiągnął ten fascynujący efekt przez stopniową podwójną ekspozycję od dołu do góry - przy czym wszystko zostało przeprowadzone bezpośrednio w kamerze, przy precyzyjnym obliczaniu taśmy i kadru; Lotte Eisner przypomina, iż w owym czasie kinematografia niemiecka nie miała jeszcze wydziałów efektów specjalnych, którymi już szczycili się Amerykanie w Hollywood ${ }^{26}$. Zresztą dzięki podwójnej ekspozycji, tyle tylko, że bardziej tradycyjnej, choć także kunsztownej, my, widzowie, widzimy jako przejrzyste widmo „niewidzialnego" w świecie przedstawionym Zygfryda, gdy w swym Tarnhelm pomaga Gunterowi w pojedynku z Brunhildą, wykonując za króla Burgundów jego zadania.

Jedną z najsłynniejszych sekwencji filmu jest tzw. "Sen o soko$l^{\prime \prime}$, autorstwa Waltera Ruttmanna. W filmie Langa przedstawienie snu Krymhildy o sokole rozszarpanym szponami dwóch orłów (zob. drugie motto do niniejszego rozdziału) w zaskakujący sposób odbiega stylistycznie od reszty dzieła. Jest to bowiem sekwencja animowana, na pograniczu abstrakcji i figuratywności, co zresztą sprawia, iż nie jest zbyt czytelna dla osób nieznających eposu o Nibelungach czy niepotrafiących rozpoznawać sylwetek ptaków ${ }^{27}$. Widzimy, jak biała plama na szarym tle przy-

${ }^{26}$ Zob.: L. H. Eisner, op. cit., s. 76; także: P. McGilligan, op. cit., s. 97.

${ }^{27}$ Gdy zna się epos i/lub sylwetki ptaków, nie ma najmniejszego problemu z rozpoznaniem, iż w sekwencji Ruttmanna biały ptak o sylwetce sokoła zostaje zaatakowany przez dwa czarne wielkie ptaki drapieżne (biorąc pod uwagę ich wielkość, w grę wchodzą tylko orły, nigdy zaś jastrzębie). Tymczasem rozmaici autorzy piszący o Nibelungach określają te ptaki zupełnie nieadekwatnie. O "gołębiu” i „krukach” pisze Iris Barry (,The Nibelungs", "The Spectator", 14 June 1924), zaś Paul M. Jensen (The Cinema of Fritz Lang, A. S. Barnes \& Co. - A. Zwemmer Limited, New York-London 1969, s. 49-50) i Siegfried Kracauer (From Caligari to Hitler: A Psychological History of the German Film, Princeton University Press, Princeton-Oxford 2004, s. 94) piszą o "czarnych jastrzębiach" i „białym gołębiu”. Polski przekład Kracauera (op. cit., s. 83) - i niech ten przykład będzie świadectwem jego jakości - wspomina o "dwóch czarnych sokołach” i „białym gołębiu”, i sekwencję nazywa „snem o sokołach" (tymczasem w eposie i filmie to sokół - jeden - jest ofiara, nie morderca - podwójnym). Tom Gunning, niepewny jak nazwać ptaki, w swej analizie pisze po prostu o białym i czarnych ptakach, ale sekwencję błędnie nazywa "Snem o jastrzębiach" (The Films of Fritz Lang: Allegories of Vision and Modernity, BFI Publishing, London 2000, s. 46-47). Ale sam Lang też chyba nie za bardzo znał się na ptakach: w sali tronowej Guntera, zapewne w roli będącego emblematem Burgundów morderczego orła, który zabije sokoła-Zygfryda, siedzi dość niegroźny myszołów. A ptak, który swym „melodyjnym śpiewem” przekazuje Zygfrydowi tajemnicę krwi smoka, to chyba... sroka (wybór wyjątkowo niefortunny). 
biera kształt sokoła. Uwijają się nad nim dwie czarne plamy, "odlatują". Odlatuje też, jakby spłoszony, biały sokół. Czarne plamy konkretyzują się jako dwa wielkie ptaki drapieżne, które swymi szponami rzucają się na sokoła. Jego rozszarpanie jest zasugerowane przez „eksplozję" bieli, po której w kadrze zapanowuje na dobre czerń. Ruttmann, czołowy artysta niemieckiej awangardy filmowej zaproszony przez Langa do kreacji tej sekwencji, zrealizował ją swą sprawdzoną techniką malowania farbą olejną na szkle, zmazywania i kładzenia na nowo kolejnych porcji farby, i obfotografowywania klatka po klatce każdej zmiany od góry przy jednoczesnym podświetlaniu „planu” z dołu, spod szkła ${ }^{28}$. W każdym razie $\mathrm{z}$ racji swej odmienności jest to istotnie jeden $\mathrm{z}$ najbardziej pamiętnych fragmentów filmu - miał szczególnie zachwycić Iris Barry.

Zdjęcia do Nibelungów rozpoczęły się późną jesienią 1922 r., a z racji ich rozciągnięcia w czasie na znaczną część roku następnego można było sfilmować te same miejsca w różnych porach roku. I tak, brzegi źródła Zygfryda pokryte są zarówno prawdziwym śniegiem, gdy Krymhilda klęczy, by zebrać do zawiniątka ziemię zroszoną krwią jej męża, jak i kobiercem kwitnących kwiatów (przezornie wcześniej zasianych przez Karla Vollbrechta), gdy Zygfryda przebija włócznia rzucona przez Hagena ${ }^{29}$. Okryte kwieciem drzewko (w wizji Krymhildy już po śmierci Zygfryda zamieni się ono w trupią czaszkę) towarzyszy spotkaniu i pożegnaniu małżonków. Natomiast dla realizacji sceny, gdy Hagen topi skarb Nibelungów w zamarzniętym Renie, ekipa czekała na zamarznięcie stawu na terenie wytwórni, dodając trochę kry z pokrytego lodem berlińskiego jeziora Wannsee ${ }^{30}$.

Nibelungi są filmem o olbrzymim metrażu - najnowsza wersja wzorcowa dostępna dziś na Blu-ray i DVD (Eureka Entertainment Ltd., London 2012), trwa niemal 5 godzin (część I - 149 minut, część II - 131 minut). Rzecz jasna, przy takich rozmiarach film musiał być pokazywany na dwóch odrębnych seansach (zreszta, obie części są tak odmienne od siebie stylistycznie, że mimo jedności tematu i ciągłości fabularnej mogą sprawiać wrażenie dwóch zupełnie odrębnych dzieł ${ }^{31}$. Premiera

${ }^{28}$ Nt. techniki animacji Ruttmanna zob.: K. Thompson, D. Bordwell, op. cit., s. 193.

29 Zob.: L. H. Eisner, op. cit., s. 75; P. McGilligan, op. cit., s. 96.

${ }^{30}$ Zob.: L. H. Eisner, op. cit., s. 75.

31 Niektórzy autorzy (niesłusznie, jak sądzę) skłonni są traktować Zygfryda i Zemstę Krymhildy jako dwa odrębne filmy, uwagę swą poświęcając zresztą na ogół Zygfrydowi - vide: Tom Gunning, op. cit., s. 34-51; David J. Levin, Richard Wagner, Fritz Lang and the Nibelungen: The Dramaturgy of Disavowal, Princeton University Press, Princeton 1998, s. 94-140. Naziści w 1933 (do czego jeszcze wrócimy) wznowili też tylko część I - zresztą pod zmienionym tytułem, skróconą i udźwiękowioną nie z oryginalną muzyką Huppertza, a z muzyką Wagnera. 
części I, Zygfryd (Siegfried) ${ }^{32}$, miała miejsce 14 lutego ${ }^{33}$, zaś części II, Zemsta Krymhildy (Kriemhilds Rache), 26 kwietnia 1924 r. - jak zwykle zreszta w wypadku wielkich filmów Langa z lat dwudziestych w kinie Ufa-Palast am Zoo. Premierowy pokaz Zygfryda był zresztą jako seans katastrofą na wieczorną galę z udziałem wielu znakomitości i dygnitarzy film nadal nie był zmontowany! Pospiesznie montowane szpule dostarczano kolejno z montażowni w Neubabelsbergu do kina w centrum Berlina, oddalonego o 40 minut jazdy samochodem. Nieuniknione liczne przerwy między kolejnymi aktami ekskluzywna publiczność wprawdzie znosiła dość cierpliwie (także dzięki orkiestrze pod batutą węgiersko-amerykańskiego dyrygenta zakontraktowanego przez Ufę, Ernö Rapée, która w trakcie projekcji grała specjalnie skomponowaną do filmu muzykę Gottfrieda Huppertza), niemniej pod koniec przeciągniętego nad miarę, nieustannie przerywanego seansu, nie była zbyt uważna. Toteż brawa, zwyczajowe na premierach - nawet filmów niedobrych, a Zygfryd jest naprawdę arcydziełem - nie były tym razem zbyt rzęsiste ${ }^{34}$.

Z kolei premierowy seans Zemsty Krymhildy został zakłócony przez nacjonalistów, urażonych „świętokradczą" reklamą Ufy i raczej mało pobudzającą narodowe uczucia wizją opętanej zemstą tytułowej bohaterki ${ }^{35}$. Za to po premierze odbył się bankiet, na którym minister spraw zagranicznych Gustav Stresemann wygłosił mowę witającą film jako „więź między narodami i most między kulturami". Frederick Ott zauważa, iż Stresemann mówił wprawdzie o kinie w ogólności, ale niewątpliwie miał nadzieję, jak i liczni Niemcy, że Nibelungi będą dobrą reklamą Niemiec i niemieckiej kultury za granica, szczególnie w państwach Ententy, nadal traktujących Niemcy podejrzliwie i z wrogością ${ }^{36}$.

$\mathrm{Z}$ Nibelungami było $\mathrm{w}$ sumie odwrotnie niż miało być za trzy lata z Metropolis, kiedy entuzjazmu na premierowej gali nie potwierdziła

${ }^{32}$ Zwracam uwagę, iż prawidłowy, oryginalny tytuł części I, to po prostu imię bohatera - Siegfried. Podawany w wielu źródłach tytuł Siegfrieds Tod (Śmierć Zygfryda) nosi nazistowskie "opracowanie" Zygfryda z 1933 r., z muzyką niecierpianego przez Langa Wagnera. Zresztą mamy tu też do czynienia prawdopodobnie z interferencją filmu Langa i dramatycznego cyklu Friedricha Hebbla Die Nibelungen, który [nie licząc jednoaktowej Vorspiel - Der gehörnte Siegfried (Zygfryd o rogowej skórze)] ma podobną dwudzielną kompozycję, składając się z dwóch 5-aktowych sztuk: Siegfrieds Tod i Kriemhilds Rache.

${ }_{33}$ P. McGilligan (op. cit., s. 100) i F. W. Ott (op. cit., s. 26) podają jako datę tej premiery 24 lutego 1924. Jest to datowanie błędne, o czym świadczą recenzje, które w berlińskiej prasie ukazały się już 15 i 16 lutego. Inne miarodajne opracowania premierę tę datują prawidłowo na 14 lutego 1924. Por.: L. H. Eisner, op. cit., s. 408; E. Ann Kaplan, Fritz Lang: A Guide to References and Resources, G. K. Hall \& Co., Boston 1981, s. 46.

${ }^{34}$ Okoliczności premiery Zygfryda opisuje P. McGilligan (op. cit., s. 100-101).

${ }^{35}$ Zob.: ibidem, s. 102.

36 Zob.: F. W. Ott, op. cit., s. 26-27. 
późniejsza frekwencja. Tymczasem po premierowych kłopotach Nibelungi okazały się filmem zyskownym - choćby z tego powodu, iż sfinansowane za niewaloryzowane pieniądze inflacyjne zarabiały $w$ twardej, stabilnej walucie, jaką była obowiązująca już w 1924 r. nowo wprowadzona Reichsmarka. Ten ekonomiczny sukces wystarczył, by przedłużyć Langowi wielki kredyt zaufania po sukcesie Doktora Mabuse, gracza, wkrótce jednak znacznie nadwątlony po finansowej (i chyba też jednak artystycznej) katastrofie Metropolis. Choć z drugiej strony, jak zauważa Patrick McGilligan, nie były Nibelungi Langa filmem jakoś nadzwyczaj popularnym i cieszącym się jednomyślną aprobatą wśród niemieckiej publiczności. Powodem był i zbyt długi metraż, i, co istotniejsze, nieprzystawalność ich pesymizmu czy wręcz nihilizmu, do anektującej już od czasów romantyzmu mit Nibelungów i jego rozmaite artystyczne opracowania tradycji niemieckiego nacjonalizmu ${ }^{37}$.

\section{Der Nibelungen-Film: głosy krytyki}

Rozziew opinii krytycznych, jak niemal za każdym razem w przypadku filmów Langa z lat dwudziestych, był znaczny. Do najentuzjastyczniejszych recenzentów należał podpisany literami H. Fr. autor tekstu opublikowanego po premierze Zygfryda w berlińskim piśmie „Lichtbildbühne”. Autor ów wychwala właściwie wszystkie aspekty filmu - znakomitą adaptację eposu przez Theę von Harbou, imponującą scenografię autorstwa Ottona Hunte, aktorstwo i zdjęcia. Nie jest to zwykły film kostiumowy czy tzw. film monumentalny (der Monumentalfilm), ale dzieło wspaniałe we wszystkich wymienionych aspektach, stworzone dzięki malarskiemu talentowi Langa ${ }^{38}$.

Ernst Ulitzsch w bardzo pochlebnej recenzji osadził pierwszą część Langowskich Nibelungów w niemieckiej tradycji narodowej, uznając duet Lang - von Harbou za jej kontynuatorów i komplementując dzieło z ewidentnie nacjonalistycznej perspektywy. Ulitzsch chwali Langowskie zastosowanie światła i cienia oraz fakt, iż reżyserowi udało się, jak Goethemu, zbudować cały świat wiarygodnie przedstawiający wieki średnie. Lang to Wagner filmu, który stworzył coś wielkiego i prawdziwie germańskiego. Thea von Harbou, zdaniem recenzenta, uczyniła więcej dla mitu Nibelungów niż Hebbel czy Wagner. Sam film nie ma może dramatyzmu eposu, będąc bardziej lirycznym i epizodycznym utworem, za to jest

37 Por.: P. McGilligan, op. cit., s. 103.

${ }^{38}$ H.Fr., Der Nibelungen-Film, „Lichtbildbühne”, 16Februar 1924. Referujęza: E. A. Kaplan, op. cit., s. 140. 
przepięknie zrealizowany. Styl filmu Ulitzsch chwali za to, iż jest raczej nordycki niż gotycki. Podziwia czystość linii i sylwetek. Rozmaite rozwiązania techniczne są rzeczywiście wysokiej próby, a dobór obsady jest trafny ${ }^{39}$.

Zupełnie odmienne stanowisko zajął Martin Dey, recenzując w wydanej w 1924 r. broszurze zarówno dzieło Langa, jak i opublikowaną nieco wcześniej, w ramach promującej film „kampanii multimedialnej”, książkę Thei von Harbou, będącą jej własną adaptacją eposu Das Nibelungenlied i zawierającą fotosy z realizowanego filmu ${ }^{40}$. Dey każdemu pokoleniu przyznaje prawo do własnej wizji legendy Nibelungów, ale jego zdaniem wytwór duetu Lang - von Harbou trywializuje, usensacyjnia i dostosowuje do popularnych gustów wielki oryginał. Zobrazowanie w Zemście Krymhildy Hunów przeczy rozmaitym historycznym świadectwom, główne zaś postacie, by dostosować je do gustów kinowej publiczności, uczyniono nazbyt sentymentalnymi. Jeśli to wszystko, co może zaoferować adaptacja wielkiej literaury, to lepiej, by może film w ogóle nie miał z nią nic wspólnego - choć może jeszcze kiedyś powstanie jakiś prawdziwszy film o Nibelungach ${ }^{41}$.

Nie szczędzi filmowi słów krytyki również recenzja opublikowana w piśmie "Der Kritiker" po kwietniowej premierze Zemsty Krymhildy. Remy M. Hardt uważa, iż jest rzeczą śmieszną próbować zrobić film na podstawie eposu o Nibelungach. „Monumentalna” jest w filmie Langa tylko nuda, a jeżeli coś jest już w nim interesujące, to tylko obrazy i pewne aspekty techniczne. Film ten przypomina paradę obrazów w muzeum, brak mu jakiejkolwiek witalności i ruchu. Ostatecznie, jest to kicz, a nie dzieło sztuki. Gdy wcześniejsze filmy Langa, jak np. Zmęczona Śmierć, były naprawdę dobrze wyreżyserowane, tu nic nie jest naprawdę „filmowe". Nie sposób jednak negować jego zalet: zdjęć Carla Hoffmanna, malarskiego oka Langa, dekoracji Huntego. Sugestywny jest kontrast między Burgundami a Hunami, kulturą a chaosem. Gdyby tylko Lang myślał w kategoriach kina, mógłby to być piękny film ${ }^{42}$.

Jak zwykle przy kolejnych weimarskich filmach Langa, głos zabrał też Herbert Ihering. Uważa on, iż w Zygfrydzie reżyser próbował znaleźć styl, który zjednoczyłby malarskie i architektoniczne elementy, stosowne dla

39 Ernst Ulitzsch, "Die Nibelungen": Uraufführung des ersten Teilen "Siegfried" am Ufa-Palast am Zoo, „Der Kinematograph” (Düsseldorf), 17 Februar 1924. Referuję za: E. Ann Kaplan, op. cit., s. 141-142.

40 Thea von Harbou, Das Nibelungenbuch, Drei Masken Verlag, München 1923.

${ }^{41}$ Martin Dey, Nibelungenbuch und Nibelungenfilm: Betrachtungen eines Laien, Rufus, Dortmund 1924.

${ }^{42}$ Remy M. Hardt, Ufa-Palast: "Kriemhilds Rache”, „Der Kritiker”, Mai-Juni 1924 (referuję za: E. Ann Kaplan, op. cit., s. 140). 
prezentacji tej sławnej legendy. Rezultat jest jednak taki, iż film jest po prostu niefilmowy: sztywność i statyczność Zygfryda wynika z jednostronności koncepcji. Zdaniem Iheringa, filmowi brak dramatycznej intensywności, jest zbyt akademicki i dekoracyjny. Pewna teatralność była zresztą zawsze słabością filmów Langa - reżyser ten zbyt polega na technicznych niespodziankach, nie wiedząc, jak w inny sposób osiągnąć prawdziwie filmowe efekty. Byłoby lepiej, gdyby Lang zrealizował żywszy, bardziej „ludzki" film ${ }^{43}$.

Erich Vogeler w recenzji Zygfryda opublikowanej w „Berliner Tageblatt" stwierdza, że Das Nibelungenlied to wielka legenda, opierająca się wtłaczaniu w jakąś rygorystyczną formę. Thei von Harbou udało się stworzyć klarowny scenariusz, unikając jednocześnie kiczu. Autor podziwia reżyserię Langa, a zwłaszcza wiele stworzonych przezeń wspaniałych obrazów. Całość jest jednak nieco chłodna, nie ewokując legendy, sagi czy pieśni, lecz raczej dramat historyczny ${ }^{44}$.

Autorem jednej z najbardziej syntetycznych recenzji Nibelungów, opublikowanej w tygodniku "Das Tage-Buch” już ze znajomością obu części filmu i jakby zbierającej razem argumenty "za" i „przeciw” innych krytyków, jest Kurt Pinthus. Rozpoczyna on ją konstatacją: "Jest bezdyskusyjne: film ten kosztował więcej pieniędzy niż jakikolwiek zrealizowany dotąd w Niemczech i realizowano go dłużej niż jakikolwiek inny film na świecie. Z tego wkładu ilościowego nie wynikają wprost wnioski o jego jakości. Mówi to jednak coś o energii, jaką z fanatycznym poświęceniem Fritz Lang kierował przez dwa lata na obrócenie nieporęcznego i na pozór niefilmowego materiału i postaci w obrazy filmowe ${ }^{\prime \prime 45}$. Lang nie próbował jednak zilustrować tematu „kolosalnymi obrazami” typowymi dla filmów historycznych, ale w swej wizji rozwinął jednorodny, monumentalny styl, znacząco różny od produkcji, które same siebie zwą Monumentalfilme. Byłoby czymś nie do zniesienia oglądać przez dwa długie wieczory uformowanych (czy raczej zdeformowanych) przez nacjonalistyczno-pedagogiczną tradycję brodatych wojowników w rogatych hełmach, w zbrojach i zwierzęcych skórach, tak ohydnie natrętnych w operach Wagnera.

${ }^{43}$ Herbert Ihering, Der erste Nibelungen-Film, "Berliner Börsen-Courier”, 15 Februar 1924. Przedruk: Herbert Ihering, Von Reinhardt bis Brecht: Vier Jahrzehnte Theater und Film, Bd. 2: 1924-1929, Aufbau Verlag, Berlin 1959, s. 474-475). Zob. też: E. Ann Kaplan, op. cit., s. 141.

${ }^{44}$ Erich Vogeler, Der Nibelungenfilm: 1. Teil: „Siegfried”, „Berliner Tageblatt” 1924, Nr. 79 (15 Februar). Referuję za: E. Ann Kaplan, op. cit., s. 142.

${ }^{45}$ Kurt Pinthus, Der Nibelungen-Film, "Das Tagebuch” 1924, Nr. 18 (3 Mai). Przedruk [w:] Fritz Lang. Leben und Werk. Bilder und Dokumente, Red. Rolf Aurich, Wolfgang Jacobsen, Cornelius Schnauber, Filmmuseum Berlin-Deutsche Kinemathek und jovis Verlag GmbH, Berlin 2001, s. 84-97 (cyt. miejsce: s. 84). 
„Toteż Lang i jego scenarzystka Thea von Harbou wybrali nie starsza i dzikszą tradycję Eddy, ale powstałego pod wpływem chrześcijaństwa i międzynarodowej kultury dworskiej eposu o Nibelungach. W kreacji filmu Langiem kierowały dwie zasady: prostota (Einfachheit) i obrazowość (Bildhaftigkeit). Przylgnął do tych zasad z uporczywą konsekwencją od projektu kostiumów i budynków po strukturę zdarzeń, ukształtowanie postaci i scenerii. Zasady te leżą u podstaw zarazem zalet, jak i wszystkich słabości filmu" ${ }^{\prime 4}$. Film obywa się bez obecnych w eposie wątków i postaci podrzędnych (chyba że stwarzają pretekst do kreacji efektownych obrazów), a relacje między głównymi osobami dramatu przedstawia bez upiększeń. Rezultatem jest fabularna koncentracja, ale też pewne znużenie zbyt wieloma długimi scenami o mało budującym życiu rodzinnym, wiodącymi do dramatycznego finału, w którym stają naprzeciw siebie: radykalna zemsta i radykalna - aż do całkowitej samozagłady klanu - plemienna lojalność (Treue).

Każda z postaci - stwierdza dalej Pinthus - zobrazowana jest jako czytelna, jednoznaczna, pozbawiona niuansów, ambiwalencji, wahań. Jedna tylko Krymhilda ewoluuje od nieśmiałej panny do demona zemsty. Ale Hagen i Gunter, Volker i Etzel zachowują ich niezmienne tożsamości od sceny do sceny. Taka koncepcja postaci współgra z prostotą kostiumów, dekoracji, linearnością fabuły, wiedzie jednak zarazem do sztywności aktorstwa: bohaterowie wydają się raczej posągami niż istotami ludzkimi. Na przykład Hagen jest zawsze równie nieporuszony, bez choćby jednej sceny, w której odsłoniłby swe wnętrze. Krymhilda w drugiej części obnosi nieustannie ten sam kamienny i lodowaty wyraz twarzy, chłodno wyczekując i wreszcie chwytając nadarzającą się sposobność odwetu. Nic zatem dziwnego, że w tym wielkim filmie nie ma ani jednej wielkiej roli - co zresztą typowe dla Langa, skupiającego się nie na aktorach, lecz na obrazach. Ciekawe, że najbardziej poetycki aspekt eposu - to, co ludzkie (das Menschliche) - w filmie znika, zredukowany do opowieści o morderstwie i rzezi. Natomiast to, co w eposie niemal niedostrzegalne, staje się najwartościowszym komponentem filmu: obrazowanie (das Bildhafte), scenerie, element idylliczny (das Idyllische), ruch (die Bewegung). „Fritz Lang był i nadal jest malarzem - a jego najpiękniejsze obrazy to te, w których ludzie nie są niczym więcej niż sztafażem i ruchomymi masami. Dlatego też najlepsze partie filmu to nie perypetie Nibelungów, ale to, co swym kolorytem upiększa tę ponurą historię: zdobycie przez Zygfryda sławy, jego wędrówka i przygody, podbój Brunhildy, znalezienie i zatopienie skarbu, roje szaleńczo galopujących, łapczywych, skocznych, morderczych Hunów w ich płaskim krajobrazie, w ich pieczarach i norach.

${ }^{46}$ Cyt. za: Fritz Lang. Leben und Werke..., s. 92. 
Dość znaczące, że trzy główne postacie w tych trzech kręgach - Zygfryd, Brunhilda i Etzel - są najbardziej uczłowieczonymi i fizycznie najżywszy$\mathrm{mi}$, oraz najbardziej przykuwającymi oko ludzkimi figurami filmu"47.

Główną zasługą Langa jest cudowne obrazowanie - podziwiamy nastrojowe krajobrazy, wymyślne tricki (smok, ogniste morze wokół zamku Brunhildy), niewidzianą we wcześniejszych filmach historycznych choreografię tłumów. Nawet finałowa krwawa łaźnia stanowi ruch przyciaggający oko - i straszliwe emocje do duszy. Jednak ten sam typ ruchu, który trwa nazbyt długo, staje się równie męczący, jak brak ruchu (a jedno i drugie jest słabością tego filmu). Predylekcja Langa dla pięknych, stylowo skomponowanych obrazów wiedzie do zastygania postaci i ich grup w statyczne i nieskuteczne „ożywione obrazy” (lebender Bilder), które właściwie należałoby nazwać „martwymi obrazami” (tote Bilder).

Lang być może wybrał jedyny sposób, by temat Nibelungów uczynić w filmie znośnym, i znalazł styl dla filmu o przeszłości, który leży na antypodach konwencjonalnego stylu filmów historycznych. Ale podziw dla jego osiągnięcia nie może przesłaniać faktu zasadniczej „niefilmowości” dzieła, tego, że nie jest to osiągnięcie s z t u k i k i n a. Temat Nibelungów - surowa opowieść o przygodach, morderstwie, klanowej lojalności i zemście - jest współczesnym na tyle obcy i odległy, że wypada żywić nadzieję, iż nigdy więcej nie pojawi się on na ekranie. Przyszłość filmu leży w tematach dotyczących teraźniejszości i przyszłości, a nie, choćby i największej, historii - czego dowodzą filmy amerykańskie. Wielkie dzieło filmowe dotyka tego, co porusza nasze serca i nerwy - i z tego właśnie powodu Zmęczona Śmierć i Doktor Mabuse więcej wnoszą do rozwoju sztuki filmowej niż niewątpliwie żądający więcej energii i determinacji artysty Der Nibelungenfilm ${ }^{48}$.

Monumentalny film Langa wzbudził spore zainteresowanie za granica, zwłaszcza w kręgu anglosaskim, choć, jak zwykle, nie prezentowano tam integralnej wersji autorskiej. Już dwa dni po berlińskiej premierze Zygfryda ukazała się w londyńskim "The Times" bardzo pochlebna dla filmu recenzja niemieckiego korespondenta gazety, który pisał, iż Der Nibelungen-Film pokazuje, jakie cuda może zdziałać kinematograf w rękach artysty. Powstały już wprawdzie udane filmy historyczne o rozmaitych epokach, ale czymś znacznie trudniejszym było stworzenie scenerii i postaci rodem z baśni i balladowej poezji i ożywienie ich w wyobraźni. A „Herr Langowi” udało się tego dokonać. Wartością jego filmu są cudownie piękne sceny, rozgrywające się w baśniowej krainie. „Nie jest ona zdjęta z natury; nie mogła być. Drzewa, z ich niebotycznymi pniami, ogromny-

\footnotetext{
47 Ibidem, s. 93.

48 Ibidem, s. 96-97.
} 
mi korzeniami i nieprzeniknionym cieniem, są sporządzone ręką artysty z dykty i gipsu, i przeniesione na ekran z wielkim fotograficznym talentem oraz wyczuciem przez artystę kompozycji i efektu. Podobnie zresztą widmowa kraina Nibelungii, gdzie Zygfryd znajduje skarb i sławę; wszystko to jest «feeryczne» i cudowne, i popada się pod jego urok. Zapominamy, iż mówiono nam, ile litrów benzyny trzeba było użyć na stworzenie ognistego morza oraz że fantastyczne skały i drzewa to tylko płótno i farba. Można dyskutować, czy Herr Lang miał rację, pokazując smoka. Żaden sztuczny smok nie może naprawdę być wyzwaniem dla fantazji, ale choćby tylko jako osiągnięcie techniczne smok jest cudem i z pewnością pozostanie clou filmu. Niektóre sceny na zamku w Wormacji pełne są poetyckiego, pięknego i prawdziwie romantycznego nastroju, i również z nich przebija niezwykły autorski zmysł dekoracyjnego efektu i harmonijnych kompozycji grupowych" 49 .

Iris Barry, postać, która niebawem miała wielce zasłużyć się dla światowej kultury filmowej swą pracą w filmotece nowojorskiego Museum of Modern Art, opublikowała swą recenzję w "Spectatorze" po brytyjskiej premierze Zygfryda w londyńskim Albert Hall w czerwcu 1924. Na wstępie autorka zauważa, że najważniejsze eksperymenty artystyczne kina nadal napływają z kontynentu. Lang zdobył już w Anglii sławę Zmęczona Śmiercia (Barry mylnie mu zresztą przypisała drugi tytuł do niej - film Ernsta Lubitscha Sumurun, 1920). Z racji swej malarskiej przeszłości Lang całkowicie podporządkowuje element dramaturgiczny wizualnemu. Legendarne postacie - królowie i królowe w ponurych niedostępnych zamkach na szczytach gór - zachowują się z beznamiętnością i godnością aktorów w historycznych "żywych obrazach". Prawdziwymi protagonistami są natomiast architektura, drzewa, smok, karły i spowite w mgłę lasy. Toteż powikłana i złowieszcza intryga miłosnych perypetii Zygfryda i jego szwagra Guntera, jest odpowiednio umniejszona, by dopasować się do autorskiej koncepcji. Wydaje się niewiarygodne, iż cały film zrealizowano $\mathrm{w}$ berlińskich studiach kompanii Ufa-Decla. Ale jeszcze bardziej zdumiewa, iż co wieczór widownia w Albert Hall reaguje aplauzem nie na porywające aktorstwo, ale na o b r a z y: zamglone lasy, skamienienie karłów i Alberyka (swoją droga istotnie tworzą piękną rzeźbę), morze płomieni wokół islandzkiej twierdzy Brunhildy, i - przede wszystkim na prosty i przerażający symbolizm proroczego snu Krymhildy. Kamera słusznie tu rezygnuje z filmowania rzeczywistości profilmowej - sfilmowanie prawdziwych ptaków nie mogłoby dorównać intensywnością i znaczeniem czarnym i białym ptakopodobnym kształtom, które zresztą Barry błędnie określa jako „gołębia” i „kruki”. Mankamentem prezento-

49 „The Times”, 16 February 1924 (przedruk: F. W. Ott, op. cit., s. 110, 112, skąd cytat). 
wanej w Londynie wersji filmu jest fatalny angielski przekład napisów. Autorka konkluduje swój tekst wskazaniem wagi Nibelungów jako filmu, w którym chodzi nie o sprawne opowiedzenie jakiejś historii (jak to dotąd na ogół bywało), ale o czystą wizualnośćc ${ }^{50}$.

Zemsta Krymhildy miała w Anglii mniej szczęścia niż Zygfryd - trafiła na brytyjskie ekrany rok później, w roku 1925, pod tytułem The She-Devil (Diablica) ${ }^{51}$. Reprezentatywna recenzja stwierdza, iż druga część Nibelungów „wydaje się groteskowym nonsensem, ale nonsensem wywierającym wrażenie, jak najgorsze rzeczy braci Grimm, i zarazem absolutnym wcieleniem grozy" 52 .

Nibelungi były pierwszym filmem reżysera, cieszącym się autentycznie dużym zainteresowaniem w Stanach Zjednoczonych, na co wpływ miała zapewne także związana z promocją filmu amerykańska podróż Langa i Pommera jesienią 1924, oraz fakt, iż jest to jednak coś, w czym Amerykanie zawsze gustowali - wielkie widowisko. Jak zauważa Patrick McGilligan, szczególnie dużo miejsca Nibelungom poświęcił „New York Times" ${ }^{\prime \prime}$. W korespondencji z Berlina z dnia 29 kwietnia 1924 T. R. Ybarra opisałburzę wokół premiery Zemsty Krymhildy: przerwanie premierowego seansu przez nacjonalistów protestujących przeciw obrazowi Krymhildy jako zdradzieckiej morderczyni i przeciw reklamie Ufy, anonsującej film "o bandzie fałszywych morderców" ${ }^{\prime 54}$. Teksty, które pojawiły się na tych łamach w roku 1925 - przy okazji amerykańskiej premiery Zygfryda - dotyczyły już samego filmu, a ściślej - jego atrakcyjności jako widowiska.

Mordaunt Hall w swej recenzji za punkt odniesienia przyjmuje - niesłusznie zresztą - nie epos, ale tetralogię operową Wagnera, odnotowując, iż film Langa wdziera się w „uświęconą" dziedzinę opery i całkiem inaczej prezentuje znane heroiczne figury. Trzeba go jednak potraktować serio - opowieść, mimo atelierowej estetyki, jest fascynująca z racji przyswojenia typowej dla starych legend techniki narracyjnej. Dostojny rozwój scen wspomaga "czarodziejstwo kamery”. Wielkie wrażenie wywierają zwłaszcza pojedynek Zygfryda ze smokiem i ogromne dekoracje. Hall wychwala „dostojność” aktorstwa Hanny Ralph jako Brunhildy,

${ }^{50}$ Iris Barry, "The Nibelungs", "The Spectator", 14 June 1924, s. 955 (przedruk obszernego fragmentu: F. W. Ott, op. cit., s. 113-115; zob. też: E. Ann Kaplan, op. cit., s. 139-140).

${ }^{51}$ Zob.: P. M. Jensen, op. cit., s. 47.

52 Letters and Art: Wagner Thirty Miles Away, "Literary Digest”, 26 September 1925 (cyt. za: P. M. Jensen, op. cit., s. 47).

${ }_{53}$ Zob.: P. McGilligan, op. cit., s. 102.

${ }^{54}$ T. R. Ybarra, "Die Nibelungen” Meets Disaster in Berlin: First Showing of Nationalist Propaganda Film Interrupted on Account of Protests, „New York Times”, 29 April 1924. Artykuł Ybarry i zdarzenia przezeń opisane omawiają: P. McGilligan, op. cit., s. 102; P. M. Jensen, op. cit., s. 54; E. Ann Kaplan, op. cit., s. 142. 
choć czasami wydaje się ona zbyt normalna i współczesna. Za godne uwagi uważa też aktorstwo Paula Richtera (Zygfryd), Margarethe Schön (Krymhilda) i Hansa Adalberta von Schlettow (Hagen) ${ }^{55}$.

Zygfryd wzbudził w Stanach zainteresowanie jako imponujący spektakl, toteż późniejszy o dwa tygodnie anonimowy tekst z „New York Times” prezentuje czytelnikom szczegóły uzyskane od Fredericka Wynne-Jonesa, przedstawiciela Ufy na Amerykę: jak stworzono i sfilmowano smoka, jak osiągnięto fascynujące efekty oświetlenia, jak wytworzono mgłę, jak zbudowano małe modele dużych obiektów na podstawie drobiazgowej analizy praw perspektywy i dzięki jakim obiektywom stworzono pewne efekty specjalne. Recenzent zwraca uwagę na pedanterię realizacji, zwłaszcza na osiągnięcie właściwego rytmu akcji ${ }^{56}$.

Złej tradycji stało się jednak zadość i mimo dobrego przyjęcia Nibelungi nie były za oceanem prezentowane w integralnej wersji autorskiej. Obie części skrócono (choć nie tak drastycznie, jak Doktora Mabuse czy Metropolis), prezentowano je nie ze specjalnie skomponowaną muzyką Huppertza, lecz z niechcianą przez Langa muzyką Wagnera, a, co gorsza, Zemsta Krymhildy trafiła na amerykańskie ekrany trzy lata później niż Zygfryd, w roku 1928. Z racji tej separacji współczesne recenzje nie ogarniały całościowego konceptu dzieła: krytycy oceniali każdą z części jako samodzielny film, nawet nie uświadamiając sobie, iż stylistyczny kontrast między nimi jest świadomym, precyzyjnie zrealizowanym autorskim zamysłem $^{57}$.

\section{Ein deutsches Heldenlied in 14 Gesänge}

Paul M. Jensen podaje, iż pierwotnie dyptyk Langa miał nosić podtytuł: Ein deutsches Heldenlied (Niemiecka pieśń bohaterska) ${ }^{58}$. Wprawdzie nie widnieje on w czołówce filmu ani nie spotkałem go w żadnym innym źródle, niemniej wydaje się, iż rzeczywiście Lang mógł planować taki podtytuł dla swego dzieła. Po pierwsze, nawiązuje on ewidentnie do będącego zasadniczą podstawą scenariusza eposu Pieśń o Nibelungach (Das Nibelungenlied $)^{59}$, po drugie - podobnie jak Nibelungenlied podzielona jest

${ }^{55}$ Mordaunt Hall, „,Siegfried”, „,New York Times”, 24 August 1925 (referuję za: E. Ann Kaplan, op. cit., s. 143).

56 Anonim, How "Siegfried" Was Produced, „New York Times”, 6 September 1925 (referuję za: E. Ann Kaplan, op. cit., s. 142-143).

${ }_{57}$ Nt. amerykańskiej recepcji Nibelungów - zob.: P. M. Jensen, op. cit., s. 46-47.

58 Ibidem, s. 48.

${ }^{59}$ Pochodzący w znanej nam postaci z przełomu XII i XIII w., spisany w języku średnio-wysoko-niemieckim epos dotarł do nas w trzech podstawowych źródłach, nieco 
na będące wyrazistymi, odrębnymi segmentami dramaturgicznymi i znaczeniowymi „przygody” (âventiuren) ${ }^{60}$, film Langa dzieli się na "pieśni” (Gesänge). Każdy Gesang jest dość autonomiczną całostką dramaturgiczną, o zwartej akcji i wyrazistej poincie, i istotnie wydaje się strukturalnie analogiczny do jednej âventiure eposu. „Przygód” w Nibelungenlied jest 39, zaś Nibelungen-Film Langa zawiera 14 Gesänge, po siedem w każdej z części. Wszystkie napisy filmu - ekspozycyjne i dialogowe, napisy czołówki, tytuły każdego z 14 Gesänge - prezentowane są stylizowaną na gotyk czcionką. Obie części poprzedzone są też dedykacją ",dla narodu niemieckiego" (Dem Deutschen Volke zu eigen).

\section{Część I: Zygfryd (Siegfried)}

\section{Pieśń I: „Jak Zygfryd zabił smoka” (Der erste Gesang: Wie Siegfried} den Drachen erschlug). W wykrocie ogromnego drzewa na skraju polany tajemniczego lasu mieści się kuźnia kowala Mime. Terminujący tam Zygfryd wykuł miecz tak ostry, że przecina na pół rzucone w powietrzu piórko. Mime radzi uczniowi wrócić do domu, na dwór króla Zygmunta w Xanten, mówiąc, że niczego więcej nie może go już nauczyć. Przed odjazdem Zygfryd wysłuchuje opowieści leśnego starca o wspaniałym zamku królów Burgundii w Wormacji nad Renem (narracja filmu wizualizuje dostojny pochód królewskiego orszaku w asyście rycerzy i mszę w katedrze, w której uczestniczy królewska siostra, Krymhilda). Zygfryd wzbudza śmiech starca i jego słuchaczy, gdy obwieszcza, że zdobędzie piękną Krymhildę. Zagniewany, napada na starca i żąda wskazania mu drogi do Wormacji. Drogę tę wskazuje mu kowal, ale po jego odjeździe mówi do siebie ze złowrogą miną: „Żegnaj, Zygfrydzie, synu króla Zygmunta. Nigdy nie dotrzesz do Wormacji". Zygfryd, przemierzający na białym koniu prastary las o ogromnych drzewach, napotyka przy źródle zionącego

różniących się od siebie, znanych jako rękopisy A, B i C. Tytuł eposu pochodzi od jego ostatnich słów: w rękopisach A i B - der Nibelunge Nôt (Niedola Nibelungów), w rękopisie C der Nibelunge Liet (Pieśń o Nibelungach). Mimo iż za najbardziej „kanoniczną” wersję dzieła, będącą podstawą większości nowożytnych wydań i przekładów, uchodzi rękopis B, to w nowożytnym języku niemieckim przyjął się - za rękopisem C - tytuł Das Nibelungenlied (Pieśń o Nibelungach). Z trzech polskich przekładów eposu, dwa zatytułowane są Pieśń o Nibelungach (Antoniego J. Szabrańskiego, 1881 i Andrzeja Lama, 1994), jeden zaś - Niedola Nibelungów (Ludomiła Germana, 1884). Nt. tytułu eposu, zob.: The Nibelungen Tradition: An Encyclopedia, eds. Francis G. Gentry, Winder McConnell, Ulrich Müller, and Werner Wunderlich, Routledge, New York-London 2002, s. 164-165; Ludomił German, Wstęp, [w:] Niedola Nibelungów, s. 6; Pieśń o Nibelungach, przeł. Andrzej Lam, Unia Wydawnicza „Verum”, Warszawa 1995, s. 338; Robert Stiller, Posłowie, [w:] Krymhilda: Opowieść rycerska o Nibelungach, według średniowiecznego eposu napisał Robert Stiller, Nasza Księgarnia, Warszawa 1974, s. 444.

60 Zob. hasło "âventiure", [w:] The Nibelungen Tradition: An Encyclopedia, s. 143. 
ogniem smoka. Zabija go po walce, a posmakowawszy jego krwi, nagle rozumie śpiew ptaka, który obwieszcza, iż jeśli pogromca smoka skąpie się w jego krwi, nigdy nie zwycięży go miecz ani włócznia. Zachęcony bohater nadstawia się pod strumień wypływający z rany smoka. Zdychający potwór macha jednak ogonem, co powoduje, iż strącony podmuchem liść lipy opada na bark Zygfryda - miejsca tego nie obmyje krew smoka i nie będzie ono odporne na śmiertelne zranienie.

Pieśń II: „Jak Volker śpiewał Krymhildzie o Zygfrydzie, i jak Zygfryd przybył do Wormacji" (Der zweite Gesang: Wie Volker vor Kriemhild von Siegfried sang, und wie Siegfried nach Worms kam). W sali tronowej króla Burgundów Guntera bard Volker śpiewa o wyczynach Zygfryda (obecni są też królewscy bracia, Gernot i Giselher, ich siostra Krymhilda, matka Uta i doradca Hagen Tronje). Narracja filmu ilustruje pieśń Volkera: karzeł Alberyk, Nibelung, założywszy Tarnhelm, napada przejeżdżającego przez mglistą krainę Zygfryda, który pokonuje niewidzialnego przeciwnika i zdarłszy mu Tarnhelm, czyni go widzialnym. Alberyk darowuje zwycięzcy Tarnhelm, informując, iż pozwala nie tylko stać się niewidzialnym, ale też przybrać dowolną postać. Obiecuje też, iż za darowanie życia uczyni Zygfryda najbogatszym królem na ziemi. Na ścianie pobliskiej groty karzeł za pomocą świetlistej kuli wyczarowuje Zygfrydowi niczym na ekranie filmowym obraz wykuwania olbrzymiej korony Króla Północy przez Nibelungów. Później Alberyk pokazuje Zygfrydowi skarb Nibelungów, umieszczony na ogromnej misie, którą w charakterze atlasów podtrzymują skute łańcuchami karły. Odwracając uwagę Zygfryda niezrównanym mieczem Balmungiem, wykutym przez Nibelungi w krwawym ogniu, próbuje zamachu na niego, zarzucając mu płaszcz na głowę. Pokonany przezeń po raz wtóry, rzuca klątwę na dziedzica skarbu, a sam z karłami-atlasami obraca się w kamień. Zygfryd triumfalnie podnosi Balmunga. Volker kończy swą pieśń peanem na cześć pogromcy smoka, który stał się panem skarbu Nibelungów, a z dwunastu królów uczynił swych wasali. Krymhilda w podzięce za pieśń wręcza bardowi wyszyty własnoręcznie cenny płaszcz. Tymczasem trębacze obwieszczają przybycie na zamek z dwunastoosobową drużyną Zygfryda, który prosi króla Guntera o posłuchanie. Wbrew radzie Hagena, Gunter decyduje się przyjąć pogromcę smoka. Krymhilda, która wróciła do swej komnaty, opowiada matce sen o białym sokole rozszarpanym przez dwa czarne orły. Tymczasem podczas audiencji Zygfryd prosi Guntera o rękę Krymhildy. Hagen żąda, by Zygfryd, niepokonany bohater, pomógł zdobyć Gunterowi za żonę królową Islandii, Brunhildę (przebitka na nią), która swym konkurentom postawiła trudne warunki: muszą ją trzykrotnie pokonać lub zginąć. Urażony w swej dumie Zygfryd odpowiada Hagenowi, że choć ma dwunastu królów za wasali, sam nie jest i nie będzie niczyim wasalem. Ludzie Zygfryda 
przyjmują szyk obronny. Sytuację rozładowuje wejście Krymhildy, która przynosi czarę z napojem - Zygfryd z niej upija, ich dłonie się spotykają. Zachwycony wybranką bohater godzi się na warunek Hagena. Przybija rękę na zgodę z Gunterem, a zgodę tę pieczętuje Hagen.

Pieśń III: „Jak Zygfryd zdobył Brunhildę dla Guntera" (Der dritte Gesang: Wie Siegfried Brunhild für Gunther gewann). Islandia: stara wieszczka ostrzega Brunhildę, iż "statek smoka” z cudzoziemcami przybił do jej brzegów, a narracja wizualizuje nam, że to przybył Zygfryd z Burgundami. Wieszczka mówi królowej, iż jeśli jej konkurent będzie wystarczająco silny, zagradzające cudzoziemcom drogę do jej zamku ogniste morze zagaśnie - co istotnie ma miejsce. Wzburzona Brunhilda prosi swe panny o zbroję na niewidziany dotąd bój. Przyjmuje przybyszów w sali tronowej, witając Zygfryda jako tego, który rzucił jej wyzwanie. Gdy jednak ten przeczy, wskazując jako konkurenta do jej ręki Guntera, Brunhilda patrzy z niedowierzaniem i zapowiada, że wieczorem strzaskana broń martwego króla ozdobi ściany jej pałacu. Zygfryd prosi Guntera o pozwolenie powrotu na statek, by przygotować go do powrotu ze zdobytą przez króla narzeczoną (tym samym przedstawia się jako wasal Guntera, a w dodatku znieważa Brunhildę). Za bramą zamku Zygfryd nakłada Tarnhelm i niewidzialny wraca na plac potyczki (tylko Hagen zauważa jego cień i pokazuje go Gunterowi, tak krzepiąc przerażonego króla). Markując gesty, Gunter pozwala, by niewidzialny pomocnik wykonał za niego potrójne zadanie: dzięki temu jego kamień ląduje dalej niż rzucony przez Brunhildę, jego skok jest dłuższy, a jego włócznia roztrzaskuje tarczę Brunhildy, która pada pod ciosem na ziemię i, pokonana po raz trzeci, bezsilnie płacze.

Pieśń IV: „Jak Brunhilda zawitała do Wormacji, i jak królowie świętowali swe wesele" (Der vierte Gesang: Wie Brunhild zu Worms einzog, und wie die Könige sich vermählten). Płonące ognie przekazują wieść o zbliżaniu się statku z królewską narzeczoną. Do Wormacji przybywa też umyślny, by o tym uprzedzić. Gdy statek już dobił do celu, Brunhilda ignoruje zaproszenie Guntera do zejścia na ląd. Powala go na ziemię, ręce krępuje mu pasem i z niedowierzaniem pyta, czy aby na pewno jest on mężem, który po trzykroć pokonał ją w walce. Świadkiem upokorzenia króla jest Hagen. Brunhilda deklaruje uwolnionemu Gunterowi, iż jest jego jeńcem, ale nigdy nie będzie jego żoną. Po moście ze stojących w wodzie rycerzy i ich tarcz Brunhilda z Gunterem schodzą na brzeg. Na stopniach katedry Brunhilda chłodno przyjmuje powitanie przez Utę i księdza, gwałtownie zaś reaguje, gdy Zygfrydowi proszącemu o dotrzymanie obietnicy Gunter mówi, iż jeśli tylko Krymhilda się zgodzi, tego dnia odbędą się podwójne zaślubiny. „Od kiedy jest 
zwyczajem Burgundów oddawać królewską córkę wasalowi?" - pyta wzburzona Guntera i dowiaduje się (wbrew temu, co wmówiono jej w Islandii), że Zygfryd nie jest jego wasalem. W katedrze ksiądz udziela podwójnego ślubu dwóm parom królewskim. Wieczorem sama w swej komnacie Brunhilda przeżuwa gorycz porażki, a Gunter i Zygfryd w celebrowanej przez Hagena ceremonii zawierają braterstwo krwi. Nocą w sali tronowej odbywa się narada królewskich szwagrów z Hagenem. Żąda on od Zygfryda, by pomny łączących go z Gunterem więzów, pomógł królowi złamać opór Brunhildy, przybrawszy dzięki Tarnhelmowi jego postać. Zygfryd się zgadza i pod postacią Guntera, który tymczasem przeżywa na zewnątrz komnaty męki zazdrości, pokonuje kolejny raz Brunhildę, zabierając jako trofeum zerwany z niej w walce naramiennik. Zygfryd chowa zdobycz za pas i udaje się do komnat Krymhildy, a złamana Brunhilda klęczy u stóp stojącego nad nią z pochodnią Guntera.

Pieśń V: „Jak po sześciu miesiącach ślubny dar Zygfryda, skarb Nibelungów, przybył do Wormacji, i jak królowe pokłóciły się ze sobą" (Der fünfte Gesang: Wie nach sechs Monden Siegfrieds Morgengabe, der Nibelungen Hort, zu Worms eintraf, und wie die Königinnen miteinander stritten). Do Wormacji ciągnie tabor ze skarbem Nibelungów. Hagen radzi Gunterowi przyjąć skarb, ponieważ chwała Burgundów zmierzcha. Służka Krymhildy znajduje w kufrze zaplątany w ślubny welon naramiennik Brunhildy i przekazuje go swej pani, która z upodobaniem go przymierza i pokazuje Zygfrydowi, gdy spotykają się pod kwitnącym drzewkiem. Przerażony Zygfryd zdradza Krymhildzie jego sekret i radzi głęboko ukryć go przed ludzkim wzrokiem. Tymczasem Giselher i Gernot towarzyszą rozładowaniu wozów ze skarbem. Dołącza do nich Zygfryd, który wśród zgromadzonej na dziedzińcu gawiedzi rozrzuca precjoza ze skarbu. Obserwują to z okna Gunter oraz Hagen i Brunhilda, którzy nalegają na króla, by oddalił Zygfryda; Gunter jednak się nie zgadza. Gdy rozlega się wzywający na mszę dzwon, Brunhilda postanawia pójść do katedry w regaliach królowej Burgundów. Na schodach kościoła Brunhilda zabiega drogę szwagierce, rozkazując jej jako „żonie wasala” ustąpić drogi swej władczyni. Urażona Krymhilda nie tylko nie ustępuje, ale w złości pokazuje bratowej naramiennik, wykradziony jej przez "tego, który nią wzgardził, odtrącił i przebrany za Guntera pokonał". Upokorzona publicznie Brunhilda pyta nadchodzącego Guntera, czy to wszystko prawda, a zrozumiawszy, że tak, pragnie rzucić się w przepaść ze zwodzonego mostu. Powstrzymana przez Hagena i Guntera, żąda od nich śmierci Zygfryda. Zygfryd zaalarmowany przez Volkera, biegnie z dziedzińca ku katedrze i tuli płaczącą Krymhildę. Hagen gani Zygfryda, mówiąc, że jego paplanina była gorsza od morderstwa. Brunhilda nadal nalega na Guntera, by zabił szwagra, ale król broni się wskazując, iż skąpany w krwi smoka 
Zygfryd jest niezwyciężony. Hagen przypomina o czułym miejscu tam, gdzie upadł liść lipy. A gdy Brunhilda rozbudza zazdrość i rani dumę Guntera przyznaniem, że ten, kto skradł jej naramiennik, odebrał również jej dziewictwo, król wyraża zgodę na usunięcie Zygfryda podczas polowania, które rozkazuje zorganizować Hagenowi.

Pieśń VI: „Jak Gunter zdradził Zygfryda” (Der sechste Gesang: Wie Gunther Siegfried die Treue brach). Hagen, udając zatroskanie o Zygfryda w razie wojny, o której rychłym wybuchu tajne wieści jakoby go doszły, skłania podstępem Krymhildę do wskazania mu miejsca, na które padł liść lipy - „po to, by osłonić je w zamęcie bitwy”. Wyruszającemu na polowanie Gunterowi Brunhilda obwieszcza, że nie będzie jadła ani piła, dopóki jej hańba nie zostanie pomszczona. Hagen wybiera na swe łowy odpowiednią włócznię. Krymhilda czułe miejsce Zygfryda oznacza na jego ubraniu wyszytym krzyżykiem; pełna jednak złych przeczuć prosi go, by zrezygnował z polowania i został z nią. Zygfryd lekceważy jej sny o dziku, który rozdarł go na strzępy, i o dwóch górach, które się nań zawaliły - na tle kwitnącego drzewka śle jej swe ostatnie pożegnanie. Zapłakana Krymhilda pada w ramiona matce mówiąc, iż czuje jakby krew wyciekała z jej serca. W trakcie łowów w Odenwaldzie zabrakło wina - spragnionemu Zygfrydowi Hagen wskazuje źródło nieopodal i proponuje wyścig do niego „o pierwszy łyk”. Zygfryd chętnie podejmuje wyzwanie, ale przedtem pragnie pojednać się z Gunterem. Chmurny król odkłada to na jego powrót od źródła. Zygfryd, nie zauważywszy, iż Hagen wcale się z nim nie ścigał, dopada po biegu źródła. Gdy pochylony nad wodą pije, rzucona przez Hagena w oznaczone krzyżykiem miejsce włócznia przebija go. Ugodzony, zdoła jeszcza zrobić wiele kroków przez las, aż przywiedziony przez Giselhera i Gernota pada przed Gunterem i Hagenem. Młodsi bracia Krymhildy, widząc ich reakcję, uświadamiają sobie, kto zabił ich szwagra i z czyim przyzwoleniem - i ze smutną rezygnacją jakby przyjmują współwinę. Ponury Hagen obwieszcza: „Polowanie skończone!”

Pieśń VII: "Jak Krymhilda poprzysięgła zemstę Hagenowi Tronje" (Der siebente Gesang: Wie Kriemhild Hagen Tronje Rache schwur). Krymhildę budzi nocą powiew wiatru i ujadanie psa. Orszak z marami Zygfryda przez zwodzony most wkracza na dziedziniec wormackiego zamku. Zaalarmowana przez pazia Krymhilda odkrywa ciało męża przed wejściem do swej komnaty. W jej wizji kwitnące drzewko, na tle którego Zygfryd słał jej ostatnie pożegnanie, traci kwiecie, liście, usycha, aż w końcu zmienia się w trupią czaszkę. Gunter powiadamia Brunhildę, iż może ona zakończyć swój post - Zygfryd nie żyje. Histerycznie się śmiejąc, Brunhilda wypomina królowi, iż z powodu kłamstwa kobiety zgładził 
swego najlojalniejszego druha. Gdy przy marach Zygfryda pojawia się Hagen, z rany denata wypływa krew, wskazując mordercę. Krymhilda żąda od Guntera sprawiedliwej dlań kary, ale odmawia nie tylko król: po stronie Hagena stają, prócz osłaniającego go przed Krymhildą Guntera, także Volker, Gernot i Giselher. Rozkładając ramiona, Gernot wygłasza deklarację wzajemnej klanowej lojalności (Treue): „Jego czyn jest naszym czynem. Jego los jest naszym losem. Nasza pierś jest jego tarczą". Służba zabiera mary, a Krymhilda poprzysięga Hagenowi zemstę, choćby ukrył się pośród jej rodziny, ołtarzy Boga czy na końcu świata. Jakiś czas później, przy wystawionych w katedrze marach Zygfryda Krymhilda odkrywa zwłoki Brunhildy z wbitym po rękojeść w pierś mieczem. Rozkazuje czuwającym strażom powiadomić Guntera, iż królowa Burgundów nie żyje, a sama klęka u wezgłowia nieboszczyka. „Tak kończy się opowieść o Zygfrydzie” (So endet die Mär von Siegfried) - powiadamia finalny napis części I.

\section{Część II: Zemsta Krymhildy (Kriemhilds Rache)}

Pieśń I: „Jak Krymhilda opłakiwała Zygfryda, i jak król Etzel prosił o jej rękę przez Rydygiera z Bechlarn" (Der erste Gesang: Wie Kriemhild um Siegfried trauerte, und wie König Etzel durch Rüdiger von Bechlarn um Sie warb). Krymhilda opłakuje męża u jego grobu, a Gunter przyjmuje posła króla Hunów Etzela, Rydygiera z Bechlarn, proszącego w imieniu swego władcy o jej rękę. „Obawiam się, że król Etzel nie wie, o kogo się stara" - odpowiada przygnębiony Gunter. Tymczasem Krymhilda po wyjściu z krypty grobowej Zygfryda rozdaje wśród ludu złoto „,w imieniu Zygfryda, którego zamordowano i którego morderca żyje”, z przykazaniem, by pamiętano o tym, jak zginął. Rozdawnictwo to obserwuje zafrasowany Hagen. Dankwart prowadzi wdowę na dwór, gdzie Rydygier przekazuje jej oświadczyny Etzela. Krymhilda przedstawia posłowi swe trudne położenie na burgundzkim dworze i w jego obecności jeszcze raz żąda od Guntera wydania jej mordercy Zygfryda. Powołując się na wzajemną lojalność, Gunter stanowczo i nieodwołalnie odmawia. Gdy wchodzi Hagen, Krymhilda opuszcza zebranych, ale później przez swego pazia zaprasza do siebie na wieczór Rydygiera. Hagen ostrzega króla i jego braci przed ciężkimi czasami dla Burgundów. Gdy Krymhilda przyjmuje posła, Hagen wynosi ze skarbca będący jej dziedzictwem jako wdowy po Zygfrydzie skarb Nibelungów i topi go w Renie. Rydygier przysięga w imieniu króla Etzela, że gdyby na jego dworze spotkała Krymhildę jakakolwiek krzywda, król z pewnością będzie wiedział jak ją pomścić (na żądanie Krymhildy przysięgę tę składa nie na krzyż, czy raczej na ustawiony jak krzyż miecz, jak zamierzał, lecz na nagie ostrze miecza). Posłuchanie przerywa paź, alarmując, iż Hagen zrabował skarb Nibelungów. Krymhilda pospiesznie daje Rydygierowi swe słowo, opuszcza go i przed opu- 
stoszałym skarbcem pyta Hagena, gdzie jest skarb. Morderca jej męża odpowiada zuchwale: „,W takim miejscu, pani, gdzie nikt nie będzie mógł użyć złota, by wykuć broń przeciw królom burgundzkim!"” Obraz skarbu zatopionego na dnie rzeki zamyka tę pieśń.

Pieśń II: „Jak Krymhilda żegnała rodzinne strony i jak przyjął ją pan Etzel" (Der zweite Gesang: Wie Kriemhild von der Heimat Abschied nahm, und wie Sie von Herrn Etzel empfangen wurde). U źródła, przy którym zginął Zygfryd, Krymhilda wygrzebuje spod śniegu ziemię, kładzie ją do zawiniątka i przyrzeka, że ziemię tę, zroszoną krwią jej męża, kiedyś nasyci krwią Hagena. Przed wyjazdem jeszcze raz odwiedza kryptę grobową Zygfryda. Mimo nalegań królowej Uty i księdza nie zamierza ani pożegnać się z Gunterem, ani pojednać z rodziną. Ignoruje kilkakrotnie wyciągniętą rękę Volkera i dołącza do sformowanego przez Rydygiera orszaku. Pytana przez Rydygiera, czy zechce po raz ostatni pozdrowić swych bliskich, odpowiada odmownie, wzbudzając ból machających do niej ze szczytu murów matki, Giselhera i Volkera. Gdy dociera do kraju Hunów, nastała już wiosna. Hunowie, którzy wypatrywali jej w stepie z dziwnego, kaktusowatego drzewa, po dostrzeżeniu orszaku pędzą konno na łeb, na szyję, by powiadomić o zbliżaniu się narzeczonej swego króla. Ten, który uczynił to pierwszy, otrzymuje od Etzela sakwę złota. Król rozkazuje swemu bratu Blaodelowi wyjechać Krymhildzie na spotkanie. Na wejście narzeczonej i Rydygiera Etzel przerywa dziki ubaw wokół i zawstydzony błotem na klepisku swej siedziby ściele przed Krymhildą swój płaszcz. Urzeczony urodą wybranki ofiarowuje Rydygierowi dowolne królestwo ze swych ziem za skuteczne spełnienie jego misji. Krymhilda pyta Rydygiera, czy król jest gotów powtórzyć przysięgę, którą poseł złożył w jego imieniu. Etzel uroczyście przyrzeka, że ktokolwiek ośmieli się jej uchybić, zginie stokrotną śmiercią. Tak zapewniona, Krymhilda wyciąga rękę, do której Etzel kornie chyli czoło.

Pieśń III: „Jak król Etzel Rzym oblegał, i jak Krymhilda zaprosiła swych braci" (Der dritte Gesang: Wie König Etzel vor Rom lag, und wie Kriemhild ihre Brüder entbieten ließ). W obozowisku wojennym Hunowie narzekaja, iż król Etzel nie dotrzymał swych obietnic i nie obrócił kościołów Rzymu w stajnie dla ich koni. Upewniwszy się, że władca śpi, Werbel, huński bard, gra i śpiewa frywolną pieśń o tym, jak króla Etzela, przed którego biczem drżał do niedawna cały świat, uśpiła i obezwładniła swymi złotymi lokami biała kobieta. Zuchwały Werbel przypłaciłby życiem swój występ, gdyż przebudzony król już miał dokonać jego egzekucji swą zakrzywioną sierpowato szabla, ale ratuje go nagłe przybycie konnego posłańca z wieścią, iż królowa powiła syna. Rozradowany Etzel łamie szablę i rusza na koń, a za nim inni Hunowie. Krymhilda tymczasem większą czułością obdarza zawiniątko z ziemią zroszoną krwią swego pierwszego 
męża niż swe nowo narodzone dziecko. Hunowie z Etzelem na czele pędzą na łeb, na szyję spod Rzymu do Etzelnburga, przystając tylko na moment przy nagich dzieciach w wiankach na głowie, tańczących wokół drzewka w polu. W komnacie Krymhildy Etzel czołga się do niej na kolanach, a następnie czule pieści dziecko. Rozradowany mówi żonie, iż spełni każde jej życzenie. Krymhilda prosi, by Etzel ugościł na swym dworze jej braci. Król wzywa Blaodela, by natychmiast wyruszył do Wormacji z zaproszeniem dla jego królewskich szwagrów.

Pieśń IV: "Jak Krymhilda przyjęła swych braci" (Der vierte Gesang: Wie Kriemhild ihre Brüder empfing). Werbel i Blaodel u Krymhildy zdaja jej sprawozdanie. Werbel opowiada o ponadmiesięcznej gościnie jej braci u Rydygiera, zaręczynach jego córki Dytlindy z Giselherem i zawartym $\mathrm{w}$ ten sposób przymierzem między Burgundią a Bechlarn. Blaodel z kolei informuje o powitaniu, które jej braciom zgotował Etzel, wysyłając do nich najszlachetniejszego ze swych rycerzy - Dytrycha z Bern, który ostrzega ich przed niebezpieczeństwem grożącym im ze strony Krymhildy. Na odchodnym Krymhilda mówi swym huńskim informatorom, że ktokolwiek chce zyskać jej wdzięczność, musi pamiętać o jej wielkim strapieniu. Dzień przed letnim przesileniem Słońca Burgundowie przybywają do stolicy Etzela król Hunów pokazuje im kwaterę i zaprasza na ucztę nazajutrz. Krymhilda, przypominając Etzelowi jego przysięgę, żąda od niego głowy Hagena - król proponuje, że wyzwie go na pojedynek. Gdy Krymhilda oponuje, że morderca nie jest tego godny, zirytowany Etzel deklaruje, że nie złamie świętego prawa gościnności i póki Hagen nie złamie pokoju jego domostwa, będzie dlań nietykalny. Krymhilda odwiedza nocą tłum Hunów, podburzanych dodatkowo dla jej sprawy przez Blaodela, i obiecuje za głowę Hagena tarczę pełną złota - żąda jednak bezpieczeństwa dla swych braci. Gdy Gunter, Gernot i Giselher śpią kamiennym snem, Hagen i Volker czuwaja, co odstrasza żądnych nagrody Krymhildy Hunów, którzy z nożami w zębach, pod osłoną ciemności usiłowali niepostrzeżenie zakraść się do kwatery gości.

Pieśń V: „Jak Hunowie z Nibelungami ${ }^{11}$ świętowali letnie przesilenie Słońca" (Der fünfte Gesang: Wie die Hunnen mit den Nibelungen das Sonnwendfest feierten). Po tak niebezpiecznej nocy Burgundowie-

${ }^{61}$ Nazwa "Nibelungi", „Nibelungowie” jest dość tajemnicza i niejasna. W eposie Das Nibelungenlied odnosi się ona do mieszkańców krainy podbitej przez Zygfryda, nazwanych tak za królem Nibelungiem, ojcem dwóch książąt, Szilbunga i Nibelunga, których Zygfryd zabija i skarb - wraz z Tarnhelmem i mieczem Balmungiem - zagarnia. Sługą zabitych książąt - zatem także Nibelungiem - był karzeł Alberyk. Nazwa ta wydaje się potem przechodzić na kolejnych właścicieli skarbu - bo najpierw przysługuje Zygfrydowi i jego ludziom, potem zaś Burgundom (nieznane są jednak powody tego transferu). W tetralogii Wagnera Pierścień Nibelunga Nibelungi to karły wydobywające złoto dla Alberyka, który 
-Nibelungowie na bankiet w królewskim pałacu zjawiają się w pełnym rynsztunku, co budzi gniew i zdziwienie Etzela: "Czy jest w zwyczaju na waszym dworze zasiadać do stołu uzbrojonym od stóp do głów?" Krymhilda złośliwie komentuje, że Hagen Tronje dobrze wie, dlaczego nigdy nie odkłada swego miecza. Atmosfera uczty jest ponura - Krymhilda nie odwzajemnia toastu Guntera, demonstracyjnie odstawiając puchar do góry dnem. Tymczasem gdzieś w innym miejscu Etzelnburga burgundzka czeladź z bratem Hagena, Dankwartem, bawi się z Hunami. Goście nieświadomi są tego, że gospodarze, zainspirowani przez Krymhildę i kierowani przez Blaodela, planują ich rzeź, ściągając do sali biesiadnej coraz to nowe posiłki uzbrojonych pobratymców i zaopatrując po kryjomu tych już obecnych w noże. Dankwart i pozostali Burgundowie rozbawieni przyglądają się występowi Werbla, dając się porwać beztroskiej (na pozór) ogólnej wesołości. Tymczasem podczas uczty pałacowej Krymhilda - prowokując krwawe wypadki - sugeruje, że na takiej uroczystości nie powinno zabraknąć królewskiego dziedzica. Hildebrand przynosi dziecko, a Etzel z radością pokazuje je zgromadzonym. Pośpiesznie jednak odbiera je Hagenowi, gdy ten złowrogo mówi, iż „,coś mu się widzi, iż dziecko długo nie pożyje". W sali czeladnej do występu Werbla przyłącza się Blaodel - symulują pojedynek na noże. W pewnym momencie znienacka odskakując od siebie, rzucają się na burgundzkich widzów, inicjując rzeź. Dankwart walczy z Werblem, któremu w sukurs przychodzi Blaodel. Bratu Hagena udaje się przedrzeć przez zastępy Hunów i dobiec do schodów pałacu Etzela, gdzie trafia go jednak strzała Blaodela, którego głowę z kolei rozłupuje rzucony przez Dankwarta toporek. Przeszyty strzałą Dankwart zdoła jednak przed śmiercią wbiec na salę bankietową i obwieścić zdradę Hunów. Burgundowie bronią wejścia do pałacu przed naporem nadciągających Hunów. W zaistniałym zamieszaniu Hagen zabija królewskiego dziedzica. Krymhilda ukazuje Etzelowi, do czego zdolny był tak chroniony przezeń gość, a król Hunów zapowiada w odwecie rzucenie przeciw Nibelungom wszystkich swych sił. Dytrych i Rydygier bronią dostępu do pary królewskiej atakującym Burgundom. Dytrych żąda bezpiecznego odwrotu dla siebie i swych ludzi, a przez szacunek dla tego znamienitego rycerza Gunter wyraża na to zgodę. Burgundowie rozstępu-

\footnotetext{
rządzi nimi przy pomocy magicznego pierścienia. W filmie Langa wydaje się ona odnosić wpierw jedynie do Alberyka i karłów, które wykuły Balmunga, wykuwają olbrzymią koronę dla Króla Północy i są strażnikami/niewolnikami skarbu, który zagarnia Zygfryd i który zwany jest „skarbem Nibelungów”. Znienacka w II części filmu przysługuje ona Burgundom po przybyciu do państwa Etzela - czyżby po zagarnięciu skarbu przez Hagena? W każdym razie film w swym nieumotywowanym przeniesieniu tej nazwy na Burgundów idzie w ślad za eposem. Nt. nazwy zob. hasła: "Nibelung”, "Nibelungs", [w:] The Nibelungen Tradition: An Encyclopedia, s. 102-103.
} 
ją się i wraz z Dytrychem, Rydygierem i ich ludźmi Etzel z Krymhildą bezpiecznie opuszczają salę. Po ich wyjściu wrota zostają przez Burgundów-Nibelungów zamknięte, a sala bankietowa zamienia się w desperacko bronioną przez gości, oblężoną przez gospodarzy, twierdzę.

Pieśń VI: „Niedola Nibelungów” (Der sechste Gesang: Der Nibelungen Not). Hagen wypuszcza z sali bankietowej spętanego Huna, który podbiega do obserwującej oblężony pałac z naprzeciwka Krymhildy i powiadamia ją, iż prócz niego nie uszedł tam z życiem ani jeden Hun. Krymhilda okrzykiem: „Hunowie, pomścijcie waszych poległych!", zachęca do kolejnego szturmu. Hunowie rzucają się na wrota, waląc w nie toporami, ale wypad zza nagle otwartych wrót zasłoniętych tarczami Burgundów-Nibelungów powoduje wśród oblegających duże straty po walce na schodach pałacu i konieczność wycofania się (ginie ów wypuszczony przez Hagena). Krymhilda ponownie zachęca Hunów do pomszczenia poległych i królewskiego potomka. Tym razem przypuszczają szturm na dach pałacu przy użyciu drabinek sznurowych. Na dachu trwają zacięte walki - Nibelungowie strącają lub odcinają drabinki ze szturmującymi, trwają też walki wręcz. Giselher zauważa z dachu Krymhildę, wołając: „Siostro, pomyśl o naszej matce!" Krymhilda nieugięcie jako warunek ich wolności żąda wydania mordercy Zygfryda. Nibelungowie tarczami osłaniają odwrót Giselhera, do którego mierzą strzałami huńscy łucznicy. Walkę obserwują z naprzeciwka Dytrych, Rydygier i Hildebrand. Dytrych prorokuje, iż świt nie zastanie żadnego z Nibelungów żywym. Razem z Hildebrandem musi on powstrzymywać Rydygiera, pragnącego wspomóc narzeczonego swej córki. „Krew woła o krew!” - sentencjonalnie tłumaczy Rydygierowi Hildebrand konieczność jego pozostania na uboczu. Gdy kolejny szturm Hunów zostaje odparty, Krymhilda wzywa na pomoc Rydygiera, żądając odeń wypełnienia złożonego jej w Wormacji ślubu. Rydygier rozdarty jest między wiernością tej przysiędze a przymierzem zawartym z narzeczonym swej córki i burgundzkim domem. „Krew woła o krew!” - uzasadnia Rydygierowi Krymhilda konieczność jego zaangażowania po jej stronie. Rydygier próbuje jeszcze błagać Etzela o niewysyłanie go do tej walki, w której jego lojalność jest wewnętrznie skłócona: „Panie, nie każ zabijać mi mego jedynego dziecka!" - mając na myśli Dytlindę, która nie przeżyłaby śmierci Giselhera. Ale gdy król pokazuje mu tulone nieprzerwanie zwłoki swego synka, poddaje się i zbolałym krokiem rusza spełnić rozkaz Krymhildy.

Pieśń VII: „Koniec Nibelungów” (Der siebente Gesang: Der Nibelungen Ende). Burgundowie z nadzieją wpuszczają do sali bankietowej kołaczącego Rydygiera. Ale gdy rozradowany Giselher pyta go: „Cóż nam przynosisz, teściu?”, ten odpowiada: „Śmierć!” Na zewnątrz Dytrych błaga 
Etzela, by nie dopuścił, aby ci którzy się kochaja, pozabijali się nawzajem. Nieustępliwy król odpowiada, iż puści ich wolno, gdy wydadzą mu mordercę jego dziecka. „Królu Etzelu, nie znasz lojalnej germańskiej duszy" - replikuje Dytrych. Rydygier mówi Burgundom, iż jego przysięga dla Krymhildy starsza jest od jego przymierza z nimi. Wyzywa do walki Hagena - i trafia Giselhera, który mordercę Zygfryda zasłonił swym ciałem. Giselher umiera na rękach swych starszych braci, a zrozpaczony jego śmiercią Rydygier ginie z ręki Volkera. Gernot wynosi na schody ciało brata, pokazując je Krymhildzie: „O siostro, do czego doprowadziłaś!” Nieugięta Krymhilda nadal żąda Hagena, a zaatakowany przez Hunów Gernot ginie na jej oczach. Na schodach pałacu pojawia się Hagen, który rzuca pod stopy Krymhildy tarczę. Pod osłoną tarcz Nibelungowie zabierają zwłoki królewskich braci i wycofują się do sali bankietowej. Krymhilda rozkazuje podpalić pałac. Od płonących strzał huńskich łuczników szybko zajmują się jego dach i strop - próby ugaszenia ognia przez Guntera i jego rycerzy są daremne. O rozkazie Krymhildy Hildebrand powiadamia Etzela. Król Hunów popiera go - dobiegając do przyglądającej się pożarowi Krymhildy dziękuje jej za to, iż choć nigdy się nie kochali, to przynajmniej teraz jednoczą się w nienawiści. Ale Krymhilda kolejny raz głęboko go rani, mówiąc, iż nigdy jej serce nie było bardziej przepełnione miłością, co oznacza, iż zemsta jednoczy ją nie z Etzelem, ale z Zygfrydem. Nie chcąc, by ranny Gunter zginął w płomieniach, Hagen zamierzać oddać się Krymhildzie. Gunter i pozostali Nibelungowie oponują: „Lojalność, której nie zmogło żelazo, nie roztopi się w ogniu, Hagenie Tronje". Sala bankietowa pełna jest ognia i dymu, z góry spadają płonące belki. Walący się strop grzebie wszystkich Nibelungów, z wyjątkiem Hagena i osłoniętego jego tarczą Guntera, oraz Volkera, przy akompaniamencie skrzypiec śpiewającego swą ostatnią pieśń. Słucha jej Krymhilda i inni widzowie pożaru na zewnątrz. „Nie jesteś człowiekiem, pani Krymhildo” - mówi Hildebrand. „Nie, umarłam, kiedy umarł Zygfryd" - odpowiada nieporuszona królowa. Gdy Dytrych otwiera wrota dopalającego się pałacu, strzała wystrzelona do środka przez umierającego na schodach Huna trafia i zabija Volkera. Dytrych wyprowadza na schody Hagena i Guntera. Krymhilda, z Zygfrydowym Balmungiem w ręku, odebranym Hagenowi i przekazanym jej przez Dytrycha, indaguje swego największego wroga o skarb Nibelungów. Hagen odpowiada, iż przysiągł nie zdradzić jego miejsca, póki żyje choćby jeden z królów burgundzkich. Na te słowa Krymhilda wydaje rozkaz ścięcia Guntera. Widząc głowę swego króla w ręku Huna, Hagen śmieje się złośliwie, mówiąc, iż teraz tajemnicę skarbu zna tylko on i Bóg, który nie jest bardziej dyskretny od niego. Krymhilda Balmungiem zabija Hagena i na jego ciało upuszcza zawiniątko z ziemią zroszoną krwią Zygfryda, by ta nasyciła się teraz krwią mordercy. Ugodzona mieczem 
przez Hildebranda Krymhilda umiera, a nad jej ciałem Etzel wydaje dyspozycję, by zabrać ją do ojczyzny, do jej zmarłego męża Zygfryda, gdyż należała tylko do niego i do żadnego innego mężczyzny. Ostatni napis obwieszcza: „Tutaj opowieść ma swój kres” (Hier hat die Mär ein Ende).

Jeden Gesang filmu Langa odpowiada dwóm aktom (w rozumieniu technicznym, jako szpulom filmu $35 \mathrm{~mm}$ ), czym Nibelungi nieco przypominają Zmęczona Śmierć, gdzie segmentacja techniczna korespondowała - choć trochę inaczej - z dramaturgiczną ${ }^{62}$. Ale prócz tego aspektu oraz korespondencji Gesänge z âventiuren eposu istotne wydaje się, że dzięki takiej budowie dzieła Lang uwypuklił jedną z podstawowych zasad formalnych $\mathrm{w}$ Nibelungenlied, mianowicie tzw. Vorausdeutung ${ }^{63}$. Polega owa zasada na zapowiadaniu $\mathrm{w}$ narracji przyszłych wydarzeń fabularnych, co rodzi szczególne poczucie odbiorcy, iż muszą się one wydarzyć nieuchronnie. Technika ta, choć może sprawiać wrażenie determinizmu (i być może stąd zainteresowanego „machiną Przeznaczenia” Langa skusiła Pieśn o Nibelungach), tak naprawdę jest przede wszystkim chwytem epickim, objawiającym, iż opowieść dotyczy przeszłości - najczęściej odległej i zamkniętej, której na jotę nie można już zmienić. W przytoczonym jako drugie motto fragmencie eposu objawia się owa technika zapowiadania przyszłych wypadków w całej pełni: z góry wiemy, iż Krymhilda przyniesie zagładę wielu mężom, że królowie burgundzcy stoczą „cudowne boje w krainie Attyli” (Etzela), że rój burgundzkich mężów „zginie potem marnie dla dwóch kobiet kłótni", że Krymhilda straci męża-sokoła, i że "pomsty podejmie się krwawej na zabójcach, na własnej rodzinie”. Vorausdeutung $\mathrm{w}$ filmie przejawia się m.in. w najprostszy z możliwych i właściwie dość „niefilmowy” sposób - poprzez zapowiedź zawartości fabularnej poszczególnych Gesänge w ich tytułach. Ale, rzecz jasna, nie wyczerpuje to obecności w filmie zapowiedzi dalszych wydarzeń - mamy tu przecież i zwizualizowany przez Ruttmanna "sen o sokole”, i jedynie sygnalizowane przekazującymi słowa Krymhildy napisami sny o dziku i dwóch górach. Podobnie zresztą trzeba traktować jako Vorausdeutung samozrealizowaną prognozę Hagena, że syn Etzela długo nie pożyje czy proroctwo Dytrycha z Bern, że świt nie zastanie żadnego z Nibelungów żywym. Podkreślam jednak, że w tym miejscu chodzi mi o Vorausdeutung uwypuklone przez segmentację dzieła na Gesänge.

Na przykład w Pieśni I pokonanie przez Zygfryda smoka wydaje się triumfem bohatera, tym bardziej, że nabywa on dzięki kąpieli w krwi

62 Por.: T. Gunning, op. cit., s. 41.

63 Zob.: Brian Murdoch, Politics in the "Nibelungenlied", [w:] A Companion to the „Nibelungenlied”, ed. Winder McConnell, Camden House, Columbia (SC) 1998, s. 235-242. 
smoka a tr o s j i („,niezranialności” $)^{64}$. Smok jednak odnosi coś w rodzaju pośmiertnego triumfu - jego przedśmiertne machnięcie ogonem uruchamia typową dla filmów Langa „machinę Przeznaczenia”, w której tak niepozorny szczegół, jak liść lipy, ma tak brzemienne skutki ${ }^{65}$. Nie przypadkiem ujęcie liścia, przyklejonego do barku Zygfryda zamyka epizod, stanowiąc zarówno mocną pointę wizualna, jak i wyrazisty przejaw Vorausdeutung, uwypuklony właśnie przez takie usytuowanie w narracji. Miejsce oznaczone liściem lipy zapowiada nieszczęsny krzyżyk wyszyty na ubraniu Zygfryda przez Krymhildę i, rzecz jasna, cios Hagena. Podobnie zresztą wyrazistą pointą Pieśni II jest ostatnie jej ujęcie: Hagen kładący swą dłoń niczym mistrz ceremonii na podane sobie wzajemnie jako znak porozumienia prawice Guntera i Zygfryda. Jako Vorausdeutung jest to jednak dwuznaczne, zarówno antycypując zawarte w Pieśni IV między szwagrami braterstwo krwi (gdzie znów mistrzem ceremonii będzie Hagen), jak i na zasadzie tragicznej ironii kontrapunktując zdradę Zygfryda przez Guntera - znowu zainspirowaną przez Hagena. Zresztą już choćby wizualnie finał II Gesang - zbliżenie Hagena - antycypuje pointę VI Gesang, kiedy po zamordowaniu Zygfryda Hagen jakby z tragiczną kpiną oznajmia: „Polowanie skończone!” Można rzec, iż Vorausdeutung w filmie Langa jest nie tyle zapowiedzią sensu stricto (jak w eposie), ale ma cechy raczej bardziej nieokreślonej antycypacji, czasem wprost (liść lipy/śmiertelna rana, zgoda/braterstwo krwi), a czasem à rebours (zgoda/zdrada).

Aż trzy z siedmiu Gesänge Zygfryda (III, IV i VII) kończą się obrazem pokonanej Brunhildy. Jej pokonanie w Pieśni III przez Guntera, k tó r e go rękę prowadziła ręka Zygfryda, zapowiada jeszcze dwuznaczniejszą jej porażkę z Zygfrydem w posta ci Guntera (Pieśń IV). Brunhilda tak naprawdę przegrywa za każdym razem z Zygfrydem, ale rzeczywistość widzialna ukazuje - i jej samej, i także widzowi - jej bezsilność i uległość wobec Guntera, w którym trafnie rozpoznaje ona słabeusza (stąd być może jej porażki są dla niej tak haniebne). Toteż można powiedzieć, iż finały III i IV Gesänge pokazują p r a w d z i w ą p o r a ż kę (Brunhildy), fałszywe zwycięstwo (Guntera) i zwycięstwo pyrrus owe (Zygfryda). Pointy III i IV Gesänge kontrastują zresztą na zasadzie kontrapunktu z jedną z pierwszych scen IV Gesang, kiedy Brunhilda potwierdza swą pogardę dla Guntera łatwo odniesionym nad nim zwycięstwem (co nie tylko nie przynosi jej satysfakcji, ale wzmaga jej

\footnotetext{
${ }^{64}$ Nt. pojęcia atrosji, zob.: Bogusław Bednarek, Śmiercia naznaczon i sława: Notatki o "Niedoli Nibelungów”, [w:] Niedola Nibelungów, reprint jubileuszowy, przeł. Ludomił German, Wydawnictwo Wacław Bagiński i Synowie, Wrocław 1994, s. 375-377.

65 Por. analizę sekwencji kąpieli Zygfryda w krwi smoka przez Toma Gunninga (op. cit., s. 35-36).
} 
niepokój). Rzecz jasna, w kontekście finału tej Pieśni bezsilność fizyczna Guntera wobec przyszłej żony jawi się jako metonimia jego seksualnej impotencji. Finał Pieśni III jest antycypacją finału Pieśni IV. Konotacje tarczy kobiety rozbitej silnie pchniętą włócznią mężczyzny są w oczywisty sposób seksualne, choć wyrażone jeszcze w sposób symboliczny. Sens seksualny w oczywisty sposób się ujednoznacznia - choć także nie do końca - w Pieśni IV, gdy chodzi już nie o walkę na arenie, by tak rzec, sportowej, ale o konieczność złamania oporu niechętnej kobiety w małżeńskiej sypialni. Zerwany przez Zygfryda naramiennik jest symbolem z a r a z e m dokonanego przezeń gwałtu, jak i możliwości jego niedokonania (w wymiarze seksualnym, nie zaś przemocy fizycznej, która z pewnością miała miejsce). Narracja daje nam tu dwuznaczne wskazówki: obraz nie wizualizuje nam gwałtu, a po śmierci Zygfryda Brunhilda mówi Gunterowi, iż uwierzył w jej kłamstwo o „pierwszeństwie” Zygfryda; kłóci się to jednak ze wzburzeniem zarówno Zygfryda, jak i Brunhildy, gdy Krymhilda pokazuje każdemu z nich naramiennik, przedmiot niewątpliwie s k a n d a l i c z n y. Podobna dwuznaczność i nierozstrzygalność zagadki „,złamania oporu" Brunhildy ma miejsce także w eposie - z tym, że tam zabranymi przez Zygfryda jego „przeciwniczce” przedmiotami są pierścień i pas, obiekty o znacznie bardziej seksualnych konotacjach niż naramiennik. W każdym razie te dwa pointujące dwie pieśni obrazy Brunhildy n a k ol a n a ch, zapowiadają ostatni obraz z tej serii, pointujący Pieśń VII i całą I część filmu: odkryte przez legalną wdowę, Krymhildę, jakby adorujące nieżyjącego Zygfryda, martwe ciało Brunhildy, jeszcze jednej wdowy po herosie, znowu w pozycji pokonanej...

Zemsta Krymhildy, z racji tej, iż zdarzenia się już „wypełniają”, zawiera mniej antycypacji. Niewątpliwie jednak pointa Pieśni I (konfrontacja Krymhildy i Hagena przed opustoszałym skarbcem, a zaraz potem obraz skarbu Nibelungów na dnie rzeki) oraz początek Pieśni II (Krymhilda obiecująca ziemi zroszonej krwią Zygfryda, że napoi ją krwią mordercy) - zapowiadają dramatyczną konfrontację Krymhildy i Hagena w finale filmu. Pamięć o tamtych scenach wzmaga poczucie widza, że oboje odnoszą pyrrusowe zwycięstwo: ona - swą dopełnioną zemsta, on - swym nadaremnym zagarnięciem i zatajeniem miejsca spoczynku skarbu po wygaśnięciu domu Burgundów-Nibelungów, które zresztą sam sprowokował. Z kolei pointy Pieśni III i Pieśni VI obrazują dramat Etzela: radość króla, tulącego upragnionego potomka, antycypuje nie świetną przyszłość dziedzica tronu, ale granicząca z jakimś katatonicznym odrętwieniem rozpacz ojca, gdy zwłoki syna pokazuje jako argument znękanemu trwogą o los jedynego dziecka Rydygierowi.

Stylizacja dyptyku Langa na średniowieczny epos, prawdziwą Deutsches Heldenlied, przejawia się nie tylko w formalnym podziale na 
14 Gesänge, lecz i na uwypukleniu roli słowa, a ściślej - narracji werbalnej, w prezentacji świata przedstawionego. Słowo w filmie Langa (filmie niemym!) co jakiś czas wyrywa nas $\mathrm{z}$ zanurzenia $\mathrm{w}$ widzialności, przerywając - o ile $\mathrm{w}$ ogóle $\mathrm{w}$ przeżywaniu kina ma on faktycznie miejsce - mechanizm projekcji-identyfikacji. Showing, prezentacja unaoczniająca, regularnie objawia swe zapośredniczenie przez telling, co oczywiście może nasuwać skojarzenia z Brechtowskim Verfremdungseffekt. Wydaje mi się jednak, że u Langa nie tyle chodzi o ideologiczną samoświadomość tekstu i odbiorcy, co o ukazanie (s)twórczej mocy słowa, dzięki któremu (i tylko dzięki któremu) - poprzez o p o w i a d a n i e, f a b u l a cję, n a r rację historyczną - może ujawnić się zarówno historyczna przeszłość, jak i mit. Słowa zwracają uwagę widza Nibelungów samą swą formą graficzną (gotycka czcionka napisów) i swym stylem (ewokowanie tytułami poszczególnych pieśni tak nagłówków baśni, jak i kronik historycznych). Wreszcie wydaje się, iż słowo to pojawia się częściej niż można by to uznać za funkcjonalne - o ile zrozumiałe jest zaopatrzenie poszczególnych Gesänge w nagłówki czy tytuły, bo koresponduje to z naszym przyzwyczajeniem do tytułów rozdziałów w powieści i jednocześnie działa jako istotna dla "nieodwołalności” zdarzeń przedstawionych ich zapowiedź, Vorausdeutung, to zbędne wydaje się zamykanie każdej z czternastu pieśni i obu z dwóch części stwierdzeniami typu "So endet der erste Gesang" czy "So endet die Mär von Siegfried”. Ale ta "zbędność" ewokuje zarazem „powagę" przekazu, jego autorytet w przekazaniu relacji o mitycznej i historycznej przeszłości.

Rola narracji werbalnej ujawnia się w Nibelungach nie tylko jednak na poziomie narracji samego filmu Langa (jak w wypadku plansz z napisa$\mathrm{mi})$, ale też $\mathrm{w}$ obrębie samego świata przedstawionego, w którym mamy do czynienia z narratorami formalnymi, opowiadającymi jakiemuś wewnątrzdiegetycznemu audytorium o wypadkach czy osobach zachodzących/znajdujących się gdzie indziej i/lub kiedy indziej. Gdy w pieśni IV części II Werbel opowiada Krymhildzie o zaręczynach Giselhera i Dytlindy, a Blaodel o powitaniu Burgundów-Nibelungów przez Dytrycha z Bern, zaś narracja filmu te ich relacje wizualizuje, nie ma właściwie nic w tym niezwykłego: taka przynależność jakichś partii filmu do czyichś opowieści, zapośredniczenia części zdarzeń przedstawionych przez ustne relacje czy wspomnienia formalnych narratorów, jest w filmach fabularnych czymś bardzo częstym, konwencjonalnym i nierzadko niekonsekwentnym logicznie. Ciekawszym przypadkiem są przebitki Brunhildy, gdy Hagen informuje Zygfryda o planach matrymonialnych Guntera (część I, Pieśń II), i Etzela, gdy wobec Guntera Rydygier nazywa króla Hunów „Panem Ziemi” (cz. II, Pieśń I). Brunhildę widzimy w zbroi, strzelającą z łuku, a Etzela nieruchomego, w przypominającej tiarę koronie, 
siedzącego z zakrzywioną sierpowato szablą w jakimś ozdobnym kręgu, niczym posag jakiegoś dalekowschodniego bóstwa (przychodzi do głowy zarówno Budda, jak i Kali). Ujęcia Brunhildy i Etzela nie są "opowieścią" o przeszłości; są wyrwanymi z porządku czasowego „ikonami”, a ich usytuowanie w narracji czyni z sekwencji, w której się znajduja, przykład montażu paralelnego o niejasnym, dwuznacznym statusie zarówno montażu symultanicznego (przebitka może prezentować równoczesność aktu wypowiadania słów przez Hagena czy Rydygiera), jak i „paralelnego ideowego" (przebitka ma jednak raczej, mimo konkretności obrazu, charakter „ideowy”, prezentacji jakiegoś permanentnego czy ogólnego stanu rzeczy).

Podobny status - przynależna jakiemuś formalnemu narratorowi sekwencja jest zarazem prezentacją symultaniczności, jak i bezczasowego "permanentnego stanu rzeczy” - posiada relacja „leśnego człowieka" o wspaniałościach Wormacji i dworu Burgundów, z której Zygfryd w Pieśni I dowiaduje się o Krymhildzie. Relacja ta jest jednak bardzo interesująco w filmie usytuowana, co dodatkowo komplikuje jej status. Tak o tym pisze Tom Gunning: „Ustny opis grodu Wormacji i pięknej Krymhildy jest dla Zygfryda natchnieniem, by wyruszyć ku swym przygodom na początku filmu, a widziane przez nas obrazy traktujemy jako wizualne ekwiwalenty opowieści, którą on słyszy. Gdy Erste Gesang (Pieśń I) kończy się fatalnym wylądowaniem liścia na plecach Zygfryda, drugi Gesang rozpoczyna się obrazem burgundzkiego minstrela Volkera wykonującego na wormackim dworze epicką pieśń o Zygfrydzie, pogromcy smoka. Możemy założyć, iż poprzedni Gesang faktycznie w całości został wyśpiewany przez owego minstrela. Następna przygoda Zygfryda, jego zdobycie od Alberyka skarbu Nibelungów, również obramowana jest występem Volkera (napis obwieszcza, po tym, gdy Zygfryd chwyta miecz Balmung: So sang Volker - „Tak śpiewał Volker"). Zatem najbardziej mitologiczna część historii Zygfryda jest prezentowana przez pośrednictwo tradycji ustnej i szczególny akt narracji [narrative performance]"66.

David Levin zwraca uwagę na fakt, iż Zygfryd i Krymhilda dowiadują się o sobie nawzajem z cudzych relacji ${ }^{67}$, w czym może nie byłoby nic dziwnego, gdyby jednak nie komplikacje logiczne w statusie narracji. O wyczynach „pogromcy smoka” siostra króla Burgundów dowiaduje się z pieśni minstrela - zatem można by oczekiwać, że tak sławny, iż opiewany w pieśniach bohater, oddalony jest o jakiś dystans czasowy od „teraźniejszości": musiał minąć jakiś czas, by jego przygody zdobyły sławę, stały się legendą. Tymczasem niemal natychmiast po wyśpiewaniu przez Volkera „eposu” o Zygfrydzie, jego bohater zjawia się na wormackim

${ }^{66}$ T. Gunning, op. cit., s. 41.

67 Zob.: D. Levin, op. cit., s. 104. 
dworze we własnej osobie! A jeżeli, zgodnie z hipotezą Gunninga, także Erste Gesang, był wyśpiewany przez Volkera, to z pewnością logiczną niekonsekwencją jest zamieszczenie w nim relacji „leśnego człowieka” o wspaniałościach Wormacji: opowieści przeglądają się w sobie nawzajem jak w lustrach, kreując jakiś niepokojący efekt, trochę w stylu mise-en-abyme, ale może jeszcze bardziej zawrotny, bo nie ma metarzeczywistości, ani w ogóle żadnej innej rzeczywistości, poza tą (tymi?), o której (których?) prawią opowieści, niewytłumaczalnie zawarte jedna w drugiej. Oczywiście, jest to nielogiczne, za to ma niewątpliwą siłę poetycka, chyba trafnie oddającą ducha epoki, w której tak łatwo mieszają się mit czy legenda i historia; mit wkracza w historię, która go zawłaszcza, czyniąc z niego legendarne zdarzenie założycielskie danej społeczności, po czym ona sama po stuleciach staje się mitem, ubrana w szatę eposu, gdzie to, co historyczne i legendarne, choć poprzez konfrontację z innymi przekazami można je ewentualnie odzielić od siebie, tworzy zadziwiająco jednorodną opowieść o wielkości i grozie „dawnych czasów” ${ }^{68}$. Wystarczy przytoczyć I strofę eposu o Nibelungach: „Prawią nam stare pieśni o przeszłości cudach: / O bohaterach słynnych, o znojach, o trudach, / O godach i rozkoszy, o łzach i boleści, / O bojach i zapasach - słuchajcie powieści!"69.

Słowo w filmowym eposie Langa ma zatem taką moc stwórcza, że legendarna przeszłość (Zygfryda) natychmiast konkretyzuje się jako teraźniejszość, symultaniczność - co jest właściwie nie do pojęcia, bo jak można opowiadać czy, co więcej, śpiewać artystycznie skomponowany utwór, o czymś, co d zi eje się równocześnie i gdzie indziej?

${ }^{68}$ Epos o Nibelungach zawiera echa rzeczywistych wydarzeń historycznych zaszłych kilkaset lat przed spisaniem poematu w znanej nam postaci (na przełomie XII i XIII w.), ale dość beztrosko poplątanych. Dotyczą one: 1) zagłady przez Hunów nadreńskiego królestwa Burgundów w 437 r. (ale nie pod wodzą sławnego Attyli - Etzela z eposu - tylko rzymskiego wodza Aecjusza); 2) okoliczności śmierci samego Attyli w 453 r. podczas nocy poślubnej z dziewczyną o germańskim imieniu Hildico (Krymhildą?); 3) wyczynów króla Ostrogotów, Teodoryka Wielkiego (Dytrych z Bern), niebędącego jednak wasalem Attyli, bo żył od niego później - doradcą słynnego króla Hunów był natomiast jego ojciec Tiudimer (Dytmar); 4) intryg dworskich w VI w. na dworze Merowingów, których król Chlodwig I zawarł przymierze z Burgundami. Wizygocka królewna Brunichilde poślubiła w $567 \mathrm{r}$. merowińskiego króla Sigiberta, w 675 zamordowanego, m.in. na skutek jej intryg, podczas polowania. W 613 r. wdowę spotkał podobny los (por.: R. Stiller, op. cit., s. 419-420; także: hasła osobowe i geograficzno-historyczne, [w:] The Nibelungen Tradition: An Encyclopedia). W eposie zespół zniekształconych faktów historycznych sąsiaduje z zespołem mitologicznym, dotyczącym głównie osób Zygfryda i Brunhildy, którego głównymi źródłami literackimi są sagi skandynawskie (Eddy, Volsunga Saga), zresztą również zawierające echa wydarzeń historycznych i takich postaci, jak Attyla (Atli) czy Teodoryk (Piðrek). Np. Wagner, w przeciwieństwie do Hebbla czy Langa, czerpał głównie nie z Nibelungenlied, a z sag, i w dodatku konfabulował.

${ }^{69}$ Niedola Nibelungów, s. 16. 
Analogicznie - choć w istocie na odwrót - dzieje się w Pieśni III, gdy wróżona przez wieszczkę Brunhildy przyszłość, natychmiast staje się teraźniejszością. Przytoczmy znów Gunninga: „Przybycie Zygfryda i Guntera do Islandii, królestwa Brunhildy, jest przepowiedziane przez mądrą wieszczkę, która odczytuje runy. Jej odczytywanie przyszłości jest w rzeczywistości odczytywaniem równoczesności, gdy Lang używa montażu równoległego, by odsłonić prawdę jej prognoz. Każdy etap podróży Zygfryda jest wyczytany przez kobietę w znakach runicznych: jego przybycie na wybrzeże, jego przekroczenie ognistego morza, aż do chwili, gdy straż spieszy obwieścić przybycie bohatera do bram zamku. Lang nie tylko wizualizuje zawartość owych relacjonowanych przez kogoś opowieści, ale $\mathrm{w}$ tym przypadku kreuje paralelę między odczytywaniem przez wieszczkę znaków runicznych a filmową techniką montażu symultanicznego"70.

Można zatem powiedzieć, że narracja werbalna staje się w eposie Langa $\mathrm{w}$ pewnym sensie figurą chwytów filmowych, a postacie narratorów - zwłaszcza Volkera i wieszczki - figurami artysty. Jest jednak w Nibelungach moment, kiedy kino ewokowane jest w sposób niewątpliwy: to moment, kiedy karzeł Alberyk przy pomocy swej szklanej kuli wyczarowuje Zygfrydowi na ścianie groty obraz wykuwania przez Nibelungów korony Króla Północy. Alberyk jawiłby się zatem jako kolejna - po Zmęczonej Śmierci w zagadkowy sposób demonstrującej Dziewczynie "Historie trzech świec” i doktorze Mabuse we wcieleniu Sandora Weltmanna mamiącego zahipnotyzowaną publiczność filharmonii fantomatyczną karawaną - figura filmowca. I po raz kolejny byłaby to figura negatywna, jeśli nie wręcz demoniczna - zwłaszcza w świetle analizy postaci Alberyka i sceny w grocie przez Davida Levina.

Zdaniem tego autora, niespecjalnie istotna jest zawartość „filmowego” obrazu, tzn. to, co Alberyk „,wyświetla” Zygfrydowi. Ważny jest sam fakt, że dysponuje on "aparatem” filmu (w medialno-ideologicznym, à la Jean-Louis Baudry, rozumieniu kategorii aparatu) - jego figura jest rozświetlona szklana kula. Zygfryd reaguje naiwnie, jak ponoć widzowie pierwszych filmów - usiłuje po zniknięciu "filmu" podążyć za nim, schwycić go, ale natrafia tylko na ścianę groty, ,"ekran”, na którym film był wyświetlany. Zygfryd jest widzem naiwnym, bezrefleksyjnym, a co więcej-jest cynicznie manipulowany przez dysponenta „,aparatu”, Alberyka. Levin, autor z wyraźną predylekcją do krytyki ideologicznej lewicowej proweniencji i do wydobywania gdzie się da znaczeń symptomatycznych, odczytuje złowrogiego karła (pamiętajmy, że mimo oferowanego bohaterowi skarbu, dwukrotnie dokonuje on na niego zamachu i rzuca nań klątwę) jako figurę żydowskiego przedsiębiorcy filmowego i metonimiczną

70 T. Gunning, op. cit., s. 41. 
reprezentację Hollywoodu: „Scena wyświetlana na ekranie (czy na ścianie) odtwarza istotną fantazję kinematograficznej autodefinicji, gdyż Alberyk jest tu ukazany $\mathrm{z}$ aparatem kina w swej garści. Co równie ważne (jeśli nawet mniej dosłowne), ma on w swej garści także Zygfryda, oczarowanego wyświetlanym obrazem. Warto by dobrze przyjrzeć się tej ręce - faktycznie, palce otaczające kryształową kulę są długie i zakrzywione, sama dłoń jest brudna, ręce zbyt długie, ramiona pochyłe, twarz zdeformowana, nos haczykowaty, oczy świdrujące. Alberyk nie tylko ucieleśnia kontrolę nad aparatem, jest także wcieleniem Żyda: jego zdradzieckość, pokraczność i intryganctwo odpowiadają dominującym niemieckim stereotypom żydowskiej powierzchowności i żydowskiej natury. W dodatku jego zachowanie przedstawia wyrazistą wizualizację żydowskiego jammern, kombinacji skradania się i błaganiny, drżenia i grymasów, wizualnej gadatliwości, która w zestawieniu z niemotą medium jest tym bardziej wymowna. [...] Der Nibelungen-Film jest reakcją przeciw filmowi hollywoodzkiemu, przedstawiając zarazem jego wizję jako znajdującego się w rękach żydowskich"71.

I tak od naśladującej epos formy przez rolę słowa, figury artysty i metaforę kina doszliśmy do politycznych konotacji Nibelungów. Swą bardzo dyskusyjną i jednak zbyt daleko, jak sądzę, idącą interpretację "filmu Alberyka" jako metafory komercyjnego, pozbawionego duchowej głębi, pozostającego w żydowskich rękach kina amerykańskiego, Levin podpiera wypowiedziami expressis verbis Thei von Harbou (znanej z nacjonalistycznych predylekcji) i samego Langa (czy też Langowi przypisywanych ${ }^{72}$. Wedle nich, propozycją alternatywną wobec tego kina ma być film taki jak Nibelungi, nie po prostu adaptacja, ale coś, co czerpie z "duchowej świątyni narodu"73. Ale czy istotnie tak jednoznacznie i prosto der Nibelungen-Film wpisuje się w tradycję niemieckiego nacjonalizmu, i czy nie jest to raczej kolejny przykład zawłaszczania przez nią aż nazbyt chętnie tematu w gruncie rzeczy niemającego z nią wiele wspólnego?

\section{„Narodowi niemieckiemu"?}

Historia tematu Nibelungów w kulturze niemieckiej to fascynujący temat, którego nie sposób tu wnikliwie omówić i z racji ogromu zagadnienia, i szczupłości miejsca, i wreszcie dlatego, że książka ta jest jednak

${ }^{71}$ D. J. Levin, op. cit., s. 123-124.

72 Zob.: ibidem, s. 96-140.

${ }_{73}$ Zob.: Fritz Lang, Worauf es beim Nibelungen-Film ankam, [w:] Fritz Lang: Die Stimme von Metropolis, Red. Fred Gehler, Ullrich Kasten, Henschel Verlag, Berlin 1990, s. 170-174 (cyt. ze s. 170). 
zasadniczo o czymś innym ${ }^{74}$. Z drugiej jednak strony, nie można go też tu całkowicie pominąć, choćby i z tej racji, iż film Langa wpisuje się - w dobrym i w złym - w tradycję, a jako dzieło wybitne stał się sam ważną pozycją w „nibelungologicznym” kanonie.

Epos o Nibelungach dotrwał do naszych czasów w 35 rękopisach, z których 11 jest kompletnych lub niemal kompletnych, 23 to fragmenty, zaś jeden to tylko szczątkowe ślady ${ }^{75}$. Pochodzą one generalnie z XIII-XVI w., co świadczy o dużej popularności eposu w tym okresie, po czym na ponad dwa i pół stulecia został on zapomniany. W drugiej połowie XVIII w. odnaleziono $w$ trzech różnych miejscach trzy rękopisy, znane dziś jako $\mathrm{C}$ (w roku 1755), B (1769) i A (1779). Ustanawiają one - mimo pewnych różnic między sobą, czasem dość znacznych - coś, co można by określić jako pewien „wzorzec” eposu, choć mimo poszukiwań, nie odnaleziono wersji, którą można by uznać za "ostateczną" albo, odwrotnie, "oryginalną" i „pierwotną"; w ogóle wobec problemu kanonicznego tekstu i autorstwa Nibelungenlied blednie nawet kwestia homerycka. Do dziś - o czym świadczą najnowsze fundamentalne opracowania - brak tu jednoznacznych rozstrzygnięć i nadal wysuwane są rozmaite hipotezy.

Choć właśnie Nibelungenlied jest podstawowym i najważniejszym literackim przekazem legendy o Nibelungach - tak jak nie ma bardziej kanonicznej wersji historii wojny trojańskiej niż Iliada - to doczekała się ona w kulturze niemieckiej rozmaitych innych artystycznych opracowań (wyłączam $\mathrm{z}$ tego szeregu, zastanawiająco zbieżne w motywach, imionach, ewokowanych faktach historycznych, opracowania skandynawskie, jako przynależne do odmiennego kręgu kulturowego) ${ }^{76}$. Najwcześniejsze należą do literatury średnioniemieckiej: poematy z XIII w. Diu Klage (Skarga) i Der Rosengarten (Ogród różany) oraz pochodzący z przełomu XIV i XV w. poemat Der hürnen Seyfrid (Zygfryd o rogowej skórze), który w XVI w. zainspirował Hansa Sachsa do widowiska dramatycznego Der hörnen Sewfriedt (1557). To ostatnie jest utworem o tyle ważnym, że właśnie od niego rozpoczyna się historia dramatyzacji eposu, co prawda podjętej na nowo dopiero dwa i pół stulecia później-gdy od epoki romantycznej, po odkryciu

${ }^{74}$ Zainteresowanym, na wejście $\mathrm{w}$ problematykę polecam komentarze $\mathrm{w}$ polskich wydaniach eposu: R. Stiller, op. cit., s. 413-469; B. Bednarek, op. cit., s. 369-398; Andrzej Lam, Przedmowa, [w:] Pieśń o Nibelungach, s. 5-24. Natomiast pragnących głębiej wniknąć w „nibelungologię” odsyłam do najpoważniejszych dziś w literaturze światowej pozycji, zbierających dotychczasowy stan badań i uwzględniających najnowsze hipotezy i odkrycia: A Companion to the "Nibelungenlied"; The Nibelungen Tradition: An Encyclopedia; Otfrid Ehrismann, „Nibelungenlied”: Epoche - Werk - Wirkung, Beck, München 1987.

75 Zob.: Joachim Heinzle, The Manuscripts of the "Nibelungenlied", [w:] A Companion to the "Nibelungenlied", s. 105.

${ }^{76}$ Najważniejsze to: Edda poetycka, Volsunga saga, Edda młodsza, Thidreks saga. 
rękopisów i licznych wydaniach eposu, rozpocznie się prawdziwy renesans tematu Nibelungów, to zainspiruje on pisarzy przede wszystkim do tworzenia dzieł dramatycznych. Być może dlatego, że struktura tragicz$\mathrm{na}, \mathrm{z}$ rozpisaniem na dramatis personae, jest $\mathrm{w}$ nim immanentna, a pewnie też dlatego, iż dramatyzacja Nibelungenlied umożliwiała kreację tragedii z rozbudowana, epicką fabułą o straszliwych, pełnych grozy wypadkach, co pozwalało ożywić niemiecką tradycję Trauerspiel ${ }^{77}$.

W szeregu licznych dzieł, które poprzedzają dyptyk Langa, wypada chyba wymienić trylogię dramatyczną Friedricha de la Motte Fouqué Der Held des Nordens (Bohater Pótnocy, 1810), dramat Ludwiga Uhlanda Die Nibelungen (1817), dramat Ernsta Raupacha Der Nibelungenhort (Skarb Nibelungów, 1834), epicką opowieść Emanuela Geibla König Sigurds Brautfahrt (Podróż żony króla Sigurda, 1846) i tegoż autora tragedię Brunhild (1857). Najgłośniejszą i najwybitniejszą z tych dramatyzacji jest trylogia Friedricha Hebbla Die Nibelungen (1855-1860), obejmująca jednoaktową Vorspiel pt. Der gehörnte Siegfried oraz dwie pięcioaktowe tragedie: Siegfrieds Tod i Kriemhilds Rache. Z tej samej mniej więcej epoki pochodzi tetralogia operowa Richarda Wagnera Pierścień Nibelunga (Der Ring des Nibelungen: Ein Bühnenfestspiel für drei Tage und einen Vorabend, 1853-1874), na którą składają się: Złoto Renu (Das Rheingold), Walkiria (Die Walküre), Zygfryd (Siegfried) i Zmierzch bogów (Götterdämmerung). Cykle Hebbla i Wagnera odegrały zasadniczą rolę $w$ recepcji tematu Nibelungów do II wojny światowej, a i do dziś są wystawiane i wydawane w edycjach książkowych (w wypadku Wagnera libretto oper). Po tej kulminacji żaden z utworów (aż do filmu Langa) nie osiągnął porównywalnego rozgłosu ani poziomu artystycznego. Dla porządku wymieńmy jednak tragedię Adolfa von Wilbrandta Kriemhild (1877), dwuczęściowy epos Wilhelma Jordana Nibelunge (1867-1874), tragedie Paula Ernsta Brunhild (1909) i Chriemhild (1918), i olbrzymi rozmiarami epos tego ostatniego autora Das Kaiserbuch (Księga cesarska, 1922-1928) ${ }^{78}$.

Istotne jest pytanie, które z dzieł artystycznych poprzedzających Der Nibelungen-Film było dlań inspiracją. Znając już wcześniej epos, oceniłem, iż dzieło Langa jest po prostu jego adaptacją - i to bardzo twórczą, znakomitą adaptacją. Skłoniła mnie jednak do konfrontacji z dwoma innymi

${ }_{77}$ Nt. Trauerspiel, zob.: Walter Benjamin, The Origin of German Tragic Drama, transl. John Osborne, Verso, London-New York 2003, s. 149-253.

${ }^{78}$ Literackie opracowania tematu Nibelungów przytaczam za: R. Stiller, op. cit., s. 456-467. Nie wymieniam utworów późniejszych niż film Langa, ale rzecz jasna, do dziś powstają dzieła literackie (co ciekawe, już nie dramaty, a głównie epika) eksplorujące legendę Nibelungów. Zainteresowanych odsyłam do arcyciekawego artykułu Wernera Hoffmanna The Reception of the "Nibelungenlied" in the Twentieth Century, [w:] A Companion to the "Nibelungenlied", s. 135-142. 
niż epos ewentualnymi pierwowzorami przytaczana w książce Fredericka W. Otta ta oto wypowiedź Thei von Harbou: „Zaczęłam scenariusz Zygfryda od próby nadania nowej formy temu cudownemu i smutnemu poematowi o miłości Zygfryda i Krymhildy. Było niemożliwością ograniczenie się tylko do jednej wersji tradycji, gdyż ta albo inna mogła akurat zaniedbać być może ciągle żywą wśród odbiorców pamięć o Zygfrydzie pogromcy smoka, Nibelungach czy o królu Etzelu. Z tego powodu nie podążałam w ślad za jedną tradycją. Przeciwnie, postawiłam przed sobą zadanie polegające na tym, by wziąć to, co najpiękniejsze z wszystkich wariantów historii o Zygfrydzie, a jest tego więcej niż ludzie sądzą. Najpiękniejsze motywy zostały wtopione $\mathrm{w}$ jedną cudowną opowieść. Konieczne było zmieścić wszystkie zasadnicze zdarzenia w małej i ograniczonej czasoprzestrzeni, by dostosować się do naszych dzisiejszych odczuć i w żaden sposób nie zepsuć urody całości. W starej heroicznej pieśni odnajdywałam jedno piękno za drugim, a możliwości filmu wydawały się nieograniczone"79.

Paul M. Jensen wskazał na podobieństwa filmu do cyklu dramatycznego Hebbla ${ }^{80}$, gdy jednak sięgnąłem do tekstu niemieckiego dramaturga, inspiracje wydały mi się drugorzędnej natury: owszem, film składa się z dwóch części, jak cykl Hebbla z dwóch tragedii (pomijam Vorspiel), ale zupełnie podobną dwudzielną budowę (mimo braku formalnego podziału) ma epos, z cezurą śmierci Zygfryda i oświadczyn Etzela mniej więcej w połowie tekstu. Owszem, w filmie jedynym królem Burgundów jest Gunter, podobnie jak u Hebbla, ale w eposie młodsi bracia Guntera, Gernot i Giselher, tylko formalnie tytułowani są królami, faktycznie nie mając żadnej władzy. Owszem, na dworze wormackim w filmie i u Hebbla przygody Zygfryda relacjonuje Volker, a nie Hagen, jak w eposie. Być może też za Hebblem bardziej rozbudowana niż w eposie jest postać króla Etzela, ale w sumie film Langa wydaje się znacznie bardziej niż dramat ewokować posępnego, przedchrześcijańskiego ducha eposu i z prawdziwą artystyczną intuicją wydobywać zasadniczy w eposie, do czego jeszcze wrócę, temat mimetycznej przemocy ${ }^{81}$.

$\mathrm{Z}$ całą pewnością film Langa niewiele ma wspólnego $\mathrm{z}$ tetralogią Wagnera. Co najwyżej, wydaje się, iż echa trzeciej z oper - Zygfryda, pobrzmiewają w dwóch pierwszych Gesänge części I (postać kowala Mime, nieobecna w eposie; pewne rysy Alberyka). W sumie jednak porównywanie Nibelungów Langa i libretta Pierścienia Nibelunga, w którym Wagner

${ }^{79}$ Cyt. za: F. W. Ott, op. cit., s. 107.

80 Zob.: P. M. Jensen, op. cit., s. 47-48.

${ }^{81}$ Korzystałem z następującego wydania dramatu: Friedrich Hebbel, Die Nibelungen: Ein deutsches Trauerspiel in drei Abteilungen, Philipp Reclam Jun. GmbH 7 Co., Stuttgart 1995. 
oparł się raczej na źródłach skandynawskich niż na eposie i w dodatku samemu wymyślił dość "prywatną", „idiomatyczną” mitologię, ignorującą symboliczne sensy postaci i powiązania między nimi w źródłach, z których korzystał, wydaje mi się bezzasadne ${ }^{82}$. Tym bardziej, że muzyki Wagnera Lang nie znosił i był zdecydowanie przeciwny zarówno nazistowskiej, jak i amerykańskiej wersji Nibelungów - nie dość, że okrojonym, to jeszcze z muzyką Wagnera zamiast naprawdę znakomicie funkcjonalnej wobec filmowych obrazów partytury Huppertza ${ }^{83}$.

Postanowiłem zaniechać konfrontacji z innymi utworami jako możliwymi podstawami adaptacji Thei von Harbou, tym bardziej, że są to teksty zapomniane i bardzo trudno dziś dostępne. Skoro w dwóch zasadniczych, prócz eposu, „nośnikach” tematu Nibelungów, uprzednich wobec filmu, i też jedynych, które przetrwały próbę czasu, trudno odnaleźć coś, co w sposób zasadniczy inspirowałoby film, uznałem, iż dość mało rzeczowa i egzaltowana wypowiedź scenarzystki nie obliguje do dalszych porównań. Zresztą znakomita recenzja Kurta Pinthusa i fakt przywoływania w innych recenzjach eposu jako punktu odniesienia dla filmu utwierdziły mnie w trafności pierwszego wrażenia, iż podstawą adaptacji jest Das Nibelungenlied.

Zasadniczym jednak rysem funkcjonowania tematu Nibelungów w kulturze niemieckiej do II wojny światowej jest jego anektowanie przez niemiecki nacjonalizm. Wymienione wyżej dzieła - łącznie z najwybitniejszymi, Hebbla i Wagnera - powstawały z jawnie nacjonalistyczną intencją bardziej może nawet niż $\mathrm{w}$ nich samych obecną $\mathrm{w}$ rozmaitych expressis verbis wypowiedziach autorów. Moment, kiedy nastąpił przełom w recepcji Nibelengunlied - początek XIX w.: czasy politycznego rozbicia Niemiec, wojen napoleońskich, kultu średniowiecza, romantycznego poszukiwania narodowej tożsamości $\mathrm{w}$ dawnym piśmiennictwie - wyjątkowo zresztą sprzyjał odbiorowi eposu w kategoriach narodowych. Ponoć wśród młodych Niemców wyruszających na wojnę z Napoleonem zapotrzebowanie na epos było tak wielkie, że wydrukowano specjalne wydanie polowe ${ }^{84}$. A sytuacja powtórzy się w XX w., kiedy epos będzie punktem odniesienia dla nacjonalistycznych polityków zarówno ery wilhelmińskiej, Republiki Weimarskiej, jak i Trzeciej Rzeszy. Tak np. kanclerz Bernhard von Bülow w przemówieniu w Reichstagu 29 marca 1909 podczas kryzysu w Bośni użyje określenia Nibelungentreue (lojalność Nibelungów) na określenie

${ }^{82}$ Korzystałem z następującego wydania libretta tetralogii Wagnera: Wagner's „Ring of the Nibelung": A Companion, The full German text with the acclaimed English translation by Stewart Spencer, Thames \& Hudson, New York 2000.

${ }^{83}$ Nt. niechęci Langa do Wagnera - zob.: P. McGilligan, op. cit., s. 103.

${ }^{84}$ Zob.: R. Stiller, op. cit., s. 446. 
przymierza Niemiec i Austro-Węgier. W 1914 r., gdy wybuchnie I wojna światowa, poseł do Reichstagu, Franz von Liszt, zrówna Hagena z Niemcami i Volkera z Austrią. Profesorowie języka niemieckiego, jak np. Gustav Roethe, gloryfikowali Nibelungentreue jako prawdziwie niemiecką cnotę. Powołane przez Goebbelsa 4 sierpnia 1934 berlińsko-lipskie wydawnictwo, które opublikuje do 1944 dosłownie miliony antyżydowskich i antykomunistycznych diatryb, nazwane zostanie Nibelungen-Verlag. 38. Dywizja Pancerna Grenadierów SS nosiła oficjalną nazwę Nibelungen Division. 30 stycznia 1943 nazistowski marszałek Hermann Göring w przemówieniu do Wehrmachtu porówna bitwę stalingradzką do ostatniego pola walki Nibelungów w pałacu Etzela, gdzie oblężeni bohaterowie zaakceptowali swój los. Ciąg niemieckich fortyfikacji z lat I wojny światowej wzdłuż granic z Francją, Belgia, Luksemburgiem i Holandią Niemcy nazwali „linią Zygfryda”. Niemiecka operacja we Włoszech z 17 stycznia 1945 przeciwko oddziałom brytyjskim i kanadyjskim miała kryptonim „Unternehmen Nibelungen”. Zaś prawdziwie populistycznym sloganem politycznym nacjonalistów w okresie Republiki Weimarskiej był Dolchstoß - "cios w plecy”; tzw. Dolchstoßlegende wyjaśniała porażkę Niemiec w I wojnie światowej zdradzieckim ciosem w plecy, który niemiecka armia otrzymała - tak jak Zygfryd - niespodziewanie, od zdrajców w domu. Na ów "cios w plecy" powołali się - niezależnie od siebie szef niemieckiego Sztabu Generalnego z lat I wojny Erich von Ludendorff, Hitler w Mein Kampf (1925) i prezydent Paul von Hindenburg w swym politycznym testamencie. Z kolei nieudana ofensywa niemiecka na froncie francuskim w lipcu 1918 miała kryptonim „Hagen Offensive" ${ }^{85}$.

W takim kontekście poprzedzająca film Langa dedykacja „Dem Deutschen Volke zu eigen" nie wydaje się, doprawdy, niewinna. Oczywiście, można by obarczyć za nią wyłącznie Theę von Harbou - zwłaszcza w świetle zarówno jej późniejszego politycznego wyboru, jak i nacjonalistycznych inklinacji objawionych już w latach I wojny światowej. Niemniej, przywołana tu wypowiedź sygnowana przez Langa o czerpaniu z "duchowej świątyni narodu" ${ }^{86}$ każe obarczyć za nią także jego. Co prawda, zawartość fabularna samego filmu moim zdaniem zupełnie nie uzasadnia oskarżania go o nacjonalizm - pomimo dedykacji i pomimo jednego napisu, który przekazuje odpowiedź Dytrycha z Bern, gdy Etzel uzależnił odstąpienie od walki na śmierć i życie z Burgundami-Nibelungami od wydania mu Hagena: „Królu Etzelu, nie znasz lojalnej germańskiej duszy".

85 Przykłady politycznych zawłaszczeń Nibelungów podaję za: The Nibelungen Tradition; An Encyclopedia, s. 305-319. W. Hoffmann, op. cit., s. 142-152.

86 Zob. przypis 73. 
Gdy wniknąć w fabułę zarówno Nibelungenlied, jak i filmu, nie bardzo nadaje się ona (a raczej - w ogóle się nie nadaje) na temat bohaterskiego eposu narodowego: jest to historia o zdradzieckiej zbrodni, obłędnej zemście niecofającej się przed brato- i dzieciobójstwem, i obłędnej, wiodącej do samozagłady nie tylko klanu, ale i państwa, lojalności wobec mordercy. Wiedzie to do antynomii w odbiorze, wręcz do jego schizofrenii: jeżeli, zgodnie z pewnym stereotypem, Zygfryd jest niezłomnym, wzorcowym, germańskim herosem, który zdradziecko otrzymał Dolchstoß, to jak jednocześnie można gloryfikować jego mordercę, Hagena, jako uosobienie Treue - lojalności, wierności, wzajemnego oddania pobratymcom? Czyż nie jest schizofrenią używanie przez tę samą armię w tej samej wojnie jednocześnie kryptonimów "Zygfryd” i „Hagen” w dobrej wierze, jako imion swych „patronów"? Jeżeli potępia się Krymhildę za jej zemstę za śmierć uwielbianego przez potępiających i przez potępianą Zygfryda, czyż nie jest to antynomią? Wydaje się, iż zamieszki na premierze Zemsty Krymhildy wywołane przez nacjonalistów, wyniknęły nie tyle z oburzenia reklamową broszurą Ufy, co z uświadomienia sobie antynomii identyfikacji, jaką musi II część filmu i eposu budzić wśród tych, którzy oczekują od Nibelungów klarownego, bohaterskiego etosu. Bo Krymhilda jest zarówno okrutnie skrzywdzoną ofiara, jak i bezwzględną morderczynią. Hagen zaś i Burgundowie stanowią zarówno przykład niezłomnej Treue - lojalności, wierności, braterstwa, jak i „bandę zdradzieckich morderców”. Zapewne aby uniknąć tej schizofrenii, naziści w 1933 wznowili tylko Zygfryda z pompatyczną wagnerowską muzyka, i w dodatku jako Śmierć Zygfryda, chyba po to, by zaakcentować Dolchstoß. Ani Das Nibelungenlied, genialny artystycznie, porównywalny w sile wyrazu z Iliada i tragediami greckimi czy Szekspirowskimi, jeden z największych w światowej literaturze epos, ani naprawdę wielki siłą obrazu i znakomitą transkrypcją na ekran dość strasznych rewelacji eposu Der Nibelungen-Film Langa, nie mogą być obarczane za nieadekwatną recepcję w narodzie, który je wydał. Choć z drugiej strony, czy ta właśnie recepcja nie mówi wiele o przerażającej "duszy” tego narodu? - zwłaszcza w świetle historii, zarówno dawnej, jak i nie tak odległej, niepokojąco do fabuł eposu i filmu analogicznej.

\section{Smocze plemię}

W liście do Lotte Eisner z 3 października 1968 r. Lang całkowicie się odcina od traktowania Nibelungów jako wyrazu ducha niemieckiego Volk, co oczywiście kłóci się z określaniem przezeń (w latach dwudziestych) eposu jako „duchowej świątyni” tegoż Volk - choć przecież nie może dziwić ewolucja poglądów, zwłaszcza po doświadczeniach nazizmu i II wojny 
światowej. W świetle tego listu zrozumiała jest jednak rezygnacja z podtytułu filmu: Ein deutsches Heldenlied - o ile rzeczywiście podtytuł taki Lang planował. Lang pisze do swej przyszłej monografistki: „Jeśli bliżej przyjrzysz się Pieśni o Nibelungach, ujrzysz, iż wcale nie jest to bohaterski epos niemieckiego ludu [so ist es ja kein Heldenlied des Deutschen Volkes]; tym uczynili go prawicowi idioci [Rechts-Idioten] przed i pod Hitlerem; ale ich «najdroższym dobrem» było Mein Kampf... że już nie wspomnę o bohaterze. [...] Jest to «bohaterski» epos rządzącej klasy wyższej. Gdzie tu jakiekolwiek odniesienie do ludu? [Es ist ein «Helden»-Lied der herrschenden Oberschicht! Wo ist vom Volk irgendwo die Rede?]. Widziałem królów burgundzkich w ich wspaniałych szatach jako dekadencką klasę społeczną [decadente Gesellschaftsklasse], już schyłkową i zdecydowaną wszelkimi środkami osiągnąć swe cele. [...] I ci dekadenccy Burgundowie podążają ku zagładzie, gdy tylko zderzają się z nowa, «dziką», wciąż kształtującą się warstwą społeczną [Gesellschaftsschicht]: Hunami. Nie, najdroższa Lotte, nie jest to żaden bohaterski epos niemieckiego ludu. W całej Pieśni o Nibelungach nie ma nigdzie wzmianki o ludzie [Volk]"87.

Lang z celną intuicją odczytuje nieadekwatność zawłaszczania eposu o Nibelungach przez niemiecki nacjonalizm. Trafnie określa Burgundów jako społeczność dekadencka, skazaną na zagładę w zestawieniu z inną społecznością będącą in statu nascendi: dzikimi, dynamicznymi Hunami. Ale dokonuje zarazem pewnego ideologicznego przesunięcia, zaciemniającego prawdę obrazu i czyniącego tę interpretację ponownie nietrafną: z Volk (ludu, narodu) czyni kategorię społeczna, klasowa, nie zaś etniczną (a tak generalnie pojmował ją nacjonalizm), zaś starcie dwóch narodów, dekadenckiego i dopiero tworzącego się - przedstawia jako starcie klasowe. Przerażające antropologiczne rozpoznanie, którego dokonuje epos - i jego własny film - zmienia w fałszywą konstatację z ducha krytyki ideologicznej.

Klucza zarówno do Nibelungenlied, jak i do Nibelungen-Film, dostarcza, jak sądzę, hermeneutyka René Girarda, którego wszystkie w zasadzie prace traktują ciągle - choć za każdym razem równie fascynująco i odsłaniając coraz to nowe aspekty - o jednym: o tzw. mimetycznej przemocy w kulturach i społecznościach przed- i niechrześcijańskich, w każdym razie takich, które nie wpisały w swe mechanizmy regulujące przykazań objawionych przez Jezusa w Ewangeliach. Brak uwewnętrznienia zarówno przez jednostkę, jak i społeczności, tych zasad prowadzi do eskalacji przemocy, wzajemnej wojny wszystkich ze wszystkimi (tzw. kryzys mimetyczny) i do rozwiązania kryzysu poprzez jednoczącą społeczność

${ }^{87}$ Fragmenty listu Fritza Langa do Lotte H. Eisner z 3 X 1968, cyt. za: Fritz Lang. Leben und Werke. Bilder und Dokumente, s. 97-98. 
przemoc wobec innych: jakiegoś narodu, klasy społecznej, grupy czy jednostki, wskazanej jako winowajca i skazanej na bycie kozłem ofiarnym. Te nieodzowne dla uniknięcia kryzysu mimetycznego, dla niedopuszczenia do zapanowania władztwa szatana (Girard absolutnie serio, bez cudzysłowu, traktuje kategorię osobowego, metafizycznego zła), reguły, to: 1) rezygnacja z pożądania tego, co posiadają lub czego pożądają inni, i z dążenia do niepohamowanego zaspokajania swych pragnień: materialnych, seksualnych, związanych ze społecznym statusem; 2) wyrzeczenie się dążenia do górowania czy panowania nad innymi; 3) wyrzeczenie się stosowania przemocy i wszelkiej siły wobec drugich, nawet pozornie uzasadnionej - jak np. w wypadku odpłaty za uczynione zło; 4) rezygnacja z kierowania się wyłącznie więziami partykularnymi - z własnym narodem, klasa, jakąś grupa, rodziną - na rzecz prymatu uniwersalnej więzi miłości z ludzkością i z każdym człowiekiem z osobna: „miłujcie nieprzyjacioły swoje". Girard, analizując przekazy rozmaitych kultur (np. ich mity czy dokumenty historyczne) i wielkie dzieła literackie (Szekspira, Balzaka, Dostojewskiego, Prousta), oraz konfrontując je z przekazami staro- i nowotestamentowymi, ujawnia fundamentalną w historii ludzkości rolę chrześcijaństwa w zdemaskowaniu i częściowym przynajmniej powstrzymaniu mimetycznej przemocy ${ }^{88}$.

Artystyczna siła i działająca katartycznie groza Nibelungów polega właśnie na tym, iż ujawniony przez Girarda i wnikliwie przezeń skomentowany mechanizm leży tu właściwie na wierzchu, wcale niezakamuflowany, jak to często w mitach czy utworach artystycznych bywa, a jego zasadnicze elementy - zapośredniczone przez innych pożądanie, dążenie do górowania nad innymi, reguła "oko za oko" i prymat partykularnej więzi, tak afirmowanej przez niemiecki nacjonalizm Nibelungentreue - odsłaniają się we wszystkich swych zgubnych konsekwencjach.

Uderzające jest podobieństwo Nibelungów do zamieszczonego jako motto fragmentu z Owidiuszowych Przemian, przedstawiającego historię założyciela Teb, Kadmusa. Dotyczy ono dwudzielnej kompozycji eposu i tego fragmentu oraz dwóch podstawowych szczegółów fabularnych: Kadmus, tak jak Zygfryd, zabija smoka i "sam nim się staje”, a "zasiany" przezeń ród wybija się nawzajem w bratobójczej walce. Smok jest oczywiście baśniowym i mitologicznym emblematem zła (w tym sensie

\footnotetext{
${ }^{88}$ Po polsku ukazało sięjuż sporo prac Girarda. Wydaje mi się, że najlepszym wprowadzeniem w jego myśl jest blok materiałów w monograficznym numerze „Literatury na Świecie” 1983, nr 12 (149), a spośród książek: René Girard, Kozioł ofiarny, przeł. Mirosława Goszczyńska, Wydawnictwo Łódzkie, Łódź 1987; René Girard, Widziałem szatana spadajacego z nieba jak błyskawica, przeł. Ewa Burska, Instytut Wydawniczy Pax, Warszawa 2002.
} 
jego zabicie jest czynem "dobrym" i z pewnością heroicznym), ale zarazem w wielu kulturach (np. w Chinach, w Walii) jest on zwierzęciem królewskim, emblematem władzy. Kadmus, jak mu zapowiada Atena, "sam staje się smokiem", tzn. królem, założycielem nowej dynastii. Smok przezeń zabity należał jednak do boga wojny Marsa, toteż tragiczną reguła w dziejach założonej przez Kadmusa dynastii, "smoczego plemienia”, będzie bratobójcza walka (prócz walki "zasianych” rycerzy unaocznia ją szczególnie „wewnątrzrodzinna przemoc” w historii Lajosa i Edypa, Eteoklesa i Polinika, Kreona i Antygony). A przecież, jak sugeruje dalszy ciąg Owidiuszowego poematu o Kadmusie, jedynym sensownym wyjściem jest powstrzymanie przemocy. Oto, co dzieje się w nim od wiersza bezpośrednio następującego po tym, którym zamknąłem pierwsze motto:

Już młodzież obdarzona krótkich dni udziałem,

Usłała krwawą matkę bratobójczym ciałem;

Zostało tylko pięciu, Echion między niemi:

Ten za radą Minerwy złożył broń na ziemi,

Tak pierwszy niosąc dowód miłości braterskiej.

Dał i otrzymał zakład przyjaźni rycerskiej ${ }^{89}$.

Owidiusz, Kadmus (Przemiany, III, 127-132)

Możliwość przetrwania zapewnia tylko rezygnacja z przemocy i „miłość braterska”. Niestety, rada Minerwy nie osiąga uniwersalizmu Jezusowego przesłania: miłość braterska obowiązuje nie jako reguła powszechna, a jako „przyjaźń rycerska” obwarowana gwarancja, zakładem. Zawężona do więzi plemiennej, niczym germańska Treue, stanie się w przyszłości źródłem nieuniknionej antynomii (vide: historia Polinika i Eteoklesa, Antygony i Kreona).

Ale czy analogia z Kadmusem jest trafna, czy Zygfryd „staje się smokiem" i założycielem dynastii? Otóż jego kąpiel w krwi smoka oznacza nie tylko nabycie atrosji, „niezranialności”, ale także właśnie stanie się smokiem - widać to wyraźnie w innych niż epos i film wersjach legendy Nibelungów, kiedy po kąpieli w krwi zabitego potwora skóra Zygfryda rogowacieje, stając się jak skóra smoka odporna i nie do przebicia (to właśnie oznacza tytuł przed-sztuki Hebbla Der gehörnte Siegfried i podobne tytuły wcześniejszych utworów). Po zabiciu smoka, czego nie widzimy, ale o czym dowiadujemy się z pieśni Volkera, Zygfryd podporządkowuje sobie 12 królów, którzy stają się jego wasalami. Zatem królem zostaje nie tylko jako syn króla Zygmunta, ale i jako self-made-king, który zdobył po zabiciu smoka skarb. Zygfryd zostaje zabity w pół roku po ślubie i nie

${ }^{89}$ Owidiusz, op. cit., s. 66. 
ma (w filmie) dzieci; ustanawia jednak, wprawdzie nie „dynastię", lecz „dziedzictwo": dziedzictwo skarbu, którego posiadanie zdaje się zapewniać właścicielowi zagadkowe miano „Nibelungów”, przez niego także zagarnięte od Alberyka. W tym sensie jego dziedzicami, jego „smoczym plemieniem" są Burgundowie, którzy wyginą w bratobójczej walce z ich siostra/rodaczką Krymhildą (wdową po Zygfrydzie), zupełnie jak rycerze posiani przez Kadmusa i wyrośli z zębów smoka.

Ale smok to emblemat nie tylko Zygfryda - widnieje on w herbie obok tronu Guntera i na wrotach, którymi ze zwodzonego mostu wjeżdża się na dziedziniec wormackiego zamku. W dwuznaczny sposób smoka przedstawia figura dziobowa statku, na którym $\mathrm{z}$ Wormacji wyprawiono się po Brunhildę do Islandii; dwuznaczny, bo konfliktowo odnosi się ona do "pogromcy smoka”, skąpanego w jego krwi Zygfryda, i do Guntera, słabego króla imponującego państwa. Co więcej, na kobiercach w siedzibie Etzela, władcy tak potężnego, że oblega Rzym i zwany jest „Panem Świata", również widnieją smoki. Konflikt między nosicielami tego królewskiego emblematu, oznaczającego zarazem przemoc i posiadanie skarbu, wydaje się nieunikniony. Szczególnie to widać w Pieśni II części I, gdy Zygfryd z butą przybywa do Wormacji, otoczony zbrojną drużyna, która w pełnym rynsztunku wkracza na dwór obcego władcy; jest to nie tylko złamanie etykiety, ale też rzucenie wyzwania (w eposie jest wprost powiedziane, że Zygfryd przybył do Wormacji nie tyle prosić o rękę Krymhildy, co podbić i podporządkować sobie państwo Burgundów). Podobny zresztą charakter rzucenia wyzwania przez jednego smoka drugiemu ma wkroczenie uzbrojonych po zęby Burgundów-Nibelungów na bankiet króla Etzela.

Willy Hast dokonuje bardzo interesującej analizy Pieśni o Nibelungach jako poematu o podboju ${ }^{90}$ (stąd też być może taka fascynacja nim tak ekspansywnych w swej historii Niemców). Dokonuje się on zresztą nie tylko w walce (tej w eposie jest znacznie więcej niż w filmie, gdzie wyeliminowano wojny z Sasami i Duńczykami), ale też drogą matrymonialną. Bella gerant alii, tu, felix Austria, nube! - „Inni niech wiodą wojny, a ty, szczęsna Austrio, żeń się!": zasadę tę autor eposu (zresztą film także) ewidentnie ukazuje jako jeszcze jeden wariant ucieleśniającej pożądanie mimetyczne polityki podboju. Są aż cztery takie „polityczne” małżeństwa w eposie i filmie: Zygfryda i Krymhildy, Guntera i Brunhildy, Etzela i Krymhildy, Giselhera i Dytlindy. Zygfryd próbuje dokonać podboju Burgundii przez ślub z Krymhilda, podobnie zresztą później Etzel, starając się o wdowę po Zygfrydzie. Doskonale rozumie to najbardziej dalekowzroczna

90 Willy Hast, From Battlefields to Bedchambers: Conquest in the "Nibelungenlied", [w:] A Companion to the "Nibelungenlied", s. 79-93. 
politycznie z wszystkich postaci filmu - Hagen, sprzeciwiający się wobec Guntera obu małżeństwom Krymhildy. Toteż radzi królowi, by zgodę na ślub z Krymhildą wyraził po udzieleniu mu przez Zygfryda u sł u g i, czyli zadeklarowaniu się jako wasal, co, rzecz jasna, jest dla pogromcy smoka nie do przyjęcia. Zygfryd jednak rezygnuje z jednego pożądania mimetycznego (władzy, podboju), ulegając drugiemu (pragnienie erotyczne po ujrzeniu Krymhildy), zupełnie nie wykazując zmysłu politycznego. Dlatego też Hagen, cyniczny polityk, tak chętnie przybija zgodę między Gunterem a Zygfrydem: czego Zygfryd nie uczynił z powodu ambicji, pychy i swej rzeczywistej siły, uczyni dla libido, a w dodatku publicznie deklarując się wobec przyszłej królowej burgundzkiej jako wasal Guntera, sam zdegraduje status swego związku z Krymhildą. Stworzy to potem konflikt statusu obu królowych, przyspieszając, zapewne i tak przewidywane przez Hagena, usunięcie Zygfryda i zagarnięcie jego skarbu. Tak zatem, wbrew początkowej hybris Zygfryda, podbój dokonał się w drugą stronę i to Burgundowie zagarnęli skarb Nibelungów, a nie król Niderlandów i Nibelungii podporządkował sobie Burgundię z jej wspaniałą stolica, Wormacją.

Dla Brunhildy, gdy utraciła swe przypominające świat Seksmisji, zamieszkałe wyłącznie przez kobiety państwo, a pokonał ją w dodatku w niewytłumaczalny sposób tchórzliwy słabeusz, jedyną kompensatą jest ranga żony suwerena. Stąd tak nerwowo reaguje na to, iż jej szwagierka ma zostać żoną wasala. Gdy Krymhilda istotnie zostaje żoną Zygfryda (co gorsza w tym samym momencie, przy tym samym ołtarzu, co ona żoną Guntera), a Zygfryd w dodatku po pół roku wwozi z pompą do Wormacji bajeczny skarb, zagrożona w swym statusie Brunhilda żąda od męża oddalenia jego szwagra. A jest to niemożliwe, skoro Zygfryd jest suwerennym królem ościennego państwa. Toteż w swej desperacji planuje pognębić szwagierkę jako żonę „wasala”, która powinna w drodze do katedry dać pierwszeństwo jej, władczyni, w dodatku przybranej w regalia królowej Burgundów. Oczywiście, jest to sytuacja dla dumnej Krymhildy, królowej i siostry drugiego króla zarazem, nie do przyjęcia. W słynnej scenie kłótni królowych na stopniach wormackiej katedry elementem równie jednak ważnym jak hybris, poczucie swego statusu i żądza władzy, jest zazdrość erotyczna, pożądanie tego samego obiektu, którego jeśli już nie można posiadać, to lepiej go choćby zniszczyć niż przeżywać gorycz jego przynależności do kogoś innego (pożądanie mimetyczne traktuje „ukochanych" przedmiotowo, w kategoriach posiadania). Brunhilda, kobiecą intuicją rozpoznając w Zygfrydzie jedynego godnego jej mężczyznę (i przeciwnika), nie potrafi zaakceptować jego szczęścia z Krymhildą; upokarzając szwagierkę na schodach katedry, mści się na obojgu. Krymhilda, gdyby bezwarunkowo kochała Zygfryda, bez jakiejś ambiwalencji i zastrzeżeń, 
nie ujawniłaby Brunhildzie skandalicznego naramiennika. Zdradzając zaufanie męża, odreagowywała w ten sposób zazdrość, którą musiało w niej wzbudzić wyręczanie przez Zygfryda Guntera w „złamaniu oporu" Brunhildy, przy okazji publicznie ją upokarzając (z II części filmu wiemy już, że dla smaku zemsty i wyegzekwowania tego, co się jej od innych "należy”, gotowa jest poświęcić wszystko inne - i innych). Czyż zresztą podobnej ambiwalencji wyrazem - podświadomej chęci ukarania Zygfryda - nie jest aż nazbyt gorliwe wskazanie Hagenowi miejsca, na które upadł liść lipy?

$\mathrm{O}$ ile dla Etzela małżeństwo z wdową po Zygfrydzie (właścicielką skarbu Nibelungów) i siostrą panującego władcy Burgundów, ma oczywisty wymiar polityczny podboju à la felix Austria ${ }^{91}$, o tyle Krymhilda szuka w nim po prostu sposobności zemsty, która dla żony najpotężniejszego, być może, ówczesnego władcy, powinna być łatwiejsza niż dla biednej wdowy-rezydentki na dworze brata, w nieustannej bliskości znienawidzonego Hagena. Ten ostatni rozumie zresztą niebezpieczeństwo jej małżeństwa z królem Hunów (podobnie zresztą jak wcześniejszego z Zygfrydem) choćby z tego powodu, iż dla żony lojalność wobec domu męża, także lojalność polityczna, stawała we wczesnym średniowieczu $\mathrm{w}$ konflikcie z lojalnością klanową plemienną czy rodzinną. Oba rodzaje Treue, w wypadku takich dramatów, jak dramat Krymhildy, w sytuacji odrzucenia czy nieuwewnętrznienia powierzchownego jeszcze wówczas chrześcijaństwa, okazywały się nie do pogodzenia.

O ostatnim z czterech związków - zaręczynach Dytlindy i Giselhera wiemy najmniej, poza tym, iż młodzi się pokochali (tak zresztą jak Zygfryd i Krymhilda), a małżeństwo w kategoriach politycznych chętnie widziane jest zarówno przez Burgundów (zawierają przymierze z Rydygierem z Bechlarn, jednym z najpotężniejszych wasali króla Hunów), jak i przez Rydygiera (oddaje córkę przedstawicielowi królewskiego rodu Burgundów). Ale związek ten stworzy w II części eposu i filmu jeden z najtragiczniejszych dylematów skonfliktowanych z sobą partykularnych lojalności: teścia wobec przyszłego zięcia i wasala wobec swego króla i królowej. Rydygier, zmuszony przez bezwzględną Krymhildę i zrozpaczonego Etzela do stanięcia przeciwko narzeczonemu córki i swym świeżo upieczonym sojusznikom, Burgundom-Nibelungom, zabija w niechcianej i bezsensownej walce niedoszłego zięcia ${ }^{92}$, po czym sam ginie. W oblężonej sali bankietowej, zmuszając się do walki wbrew swej woli, powołuje gier).

${ }^{91} \mathrm{Nb}$. państwo Hunów w eposie zajmowało istotnie tereny dzisiejszej Austrii (i Wę-

92 Tak jest w filmie. W eposie z ręki Rydygiera zamiast Giselhera ginie Gernot (Rydygier i Gernot zabijają się nawzajem w morderczej walce). 
się na wynikające po prostu z uprzedniości pierwszeństwo swej przysięgi Krymhildzie wobec przymierza z Burgundami. Rydygier wydaje się jedną z najmoralniejszych postaci eposu, a jego dramat wynika - tak jak np. dramat Jeftego w Księdze Sędziów - z nieopatrznie złożonej przysięgi. Ale jest także oznaką dramatyzmu dylematów społeczeństwa feudalnego, w którym zasady chrześcijaństwa nie były mocno zakorzenione. Warto zwrócić uwagę, iż ślubowanie, do którego zmusza go Krymhilda przed swym przyjęciem oświadczyn Etzela, jest wyrzeczeniem się przez Rydygiera chrześcijaństwa. Rydygier, pragnący ślubować na krzyż (bo ustawił do przysięgi swój miecz jak krzyż), zostaje zmuszony do przysięgi na ostrze miecza. Nie ma chyba wyrazistszego w filmie znaku świadomego odrzucenia chrześcijańskich zasad na rzecz nagiej przemocy - co nie jest dziwne w świecie kultu miecza („mądrość”, jaką zdobył terminujący u kowala Mime Zygfryd, to wykucie miecza tak ostrego, iż przecina na pół piórko i przebija smoka, zaś najcenniejszy dla niego element skarbu Nibelungów to sławetny miecz Balmung; tymże „świętym” mieczem Krymhilda zabija Hagena). Natomiast dwa inne momenty, ukazujące wyraźnie odrzucenie czy też nieuwewnętrznienie chrześcijaństwa, wiążą się z obiema królowymi (zresztą za każdym razem u stóp katedry, gdzie kiedy indziej dochodzi do ich pamiętnej kłótni). Brunhilda ignoruje serdeczne jej powitanie w Wormacji jako królewskiej narzeczonej, odpychając przyszłą teściową i księdza z krzyżem (co, choć znaczące, jest zrozumiałe, jako iż jest to poganka). Krymhilda natomiast przed odjazdem do Etzela odtrąci chcących pożegnać ją bliskich (Utę, Giselhera, Volkera) - i księdza, nawołującego ją do pojednania z rodziną. O obowiązku tym delikatnie jej przypomni jeszcze Rydygier, gdy będą już za murami Wormacji, ale Krymhilda nie obróci się, by przesłać pozdrowienie matce, bratu i bardowi, i zignoruje ich pożegnalne gesty.

Najbardziej może przerażającym aspektem mimetycznej przemocy jest zasada "oko za oko” (czy też ",krew woła o krew”, jak to formułują wobec Rydygiera Hildebrand i Krymhilda). Egzekwowanie „należnej” sprawiedliwości wiedzie Krymhildę do rozpętania dla pomszczenia jej „wdowiej krzywdy" kryzysu mimetycznego na skalę niebywałą wręcz, bo prowadzącą do zagłady dynastii i zapewne państwa. Ale w Krymhildzie świadomość owej „prawnej” słuszności nakłada się na kryzys psychiczny, związany z „nieprzepracowaną" żałobą po śmierci Zygfryda: oznaką niemożności akceptacji rozłąki ze zmarłym - koniecznej dla normalnego funkcjonowania osoby w żałobie - jest przesiadywanie przy marach Zygfryda i w jego krypcie grobowej, pielgrzymka do źródła, gdzie zginął, troskliwe tulenie zawiniątka ze „świętą ziemią" zroszoną krwią męża, a wreszcie nasycenie jej krwią własnoręcznie zabitego Hagena. Być może zresztą ostentacją swej żałoby Krymhilda tłumi poczucie winy z powodu śmierci 
męża: to w końcu jej niedyskrecja dwukrotnie (ujawnienie Brunhildzie naramiennika i znajomości jego sekretu, zdradzenie Hagenowi „czułego miejsca”) ściąga na Zygfryda niebezpieczeństwo. Krymhilda w II części filmu zachowuje się jak zombie, chodząc sztywno, spoglądając gdzieś w dal nie widzącym rozmówcy wzrokiem. Jej przemianę uosabia zastąpienie białej sukni z części I ciemnymi, wdowimi szatami w części II. Krymhilda w swej żałobnej melancholli, która przeradza się w agresję skierowaną nie tylko ku winowajcy zbrodni, ale właściwie ku wszystkim innym napotkanym osobom, przypomina poniekąd Dziewczynę ze Zmęczonej Śmierci, żądająca życia innych osób za życie jej ukochanego. Ale o ile w wypadku bohaterki tamtego filmu była to krótka faza (może dlatego, iż wszystko stało się praktycznie jednego wieczoru), w wypadku Krymhildy jest to długotrwały, przerażająco permanentny stan. Krymhilda zapomina w uporczywym dążeniu do wymierzenia "sprawiedliwości” o więzach krwi - właściwie bez żalu patrzy na śmierć Giselhera i Gernota, rozkaz zaś egzekucji Guntera wydaje ona sama. Najbardziej jednak posępnym jej rysem jest brak macierzyńskiej miłości do syna Etzela, a co gorsza, chyba świadome przyczynienie się do śmierci dziecka poprzez ściągnięcie go na feralny bankiet. Prowokując Hagena do dzieciobójstwa (ten zastanawiająco chętnie, jakby przyspieszając przeznaczenie, podejmuje z nią mroczną grę), osiąga swój cel, jakim jest wciągnięcie do sprawy zemsty króla Etzela.

Etzel, mimo swej złej sławy i dzikiego wyglądu, wydaje się osobą o dość silnym poczuciu moralności. To on, a nie opętana zemstą i rozpamiętująca nieżyjącego Zygfryda matka, przejawia rodzicielską czułość wobec syna, do którego galopuje na łeb, na szyję spod Rzymu. On też zdecydowanie się sprzeciwi jakimkolwiek podstępom wobec burgundzkich gości (co najwyżej godząc się wyzwać na pojedynek Hagena), gdyż prawo gościnności jest dlań święte. Jest to jednak moralność niechrześcijańska, plemienna, w której po doznanej krzywdzie nie przebacza się winowajcy, lecz wymierza straszliwą zemstę. Krymhilda popełnionym przez Hagena, a przez siebie sprowokowanym, dzieciobójstwem osiąga swój cel - i Etzel ma tak jak i ona już tylko jeden cel przed sobą: zabić Hagena, choćby przy okazji miały zginąć setki innych osób. Etzel, jak i Krymhilda, nie potrafi „przepracować” swej żałoby: po śmierci syna patrzy na wszystkich obłąkanym, niewidzącym wzrokiem, nieprzerwanie tuląc jego zwłoki.

Podobnie zasada „oko za oko” rządzi poczynaniami Brunhildy. Królowa Burgundów mści się na Zygfrydzie za odtrącenie, za utratę swego królestwa (Islandii), swego dziewictwa, swej mocy i za swe publiczne poniżenie przez znienawidzoną rywalkę. To Brunhilda jest inicjatorką intrygi zgładzenia Zygfryda, żądając jego śmierci jako kompensaty swych strat i swej niesławy. Ale osiągnąwszy cel - śmierć Zygfryda - Brunhilda przegrywa. Zniszczywszy obiekt swej jedynej miłości, nie widzi dłużej sensu 
życia. Nie potrafiąc - tak jak później Krymhilda, jak Etzel - wykonać koniecznej Trauerarbeit, popada $\mathrm{w}$ depresję i popełnia przy marach Zygfryda samobójstwo. Zresztą jego powodem może być też poczucie winy. Smierć Brunhildy to inwencja scenariusza filmu ${ }^{93}$, moim zdaniem bardzo udana i logiczna: jej wspólne odejście ze świata z Zygfrydem oznacza definitywne odejście świata mitu, legendy, cudowności ${ }^{94}$, ale zarazem też nieuchronną klęskę pogańskiego etosu, który destrukcyjne mimetyczne pożądanie i mimetyczną przemoc uwznioślił jako heroizm, siłę i wzniosłość. Po śmierci obojga w II części filmu nie będzie już nas uwodzić „feeryczna”, ,magiczna” aura nordyckich legend: mit ustąpi miejsca historii, a naga przemoc, wyzbyta mitologicznych upiększeń, ukaże się w całej swej ohydzie i potworności.

Eskalacja wzajemności w Nibelungenlied dotyczy nie tylko zemsty, ale też graniczącego z szaleństwem i przypominającego sławetny indiański potlatch rozdawnictwa darów. Epos obfituje w opisy rozmaitych podarunków, ich nieprawdopodobnej liczby i jakości, gdy na dwór przybywali goście, gdy obdarowywano kogoś przy wyjeździe, albo gdy przybywało się w gościnę na jakiś obcy dwór. To rozdawnictwo nie jest bynajmniej wyrazem hojności czy szlachetności bohaterów eposu, lecz znakiem ich pozycji, nieodzownym atrybutem ich formy jako potężnych władców, którzy nie tylko nie są niczyimi wasalami, ale są na tyle możni, by szczodrze innym ze swego udzielać. Rozdawnictwo darów jest oznaką s u w e renności politycznej postaci i jako takie jest przejawem rywaliza cj i sy mbolicznej: jedynie symbolicznej, bo tak naprawdę wszyscy pożądają bogactw, a zwłaszcza sławetnego skarbu Nibelungów.

Film w znacznej mierze wyeliminował te, dla nas być może trochę trudne do pojęcia, sceny hojności. Ale ich echa w filmie pozostały. Krymhilda wręcza Volkerowi w podzięce za jego pieśń własnoręcznie przez siebie wyszyty, kosztowny płaszcz. Tabor wwozi do Wormacji skarb Nibelungów, z którego podczas jego rozładowywania Zygfryd hojnie rozdaje zgromadzonej na dziedzińcu gawiedzi. Hagen radzi Gunterowi nie wzbraniać się przed przyjęciem skarbu, bo Burgundia jest w potrzebie, a Krymhilda warta jest każdej ceny; nie znając tej eskalacji szczodrości z eposu, nie bardzo można zrozumieć opory Guntera - jednak w kontekście znajomości jej sensu obawy króla są zrozumiałe: Zygfryd wcale nie jest hojny, ale stosuje wobec Burgundów świadczącą o jego suwerenności

${ }^{93} \mathrm{~W}$ eposie Brunhilda nadal żyje na dworze burgundzkim jako żona Guntera, ale padają o niej nieliczne wzmianki. $Z$ aktywnej roli $w$ fabule zupełnie wypada, jakby znikając w mrokach historii. W pewnym sensie scenariusz filmu wybrał logiczniejsze, bardziej umotywowane symbolicznie i psychologicznie rozwiązanie.

94 Por.: T. Gunning, op. cit., s. 45. 
nad nimi przemoc symboliczną. Krymhilda, już jako wdowa, rozdaje także szczodrze na wormackim dziedzińcu z mężowskiego skarbu, co ma wymiar nie tylko hojności, ale i zjednywania stronników dla planów swej zemsty. Wreszcie olśniony Krymhildą Etzel ofiarowuje Rydygierowi dowolne królestwo ze swych ziem za udane spełnienie misji.

Ale niech nas szczodrość nie zwiedzie: pożądanie materialne (obok pragnienia erotycznego i żądzy władzy) jest jednym z punktów wyjściowych dla przemocy mimetycznej - i kto wie, czy nie najważniejszym. Klątwa Alberyka rzucona na posiadaczy skarbu Nibelungów alegorycznie wyraża rozpętanie przez pożądanie bogactw eskalacji przemocy. Gunter wprawdzie wzbrania się przed przyjęciem do Wormacji skarbu, ale Hagen ignoruje symboliczny wymiar uzurpacji Zygfryda, mając świadomość, że dzięki temu napływowi bogactwa na jego dwór realna będzie władza Guntera, Zygfryda zaś da się usunąć. Nie można jednak dopuszczać do trwonienia skarbu - toteż z okna nad dziedzińcem Gunter, Hagen i Brunhilda chmurnie obserwują szczodrość Zygfryda dla tłumu, rozmawiając jednocześnie o konieczności o d d a le n i a męża Krymhildy. Czy aby tak nie została po raz pierwszy, acz eufemistycznie, sformułowana konieczność jego u sun ię cia? Tom Gunning zwraca uwagę na kadr, w którym ciemne sylwetki Hagena, Guntera i Brunhildy na tle białej plamy półkolistego okna tworzą w tej scenie kształt czaszki ${ }^{95}$ : ten scenograficznie trochę zakamuflowany, ale jednak trafiający do podświadomości emblemat śmierci jest oznaką że to właśnie podczas obserwacji rozładowywania skarbu, a nie dopiero po kłótni królowych na schodach katedry zawiązał się triumwirat na zgubę Zygfryda. Gunning jednak nie zauważa w tym kadrze innych równie znaczących elementów: na lewo od okna i spiskowców znajduje się tron Guntera i herb ze smokiem, zaś na prawo - ptak drapieżny (co prawda nie orzeł, ale zapewne "grający" go myszołów). A pamiętajmy, że w domyślnej przestrzeni pozakadrowej, na dziedzińcu, na który z góry patrzą spiskowcy, znajduje się rozdający kosztowności ze skarbu Zygfryd. Zatem obecność burgundzkiego smoka i ptaka drapieżnego n a d Z y g f r y d e m to może nie ostentacyjny, ale trafiający do nieświadomości sygnał spełnienia się wkrótce feralnego snu Krymhildy.

Hagen postanawia zatopić w Renie skarb Nibelungów - schedę Krymhildy po Zygfrydzie - widząc, po pierwsze, jak trwoni ona majątek, po drugie, jak obraca go na zjednywanie stronników nie tylko przeciwko niemu samemu, ale w jego pojęciu także przeciwko dynastii burgundzkiej. Krymhilda zresztą natychmiast opuszcza Rydygiera, gdy tylko paź daje jej znać o zawłaszczeniu skarbu przez Hagena. W finale okazuje się, iż jego odzyskanie było równie silnym motywem jej destrukcyjnej akcji, co

95 Ibidem, s. 46. 
zemsta - na tyle silnym, że dla uzyskania informacji o miejscu jego ukrycia nie waha się natychmiast oddać katu własnego brata! (inna sprawa, że chyba doskonale zdawała sobie sprawę z roli Guntera w spisku przeciw Zygfrydowi). Chciwość jest też motorem podstępnych i krwawych wyczynów Hunów - to dla obiecanego przez Krymhildę złota zakradają się nocą do siedziby burgundzkich gości, skąd jednak odstraszyli ich Hagen z Volkerem, a w feralny dzień letniego przesilenia Słońca inicjują podczas niby to wesołej zabawy rzeź burgundzkiej czeladzi.

Wywołujące kryzys mimetycznej przemocy pożądania - pożądanie erotyczne, pożądanie dóbr, żądzę władzy, oraz lojalności plemienne, partykularne, nieuchronnie $\mathrm{z}$ sobą skonfliktowane $\mathrm{z}$ racji skierowania swych dążeń i żądz ku tym samym obiektom - wszystkie te Girardowskie kategorie odnajdujemy w mrocznym świecie Nibelungów. Elementem, który wydaje się mniej oczywisty, nieco zakamuflowany, jest kozioł ofiarny. Ale i on niewątpliwie jest obecny - jest nim Zygfryd. Ten superheros ma wszystkie atrybuty predestynujące go, niczym opisanego przez Jamesa George’a Frazera w Złotej gałęzi „świętego króla”96, na bycie ofiarą: wyróżnia się siłą urodą i męskościa, ale jednocześnie jest obcy i monstrualny ${ }^{97}$ (bo czymś monstrualnym jest - atrybut wprawdzie w filmie niewymieniony - jego zrogowaciała smocza skóra, będąca źródłem atrosji). Zresztą owa „niezranialność” jest dwuznaczna jako niecałkowita - umiejscowienie tego jednego jedynego punktu, którego nie obmyła krew smoka, objęte jest wprawdzie tajemnica, ale wszyscy o nim wiedzą i aż się on prosi, by weń wymierzyć... Krymhilda, w jakiejś tajemniczej i dwuznacznej współpracy z Hagenem w wypełnianiu przeznaczenia wyda mu sekret Zygfryda wyjątkowo łatwo (podobnie zresztą jak wystawi mu dziecko podczas feralnego bankietu), a Hagen „zrewanżuje się" jej sprowokowaniem egzekucji Guntera, którego przez cały czas oblężenia sali bankietowej tak pieczołowicie chronił! Zygfryda zresztą predestynowało do roli kozła ofiarnego faktyczne łamanie przezeń burgundzkich reguł gry - jego butne zjawienie się na dworze, jego niedyskrecja, jego nierozważna zgoda na „,złamanie oporu” Brunhildy (czy nie była to czasem prowokacja Hagena?), jego obnoszenie się z bogactwem. Gdy skompromitowana publicznie przez szwagierkę i pełna urazy Brunhilda woła do Guntera i Hagena: „Śmierć Zygfrydowi!”, wypowiada głośno to, co Hagen - wormacki mistrz ceremonii i spiritus movens burgundzkiej polityki - wcześniej zapewne zaplanował.

96 James George Frazer, Złota gałaź, przeł. Henryk Krzeczkowski, Państwowy Instytut Wydawniczy, Warszawa 1978, s. 27-37.

97 Atrybuty „kozła ofiarnego” wskazuje, za Mirceą Eliadem, Girard (zob.: Kozioł ofiar$n y$, s. 48-60). 
Niepokojącym faktem jest także to, iż feralna uczta Etzela dla uczczenia jego szwagrów ma miejsce w dzień czerwcowego przesilenia Słońca (czyli letniego solstycjum) - nadaje to rzezi Burgundów-Nibelungów charakter solarnej ofiary składanej przez Hunów, lud o pochodzeniu wschodnim; a właśnie gdzieniegdzie w tradycji Wschodu figura smoka (emblemat zarówno Hunów, jak i ich nieszczęsnych gości) związana była z solstycjami ${ }^{98}$.

Doprawdy, trudno pojąć, jak porażający sugestywnym odsłonięciem rozpętanej mimetycznej przemocy epos i jego genialna filmowa adaptacja mogły uchodzić dla Niemców za dzieła ewokujące bohaterski etos i ożywiające narodowego ducha!

\section{Cztery światy i ornament z mas}

W wypowiedzi wygłoszonej w roku 1966 na Uniwersytecie Yale Lang określił powody ewidentnego dla widza zróżnicowania stylistycznego Nibelungów: film ten opisuje cztery różne światy, całkiem do siebie niepodobne i niewspółmierne ze soba, a każdy z nich przedstawiony jest w odmiennym kluczu scenografii i stylu zdjęć. „Interesowało mnie, by ożywić germańską sagę w sposób odmienny od Wagnerowskiej opery, bez bród i tym podobnych rzeczy. Próbowałem pokazać w Nibelungach cztery różne światy: pierwotny las, gdzie żyje kaleki Mime, od którego Zygfryd uczy się wykuwać miecz, gdzie jest smok i tajemnicza podziemna dziedzina Alberyka, pokracznego, karłowatego strażnika skarbu Nibelungów, na który rzuca on klątwę, gdy zabija go Zygfryd. Po drugie, otoczony płomieniami zamek islandzkiej królowej Amazonek, Brunhildy. Po trzecie, wystylizowany, nieco zdegenerowany, przerafinowany świat królów Burgundii, właściwie tuż przed jego dezintegracją. I na koniec świat dzikich azjatyckich hord Hunów, oraz jego zderzenie ze światem Burgundów, którzy po zagarnięciu skarbu zmienili miano na Nibelungów" 99 .

Pierwszy ze światów, ewidentnie fantastyczny, należący do dziedziny mitu, jest zasadniczo niedookreślony. Jego atrybutami są olbrzymie pnie i wykroty monstrualnych niczym sekwoje drzew "pierwotnego lasu", mgła spowijająca krajobraz, w którym Alberyk zaczaja się na Zygfryda, miękkość konturu. Dominuje coś, co Niemcy nazywają Stimmung - nastrój, aura, atmosfera. Lang w dwóch pierwszych Gesänge części I odwołuje się

98 Zob. hasło „dragon”, [w:] Jean Chevalier, Alain Gheerbrant, A Dictionary of Symbols, transl. John Buchanan-Brown, Penguin Books, London 1996, s. 309.

99 Wypowiedź Fritza Langa w Yale University w 1966; cyt. za: L. H. Eisner, Fritz Lang, s. 76. 
do tradycji postromantycznego malarstwa niemieckiego, np. stylizując kadry pokazujące Zygfryda na białym koniu na znany obraz Arnolda Böcklina Das Schweigen im Walde (Milczenie w lesie, 1885) ${ }^{100}$ albo ogólny plan spowitych mgłą wież wormackiego zamku w opowieści „leśnego człowieka" na obraz Wenzla Hablika Aussichtstürme (Wieże, 1916) ${ }^{101}$.

Równie nastrojowa - ze względu na fakt, iż podobnie jak „pierwotny las", to także kraina mitu, a nie historii - jest Islandia, drugi z wymienionych przez Langa światów. Fantastyczną aurę określają płomienie ognistego morza na płaskowyżu wiodącym do zamku Brunhildy oraz rozświetlająca nieboskłon zorza polarna. Ale w odróżnieniu od lasu i od „Nibelungii" Alberyka nie jest to świat statyczny, pełen ciszy i melancholii. „Amazonki”, czy raczej „walkirie” Brunhildy, są niesłychanie dynamiczne - przed wielkim pojedynkiem swej królowej z burgundzkim konkurentem do jej ręki, biegaja, skacza, miotają się w tę i we w tę ogromnie podekscytowane. Podczas zaś samego pojedynku otaczają arenę zmagań Brunhildy i Guntera niczym rozentuzjazmowani kibice na stadionie. Islandia jawi się w wizji Langa jako pierwotne społeczeństwo matriarchalne, dzikie, wojownicze, okrutne. Oczywiste - ze względu na lokalizację geograficzną i skrzydlaty hełm Brunhildy - są konotacje "walkirii” z Wikingami. W konfrontacji z "męską” siłą kontynentalnej i sformalizowanej kultury Burgundów czar Islandii pryska: ogniste morze wygasa wokół niedostępnego dotąd zamku Brunhildy, a ona sama, pokonana, traci swe państwo, w którym rządziła niepodzielnie, stając się po prostu żoną obcego króla.

Dominującym światem w I części filmu jest jednak dekadencki dwór Burgundów. To właśnie wizja Wormacji w Zygfrydzie przyczyniła się do sformułowania przez Siegfrieda Kracauera w książce Od Caligariego do Hitlera krytycznej oceny Langa jako twórcy aranżującego przestrzeń filmu przede wszystkim na sposób architektoniczny i wkomponowującego w nią ludzi na zasadzie jedynie sztafażu czy ornamentu. Oczywiście, takie traktowanie postaci człowieka równa się depersonalizacji i uprzed-

100 Obraz ten przedstawia nimfę na jednorożcu. Zob.: Katalog wystawy Fritz Lang: Filmbilder, Vorbilder, Red. Heide Schönemann, Hentrich Verlag, Berlin 1992, Tafel 16; Lotte H. Eisner, The Haunted Screen: Expressionism in the German Cinema and the Influence of Max Reinhardt, University of California Press, Berkeley-Los Angeles 1973, s. 154, 158 (polskie wydanie książki L. Eisner Ekran demoniczny nie zawiera tego zestawienia obrazu Böcklina z kadrami filmu i w ogóle w porównaniu z angielską edycją cechuje je niesłychane ubóstwo ilustracji).

101 Zob.: Fritz Lang: Filmbilder, Vorbilder, Tafel 6. Mimo że ujęcie stylizowane na obraz Hablika przedstawia zamek w Wormacji - a więc świat Burgundów - to zupełnie stylistycznie odbiega od tego "trzeciego świata”, zbliżając się stylem do romantycznego sztafażu świata mitu. Zresztą zawarte jest w „mitologicznej” Pieśni I. 
miotowieniu, tym bardziej, że chodzi o kompozycję z mas czy grup ludzkich, tworzących fascynujące plastycznie, abstrakcyjne układy filmowane w planach ogólnych. Kracauer tak opisywał analogię między filmem Langa a nazistowskimi spektaklami o podobnej koncepcji scenografii i choreografii: „Jest to całkowity triumf ornamentu nad człowiekiem. Absolutna władza podkreśla swoją potęgę, tworząc ze swych poddanych efektowne ornamenty. Zjawisko to występuje również $\mathrm{w}$ reżimie hitlerowskim, który przy organizowaniu mas zdradzał duże inklinacje do dekoracyjnej oprawy. Kiedy Hitler przemawiał do ludu, dominował on nie tyle nad setkami tysięcy słuchaczy, ile nad olbrzymią dekoracją składającą się z setek tysięcy cząsteczek. Triumf woli, film nakręcony przez oficjalne czynniki hitlerowskie podczas kongresu Partii w Norymberdze w roku 1934 jest dowodem, że dekoratorzy hitlerowscy czerpali natchnienie z Nibelungów. Teatralni trębacza Zygfryda, efektowne schody, wzory autokratycznych władców występują w tym współczesnym norymberskim widowisku w znacznym powiększeniu" ${ }^{\prime 102}$.

Stanowisko Kracauera - a przecież to niesłychanie wpływowy autor, który swoimi sądami na lata całe zaważył na recepcji kina niemieckiego - jest tu dość niejasne: czy film Langa był inspiracją dla nazistowskich ceremonii (wydaje się, że istotnie miało to miejsce, ale za to twórca nie może być odpowiedzialny), czy sam jest wyrazem „tendencji totalitarnej"? W kontekście negatywnej oceny Metropolis - zresztą dużo bardziej zasadnej - zawartej w tej samej książce, wydaje się, iż sąd Kracauera jest raczej oskarżeniem o to drugie niż neutralną konstatacją pierwszego. Oskarżenie takie jest poważne, ale, jak sądzę, nie znajduje ono potwierdzenia w samym filmie, choć wydaje się, że potwierdzają je inne okoliczności: wpisywanie Nibelungów, także przez niefortunną wypowiedź samego Langa o "duchowej świątyni narodu”, w tradycję niemieckiego nacjonalizmu, czy np. fakt, iż jako pozytywny wzór dla kina nazistowskich Niemiec Goebbels na spotkaniu z pracownikami kinematografii 28 marca 1933 w Hotelu Kaiserhof wymienił, obok trzech innych filmów, właśnie Nibelungi ${ }^{103}$.

Sądzę, iż estetyka "ornamentu z mas” (tak ją umownie nazwijmy, nawiązując do znanego felietonu Kracauera z „Frankfurter Zeitung”104) w sposobie przedstawienia świata Burgundów, nie tylko nie jest wyrazem

102 S. Kracauer, op. cit., s. 84.

103 Zob. np.: P. McGilligan, op. cit., s. 172.

${ }^{104}$ S. Kracauer, Der Ornament der Masse, „Frankfurter Zeitung”, 9-10 Juni 1927; w wyd. książkowym: S. Kracauer, The Mass Ornament: Weimar Essays, transl. and ed. Thomas Y. Levin, Harvard University Press, Cambridge (Mass.)-London 1995, s. 74-86. Felieton ten analizuje zjawisko „ornamentu z mas” we współczesnej kulturze masowej na przykładzie choreografii żeńskiego zespołu Tiller Girls. 
„tendencji totalitarnej”, ale stanowi wręcz jej demaskację. Dekoracje i choreografia ludzi na wormackim dworze unaoczniają predylekcję kultury pełnej mimetycznej przemocy do monumentalizmu, sztywności form, wpisywania postaci w architekturę; a wszystko to jest wyrazem uprzedmiotowiającego stosunku do drugiego człowieka i instrumentalnego traktowania go. Zwróćmy uwagę, że Lang określa świat Burgundów jako „zdegenerowany", „przerafinowany", gdzie indziej (w liście do Lotte Eisner z 1968) jako „dekadencki”. Uprzedmiotowienie człowieka w filmowej Wormacji nie jest przykładem do naśladowania dla kogokolwiek, ale unaocznieniem potworności reifikacji poprzez przemoc symboliczną. Najbardziej wyraziste jej przykłady opisuje Lotte Eisner: „Postacie nierzadko stają się częścią wystroju; np. rząd wojowników stojących jak kolumny na pierwszym planie, odwróconych plecami do kamery, identycznie ubranych $\mathrm{w}$ kostium $\mathrm{z}$ geometrycznym ornamentem i wszyscy w jednakowej postawie, z jedną ręką na głowicy miecza, drugą trzymającą tarczę; a za tą palisadą z ciał procesja królów i rycerzy powoli zdąża do katedry. Lang używa tu wojowników, by ukazać potęgę Burgundów w stanie czystym”105. „Podobnie, gdy Brunhilda wysiada ze statku, podwójny szereg wojowników z opuszczonymi maskami hełmów trzyma w górze tarcze, tak iż tworzą coś w rodzaju mostu pontonowego. Ich hełmy i ramiona zdają się wyrastać z wody jak ozdobne przęsła. Na brzegu inni statyści, także nieruchomi, z ciemnymi konturami sylwetek pod światło (Lang wyjaśnia, iż usytuowani byli przed pomalowaną na niebiesko ścianą) tworzą szpaler. I znowu, w Zemście Krymhildy, gdy Krymhilda żegna grób męża przed odjazdem do kraju Hunów, otaczają ją jej służebne. Twarze i figury znikają pod ciężkimi fałdami ich szat i narzutek na głowę. Pochylone głowy i ramiona wydają się, niczym płaskorzeźba, częścią krypty, odpersonalizowane zamianą w dekoracyjne motywy, mozaikowe ornamenty absydy. Ludzcy statyści wydają się pozbawieni twarzy w tym wystylizowanym świecie herosów, ponieważ stanowią rodzaj chóru, bez żadnej istotnej funkcji w rozwoju akcji"106.

Ale wtopione $\mathrm{w}$ architekturę czy ukazane niczym posągi jawią się także główne postacie - np. Hagen, w zadumanej pozie czekający na Krymhildę przed jej komnata, by wydobyć od niej tajemnicę „liścia lipy”, prezentuje się $\mathrm{w}$ swym skrzydlatym hełmie, $\mathrm{z}$ mieczem na kolanach niczym monumentalna figura jakiegoś nordyckiego bóstwa. Z kolei gdy Hagen i Krymhilda stoją gniewnie naprzeciw siebie przy wejściu do ogołoconego skarbca, wydaje się, że ewokują sławne słowa Heinego: „Nie ma bardziej strzelistej wieży, nie ma twardszego kamienia niż okrutny Hagen

105 L. H. Eisner, Fritz Lang, s. 70.

106 Ibidem, s. 73. 
i mściwa Krymhilda"107. A podczas kłótni królowych na stopniach katedry one same i ich orszaki jawią się jak figury szachowe: białe (orszak Krymhildy) i czarne (orszak Brunhildy).

Jednym z najciekawszych przejawów "ornamentalizacji” postaci ludzkich na dworze burgundzkim jest przyozdobienie strojów ludzkich, tarcz, pewnych obiektów (np. statku Guntera, szkatułki Krymhildy) i architektury wnętrz (belkowań, framug) w rozmaite desenie geometryczne - jakieś romby, zygzaki, linie łamane, kąty ostre. Rzecz jasna, wtapia to postaci w dekoracje o podobnym ornamencie (szczególnie Krymhildę w wystrój jej komnat), a jednocześnie wprowadza zaskakującą ekspresywność, rodem zupełnie nie z epoki, którą ewokuje fabuła. Lotte Eisner nie wiąże jednak tego abstrakcyjnego design z ekspresjonizmem - w Nibelungach te formy są znacznie sztywniejsze, bardziej regularne, niż ekstatyczne deformacje i rozmaite dziwne kąty, jak np. w filmach Roberta Wiene (Gabinet doktora Caligari, Raskolnikow). Zdaje się, iż głównym źródłem inspiracji dla tej geometrycznej ornamentalizacji kostiumów i elementów scenografii były prace Carla Ottona Czeschki: projekt kostiumów do Wagnerowskiej opery Tristan i Izolda z 1908 r., pokrytych właśnie takimi abstrakcyjnymi geometrycznymi wzorami, oraz znakomite ilustracje do książki Die Nibelungen z roku $1909^{108}$.

Ta geometryczność w połączeniu z długością i statycznością ujęć, często $\mathrm{w}$ bardzo ogólnych planach, i hieratycznością ruchów postaci, rodzi w widzu wrażenie martwoty świata Wormacji, jego dekadencji i wymyślności. Były też zresztą przyczyną ataków wielu recenzentów na zasadniczą „niefilmowość" Zygfryda.

Druga część Nibelungów jest tak kompletnie inna stylistycznie niż pierwsza właśnie dlatego, iż jej akcja dzieje się głównie w państwie Hunów - geometrię, martwy ład Wormacji po pierwszych dwóch Gesänge Zemsty Krymhildy zastępuje dynamizm, żywioł, chaos Hunów. Są oni w nieustannym ruchu, galopują po stepie, zeskakują z drzew, które wypatrując Krymhildy obwieszają jak gruszki, skaczą z murów i swych „pieczar" z bardzo dużej wysokości albo się tam wspinają ze zwinnością małp (swoją droga, wydaje się, że statyści ryzykują nieraz tam życiem), pełzają niczym gady, skradają się, łapczywie rzucają się do jadła albo do... zabijania, nieustannie tańcza, podskakuja, przyśpiewują. Są nieobliczalni i - z wyjątkiem niewątpliwie przestrzegającego pewnego moralnego kodeksu Etzela - fałszywi, w zenicie hucznej zabawy rzucając się z nożem na swych gości. Aż dziwne, iż wasalami ich dzikiego imperium są

107 Heinrich Heine, Die romantische Schule, cyt. za: Lotte H. Eisner, Ekran demoniczny, przeł. Konrad Eberhardt, Wydawnictwa Artystyczne i Filmowe, Warszawa 1974, s. 109.

${ }_{108}$ Zob.: Fritz Lang: Filmbilder, Vorbilder, Tafeln 7, 10, 12-14. 
tak rycerskie, monumentalne postacie, jak Dytrych z Bern, Rydygier czy Hildebrand.

Bardzo szczególna jest architektura Etzelnburga, ich stolicy: przypominający trochę budowle chińskie pałac Etzela ma dach kryty strzechą niczym jakaś chata, co zresztą powoduje tak błyskawiczne rozprzestrzenienie się pożaru. Ale prowadzące doń schody i łukowate wrota wydają się echem wejścia do wormackiej katedry. W sali biesiadnej Etzela, gdy po raz pierwszy przyjmuje Krymhildę, nie ma posadzki, tylko klepisko pokryte takimi kałużami, że zawstydzony król ścieli przed swą narzeczoną zakrywający błoto płaszcz. Choć z drugiej strony, ściany pokrywają kunsztowne kobierce, m.in. z emblematami smoka. Większość Hunów wydaje się mieszkać w jakichś lepiankach albo w pieczarach, rozmieszczonych jedna nad drugą w ni to skałach, ni to ciastowatych budowlach, z labiryntami schodów i tuneli. Hunowie przypominają skrzyżowanie stereotypowego wyobrażenia „azjatyckich hord” z ludźmi jaskiniowymi, raczej słusznie wzbudzając zastrzeżenia krytyków co do adekwatności historycznej ich filmowego obrazu, mimo iż konsultantem Langa, jeśli chodzi o odtworzenie ich świata, był Heinrich Umlauff, kustosz Muzeum Etnograficznego w Hamburgu. Zaopatrzył on Hunów Langa w broń rodem z Azji i Afryki, i pozostawił właściwie półnagimi, przyodziewając w jakieś skąpe skóry i szmaty ${ }^{109}$.

O ile I część Nibelungów może, mimo swej niewątpliwej atrakcyjności, zmęczyć niewyrobionego odbiorcę swą statycznością, drugiej grozi to $\mathrm{z}$ racji swej zbytniej dynamiki i trudności percepcyjnego nadążania odbiorcy za akcją - zwłaszcza od Pieśni III. Toteż Lang postarał się o chwile - nieliczne - percepcyjnego wytchnienia: np. gdy uszczęśliwiony Etzel tuli swego nowo narodzonego potomka albo gdy przenosimy się na dwór Rydygiera w scenie zaręczyn Dytlindy z Giselherem. Najbardziej jednak zaskakujący z tych lirycznych momentów ma miejsce, kiedy pędzący na czele z Etzelem spod Rzymu ku Etzelnburgowi i Krymhildzie Hunowie napotykają w gołym stepie drzewko, wokół którego tańczy gromadka nagich dzieci w wiankach na głowie. Konfrontacja kadrów z filmu z grafiką Hansa Thomy (Frühlingsreigen, 1875) ${ }^{110}$ pozwala odczytać ten zaskakujący przerywnik jako obraz jakiegoś pogańskiego święta wiosny, ale w trakcie normalnego odbioru sens ten wydaje się niejasny, a sama scena budzi mieszane uczucia swymi konotacjami niewinności i perwersyjności zarazem.

Czwarty ze światów Nibelungów przynosi trzeciemu - sformalizowanemu, wyrafinowanemu światu burgundzkiej dynastii - definitywną zagładę. Kultura Zachodu ginie $\mathrm{w}$ dniu letniego przesilenia

109 Zob.: Lotte H. Eisner, Fritz Lang, s. 79.

110 Zob.: Fritz Lang: Filmbilder, Vorbilder, Tafeln 17-18. 
Słońca w apokaliptycznym zmaganiu z barbarzyńskimi hordami z Azji. Pesymistyczny i potężny wizualnie finał dyptyku Langa koresponduje $\mathrm{z}$ powszechnym $\mathrm{w}$ Europie lat dwudziestych nastrojem katastrofizmu - o czym świadczy choćby popularność w ówczesnych Niemczech Zmierzchu Zachodu Spenglera i podobieństwo filmowych Hunów (w ich miksturze dzikości, okrucieństwa, dyplomacji i etykiety) do zalewających Polskę Chińczyków w finale Witkacowskiego Nienasycenia (1927). 


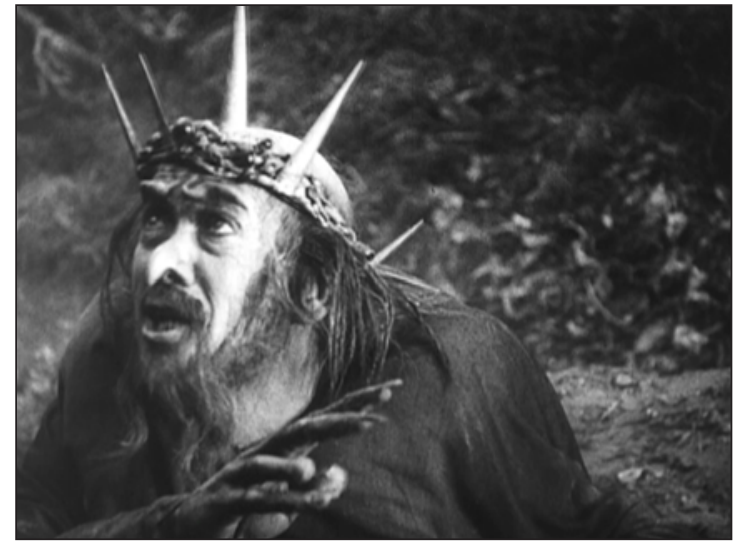

1. Nibelungi (1924, reż. Fritz Lang). Pokonany przez Zygfryda Alberyk - żydowskie konotacje strażnika skarbu Nibelungów

2. Nibelungi (1924, reż. Fritz Lang). Petryfikacja karłów dźwigających skarb Nibelungów
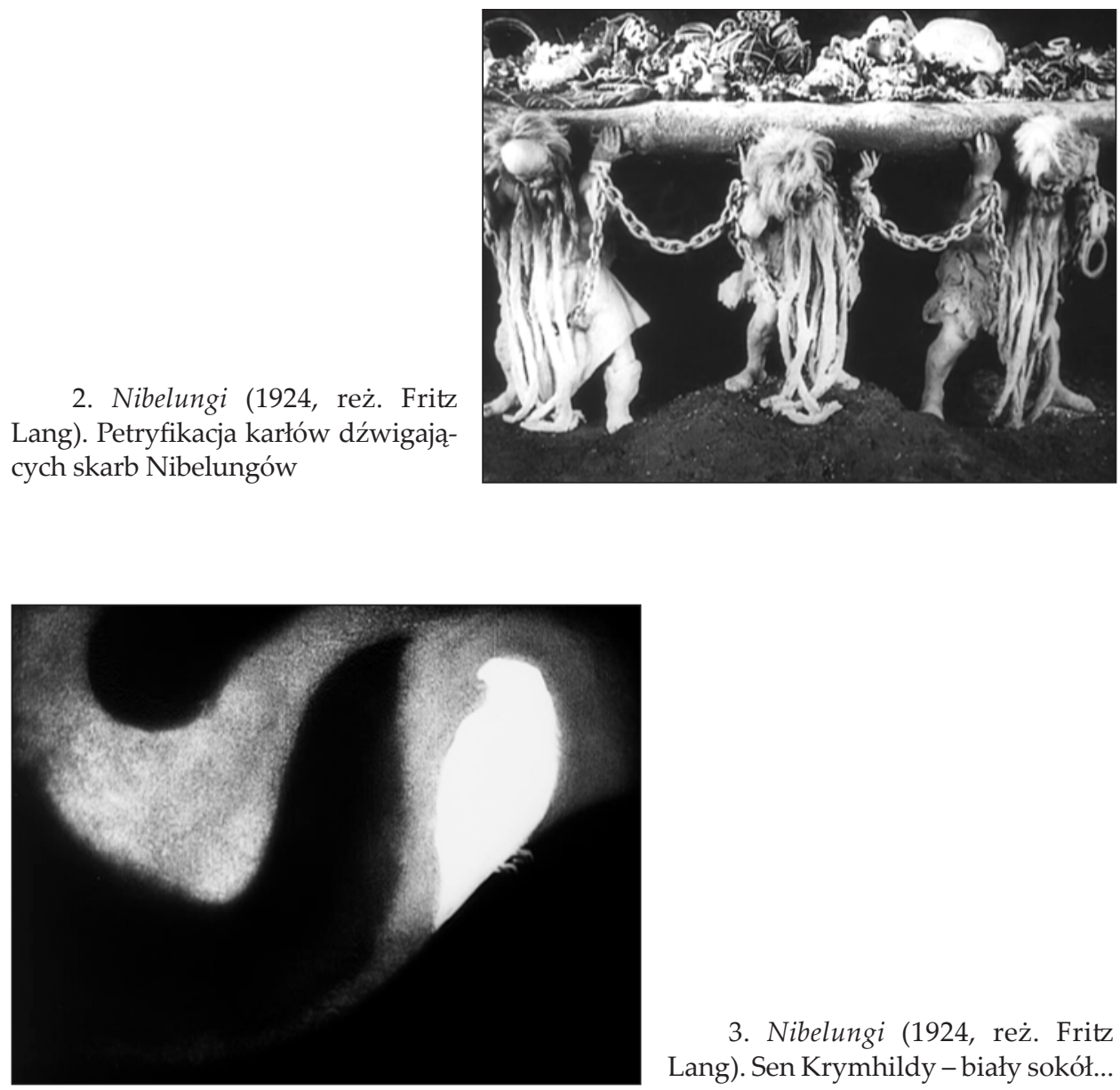

3. Nibelungi (1924, reż. Fritz Lang). Sen Krymhildy - biały sokół... 


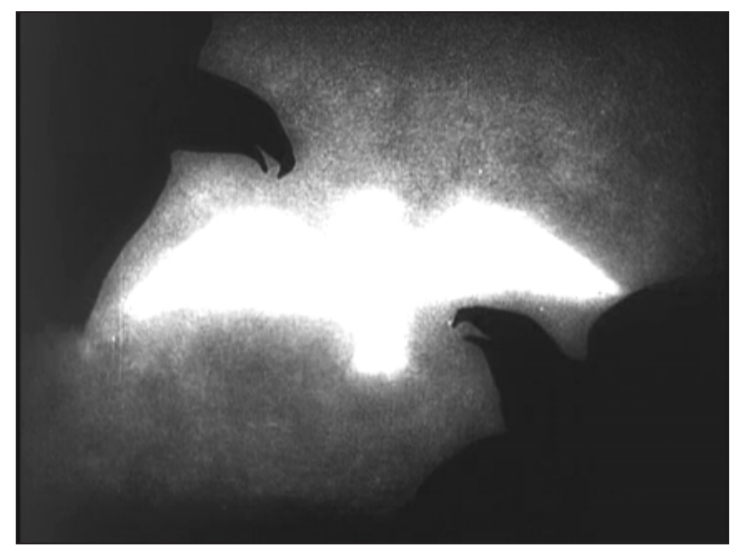

4. Nibelungi (1924, reż. Fritz Lang). Sen Krymhildy - ...i dwa czarne orly

5. Nibelungi (1924, reż. Fritz Lang). Gunter w pojedynku z Brunhilda, wspomagany przez niewidzialnego (nie dla widza) Zygfryda
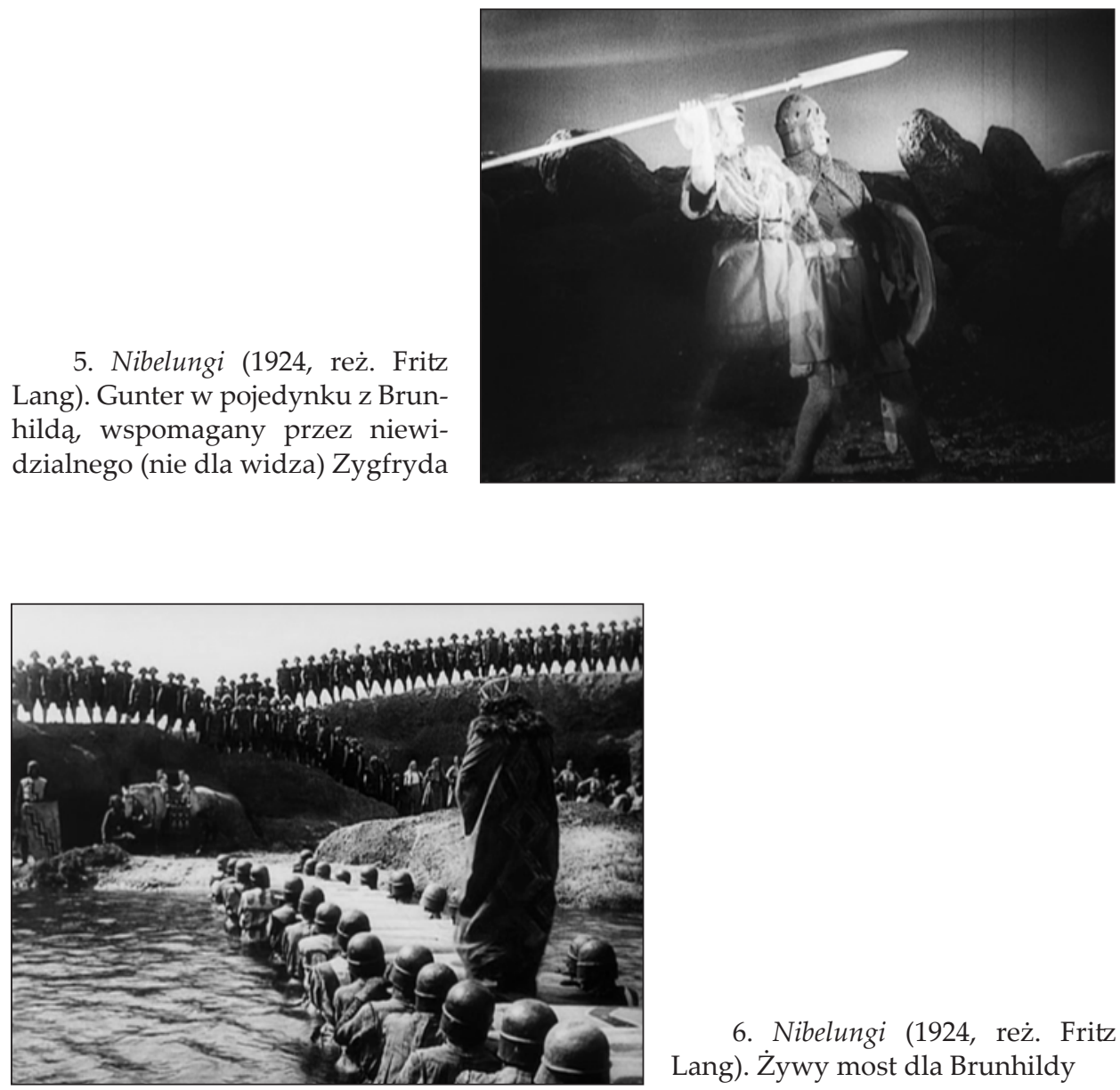

6. Nibelungi (1924, reż. Fritz Lang). Żywy most dla Brunhildy 


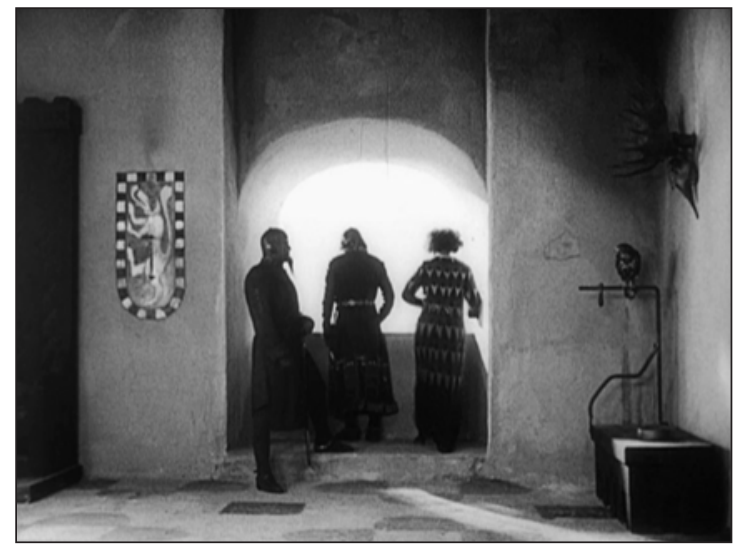

7. Nibelungi (1924, reż. Fritz Lang). Triumwirat na zgubę Zygfryda - Hagen, Gunter i Brunhilda. W kadrze smok, trupia czaszka i drapieżny ptak
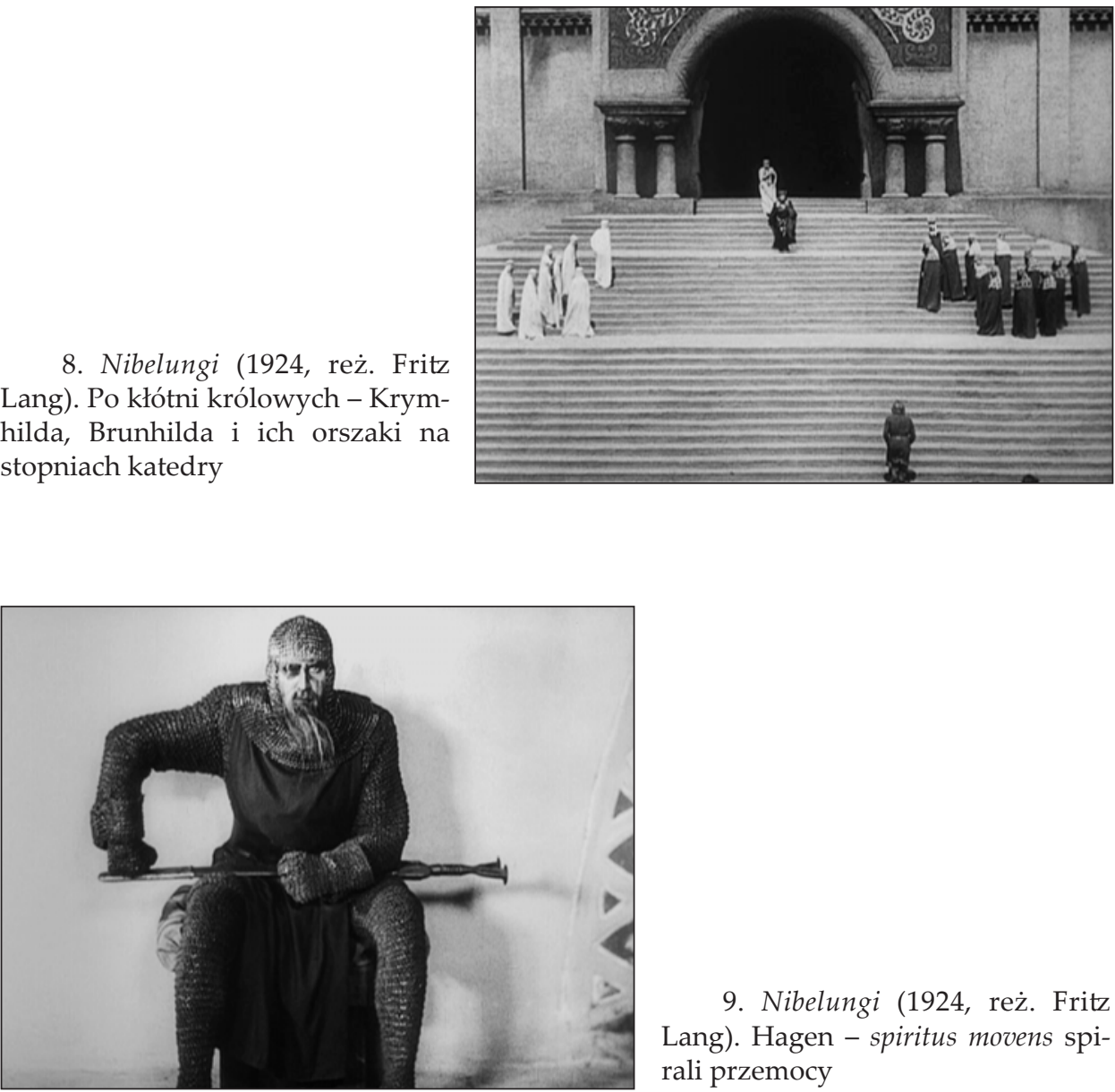

9. Nibelungi (1924, reż. Fritz Lang). Hagen - spiritus movens spirali przemocy 


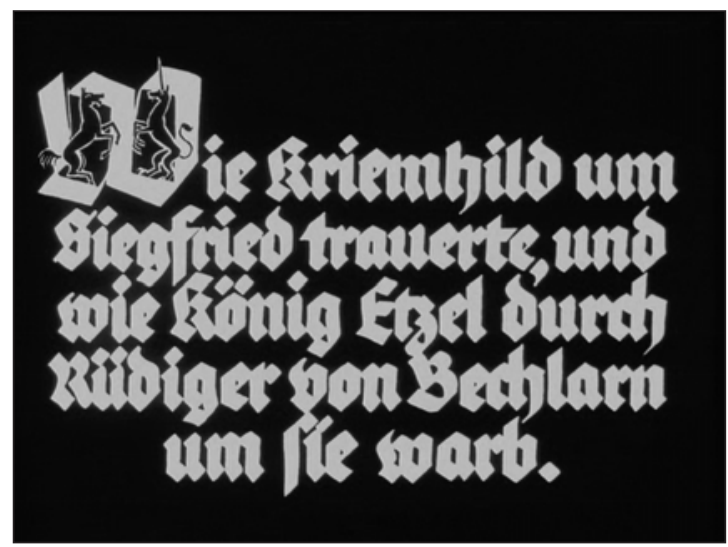

10. Nibelungi (1924, reż. Fritz Lang). Vorausdeutung - zapowiedź fabularnych zdarzeń Pieśni w stylizowanych na gotyk napisach

11. Nibelungi (1924, reż. Fritz Lang). Hunowie wydostają się ze swych pieczar
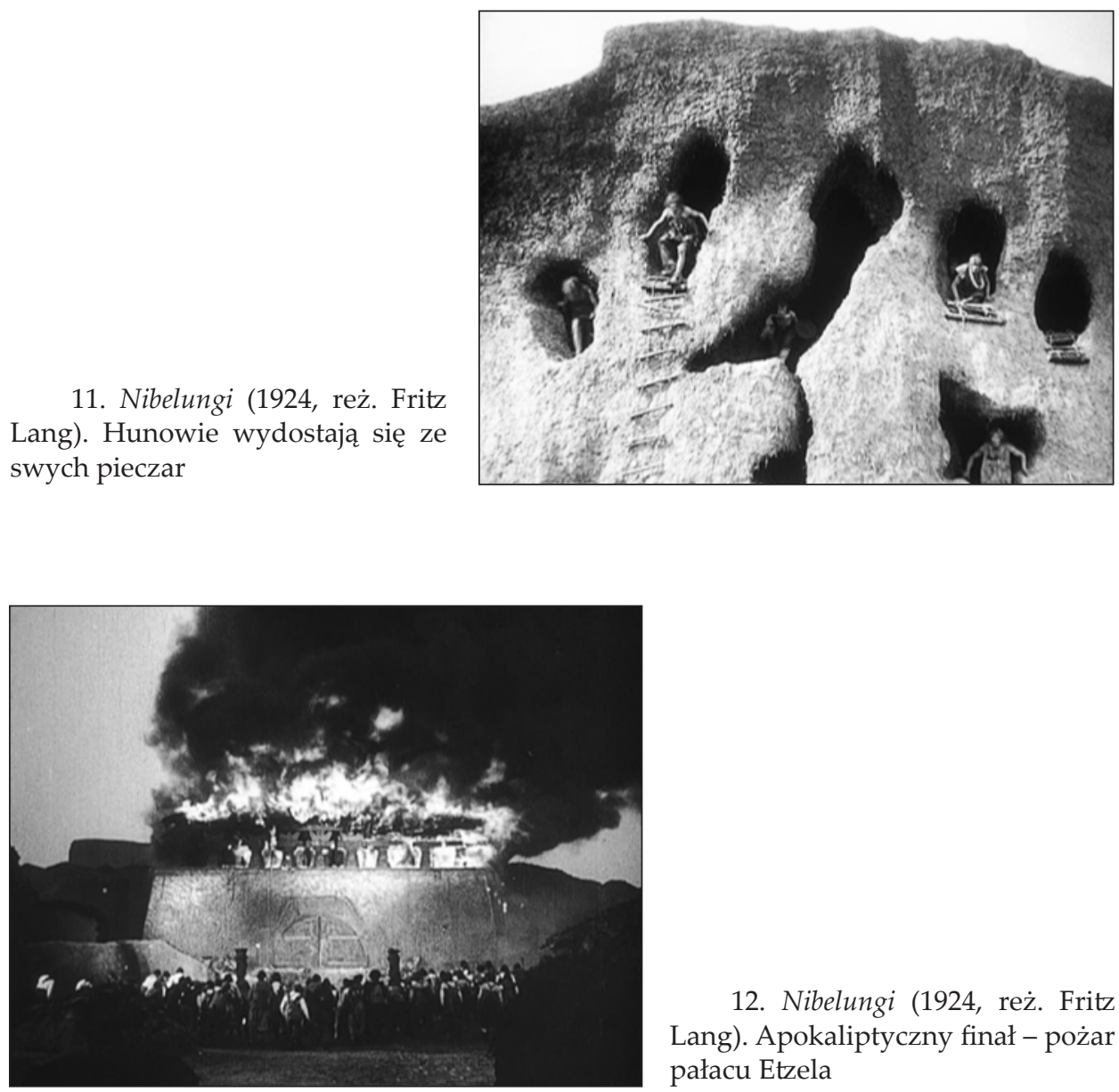

12. Nibelungi (1924, reż. Fritz Lang). Apokaliptyczny finał - pożar pałacu Etzela 
Część 2

\section{ZEITSPIEGEL: BURZLIWE LATA DWUDZIESTE}





\title{
Rozdział 3
}

\section{DZIKOŚĆ LWA I JAD WĘŻA: DOKTOR MABUSE, GRACZ}

\begin{abstract}
„Bez względu na to, jakie peany śpiewamy na cześć Rozumu - powiedział kiedyś do Pöklera [profesor Laszlo Jamf] - umiaru i kompromisu, istnieje jeszcze lew. Lew w każdym $\mathrm{z}$ was. Lew ten albo jest poskromiony - nadmierną dawką matematyki, opisami budowy, procedurami korporacyjnymi - albo pozostaje dzikim zwierzęciem, wiecznym drapieżnikiem.

Lew nie rozróżnia subtelności i półśrodków. Nie przyjmuje uwspólnienia jako podstawy niczego! Bierze i trzyma! Nie jest ani bolszewikiem, ani Żydem. Nie słyszał o relatywizmie. To absolutysta. Życie i śmierć. Zwycięstwo i przegrana. Żadnych rozejmów, układów, tylko radość kryjąca się w skoku, ryk, krew".

Jeżeli była to chemia narodowosocjalistyczna, winić należy coś, co było wówczas w powietrzu, Zeitgeist. Profesor doktor Jamf nie okazał się odporniejszy niż inni. Tak samo jego student Pökler. Lecz skutkiem inflacji i kryzysu idea lwa u tego drugiego przybrała ludzką twarz, twarz z ekranu kinowego, natürlich, należącą do aktora Rudolfa Klein-Roggego, którego Pökler idealizował* i starał się naśladować. [...]

Klein-Rogge zapisał się w pamięci widzów przede wszystkim rolą doktora Mabuse. Kojarzył się z Hugonem Stinnesem, niezmordowanym przedsiębiorcą poruszającym zza kulis sznurkami pozornej inflacji, pozornych dziejów: hazardzista, finansowy cudotwórca, arcygangster... Ruchliwe usta burżuja, szczęki, toporne ruchy, pierwsze wrażenie to komiczny technokrata... a jednak gdy odzywała się w nim natura szaleńca, wyzierając spod maski racjonalisty, gdy jego lodowate oczy stawały
\end{abstract}

* Przytaczam istniejący polski przekład, ale jest on w tym miejscu błędny; w oryginale jest nie „whom Pökler idealised”, lecz „whom Pökler idolised”: „którego Pökler ubóstwiał” lub „z którego Pökler uczynił idola”. Por.: Thomas Pynchon, Gravity's Rainbow, Bantam Books, New York 1972, s. 674. 
się oknami ukazującymi nagi step, wówczas objawiał się prawdziwy Mabuse, pełen sił żywotnych i dumy na przekór otaczającym go szarym siłom, gnany ku przeznaczeniu, przed którym - z pewnością o tym wiedział - nie było ucieczki, milczące inferno karabinów, granatów, ulic pełnych wojska atakującego jego kwaterę, i ten własny obłęd na końcu tajemnego tunelu... I kto doprowadził do jego zguby, jeśli nie bohater poranków, Bernhard Goetzke, jako prokurator von Wenk, Goetzke, który grał wrażliwa, zadumaną biurokratyczną Śmierć w Zmęczonej Śmierci, rola w sam raz dla niego, nazbyt potulny, za delikatny dla zblazowanej hrabiny, której pożądał - Klein-Rogge wskoczył, rozczapierzone pazury, przywiódł jej zniewieściałego męża do samobójstwa, chwycił ja, rzucił na łóżko tę omdlewającą dziwkę - wziął ją! - a delikatny Goetzke siedział w biurze wśród papierzysk i sybarytów - Mabuse próbuje go zahipnotyzować, otruć, podłożyć bombę - wszystko na próżno, za każdym razem weimarska inercja, kartoteki, hierarchie i procedury ratują go od śmierci. Mabuse był dzikim atawizmem, charyzmatycznym błyskiem, którego nie potrafiła utrwalić żadna niedzielna klisza Agfy, za każdym razem odbitka $\mathrm{w}$ falującym roztworze jaskrawi się tą samą unicestwiającą martwą bielą $[\ldots]^{1}$

Thomas Pynchon, Tẹcza grawitacji

\section{Kampania multimedialna}

Przytoczony powyżej fragment powieści Thomasa Pynchona Tęcza grawitacji (Gravity's Rainbow, 1973), jednego z najważniejszych dzieł amerykańskiej literatury postmodernistycznej, świadczy, iż film Fritza Langa z 1922 r. Doktor Mabuse, gracz (Dr. Mabuse, der Spieler) zapłodnił wyobraźnię nie tylko generacji widzów swej premiery. Jak zresztą suponuje ów fragment, na publiczność epoki nie był to wpływ niewinny: dla Pynchonowskiego bohatera, Franza Pöklera, w latach 20. namiętnego kinomana i wielbiciela filmów Langa, później - stronnika nazizmu i naukowca pracującego nad tajną bronią Hitlera V2, wizerunek Rudolfa Klein-Rogge jako doktora Mabuse stał się ikoną idola. Nie tylko zresztą Mabuse, ale i inne postaci, w które wcielił się Klein-Rogge - król Hunów Attyla w Nibelungach, szalony naukowiec Rotwang w Metropolis ${ }^{2}$ - uosabiały dla Pöklera „lwią naturę" "nadczłowieka”, wielkiego indywidualisty, żyjącego na wysokich obrotach, niewahającego się narzucać swą wolę przemoca, dążącego do

1 Thomas Pynchon, Tęcza grawitacji, przeł. Robert Sudół, Prószyński i S-ka, Warszawa 2001, s. 455-456, 457.

2 Por.: ibidem, s. 456. 
osiągnięcia swych celów choćby i - dosłownie - po trupach, a co więcej, gotowego rzucić się w otchłań samozagłady, by nawet za taką cenę ujawnić „wolę mocy” i zaznać niepohamowanej intensywności istnienia swego olbrzymiego i przesłaniającego świat , ja" ${ }^{\prime \prime}$.

Byłby zatem Doktor Mabuse..., jak chce Siegfried Kracauer, „wyrazem" tendencji totalitarnych, a jego tytułowy bohater jeszcze jedną w kinie Republiki Weimarskiej figurą prenazistowskiego "tyrana”? ${ }^{4}$ Otóż nie negując bynajmniej tej klasycznej już interpretacji, trzeba zarazem skonstatować, iż jest ona jednostronna; ujmując jeden aspekt filmu i jego bohatera, nie dostrzega, iż Mabuse jako fantazmat ucieleśnia $\mathrm{z}$ a r a z e m sensy znajdujące się pozornie na antypodach tych wskazanych przez Kracauera i Pöklera. Mabuse - jak pokaże w dalszym toku rozbiór filmu Langa-uosabia bowiem także i to, co fragment powieści Pynchona również wskazuje, ale sytuuje po stronie Mabusemu przeciwnej: relatywizm, „uwspólnienie”, ,żydostwo", „bolszewizm”. Pynchon/Pökler - niejasność tożsamości narratora wyraża zastosowany chwyt dwuznacznej narracji w mowie pozornie zależnej - w drugiej części przywołanego fragmentu podważa zresztą wskazany wcześniej „,absolutyzm” doktora Mabuse: spod „maski racjonalisty" wyziera w nim "natura szaleńca”, a "finansowy cudotwórca" i "arcygangster" przegrywa, o ironio, ze zniewieściałym biurokratą Wenkiem, kartotekami, hierarchiami i procedurami „weimarskiej inercji”.

Niezależnie od wymowy filmu, był on pierwszym prawdziwie wielkim triumfem Langa jako reżysera, bo w porównaniu z nim niemiecką recepcję wcześniejszej Zmęczonej Śmierci można uznać tylko za umiarkowany sukces, w dodatku spóźniony i wtórny, gdy film wzbudził już entuzjazm za granica. Triumf Doktora Mabuse... był natychmiastowy, bezsporny, co więcej - trwały. I nie tylko dlatego, że późniejsze o pół wieku arcydzieło literatury światowej, jakim jest powieść Pynchona, czyni z niego emblemat epoki. „W Niemczech Mabuse jest prawdziwym fenomenem kultury popularnej, a jego nazwisko jest rozpoznawane jako emblemat horroru na równi z Drakulą czy Frankensteinem” ${ }^{5}$. „Ankieta wśród niemieckich nastolatków przeprowadzona w połowie lat 80 . XX wieku wykazała, że aż 95\% z nich rozpoznaje nazwisko Mabuse, i że jeśli nawet nie widzieli żadnego z filmów czy nie czytali którejś z książek, to jednak

${ }^{3}$ Ciekawej analizy recepcji przez Pöklera filmów Langa, w aspekcie zarówno ideologicznym, jak i formalnym, dokonuje Thomas Elsaesser w książce Weimar Cinema and After: Germany's Historical Imaginary, Routledge, London-New York 2000, s. 161-164.

${ }^{4}$ Por.: Siegfried Kracauer, Od Caligariego do Hitlera: Z psychologii filmu niemieckiego, przeł. Eugenia Skrzywanowa, Wanda Wertenstein, Filmowa Agencja Wydawnicza, Warszawa 1958, s. 72-75.

${ }^{5}$ David Kalat, The Strange Case of Dr. Mabuse: A Study of the Twelve Films and Five Novels, McFarland \& Company, Inc., Publishers, Jefferson-London 2001, s. 6. 
potrafią powiązać to nazwisko z lękiem, paranoją kontrolą nad umysła$\mathrm{mi}$, tyrania totalitaryzmem" ${ }^{\prime \prime}$. Mabuse stał się w historii kina światowego jedną $\mathrm{z}$ „wędrujących postaci" $\mathrm{i}$ - zupełnie jak James Bond - posiada swą „kanoniczną" serię ${ }^{7}$ (choć w skali światowej nie zdobyła ona podobnej, jak Bondowska, popularności). Co więcej, wydaje się, że sławetne przedstawianie się agenta 007 (,My name is Bond... James Bond") jest echem autoprezentacji Mabusego: "Mein Name ist Mabuse... Doktor Mabuse"8. Wpływ filmów Langa o demonicznym doktorze na serię Bondowską widać też w poetyce: rozpoczynania od efektownego prologu dość luźno związanego z dalszą akcją epatowania widza "gadżetami", mnożenia aż nazbyt wymyślnych i kunsztownych pułapek zastawianych przez "siły zła” na „przedstawiciela prawa i porządku”, których „barokowość” i komplikacja ułatwia niedoszłej ofierze szczęśliwe wymknięcie się.

Postać doktora Mabuse nie jest rezultatem inwencji jedynie Langa i Thei von Harbou, choć to właśnie głównie poprzez ich film z roku 1922 stała się ona składnikem zbiorowej wyobraźni Niemców. Stworzył tę figurę zapomniany dziś pisarz, Luksemburczyk z urodzenia, Norbert Jacques. Niezmordowany tropiciel „dziwnego przypadku doktora Mabuse”, amerykański historyk filmu David Kalat, tak przedstawia sylwetkę autora: „Ojciec Mabusego, co nie dziwi, był dziennikarzem. Był również cenionym autorem zarówno 55 książek, jak i setek esejów, artykułów, opowiadań oraz rozmaitych niepublikowanych utworów. Tomasz Mann uznawał

${ }^{6}$ Ibidem, s. 282.

7 W skład kanonu wchodzą trzy filmy Fritza Langa: Doktor Mabuse, gracz (1922), Testament doktora Mabuse (Das Testament des Dr. Mabuse, 1933) i Tysiac oczu doktora Mabuse (Die 1000 Augen des Dr. Mabuse, 1960) oraz seria filmów wyprodukowanych przez Artura Braunera. Ostatni z filmów Langa jest zarazem pierwszym filmem serii Braunera. Po Tysiacu oczu doktora Mabuse nastąpiły: W stalowej sieci doktora Mabuse (Im Stahlnetz des Dr. Mabuse, 1961, reż. Harald Reinl), Testament doktora Mabuse (Das Testament des Dr. Mabuse, 1961, remake filmu Langa w reż. Wernera Klinglera), Niewidzialne szpony doktora Mabuse (Die Unsichtbaren Krallen des Dr. Mabuse, 1962, reż. Harald Reinl), Scotland Yard kontra doktor Mabuse (Scotland Yard jagt Dr. Mabuse, 1963, reż. Paul May), Promienie śmierci doktora Mabuse (Die Todesstrahlen des Dr. Mabuse, 1964, reż. Hugo Fregonese), Zemsta doktora Mabuse (La venganza del Dr. Mabuse, 1970, reż. Jesús Franco). Ten ostatni film, choć wyprodukowany jest przez Braunera, to poza jego berlińską spółką CCC, w Hiszpanii. Jakby chcąc podkreślić uzurpację (jak można było zrealizować „,kanoniczny” film o Mabusem poza Niemcami?), niemieccy dystrybutorzy zmienili tytuł na zachowujący nazwisko "Mabuse”, ale w sposób dezawuujący: Człowiek, który nazywat sie Mabuse (Der Mann, der sich Mabuse nannte). A gdy po latach ponownie wypuszczono ten film na niemieckie ekrany, zatytułowano go Doktor M. kontratakuje (Dr. M. schlägt zu), jeszcze mocniej zacierając jego przynależność do serii. Por.: D. Kalat, op. cit., s. 239.

8 Tak w Langowskim Testamencie doktora Mabuse przedstawia się Hoffmeistrowi opętany "duchem" i ideami Mabusego profesor Baum. W Doktorze Mabuse, graczu demoniczny bohater, zaskoczywszy prokuratora Wenka w jego własnym biurze, przedstawia się: „Gestatten Sie: Dr. Mabuse". 
go za wielki talent, a opinię tę powszechnie podzielano w pierwszych dekadach XX w. Pod koniec stulecia jednak jego reputacja przygasła - nie wskutek jakichś miażdżących opinii o jego talencie twórczym, ale z powodu pewnego historycznego zdarzenia: wprowadził w świat figurę, która wymknęła mu się spod kontroli" ${ }^{\prime 9}$. Figurą tą był, rzecz jasna, Mabuse.

W tekście z roku 1950, będącym fragmentem wydanej wtedy autobiografii pisarza Mit Lust gelebt, opublikowanym ponownie wraz ze wznowieniem powieści w latach $90 .{ }^{10}$, Jacques przywołuje sytuację, która ponoć zainspirowała go do stworzenia swej najsłynniejszej, a tak niefortunnej dla jego literackiej renomy postaci. Pewnego dnia podczas rejsu po Jeziorze Bodeńskim naprzeciw Jacques'a miał siedzieć mężczyzna, w którego samym wyglądzie - wyrazie oczu, zarysie czoła, ogólnej postawie - było coś mocno niepokojącego, powodującego, iż usytuowany vis à vis pisarz czuł się nieswój. „ «Bohater to czy łotr?» - zastanawiał się autor. [...] W tym tajemniczym człowieku, który przez cały czas siedział nieruchomo i w milczeniu, Norbert Jacques wyczytał ws zystko to, co było złe we ws półczesnych $\mathrm{N}$ i e m c z e ch"11. Zainspirowany, natychmiast po powrocie do domu rozpoczął pisać powieść, którą ukończył w 14 dni ${ }^{12}$.

Niezależnie od prawdziwości tej anegdoty, wydaje się ona warta przytoczenia, gdyż uświadamia to, co jest może bardziej oczywiste podczas oglądania filmu Langa: Mabuse jest w pewnym sensie „pustym miejscem", signifiant jedynie potencjalnym, w które można wpisać rozmaite znaczenia, w zależności od semantycznej ",aury”, jaką w danym momencie stwarza dookolny kontekst. Dzięki temu Mabuse może być odczytywany zarówno jako (pre)nazista (wedle Kracauera czy Pynchona), jak i jako winny inflacji „żydowski spekulant"13 (o czym w dalszym toku). Alegorycznym wyrazem „znaczeniowej otwartości” doktora Mabuse jest jego zdolność transformacji i nieustanne przebieranki, którym się oddaje.

Natychmiastowy sukces odbiorczy powieści Jacques'a i filmu Langa to rezultat starannie przemyślanej strategii marketingowej i wzorowo przeprowadzonej - w aspekcie zarówno nagłośnienia, jak i synchronizacji - kampanii multimedialnej, w której powieść i film nawzajem się promowały ${ }^{14}$. Powieść opublikowano najpierw w odcinkach na łamach „Berliner

${ }^{9}$ D. Kalat, op. cit., s. 11.

10 Norbert Jacques, Dr. Mabuse, I Presume, [w:] idem, Dr. Mabuse, der Spieler, Rogner und Bernhard, GmbH, Hamburg 1994. Prwdr. [w:] Norbert Jacques, Mit Lust gelebt, Hoffmann \& Campe, Hamburg 1950.

${ }^{11}$ D. Kalat, op. cit., s. 14. Podkreślenie moje - T. K.

${ }^{12}$ Ibidem.

${ }^{13}$ Por.: Bernd Widdig, Culture and Inflation in Weimar Germany, University of California Press, Berkeley-Los Angeles-London 2001, s. 121-123; Tom Gunning, The Films of Fritz Lang: Allegories of Vision and Modernity, BFI Publishing, London 2000, s. 102, 486.

${ }_{14}$ Por.: Klaus Kreimeier, The Ufa Story: A History of Germany's Greatest Film Company, 1918-1945, University of California Press, Berkeley-Los Angeles-London 1999, s. 88-89; 
Illustrirte Zeitung", a serializacja wystartowała „,Z wielkimi fanfarami”, jak pisze Bernd Widdig, w numerze 39 z 25 września 1921. „Na stronie tytułowej «Berliner Illustrirte» tego dnia widniał portret brodatego autora wraz z żona, oboje w typie sportowym, na własnym jachcie, scena jak z marzeń, która ostro kontrastowała z ogólną nędzą epoki"15. Serializacja trwała do stycznia 1922 - „czytelnicy pochłaniali powieść Jacques'a, a gazeta odnotowała wielki wzrost sprzedaży"16. Ostatnie odcinki zawierały fotosy z produkowanego równocześnie filmu Langa ${ }^{17}$, co oczywiście niezwykle pobudzało apetyty czytelników na wersję filmową. Współpraca pisarza z duetem Lang - von Harbou przy adaptacji scenariusza była ponoć wzorowa, a realizacja przebiegała bez zakłóceń. W lutym 1922, gdy dobiegła końca serializacja powieści na łamach „Berliner Illustrirte Zeitung”, odpowiedzialny za nią gigant wydawniczy i prasowy, Ullstein, opublikował powieść w edycji książkowej. W pierwszym roku sprzedaż przekroczyła 100 tys., a ostatecznie sięgnęła pół miliona egzemplarzy, co czyni z powieści Jacques'a jeden z największych niemieckich sukcesów wydawniczych tej epoki ${ }^{18}$.

W takich okolicznościach film Langa - niezależnie od jego wspaniałego poziomu artystycznego - nie mógł nie odnieść komercyjnego sukcesu. Ciekawe jest zresztą porównanie skutków takiego sukcesu dla pisarza i dla filmowca: Jacques bieżący rozgłos i duże pieniądze przypłacił jednoczesnym naznaczeniem własnej osoby jako autora jedynie popularnych, sensacyjnych powieści i tym samym utratą literackiego prestiżu ${ }^{19}$; Lang - przeciwnie, odniósłszy sukces kasowy, uzyskał w kinematografii niemieckiej kredyt zaufania przyszłych producentów, a tym samym silniejszą pozycję i większą swobodę właśnie jako a rtysta. To właśnie sukces Doktora Mabuse, gracza sprawił, iż wyróżnikami twórczości Langa na całe lata - choć jednak zwłaszcza w okresie weimarskim - stały się dwa atrybuty wskazane przez Marka Hendrykowskiego: „1) poszukiwanie tematów możliwie najbardziej atrakcyjnych z punktu widzenia

T. Elsaesser, op. cit., s. 156, 190-191; D. Kalat, op. cit., s. 16, 27-28; korespondencja pomiędzy Jacques'iem, Langiem i von Harbou opublikowana [w:] Michael Farin, Günter Scholdt, Dr. Mabuse, Medium des Bösen, Rogner und Bernhard, GmbH, Hamburg 1994, s. 217-255.

15 B. Widdig, op. cit., s. 113-114. Reprodukcję tej okładki można znaleźć w tomie Fritz Lang. Leben und Werke. Bilder und Dokumente, Red. Rolf Aurich, Wolfgang Jacobsen, Cornelius Schnauber, Filmmuseum Berlin-Deutsche Kinemathek und jovis Verlag GmbH, Berlin 2001, s. 76.

${ }^{16}$ Ibidem, s. 114.

17 T. Elsaesser, op. cit., s. 190; K. Kreimeier, op. cit., s. 89.

18 Por.: B. Widdig, op. cit., s. 114; D. Kalat, op. cit., s. 16. A nie zapominajmy też o przekładzie powieści na angielski, który również cieszył się powodzeniem (Norbert Jacques, Dr. Mabuse, Master of Mystery, authorized translation by Lilian A. Clare, Allen \& Unwin Ltd., London 1923).

${ }_{19}$ Por.: D. Kalat, op. cit., s. 16. 
masowej widowni [...]; 2) umiejętność kojarzenia aktualnego wydźwięku społecznego poruszanych tematów $\mathrm{z}$ ich oryginalna, $\mathrm{w}$ pełni samoistną wizją filmową"20. A duet Fritz Lang - Thea von Harbou kontynuował „multimedialną" strategię, aż do 1932 r., czyli do ich artystycznego, ideowego i małżeńskiego rozstania. „Powieści cieszących się powodzeniem autorów (zazwyczaj samej Harbou) Lang i Harbou wspólnie przerabiali na scenariusze. Wtedy Ullstein albo Scherl wydawali je w formie książek ilustrowanych fotosami z produkcji filmu, a edycja zbiegała się z premierą filmu; na premierze Ufa sprawiała $\mathrm{w}$ prezencie oprawione $\mathrm{w}$ jedwab podpisane egzemplarze gościom, którzy otrzymali na ceremonię ozdobne zaproszenia" 21 . I przynajmniej do 1927 r., tj. do czasu finansowej katastrofy Metropolis, która jednak nadszarpnęła nieco wiarę w złotodajność projektów artystyczno-małżeńskiego duetu, kredyt, jakim obdarzano Langa i Theę von Harbou (nie tylko zaufania; także olbrzymie pieniądze lokowane w realizację filmów), wydawał się niemal nieograniczony.

\section{Ein Bild der Zeit, Menschen der Zeit}

Z racji olbrzymiego metrażu (ponad 4 i pół godziny projekcji) film Langa został podzielony na dwie części, wyświetlane na osobnych seansach ${ }^{22}$. Premiera pierwszej, zatytułowanej Wielki gracz-obraz epoki (Dr. Mabuse, der Spieler. Erster Teil: Der große Spieler - Ein Bild der Zeit), odbyła się 27 kwietnia 1922, premiera drugiej pt. Inferno - film o ludziach naszych czasów (Dr. Mabuse, der Spieler. Zweiter Teil: Inferno - Ein Spiel von Menschen unserer Zeit $)^{23} 26$ maja 1922; obie zreszta, jak zazwyczaj w przypadku niemieckich filmów Langa, w berlińskim kinie Ufa-Palast am Zoo ${ }^{24}$.

${ }^{20}$ Marek Hendrykowski, Fritz Lang a problem atrakcyjności kina, [w:] Niemiecki ekspresjonizm filmowy, red. Alicja Helman, Alina Madej, Uniwersytet Śląski, Katowice 1985, s. 33.

${ }^{21}$ K. Kreimeier, op. cit., s. 89.

${ }_{22}$ Doktor Mabuse, gracz nie jest tu wyjątkiem. Inne wystawne, wysokobudżetowe filmy niemieckie tej epoki, z powodu swej długości wyświetlane jako dwa pełnometrażowe filmy na odrębnych seansach, to np. Indyjski grobowiec (Das Indische Grabmal, 1921, reż. Joe May), ze scenariuszem Fritza Langa i Thei von Harbou, czy następne wielkie przedsięwzięcie reżyserii Langa - Nibelungi (Die Nibelungen, 1924).

${ }^{23}$ Wieloznaczność niemieckiego słowa Spiel powoduje, iż podtytuł drugiej części można by przetłumaczyć także jako Gra ludzi naszych czasów. O podobnym dylemacie translatorskim w tłumaczeniu na angielski frazy Ein Spiel von Menschen unserer Zeit świadczą odmienne jej przekłady: A Game of People of Our Time (w menu albumu DVD Dr. Mabuse, der Spieler, wydanego przez Transit Film, GmbH, München 2004), A Play About People of Our Times (w filmografii zawartej w biograficznej książce Patricka McGilligana, Fritz Lang: The Nature of the Beast, St. Martin's Press, New York 1997, s. 487).

${ }_{24}$ Por.: E. Ann Kaplan, Fritz Lang: A Guide to References and Resources, G. K. Hall \& Co., Boston 1981, s. 41; D. Kalat, op. cit., s. 297. 
Premierze towarzyszyła przygotowana na nią specjalnie przez dystrybutora broszura, której tekst, jak zauważa Lotte Eisner, jest raczej nietypowy jak na program reklamujący film ${ }^{25}:,[\ldots]$ reżyser Fritz Lang miał zamiar zrealizować nie przebój kasowy, nie film kryminalny, nie jedynie film o społeczeństwie, lecz podążając za wskazówkami powieści stworzyć obraz epoki, w którym rok produkcji odgrywa równie ważną rolę, jak aktorzy, scenografowie, zdjęcia. Każda epoka ma swe epopeje, w których mniej lub bardziej wyraźnie ujawnia się duch czasu. Film ten jawi się jako obraz swego czasu, potężny z racji swej bezpośredniości dokument dla przyszłych pokoleń. Świat, który otwiera się przed naszymi oczyma, to świat, w którym wszyscy żyjemy. Jest tylko skondensowany, w szczegółach przesadzony, skupiony na rzeczach zasadniczych, wszystkie jego zdarzenia w swym tętnie współgrają z gorączkowym oddechem tych lat; zawieszony między kryzysem a uzdrowieniem, kroczy somnambulicznie na krawędzi przepaści w poszukiwaniu mostu przerzuconego nad otchłanią. Ów gracz, doktor Mabuse, nie był jeszcze możliwy w roku 1910; nie będzie już dłużej możliwy - miejmy nadzieję - w roku 1930. Ale dla czasów około roku 1920 jest czymś więcej niż najprawdziwszą z prawdziwych podobizną - jest niemal symbolem, a co najmniej symptomem. Ludzkość, zdziesiątkowana i stłamszona przez wojnę i rewolucję, kompensuje sobie lata cierpienia i nędzy przez zżerające ją żądze i pogoń za przyjemnością"26.

Być może zresztą tekst reklamowej broszury pochodzi w dużej mierze od samego Langa, bowiem współbrzmi nie tylko z podtytułami obu części, ale i z tym, co reżyser powiedział o Mabusem po latach, w wywiadzie z 1964 r.: „Okres po I wojnie światowej był dla Niemiec czasem najgłębszej rozpaczy, histerii, cynizmu, nieposkromionego występku. Najstraszliwsza nędza sąsiadowała $z$ niezmiernym nowym bogactwem. Berlin ukuł nowe słowo, Raffke ("zgarniacz zysków”), od zusammenraffen des Geldes („zgarniać pieniądze”). Raffke - tak właśnie nazywaliśmy nowobogackich. Doktor Mabuse jest prototypową postacią tej epoki" ${ }^{27}$.

Recenzenci z rozmaitych pism - o różnej zresztą orientacji politycznej - dość zgodnie chwalili film Langa za niezwykle przekonująco uchwycony

${ }^{25}$ Lotte H. Eisner, Fritz Lang, Da Capo Press, New York 1986, s. 57.

${ }^{26}$ Zob.: D. Kalat, op. cit., s. 40; L. H. Eisner, op. cit., s. 57. Cytuję za dwoma źródłami - w każdym z nich przytoczono tylko fragmenty broszury, na podstawie których można było jednak zrekonstruować taki oto ciągły i zwarty tekst. Zwraca uwagę optymizm broszury - realność społeczna odpowiadająca symbolice Mabusego w latach 30. nie tylko nie zniknie, ale przybierze znacznie groźniejszą niż inflacja i moralny nieład (choć będącą ich rezultatem) postać narodowego socjalizmu.

${ }^{27}$ Fragment tego wywiadu odnajdziemy, w nieco różnych przekładach, [w:] D. Kalat, op. cit., s. 40; K. Kreimeier, op. cit., s. 88. Cytuję za oboma źródłami. 
Zeitgeist powojennego kryzysu, którego może najbardziej widomym objawem była inflacja i jej liczne a różnorodne reperkusje ${ }^{28}$. Recenzent socjaldemokratycznej gazety „Vorwärts” pisał: „Wszystkie te nielegalne interesy i prostytucja dnia dzisiejszego, policyjne naloty i wyzysk w salonach gry, cała dzisiejsza obsesja hazardu, wariactwo na punkcie giełdy, szalbierstwa związane z okultyzmem, nocne sutenerstwo, oszukaństwo zdegenerowanego społeczeństwa - wszystko to uchwycone jest bardzo umiejętnie i znajduje swój fikcyjny, ale bardzo na czasie wyraz w figurze doktora

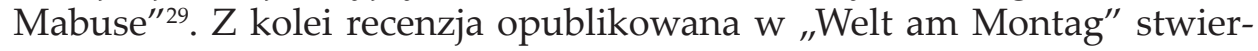
dzała: „Ten film jest dokumentem naszych czasów, wspaniałym portretem wyższych sfer z ich namiętnością do hazardu i szaleństwem dancingu, ich histerią i dekadencja, ich ekspresjonizmem i okultyzmem"30.

Inne gazety publikują recenzje równie entuzjastyczne i zawierające podobne wyliczanki elementów. Dziennik klasy średniej, „B. Z. am Mittag”, chwali film za ",sensacje, przygody, które w gwałtownym tempie następują jedna za druga, kondensację ducha epoki, atrakcyjne odtworzenie realiów i zwierciadło życia” ${ }^{31}$. Ta sama recenzja dalej stwierdza: „Sukces tego

${ }^{28}$ Nt. kryzysu lat 1918-1923, zwłaszcza zaś inflacji, godne polecenia są: Gerald D. Feldman, The Great Disorder: Politics, Economy and Society in the German Inflation 1914-1924, Oxford University Press, Oxford 1997; Bernd Widdig, op. cit.; Detlev J. K. Peukert, The Weimar Republic: The Crisis of Classical Modernity, transl. by Richard Deveson, Hill and Wang, New York 1992, s. 21-77. Druga z pozycji, tj. książka Widdiga Culture and Inflation in Weimar Germany wydaje mi się szczególnie interesująca z racji frapującej analizy "semiotyki inflacji” w kulturze Republiki Weimarskiej. Nie najmniej ważną rolę w tej analizie (i w tej semiotyce) odgrywa kino, w tym dwa filmy Langa, Doktor Mabuse, gracz i Metropolis, oraz film Georga Wilhelma Pabsta Zatracona uliczka (Die freudlose Gasse). Zob.: B. Widdig, op. cit., s. 113-133, 159-165, 215-220.

29 "Vorwärts”, 30 April 1922 (cyt. za: Dr. Mabuse: Roman - Film - Dokumente, red. Günter Scholdt, Werner J. Röhrig Verlag, St. Ingbert 1987, s. 182). Inne fragmenty tej samej recenzji przytacza Lotte H. Eisner (op. cit., s. 57, 65).

30 „Welt am Montag”, 1 Mai 1922 (cyt. za: L. H. Eisner, op. cit., s. 57).

31 Ciekawe, że większość niemieckich recenzji chwali gwałtowne tempo i szybki, nerwowy rytm filmu, podczas gdy za oceanem, gdzie filmy akcji są w ogóle znacznie żywsze, a montaż szybszy niż w Europie, reakcja była odwrotna. Amerykański monografista twórczości Langa, Paul M. Jensen, na ogół entuzjastyczny wobec filmów reżysera, wobec Doktora Mabuse, gracza jest niezwykle surowy: "tempo całego filmu jest irytująco powolne, a w długich jego partiach nic w ogóle się nie dzieje" (Paul M. Jensen, The Cinema of Fritz Lang, A. S. Barnes \& Co.-A. Zwemmer Ltd., New York-London 1969, s. 37). Prawda leży pośrodku - film ma zmienny rytm, a sekwencje o szybkim tempie i gwałtownym montażu symultanicznym, sąsiadują z partiami dość statycznymi. Zresztą ta zmienność rytmu wydaje się frapującą jakością estetyczną filmu. W każdym razie „niecierpliwość" nie tyle amerykańskiej widowni, co amerykańskich dystrybutorów i znawców rzekomych gustów widowni, spowodowała, iż gdy w 1927 r. Doktor Mabuse... trafił na amerykańskie ekrany, to poważnie okaleczony - zrezygnowano z podziału na 2 części i skrócono go z 4,5 godziny do 90 min, przez co wypadło wiele kluczowych scen, a fabuła stała się niemal 
filmu nie polega na jego intrydze [...], ale na epizodycznych detalach, nie na sekwencji fabularnych wypadków, ale na poszczególnych zdarzeniach, które żywo wyrażają epokę, a są powiązane przez świadomą intencję artystyczna, przez rytm i prędkość, przez styl i atmosferę. Mamy tu nagromadzenie tańca i zbrodni, namiętności do hazardu i nałogu kokainowego, jazzu i ubawu. Nie brak tu żadnego istotnego objawu lat powojennych. Spekulacje giełdowe, okultystyczna szarlataneria, prostytucja i obżarstwo, szmugiel, hipnoza i fałszerstwo, ekspresjonizm, przemoc i morderstwo!

Nie ma żadnego celu, żadnej logiki w demonicznym zachowaniu odczłowieczonej ludzkości - wszystko jest grą. Gdy jednak inni znajdują rozrywkę w oddawaniu się grze, doktor Mabuse gra ludzkim życiem i ludzkim przeznaczeniem. Wszystko inne jest dlań tylko środkiem do celu..." ${ }^{32}$

Autorem jednej z najwnikliwszych recenzji - choć bynajmniej nieodbiegającej duchem swych sądów od recenzji już przywołanych - jest Kurt Pinthus. Zatytułowana Dr. Mabuses Welt (Świat doktora Mabuse), ukazała się w "Das Tage-Buch” z 6 maja 1922. Oto, jak Pinthus opisuje ów świat: „Figury w tym filmie są sprowadzone do stereotypów nawet bardziej niż w powieści Jacques'a. I wszystkie są uformowane przez naszą pospieszna, zepsuta, chaotyczną epokę i na powrót wtopione w ten świat. To właśnie tu jesteśmy świadkami, jak arystokratka rozpaczliwie tęskni, pośród jej własnego kulturalnego milieu, za przygoda, która - jak odczuwa - już się zbliża; jak rozleniwiony słabeusz przegrywa w martwej świątyni artystycznych dogmatów, obfitującej w ekspresjonizm; jak tancerka staje się niewolnicą czarnej magii łotra tylko po to, by ten zdeptał jej miłość... I wtedy reżyseria Langa zagęszcza wszystkie te nadmierne podniety, dekadencję, sensacje i spekulacje, które na nas spadły w ostatnich kilku latach: gruntownie obmyślone przestępstwa; tumult giełdy z jej spekulacyjnymi bessami i hossami; ekscentryczne jaskinie hazardu; hipnozę, sugestię, kokainę; spelunki, które są schronieniem rozpustników i graczy w bakarata... złowrogie, duchowo i seksualnie zniewolone istoty, i wszystkie te wykorzenione egzystencje, których brak skrupułów jest sam przez się zrozumiały, skoro nie mają nic do stracenia prócz życia, które byłoby jeszcze bardziej stracone bez tego braku skrupułów.

„Nie da się zaprzeczyć, że reżyser przegina, przesadza, przedawkowuje to wszystko. Ale choć za wszelką cenę stara się wywrzeć wrażenie,

niezrozumiała. Gdy ponownie wprowadzono go na amerykańskie ekrany, zmieniono a jakże! - tytuł na The Fatal Passions (Fatalne namiętności) - por.: P. M. Jensen, op. cit., s. 36. Nic dziwnego, że w takiej postaci jeden z najlepszych i najatrakcyjniejszych filmów w całej historii kina niemego nie odniósł w Stanach wielkiego sukcesu.

${ }^{32}$ Cyt. za: L. H. Eisner, op. cit., s. 58. 
wszystko jest ze smakiem, talentem, poczuciem formy. [...] Reżyser stara się zagęścić tę niepokojąca, odrętwiającą atmosferę w obrazie, szaleńczym tempem, pełnym entuzjazmu ożywieniem. Jest to tak zapalne, ponieważ tylko rozpalone osoby mogą egzystować w tej atmosferze, przepełnionej występkiem, żądzą i namiętnościami, za których istnienie wina spada na nas wszystkich, niezależnie od tego, czy aktywnie w nich uczestniczymy, czy choćby dlatego, że przyzwalamy na taką antyspołeczną aktywność w epoce demokracji i socjalizmu" ${ }^{\prime 3}$.

Zwięzłym podsumowaniem tych rozmaitych recenzji niech będzie fragment jeszcze jednej $z$ nich, opublikowanej $w$ popularnej gazecie „Berliner Lokalanzeiger": „Nie zapomniano o żadnym z występków naszych czasów... Jest to zwierciadło epoki, niespecjalnie budujące ani uszlachetniające w swym rezultacie. Ale jest prawdziwie odczute, sugestywne wizualnie pod reżyserską batutą Fritza Langa" ${ }^{34}$.

Interesujące wydaje się $w$ tych recenzjach wymienianie jednym tchem w dość do siebie podobnych katalogach „znaków epoki” pośród rozmaitych rzeczywistych występków czy objawów dekadenckiego „używania” (jak giełda, seks, dancing, nałogi, okultyzm, hazard) także... ekspresjonizmu. Recenzenci podchwycili tu daną przez Mabusego w rozmowie z hrabią Toldem definicję ekspresjonizmu. „Ekspresjonizm to gra... Ale właściwie, czemu nie?... Wszystko jest dziś grą" - mówi hrabiemu Mabuse, nie tylko deprecjonując prywatną kolekcję Tolda, ale sprowadzając na wspólną płaszczyznę z „występkami” najmodniejszy trend współczesnej sztuki, z racji braku substancjalnych wartości skazanej na relatywizm ocen, a tym samym na nihilizm. Umożliwia to Langowi zdystansowanie się wobec ekspresjonizmu na płaszczyźnie wewnątrzdiegetycznej, co zresztą później wielokrotnie potwierdzi dystansowanie sie przez Langa od tego trendu expressis verbis w wywiadach. Do sprawy tej powrócimy jeszcze, warto jednak zauważyć, iż sztuka współczesna w filmie Langa funkcjonuje podobnie jak rozmaite artystyczne i intelektualne „potworności” w powieściach czy dramatach Witkacego, objaw zdegenerowania i zbydlęcenia "tak zwanej ludzkości w obłędzie”. Katalog zaś „występków” obecnych np. w Pożegnaniu jesieni czy Nienasyceniu wydaje się dość zbliżony do tych, jakie przedstawiali recenzenci Doktora Mabuse, gracza. Co zresztą świadczy o tym, iż Zeitgeist międzywojennej Polski nie różnił się aż tak bardzo od ducha Weimaru może tylko wlókł się za nim nieco w tyle.

${ }^{33}$ Kurt Pinthus, Dr. Mabuses Welt, „Das Tage-Buch” 6 Mai 1922, Nr. 18. Cyt. za: Fritz Lang. Leben und Werke. Bilder und Dokumente, s. 74-75, 78. W tomie tym w całości jest przedrukowana recenzja Pinthusa (s. 74-80).

${ }^{34}$ Cyt. za: L. H. Eisner, op. cit., s. 57. 
Ów Zeitgeist miał się w filmie najwyraziściej przejawić w niegdyś ponoć go otwierającej, a dziś jakoby zaginionej, sekwencji montażowej, przedstawiającej $w$ zapierającym dech tempie sceny walk ulicznych podczas powstania Związku Spartakusa w 1919 r., pucz Kappa z 13 marca 1920, zamordowanie ministra spraw zagranicznych Walthera Rathenaua i inne jeszcze gwałtowne wydarzenia z najnowszej historii Niemiec. Po tej sekwencji miały następować dwa napisy: pierwszy, zadający pytanie („Kto za tym wszystkim stoi?") i drugi, zawierający odpowiedź: „Ja”. Słowo "Ich" miało pędzić z głębi ekranu ku odbiorcy, stając się coraz większe, aż niemal wypełniało cały ekran. Dopiero teraz miał następować znany nam z zachowanych kopii (także z najpełniejszej rekonstrukcji dokonanej przez Friedrich-Wilhelm-Murnau-Stiftung na podstawie różnych kopii eksploatacyjnych i wydanej jako dwupłytowy album DVD) ${ }^{35}$ pierwszy obraz filmu: ręce Mabusego tasujące niczym karty do gry jego fotografie $w$ rozmaitych wcieleniach ${ }^{36}$. Ujęcie to oczywiście dopełniałoby słowną odpowiedź - choć nie w pełni czytelnie, skoro ta sama i zarazem inna twarz dana tu jest jedynie pośrednio, poprzez fotografie, zaś osoba jedynie przez obecne w kadrze dłonie ${ }^{37}$.

Niemniej, wydaje się, iż Doktor Mabuse, gracz nigdy nie rozpoczynał się taką sekwencją. Niejasne jest np. kiedy i po co miano by ją usunąć, skoro opis sugeruje, iż gdyby istniała, mogła być jednym z najefektowniejszych fragmentów filmu. Lang sugerował, że może cięć dokonano w latach 20., kiedy nie chciano przypominania bolączek epoki (ale przecież o tym traktuje cały film - a recenzje unaocznienie tych bolączek powitały entuzjastycznie), albo też później, w NRD-owskim archiwum, które posiadało negatyw, i gdzie może wolano nie przypominać powstania Spartakusa ${ }^{38}$. Ta ostatnia hipoteza o tyle jest bezsensowna, że akurat w NRD powstanie to było składnikiem oficjalnej „,socjalistycznej tożsamości” państwa, a za jego negatywny obraz w filmie można było obwinić „burżuazyjną" Republikę Weimarską, która stłumiła płomień rewolucji. Przeciwko wersji o istnieniu

${ }^{35}$ Zob. przypis 23.

${ }^{36}$ Por. opisy „zaginionej” sekwencji w: L. H. Eisner, op. cit., s. 59; T. Elsaesser, op. cit., s. 156.

${ }^{37}$ Gdy się wie o stosowanej przez Langa, podobnej Hitchcockowskiemu pojawianiu się w kadrze własnych filmów, zabawie, polegającej na pojawianiu się w kadrze jako ręce (zazwyczaj w subiektywnych ujęciach, tzw. point-of-view shots, POV), można by odczytać to ujęcie jako gag autotematyczny - bo przecież „za tym wszystkim stoi" tak naprawdę reżyser. Tylko jak widz ma zweryfikować, czy to aby rzeczywiście dłonie Langa za każdym razem pojawiają się w kadrze? Jednak anegdota o takiej fizycznej obecności Langa we własnych filmach wydaje się o tyle prawdopodobna, że subiektywnych ujęć z dłońmi jest $\mathrm{w}$ jego dziełach rzeczywiście wiele.

${ }_{38}$ Por.: L. Eisner, op. cit., s. 59. 
tej sekwencji przemawia też anachronizm - Rathenaua zamordowano 24 czerwca 1922, niemal dwa miesiące po premierze I części filmu. Sekwencją montażową bardzo podobną do opisanej, nieistniejącej sekwencji Doktora Mabuse, gracza, rozpoczynają się natomiast Szpiedzy (Spione, 1928) - zawiera ona krótkie scenki, obrazujące "gwałtowność epoki”, m.in. aluzję do zabójstwa Rathenaua, oraz napisy z takim samym pytaniem i odpowiedzią: „Kto za tym wszystkim stoi?" - „Ja" (po tej odpowiedzi następuje portretowy plan Haghiego, superzbrodniarza w tym filmie). Być może zatem Lang po latach nie tyle znowu konfabulował (jak w przypadku historii o spotkaniu z Goebbelsem i „ucieczce z Niemiec” w 1933), ile po prostu zawiodła go pamięć i sekwencję z późniejszego filmu przypisał wcześniejszemu ${ }^{39}$. Tak czy inaczej, zabójstwo Rathenaua musiało wywrzeć na Langu niemałe wrażenie, skoro odbija się ono echem $w$ aż czterech jego filmach, w scenach, kiedy gwar ruchu ulicznego zarazem umożliwia i maskuje zbrodnię: w Szpiegach (zabójstwo dygnitarza w sekwencji wstępnej), w Kobiecie na Księżycu (uśpienie i obrabowanie Heliusa), w Testamencie doktora Mabuse (zamordowanie doktora Kramma) i w Tysiacu oczu doktora Mabuse (zabójstwo dziennikarza Petera Bartera).

Zwrócmy jednak uwagę, iż nawet w wypadku nieistnienia otwierającej sekwencji montażowej, jest w Doktorze Mabuse, graczu scena bardzo podobna do wyżej wymienionych - to scena, kiedy Mabuse w przebraniu komunistycznego agitatora podburza tłum do zatrzymania policyjnego powozu, którym przewożony jest przeznaczony przezeń do likwidacji Pesch. Tłum żąda uwolnienia przez policję "Johannesa Guttera", jakiegoś lewicowego bojownika, a gdy konwojent wyciąga Pescha z powozu, by zademonstrować, że konwojowany więzień jest kimś innym, niż ten, kogo uwolnienia żądają, w zamieszaniu pada strzał i wystawiony bezmyślnie przez policję Pesch ginie od kuli snajpera Mabusego. „ «Niewłaściwy» człowiek był jak najbardziej właśnie tym, o którego chodziło" - zauważa Thomas Elsaesser ${ }^{40}$. Premiera II części filmu, w której ta scena się znajduje, o niecały miesiąc wy przedza zabójstwo Rathenaua. Była ona profetyczna, czy może była inspiracją tej najsławniejszej weimarskiej zbrodni politycznej, powodując u reżysera traumę, nakazującą jej wariantowe powtarzanie aż do ostatniego z niemieckich i w ogóle swego ostatniego - filmu?

W Doktorze Mabuse, graczu znalazł wyraz Zeitgeist nie tylko zrodzonej $\mathrm{w}$ konwulsjach przemocy oraz pogrążonej w moralnym, ekonomicznym i ideowym chaosie Republiki Weimarskiej, ale i w ogóle świata po I wojnie światowej. Ówczesnej widowni finałowe sceny II części filmu, z wojskiem

39 Taką hipotezę stawia Tom Gunning w swej analizie Szpiegów (op. cit., s. 118).

${ }^{40}$ T. Elsaesser, op. cit., s. 178. 
oblegającym dom Mabusego i obrazami regularnej walki na ulicy miasta, przypominać musiały stosunkowo niedawne wydarzenia wojny i krwawo stłumionych prób komunistycznego przewrotu w 1919. Lang czerpał jednak też z wydarzeń zagranicznych - właśnie te same sceny wymodelował nie tylko na polityczno-historycznych wypadkach w kraju, ale i na słynnym zdarzeniu kryminalnym we Francji z 1921 r., gdy bandyci, którzy obrabowali bank (tzw. sprawa Fort Chavrol), otoczeni w zabarykadowanym domu na przedmieściach Paryża, wdali się w regularną wymianę ognia z oblegającą ich policją ${ }^{41}$.

W wywiadach udzielanych po latach Lang będzie twierdził, że jedną z inspiracji scenariusza pierwszego filmu o Mabusem była nie tylko powieść Jacques'a, ale i książka o Alu Capone przysłana mu przez „zaprzyjaźnionego hollywoodzkiego producenta" ${ }^{\prime 2}$. Rzecz jasna, Al Capone jako król brudnych interesów w Chicago jest figurą przypominającą nieco Mabusego, a fama zamaskowanych, nielegalnych w dobie prohibicji amerykańskich knajp (tzw. speakeasies), do których klientów wpuszczano na hasło, mogła wpłynąć na obraz rozmaitych nielegalnych lokali w filmie Langa, jak „Klub Oczko"43, „Grill Schramma”, „Palais Andalusia” czy "Casino Petit”. Niemniej, wydaje się, że „,sznyt” tych lokali - choćby z racji "dekadenckiego", awangardowego wystroju - jest zdecydowanie berliński, zaś inspirowanie się w 1921 r. postacią Ala Capone (choć już rozpoczął swą niesławną karierę) jawi się jako kolejny, obok zabójstwa Rathenaua, anachronizm, świadczący znowu na niekorzyść przytaczanej przez reżysera wersji. Przecież najsławniejszy, kulminacyjny moment kariery gangu Capone - zmitologizowana przez kino i kulturę popularną masakra w dniu św. Walentego (14 lutego 1929) - miał nadejść dopiero za kilka lat. Co nie wyklucza oczywiście, iż roaring twenties w Stanach jednak przypominają w wielu aspektach (zwłaszcza przestępczego półświatka, kultury masowej i „wyzwolonej” obyczajowości) tę samą dekadę w tańczącym na wulkanie Berlinie. Jak pisze Thomas Elsaesser, „Langowski «portret epoki» z jej atmosferą bezwzględnego, dynamicznego rozprzężenia, raczej dobrze przystaje do obrazu, jaki wciąż posiada się o Berlinie w bajecznych latach dwudziestych, choć kiedy film miał premierę w 1922 r., dekada ta ledwie się rozpoczynała"44.

${ }^{41}$ Ibidem, s. 157. Jednak w wywiadzie dla Gero Ganderta z 1963, przytaczanym przez Lotte Eisner (op. cit., s. 67), Lang określa Chavrola, prototyp doktora Mabuse, jako złodzieja samochodów.

${ }^{42}$ Por.: Patrick McGilligan, op. cit., s. 82; L. Eisner, op. cit., s. 67.

${ }^{43}$ W oryginale: "Club $17+4$ ".

44 T. Elsaesser, op. cit., s. 157. 


\section{Serial w dwunastu aktach}

Sławny i władający zbiorową wyobraźnią przestępca istotnie jednak zainspirował zarówno Langa, jak i Norberta Jacques'a, choć nie był nim raczej Al Capone ani w ogóle żadna postać rzeczywista. Nazywał się Fantomas i był płodem wyobraźni spółki francuskich autorów, Pierre'a Souvestre'a i Marcela Allaina, którzy w 1911 rozpoczęli publikację powieści w odcinkach o wyczynach nieuchwytnego superprzestępcy; nowe przygody Fantomasa ukazywały się co miesiąc przez 32 miesiące, przy czym kolejne rozdziały pisali na zmianę Souvestre i Allain ${ }^{45}$. Tom Gunning przytacza jeden z początkowych fragmentów powieści Souvestre'a i Allaina, unaoczniający, iż Fantomas jest, podobnie jak Mabuse, potencjalnym signifiant, pustym miejscem, w które wpisać można wszelkie zło czy przestępczość współczesności ${ }^{46}$. W roku 1913 Louis Feuillade, francuski reżyser pracujący dla kompanii Gaumonta, zrealizował serial kinowy $\mathrm{w}$ pięciu częściach, opowiadający o wyczynach Fantomasa. O jego wpływie na film Langa wyraźnie świadczą trzy rzeczy:

1. Plakat reklamowy Doktora Mabuse, gracza wypuszczony przez kompanię Decla-Bioskop, autorstwa Teo Matejki; ikonografią swą - Mabuse w cylindrze, fraku i eleganckim płaszczu górujący niczym Godzilla nad miastem u jego stóp - nawiązuje on zarówno do okładki pierwszej książki o Fantomasie, jak i plakatu do serialu Feuillade'a, autorstwa Gina Starace ${ }^{47}$.

2. Przywołane już otwierające ujęcie dłoni Mabusego tasujących niczym karty fotografie z jego rozmaitymi wcieleniami; ewokuje ono, jak zauważa Gunning, dwa typy początków filmu popularne w dwóch pierwszych dekadach kina - plan emblematyczny i prolog aktorski. P l a n e $\mathrm{m}$ b l e $\mathrm{m}$ a t y c z n y, nie przedstawiając jakiegoś konkretnego zdarzenia fabuły, syntetycznie ujmuje jej „istotę", „kwintesencję” (w filmie Langa jest to obraz dwóch aspektów tytułowego słowa Spieler: zarazem "gracza” w karty i „aktora” przybierającego rozmaite tożsamości). P r olo g a ktorski - popularny w połowie lat 10., a dziś znany głównie z seriali telewizyjnych, zwłaszcza telenowel - przedstawia aktorów właśnie jako aktorów odtwarzających daną rolę w filmie i tym samym jest elementem niediegetycznym filmu, należąc nie do świata przedstawionego,

45 Por.: D. Kalat, op. cit., s. 9.

46 „-Fantomas - Co powiedziałeś? - Powiedziałem: Fantomas - A cóż to znaczy? - Nic... Wszystko! - Ale kto to jest? - Nikt... a jednak, tak, jest to ktoś! - A cóż ten ktoś robi? - Szerzy Terror!" (Marcel Allain, Pierre Souvestre, Fantomas, William Morrow, New York 1986, s. 11; cyt. za: T. Gunning, op. cit., s. 95).

47 Porównanie okładki książki oraz plakatów serialu Feuillade’a i filmu Langa przeprowadza David Kalat (op. cit., s. 10-12). 
a do formalnej „ramy” (jak czołówka czy ewentualnie napisy końcowe). W swym Fantomasie Feuillade posłużył się prologiem aktorskim nie tylko dla przedstawienia odtwórców głównych ról, ale i dla pokazu rozmaitych przebrań wykorzystanych przez tytułowego superprzestępcę - co z pewnością musiało zainspirować Langa ${ }^{48}$.

3. Sama formuła serialu, która w filmie Langa wyraża się nie tyle podziałem olbrzymiego materiału na dwie pełnometrażowe części, co podziałem każdej z nich na 6 „aktów” (jak głoszą napisy; oczywiście, nie chodzi tu o akt w rozumieniu technicznym, jako szpulę filmu); każdy z tych aktów zawiera jakąs partię fabuły wyraziście powiązaną $\mathrm{z}$ aktem poprzednim i następnym (co stanowi o ciągłości fabularnej), lecz zarazem względnie samodzielną (co przesądza o wrażeniu odbiorcy, iż konstrukcja jest epizodyczna i dość luźna). Wyrazem zarówno ciągłości, jak i epizodyczności, są zakończenia każdego z aktów: zbliżając się do tzw. cliffhanger endings, pozostawiających którąś $\mathrm{z}$ postaci $\mathrm{w}$ bezpośrednim niebezpieczeństwie, pobudzają suspens i zaciekawienie widza dalszym ciagiem, a dobitnie dopełniając zdarzenia danego aktu jakąś dramatyczną kropką nad „i", np. śmiercią jakiejś innej postaci, zarazem czynią z aktu względnie samoistną całostkę dramaturgiczna, poruszającą swym tragizmem. Wyraźna nić ciaggłej akcji fabularnej łączy - mimo rozbicia na epizody akty od drugiego w I części filmu po ostatni akt części II. Wyjątkiem jest właśnie akt pierwszy - przedstawiona w nim historia spekulacji giełdowej Mabusego przeprowadzonej dzięki kradzieży i „odnalezieniu się” szwajcarsko-holenderskiego kontraktu handlowego - nie ma związku z przebiegającą przez następne epizody intrygą kryminalną, w którą uwikłani są prokurator von Wenk, Hull, Carozza i hrabiostwo Told. Akt I służy jako efektowny prolog, unaoczniający precyzję działań i potęgę Mabusego.

Prześledźmy może budowę "serialu” Langa, przedstawiając zawartość fabularną jego poszczególnych aktów-odcinków i akcentując dramaturgiczne pointy każdego z nich.

Część I. Akt 1. Z „talii” fotografii pokazujących rozmaite swe przebrania Mabuse losowo wybiera jedną (elegancki starszy pan, noszący się „z rosyjska”) i przekazuje służącemu, Spoerriemu, z zadaniem przygotowania odpowiedniej charakteryzacji. Przy okazji beszta Spoerriego za nadużywanie kokainy. Mabuse spogląda niecierpliwie na zegarek. W tym czasie jego ludzie przeprowadzają starannie obmyśloną i precyzyjnie zsynchronizowaną akcję: Georg napada w przedziale międzynarodowego pociągu kuriera przewożącego tajną szwajcarsko-holenderską umowę handlowa, wyrzuca teczkę ze skradzionym dokumentem przez okno, a ta ląduje dokładnie na siedzeniu przejeżdżającego pod wiaduktem

${ }^{48}$ Por.: T. Gunning, op. cit., s. 99-100. 
kolejowym samochodu, który prowadzi inny z ludzi Mabusego. Kierowca, widząc powodzenie akcji, dmie $\mathrm{w}$ róg, a przebrany za robotnika naprawiającego linię telefoniczną i usytuowany na jej słupie inny uczestnik akcji, dzwoni do Mabusego, powiadamiając go o sukcesie. Georg w tym czasie wyskakuje z pociagu. Mabuse pisze coś na dostarczonych mu przez Spoerriego szwajcarskich banknotach i wysłuchuje raportu Pescha o notowaniach platyny i jakichś międzynarodowych transportach bawełny (nie jest jasne, o co tu chodzi, ale odnosimy wrażenie, iż Mabuse ma nielegalną kontrolę nad interesami na olbrzymia, europejską skalę). Beszta Pescha za 10-minutowe spóźnienie i ostrzega go przed powtarzaniem się takich zaniedbań. W przebraniu starego, bogatego „Rosjanina” w futrzanej czapie Mabuse wychodzi i na progu swego domu daje jako „datek” do kapelusza jednonogiemu żebrakowi o kulach podpisane uprzednio banknoty - to zapłata za akcję (nie dziwne, iż w dobie inflacji w obcej walucie) czy może jakieś tajne instrukcje, przekazane $\mathrm{w}$ „,konspiracyjny” sposób? ${ }^{49}$ Samochód Mabusego-„,Rosjanina” zderza się z innym wozem, co okazuje się tylko zaaranżowanym celowo (ale właściwie po co?) wypadkiem, dzięki któremu „poszkodowany” starszy pan, czyli Mabuse, przesiada się do samochodu winowajcy, a tam zapoznaje się ze skradzionym dokumentem. W samochodzie instruuje Spoerriego, by wydania specjalne, wpierw obwieszczające kradzież umowy, a następnie wiadomość o jej odnalezieniu, we właściwym momencie trafiły na giełdę. W kwaterze przestępców Pesch skarży się Georgowi na tempo pracy dla Mabusego („,200 km/h - to nowoczesne ludożerstwo!"), a Georg, człowiek silny i faworyt szefa, daje do zrozumienia nerwowemu słabeuszowi, że istnieje jeszcze „wydział likwidacji”. W ponurym zaułku samochód wyrzuca Mabusego w przebraniu „plebejskim”, wystylizowanym nieco „z francuska”. Mabuse i pracująca dlań Fine odgrywają na pustej ulicy (właściwie przed kim?) komedię „powrotu pijanego plebejusza do domu”, przy czym Fine „niepostrzeżenie”, w rzuconym „w gniewie" kłębku wełny przekazuje szefowi klucz. Dzięki niemu Mabuse wchodzi do prowadzonej przez grubasa Hawascha tajnej wytwórni pieniędzy, w której produkcją fałszywych banknotów zajmują się ślepcy. Mabuse wydaje instrukcje, by tak długo, jak waluta europejska będzie opadać, produkować wyłącznie banknoty dolarowe.

49 Ten niejasny moment filmu tak interpretuje Noël Burch: „Mabuse używa prawdziwych banknotów jako papieru do pisania, a banknotów fałszywych jako pieniędzy. Pisanie na banknotach stawia Doktora poza porządkiem społecznym przynajmniej w tym samym stopniu co fabrykowanie fałszywych. Wiadomość, jaką zapisuje, niewątpliwie jest zakodowana, a w każdym razie jest nieczytelna... ale znów, jak zawsze, materia opowiadania jest mało istotna: to, co się liczy, to archetypowe, symboliczne gesty, urzeczywistnione przez postęp opowiadania" [Noël Burch, Notes on Fritz Lang's First Mabuse, "Ciné-Tracts" 1981, vol. 4, no. 1 (Spring), s. 5]. 
Nadzwyczajny dodatek gazety obwieszcza kradzież dokumentów i obawy, że możliwość wycofania się z kontraktu Szwajcarii po upublicznieniu danych, postawi w trudnej sytuacji holenderskie koncerny kawowe i kakaowe. Wiadomość wywołuje gwałtowną wyprzedaż akcji, w wyniku której notowania zaangażowanych spółek spadają kilkunastokrotnie. Gdy bessa osiąga dno, Mabuse (w postaci eleganckiego biznesmena w cylindrze) skupuje akcje po najniższym kursie. Kolejny dodatek nadzwyczajny obwieszcza odnalezienie się zaginionych dokumentów „nietkniętych” - ktoś rozrzuca istny deszcz jego egzemplarzy pośród giełdowych graczy. Notowania zaczynają gwałtownie rosnąć. Mabuse, spokojny, nieruchomy niczym skała pośród rozgorączkowanych graczy, odmawia sprzedaży pożądanych walorów. Decyduje się wreszcie na sprzedaż, gdy przebicie jest kilkunastokrotne i na chwilę przed tym, jak giełdowy zegar (o 24-godzinnej tarczy) obwieści godzinę zamknięcia giełdy. Ostatni obraz tego prologu przedstawia opustoszały parkiet gieł$\mathrm{dy}, \mathrm{z}$ walającymi się wszędzie rozrzuconymi papierami (egzemplarze drugiego ekstradodatku), na który zostaje nałożona w podwójnej ekspozycji olbrzymia twarz Mabusego, niewątpliwego zwycięzcy przedstawionej sesji.

Akt 2. Wieczór. Dr Mabuse, psychoanalityk, wygłasza odczyt „Psychoanaliza jako czynnik w nowoczesnej terapii", w którym przedstawia opinię, iż 80\% wszystkich chorób nerwowych będzie leczonych przez psychoanalizę pod warunkiem, że wyeliminuje się jakikolwiek wpływ czynników zewnętrznych na relację lekarz - pacjent. Klub „Folies Bergères”: zblazowana publiczność - głównie męska - przyjmuje bez entuzjazmu występ na estradzie nagiej dziewczyny w tableau ewokującym Narodziny Wenus Botticellego (wyjątkiem jest podekscytowany i strofowany przez żonę prowincjusz). Podczas kolejnego występu - Cary Carozzy, "sensacji wieczoru" - przybywa do lokalu Mabuse, w nowym przebraniu: tym razem starszego pana z obfitym wąsem (zmiany charakteryzacji dokonał w samochodzie, w drodze z wykładu). Gdy na scenie Carozza odgrywa znalezienie się $\mathrm{w}$ kleszczach dwóch ekspresjonistycznych monstrów, Mabuse w swej loży czyta notatkę, lokalizującą mu lożę jego ofiary - Edgara Hulla, jedynego syna bogatego przemysłowca, spadkobiercy olbrzymiej fortuny, członka ekskluzywnego „Klubu Oczko”. Mabuse obserwuje Hulla przez lornetkę. Carozza w swym występie wydaje się triumfować nad monstrami, tańcząc na ich olbrzymich, fallicznych nosach, ale nagły podmuch zwiewa jej górę ubrania. Gdy półnaga, zasłaniając się, kończy występ, nagradzają go rzęsiste brawa męskiej publiczności - zwłaszcza Hulla i starszego Raffkego. Po swym numerze, zasypywana na 
estradzie kwiatami, Carozza tuli w ramionach wielkie dzieciątko-lalkę ${ }^{50}$. Obojętny na sukces, jak już wkrótce będzie dla widza jasne, swej kochanki i agentki, Mabuse przeszywa wzrokiem Hulla, który pod wpływem jego spojrzenia odczuwa bóle karku i głowy. Zahipnotyzowanego Hulla, który chciał porzucić swoje towarzystwo i udać się do domu, Mabuse zaczepia w wyjściu i skłania do wzięcia ze sobą do „Klubu Oczko”. Gdy Hull wprowadza nowego „znajomego” (jako pana "Hugona Ballinga”) do tej ekskluzywnej jaskini hazardu, Carozza w swej garderobie wśród bukietów od wielbicieli znajduje - z nadzieją - bilecik od Mabusego, zawierający - ku jej rozczarowaniu - jedynie instrukcję, by stawiła się $\mathrm{w}$ zarezerwowanym dla niej pokoju 111 w Hotelu Excelsior. W „Klubie Oczko" Hull przegrywa do „pana Ballinga” ,jak szalony”. Wskazówki stylowego zegara w klubie przesuwają się na piątą rano. O tej godzinie Hull - wbrew radom członków klubu - decyduje się zagrać va banque. Mimo iż ma w ręku najlepsze z możliwych kart - dziesiątkę i asa - pod wpływem spojrzenia Mabusego rzuca karty, uznając się za pokonanego. Niezdolny do zapłacenia od razu całej sumy, prosi „pana Ballinga” o wizytówkę i o przyjęcie rewersu na 150 tys. marek długu. Po wyjściu Mabusego Hull przytomnieje: „Grałem... przegrałem... Z kim właściwie?" Znajomi z klubu odkrywają jego zwycięskie karty, które uznał za przegrywające. Na zamykający ten akt obraz skonsternowanego Hulla i jego znajomych klubowiczów nakłada się (w podwójnej ekspozycji) dana przez Mabusego wizytówka: „Hugo Balling, Hotel Excelsior, pokój 112".

Akt 3. Nazajutrz w pokoju 112 Hotelu Excelsior Hull, który przyszedł tam, by spłacić swój karciany dług „panu Ballingowi”, odkrywa, iż mieszkający tam człowiek o tym nazwisku to ktoś całkiem inny niż jego wierzyciel (prawdziwy Hugo Balling sprawia wrażenie bogatego prowincjusza, niemogącego otrząsnąć się z kaca po nocnych wyczynach w metropolii) $^{51}$. Nasłuchująca w pokoju 111 Carozza spotyka "przypadkiem”

50 „Jakaż wizualna ironia w obrazie Carozzy, dziękującej entuzjastycznej publiczności, z olbrzymią lalką w ramionach - «dzieckiem, którego nigdy nie będzie miała», ani od Mabusego, ani od Hulla" (N. Burch, op. cit., s. 7). A swoją droga świat filmu Langa to świat bez dzieci - zatem: bez przyszłości. Nie mają dzieci Toldowie, smętny i pusty wydaje się bez nich ich pałac, podobnie zresztą jak ogromne, bogate mieszkania Hulla i Mabusego. Jedyne dziecko w filmie to boy w Hotelu Excelsior.

51 Raffkem mógł być zarówno ktoś gwałtownie wzbogacony na rozmaitych legalnych i nielegalnych interesach doby wojny i inflacji (vide: przedstawiony w tym samym ",akcie” Schramm), jak i profitujący z horrendalnych cen żywności w tej epoce rolnik, zamieniający - jak głosiła fama w głodujących miastach - swą izbę w salon z pianinem i orientalnymi bibelotami albo szastający pieniędzmi w lokalach i domach publicznych metropolii (por.: B. Widdig, op. cit., s. 86-87, 208-211). Takim wzbogaconym prowincjuszem wydaje się i (prawdziwy) Hugo Balling, i gość „Folies Bergères” zachwycony Narodzinami Wenus. 
w korytarzu Hulla i opuszcza hotel na tyle wolno, by podekscytowany Hull zdążył jej oddać upuszczoną „przypadkiem” chusteczkę. Opadające kartki kalendarza unaoczniają czas, jaki upłynął od owego dnia (9 listopada) do tego, kiedy Hull niecierpliwie oczekuje u siebie Carozzy, a zamiast niej przychodzi doń najpierw prokurator von Wenk (27 listopada). Prokurator, wiedząc o przegranej Hulla, mówi mu o swych podejrzeniach, iż mógł on paść ofiarą tego samego przestępcy, który obrabował innych graczy. Wenk przypuszcza, iż za rozmaitymi tożsamościami zwycięzców nieprawdopodobnych wygranych w rozmaitych kasynach może kryć się jeden i ten sam człowiek (te jego słowa kontrapunktuje przebitka pokazująca, jak Mabuse w swym laboratorium pobiera jad z zębów jadowych węża). Wenk, przekonany iż tajemniczy „pan Balling” przedstawi jeszcze Hullowi do zapłaty ów rewers z "Klubu Oczko”, prosi Hulla o współpracę i dyskrecję, ale nieuważny Hull jest już myślami przy czekającej go wizycie Carozzy, na cześć której zbudował w pokoju miniołtarzyk. Tymczasem Mabuse ignoruje żałosną skargę zakochanej Carozzy („czy jest już dlań tylko narzędziem?”) i gromi ją za spóźnianie się na randkę z Hullem. U Hulla Carozza mija się z Wenkiem i chwilę po euforycznym powitaniu z "ukochanym" odkrywa zostawioną przez prokuratora okręgowego wizytówkę. Ostrzega Hulla, by ta niebezpieczna znajomość nie wpędziła ich w tarapaty. Następuje teraz krótka, ale efektowna sekwencja montażowa, składająca się z dwóch części. Pierwsza pokazuje w kilku ujęciach bieżący stan posiadania Emila Schramma, właściciela luksusowej restauracji o ekspresjonistycznym wystroju („Grill Schramma”), ekskluzywnego lokalu z jazz-bandem i parkietem do artystycznych występów ${ }^{52}$ („Palais Schramma”) oraz zakamuflowanego domu gry („cercle privat" Schramma). Druga część tej sekwencji w serii krótkich retrospekcji przedstawia karierę właściciela: w 1912 wędrownego handlarza ulicznego, w latach 1913-1918 urzędnika siedzącego za górami teczek i papierów, w 1919 eksperta szacującego dawane przez Żyda do wyceny brylanty, w 1922 Raffkego w ekskluzywnym lokalu liczącego grube pliki pieniędzy, palącego cygaro i zapijającego szampanem ${ }^{53}$. W "Grillu Schramma” widzimy za

${ }^{52} \mathrm{Na}$ tym parkiecie widzimy przebraną w męski smoking, zmaskulinizowaną "chłopczycę", stepującą w rytm amerykańskich melodii - niewątpliwy signum temporis "Szalonych lat 20.".

53 Scenka z 1919 wydaje się nawiązywać do ukazanej we wcześniejszym filmie Langa Walczace serca (Kämpfende Herzen, 1920) "giełdy brylantów” (Brillantenbörse). Data "1922” pojawia się w wieńcu laurowym, na planszy, na której widnieje także napis: „Handwerk hat goldenen Boden" - „Rzemiosło ma złote podłoże”, w oczywisty sposób ironiczny. Rzecz jasna, Emil Schramm to Raffke wręcz modelowy. Bernd Widdig zwraca uwagę na niemal „Brechtowski” efekt tej sekwencji, przerywającej płynny tok fabuły (op. cit., s. 115). Interesująca jest też nieścisłość datowania: skoro $\mathrm{w}$ akcji filmu jest listopad, data 
stolikiem Wenka i delegowanego do penetracji podobnych lokali policyjnego agenta, Karstena. Za tajemniczą nieznajoma, przechodzącą przez restaurację, podążają oni do „cercle privat”, gdzie już na dobre trwa gra (przy stole są m.in. Hull, Carozza i Mabuse we wcieleniu "młodego blondyna”). Hull wita prokuratora, Carozza spojrzeniem wskazuje Wenka Mabusemu. Karsten przedstawia Wenkowi znaną w kręgach graczy jako „nieaktywna" nieznajomą (później dowiemy się, iż to hrabina Told). Hrabina, spoczywając na szezlongu, obserwuje grę z daleka; zwierza się prokuratorowi ze swej potrzeby wyjątkowych doznań, aby ożywić "zastygła krew" i znieść życie, ale zarazem mówi, iż namiętności gry woli oglądać w lustrze innych, studiując charaktery. Uwagę ich przyciąga reakcja na przegraną bogatej Rosjanki, która postawiła w grze perły za 50 tys. \$ od Tiffany'ego. Obwinia ona za przegraną trzymającego w trakcie gry bank Mabusego, przez którego nie mogła dobrać kart: „Spojrzał na mnie swoimi złymi oczami - jak diabeł... jak drapieżny zwierz". Obwiniany zdążył się już ulotnić z łupem. Hrabina, zauważywszy męża, który niespodziewanie znalazł się na sali w towarzystwie jakiegoś mężczyzny, prosi Wenka o pomoc w niepostrzeżonym wymknięciu się. Wenk gasi światło. Carozza usiłuje zapobiec ucieczce hrabiny, ściera się z Wenkiem. Kelner, który wywołuje Hulla, przekazuje mu wiadomość od „pana Ballinga”, przypominającego swój dług i żądającego jego spłaty, gdyż minął już jej termin (21 listopada, godz. 16): „Gra to gra. To sprawa między mną a panem, bez prokuratora". Hull pokazuje wiadomość Wenkowi, a Carozza z triumfem i pogardą przygląda się przygnębionemu „ukochanemu".

Akt 4. Nazajutrz rano: Wenk u Hulla ostrzega go przed Carozza, która, zadomowiona u milionera, podsłuchuje to z pokoju na górze. Wenk w swym biurze - przymierza perukę i sztuczne wąsy, szykując się do odwiedzenia incognito tajnych kasyn, których listę zleca Karstenowi wydobyć od Carozzy. Zaproszony na piątą przez hrabinę Told, podziwia w salonie zgromadzoną przez hrabiego imponującą kolekcję dzieł sztuki nowoczesnej i egzotycznej (dominują ekspresjonizm i kubizm). Gdy hrabina jeszcze raz mówi o potrzebie wrażeń i sensacji, by zabić nudę i martwotę swego

na planszy powinna obwieszczać rok 1921, a nie 1922 (listopad 1922 w chwili premiery filmu był przyszłością). Ale to datowanie „listopad 1922” jest prorocze, jeśli uznać karierę Schramma i w ogóle cały film za alegorię inflacji: latem 1922, mniej więcej 3 miesiące po premierze filmu, nastąpił olbrzymi skok ilościowy i jakościowy - niemiecka inflacja przerodziła się w galopującą w zastraszającym tempie i porażającą astronomicznymi liczbami hiperinflację, o czym świadczy porównanie średniego miesięcznego kursu dolara do marki w różnych momentach: 1 : 4,2 (styczeń - wrzesień 1914), $1: 262,96$ (listopad 1921), $1:$ 493,22 (lipiec 1922), 1 : 1134,56 (sierpień 1922), $1: 4620455$ (sierpień 1923), 1 : 25,2 mld (październik 1923), $1: 4,2$ biliona (grudzień 1923). Bilion to $10^{12}$, jedynka z dwunastoma zerami. Por.: B. Widdig, op. cit., s. 37. 
życia, Wenk namawia ją do wielkiej przygody - współpracy w zdemaskowaniu wielkiego i niebezpiecznego przestępcy. Hrabina zgadza się warunkowo, żądając jakiegoś dowodu. W tym samym czasie Carozza ostrzega przed Wenkiem Mabusego, wywołując atak jego wściekłości. Hrabina przedstawia prokuratora mężowi, który właśnie się zjawił, a zatroskana Carozza mówi Mabusemu na odchodne: „Bawisz się pieniędzmi, ludźmi, losami... Najokropniejsze, że sobą samym". Wenk otrzymuje od Karstena listę tajnych domów gry z adresami i hasłami. Wieczorem udaje się $\mathrm{w}$ przebraniu do „Palais Andalusia”, którego restauracja o florealno-secesyjnym wystroju jest przedsionkiem mocniejszych wrażeń. Na hasło „Ananas” kelner zadaje Wenkowi pytanie: „Kokaina czy karty?”, a następnie prowadzi go przez podwórze do zakamuflowanej w jakimś mieszkaniu szulerni, której wnętrze tonie w oparach dymu. Od jednego ze stolików odchodzi załamany i zgrany gracz, łapiąc się za tył głowy (ten gest wskazuje, iż zapewne to ofiara Mabusego). Jego miejsce zajmuje Wenk, ostentacyjnie kładąc przed sobą gruby plik banknotów. Przebrany za trzęsącego się starca i trzymający, jak zwykle, bank Mabuse, oczywiście zauważa przynętę. Za jego plecami czuwają Spoerri i Hawasch. Rozpoczyna się gra, podczas której Mabuse usiłuje zahipnotyzować Wenka przy pomocy chińskich okularów z Tsi-Nan-Fu. Wenk jednak nie ulega, a Mabuse, uświadamiając sobie, że ma do czynienia z niebezpiecznym przeciwnikiem, udaje wyczerpanie i wymyka się z lokalu. Ludzie Mabusego usiłują powstrzymać prokuratora (w lokalu w wybucha ogólne zamieszanie), ale w końcu Wenkowi udaje się nie stracić z oczu swego przeciwnika i dorożką oraz samochodem podąża za wozem Mabusego do Hotelu Excelsior. W pokoju 321, jak informuje Wenka hotelowy boy, mieszka ",holenderski profesor". Zmylony przez wystawione przed drzwiami tego numeru damskie kozaki, Wenk odstępuje od drzwi i udaje się do recepcji zasięgnąć informacji, co umożliwia Mabusemu wymknięcie się w tym samym czasie z hotelu w charakteryzacji kierownika hotelowej kancelarii. „Kierownik” wydaje czekającemu przed hotelem Georgowi polecenie, by zmienić numery rejestracyjne wozu i coś tam zainstalować, po czym gdzieś znika. A Wenk i służba hotelowa odkrywają pusty pokój 321 i to, że szef kancelarii w ogóle jej nie opuszczał. Przed hotelem zrezygnowany Wenk wsiada do "taksówki", prowadzonej przez... Georga, który odizolowany od kabiny pasażera wpuszcza do niej obezwładniający gaz. Wenk na tylnym siedzeniu pada nieprzytomny.

Akt 5. Rano Wenk budzi się na łódce dryfującej na środku jeziora. Mabuse zirytowany pije whisky, w przyniesionych przez Georga papierach Wenka odkrywa listę tajnych kasyn i haseł do nich (uświadamia sobie istnienie "wtyczki"), beszta Spoerriego i Hawascha za wymknięcie się Wenka z „Andalusii”, a gdy przychodzi Carozza, obwieszcza, iż Hull 
i Wenk muszą zniknąć. Wykonawcą ma być Georg, Spoerri i Hawasch pomocnikami, a Carozza rzecz zaaranżuje. Wenk, uratowany przez rybaków, po powrocie do biura zastaje paczkę ze swymi rzeczami zwróconą mu przez Mabusego. Rozentuzjazmowana Carozza wpada do Hulla, by powiedzieć, iż koniecznie muszą być wieczorem na otwarciu nowego fantastycznego lokalu. Ze zgubionej przez Carozzę - znowu „przypadkiem”? kartki, Hull dowiaduje się, iż „ukochana” celowo wabi go na wieczór z polecenia kogoś, kto nie życzy sobie obecności tam Wenka. Gdy Mabuse instruuje swych ludzi co do szczegółów planu, Hull dzwoni do Wenka, który radzi mu iść z Carozza, nie wzbudzając jej podejrzeń, a sam zapewnia o zagwarantowaniu na miejscu ochrony. Wenk dzwoni do hrabiny, ale od służącego dowiaduje się, iż hrabiostwo zostali na wieczór zaproszeni na seans spirytystyczny. W zakamuflowanym na Haydnstraße 11 "Casino Petit” (hasło: „Mirabeau”), lokalu o secesyjno-mauretańskim wystroju, Hulla z Carozzą witają Wenk i Karsten. Carozza z przekąsem zauważa: „Wydaje się, jakby miał pan, panie prokuratorze, hasło «Sezamie, otwórz się!» do wszystkich tajnych lokali", a Hull ponuro i bez uprzedniej czułości patrzy na podekscytowaną "ukochaną". W kasynie loże gości usytuowane są na obwodzie koła, w którego środku spod podłogi wyłania się właściciel lokalu i do którego spływać będą rynienkami stawki graczy. Właściciel demonstruje gościom zaletę lokalu - w razie nalotu policji możliwość błyskawicznej zmiany wystroju z kasyna na lokal rozrywkowy z występami artystycznymi, co dokonuje się przez opuszczenie olbrzymiego żyrandola i jego przekształcenie $\mathrm{w}$,"estradę". Po tej demonstracji rozpoczyna się gra. W tym samym czasie (montaż naprzemienny) hrabina Told poznaje tuż przed rozpoczynającym się seansem spirytystycznym znamienitego psychoanalityka, doktora Mabuse. Seans nie udaje się, bo medium (egzaltowana dama w bieli) informuje o obecności jakiegoś obcego elementu. Rozbawiona hrabina uznaje, że to jej wina, odchodzi od stołu, a Mabuse jej towarzyszy. W rozmowie hrabina wyznaje niemożność zaspokojenia swego pragnienia wrażeń i odegnania nudy przez cokolwiek w świecie, a Mabuse przytakuje jej, mówiąc, iż „nic na świecie nie jest na dłuższą metę interesujące - prócz jednego: gry ludźmi i ludzkimi losami”. Hrabina informuje męża o zaproszeniu doktora na czwartek. Tymczasem Wenk wymyka się z "Casino Petit”, by ściągnąć tam policję, przykazując jednocześnie Karstenowi nie spuszczać Hulla z oka. Carozza, udając niepokój zniknięciem prokuratora, namawia Hulla i Karstena do opuszczenia kasyna, i w zaułku nieopodal lokalu wystawia obu na strzały Georga. Umierający milioner woła do Wenka, który za późno wrócił, by aresztować uciekającą Carozzę. Policja ją zatrzymuje, a zasępiony prokurator stoi nad martwymi ciałami Karstena i Hulla. 
Akt 6. Mabuse nie przejmuje się aresztowaniem Carozzy („,Co mnie teraz obchodzi Carozza? Niech zostanie tam, gdzie jest!" - odpowiada zatroskanemu o nią Spoerriemu). Za to na usunięcie Wenka daje on swym ludziom jeszcze tydzień. Carozzę Wenk odwiedza w areszcie, ale nic nie jest $\mathrm{w}$ stanie $\mathrm{z}$ niej wydobyć. Inwentaryzującemu swą kolekcję Toldowi hrabina mówi, że chciałaby odwołać zaproszenie Mabusego - sama nie wie, dlaczego go zaprosiła i dlaczego chciałaby to odwołać. Hrabia pociera tył głowy - to znak opanowania już jego woli przez wolę Mabusego. Mabuse zleca Peschowi dostarczenie planu pałacu Toldów, sam zaś wydaje się opętany myślą o hrabinie, dla której każe przygotować Spoerriemu owalny pokój, dotąd zamieszkany przez Carozzę. Tymczasem Wenk prosi hrabinę o pomoc - ma ona "dać się aresztować” i w rozmowie „jak kobieta z kobietą" wydobyć co tylko się da od Carozzy. Wieczorem w policyjnym areszcie: zatrzymana rzekomo podczas nalotu u Schramma hrabina trafia do celi Carozzy. Jest jednak na tyle niezręczna, by Carozza bez trudu przejrzała jej grę. Carozza w euforii wykrzykuje hrabinie: „Nikt nie wie, kim on jest. Ale on jest! Żyje! Wznosi się nad miastem potężny jak wieża. On jest potępieniem i zbawieniem. On jest największym żyjącym człowiekiem! I on mnie pokochał!" Poruszona zakochaniem Carozzy, a tym samym odkryciem istnienia nieznanego jej dotąd uczucia miłości, hrabina prosi Carozzę o wybaczenie, a Wenkowi śle list, w którym informuje go o rezygnacji ze współpracy. Czwartkowe przyjęcie u Toldów - kolekcja hrabiego jawi się podczas niego w całym swym przepychu (zwraca zwłaszcza uwagę wiszący nad kominkiem ekspresjonistyczny obraz demona, rzucającego z oczu promienie, przy którym, niczym przy ołtarzu Lucyfera, stoi Mabuse). Zapytany przez Tolda, jak mu się podoba ekspresjonizm, Mabuse daje swą wielekroć potem komentowaną przez krytyków definicję: „Expressionismus is Spielerei... Aber warum auch nicht? Alles ist heute Spielerei-!"' Jakby pod wpływem tej odpowiedzi i wzrokowej sugestii Mabusego hrabia ze swym towarzystwem przechodzi do stołu gry. Hrabina w rozmowie z doktorem wyraża zdziwienie, iż mąż zasiadł do gry, bo nigdy nie grał. Następnie zwierza się ze swego poruszenia odkryciem rzeczy, w którą nie wierzyła - miłości. Mabuse z pogradą replikuje: „Nie ma żadnej miłości... jest tylko pożądanie! Nie istnieje żadne szczęście - tylko wola mocy!” Aby dowieść mocy swej woli, Mabuse hipnotyzuje Tolda, który łapie się za kark, a następnie oszukuje w kartach, na czym łapie go jeden z graczy z okrzykiem „Szuler!” Zgorszeni gracze odchodzą od stołu, goście gremialnie opuszczają salon, a w ogólnym zamieszaniu Mabuse unosi zemdloną hrabinę do stojącego przed pałacem auta z Georgiem za kierownicą. W opustoszałym salonie idący bezwolnym krokiem hrabia nie może zrozumieć, co się stało, a Mabuse w swym apartamencie rzuca hrabinę na fantazyjne łoże w owalnym pokoju, z okrzykiem: „Moja!” 
Część II. Akt 1. „Ludzie, którzy nie mogą spać” - głosi nam otwierający ów akt napis, a montaż symultaniczny przenosi nas między tymi ludźmi: Carozzą w jej celi, hrabią Toldem w opustoszałym pałacu, Wenkiem w swym biurze czytającym list hrabiny, Mabusem w dzikiej pijatyce świętującym ze swymi ludźmi sukces. Śpi natomiast hrabina, uwięziona w owalnym pokoju. Wenk zauważa z okna moknącego na deszczu hrabiego i wprowadza go do biura. Told zwierza się, iż oszukał w grze wbrew swej woli, a retrospekcja unaocznia nam jeszcze raz sytuację przyłapania hrabiego przez gracza. Indagowany przez prokuratora Told wyznaje, iż znał wszystkich gości prócz jednego: psychoanalityka, którego zaprosiła żona. Hrabia przypuszcza, że nie mogąc znieść jego hańby, żona opuściła go, udając się do matki. Rozbudzona hrabina nie rozumie, gdzie się znajduje i bezskutecznie próbuje wydostać się z owalnego pokoju. „Te drzwi otwierają się tylko wtedy, gdy ja tego chcę!" - odbiera jej nadzieję Mabuse, gotów już do gwałtu. Ale przerywa mu Spoerri, anonsując telefon hrabiego, który z biura Wenka dzwoni, by poprosić doktora o kurację. Mabuse umawia się z Toldem w jego pałacu nazajutrz o jedenastej.

Akt 2. Carozza z policyjnego aresztu zostaje przewieziona do więzienia dla kobiet, czego świadkiem na dziedzińcu komisariatu jest m.in. jakiś mętny typ. O godzinie jedenastej Mabuse udziela Toldowi konsultacji, godząc się na leczenie hrabiego pod warunkiem, iż ten całkowicie odizoluje się od otoczenia, nie kontaktując się ani osobiście, ani telefonicznie z nikim, kto przypominałby mu wcześniejsze życie. W obecności doktora hrabia wydaje służącemu stosowne polecenia; toteż gdy dzwoni Wenk z wieścią dla Tolda, iż jego żony nie ma u matki, służący odpowiada, iż oboje państwo wyjechali. Mabuse w przebraniu wędrownego żydowskiego przekupnia odgrywa w zaułku nieopodal „wytwórni” Hawascha komedię przed jakąś dziewczyną w oknie, oferując jej korale, po czym „przypadkiem” napotyka Georga i Fine, przed którymi odgrywa ciąg dalszy. Fine ukradkiem dostarcza mu przekazaną przez brata wiadomość o przeniesieniu Carozzy do więzienia dla kobiet, podając nawet numer celi. W swej "fabryczce” Hawasch demonstruje "Żydowi" środki bezpieczeństwa: właz w podłodze, który od dołu można otworzyć nawet kciukiem, zaś bez klucza nie do otwarcia od góry. W trakcie tej inspekcji Mabuse rozkazuje Fine ubrać się porządnie i zgłosić u niego w domu - zapewne do usług i strzeżenia hrabiny. Hrabina, w swym owalnym więzieniu, grozi Mabusemu tym, że upomną się o nią jej „przyjaciele". Mabuse znów odbiera jej nadzieję: prokurator Wenk nie nacieszy się długo swym życiem (przebitka na Pescha i Georga, przygotowujących bombę zegarową) $)^{54}$, a mąż hrabiny znajduje się „pod jego opieką lekarską”. W kobiecym więzieniu Georg przebiera się w mundur współpracującego

${ }^{54}$ Jeszcze jeden Langowski zegar - dość co prawda szczególny. 
z gangiem strażnika. Gdy Wenk usiłuje zmiękczyć Carozzę w jej celi sugestia, że może jakaś inna kobieta zajęła miejsce w sercu jej mocodawcy, Pesch pod pretekstem sprawdzenia instalacji elektrycznej podrzuca bombę $\mathrm{w}$ biurze prokuratora. Carozza, zakochana w Mabusem, nie zamierza go wydawać, ale gra na zwłokę, prosząc Wenka o dwa dni do namysłu. Podsłuchuje to pełniący straż pod celą Carozzy Georg, który uznawszy, iż Carozza może sypać, zaraz informuje o tym szefa (wsiada, już w cywilnym ubraniu, do samochodu Mabusego, który wydaje mu rozkaz zlikwidowania kochanki i przekazuje truciznę). Pesch, który po podłożeniu bomby chciał się ulotnić z biura Wenka pod pretekstem pójścia po drabinę, nie zostaje wypuszczony stamtąd przez urzędników. Próbuje uciec przez okno, a gdy wchodzący do pokoju Wenka jego ludzie to spostrzegaja, ciska im pod nogi bombę, która wybucha i jednego z nich zabija. Pesch zostaje złapany na ulicy, a Wenk, który właśnie wrócił i szczęśliwie uniknął eksplozji, pokazuje mu ofiarę jego zamachu: „To będzie kosztować cię głowę, mój chłopcze. Na czyje polecenie to zrobiłeś?" Wenk zamierza przeprowadzić konfrontację Pescha z Carozza, ale jest już za późno: przebrany za strażnika Georg wymusza na Carozzy samobójstwo, przekazując jej truciznę. Carozza, rozumiejąc, że to wyrok Mabusego, łyka ją z rozpaczą i okrzykiem niedowierzania: „Ty?”

Akt 3. Wenk, przed zamierzoną konfrontacją odkrywa w celi zwłoki Carozzy. Wprowadzony tam Pesch woła w przerażeniu: „On ją zabił!”, nie chcąc jednak zdradzić tożsamości zabójcy. Wenk, planując jej wydobycie od więźnia w krzyżowym ogniu pytań, rozkazuje odwieźć Pescha na komendę policji pod podwójną strażą i inną niż zwykle drogą. Mabuse ucharakteryzowany jako „młody [sic!] działacz rewolucyjny" - w jakimś zadymionym lokalu z proletariacką klientelą nawołuje do uwolnienia „Johannesa Guttera”. Akcja przynosi wiadomy skutek: w ulicznym zamieszaniu, kiedy tłum z lokalu otoczył na ulicy policyjny powóz, ginie Pesch. Wenk dochodzi do wniosku, iż jego nieznajomy przeciwnik musiał mieć w więzieniu wspólników (skąd Carozza wzięła truciznę?), ale zamiast więźnia na przesłuchanie przybywa doń eskorta z wieścią o jego śmierci. Mabuse, po udanej akcji zlikwidowania Pescha, wyznaje hrabinie swe pożądanie (bo chyba jednak nie miłość, w którą nie wierzy) i proponuje jej wspólny wyjazd za granicę. "Jedzie pani ze mną dobrowolnie, czy jako więzień?" Gdy hrabina odmawia i wspomina o swym pragnieniu powrotu do męża, Mabuse obwieszcza: „Właśnie wydała pani na męża wyrok śmierci”. Noc, pałac Toldów - pijany hrabia zasiada do stołu, przy którym toczyła się feralna gra, razem z pięcioma widmowymi sobowtórami samego siebie. Z rozrzuconych na stole kart hrabia wyciaga asa, po czym ucieka do salonu przed widmami, które go ścigają. Gdy rzuca w nie kandelabrem, znikają. Rano hrabiego - ledwie przytomnego i poruszającego się jak somnambulik, otoczonego przez zastawę butelek na stole - odwiedza 
Mabuse. Jego „terapia” polega na wręczeniu przepitemu Toldowi kieliszka z alkoholem (hrabia wypuszcza go z rąk), poinformowaniu, że żona opuściła go na zawsze i zamierza go oddać do domu wariatów, wreszcie sugestii, iż nie chce już dalej żyć. Słysząc to, hrabia machinalnie przeciąga ręką po gardle. Wychodząc od Tolda, Mabuse mówi służącemu, iż hrabia koniecznie musi być teraz sam, gdyż każda przeszkoda mogłaby doprowadzić do katastrofy. Po odprowadzeniu doktora do drzwi, zaniepokojony służący udaje się do pokoju Tolda. Wybiega przerażony, dzwoni do Wenka i chwytając się za gardło, woła: „Brzytwą!”

Akt 4. Wenk w pałacu Toldów: służący przyznaje się mu do kłamstwa z polecenia hrabiego i zauważa, że z tym ostatnim było coraz gorzej, odkąd doktor Mabuse podjął się kuracji. W tym czasie Mabuse informuje hrabinę o śmierci jej męża i przedstawia jej ludzi, którzy za granicą „będą mieli honor pozostawać na jej osobistej służbie” (tzn. swych zbirów). Bezradna i jakby niespełna rozumu hrabina usiłuje się wymknąć, m.in. próbując dać Georgowi jakieś swe kosztowności. Wenk, znalazłszy w książce telefonicznej adres doktora Mabuse, psychoanalityka, udaje się tam, ale spod drzwi odprawia go Spoerri, mówiąc, iż doktor wyszedł. Za to gdy Wenk wraca do biura, Mabuse zaskakuje go, siedząc w fotelu jego osobistego gabinetu, zanim on sam tam wszedł. Wenk konstatuje dziwny zbieg okoliczności - właśnie chciał powiadomić doktora o śmierci jego pacjenta, Mabuse zaś udaje, że przyszedł do prokuratora, by zapobiec temu nieszczęściu. Mabuse wnioskuje, że hrabia mógł być pod wpływem jakiejś potężnej mocy, która opanowała jego wolę. Sugeruje, że prokurator powinien zapoznać się (tego samego wieczoru w filharmonii) z eksperymentem Weltmanna, który hipnozą zmusza ludzi do rozmaitych czynów, jakich świadomie by nie popełnili. Wenk obiecuje pójść za tą rada, pyta odchodzącego doktora, czy nie zna miejsca pobytu hrabiny Told, a po jego wyjściu beszta pracowników za pomysł wpuszczenia nieznajomego do swego gabinetu bez jego wiedzy. "Jak właściwie na to wpadliśmy?" - zastanawiają się urzędnicy. Wieczorem Mabuse przymierza przy pomocy Spoerriego charakteryzację na swój występ jako "Sandora Weltmanna" i wydaje Georgowi polecenia przed akcją mającą na celu definitywne usunięcie prokuratora. „Naradę bojową" ze swymi ludźmi przed wieczorem w filharmonii odbywa także Wenk, świadomy, że ma do czynienia z groźnym i nieobliczalnym przeciwnikiem.

Akt 5. Sandor Weltmann (czyli Mabuse w kolejnym wcieleniu) na inaugurację swego wieczoru zapowiada widowni "typowy przypadek sugestii zbiorowej, opierający się na podstawach podobnych do tricków indyjskich fakirów". Weltmann wyczarowuje publiczności (i widzowi fil$\mathrm{mu}$ ) karawanę, która z głębi sceny podąża ku rampie, a następnie wędruje przejściem między fotelami - i na gest jego ręki gwałtownie znika. 
Publiczność bije brawo. Następnie demonstruje "jasnowidzenie" i siłę swej hipnozy $\mathrm{w}$ numerze $\mathrm{z}$ „przypadkowymi” widzami (jednym z nich jest Wenk): ujawnia zawartość portfela prokuratora i fakt, że ma on w kieszeni rewolwer, a zahipnotyzowanej damie każe zabrać tę broń i dać innemu widzowi (Wenk przezornie wyjmuje magazynek). Widownia znów nagradza numer oklaskami. Weltmann prosi Wenka o dalszy udział w jego eksperymencie, a dla niepoznaki (bo przecież chodzi mu o prokuratora) wzywa do udziału w nim kilkoro ochotników (wśród tych ostatnich są też agenci Wenka). Weltmann zapisuje coś na kartce, kładzie ją do zamkniętej koperty i obwieszcza, że „pan z fotela 11” (czyli Wenk) wykona polecenie tam zapisane. $W$ trakcie hipnotyzowania prokurator po raz drugi silnie opiera się mocy Mabusego, a hasło Tsi-Nan-Fu przypomina mu przygodę z „Palais Andalusia”. Półprzytomny, konstatuje tożsamość Weltmanna, doktora Mabuse i tropionego przez siebie superprzestępcy. W końcu jednak ulega hipnozie, odprowadza jedną z ochotniczek na jej miejsce i opuszcza filharmonię, by zgodnie z sugestią z kartki wsiąść do podstawionego przez Georga samochodu i skierować go w przepaść urwiska Melior. Weltmann tymczasem podmienia niepostrzeżenie koperty, toteż odczytany głośno publiczności tekst polecenia dla „pana z fotela 11" mówi, iż miał on odprowadzić na miejsce damę, a następnie opuścić gmach i udać się do domu spać. Roześmiana publiczność bije brawo. Zdezorientowani ludzie Wenka widząc, że szef znienacka odjechał w nieznane, postanawiają jechać za nim i w ostatniej chwili, w pełnym biegu, przechwytują go z jego samochodu, zanim ten stoczy się z urwiska. Uratowany i oprzytomniały już Wenk obwieszcza swym ludziom tożsamość poszukiwanego złoczyńcy: „Doktor Mabuse - lekarz, gracz, przestępca”, i jedzie z nimi po policyjne posiłki. „Finał” - obwieszcza napis. O wpół do czwartej rano budzą się ludzie Mabusego. Georg, który miał wyjść po samochód, konstatuje, iż policja otoczyła dom. Zbudzony przez Georga Mabuse gasi światło i patrzy przez okno na policyjny kordon przed domem. „A więc... walka!!!”

Akt 6. Ludzie Mabusego blokują drzwi, ostrzeliwują się z okien (giną trafieni policjanci), a sam doktor pali papiery ze swego biurka. Wenk telefonuje z żądaniem, by Mabuse się poddał. Doktor odmawia i informuje Wenka, że trzyma u siebie hrabinę Told. Zasępiony Wenk każe swym ludziom wezwać na pomoc wojsko. W trakcie wymiany ognia z żołnierzami Mabuse zostaje lekko trafiony, a Fine i Hawasch giną. Mabuse usiłuje uciec z porwaną hrabina, ale ta się wymyka. Georg radzi mu dać sobie z nią spokój i ratować siebie. Mabuse ucieka przez właz w kuchni do kanałów, a Georga, goniącego hrabinę po klatce schodowej, łapią ludzie Wenka. Georg każe milczeć pytanemu przez Wenka o Mabusego Spoerriemu i pamiętać o Peschu. Wyczerpana i nie całkiem przytomna hrabina mówi 
Wenkowi: „Do domu!” Kanałami Mabuse dostaje się do „wytwórni” Hawascha, ale trochę wystraszony widokiem ślepców popełnia błąd i zatrzaskuje właz, którym się tu dostał. Daremnie usiłuje podważyć go nożem. Wenk pyta przesłuchiwanego Spoerriego o klucz, znaleziony przy ciałach Fine i Hawascha. Mabusego w jego pułapce osaczają widma jego ofiar: Hulla, Pescha, hrabiego Tolda i Carozzy, a w dodatku ślepcy wydają się mu grozić. Spoerri identyfikuje prokuratorowi klucz jako otwierający tajną wytwórnię pieniędzy Hawascha. Georg, umieszczony już w celi, zarzuca na kraty okna szelki, by się powiesić, przed śmiercią wypisując jednak na ścianie: „Götz von Berlichingen”. Mabusemu wydaje się, iż ślepcy zmieniają się w ubrane na czarno widma jego czterech ofiar, które zapraszają go do stołu do gry w karty. „Pan trzyma bank, doktorze Mabuse” - mówi doń widmo Hulla, a rozdawanie kart przerywa mu widmo Tolda z okrzykiem: „Szuler!” Widma znikają. Mabuse rzuca ku ślepcom banknoty. Maszyna drukarska wydaje się zmieniać w jego wizji w trzy ekspresjonistyczne demony, pomiędzy którymi pada bezwładnie na podłogę na stertę banknotów. Gdy Wenk z policją włamują się do lokalu od ulicy, widzą tam tulących się pod ścianą ślepców i postarzałego Mabusego z nieprzytomnym spojrzeniem zgarniającego z podłogi garściami fałszywe banknoty. Policja wyprowadza ślepców, a Wenk z agentem - oszalałego Mabusego, tulącego kurczowo bezwartościowe papiery. Ostatni napis filmu głosi: „Człowiek, który był doktorem Mabuse”.

\section{Alegoria inflacji}

Przywołane wcześniej recenzje z epoki dość jednogłośnie dostrzegły w filmie Langa obraz czasu, z jego gospodarczym i politycznym chaosem, libertynizmem obyczajów, dekadenckimi rozrywkami i takąż sztuką przestępczościa, rozkwitem półświatka. W zasadzie jednak nie nazywały po imieniu największej społecznej bolączki Niemiec w latach tuż po I wojnie światowej, której wymienione zjawiska były w znacznej mierze rezultatem. Bolączka ta była jednym z najbardziej traumatycznych doświadczeń Niemców, doświadczeń, którego dalekosiężne i pośrednie skutki były dużo bardziej niebezpieczne niż te bezpośrednie, jak sam fakt głodu i niedoboru dóbr, gwałtownej pauperyzacji i deklasacji wielkich rzesz ludzi czy ekonomicznego rozwarstwienia społeczeństwa. Bolączką tą była in $\mathrm{fla} \mathrm{cja.} \mathrm{Dwie} \mathrm{bodaj} \mathrm{najciekawsze} \mathrm{ze} \mathrm{znanych} \mathrm{mi} \mathrm{interpretacje} \mathrm{Doktora}$ Mabuse, gracza, autorstwa Bernda Widdiga i Toma Gunninga ${ }^{55}$, ujmuja

55 B. Widdig, Culture and Inflation in Weimar Germany, s. 113-133; T. Gunning, The Films of Fritz Lang: Allegories of Vision and Modernity, s. 87-116. 
ten film przede wszystkim właśnie jako alegorię inflacji. Tak też uważa historyk inflacji, Gerald D. Feldman, który uznaje postać Langowskiego superprzestępcy za ",autentyczny i świadomy wytwór inflacji”, a rok 1922 nazywa „rokiem doktora Mabuse ${ }^{\prime 56}$. Choć to dopiero w jakieś trzy miesiące po premierze filmu dokonał się jakościowy skok: inflacja przerodziła się w hiperinflację, a jej apogeum (a raczej-dnem) był koniec roku 1923, kiedy już nawet 4 biliony marek nie wystarczały, by otrzymać w zamian 1 dolara! $!^{57}$

O tym, że właśnie inflacja jest poniekąd zasadniczą referencją filmu świadczą dwie bardzo mocne wizualnie sceny, tym mocniejsze, że stanowią dramaturgiczne pointy - będącego prologiem aktu I, 1 i całego filmu. Obraz filmowy pokazuje nam przestrzeń zasypaną be zwa r to ści owymi papierami. W finale prologu niezliczone egzemplarze "dodatku nadzwyczajnego" zaściełają parkiet opustoszałej giełdy, świadcząc o niedawnym triumfie Mabusego, a tym samym - o arbitralnej, nierzeczywistej, nieuchwytnej, manipulowanej, spekulacyjnej wartości akcji. Finał całości jest $\mathrm{w}$ pewnym sensie odwrotnością prologu, unaoczniając nam tym razem nie triumf, ale klęskę sprawcy wielkiego finansowego chaosu: oszalały, usiłuje zagarnąć jak najwięcej banknotów rozsypanych na podłodze, niepomny, iż jedyna wartość, jaką posiadaja, to ta, którą sam im nadał, zasypując nimi rynek, jako że są to banknoty fałszywe. Pieniądz spekulacyjny i pieniądz fałszywy, choć wcale nie muszą być koniecznymi przejawami doby inflacji, to jednak podobnie jak pieniądz inflacyjny nie mają realnej, substancjalnej wartości i tym samym nadają się na jego wyraziste unaocznienie; tym bardziej zreszta, że wskazują konkretnego winowajcę: spekulanta i fałszerza, podczas gdy faktycznie winne inflacji państwo, świadomie prowadzące taką a nie inną politykę monetarną było zbyt niekonkretnym, zbyt abstrakcyjnym podmiotem, nienadającym się do oczywistej dla widza reprezentacji. W każdym razie $w$ dobie noszenia w walizkach i wożenia wózkami pieniędzy o astronomicznych nominałach i znikomej wartości ${ }^{58}$ obraz stosu rozrzuconych bezładnie bezwartościowych papierów jest wymownym i czytelnym znakiem katastrofalnej dewaluacji waluty.

Tak wspominał okres inflacji sam reżyser: „Pieniądz bardzo szybko tracił na wartości. Pracownicy otrzymywali wypłaty nie w rytmie

${ }_{56}$ G. D. Feldman, op. cit., s. 513.

57 Por. przypis 53.

${ }^{58}$ Por.: B. Widdig, op. cit., s. 4-6. Opisane przez Widdiga i zapamiętane przez jego dziadka trójkołowe wózki, którymi przewożono góry bezwartościowych banknotów, to obraz powszechny w roku astronomicznej hiperinflacji - 1923, a więc rok po premierze filmu Langa. 
tygodniowym, ale w dniówkach, ale nawet wtedy, kiedy wracali do domu po godzinach pracy, sklepy były zamknięte, a nazajutrz ich żonom ledwo starczało na dwie bułki czy ćwierć kilo kartofli za całodniową stawkę.

W tym samym czasie nocne kluby były pełne, dzięki łatwo zarobionym pieniądzom lat wojny - i inflacji; kto miał zyski, myślał - albo i był tego pewien - że może wszędzie i wszystko kupić, łącznie z głodującymi i zbiedniałymi kobietami z byłych klas wyższych i średnich. W piwnicach i prywatnych mieszkaniach mętne światła rozbłyskiwały tylko nocą po to, by zniknąć dwie czy trzy doby później - jak tylko miejsca te stały się zbyt znane ogółowi i policji.

W miejscach takich wybijająca się właśnie klasa nowobogackich mogła grać aż po świt. Bogate i zblazowane żony nuworyszy również je odwiedzały, chorobliwie wypatrując niedwuznacznych zaproszeń, wulgarnych i nędznych, gdy już nadchodziły - każda seksualna zachcianka znajdowała spełnienie.

Panoszyły się przestępstwa. Od czasu do czasu jakiś samotnik usiłował powstrzymać ten sabat czarownic. Któregoś ranka pojawiły się w całym Berlinie plakaty pokazujące półnagą ponętną kobietę w objęciach kościotrupa, podpisane: «Berlinie - tańczysz ze Śmiercią». Ale kto się tym przejął? Po czterech latach wojny Śmierć straciła swą grozę.

Religia? Bóg? Odesłano Go, by rozprowadzał swój towar gdzie indziej.

W atmosferze takiego «Bierz, co swoje - i w diabły!» uderza stały, nieustanny pociąg do fantastyczności, tajemniczości, makabry, do dusznej grozy mroku.

W pierwszej połowie lat dwudziestych kino niemieckie odzwierciedlało ponure czasy i nastrój beznadziei w równie ponurych i pełnych przeczuć filmach. Pensjonariusze dziwacznego zakładu dla obłąkanych i jego złowieszczy dyrektor w Gabinecie doktora Caligari doktora Wiene, straszliwy wampir Nosferatu Murnaua, czy Golem Wegenera, mogły powstać tylko w takiej epoce.

Sam dołączyłem do tych filmowców z dwoma postaciami: superprzestępcą w Doktorze Mabuse, graczu i superszpiegiem Haghim w Szpiegach"59.

Choć słowa te wypowiedział Lang w związku z pokazem na amerykańskiej uczelni swego filmu Szpiedzy, ich przytoczenie wydaje się równie stosowne przy okazji właśnie Doktora Mabuse, gracza. Zwraca uwagę zaprezentowana przez Langa sekwencja: rezultatem inflacji jest głód, pauperyzacja, deklasacja klas wyższych i średnich, hazard, używanie „na całego", a w szerszym wymiarze - zanik aksjologii; inflacji

59 Słowo wstępne Langa przed projekcją filmu Szpiedzy, wygłoszone 28 czerwca $1967 \mathrm{r}$. w University of California (Riverside Extension). Cyt. za: L. H. Eisner, op. cit., s. 95-96. 
pieniądza towarzyszy inflacja wartości życia, wynikła też z jej deprecjacji w latach wojny. Można się tylko zastanowić, czy „odesłanie Boga do lamusa” i niewrażliwość na "moralizowanie”, to kulminacja historycznego procesu o podłożu politycznym i ekonomicznym (jakby wynikało z sekwencji w tekście), czy raczej ź r ó dł o weimarskiego nihilizmu aksjologicznego (sam tak właśnie widzę kolejność rzeczy). Ciekawe jest usytuowanie $\mathrm{w}$ perspektywie historycznej i aksjologicznej filmów niemieckich tych lat - Lang, tylekroć sprzeciwiający się Kracauerowskiej wizji kinematografii weimarskiej, tym razem sam przyznaje mu rację, dostrzegając w tych filmach w y r a z demonicznych i nihilistycznych tendencji.

Zatrważająca, acz sugestywną i przekonującą analizę dalekosiężnych i najbardziej potwornych skutków inflacji, przedstawia Elias Canetti w książce Masa i władza (Masse und Macht, 1960). Jak zobaczymy, w filmie Langa antycypacja tych skutków jest już obecna w postaci alegorycznego przedstawienia winowajcó w kryzysu, w którym znajdzie wyraz stereotyp zbiorowej (nie)świadomości. Przedtem oddajmy jednak głos Canettiemu: „Cóż [...] dzieje się podczas inflacji? Jednostka pieniężna nagle traci swoją osobowość. Przekształca się w rosnącą masę jednostek; im masa jest większa, tym bardziej tracą one na wartości. Miliony, do których tak tęskniliśmy, trzymamy teraz w ręku, ale nie s ą one już milionami, tylko się tak n a y w a ją. [...] Wczorajsza marka liczy dziś dziesięć tysięcy, jutro sto tysięcy, a wreszcie milion marek. Identyfikacja ludzi z pieniądzem ulega zakłóceniu. Pieniądz stracił swoją stałość i swoje granice, co chwila jest czymś innym. Nie jest już jedną osobą, nie ma trwałości. Jego wartość stale się zmniejsza. Człowiek, który mu przedtem ufał, nie potrafi obronić się przed uczuciem, że poniżenie pieniądza jest jego własnym poniżeniem. Zbyt długo się z nim identyfikował, ufał mu jak sobie samemu. Wskutek inflacji nie tylko całe otoczenie ulega zachwianiu, nic nie jest już pewne, nic nawet przez godzinę nie pozostaje na tym samym miejscu - inflacja p o m n i e j s z a samego człowieka. On sam, albo to, czym był, staje się niczym, milion, którego tak pragnął, jest nic nie wart. Ka ż d y go ma. Ale każdy jest niczym. [...] Jest to p o d w ó j n a d e w a l u a c j a, wynikająca z podwójnego utożsamienia. P o j e d y n c z y człowiek czuje się mniej wartościowy, gdyż spadła wartość jednostki pieniężnej, której zaufał, którą szanował jak samego siebie. M a s a czuje się mniej warta, gdyż spadła wartość mi li o n a. [...] Równie mało liczy się wówczas pojedynczy człowiek, jak wszyscy razem. Kiedy pieniądz rośnie w miliony, całe milionowe narody stają się niczym" ${ }^{\prime 60}$.

${ }^{60}$ Elias Canetti, Masa i władza, przeł. Eliza Borg i Maria Przybyłowska, Czytelnik, Warszawa 1996, s. 212-213. 
Z inflacją łączy się wspomniana przez Langa deklasacja, wynikająca z jednakowego zdegradowania przez dewaluację zarówno emerytów czy rentierów, jak i pracowników etatowych; klas wyższych, ale i - szczególnie dotkliwie - inteligencji (stosunkowo mniej dotyka ona klasę robotniczą a dla rolników, z racji powrotu do handlu wymiennego, w którym za żywność mogą otrzymać niezbywalne za pieniądze znacznie cenniejsze dobra, oznacza wręcz okres prosperity) ${ }^{61}$. „Inflacja znosi różnice między ludźmi, które wydawały się odwieczne, i łączy ze sobą tych, którzy niemal się nie pozdrawiali, w jednej i tej samej masie inflacyjnej" ${ }^{62}$. Nie jest to jednak demokratyzacja, lecz tylko poniżające zglajchszaltowanie.

Zdaniem Canettiego, zarówno jednostka, jak i masa, dążą do znalezienia winnych swej dewaluacji i kompensaty swego poniżenia nie tyle przez prosty rewanż, co drogą „inflacyjną", poprzez systematyczne poniżanie i odbieranie „winnym” wartości. „Obiekt taki znalazł Hitler w czasie inflacji w Niemczech: byli nim Żydzi. Znakomicie się do tego nadawali: ich historyczne powiązanie $\mathrm{z}$ pieniądzem, dla którego zmian wartości mieli coś w rodzaju tradycyjnego zrozumienia, ich zręczność w spekulacjach, gromadzenie się na giełdach, gdzie jaskrawo odróżniali się od niemieckiego, militarnego wzorca zachowań, wszystko to w czasach niepewności i wrogości pieniądza musiało wyglądać szczególnie niepewnie i wrogo. Żydzi jako jednostki byli «źli»: żyli w dobrej komitywie z pieniądzem, w którym nikt się już nie orientował [...]

W swoim stosunku do Żydów narodowy socjalizm powtórzył jak najdokładniej proces inflacji. Najpierw uznano ich za złych i niebezpiecznych, za wrogów, następnie coraz częściej odmawiano im wszelkiej wartości; ponieważ nie było ich dosyć w kraju, szukano ich wśród członków podbitych narodów. W końcu traktowano ich dosłownie jak r o b a c t w o, które można bezkarnie niszczyć całymi milionami. Do dzisiaj nie potrafimy otrząsnąć się ze zdumienia, jak Niemcy mogli się tak daleko posunać, jak mogli uczestniczyć w takiej zbrodni, tolerować ją lub pomijać. Być może nie posunęliby się tak daleko, gdyby niedawno nie przeżyli inflacji,

${ }^{61} \mathrm{Nt}$. szczególnej degradacji inteligencji i ludzi pobierających stałe dochody (pracowników etatowych, emerytów, rentierów) zob. zwłaszcza: B. Widdig, op. cit., s. 169-195. Ciekawe, że w samym Doktorze Mabuse, graczu nie widzimy w zasadzie tych sfer społecznych (przynajmniej wprost i w rozpoznawalny sposób) - dominują rozmaici Raffke, beneficjenci i symboliczni winowajcy inflacji. Realistyczny obraz pauperyzacji i deklasacji tych sfer znajdziemy np. w filmie Georga Wilhelma Pabsta Zatracona uliczka (co prawda jego akcja rozgrywa się w Wiedniu, a nie Berlinie, ale i Austria dotknięta była inflacja, choć nie tak astronomiczną jak Niemcy) oraz w analizowanych przez Widdiga dziełach literackich - powieści Canettiego Auto-da-fé (1931) czy noweli Tomasza Manna Nieład i wczesna udręka (Unordnung und frühes Leid, 1925). Por.: B. Widdig, op. cit., s. 69-72, 170-178).

${ }^{62}$ E. Canetti, Masa i wtadza, s. 213. 
podczas której marka spadła do jednej bilionowej swej wartości. Winę za masowe zjawisko inflacji zepchnęli wówczas na Żydów"63.

W swej znakomitej analizie filmu Langa Bernd Widdig zauważa, że Mabuse jako fantazmatyczny ekran, na który rzutować można lęki i fantazje widowni, jest nie tylko figurą totalitarnego tyrana, skrycie sprawującego kontrolę nad społeczeństwem (co byłoby zgodne $\mathrm{z}$ interpretacją Kracauera), ale służy też jako kozioł ofiarny ${ }^{64}$. Widdig zadaje niepokojące pytanie: „w jakim stopniu film Fritza Langa ma udział w antysemickim dyskursie, zbudowanym na mechanizmach wyobrażonej żydowskiej kontroli, którego rezultatem było szukanie kozła ofiarnego?" I zaraz odpowiada: „Choć Doktor Mabuse, gracz z pewnością nie jest filmem antysemickim, niemniej odwołuje się do antysemickiej nieświadomości. Na powierzchni, większość z rozmaitych masek Mabusego wiąże się z tożsamością którą ówczesna publiczność mogła bardzo łatwo świadomie czy nieświadomie rozszyfrować jako «żydowską»: jego rolą jako psychoanalityka, bankiera na giełdzie, rewolucjonisty w proletariackim lokalu, czy, co najbardziej oczywiste, żydowskiego wędrownego przekupnia" ${ }^{65}$.

W swej monografii poświęconej kinu okresu Trzeciej Rzeszy Eric Rentschler dokonuje interpretacji osławionego antysemickiego filmu Veita Harlana Żyd Süss (Jud Süß, 1940), wskazując, iż jego bohater, Süss-Oppenheimer, przejawia wiele cech, które były także atrybutami doktora Mabuse w filmie Langa: i Mabuse, i Oppenheimer, nie mieli jakiegoś ani społecznego, ani geograficznego zakorzenienia, obaj zmieniali wygląd, przebierali się za kogoś innego, kontrolowali gospodarkę państwa, wprowadzając do niej chaos, grozili społeczeństwu zamętem i destrukcja, wreszcie - niewolili kobiety, stosując wobec nich przemoc i gwałt ${ }^{66}$. „Zasadniczą żydowskość" Mabusego zresztą wcześniej odnotował już narodowosocjalistyczny krytyk, który w recenzji z 1 września 1925, opublikowanej w „Völkische Kurier” pisał: „Oto obraz Wiecznego Żyda... wędrującego przez stulecia, zawsze z jednym celem w umyśle: zawładnąć światem, choćby całe narody miały wyginąć' ${ }^{67}$. Nazistowski recenzent

63 Ibidem, s. 214.

${ }^{64}$ Por.: B. Widdig, op. cit., s. 121. Na temat mechanizmu „kozła ofiarnego”, który rozładowuje poważne kryzysy społeczne drogą przemocy zbiorowości wobec jakiegoś fantazmatycznego „winowajcy” (często zresztą właśnie Żydów), zob.: René Girard, Kozioł ofiarny, przeł. Mirosława Goszczyńska, Wydawnictwo Łódzkie, Łódź 1987, passim.

65 B. Widdig, op. cit., s. 121-122. Żydowskie konotacje odnotowuje też Tom Gunning (op. cit., s. 102, 486).

${ }^{66}$ Zob.: Eric Rentschler, The Ministry of Illusion: The Nazi Cinema and Its Afterlife, Harvard University Press, Cambridge (Mass.) 1996, s. 156.

${ }^{67}$ Cyt. za: B. Widdig, op. cit., s. 122. Tę samą recenzję przytacza też: Dr. Mabuse: Roman - Film - Dokumente, Red. Günter Scholdt, W. J. Röhrig Verlag, St. Ingbert 1987, s. 149. 
odnotowuje dalej, iż ucieczka Mabusego w szaleństwo uniemożliwia wymierzenie mu kary (co typowe w przypadku żydowskich przestępców). Pointą zaś tekstu są ledwo zawoalowane groźby wobec Żydów, odpowiedzialnych za inflację i gospodarczą katastrofę państwa ${ }^{68}$.

\section{Oblicza „Żyda"}

Podstawową tożsamością bohatera filmu Langa, co wyraża pewna „neutralność" czy "naturalność” twarzy Rudolfa Klein-Rogge i fakt, że takim go widzimy każdorazowo przed przymiarką czy przy pozbywaniu się bardziej ostentacyjnej, bardziej wyrazistej charakteryzacji, jest tożsamość psychoanalityka, doktora Mabuse ${ }^{69}$. Zresztą świadczy o tym także tytuł filmu i fakt, że pod tym nazwiskiem i tytułem Wenk bez problemu lokalizuje go w książce telefonicznej (nie mając zresztą jeszcze wiedzy, że to poszukiwany przez niego superprzestępca). Psychoanaliza zostaje w filmie Langa ewidentnie zdyskredytowana przedstawieniem jej jako manipulacji (vide: zarówno wykład Mabusego, inaugurujący akt I, 2, jak i praktyczna realizacja przez doktora idei odcięcia relacji lekarz - pacjent od wszelkich wpływów zewnętrznych w „kuracji”, którą doprowadza Tolda do samobójstwa $)^{70}$. Jak powszechnie wiadomo, Freud był Żydem, co miało

${ }^{68}$ Zob.: B. Widdig, op. cit., s. 122-123, lub: Dr. Mabuse: Roman - Film - Dokumente, s. 150.

${ }^{69}$ Paul M. Jensen pisze: „Rudolf Klein-Rogge zręcznie dostosowuje swe aktorstwo do rozmaitych przebrań, ale w scenach kiedy Mabuse jawi się właśnie jako Mabuse, aktor nie jest równie przekonujący czy fascynujący. Może w niektórych kręgach zabrzmi to jak herezja, ale jest on generalnie źle obsadzony jako Mabuse. Brak mu groźnego, tajemniczego autorytetu, który mogłyby nadać roli ostre, posągowe rysy Bernharda Goetzke [zagrał Wenka - T. K.] czy kanciasta, ascetyczna aparycja Alfreda Abla [zagrał hrabiego Tolda - T. K.]. Klein-Rogge jest zbyt przysadzisty i pucołowaty, brak mu też niezbędnej intensywności i siły" (P. M. Jensen, op. cit., s. 42-43). Ale może błędem filmu, odzierającym tytułową postać z czaru, jest to, iż w ogóle jest jakieś „normalne” wcielenie Mabusego. Jensen uważa, że było ono niezbędne jako punkt odniesienia dla rozpoznania pozostałych wcieleń, ale rację ma chyba Aljoscha Zimmermann, kompozytor muzyki do wersji filmu zrekonstruowanej przez Murnau-Stiftung, iż narracja bazuje nie na odmienności, ale na podobieństwie rozmaitych tożsamości tytułowej postaci, tak, by widz nie miał najmniejszych kłopotów z rozpoznaniem Mabusego (wypowiedź Zimmermanna na płycie DVD).

70 Zwróćmy jednak uwagę, iż tak naprawdę „kuracja” Mabusego jest antytezą metody Freuda: Mabuse odcina hrabiego od wszelkich wpływów zewnętrznych po to (jak mówi „pacjentowi”, czy raczej ofierze), by nic mu nie przypominało przeszłości; podczas gdy w prawdziwej terapii psychoanalitycznej chodzi o wydobycie na jaw z przeszłości sceny traumatycznego doświadczenia pacjenta, po to, by uświadomiona trauma została przezwyciężona. 
swoje konsekwencje u schyłku jego życia w znazyfikowanej już Austrii. Konotacje psychoanalizy jako dziedziny ",żydowskiej” unaocznia w filmie Langa obraz audytorium wykładu Mabusego: starych uczonych o karykaturalnie semickich rysach, jako żywo przypominających też tłum graczy giełdowych w bezpośrednio poprzedzającej scenę wykładu sekwencji giełdy.

Zresztą mimo swego tytułu „doktora psychoanalizy” Mabuse jawi się nam nie jako terapeuta $z$ pacjentem na kozetce, lecz jako używający mrocznych, okultystycznych sił hipnozy, telepatii i sugestii charyzmatyczny "nadczłowiek” (konotacje nietzscheańskie ewokuje sam Mabuse, mówiąc w rozmowie z hrabiną - akt I, 6 - o „woli mocy” jako czymś jedynie realnym w porównaniu z urojonym konceptem szczęścia). Być może to wcale nie sceptyczna hrabina była zakłócającym seans spirytystyczny „obcym elementem”, ale właśnie Mabuse z racji swej demonstrowanej kilkakrotnie w filmie paranormalnej mocy. Mabuse wydaje się nie tyle „doktorem" o jakichś naukowo uzasadnionych umiejętnościach (np. hipnotycznych), co figurą z dziedziny opisanego przez Freuda das Unheimliche, Niesamowitego ${ }^{71}$, szczególnie przypominając postać z analizowanego w tej rozprawie opowiadania Hoffmanna Piaskun (Der Sandmann): demonicznego wędrownego optyka Coppeliusa. Podobnie jak Coppelius swymi optycznymi cackami (okularami, lornetkami) obezwładnia Hoffmanowskiego bohatera ${ }^{72}$, tak Mabuse jako "holenderski profesor" usiłuje zaczarować Wenka chińskimi okularami z Tsi-Nan-Fu ${ }^{73}$. Inną Hoffmanowską postacia, która przychodzi do głowy w związku z ,talentami" Mabusego, jest Alban, tytułowy bohater opowiadania Magnetyzer (Der Magnetiseur) $)^{74}$. W każdym razie o ile naukowe uzasadnienie i tytuł Mabusego poniekąd legitymizuje "charyzmę" Wielkiego Człowieka, to z drugiej strony, demonizm i okultyzm, paranormalność i szarlataneria (bo i tej jest trochę w występie Sandora Weltmanna, który podmienia koperty, albo podaje zawartość portfela Wenka, uprzednio ją poznawszy), kompromitują „naukowość" psychoanalizy jako dziedziny „,żydowskiej"75.

W listopadzie 1921 r., gdy rozpoczęto zdjęcia do Doktora Mabuse, gracza, Niemcy ogarnęła gorączka spekulacji giełdowych ${ }^{76}$. Dynamiczna,

${ }^{71}$ Por.: Sigmund Freud, Niesamowite, przeł. Robert Reszke, [w:] S. Freud, Dzieła, t. 3: Pisma psychologiczne, Wydawnictwo KR, Warszawa 1997, s. 235-262.

${ }^{72}$ Zob.: E. T. A. Hoffmann, Piaskun, przeł. Felicjan Faleński, [w:] E. T. A. Hoffmann, Dzieła wybrane: Opowieści fantastyczne, Czytelnik, Warszawa 1959, s. 270-271.

${ }^{73}$ To podobieństwo zauważa też Tom Gunning (op. cit., s. 109).

${ }^{74}$ E. T. A. Hoffmann, Magnetyzer. Zdarzenie z życia rodzinnego, przeł. Jerzy Ficowski,

[w:] E. T. A. Hoffmann, Dzieła wybrane: Opowieści fantastyczne, s. 43-92.

${ }^{75}$ Por. uwagi Noëla Burcha, op. cit., s. 12.

76 Por.: G. D. Feldman, op. cit., s. 390; T. Gunning, op. cit., s. 101. 
apokaliptyczna scena giełdy z filmu Langa musiała zapewne zainspirować podobne sceny w późniejszych filmach - Końcu Sankt-Petersburga (1927) Wsiewołoda Pudowkina, Pieniadzu (1928) Marcela L'Herbier czy Zaćmieniu (1962) Michelangelo Antonioniego. Giełda jest oczywiście „żydowską dziedziną" par excellence: roznamiętnieni udziałowcy, gorączkowo wyprzedający swe walory podczas bessy i usiłujący je łapczywie skupić podczas hossy na przedstawionej w filmie sesji giełdy, to - zgodnie z ikonograficznym stereotypem - przede wszystkim Żydzi. Sam Mabuse nie wygląda może zbyt semicko w tej akurat sekwencji, niemniej przecież konotacje (nie)świadomości zbiorowej wiążą „żydowskość” nie tylko z wyglądem, ale i z funkcją z a ku lis ow ej man i pula cji. Jak słusznie zauważa Tom Gunning, Mabuse kradnie szwajcarsko-holenderską umowę handlową nie tyle, by odkryć jej zawartość, ile po to, by sprawować kontrolę nad obiegiem informacji, w odpowiednich momentach to wstrzymując dane (umowa może nie dojdzie do skutku, skoro jej kradzież grozi wycofaniem się jednego z kontrahentów), to uwalniając je (umowa jednak zostanie sfinalizowana, bo odnalazła się „nietknięta” ${ }^{77}$. To właśnie kontrola obiegu informacji umożliwia Mabusemu jego udaną manipulację giełdowymi kursami spółek - i aż dziwne, że po spekulacji, zakończonej tak fantastycznym sukcesem, na skalę wstrząśnięcia posadami gospodarki państwa i krajów ościennych, Mabuse ogranicza się do przestępstw na mniejszą skalę, chciałoby się rzec, skalę tylko "prywatną" - ogrywania $\mathrm{w}$ kasynach i nielegalnych szulerniach bogatych graczy ${ }^{78}$.

Warto zwrócić uwagę, iż Mabuse - niezależnie od bezpośrednio żydowskich konotacji - przyjmuje tożsamości ewokujące osoby z państw ościennych. Udając się po skradziony kontrakt, wygląda "z rosyjska", w grubym płaszczu i futrzanej czapie, niczym zapewne nierzadki w Berlinie tych lat przedstawiciel „białej”, porewolucyjnej emigracji. Do wytwórni fałszywych pieniędzy Hawascha po raz drugi udaje się istotnie

77 Por.: T. Gunning, op. cit., s. 101-102.

${ }^{78}$ David Kalat zauważa, że efektowny, dynamiczny prolog obiecuje znacznie więcej niż jest w stanie spełnić reszta "gargantuicznego" rozmiarami filmu Langa (D. Kalat, op. cit., s. 37). Ale sądzę, że to niespełnienie wynika nie tyle z racji mniej efektownej formy reszty filmu niż w tych pierwszych 20 minutach, co sugeruje Kalat (inne sekwencje również obfitują $\mathrm{w}$ arcyciekawe filmowo rozwiązania), ile $\mathrm{z}$ racji stopniowego „umniejszania się" Mabusego: Mabuse zamiast trząść giełdą - hipnotyzuje graczy, pożąda hrabiny, triumfalnie się upija, gdy ją porywa, a w dodatku okazuje się, że krąg podległych mu osób jest doprawdy niewielki, a co więcej, sam niektóre z nich (Carozzę, Pescha) usuwa. Skala postaci Mabusego w prologu wynika chyba z tego, iż sekwencja ta jest dramaturgiczną inwencją Langa i Thei von Harbou, i nie ma prototypu w powieści Jacques'a. Począwszy od II aktu akcja mniej więcej podąża za piewowzorem literackim, który mocno ograniczył "gargantuiczną" (o czym świadczą inne filmy) wyobraźnię duetu Lang - von Harbou. 
jako żydowski handlarz-domokrążca, ale po raz pierwszy - jako pijany plebejusz, w swym berecie wyglądając bardzo „z francuska”. Gdy usiłuje ograć Wenka w "Palais Andalusia”, to jako „stary holenderski profesor". Podczas swego show w filharmonii występuje jako Sandor Weltmann przynajmniej imię sugeruje rodowód węgierski, a w kombinacji z nazwiskiem - austro-węgierski lub... właśnie żydowski ${ }^{79}$. Wreszcie Wenk informuje Hulla (w akcie I, 3), iż jednym z podejrzanych zwycięzców w grze w rozmaitych kasynach jest ,jasnowłosy Amerykanin" (może to zresztą właśnie w tym wcieleniu ogrywa u Schramma bogatą i grubą emigrantkę z Rosji; nie odnajdując specjalnie w tym przebraniu atrybutów ",amerykańskości”, określiłem je wcześniej jako „młodego blondyna”). W każdym razie w przebierankach Mabusego za osobników rozmaitych nacji mamy, jak sądzę, do czynienia z freudowskim mechanizmem "przesunięcia": „,żydowskość" Mabusego została zakamuflowana jako „obcość", „cudzoziemskość". Zresztą w tradycji kultury niemieckiej charakterystyczne jest nazywanie z cudzoziemska postaci demonicznych i złowrogich (vide: Coppelius w Piaskunie Hoffmanna, Scapinelli w Studencie z Pragi Stellana Rye czy może najsłynniejszy z podobnych osobników - Caligari w filmie Roberta Wiene). Natomiast "zakamuflowanie” przez "cudzoziemskość” tożsamości żydowskiej przypomina wyparcie się jej przez samego Langa (akcentującego na ogół swą „,niemieckość”, ,"katolicyzm”, ,"rodowód wiedeński”) czy np. przez Chaplina, przypisującego swej babce „cygańskość" czy „irlandzkość”. Zresztą już dość podejrzany jest również fakt, iż to sprawa kontraktu szwajcarsko-holenderskiego (a zatem zawartego przez sąsiedzkie i niekoniecznie dobrze ustosunkowane do Niemiec państwa) tak mocno wstrząsa niemiecką giełdą.

Jeszcze jednym wcieleniem Mabusego o żydowskich konotacjach jest komunistyczny agitator, podburzający $\mathrm{w}$ proletariackim lokalu tłum do zamieszek niby to w celu uwolnienia "Johannesa Guttera”, a tak naprawdę dla ukrytych własnych niecnych celów. Mabuse w tym wcieleniu wystylizowany jest na Karla Radka (zresztą istotnie Żyda z pochodzenia), kominternowskiego agenta na Niemcy, który odegrał ważną rolę w utworzeniu w 1919 Związku Spartakusa i jego próbie wywołania w Niemczech bolszewickiej rewolucji, zaś w okresie realizacji filmu prowadził zakulisowe rozmowy z Rathenauem, których rezultatem był niemiecko-sowiecki traktat w Rapallo (16 kwietnia 1922). Niezależnie od możliwości odnalezienia w tym wcieleniu Mabusego antysemickiego podtekstu, trzeba stwierdzić, iż Lang miał poczucie zagrożenia nie tylko Niemiec, ale

79 Ciekawa jest semantyka tego imienia i nazwiska. „Sandor” to po węgiersku „Aleksander", które to imię w połączeniu z nazwiskiem „Weltmann” sugeruje władzę jego nosiciela nad światem. Por.: T. Gunning, op. cit., s. 119-120. 
i Europy, komunistycznym totalitaryzmem, a wyraz temu dał kilka lat później w Szpiegach, dziejących się „gdzieś w Europie”, Europie terroryzowanej przez wystylizowanego zarówno na Lenina, jak i na Trockiego, superprzestępcę Haghiego.

Do prowadzonej przez Hawascha nielegalnej wytwórni Mabuse udaje się w II części filmu jako żydowski handlarz-domokrążca, jedyny raz przybierając jawnie i bezdyskusyjnie żydowską tożsamość. Być może to właśnie ostatecznie skłoniło cytowanego wcześniej nazistowskiego recenzenta do tak kategorycznego stwierdzenia, iż to właśnie Żydzi odpowiedzialni są za kryzys ekonomiczny. $W$ każdym razie $w$ tej akurat scenie brodaty i pejsaty "Ż̇yd" nadzoruje produkcję wypuszczanego na rynek fałszywego pieniądza. Czy narodowosocjalistycznemu recenzentowi trzeba było czegoś więcej dla podparcia swych tez niż ten alegoryczny obraz? Warto zwrócić też uwagę, iż komedia z oferowaniem dziewczynie w oknie korali czy ulicznych "targów” "Ż̇yda” ze swymi ludźmi, Georgiem i Fine, podobnie zresztą jak wcześniejsze komedie "stłuczki z przesiadką" „Rosjanina” czy powrotu do domu „pijanego plebejusza ubranego z francuska", w kategoriach fabularnej funkcjonalności są całkowicie zbędne, narracyjnie „bezinteresowne”. Ale właśnie ta „bezinteresowność" służy znakowi, symbolowi, alegorii, przenosząc scenę z osi narracyjnej (metonimicznej) na oś metaforyczna, co sprawia, iż mimo pewnego kamuflażu przez realistyczny sztafaż cały czas mamy do czynienia z tak ostentacyjnym w Zmęczonej Śmierci stylem alegorycznym.

Noël Burch i Paul M. Jensen zauważają „,bezinteresowność” czy wręcz „bezcelowość" tych scen z punktu widzenia dramaturgii, nie kusząc się jednak o próbę jakiegoś ogólniejszego wyjaśnienia ich funkcji ${ }^{80}$. Obaj przywołują scenę szczególnie, wydawałoby się, bezcelową fabularnie, kiedy Mabuse przy pomocy Georga w swej kuchni-laboratorium z zębów jadowych węża ekstrahuje jad. Burch wprawdzie zauważa, iż mogłaby być ona "stosownym emblematem” zła otaczającego postać Mabusego, ale ostatecznie traktujemy ją $\mathrm{w}$ trakcie jej progresji jako przygotowania demonicznego bohatera do jakiegoś jeszcze jednego przestępstwa, przez co „emblematyczny wymiar" znika, zaś fabularny (jakie to przestępstwo?) nie zostaje $\mathrm{w}$ dalszym toku podjęty; tym samym scena jest istotnie bezcelowa i wiedzie donikąd ${ }^{81}$.

Burch nie ma racji - scena ta ma zarówno subtelnie zasugerowana, choć istotnie wcale nie oczywistą przy pierwszym oglądzie filmu, kontynuację fabularną jak i potężna, choć też zakonspirowana, wymowę alegoryczną. Jej fabularny sens jest taki, że Mabuse pobiera jad węża, by

\footnotetext{
${ }^{80}$ Por.: N. Burch, op. cit., s. 5, 9; P. M. Jensen, op. cit., s. 37.

81 Zob.: N. Burch, op. cit., s. 9.
} 
przygotować truciznę, która zabije Carozzę. O tym, że zabija ją jad węża, a nie np. cyjanek potasu, świadczy subtelna sugestia wizualna: Carozza, kiedy feralnego wieczoru została aresztowana po wyjściu z "Casino Petit” i wystawieniu na egzekucję Hulla z Karstenem, miała na sobie wymyślną suknię, którą oplatał - niczym drzewo w Edenie - wąż. W podobny sposób semantyczną „aurą", bez dookreślenia „kropką nad i”, narracja w Zmęczonej Śmierci sugerowała przeniesienie się Dziewczyny w zaświaty przy pomocy mandragory. Natomiast konotacja alegoryczna węża - w związku z sekwencją lokali, będących terenem przestępczej działalności Mabusego - jest oczywista: Mabuse posługuje się jadem jako mocą węża, a więc grzechem, a więc jest siewcą zła i sługą szatana (ten ostatni aspekt ujawnia również samotne usytuowanie Mabusego podczas przyjęcia w salonie Toldów pod obrazem Lucyfera; wygląda on tam jak sługa szatana przy jego ołtarzu). Jad jest nie tylko trucizna, która zabija Carozzę - ma on wymiar społeczny jako „miazmaty zła” rozsiewane czy sączone w dekadenckich przybytkach, w których króluje Mabuse-gracz i z których przynajmniej jednego - „Palais Andalusia” - wydaje się gospodarzem. Odkrycie przez niego w przyniesionych przez Georga papierach Wenka listy tajnych domów gry z otwierającymi ich podwoje hasłami wywołuje jego wściekły okrzyk i groźbę pod adresem "szpicla”, który zdradził jego tajemnice (akt I, 5); i wszystko jedno, czy miał tu na myśli policyjnego agenta Karstena, czy Carozzę - oboje zostali zlikwidowani. A to by świadczyło, iż nie tylko był bywalcem, ale i co najmniej miał udziały w rozmaitych nielegalnych lokalach.

Mabuse w ogóle jawi się jako organizator „weimarskiego życia kulturalnego" i "rozrywkowego": wygłasza odczyt o psychoanalizie, odnosi jako Sandor Weltmann triumf w filharmonii podczas pokazu swych paranormalnych zdolności, czuwa nad sukcesem Carozzy podczas jej występu w „Folies Bergères”, a jeśli chodzi o „Palais Andalusia”, to jego ludzie zdają się rządzić przynajmniej tą ukrytą szulernia, której podwoje otwiera hasło "Ananas". Zapewne ma też jakieś powiązania ze Schrammem, który przed wojną był ulicznym sprzedawcą (niczym on sam w swym ostentacyjnie żydowskim wcieleniu), w 1919 prowadził z Żydami jakieś mętne interesy „"w brylantach”, a w 1922 jest potężnym „przedsiębiorcą rozrywkowym". Schramm (sam zapewne także Żyd) i Mabuse jawią się zatem jako przedstawiciele środowiska, które 11 lat później nazistowski dygnitarz określi jako „motłoch z Friedrichstraße”"82 - żydowscy (głównie)

82 Określenia tego użył w 1933 r. - co prawda tylko w odniesieniu do żydowskich producentów filmowych - nowy, nazistowski prezes niemieckiego związku właścicieli kin. Z powodzeniem można je jednak rozszerzyć na biznesmenów z wymienionych dalej branż, których przybytki także były usytuowane przy Friedrichstraße. Por.: David Stewart 
producenci filmowi, przedsiębiorcy rozrywkowi, właściciele kabaretów, rewii i lokali usytuowanych m.in. przy tej sławnej berlińskiej ulicy. Za miazmaty dekadenckiej rozrywki, za ,jad węża” w szalonych latach 20. zdaniem nazistów odpowiedzialni byli właśnie Żydzi, których alegoryczną reprezentacją był Mabuse i, w mniejszym stopniu, fantastycznie wybijający się w latach wojny i inflacji Raffke - Emil Schramm.

\section{Pan i niewolnicy}

Dla Pöklera, nazisty-kinomana z powieści Pynchona Tęcza grawitacji, Mabuse uosabiał jednak raczej „dzikość lwa” niż „jad węża”, raczej tytaniczną wolę, nieposkromioną energię czynu, niepohamowaną afirmację własnego ego oraz fantastyczny, choćby i nielegalnie osiągnięty, sukces ekonomiczny, niż „żydostwo", „bolszewizm”, "dekadencję". W przytoczonym jako motto fragmencie powieści Pökler przywołuje jako referencję Mabusego osobę Hugona Stinnesa, „niezmordowanego przedsiębiorcy, poruszającego zza kulis sznurkami pozornej inflacji, pozornych dziejów". Rzecz jasna, ani inflacja, ani tym bardziej dzieje nie były „pozorne”. Ale, jak odnotowuje Bernd Widdig, prawdziwym „królem inflacji”, bodaj największym beneficjentem jej mechanizmów, które rujnowały innych, był właśnie ów przemysłowy magnat, „jak nikt inny uosabiający splot pomiędzy inflacją koncentracją przemysłu a bogactwem" ${ }^{13}$. Dla Niemców tamtej doby nazwisko "Stinnes" było równie legendarne i budzące podobne skojarzenia, co dla Amerykanów „Rockefeller”, a gdy niespodziewanie 10 kwietnia 1924 zmarł (w wieku zaledwie 54 lat i w zenicie swej potęgi), uważano, iż był to najbogatszy człowiek, jakiego kiedykolwiek znały Niemcy ${ }^{84}$. Tajemnicą sukcesu Stinnesa była zarówno „integracja pionowa", skupienie w jednym ręku wszystkich etapów produkcji przemysłowej, od dysponowania surowcami po finalny produkt (w ten sposób Stinnes niemal zmonopolizował niemiecką energetykę), jak i „integracja pozioma", czyli inwestowanie w rozmaite dziedziny, od górnictwa po rynek prasowy, od przemysłu drzewnego po produkcję samolotów. "Nikt tak dobrze nie rozumiał mechanizmów inflacji, jak Stinnes. Bezwzględnie wykorzystywał [dewaluowane - T. K.] kredyty, [...] i z sukcesem speku-

Hull, Film in the Third Reich, University of California Press, Berkeley-Los Angeles-London 1969, s. 18-19.

83 B. Widdig, op. cit., s. 134.

${ }^{84}$ Ibidem, s. 135. Szerzej na temat Stinnesa, jego mitu w niemieckiej świadomości zbiorowej i odzwierciedleniu tego mitu w niemieckiej kulturze, zob.: B. Widdig, op. cit., s. $134-165$. 
lował na postępującej deprecjacji niemieckiej marki ${ }^{85}$. W dodatku, miał rozległe udziały za granica, dostarczające mu potężny strumień wielce cennej obcej waluty. Stinnes nigdy nie zaprzeczał, iż powitał inflację jako skuteczny sposób poszerzenia swego przemysłowego imperium, a swe działania legitymizował wskazywaniem, że tworzenie miejsc pracy dzięki boomowi inflacyjnej ekonomii ma pierwszeństwo wobec stabilności cen czy oszczędności" ${ }^{86}$. Śmierć Stinnesa zbiegła się z radykalnym i skutecznym powstrzymaniem inflacji, zaś jego potężne imperium w kilka lat legło w gruzach, co też czyni z niego tym wyrazistszy emblemat inflacji.

Mabusego nie można wprawdzie uznać za przemysłowego potentata, ale raport, jakiego w prologu dostarcza mu Pesch, o notowaniach platyny i transportach bawełny do Francji przez Szwajcarię, zdaje się świadczyć jeśli już nie o rozległej skali jego interesów (w dalszym ciągu filmu wątki te nie zostaną podjęte), to przynajmniej o snutych przezeń perspektywach. Zresztą giełdowa spekulacja wokół szwajcarsko-holenderskiej umowy handlowej świadczy, iż Mabuse jest figurą na skalę międzynarodową, toteż planowany wyjazd za granicę jawi się nie jako ucieczka, ale po prostu jako zmiana miejsca jego „bazy operacyjnej”.

Mabusego jeszcze jedna rzecz - ale tylko do czasu - łączy ze Stinnesem: Mabuse jest tytanem (dość co prawda szczególnej) pracy, aktywności, energii $^{87}$. Wydaje się, że pozostaje niezmordowanie aktywny przez 24 godziny na dobę, co obrazują dwa pierwsze akty filmu: prolog, którego pierwszy napis obwieszcza „,On i jego dzień”, i akt 2, rozpoczynający się napisem: „On i jego noc". W takiej sekwencji oba akty wydają się przedstawiać w sposób ciągły jedną dobę z życia Mabusego. „Dzień" to czuwanie z zegarkiem w ręku i przy telefonie nad koordynacją akcji kradzieży kontraktu, wysłuchanie raportu Pescha, trzykrotne charakteryzacje (jako „Rosjanina”, "francuskiego plebejusza" i "giełdziarza w cylindrze"), aranżowanie skomplikowanych komedii („,datek" dla żebraka, ,,stłuczka z przesiadką”, , "powrót plebejusza do domu"), instrukcje dla Spoerriego co do losów skradzionego dokumentu, inspekcja w „,wytwórni” Hawascha, wreszcie - uczestnictwo w sesji giełdy. "Noc" to wykład o psychoanalizie, dokonanie w samochodzie kolejnej charakteryzacji (na pana „Hugona Ballinga”), „aktywny” pobyt w „Folies

${ }^{85} \mathrm{~W}$ okresie niemieckiej inflacji zawrotne kariery robili często właśnie kredytobiorcy, podczas gdy wierzyciele niewaloryzowanego długu - plajtowali.

${ }^{86}$ B. Widdig, op. cit., s. 137-138. Podobnie dla rządu Republiki Weimarskiej priorytetem było powstrzymanie bezrobocia, zwłaszcza wobec znalezienia się na rynku pracy wielkiej liczby weteranów wojennych - choćby kosztem stabilności waluty. Zresztą ta niestabilność stwarzała pretekst do niewywiązywania się Niemiec z zasądzonych przez zwycięskich aliantów olbrzymich reparacji wojennych i dawała argument przeciwko nim.

87 Stinnes słynął ze swej pracowitości, zdyscyplinowania i dość ascetycznego - mimo ogromnego majątku - trybu życia. Por.: B. Widdig, op. cit., s. 141. 
Bergères", gdzie zapoznaje się z raportem (Carozzy?) o Hullu, obserwuje występ, zleca Carozzy robotę, hipnotyzuje Hulla, wreszcie - owocny pobyt za stołem gry (aż do piątej rano) w „Klubie Oczko”, gdzie bezlitośnie ogrywa swą ofiarę.

Nie dziwne, iż tak "zapracowany", jest wymagający wobec swych ludzi - grozi Spoerriemu, że za nadużywanie kokainy "wypędzi go jak psa”, beszta Pescha za spóźnienie („Nie spóźnia się na mojej służbie!”), ponagla Carozzę, już spóźnioną na randkę z Hullem, robi karczemną awanturę Spoerriemu i Hawaschowi za wymknięcie się Wenka z „Palais Andalusia”, wreszcie nie waha się zlikwidować Carozzy i Pescha, gdy uzna swe interesy za zagrożone. Jedyne słowa uznania ma właściwie tylko dla Georga (poinformowany telefonicznie o powodzeniu akcji, woła „Brawo, Georg!”, choć ten był tylko jednym z kilku aktorów skomplikowanej akcji). Po niepowodzeniu w „Andalusii" właśnie tylko Georg nie zostaje zbesztany, choć przecież on też nawalił, skoro Wenk nie zginął (właściwie po co zagazowanego prokuratora umieszczono na łódce pośrodku jeziora zamiast po prostu wrzucić go doń i utopić?). To chyba Georg jest tajemniczym „wydziałem likwidacji", o którym sam Georg wspomina zestresowanemu Peschowi, czyniąc niedwuznaczną pogróżkę, a potwierdzają to dalsze wypadki: zastrzelenie przezeń Karstena i Hulla, a później Pescha, podrzucenie trucizny Carozzy, nakaz milczenia, jaki daje aresztowanemu przez Wenka Spoerriemu. Georg wydaje się najbliższym zaufanym Mabusego - on porywa i zagazowuje Wenka, czeka w samochodzie, który uwiezie Mabusego i uprowadzoną przezeń hrabinę Told, informuje szefa o możliwej nielojalności Carozzy i dostaje odeń truciznę do egzekucji. Spośród wszystkich niewolników Mabusego, Georg właśnie wydaje się najlojalniejszy.

Bo relacja doktora do jego ludzi przypomina stosunek pana do niewolników, albo też - w kategoriach zaproponowanych przez Freuda w jego słynnej rozprawie Psychologia zbiorowości i analiza "ego" (Massenpsychologie und Ich-Analyse) - stosunek członków hordy pierwotnej do jej „ojca”. Tekst Freuda jest bardzo intrygujący z tej racji, iż napisany w roku 1920, antycypuje przerażający stan rzeczy w Niemczech z następnej dekady: uwiedzenie społeczeństwa masowego przez charyzmatycznego lidera. O rok poprzedza też publikację powieści Jacques'a i przystąpienie do jej ekranizacji przez Langa, co podobnie jak w wypadku relacji między Zmęczona Śmiercia a rozprawą Poza zasada przyjemności, wydaje się zbieżnością co najmniej zastanawiającą. „Masa [...] wydaje się nam odrodzoną hordą pierwotną" - pisał Freud - gdyż jak i w tamtej wyłania się w niej „obdarzona wielką mocą jednostka”. „Oto psychologia tych mas [...]: zanik świadomej osobowości jednostki, zwracanie myśli i uczuć w tych samych kierunkach, dominacja emocji i nieświadomych pierwiastków psychicznych, skłonność do natychmiastowej realizacji wyłaniających się zamiarów - wszystko to 
przedstawia stan regresji do prymitywnej aktywności psychicznej, którą właśnie można by przypisać hordzie pierwotnej" ${ }^{88}$. Charyzmatyczny przywódca masy, podobnie jak ojciec hordy pierwotnej, jest wolny wobec zniewolonych jednostek, tworzących masę (hordę). "Jego akty intelektualne również $w$ jego osamotnieniu były zdecydowane i niezależne, jego wola nie potrzebowała wsparcia innych. Toteż konsekwentnie przyjmujemy, iż jego ego było w małym stopniu skrępowane przez libido, nie kochał on nikogo poza soba, a innych o tyle tylko, o ile służyli jego potrzebom. Jego ego nie miało obiektom do zaoferowania nic zbędnego.

Na początku dziejów ludzkości był on nadczłowiekiem, którego Nietzsche spodziewał się dopiero w przyszłości. Jeszcze dziś ludzie kolektywni potrzebują złudzenia, że są przez wodza kochani na równi i sprawiedliwie, on sam jednak nie musi kochać nikogo innego - wolno mu mieć naturę pana, absolutnie narcystyczną, przy tym pewną siebie i niezależną" 89 .

Wśród niezwykłych aspektów powstawania mas, podległych woli charyzmatycznego przywódcy, są też takie, „które kryją się za zagadkowymi określeniami hipnoza i sugestia”. „Hipnoza ma w sobie coś niesamowitego; niesamowitość jednak wskazuje na coś dawnego i dobrze znanego, co uległo stłumieniu ${ }^{90}$. [...] Hipnotyzer twierdzi, że dysponuje tajemniczą siła, która hipnotyzowanego pozbawi własnej woli, lub też - co na jedno wychodzi - hipnotyzowany sam w to wierzy. Ową tajemniczą siłą - popularnie często jeszcze nazywaną zwierzęcym magnetyzmem musi być ta sama siła, która u ludów pierwotnych uchodzi za źródło tabu, emanuje z królów i naczelników plemion i powoduje, że zbliżenie się do nich grozi niebezpieczeństwem (mana). Teraz hipnotyzer twierdzi, że ją posiada, w jaki jednak sposób ją objawia? Mianowicie nakazuje osobie hipnotyzowanej, by patrzyła mu w oczy; hipnotyzuje ją w typowy sposób za pomocą spojrzenia" ${ }^{91}$.

„Niesamowity, kompulsywny charakter kształtowania się mas, który przejawia się $\mathrm{w}$ łączących się $\mathrm{z}$ nim zjawiskach sugestii, można więc

${ }^{88}$ Zygmunt Freud, Psychologia zbiorowości $i$ analiza ego, [w:] idem, Poza zasada przyjemności, przeł. Jerzy Prokopiuk, Państwowe Wydawnictwo Naukowe, Warszawa 1975 , s. 332.

${ }^{89}$ Ibidem, s. 333.

${ }^{90} \mathrm{~W}$ tym miejscu swej rozprawy Freud odsyła do innej - przywołanego już w niniejszym rozdziale eseju Niesamowite (Das Unheimliche) - zob. przypis 69. Kategorię "niesamowitego", będącego powrotem w zamaskowanej formie pewnych traumatycznych stanów pierwotnych, Freud analizuje tam na przykładzie opowiadania Hoffmanna Piaskun, w którym demoniczny Coppelius posługuje się (podobnie jak Mabuse) hipnozą i sugestią.

${ }_{91}$ Z. Freud, Psychologia zbiorowości i analiza ego, s. 335-336. 
słusznie powiązać z ich pochodzeniem od hordy pierwotnej. Przywódca masy jest ciągle jeszcze praojcem, którego wszyscy się obawiają masa chce być rządzona przez władzę niczym nie ograniczona, jest ona w najwyższym stopniu żądna autorytetu, spragniona [...] podporządkowania się. Praojciec jest ideałem mas, który rządzi ego zamiast ideału ego. Hipnoza ma prawo do określenia: dwuosobowa zbiorowość; sugestię zaś można zdefiniować jako przekonanie, które nie opiera się na postrzeżeniu i pracy myśli, lecz na więzi erotycznej"92.

Rzecz jasna, rozważania Freuda z tej rozprawy musiały zainspirować Frommowski koncept „osobowości autorytarnej z kompleksem sado-masochistycznym" ${ }^{93}$, a pośrednio (lub bezpośrednio) również wywody Kracauera w książce Od Caligariego do Hitlera. Kategorie Freuda, jak i tych jego poniekąd kontynuatorów, jak ulał pasują do analizy relacji między doktorem Mabuse a jego ludźmi. Oczywiście, nie tworzą oni "masy”, ale są alegoryczną reprezentacją mas, uwiedzionych przez charyzmatycznego wodza. Właśnie - uwiedzionych. W ich stosunku do Mabusego jest niewattpliwie silny pierwiastek erotyczny, oczywisty w wypadku zakochanej kobiety (Carozza), ale wyraźny również u innych jego podwładnych, w tym wszystkich mężczyzn. Spoerri, zbesztany za wzięcie kokainy, patrzy na Mabusego jak zbity pies i wyznaje: „Jeżeli mnie pan stąd wypędzi, palnę sobie w łeb!” Noël Burch nie tylko określa relację Mabuse - Spoerri jako relację „pan - niewolnik”, ale i konstatuje jej homoseksualny wymiar ${ }^{94}$, sugerowany, być może, przez pewną zniewieściałość i cherlawość Spoerriego. Fine - to silna, przebiegła, odważna baba (podczas finałowego oblężenia domu Mabusego ostrzeliwuje z okna policjantów na ulicy i heroicznie ginie od kuli razem ze wspomagającym ją Hawaschem). Fine z lubością wdaje się z Mabusem $\mathrm{w}$ odgrywane na ulicy, nieopodal lokalu Hawascha, komedie $\mathrm{z}$ „pijanym plebejuszem” i „Żydem domokrążcą". Pesch być może nienawidzi doktora - ale boi się go jak posłuszny pies i ginie przez swą nierozumną lojalność, sparaliżowany przez strach albo przez hipnozę, choć być może zeznanie złożone Wenkowi od razu w celi martwej Carozzy ocaliłoby mu życie.

Spoerri i Pesch to słabeusze w przeciwieństwie do silnego, wysokiego, potężnie zbudowanego Georga. To Georg obezwładnia w pociągu kuriera przewożącego szwajcarsko-holenderską umowę, to on jest egzekutorem, jednoosobowym „wydziałem likwidacji”. Jest nie tylko faworytem

92 Ibidem, s. 338.

93 Erich Fromm, Ucieczka od wolności, przeł. Olga i Andrzej Ziemilscy, Czytelnik, Warszawa 1978.

94 Zob.: N. Burch, op. cit., s. 4. 
Mabusego, ale istotnie jest mu bezgranicznie oddany, co ujawnia jego troska o szefa podczas finałowego oblężenia: to on nakazuje ratować Mabusemu samego siebie i porzucić niczym zbędny balast szamoczącą się hrabinę. Wpycha Mabusego do włazu, którym ten ucieka, a sam mimo iż w niebezpieczeństwie - nie ratuje się, tylko usiłuje dogonić hrabinę (bo tak by chciał „doktor”), już zaś schwytany, pilnuje, by Spoerri nie sypał. W celi - zrozumiawszy, iż gang Mabusego rozbito i wszystko stracone - wiesza się, ale jego mina przy przygotowaniach do samobójstwa i napis, jaki gryzmoli na ścianie, świadczą, iż swą śmierć traktuje jak złośliwy kawał zrobiony prokuratorowi i policji. Cóż bowiem znaczy owo "Götz von Berlichingen”? Ów tytułowy bohater dramatu Goethego Götz von Berlichingen Żelaznoręki (Götz von Berlichingen mit der eisernen Hand, 1773) to postać historyczna, przywódca buntu chłopskiego w 1525, zresztą nie do końca - przynajmniej w dramacie - z celami tego buntu się identyfikujący. Można by zatem odczytać ewokowanie przez Georga tej postaci „ideowo", jak wypowiedzenie pod szubienicą oddania "dla sprawy” (i faktycznie, troska Georga o ucieczkę Mabusego, gdyż jego życie jest cenne, zdaje się świadczyć na rzecz tej interpretacji). Ale z drugiej strony, w języku niemieckim szczególną karierę językową zrobiło wyrażenie "cytat z Götza" (we frazach typu: „odpowiedział mu cytatem z Götza"). Ów sławetny cytat, tak szokujący i pamiętny, iż stał się przysłowiowy, brzmi: „Er kann mich im Arsch lecken" 95 - „Może mnie on gdzieś pocałować" (w dość eufemistycznym przekładzie). Czy nie to przed śmiercią chciał powiedzieć Georg, mając na myśli Wenka, któremu po raz trzeci (po Carozzy i Peschu) sprzątnął sprzed nosa ważnego świadka?

Atmosfera w oblężonym przez policję i wojsko domu Mabusego dość zastanawiająco przypomina to, co widzimy w ukazującym naczelny sztab Trzeciej Rzeszy w przedzień ostatecznej klęski nazizmu filmie Olivera Hirschbiegla Upadek (Untergang, 2004) - śmierć w walce ludzi desperacko się broniących (Fine, Hawasch), sąsiaduje z niedwuznaczną chęcią poddania się i zakończenia koszmaru (Spoerri), z próbą wymknięcia się z sieci (sam Mabuse) i z ideowym samobójstwem (Georg). Fanatyzm tego ostatniego przywodzi na myśl przerażającą desperację Frau Goebbels, która przed popełnionym wraz z mężem samobójstwem w systematyczny sposób zamorduje wszystkie swoje dzieci, by nie żyły w świecie bez narodowego socjalizmu. Czy oddany, zakochany, zahipnotyzowany Georg mógłby w ogóle żyć w świecie bez Mabusego - podobnie zresztą jak Carozza, która rozczarowana brakiem wzajemności dla swej miłości do

${ }_{95}$ Zob. przypis do dramatu Götz von Berlichingen Żelaznoręki, [w:] Johann Wolfgang Goethe, Dramaty wybrane, t. 1, Państwowy Instytut Wydawniczy, Warszawa 1984, s. 441. 
„nadczłowieka”, mimo to posłusznie łyka zaordynowaną jej przez niego truciznę? ${ }^{96}$

Relacja "pan - niewolnik” wiąże Mabusego nie tylko z członkami jego gangu, ale i z jego bogatymi ofiarami: Hullem, grubą Rosjanką u Schramma, załamanym graczem w „Palais Andalusia”, który ustępuje miejsca przy stole gry Wenkowi, hrabią Toldem. Ofiary te paraliżuje Mabuse wzrokiem, a pod wpływem jego spojrzenia albo nie dobierają kart (jak rozhisteryzowana właścicielka pereł od Tiffany'ego, tłumacząca przegraną swym sparaliżowaniem przez złe, diabelskie oczy trzymającego bank Mabusego), albo je rzucają uznając swą porażkę (jak Hull, trzymający w ręku karty najlepsze z możliwych w grze w "oczko": asa i dziesiątkę). Ciekawe jednak, że o ile Hull i Rosjanka patrzyli wprost w oczy Mabusemu i załamywali się pod jego wzrokiem (co zresztą znakomicie wyraża rozegranie tych scen we frazie ujęcia/przeciwujęcia na osi montażowej, a nie po jednej stronie osi, jak to na ogół bywa), w odniesieniu do hrabiego Tolda wystarczyło spojrzenie z tyłu i z daleka. Może dlatego, iż Mabusemu tym razem nie chodziło o wygraną od roznamiętnionego hazardem gracza, którego trzeba było bardziej „,bezpośrednio” obezwładnić wzrokiem, ale o sugestię, by hrabia w ogóle zasiadł do gry i w niej oszukiwał. Dla zasugerowania Hullowi, by mimo zafascynowania Carozzą opuścił „Folies Bergères” i zabrał „pana Ballinga” do „Klubu Oczko”, też wpierw wystarczyło spojrzenie z daleka i z tyłu. Dopiero w grze "twarzą w twarz” musiał "pan Balling” użyć przeciwko milionerowi pełni mocy swego spojrzenia w bezpośrednim pojedynku wzrokowym, tym bardziej, iż Hull miał zwycięskie karty, a w rozdawaniu kart Mabuse, zdaje się, nie oszukiwał.

Hipnotycznemu spojrzeniu Mabusego nie ulega Wenk - „czarowany” zarówno przez chińskie okulary, których błyski „holenderski profesor" jakby mimochodem rzucał na senne oczy prokuratora, jak i wprost paraliżowany wzrokiem przeciwnika, ostatecznie nie pobiera następnej karty, na co trzymający bank Mabuse nalega - i "holenderski profesor", zrozumiawszy, że ma do czynienia z niebezpiecznym rywalem, pasuje i ewakuuje się z lokalu. Drugi raz, w filharmonii, Wenk wprawdzie ostatecznie zostaje zahipnotyzowany przez Sandora Weltmanna, ale z trudem i to już po rozpoznaniu przez prokuratora tożsamości „Węgra” zarówno $\mathrm{z}$ "holenderskim profesorem”, jak i z doktorem Mabuse, dzięki czemu, po uratowaniu przez swych agentów i odzyskaniu przytomności, będzie

96 Prefiguracje nazizmu są w filmie Langa bardzo silne dla dzisiejszego widza: motyw trucizny nasuwa nieodparte skojarzenia z ampułkami z cyjankiem, które w Upadku Hitler rozdaje swym zaufanym, zaś zagazowanie Wenka w samochodzie ewokuje cyklon B w obozach czy ofiary z Chełmna gazowane w ciężarówkach. 
mógł wszcząć przeciw Mabusemu i jego ludziom decydującą akcję. Wenk jest bowiem rzecznikiem racjonalności, logiki, dyskursywności, porządku demokratycznego i prawa, a jego triumf ma wydźwięk moralizatorski, choć może nie jest $\mathrm{w}$ pełni przekonujący ${ }^{97}$ (Mabuse, który tak łatwo wyprowadził go $\mathrm{w}$ pole $\mathrm{w}$ hotelu parą damskich kozaków, mógł go potem przecież uprowadzonego przez Georga i obezwładnionego gazem łatwo zlikwidować).

Przy stole gry Wenk nie ulega Mabusemu, bo nie jest jego niewolnikiem, nie jest opętany przez hazard: wejście w hazard, w szaleństwo gry (w jakiejkolwiek formie - gry w karty czy spekulacji na giełdzie) wydawało niefortunnego gracza na łup „króla inflacji”, na zniewolenie przezeń. Gra hazardowa to królestwo chaosu, przypadku, śmiertelnego ryzyka związanego i z nieobliczalnością, i możliwością manipulacji. Jak pokazują zwłaszcza scenki z prologu (kradzież kontraktu, ,datek”, ,,stłuczka” itd.), Mabuse jest mistrzem precyzyjnego aranżowania zdarzeń, tak, by były stylizowane na przypadek, samemu na przypadek się nie zdając (jedyny raz zdaje się on na przypadek, losując z tasowanej "talii” zdjęć pierwszą tożsamość na dzień akcji z kontraktem: starego „Rosjanina”). Nadzieja graczy na szczęśliwy traf, na sprzyjający przypadek, szybki i łatwy pieniądz w wygranej grze czy udanej spekulacji giełdowej, prędko mogła przerodzić się w całkowite bankructwo, a upojenie gra, dające intensywność przeżyć à la Dostojewski - w histeryczną rozpacz (reakcja Rosjanki) albo samobójcze załamanie (reakcja gracza w „Andalusii”, który odchodzi od stołu krokiem, jakby miał zaraz palnąć sobie w łeb).

Związek szaleńczego hazardu z niemiecką inflacją po I wojnie światowej tak skomentował Bernd Widdig: „Hazard odzwierciedla tak typową dla inflacji wzmożoną cyrkulację pieniądza. Stosy pieniędzy przed graczami nie na długo przy nich zostaną; nie reprezentują one majątku zgromadzonego na koncie, ale przepływają wraz z wymianą dokonującą się wraz z każdą nową grą"98. "Jak i inflacja, hazard zagęszcza chwilę bieżącą. Szczęście (luck) dla wszystkich jest takie samo, bez względu na pozycję społeczna, edukację, płeć czy klasę. Gdy już tylko przekroczono barierę tajnego wejścia do domu gry, znikają bariery klasowe. Wytwarza się nowy

${ }^{97}$ Może także i dlatego, że Wenk jest postacią budzącą ambiwalentny stosunek odbiorcy - nie jest ani atrakcyjny fizycznie, ani nie budzi sympatii (ja np. nie potrafię uwolnić się od postrzegania w nim "zmęczonej Śmierci”). Poza tym to nie romantyczny detektyw (jak np. Sherlock Holmes w walce z profesorem Moriartym), tylko prokurator okręgowy. Ciekawe, że w następnych weimarskich kryminałach Langa - M - mordercy i Testamencie doktora Mabuse - rzecznikiem demokracji, prawa i racjonalności będzie także figura urzędowa, bez cienia romantyzmu ułatwiającego widzowi identyfikację: jeszcze bardziej fizycznie odpychający, choć może za to trochę sympatyczniejszy, komisarz Lohmann.

98 B. Widdig, op. cit., s. 129. 
porządek, zwycięzców i przegranych w grze. Los dotyka tylko indywidualnego gracza, a autonomia jednostki staje się czymś zarazem wspaniałym i przerażającym. Gracz odarty jest z wszelkich więzi społecznych; ani rodzina, ani przyjaciele, nie może pomóc graczowi w decyzjach przy stole gry $^{99}$. Tak zatem gra przypadku staje się miejscem, gdzie egalitarna utopia radykalnego indywidualizmu zostaje, w złowrogi sposób, spełniona"100.

Na łup Mabusego, prócz namiętności hazardu, wystawia jego bogate ofiary zmysłowość, bycie niczym Mozartowski Don Juan „człowiekiem estetycznym" w rozumieniu Kierkegaarda ${ }^{101}$. Zmysłowość i hedonizm Hulla, postaci dekadenckiej i słabej, czyni go łatwą ofiarą Carozzy, udającej zakochanie, a jak pokazuje pointa aktu I, 3 - naprawdę go nienawidzącej. Carozza bez skrupułów wystawia „ukochanego" na śmierć, choć sama zaraz za to zapłaci „ukąszeniem węża” - jej suknia, w której była z Hullem w "Casino Petit” jest, doprawdy, alegoryczna. Alegoryczną zapowiedzią losu Carozzy (i ona, jest jak Hull, „człowiekiem estetycznym”) jest też spektakl, w którym pozornie triumfująca nad dwoma fallicznymi monstrami (Mabusem i Hullem?), nagle porwana przez porywisty podmuch, zostaje obnażona i bezbronna. "Człowiekiem estetycznym" jest też niewątpliwie hrabia Told, koneser i kolekcjoner dekadenckiej i demonicznej sztuki. Told to prawdopodobnie, jak i Spoerri, homoseksualista, o czym świadczy jego w gruncie rzeczy obojętność wobec atrakcyjnej żony, zniewieściałość i miękkość gestów, zjawienie się u Schramma w towarzystwie mężczyzny ${ }^{102}$. Ale o ile Hulla i Carozzę gubi zbytnia namiętność, to hrabiego wydaje Mabusemu kompletny - prócz pasji kolekcjonerskiej - brak jakichkolwiek namiętności. Tak podsumowuje go Lotte Eisner: „Jest «wrażliwy», skupiony na sobie i pozbawiony kręgosłupa (spineless). Jako kolekcjoner jest tak uzależniony od nałogu dzieł sztuki, zupełnie jakby były opium" ${ }^{103}$. Hrabia jest chyba w ogóle podatny na nałogi - podprowadzenie go do samobójstwa ułatwia Mabusemu nie tylko zarządzona

99 Unaocznia to zwłaszcza sekwencja w „Klubie Oczko”, kiedy znajomi nie są w stanie powstrzymać Hulla od szaleńczego przegrywania do „pana Ballinga” i desperackiego zagrania przeciwko niemu va banque o piątej rano.

100 B. Widdig, op. cit., s. 128-129. W światowej literaturze wnikliwy opis doświadczenia hazardu dali dwaj wielcy pisarze, którzy sami przeszli przez traumatyczne doświadczenie wielkiej przegranej w grze - William Makepeace Thackeray (Yellowplush Papers oraz parę innych utworów) i Fiodor Dostojewski (Gracz).

101 Por.: Søren Kierkegaard, Albo - albo, przeł. Jarosław Iwaszkiewicz, Państwowe Wydawnictwo Naukowe, Warszawa 1976, t. 1, s. 48-154.

102 E. Ann Kaplan upatruje homoseksualizmu hrabiego i w obojętności wobec żony, i w artystycznej pasji. Zob.: E. Ann Kaplan, Fritz Lang and German Expressionism: A Reading of "Dr. Mabuse, der Spieler", [w:] Passion and Rebellion: The Expressionist Heritage, ed. Stephen Eric Bronner \& Douglas Kellner, Columbia University Press, New York 1983, s. 401.

${ }^{103}$ L. H. Eisner, Fritz Lang, s. 60. 
izolacja "pacjenta”, ale i jego alkoholizm po spowodowanej skandalem „utracie formy” (depresji Tolda raczej nie spowodowała rozpacz po odejściu żony, choć ten właśnie powód sugeruje on Wenkowi).

O tym, że Mabuse wywiera na swe ofiary hipnotyczny wpływ, świadczą też proporcje zabójstw i samobójstw w filmie. Owszem, Hull, Karsten, Pesch to ofiary zabójstw, jednak Carozza, Told i Georg popełniają samobójstwo. Georg, dostarczający Carozzy truciznę, i tak pewnie by ją zabił, gdyby się opierała, jednak Carozza zażywa śmiercionośny specyfik dobrowolnie, może nawet bardziej rozczarowana (jak wtedy, gdy w bukiecie od Mabusego po spektaklu znalazła nie miłosny bilet, a nowe instrukcje) niż przerażona wydanym przez ukochanego wyrokiem śmierci. Samobójstwo Georga ma aspekt opętanego oddania bezrefleksyjnego wyznawcy charyzmatycznemu wodzowi - zjawisko to z przerażającą mocą ujawniło się kilkanaście lat później, gdy już Republikę Weimarską zastąpiła Trzecia Rzesza.

Postacią, która przeżywa zamach Mabusego, choć przypłaca to obłąkaniem i, być może, nie jest to do końca oczywiste, gwałtem - jest hrabina. Ratuje ją jej oziębłość, brak uczuć, niechęć do zaanagażowania się w cokolwiek i niemożność koncentracji. Jej mąż jest jej równie obojętny jak ona jemu, toteż nie z miłości deklaruje chęć powrotu do męża z niewoli Mabusego. Hrabina pragnie emocji, intensywnych doznań, ale nie chce się angażować ani $\mathrm{w}$ grę (tę woli obserwować), ani w przygodę $\mathrm{z}$ namiętnie jej pożądającym Mabusem (choć przecież była poruszona - ale tylko jako słuchaczka - odkryciem miłości Carozzy), ani we współpracę z wielbiącym ja, trochę niezręcznie, Wenkiem. O jej braku koncentracji świadczy przerwanie seansu (choć to być może nie ona, ale Mabuse, stanowiła podczas niego „obcy element”) oraz bezwiedne wodzenie w salonie palcem po spiralnym wzorze swej sukni. Inna sprawa, że ten nieświadomy gest ma też wymowę alegoryczną: za chwilę obok hrabiny zjawi się wybitny psychoanalityk, doktor Mabuse, i pochwyci ją w spiralną sieć niczym pająk. Ale podkreślam jeszcze raz - właśnie chłód emocjonalny i pasywność ratują hrabinę. Stanowią one bowiem dla Mabusego przeszkodę nie do pokonania. Zdesperowany doktor mówi hrabinie (akt II, 3): „Gra między panią a mną musi się skończyć... Tak albo tak... Nie jestem tym człowiekiem, którym byłem. Robię błędy... tracę nerwy..." Skrępowane przez libido, ego Mabusego - wcześniej niezależne, totalnie egotyczne - przestaje być jaźnią godną „pana”, „ojca hordy pierwotnej”. Mabuse, ogarnięty przez niespełnione pożądanie, staje się coraz podobniejszy do swych ofiar, do swych uzależnionych od nałogów niewolników, jednym słowem - do „człowieka estetycznego". Wyrazem tego są coraz częstsze jego ataki wściekłości, sięganie do alkoholu, a zwłaszcza najmocniej go w oczach widza „umniejszająca” pijatyka, którą ze swymi ludźmi świętował chwilowe 
zwycięstwo w „wielkiej grze”: skandal w salonie Toldów i uprowadzenie hrabiny.

Do klęski Mabusego przyczynia się też jeszcze jedna rzecz - jak już zauważył Hegel, świadomość pana jest świadomością niesamoistną: potrzebuje niewolnika jako swego odniesienia ${ }^{104}$. Mabusemu w pewnym sensie udało się zbyt dobrze z eliminacją swych ofiar: pozbawiony najlojalniejszej agentki, Carozzy, Pescha - speca od bomb, Hulla i Tolda - milionerów, z których wiele można było jeszcze wycisnąć, Mabuse nieopatrznie pozbył się swych atutów, zgrał wszystkie swe asy, znalazł się w pustce, w której nie miał już kim ani po co grać, a energia opowiadania, które przez 4,5 godziny toczyło się w tak zawrotnym tempie, uległa definitywnemu wyczerpaniu ${ }^{105}$.

Klęskę Mabusego wyraża także utrata jego panowania nie tylko nad ludźmi, których sam się pozbył, ale również nad czasem i przestrzenia, panowania, które sprawował dzięki atrybutom nowoczesności, takim jak zegar, środki łączności i komunikacji (telefon, samochód, pociąg), media (prasa, a także... kino) ${ }^{106}$. W prologu jego czuwanie z zegarkiem w ręku przy telefonie umożliwia mu - tak się przynajmniej wydaje widzowi dzięki montażowi symultanicznemu przenoszącemu $\mathrm{z}$ jednej przestrzeni do zupełnie innej - kontrolę nad akcją kradzieży kontraktu. Jego ludzie - Georg i kierowca - z takimi samymi zegarkami-cebulami w ręku precyzyjnie w czasie podejmują wyznaczone im zadania, dzięki czemu pociąg (dodajmy - pociąg punktualny) i samochód, który ma uwieźć skradziony dokument, $\mathrm{w}$ ściśle oznaczonym momencie i punkcie $\mathrm{w}$ przestrzeni krzyżują swe trajektorie. Podobnie precyzyjnie zaplanowana jest stłuczka, dzięki której przebrany za „Rosjanina” Mabuse „konspiracyjnie” przesiada się do innego samochodu, w którym czeka już na niego skradziona umowa (zdarzenie to wydaje się zbędne, bezcelowe narracyjnie, ale podkreśla ono alegorycznie po raz kolejny panowanie Mabusego nad czasem i przestrzenią, ",determinizm”, poprzez który przynajmniej na pewną skalę wyeliminował on przypadek, po prostu go „aranżując”). Prasa, w stosownych momentach przekazująca na giełdę dostarczone przez Mabusego informacje, jest dlań instrumentem, dzięki któremu może manipulować kursami akcji. A samochód - czy to umożliwiający mu ucieczkę przed Wenkiem z „Palais Andalusia”, czy to (dwukrotnie) w odpowiednim momencie podstawiony Wenkowi - zjawia się w obmyślony przezeń sposób jak na zawołanie.

${ }^{104}$ Por.: Georg Wilhelm Friedrich Hegel, Fenomenologia ducha, przeł. Adam Landman, Państwowe Wydawnictwo Naukowe, Warszawa 1963, t. 1, s. 221-224.

105 Por. uwagi Thomasa Elsaessera (op. cit., s. 179-181).

106 Por.: T. Gunning, op. cit., s. 94-99. 
Mabuse jest również filmowcem - oczywiście, na modłę alegoryczną. Niemniej ten moment występu Sandora Weltmanna, w którym zahipnotyzowanej publiczności wyczarowuje on wyłaniającą się z głębi sceny i wędrującą pomiędzy widzami karawanę, ewidentnie jest metaforą kina: sytuacji, w której unieruchomiony w ciemności odbiorca doświadcza dialektyki realności-nierealności pewnego iluzyjnego świata, świata spektaklu. Nie miejsce tu, by przywoływać rozmaite teksty czy koncepty dotyczące „wrażenia realności” czy hipnotycznego wpływu kina, niemniej ten fragment filmu Langa jest potężną artystycznie alegorią kina i sytuacji widza - i aż dziwne, że nie przywołują go w swych tekstach np. Christian Metz czy Jean-Louis Baudry. Dla widza filmu doświadczającego podobnego oczarowania, co publiczność wewnątrzdiegetycznej filharmonii, jest oczywiste jednak, że „cud" Weltmanna dokonał się wyłącznie dzięki montażowi ciętemu: to właśnie montaż, nawet bez jakichś szczególnie wymyślnych trików, umożliwił kolejno pojawienie się karawany na scenie, następnie znalezienie się jej poniżej rampy sceny pośród widowni, wreszcie jej zniknięcie. A ponieważ opisane wcześniej panowanie Mabusego nad czasem i przestrzenia, w chwytach filmowych realizowało się także poprzez montaż (cięty montaż symultaniczny), to Mabuse jawi się jako „władca dyskursu”, hipnotycznie zniewalający widownię, i kolejna w twórczości Langa (po „zmęczonej Śmierci”) figura artysty filmowego.

A jednak „władca dyskursu" ponosi klęskę, którą-znowu alegorycznie - wyraża finał w nielegalnej wytwórni Hawascha. Precyzyjnie obmyślony przez jego ludzi mechanizm blokujący właz i drzwi okazuje się pułapką, a nie ratunkiem. Pan czasu i przestrzeni miota się bezradnie w mrocznej piwnicy, pośród niegdyś mu służących, a obecnie przerażających mechanizmów. W ekspresjonistycznej wizji (przypominającej trochę Molocha z Cabirii, 1913, Giovanniego Pastrone i antycypującej wizję Fredera z Metropolis) ujawnia się, wedle Toma Gunninga, typowa dla filmów Langa „machina Przeznaczenia”"107. Demonstruje ona - w jednym wymiarze - jałowość i bezcelowość projektu Mabusego, produkcji fałszywego pieniądza, którego stosy zaśmiecają podłogę. Ujawnia się jednak przede wszystkim wymiar moralny kary, jaka spotyka siewcę zła i sługę $\mathrm{s} z$ a t a n a: jeden z elementów maszyny drukarskiej, kolista tarcza z żarówkami, jawi się Mabusemu jak jakieś upiorne słońce z rozżarzonymi oczami, demon, który za chwilę go pożre. Co gorsza, dwa inne elementy mechanizmu po jego bokach, niczym jakieś ogromne świerszcze, wykonują groźne mechaniczne ruchy, jak gdyby chciały Mabusego zgnieść czy przemielić. Mabuse w obliczu tej wizji pada oszalały na podłogę. Gdy tuż

107 Ibidem, s. 116. 
przed swym triumfem w salonie Toldów stał pod awangardowym obrazem Lucyfera, niczym potężny sługa u stóp jego ołtarza, nie spodziewał się zapewne, iż niezadługo na innym, ale bardzo podobnym ołtarzu, sam zostanie pochłonięty przez złego demona o świetlistych oczach, zawsze unicestwiającego swych czcicieli ${ }^{108}$.

Jak już nadmieniłem, aż nazbyt precyzyjna realizacja scenariusza jego intrygi usunęła podstawowe figury, którymi prowadził swą grę - dalsza intryga, bez podporządkowanych jego hipnotyzującej woli istot, jest bezcelowa i niemożliwa. Mabuse to odkrywa znalazłszy się nagle w królestwie zmarłych, którymi już nie jest w stanie rządzić, a którzy, co więcej, niczym Erynie biorą odwet. Osaczenie Mabusego przez ubrane na czarno widma Hulla, Pescha, Tolda i Carozzy unaocznia mu w jego wizji jeszcze inny wymiar dotykającej go kary: wyrzuty sumienia. Postawiony wobec jedynych żywych osób w tej przypominającej Hades, jakby podziemnej przestrzeni - śl e p c ó w, nie może już dłużej korzystać ze swego podstawowego sposobu wywierania wpływu na innych: hipnotycznego spojrzenia ${ }^{109}$. Gdy Wenk przychodzi go aresztować, jego wzrok zdaje się błędny, mętny, niewidzący: czas hipnozy, jak i czas filmu, dobiegł końca ${ }^{110}$.

\section{Ekspresjonizm?}

Czy Doktor Mabuse, gracz jest filmem ekspresjonistycznym? Lang w rozmaitych wypowiedziach odżegnywał się od przypisanej mu etykietki „ekspresjonisty”, ale jak to bywa, autor nie zawsze jest najlepszym komentatorem swej twórczości, zwłaszcza autor taki jak Lang, często podający dość niewiarygodne albo zweryfikowane negatywnie informacje, związane z okolicznościami powstania swych dzieł. W rozmaitych wykazach pewnego „kanonu” dzieł filmowego ekspresjonizmu Dr. Mabuse, der Spieler figuruje na poczesnym miejscu - ostatnio np. książeczka Paula

108 Promienie, wychodzące z oczu demona na obrazie w salonie Toldów, jak i utworzone przez żarówki świetliste oczy demona w lokalu Hawascha, każą w obu widzieć przedstawienia Lucyfera - etymologicznie imię to oznacza „niosącego światło”. Eksponowanie oczu demona ironicznie wiąże się też z (byłą) potęgą Mabusego: hipnotyczną zdolnością jego wzroku.

109 Nt. relacji Mabuse - ślepcy w finale filmu zob.: T. Gunning, op. cit., s. 114; B. Widdig, s. 132-133. Widdig popełnia tu błąd rzeczowy, pisząc, iż swą ostatnią grę w karty Mabuse rozgrywa w „wytwórni" Hawascha ze ślepcami: rozgrywa ją z ubranymi na czarno widmami swych ofiar, Hullem i Toldem. Jest moment, że w wizji Mabusego ślepcy zamieniają się (po przenikaniu) w widma czterech ofiar, ale gra toczy się już z widmami: za stołem siedzą z Mabusem Told i Hull, świadkują grze, stojąc, Carozza i Pesch.

110 A swoją droga, czyż szaleństwo kogoś, kto deklarował jako jedyną realność „,wolę mocy", nie czyni z Mabusego figury analogicznej do Nietzschego? 
Cooke'a German Expressionist Film, wydana w popularnej serii zwięzłych bryków „The Pocket Essential”, omawia film Langa pośród 19 utworów, uznanych za reprezentatywne dla niemieckiego ekspresjonizmu filmowego $^{111}$. Z drugiej jednak strony, Cooke zauważa, iż w swym filmie styl ten Lang nie tyle stosuje (w dobrej wierze), ile raczej „ironizuje” na jego temat. „Ekspresjonistyczna mise en scène, zamiast użycia jej do ukazania psychologicznej głębi filmowej postaci, jak w Caligarim, jest tu raczej zastosowana dla uwypuklenia zewnętrznej strony dekadencji przedstawionego świata. Ekspresjonizm, dominujący styl epoki, staje się metaforą stanu społeczeństwa. «To tylko gra» - mówi w którymś momencie Mabuse, zapytany, co sądzi o ekspresjonistycznym malarstwie. Mabuse zatem sugeruje, iż ekspresjonizm jest stylem doskonale wyrażającym epokę, ponieważ «wszystko dziś jest grą». Ekspresjonizm, jak i Weimarskie Niemcy, jest wyzbyty znaczenia. Jest wyłącznie pozbawioną treści formą"112. W kontekście takiej dwuznaczności - bycia ekspresjonistą albo stosowania tego stylu „w złej wierze" - Doktor Mabuse, gracz jest chyba najlepszą okazja by wyjaśnić relację Langa do kierunku, uznawanego za paradygmatyczny dla kina niemieckiego lat 20.

Kwestia ekspresjonizmu nigdy nie była oczywista w historii kina. Uznawane za klasyczne monografie tego kierunku książki Siegfrieda Kracauera ${ }^{113}$ i Lotte Eisner ${ }^{114}$, tak naprawdę wcale nimi nie sa, co zresztą wyrażają podtytuły ich oryginalnych wydań: Kracauera zajmuje „psychologiczna historia", czy raczej symptomatyczna interpretacja w duchu „psychoanalizy społecznej” filmów okresu weimarskiego, Lotte Eisner zaś pisze o wpływie teatru Reinhardta i ekspresjonizmu na filmy Republiki Weimarskiej należące do rozmaitych tendencji stylistycznych, nie czyniąc zresztą wyraźnych między nimi dystynkcji. Z późniejszych ważnych opracowań tego nurtu podobna do książki Eisner nieostrość pojęciowa cechuje monografię Johna Barlowa, który włącza w obręb niemieckiego ekspresjonizmu filmowego zarówno Kammerspiel, jak i wiązany na ogół

111 Paul Cooke, German Expressionist Film, Pocket Essentials, Harpenden 2002. Cooke omawia w swej książeczce jeszcze cztery inne filmy Langa: Zmęczona Śmierć, Nibelungi, Metropolis i $M-$ morderce, a także np. trzy Straßenfilme Pabsta, reżysera jednak często niewłączanego w obręb ekspresjonizmu.

112 Ibidem, s. 39.

113 Siegfried Kracauer, Od Caligariego do Hitlera: Z psychologii filmu niemieckiego (wyd. oryginalne: S. Kracauer, From Caligari to Hitler: A Psychological History of the German Film, Princeton University Press, Princeton 1947).

${ }^{114}$ Lotte H. Eisner, Ekran demoniczny, przeł. Konrad Eberhardt, Wydawnictwa Artystyczne i Filmowe, Warszawa 1974 (wyd. oryginalne: Lotte H. Eisner, L'Écran démoniaque: Influence de Max Reinhardt et de l'expressionisme, Éditions André Bonne, Paris 1952). 
z przeciwstawianą ekspresjonizmowi Nową Rzeczowością Straßenfilm ${ }^{115}$. Stąd też np. Thomas Elsaesser w swych tekstach rewidujących zarówno kategorię ekspresjonizmu, jak i uznawanie prac Kracauera i Eisner za monografie tego nurtu, proponuje, by posługiwać się w odniesieniu do analizowanych w nich filmów, znacznie mniej kontrowersyjną i owocniejsza, bo sytuującą kino w kontekście historyczno-politycznym i społeczno-kulturowym, kategorią „kina weimarskiego” (ewentualnie: „kina Republiki Weimarskiej") $)^{116}$.

Propozycja Elsaessera jest tym bardziej sensowna, że prawdziwy kij w mrowisko w kwestii niemieckiego ekspresjonizmu filmowego wsadził Barry Salt w opublikowanym w 1979 r. artykule From Caligari to Who?, tytułem swym, rzecz jasna, nawiązującym do książki Kracauera; powtórzył zresztą swe argumenty w monumentalnej pracy Styl i technologia filmu: Historia i analiza (Film Style and Technology: History \& Analysis, $1983)^{117}$. Salt uznaje, iż za ekspresjonistyczne - z racji cech stylistycznych, przede wszystkim płaskich, teatralno-malarskich dekoracji i aktorstwa, które były świadomą transpozycją do kina ekspresjonistycznego malarstwa i teatru - uznać można w praktyce sześć, co najwyżej siedem filmów: trzy filmy Roberta Wiene - Gabinet doktora Caligari (Das Cabinet des Dr. Caligari, 1919), Genuine (1920) i Raskolnikow (1923), a także Od poranka do pótnocy (Von Morgens bis Mitternacht, 1920) Karlheinza Martina, Torgus (1920) Hannsa Kobe, Gabinet figur woskowych (Das Wachsfigurenkabinett, 1924) Paula Leniego i, nie bez zastrzeżeń, Metropolis (1926) Langa. Owszem, ogólnej wizji historii filmu, jaką prezentuje Salt, można zarzucić pewien naiwny „empiryzm”, "formalizm” i "technocentryzm”, niemniej w odniesieniu do ekspresjonizmu jako kategorii artystycznej jego propozycja istotnie porządkuje pole rozważań. Salt słusznie zauważa, że pomieszanie pojęć nastąpiło m.in. wskutek tego, iż paradygmatyczny film ekspresjonizmu - Caligari - zawierał pewne elementy nadnaturalne, co spowodowało dość mechanicznie uważanie wszystkich filmów z określoną mroczną metafizyką za ekspresjonistyczne, niezależnie od faktycznego ich stylu ${ }^{118}$. By odróżnić ową niewielką grupę filmów

115 John D. Barlow, German Expressionist Film, Twayne, Boston 1982.

116 Zob.: Thomas Elsaesser, op. cit. (szczególnie zaś rozdział: Expressionist film or Weimar cinema? With Siegfried Kracauer and Lotte Eisner (once more) to the movies, s. 18-60); Thomas Elsaesser, Weimar Cinema, Mobile Selves and Anxious Males: Kracauer and Eisner Revisited, [w:] Expressionist Film: New Perspectives, ed. Dietrich Scheunemann, Camden House, Rochester-Woodbridge 2002, s. 33-71.

117 Barry Salt, From Caligari to Who?, „Sight \& Sound”, Spring 1992, vol. 48, no. 2, s. 119 -123); Barry Salt, Styl i technologia filmu: Historia i analiza, przeł. Alicja Helman, PWSFTviT, Łódź 2003, t. 2, s. 129-133.

118 Zob.: B. Salt, Styl i technologia filmu..., s. 130. 
istotnie ekspresjonistycznych (w kategoriach historii sztuki) od filmów posługujących się innymi chwytami artystycznymi (np. stosowaniem cieni czy ekscentrycznych ujęć kamery), Salt proponuje mówić w tym drugim wypadku o „ekspresywizmie”. Ta terminologiczna propozycja wydaje mi się bardzo sensowna, pozwalając na odróżnienie ekspresjonizmu sensu stricto od "ekspresywizmu” cechującego np. Neue Sachlichkeit czy film noir. Rozwiązuje ona też pojęciowe dylematy, których świadectwem jest choćby artykuł Alicji Helman Niemiecki ekspresjonizm filmowy. Autorka stwierdza w nim, iż, z jednej strony „niemiecki ekspresjonizm filmowy jest formacją odległa, odrębną i zamkniętą", która "mówi do nas martwym, nie zawsze zrozumiałym językiem kina niemego, $\mathrm{w}$ fazie, gdy podejmowało ono eksperymenty o charakterze ekstremalnym"119, z drugiej zaś jest ekspresjonizm kategorią „multiperiodycznie powracającą". W tym drugim rozumieniu trzeba by, zgodnie z propozycją Salta, mówić o „ekspresywizmie".

Gdy student historii filmu, uczony zgodnie z powszechnym dawniej stereotypem o „ekspresjonizmie” Langa, ma wreszcie możliwość gruntownego poznania jego filmów z lat 20., odkrywa (a stało się to i moim udziałem), jak ich estetyka ma niewiele wspólnego z "caligaryczną" płaskością i zamkniętością przestrzeni. Znaczne ich partie wydają się silnie realistyczne, przestrzenna rozległość i trójwymiarowość scenografii są antypodą płaskiej „malarskości” Caligariego, a ostentacyjna stylizacja, gdy się (nierzadko) pojawia, ma swe źródła jednak całkiem gdzie indziej niż w malarskim ekspresjonizmie.

Nocne sceny uliczne, np. pościg Wenka za uciekającym z "Palais Andalusia” do hotelu Excelsior ",holenderskim profesorem” czy finałowe oblężenie domu Mabusego przez policję i wojsko, budzą podziw swym realizmem przypominającym estetykę amerykańskich filmów gangsterskich lat 30. o „ekspresywistycznej” fotografii. Jak świadczą przytaczane przez Lotte Eisner recenzje z epoki, sceny nocne w Doktorze Mabuse, graczu wzbudziły zachwyt zarówno publiczności, jak i krytyki, z racji ukazania w filmie po raz pierwszy w sposób wiarygodny ulic, rozświetlonych przez światła latarń, reflektory pędzących samochodów, migające okna przejeżdżającego wiaduktem pociągu ${ }^{120}$. Dziś osiągnięcia zespołu Langa (fantastycznego operatora Carla Hoffmanna, scenografów Ottona Hunte i Carla Stahl-Uracha oraz ekipy od efektów specjalnych) mogą się wydawać mało imponujące, ale pamiętajmy, iż we wcześniejszej zaledwie o rok

119 Alicja Helman, Niemiecki ekspresjonizm filmowy, [w:] Niemiecki ekspresjonizm filmowy, red. Alicja Helman, Alina Madej, Uniwersytet Śląski, Katowice 1985, s. 16.

${ }^{120}$ Lotte H. Eisner (Fritz Lang, s. 63-64) przytacza recenzje z „Berliner Lokalanzeiger” i „B. Z. am Mittag”. 
Zmęczonej Śmierci Langowi nie udało się do końca przekonać widza, iż finałowy pożar rzeczywiście ma miejsce nocą.

Choć istotnie są w Doktorze Mabuse stylizacje jawnie ekspresjonistyczne, to jednak Lotte Eisner słusznie zauważa, iż w przywołanych w drugim podrozdziale tego tekstu recenzjach z epoki prawdopodobnie wyczytano z filmu więcej ekspresjonizmu niż Lang zamierzył tam pomieścić121. Na przykład florealne ornamenty w „Palais Andalusia” (ale w sali głównej, nie zaś w szulerni w podwórku), a przede wszystkim wystrój "Casino Petit" (jakby trochę mauretański) ewokują tak naprawdę wiedeńską czy monachijską secesję (Jugendstil). Z kolei wystrój salonu Toldów (pomijając ekspresjonistyczne obrazy na ścianach) to typowe dla momentu powstania filmu art deco ${ }^{122}$.

Bardzo interesujące są uwagi Thomasa Elsaessera na temat obecności w dziele Langa (prócz Doktora Mabuse, także w Nibelungach, Metropolis i Kobiecie na Księżycu) elementów świadczących o jego wiedeńskim rodowodzie, elementów związanych z secesją. Jako jej znawca objawił się jeszcze $w$ latach swych nigdy nieukończonych studiów artystycznych, tworząc pastisze Egona Schiele czy Gustava Klimta. „Niektóre z najbardziej uporczywych formalnych obsesji reżysera - ornament i abstrakcja, technika i sentyment, przemoc i skamienienie, arabeska i zastygnięcie można wywieść z estetyki, ale i z historycznej problematyki Jugendstil. Już w Zmęczonej Śmierci, w najwyższym stopniu w Nibelungach, znalazłszy zaś najbardziej funkcjonalistyczną formę w Metropolis i Kobiecie na Księżycu, ludzkie uczucia i ekspresja nie tylko zastygają w geście, ale zostają «wchłonięte» przez scenografię; dążą ku nieruchomości, która transmituje pożądanie na figuralność i ornament, gdzie «umiera» ono w pięknie abstrakcyjnej kompozycji, niemal w manierze Henry Van de Velde czy Egona Schiele, albo przybiera przerażający aspekt sielskiej obojętności. Co w wymienionych filmach doświadczane jest jako efekt piktoralistyczny, odwrócenie figury i tła typowe dla ornamentu art nouveau, w Doktorze Mabuse jawi się jako wzorzysta figura na wzorzystym tle, mimikra ruchliwej energii w ornamentowym labiryncie nowoczesnej metropolii"123.

Elementy ekspresjonistyczne w Doktorze Mabuse, podkreślmy, wcale nie tak znów liczne, mają charakter albo specyficznie Langowskich „idiomów” stylistycznych, albo jawią się jako cytat, trawestacja, wzięcie w nawias - w czym nie tylko ten film, ale też Zmęczona Śmierć, Nibelungi, Metropolis i Szpiedzy zadziwiająco przypominają " cytatologię” i samoświadomość kina postmodernistycznego. Wśród elementów „idiomatycznie

\footnotetext{
121 Ibidem, s. 61.

122 Ibidem, s. 62.

${ }^{123}$ T. Elsaesser, Weimar Cinema and After..., s. 187.
} 
Langowskich" należy wymienić dziwne zegary (giełdowy zegar o 24-godzinnej tarczy, stylizowany zegar w „Klubie Oczko”, kanciasty, kubistyczno-ekspresjonistyczny zegar w salonie Toldów, wreszcie zegar $\mathrm{w}$ recepcji Hotelu Excelsior, z podwójną numeracją na tarczy, gdzie godziny od 1 do 12 zaznaczone są cyframi rzymskimi, zaś godziny od 13 do 24 - arabskimi). Do „idiomatyki” stylu Langa należą też, od czasu Zmęczonej Śmierci, kunsztowne podwójne ekspozycje (tak, w zdjęciach nakładanych, pojawiają się przed hrabią Toldem nocne widma jego sobowtórów, a przed Mabusem na progu szaleństwa - widma jego czterech ofiar). Szczególnie fascynujący przykład podwójnej ekspozycji (skombinowanej z najazdem kamery) stanowi scena, kiedy "holenderski profesor” usiłuje podczas gry w "Andalusii” zahipnotyzować Wenka. Na czarnym tle znika wówczas bezpośrednie otoczenie lokalu, a olbrzymia, oddzielona od tułowia głowa Mabusego wydaje się groźnie zbliżać ku widzowi, hipnotyzując demonicznym spojrzeniem nie tylko Wenka, ale i dzielącego jego point of view odbiorcę. Jak słusznie zauważa Tom Gunning, rezultat tego rozwiązania jest ambiwalentny, pozostawiając widza w niepewności: „czy to my przybliżamy się ku głowie, czy to głowa rusza na nas, czy może po prostu się powiększa?"'124 Duże wrażenie robią też głowa Mabusego nałożona w podwójnej ekspozycji na zamykający prolog obraz pustej i zaśmieconej giełdy czy wizytówka pana „Hugona Ballinga” na tle „Klubu Oczko” w finale aktu I, 2 - choćby z tego powodu, iż stanowią mocne wizualnie podkreślenia mocnych dramaturgicznie point aktów.

Bardzo wyraźnieekspresjonistyczny jest design "GrillaSchramma”, stylizacja ucieczki „holenderskiego profesora” na kuśtykającego Caligariego, a Mabusego unoszącego hrabinę na Cezara uprowadzającego w filmie Wienego Jane. Niewątpliwie „ekspresjonistyczne”, bo także rodem z Caligariego, są rozświetlone i nałożone w podwójnej ekspozycji na obraz napisy, będące wyrazem niebezpiecznych sugestii Mabusego dla Wenka (napis „TSI-NAN-FU”, który prokurator daremnie usiłuje zakryć karta, czy hasło "MELIOR", nakazujące siedzącemu za kierownicą Wenkowi skierować samochód w urwisko o tej nazwie) ${ }^{125}$. Ekspresjonistyczne są niewątpliwie dwa monstra z fallicznymi nosami podczas występu Carozzy w „Folies Bergères”, obrazy i maski z kolekcji Tolda (szczególnie obraz Lucyfera), podobnie zresztą jak przemiana w złowrogie demony maszyny

124 T. Gunning, op. cit., s. 109.

125 "Caligaryczne" napisy, nakładane w podwójnej ekspozycji na obraz, stały się elementem "idiomatycznym” stylu Langa - odnajdziemy je w Zmęczonej Śmierci (czary A Hai), w Metropolis („Babel”), w Szpiegach (prześladujący Sonię numer feralnego wagonu „33 133”), w Kobiecie na Księżycu (w sekwencji przygotowań do startu rakiety, a także „emitowany" przez złoża złota na Księżycu napis „Gold”). 
w „wytwórni" Hawascha (scena ta, jak już nadmieniałem, wydaje się echem Molocha z Cabirii). Wreszcie znawców historii sztuki musi uderzyć podobieństwo niektórych kadrów do ekspresjonistycznych obrazów Magnusa Zellera: pijatyka u Mabusego świętującego skandal i porwanie hrabiny ewokuje obraz Zellera Pijak (Zecher, 1918/1920), Mabuse jako bolszewik podburzający tłum w knajpie do uwolnienia "Johannesa Guttera" - obraz Agitator (Volksredner, 1920), wreszcie kadry z walk ulicznych w finale II części - obraz Ulica wolna (Straße frei, 1919/1920) ${ }^{126}$. Ale skoro są to cytaty, trawestacje, stylizacje wzięte $\mathrm{w}$ nawias obrazu na ścianie, rampy sceny czy wystroju knajpy, trudno nie zauważyć krytycznego dystansu Langa do ekspresjonizmu i jego prezentacji w filmie jako jeszcze jednego "tematu" - takiego jak inflacja, hazard, dekadenckie rozrywki czy zbrodnia.

Thomas Elsaesser w swej znakomitej książce przypomina, iż ekspresjonizm był poniekąd naśladowaniem przez kino Republiki Weimarskiej dominującego trendu "sztuki wysokiej”, zastosowanym w marketingowym celu zwabienia do kin snobistycznej, ceniącej wartości artystyczne publiczności ${ }^{127}$. A skoro tak, „to nazywanie Langa ekspresjonistą jest komplementem dwuznacznym, ponieważ przyjmuje on za prawdę oszustwo pierwszego poziomu, podczas gdy duma Langa jako prawdziwego stylisty kina musi mieścić się na drugim poziomie oszustwa, zdolnego wytworzyć pierwszy poziom nieskazitelnie i przekonująco"128. Co czyni z tego pełnego ironii metaekspresjonizmu prawdziwy wyraz opisanej przez Petera Sloterdijka „,oświeconej fałszywej świadomości” czy inaczej - „cynicznego rozumu" ${ }^{\prime 29}$.

126 Spostrzeżenia te zawdzięczam wystawie „Fritz Lang: Filmbilder - Vorbilder”, przygotowanej przez Goethe-Institut, München, i w grudniu 2004 prezentowanej w Muzeum Kinematografii w Łodzi pt. „Fritz Lang: Obrazy filmowe”. Zob. katalog tej wystawy: Fritz Lang: Filmbilder - Vorbilder, Red. Heide Schönemann, Hentrich Verlag, Berlin 1992. Ciekawe, iż mogła też zaistnieć zależność odwrotna: katalog unaocznia, że kadr z Doktora Mabuse, gracza, filmu będącego niewątpliwie wielkim wydarzeniem kulturalnym Niemiec w 1922 r., mógł zainspirować obraz Magnusa Zellera z roku 1924 Spirytyści (Spiritisten). Data powstania obrazu Straße frei sugeruje z kolei, że podobnie jak finał filmu Langa był on reminiscencją walk ulicznych podczas powstania Związku Spartakusa w 1919.

127 Zob.: T. Elsaesser, op. cit., s. 1-105, 187.

128 Ibidem, s. 187.

129 Zob.: Peter Sloterdijk, Critique of Cynical Reason, transl. Michael Eldred, University of Minnesota Press, Minneapolis-London 2001, passim. 



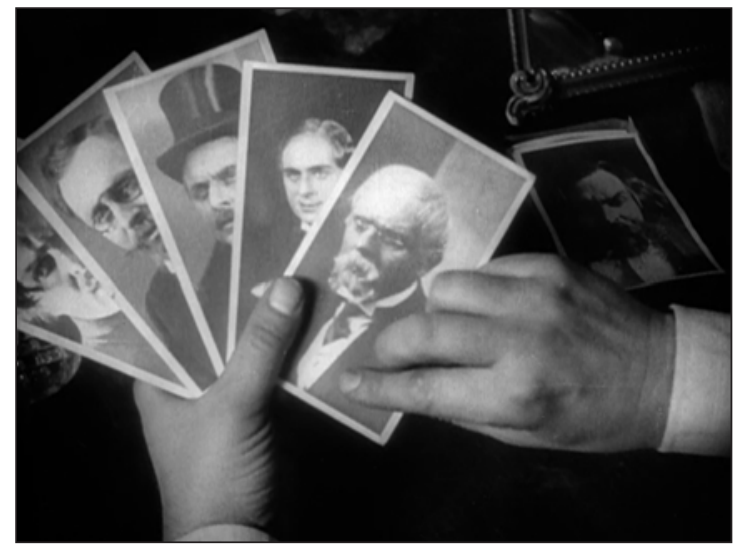

1. Doktor Mabuse, gracz (1922, reż. Fritz Lang). Talia zdjęć z wcieleniami Mabusego

2. Doktor Mabuse, gracz (1922, reż. Fritz Lang). Zwycięzca giełdowej sesji
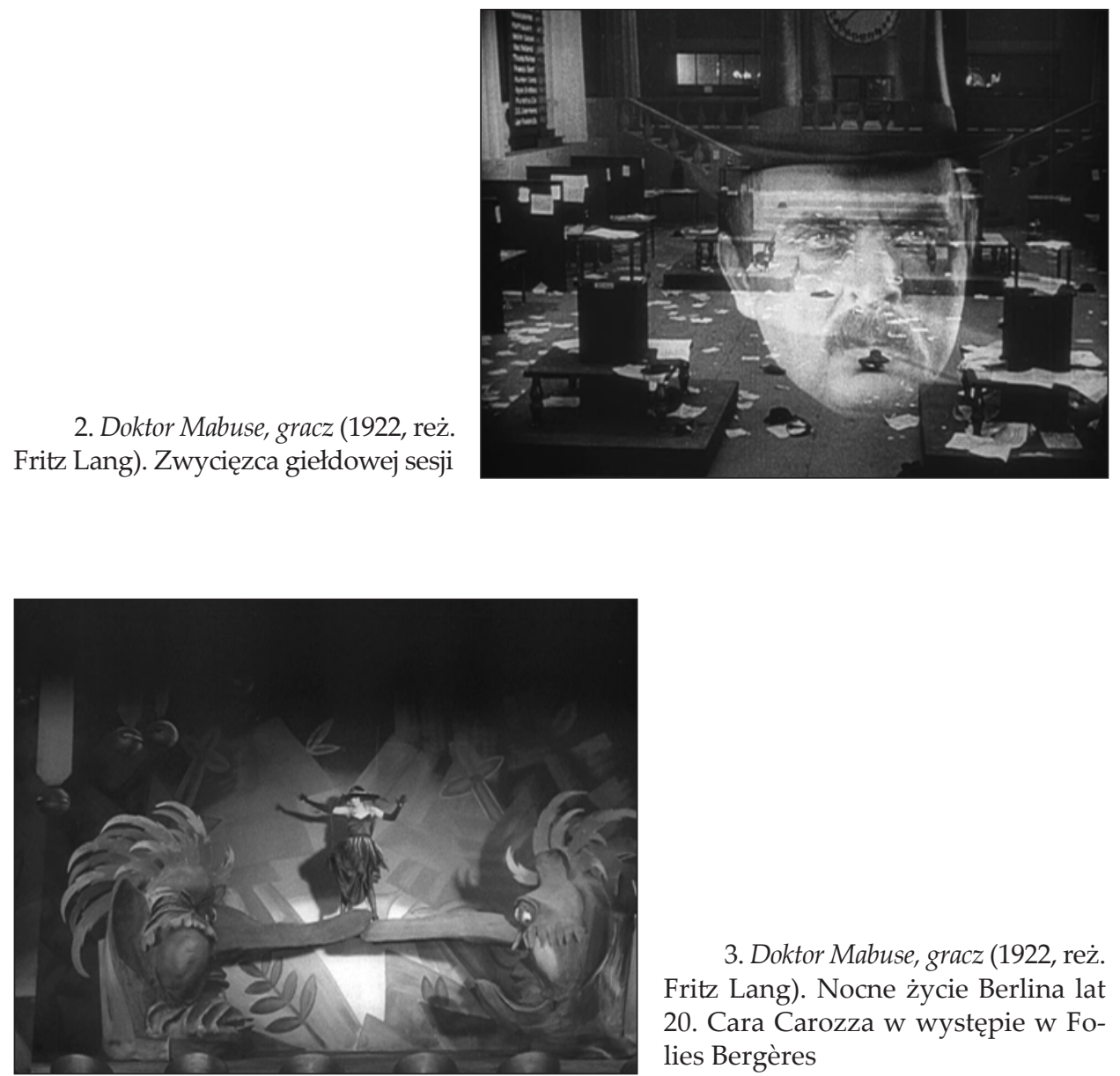

3. Doktor Mabuse, gracz (1922, reż. Fritz Lang). Nocne życie Berlina lat 20. Cara Carozza w występie w Folies Bergères 


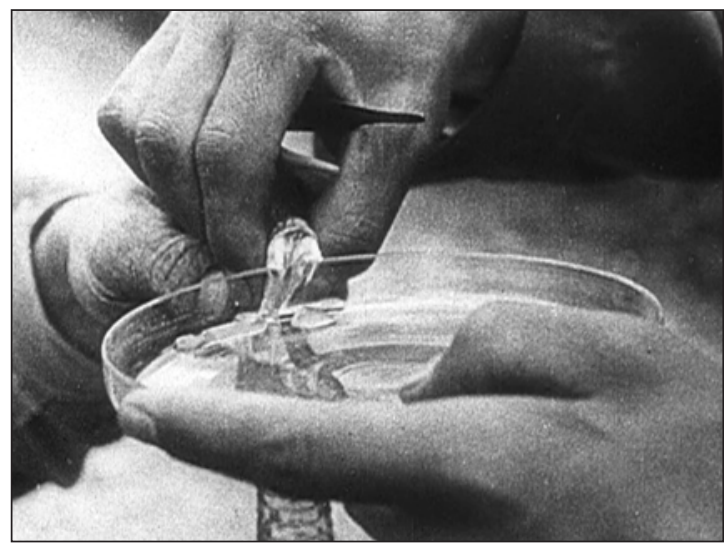

4. Doktor Mabuse, gracz (1922, reż. Fritz Lang). Mabuse pobiera jad węża

5. Doktor Mabuse, gracz (1922, reż. Fritz Lang). Ekspresjonistyczny design lokalu Schramma
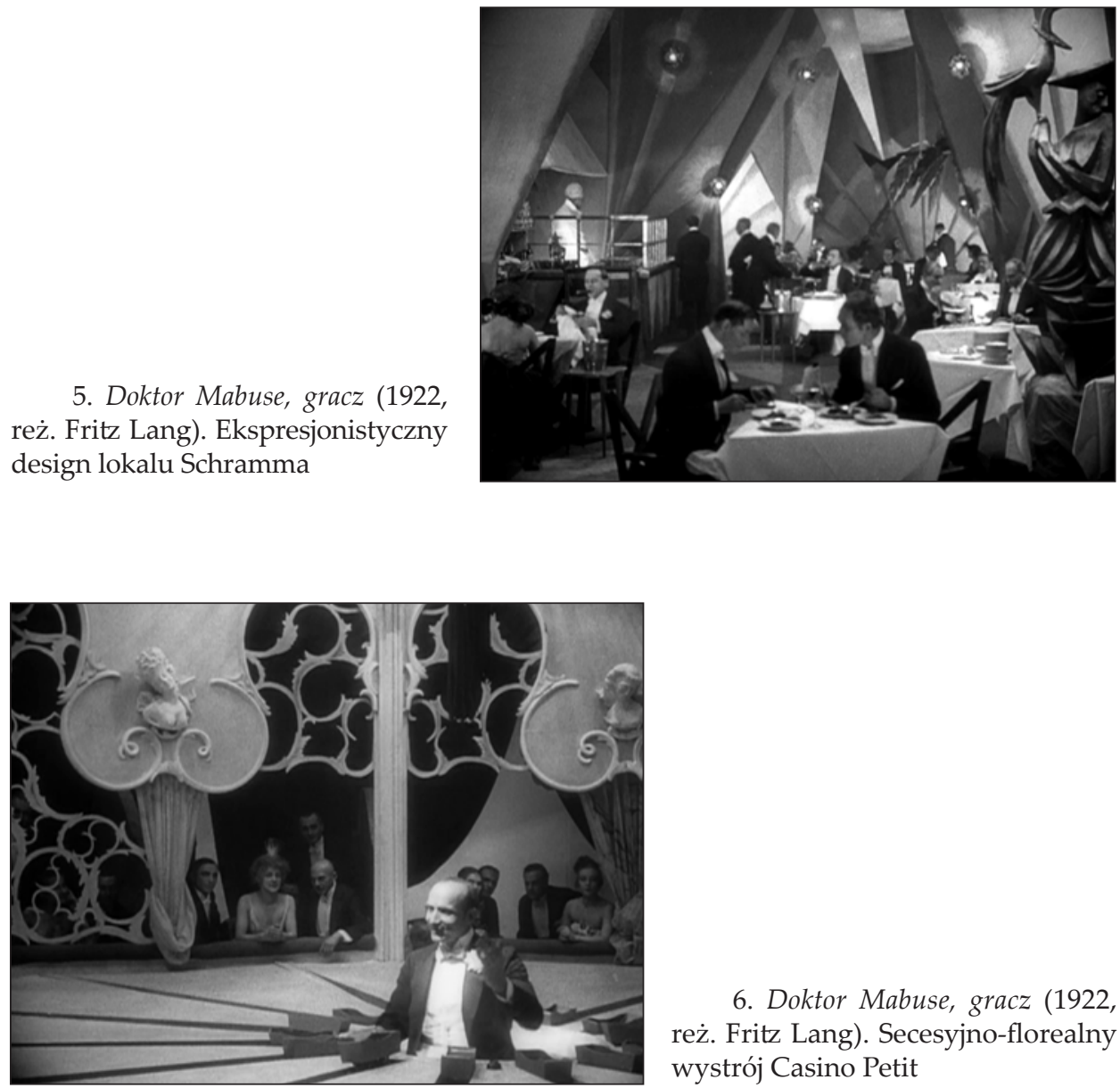

6. Doktor Mabuse, gracz (1922, reż. Fritz Lang). Secesyjno-florealny wystrój Casino Petit 


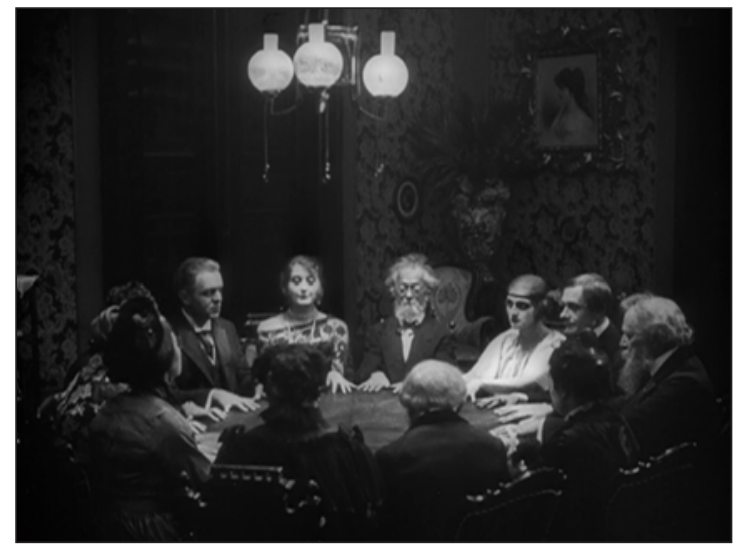

7. Doktor Mabuse, gracz (1922, reż. Fritz Lang). Seans spirytystyczny u hrabiostwa Toldów

8. Doktor Mabuse, gracz (1922, reż. Fritz Lang). Obraz Lucyfera w salonie Toldów
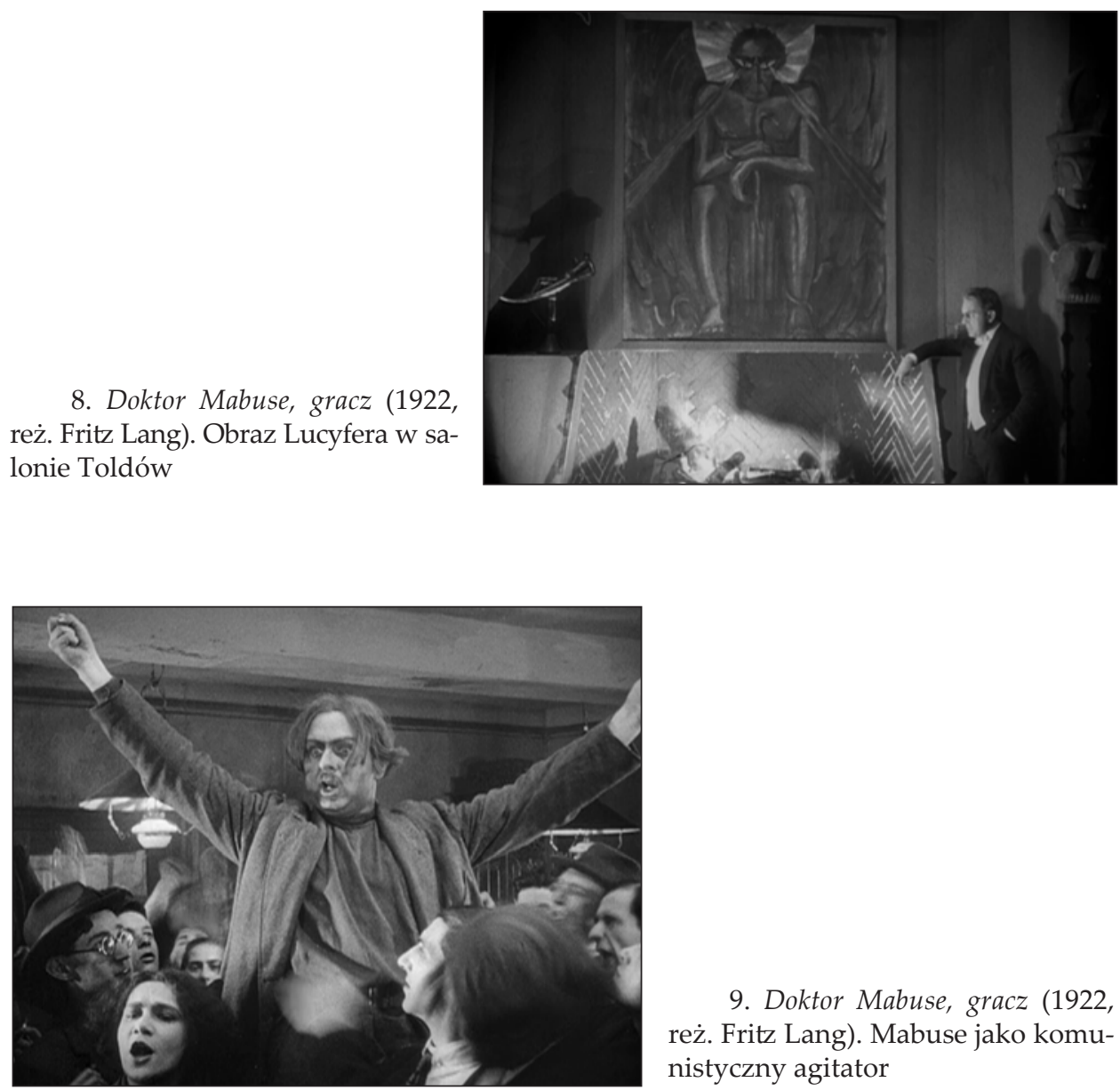

9. Doktor Mabuse, gracz (1922, reż. Fritz Lang). Mabuse jako komunistyczny agitator 


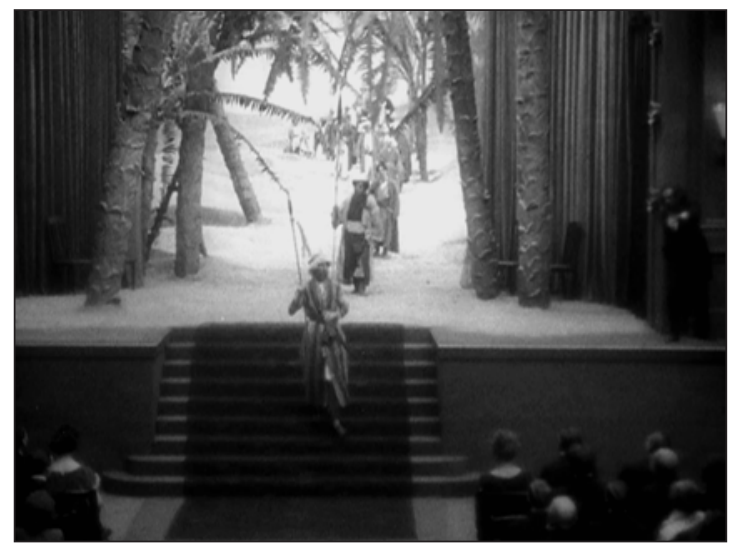

10. Doktor Mabuse, gracz (1922, reż. Fritz Lang). Halucynacyjna karawana wyczarowana przez Sandora Weltmanna widzom filharmonii

11. Doktor Mabuse, gracz (1922, reż. Fritz Lang). Wizja Mabusego transformacja maszyn drukujących fałszywe banknoty w ekspresjonistyczne monstra
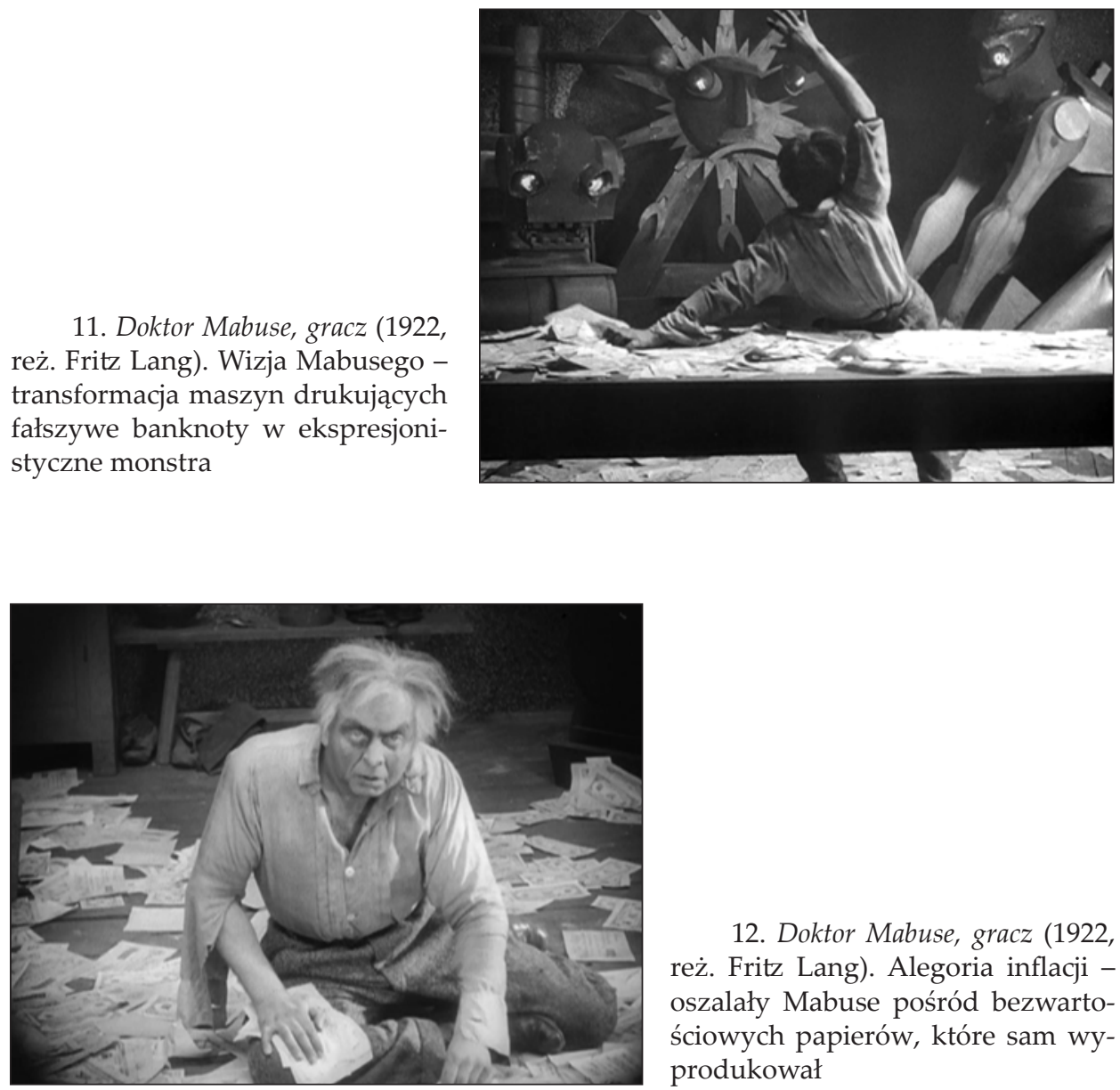

12. Doktor Mabuse, gracz (1922, reż. Fritz Lang). Alegoria inflacji oszalały Mabuse pośród bezwartościowych papierów, które sam wyprodukował 


\section{Rozdział 4}

\section{STRATEGIA PAJĄKA: SZPIEDZY}

Och, to geniusz i prawdziwy fenomen. [...] Człowiek, który w Londynie jest wszędzie, a nikt o nim nie słyszał. To stawia go na samym szczycie $\mathrm{w}$ annałach zbrodni. [...]

To Napoleon zbrodni, Watsonie. W tym wielkim mieście jest on sprawcą połowy zła i prawie wszystkiego, którego jeszcze nie wykryto. To geniusz, filozof, myśliciel abstrakcjami. Posiada pierwszorzędny mózg. Spoczywa bez ruchu, niczym pająk $\mathrm{w}$ środku sieci, ale ta sieć ma tysiące promienistych nici, a on dobrze wie o drganiu każdej z nich. Sam czyni niewiele. Tylko planuje. Ale jego agenci są liczni i wspaniale zorganizowani. Jeśli jakieś przestępstwo ma być popełnione, jakiś dokument zagarnięty, jeśli, powiedzmy, jakiś dom ma być ostrzelany, jakiś człowiek usunięty - profesorowi wystarcza słówko, a rzecz jest zorganizowana i wykonana. Agent może zostać schwytany. W takim przypadku znajdą się pieniądze na kaucję lub adwokata. Ale centrala, która posłużyła się agentem, nigdy nie wpada - i nigdy na nią nie pada nawet podejrzenie ${ }^{1}$.

Arthur Conan Doyle, The Final Problem

\section{Pierwszy i przedostatni film spółki Fritz Lang Film GmbH}

3 czerwca 1927 r. majorowi Alexandrowi Grauowi, szefowi wydziału produkcji Ufy, zarząd kompanii zlecił odbyć „,tak szybko, jak tylko możliwe, dyskusję z panem Langiem o jego następnym filmie. Wszystkie szczegóły produkcji powinny być jak najprecyzyjniej określone i zaksięgowane, tak by mieć nieustanny nadzór nad produkcją pana Langa i uniemożli-

${ }^{1}$ Conan Doyle, The Final Problem, [w:] Sir Arthur Conan Doyle, The Memoirs of Sherlock Holmes, Penguin Books, Harmondsworth 1950, s. 238, 239-240. 
wić przekraczanie kosztów" ${ }^{2}$. Rzecz jasna, powodem takiej dyrektywy był poprzedni film reżysera. "Metropolis, «największy film świata», który miał pobić Amerykanów ich własną bronią okazał się dla Ufy katastrofą. Drugiej katastrofy o porównywalnych rozmiarach trzeba było uniknąć za wszelką cenę"

Lekcja, jaką wyciągnął z tej klęski Lang (zagrożony też, jak widać, przynajmniej częściową utratą kontroli artystycznej nad dziełem), było powołanie własnej niezależnej spółki produkcyjnej Fritz Lang Film $\mathrm{GmbH}$, dla której Ufa miała służyć wyłącznie jako dystrybutor. Spółka ta zrealizowała jedynie dwa filmy, przypominając pod tym względem drugą w karierze Langa niezależną inicjatywę produkcyjną, amerykańską kompanię Diana Productions, w której powstały Scarlet Street (1945) i Secret Beyond the Door (1948). Niezależna spółka Fritz Lang Film wyprodukowała Szpiegów (Spione, 1928) i Kobietę na Księżycu (Frau im Mond, 1929), dwa ostatnie w karierze Langa filmy nieme. W czołówkach obu $\mathrm{z}$ nich widnieją loga zarówno producenta, jak i dystrybutora. Ufa nadal była potęgą ${ }^{4}$, i jak zwykle w przypadku weimarskich filmów Langa zapewniła odpowiednio atrakcyjną i spektakularną oprawę premiery. Na premierę 22 marca 1928 (tradycyjnie już) w reprezentacyjnym berlińskim kinie Ufa-Palast am Zoo, jego „fasadę udekorowano wielkim, stylizowanym i rzęsiście oświetlonym okiem. Litery tytułu filmu rozciągały się na całą szerokość centralnej fasady i zmieniały formę, stając się gigantycznymi źrenicami, a umieszczone $\mathrm{w}$ nich reflektory rzucały snopy światła na tłum na chodniku" ${ }^{\prime}$. Jako tła dla reklamy filmu Ufa nie zawahała się użyć nawet „nieba nad Berlinem", o czym donosi Fritz Olimsky w "Berliner Börsen-Zeitung” z 24 marca 1928: „Cztery samoloty leciały prawie cały czas w zwartym szyku [...] Na spodniej stronie ich skrzydeł można było odczytać wielkie litery, układające się w napis Spione"6.

${ }^{2}$ Cyt. za: Klaus Kreimeier, The Ufa Story: A History of Germany's Greatest Film Company, 1918-1945, transl. Robert and Rita Kimber, University of California Press, Berkeley-Los Angeles-London 1999, s. 157.

${ }^{3}$ Ibidem.

${ }^{4} \mathrm{I}$ to pomimo kryzysu związanego $\mathrm{z}$ finansowym załamaniem po klęskach prestiżowych superprodukcji, jak Faust Murnaua, ale przede wszystkim Metropolis, oraz z podpisaniem w grudniu 1925 niekorzystnej umowy z amerykańskimi kompaniami Paramount i Metro-Goldwyn-Mayer. Umowa ta powoływała spółkę dystrybucyjną Parufamet, dzięki której amerykańscy producenci, obchodząc obowiązujące w Niemczech kontyngenty dopuszczalnych na rodzimych ekranach filmów zagranicznych, wdzierali się na najpotężniejszy w Europie rynek filmowy. Zob.: K. Kreimeier, op. cit., s. 126-130; Kristin Thompson, Narodziny i schyłek "filmowej Europy", przeł. Tomasz Kłys, [w:] Kino Europy, red. Piotr Sitarski, Rabid, Kraków 2001, s. 28-29.

${ }^{5}$ K. Kreimeier, op. cit., s. 117.

${ }^{6}$ Fritz Olimsky, Spione, „Berliner Börser-Zeitung”, 24 März 1928 (cyt. za: Fritz Lang. Leben und Werk. Bilder und Dokumente, Red. Rolf Aurich, Wolfgang Jacobsen und Cornelius 
Nie zabrakło też sprawdzonej wcześniej metody wzajemnego promowania się filmu Langa i książki Thei von Harbou. Powieść Szpiedzy opublikowała berlińska oficyna Scherl Verlag, i to w tak ekskluzywnej formie, że Kracauer dostrzegł w niej „triumf sztuki introligatorskiej” - ale też nic ponad to ${ }^{7}$. Ta późniejsza zresztą o niemal dwudziestolecie zła opinia nie mogła przeszkodzć temu, by książka trafiła na listę bestsellerów ${ }^{8}$.

Produkcja Szpiegów w poczdamskim kompleksie studiów Neubabelsberg wystartowała w grudniu 1927 i trwała do marca 1928, piętnaście tygodni, jak pisze Patrick McGilligan" ${ }^{9}$ czy też równo 100 dni, jak wylicza Paul Jensen ${ }^{10}$. W każdym razie był to jeden $\mathrm{z}$ najszybciej zrealizowanych spośród filmów Langa lat 20., a budżet znacznie skromniejszy niż pod auspicjami Ufy zmusił Langa do, z jednej strony, znacznego powściągnięcia swego dotychczasowego rozmachu w zakresie scenografii czy zatrudniania wielkich rzesz statystów, z drugiej zaś - do niewątpliwej inwencji w zakresie stylu i rozwiązań technicznych. Rezultat tej inwencji - operowanie, wbrew swym wcześniejszym predylekcjom do monumentalnych planów ogólnych kontemplowanych w dość długich ujęciach, tym razem przede wszystkim planami bliskimi, bardzo szybko montowanymi w pełnych elips sekwencjach montażowych - jest do dziś zdumiewająco atrakcyjny i świeży artystycznie. Jensen, bardzo krytyczny wobec Doktora Mabuse, gracza (filmu w historii kina znacznie sławniejszego i wyżej ocenianego), wobec Szpiegów jest niezwykle entuzjastyczny, uznając ich za jeden z trzech najlepszych niemych filmów Langa, obok Nibelungów i Metropolis. „To prawda, Doktor Mabuse był pierwszy, ale niedoceniani Szpiedzy są daleko lepiej zrealizowani; pominąwszy już znakomity zmysł kompozycji, element nieobecny we wcześniejszym dziele, to naśladownictwo jest technicznie bardziej twórcze i płynne, z szybszym tempem i w godny podziwu sposób powściągliwym aktorstwem"11.

Schnauber, Filmmuseum Berlin-Deutsche Kinemathek und jovis Verlag $\mathrm{GmbH}$, Berlin 2001, s. 128).

7 Zob.: Siegfried Kracauer, Od Caligariego do Hitlera: Z psychologii filmu niemieckiego, przeł. Wanda Wertenstein, Eugenia Skrzywanowa, Filmowa Agencja Wydawnicza, Warszawa 1958, s. 129. Kracauer wypowiada się lekceważąco nie tylko o powieści, ale i o filmie Langa, zupełnie nie doceniając jego walorów artystycznych i ignorując - jeden z najwnikliwszych w kinie Republiki Weimarskiej - alegoryczny obraz totalitarnego zagrożenia (por.: ibidem, s. 128-129).

8 Zob.: Paul M. Jensen, The Cinema of Fritz Lang, A. S. Barnes \& Co.-A. Zwemmer Limited, New York-London 1969, s. 78.

9 Zob.: Patrick McGilligan, Fritz Lang: The Nature of the Beast, St. Martin's Press, New York 1997, s. 136.

10 Zob.: P. M. Jensen, op. cit., s. 78.

${ }^{11}$ Ibidem, s. 70. 
Jak pisze biograf reżysera, Patrick McGilligan, prawdziwą obsesją reżysera, jego "piętą Achillesową" była nie tyle wolność finansowa, ile wolność twórcza. Toteż mając zapewnioną ją we własnej spółce produkcyjnej, Lang wykrzesał z siebie rzeczywiście wiele pomysłowości, z frapującym artystycznie rezultatem. Nie obyło się jednak bez typowego dla niego marnotrawstwa taśmy i kręcenia niezliczonych dubli, choć oczywiście już nie na taką skalę, jak w Nibelungach czy Metropolis ${ }^{12}$. Paul Hörbiger, który zagrał w Szpiegach jedną z ważnych ról drugoplanowych - Franza, kierowcy Agenta 326 - wspomina, jak Lang żądał od niego właściwego zapukania w ścianę hotelowego pokoju w bardzo prostej, nienasuwającej żadnych trudności technicznych scenie: „Musiałem to zrobić co najmniej 23 razy, zanim pukanie w końcu mu się spodobało. Przysięgam, za każdym razem pukałem dokładnie tak samo jak poprzednio. I był to film niemy, zatem i tak nie byłoby słychać pukania"13. Nie mógł się też Lang powstrzymać od zwyczajowej, graniczącej z brutalnością tyranii na planie (jej ofiarą padała zwłaszcza jego nowa gwiazda, grająca Sonię Gerda Maurus), ani od niepotrzebnego narażania życia członków ekipy (gdy dla osiągnięcia efektu kuli roztrzaskującej szybę obok głowy aktorki, stosował prawdziwe naboje, wystrzeliwane własnoręcznie z coraz to innych typów broni) ${ }^{14}$.

Opinie o stronie artystycznej Szpiegów były jednak spolaryzowane. Zacznijmy może od entuzjastycznych. „Niezwykłe bogactwo zdarzeń zostaje wprawione w ruch już wraz z pierwszym obrazem. Jest tego tak wiele, że każde poszczególne zdarzenie musi jawić się samo w sobie jako mały, marginalny epizod. Dopiero dużo później uświadamiamy sobie, jak te wszystkie odrębne małe epizody stanowią w rzeczywistości precyzyjnie dopasowane koła napędowe nadzwyczaj wymyślnej intrygi" (A. Kraszna-Krausz) ${ }^{15}$.

„Fritz Lang porzucił formalizm i stylizację Nibelungów czy Metropolis. Powrócił do stylu Doktora Mabuse. Zrealizował budzący dreszcz emocji, zapierający dech film sensacyjny... Fritz Lang coraz to wyraźniej przechodzi od obrazowości i wizualności ku ruchowi i zdarzeniom" (Herbert Ihering $)^{16}$.

„Znowu reżyser ten wynalazł kilka nowych technik kinematograficznych.... Sposób, w jaki Fritz Lang zestawia z sobą różne ujęcia, nadaje całemu filmowi nadzwyczajny rytm życia, który nie zawsze jest logiczny czy

\footnotetext{
${ }^{12}$ Zob.: P. McGilligan, op. cit., s. 136-137.

${ }^{13}$ Paul Hörbiger, Ich habe für Euch gespielt, Herbig, München-Berlin 1979 (cyt. za: P. McGilligan, op. cit., s. 137).

14 Por.: P. McGilligan, op. cit., s. 137.

15 „Filmtechnik”, 31 März 1928, Nr. 7 (cyt. za: Lotte H. Eisner, Fritz Lang, Da Capo Press, New York 1986, s. 95-96).

16 „Berliner Börsen-Courier”, 23 März 1928 (cyt. za: L. H. Eisner, op. cit., s. 96).
} 
regularny, ale który to gwałtownie przyspiesza w gmatwaninie zdarzeń, to znienacka zwalnia tempo; musi to wywołać dziwaczny efekt $\mathrm{u}$ widza, któremu gra na nerwach nieustanny strumień wrażeń" (E. Hellmund-Waldow ${ }^{17}$.

Bardzo interesująca jest anonimowa recenzja, która ukazała się w październiku 1929 w „Filmkritische Rundschau”. Recenzent odnotowuje, iż Lang uniknął niebezpieczeństwa grożącego mu w wypadku kolejnego po Doktorze Mabuse, graczu filmu o tematyce współczesnej, po prostu skopiowania estetyki tamtego dzieła. Szpiedzy szczęśliwie łączą prawdziwy obraz życia z napięciem i suspensem nieodzownymi dla ukazania nieprawdopodobnych wypadków. Nielinearna sekwencja przedstawionych zdarzeń wymaga od odbiorcy umiejętnego powiązania ich ze sobą. Niektóre sceny wypadałoby skrócić, pewne luki wypełnić napisami ekspozycyjnymi, jeśli widz istotnie podążać ma za intensywnym strumieniem emocji. A chociaż każdy film Langa jest technicznie zdumiewający, w niektórych scenach Szpiegów reżyser przeszedł sam siebie. Recenzent chwali też znakomite aktorstwo Willego Fritscha (Agent 326) i Herthy von Walter (Lady Leslane), dla których film ten rozpoczyna nową erę $\mathrm{w}$ karierze ${ }^{18}$.

Lotte Eisner, która w swej monografii Langa, wydanej po raz pierwszy w roku 1976, przedstawiła wnikliwą i zdecydowanie pochlebną dla dzieła analizę Szpiegów ${ }^{19}$, we wcześniejszym o prawie ćwierćwiecze Ekranie demonicznym jest bardzo wobec tego filmu krytyczna. Uznaje tam, że pochodzący od Thei von Harbou sentymentalizm spowolnił akcję, osłabił rytm opowieści i dynamikę montażu. Surowo ocenia też aktorstwo: "Gerda Maurus, pomimo swych kocich oczu jest bardzo przeciętną aktorka, podobnie jak Willy Fritsch, który jest jeszcze bardziej płaski niż Gustaw Fröhlich. Nawet Rudolf Klein-Rogge, ulubiony aktor Langa celujący w rolach zbrodniczych nadludzi, traci swą siłę w Szpiegach"20. Jedyne słowa uznania dla Szpiegów w Ekranie demonicznym dotyczą sekwencji z doktorem Matsumoto (świetna rola znanego reżysera Lupu Picka), kiedy w ekspresjonistycznej wizji ukazują mu się widma trzech zamordowanych kurierów, a następnie popełnia harakiri. „Prawdziwy” Lang ujawnia się też „wtedy, gdy cienie, jakby wywołane przez czarną magię, parokrotnie biorą ekran w posiadanie, wyprzedzając realną akcję, lub wtedy, gdy reżyser

17 "Close Up", June 1928 (cyt. za: Frederick W. Ott, The Films of Fritz Lang, The Citadell Press, Seacaucus, NJ 1979, s. 145).

18 Anonim, "Spione”, „Filmkritische Rundschau” 1929, Nr. 10 (Oktober). Referuję za: E. Ann Kaplan, Fritz Lang: A Guide to References and Resources, G. K. Hall \& Co., Boston 1981, s. $158-159$.

${ }^{19}$ L. H. Eisner, op. cit., s. 95-105.

${ }^{20}$ Eadem, Ekran demoniczny, przeł. Konrad Eberhardt, Wydawnictwa Artystyczne i Filmowe, Warszawa 1974, s. 166. 
okazuje z właściwą sobie troską nieuchronne zbliżanie się policjantów. Niektóre fragmenty (wypadek spowodowany w pociągu) przypominają napięcie dramatyczne pierwszego Dr Mabuse"21. Wydaje się, że tak krytyczna ocena Szpiegów - później znacznie zweryfikowana na korzyść filmu - wynikała z przyjęcia wówczas przez Lotte Eisner pewnej dogmatycznej koncepcji tego, czym powinien charakteryzować się wybitny reprezentant estetyki ekspresjonistycznej. Tymczasem jest to kryterium zupełnie chybione w odniesieniu do Szpiegów, filmu znajdującego się wręcz na antypodach estetyki ekspresjonistycznej, a spośród wszystkich filmów Langa z lat 20. mającego też najmniej elementów „ekspresywistycznych”22.

Wśród negatywnych głosów krytycznych pochodzących z epoki premiery należy wymienić przede wszystkim opinię Rudolfa Arnheima. Zwraca on uwagę na niedbałość intrygi fabularnej sprokurowanej przez Theę von Harbou, lekceważącej spójność czy logikę zdarzeń. Postacie, mimo swej funkcji "szpiegów”, raczej niż agenturalnym zadaniom podporządkowane są technice, a choć ogarnięte namiętnościami, pozostają (jak zazwyczaj u Langa) martwe i nierealne. Choć film niewątpliwie jest warsztatowo sprawny, trudno uznać go za osiągnięcie sztuki filmowej. To raczej jakby luksusowa edycja brukowej powieści sensacyjnej ${ }^{23}$.

Zgryźliwa i reprezentatywna $\mathrm{w}$ tonie dla wielu innych opinii z epoki recenzja, podpisana przez autora kryjącego się za inicjałami H. P., ukazała się w miesięczniku „Der Bildwart”. H. P. utyskiwa na infantylizm fabuły, która rozgrywa się w świecie składającym się całkowicie ze szpiegów i kontrszpiegów. Jak zwykle w filmach Langa, reżyseria i strona techniczna to prawdziwe zawodowstwo, ale nie dorównuje mu marny scenariusz Thei von Harbou. Dwa aktorskie odkrycia, Gerda Maurus (Sonia) i Lien Deyers (Kitty), powinny pojawić się w lepszych filmach. Na szczęście nie zmarnowano na Szpiegów aż tylu pieniędzy co na Metropolis. Niestety, wzorcem do naśladowania było tu kiepskie kino amerykańskie zamiast rzeczywiście wielkiej sztuki filmowej ${ }^{24}$.

Zdaniem Rolanda Schachta, który swą recenzję opublikował w berlińskiej gazecie „B. Z. am Mittag”, sensacyjności filmu szkodzi to, iż jej koncepcja jest natury powieściowej, a nie kinematograficznej. Film dezorientuje widza i rozpada się jako całość, próbując zawrzeć w niej ważne i rozbudowane intrygi podrzędne [Lady Leslane, Jellusić, Matsumoto -

${ }^{21}$ Ibidem.

${ }^{22}$ Nt. rozróżnienia „ekspresjonizm - ekspresywizm” zob.: Barry Salt, Styl i technologia filmu: Historia i analiza, przeł. Alicja Helman, t. 2, PWSFTviT, Łódź 2003, s. 132-133.

${ }^{23}$ Rudolf Arnheim, „Spione”, „Das Stachelschwein” 1928, Nr. 5 (Mai). Referuję za: E. Ann Kaplan, op. cit., s. 155.

${ }^{24}$ H. P., "Spione”, „Der Bildwart” 1928, Nr. 5 (Mai). Referuję za: E. Ann Kaplan, op. cit., s. 156. 
T. K.]. Postaciom nie dane jest rozwinąć się w pełne osobowości, pozostają pionkami, przesuwanymi na szachownicy. Niemniej, jest to jednak film Langa, toteż w zakresie obrazowania, fotografii i technicznej sprawności jest tu wiele do odnotowania ${ }^{25}$.

Z kolei korespondent „New York Timesa”, w maju 1928 donoszący amerykańskiemu czytelnikowi o nowych filmach niemieckich, odnosi Szpiegów do „zapierającego dech" Doktora Mabuse. Szpiedzy sąjednak zaledwie imitacją tamtego arcydzieła, posługując się tym samym tematem tajemniczego przestępcy, którego tożsamość nie zostaje w pełni odsłonięta. Film nie dorównuje jednak analogicznym filmom hollywoodzkim - intryga wydaje się śmieszna, a reżyseria mało oryginalna. Omówienie Szpiegów pojawiło się $\mathrm{w}$ tym artykule $\mathrm{w}$ kontekście refleksji nad partią nowych filmów niemieckich, które odzwierciedlają „dobre, solidne rzemiosło w manierze kontynentalnej, ale nie są dość sensacyjne, by wynieść je nad poziom europejskiej produkcji"26. A swoją drogą zabawne - wychwalany tu Doktor Mabuse, gracz, został przecież przez amerykańskich dystrybutorów nie tylko skrócony, ale wręcz zmasakrowany jako zbyt długi, statyczny, powolny ${ }^{27}$. Przemontowania i skrótów na rynek amerykański nie uniknęli zresztą i Szpiedzy. Nie były one jednak tak drastyczne, jak w wypadku Doktora Mabuse czy Metropolis, toteż Lang sam uznał, iż w Ameryce jest to „jeden z najmniej pokiereszowanych jego filmów" ${ }^{28}$. A ciekawostką jest też fakt, iż Szpiedzy byli pierwszym filmem przetransportowanym z Europy do Ameryki drogą powietrzną - zeppelinem ${ }^{29}$.

Podsumowując te opinie na temat wartości artystycznej Szpiegów, warto zwrócić uwagę, iż te same elementy - aktorstwo i reżyseria, symultaniczność i epizodyczność konstrukcji, technika filmowa i rytm monta$\dot{z} u$ - są przez rozmaitych recenzentów wręcz odwrotnie waloryzowane.

${ }^{25}$ Roland Schacht, „Spione”, „B. Z. am Mittag”, 23 März 1928. Referuję za: E. Ann Kaplan, op. cit., s. 158.

${ }^{26}$ C. Hooper Trask, Some New German Films, „New York Times”, 20 May 1928, s. 8. Zreferowanie artykułu za: E. Ann Kaplan, op. cit., s. 157.

27 Zob.: P. M. Jensen, op. cit., s. 36-37.

${ }^{28}$ Cyt. za: P. M. Jensen, op. cit., s. 79. Z wersji amerykańskiej, jak podaje Jensen, praktycznie został usunięty wątek pułkownika Jellusicia, przez co zniknęło jedno z najważniejszych zadań Agenta 326 (tropienie go), a widz odnosił wrażenie, że 326 nie ma innych zadań w fabule niż romans z Sonią (zob.: ibidem, s. 72). Także Tom Gunning w swej analizie Szpiegów (zob.: T. Gunning, The Films of Fritz Lang: Allegories of Vision and Modernity, BFI, London 2000, s. 117-138) wymienia zasadnicze różnice między niemiecką a amerykańską wersją. W tej drugiej prócz Jellusicia brak też np. "piętrowego" inwigilowania, które w sekwencji randki Soni i Agenta 326 na Parkstraße 24, jest w wersji niemieckiej: Sonię i 326 inwigilują Japończycy, których inwigiluje Haghi. W wersji amerykańskiej Haghi bezpośrednio inwigiluje Sonię i Agenta 326.

${ }^{29}$ Zob.: P. M. Jensen, op. cit., s. 70, 78. 
Ale nie jest to bynajmniej argument na rzecz prawdziwości (fałszywej, jak sądzę) sentencji: De gustibus non est disputandum. Raczej świadczy o tym, iż ten istotnie nowatorski estetycznie i odmienny od innych dzieł Langa film, zdezorientował recenzentów, dla których punktem odniesienia były bądź to poprzednie filmy reżysera, bądź ekspresjonizm, bądź klasyczny film hollywoodzki. Dla wielu z nich stylistyka Szpiegów, zarówno wpisująca się w estetykę Neue Sachlichkeit, jak i korzystająca ze zdobyczy sowieckiej szkoły montażu, okazała się po prostu jakościowo zbyt odmienna od paradygmatów już „oswojonych".

\section{Referencje: sowiecka agentura ("gdzieś w Europie") i pułkownik Redl}

Działalność w latach dwudziestych niemieckiej grupy komunistycznej IAH (Die Internationale Arbeitershilfe - Międzynarodowa Pomoc Robotnikom), która założyła niemiecko-sowiecką firmę dystrybucyjną Prometheus z siedzibą w Berlinie i powołała powiązaną z Prometheusem jedną z najważniejszych sowieckich spółek produkcyjnych, Mieżrabpom, przyczyniła się z pewnością do wielkiego sukcesu filmów sowieckiej szkoły montażu wśród intelektualno-artystycznych, zwłaszcza lewicowych, elit Niemiec ${ }^{30}$. Wpływ kina sowieckiego na estetykę Szpiegów wydaje się ewidentny, zarazem jednak film ten znajduje się na jego ideologicznych antypodach. O ile w Doktorze Mabuse można, czy wręcz należy, upatrywać w pewnych aspektach przeczucia nazizmu, to Szpiedzy w sposób znacznie bardziej świadomy i mniej dwuznaczny ideowo ewokują zagrożenie komunistyczne. Koncepcja wszechobecnej inwigilacji poprzez „medialną pajęczynę" o 20 lat wyprzedza wizję George'a Orwella z Roku 1984, przy czym pajęczyna owa oplata nie tylko „wolny świat”, ale i nieustannie sygnalizuje totalitarnej władzy wszelkie poczynania jej własnych narzędzi.

Ani przytłaczająca wizja w powieści Orwella, ani lżejsza, bo dostarczająca widzowi przede wszystkim sensacji, suspensu i wizualnych atrakcji, wizja Langa w Szpiegach, nie są jedynie fantazmatycznymi projekcjami lęku przed komunizmem: Orwell znał „od podszewki” działalność Brytyjskiej Partii Komunistycznej i poczynania stalinistów w Hiszpanii, Lang zaś nawiązał do ujawnienia działalności sowieckiej agentury w Wielkiej Brytanii, które opinii publicznej państw zachodnioeuropejskich w połowie lat 20. dość wyraźnie uświadomiło czające się na

30 Zob.: K. Thompson, op. cit., s. 35-37; Denise Hartsough, Soviet Film Distribution and Exhibition in Germany, 1921-1933, "Historical Journal of Film, Radio and Television” 1986, vol. 5, no. 2, s. 131-148. 
Wschodzie niebezpieczeństwo. Nie przypadkiem zresztą mniej więcej w tym samym czasie (o rok wcześniej, w roku 1927) ukazuje się może najwybitniejsze artystycznie ostrzeżenie przed bolszewizmem - genialna powieść Stanisława Ignacego Witkiewicza Pożegnanie jesieni. Co ciekawe, podobnie jak film Langa jest ona opisem zdegenerowanego, dekadenckiego świata, którego znakami są np. narkotyki, panerotyzm, dancing, kult sportu (w Szpiegach wyrazem tej dekadencji są: palarnia opium, w której Haghi nakrył Lady Leslane, „Cafe Danielli”, gdzie parkiet taneczny mieści się wokół ringu bokserskiego, oraz „Grand Bar”, w którym Agent 326 upija się z rozpaczy po zniknięciu Soni, a Matsumoto odkrywa mu, iż jest ona agentką). W taki nihilistyczny, pozbawiony aksjologicznych zabezpieczeń świat ideologia wchodzi jak w masło, a on sam wkrótce staje się łatwym łupem totalitarnej tyranii.

W wykładzie poprzedzającym pokaz Szpiegów 28 czerwca 1967 na kalifornijskim uniwersytecie Lang tak wyjaśniał genezę filmu: „Incydent, o który zostali oparci Szpiedzy, to tak zwany nalot na ARCOS w Londynie, w połowie lat 20. Wydział specjalny Scotland Yardu przeprowadził akcję na Rosyjskie Przedstawicielstwo Handlowe, ARCOS - skrót od «All Russian Co-Operative Society» (Wszechrosyjskie Towarzystwo Spółdzielcze) wskutek podejrzeń, iż jest ono w istocie centrum szpiegowskim. Toteż, jak zobaczycie, aktor Rudolf Klein-Rogge zagrał zmyślonego superszpiega Haghiego w charakteryzacji politycznego superintryganta Trockiego"31.

Choć sam Lang wskazał Trockiego jako model dla postaci jednego ze swych najsugestywniejszych superprzestępców, inni autorzy odnajdują w zaczesywanej łysinie, koziej bródce i (udawanym) paraliżu Haghiego podobieństwo raczej do Lenina ${ }^{32}$. Sowieckie odniesienia i podobieństwo Haghiego do Lenina odnotowały też, rzecz jasna, recenzje z epoki. Np. Fred Hildebrandt w recenzji zamieszczonej w „Berliner Tageblatt” 23 marca 1928 pisał, iż Rudolf Klein-Rogge pojawił się „w przebraniu Lenina” [...], „z serwetką na kolanach, z zawsze obecną za jego plecami pielęgniarka; choć sparaliżowany, był potężnym i złowrogim regentem pracującym dla potężnych i złowrogich sił"33. Krytyk piszący dla tygodnika „Reichsfilmblatt” stwierdza jednoznacznie, iż w tym filmie „wszystko...

31 Fritz Lang, Wykład wprowadzający do filmu Szpiedzy, University of California (Riverside Extension), 28 June 1967 (cyt. za: L. H. Eisner, Fritz Lang, s. 96). Zob. też: P. M. Jensen, op. cit., s. 70; T. Gunning, op. cit., s. 119; F. W. Ott, op. cit., s. 143.

32 Por. np.: F. W. Ott, op. cit., s. 143; Nicole Brenez, Symptome, exhibition, angoisse: réprésentation de la terreur dans l'œuvre allemande de Fritz Lang, "Cinématheque" 1993, no. 3 (Printemps/Été), s. 6.

33 „Berliner Tageblatt”, 23 März 1928, Nr. 142 (cyt. za: Fritz Lang. Leben und Werke. Bilder und Dokumente, s. 126). 
[wskazuje] na Sowiecką Rosję"34. Recenzent podpisany inicjałem D. (być może Ernst Degner) napisał w socjaldemokratycznej gazecie „Vorwärts” co następuje: „Tajemniczy szef rosyjskiej siatki szpiegowskiej, który pojawia się skryty za wieloma maskami i przebraniami, ma pod nieustanną obserwacją drugą stronę przyciężkiego i biurokratycznego aparatu państwa (można sobie łatwo wyobrazić, że przedstawiono tu Francję czy Anglię)" $)^{\prime \prime 35}$.

Ale konotacje rosyjskie były już expressis verbis wyrażone na poziomie wewnątrzfabularnym: Sonia Barranikowa, agentka Haghiego, to Rosjanka, której brat Aleksander Mikołajewicz Barranikow („Sasza”) i ojciec Mikołaj Fiodorowicz Barranikow, zginęli - prawdopodobnie za działalność rewolucyjną - z wyroku carskiego sądu. Haghi, chcąc zmusić Sonię do inwigilowania Agenta 326, używa argumentu zarazem „ideowego", jak i osobistego: Agent 326 jest w gruncie rzeczy po tej samej stronie, co jej wrogowie, carska Ochrana, przez którą zginęli jej brat i ojciec. Dookreśla to Sonię i jej tragicznie zmarłych bliskich jako reprezentantów antycarskiej opozycji (o tym, iż wcale niekoniecznie jako bolszewików, dodatkowo jeszcze świadczy religijność Soni), Haghiego zaś jako bolszewika cynicznie odwołującego się do historycznych, antycarskich argumentów dla własnych celów politycznych (zupełnie podobnie postępowali Lenin czy Stalin, później zresztą bezwzględnie rozprawiając się z dawną antycarską opozycją). Prócz wyglądu samego Haghiego, przywołującego skojarzenia z Leninem bądź Trockim, konotacje z bolszewikami nasuwają jego ludzie, $\mathrm{w}$ płaszczach i czapkach przypominających ubiór komisarzy z lat rewolucji, oraz rosyjskie napisy w kamuflowanej przez bank kwaterze głównej Haghiego, nie przypadkiem chyba obecne pośród napisów angielskich, niemieckich i francuskich. Zresztą Haghi, podmieniając w telegramie numery banknotów wypłaconych faktycznie Jellusiciowi, a później przechwytując "traktat japoński”, podsuwa Jasonowi „rosyjski trop", tyle tylko, że pierwszym faktycznie odwraca uwagę od siebie, natomiast traktat zamierza wywieźć za granicę nie przez wskazanego kuriera i nie tym pociągiem - choć prawdopodobnie także do Rosji, co wydaje się sugerować nazwa pociągu, którym podróżuje Sonia: „Nord Express”.

$\mathrm{W}$ ostatniej z przytoczonych recenzji z epoki autor wskazuje istotne novum Szpiegów: w przeciwieństwie do Doktora Mabuse, gracza, gdzie realia były zdecydowanie niemieckie, czy wręcz - berlińskie, tym razem usytuowanie akcji wcale nie jest jednoznaczne. Owszem, są tu akcenty niewątpliwie niemieckie, inne jednak elementy wskazują na Francję, Anglię,

34 „Reichsfilmblatt”, 24 März 1928, Nr. 12 (cyt. za: Fritz Lang. Leben und Werke..., s. 126-127).

35 „Vorwärts”, 23 März 1928, Nr. 142 (cyt. za: Fritz Lang. Leben und Werke..., s. 127). 
Austrię, przez co powstaje wrażenie, iż akcja dzieje się „gdzieś w Europie”, Europie zagrożonej działalnością bolszewickiej agentury. Wśród niemieckich filmów Langa dziejących się współcześnie (Wędrujący obraz, Walczące serca, Doktor Mabuse, gracz, M - morderca, Testament doktora Mabuse i Tysiac oczu doktora Mabuse) Szpiedzy z ich kosmopolityzmem realiów są absolutnym wyjątkiem.

Do elementów niewątpliwie niemieckich należą: słynna berlińska wieża radiowa Funkturm (animowane ujęcie we wstępnej sekwencji montażowej) $^{36}$, adres domu Soni (Parkstraße 24), ulice Berlina, którymi Sonia i Agent 326 ścigają uciekającego Morriera ${ }^{37}$, rozwieszone na ulicy listy gończe z portretem Haghiego oferujące za jego wskazanie 10 tys. marek. Niemieckie są też niewątpliwie akcenty autotematyczne: rozlepione na ulicy w tle za Agentem 326, gdy podążał za Sonią do Jellusicia, plakaty do Metropolis, czy Hotel Atlantic, wokół którego policja ustawia blokadę (o tym, że jest to swoisty hołd dla wielkiego kolegi „po kamerze”, świadczą pamiętne z filmu Murnaua obrotowe drzwi hotelu) ${ }^{38}$. Choć z drugiej strony, nazwy filmowych hoteli - Olympic, Atlantic - są na tyle kosmopolityczne, iż mogą równie dobrze jak Berlin ewokować np. Londyn.

W prologu widzimy wyjęty $\mathrm{z}$ sejfu i wkładany do koperty dokument z pieczęcią Ambasady Francuskiej, a zaraz później napis informuje nas o „sensacyjnej kradzieży dokumentów” z Ambasady Francuskiej w Szanghaju. „Orient Express”, którym Jellusić odjeżdża do „swego kraju", jak powszechnie wiadomo odjeżdżał z Paryża (choć miał też wagony londyńskie). Nazwa lokalu, w którym Matsumoto pociesza i poucza zarazem pijanego z rozpaczy Agenta 326, także ewokuje Francję. Choć z drugiej strony, wystrój i klientela „Grand Baru” są w równym stopniu „paryskie”, co „weimarskie”. Na kopiach, którymi dysponowałem ${ }^{39}$, nie

${ }^{36}$ Jej pochyłe skadrowanie i raczej znakowy niż realistyczny obraz koliście rozchodzących się z jej czubka fal radiowych, wpłynął na obraz Oskara Nerlingera Funkturm (1929). Zob.: katalog przygotowanej przez Goethe-Institut, München, wystawy Fritz Lang - Filmbilder, Vorbilder, Red. Heide Schönemann, Hentrich Verlag, Berlin, Tafel 36.

37 Sposób sfilmowania wielkomiejskiego pejzażu w sekwencji pościgu nosi niewątpliwy wpływ stylistyki słynnego filmu dokumentalnego Waltera Ruttmanna ze zdjęciami Karla Freunda Berlin, symfonia wielkiego miasta (Berlin, die Sinfonie der Großstadt, 1927).

38 Chodzi oczywiście o film Friedricha Wilhelma Murnaua Portier z hotelu Atlantic (Der letzte Mann, 1924).

39 Dysponowałem kasetą VHS z włoskimi napisami oraz wydaną przez Kino Video w 2004 r. w boksie Fritz Lang Epic Collection płytą z napisami angielskimi, będącą rekonstrukcją dokonaną przez Friedrich-Wilhelm-Murnau-Stiftung. Obie wersje, prócz odmiennej ścieżki dźwiękowej, nie różnią się zasadniczo, z jednym dość istotnym wyjątkiem: w czołówce wersji włoskiej przy nazwisku Willy Fritscha pojawia się informacja, iż odtwarza on „Numer 326, Donalda Tremaine” (choć w trakcie samego filmu ani razu napisy 
pada wprawdzie nazwisko Agenta 326, ale rozmaite źródła, z których korzystam (np. Gunning, Lotte Eisner, Jensen, Ott), podają iż nazywa się on „Donald Tremaine” ${ }^{40}$. Rzecz jasna, imię jest zdecydowanie anglosaskie, nazwisko jednak ma zarówno angielski, jak i francuski posmak, a może nawet bardziej ten drugi.

Konotacje świata przedstawionego wydają się jednak przede wszystkim angielskie. Wywiad, na którego czele stoi Jason (wybitnie anglosaskie nazwisko), przypomina swą strukturą powszechny stereotyp Scotland Yardu albo też znaną z serii Bondowskiej brytyjską Secret Service (co zresztą świadczy, iż w filmach Langa może mieć źródło nie tylko autoprezentacja agenta 007, ale i ironiczny obraz zatrudniającej go instytucji). Żona rodzimego, jak się wydaje, dyplomaty, Rogera Leslane'a, ma tytuł „Lady”. Gdy Haghi wręcza Kitty fotografię doktora Matsumoto, widnieje pod nią adres Japończyka „17 Strand”. A przecież nie może tu chodzić o tę słynna, uwiecznioną choćby przez Conrada londyńską ulicę, skoro "Strand”, przy którym mieszka Matsumoto, i „Parkstraße 24" (adres Soni) znajdują się w jednym mieście. Jellusić z Haghi Banku otrzymuje za swe szpiegowskie rewelacje honorarium $\mathrm{w}$ funtach. Wreszcie Agent 326 (niezależnie od swego imienia, nieobecnego w analizowanej przeze mnie wersji) jest na wskroś typem angielskiego detektywa - przystojny, zamożny, z luksusowym samochodem i zaufanym kierowcą-służącym ${ }^{41}$, w każdym calu dżentelmen, świetnie ubrany i o nienagannych manierach, choć z drugiej strony po Bondowsku bezceremonialny; w tym wszystkim niczym nie przypomina raczej nieatrakcyjnych, niewątpliwie niemieckich detektywów z innych weimarskich filmów Langa: prokuratora von Wenka (Doktor Mabuse, gracz) i komisarza Lohmanna ( $M$ - morderca, Testament doktora Mabuse). Anglosaskim rysem Agenta 326 wydaje się też zamiłowanie do boksu - bo chyba nie przypadkiem wyznaczył Soni randkę w lokalu, w którego centrum znajdował się ring.

Spora liczba konotacji angielskich jest z pewnością nieprzypadkowa, skoro to właśnie w Wielkiej Brytanii zdekonspirowano ARCOS jako sowiecką agenturę. Ale, jak wskazuje Frederick W. Ott, innym źródłem fabularnego pomysłu i antysowieckiej wymowy Szpiegów, może być sprawa „listu Zinowjewa" ${ }^{42}$, która w 1924 r. na tyle wstrząsnęła brytyjską opinią publiczna, iż radykalnie odwróciła się od lewicy i Labour Party przegrała

nie nazywają bohatera inaczej niż Numerem 326). W wersji z napisami angielskimi nazwisko „Donald Tremaine” nie pada nawet w czołówce.

${ }^{40}$ Widocznie na niektórych kopiach eksploatacyjnych tak nazywano bohatera. W każdym razie nazwisko to nie pochodzi z powieści Thei von Harbou Spione, w której bohater nazywany jest po prostu Agentem 326.

${ }^{41}$ Ale ów zaufany nosi z kolei niemieckie imię Franz!

42 Zob.: F. W. Ott, op. cit., s. 143. 
zdecydowanie w wyborach. Otóż prasa angielska opublikowała tzw. „tajny list Zinowjewa”, zawierający wytyczne ówczesnego przewodniczącego Kominternu dla brytyjskich komunistów. „Spór o to, czy ten list był fałszywy, czy autentyczny, trwa do dziś" - pisał w 1982 r. opozycyjny rosyjski historyk Związku Sowieckego, Michał Heller. - „Ale nawet jeśli był to falsyfikat, to nie zawiera on niczego, czego Zinowjew nie mógłby napisać. Dyrektywa, która szczególnie oburzyła angielską opinię publiczną - nakaz prowadzenia działalności wywrotowej $\mathrm{w}$ armii - wchodziła w skład 21 warunków, obowiązujących wszystkie partie komunistyczne" ${ }^{\prime \prime 3}$.

Dość ważnym elementem intrygi Szpiegów jest „,najważniejszy w obecnym stuleciu traktat, jaki podpisała Japonia" - jak obwieszcza swym agentom doktor Matsumoto. Wysyła on ich w ryzykowną misję z bezwartościowymi ścinkami w zalakowanych kopertach, po to, by służąc jako przynęta dla starającego się zdobyć ów dokument Haghiego, odwrócili uwagę od niego, w którego posiadaniu dokument cały czas faktycznie się znajdował. Gdy Haghi jednak przez swą agentkę Kitty wydobędzie dokument, a Matsumoto, by „być godnym miana Japończyka” popełni rytualne harakiri, minister, który traktat podpisał, straszy szefa wywiadu Jasona, iż wpadnięcie traktatu $\mathrm{w}$ nieodpowiednie ręce grozi wybuchem wojny na Wschodzie. W tym niby to fantastycznym wątku "dalekowschodnim” znajdujemy echa napiętej sytuacji politycznej w Azji w latach 1924-1927, spowodowanej m.in. militarną i agenturalną działalnością Związku Sowieckiego na Dalekim Wschodzie, zwłaszcza w Chinach ${ }^{44}$. Jej też właśnie echem jest dość enigmatycznie ukazana we wstępnej sekwencji montażowej kradzież dokumentów z francuskiej ambasady w Szanghaju jak sugeruje narracja, również będąca robotą Haghiego, czyli Sowietów. A w kwaterze głównej Haghiego, jak pokazują różnojęzyczne napisy, „Wydział Japoński” (czyli dalekowschodni), wydaje się równie ważny jak zajmujący się „Europa”” "Wydział Zagraniczny”.

W recenzjach z epoki wielu krytyków wskazywało, iż obecny w filmie Langa motyw samobójstwa popełnionego przez człowieka przyłapanego na szpiegostwie na rzecz obcego mocarstwa, ewokuje pamiętną aferę pułkownika Alfreda Redla (po latach podejmie ją słynny węgierski film w reżyserii Istvána Szabó Pułkownik Redl, 1984). W Szpiegach są dwa takie samobójstwa - finałowe Haghiego, dokonane publicznie na scenie podczas jego występu jako klowna Nemo, oraz wymuszone przez zwierzchników, a później zatuszowane jako „atak serca” samobójstwo pułkownika

${ }^{43}$ Michał Heller, Aleksander Niekricz, Utopia u władzy: Historia Zwiazku Sowieckiego, przeł. Andrzej Mietkowski, Polonia Book Fund Ltd., Londyn 1985, t. 1, s. 172.

${ }^{44}$ Por.: ibidem, s. 173. 
Jellusicia. Oczywiście, oba z nich mogą być echem sprawy Redla, z tym, że w wypadku tego drugiego jest to ewidentne: Redl był oficerem armii austro-węgierskiej, który przyłapany na szpiegostwie na rzecz Rosji, popełnił samobójstwo w roku 1913. Sprawa Redla, pierwotnie zatuszowana, skoro rzecz dotyczyła członka Sztabu Generalnego i protegowanego arcyksięcia Ferdynanda, została wydobyta na światło dzienne przez „wszędobylskiego reportera”, Egona Erwina Kischa, który prócz poczytnych reportaży po latach poświęci jej nawet dramat ${ }^{45}$. Lotte Eisner podaje, iż Langa fascynowała ta historia ${ }^{46}$; niewątpliwie, temat wymuszonego samobójstwa jest jednym z mrocznych lejtmotywów jego twórczości, a otwierające po latach Banniona (The Big Heat, 1953) zbliżenie leżącego na biurku rewolweru, którego za chwilę użyje w samobójczym strzale skorumpowany policjant Tom Duncan, nieodparcie musi przywodzić podobne ujęcie ze Szpiegów: dłoni kładącej na wzorzystej serwecie stołu rewolwer, "ostatnie życzenie" Jellusicia łaskawie spełnione i podsunięte mu przez jego zwierzchników.

Realia ojczystego kraju Jellusicia są zdecydowanie austriackie, czy nawet - austro-węgierskie. Dojeżdża się doń z "zachodniej Europy" „Orient Expressem”, a zatem musi leżeć on gdzieś na wschód od niej, np. w Europie Środkowej. „Jugosłowiańskie” nazwisko pułkownika oraz mundury jego i jego zwierzchników (jakby sprzed I wojny światowej) sugerują nie powojenną Austrię, ale obejmującą południową Słowiańszczyznę monarchię habsburską. Porównanie fotografii autentycznego Redla i Fritza Raspa w roli Jellusicia, noszącego tak samo wypomadowane, nastroszone wąsy, świadczy, iż właśnie Redl był modelem Langowskiego zdrajcy. Wreszcie - szpiegował on dla Haghiego, czyli dla "Rosjan”. Zbudowanie przez Langa świata przedstawionego Szpiegów poprzez wskazane tu anachronizmy oraz kondensację w jednej przestrzeni elementów sugerujących rozmaite państwa, zdezorientowało nieco Hansa Felda, recenzenta gazety "Film Kurier”, który w recenzji z 23 marca 1928 popełnił błąd dość zawstydzający. Owszem, rozpoznał w Jellusiciu opisanego przez Kischa pułkownika Redla, lecz napisał, iż film ten wystawia "celuloidowy pomnik" byłemu szefowi Sztabu Geberalnego 8. Korpusu Armii Austro-Węgierskiej, który szpiegował dla Związku Sowieckiego [sic! $]^{47}$. Interferencja w jednej postaci filmu aktualnego odniesienia politycznego (agenci sowieccy) z referencją historyczną (szpieg carskiej Rosji) sprowadziła na manowce niezbyt rozważnego

${ }^{45}$ Por.: Fritz Lang. Leben und Werke. Bilder und Dokumente, s. 127.

${ }^{46}$ Zob.: L. H. Eisner, Fritz Lang, s. 98.

47 „Film Kurier”, 23 März 1928, Nr. 72 (cyt. za: Fritz Lang. Leben und Werke. Bilder und Dokumente, s. 127). 
recenzenta. W każdym razie Kurt Pinthus - tradycyjnie recenzujący już premierowe filmy Langa w latach 20. - odnotował, iż potraktowanie w Szpiegach sprawy pułkownika Redla jest „doskonałe" ${ }^{48}$.

\section{Eliptyczny sjużet, paralelizmy i synekdochiczne kadry}

Spośród wszystkich filmów Langa z lat 20. Szpiedzy mają najżywsze tempo, a rytm obrazów wydaje się szybkim, nerwowym rytmem współczesności, wyznaczanym przez środki komunikacji (samolot, samochód, pociąg, motocykl) oraz służące łączności, informacji i kontroli media (prasa, radio, telefon, interkom, telegraf, dalekopis, mikrofony podsłuchowe, fotografia, kino). Ten aspekt filmu w przywołanych recenzjach wyeksponowali A. Kraszna-Krausz, Herbert Ihering, E. Hellmund-Waldow, a spośród autorów piszących później o Szpiegach - Lotte Eisner ${ }^{49}$, Paul Jensen ${ }^{50}$, Noël Burch ${ }^{51}$, Tom Gunning. Ten ostatni tak podsumował estetykę filmu: „Szpiedzy sytuują swe intrygi w wyraziście zarysowanym świecie, który zdominowały pogoń za informacją i rytm maszyn, świecie nacechowanym raczej przez prędkość, ruchliwość i precyzję niż przez ociężałość ogromnych maszyn, jak w Metropolis" 52 .

Widomym przejawem „żywości” filmu jest jego sjużet - czyli, z grubsza mówiąc, tekstualny układ zdarzeń przedstawionych wraz z jego segmentacją na jednostki dramaturgiczne. W przeciwieństwie do Zmęczonej Śmierci, Doktora Mabuse, gracza i Nibelungów, które charakteryzował wyrazisty podział na wyodrębnione, raczej "domknięte” kompozycyjnie i względnie autonomiczne w strukturze filmu "akty”, w wypadku Szpiegów trudno by przeprowadzić taką klarowną i bezdyskusyjną segmentację. Lang także we wcześniejszych filmach często stosował dość gwałtownie wyrywający widza z przedstawionej przestrzeni montaż równoległy, czy to o charakterze montażu symultanicznego (a zatem przenoszącego odbiorcę do akcji dziejącej się równocześ n i e w jakimś innym miejscu), czy to o charakterze montażu p a r a l e lnego ideowego (a zatem budującego przez zestawienie obrazów pewne znaczenia, porównania, metafory), ewentualnie - zawierającego oba te wymiary zara zem (gdy np. kontrapunktem rozmowy Wenka z Hullem była przebitka na Mabusego, pobierającego jad węża). Przeskoki

48 "Das Tagebuch”, 31 März 1928, Nr. 13 (cyt. za: Fritz Lang. Leben und Werke..., s. 127).
${ }^{49}$ L. H. Eisner, Fritz Lang, s. 96-104.
${ }^{50}$ P. M. Jensen, op. cit., s. 75-76.
${ }_{51}$ Noël Burch, Fritz Lang: German Period, [w:] Cinema: A Critical Dictionary, ed. Richard Roud, Secker \& Warburg, London 1980, s. 589-591.

52 T. Gunning, op. cit., s. 118-119. 
montażowe w poprzednich filmach odbywały się jednak w obrębie klarownie wyodrębnionych całostek dramaturgicznych. W Szpiegach bywa natomiast, że jakaś scena wydaje się kontynuacją danego segmentu, a tak naprawdę zapoczątkowuje już nowy wątek, nowy temat, otwierając następną jednostkę dramaturgii (np. zbliżenie wezwania na policję dla „Hansa Pockzerwinskiego” wydaje się kolejnym ważnym dokumentem w serii dokumentów zaprezentowanych w sekwencji montażowej prologu, zatem jawi się zrazu jako jej dalszy ciąg, ale faktycznie zapoczątkowuje ono pierwszą rozbudowaną scenę filmu: prezentację Agenta 326). Rozbudowane sceny mogą też mieć krótkie, kontrapunktowe przebitki jakiejś innej akcji, na pozór nierozsadzające zwartości danej sceny, ale zaraz okazuje się, że przebitka była „przedwczesnym wtargnięciem" następnej sceny, następnej akcji (montażowy przeskok na Haghiego podczas rozmowy Jasona z Agentem 326 w pierwszej rozbudowanej scenie filmu, po którym powracamy do rozmówców w siedzibie wywiadu, jest jednak zarazem pierwszym ogniwem kolejnego wyrazistego segmentu: „kwatera główna Haghiego”). W całościowej strukturze filmu ważne są też pewne p a r a leli z m y, budujące podobieństwa bądź różnice między wątkami. Znacznie wyrazistsze niż w tradycyjnym filmie fabularnym są też e li p s y, bo nie tylko pomijają - jak to na ogół bywa - Hitchcockowskie "plamy nudy", partie fabuły niespecjalnie atrakcyjne dramaturgicznie dla unaoczniającej prezentacji, ale i kluczowe momenty w obrębie jakiegoś segmentu (np. przebieg randki Soni i Agenta 326 czy wykradnięcie przez Kitty z walizki doktora Matsumoto „traktatu japońskiego").

Wskutek elips, montażu równoległego i zazębiania się poszczególnych całostek akcji trudno zatem zaproponować jakąś bezdyskusyjną segmentację filmu. Dla przedstawienia przebiegu fabuły zdecydowałem się na następujący jej wariant.

1. "Zamęt w świecie". Sekwencja montażowa, pokazująca polityczne przestępstwa i spowodowany nimi globalny chaos. Zasadnicze wydarzenia tej sekwencji to kradzież dokumentów z Ambasady Francuskiej w Szanghaju, dokonane $\mathrm{z}$ pędzącego samochodu zastrzelenie jadącgo innym samochodem ministra handlu, połączone z kradzieżą przewożonych przezeń dokumentów, chaos w rozmaitych instytucjach rządowych odpowiedzialnych za bezpieczeństwo, wreszcie zastrzelenie w gmachu jakiegoś bardzo ważnego urzędu (ministerstwa?) kuriera, który już miał złożyć raport o (być może) sprawcy tego zamętu. Gdy będący świadkiem tej ostatniej zbrodni urzędnik wypowiada w przerażeniu słowa: „Wszechmocny Boże, jaka potęga za tym wszystkim stoi?”, pojawia się przebitka z portretowym planem Haghiego i wielki napis: "Ja". 
2. „Agent 326”. Pod pretekstem wezwania na policję, przebrany za lumpa Agent 326 trafia "konspiracyjnie" do szefa wywiadu Jasona i demaskuje jako obcego agenta jego pracownika, Vincenta, który ukrytym $\mathrm{w}$ klapie miniaturowym aparatem chciał mu zrobić zdjęcie. Ironia polega jednak na tym, że wchodząc do Jasona, Nr 326 dał się dwukrotnie sfotografować - lumpowi przed posterunkiem i panu w cylindrze już na komisariacie, o czym świadczy przebitka: wymienieni wręczają Haghiemu w jego kwaterze zdjęcia Agenta 326, a nawet jego odciski palców. Jason prezentuje Numerowi 326 album z fotografiami agentów, którzy byli już na tropie tajemniczego zleceniodawcy Vincenta, ale zostali zamordowani.

3. "Kwatera główna Haghiego". Prezentacja tajnego gabinetu „wroga publicznego numer 1”, „Wydziału Zagranicznego” i przepastnej klatki schodowej jego kwatery głównej, z gorączkową krzątaniną w tę i we w tę jego ludzi. Haghi (w zasadzie aż do finału widzimy go na wózku inwalidzkim pod opieką odpychającej, zmaskulinizowanej pielęgniarki) przyjmuje poddańczy hołd uprowadzonego przez jego agentów spod szafotu bandyty Morriera, a następnie przygotowuje się do wizyty Lady Leslane (interkom już poinformował go o jej zdążaniu do Haghi Banku). Interludium pokazuje pułkownika Jellusicia odbierającego jakąś wiadomość na poste restante - matematycznie absurdalnym, niemożliwym do zapamiętania przez pocztowego urzędnika kodem i znikającym atramentem udaje mu się przechytrzyć śledzącego go policyjnego agenta. W samochodzie czeka już na niego Sonia Barranikowa, agentka Haghiego, co obserwuje zza gazety japoński agent, doktor Matsumoto. Tymczasem Haghi przyjmuje Lady Leslane jako dyrektor banku (w innej charakteryzacji). Żąda od niej, jako żony dyplomaty, informacji na temat przygotowywanego do podpisania traktatu japońskiego, szantażując zdjęciami wykonanymi w palarni opium, którą Lady regularnie i potajemnie odwiedza.

4. „Sonia. Incydent w Hotelu Olympic”. Gdy zmęczony Agent 326 przesypia w jakiejś kryjówce całe popołudnie, Haghi wypytuje Sonię o Jellusicia i instruuje, jak (z pomocą znanego już nam „pana w cylindrze") zastawić wieczorem na niego pułapkę. Wieczorem Nr 326 zakrada się po dachach (właściwie dlaczego w taki sposób?) do Hotelu Olympic, gdzie czeka już na niego jego służący i zaufany, Franz. Słyszą strzał i do ich apartamentu wpada roztrzęsiona Sonia, mówiąc, iż zastrzeliła molestującego ją mężczyznę. Gdy zwabiona strzałem policja i obsługa hotelowa gromadzi się na zewnątrz, Nr 326 ukrywa Sonię w przyległym pokoju. Policja mimo przeszukiwania jego apartamentu niczego nie odkrywa, za to okazuje się, iż "ofiara" Soni żyje, a kula wystrzelona przez nią przestrzeliła książkę (hotelowy rozkład jazdy pociągów). Wykąpany, ogolony Agent 326 zrzuca kostium lumpa i ukazuje się Soni, która zdążyła tymczasem przejrzeć jego papiery, jako atrakcyjny, przystojny, dobrze ubrany 
mężczyzna. Zakochują się z wzajemnością ale gdy on wydaje w pokoju obok jakieś instrukcje Franzowi, Sonia znika, zostawiwszy kartkę, iż „lepiej byłoby, gdyby się już nie spotkali". Wybiegającemu za nią z pokoju Numerowi 326 kłania się w drzwiach naprzeciw dr Matsumoto, a 326 niepewnie ten ukłon odwzajemnia.

5. „Sztuka perswazji”. Gdy Sonia wyznaje, że wolałaby nie pracować przeciwko Agentowi 326, Haghi przypomina jej męczeńską śmierć jej brata i ojca z wyroku carskiego sądu, i sytuuje Agenta po tej samej stronie jej wrogów. Zmusza ją do napisania listu, zapraszającego Nr 326 na czwartą do jej domu na rosyjską herbatę.

6. „Parkstraße 24". Dom Soni pod tym adresem inwigilowany jest przez Japończyków - przed przybyciem Numeru 326 jeden z japońskich agentów zdejmuje odcisk zamka, inny śledzący z naprzeciwka akcję informuje o niej telefonicznie dr. Matsumoto. $W$ pełnym ikon i rosyjskich bibelotów domu szaleńczo w sobie zakochani Sonia i 326 spędzają całe popołudnie, niepomni upływającego czasu. Agent 326 zaprasza Sonię na dziewiątą do Daniellego. W samochodzie Sonia wręcza ukochanemu wyjęty z modlitewnika prawosławny medalik przedstawiający Madonnę z Dzieciątkiem. Matsumoto wydaje swym ludziom instrukcje na wieczór. Umieszczony $\mathrm{w}$ wazonie mikrofon transmituje podsłuchiwane rozmowy Japończyków do Wydziału Japońskiego w kwaterze Haghiego, skąd dalekopisem trafiają na biurko superszpiega. Haghi dzwoni na Parkstr. 24, a pokojówka Soni - także jego agentka - informuje go: „Danielli”.

7. „Danielli. Poszukiwania Soni”. U Daniellego Soni, szczęśliwej w objęciach Agenta 326, ktoś wręcza w tańcu kartkę od Haghiego, by natychmiast stawiła się u Jellusicia. Odnalazłszy na sali Haghiego, posłusznie wykonuje ona jego polecenie: zrywa na parkiecie naszyjnik, a gdy 326 wraca od stolika, by znaleźć tę „zgubę", ona wymyka się. W taksówce czyta instrukcje od Haghiego, by zapłacić Jellusiciowi za jego informacje pod warunkiem, iż tej nocy przekroczy on granicę, a samej nie wracać do domu, tylko osobiście złożyć mu raport. Zrozpaczonemu zniknięciem Soni Agentowi 326 sprytny chłopiec wskazuje za gratyfikacją kierunek, w którym się udała. Samochodem, z Franzem za kierownica, 326 wyrusza na poszukiwania. Po sfinalizowaniu szpiegowskiej transakcji (tajne plany wojskowe w zamian za 20 tys. funtów) Jellusić molestuje Sonię przy wyjściu z jego domu, czego świadkiem jest $\mathrm{Nr} 326$. Sonia wymyka się, a Jellusić daje do zrozumienia natarczywemu agentowi, iż Sonia jest jego „damą” i zatrzaskuje przed nim drzwi. Na Parkstr. 24 Agent 326 zastaje dom kompletnie pusty, ogołocony z wszelkich mebli. Haghi tymczasem studiuje plany od Jellusicia, dostarczone przez Sonię, a gdy ta zdradza się z miłością do Agenta 326, postanawia ją uwięzić w swej kwaterze, rozkazując jej nie opuszczać pokoju bez jego rozkazu i oddając pod nadzór swej demonicznej pielęgniarki. 
8. „Grand Bar. Kitty”. Zasępiony ucieczką Soni Agent 326 w „Grand Barze" topi smutek $\mathrm{w}$ alkoholu, nie wiedząc, iż ta, uwięziona przez Haghiego, całuje jak talizman jego zdjęcie i płacze nad nim. Dr Matsumoto informuje go, mocno już wstawionego, iż Sonia jest niebezpiecznym szpiegiem i poucza, że nic, nawet kobieta, nie może sprowadzić mężczyzny ze ścieżki swego obowiązku. To pouczenie ma wydźwięk ironiczny w kontekście tego, co następuje zaraz po rozstaniu Japończyka i Numeru 326 przed barem: Matsumoto poruszony widokiem tulącej się do muru w ulewnym deszczu dziewczyny i jej opowieścią o strasznym domu („ojciec sadysta, matka - dziwka i pijaczka"), zabiera ją do siebie, nie wiedząc (o czym informowała wcześniejsza przebitka), iż to nasłana nań agentka Haghiego, Kitty. Sceny z Japończykiem i Kitty kontrapunktuje krótka scenka z Agentem 326, ze złością ciskającego na podłogę medalik od Soni.

9. „Jellusić". Agent 326 w pokazanym mu przez Jasona albumie osób podejrzanych o szpiegostwo odnajduje fotografię Jellusicia, który tymczasem zdąża "Orient Expressem” do „swego kraju”. Jellusić w pociągu adresuje kopertę $\mathrm{z}$ honorarium od Haghiego na poste restante, a tymczasem człowiek Jasona rezerwuje telefonicznie bilet dla Agenta 326 na „Aero-Orient-Express”, czyli samolot, który przybędzie do kraju Jellusicia wkrótce po pociągu. O rezerwacji tej dowiaduje się Haghi, który obawiając się denuncjacji przez chciwego szpiega, wydaje swemu człowiekowi polecenie, by ujawnić zdradę Jellusicia jego wojskowym zwierzchnikom. Jellusicia, już w kraju, śledzi przebrany za ślepca agent Jasona, który odnotowuje adres poste restante, gdy pułkownik wrzuca kopertę z 20 tys. funtów do skrzynki. W mieszkaniu Jellusicia czekają już na niego dwaj wojskowi w wysokiej randze, łaskawie zezwalając mu na jedno życzenie. Przerażony Jellusić prosi o rewolwer.

10. „Traktat japoński. 20 tys. funtów”. Haghi, w obecności Soni, otrzymuje wiadomość (od Lady Leslane?) o miejscu i sygnatariuszach „traktatu japońskiego". Obraz unaocznia podpisanie tego traktatu w Ambasadzie Japonii. Dr Matsumoto wręcza każdemu ze swych trzech agentów zalakowaną kopertę, mówiąc, iż w jednej z nich znajduje się dokument. „Wyruszycie do Tokio trzema różnymi drogami. Kto nie dostarczy zalakowanego i nienaruszonego listu, ten nie będzie godzien miana Japończyka". Haghi zapowiada Soni, iż będzie mieć traktat jeszcze tej nocy, Sonia zaś odrzuca oferowane jej przez Haghiego perly i kieliszek szampana "na zgodę". Tymczasem Nr 326 po wylądowaniu „Aero-Orient-Expressu” dowiaduje się od agenta Jasona, iż wedle prasowej notki Jellusić zmarł nagle na atak serca po powrocie z urlopu. Odbierają na poczcie ze skrytki Jellusicia kopertę z 20 tys. funtów o kolejnych numerach seryjnych - Nr 326 telegrafuje do Jasona z prośbą o sprawdzenie, jaki bank je wypłacił. Treść telegramu poznaje jednak agent Haghiego, prostym podstępem zmuszając Nr 326 do napisania tekstu depeszy w miejscu, pod którym ukryta była 
kalka. Haghi (ewidentnie to dalszy ciąg przerwanej przez symultaniczną akcję jego rozmowy z Sonią) zasępia się, poznawszy treść telegramu. Daje Soni ultimatum: „Musisz się zdecydować, Soniu - po czyjej jesteś stronie?” Kolejną porażką Haghiego jest odkrycie, iż w przyniesionych mu zalakowanych kopertach nie ma traktatu japońskiego, tylko ścinki gazet. Widząc Schadenfreude Soni ze swego zawodu, zapowiada jej, że nie zgrał jeszcze wszystkich swych atutów. Jednym z tych atutów jest oczywiście Kitty (kolejna akcja symultaniczna) - widząc przygotowania doktora Matsumoto do odjazdu, odgrywa ona komedię rozpaczy zakochanej do szaleństwa biednej sieroty i skutecznie skłania Japończyka do spędzenia z nią jeszcze przynajmniej paru godzin. Sonia natomiast odmawia sojuszu z Haghim, a ten zapowiada jej, iż będzie ona jego więźniem dopóki jeden z nich - on sam albo 326 - nie zwycięży.

11. „Harakiri”. Samotne przebudzenie Matsumoto, który odkrywa, że Kitty zniknęła wraz z traktatem. W wizji doktora zjawiają się przed nim na tle japońskiej flagi widma trzech zamordowanych przez Haghiego kurierów, wręczając zalakowane koperty. Matsumoto kłania się widmom, a następnie przed posągiem Buddy popełnia rytualne samobójstwo (harakiri, seppuku). Scena ta kontrapunktowana jest przebitką na Kitty, która łapczywie chwyta rzucone jej z pogardą przez Haghiego honorarium: sznur pereł.

12. „Klown Nemo alias Agent 719”. Jason w swym biurze prosi Agenta 719 (Nemo) o sprawdzenie źródła banknotów wypłaconych Jellusiciowi, ale Nr 719, korzystając z roztargnienia i krótkowzroczności szefa wywia$\mathrm{du}$, podmienia telegramy, podrzucając własny, z innymi numerami seryjnymi niż wskazane przez Agenta 326 . W towarzystwie tego ostatniego Jason zapowiada się na wieczór w garderobie klowna. Tymczasem telefon ministra informuje Jasona o niebezpieczeństwie wybuchu wojny na Wschodzie w związku ze zniknięciem traktatu i nakazuje blokadę granic. Agent Haghiego informuje szefa o zastawieniu pułapki na Nr 326 w ostatnim wagonie pociągu (o numerze 33 133), który ma zostać wykolejony w tunelu. Haghi prosi Sonię o spełnienie dlań ostatniej misji, po której ją uwolni: wywózkę za granicę kopii traktatu. Sonia z radością zgadza się, z niepokojem odnotowując na biurku Haghiego karteczkę z numerem 33 133, którą Haghi, zauważywszy jej wzrok, skrzętnie chowa. W swej garderobie klown Nemo wręcza agentowi 326 bilet na ekspres w przedziale obok rosyjskiego kuriera, który może starać się wywieźć traktat.

13. „33 133". Sonia, ulokowana w „Nord Expressie”, odnotowuje w pociągu odjeżdżającym z przeciwnej strony peronu Agenta 326. Franz, żegnając w przedziale swego szefa, wręcza mu znaleziony medalik od Soni. Sonię zaś niepokoi numer jego wagonu - 33 133, który zdaje się ją prześladować, tak iż myśląc o nim intensywnie, nie może zasnąć. W pociągu, którym jedzie 326, w konduktorze $i$ „,rosyjskim kurierze” rozpoznajemy ludzi 
Haghiego (ten drugi to Morrier). Wieczorem, gdy wszyscy śpią, odłączają oni ostatni wagon - 33133 - od składu, tak, by na nieoświetlony wagon najechał zbliżający się ekspres. Gdy odłączony wagon nieruchomieje, medalik z Madonną spada z góry, co Agenta 326 budzi i ratuje mu życie, gdyż w porę mógł oddalić się od miażdżącej wagon lokomotywy. Sonia, zauważywszy nerwową krzątaninę kolejarzy i dowiedziawszy się od nich o katastrofie wagonu 33 133, uświadamia sobie intrygę Haghiego, którego zbliżeniem w oparach dymu kończy się niniejsza sekwencja.

14. „Ratunek i pościg”. Sonia podąża na miejsce katastrofy pociągiem ratunkowym i w zmiażdżonym wagonie, dzięki medalikowi trzymanemu w zaciśniętej ręce, lokalizuje ukochanego. Zanim jednak z pomocą innych wydobędzie go spod zwałów żelastwa, muszą oboje stoczyć walkę z Morrierem, który przybył na miejsce, by upewnić się, że Agent 326 nie żyje. Morrier ucieka samochodem wraz z „,konduktorem”, a Sonia i 326 ścigają go motocyklem zabranym filmującemu katastrofę operatorowi kroniki. Po drodze informują policję, która zdąży w mieście przygotować blokady. Szaleńczy pościg szosami i wielkomiejskimi ulicami kończy się wjechaniem samochodu Morriera do jakiegoś lokalu, gdzie ostrzeliwując się i wywołując panikę podąża on do mikrofonu (prawdopodobnie przeprowadzano stamtąd bezpośrednią transmisję radiową). Drogą radiową informuje on Haghiego, iż 326 żyje, a Sonia zdradziła, po czym skonstatowawszy, że nie ma amunicji, by ostrzeliwać się, łyka ampułkę z trucizną. Haghi odkłada słuchawki, rozumiejąc, iż nadszedł kres jego imperium.

15. „Akcja w Haghi Banku”. Po rozstaniu z Numerem 326 nieopodal Haghi Banku Sonia i Franz wpadają w pułapkę Haghiego i zostają uprowadzeni do jego kwatery (uliczny sprzedawca, zamiast orzechów kokosowych, miał granaty dymne). Policja pod wodzą Jasona i Agenta 326 wkracza do banku, wyprowadza urzędników i klientów, żąda od wicedyrektora kluczy do sejfów. Numer 326 otrzymuje informację od Haghiego, iż więziona przezeń Sonia zginie, jeśli policja nie wycofa się $\mathrm{z}$ banku w ciągu kwadransa. Ludzie Jasona usiłują desperacko znaleźć kwaterę Haghiego w przeciągu tych niewielu pozostałych minut, kując ściany, tnąc palnikami sejfy, intensywnie szukając tajemnych przejść. Haghi nakazuje swym ludziom spalić dokumenty, wysadzić sejfy, wpuścić do banku gaz. Przed zostawieniem Soni i Franza na pastwę egzekutorów, Haghi odkrywa swej eks-agentce ostatnią tajemnicę: nie był inwalida, może chodzić. Gaz zmusza Agenta 326 do ewakuacji większości swych ludzi, ale sam desperacko poszukuje Soni. Tymczasem Franzowi udało się wydobyć z więzów, toteż o wyznaczonej godzinie egzekucji może stoczyć z ludźmi Haghiego desperacką walkę, ratując siebie i Sonię. Sonia pada w ramiona ukochanego, wybuch niszczy biurko, zza którego Haghi sprawował swą władzę, a gaz powoduje panikę w kwaterze głównej. Policja na zewnątrz banku 
aresztuje wychodzących z podziemi, wykurzonych gazem jak szczury, ludzi Haghiego. W żadnym $z$ aresztowanych Sonia nie rozpoznaje swego eks-szefa. Wieczorem w swej garderobie klown Nemo czyta w gazecie list gończy, ze zdjęciami Haghiego jako dyrektora, oferujący zań 10 tys. marek nagrody. Ten sam list rozlepiono na ulicznych afiszach, przed którymi gromadzą się ciekawscy. Tymczasem księgowy zgłasza Jasonowi niezgodność numerów banknotów funtowych wypłaconych przez Haghi Bank Jellusiciowi z podanymi w telegramie. Jason i 326 rozumiejąc, iż to Agent 719 podmienił depesze, konkludują: klown Nemo to Haghi!

16. „Wieczór kuglarza”. Klown Nemo w swym ostatnim wielkim występie: strzela do monstrualnych nutek, „zabija” z rewolweru wielką muchę. W trakcie spektaklu zauważa on to, czego nie widzi nieświadoma niczego publiczność: scena jest obstawiona z wszystkich stron przez policjantów, których broń jest weń skierowana. Wśród sił bezpieczeństwa są Jason, Agent 326 i Sonia. Po „zastrzeleniu” monstrualnej pchły, grozi bronią oskrzydlającym scenę funkcjonariuszom. Złośliwie śmiejąc się, wymierza lufę rewolweru we własną głowę i strzela z okrzykiem: „Kurtyna!” Rozentuzjazmowana widownia bije brawo, myśląc, że to numer, a kurtyna, opadając, definitywnie zamyka świat filmu.

Jak już nadmieniałem, wskutek częstych zastosowań montażu równoległego, zacierają się w Szpiegach granice między jednostkami dramaturgicznymi, w poprzednich filmach wyraźnie zaznaczone. Ten montaż równoległy może mieć rozmaite funkcje. Jedną z nich jest funkcja „m o n tażu erotetycznego", czyli natychmiastowego udzielania odpowiedzi przez następujące po pytaniu ujęcie ${ }^{53}$. I tak np. w segmencie 1 , gdy przerażony zamordowaniem kuriera urzędnik w ministerstwie zadaje pytanie: „Wszechmocny Boże, jaka potęga za tym wszystkim stoi?”, odpowiedź zostaje udzielona natychmiast w postaci portretowego planu Haghiego (w jego „leninowskim” wydaniu) i planszy z napisem "Ja”. Gdy Haghi mówi Soni, po porażce z przechwyconymi kopertami-atrapami, iż nie zgrał jeszcze wszystkich swych atutów, montaż przenosi nas do Kitty skutecznie udaremniającej misję doktorowi Matsumoto. Gunning słusznie zauważa, że „Haghi wydaje się mieć taką wszechwiedzę, jaka może być przynależna jedynie narracji filmu" ${ }^{\prime 54}$. Ale czyż Haghi nie jest po-

53 Ten „montaż erotetyczny” analizowali w filmie Doktor Mabuse, gracz Thomas Elsaesser (Weimar Cinema and After: Germany's Historical Imaginary, Routledge, LondonNew York 2000, s. 173-177); Noël Burch (Notes on Fritz Lang's First Mabuse, „Ciné-Tracts” 1981, vol. 4, no. 1 /Spring/, s. 9). W Szpiegach wskazują go np. Lotte Eisner (Fritz Lang, s. 98) czy Tom Gunning (op. cit., s. 122).

54 T. Gunning, op. cit., s. 122. 
niekąd władcą dyskursu, jak była nim „zmęczona Śmierć” czy Mabuse? Świadczą o tym inne miejsca w filmie, kiedy pojawia się portretowy plan Haghiego, kontrapunktujący jakąś akcję, a przede wszystkim finał, kiedy po jego samobójczym strzale w głowę i okrzyku: „Kurtyna!”, rzeczywiście opada kurtyna, oznaczając nieodwołalne "zasłonięcie” świata przedstawionego i kres spektaklu, który oglądaliśmy, spektaklu reżyserowanego przez Haghiego - przy czym nie chodzi tu tylko o jego występ jako klowna Nemo, ale o cały film, którego był on znaczeniowym i narracyjnym centrum. Do tego zagadnienia jeszcze wrócimy.

Interesujące jest to, iż gdy w powyższym przykładzie z odpowiedzią „Ja" na pytanie, którego w danym momencie raczej nie mógł słyszeć nawet jeśli uwzględnimy jego pajęczynę podsłuchu - Haghi uzurpował sobie prerogatywy narracji, to zdarza się i rzecz odwrotna: gdy Haghi mógłby samemu odpowiedzieć na skierowane wprost do niego pytanie, wyręcza go w tym narracja. Dzieje się tak w segmencie 10, gdy po pytaniu Soni: "Gdzie on jest?” (chodzi o Agenta 326), zamiast Haghiego odpowiadającego Soni, narracja filmu bez jego pośrednictwa odpowiada widzowi, przeskokiem montażowym przenosząc nas na lotnisko, gdzie 326 wysiada $\mathrm{z}$ "Aero-Orient-Expressu”.

Bardzo zbliżone do montażu erotetycznego są momenty, kiedy montaż równoległy pełni rolę ironicznego kontrapunktu. Dzieje się tak np. w segmencie 2, gdy po zdemaskowaniu Vincenta załamany napomnieniami ministra i paszkwilami opinii publicznej Jason, mówi do Agenta 326 śmiejącego się z tarapatów przełożonego: „Łatwo ci się śmiać, u diabła, skoro udało ci się uniknąć sfotografowania przez tego przeklętego szpiega!" Przebitka pokazuje jednak, że triumf Agenta 326 był pozorny i że choć uniknął trzeciej pułapki, to i tak nie ma to znaczenia, bo jest już zdekonspirowany przez wroga: zaledwie parę chwil wcześniej, gdy nieopatrznie wczytywał się na ulicy w swe fikcyjne „wezwanie” na policję i rzucił na chodnik peta, schylający się po niego lump musiał ukradkiem zrobić mu zdjęcie. Świadczy o tym fakt, iż Haghi otrzymuje na swe biurko zdjęcie Agenta 326 odpowiadające miną poza, ubraniem, sytuacji, w której widz oglądał go na ulicy przed posterunkiem policji. Z kolei z peta muszą pochodzić zamieszczone pod zdjęciem odciski palców. Co więcej, Haghi dostaje dwa zdjęcia Agenta 326 - drugie wydaje się zrobione już na terenie samego posterunku, gdy 326 czekał na wprowadzenie do Jasona, a jego autorem musiał być „pan w cylindrze” pilnie studiujący coś na ścianie, bo to właśnie on wręcza fotografie Haghiemu, a później będzie współpracował z Sonią jako człowiek rzekomo ją molestujący i rzekoma ofiara, gdy Haghi zleci obojgu zastawienie pułapki na Nr 326 w Hotelu Olympic.

Podobnie ironiczny wydźwięk ma zestawienie morałów o ostrożności i obowiązku mężczyzny, jakie Matsumoto prawi w "Grand Barze" 
Agentowi 326, z przerywającą tę scenę przebitką na Kitty, która otrzymuje od Haghiego zdjęcie Japończyka z jego adresem i aż oblizuje się lubieżnie na widok swej ofiary. Zaraz po rozstaniu z 326 przed barem Matsumoto zauważy moknące w ulewnym deszczu, skulone pod murem „biedne dziecko", którego zabranie do własnego domu przypłaci on klęską powierzonej mu politycznej misji, utratą honoru i rytualnym samobójstwem dla honoru tego odzyskania. Można powiedzieć, że kropla deszczu, która spada mu na dłoń po rozstaniu z Numerem 326 i która jest pierwszym objawem następującej zaraz gwałtownej ulewy, uruchamia - jak to ujmuje Tom Gunning - Machinę Przeznaczenia (fatalnego przeznaczenia), a w swej niepozornej postaci jest analogiczna do strąconego ogonem zdychającego smoka liścia lipy, który opadając na bark Zygfryda w Nibelungach, uczyni bohatera w jednym punkcie bezbronnym wobec przemocy i zamierzonej przez jego wrogów zguby ${ }^{55}$. Kropla, która spada na dłoń dr. Matsumoto, przypomina łzę i może być oznaką nie tylko nachodzącego deszczu, ale i czułości Japończyka - czułości, którą okazał pijanemu i zrozpaczonemu Agentowi 326, i którą nieopatrznie zaraz okaże Kitty. Zgubą Matsumoto jest jednak fakt, iż czułość ta zmiesza się z pożądaniem, do czego w mistrzowski sposób doprowadza Kitty. Sprytna agentka przemienia miłosierdzie, troskliwość i opiekuńczość Japończyka - w zasadzie świadczące o jego caritas - w mącące mu trzeźwą ocenę sytuacji, niezdolne do powściagnięcia libido (jej sposoby to np. umiejętne rozchylenie kimona, tak by odsłonić ponętną pierś, czy obsypanie Matsumoto gradem pocałunków). Gunning odnotowuje, iż in scenizacja pożądania przez Haghiego święci w tym wypadku triumf $^{56}$, a wyraża to pointa historii Kitty i Matsumoto, gdzie montaż równoległy uwypukla zarazem ironiczny i tragiczny jej wymiar, kontrapunktując scenę harakiri ujęciem Kitty tak chciwie rzucającej się na rzucony jej przez Haghiego sznur pereł, iż próbuje nawet gryźć naszyjnik w jakimś paroksyzmie perwersyjnej rozkoszy.

Haghi wcześniej dokonał jeszcze jednej „inscenizacji pożądania”, podsyłając w Hotelu Olympic Agentowi 326 Sonię. Sprawy jednak wymknęły mu się z rąk i gwałtowna wzajemna miłość obojga, po pierwsze, wyzwala Sonię spod jego wpływu, po drugie, będąc miłością a nie pożądaniem, rodzi wzajemną troskę zakochanych o siebie, co uruchamia Machinę Opatrzności, niweczącą zgubny kierunek Machiny Przeznaczenia, uruchomionej przez Haghiego. Ciekawa jest paralela między Sonią a Kitty, gdzie początkowe podobieństwo obu agentek, zmienia się w gwałtowne ich przeciwieństwo. Oczywiście, w tym wypadku mamy do czynienia nie tyle z prostym, bezpośrednim zestawieniem scen

\footnotetext{
55 Por.: ibidem, s. 124-125.

${ }^{56}$ Ibidem.
} 
przez montaż równoległy (choć i to się zdarza, gdy pod koniec segmentu 10 przechodzimy od Soni do Kitty i z powrotem), co z paralelizmem na poziomie całościowej kompozycji filmu. Na początku segmentu 4 Sonia, w luksusowym, eleganckim, „wyjściowym” stroju, siedzi rozluźniona, swobodna i pewna swego sex appealu na biurku Haghiego, reagując śmiechem i zabawną miną na zdjęcie zleconej sobie ofiary - Agenta 326 $\mathrm{w}$ stroju włóczęgi. W podobnej pozie w tym samym miejscu niezadługo (segment 8) będzie siedzieć Kitty, oblizująca się na widok wręczonego jej przez Haghiego zdjęcia dr. Matsumoto, zapewne przeżywając w myślach rozkosz zastawionych przez siebie sideł. Ale podobieństwo przechodzi w przeciwieństwo - wkrótce Sonia ubrana skromnie, „po męsku", z zatarciem śladów swej uwodzicielskiej wcześniej kobiecości, będzie po prostu więźniem Haghiego, a gdy ten oferuje jej „pojednanie", odstawi proponowany kieliszek szampana z przywiązanym do jego nóżki sznurem pereł, z pytaniem: „Czyją krew mam teraz nosić wokół szyi, Haghi?" Kitty zaś zupełnie nie przeszkadza, że będzie „nosić wokół szyi krew Matsumoto" - pod koniec segmentu 11 przebitka na jej niemal zwierzęca, zachłanną radość z rzuconych jej z pogardą przez Haghiego pereł, przerywa scenę rytualnego samobójstwa Japończyka, dobitnie unaoczniając prawdziwość i grozę diagnozy Soni: ceną usługi dla Haghiego jest czyjaś krew.

Podobnym paralelizmem - z tym że w wypadku Soni jest to subiektywna interpretacja Agenta 326, niezgodna z faktycznym, obiektywnym stanem rzeczy, tj. intencjami Soni - jest odkrycie zdrady kochanek przez puste miejsce po nich, przez ich nieobecność: Agent 326 odkrywa na Parkstr. 24 pusty, ogołocony z mebli dom, przez co cała urzekająca go rosyjskość Soni i jej rzeczy wydaje się czymś kompletnie nierealnym, fantazmatem, natomiast ręka przebudzonego Matsumoto nie znajduje Kitty na posłaniu obok. Ciekawe, że w Zmęczonej Śmierci i $M$ - mordercy Lang pokazał poprzez nieobecność i puste miejsce śmierć, gwałtowne odejście osoby, teraz zaś ten sam chwyt wyraża dwukrotnie zdradzone uczucie.

Haghi zainicjował, fatalny dla obu inwigilowanych przezeń agentów (326 i Matsumoto), mechanizm Machiny Przeznaczenia zrobieniem im fotografii i ich przekazaniem swym kusicielskim wysłanniczkom. W wypadku Soni i Numeru 326 w Machinę Opatrzności zmienia jednak ów mechanizm miłość wzajemna, objawiająca się jednak nie tyle w fizycznym pożądaniu (choć iskrą ją rodzącą jest, owszem, wzajemna fizyczna atrakcyjność kochanków), co w zatroskaniu. Zatroskanie każe Soni wręczyć ukochanemu strzegący go medalik z Madonną zatroskanie każe Soni przybyć pociagiem ratunkowym na miejsce katastrofy wagonu 33133 w samą porę, by uchronić go przed zbrodniczym Morrierem, zatroskanie każe Agentowi 326 desperacko szukać Soni w zakamarkach Haghi Banku, 
pomimo duszącego gazu i niewielkiej nadziei na ocalenie wobec szybko upływającego terminu wyroku, który określił Haghi.

Machina Przeznaczenia uległa jednak przemianie w Machinę Opatrzności dzięki temu, że w tej miłości obecny był wymiar religijny. Gdy Sonia w swym mieszkaniu (segment 6) uświadamia sobie swą miłość do Agenta 326 po dostaniu odeń kwiatów i pocieszającego listu, rozkłada ramiona jak u krzy ż ow a na. Powtórzy tę pozę w biurze Haghiego, indagowana przezeń, czy kocha Agenta 326, świadoma, że wyznanie tej miłości wyda ją bezbronną na łup groźnego mocodawcy. Sonia czyni jednak z siebie męczennicę miłości i potwierdza prawdziwość swego uczucia późniejszym zaangażowaniem: gotowością ostatniej, niebezpiecznej misji dla Haghiego, byleby połączyć się z ukochanym; niepokojem związanym z numerem 33 133, który nie pozwalał jej spać i który miał wymiar modlitewnego zaangażowania w los ukochanego; natychmiastowym podążeniem na miejsce katastrofy i stoczeniem tam desperackiej walki z Morrierem.

Sonia mogła uruchomić Machinę Opatrzności dzięki swej religijności. Jej mieszkanie na Parkstr. 24 pełne jest ikon, które są nie tylko znakami jej rosyjskiego pochodzenia. Widać, że przed zbudowanym z ikon ołtarzykiem Sonia musi się modlić, bo z modlitewnika wydobywa medalik z Madonną dla ukochanego. Agent 326 o mało nie marnuje tego jej daru, gdy w złości ciska go na podłogę po uświadomieniu sobie jej roli szpiega (finał segmentu 8). Ale to właśnie ten, odnaleziony przez Franza i wręczony mu przed wyruszeniem $\mathrm{w}$ feralną podróż pociagiem, przedmiot uruchamia tuż przed katastrofą Machinę Opatrzności, spadając mu w dłoń i budząc. Dzięki temu trzymanemu w dłoni darowi Sonia zlokalizuje ukochanego we wraku wagonu wcześniej niż Morrier-zabójca. A jej wpatrywanie się w celi w kwaterze Haghiego w fotografię Agenta 326 (gdy ten zapijał jej „zdradę" w "Grand Barze") czy obsesyjny niepokój związany z numerem jego wagonu, jako de facto modlitwy, pozwoliły, by Opatrzność zechciała uruchomić swą Machinę, udaremniającą knowania zwykłego ziemskiego zła, przebranego za Przeznaczenie. W motywie medalika (i w ogóle w koncepcie Opatrzności, tu po raz pierwszy w filmach Langa pozytywnej, realnej siły, mogącej udaremnić knowania zła) uwyraźnia się, jak sądzę, tak często deklarowany przez Langa jego katolicyzm. Nie ma tu ponurego determinizmu Zmęczonej Śmierci czy Nibelungów albo upozowanej na przesłanie religijne dość podejrzanej ideologii, jak w Metropolis. O tym, iż motyw medalika z Madonną musi pochodzić od Langa jako współautora scenariusza, świadczy porównanie filmu z powieścią Thei von Harbou, gdzie mowa jest o wyrzeźbionej w kości słoniowej podobiźnie „nieznanej świętej” ${ }^{57}$. Może

\footnotetext{
57 Podaję tę informację za: P. McGilligan, op. cit., s. 138.
} 
właśnie w tym aspekcie ujawnia się najbardziej różnica między Langiem a jego drugą żoną, skłonną raczej do nieokreślonego mistycyzmu, gdzie przemieszane są pierwiastki chrześcijańskie, gnostyckie i orientalne, i chyba jednak bardziej niż on odpowiedzialną za dość „, heretycką”, pseudochrześcijańską religijność Zmęczonej Śmierci czy Metropolis.

Romans Soni z Agentem 326 umożliwia poza tym widzowi po raz pierwszy $w$ filmach Langa jakąś bezwarunkowa nieobwarowaną odstręczającymi aspektami (jak np. w wypadku czterech par kochanków w Zmęczonej Śmierci, Zygfryda i Krymhildy w Nibelungach czy Fredera i Marii w Metropolis) identyfikację odbiorcy z parą bohaterów. Sonia dzięki miłości przeżywa iście „Kmicicowe” nawrócenie (duchowe i polityczne), Agent 326 pracuje po stronie walczącego z terrorystycznym i totalitarnym zagrożeniem demokratycznego państwa. A że odtwarzają te postacie naprawdę znakomici i atrakcyjni aktorzy - Gerda Maurus i Willy Fritsch, później zresztą czołowy amant kina niemieckiego - nie razi nawet pewien patos wątku romansowego i rzeczywiście, pewne spowolnienie przez niego szybkiego rytmu filmu, co odnotowywała dwukrotnie, w monografii Langa i w Ekranie demonicznym, Lotte Eisner ${ }^{58}$. Sukces tego duetu przyczyni się do ponownego ich obsadzenia jako pary amantów w następnym filmie Langa - Kobiecie na Księżycu, z o tyle mniejszym sukcesem, o ile ów drugi film w ogóle jest od Szpiegów słabszy artystycznie (a, jak sądzę, ta różnica poziomu jest znaczna). W każdym razie $\mathrm{w}$ ostatnim $\mathrm{z}$ weimarskich filmów Langa - Testamencie doktora Mabuse (1933) - znowu pojawi się para kochanków (Tom Kent i Lilli), mających być miejscem bezdyskusyjnej identyfikacji emocjonalnej widza, z tym, że bardziej skomplikowana, „nawracającą się" postacią będzie tym razem mężczyzna. Jednak wskutek i nie najbardziej przekonująco zarysowanego w scenariuszu wątku, i nie najciekawszych wcieleń aktorskich (zarówno w niemieckiej, jak i francuskiej wersji filmu), romans ten nie będzie tak poruszający emocjonalnie dla widza, jak historia Soni Barranikowej i Agenta 326.

Romans Soni i 326 jest poza tym „miłością czystą”. Świadczy o tym bardzo interesująca sekwencja ich randki na Parkstraße 24. Ubrana „,z rosyjska" Sonia przygotowuje w samowarze herbatę, prezentuje Agentowi 326 ikony, podaje mu alkohol do herbaty, ciasteczka, cukier, papierosy, ale 326 nie chce żadnej z oferowanych rzeczy, zachwycony wpatrując się w gospodynię. „Na pewno niczego pan nie chce?” - pyta Sonia. Ujęcie po tym napisie pokazuje zbliżające się ku sobie ich twarze. Później widzimy zbliżenie ich splecionych dłoni. Następuje plan pokazujący dom Soni z zewnątrz, z oświetlonym wnętrzem niewidocznym za spuszczonymi zasłonami. W podwójnej ekspozycji na ten obraz nałożony jest plan rosyjskiego

${ }^{58}$ Por.: L. H. Eisner, Ekran demoniczny, s. 166; L. H. Eisner, Fritz Lang, s. 96-97. 
zegara z wahadłem [sic!]. W nieokreślonym oknie - chyba jakiegoś sklepu - opuszczane są rolety. Na rosyjskim zegarze jest już siódma pięć (wiemy, że randka rozpoczęła się o czwartej). Widzimy pakunek z wieczornym wydaniem gazety: „,8 Uhr Abendblatt”. Widok okna. Powrót, ale już po ciemku, do splecionych dłoni Soni i 326, tak jakby przez te 4 minione godziny wyłącznie trzymali się za ręce. Uwagę bohaterów zwraca dochodzący zza okna okrzyk gazeciarza, reklamującego wieczorne wydanie. Całują się. Agent 326 udziela jakby spóźnionej cztery godziny odpowiedzi na pytanie Soni: „Na pewno niczego pan nie chce?”. Mówi: „Zrób mi podarunek z tego wieczoru. Będę u ciebie o dziewiątej, pójdziemy do Daniellego, zgoda?"

Tom Gunning tak komentuje tę sekwencję montażową: „Odskok [od bohaterów] pełni częściowo funkcję zgryźliwego przytyku do cenzury. Z pewnością zakładamy, że w trakcie wieczoru Tremaine i Sonia zostali kochankami, a Tremaine w końcu poprosił ją o to, czego istotnie najbardziej chciał, zaś te niewinne obrazy posłużyły za wygodne przemieszczenie zakazanych widoków. Czy rzeczywiście niewinnie trzymali się cały czas za ręce? Zaskoczenie Soni i Tremaine’a na głos gazeciarza anonsującego na ulicy wieczorne wydanie wyjaśnia tę aż-nazbyt-niewinną randkę: zupełnie stracili poczucie czasu. Jest to obietnica oferowana przez pożądanie w filmach Langa: wyrwać się z czasu, wyrwać się z nieustannej Machiny Przeznaczenia" 59 . Gunning ma rację, iż jest to aż nazbyt cenzuralne rozwiązanie filmowe randki zakochanych w sobie nawzajem do szaleństwa bohaterów, i że zarazem sygnifikuje ono ich „zapomnienie o świecie", ich wyrwanie się z osi czasu. Jednocześnie jednak jego komentarz wydaje mi się niewystarczający: powrót do splecionych dłoni jest nie tylko metonimią ich "zostania kochankami", ale z a r a z e m oznacza c z y s to ść ich miłości, która bardziej niż zapomnienie wyrywa ich z Machiny Przeznaczenia i sytuuje w obrębie Machiny Opatrzności. Ich splecione dłonie w obliczu ołtarza Soni świadczą raczej o zawarciu przez nich ślubu niż o zostaniu kochankami. Taki „sakramentalny” wymiar tej miłości uwypukla kontrast z elipsa, omijającą noc spędzoną przez Kitty i Matsumoto: elipsa niewątpliwie ma tam również wymiar spełnienia cenzuralnego wymogu „odskoku” od sceny erotycznej, ale jednocześnie nie sposób wątpić, iż Kitty i Japończyk zostali kochankami, skoro ten szuka jej po omacku ręką w łóżku.

Randka na Parkstr. 24 to druga wyrazista sekwencja montażowa w tym filmie. Pierwszą z nich jest oczywiście prolog, ukazujący zamęt w świecie, „za którym”, jak świadczy pointa tej sekwencji, stoi Haghi. Przypomnijmy, iż sekwencja montażowa jest obok sceny jedną z dwóch

59 T. Gunning, op. cit., s. 126. 
typowych jednostek dramaturgicznych w filmie fabularnym. Oczywiście, większość tradycyjnych filmów składa się na ogół ze scen. S c e n a jako segment jest na ogół czasowo i przestrzennie zamknięta, czy raczej - ograniczona, mamy w niej jednak na ogół do czynienia z otwartością na poziomie progresji wątków fabularnych. Każda scena na ogół zamyka jakiś wątek czy problem znany z wcześniejszych scen, ale jednocześnie kontynuuje czy inicjuje inny, kontynuując czy otwierając przyczynowo-skutkowe ciągi składające się na logikę fabularną. S e k w e n cje m on ta ż o we na ogół funkcjonują w filmie jako segmenty "przejściowe” („tranzytywne"). Streszczają one jakiś dłuższy upływ czasu, „robią unik”, ukazując to, co typowe, ale dość nudne i fabularnie nieatrakcyjne w krótkich migawkowych ujęciach wystarczających dla orientacji widza lub kondensują jakiś proces, ukazując go poprzez punkty szczytowe ${ }^{60}$.

Już nawet z pobieżnego zapisu sjużetu, przedstawionego powyżej, widać, iż wiele segmentów Szpiegów trudno jednoznacznie zakwalifikować. O ile segment 1 jest niewątpliwie sekwencją montażową a ostatni - wyrazista, zamkniętą sceną rozegraną w określonej przestrzeni, to segment 6, choć wydaje się ostatecznie sekwencją montażową, zaczyna się jednak jak scena. A jak zakwalifikować np. segment przedostatni, „Akcję w Haghi Banku", z jego suspensem i deadlinem mający niewątpliwie charakter sceny, zaś wskutek wielości wątków, miejsc i postaci oraz z racji szalonego tempa zbliżony do sekwencji montażowej? Wydaje się, iż Lang, aby osiągnąć efekt szalonego tempa współczesności, celowo zatarł dystynkcje między tymi dwoma typami jednostek dramaturgicznych, a wskutek tego jednym z podstawowych chwytów stylistycznych tego filmu jest stosowana bardziej ostentacyjnie niż zazwyczaj w filmach fabularnych, konstytutywna dla sekwencji montażowej, e l i p s a.

Przyjrzyjmy się pierwszym dziesięciu ujęciom ${ }^{61}$ początkowej sekwencji montażowej. 1. Plansza z napisem: „Dziwne rzeczy wydarzały się w różnych miejscach świata". 2. Zbliżenie rąk w gumowych rękawiczkach otwierających jakiś sejf. 3. Dłonie w gumowych rękawiczkach wkładają dokument z pieczęciami do koperty z pieczątką Ambasady Francuskiej. 4. Ujęcie (monumentalizujące, od dołu) pędzącego motocyklisty ${ }^{62}$.

${ }^{60}$ Nieco szerszą charakterystykę sceny i sekwencji montażowej jako jednostek dramaturgii filmu przedstawiam w książce: Tomasz Kłys, Film fikcji $i$ jego dominanty, Wydawnictwo Naukowe Semper, Warszawa 1999, s. 87-90.

${ }^{61}$ Przy uznaniu za ujęcia także plansz z napisami.

${ }^{62}$ Rzecz jasna, takie skadrowanie byłoby raczej niemożliwe przy filmowaniu motocyklisty naprawdę pędzącego szosą. Lotte Eisner przywołuje informację reżysera: „Lang wyjaśnia, że owo ekscytujące ewokowanie prędkości osiągnięto, zawieszając motocykl na drewnianym słupie i wytwarzając za pomocą dmuchawy chmurę pyłu" (L. H. Eisner, Fritz Lang, s. 97-98). 
5. Animowane ujęcie berlińskiej wieży radiowej Funkturm, z której koliście rozchodzą się fale, docierające do znajdującej się po prawej stronie kadru w głębi innej wieży; ta wieża wydaje się transmitować dalej fale odebrane z Funkturm. 6. Na koliście rozchodzące się fale radiowe, w podwójnej ekspozycji nakładają się napisy: „Sensacyjna kradzież dokumentów... Ambasada Francuska w Szanghaju..." 7. Elegancko ubrany dygnitarz w kabriolecie zostaje zastrzelony przez kogoś z mijającego go w pędzie innego samochodu ${ }^{63}$. 8. Zbliżenie: $\mathrm{z}$ tylnego siedzenia samochodu zamordowanego dygnitarza ręka zabiera teczkę. 9. Kabina telefoniczna: jakiś rozgorączkowany mężczyzna wydaje się podawać przez telefon jakieś sensacyjne wiadomości. 10. Nagłówki w dodatku nadzwyczajnym gazety („Extrablatt”): „Zamach na ministra handlu!”, ,"Minister umiera od ran", "Skradziono tajne dokumenty", „Żadnych śladów sprawcy".

Dziewięć ujęć (od 2 do 10) jest prezentacją dwóch zdarzeń, które w sekwencji montażowej prologu składają się na wrażenie "zamętu w świecie”, zapowiedzianego przez planszę z napisem (1). Ujęcia 2-6 składają się tak się nam przynajmniej wydaje - na "sensacyjną kradzież dokumentów z Ambasady Francuskiej w Szanghaju”, ujęcia 7-10 na "zamordowanie ministra handlu i kradzież ważnych dokumentów". Zwraca uwagę nieciągłość prezentacji i jej fragmentaryczność. Dopiero w kontekście ujęcia 6 możemy odczytać - zresztą też dopiero w analitycznym, a więc nienaturalnym odbiorze, nie zaś podczas normalnego pierwszego odbioru, kiedy przedstawione obrazy migają nam niezwykle szybko przed oczyma - ujęcia 2 i 3 jako „kradzież dokumentów z Ambasady Francuskiej w Szanghaju". Sens ujęć 7 i 8 ujawnia się również retrospektywnie, w ujęciu 10. Widzimy fragmenty akcji - co prawda fragmenty kulminacyjne (otwieranie sejfu, strzał do ministra, zabranie teczki) - w którą zostaliśmy wprowadzeni niezwykle gwałtownie, in medias res, i której sens ujawnia się nam znienacka, po gwałtownej elipsie (między ujęciami 2-3 a 5-6 oraz 7-8 a 10 istnieje tylko - i to też nie najmocniejsza - więź logiczna, a nie czasoprzestrzenna). Sama prezentacja tego, co w ogóle zostało nam unaocznione, a nie tylko dane do domniemania, ma natomiast charakter s y n e k d o c h, prezentacji większych całości poprzez część, poprzez fragment, szczególnie wyrazisty detal. Dłonie w gumowych rękawiczkach otwierające sejf czy ręka zabierająca z tylnego siedzenia samochodu teczkę muszą nam wystarczyć jako prezentacja „,kradzieży dokumentów”. Jak zauważa Tom Gunning, tożsamość rzeczy i zdarzeń w Szpiegach budujemy z fragmentów ${ }^{64}$, dookreślając mentalnie brakujące ogniwa zdarzenia

${ }^{63}$ To oczywiście echo zabójstwa Rathenaua, zamordowanego w podobnych okolicznościach.

${ }^{64}$ Por.: T. Gunning, op. cit., s. 127-131. 
czy dopełniając przestrzennie dany nam jako metonimia czy synekdocha całości detal. To charakterystyczne dla stylu Szpiegów połączenie elips i synekdoch wskazuje też Noël Burch, rozciągając uwagi z analizy początkowej sekwencji montażowej na styl całego filmu ${ }^{65}$.

W kontekście zawarcia ujęć 4-5 wewnątrz sekwencji eliptycznie i synekdochicznie prezentującej nam „kradzież dokumentów z Ambasady Francuskiej w Szanghaju”, umieszczamy je jako „brakujące ogniwa” pomiędzy "zdarzeniem" (ujęcia 2 i 3) a medialną informacją o nim (ujęcie 6). Dość neutralny animowany obraz dwóch wież radiowych emitujących koliście rozchodzące się fale (uj. 5) z pewnością może być w kontekście ujęcia 6 (napisy z wiadomością na tle kolistych fal) uznany za takie ogniwo. $\mathrm{Z}$ ujęciem pędzącego motocyklisty (4) sprawa nie jest jednak taka prosta. Czy jest on „kurierem”, pędzącym, by przekazać jakąś sensacyjną wiadomość opinii publicznej? Czy może raczej jest on sprawcą albo współuczestnikiem kryminalnej akcji w ambasadzie? Pierwszą odpowiedź sugerują następujące zaraz po jego obrazie ujęcia "transmisji radiowej” oraz przybycie pod koniec prologu tak samo ubranego w kombinezon i pilotkę kuriera (tyle tylko, że samochodem, a nie motocyklem) do jakiegoś bardzo ważnego gmachu (z pompatyczną, neoklasyczną kolumnadą), by złożyć meldunek o jakimś tajemniczym człowieku. Kurier ten ginie, zastrzelony przez kogoś za oknem, dosłownie w pół słowa swego raportu. Ale niewykluczona, a może i bardziej prawdopodobna jest druga odpowiedź, która jak i pierwsza również może ujawnić się retrospektywnie, zdają się na nią jednak naprowadzać pewne atrybuty kadru z motocyklistą. Otóż widz odnosi wrażenie, iż człowiek na motocyklu śmieje się - może z satysfakcja a może złośliwie. Czyżby zatem była to radość przestępcy z udanej akcji? Lotte Eisner zauważa, iż motocyklista w tym kadrze (z racji promieniście rozchodzących się szprych koła) wygląda jak „jakiś gigantyczny pająk w groteskowym skrócie perspektywicznym" ${ }^{\prime \prime 6}$. Uwzględniwszy zaś ukrytą, ale zasadniczą dla figury Haghiego jego konotację jako "pająka w (medialnej) sieci", widzimy, że taka sugestia prowadzi jednak do uznania motocyklisty za człowieka Haghiego. Rzecz jasna, można to skonstatować dopiero podczas uważnej analizy filmu, i to dopiero za którymś oglądem.

Taka fragmentaryczność i niedookreślenie kontekstu (zarówno przyczynowo-skutkowego, jak i czasoprzestrzennego) powoduje, iż Szpiedzy - mimo żywego tempa i swej atrakcyjności wizualnej - nie są filmem łatwym w odbiorze dla widza nawykłego do dość klasycznego, bardziej redundantnego sposobu dawkowania przez narrację informacji fabularnych. Jaskrawych przykładów niedookreślenia dostarczają w dalszym

65 Zob.: N. Burch, Fritz Lang: German Period, s. 590-591.

${ }^{66}$ L. H. Eisner, Fritz Lang, s. 97. 
toku filmu choćby kwestia fotografii, jakie przed posterunkiem policji i już na jego terenie musieli „pstryknąć” Agentowi 326 ludzie Haghiego albo strzał Soni z rewolweru w Hotelu Olympic. Gdy 326 zamyślony nad swym „wezwaniem” rzuca na chodnik peta, którego podnosi, uważnie patrząc ku górze (zatem na bohatera) jakiś lump, domyślamy się, iż coś jest nie tak; samego aktu fotografowania bohatera nie widzimy jednak. Gdy już wewnątrz komisariatu Nr 326 czeka na wprowadzenie do Jasona (z zachowaniem całej "konspiracyjnej” maskarady), "pan w cylindrze" coś studiujący na ścianie wydaje się tylko jednym z interesantów, a może wezwanych, i do głowy nie może przyjść nam podczas pierwszego oglądania filmu, że robi on zdjęcie Agentowi 326. Zresztą tempo wydarzeń, po namyśle, gdy już przestudiujemy analitycznie cały film, wydaje się nieprawdopodobne. Gdy 326 rozmawia - powiedzmy, parę minut później - z Jasonem w jego gabinecie, Haghi otrzymuje już wywołane zdjęcia od obu swych szpiegów, a pod nim, co więcej, zdjęte prawdopodobnie z rzuconego przez Agenta 326 peta odciski jego palców. Takie tempo jest dość nierealistycznie zawrotne, ale wydaje się, że ten brak realizmu podkreśla potęgę i wszechobecność Haghiego, którego ludzie mogą czaić się wszędzie.

Bardzo niejasna jest przez długi czas dla widza scena w Hotelu Olympic. Owszem, wiemy, że Haghi wysłał Sonię, by zastawiła na Agenta 326 pułapkę, ale nie wiemy, na czym ma ona polegać. Akcja Soni dana jest nam w synekdochicznym ujęciu, kiedy kobieca ręka (w zbliżeniu) strzela z miniaturowego rewolweru (do kogo? do czego? - plan dłoni z rewolwerem wyrwany jest z czasoprzestrzennego kontekstu). Później Sonia wbiega do apartamentu Agenta 326, opowiada historię o zastrzeleniu molestującego ją człowieka, a policja i obsługa hotelowa na korytarzu usiłuje dostać się do pokoju bohatera. Rozmaite przebieranki, ukrywanie Soni w pokoju obok, rewizja policji, maskowanie przez Franza śladów dachowej eskapady i włóczęgowskiego kostiumu jego pana - wszystko to jest źródłem niewątpliwego suspensu, obawy widza, że w jakiś sposób mogą wpaść czy to Sonia, czy 326, ale obawy te są niekonkretne, bo nie wiemy, co tak naprawdę się stało, i co może grozić ze strony policji Agentowi 326 (wydaje się nam, iż raczej jest po stronie rządu i demokratycznego porządku, ale $\mathrm{w}$ tym momencie filmu nie jest to jeszcze takie oczywiste). A wyjaśnia, co się stało, ujęcie "ofiary" Soni (żywo tłumaczącego „zdarzenie” policji znanego już nam "pana” - bez cylindra, tym razem) oraz kolejny, dany z opóźnieniem synekdochiczny plan: zbliżenie książki (hotelowy rozkład jazdy pociągów) z utkwioną w niej rewolwerową kulą. Dla widza niecierpliwie pragnącego od razu wiedzieć, co się stało, takie szczątkowe unaocznienie wydarzenia przez jego synekdochiczne reprezentacje i danie z opóźnieniem (zresztą również bardzo enigmatycznie, bez jakiejś 
satysfakcjonującej opisowości) wyjaśnienia jego przebiegu i sensu, może być bardzo wymagającym doświadczeniem odbiorczym - o czym zresztą świadczą niektóre z przytoczonych recenzji z epoki.

Interesującymi przykładami stylu eliptyczno-synekdochicznego w dalszym przebiegu filmu są choćby omówiona już sekwencja randki na Parkstraße 24 czy samobójstwo Jellusicia. Zwierzchnicy pułkownika mówią (plansza): „Może pan wyrazić jedno życzenie”. Półzbliżenie przerażonego Jellusicia, który wypowiada następujące słowa: „Proszę o...” Po planszy z tym tekstem następuje zbliżenie rewolweru, który jakaś dłoń kładzie na wzorzystej serwecie stołu. Jakiś czas później w sjużecie, gdy Nr 326 wysiada na lotnisku z "Aero-Orient-Expressu”, agent Jasona pokazuje mu gazetę donoszącą o nagłym ataku serca pułkownika Jellusicia po powrocie z urlopu. Zdarzenie zostało ukazane nie tylko "eliptycznie" i „synekdochicznie”, ale i „nie wprost”, poprzez kłamliwy, tuszujący faktyczny jego przebieg tekst prasowy.

Zamiłowanie Langa, jako niedoszłego architekta, do prezentacji monumentalnej scenografii, w którą mógłby wkomponować frapujące układy choreograficzne mas ludzkich (vide: Zmęczona Śmierć, Nibelungi, Metropolis), musiało z racji mniejszych niż przy wymienionych filmach nakładów finansowych ulec nieco poskromieniu. Stało się to jednak z korzyścią dla artystycznej innowacji, którą twórca Metropolis niewątpliwie się tu wykazał. Otóż w Szpiegach ogrom i frapujący monumentalizm obiektów czy miejsc dany jest nam tylko synekdochicznie, przez fragmenty. O rozmiarach Hotelu Olympic świadczy tylko wielkość jego monstrualnego neonu, gdy 326 zakrada się do hotelu po dachach ze swej kryjówki. Podobnie fragmentarycznie dana jest nam nowoczesna, olbrzymia fasada Haghi Banku z gigantycznymi literami jego nazwy u jej szczytu. Najbardziej frapującym miejscem tak fragmentarycznie pokazanym jest natomiast klatka schodowa w kwaterze głównej Haghiego, gdzieś na zapleczu jego banku, z otchłanną "studnią" i plątaniną schodów i pomostów, po których w tę i we w tę gorączkowo krzątają się funkcjonariusze superszpiega. Do analizy tej klatki jeszcze powrócimy, ale jednym z najbardziej intrygującym jej aspektów jest to, iż nigdy nie widzimy jej w całości, ani nie przemierzamy z postaciami, przez co sugeruje nam ona ogrom, niedostępność królestwa Haghiego czy wręcz to, że jest ono zakazane dla naszego oka.

O tym, iż w Szpiegach dominuje styl eliptyczno-synekdochiczny świadczy znacznie mniejsza niż w poprzednich filmach Langa liczba planów ogólnych, o charakterze planów lokalizująco-ustanawiających (establishing shots), przez co liczne plany portretowe czy zbliżenia detali pozbawione są bezpośredniego odniesienia przestrzennego czy czasoprzestrzennego, a widz musi tworzyć „mapy kognitywne” świata przedstawionego i samemu wnioskować o jego „kalendarzu”. Nie zawsze się 
to zresztą udaje, bo wskazówki tekstualne są dwuznaczne. Na przykład w sekwencji „Grand Bar” pojawia się dokładnie to samo portretowe ujęcie muzyka grającego na skrzypcach, co w scenie dancingu u Daniellego. Wiemy, że w "Grand Barze" także wre zabawa, ale dlaczego Lang dla jej pokazania posłużył się tym samym ujęciem, co poprzednio? A może jest to retrospekcja, wyraz świadomości Agenta 326, rozpamiętującego swe niedawne szczęście na dancingu z Sonią? Taka interpretacja w uważnym, analitycznym oglądzie wydaje się dość prawdopodobna, (Nr 326 zatyka uszy i ściska głowę, nie mogąc znieść w swej rozpaczy wspomnienia chwili szczęścia), ale w pierwszym, zwyczajnym odbiorze wydaje się, iż skrzypek przygrywa w "Grand Barze” (326 zatyka uszy nie mogąc znieść muzyki w lokalu); tym bardziej, iż w pierwszym odbiorze widz może nie pamiętać króciutkiego ujęcia sprzed iluś tam minut.

Innym przykładem dwuznaczności jest fakt, iż Sonia i 326 jadą różnymi pociągami. Widz ma wrażenie, że „traktat japoński” ma być wywieziony do Rosji, zatem Sonia, jako prawdziwy kurier Haghiego, powinna jechać tym samym pociągiem, co zwabiony przez Haghiego w pułapkę i śledzący „rosyjskiego kuriera” Agent 326. A jednak są w różnych pociągach, które w scenie dworca wydają się odjeżdżać w przeciwne strony. Skoro zaś jadą w przeciwne strony, to dlaczego Sonia po całej nocy podróży jest blisko feralnego wagonu 33133 i szybko dociera pociagiem ratunkowym na miejsce katastrofy? Oczywiście, można dopatrywać się w takich sprzecznościach tekstualnych „niedoróbek warsztatowych" albo braku logiki scenariusza, ja jednak upatrywałbym w nich, jak i w ogóle w stylu Szpiegów, wpływu sowieckiej szkoły montażu, gdzie dla ekspresywności bądź ideowego czy emocjonalnego przekazu, często poświęca się spójność świata przedstawionego na poziomie fizykalnym albo przyczynowo-skutkową logikę fabuły ${ }^{67}$. Choć zarazem to uwewnętrznienie stylistyki modnych w niemieckich kręgach intelektualnych filmów sowieckich, nie przeszkodziło temu, by jako ostrzeżenie przed zagrażającym Europie bolszewickim terrorem i totalitaryzmem, film Langa znalazł się na ich ideologicznych antypodach.

\section{Pająk i jego sieć}

To, co charakteryzowało doktora Mabuse w pierwszym pamiętnym „akcie" tamtego filmu, to panowanie nad nowoczesnymi środkami łączności i komunikacji, dzięki któremu osiągnął swój fantastyczny sukces giełdowy.

\footnotetext{
${ }^{67}$ Odsyłam do analizy stylistycznej sowieckiej szkoły montażu w: David Bordwell, Narration in the Fiction Film, University of Wisconsin Press, Madison 1985, s. 234-272.
} 
Panowanie to nie było może nawet realne, ale sugerował je montaż: Mabuse, nieruchomy jak pająk za swym biurkiem, z zegarkiem w ręku i telefonem przy uchu, wydawał się precyzyjnie zgrywać w czasie i przestrzeni działania swych ludzi oraz trajektorie pociągu i samochodu. A ściśle obliczone dawkowanie sensacyjnych wiadomości podczas sesji giełdy o kradzieży i „odnalezieniu się" szwajcarsko-holenderskiej umowy handlowej było już faktycznie jego umiejętnym wykorzystaniem potęgi prasy i raczej relatywnej, powiązanej z informacją niż substancjalnej, wartości akcji.

Temat medialnego panowania nad światem nie został jednak w Doktorze Mabuse, graczu konsekwentnie rozwinięty - superprzestępca jakby niepomny rozmiarów sukcesu swej spekulacji, w dalszym toku filmu oddaje się ogrywaniu bogatych hazardzistów w rozmaitych kasynach i szulerniach, a o jego potędze świadczą dalej nie panowanie nad mediami, ale sposoby w zasadzie nadnaturalne - telepatia, hipnoza, sugestia. Temat „kontroli świata poprzez media” rozwiną dopiero Szpiedzy, a superprzestępca z tego filmu - Haghi (znowu w aktorskim wcieleniu Rudolfa Klein-Rogge) - choć pozbawiony nadprzyrodzonych zdolności Mabusego, jest jednak postacią o znacznie potężniejszej władzy i znacznie większym, bo już światowym, zasięgu swego działania. Żerujący na hazardowej gorączce Mabuse był (poza prologiem) przestępcą „prywatnym”; Haghi to wróg publiczny numer jeden. Segment 3 filmu, prezentujący kwaterę główną Haghiego, rozpoczyna się od planszy z napisem: „Wróg”.

Haghi wielce przypomina przywołanego w motcie tego rozdziału profesora Moriarty'ego, superprzestępcę z opowiadania Conan Doyle'a The Final Problem, który przyczyni się do zguby słynnego detektywa. Tak jak i Moriarty, Haghi ",spoczywa bez ruchu, niczym pająk w środku sieci” i dobrze wie o drganiu każdej z "tysiąca promienistych nici". Sam w zasadzie jest nieaktywny, planuje tylko działania swych "licznych i wspaniale zorganizowanych agentów". Nieruchomość Haghiego - przykucie do inwalidzkiego wózka - jest kamuflażem nawet dla najbardziej zaufanych podwładnych, jak Sonia czy Morrier. Jak i niby to nieruchomy pająk, Haghi potrafi znienacka szybko przemieścić się i zadać cios z ukrycia (vide: finał, ale także jego aktywność w przeciwnym obozie jako Agenta 719). O tym, iż na pozór nieruchomy Haghi-pająk uderza błyskawicznie i jest szczególnie niebezpieczny, gdy zbyt blisko niego podejść, świadczy moment pod koniec segmentu 7, kiedy odkrywszy miłość Soni do Agenta 326, nie wstając ze swego wózka, brutalnie rzuca ją o ścianę. Konotacje Haghiego potwierdza jego finałowy występ jako klowna Nemo: jak i pająk, uśmierca on owady (muchę i pchłę), a ,jad", którym je zabił, którym grozi otaczającym scenę policjantom i agentom, i którym ostatecznie uśmierci sam siebie, jest jak najbardziej realny i niebezpieczny: prawdziwe kule w prawdziwym rewolwerze. 
Haghi, podobnie jak Mabuse, nie ma jednej tożsamości, ale też nie ma ich tak wielu jak bohater poprzedniego filmu. W przedostatnim segmencie afisze gończe rozlepione na ulicach i opublikowane w prasie prezentują faktycznie tylko jedna, by tak rzec "publiczną" czy "oficjalną” jego tożsamość: dyrektora banku (trochę zabawne, że drugie z zamieszczonych zdjęć nie przedstawia jego istotnie alternatywnego, "leninowskiego" wcielenia, a jedynie dyrektora Haghi Banku... bez bródki). Tę tożsamość - eleganckiego biznesmena w garniturze - przybiera występując przed klientami banku (w rozmowie z Lady Leslane) czy zjawiając się w miejscach publicznych (u Daniellego, gdy nadzorował, czy Sonia wypełni jego polecenia). Oczywiście, w tym wcieleniu jako publicznym i ,jjawnym", występuje wyłącznie na wózku inwalidzkim. Podobnie zresztą jak w drugim wcieleniu, które znali tylko jego ludzie w zakamuflowanej bankiem kwaterze głównej. To w tym wcieleniu - jako łysawy brunet z kozią bródką, czarnym golfie i marynarce ewokującej raczej ascetyczny uniform niż garnitur - przypomina Lenina czy Trockiego. I właśnie w tym wcieleniu Haghi wydaje się najbardziej niebezpieczny, ogarnięty jakimś fanatyzmem czy przekładającą się na terror ideologia, o czym najmocniej świadczy scena ukazująca jego sztukę perswazji: gdy chcącą się wycofać ze śledzenia Agenta 326 Sonię skłania do dalszej „roboty” przypomnieniem śmierci dla (antycarskiej) sprawy jej brata i ojca.

Niewiele wiemy o wyglądzie trzeciego wcielenia Haghiego, jakim jest pracujący dla Jasona Agent 719. Gdy 719 rozmawia z Jasonem o telegramie od Agenta 326, dotyczącym numerów banknotów wypłaconych Jellusiciowi, kamera filmuje go od tyłu, uniemożliwiając widzowi rozpoznanie Rudolfa Klein-Rogge. Oczywiście sugestia, że coś jest nie tak z Agentem 719, jest fakt podmiany przez niego telegramów, ale pewności, że to akurat Haghi, mieć nie możemy. Gdy z kolei w garderobie wręcza Numerowi 326 bilet na feralny pociąg, jest już częściowo ucharakteryzowany na swe czwarte wcielenie - klowna Nemo, co oczywiście również uniemożliwia widzowi identyfikację z wyglądu. Wiemy co prawda, że Haghi planuje zamach w pociągu na Agenta 326, ale szczegóły rozmowy Nemo/719 z Jasonem i 326 w garderobie nie dają całkowitej pewności, że to ta sama intryga. Można powiedzieć, że w kategoriach zaproponowanych przez Davida Bordwella w książce Narration in the Fiction Film, narracja Szpiegów jest znacznie bardziej skryta niż narracja Doktora Mabuse, gracza, gdzie wszystkie, niby to różne tożsamości superprzestępcy miały być i były natychmiast dla odbiorcy rozpoznawalne ${ }^{68}$. Narracja, zamiast klarownej informacji, że Agent 719 to Haghi, w scenie gdy pojawia się

${ }^{68}$ Por.: D. Bordwell, op. cit., s. 59-60. Mniejszą „komunikatywność” narracji Szpiegów w porównaniu z narracją Doktora Mabuse odnotowuje też Tom Gunning (op. cit., s. 121). 
on po raz pierwszy w gabinecie Jasona, daje nam jedynie odwołującą się raczej do podświadomości sugestię: podobnie od tyłu dość często filmowany jest Haghi ${ }^{69}$ (np. gdy przyjmował swych szpicli, wręczających mu zdjęcia Agenta 326).

Jakie są sensy czterech (zaledwie czterech) wcieleń Haghiego? Jako dyrektor wielkiego banku jest finansistą. "Jestem bogatszy niż Ford, nawet jeśli płacę mniejsze podatki" - mówi z ironią i pogardą chcącej opłacić gotówką jego szantaż Lady Leslane. Paul Jensen słusznie zauważa, że nie pierwsze to i nie ostatnie $\mathrm{w}$ weimarskiej twórczości Langa ukazanie powiązania działalności przestępczej z operacjami finansowymi na międzynarodową skalę (wcześniej była giełdowa spekulacja Mabusego wokół szwajcarsko-holenderskiej umowy handlowej, w następnym zaś filmie, Kobiecie na Księżycu, międzynarodowe grono finansowych potentatów będzie dążyło do opanowania niezbyt czystymi sposobami zasobów złota na "Srebrnym [sic!] Globie”). Jensen wiąże takie przedstawianie finansjery z niemiecką traumą lat dwudziestych, kiedy w dobie inflacji zostały zachwiane podstawy nie tylko niemieckiej ekonomii, ale i powiązany z nią system wartości ${ }^{70}$. Nietrudno zresztą dopatrzeć się w tym nieświadomego i ukrytego antysemityzmu $z$ racji tradycyjnego uznawania międzynarodowych finansistów za Żydów. Z drugiej zaś strony Haghi Bank to, jak sowiecki ARCOS w Londynie, kamuflaż, legalna instytucja skrywająca za swą fasadą działalność de facto agenturalną. Fakt, iż „przedstawicielstwo handlowe" zostało zastąpione bankiem, wydaje się jednak dość znaczący.

W swym wcieleniu ",bolszewickim" Haghi wydaje się najniebezpieczniejszy. To właśnie jego „leninowski” portret w zbliżeniu groźnie pointuje otwierającą film sekwencję montażową sugerując „bolszewizm” stojący za ukazanymi w niej przestępstwami politycznymi o międzynarodowym wymiarze. To właśnie ujęcie Haghiego-bolszewika jest groźną pointą segmentu 6 czy 13. To Haghi-bolszewik ujawnia się jako ostatnie ogniwo inwigilacji dr. Matsumoto (segment 6) czy zleceniodawca zamordowania japońskich kurierów dla zdobycia traktatu (segment 10). Haghi w tym wcieleniu często ukazywany jest jako wpatrzony intensywnie w kamerę. Ciekawe porównanie na pozór podobnych spojrzeń do kamery Mabusego i Haghiego przeprowadza Tom Gunning: „Intensywność spojrzenia Mabusego do kamery wyraża jego nadnaturalną władzę hipnotycznej sugestii, jego zdolność naginania innych do wykonywania jego rozkazów poprzez zogniskowaną moc jego woli. Spojrzenie Haghiego do kamery pełni bardziej abstrakcyjną rolę. Często te ujęcia są izolowane; patrzy on

${ }^{69}$ Odnotowuje to Gunning (op. cit., s. 120).

${ }^{70}$ Por.: P. M. Jensen, op. cit., s. 77. Por. także: Elias Canetti, Masa i władza, przeł. Eliza Borg i Maria Przybyłowska, Czytelnik, Warszawa 1996, s. 209-214. 
raczej z ekranu niż na jakąś postać, przeciwujęcia dla jego spojrzenia nie są dane. Spojrzenie Haghiego unosi się w abstrakcyjnej przestrzeni planu bliskiego i sklejek w montażu naprzemiennym pomiędzy scenami. Jego skierowany ku kamerze wzrok, raczej niż wyrażając dosłowną władzę tego spojrzenia (jak mesmeryzm Mabusego), staje się emblematem jego kontroli, jego wszechwiedzy, jego intryg, jego autorstwa. Haghi aranżuje dla swych ofiar bardziej zawiłe dramaty niż czynił to Mabuse, dramaty, które zdaje się reżyserować i którymi jednocześnie zdaje się napawać. Autorstwo Haghiego w Szpiegach, jego kontrola nad ludzkimi przeznaczeniami jawi się jako teatr nawet bardziej eksplicytnie niż podobne gry Mabusego we wcześniejszym filmie"71.

Brak fabularnego alibi dla ujęć patrzącego na nas z ekranu Haghiego przekształca go może wyraźniej we „władcę dyskursu” niż, jednak w rozmaity sposób diegetycznie motywowane, podporządkowanie montażu potędze postaci w Zmęczonej Śmierci czy Doktorze Mabuse. Nic zatem dziwnego, że finałowe wcielenie jego osoby - klown Nemo - staje się figurą artysty, poniekąd reżyserskiego porte parole, na którego okrzyk: „Kurtyna!” (co ciekawe, okrzyk niemal pośmiertny, wydany już po samobójczym strzale $w$ głowę), faktycznie opada kurtyna na zawsze zasłaniająca nie tylko scenę śmierci Haghiego publiczności wewnątrzfilmowej, ale i świat przedstawiony Szpiegów widzom filmu. Pięknie podsumowuje zaskakujący patos i liryzm autotematycznego finału, tego tragicznego „wieczoru kuglarza”, Paul Jensen: „Niemal Bergmanowskie zakończenie, z maską klowna kryjącą twarz przestępcy, zestawia rzeczywistość i iluzję, gdy widownia uznaje śmierć Haghiego za coś wykreowanego dla jej zabawienia"72.

Ale Tom Gunning wydobywa jeszcze inne aspekty tego finałowego wcielenia Haghiego. Zwraca uwagę, iż imię „Nemo”, oznaczające po łacinie "Nikt”, czyni z Haghiego puste miejsce, „zaledwie tabula rasa oczekującą wpisania fałszywej tożsamości" w znacznie większym stopniu niż był nim przybierający rozmaite tożsamości Mabuse ${ }^{73}$. Co ciekawe, imię to jest przeciwieństwem semantycznym imienia może najbardziej megalomańskiego wcielenia Mabusego - Sandora Weltmanna, ewokującego tą węgiersko-niemiecką zbitką Aleksandra Wielkiego, zdobywcę świata ${ }^{74}$. "Nikt" to także imię, jakie przemyślny Odys podał oślepionemu przez

${ }^{71}$ T. Gunning, op. cit., s. 122. A swoją drogą brak bezpośrednich czasoprzestrzennych kontekstów dla tych ujęć wpatrzonego w kamerę Haghiego to kolejny przykład wpływów stylistycznych sowieckiej szkoły montażu.

${ }^{72}$ P. M. Jensen, op. cit., s. 78.

${ }_{73}$ T. Gunning, op. cit., s. 120.

${ }^{74}$ Ibidem, s. 119-120. 
siebie Cyklopowi Polifemowi, imię dwuznaczne, zniechęcające do udzielenia pomocy Polifemowi innych Cyklopów, sygnifikujące podstępność i cynizm Odysa - również niewątpliwe atrybuty Haghiego. Wreszcie "Nemo" to nazwisko oznaczające anonimowość i nieuchwytność kapitana „Nautilusa”, bohatera dwóch powieści Jules Verne'a (20 000 mil podmorskiej żeglugi, Tajemnicza wyspa), „którego nienawiść do brytyjskiego imperializmu ostatecznie staje się nienawiścią do całego nowoczesnego świata, który używa swego technicznego geniuszu dla zwalczania nowoczesności jej własnymi narzędziami"75. Rzecz jasna, w kontekście antycywilizacyjnych i antybrytyjskich aspektów postaci Haghiego, sięgnięcie przez Langa i Theę von Harbou, admiratorów powieści przygodowych, po nazwisko akurat tej postaci z Verne'a, jest wyborem niezwykle znaczącym.

I wreszcie Agent 719, wcielenie Haghiego, którego twarzy tak naprawdę nigdy nie poznajemy. Ta niepoznawalność oznacza groźbę przeniknięcia do najgłębszych, najtajniejszych, obronnych struktur demokratycznego państwa jego śmiertelnych wrogów - co, jak wiemy z historii politycznej dawnej i nowej - nie jest bynajmniej political fiction, a w czym, jak skądinąd wiadomo, agentura komunistyczna i w Niemczech, i w Wielkiej Brytanii miała spore sukcesy. Agent 719 (zarazem dla odwrócenia uwagi od Haghi Banku, jak i dla uwiarygodnienia swej wywiadowczej przydatności) dość bezczelnie dwukrotnie podsuwa Jasonowi "rosyjski trop" - sugerując, że pieniądze dla Jellusicia pochodziły z Rosji i że tamże zostanie prawdopodobnie wywieziony "traktat japoński”. Ironię i tragizm obecności w strukturach „europejskiej” Secret Service „bolszewickiego” konia trojańskiego podkreśla fakt, iż Jason i Agent 326 rozmawiają twarzą w twarz z najbardziej poszukiwanym przez nich człowiekiem, a co więcej - bez cienia podejrzenia wpadają w zastawioną przezeń pułapkę.

Haghi, podobnie jak Mabuse (albo „zmęczona Śmierć” swą komnatę świec), ma swój gabinet, który stanowi swoiste centrum dowodzenia, sam środek medialnej pajęczyny. Najważniejszym miejscem tego gabinetu jest proste, nowoczesne, ostentacyjnie funkcjonalne biurko, $w$ atrybutach tych rodem jakby z Bauhausu ${ }^{76}$. To zza tego biurka, usytuowany $\mathrm{w}$ fotelu inwalidzkim na kółkach, Haghi przesłuchuje swych ludzi zdających raporty albo dostarczających jakieś materiały, przyjmuje Sonię czy uratowanego od szafotu Morriera. Na jego przedzie, ustawiony cyferblatem w pionie wprost przed Haghim, stoi zegar o przejrzystej, 24-godzinnej tarczy. Przezroczystość zegara i 24-godzinna numeracja są znakiem tego, iż Haghi pragnie ogarnąć swym spojrzeniem całą dobę, być poniekąd „panem czasu", czasu precyzyjnie obliczonego i zagospodarowanego (zresztą

75 Ibidem, s. 120.

${ }^{76}$ Jako „modernist Bauhaus-like desk” określa biurko Haghiego Gunning (op. cit., s. 119). 
w kwaterze głównej, na zewnątrz gabinetu, znajduje się jeszcze inny wielki zegar, o tarczy 12-godzinnej, za to z podwójną numeracja, 1-12 i 13-24). Ale biurko to oznacza - może zresztą $\mathrm{w}$ większym jeszcze stopniu - panowanie Haghiego nad przestrzenią. Jest na nim telefon, mikrofon interkomu, poprzez który Haghi wydaje swym ludziom polecenia, słuchawki, poprzez które odbiera on radiową informację od Morriera, dochodzą tam dwie tuby poczty pneumatycznej (z jednej np. Haghi po naciśnięciu jakiegoś guzika pobiera gazetę donoszącą o uprowadzeniu spod szafotu Morriera, do drugiej wrzuca przeczytaną gazetę; zapewne tą drogą otrzymuje on wydruk dalekopisu, sporządzony przez jego ludzi z podsłuchu Japończyków). Biurko zdaje się zresztą pełnić jakieś inne komunikacyjne, ale nieokreślone bliżej funkcje, o czym świadczą rzędy rozmaitych przycisków i pulsujące światełka. To istotnie „konsola” w sensie dosłownym, nie tylko zaś metaforycznym, jak komnata świec czy biurko Mabusego; miejsce, skąd wydając polecenia przez telefon, interkom czy przyciśnięcie jakichś guzików, dysponuje się zarazem ludzkimi losami. Nie przypadkiem tak znaczącym momentem przedostatniej sekwencji filmu wydaje się zniszczenie tego biurka, obalonego przez wybuch. To nie tylko metaforyczny, ale i rzeczywisty kres władzy Haghiego, porażka jego „strategii (medialnego) pająka”.

W gabinecie naprzeciw biurka znajduje się inny ważny element w medialnym królestwie Haghiego - ekran interkomu, na którym wyświetlane są napisy, przekazujące informacje od jego agentów. Tą właśnie drogą Haghi dowiaduje się o zbliżaniu się do banku Lady Leslane (na tyle wcześnie, by zdążyć dokonać zmiany charakteryzacji na swój publiczny, dyrektorski wizerunek) czy też o zarezerwowaniu przez tajne służby Jasona biletu na "Aero-Orient-Express" (co umożliwia mu uprzedzającą zagrywkę, udaremniającą zamiary przeciwnika: zlikwidowanie Jellusicia poprzez zadenuncjowanie go jego przełożonym).

Haghi posługuje się tymi samymi metodami, co siły rządowe: inwigilacją, robieniem ukradkowych fotografii, katalogowaniem danych. Ludzie Jasona, może dzięki bezpośredniemu śledzeniu delikwenta, a może dzięki jakimś informatorom $\mathrm{w}$ biurze podróży czy na dworcu, wiedzą, że Jellusić wraca do swego kraju „Orient Expressem”. Ale Haghi równie szybko (podsłuch? informator na lotnisku albo w biurze podróży?) dowiaduje się o rezerwacji biletu na samolot, co umożliwia mu skuteczną kontrakcję. Jason pokazuje Agentowi 326 grube albumy - w jednym znajdują się zdjęcia pracujących dlań ludzi z numerem ewidencyjnym pod fotografią (z tym, że 326 ogląda tylko oznaczone krzyżykiem fotografie osób zlikwidowanych przez przeciwnika ${ }^{77}$ ), w drugim - fotografie osób

77 Wśród ofiar Haghiego tam uwiecznionych znajduje się Agentka 325 - numer wskazuje, iż to bezpośrednia poprzedniczka Agenta 326, co powinno być dla niego (a nie jest) groźnym memento. 
podejrzewanych o szpiegostwo lub rozpoznanych jako obcy agenci (to tam 326 identyfikuje Jellusicia). Ale zupełnie tak samo „inwentaryzuje” ludzi przeciwnika Haghi, wręczając swym agentkom zdjęcia Numeru 326 i doktora Matsumoto. Do zdjęć Agenta 326 dołączone sa, zdobyte najprawdopodobniej z rzuconego nieopatrznie peta, odciski palców (co jest już zupełnie policyjną rutyną), do fotografii Japończyka - jego adres. W tym świecie obowiązuje zasada ukrywania tożsamości i zasadniczo niedowierzania innym (zatem łatwość, z jaką 326 i Matsumoto wpadają w sieci Soni i Kitty, wydaje się dramaturgicznie naiwna). Nazwisko agenta zastępuje numer, a tożsamość buduje co najwyżej adres (Parkstr. 25, 17 Strand), który łatwo "zlikwidować" - o czym świadczy casus mieszkania Soni. Jellusić odbiera swą korespondencję zarówno u siebie w kraju, jak i „za granicą", na poste restante, a namierzenie skrytki utrudnia stosowaniem znikającego atramentu i trudnym do zapamiętania, matematycznie absurdalnym kodem. Poczta zresztą jako miejsce korespondencji i wymiany informacji jest inwigilowana tak przez siły rządu, jak i wroga, a popełnienia tam błędów nie zdołają uniknąć obie strony: Jellusić mimo swej ostrożności umożliwi podejrzenie adresu na wrzucanej do skrzynki kopercie „ślepcowi”, który jest agentem Jasona, zaś Agent 326 nabierze się na prosty trick szpicla Haghiego i napisze telegram do Jasona przez podłożoną pod bibułą pulpitu kalkę. Należy ukrywać swój prawdziwy wygląd (stąd przebieranki Haghiego i Agenta 326), zaś dać się sfotografować oznacza zostać zdekonspirowanym i narazić się na niebezpieczeństwo (co stało się udziałem zarówno 326 i Matsumoto, jak i Jellusicia). Motyw „oczu” obecny na plakatach filmu i w kampanii reklamowej podczas premiery, wiąże się właśnie z obsesją obserwacji wizualnej, w pełnym mediów świecie niemal nie do uniknięcia. Choć w Szpiegach ta obsesja przekłada się tylko na medium fotografii, to $\mathrm{w}$ połączeniu $\mathrm{z}$ obecnymi $\mathrm{w}$ filmie innymi technikami, pełniącymi aktywną rolę dramaturgiczną $\mathrm{m}$ e d i a $\mathrm{m}$ i $\mathrm{tr}$ a $\mathrm{ns} \mathrm{m}$ is y j $\mathrm{n}$ y $\mathrm{m}$ i (radio, mikrofony, dalekopis, interkom, telefon), wyraża ona w gruncie rzeczy lęk przed inwigilującą telewizją. To niebezpieczeństwo zostanie w pełni unaocznione w Roku 1984 Orwella oraz w ostatnim w ogóle filmie Langa Tysiac oczu doktora Mabuse (1960), w którym kolejna inkarnacja Mabusego, Cornelius/Jordan śledzi gości naszpikowanego kamerami Hotelu Luxor (zbudowanego jeszcze przez nazistów) ze swego pełnego monitorów telewizyjnych sekretnego studia.

Hotel Luxor z ostatniego filmu Langa wydaje się „telewizyjnym wariantem" wymyślonego przez Jeremy'ego Benthama i nagłośnionego przez Michela Foucault w książce Nadzorować i karać: Narodziny więzienia (Surveiller et punir: Naissance de la prison, 1975) idealnego więzienia, jakim był Panopticon. W Szpiegach natomiast odnajdujemy w królestwie Haghiego bliższy Benthamowi, bo nie „technologiczny” i "medialny”, ale 
właśnie architektoniczny wariant Panopticonu. Jest nim klatka schodowa w kwaterze głównej Haghiego, pokazana wprawdzie dość enigmatycznie, w metonimiczny czy synekdochiczny sposób, ale będąca bodaj najbardziej pamiętnym i wizualnie frapującym obrazem tego filmu. W jej studni biegną $\mathrm{w}$ górę i w dół dramatycznie krzyżujące się w kadrze pomosty schodów, a na kolejnych piętrach wokół tej czeluści znajdują się korytarze z wejściami do... biur? cel? Na klatce tej trwa gorączkowa krzątanina zarówno na piętrach, jak i na schodach, którymi ciągle jacyś ludzie wbiegają i zbiegają. Przepaść tej klatki łatwo ogarnąć z góry, a właśnie na ostatnim piętrze, jak świadczy scena ze strażnikami wiodącymi do Haghiego uprowadzonego Morriera, znajduje się gabinet superszpiega. W tak skonstruowanej kwaterze głównej Haghi może osiągnać to, co było zasadniczym celem Panopticonu: „wywołać u więźnia poczucie świadomej i permanentnej widzialności, które zapewnia automatyczne funkcjonowanie władzy. Spowodować, by nadzór był permanentny w swych skutkach, nawet jeśli w działaniu jest nieciągły; by doskonałość władzy zmierzała do uczynienia zbędnym jego aktualnego stosowania; by to urządzenie architektoniczne stało się maszyną tworzącą i podtrzymującą stosunek władzy niezależny od tego, kto ją sprawuje. Dlatego bezustanne obserwowanie więźnia przez nadzorcę to jednocześnie nazbyt dużo i nazbyt mało: nazbyt mało, gdyż rzeczą najważniejszą jest, by więzień wiedział, że jest nadzorowany; nazbyt dużo, ponieważ faktycznie obserwowany być nie musi"78. Ciekawy jest także plastyczny pierwowzór owych ujęć w Szpiegach, przedstawiających klatkę schodową kwatery Haghiego: to Fantastyczne więzienia (Carceri d'invenzione) Giovanniego Battisty Piranesiego, a ściślej jedno z nich, z 1761 r. ${ }^{79}$ Także Gustaw Herling-Grudziński w Więzieniach Piranesiego upatrywał doskonałej metafory zamknięcia, zniewolenia, kontroli, nazywając je „sennym i przejrzystym zarazem majakiem wiecznej opresji" ${ }^{\prime 00}$.

Oczywiście, ludzie Haghiego to nie dosłownie jego więźniowie, ale raczej zdyscyplinowani funkcjonariusze, trzymani $\mathrm{w}$ ryzach strachem, obawą inwigilacji w medialnej pajęczynie i obserwacji w "Panopticonie", wreszcie - fanatyzmem ideologicznym i/bądź kultem „wodza”. O tym ostatnim świadczy np. histeryczna apoteoza tajemniczego szefa, wykrzyczana przez zdekonspirowanego i odprowadzanego do aresztu Vincenta

${ }^{78}$ Michel Foucault, Panoptyzm, przeł. Tadeusz Komendant, „Literatura na Świecie” 1988, nr 6 (203), s. 281. Panoptyzm to poświęcony pomysłowi Benthama rozdział z Nadzorować $i$ karać opublikowany w tym monograficznym, „foucaultowskim” numerze „Literatury na Świecie".

79 Por.: katalog wystawy Fritz Lang: Filmbilder, Vorbilder, Tafel 57.

${ }^{80}$ Gustaw Herling-Grudziński, Dziennik pisany noca 1980-1983, Res Publica, Warszawa 1990, s. 222. 
(segment 2) czy stosunek do Haghiego Morriera, jako żywo przypominający relację faworyta Mabusego, Georga, do jego pana. Morrier, ocalony od szafotu, pada przed Haghim na kolana i całuje jego ręce, a w finale, osaczony, myśli tylko o tym, by powiadomić szefa o grożącym niebezpieczeństwie, po czym - zupełnie tak samo jak Georg - popełnia samobójstwo (ampułka z trucizna, podobnie jak w samobójstwie Carozzy, znów jak się wydaje antycypuje ostatni bunkier Hitlera). Wreszcie Haghi może swych ludzi - a dotyczy to, zdaje się, głównie kobiet - kupować, jak Kitty, której za wykradzenie "traktatu japońskiego" płaci odrzuconymi wcześniej przez Sonię perłami. Rzuca jednak je swej tak kupionej agentce z nieukrywaną pogardą.

Dlaczego mimo „panoptikonu”, „medialnej pajęczyny”, rozbudowanej siatki szpiegów, wielkich pieniędzy i międzynarodowej skali swej działalności, Haghi przegrywa? W porównaniu z Mabusem wydaje się człowiekiem znacznie bardziej opanowanym, chłodnym, wolnym od zgubnego nałogu (Mabuse pił na umór, Haghi tylko pali) i od poddania się zaciemniającemu mu trzeźwą ocenę sytuacji libido ${ }^{81}$. Choć czy rzeczywiście jest on wolny od pożądania? Odkrycie przezeń miłości Soni do Numeru 326 wywołuje jego brutalność, uwięzienie swej najlepszej agentki i postawienie jej w końcu ultimatum: „on albo ja” (wcześniej może skutecznie tłumił swe pożądanie wskutek konsekwentnie odgrywanej roli inwalidy). Być może to rywalizacja o Sonię każe mu zastawić na Agenta 326 aż nazbyt kunsztowną pułapkę z katastrofą wagonu 33 133, która, jak to na ogół bywa z takimi pułapkami w opowieściach o superprzestępcach (vide: Doktor Mabuse, gracz, s. 275), zawodzi. „Morrier, agent Haghiego w pociagu, mógł po prostu wpakować Tremaine'owi kulę w łeb, gdy ten spał, zamiast liczyć na śmiertelny rezultat wielkiej katastrofy kolejowej, tak jak Mabuse mógł niewątpliwie pozbyć się Wenka w prostszy sposób niż hipnotyzując go, by skierował samochód w przepaść. Mamy tu do czynienia raczej z konwencją gatunkową niż ze zdrowym rozsądkiem, a gatunek żąda wymyślnie teatralnych intryg i efektów, które zobrazują superprzestępcę jako reżysera raczej widowiskowych efektów niż logicznej akcji. Takie konwencje gatunkowe dostarczają Langowi doskonałego kontekstu dla zobrazowania mechanizmów Machiny Przeznaczenia i aspiracji superprzestępcy do posiadania autorytetu i autorstwa jako władca dyskursu (grand enunciator)" 82.

Zwróćmy jednak uwagę, iż przyczyną ostatecznej wpadki Haghiego jest dociekliwość księgowego, który konfrontuje numery banknotów

81 Tak uważa np. Paul Jensen, uznając, iż jego „brak romantycznych uwikłań w przeciwieństwie do seksualnej aktywności Mabusego” czyni go skuteczniejszym reżyserem na pozór „przypadkowych” wypadków (por.: P. M. Jensen, op. cit., s. 77).

82 T. Gunning, op. cit., s. 122. 
wypłaconych Jellusiciowi przez Haghi Bank z podanymi w podmienionym przez Agenta 719 telegramie. Tak jak inny „wróg publiczny numer jeden", Al Capone, superprzestępca Langa wpada dzięki pedanterii nudnego, niemającego za grosz romantyzmu urzędnika, skrupulatnie i sumiennie wypełniającego swoje zawodowe obowiązki.

\section{Neue Sachlichkeit}

Jak już wspomniałem, negatywna opinia Lotte Eisner o Szpiegach w Ekranie demonicznym wynika $\mathrm{w}$ dużej mierze $\mathrm{z}$ zastosowania $\mathrm{w}$ odniesieniu do nich kryteriów ekspresjonizmu, których ten film - chyba w najwyższym stopniu pośród filmów Langa z lat 20. - istotnie nie spełnia. Widać to już choćby w dominującej w tym filmie, zamiast osławionych ekspresjonistycznych kontrastów czerni i bieli, tonacji jakby monochromatycznie szarej. Tom Gunning wiąże ją z użyciem tu na większą skalę taśmy panchromatycznej, która wyprodukowała szeroką gamę szarości, zaś twarze i charakteryzację aktorów uczyniła bardziej realistycznymi w wyglądzie ${ }^{83}$. Andreas Huyssen odnotował w Metropolis tematyczne i stylistyczne napięcie między ekspresjonizmem a Neue Sachlichkeit ${ }^{84}$, zaś Gunning odnotowuje, iż jest ono „wciąż widoczne w Szpiegach (z nielicznymi scenami czerpiącymi otwarcie z elementów ekspresjonistycznych, jak wizja Matsumoto z zamordowanymi kurierami), choć późniejszy styl nowej rzeczowości dominuje" 85 .

Termin Neue Sachlichkeit (który najtrafniej oddać po polsku jako Nowa Rzeczowość) został ukuty przez Gustawa Hartlauba, dyrektora Kunsthalle w Mannheim, na określenie stylu obrazów, charakteryzujących się „dotykalną rzeczywistością" i prezentowanych podczas tak zatytułowanej wystawy w połowie 1925 r. ${ }^{86}$ Fraza szybko się przyjęła jako nazwa nowego postekspresjonistycznego trendu. „Była to fraza, która zdawała się zawierać w pigułce ducha czasu, przywołując zarówno Gegenständlichkeit (przedmiotowość) berlińskich dadaistów, jak i Sachlichkeit (rzeczowość) przedwojennego Werkbundu, tę samą Sachlichkeit, którą wskazywano

83 Por.: ibidem, s. 118.

84 Andreas Huyssen, The Vamp and the Machine: Fritz Lang's "Metropolis", [w:] Fritz Lang's "Metropolis": Cinematic Visions of Technology and Fear, eds. Michael Minden, Holger Bachmann, Camden House, Rochester-Woodbridge 2000, s. 201.

85 T. Gunning, op. cit., s. 118.

86 Por.: John Willett, Art \& Politics in the Weimar Period: The New Sobriety 1917-1933, Pantheon Books, New York 1978, s. 111. Siegfried Kracauer (Od Caligariego do Hitlera, s. 140) lokuje utworzenie terminu Neue Sachlichkeit w roku 1924. 
jako probierz dobrego dziennikarstwa Egona Erwina Kischa"87. Kracauer cytuje list Hartlauba do Alfreda H. Barra, dalej dookreślający to pojęcie: „Wiązało się ono z powszechnym wówczas w Niemczech poczuciem rezygnacji i cynizmu po okresie wybujałych nadziei, które znalazły ujście w ekspresjonizmie. Cynizm i rezygnacja to negatywna strona Neue Sachlichkeit; pozytywna wyraża się w entuzjazmie dla bezpośredniej rzeczywistości wskutek pragnienia traktowania rzeczy całkowicie obiektywnie, na podstawie materialnej, bez obdarzania ich zaraz idealnymi implikacjami" ${ }^{88}$.

Charakterystyczne dla Neue Sachlichkeit są przede wszystkim tematy - pejzaż miejski, z jego ruchem, gorączkową krzątanina, ludźmi na tle architektury; portret $\mathrm{i}$ akt, ale nie naturalistyczne, tylko jakby nieco „spotworniałe" w wyrazie, graniczące np. u Ottona Dixa, Georga Grosza czy Rudolfa Schlichtera z karykatura, albo niepokojąco udziwnione przez hiperrealistyczną „namacalność” czy "fotograficzność", jak u Christiana Schada czy Ottona Griebla; obrazy rozmaitych miejsc, często z półświatka - knajp, kabaretów, tingel-tangli, domów publicznych; sport i rozmaite rozrywki. Technika i styl sztuki nowej rzeczowości były rozmaite - od olejów zbliżonych kolorytem, faktura, linią do ekspresjonizmu przez delikatne akwarele, wyrafinowane technicznie hiperrealistyczne oleje po kolaże i fotomontaże ${ }^{89}$. Wyróżnikiem tej sztuki jest też pewien dystans emocjonalny, chłodna, beznamiętna obserwacja, czasem coś w rodzaju ironii czy zgryźliwości wobec niewątpliwej brzydoty czy nawet ohydy obiektu, a nawet odczucie jakiejś samobójczej Schadenfreude z apokaliptycznej wizji „ducha czasu”. Obrazy tego nurty byłyby idealnymi ilustracjami Witkacowskiego Pożegnania jesieni czy Nienasycenia.

Tę jakąś fundamentalną dwuznaczność Neue Sachlichkeit, przy pozorach jej bezstronności i obiektywizmu, krytykuje Kracauer, opierając się na atrybutach wskazanych przez Hartlauba: „Innymi słowy, Nowa Rzeczowość oznacza stan paraliżu. Cynizm, rezygnacja, pozbawienie złu-

87 J. Willett, op. cit., s. 111.

${ }_{88}$ G. Hartlaub, list cytowany [w:] Siegfried Kracauer, From Caligari to Hitler: A Psychological History of the German Film, revised and expanded edition, edited by Leonardo Quaresima, Princeton University Press, Princeton-Oxford 2004, s. 165. Dysponując oryginałem, zdecydowałem się na własny przekład, mając pewne zastrzeżenia do istniejącego tłumaczenia polskiego.

${ }_{89}$ Wielkim przeglądem sztuki Neue Sachlichkeit, w którym miałem okazję uczestniczyć, była zorganizowana w roku 1987 na 750-lecie Berlina w Martin-Gropius-Bau wystawa Ich und die Stadt (Ja i miasto). Atrybuty Neue Sachlichkeit tu przedstawione są poniekąd wyciagiem na podstawie katalogu tej wystawy: Ich und die Stadt: Mensch und Großstadt in der deutschen Kunst des 20. Jahrhundert, Red. Eberhard Roters, Bernhard Schulz, Nicolaische Verlagsbuchhandlung, Berlin 1987. 
dzeń: tendencje te wskazują na mentalność nieskłonną do zaangażowania w jakimkolwiek kierunku. Główną cechą Nowej Rzeczowości jest niechęć do zadawania pytań, do zajmowania stanowiska. Rzeczywistość portretowano nie tak, by fakty ujawniały swe implikacje, ale by utopić wszystkie implikacje w oceanie faktów, jak w Kulturfilme Ufy" ${ }^{\prime 90}$.

Formułą filmu, szczególnie odpowiednią dla tego „topienia znaczeń w oceanie faktów", okazał się film montażowy, ukazujący świat migający nam w szybko zmieniających się przed oczami kalejdoskopowych obrazach. Paradygmatyczny jest tu oczywiście Berlin, symfonia wielkiego miasta (1927) Waltera Ruttmanna, ale strategia ta odzwierciedliła się także w filmach fabularnych, o dość luźnej strukturze dramaturgicznej, choć niewolnych (wbrew opiniom Kracauera) od np. ambicji socjologicznych [np. Ludzie w niedziele (Menschen am Sonntag, 1929) Roberta Siodmaka] czy deklaratywnych ideologicznie (Kuhle Wampe, 1932, Slatana Dudowa). Odpowiednikiem zaś filmowym tematyki wielkomiejskiej, ulicznej, półświatkowej, obecnej w malarstwie Neue Sachlichkeit, stały się przede wszystkim Straßenfilme - "filmy uliczne”, zapoczątkowane przez słynną Ulice (Die Straße, 1923) Karla Grune; ich najwybitniejszym twórcą w latach 20. był Georg Wilhelm Pabst.

Szpiedzy, z racji swego rytmu, efektownych sekwencji montażowych, zatarcia granic między sceną a sekwencją montażowa, wytwarzają w odbiorcy podobne wrażenie „kalejdoskopowego" obrazu świata, co słynny film Ruttmanna. Efektowny prolog, sekwencja pościgu Soni i Agenta 326 za Morrierem czy akcja w Haghi Banku rodzą chwilami poczucie oglądania niemal fragmentu kroniki filmowej (filmujący katastrofę operator, któremu Sonia i 326 zabierają motocykl, jest niewątpliwym signum temporis epoki). Sfilmowane w sekwencji pościgu ulice Berlina rodzą w widzu efekt wtargnięcia akcji w biegnący niezależnie i tak afirmowany w Teorii filmu Kracauera „strumień życia”. A niewątpliwie wykonane w studio elementy scenografii (fasada Haghi Banku, neon Hotelu Olympic, klatka schodowa à la Piranesi), nie udając w pełni obiektów z realnej rzeczywistości pozafilmowej, są jednak w jakiś sposób silnie realistyczne, przypominając tą dialektyką sztuczności i prawdziwości miejskie pejzaże z malarstwa Neue Sachlichkeit.

Rodem z tego ostatniego są też niewątpliwie obrazy "ojca sadysty" i „matki - dziwki i pijaczki” z opowieści, którą Kitty rozczula dr. Matsumoto, oraz dekadenckie lokale - "Cafe Danielli" z parkietem tanecznym wokół bokserskiego ringu, "Grand Bar” z jego fauną ludzką (podpici utracjusze, czarny barman, prostytutka niczym z obrazu Dixa, Grosza albo

90 S. Kracauer, From Caligari to Hitler..., s. 165-166 (przekład z oryginału; odnośny ustęp w polskim wydaniu, Od Caligariego do Hitlera..., s. 140-141). 
Schlichtera). Wraz z pamiętnymi lokalami i szulerniami z Doktora Mabuse, gracza oraz Yoshiwarą z Metropolis, stanowią one potężny wkład Langa do wykreowania $\mathrm{w}$ świadomości następnych generacji zmitologizowanej aury Berlina w ",szalonych latach 20." i u schyłku Republiki Weimarskiej, którą Sally Bowles z Kabaretu (1972) Boba Fosse - filmu niewątpliwie odwołującego się do tej mitologii - określiła w pamiętnych dwóch słowach: „boska dekadencja”. 



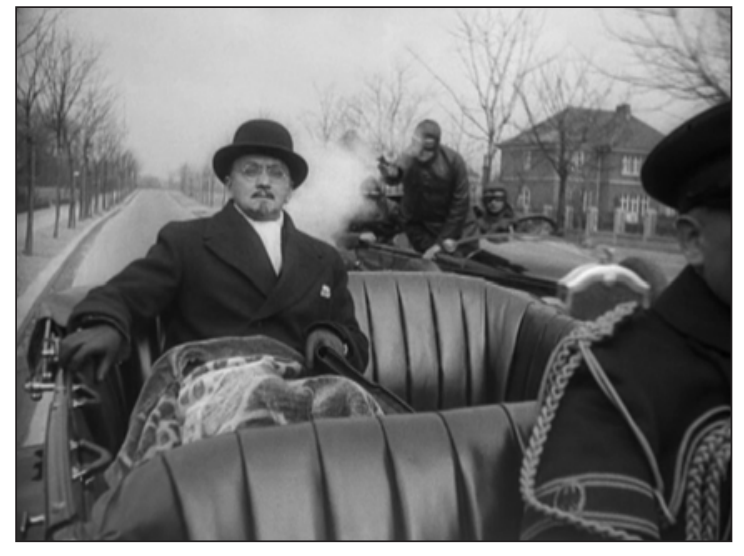

1. Szpiedzy (1928, reż. Fritz Lang). Zamach na ministra handlu - jedno z kilku w filmach Langa ech zabójstwa Waltera Rathenaua

2. Szpiedzy (1928, reż. Fritz Lang). Maskarada - agent $326 \mathrm{w}$ przebraniu lumpa z wezwaniem na policje
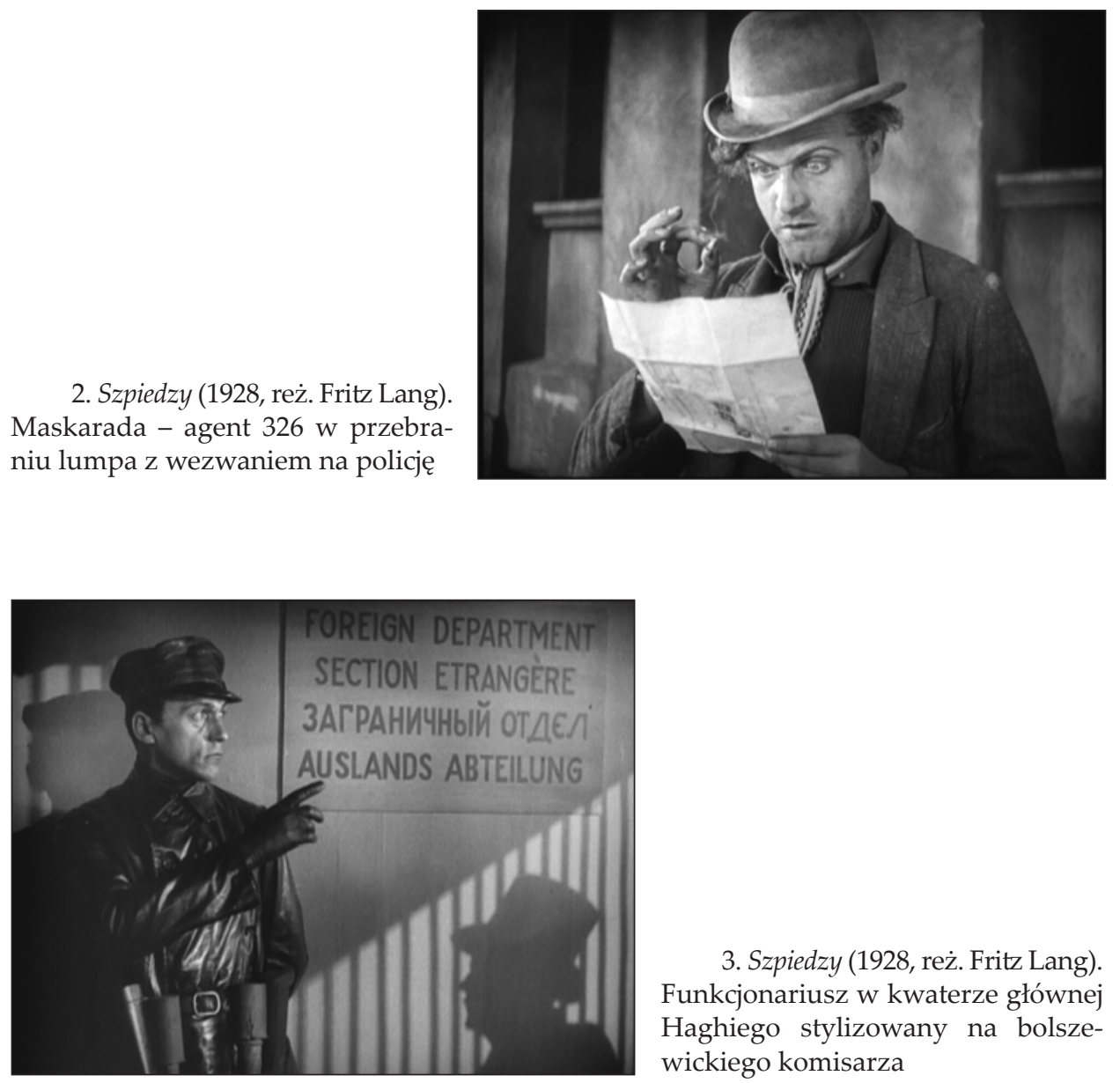

3. Szpiedzy (1928, reż. Fritz Lang). Funkcjonariusz w kwaterze głównej Haghiego stylizowany na bolszewickiego komisarza 


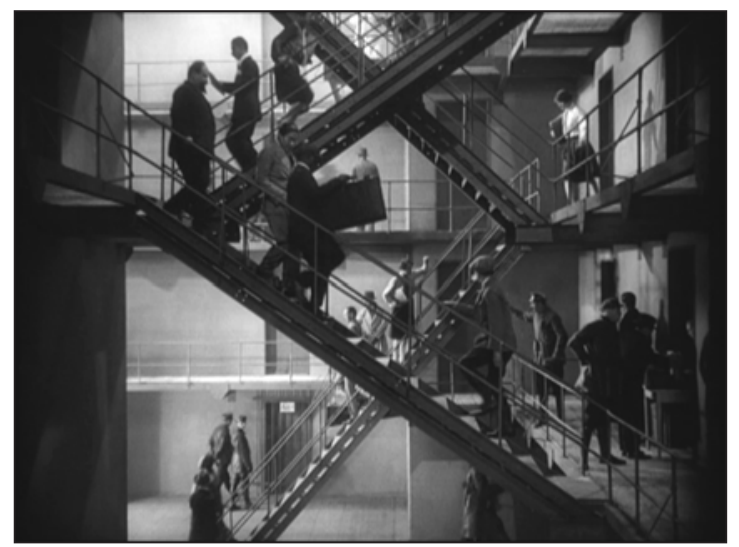

4. Szpiedzy (1928, reż. Fritz Lang). Klatka schodowa à la Piranesi w kwaterze głównej Haghiego

5. Szpiedzy (1928, reż. Fritz Lang). Fasada Banku Haghiego
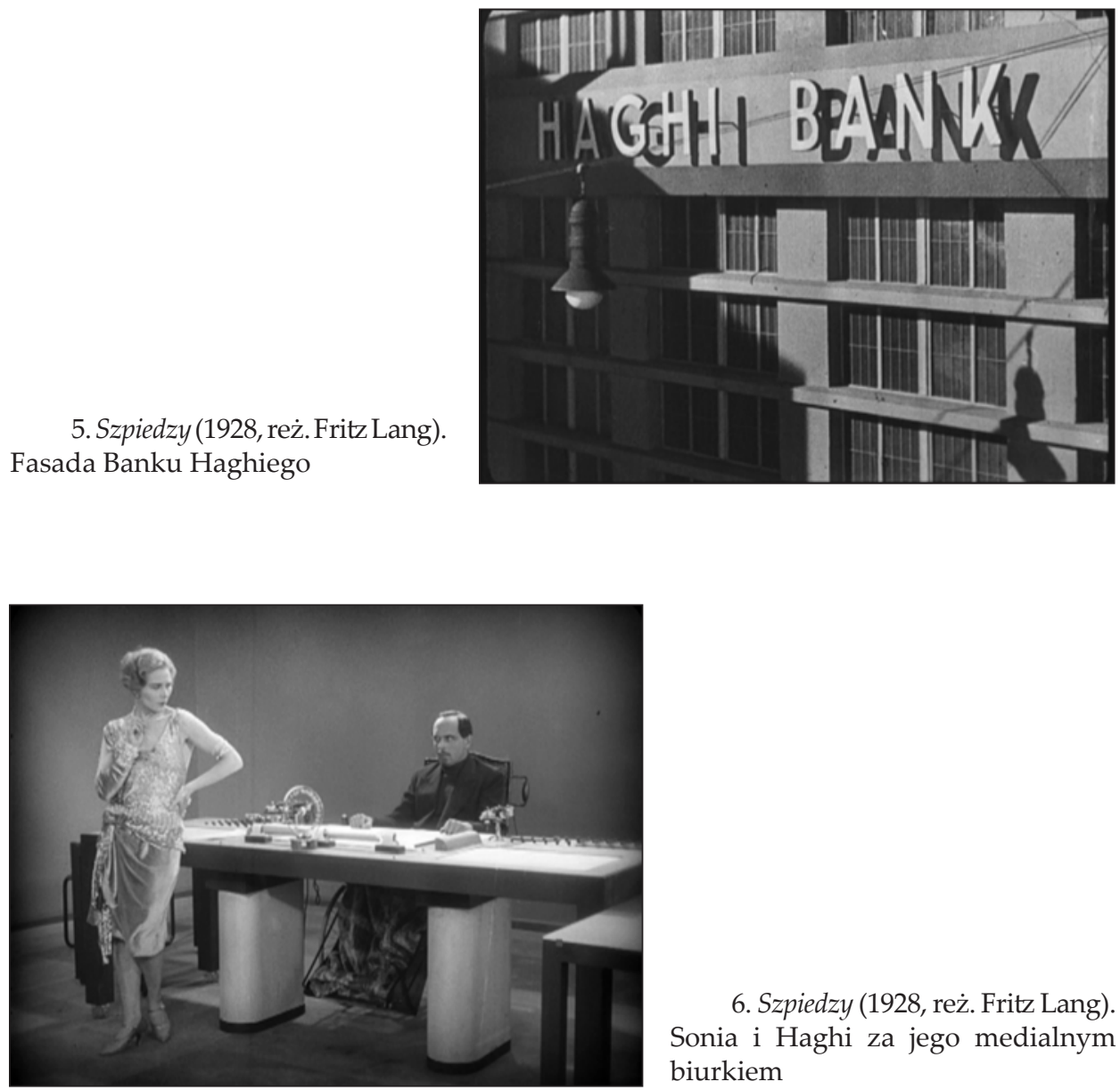

6. Szpiedzy (1928, reż. Fritz Lang). Sonia i Haghi za jego medialnym biurkiem 


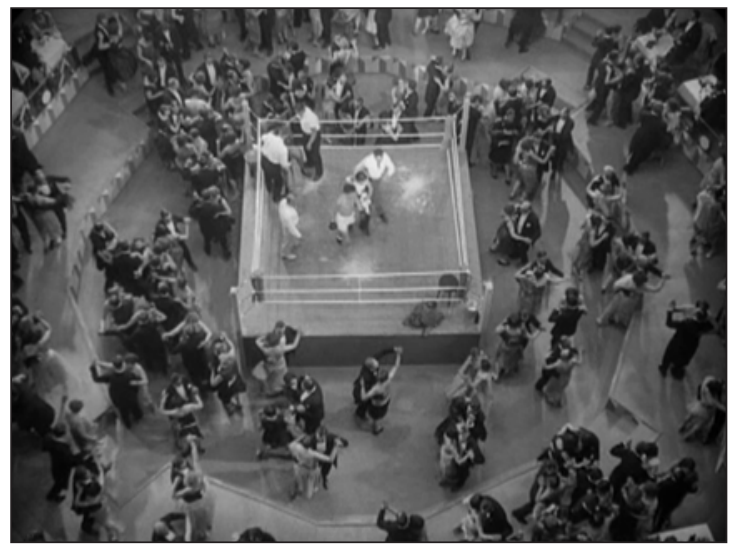

7. Szpiedzy (1928, reż. Fritz Lang). Dansing wokół bokserskiego ringu w Cafe Danielli

8. Szpiedzy (1928, reż. Fritz Lang). Synekdochiczny styl filmu - ostatnie życzenie Jellusicia łaskawie spełnione przez jego wojskowych przełożonych
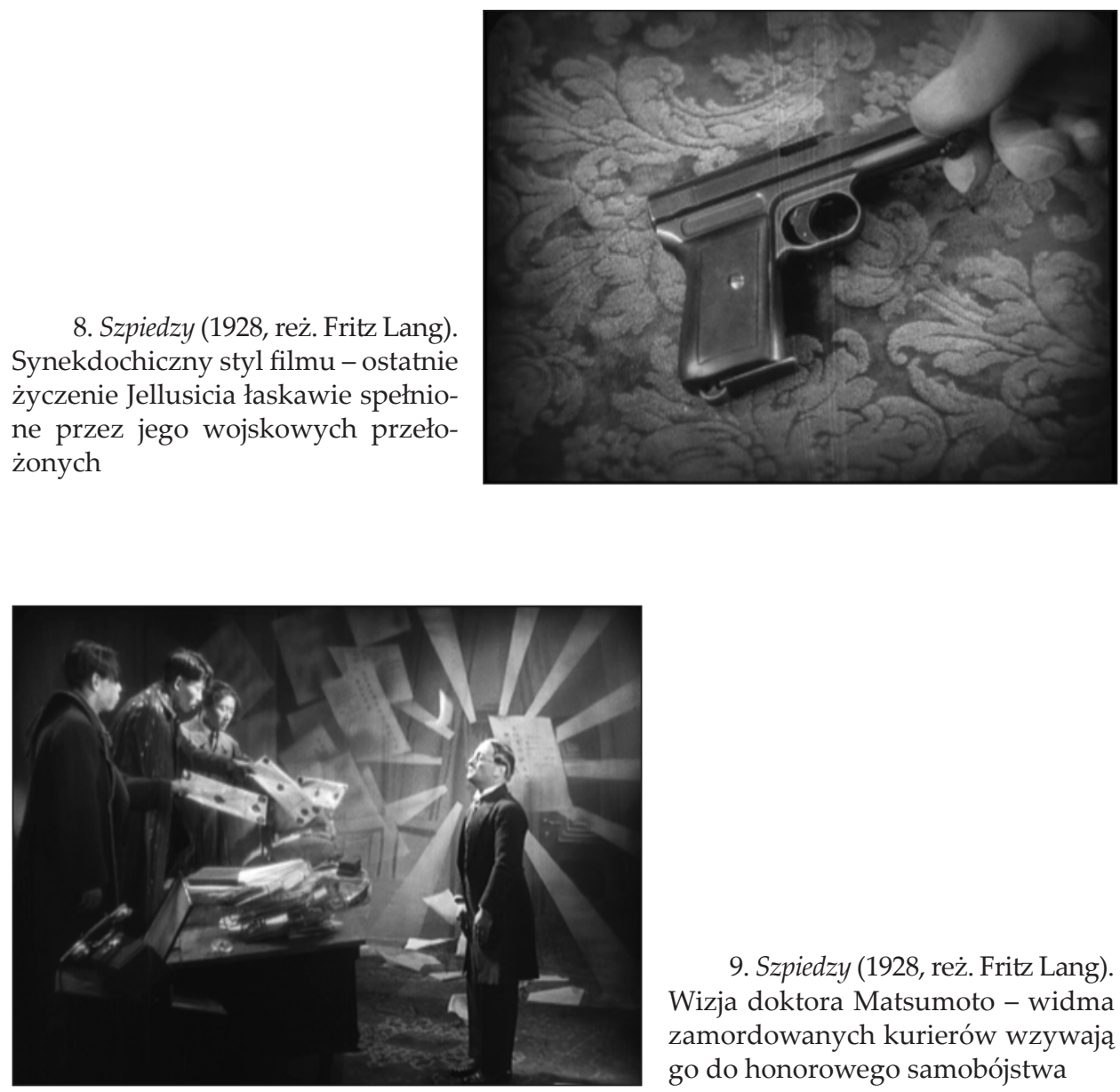

9. Szpiedzy (1928, reż. Fritz Lang). Wizja doktora Matsumoto - widma zamordowanych kurierów wzywają go do honorowego samobójstwa 


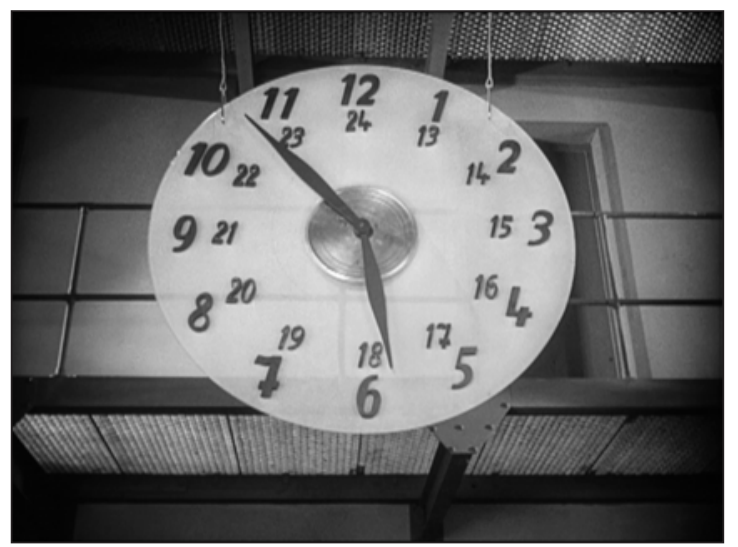

10. Szpiedzy (1928, reż. Fritz Lang). Jeden $z$ wielu dziwnych Langowskich zegarów - odmierza czas życia Soni

11. Szpiedzy (1928, reż. Fritz Lang). Sonia i kierowca agenta 326 w walce o życie
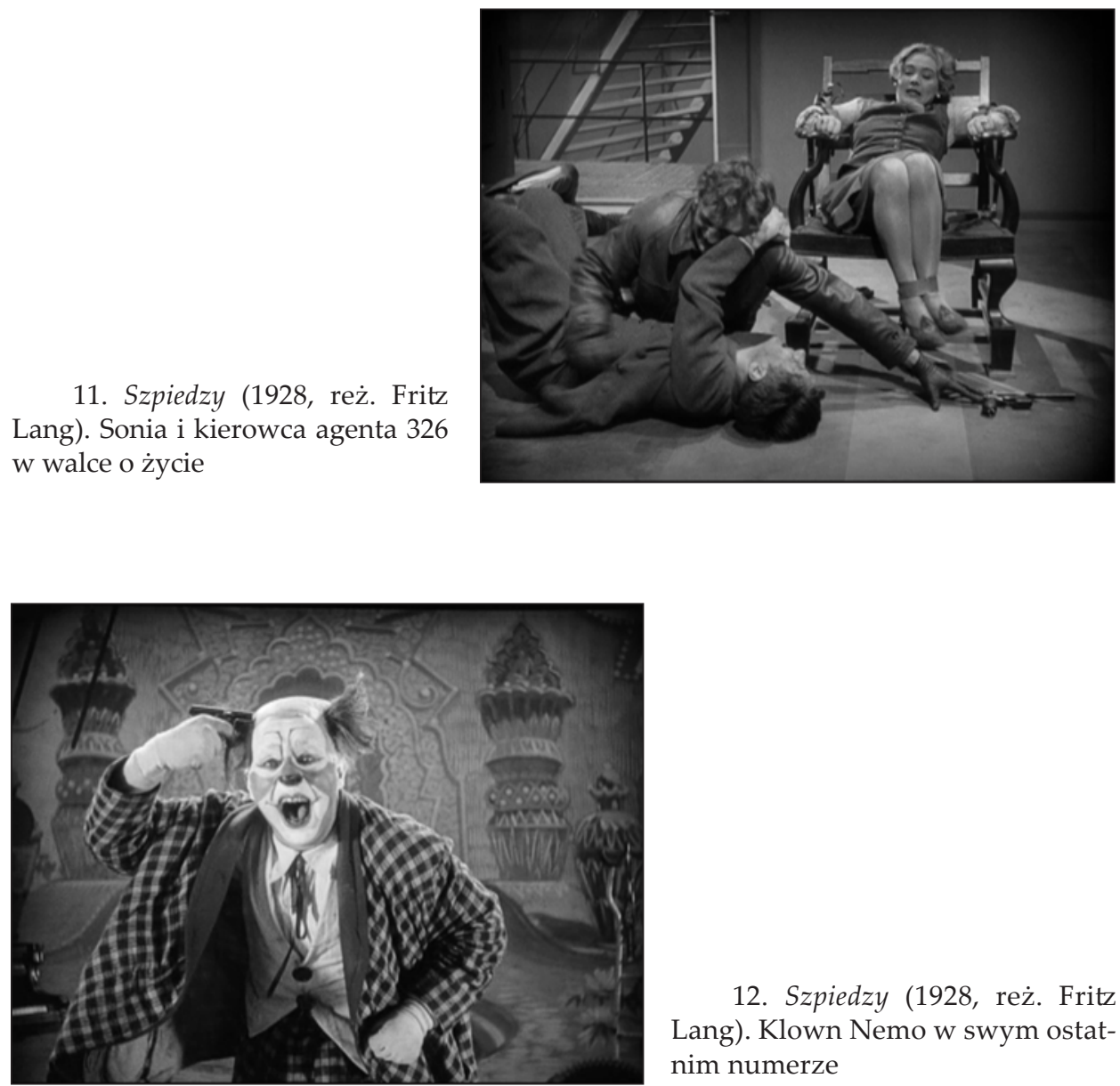

12. Szpiedzy (1928, reż. Fritz Lang). Klown Nemo w swym ostatnim numerze 
Część 3

\section{KSZTAŁT RZECZY, KTÓRE NADEJDĄ}





\section{Rozdział 5}

\section{CZAS APOKALIPSY: METROPOLIS}

I przyszedł jeden z siedmiu aniołów, którzy mieli siedem czasz, i odezwał się do mnie, mówiąc: Chodź, pokażę ci potępienie wielkiej wszetecznicy, która siedzi „nad wodami wielkimi, z którą nierząd uprawiali królowie ziemi, i opili się" winem jej nierządu mieszkańcy ziemi.

I zaniósł mię $\mathrm{w}$ duchu na pustynię. I widziałem niewiastę siedzącą na bestii szkarłatnej, pełnej imion bluźnierczych, mającej siedem głów i dziesięć rogów. A niewiasta przyobleczona była w purpurę i karmazyn i ozdobiona złotem i drogimi kamieniami i perłami, trzymała złoty puchar w swej ręce, pełny obrzydliwości i plugawej rozpusty swojej, a na czole swoim napisane imię: Tajemnica; Babilon wielki, matka rozpusty i obrzydliwości ziemi. [...]

I rzekł mi: Wody, które widziałeś, gdzie siedzi wszetecznica - to są ludy i narody i języki. A dziesięć rogów, które widziałeś na bestii - ci będą mieć w nienawiści wszetecznicę i spustoszą ją i ogołocą i ciało jej jeść będą a ją samą spalą ogniem. [...] I niewiasta, którą widziałeś - to miasto wielkie, które panuje nad królami ziemi ${ }^{1}$.

Apokalipsa św. Jana 17, 1-5; 15-16; 18

Klein-Rogge wynosił atrakcyjne aktorki na dachy domów w czasach, gdy King Kong jeszcze wchodził pod szafę i nie wdrapałby się nawet na deskę klozetową. No, wyniósł przynajmniej jedną atrakcyjną aktorkę, Brigitte Helm w Metropolis. Świetny film. Przedstawiał dokładnie taki świat, o jakim Pökler i jeszcze paru innych marzyli, korporacyjne miasto-państwo, gdzie technika była źródłem siły, inżynier pracował w ścisłym związku z zarządca, masy tyrały niewidoczne głęboko pod ziemia, a całkowita władza spoczywała w rękach pojedynczego przywódcy na samym szczycie hierarchii, sprawiedliwego i łaskawego ojca, który nosił wspaniałe garnitury i którego nazwiska Pökler nie pamiętał, bo nazbyt pochłonął go Klein-Rogge grający szalonego naukowca, takiego, jakim on i inni uczniowie Jamfa pragnęli zostać - niezastąpiony obywatel dla władców Metropolis, a jednak, w finale, nieposkromiony lew,

${ }^{1}$ Cyt. za: Pismo Święte Starego i Nowego Testamentu w przekładzie W. O. Jakuba Wujka SJ, Wydawnictwo Apostolstwa Modlitwy, Kraków 1962, s. 1445. 
który potrafił unicestwić to wszystko, dziewczynę, państwo, masy, samego siebie, dowodząc swojej rzeczywistości na przekór tamtym jednym długim skokiem z dachu na ulicę, rycząc... ${ }^{2}$

Thomas Pynchon, Tęcza grawitacji

\section{Paradygmatyczny film Ufy}

Dwa teksty, zamieszczone jako motta do niniejszego rozdziału, wyrażają poniekąd Janusowy, dwoisty, ambiwalentny charakter Metropolis, tego najsłynniejszego z filmów Langa, obok Gabinetu doktora Caligari z pewnością najczęściej przywoływanego, komentowanego, trawestowanego filmu z klasycznej epoki kina niemieckiego - i kto wie, czy nie w ogóle jedynego filmu z epoki niemej, który jest do dziś niewątpliwie „kultowy” (jeśli już posługiwać się tą wątpliwą kategorią). Cytat z Apokalipsy św. Jana nawiązuje do strategii filmu, by futurystyczną antyutopię, obrazującą kryzys społeczny „czasów, które nadejdą" oraz przezwyciężenie tego kryzysu w duchu pojednania między zantagonizowanymi klasami, przedstawić w kategoriach eschatologicznych jako opis „czasów ostatecznych”, kiedy po paroksyzmie triumfu zła następuje jego zdemaskowanie i obalenie przez zbawiciela, który ustanawia królestwo pokoju. Wnikliwsza refleksja nad tym aspektem filmu odkryć musi, iż ostentacyjne biblijne konotacje zdarzeń przedstawionych (rodem z Księgi Rodzaju, Ewangelii i Apokalipsy) są jednak niestosownym nadużyciem, czy wręcz uzurpacją w świecie przedstawionym, który zupełnie nie ewokuje wymiaru transcendentnego i w którym "religia” ma jedynie wymiar polityczny i społeczny ${ }^{3}$. W każdym razie biblijna, a zwłaszcza ewangeliczna i apokaliptyczna stylizacja, nadaje Metropolis drażniące chyba nie tylko dzisiejszego widza (o czym

2 Thomas Pynchon, Tęcza grawitacji, przeł. Robert Sudół, Prószyński i S-ka, Warszawa 2001, s. 456.

${ }^{3}$ Swoją droga w ani jednym ze znanych mi tekstów o Metropolis nie napotkałem stwierdzenia o zawłaszczeniu konotacji biblijnych i chrześcijańskich przez tekst w swej istocie zupełnie niemetafizyczny i niereligijny - autorzy analiz tego filmu konstatują obecność „symboliki religijnej”, wskazują rozmaite biblijne odniesienia i co najwyżej, jak np. R. L. Rutsky, zauważaja, iż chrześcijański symbolizm jest tu „,aż-nazbyt-oczywisty”, co chyba jest jakimś nie do końca klarownie wyrażonym rozpoznaniem, iż jest on po prostu nie na miejscu (por.: R. L. Rutsky, The Mediation of Technology and Gender: "Metropolis”, Nazism, Modernism, „New German Critique” 1993, no. 60 /Fall/, s. 5; ten sam tekst przedrukowany w antologii tekstów Fritz Lang's "Metropolis": Cinematic Visions of Technology and Fear, ed. Michael Minden, Holger Bachmann, Camden House, Rochester-Woodbridge 2000; cyt. miejsce na s. 219). Antologia Mindena i Bachmanna skupia najważniejsze interpretacje filmu Langa, łącznie z recenzjami z epoki premiery, pochodzące spoza poświęconych Langowi monografii (jak książki Jensena, Otta, Eisner, Gunninga etc.). 
świadczą recenzje z roku premiery) solemność, fałszywy patos czy też graniczącą ze śmiesznością i kiczem bombastyczność. Stylizacja ta jest kanwą dla osławionego „przesłania” filmu, na którym większość piszących o filmie autorów nie zostawiła suchej nitki: "Mittler zwischen Hirn und Hände muß das Herz sein" - „Pośrednikiem między mózgiem a rękoma musi być serce".

Z kolei nazista Pökler, postać z powieści Pynchona Tęcza grawitacji, przywołuje w swych wspomnieniach Rotwanga, szalonego naukowca z Metropolis, jeszcze jedna, prócz doktora Mabuse i Attyli w Nibelungach, rolę uwielbianego przez siebie aktora, Rudolfa Klein-Rogge. Rotwang w interpretacji Pöklera - ponownie uosabia "dzikość lwa” i „,wolę mocy”, gotową dowieść swej rzeczywistości na przekór wszystkim, choćby za cenę świadomego samozatracenia. Ale rozważania Pöklera unaoczniają także, iż dla nazisty in spe obraz spolaryzowanego świata, w którym niewidzialne masy w podziemiach tyrały dla rządzącego jedynowładcy i kasty wybrańców, wcale nie jawił się jako antyutopia, ale jako stan idealny, utopijna idée fixe... W takim kontekście ujawnia się fundamentalna dwuznaczność niby to religijnego i niby to chrześcijańskiego finału filmu: ilustrujące abstrakcyjne przesłanie o sercu, które pośredniczy między mózgiem a rękoma, finałowe pojednanie między „,władzą" a „,światem pracy”, okazuje się naprawdę kapitulacją "rąk”, dobrowolnym oddaniem siebie $\mathrm{w}$ bynajmniej nie słodkie jarzmo, pod bynajmniej nie lekkie brzemię... czego zamaskowanie ułatwiają nie tylko „chrześcijańskie” konotacje, ale i fakt, iż w strukturze fabularnej filmu pojednanie to jawi się jako okraszony dużą dawką sentymentalizmu i patosu happy end, szczęśliwe rozwiązanie pogmatwanych wątków.

Ze wspomnień Pöklera wynika także, iż Metropolis to był film niewątpliwie atrakcyjny, w którym magnesem dla publiczności była nie tylko widowiskowa wizja (wszystko jedno, pociągająca jako utopia, czy odstręczająca jako antyutopia), ale i seks, uosobiony w "atrakcyjnej aktorce", Brigitte Helm.

Rzecz jasna, Brigitte Helm wcale nie miała być clou filmu, zamierzonego jako superprodukcja zdolna pobić Amerykanów ich własną bronią: rozmachem produkcyjnym, widowiskowością, poziomem techniki filmowej. Kampania reklamowa, która wystartowała na kilka miesięcy przed premierą (10 stycznia 1927) przygotowywała potencjalnych widzów na niesłychane atrakcje, podsycając ciekawość i niecierpliwe oczekiwanie reportażami z planu, rozmaitymi szczegółami technicznymi i przede wszystkim imponującymi liczbami: „Każdy przed premierą musiał wiedzieć, że Metropolis to jak dotąd najdroższa i najambitniejsza produkcja filmowa w Europie, na niesłychany koszt 5,3 miliona Reichsmarek (co ponadtrzykrotnie przekraczało budżet, przyczyniając się w międzyczasie do 
bankructwa Ufy); że proporcja ostatecznie wykorzystanego do nakręconego materiału filmowego wynosiła 1:300 (ponad milion metrów wywołanej taśmy); i że zatrudniono 36000 statystów, w tym 750 dzieci i 1000 bezrobotnych, którym setka fryzjerów ogoliła głowy dla sceny, która w ostatecznym montażu nie trwała nawet minuty. «Film tytanicznych rozmiarów», «największy film, jaki kiedykolwiek zrealizowano, jedno z wiecznych arcydzieł wszechczasów», «Über-film» i inne slogany obiecywały film, który mógł konkurować z takimi amerykańskimi spektaklami kultury wysokiej, jak Griffithowskie Narodziny narodu (1915) czy Nietolerancja (1916) albo ekstrawagancki, trzygodzinny Złodziej z Bagdadu (1924) Raoula Walsha [z Douglasem Fairbanksem], pokazywany w Berlinie parę lat wcześniej"4.

Imponujące dane liczbowe dotyczące tej superprodukcji ukonkretnia m.in. Patrick McGilligan, biograf reżysera: „Prócz ośmiorga odtwórców ról głównych, zaangażowano 750 aktorów do mniejszych ról, 26000 statystów-mężczyzn, 11000 statystujących kobiet, 750 dzieci, 100 Murzynów i 25 Chińczyków" ${ }^{\prime 5}$. Klaus Kreimeier dodaje jeszcze ponad 500 modeli drapaczy chmur, 1,3 mln metrów zużytej taśmy filmowej oraz aż 1,6 mln marek na same honoraria (spośród 5,3 mln marek ostatecznego budżetu, wstępnie zaś szacowanego na 1,5 miliona $)^{6}$. Holger Bachmann, za specjalnym wydaniem „Ufa-Magazine” z 1927 dorzuca jeszcze 200000 Reichsmarek

${ }^{4}$ Anton Kaes, Metropolis: City, Cinema, Modernity, [w:] Expressionist Utopias: Paradise, Metropolis, Architectural Fantasy, ed. Timothy O. Benson, Los Angeles County Museum of Art-University of California Press, Berkeley-Los Angeles-London 2001, s. 146. Artykuł Kaesa w nieznacznie tylko odmiennej postaci ukazał się wcześniej jako: Anton Kaes, Cinema and Modernity: On Fritz Lang's "Metropolis", [w:] High and Low Cultures: German Attempts at Mediation, ed. Reinhold Grimm, Jost Hermand, The University of Wisconsin Press, Madison 1994 (cyt. miejsce: s. 19).

${ }^{5}$ Patrick McGilligan, Fritz Lang: The Nature of the Beast, St. Martin's Press, New York 1997, s. 115.

${ }^{6}$ Zob.: Klaus Kreimeier, The Ufa Story: A History of Germany's Greatest Film Company, 1918-1945, transl. Robert and Rita Kimber, University of California Press, Berkeley-Los Angeles-London 1999, s. 152-153. Trochę inne dane dotyczące kosztów filmu podaje Thomas Elsaesser w monografii filmu, wydanej w renomowanej serii „BFI Film Classics”: „Zyski kompanii netto w latach 1924-1925 wynosiły 3,1 mln Reichsmarek; w tym czasie przeciętny koszt produkcji pełnometrażowego filmu wynosił 175000 Reichsmarek. Budżet Metropolis pierwotnie skalkulowano na 800000 Reichsmarek, ale ostatecznie wyniósł on jak twierdzi Ufa, Lang zaś podważał - około 4,2 mln Reichsmarek, połowę budżetu całej produkcji w sezonie 1925-1926. Reszta miała przypaść innym 22 filmom realizowanym w tym sezonie" (Thomas Elsaesser, Metropolis, BFI Publishing, London 2003, s. 12). Elsaesser podaje swe dane za niepublikowaną pracą doktorską Ann Drummond Fritz Lang's "Metropolis" (University of Edinburgh, 1982, s. 8-9), podczas gdy Kaes, McGilligan, Kreimeier opierają się na specjalnym wydawnictwie Ufy z 1927, przygotowanym z okazji premiery filmu Langa: "Metropolis”, Sondernummer des Ufa-Magazins, Red. Stefan Lorant, Bukwa, Press Abteilung der Ufa, Berlin 1927. 
wydanych na kostiumy, 3500 par butów, 75 peruk, 50 specjalnie zaprojektowanych samochodów oraz oświetlenie, farbę, drewno i zaprawę warte 400000 Reichsmarek $^{7}$. Produkcja wystartowała 22 maja 1925, oficjalnie zaś etap zdjęciowy zakończono 17 miesięcy później, 30 października 1926 (same zdjęcia pochłonęły 310 dni i 60 nocy).

Klaus Kreimeier w swej arcyciekawej monografii największej niemieckiej kompanii filmowej uznaje Metropolis za film wręcz emblematyczny dla polityki Ufy w latach 20 . - z racji zarówno produkcyjnego rozmachu i warsztatowej perfekcji, jak i niesłychanego marnotrawstwa środków oraz ideowej czy znaczeniowej niezborności. Co więcej, rozmaite sprzeczności i losy filmu wydają się wręcz paradygmatyczne dla całej Republiki Weimarskiej. Kreimeier pisze: „Jeżeli istniała jakaś «estetyka Ufy»-estetyka, z którą wiązała się «filozofia», strategia marketingowa, relacja do zbiorowej świadomości i do struktury realnej władzy politycznej - to najwyraziściej została ona ucieleśniona w Metropolis Fritza Langa, filmie, który mógł powstać tylko w Niemczech, tylko w zenicie Republiki Weimarskiej i tylko w Neubabelsbergu. W filmie tym odnajdziemy wszystkie elementy, które umożliwiły zdominowanie przez Ufę kinematografii od 1917, które przyczyniły się do triumfów wytwórni i przywiodły ją na krawędź katastrofy, i które ostatecznie przyspieszyły jej podporządkowanie dyktaturze: pokaźny, beztrosko marnowany kapitał, talent do organizacji przedsięwzięcia na wielką skalę i skłonność do rozpraszania się w mikroszczegółach; dbałość o wysoki poziom artystyczny i jej wynaturzenie, pusty perfekcjonizm; upodobanie w pełnym inwencji zastosowaniu techniki i w jego rewersie, będącym zaledwie techniczną gładkością; dążenie do filozoficznego przesłania, ale przeprowadzane w intelektualnej próżni; «wolę formy», która wyprodukowała amorficzną ruinę; rzemiosło, wyobraźnię i uporczywość, a zarazem marnowanie wszystkich tych zalet przez intelektualną arogancję i brak nadrzędnego konceptu. Los Metropolis przypomina, z wielu względów, los pierwszej niemieckiej republiki"9.

Lang, jak to miał w zwyczaju, zmitologizował genezę filmu, wskazując jako zasadniczą jego inspirację panoramę rzęsiście oświetlonego Nowego Jorku widzianą w październiku 1924 z zakotwiczonego koło Ellis Island statku SS „Deutschland”, kiedy wskutek problemów wizowych wraz z towarzyszącym mu w podróży do Ameryki producentem Ufy, Erichem Pommerem, musiał przez jeszcze jedną noc pozostać na

7 Holger Bachmann, The Production and Contemporary Reception of "Metropolis", [w:] Fritz Lang's „Metropolis": Cinematic Visions of Technology and Fear, s. 30.

${ }^{8}$ P. McGilligan, op. cit., s. 115, 128.

${ }^{9}$ K. Kreimeier, op. cit., s. 151-152. 
pokładzie $^{10}$. „Widziałem ulicę oświetloną jakby w pełnym słońcu przez światła neonów i znajdujące się nad nimi gigantyczne świetliste reklamy poruszające się, obracające, rozbłyskujące, wirujące... było to $\mathrm{w}$ tamtych czasach coś kompletnie nowego i niemal bajkowego dla Europejczyka... Budynki zdawały się być jakimś pionowym welonem, świetliście rozedrganym, niemal nieważkim, luksusową tkaniną zwisającą z ciemnego nieba, by olśniewać, odwracać uwagę, hipnotyzować. Nocą miasto nie sprawiało wrażenia żywego; żyło, tak jak żyją iluzje. Wiedziałem już, że muszę zrobić film o wszystkich tych wrażeniach"11. W niemal tych samych, co przytoczone tu, słowach, w swym słynnym wywiadzie dla Gretchen Berg z 1965 r., tzw. wiedeńskiej nocy ${ }^{12}$, Lang opisuje swe wrażenia z pierwszej wizyty w Nowym Jorku; wynika jednak z kontekstu, iż są to już wrażenia z przechadzki po mieście, a nie zauroczenie panoramą Manhattanu widzianą ze statku. Prócz wrażeń urbanistycznych, olśnienia metropolią na nieznaną mu dotąd skalę, reżyser dorzucił tu niepokojące odczucie natury społecznej, ujrzenia w Nowym Jorku „gąszczu krzyżujących się licznych i sprzecznych sił ludzkich, zaślepionych i zderzających się nawzajem, $\mathrm{w}$ nieodpartym pragnieniu wyzysku innych, żyjących w permanentnym strachu"13. Rzecz jasna, tłumaczy to ex post genezę Metropolis jako filmu, w którym konflikt społeczny został rzutowany na supernowoczesna, zurbanizowaną scenerię. „Gdy wróciłem do Berlina, [...] Thea von Harbou zaczęła pisać scenariusz"14.

Choć oczywiście nie można negować, że Nowy Jork mógł zrobić na reżyserze wielkie wrażenie podczas jego amerykańskiej podróży jesienią 1924 r., to rozmaite fakty świadcza, iż mamy tu znowu do czynienia z typowym dla Langa "fabularyzowaniem” zarówno faktów swego życia, jak i okoliczności powstania swych filmów (vide: sen o „dobrotliwej Śmierci”

10 Zob. np.: T. Elsaesser, Metropolis, s. 9; Peter Bogdanovich, Fritz Lang in America, Studio Vista, London 1967, s. 15.

11 Fritz Lang, Was ich in Amerika sah, „Film-Kurier”, 11 Dezember1924. Na tę wypowiedź Langa powoływały się później rozmaite teksty omawiające Metropolis - np.: Anton Kaes, Metropolis: City, Cinema, Modernity, s. 146 (skąd cytat); Siegfried Kracauer, Od Caligariego do Hitlera: Z psychologii filmu niemieckiego, Filmowa Agencja Wydawnicza, Warszawa 1958, s. 127; Paul M. Jensen, The Cinema of Fritz Lang, A. S. Barnes \& Co.-A. Zwemmer Limited, New York-London 1969, s. 59; Frederick W. Ott, The Films of Fritz Lang, The Citadell Press, Seacaucus 1979, s. 124.

12 Fragmenty tego wywiadu opublikowano po polsku, nie wiedzieć czemu, tytułując go Wenecka noc (zob.: Wenecka noc, przeł. Ireneusz Dembowski, „Film na Świecie” 1978, nr 6, s. 53-54).

${ }^{13}$ Gretchen Berg, The Viennese Night: A Fritz Lang Confession, Parts One and Two, [w:] Fritz Lang, Interviews, ed. Barry Keith Grant, University of Mississippi, Jackson 2003, s. 68-69.

${ }^{14}$ Ibidem, s. 69. Por. także: A. Kaes, Metropolis: City, Cinema, Modernity, s. 148. 
czy „wyobrażony film” o „ucieczce z Niemiec"). Fakty mówią co innego - o projekcie Metropolis Erich Pommer wypowiadał się już publicznie po berlińskiej premierze Zygfryda zimą 1924 r., scenograf Erich Kettelhut już wiosną zapoznał się z pierwszą wersją scenariusza, zaś wiedeńska gazeta "Illustriertes Wiener Extrablatt” obwieściła w numerze z 4 lipca 1924, iż reżyser wraz ze swą żoną-scenarzystką po opuszczeniu stolicy Austrii udali się na wakacje w Alpy, do Salzkammergut niedaleko Salzburga, „by ukończyć scenariusz do swego nowego filmu Metropolis..."15 Wszystko to, rzecz jasna, nie wyklucza, że po amerykańskiej peregrynacji wizja Metropolis skonkretyzowała się dla Langa jako swego rodzaju mega-Nowy Jork.

Tradycyjnie już dla duetu Lang - von Harbou film i powieść Metropolis wzajemnie się promowały $\mathrm{w}$ precyzyjnie przeprowadzonej „kampanii multimedialnej”. Edycja książkowa, nakładem należącego do Alfreda Hugenberga ${ }^{16}$ wydawnictwa August Scherl Verlag, zbiegła się z premierą filmu (styczeń 1927), natomiast kilka miesięcy wcześniej, od sierpnia 1926, powieść Thei von Harbou ukazywała się w odcinkach na łamach pisma "Das Illustrierte Blatt”. Trudno powiedzieć, co było pierwsze - powieść czy scenariusz. Prawdopodobnie Thea von Harbou pisała powieść podczas pobytu Langa w Ameryce, ale wiemy o ich wcześniejszej wspólnej pracy nad scenariuszem ${ }^{17}$. Thomas Elsaesser odnotowuje różnice tekstu pomiędzy serializowaną a książkową edycją powieści, co sugeruje pewne jej przeróbki. Ponieważ zdjęcia ruszyły w maju 1925, to scenariusz musiał być już wtedy gotów, a powieść wydaje się zarówno poprzedzać scenariusz, jak i uzyskać definitywną postać już po jego powstaniu ${ }^{18}$ - zatem trudno mówić tu (jak np. w przypadku Doktora Mabuse, gracza, gdzie powieść Jacques'a niewątpliwie poprzedzała scenariusz) o adaptacji.

Przeciwko wersji reżysera o nowojorskiej impresji jako pierwszej inspiracji filmu przemawiają też świadectwa, iż w ciągu niemal całego roku 1924 Thea von Harbou oddawała się lekturom, przedstawiającym cywilizacje przyszłości, takim jak: fantastyczne powieści Jules Verne’a (500 milionów hinduskiej władczyni), Claude’a Farrère'a (Les Condamnés à mort) i Herberta George'a Wellsa (When the Sleeper Wakes), teatralna trylogia Georga Kaisera Koralle, Gas I i Gas II, sztuka Ernsta Tollera o zdławionej

15 Zob.: P. McGilligan, op. cit., s. 108-109; T. Elsaesser, Metropolis, s. 9-10.

16 Od marca 1927 objął on również kierownictwo Ufy.

17 Zob.: T. Elsaesser, Metropolis, s. 12.

18 Ibidem, s. 76. Zob. też: Leonardo Quaresima, Ninon, la hermana de Maria: "Metropolis" y sus variantes, „A Archivos de la Filmoteca de Valencia”, VI 1994, vol. 17, s. 5-7; H. Bachmann, The Production and Contemporary Reception of "Metropolis", s. 11. 
rewolucji robotniczej w latach 30. XIX w. Die Maschinenstürmer, Ottona Ludwiga Zwischen Himmel und Erde (skąd motyw walki na dachu katedry), Hugona von Hofmannstahla Das Salzburger Große Welttheater (skąd motyw "tańca śmierci") czy inna jeszcze sztuka XIX-wiecznego niemieckiego dramaturga C. D. Grabbego ${ }^{19}$. Rzecz jasna, nie jest to pełna lista tekstów, które wywarły wpływ na Metropolis, albo raczej - do których z pewnością sięgnęli Lang i von Harbou, kreując synkretyczny świat zarówno powieści, jak i filmu. Prócz Biblii (Ksiega Rodzaju, Apokalipsa, Ewangelie) trzeba tu wymienić Frankensteina Mary Shelley, L'Ėve future Augusta Villiers de L'Isle-Adama, sztukę Karela Čapka R.U.R. (wszystkie te utwory łączy motyw sztucznego człowieka), opublikowaną właśnie w 1924 powieść Berge, Meere und Giganten Alfreda Döblina, Wehikut czasu Herberta George'a Wellsa (motyw dolnego i górnego świata), Katedre Marii Panny w Paryżu Wiktora Hugo, a nawet... Quo vadis Henryka Sienkiewicza (motyw „kazań w katakumbach”). Z tym że w wypadku dwóch ostatnich dzieł to bezpośredni wpływ wywarły nie tyle same powieści, co raczej ich filmowe wersje w roku 1924 obecne na niemieckich ekranach: The Hunchback of Notre Dame (1923) Wallace'a Worsleya z Lonem Chaneyem w roli Quasimoda, oraz Quo vadis (1924) Artura Ambrosio, Gabriellina D’Annunzio i Georga Jacoby'ego, z Emilem Janningsem w roli Nerona. Wśród filmów, których wpływ na Metropolis wydaje się niewątpliwy, wymienić też trzeba Cabirię (1913) Giovanniego Pastrone (sekwencja Molocha), Gabinet doktora Caligari (1919) Roberta Wiene, sowiecki film fantastycznonaukowy Aelita (1924) Jakowa Protazanowa, Balet mechaniczny (1924) Fernanda Légera i Dudleya Murphy'ego (prolog z maszynami), L'Inhumaine (1924) Marcela L'Herbiera, czy wreszcie abstrakcyjne filmy Waltera Ruttmanna ${ }^{20}$.

Ta intertekstualność, która charakteryzowała także Zmęczona Śmierć czy Doktora Mabuse, gracza, w przypadku Metropolis jest jednak wyjątkowo imponująca, co czyni z tego filmu tekst postmodernistyczny avant la lettre, co więcej - sam schwytany w postmodernistycznej epoce w sieć intertekstualnych odniesień do siebie samego, „w takich «klasykach współczesności», jak Powrót Batmana (1992) i Gwiezdne wojny (1977), Brazil (1985), Terminator 2 (1991), Seven (1995), Dark City (1998) i Piaty element (1997), przede wszystkim zaś Blade Runner (1982) Ridleya Scotta [...]"21 Tom

19 Zob.: T. Elsaesser, Metropolis, s. 12-13.

${ }^{20}$ Pozwolę sobie pominąć tu uszczegółowienie, który z tekstów o Metropolis które źródła inspiracji wskazuje, gdyż albo przypis byłby zbyt skomplikowany, albo byłoby zbyt wiele przypisów w bliskim sąsiedztwie. W każdym razie powyższa lista jest moją „syntezą" inspiracji wskazywanych przez rozmaitych autorów.

${ }^{21}$ Ibidem, s. 57. 
Gunning wskazuje jednak, że entuzjazm epoki postmodernistycznej dla Metropolis (to właśnie w połowie lat 80., gdy pojawiła się wersja Morodera z rockową ścieżką dźwiękowa, film Langa stał się „"kultowy”) wynika jednak z czegoś więcej niż zwyczajna "cytatologia”. Jako tekst rozsadzany przez sprzeczności ideologiczne i estetyczne, łączący beztrosko kulturę popularną i wysoka, niewątpliwy kicz z równie niewątpliwym artyzmem, mógł być traktowany jako właśnie postmodernistyczny avant la lettre, będąc jednocześnie wdzięcznym obiektem symptomatycznych interpretacji czy krytyki ideologicznej, które stały się wtedy - i trwa to właściwie do dziś - podstawowym sposobem lektury i analizy filmów ${ }^{22}$. Co w wypadku Metropolis o tyle było ułatwione, iż pęknięcia i sprzeczności tekstu znajdują się tu właściwie na widoku i wcale nie trzeba dokopywać się ich pod na pozór oczywistą spójną i jednoznaczną powierzchnią. Być może zresztą dlatego współczesne, postmodernistyczne z ducha odczytania Metropolis, wydają się jakoś przedziwnie jałowe poznawczo i niesłychanie do siebie podobne w "dekonstrukcyjnym” eksplorowaniu psychoanalizy, krytyki ideologicznej, feminizmu, uderzając odbiorcę, gdy czytane hurtem - jak przydarzyło się to mnie, gdy przygotowywałem niniejszy rozdział - raczej swą monotonną i niezbyt klarowną retoryką niż merytorycznością ${ }^{23}$.

Ale z epoki, która rzuciła się do symptomatycznej lektury filmu Langa, wróćmy do jego własnej epoki, a ściślej - do momentu jego premiery. Nic dziwnego, że po tak rozbudzonych przez kampanię reklamową apetytach oczekiwania były ogromne. 10 stycznia 1927 w kinie Ufa-Palast am Zoo, najbardziej reprezentacyjnym przybytku X Muzy w Berlinie i „flagowym” kinie Ufy, zgromadziło się nie mniej niż 1200 widzów - w tym kanclerz Wilhelm Marx, kilkunastu ministrów i posłów do Reichstagu, ambasadorowie obcych państw, potentaci finansjery i przemysłu, i nawet przedstawiciele rodzin królewskich ${ }^{24}$. Projekcji towarzyszyła orkiestra, dyrygowana przez kompozytora Gottfrieda Huppertza, autora muzyki także

${ }^{22}$ Por.: Tom Gunning, The Films of Fritz Lang: Allegories of Vision and Modernity, BFI Publishing, London 2000, s. 53.

${ }^{23}$ Przykładem takich analiz są teksty zgromadzone w części III i IV antologii Mindena i Bachmanna Fritz Lang's "Metropolis": Cinematic Visions of Technology and Fear, s. 161-309); także np.: Paul Coates, Maria, mit i Inny: obraz, kult $i$ tabu, przeł. Teresa Rutkowska, „Kwartalnik Filmowy” 2003, nr 41-42 (wiosna-lato), s. 46-64. Miażdżącą krytykę retoryki tego typu analiz i interpretacji przeprowadza David Bordwell w książce Making Meaning: Inference and Rhetoric in the Interpretation of Cinema, Harvard University Press, Cambridge (Mass.)-London 1989.

${ }^{24}$ Por.: T. Elsaesser, Metropolis, s. 29; A. Kaes, Metropolis: City, Cinema, Modernity, s. 148. Liczbę 1200 widzów podaje Elsaesser, Kaes zaś dwukrotnie wyższą - 2,5 tys., która wydaje się wygórowana i nieprawdopodobna choćby z tego powodu, iż kino Ufa-Palast am Zoo mieściło nieco ponad 2100 widzów (por. informacja Holgera Bachmanna, The Production and Contemporary Reception of "Metropolis", s. 25). 
do Nibelungów $w^{25}$. Rozprowadzano także zestaw płyt gramofonowych, zawierających prócz orkiestralnej aranżacji muzyki Huppertza także słowne wprowadzenie do filmu, wypowiadane przez samego Langa. Prominentni widzowie otrzymywali oprawne w skórę luksusowe egzemplarze specjalnie zsynchronizowanej z premierą książkowej edycji powieści Thei von Harbou. A broszura, przygotowana na premierową galę, natychmiast stała się prawdziwym kolekcjonerskim rarytasem ${ }^{26}$.

Po tej pełnej splendoru premierze w Ufa-Palast am Zoo film przez około 3 miesiące wyświetlano jednak gdzie indziej - w specjalnie odnowionym na pokazy tak reprezentacyjnego filmu Ufa Pavillion na Nollendorfplatz. „Zewnętrzne ściany kina pokryto lśniącą srebrną powłoką. Olśniewający wspaniałym blaskiem nocą i łagodnie połyskliwy za dnia, budynek promieniał aurą niesamowitości i innego świata. Będąc zarazem chwytem reklamowym, jak i technicznym osiągnięciem, projekt srebrnego kina kojarzył nowoczesność z metaliczną maszynerią. Futurystyczna technika objawiała się nie tylko w fikcyjnym świecie filmu, ale i na zewnątrz, w przestrzeni publicznej, która stała się tym samym ekstensją scenografii filmu. Zbliżając się do kina, berlińczycy konfrontowani byli z gigantyczną stalową rzeźbą wziętą z planu filmowego i zamontowaną przy wejściu. Przypominająca gong rzeźba przedstawiała bijące serce, stanowiąc humanistyczny kontrapunkt dla chłodnego, mechanicznego wystroju ścian zewnętrznych. Centralny konflikt filmu, między maszynopodobną nowoczesnością a sentymentalizmem serca, był ewokowany jeszcze zanim przestąpiło się próg kina"27.

Po galowej projekcji reżyserowi, scenarzystce i odtwórcom głównych ról urządzono owację na stojąco, a podczas popremierowego przyjęcia dla ekipy "niepodzielnie panował duch powszechnego braterstwa”, jak to, czyniąc aluzję do moralnego przesłania i fabularnego finału filmu, nieco ironicznie ujął jeden ze scenografów, Erich Kettelhut ${ }^{28}$. Nazajutrz okazało się jednak, że te zachwyty (zresztą tradycyjne podczas premierowych gali czy snobistycznych wernisaży) bynajmniej nie udzieliły się wszystkim widzom ani recenzentom, a skutki ich braku entuzjazmu trwają do dziś w postaci definitywnego, jak się wydaje, zniszczenia filmu w tej postaci, w jakiej oglądali go widzowie pamiętnego wieczoru 10 stycznia 1927 w Ufa-Palast am Zoo i jeszcze przez kilkanaście tygodni w Ufa Pavillion.

${ }^{25}$ Szczęśliwie partytury do obu filmów zachowały się, i na przygotowanych przez Friedrich-Wilhelm-Murnau-Stiftung najnowszych płytowych edycjach Nibelungów i Metropolis możemy usłyszeć tę samą ilustrację muzyczną, co widzowie ich premier.

${ }^{26}$ Zob.: T. Elsaesser, Metropolis, s. 29.

27 A. Kaes, Metropolis: City, Cinema, Modernity, s. 148.

${ }^{28}$ Zob.: T. Elsaesser, Metropolis, s. 29-30. 


\section{Recepcja: między potęgą (obrazu) i absurdem (fabuły)}

Polaryzacja niemieckich opinii krytycznych po premierze Metropolis wydaje się dość podobna do biegunowości sądów o innych filmach Langa z lat 20.; a jednak tamte filmy - Zmęczona Śmierć, Doktor Mabuse, gracz, Nibelungi, Szpiedzy - okazały się w ostatecznym rozrachunku sukcesami zarówno artystycznymi, jak i komercyjnymi, podczas gdy Metropolis pozostaje jedną z największych $\mathrm{w}$ historii kina (i największą $\mathrm{w}$ dziejach kina niemieckiego) katastrof finansowych. Publiczność nie dopisała tak, jak na to liczyła Ufa, by choćby odzyskać wkład, nie mówiąc już o zyskach; zawojowanie zaś rynku amerykańskiego przez okrojoną i przemontowaną wersję okazało się zupełnie nierealne w dobie przygotowań hollywoodzkiego przemysłu filmowego do eksploatacji nowinki technicznej, która miała ściągnąć tłumy do kin: filmu dźwiękowego. Ciekawe zreszta, że zarówno afirmatywne, jak i negatywne recenzje jednogłośnie akcentowały budzącą niekłamany podziw, znakomitą stronę wizualną filmu i jego niesłychanie wysoki, niedościgniony nawet przez Amerykanów poziom techniczny. Afirmatywnym to wystarczało, by Metropolis uznać za arcydzieło i epokowe wydarzenie w dziejach kina, negatywne zaś uznały, że wizualna sugestywność i poziom warsztatu nie są w stanie zrównoważyć niedorzeczności i niespójności fabuły, naiwnego i dość podejrzanego ideowo przesłania, wreszcie zasadniczej fałszywości wizji przedstawionego świata jako modelu przyszłości.

Zacznijmy może od entuzjastów filmu. „Niemiecka prasa poprzez cały zakres politycznego spektrum wychwalała film jako znaczące osiągnięcie: liberalno-demokratyczny «Berliner Morgenpost» podziwiał «zdumiewające dzieło», «Der Tag» twierdził nawet: «Można to odczuć: jest to film nad filmy - Über-film!», a prawicowe gazety «Berliner LokalAnzeiger» (w posiadaniu Alfreda Hugenberga), «Deutsche Zeitung» i nacjonalistyczna «Neue Preußische Kreuz-Zeitung» wynosiły film jako «główne wydarzenie sezonu» $\mathrm{i}$ «największy jak dotąd film niemiecki»"29. Anonimowa recenzja $\mathrm{z}$ „Kinematograph” daje z kolei próbkę nie tyle niedostrzegania mankamentów filmu (bo zostały zauważone przez jej autora), ile ich zignorowania wobec jego warsztatowej doskonałości: „Istotnie, niektóre aspekty fabuły filmu mogą wydawać się dosyć dyskusyjne. Nie to jednak jest ważne w tym filmie, gdyż nawet wielkie role Alfreda Abla, Georgego, Klein-Roggego, całkiem udany występ Fröhlicha i doskonały Brigitte Helm, są wtórne wobec czysto dekoracyjnych i technicznych

29 Pressestimmen über „Metropolis”, ,Kinematograph”, 16 Januar 1927, s. 17-18 (cyt. za: H. Bachmann, op. cit., s. 27). 
aspektów filmu. To, co widzimy, jest w kategoriach czysto wizualnych wspaniałe. [...] Pomimo zastrzeżeń co do rozmaitych konkretów, jest to największy film, jaki kiedykolwiek zrealizowano w tym kraju"30.

Najbardziej wpływowi krytycy filmowi Republiki Weimarskiej Rudolf Arnheim, Willy Haas, Roland Schacht, Herbert Ihering, Paul Ickes, Axel Eggebrecht - akcenty jednak rozłożyli odwrotnie: imponująca strona wizualna i poziom techniczny nie mogą odkupić fabularnych nonsensów i myślowej miałkości Metropolis.

Arnheim omawia towarzyszącą Metropolis medialną wrzawę i konkluduje, że „zbudowany na pustyni scenariusza i powieści von Harbou” twór, jakim jest ten film, musiał w końcu okazać się jałowy. Owszem, film posiada niewątpliwą wartość wizualną, kilka wielkich scen (np. powódź) i parę znakomitych ról, ale treść jest godna politowania. Film ten uosabia fuzję kina amerykańskiego i niemieckiego; są tu, z jednej strony, chłopięce fantazje o stechnicyzowanej przyszłości, z drugiej zaś - rozmaite tradycje literatury europejskiej, bezładnie przemieszane. Nie ma za to śladów Neue Sachlichkeit - sztuki odzwierciedlającej współczesność. Sentymentalizm Thei von Harbou trzeba wręcz uznać za szkodliwy w zastosowaniu do tematyki społecznej. „Uwaga: wymanicurowane ręce nie powinny mieszać się do socjalizmu!" 31

Willy Haas, który opublikował swą recenzję pod inicjałami W. H., przyznaje, iż Metropolis jako cud techniki filmowej przewyższa nawet oczekiwania rozbudzone przez poprzedzające 1,5 roku premierę pogłoski i kampanię reklamowa, pozostawiając pod tym względem Amerykanów daleko w tyle. Lang doskonale kontroluje ruch w kadrze i jego kompozycję, kreując porywające efekty, jak np. w scenie, kiedy Maria w katakumbach zostaje schwytana w pułapkę przez punktowe światło latarki. Podziw budzą także plany ogólne miasta - z zawieszonymi w przestrzeni stalowymi mostami, po których pojazdy zdają się płynąć, z unoszącymi się lekko w przestworzu samolotami. Ale zawartość treściowa i myślowa jest niewspółmiernie nikła do kosztów i wysiłku realizacji. Scenariusz wziął drobne, starannie odmierzone porcyjki rozmaitych aspektów histo-

30 Anonim, Metropolis, „Kinematograph”, 16 Januar 1927, s. 21 (cyt. za: Fritz Lang's "Metropolis": Cinematic Visions of Technology and Fear, s. 83).

31 Rudolf Arnheim, „Metropolis”, „Das Stachelschwein”, 1 Februar 1927, s. 52-53 (przedruk: Rudolf Arnheim: Kritiken und Aufsätze zum Film, Red. Helmut H. Diederichs, Fischer, München 1976, s. 184-186). Por. także: E. Ann Kaplan, Fritz Lang: A Guide to References and Resources, G. K. Hall \& Co., Boston 1981, s. 147. Z zarzutem nieobecności Neue Sachlichkeit nie zgodzi się po latach Andreas Huyssen, dostrzegając w Metropolis stop estetyki ekspresjonizmu i właśnie Neue Sachlichkeit (zob.: Andreas Huyssen, The Vamp and the Machine: Fritz Lang's "Metropolis", [w:] Fritz Lang's "Metropolis: Cinematic Visions of Technology and Fear, s. 200-201, 215). 
rii świata i wymieszał je na aluzyjno-alegoryczną modłę: „Trochę chrześcijaństwa, z ideą "pośrednika», religijnej posługi w katakumbach, świętej matki ludzkości Marii [...] jako substytutu nieobecnego syna; trochę socjalizmu, z całkiem nowoczesnym kultem maszyny, zniewolonym i obrabowanym $\mathrm{z}$ dusz proletariatem, i doskonała, by ując to $\mathrm{w}$ kategoriach całkowicie marksistowskich, «akumulacją kapitału», która czyni z jednego człowieka niewidzialnego władcę świata; trochę nietzscheanizmu, z kultem nadczłowieka. Wszystko jest wymieszane tak uważnie, by scenariusz gładko uniknął jakiejkolwiek bezkompromisowej idei, by żadna «tendencja» - Boże broń! - nie była w stanie się rozwinąć"32. Taki eklektyzm i bezkonkluzywność jest zresztą przekleństwem Großfilme, czyli wysokobudżetowych produkcji, takich jak Metropolis: muszą dostosować się do każdego smaku, nikogo nie urazić i być całkiem niezobowiązujące ideowo, "dając po trochu ze wszystkiego i tak naprawdę niczego z czegokolwiek". Metropolis sięga w przeszłość (średniowieczny i romantyczny gotycyzm) i w przyszłość, by faktycznie uniknąć problemów dnia dzisiejszego. Jedyny naprawdę intrygujący motyw tego filmu to wątek dualizmu kobiecej natury, rozpiętej między czystością a piekłem rozpętanych żądz - przez sentymentalną scenarzystkę raczej jednak niezamierzony ${ }^{33}$.

Roland Schacht skomponował swą recenzję odwrotnie niż Haas, pointując ją komplementami dla strony warsztatowej, niedościgłej nawet dla Amerykanów, rozpoczynając zaś od sentymentalizmu Thei von Harbou, która swym pomysłem „serca pośredniczącego między rękoma a rozumem" dostarcza nieadekwatnego remedium dla rozwiązania rozmaitych bolączek społecznych. Metropolis, zdaniem Schachta, to film zarazem piękny i mętny, oryginalny i niesmaczny, fantastyczny i perwersyjny. Zaczyna się znakomicie, nieskazitelnymi obrazami, lecz później robi się pompatyczny, a fabuła grzęźnie w przytłaczających scenach masowych ${ }^{34}$.

Herbert Ihering nazywa Metropolis „światopoglądowym filmem bez jakiegokolwiek światopoglądu" (ein Weltanschauungsfilm ohne Weltanschauung $)^{35}$. Nie do pogodzenia są zresztą ze sobą wizja stechnicyzowanego miasta przyszłości i nieznośny sentymentalizm anegdoty. „Thea von Harbou wymyśla absurdalną fabułę, której tematy i motywy trzeszczą

32 Willy Haas, Two Major Film Premieres, transl. Holger Bachmann, Meg Tait, [w:] Fritz Lang's "Metropolis": Cinematic Visions of Technology and Fear, s. 85 [prwdr.: W. H., Zwei große Filmpremieren, „Die Literarische Welt” 1927, Nr. 3 (21 Januar), s. 7].

33 Ibidem, s. 84-86 (prwdr.: s. 7).

${ }^{34}$ Roland Schacht, Der Metropolisfilm der Ufa, "Der Kunstwart” 1927, Nr. 5 (referuję za: E. Ann Kaplan, op. cit., s. 152).

${ }^{35}$ Holger Bachmann taką bezideowość przy pozorach ideowości uważa za reprezentatywną dla kina weimarskiego i kultury Republiki Weimarskiej w ogólności. Zob.: H. Bachmann, The Production and Contemporary Reception of "Metropolis", s. 10. 
w szwach. Fritz Lang stylizuje te założenia i pozwala, by jeden obraz walczył z drugim. Średniowieczny taniec śmierci tu, nowoczesny taniec śmierci tam. Tu aluzje do naszej epoki, tam aluzje do naszego kulturowego dziedzictwa, ale żadna orientacja z tych tematów nie wynika". Zreszta, wymogi współczesnego Großfilm i regresywna, powieściowa wyobraźnia Thei von Harbou niewiele mają ze sobą wspólnego ${ }^{36}$.

Co ciekawe, jeden z najostrzejszych i najbardziej złośliwych retorycznie ataków na film wyszedł od Paula Ickesa, redaktora naczelnego branżowego magazynu „Die Filmwoche”, którego właścicielem był powiązany z Ufą i już niebawem mający nią rządzić Alfred Hugenberg. Ickes, choć poświęcił stronę tytułową pisma superprodukcji Ufy, w recenzji nie zawahał się w mocnych słowach skrytykować rozziewu między jej techniczną perfekcją a myślową pustką: „Wielce Łaskawa Pani von Harbou, film ten głęboko mnie zatroskał; nie widziałem dotąd filmu, który tak pozbawiłby mnie zabawy i zmusił do roztrząsania wątpliwości $\mathrm{w}$ takim stopniu i przez tak długi czas. I Drogi Panie Lang: pomimo nieludzkiego wkładu pracy, w aspekcie tematycznym jest to chyba film najbardziej beznadziejny z możliwych. [...] Drogi Panie Lang, niech Pan przykłada większą uwagę do zwykłego zdrowego rozsądku - tylko on naprawdę się liczy, niech Pan nie myśli zawsze wyłącznie o pojedynczych obrazach! Jest to Pańskim nieszczęściem, że liczy się dla Pana tylko obraz, a nie idea: jest Pan więźniem obrazów. Proszę nie wątpić, iż wiele z Pańskich obrazów jest cudownych, że technika jest wyborna - ale całość musi mieć znaczenie i treść, musi być dla nas sensowna!" ${ }^{37}$

Równie jadowita jest recenzja Axela Eggebrechta, który uznaje Metropolis zarówno za prawdziwe zwierciadło epoki (Zeitspiegel), jak i za gigantyczny labirynt półprawd i nieporozumień. Lang zamierzył zobrazować rozmaite tendencje i możliwości Zeitgeistu, i pogodzić je w jakimś „Super-Chicago" przyszłości. Zaczerpnął trochę z klasowej świadomości, trochę z wielkoprzemysłowego cezaryzmu, sporo z siły Kościoła i wymieszał to wszystko z setką innych konceptów. Autorka powieści i scenariusza zapomniała jednak dostarczyć filmowi jakiejś nadrzędnej, wiodącej idei. Olbrzymia układanka żałośnie się rozpada. Langowi brakuje elementarnego choćby zrozumienia technologii przemysłowej jego własnej epoki, toteż przedstawia jako problem coś, co dawno już przezwyciężono.

${ }^{36}$ Herbert Ihering, Der Metropolis-Film, „Berliner Börsen-Courier”, 11 Januar 1927 (przedruki: Herbert Ihering, Von Reinhardt bis Brecht: Vier Jahrzehnte Theater und Film, vol. 2: 1924-1929, Aufbau Verlag, Berlin 1959, s. 523-524; lub: Herbert Ihering, The "Metropolis"Film, transl. Holger Bachmann, Meg Tait, [w:] Fritz Lang's „Metropolis": Cinematic Visions of Technology and Fear, s. 86-87).

37 Paul Ickes, Kritik der Leinwand: „Metropolis”, „Die Filmwoche”, 19 Januar 1927, s. 60 (cyt. za: H. Bachmann, op. cit., s. 29). Podkreślenie autora. 
Dzieło jego jest typowym przykładem reakcyjnego wpływu domniemanie postępowej klasy intelektualistów w przejściowej fazie historii. Fałszywe jest sportretowanie przez niego tak proletariatu, jak i psychologii kapitalisty. Aby ożywić przyszłość, której nie potrafi sobie wyobrazić, Lang ożywia symbole przeszłości. Konstruktor sztucznego człowieka ma atrybuty, strój i pentagram doktora Faustusa, nierządnica babilońska tańczy pośród panów z wyższych sfer, masy znikają w żarłocznej gardzieli bożka Molocha. A w pojednaniu mózgu i rąk miasta przez serce syna bogatego władcy (to zresztą najsłabsza część filmu) odczuć można rozpaczliwą tęsknotę epoki za baśniowym happy endem rozwiązującym wszystkie jej problemy. Film ten jest banałem niewiarygodnych rozmiarów. Prawdziwy geniusz wizualny dwóch operatorów pracował na marne ${ }^{38}$.

Fred Hildebrandt, który wcześniej odwiedzał plan filmowy Metropolis i był pod dużym wrażeniem tego, co tam zobaczył, w artykule opublikowanym nazajutrz po premierze zreferował to, co usłyszał w berlińskim barze "Schwannecke", odwiedzanym przez artystów i intelektualistów; 10 stycznia 1927 było tam wielu widzów premierowego pokazu. Chwaląc cudowne zdjęcia i niezrównaną technikę, wskazywali jednak przede wszystkim słabe strony filmu: sztuczną, wymyślną fabułę, fałszywą moralność, sentymentalny i pretensjonalny kicz, zgrane tricki (obok nowych), pusty symbolizm, pustosłowie dialogów, nadmiernie ciążenie bądź to ku realizmowi, bądź ku romantyzmowi, nieprawdopodobną treść, zbytnią zależność od powszechnie znanych dzieł literackich. Hildebrandt dominujące rozczarowanie wiąże z rozbudzonymi uprzednią kampanią reklamową i hałaśliwą publicity nadmiernymi oczekiwaniami publiczności ${ }^{39}$.

Podobną biegunowość zalet (strona wizualna, technika) i wad filmu (absurd fabuły, mętność ideowa) wskazują nie tylko niemieckie, ale i zagraniczne recenzje z 1927 r. I podobnie jak w niemieckich, akcent pada w nich raczej na stronę negatywną, przesądzająca, że jest Metropolis filmem nieudanym. Trzeba jednak pamiętać, że recenzenci i widzowie amerykańscy, brytyjscy czy zachodnioeuropejscy mieli do czynienia z wersjami okrojonymi, znacznie krótszymi, z których usunięto całe sekwencje, przez co fabuła mogła widzom wydać się jeszcze mniej sensowna i logiczna niż publiczności, która oglądała film na berlińskiej premierze czy jeszcze przez kilkanaście tygodni w „Ufa Pavillion”. Wśród najsłynniejszych

38 Axel Eggebrecht, „Metropolis”, „Die Weltbühne”, 1927 Nr. 3 (18 Januar). Referuję za: E. Ann Kaplan, op. cit., s. 149-150. Ciekawe, że ta bardzo negatywna recenzja posłużyła się pewnym fikcyjnym konceptem - historii filmu napisanej w roku 2003. Tymczasem mamy tę datę za soba, a Metropolis stało się filmem „kultowym”, znacznie lepiej ocenianym z perspektywy historii kina niż $\mathrm{w}$ roku premiery.

39 Fred Hildebrandt, „Metropolis”, „Berliner Tageblatt” 1927, Nr. 17 (11 Januar). Referuję za: E. Ann Kaplan, op. cit., s. 151-152. 
zagranicznych recenzji należy z pewnością wymienić teksty Luisa Buñuela, Iris Barry i Herberta George'a Wellsa, często przywoływane w rozmaitych tekstach o Metropolis, cytowane, antologizowane.

Buñuel wyraźnie podkreśla pęknięcie filmu: „Metropolis to nie jeden film. Metropolis to dwa filmy, połączone wspólnym biodrem, ale o rozbieżnych dążeniach duchowych, które są sobie diametralnie przeciwne. $\mathrm{Ci}$, którzy pojmują kino jako prosty mechanizm opowiadania historii, będą Metropolis głęboko rozczarowani. To, co ten film opowiada, jest banalne, nadęte, pedantyczne i staroświecko romantyczne. Ale jeśli od fabuły wolimy «plastyczno-fotogeniczne» tło filmu, wtedy Metropolis spełni nasze najdziksze marzenia jako najbardziej zdumiewająca księga obrazów, jaką można skomponować. Składa się zatem z dwóch sprzecznych pierwiastków [...] Pierwszy z nich, który moglibyśmy nazwać «czysto lirycznym» jest doskonały, drugi - anegdotyczny czy też ludzki, bywa irytujący. [...] Nie pierwszy to raz, kiedy obserwujemy taki niepokojący dualizm w dziele Langa. Przykład: niewypowiedzianie piękny poemat Zmęczona Śmierć zawierał fatalne, krańcowo niesmaczne sceny. Jeżeli rola współwinowajcy przypada tu Langowi, to jako autora tych eklektycznych poczynań, tego niebezpiecznego synkretyzmu, trzeba potępić jego żonę, scenarzystkę Theę von Harbou" ${ }^{\prime 0}$.

Buñuel wychwala dalej pracę świetnego operatora Karla Freunda, architekta Ottona Hunte i mylnie przypisuje współudział w realizacji Walterowi Ruttmannowi. Być może dlatego, że najbardziej zachwyca go w Metropolis to, co bliskie jest uprawianemu przez Ruttmanna filmowi „,czystemu" czy „, absolutnemu” : „[...] jakaż fascynująca symfonia ruchu! Jak maszyny śpiewają pośród wspaniałej przejrzystości, «Łuku Triumfalnego» utworzonego przez iskrzenia elektryczności! [...] Najjaśniejszy błysk stali, rytmiczne następstwo kół, tłoków, nigdy dotąd niestworzonych mechanicznych form, kreują niewidziany dotąd poemat dla oczu. Fizyka i Chemia zostają cudownie przekształcone w rytmikę. Ani jednego statycznego momentu! Nawet napisy, wznosząc się, opadając, obracając, gwałtownie wpadając w odpryski światła czy uchodząc w cień, stają się częścią ogólnego ruchu: im także udało się zostać obrazami" ${ }^{41}$.

Ale prócz tych czysto wizualnych jakości jest jeszcze nieszczęsna anegdota. I tłum, który zamiast być podmiotem działań, motorem akcji, jak w Eisensteinowskim Pancerniku Potiomkinie, pełni rolę jedynie czysto dekoracyjną jakiegoś baletu na wielką skalę, który ma nas jedynie

40 Luis Buñuel, "Metropolis", transl. Carol O'Sullivan, [w:] Fritz Lang's "Metropolis": Cinematic Visions of Technology and Fear, s. 106 [prwdr.: "Gazeta Literaria de Madrid” 1927; przedruk także w: „Cahiers du Cinéma” 1971, no. 223 (août - septembre), s. 20-21].

${ }^{41}$ Ibidem, s. 107. 
zachwycić piękną choreografia, nie objawiając duszy, czynnika ludzkiego. Choć są też sceny - jak sekwencje Wieży Babel, robotniczej rewolty czy egzekucji robota - gdzie oba bieguny tłumu, podmiotowy i przedmiotowy, osiągają pełny potencjał.

Tyle tylko, że wykreować tę fotogenię można było znacznie mniejszym kosztem. Buñuel porównuje Metropolis, film o horrendalnym budżecie, ze skromnym filmem Alberto Cavalcantiego Mijaja godziny (Rien que les heures), który kosztował zaledwie 35000 franków. „Na początku musi być wrażliwość i inteligencja; wszystko inne, nie wyłączając pieniędzy, jest wtórne" 42 .

Iris Barry, przyszła dyrektor archiwum filmowego w nowojorskim Museum of Modern Art, opublikowała w londyńskim "Spectatorze" recenzję, mimo pewnych zastrzeżeń, dla Metropolis jedną z najpochlebniejszych. Rozmaite mankamenty filmu Langa kładzie ona na karb nie tyle znakomitych niemieckich realizatorów, tematu czy parabolicznego charakteru filmu, ile raczej niedojrzałości środków wyrazowych samego kina, medium o mentalności 17-latka. Barry podziwia wyobraźnię reżysera, jego architektów i scenografów, która dała życie wiarygodnej wizji miasta przyszłości, potrafiła przekonująco przedstawić takie cuda, jak stworzenie sztucznego człowieka czy telewizja. Równie sugestywne i budzące nasze współczucie jest przedstawienie zniewolenia robotników w tym zmechanizowanym świecie. Fałszywe wydaje się natomiast przedstawienie bytowania klasy wyższej, przebranej w niewiarygodne kostiumy, zabawiającej się w kiczowatych, zapełnionych pawiami „wiecznych ogrodach rozkoszy". Jest tu zresztą niespójność stylistyczna, bo ekspresjonistyczne i naturalistyczne partie filmu (właśnie prezentujące proletariat) sąsiadują z obrazami o charakterze pocztówek. Fabuła - o melodramatyzmie iście Griffithowskim - jest najsłabszą stroną filmu (okropne i w dużej mierze zbędne są też napisy), ale niedojrzałe medium ciągle zatroskane jest bardziej same sobą niż tym, co można poprzez nie powiedzieć. I tak jednak Metropolis to "najdoroślejszy” z powstałych dotąd filmów. Prawdziwą wielkość osiąga w choreografii tłumów, architekturze, kompozycji obrazu, fotografii, aktorstwie (zwłaszcza, kiedy widać jego stylizację). Wielkie momenty filmu to oblekanie się robota $\mathrm{w}$ ciało oraz dwa inne: jeden, kiedy fałszywa Maria mruga do władcy Metropolis, drugi, kiedy nadzorca przywołuje gwizdem do porządku zrewoltowanych robotników. Pierwszy, ,który łatwo mógłby stać się zaledwie komiczny, rodzi wysoce dramatyczny efekt, niczym retoryczna fraza w dramacie elżbietańskim; mówi nam on wszystko o robocie". Drugi, który umyka na wpół niedostrzeżony, „mówi nam wszystko o robotnikach”. Co ciekawe, Barry nie

${ }^{42}$ Ibidem, s. 107-108. 
dyskwalifikuje społecznego tematu filmu, zastanawiając się na koniec swej recenzji, jak odbiorą film w przemysłowym Glasgow lub w górniczych regionach południowej Walii, oraz czy zaproszenia nań dostali członkowie Związku Właścicieli Kopalń? ${ }^{43}$

Recenzja Herberta George'a Wellsa, opublikowana w ,The New York Times Magazine" ${ }^{\prime 4}$, a później z dużą dozą Schadenfreude przedrukowana i przywoływana $\mathrm{w}$ prasie niemieckiej ${ }^{45}$, należy do najbardziej miażdżących krytyk filmu. Wells, bodaj najwybitniejszy z wówczas żyjących pisarz science-fiction, skrytykował aspekty tematyczne Metropolis, w odróżnieniu od innych recenzentów nie znajdując ani jednego dobrego słowa dla wizualnej i technicznej strony filmu („Nie potrafię sobie wyobrazić, na co wydano tak ogromne sumy. Większość efektów można było osiągnąć przy użyciu modeli, które drogie nie są"46). Pisarz zaczyna od nazwania Metropolis najgłupszym filmem, jaki widział. Metodę „,zapożyczania" przez Theę von Harbou motywów ze światowej literatury nazywa wprost plagiatowaniem - wskazując jako źródło fabularnych pomysłów scenarzystki R.U.R. Karela Čapka, Frankensteina Mary Shelley, a przede wszystkim własną powieść When the Sleeper Wakes (Kiedy śpiacy budzi się, $1899)^{47}$. Wells uznaje przeniesienie własnych młodzieńczych idei sprzed 30 lat do współczesnego filmu o ambicjach futurystycznej prognozy za naiwne i anachroniczne - np. społeczny i ekonomiczny rozwój XX-wiecznych miast amerykańskich wskazuje całkiem inny kierunek rozwoju niż jego jeszcze XIX-wieczna powieść i film Langa. Robotnicy przyszłości nie tylko nie będą otumanionymi niewolnikami maszyn, ale będą musieli posiadać wysokie kompetencje do ich obsługi. Mechanizacja nie tylko nie zniewoli klasy robotniczej, ale przyczyni się do wzrostu zarobków, upodmiotowienia robotników i wzrostu produkcji (tymczasem nie widać, by maszyny w Metropolis cokolwiek produkowały - jedynym ich celem wydają się męczarnie obsługujących je ludzi). Zresztą wiele rzeczy w tym filmie jest bezcelowych i niewytłumaczalnych - dlaczego np. Wieżę

43 Iris Barry, The Cinema: "Metropolis”, „Spectator”, 26 March 1927, s. 540 (przedruk: Fritz Lang's "Metropolis": Cinematic Visions of Technology and Fear, s. 104-105).

${ }^{44}$ Herbert George Wells, Mr. Wells Reviews a Current Film, „The New York Times Magazine”, 17 April 1927, s. 4, 22 (przedruk [w:] Fritz Lang's „Metropolis": Cinematic Visions of Technology and Fear, s. 94-100).

45 Przekład niemiecki recenzji Wellsa opublikowano we „Frankfurter Zeitung”, 3 Mai 1927. Komentarze: Filmschau: "Metropolis", "Der Bildwart”, April/Mai 1927, s. 326-329; Hans Siemsen, Eine Filmkritik, wie sie sein soll, „Die Weltbühne” 1927, Nr. 24 (14 Juli), s. 947-950.

${ }^{46}$ Fritz Lang's "Metropolis": Cinematic Visions..., s. 99.

47 Swoją drogą ciekawe, że Wells nie wskazuje tu jako źródła innej swej, z pewnością bardziej znanej powieści - Wehikut czasu (The Time Machine), która również przychodzi do głowy jako inspiracja dla Thei von Harbou. 
Babel muszą budować niezliczone rzesze... łysych? Ukoronowaniem „debilizmu" filmu jest nadanie robotowi podobieństwa do Marii, co wiąże go z niemieckim upodobaniem do motywów demonicznych, niesamowitych i magicznych, w których jak się wydaje lubują się też produkcje Ufy („Noc Walpurgi patronuje niemieckiej wyobraźni poetyckiej, a narodowa wyobraźnia nieustannie wspiera się miotłą między nogami" ${ }^{48}$ ). Całość jest nudna, męcząca, pozbawiona humoru. Zamiast bezwstydnie naśladować powieść sprzed 30 lat, ożywiając banalne morały z epoki wiktoriańskiej, lepiej by było, gdyby skonsultowano prognozy dotyczące rozwoju techniki, architektury, przemysłu, trendów społecznych, autorstwa kompetentnych ekspertów, których nie brakuje. Widząc tłumy widzów, zwabionych na mocno nagłośnioną premierę, Wells zastanawia się, jak ocenią oni zaprezentowaną w Metropolis wizję przyszłości: „Nie wiem, czy uznają za beznadziejnie głupi ów film, czy ocenią jako beznadziejnie głupią przyszłość rodzaju ludzkiego - ale z pewnością trzeba przyjąć, że albo jedno, albo drugie" ${ }^{\prime \prime 9}$.

Oczywiście, Wells miał wiele racji, krytykując jako nieuzasadnioną i mało prawdopodobną wizję przyszłości w filmie Langa. Ironia losu sprawiła jednak, że Metropolis jest dziś powszechnie znanym, „kultowym” utworem, podczas gdy jego własna odpowiedź na Metropolis - Rok 2000 (Things to Come, 1936), okazała się znacznie większym niewypałem: ponosząc klęskę kasowa, wzbudzając w roku premiery salwy (niezamierzonego) śmiechu widowni i będąc dziś filmem niemal zupełnie zapomnianym ${ }^{50}$. Nie mówiąc już o tym, że prognozy „eksperta” okazały się równie chybione, jak kiczowata wizja Thei von Harbou; jak i ona, przedstawiały „kształt rzeczy, które nigdy nadejść nie miały”.

\section{W poszukiwaniu pierwotnego tekstu: wciąż-odbudowywana-ruina}

Wersja Metropolis, oglądana przez widzów pierwszej berlińskiej premiery, liczyła 4189 metrów i trwała 153 minuty przy tempie projekcji 24 klatki na sekundę - takie przynajmniej parametry wynikają z zapisów urzędu

${ }^{48}$ Fritz Lang's "Metropolis": Cinematic Visions..., s. 98.

49 Ibidem, s. 100.

${ }^{50}$ H. G. Wells na podstawie własnej rozprawy The Shape of Things to Come (Ksztatt rzeczy, które nadejda) przygotował scenariusz filmu Things to Come (Rok 2000 to polski tytuł ekranowy). Była to prestiżowa i niesłychanie droga (350 000 funtów) produkcja Alexandra Kordy, pomyślana właśnie jako bezpośrednia odpowiedź Wellsa na Metropolis (tak sugeruje Holger Bachmann - op. cit., s. 41). Na temat samego filmu, wyreżyserowanego przez Williama Camerona Menziesa, zob.: Andrzej Kołodyński, 100 filmów angielskich, Wydawnictwa Artystyczne i Filmowe, Warszawa 1975, s. 36; idem, Dziedzictwo wyobraźni: Historia filmu sf, Wydawnictwa "Alfa”, Warszawa 1989, s. 72-75. 
cenzorskiego (Filmprüfstelle), który dopuścił film na ekrany 13 listopada $1926 r{ }^{51}$ Wersję tę prócz berlińczyków obejrzeć mogli (choć nie jest to całkiem pewne) także widzowie $\mathrm{w}$ Wiedniu ${ }^{52}$ i w Szczecinie ${ }^{53}$. Ale jeszcze przed tą premiera, w grudniu 1926 przedstawiciel Ufy na Stany dostarczył za ocean jeden z trzech oryginalnych negatywów z przeznaczeniem przygotowania wersji filmu na rynek amerykański (konsekwencją osławionej umowy Parufamet, w zamian za pożyczkę $4 \mathrm{mln}$ \$ uzależniającej Ufę od amerykańskich rywali, było m.in. przyznanie w 1926 wyłącznych praw do wersji amerykańskiej Paramountowi). Kierownictwo Paramountu krytycznie oceniło pierwotną wersję: wedle hollywoodzkich kryteriów był to film bez gwiazd, z mało wyrazistą linią fabularna, a na domiar złego dwuipółgodzinny czas projekcji znacznie wykraczał ponad rozmiary standardowego seansu. Podjęto zatem decyzję o skróceniu filmu do godziny i trzech kwadransów, tj. z dwunastu szpul do standardowych siedmiu ${ }^{54}$.

Zadanie skrócenia filmu z jednoczesnym napisaniem na nowo napisów i skomponowaniem ciągłej, logicznej linii fabularnej powierzono zespołowi pod kierownictwem specjalnie wynajętego do tego zadania dramaturga, Channinga Pollocka. Wyprodukował on dwie wersje, bardzo do siebie zbliżone, ale nie identyczne - jedną przeznaczoną na rynek amerykański, drugą na brytyjski i Commonwealthu. 7 marca 1927 w nowojorskim kinie "Rialto” w obecności około 10000 widzów miała miejsce premiera wersji amerykańskiej, skróconej o jedną czwartą, do długości $3170 \mathrm{~m}^{55}$. Równie wielkie zainteresowanie towarzyszyło

51 Por.: T. Elsaesser, Metropolis, s. 30; Enno Patalas, The City of the Future - A Film of Ruins: On the Work of Munich Film Museum, transl. Holger Bachmann, Meg Tait, [w:] Fritz Lang's "Metropolis": Cinematic Visions of Technology and Fear, s. 113-114. Przy innej prędkości wyświetlania pierwotna wersja mogła trwać do nawet 205 minut (por.: T. Elsaesser, Metropolis, s. 31).

52 Premiera wiedeńska miała mieć miejsce 10 lutego 1927 - jedynym źródłem, które ją odnotowuje jest: Bernard Eisenschitz, "Metropolis", UFA et le cinéma allemand, [w:] "Metropolis": Images d'un tournage, Cinémathèque Française, Paris 1985, s. 142.

53 Enno Patalas twierdzi w wywiadzie udzielonym Lorenzo Codellemu, że premierową wersję berlińską pokazano też „przez omyłkę" w Szczecinie [zob.: Lorenzo Codelli, Wywiad z Enno Patalasem, konserwatorem Filmoteki Monachijskiej (o "Metropolis" i kilku innych filmach Fritza Langa), przeł. Ireneusz Dembowski, "Film na Świecie” 1985, nr 318-319 (czerwiec-lipiec), s. 90].

${ }^{54}$ T. Elsaesser, Metropolis, s. 30.

55 Elsaesser (op. cit., s. 30) podaje 7 III 1927 jako datę nowojorskiej premiery oraz 3100 m jako długość wersji Pollocka. 5 III 1927 jako datę premiery w kinie „Rialto” podaje Holger Bachmann (op. cit., s. 37). Natomiast długość wersji amerykańskiej na $3170 \mathrm{~m}$ podaje Giorgio Bertellini (Restoration, Genealogy and Palimpsests: On Some Historiographical Questions, [w:] Fritz Lang's "Metropolis": Cinematic Visions of Technology and Fear, s. 149; prwdr: „Film History” 1995, vol. 7, no. 3 (Autumn), s. 277-290. 
premierze londyńskiej, która miała miejsce 21 marca w Marble Arch Pavilion $^{56} .13$ marca 1927 w „New York Times” ukazał się dość kuriozalny tekst, autorstwa Randolpha Bartletta, uzasadniający konieczność przemontowywania i skracania dla widowni amerykańskiej filmów niemieckich, gdyż jakkolwiek Niemcy wspaniale kreują obraz i posługują się światłem, nie mają wyczucia filmowej dramaturgii i nie potrafią komponować sensownych fabuł. Bartlett, który znał niemiecką wersję, ocenia przeróbki dokonane przez zespół w składzie Channing Pollock, Julian Johnson i Edward Adams jako „największe znane mu osiągnięcie sztuki montażu" i wyraża przypuszczenie, że wersja, którą można zobaczyć w "Rialto" bliższa jest idei Fritza Langa niż ta obecna na ekranach niemieckich ${ }^{57}$. Metropolis, przy okazji premiery którego pojawił się ów tekst, było tylko jedną z egzemplifikacji - główną co prawda - w uzasadnianiu notorycznego procederu amerykańskich dystrybutorów, bez skrupułów masakrujących na rodzimy rynek produkcję potencjalnie najniebezpieczniejszego konkurenta Hollywoodu.

Gdy po paru tygodniach eksploatacji okazało się, że film cieszy się w Berlinie znacznie mniejszym powodzeniem niż oczekiwano, 5 kwietnia 1927 Rada Nadzorcza Ufy podjęła decyzję, by przygotować nową wersję dla dystrybucji na Niemcy, podążając zasadniczo za skrótami poczynionymi w wersji Pollocka (sugerowano szczególnie, by maksymalnie wyeliminować napisy z "komunistycznymi podtekstami”). Dystrybutorzy mieli natychmiast wstrzymać pokazy filmu i wypuścić nowo opracowaną wersję w sierpniu. 5 sierpnia urząd cenzorski, Filmprüfstelle, dopuścił na ekrany drugą wersję niemiecką, skróconą do 3241 metrów (zatem nieco dłuższą od amerykańskiej, ale zasadniczo podążającą za zmianami przez nią dokonanymi). Nie tylko dokonano skrótów, ale zredagowano też na nowo napisy - z pierwotnych 175 napisów na planszach 36 wyeliminowano, a 45 zmieniono. Prawdopodobnie z powodu kosztów i presji czasu Ufa, przygotowując wersję na drugą premierę niemiecką, dokonała cięć $\mathrm{w}$ oryginalnym negatywie i zaniedbała sprawę zachowania wyciętego materiału (około $1000 \mathrm{~m}$ ), zawierającego wiele scen bardzo podziwianych podczas premiery styczniowej. Gdy zatem 26 sierpnia 1927 film Langa w nowej, skróconej wersji, po raz drugi miał swą premierę na ekranach Niemiec (tym razem $\mathrm{w}$ całym kraju), postać, w jakiej oglądano Metropolis nie tylko na pierwszej

${ }^{56}$ H. Bachmann, op. cit., s. 37; T. Elsaesser, Metropolis, s. 30.

57 Randolph Bartlett, German Film Revision Upheld as Needed Here, „The New York Times", 13 March 1927 (przedruk: Fritz Lang's „Metropolis": Cinematic Visions of Technology and Fear, s. 89-90). 
premierze styczniowej, ale jeszcze na początku kwietnia, była już prawdopodobnie definitywnie zniszczona ${ }^{58}$.

Zmiany nie pomogły - w Stanach czy Wielkiej Brytanii, po wrzawie medialnej wokół premier, które rzeczywiście cieszyły się niespotykanym zainteresowaniem, film szedł jednak dość marnie. Okazał się też klapą na rynku rodzimym, przynosząc Ufie ogromne straty, i na zawsze odbierając Langowi i Thei von Harbou ogromny kredyt zaufania, jakim producenci, dystrybutorzy i wydawcy obdarzyli ich po sukcesach Doktora Mabuse i Nibelungów. Za to wskutek tych cięć i zaginięcia pierwotnej postaci filmu Metropolis stało się jedną z legend kina, jako jedno $\mathrm{z}$ „poronionych arcydzieł", może nie do końca udanych, a może zbyt ambitnych w danym momencie historii filmu, w każdym razie bezpowrotnie okaleczonych przez goniących wyłącznie za zyskiem producentów; w tym aspekcie film Langa dzieli los np. Chciwości Ericha von Stroheima czy Wspaniałości Ambersonów Orsona Wellesa.

Nie miejsce tu, by szczegółowo referować zawiłe dzieje "tekstualne" Metropolis - zwłaszcza że gdzie indziej wyczerpująco uczynili to inni autorzy ${ }^{59}$. W każdym razie zrekonstruowanie filmu w postaci możliwie bliskiej pierwotnej wersji, prezentowanej podczas pierwszej niemieckiej premiery 10 stycznia 1927, stało się jednym z najsłynniejszych i najambitniejszych dążeń historyków i archiwistów filmu. Wielkie zasługi położył tu Enno Patalas, w latach 1966-1995 dyrektor monachijskiego Filmmuseum. Dzięki jego niezmordowanym wysiłkom, uporczywemu i konsekwentnemu tropieniu losu negatywów, rozmaitych kopii eksploatacyjnych filmu, nabywaniu źródeł dokumentujących pierwotny kształt dzieła, została sporządzona tzw. wersja monachijska filmu Langa. „W roku 1987 wersja «monachijska» (3153 metry, zmontowana przez Gerharda Ullmanna i Klausa Volkmera) miała swą premierę w Moskwie, a następnie w Monachium, za każdym razem prezentowana z oryginalną muzyką Huppertza, raz w aranżacji na pianino, raz na pełną orkiestrę. Kopia ta, chociaż pokazywana na całym świecie, nie istnieje w ogólnej dystrybucji, po części wskutek nierozwiązanych spraw własnościowych z Fundacją Murnaua [sukcesorem praw Ufy - T. K.], po części dlatego,

${ }^{58}$ Historię trzech oficjalnych, premierowych wersji Metropolis (pierwszej niemieckiej, Pollocka i drugiej niemieckiej) referują: E. Patalas, op. cit., s. 113-115; T. Elsaesser, Metropolis, s. 30-34; H. Bachmann, s. 33-38.

${ }_{59}$ Martin Koerber, Notes on the Restoration of "Metropolis", broszura dołaczona do edycji Metropolis na DVD, Kino-Video, New York 2002 [edycja ta zawiera wersję filmu opracowaną przez Friedrich-Wilhelm-Murnau-Stiftung w roku 2001 na 75 rocznicę powstania filmu; Martin Koerber był kierownikiem projektu tej rocznicowej rekonstrukcji fil$\mathrm{mu}$ ); T. Elsaesser, Metropolis, s. 34-42; E. Patalas, op. cit., s. 111-122; G. Bertellini, op. cit., s. $140-157$. 
że monachijskie Filmmuseum nie zainwestowało w kopię dystrybucyjna, nieustannie myśląc o przywróceniu wpierw oryginalnych napisów, i jeśli możliwe - wirażowania. Wersja monachijska jest do dziś dnia [tj. do 2000 r., kiedy ukazało się pierwsze wydanie książki Elsaessera o Metropolis - T. K.] filologicznie najbardziej adekwatną kopią Metropolis, ale jak Enno Patalas nigdy nie omieszkiwa zauważyć, jest to «wciąż-odbudowywana-ruina» [ruin-in-progress]"60.

W historii "tekstualnej” filmu Langa nie można, rzecz jasna, pominać również wersji opracowanej przez włoskiego kompozytora muzyki filmowej, Giorgio Morodera. Jak zauważa Thomas Elsaesser, narodziny Metropolis jako filmu "kultowego" datują się właśnie od jej pokazu na canneńskim festiwalu w roku 1984; jest to, jak określa Elsaesser, „ciekawa hybryda archiwalnej rekonstrukcji, świętokradczego majstrowania przy szacownym klasyku i ikonoklastyczne performance $\mathrm{w}$ duchu pop-postmodernistycznym” ${ }^{61}$. „Re-edycja Morodera, kosztująca niemal tyle, co straty Ufy, i ze skomponowaną przez niego samego nowofalową ścieżką dźwiękowa, wykonywaną przez tak modnych wykonawców, jak Freddie Mercury, Bonnie Tyler, Adam Ant i Pat Benatar, musiała oburzyć purystów, choćby tylko dlatego, iż pachniała tak krańcowym komercjalizmem i w sposób oczywisty jawiła się tak skalkulowana, by przeskoczyć kulturalną barierę między "sztuką» a "pop»" 62 . Choć dzięki swej przełomowej roli w recepcji Metropolis wersja Morodera ma swoje trwałe miejsce $\mathrm{w}$ historii kina, to $\mathrm{z}$ racji nonszalancji wobec formalnych rozwiązań autorskich i anachroniczności rockowej ścieżki dźwiękowej w filmie z roku 1926, nie sposób uznać jej za postęp w dziele rekonstruowania „wciąż-odbudowywanej-ruiny”, jaką jest film Langa i czynić ją np. podstawą interpretacji czy analizy tekstualnej bądź formalnej ${ }^{63}$.

Takim nowym krokiem $\mathrm{w}$ dziele przybliżania się do pierwotnej postaci była natomiast z pewnością wersja przygotowana przez Friedrich-Wilhelm-Murnau-Stiftung, przy współudziale Bundesarchiv-Filmarchiv, monachijskiego Filmmuseum i Deutsches Filminstitut w Wiesbaden. Po

60 T. Elsaesser, Metropolis, s. 36-37.

${ }^{61}$ Ibidem, s. 38.

62 Ibidem. Nt. wersji Morodera zob. też: Thomas Elsaesser, Niewinność przywrócona, przeł. Lech Niedzielski, „Film na Świecie” 1985, nr 318-319 (czerwiec-lipiec), s. 97-100; Thomas Elsaesser, „,Metropolis", przeł. Lech Niedzielski, „Film na Świecie” 1985, nr 318-319, s. 101-103; Brigitte Cieutat, Fritz Lang z-MORODER-nizowany, czyli o sztuce sprzeniewierzenia: „Metropolis", przeł. Ireneusz Dembowski, „Film na Świecie” 1985, nr 318-319, s. 83-88.

63 Wersja Morodera dość późno, bo dopiero w 2011 r., doczekała się edycji DVD (wydawca: „Kino Classics”, New York 2011) - prawdopodobnie z racji problemów z prawami autorskimi do ścieżki dźwiękowej autorstwa rozmaitych popularnych gwiazd muzyki pop. 
raz pierwszy została zaprezentowana $w$ 75. rocznicę powstania filmu na berlińskim festiwalu w roku 2001. W 2002 r. otrzymała nagrodę „Heritage Award for Restoration", przyznawaną przez National Society of Film Critics; w tymże roku ukazała się na płycie DVD. Na tej właśnie wersji oparłem zarówno prezentację układu fabuły, jak i moją interpretację filmu, napisaną w roku 2005 i przedstawioną w mojej książce habilitacyjnej ${ }^{64}$.

W roku 2008 niespodziewanie jednak odnaleziono w filmotece w Buenos Aires kopię filmu, która mimo iż nadal zawierała pewne luki, to jednak na tyle niewielkie, iż z hukiem i pewną przesadą wiosną 2008 r. obwieszczono światu o odnalezieniu Metropolis w "pierwotnej”, ,pełnej”, , oryginalnej" postaci. Była to jednak - pomijając już owe niewielkie luki materiału - kopia bardzo zniszczona, w dodatku na taśmie $16 \mathrm{~mm}$. Obrazowi, bardzo kiepskiej jakości, brakowało skutkiem niestarannego przekopiowania, oryginalnych proporcji kadru z wersji $35 \mathrm{~mm}$. Jednak dzięki materiałom argentyńskim możliwe stało się zmontowanie wersji filmu już maksymalnie bliskiej - przynajmniej w układzie sjużetu - wersji premierowej. Napisy hiszpańskie z kopii argentyńskiej przełożono na niemiecki dzięki tzw. Zensurkarte (czyli zapisom cenzury, której przedstawiano film do aprobaty). Aby oznaczyć właściwe miejsce w kadrze elementów usuniętych z negatywu $16 \mathrm{~mm}, \mathrm{w}$ zrekonstruowanej kopii brakujące partie kadru oznaczono na czarno. Napisy międzyujęciowe odtworzono w ich oryginalnej formie graficznej. Innej niestylizowanej czcionki użyto w tych napisach, które streszczają akcję kilku nadal brakujących scen; streszczenia te wydają się konieczne dla zrozumienia i tak dość pogmatwanej i nie całkiem w scenariuszu logicznej akcji filmu. Krótsze luki w materiale filmowym oznaczone są poprzez czarne klatki filmu.

Tak opracowana, najpełniejszą dziś, choć wbrew reklamie nadal trochę niekompletną wersję filmu, pokazano wpierw publicznie na Berlinale w lutym 2010. Zawiera ją też, w formacie DVD i Blu-ray, edycja Metropolis przygotowana (rzecz jasna, we współpracy z Friedrich-Wilhelm-Murnau-Stiftung) przez wydawnictwo Eureka Video (London 2010) w renomowanej serii "Masters of Cinema”. Fragmenty znane tylko z kopii argentyńskiej wyróżniają się niestety dość kiepską jakością techniczna, której nawet $\mathrm{w}$ dobie cudów $\mathrm{z}$ opracowaniami na nowo starych filmów możliwych dzięki digitalizacji, nie sposób było uczynić wiele lepszą przy bardzo złym stanie materiału wyjściowego. W prezentowanym poniżej zapisie sjużetu streszczenia owych partii filmu ujęte są w nawias kwadratowy. Streszczenia scen wciąż zaginionych podaję kursywą.

64 Tomasz Kłys, Dekada doktora Mabuse: Nieme filmy Fritza Langa, Wydawnictwo Uniwersytetu Łódzkiego, Łódź 2006. 
Metropolis składa się z trzech części, których nazwy ewokują muzyczną kompozycję filmu: Preludium (Auftakts), Intermezzo (Zwischenspiel) i Furioso. Całość poprzedza motto, które pojawi się jeszcze w środku filmu jako morał „kazania” Marii o Wieży Babel, oraz jako ostatni, pointujący film napis: "Mittler zwischen Hirn und Hände muß das Herz sein” „Pośrednikiem między mózgiem a rękoma musi być serce”.

Preludium. Pejzaż miejski, z fantastycznymi drapaczami chmur, których monstrualne sylwetki nieustannie są wydobywane $\mathrm{z}$ mroku przez olbrzymie snopy rzęsistego światła. Kolejne obrazy ukazują jakieś tłoki, koła, przekładnie, rytmicznie poruszające się w górę i w dół, wirujące, pulsujące mechanicznym tętnem na pozór bez jakiegokolwiek udziału człowieka: to mechaniczny, szalony, rozgorączkowany rytm Metropolis. Inny plan pokazuje nam mały zegar o 24-godzinnej tarczy i umieszczony niżej większy zegar o tarczy 10-godzinnej: tyle trwa jedna "szychta", czas pracy podczas jednej zmiany. Olbrzymi gwizdek sygnalizuje strumieniami pary i snopami światła nową zmianę. W tunelu mijają się dwie kolumny robotników w jednakowych kombinezonach, podążających wolno, ponuro, bezwładnie, noga za nogą - jedni ku monotonnej 10-godzinnej pracy, drudzy, wykończeni szychta, na odpoczynek. Ci drudzy zjeżdżają podobnymi klatkom windami w przypominających kopalniane szybach, a ten ruch w dół (robotników i kamery) udziela się też napisowi, który jakby spływa z góry do dołu ekranu, obwieszczając: „Daleko pod powierzchnią ziemi leży Miasto Robotników”. Skupia się ono wokół centralnego placu, na którego środku znajduje się umieszczony na piedestale wielki gong, a tworzą je olbrzymie, ponure, kilkunastopiętrowe budynki o małych oknach. Nad siedzibami robotników nie unosi się nieboskłon sklepienie jest ciemne i sztuczne. Powracający z szychty (nadal w szyku) stopniowo znikają u wejść do rozmaitych budynków.

Napis, płynący tym razem z dołu do góry, obwieszcza: „Jak głęboko pod ziemią leżało Miasto Robotników, tak wysoko ponad nią wznosił się kompleks nazwany Klubem Synów, z jego salami wykładowymi, bibliotekami, teatrami i stadionami". Na olbrzymim stadionie pod gołym niebem, którego koronę zdobią antyczne w stylu posagi, ścigają się synowie elity; zwycięzcą biegu jest Freder, syn Joh Fredersena - władcy miasta. Narracja przenosi nas zaraz do „Wiecznych Ogrodów”; ich cuda stworzyli dla swych synów ojcowie, „którym każdy obrót koła maszyny przynosił złoto" (o czym obwieszcza napis). W ogrodach tych znajdują się sztuczne groty i wodotryski, rosną egzotyczne rośliny, spacerują po nich pawie i białe czaple. "Mistrz ceremonii” pyta ubrane ekscentrycznie i jakby karnawałowo młode damy, która z nich podejmie się zabawić syna władcy. Damy grają z Frederem w coś w rodzaju berka, potem jedna z nich bawi się z nim w chowanego wokół fontanny z syreną. Ich pocałunek nie 
dochodzi do skutku, bo przerywa go wtargnięcie do ogrodów gromady obszarpanych dzieci, otaczającej młodą kobietę o blond włosach i rozpłomienionych oczach, ubraną w purytańsko skromną zapiętą po szyję szarą suknię, mocno kontrastującą z roznegliżowanym, wyzywającym strojem partnerki Fredera. „Popatrzcie, oto wasi bracia!” - mówi swym małym podopiecznym czarowna zjawa, na widok której Freder (nie po raz ostatni) chwyta się z przejętą miną za serce. Wyproszona przez służbę na polecenie "mistrza ceremonii", dziewczyna zabiera dzieci i znika tam, skąd przyszła. Freder podejmuje decyzję: składa w uniesieniu dłonie na piersi i wybiega za zjawa, w dół, przez wahadłowe drzwi (odtąd Freder nieustannie będzie przekraczał jakieś drzwi).

Trafia on do maszynowni, gdzie szeregi robotników manipulują jakimiś dźwigniami, obracają jakieś tarcze, kontrolują jakieś tablice rozdzielcze. Freder jest świadkiem, jak padający z wycieńczenia robotnik nie jest w stanie powstrzymać przegrzania się obsługiwanej przez siebie maszyny, co powoduje eksplozję. Zabija ona kilku ludzi, których ciała spadają z wysoka i natychmiast zostają usunięte, i którzy natychmiast zostają zastąpieni na swych stanowiskach nowymi robotnikami. Zszokowany tym, co ujrzał i utraciwszy po wybuchu przytomność, Freder ma wizję, w której maszyna zmienia się w pożerającego ludzi Molocha; w jego ognistej gardzieli znikają kolumny spętanych łańcuchami ludzi, których nieustannie poruszające się tryby wewnątrz "paszczy” wydają się mleć na miazgę. Freder, porażony wizją i tym, że jakby nic się nie stało, praca w maszynowni dalej wre, ucieka stamtąd. Docierając do luksusowego białego samochodu, rozkazuje kierowcy zawieźć się do Nowej Wieży Babel, siedziby jego ojca, górującej nad całym miastem. Przejazdowi jego samochodu towarzyszą jakby salutujące synowi władcy, oświetlające trasę wozu rozbłyski snopów światła. Sekwencja podróży jest pretekstem do prezentacji ujęć unaoczniających rozmach miasta, z imponującymi ciągami komunikacyjnymi i olbrzymimi drapaczami chmur, pomiędzy którymi latają (wyglądające dość anachronicznie w futurystycznym świecie) staroświeckie aeroplany $\mathrm{z}$ lat dwudziestych $\mathrm{XX}$ w.

W biurze Fredersena, za którego ogromnymi szybami roztacza się imponująca panorama Metropolis, wzburzony Freder usiłuje poruszyć ojca relacją o straszliwej pracy robotników. Ale władcę oburza co innego: fakt, że Freder trafił do podziemi, że to od niego, a nie od swego sekretarza Jozafata, dowiaduje się o eksplozji, i że to nie Jozafat, a nadzorca robotników Grot informuje go o odręcznych planach znalezionych przy zabitych robotnikach. Poucza syna, który nagle odkrył w robotnikach swych braci, że właściwym ich miejscem są podziemia, gdzie przebywają. Dymisjonuje też za zaniedbania Jozafata. Poruszony Freder wybiega za 
sekretarzem - w samą porę, by udaremnić mu samobójczy strzał w głowę. Prosi Jozafata, by czekał w mieszkaniu na wieści od niego, a sam znowu udaje się do podziemi, do swych nowo odkrytych braci... Fredersen natomiast wzywa Chudego (Der Schmale), każąc mu śledzić syna i donosić o każdym jego kroku.

Freder dociera do jakiegoś pogrążonego w kłębach pary pomieszczenia, gdzie zastępuje przy jakiejś niepojętej w swym działaniu maszynie młodego robotnika o numerze 11811 (numer ten i jego imię - Georgy - wypisane są na czapce kombinezonu). Maszyna ta (za powieścią nazwijmy ją Paternostermaschine) ma przypominającą zegar tarczę z trzema wskazówkami, które trzeba nieustannie koordynować monotonnymi, rytmicznymi ruchami swego ciała przez całe 10 godzin $^{65}$. Freder zastępuje Georgy'ego na stanowisku, przebierając się w jego ciemny kombinezon, a jemu dając swe białe ubranie i prosząc, by udał się $\mathrm{z}$ wiadomością do Jozafata i by obaj na niego zaczekali. [Nr 11811 pokazuje kierowcy adres Jozafata. Ale znalazłszy w ubraniu Fredera dużą sumę pieniędzy, ulega pokusom miasta i nocy, i zamiast do Jozafata każe się wieźć do Yoshiwara, dzielnicy rozrywek... Śledzi go Chudy, myśląc, że to Freder].

Narracja przenosi nas do dziwnego starego domu, "zapomnianego przez stulecia", wciśniętego w środku Metropolis między olbrzymie wieżowce. Mieszkającemu tam demonicznemu wynalazcy, Rotwangowi, służący mu karzeł obwieszcza przybycie Joh Fredersena. [Czekając na gospodarza, Fredersen odkrywa za kotarą olbrzymią kamienną głowę kobiety. Napis na postumencie informuje, iż to nieżyjąca już ukochana Rotwanga, Hel, którą odbił mu właśnie Fredersen; przy narodzinach jego syna Fredera Hel zmarła. Rotwang wpada w gniew, odkrywając eks-rywala przed pomnikiem ukochanej. Ale na gniew wynalazcy Fredersen reaguje ze spokojem, mówiąc, iż umysł taki jak Rotwang powinien umieć zapomnieć]. Rotwang obwieszcza, iż o n a ż y j e, i pokazując swą żelazną dłoń, pyta Fredersena, czy uważa utratę ręki za zbyt wielką cenę za odtworzenie Hel? Po czym demonstruje mu swe osiągnięcie - mechaniczną kobietę. „Daj mi jeszcze 24 godziny, a nikt nie odróżni mojego robota od śmiertelnika... Kobieta jest moja, Joh Fredersenie, syn Hel jest twój" - woła rozgorączkowany Rotwang. Od tego momentu montaż symultaniczny przeplata wątek Rotwanga i Fredersena z wątkiem Fredera, umęczonego przy Paternostermaschine. Władca Metropolis mówi, że przyszedł prosić Rotwanga o rozszyfrowanie dziwnych planów znalezionych

${ }^{65}$ Komentarz Enno Patalasa, towarzyszący filmowi na płycie przygotowanej przez Murnau-Stiftung, informuje, że nazywające się w powieści „Paternostermaschine” urządzenie koordynuje system wind. W filmie wydaje się nie mieć żadnej innej funkcji prócz męczarni, jakie sprawia obsługującej je osobie. 
przy robotnikach, a Freder w ubraniu robotnika 11811 też znajduje taki plan (co wiąże oba wątki). Jakiś nowo przybyły robotnik mówi poufnie Frederowi, że o n a znowu ich wzywa pod koniec szychty, o drugiej. Pod koniec swej zmiany Freder jest krańcowo wyczerpany. Wołając: „Ojcze! Ojcze! Czy to 10 godzin nigdy się nie skończy?”, wydaje się niemal ukrzyżowany na gigantycznych wskazówkach przypominającej zegar tarczy Paternostermaschine, nie przypadkiem tak się nazywającej. Gwizdek obwieszcza koniec zmiany - Freder, jak inni, umęczonym krokiem i ze zwieszoną głową odchodzi ze swego stanowiska tortur, przy którym ktoś natychmiast go zastępuje. Tymczasem Rotwang, wyjaśniwszy Fredersenowi, że plany dotyczą starożytnych katakumb, prowadzi go w owo miejsce. Inną drogą podążają tam po szychcie robotnicy.

W katakumbach Freder odkrywa, iż Maria, duchowa przywódczyni proletariuszy, to poranna zjawa z ogrodów, której potem daremnie szukał i w której zakochał się od pierwszego wejrzenia. Klęka - przed nią czy przed "ołtarzem", gdzie wprawdzie nie ma krucyfiksu, za to jest dziesięć gołych krzyży, chaotycznie i ekspresywnie rozmieszczonych? Maria, którą do księdza upodabnia jej pozycja przed ołtarzem i przypominająca stułę szarfa jej stroju, opowiada zebranym robotnikom Legendę o Wieży Babel: wymyślonej przez „mózg” (władcy? kapłana? architekta?), budowanej „rękoma” (tysięcy półnagich niewolników z ogolonymi głowami) i tymiż "rękoma” zniszczonej, ponieważ pomiędzy "mózgiem” a "rękoma” zabrakło „pośrednika” - „serca”. Poruszeni „kazaniem” robotnicy pochylają w skupieniu głowy, składają modlitewnie ręce na piersi, klękają. Jednak jeden z robotników pyta: „Ale gdzie jest n a s z Pośrednik, Mario?” „Poczekajcie! Z pewnością przyjdzie!” - odpowiada natchniona prorokini. „Poczekamy, Mario, ale już niedługo!” - z niedwuznaczną groźbą dla „mózgu” odpowiada niecierpliwy. Gdy już „kaplica” w katakumbach opustoszała, klęczącego przed nią Fredera Maria pyta: „Och, Pośredniku, w końcu przyszedłeś?” „Wezwałaś mnie - oto jestem!” - odpowiada zakochany Freder, a Maria całuje go w policzek. Zdarzenia w "kaplicy” obserwowali z ukrycia Rotwang i Fredersen (który jednak nie rozpoznał przebranego $\mathrm{w}$ robotniczy kombinezon syna). Zamyślony Fredersen, chcąc zasiać niezgodę pomiędzy robotnikami i Marią, i zniszczyć ich wiarę w nia, prosi Rotwanga, by nadał robotowi jej oblicze. Wiedząc to, czego nie wie eks-rywal - że Freder jest w Marii zakochany - Rotwang godzi się, mówiąc po odejściu Fredersena: „Głupcze! Stracisz teraz jedyną rzecz, która została ci po Hel - twego syna!” Maria i Freder wyznaczają sobie nazajutrz spotkanie w katedrze. Po odejściu Fredera Marię osacza w ciemnych korytarzach katakumb Rotwang, przerażając ją i zapędzając w pułapkę światłem swej latarki. 
Intermezzo. Nazajutrz Freder (cały czas w robotniczym kombinezonie) przybywa do katedry, rozglądając się za Marią, ale są tam tylko jakieś czarno ubrane postacie (zakonnice?) Zamiast Marii, Freder widzi mnicha, przepowiadajacego rychte nadejście czasów, o których mowa w Apokalipsie, i zapowiadajacego słowami tej księgi panowanie babilońskiej nierzadnicy. [W tym samym czasie Rotwang zwraca się do stworzonego przez siebie robota, siedzącego niczym egipskie bóstwo: „Zniszczysz Joh Fredersena, jego miasto i jego syna"]. Freder dochodzi do nawowego ołtarza, którego gotyckie płaskorzeźby przedstawiają Śmierć jako Ponurego Żniwiarza i Siedem Grzechów Głównych [sic!] klęka przed figurą Śmierci, modląc się do niej, by trzymała się z dala od niego i ukochanej. [Rozczarowany niestawieniem się Marii na spotkanie, Freder udaje się do Jozafata, gdzie ma nadzieję znaleźć Nr 11811. Ale ten, po przepuszczeniu wszystkich pieniędzy Fredera w Yoshiwara zostaje schwytany przez Chudego i odesłany do swej maszyny. Freder mówi Jozafatowi, że na własną rękę spróbuje odnaleźć człowieka (z tajnego związku robotników), do którego Georgy miał go zaprowadzić. Wkrótce po wyjściu Fredera do mieszkania Jozafata wdziera się Chudy, usiłując nakłonić go - przekupstwem, groźbami - do opuszczenia miasta i nieczekania na Fredera. Wywiązuje się walka pomiędzy Chudym a Jozafatem, w której ten ostatni przegrywa i, nieprzytomny, zostaje uwięziony w pokoju].

Tymczasem Freder, na ulicy nieopodal domu Rotwanga, słyszy krzyki walczącej z wynalazcą Marii, dobiegające przez świetlik w dachu. Freder usiłuje sforsować drzwi z pentagramem. Stalowa ręka Rotwanga tłumi krzyki Marii. Nagle drzwi domu Rotwanga się otwierają - Freder wbiega tam, ale dom wciąga go w pułapkę, otwierając przed nim zapraszająco szereg coraz to kolejnych drzwi i znienacka je zamykając. Freder, schwytany w potrzask, daremnie próbuje się zeń wydostać - przy okazji znajduje szarfę Marii, którą zgubiła w walce z Rotwangiem. Tymczasem nie niepokojony już wynalazca dokonuje "transferu" fizycznego wyglądu zamkniętej w szklanym sarkofagu i podłączonej do jakichś elektrod Marii na robota, siedzącego niczym na tronie pod odwróconym pentagramem. To oblekanie robota w ciało Marii jest efektownym spektaklem elektrycznego światła $w$ formie iskrzących błyskawic i kolistych promieni. Eksperyment udaje się - robot staje się sobowtórem Marii. Wyrwanemu z odrętwienia Frederowi Rotwang mówi, że Maria jest z jego ojcem. Gdy Fredersen mówi fałszywej Marii, iż życzy sobie, by zniweczyła wśród robotników dzieło kobiety, której jest sobowtórem, ona puszcza mu porozumiewawczo oko (właśnie ten moment tak spodobał się Iris Barry). Freder, chcąc sprawdzić słowa Rotwanga, zaskakuje ojca i fałszywą Marię, gdy wydają się obejmować. Zszokowany, nie wiedząc, że to nie ukochana, ale robot o jej obliczu, cofa się przed tym widokiem, a potem ogarnia go gorączka i traci przytomność (sekwencja zdjęć nakładanych i animacji oddaje subiektywizację narracji, wyrażającej teraz jego perspektywę wewnętrzną). 
Chorego Fredera, leżącego w łóżku, odwiedza ojciec; zostawia on na stoliku zaproszenie na wieczór, podczas którego Rotwang zaprezentuje swe dzieło jako „nową tancerkę tańca erotycznego”. Podczas owego wieczoru, skupiającego eleganckie i wyłącznie męskie towarzystwo, fałszywa Maria wyłania się z olbrzymiej szkatuły, dźwiganej przez czarnych ",atlasów”. Przybrana w diadem, podświetlona tak, że jej ciało tworzy ciemny kontur jakby w świetlistej szacie, wykonuje pełen erotycznej ekspresji taniec, prowokując pożądliwe spojrzenia mężczyzn. Dwuznaczność narracji, która utrzymuje się do końca Intermezza powoduje, iż nie jest pewne, czy to akcja symultaniczna do choroby Fredera, czy też wizja jego ogarniętego gorączką i rozpaczą umysłu, ewokującego kazanie z katedry o „babilońskiej nierządnicy". Tę drugą ewentualność sugeruje fragment usunięty z pierwotnej wersji niemieckiej przez „adaptatorów": Chudy, realnie obecny przy łóżku Fredera, [w subiektywnej wizji Fredera zmienia się w mnicha z katedry, obwieszczającego rychłe nadejście dni, o których mowa w Apokalipsie, kiedy rządzić będzie babilońska wszetecznica]. Na przyjęciu Rotwanga wirująca w ekstatycznym tańcu fałszywa Maria wzbudza prawdziwy szał pożądania mężczyzn - ich spojrzenia autonomizują się, patrzą na nią już nie twarze, ale same oczy. Freder, pojony przez pielęgniarkę, jakby wpatrzony w swą wizję, patrzy gdzieś w przestrzeń nieprzytomnymi oczami. Rozentuzjazmowani mężczyźni bluźnierzo ofiarowują tancerce „wszystkie siedem grzechów głównych”, podbiegają do podium jej występu z wyciągniętymi rękami. W wizji Fredera ożywają kamienne figury Grzechów i Śmierci, widziane przezeń w katedrze. Śmierć idzie ku niemu (i ku widzowi), złowróżbnie machając kosą i wydaje się, że ostatni zamach pozostawia białe zadrapanie na pociemniałej taśmie. Freder pada nieprzytomny.

Furioso. Ozdrowiały Freder (w białym ubraniu jego „stanu”) czyta Ksiegę Apokalipsy. Odwiedza go Jozafat, mówiąc, że przebrał się za robotnika, by uniknąć szpiegowania Chudego. [W tymże czasie Chudy informuje Fredersena o podżeganiu robotników do buntu przez fałszywą Marię i że powstrzymuje ich od niego tylko nadzieja na Pośrednika. Z kolei Jozafat relacjonuje Frederowi zdarzenia, które zaszły od chwili, kiedy zaniemógł]: bratobójcze pojedynki i rozmaite szaleństwa, do których doprowadza mężczyzn Maria (rzecz jasna, fałszywa, o czym Jozafat nie wie). Gdy gwizdek obwieszcza kolejną szychtę, Freder i Jozafat wyruszają do Miasta Robotników, [podczas gdy Fredersen instruuje Chudego, by w razie buntu robotników pozwolić im na niszczycielskie działania, aby mieć w ten sposób powód do użycia przeciwko nim siły]. O takich planach władcy Metropolis, których wykonawcą ma być robot, podżegający robotników do buntu i niszczący ich wiarę w Pośrednika, Rotwang informuje więzioną przez siebie prawdziwą Marię. Mówi jej też, iż oszukał Fredersena, 
a robot posłuszny jest nie woli władcy, tylko jego własnej. W katakumbowej „,kaplicy” fałszywa Maria wzbudza nienawiść robotników do maszyn, karmionych ich krwią i ciałem, i wzbudzając euforię zgromadzonych, wzywa: „Niech maszyny głoduja, głupcy! Śmierć maszynom!” Gdy obserwujący zebranie z Jozafatem i Numerem 11811 Freder demaskuje Marię jako uzurpatora („Nie jesteś Marią! Maria głosiła pokój, nie zabijanie!”), fałszywa Maria reaguje śmiechem. Jeden ze zbuntowanych robotników rozpoznaje we Frederze syna władcy i nawołuje do zabicia go. Śmiertelny cios nożem otrzymuje Nr 11 811, który zasłonił Fredera własnym ciałem a to męczeństwo Georgy'ego, jak zauważa w komentarzu na płycie Enno Patalas, poniekąd pieczętuje "mesjański los Fredera”.

Niesiona na ramionach robotników i triumfalnie rozkładająca ręce fałszywa Maria prowadzi ich, niczym „wolność wiodąca lud na barykady", "na maszyny" (w muzyce Gottfrieda Huppertza pojawia się temat Marsylianki). Tymczasem Fredersen, który udał się do Rotwanga po radę, podstuchuje zwierzenia wynalazcy wobec Marii, jak to oszukat władce Metropolis i ukrył przed nim miłość jego syna do niej oraz fakt, że to on ma być Pośrednikiem. Fredersen atakuje wynalazcę, stacza z nim zwycięska walkę, podczas której Marii udaje się wymknać: widzimy, jak pośpiesznie opuszcza dom Rotwanga.

Fałszywa Maria zwołuje na centralnym placu Miasta Robotników kobiety i mężczyzn: „Niech nikogo dziś nie zabraknie! Śmierć maszynom!” Tłum pod przywództwem robota windami i tunelami przemieszcza się ku maszynowniom, obala kratę [i podąża ku Herzmaschine, centralnej stacji mocy Metropolis. Nadzorca Grot zamyka bramy] i przez wideofon informuje Fredersena o zagrożeniu. Ale władca wydaje niepojęty dlań rozkaz, by otworzyć bramy. [Gdy po otwarciu bram, tłum przypuszcza szturm na Herzmaschine], Grot usiłuje powstrzymać jej destrukcję: „Czyście poszaleli? Jeżeli zniszczycie Herzmaschine, całe Miasto Robotników zostanie zatopione!" Bezskutecznie - zostaje obalony, a fałszywa Maria uruchomieniem jakiejś dźwigni rozpoczyna dzieło zniszczenia. Gdy tłum w upojeniu patrzy na pirotechniczny spektakl, robot ukradkiem wymyka się do Yoshiwara... Wśród iskier, błyskawic, ognia, dymu i huku, spadania jakichś konstrukcji, Herzmaschine ulega zagładzie.

Tymczasem prawdziwa Maria, która przybyła windą na centralny plac Miasta Robotników, widzi z przerażeniem eksplozje, zniszczenie wind, które $\mathrm{z}$ hukiem spadają pękanie betonowej nawierzchni, spod której woda, wyciekając najpierw małymi strużkami, wytryska w końcu z mocą niczym gejzer. Podobne gejzery wybuchają też w stacji pomp. Na zalewanym wodą placu Maria zaczyna uderzać w olbrzymi gong, gromadząc wokół siebie dzieci robotników, opuszczone przez ogarniętych amokiem zniszczenia rodziców. Pod naporem lejącej się wszędzie wody walą się domy robotników. Freder i Jozafat drabinkami w przepastnych 
szybach śpieszą ku gongowi, na ratunek Marii i dzieciom. Zniszczenie Herzmaschine powoduje, iż rzęsiście wprzódy oświetlone górne miasto ogarniają ciemności. „Czy wie pan, że pański syn jest pośród robotników?" - pyta Chudy przerażonego tą wieścią Fredersena w jego biurze, oświetlonym teraz tylko światłem latarki. Freder dociera do gongu, padają sobie z Marią w ramiona, ale ponaglani przez Jozafata groźbą całkowitego zatopienia miasta wodą ze zniszczonych zbiorników, pośpiesznie przeprowadzają ewakuację dzieci zalewanymi szybami do górnego miasta. Miasto Robotników ulega zagładzie, a Freder i Maria znajdują schronienie dla ocalonej w ostatniej chwili trzódki w Klubie Synów.

Tymczasem w maszynowni, na zgliszczach maszyny-Molocha, tłum w opętańczych korowodach tańczy karmaniolę, a może taniec śmierci. Wyrwani z transu gwizdem przez Grota (jeszcze jeden moment podziwiany przez Iris Barry), robotnicy uświadamiają sobie poniewczasie, że niszcząc maszyny, zatopili swe siedziby i narazili na niebezpieczeństwo, a może bezpowrotnie utracili, swe dzieci. Odreagowując stratę, ogarnięci chęcią zemsty na "czarownicy, która ich do tego podburzyła”, stają się żądną linczu tłuszczą. A w Yoshiwara fałszywa Maria, niesiona na czyichś barkach, triumfalnie wyprowadza na ulicę pochód z lampionami, nawołując kompanię bogatych straceńców, by „patrzyli, jak świat idzie do diabła!" Robotnicy, poszukując podżegaczki, wędrują ulicami górnego miasta. [Rotwang, niespełna rozumu, ślubuje przed posagiem Hel, że przywiedzie ją do domu,] i somnambulicznym krokiem wyrusza na miasto. [Tymczasem prawdziwa Maria po odprowadzeniu dzieci do Klubu Synów, natyka się na żądny zemsty tłum. Robotnicy rzucają w nią narzędziami - uderzonej, udaje jej się zbiec w ostatniej chwili]. Droga ucieczki prawdziwej Marii krzyżuje się z pochodem wiedzionym przez Marię fałszywą. I to tę drugą łapie nadzorca Grot, z okrzykiem: „Na stos z nią!” Przed katedrą tłum buduje stos z wraków samochodów i wlecze nań fałszywą Marię. Tłum tańczy w szaleńczej radości wokół wijącej się w ogniu fałszywej Marii. Myśląc, że to ukochaną spotkał ten straszny los, Freder trzymany przez robotników, daremnie wyrywa się na ratunek - nic nie może też wskórać chcący pomóc jemu i Marii Jozafat, również zatrzymany przez tłum. Tymczasem ukrywającą się we wnęce katedry prawdziwą Marię zauważa opętany Rotwang, sądząc, że to jego ukochana Hel. Dziewczyna, uciekając przed nim po schodach wiodących na wieżę dzwonnicy, chwyta się liny dzwonu, co powoduje jego rozkołysanie. Dzwon ten zwraca uwagę robotników, którzy patrzą jak Maria ucieka przed Rotwangiem na dach. A gdy płomienie coraz mocniej pochłaniają stos, odsłania się ukryty poprzednio pod cielesną powłoką Marii metaliczny korpus robota. Freder, teraz zrozumiawszy, gdzie naprawdę jest ukochana i jakie jej grozi niebezpieczeństwo, wbiega na dach katedry, gdzie 
stacza walkę z Rotwangiem. $Z$ dołu patrzy na to posiwiały ze zmartwienia Fredersen - Grot, bardziej lojalny wobec władcy niż wobec robotników, których niby jest reprezentantem, odpędza od niego groźny tłum, wskazując, że to właśnie dzięki jego synowi Frederowi ich dzieci zostały ocalone. Rotwang powala Fredera i unosi Marię w górę po spadzistej stromiźnie dachu. Rotwang i Freder, sczepieni, staczają się na krawędź dachu, przy czym wynalazca spada na bruk przez nadkruszoną zębem czasu barierkę i zabija się. Freder i Maria, ocaleni, padają sobie w objęcia.

Tłum robotników w szyku trójkąta, na czele którego stoi Grot, rytmicznie zbliża się do wejścia katedry. Nadzorca podchodzi ku Marii, Fredersenowi i Frederowi. Grot i władca Metropolis niepewnie wyciagają do siebie ręce, następnie je wycofuja, zaciskają w pięści. Maria prosi ukochanego: "Głowa i ręce muszą się połączyć, ale nie mają serca, by to uczynić... Och, Pośredniku, pokaż im drogę ku sobie nawzajem..." Freder łączy ręce Grota (dość opornego w wyciągnięciu dłoni) i ojca (bardziej biernego). Tekst, który otwierał film jako motto - „Pośrednikiem między mózgiem a rękoma musi być serce" - pojawia się jeszcze raz jako jego epigraf.

\section{Antyutopia i jej referencje}

Apokaliptyczne konotacje, podział świata przedstawionego na opływającą w luksus "górę" i zniewolony pracą proletariat „dołu”, kontrast między zaawansowaniem techniki a nędzą wiedzionej egzystencji, sprawiają, że Metropolis na pierwszy rzut oka wydaje się mieć przede wszystkim atrybuty gatunkowe antyutopii. Antyutopia, poprzez kreację świata przyszłości, projektuje nań w hiperbolicznej formie pewne zjawiska czy trendy współczesności, ukazując ich realne czy potencjalne niebezpieczeństwo, drugie dno, niechciane czy nieprzewidziane konsekwencje. Antyutopia jako struktura gatunkowa ma - zresztą podobnie jak i utopia, której jest antytezą - wymiar przede wszystkim społeczny i polityczny. Udana artystycznie antyutopia ma charakter uogólnionego modelu przyszłości, skonstruowanego na podstawie dostępnych współcześnie danych czy prognoz, a zatem w sposób istotny jest utworem fantastyczno-n a u k o w y m; w tym dwudzielnym epitecie, będącym zarazem kwalifikacją genologiczna, drugi człon nie powinien figurować jedynie od parady. „Modelowość" i „naukowość” antyutopii nie wyklucza jednak tego, a co więcej, nawet się tego domaga, by dość wyraźnie było zaznaczone jej własne stanowisko światopoglądowe; stąd też antyutopie przyjmują nierzadko charakter jadowitej satyry społecznej czy krytyki politycznej (vide: Podróże Guliwera Jonathana Swifta, My Eugeniusza Zamiatina czy Rok 1984 George’a Orwella). 
Metropolis ma raczej jednak (wyrazisty, co prawda) pozór antyutopii niż jest antyutopią sensu stricto. Owszem, są w świecie tego filmu odniesienia do rozmaitych zjawisk świata współczesnego, ale nie składają się one na jakiś spójny i konsekwentny model przyszłości jako rezultatu trendów "dzisiejszości". O jakimś jednoznacznym klarownym stanowisku światopoglądowym mowy nawet być tu nie może. Nie służy też gatunkowej formule antyutopii nieprzezwyciężony rozdźwięk w tym filmie między formą klasycznego filmu fabularnego (założoną, ale ostatecznie niezrealizowaną wskutek bierności postaci i pozorności ich akcji) a trybem alegorycznym (o czym dalej będzie jeszcze mowa) oraz nieadekwatność w futurystycznym i antyutopijnym kontekście takich a nie innych konotacji alegorycznych. Niemniej, mimo tej niespójności, są w Metropolis typowo antyutopijne tematy: obraz miasta przyszłości z jego dualizmem przestrzennym i klasowym, ekstensja ekonomicznych problematów XX w. (alienacja pracy, kumulacja kapitału), wreszcie - symboliczne przedstawienie niedawnych traumatycznych doświadczeń własnego społeczeństwa (wojna, inflacja wraz z jej „królem” i jej domniemanymi „winowajcami"). Tyle tylko, że są to "osobne" odniesienia, a nie tworzący modelową reprezentację zwarty system.

Już sam tytuł filmu wskazuje, iż centrum jego futurystycznej wizji jest prognoza urbanistyczna: obraz wielkiego miasta za, powiedzmy, sto lat ${ }^{66}$. Ale jak zauważa Herbert George Wells w swej obszernej, przywołanej już recenzji, zupełnie chybiona jest wizja miasta zbudowanego wzdłuż osi pionowej, jakiegoś super-Chicago czy Nowego Jorku, gdzie zresztą wertykalizacja przestrzeni i architektury przekłada się na stosunki społeczne (a raczej - jest ich wyrazem): „Teraz bardzo się oddaliliśmy od dobrego, starego roku $1897^{67}$, kiedy może było wybaczalne symboliczne przedstawienie relacji społecznych w ten sposób, ale to było 30 lat temu, a po drodze co nieco przemyśleliśmy i nabraliśmy co nieco doświadczeń. Wiemy teraz, że to wertykalne miasto przyszłości, jest, mówiąc łagodnie, wysoce nieprawdopodobne. Nawet w Nowym Jorku czy Chicago, gdzie jest ogromna presja na tereny centralne, wysoko nad ziemię wznoszą się tylko centralne urzędy i dzielnica rozrywek. A to samo dośrodkowe ciśnienie, które wiedzie do maksymalnego wyeksploatowania walorów

${ }^{66}$ W wersji Morodera akcja rozgrywa się w roku 2026 - równo 100 lat od powstania filmu. W wersji Paramountu jest rok 3000 (spora rozbieżność, trzeba przyznać). Materiał reklamowy przygotowany przez Parufamet w roku 1926 określa czas akcji na rok 2000 (zob.: "Metropolis": Das Schicksal einer Menscheit im Jahre 2000, Parufamet Presse- und Propagandaheft, Berlin 1926). Na kopii, którą analizowałem - wersji Murnau-Stiftung z roku 2010 [sic!] - nie pada konkretna data.

${ }^{67} \mathrm{~W}$ tym roku Wells napisał swą powieść When the Sleeper Wakes, której splagiatowanie zarzucił scenariuszowi Thei von Harbou. 
przestrzennych centrum, wiedzie zarazem do wyprowadzania przemysłu i pracy z mieszkalnego centrum do tańszych dzielnic, a zamożniejszych rezydencji w bardziej przestronne i przewiewne obszary. O tym wszystkim dyskutowano i pisano już przed rokiem 1900. Gdzieś około roku 1930 geniusze ze studiów Ufy natkną się na księgę antycypacji, spisanych zaledwie ćwierć wieku temu. Brytyjski spis powszechny z roku 1901 dowiódł, że populacje miejskie zaczęły stawać się odśrodkowe, a każdy postęp $\mathrm{w}$ horyzontalnych udogodnieniach komunikacyjnych powoduje dalsze rozpraszanie się miast. Ta pionowa stratyfikacja społeczna to już stara i zwietrzała sprawa. Bardzo oddalone od wizji świata za sto lat, Metropolis jest w swych formach i kształcie jako możliwość już przestarzałe o jedną trzecią stulecia" ${ }^{\prime 68}$.

Wells ma niewątpliwie rację, oskarżając Theę von Harbou o zbytnie „uwewnętrznienie" jego własnych konceptów z powieści When the Sleeper Wakes, utworu, który zdaniem Juliusza K. Palczewskiego stał się modelową antyutopią XX w., wytyczając szlak takim pisarzom, jak Eugeniusz Zamiatin, Aldous Huxley, George Orwell czy Ursula Le Guin (by przywołać autorów najbardziej znanych antyutopii) - i Thea von Harbou, chciałoby się dodać. „Kontrutopia w ich wydaniu przybiera zwykle kształt piramidalny, gdzie u szczytu plasuje się rządząca elita, której przewodzi zazwyczaj jednostkowy dyktator, u dołu zaś bezkształtna, bezwolna, bezimienna masa, odziana najczęściej w robocze mundury. Jest to cywilizacja zmechanizowana, stechnicyzowana, całkowicie odgrodzona od otaczającej przyrody, ślady przeszłości zostają w niej wymazane zarówno z ksiąg, jak i z ludzkiej pamięci.

W omawianej powieści Wellsa fabryki, hale, warsztaty, praca fizyczna jako taka, zostają zepchnięte pod ziemię, trudnią się nią ludzie wynędzniali, anemiczni, bladzi, ubrani we fioletowe kombinezony-mundury Powszechnej Organizacji Pracy. Szarzyzna, monotonia, standaryzacja życia podziemnego osiąga skrajność [... $]^{\prime 69}$.

Trudno nie dostrzec tu podobieństwa, z jednej strony, z jedynowładztwem Joh Fredersena, z drugiej zaś - z Miastem Robotników w filmie Langa. Ale w świecie Metropolis brak logiki. Skoro górne miasto, migające nam zresztą dość krótko na ekranie, jest tak ogromne, to trzeba zakładać, iż zamieszkują je miliony ludzi. Ale zarazem trudno przypuszczać, by w miliony szła liczba "wybrańców”, zabawiających się w „Wiecznych Ogrodach”, których ojcom „każdy obrót koła maszyny przynosi złoto”.

${ }^{68}$ H. G. Wells, Mr. Wells Reviews a Current Film, [w:] Fritz Lang's „Metropolis": Cinematic Visions of Technology and Fear, s. 95.

69 Juliusz K. Palczewski, Wstęp [do:] Herbert George Wells, Wehikut czasu, przeł. Feliks Wermiński, BN, S. II, nr 216, Ossolineum, Wrocław 1985, s. XXX. 
Wells słusznie stawia pytanie, do kogo np. należą rzędy jednakowych samochodów na imponujących ciągach komunikacyjnych Metropolis. Nie do robotników (bo ci przecież przemieszczają się tylko klatkami wind między swymi podziemnymi siedzibami a maszynowniami) - i raczej nie do „wybrańców”, bo ci nie zechcieliby jeździć zestandardyzowanymi, masowo produkowanymi wozami. A może powinno być dla widza oczywiste, że do ludzi takich jak Jozafat przed swym zdymisjonowaniem - czyli do klasy urzędników/menedżerów, zamieszkującej górne miasto. Tylko dlaczego spośród domniemanych milionów ma być on w zasadzie jedynym reprezentantem ${ }^{70}, \mathrm{w}$ dodatku nieuwikłanym $\mathrm{w}$ rozgrywkę $\mathrm{i}$, filozofię" filmu, nie będąc ani „mózgiem”, ani „rękoma”. Ani „sercem”, bo ta zaszczytna rola przypadła wyłącznie synowi władcy.

W Metropolis nie widać też policji, wojska czy jakichś sił bezpieczeństwa, które wyegzekwowałyby posłuch od zniewolonej klasy robotniczej (doprawdy, dziwne, że dobrowolnie godzi się ona na egzystencję, jaką wiedzie) czy przywróciły zakłócony porządek: przywrócenie go przez „Pośrednika” u wrót katedry nie tylko jest utopijne - jest po prostu idiotyzmem. A wbrew temu, co możemy wyczytać w zamieszczonym jako drugie motto do tego rozdziału fragmencie powieści Pynchona Tęcza grawitacji, nie ma w filmie „współpracującego z zarządcą inżyniera” - ani żadnego innego reprezentanta klasy przemysłowych menedżerów, która w stechnicyzowanym świecie supermetropolii przyszłości wydaje się absolutnie nieodzowna ${ }^{71}$.

Najbardziej przerażającym - ale też wedle zarówno krytyk ekspertów w rodzaju Wellsa, jak i po prostu zdrowego rozsądku, najbardziej absurdalnym - antyutopijnym aspektem Metropolis jest obraz zniewolenia człowieka przez pracę w zmechanizowanym świecie. „Widok wielkiego fizycznego wysiłku robotników przy obsłudze maszyn oburzał każdego inżyniera, nie tylko dlatego że nijak się to miało do faktycznych warunków w nowoczesnej fabryce, ale też z tej racji, iż samym celem maszyn jest redukcja zależności przemysłu od pracy ręcznej"72. Recenzje z epoki - oczywiście, Wellsa jest pośród nich najsłynniejsza - podkreślały niefunkcjonalność, anachroniczność i bezsensowność niemal każdej maszyny ukazanej w filmie, także z perspektywy ich przydatności dla panującego.

${ }^{70}$ No, w chwili gdy Freder wbiega do biura ojca, są tam prócz Jozafata jeszcze jacyś dwaj młodzi urzędnicy, którym Fredersen coś dyktuje. Ale to zupełnie marginesowe postaci filmu. Do tej domniemanej klasy średniej można też chyba zaliczyć Chudego.

${ }^{71}$ Wyliczankę tego, czego w filmie nie ma, a być powinno, znajdziemy np. w: T. Elsaesser, Metropolis, s. 43.

72 Ibidem. Zob. też: Siegfried Hartmann, Metropolis-Technik, „Deutsche Allgemeine Zeitung", 20 Januar 1927. 
„Hasłem Mastermana ${ }^{73}$ jest efektywność, a nam się daje do zrozumienia, że to straszne słowo; ci zaś, którzy wymyślili ten idiotyczny spektakl wykazują tak beznadziejną ignorancję w zakresie pracy, która ma się wykazać przemysłową efektywnościa, że przedstawiają go jako eksploatującego operatorów jego maszyn aż do kresu wytrzymałości, tak iż ci mdleją maszyny eksploduja, a poparzeni ludzie giną. Widzimy operatorów maszyn w męczarniach obracających dźwignie w reakcji na jakieś sygnały. Z naciskiem podkreśla się fakt, iż praca robotników jest bezduszną beznadziejną harówką wykonywaną niechętnie i mechanicznie. Ale w mechanicznej cywilizacji nie ma miejsca na jedynie harówkę. Im skuteczniejsza maszyneria, tym mniejsza potrzeba quasi-mechanicznego jej operatora. Tylko nieefektywna fabryka potrzebuje niewolników, tylko źle zorganizowana kopalnia zabija ludzi. Etap beznadziejnej harówki w pracy człowieka leży już poza nami. Z rodzajem złośliwej głupoty ów film faktom tym zaprzecza"74.

Metropolis tak dramatycznie przedstawia „,alienację pracy w zmechanizowanej przemysłowej cywilizacji" być może dlatego, że inspiracją Langa i Thei von Harbou wcale nie był stan faktyczny, ale rozmaite dzieła artystyczne - jak powieści Wellsa (prócz When the Sleeper Wakes, także Wehikut czasu) czy np. obraz Kurta Schmidta Der Mann am Schaltbrett (Człowiek przy tablicy rozdzielczej, 1924 $)^{75}$. Ten ostatni ewidentnie jest inspiracją dla sceny „ukrzyżowania Fredera na zegarze”, równie fascynującej wizualnie, co merytorycznie absurdalnej, a uwzględniwszy religijne odniesienia - wręcz niesmacznej. Ciekawe zresztą, że film Langa, choć przecież tuż po premierze mocno skrytykowany za takie przedstawienie pracy, właśnie $\mathrm{w}$ tym aspekcie wpłynął na dwa późniejsze, zresztą wybitne filmy, podobnie jak i Metropolis, o posmaku antycywilizacyjnej antyutopii: Niech żyje wolność! (À nous la liberté, 1931) René Claira i Dzisiejsze czasy (Modern Times, 1936) Charlie Chaplina. Widocznie dla mistrzów obrazu ważniejsza jest siła i sugestywność wizji niż jej logika i zawartość merytoryczna.

Choć z drugiej strony, filmy Claira i Chaplina jako bezpośrednie odniesienie miały może nie tyle wprost film Langa, ile ideologie, wobec których i one, i Metropolis, są ewidentnie polemiczne. Chodzi o naukowe zarządzanie praca, czyli t a y l o r y z m, i o zasady masowej produkcji przemysłowej, czyli f o r d y z m.

Idee naukowego zarządzania upowszechnił amerykański inżynier Frederick Winslow Taylor (1856-1915), którego dzieło Principles of Scientific

\footnotetext{
${ }^{73} \mathrm{~W}$ przygotowanej przez Channinga Pollocka wersji anglosaskiej Joh Fredersen stał się Johnem Mastermanem, Freder - Erikiem, Jozafat - Józefem, a Nr 11811 - Numerem 7.

${ }^{74}$ H. G. Wells, op. cit., s. 96.

75 Por. katalog wystawy: Fritz Lang - Filmbilder, Vorbilder, Red. Heide Schönemann, Hentrich Verlag, Berlin 1992.
} 
Management (1911) już w 1913 przełożono na niemiecki. Tayloryzm podkreślał wagę systemu zarządzania dla sensownego sterowania procesem produkcji i sprawowania nad nią kontroli. „Takie usprawnienie administracji, by poprzez centralizację i standardyzację zadań kierowniczych uniknąć marnowania wysiłku, potężnie wyraża się w zobrazowaniu surowego w wystroju, wysoce zautomatyzowanego i efektywnego biura Fredersena $^{76}$. W wydaniu Taylora teoria naukowego zarządzania wiązała się z racjonalnością i efektywnością. Pociągała za sobą znalezienie najlepszej osoby do każdego zadania, rozbicie pracy na konstytuujące ją zadania składowe, by zanalizować, jak każde z nich może zostać najskuteczniej zrealizowane, a następnie wyszkolić robotników, by stosowali to (i tylko to) podejście. Taylor i jego następcy utrzymywali, iż ich metody radykalnie podniosły efektywność, a tym samym produktywność" ${ }^{77}$.

Absolutyzacja kryteriów skuteczności i wydajności produkcji wiązała się z degradacją czynnika ludzkiego w pracy - Taylor wprost dawał do zrozumienia, że im mniej "ludzki” robotnik, tym lepszy z niego pracownik (pewne elementarne i nieskomplikowane zadania mógłby efektywniej od człowieka wykonać np. inteligentny i przyuczony do nich goryl $[$ sic! $])^{78}$. Ludmilla Jordanova zauważa, iż konsekwencje takich poglądów „są wyraźnie podjęte i przesadzone w Metropolis, gdzie robotnicy poruszają się w bezwolnej masie, pozbawieni indywidualności. Ukazani są jako zdominowani i wręcz zniewoleni przez czas, mając ciała wpędzone poza fizjologiczną efektywność - cel tayloryzmu - w otępienie. Szychty w Metropolis trwają dziesięć godzin i odpowiednio do tego nawet zegary

${ }^{76}$ Mieści się ono na szczycie imponującej Nowej Wieży Babel, skąd można ogarnąć wzrokiem leżące u jej stóp miasto, co podobnie jak usytuowanie gabinetu Haghiego w Szpiegach u szczytu przepastnej klatki schodowej, wyraża poniekąd ideę Benthamowskiego Panopticonu. Do wyposażenia biura Fredersena należą m.in. konsola z rozmaitymi przyciskami, interkom, na którym pokazują się notowania akcji, wideofon, którym łączy się z nadzorcą Grotem, zegar o 10-godzinnej tarczy (czas trwania szychty). Trzeba jednak przyznać, że gabinet Haghiego - medialnego pająka-jest lepiej przemyślany, a przede wszystkim funkcjonalniej wykorzystany dramaturgicznie. W każdym razie biuro Fredersena to jedno z ogniw w Langowskiej sekwencji "gabinetów tyranów" - vide: komnata świec Zmęczonej Śmierci, biurko Mabusego, centrum dowodzenia Haghiego, sala konferencyjna "pięciorga mędrców” w Kobiecie na Księżycu, gabinet profesora Bauma w Testamencie doktora Mabuse, pełne telewizyjnych monitorów centrum Corneliusa/Jordana w Tysiacu oczu doktora Mabuse.

77 Ludmilla Jordanova, Science, Machines and Gender, [w:] Fritz Lang's "Metropolis": Cinematic Visions of Technology and Fear, s. 180. Por. także: C. S. Maier, Between Taylorism and Technocracy: Ideologies and the Vision of Industrial Productivity in the 1920s, "Journal of Contemporary History" 1970, no. 5, s. 27-61.

78 Zob.: Frederic Winslow Taylor, The Principles of Scientific Management, Harper, New York 1911, s. 40. 
mają 10-godzinne tarcze. Praca wedle ustalonego rozkładu czasu była centralna nie tylko dla wczesnej industrializacji, naukowe zarządzanie rozciągnęło zakres tego aspektu poprzez nacisk na wykonanie zadania w określonym czasie, wagę unikania zbędnego wysiłku, potrzebę rozplanowania produkcji, ustanowienie skali zarobków i systemu premii"79. Być może zresztą zniewolenie robotników przez "czas szychty" dlatego wygląda w Metropolis tak dramatycznie, iż dla "saturnicznej”, pełnej obsesji na punkcie zegarów i czasu wyobraźni Langa, podporządkowanie człowieka regularnemu rytmowi godzin pracy jawiło się wyjątkowo odrażająco.

Jordanova we fragmencie swego artykułu, poświęconym przesadzonemu i zdemonizowanemu obrazowi tayloryzmu w filmie Langa, zwraca uwagę na dwa istotne pominięcia w przedstawieniu tej ideologii przez Metropolis. Po pierwsze, centralna dla tayloryzmu jest rola zarządzania i ekspertyzy technicznej, nie do pomyślenia i nie do zrealizowania bez entuzjastycznej współpracy klasy menedżerów i inżynierów-ekspertów. Tej decydującej dla systemu naukowego zarządzania grupy profesjonalistów z middle-class w filmie w ogóle nie widzimy, a zapewne to ona musi tworzyć rdzeń górnego miasta. Po drugie, tayloryzm podkreślał powiązanie wysokiej wydajności pracy z zarobkami - wyższa produktywność była w interesie pracownika, wiodąc do wyższych zarobków. Co z kolei prowadziło do społecznej mobilności - większa siła nabywcza przy większych zarobkach zwiększała konsumpcję, i umożliwiała podniesienie poziomu i stylu życia do takiego, który zbliżony był do pułapu klasy średniej ${ }^{80}$.

Jordanova słusznie zauważa, że dyskurs naukowego zarządzania nie był wolny od napięć i sprzeczności: z obietnicą awansu i możliwości radykalnej poprawy jakości swego życia w zasadniczo bezklasowym, stabilnym społeczeństwie kłócił się nacisk na wymaganą przez tayloryzm ścisłą specjalizację pracy i przekonanie samego Taylora, iż praktycznie niewiele dzieli pracowników fizycznych od zwierząt. Lang wydobył w filmie jedynie drugi, negatywny aspekt tej ideologii. „Co znaczące, Metropolis portretuje pracę jako raczej wymagającą fizycznego wysiłku niż wyspecjalizowanych umiejętności, robotników zaś nigdy nie widzimy, by wytwarzali jakieś produkty albo posiadali i wydawali pieniądze ${ }^{81}$. W silnym

${ }^{79}$ L. Jordanova, op. cit., s. 180-181.

80 Ibidem, s. 181.

${ }^{81} \mathrm{Nr} 11811$ wydaje w Yoshiwara tylko przywłaszczone, a nie zarobione przez siebie pieniądze. Sekwencja ta uchodziła za bezpowrotnie zaginiona, ale odnalazła się przynajmniej w części - w argentyńskiej kopii odnalezionej w roku 2008. Nienależnego robotnikowi Metropolis „konsumeryzmu” Georgy'ego nie widzieliśmy w wersjach filmu „opracowanych" po zniszczeniu i przemontowaniu wersji pierwotnej. O jego zabawianiu się w dzielnicy rozrywek wiedzieliśmy tylko ze streszczających napisów. 
kontraście do bogaczy, robotnicy są wyczerpani, kroczą jak zombies, giną $\mathrm{w}$ przemysłowych wypadkach, pracują w gorącu i pośród pary, wiodąc tak nędzny żywot. Pod tymi względami bliżsi są niewolnikom niż nowoczesnym robotnikom, których starało się stworzyć naukowe zarządzanie $^{\prime \prime 2}$.

Innym amerykańskim rzecznikiem nowoczesności, który wywarł ogromny wpływ na Niemcy lat 20. - i zapewne na film Langa - był słynny producent samochodów, Henry Ford. Jego wydana w 1922 r. autobiografia My Life and Work (Moje życie i praca) natychmiast stała się w Niemczech bestsellerem. „Niemieccy przywódcy związkowi i biznesmeni nigdy nie omieszkali podczas swych podróży do Stanów Zjednoczonych włączyć do programu wizyty u Forda w Detroit. Jego książka My Life stała się biblią dla tych wszystkich w Niemczech, którzy pragnęli zrozumieć sukces amerykańskiego wielkiego biznesu i w ten sposób podnieść Niemcy z ich własnej na wpół feudalnej zaściankowości. Ford głosił ewangelię naukowej instrumentalnej racjonalności ukutą w kategoriach humanitarnych"83. Ford polemizował z ",salonowa”", jego zdaniem, opinia, że powtarzalna, monotonna praca jest szkodliwa tak dla ciała, jak i duszy człowieka. Wprost przeciwnie, jego własne badania dowodzą czego innego - większość robotników, gdy im zaproponować jakieś inne zajęcie, woli pozostać przy dotychczasowym i wciąż od nowa wykonywać tę samą rutynową pracę $^{84}$. Ford przyjął to za wytyczną dla organizacji 7888 różnych miejsc pracy w swej fabryce samochodów, robiąc szczegółowy wykaz, iż tyle a tyle stanowisk wymaga dużej siły i pełni fizycznego zdrowia, tyle a tyle może być zajętych przez osoby zupełnie przeciętne, słabsze (jak kobiety czy młodzież) bądź o rozmaitych formach i stopniach kalectwa (przez osoby beznogie, jednonogie, bezrękie, jednorękie, niewidome, głuchonieme), czy też np. przez gruźlików ${ }^{85}$. Ford wprawdzie podkreślał, iż ludzie z pewnością nie są jedynie maszynami, ale jak zauważa Anton Kaes, „,z racji sposobu, w jaki są oni policzeni i sportretowani, z pewnością jawią się jako części (wymienne w tym aspekcie) machiny zwanej produkcją przemysłowa której poza tym udało się skrócić czas składania samochodu z 14 godzin w roku 1912 do 93 minut w roku 1914 (po tym zainstalowano taśmę montażową). Około 1925, po dalszych udoskonaleniach, nowy samochód zjeżdżał z taśmy montażowej co 10 sekund" ${ }^{86}$.

\footnotetext{
${ }^{82}$ L. Jordanova, op. cit., s. 181.

83 A. Kaes, Cinema and Modernity: On Fritz Lang's "Metropolis", s. 30.

84 Por.: Henry Ford, My Life and Work, Doubleday, Page, Garden City (N.Y.) 1922, s. 105.

85 Ibidem, s. 108.

86 A. Kaes, Cinema and Modernity: On Fritz Lang's "Metropolis", s. 30.
} 
Eksplicytną krytyką fordyzmu są przede wszystkim wymienione filmy Claira i Chaplina, których bohaterowie pracują na taśmie montażowej. W Metropolis odniesienie do idei Forda jest mniej oczywiste, choćby z tego powodu, iż nie widać, by robotnicy w tym filmie cokolwiek produkowali. Ale pojmowanie pracy jako mechanicznego powtarzania przez wiele godzin jednej i tej samej monotonnej czynności, która wydaje się autoteliczną męczarnia, oraz choreografia ich mechanicznych ruchów, upodabniających ich, zapewne dla większej efektywności, do robotów - oczywiście jest powtórzeniem odpieranych przez Forda w jego autobiografii zarzutów wobec nieludzkości systemu przemysłowej produkcji. „Ten wysoce wystylizowany, niemal baletowy obraz zracjonalizowanej i w pełni wyalienowanej pracy wizualizuje i krytykuje podstawowe zasady tayloryzmu i fordyzmu: powtarzalna praca pod dyktatem zegara musi wytworzyć ciśnienie, od którego można się tylko uwolnić w rewolucyjnym wybuchu, który film przedstawia jako naturalną katastrofę w rodzaju trzęsień ziemi czy powodzi. Zrepresjonowane przez technikę człowieczeństwo odpłaca odwetem" ${ }^{\prime 8}$.

Ludmilla Jordanova, która wnikliwie zanalizowała tayloryzm jako podstawowe antyutopijne odniesienie filmu, wskazuje także jeszcze jedną istotną referencję - choć w kontekście przywołanych jako motto do tego rozdziału rozważań Pynchonowskiego nazisty, Pöklera, oraz eksplicytnego przesłania filmu o "mózgu”, ,rękach” i „Pośredniku-sercu”, nie wiadomo, czy bardziej jawi się ona jako antyutopia, czy utopia. Referencją tą jest k o r p o r a c j o n i z m: ideologia związana z gwałtownym wzrostem w latach 20. wielkich przemysłowych kompleksów i monopoli o coraz większej władzy politycznej i ekonomicznej. „,Metropolis było takim tworem - gigantyczną pojedynczą jednostka, miastem-państwem i fabryką w jednym. Korporacjonizm stanowił ideologię zakorzenioną w transferze władzy od wybieralnych przedstawicieli czy karierowiczowskiej biurokracji do wielkich zorganizowanych sił europejskich zrzeszeń czy kół gospodarczych. Zmiana ta związana była z osłabieniem demokracji parlamentarnej, wzrastającą władzą podmiotów prywatnych, zanikiem rozróżnienia pomiędzy sektorem publicznym a prywatnym, oraz rozwojem scentralizowanych procedur negocjacyjnych, w których ważną rolę grali przywódcy związkowi" ${ }^{88}$. Niemcy lat 20. dryfowały właśnie ku korporacjonizmowi.

W swej analizie Jordanova zwraca uwagę na fakt, iż w Metropolis nie ma żadnej struktury politycznej, w której ludzie mogliby uczestniczyć, przez co jeden z fundamentów demokracji uczestniczącej - rozróżnienie sfery publicznej i prywatnej-nie ma w świecie tego miasta-państwa-fabryki

87 Ibidem, s. 30-31.

${ }^{88}$ L. Jordanova, op. cit., s. 181-182. 
żadnego zastosowania. Jeżeli przez „władzę prywatną” rozumieć kierowanie się partykularnymi interesami i władzę jednostek, to Fredersen reprezentuje właśnie taką władzę. Nie ma najmniejszej oznaki negocjacji między głównymi grupami w filmie, choćby i z tego powodu, że świat pracy nie ma głosu, będąc, dosłownie, zredukowany do „zbioru pozbawionych oblicza ciał" (collection of faceless bodies). Wymagają one menedżerskiego „mózgu”, który by nimi pokierował. „Miasto-fabryka jest zatem korporacyjnym bytem w szczególnie bezpośredni sposób, gdyż film przedstawia je jako pojedynczy organizm, żądający współpracy mózgu, rąk i serca, by przetrwać. Zakończenie może się wydawać obietnicą wynegocjowanej ugody, ale nie może być to nic więcej nad pobożne życzenie, gdyż rozwiązanie jest sentymentalne, nie praktyczne" ${ }^{\prime 89}$.

Korporacja alegorycznie przedstawiona w Metropolis ma, zdaniem Bernda Widdiga, całkiem konkretne odniesienie: to energetyczno-górnicze imperium "króla inflacji”, najbogatszego Niemca w całej historii tego narodu, Hugona Stinnesa (była już o nim mowa przy okazji rozmaitych referencji doktora Mabuse). Maszyny przedstawione w filmie Langa jawią się wprawdzie dość fantastycznie: nie produkują jakichś konkretnych rzeczy, wydając się jedynie urządzeniami dla autotelicznej tortury robotnika - ale po refleksji trzeba uznać je zasadniczo za generatory energii (świadczy o tym choćby wyłączenie oświetlenia $\mathrm{w}$ górnym mieście po zniszczeniu Herzmaschine). A czyż Westfalia-Nadrenia - silnie zurbanizowany, przemysłowy region, gdzie działało imperium Stinnesa - nie jest poniekąd jednym wielkim Metropolis? Trudno się zatem dziwić, że Widdig znajduje pierwowzór władcy Metropolis właśnie w Stinnesie, postaci niemal tak zmitologizowanej jak Rockefellerowie czy Rotszyldowie, która w bezpośrednio poprzedzającym realizację filmu okresie inflacji zawładnęła zbiorową wyobraźnią Niemców: „Podobieństwa między Joh Fredersenem a Hugonem Stinnesem są rzeczywiście godne uwagi. Jak i Hugo Stinnes, Fredersen rządzi rozległym przemysłowym imperium, które opiera się, w znacznym stopniu, na symbiotycznej relacji pomiędzy węglem a produkcją elektryczności. Pionowa aranżacja przestrzeni filmu i codzienna rutyna robotników przemieszczania się głębokimi szybami do ich miejsc pracy naśladuje środowisko górnicze. Oczywiste jest, że maszyny w Metropolis to olbrzymie turbiny i generatory, które wytwarzają elektryczność. Jest to wizjonerskie miasto Hugona Stinnesa, założyciela i prezesa gigantycznego Rheinisch Westphälische Elektrizitätswerke (RWE), właściciela wielkich kopalni węgla w Zagłębiu Ruhry. Nawet zakończenie filmu, uścisk dłoni pomiędzy Fredersenem i nadzorcą Grotem, cytuje historyczny epizod z życia Hugona Stinnesa: sławne Porozumienie

${ }^{89}$ Ibidem, s. 182. 
Stinnes-Legien z roku 1918. Świat pracy i związki zawodowe, reprezentowane przez Carla Legiena, wymieniły uścisk dłoni z korporacyjnym przywódca, Hugonem Stinnesem, i przystały na traktat, który przynajmniej na krótki czas przynióśł pokój stosunkom w przemyśle $\mathrm{w}$ powojennych Niemczech" ${ }^{\prime 90}$.

O ile wywód Widdiga na temat „króla węgla i energetyki”, Stinnesa, jako konotacji postaci Fredersena wydaje się przekonująco i solidnie unaoczniać analogię, mniej oczywiste wydaje się jego odczytanie fabuły Metropolis jako alegorycznej reprezentacji dziejów niedawnej inflacji. „By uzyskać dostęp do tej zalegoryzowanej historii, musimy przyjrzeć się centralnemu wydarzeniu Metropolis, wydarzeniu, które inicjuje dramatyczną fabułę filmu i powoduje, iż napięta sytuacja eksploduje: p o d r o b i e n i u [podkreślenie - T. K.] przez Rotwanga Marii. W tym stopniu, w jakim każda z Marii, prawdziwa i robot, jawi się jako medium, które jest w obiegu, możemy je, przynajmniej po części, interpretować jako alegoryczne figury obiegu pieniądza. Przez pęknięcie signifiantu «Maria» na dwa byty, na «przed» $i$ «po», na istotę «moralną» $i$ «niemoralną», na «matkę» $\mathrm{i}$ «nierządnicę», film przywołuje męskie lęki tyczące nieprzewidywalnych mocy kobiecości. Zarazem rozziew ten odtwarza to, co możemy nazwać «genealogią» inflacji. Akt Rotwanga jest pierwotnym czynem, który wyzwala destrukcyjną siłę inflacji: stwarza on niemoralna, scheinhafte formę medium przez naśladowanie i przedrzeźnianie jego obdarzonego zaufaniem, «całkowitego» oryginału. Dwie Marie wyrażają w zasadzie różnicę pomiędzy twardą walutą a pieniądzem inflacyjnym"191. Z prawdziwą Marią kojarzone są świadczące o stabilizacji wartości - głoszenie przez nią prawdy o stanie społeczeństwa, propagowanie solidaryzmu społecznego, jej konotacje jako matki czy troskliwej opiekunki dzieci. Fałszywa Maria krąży jak inflacyjny pieniądz między klasami, proletariat doprowadzając do rewolucyjnego wrzenia, w klasach zaś wyższych niszcząc morale poprzez rozbuchaną seksualność, gwałtownie wyzwolone mimetyczne (w rozumieniu René Girarda) żądze ${ }^{92}$, dekadencki, typowy dla lat inflacji, karnawał w lokalach rozrywkowych, z przepełnionym jakąś Schadenfreude upojnym przeżywaniem, jak „świat idzie do diabła”. Poza tym, jak zauważa Widdig, choć w filmie stworzony został tylko jeden robot, to z planów Rotwanga wiemy, iż potencjał jego powielania - niczym inflacyjnego pieniądza - jest praktycznie nieograniczony ${ }^{93}$.

${ }^{90}$ Bernd Widdig, Culture and Inflation in Weimar Germany, University of California Press, Berkeley-Los Angeles-London 2001, s. 160.

91 Ibidem, s. 161-162.

92 Unaoczniają to bratobójcze pojedynki mężczyzn z klasy wyższej o fałszywą Marię.

93 Por.: B. Widdig, op. cit., s. 162-163. 
Żydzi, domniemani winowajcy inflacji, w Doktorze Mabuse, graczu zostali symbolicznie przedstawieni jako rozmaite, ale zawsze konotujące "obcych", wcielenia tytułowego bohatera. Chyba nie przypadkiem konstruktora fałszywej Marii gra ponownie pierwszy mąż drugiej żony Langa, odtwórca roli Mabusego, Rudolf Klein-Rogge. Rotwang i Mabuse „to podobne postacie: obaj posiadają szczególną miksturę inteligencji, naukowego geniuszu i obłąkane poczucie megalomanii. Poprzez wiele subtelnych i mniej subtelnych środków filmy sugerują żydowskość obu postaci. W Metropolis dom Rotwanga oznacza anachroniczne żydowskie getto"94. Wśród najwyraźniejszych oznak „żydostwa” Rotwanga znajduje się niedopasowanie jego staroświeckiego, średniowiecznego z ducha domu, do supernowoczesnej, futurystycznej zabudowy Metropolis oraz zdobiący jego drzwi pentagram: znak szatana, ewokujący zarazem podobną doń gwiazdę Dawida (w powieści Thei von Harbou mowa jest o „pieczęci Salomona”).

Podobnie jak Niemcy w 1924 r., w finale Metropolis świat tego filmu zostaje definitywnie oczyszczony z wszelkich pozostałości inflacji: fałszywa Maria płonie na stosie z niepotrzebnych nikomu wraków samochodów, niczym palone lub mielone na miazgę inflacyjne banknoty, a Rotwang, choć był w zasadzie tylko wykonawcą pomysłu Fredersena, spełnia swą rolę kozła ofiarnego i ginie, próbując jeszcze raz zawłaszczyć prawdziwą Marię, walutę o prawdziwej wartości. Fredersenowi zaś tłum robotników wybacza - i tylko widzowie wiedza, że inflacyjny chaos był przede wszystkim jego pomysłem, którego jednak nie potrafił wykorzystać tak skutecznie jak jego realny odpowiednik, przemysłowy magnat, a zarazem „król inflacji” - Hugo Stinnes ${ }^{95}$.

Nie najmniej ważna, choć może najbardziej zakamuflowaną, z traumatycznych referencji antyutopijnych aspektów filmu, jest I wojna światowa. Anton Kaes pisze, iż w Metropolis „przedstawienie wielkiej liczby mężczyzn ubranych podobnie w ciemne uniformy i wlokących się noga za nogą w szyku musi przywodzić wspomnienia wojny, w której robotnicy maszerowali na front, oddając swe ciała podobnej bóstwu machinie wojennej. Była to pierwsza nowoczesna wojna, w której maszyny (od karabinów maszynowych po bombowce) przesądziły o wyniku. Skutki I wojny światowej - 13 milionów zabitych, 11 milionów kalek - w połowie lat dwudziestych nie były zapomniane ${ }^{\prime \prime 96}$. Ewokują tę traumę nie tylko tłumy $\mathrm{w}$ uniformach podczas zmiany szycht $\mathrm{w}$ fascynującym wizualnie prologu filmu, ale także wynoszenie rannych i zabitych robotników przez ich

\footnotetext{
94 Ibidem, s. 162.

95 Por.: B. Widdig, op. cit., s. 165.

96 A. Kaes, Cinema and Modernity: On Fritz Lang's „Metropolis", s. 24.
} 
towarzyszy po eksplozji w maszynowni (co przywodzi na myśl rannych i zabitych na polach bitew). A że tłumy zmilitaryzowanych mężczyzn padły ofiarą „podobnej bóstwu” machiny wojennej, najdobitniej świadczy sekwencja wizji Fredera: do ognistej paszczy Molocha, w ogień i na przemiał, zapędzane są siłą rzesze półnagich niewolników (alegoria niewolniczej i zabójczej pracy robotników Fredersena), podobne zaś armii zbrojne, maszerujące miarowo kolumny, wchodzą w tę czeluść dobrowolnie.

\section{Genesis, Ewangelia, Apokalipsa (według Thei von Harbou)}

Metropolis jest kolejnym po Zmęczonej Śmierci - ale też już ostatnim w twórczości Langa - filmem, gdzie tak wielką rolę w nie tylko kreowaniu znaczeń, ale i w samej koncepcji świata przedstawionego, odgrywa alegoria. Przypominam uwagi o alegorycznym trybie narracji, poczynione już przy okazji Zmęczonej Śmierci: obrazy alegoryczne, powiązane wedle typologii Jakobsona z tzw. paradygmatyczną (metaforyczną) osią tekstu, przerywają płynność linearnego toku zdarzeń fabularnych, związanych z osią syntagmatyczną (metonimiczną). Zamiast zapewniającej ciągłość przyległości elementów narracji (zdarzeń, obrazów, ujęć), co kieruje uwagę widza na anegdotę i suspens związany z przebiegiem wypadków, obrazy z osi paradygmatycznej skłaniają do zatrzymywania się nad nimi, do rozszyfrowania ich sensu, do interpretacji. Jeżeli zdarzeniowość utworu i jakościowe uposażenie świata przedstawionego pozostają z owymi obrazami w znaczeniowej i materialnej harmonii (dzięki ewokowaniu np. tego samego światopoglądu, epoki historycznej czy paradygmatu estetycznego), to nawet częste „zastyganie" fabuły i zwalnianie toku narracji nie musi niweczyć potężnego wrażenia artystycznego i emocjonalnego zaanagażowania odbiorcy - jest to przypadek Zmęczonej Śmierci, mimo pewnych zgrzytów związanych z nieuprawnionym zawłaszczeniem konotacji chrześcijańskich przez poetycki obraz żałobnej melancholii. Jeśli natomiast każdy z elementów - przebieg akcji fabularnej, materialna strona świata przedstawionego i alegoryczne konotacje - jest w permanentny sposób jawnie niewspółmierny z pozostałymi, następuje poczucie zgrzytu estetycznego, rozpad sensu i niezamierzona przez autorów śmieszność czy karykaturalność ich dzieła. Jest to właśnie, niestety, przypadek Metropolis.

Centralną sekwencją filmu, poniekąd kluczem do jego stylistyki, jest Legenda o Wieży Babel, którą Maria „opowiada” zgromadzonym w katakumbach robotnikom ${ }^{97}$. W zasadzie ramowa sytuacja narracyjna

${ }^{97}$ Za klucz do alegorycznej estetyki filmu sekwencję tę uważa Tom Gunning (op. cit., s. 56-61). 
- fakt, iż Maria obwieszcza opowiedzenie legendy - świadczy bardziej niż sama wewnątrzramowa zawartość o tym, iż jest to „opowieść". Maria (w półzbliżeniu) unosi do góry wzrok i zaczyna mówić. Plansza z napisem (wersalikami) przekazuje jej wstępne słowa: „Dziś opowiem wam legendę o Wieży Babel”. Następująca teraz sekwencja obrazów i napisów posiada na obrzeżach kadru jakby świetliste obramowanie czy rozmycie krawędzi, dające trochę efekt otaczającej kadr aureoli. Świadczy to o odmiennym statusie sekwencji jako narracji wewnątrzramowej czy niemal jako „filmu w filmie”: 1. Mężczyzna w długiej, „starożytnej” szacie na tle gwiaździstego nieba; wokół owego kapłana? proroka? władcy? - kilka postaci. 2. Plansza z napisem: „Chodźcie, zbudujemy wieżę, której szczyt dosięgnie gwiazd". 3. Postać z ujęcia 1, wokół której siedzą cztery inne osoby. 4. Plansza z napisem: „A na szczycie wieży wypiszemy słowa: «Wielki jest świat i jego Stwórca! I wielki jest człowiek!»" 5. Ziggurat, jak z obrazu Petera Breughela Starszego Wieża Babel, na tle gwiaździstego nieba. 6. Po przenikaniu: okazuje się, że to co braliśmy za wielką budowlę pod gołym niebem, jest małym modelem, wokół którego zgromadziło się kilka osób - architektów? (jedna z nich ma zadumaną pozę Rodinowskiego Myśliciela). 7. Plansza z napisem: „Lecz umysły, które poczęły Wieżę Babel, nie mogły jej zbudować. Zadanie było zbyt wielkie. Toteż za zarobek wynajęli ręce". 8. Ujęcie z wielokrotną ekspozycją: pięć niezmierzonych kolumn półnagich robotników o ogolonych głowach zmierza ponuro, z pochylonymi łysymi czaszkami, ku centrum kadru na pierwszym planie. Kompozycja kadru ewokuje dłoń z pięcioma palcami-kolumnami. Metafora „ręki”. 9. Plansza z napisem: „Ale ręce, które budowały wieżę nie wiedziały nic o marzeniu mózgu, który je zrodził”. 10. Projektodawca wieży, znany z ujęcia 1, klęczy przed Wieżą Babel, wyciągając ku niej ręce; budowla znajduje się $\mathrm{w}$ jakiejś nierealnej przestrzeni, wewnątrz kolistej tęczy. 11. Plansza z napisem wersalikami: BABEL. Litery napisu wydają się rozświetlać. 12. Plan ogólny - tłum wyglądający raczej na niewolników niż na opłacanych robotników, ciągnie gigantyczny kamienny blok. 13. Półzbliżenie robotników, padających z wysiłku pod dragami i linami, którymi ciągną blok. 14. Plansza z napisem: BABEL. Litery wydają się rozpływać ${ }^{98}$. 15. Plansza z napisem: „Hymn chwały jednego człowieka stał się przekleństwem innych ludzi". 16. Na szczycie ogromnych schodów, w głębi kadru, projektodawca wieży. U dołu kadru na pierwszym planie, kilku robotników z ogolonymi głowami podnosi do góry ręce z zaciśniętymi pięściami. 17. Plansza z napisem: „Ludzie mówili tym samym językiem, ale nie mogli się nawzajem zrozumieć". 18. Ujęcie to wygląda zrazu jak ujęcie 16. Ale okazuje się, że u stóp schodów, poniżej dolnej linii

98 „Ociekają potem? krwią?" - pyta Tom Gunning (op. cit., s. 59). A może także łzami? 
kadru, były niewidoczne wcześniej tłumy półnagich, łysych robotników, którzy gwałtownie wbiegają na szczyt schodów, zalewając je swą masą i zagrażając projektodawcy. 19. Plan wielu zaciśniętych, wyciągniętych w górę rąk; w tle Wieża Babel w kolistej tęczy. 20. Ruiny zigguratu na tle gwiaździstego nieba. Nad nimi zamieszczony na tle nieba napis, motto projektodawcy, które wobec ruin ma wydźwięk gorzkiej ironi: „Gross ist der Welt und sein Schopfer. Und Gross ist der Mensch". Ściemnienie, oznaczające koniec „legendy". Portretowe ujęcie Marii, która ręce ma złożone modlitewnie, a rozpłomieniony wzrok skierowany ku kamerze - ku widzowi i swym wewnątrzdiegetycznym słuchaczom, robotnikom. Plansza z napisem: „Mózg i ręce potrzebują pośrednika”. Znowu ujęcie Marii. Plansza z napisem: „Pośrednikiem między mózgiem a rękoma musi być serce”.

Sekwencja „opowieści” o Wieży Babel w sposób skondensowany niczym w pigułce unaocznia strategię narracyjną całego filmu: dominację w nim obrazów z osi metaforycznej i zestawianie ich $\mathrm{w}$ jako tako spójną fabułę przez wiązania werbalne, a zwłaszcza przez sensy „ideowe”. Zdarzeniowość - tak tej sekwencji, jak i całego filmu - jest w znacznej mierze pozorna: trudno powiedzieć, by „projektodawca” wieży (władca? kapłan? prorok? architekt?) był „aktantem”, którego działania generują fabułę, spójną sekwencję zdarzeń, coś, co można by nazwać „akcją”. Jedyny jego „akt” to wymyślenie wieży. Tłum „robotników” buntując się, okazuje się w pewnym sensie „aktantem”, a raczej „reaktantem”, ale jego bierność i poddaństwo nieludzkiemu wysiłkowi - jeśli są to opłacani robotnicy, a nie niewolnicy, co sugeruje nam wbrew konotacjom obrazu napis - sac zadziwiające. Zresztą „akcja” buntu dana jest nam wyjątkowo eliptycznie i synekdochicznie w sekwencji czterech ujęć (kilku robotników wygraża rękoma postaci na schodach - wbiegnięcie tłumu na schody - las wyciągniętych rąk - ruiny wieży); takie eliptyczno-synekdochiczne sekwencje znajdują się też w następnych filmach Langa: w Szpiegach (prolog, randka Soni i Agenta 326), w Kobiecie na Księżycu (kradzież rękopisu Manfeldta), w M - mordercy (zabójstwo Elsie Beckmann). W Metropolis nie ma już więcej tak eliptycznego przedstawienia jakiejś sekwencji zdarzeń, ale jest za to coś innego, co Legenda o Wieży Babel także wyraziście unaocznia: akcja ma charakter "ideowy”, ilustracyjny wobec pewnej założonej tezy (co w ogóle jest niefortunne artystycznie w dziełach sztuki). Co gorsza jednak, sama zawartość „ilustracji” kłóci się z idea, jaką ma ilustrować.

Powszechnie znana jest biblijna opowieść o Wieży Babel (Genesis 11, 1-8), w której Bóg udaremnia wzniesienie owej budowli i miasta wokół niej, karząc ludzi rozproszeniem i pomieszaniem języków. Konotacją tej przypowieści jest hybris człowieka, pycha, wskutek której ośmielił się spróbować być równym Bogu (tak samo, jak kiedy zerwał owoc w ogrodzie Eden). Zatem jest to unaocznienie zła, powodowanego przez antropo-, 
a nie teocentryczny światopogląd i system wartości. W filmie Langa hybris tę unaocznia choćby rzucone przez projektodawcę wieży zdanie, które miało wieńczyć budowlę, a ostatecznie, w zamykającym legendę obrazie, góruje nad jej ruiną: „Wielki jest świat i jego Stwórca! I wielki jest człowiek!" Bóg jest tu wymieniony na drugim miejscu, między swymi własnymi tworami, światem i człowiekiem, i tak jak one obdarzony tym samym atrybutem „wielkości”. Rzecz jasna, sentencja ta jest wyrazem hybris. Narracja filmu Langa uniemożliwia nam jednak refleksję nad tym aspektem, bo w filmowej wersji jest on zepchnięty na margines; legenda o Wieży Babel w Metropolis to unaocznienie konfliktu społecznego między projektodawcami a wykonawcami, pracodawcami a robotnikami, władcami a ludem, panami a niewolnikami. Biblijne „pomieszanie języków” staje się „niemożnością porozumienia” ludzi mówiących tym samym językiem, ale należących do różnych klas społecznych. Zanika teologiczny i metafizyczny aspekt przypowieści, a raczej zostaje zupełnie stłumiony przez wymowę społeczna, wymyśloną przez scenarzystkę. Po raz kolejny, po Zmęczonej Śmierci, film Langa zawłaszcza biblijne referencje, zmieniając zupełnie ich kontekst i wymowę.

Ale, co gorsza, „legenda” opowiedziana przez Marię, jest de facto jedynie parabolicznym exemplum w jej „kazaniu”, którego moralną lekcją jest konieczność pośrednictwa "serca” między „mózgiem” a "rękoma”. O co tu właściwie chodzi? Bez tego metakomentarza opowieść o Wieży Babel mogłaby się jawić właściwie jako komunistyczna agitka, uzasadniająca słuszność buntu klasy robotniczej wobec jej zniewolenia przez „klasę próżniaczą". Tymczasem faktycznie chodzi nie o to, by proletariat stał się podmiotem, by się wyzwolił z opresji nieludzkich warunków narzuconych przez "panów”, ale o zaakceptowanie przezeń swej kondycji. Nie chodzi o wyzwolenie i nie o solidaryzm społeczny w jakiejś pozytywistyczno-organicznikowskiej wizji, ale o dobrowolne poddanie się warunkom narzuconym przez klasę posiadająco-rządząca, choć dla niepoznaki to poddanie się ma pozór obustronnej ugody. Taki sens unaocznia finał filmu, kiedy to samo zdanie, które pointowało "kazanie” o Wieży Babel (wówczas jeszcze jako postulat, który należy zrealizować), pieczętuje jako spełnienie tego postulatu uścisk ręki między proletariatem a władcą-pracodawcą. O jego pozorności jako ugody (a faktycznie byciu kapitulacją robotników) świadczy to, iż Fredersen wymienia uścisk dłoni nie z przedstawicielem robotników, ale tak naprawdę ze swym własnym i lojalnym człowiekiem - nadzorcą Grotem. A „Pośrednikiem” jest, co więcej, jego własny syn, którego „mediatorska” rola sprowadza się do w zasadzie zupełnie zbędnej asysty w ceremonii. W kontekście tego finału i w ogóle „koncyliaryzmu” głoszonej przez Marię „Dobrej Nowiny” o „Pośredniku” dziwić może, że Fredersen chce zniweczyć jej wpływ na robotników, zamiast usilnie ją wśród nich 
promować - ale nie pierwsza to i nie ostatnia nielogiczność fabularna filmu. Przykład innej: dlaczego Fredersen każe Grotowi otworzyć bramy wiodące do Herzmaschine, skoro zniszczy to także system zasilania górnego miasta? Szukanie pretekstu do użycia przeciw robotnikom siły - zresztą jakiej, skoro w świecie Metropolis nie widać ani policji ani wojska - nie usprawiedliwia decyzji samobójczych.

Ta niedorzecznie skonstruowana anegdota, o prokorporacyjnej i chyba rzeczywiście faszyzującej wymowie społecznejej, jest jednak tym bardziej absurdalna i niesmaczna, że scenariusz narzucił postaciom i ich kwestiom odniesienia biblijne, zwłaszcza ewangeliczne, zresztą nie tylko niestosowne, ale i zupełnie nieuzasadnione wobec faktu, że „religia” ma w tym filmie wymiar jedynie polityczny i socjalny, będąc zupełnie pozbawiona elementów teologicznych czy choćby metafizycznych.

A zatem Fredersen ma konotacje Boga Ojca. Imię Joh jest aluzją do imienia Jehowa czy Jahwe. Jest on nie tylko władca, ale i "twórcą" Metropolis (choć przecież nie Stwórca, skoro to "rękoma robotników zbudowano miasto”). I jest ojcem „mesjanicznego" Pośrednika, który w dodatku podczas swego „ukrzyżowania na zegarze” zwraca się doń: „Ojcze! Ojcze! Czy te dziesięć godzin nigdy się nie skończy?!” W jego słowach, gdy prosi Rotwanga, by nadał robotowi podobieństwo do Marii („Zasieję niezgodę między nimi a nią"), pobrzmiewa echo słów Boga (Genesis 3, 15) o zasianiu niezgody między niewiastą i wężem.

Imię Maria ewokuje oczywiste konotacje: to dziewica-matka. Dziewiczość Marii (wyraźnie podkreślana w powieści Thei von Harbou) w filmie jest sugerowana wizualnie poprzez skromna, purytańska, zapiętą po szyję suknię ${ }^{100}$. Jej matczyność przejawia się w jej pierwszym pojawieniu się w filmie, otoczonej wianuszkiem ubogich dzieci, i w ratunku, który niesie dzieciom robotników podczas powodzi. Co jednak ważniejsze, pewne niezbyt zresztą konsekwentne - jak i wszystko w tym filmie - sugestie, wiążą ją z matką filmowego "Mesjasza”: dla obłąkanego w finale Rotwanga jawi się ona jako Hel, matka Fredera. Tę konotację matki „Pośrednika” ewokuje też scena, kiedy Freder zaskakuje w uścisku ojca i fałszywą Marię, nie wiedząc zreszta, że to nie Maria, tylko jej sobowtór. W interpretacji realistycznej jego zapaść jest rezultatem szoku z powodu zazdrości i odkrycia zupełnie innej natury ukochanej niż mógłby przypuszczać. W interpretacji psychoanalitycznej doznaje on jednak traumy „edypalnej”, zazdrości

99 Jako faszyzującą czy wręcz pronazistowską odczytują wymowę filmu np.: S. Kracauer, op. cit., s. 138-140; R. L. Rutsky, op. cit., s. 232-245; B. Widdig, op. cit., s. 165; Roger Dadoun, "Metropolis": Mother City - «Mittler» - Hitler, „Camera Obscura” 1986 (Autumn), vol. 15, s. 137-163.

100 Thomas Elsaesser (Metropolis, s. 70) zauważa, iż Maria jest ubrana jak kwakierka. 
chłopca o matkę ujrzaną w obcowaniu z ojcem ${ }^{101}$. Ale tak naprawdę, jak zauważa Gunning, Maria (prawdziwa) pełni wobec filmowego „zbawiciela", Pośrednika, rolę nie tyle Maryi, co Jana Chrzciciela ${ }^{102}$, głosząc jego rychłe przyjście i natychmiast, nie wiadomo zresztą na jakiej podstawie, od razu go rozpoznając. Maria w ogóle sprawuje w świecie robotników posługę „kapłańską": miejsce w katakumbach, gdzie wyznacza im spotkania, sprawia wrażenie kaplicy z ołtarzem, jej przemowa wydaje się homilią, a szarfa wokół jej zgrzebnej sukni jawi się raczej jako stuła. Jednym słowem - to prorokini i ksiądz zarazem. Jej słowa słuchacze przyjmują niczym ewangelię - klękając, modlitewnie wznosząc rozpłomienione oczy, przyciskając ręce do serca. Tylko gdzie w głoszonej przez tę „,świętą" religii jakikolwiek wymiar transcendentny, a choćby i najmniejszy sens?

Freder, stosownie do swego bycia synem Joh-Jahwe Fredersena, poświęca się - no, nie tyle za ludzkość, co za pojedynczego robotnika o numerze 11811 i przyjmuje zań „męczeństwo” zastąpienia go przez 10 godzin na jego stanowisku pracy. Po malowniczym „ukrzyżowaniu” na przypominającej zegar tarczy Paternostermaschine "zmartwychwstaje", nieustannie krążąc między górnym miastem a Miastem Robotników, gdzie - może z wyjątkiem uratowania dzieci z powodzi - nie dokonuje właściwie niczego godnego uwagi. Zapowiedziana przez prorokinię Marię jego „mesjańska” rola Pośrednika (Mittler) sprowadza się do nie żądającej szczególnej charyzmy ani trudu asysty przy uścisku ręki jego ojca z nadzorcą. Doprawdy, rola „mesjańska” w świecie zaprojektowanym przez Theę von Harbou nie wymagała od „pomazańca” zbyt wiele.

Freder jest $w$ znacznej mierze medium prowadzącym widza w świecie filmu - razem z nim przemieszczamy się kolejno ze stadionu i Wiecznych Ogrodów do maszynowni, Nowej Wieży Babel, katakumb, katedry, domu Rotwanga, Miasta Robotników i znów do katedry. Ale te przemieszczenia nie wynikają z jakiejś sensownej i zmierzającej do jakiegoś konkretnego celu akcji, są czysto mechaniczne. Freder tak naprawdę nie jest "aktantem” sensu stricto, którego działania generowałyby klasyczną w strukturze fabułę. Łańcuch scen z jego udziałem to sekwencja dość luźno i mechanicznie powiązanych ze sobą epizodów, z których żaden tak naprawdę nie jest strukturalnie konieczny i logicznie z poprzednimi i następnymi powiązany. W scenach z jego udziałem nasz Mittler jest zadziwiająco bierny, jawiąc się raczej jako widz czy świadek zdarzeń niż ich aktywny uczestnik. Tak o tym pisze Tom Gunning: „Jak na archetypowego bohatera, Freder jest zdumiewająco nieskuteczny. Jego podróż w podziemia przynosi objawienie, ale jego powrót na powierzchnię wyznaczają spotkania, które

101 Por.: T. Gunning, op. cit., s. 68-76.

102 Ibidem, s. 67. 
nie doszły do skutku, uwięzienie na jakiś czas, omdlenia i halucynacyjna gorączka w łóżku. Jego rola jako zbawiciela zostaje odstawiona na boczny tor, gdy tylko demoniczna energia filmu gwałtownie nabiera rozpędu. Może to odzwierciedlać niezdolność Thei von Harbou do skonstruowania akcji w jakiejkolwiek innej formie niż chaos czy, w ostatnim akcie, jako film «sensacyjny», z bohaterskim ratunkiem i zawisaniem nad przepaścią [cliffhanger]. Ale ten brak akcji ze strony bohatera-pośrednika odzwierciedla głęboką ambiwalencję filmu co do swej własnej mesjańskiej wizji. Prócz demonów, nikt inny nie chce podjać akcji w tym filmie; działanie wiedzie tylko do chaosu. Figury religijne [...] są zdolne tylko do wizji. Maria sama odmawia przyjęcia jakiejkolwiek innej roli niż Jana Chrzciciela, zapowiadającego i zwiastującego nadejście Mesjasza. A sam naznaczony, Freder, gubi się w labiryncie gotyckiego otoczenia Metropolis i w swej własnej wizjonerskiej psychozie"103.

Tylko siły demoniczne są zatem w tym filmie zdolne do działania, zarówno w aktach kreacji (Rotwang stwarzający sztucznego człowieka), jak i zniszczenia (orgia destrukcji, rozpusty i przemocy, rozpętana przez fałszywą Marię, istne wcielenie apokaliptycznej babilońskiej nierządnicy). Trzeba przyznać, że właśnie Rotwang i jego dzieło to jedyni prawdziwi generatorzy fabularnej zdarzeniowości, jedyne sensu stricto aktanty w narracji. I to właśnie $\mathrm{z}$ ich akcją związane są najbardziej pamiętne obrazy filmu o konotacjach biblijnych: akt stworzenia fałszywej Marii i szaleństwa robota w Yoshiwara. Pierwszy z nich, dokonujący się pod szatańskim znakiem odwróconego pentagramu, jest demoniczna, o gotycko-romantycznym rodowodzie, parafrazą aktu stworzenia człowieka z Genesis. Drugie, w sposób sensowny i niebędący nadużyciem biblijnych konotacji, ewokują zapowiedziane w Apokalipsie św. Jana (zob. pierwsze motto do niniejszego rozdziału) zepsucie i przemoc czasów ostatecznych. Obrazy triumfalnej, a zarazem kulminującej w "mimetycznej przemocy”, recepcji fałszywej Marii w lokalach Yoshiwara, przejmująco korespondują z poprzedzającym apokalipsę nazizmu i udokumentowanym przez sztukę Neue Sachlichkeit (zresztą także przez samego Langa w Doktorze Mabuse, graczu i Szpiegach) dekadenckim rozpasaniem Republiki Weimarskiej. „Patrzmy wszyscy, jak świat idzie do diabła!” - wezwanie fałszywej Marii do uczestników pochodu z lampionami w Yoshiwara z powodzeniem mogło też być dewizą wielu gości berlińskich knajp, szulerni i domów publicznych w szalonych latach 20.

Remedium, jakie scenariusz filmu proponuje na przezwyciężenie tego apokaliptycznego kryzysu (osławiona sentencja o Pośredniku między mózgiem a rękoma), jest jednak absolutnie fałszywe. Czyż zresztą mogło być

103 Ibidem. 
inne, skoro w "ołtarzu” katakumbowej „kaplicy” na żadnym z dziesięciu krzyży nie widnieje Chrystus, „katedrę” zamiast figur świętych wieńczą wilkopodobne maszkarony, a z wystroju jej wnętrza widzimy jedynie nawowy ołtarz z przedstawieniem Śmierci i Siedmiu Grzechów Głównych? I to właśnie przed alegoryczną figurą Śmierci jako Ponurego Żniwiarza klęka, gorliwie się do niej modląc Freder, figura niby-to mesjańska, żałosny Mittler żałosnej ewangelii według Thei von Harbou.

\section{Efekty specjalne. Megapolis czy Mikropolis?}

Metropolis jest filmem, który mimo krytyki jego ideologii i jego absurdalnej fabuły, wzbudził dość powszechny zachwyt swą stroną wizualna, zwłaszcza rozmaitymi rozwiązaniami technicznymi, które wyczarowały dla widza rzeczy „niemożliwe” (malkontenctwo Herberta George’a Wellsa było wyjątkiem w dość jednogłośnym w tej materii chórze pochwał). Zresztą do dziś robi on pod względem technicznym naprawdę duże wrażenie np. na studentach historii filmu - uwzględniając fakt, iż powstał w roku 1926, a więc na grubo przed erą elektroniczną i cyfrowa, to raczej twórcy rozmaitych wizji „,miasta przyszłości” powstałych w tej erze powinni się zdumieć, iż ich efekt wcale nie wydaje się bardziej atrakcyjny i przekonujący niż w takim „zabytku” jak film Langa (vide: Piaty element Luca Bessona czy Atak klonów George’a Lucasa).

Rozwiązaniem, nad którym najwięcej się rozpisywano i które istotnie zrewolucjonizowało technikę filmowa, były efekty specjalne z zastosowaniem lustrzanych odbić, Spiegeltrickverfahren; w literaturze przyjęto zwać je „trickami Schüfftanowskimi”, od nazwiska ich wynalazcy Eugena Schüfftana. Koncepcja świata przedstawionego filmu zakładała istnienie w nim wielu gigantycznych obiektów - drapaczy chmur, stadionu, katedry, maszynowni przekształconej w Molocha. Konstruowanie gigantycznych scenografii nie tylko byłoby niekiedy niemożliwe (plany ogólne miasta), ale gdyby nawet było możliwe (np. w wypadku stadionu czy katedry), pochłonęłoby zbyt wiele czasu i środków. Rozwiązaniem umożliwiającym ich sfilmowanie były właśnie tricki Schüfftanowskie, umożliwiające kombinowanie małych modeli wielkich obiektów z żywą akcją. Przed kamerą umieszczano lustro, aby odbijało obiekty znajdujące się za nią albo gdzieś obok niej, jak np. modele budynków czy krajobrazu. Lustro to było albo na wpół przejrzyste, albo umieszczone przed kamerą pod pewnym kątem, który umożliwiał jednoczesne filmowanie zarówno owych modeli, jak i aktorów. Głównym operatorem filmu był prawdziwy geniusz kamery Karl Freund, natomiast za zdjęcia z trickami Schüfftanowskimi i animacją odpowiadał inny wielki mistrz obrazu w kinie niemieckim owych 
lat - Günther Rittau. Pisał on: „za pomocą jedynie fragmentów dekoracji i modeli Schüfftanowskich na małą skalę stworzyliśmy fragmenty scen na gigantycznych ulicach i nastrojowe sceny w katedrze. [...] Najbardziej skomplikowane były wizyjne sceny z Molochmaschine, także zrealizowane przy zastosowaniu Spiegeltrickverfahren"104.

Przy użyciu tricków Schüfftanowskich sfilmowano także Miasto Robotników, stadion, lokale w Yoshiwara, Wieżę Babel, dom Rotwanga i olbrzymią głowę Hel. Tam zaś, gdzie wskutek wymaganego ruchu w kadrze nie można było uciec się do tej techniki, zastosowano filmowanie planów klatka po klatce, jak w animowanym filmie lalkowym. Najsłynniejszym przykładem użycia tego drugiego sposobu są plany pokazujące główną ulicę Metropolis, z napowietrznymi ciągami komunikacyjnymi i samolotami latającymi pośród gigantycznych drapaczy chmur. Lang prawdopodobnie podpatrzył tę technikę w studiach hollywoodzkich podczas swej amerykańskiej wizyty jesienią $1924^{105}$.

Scenograf Erich Kettelhut opisuje żmudną pracę animatorów, przygotowujących plan centralnej arterii Metropolis do filmowania klatka po klatce: „Model głównej ulicy Metropolis [...] wyrósł w małym przeszklonym studio. Budowniczowie modeli pracowali przy użyciu drucików, które miały wisieć poza kadrowanym obrazem pod tym samym kątem, jak te, które były żądane dla tras miniaturowych samolotów w trójwymiarowej przestrzeni. Wisiały one na trzech włosach, połączonych ze specjalnie wykonanymi wałkami, dzięki którym można było je opuszczać lub wciągać wyżej centymetr po centymetrze, dzięki z kolei nachylonym drucikom, manipulowanym przez biegnące od strony kamery linki, wedle kierunku, w którym miały lecieć. [...] [Włosy te] nie były widzialne w obrazie. Gdy już ukończono ten kosztowny model, musiały minąć jeszcze dwa tygodnie, zanim naprawdę mogło rozpocząć się filmowanie. Model wymagał jeszcze stosownego oświetlenia, a prędkość poruszania się samolotów, samochodów, pociaggów na napowietrznych traktach i przechodniów na chodnikach trzeba było przetestować, skoro cały model miano filmować klatka po klatce. Nie było żadnego innego sposobu, żeby zapanować nad wieloma fazami jednoczesnego ruchu. Po wielu powtarzanych próbach

104 Günther Rittau, Trickaufnahmen in „Metropolis”, „Mein Film” 1927, Nr. 60, s. 5 (cyt. za: H. Bachmann, op. cit., s. 17). Natomiast sposób realizacji sceny wizji Fredera, w której maszynownia przekształca się w Molocha, opisuje drobiazgowo jeden z genialnych scenografów filmu, Erich Kettelhut. Zob.: Erich Kettelhut, Errinnerungen, materiały niepublikowane, Archiv Filmmuseum Berlin, s. 601-603 (przedruk: E. Kettelhut, Moloch, [w:] Fritz Lang. Leben und Werk. Bilder und Dokumente, Red. Rolf Aurich, Wolfgang Jacobsen, Cornelius Schnauber, Filmmuseum Berlin-Deutsche Kinemathek und jovis Verlag GmbH, Berlin 2001, s. 115-118).

105 Zob.: H. Bachmann, op. cit., s. 17-18. 
ustaliliśmy, że pozycja samolotu między jednym a drugim kadrem musi przesunąć się o półtora centymetra, pociągów o centymetr, samochodów o około trzy czwarte centymetra, a przechodniów o zaledwie ułamek, aby osiągnąć płynność przy wiarygodnej szybkości"106.

Rittau w swych wspomnieniach daje z kolei wyobrażenie, jak powolne i pracochłonne było filmowanie tak przygotowanego planu: „Ilustracja jak trudne były te ujęcia jest fakt, iż pracowaliśmy przez prawie 8 dni, aby sfilmować $40 \mathrm{~m}$ filmu, pokazującego scenerię z modelami; każdą pojedynczą klatkę trzeba było filmować osobno, a 40 metrów filmu zawiera 2100 pojedynczych klatek. W filmie cała ta scena nie trwa dłużej niż 10 sekund"107.

Rittau też wspomina, że jednym z najbardziej ekscytujących zadań dla operatora było stworzenie efektów świetlnych w sławnej scenie oblekania się metalicznego korpusu robota w ciało Marii. „Antropogeneza dokonuje się dzięki transferowi ludzkiej formy Marii przy użyciu prądu elektrycznego. No cóż, prąd elektryczny zwykł być niewidzialny. Ale z drugiej strony, tak fantastyczne i tajemnicze zdarzenie, jakie tu zachodziło, absolutnie musiało być widzialne"108. A stało się to możliwe dzięki dość tradycyjnej technice podwójnej ekspozycji i... papierowi śniadaniowemu. „Do tej słynnej sceny Lang sfilmował jedynie obraz siedzącego robota, podczas gdy efekty specjalne - często celebrowane jako wspaniała wizja Langa - były wkładem zespołu Rittaua. Rittau umieścił czarną aksamitną sylwetkę robota przed kamera, i sfilmował dwa poruszające się w górę i w dół wzdłuż sylwetki świetliste pierścienie; ten sam fragment filmu musiał być eksponowany sześć razy, aby wywołać efekt dwunastu świetlnych pierścieni wokół figury. Jego asystent H. O. Schulze przypomina sobie, że «same pierścienie wykonano z jakiegoś rozpraszającego światło papieru śniadaniowego». Słowa te dają pojęcie o pomysłowości, z jaką zespół Rittaua stwarzał całkiem przekonywające, widowiskowe efekty specjalne"109.

Z kolei sugestywność efektu szoku, jaki eksplozja w maszynowni wywiera na Frederze, osiągnięta została dzięki inwencji Karla Freunda, który dla tego celu po prostu rozkołysał kamerę (Freund zresztą od czasu Portiera z hotelu Atlantic, 1924, którego to filmu był operatorem, uchodził za głównego specjalistę w kinie niemieckim od entfesselte Kamera - „kamery wyzwolonej").

Oczywiście, wiele rzeczy zaplanowanych czy wymarzonych przez

106 Erich Kettelhut, Errinerungen, s. 612-614 (przedruk: E. Kettelhut, Hauptstraße, [w:] Fritz Lang. Leben und Werk. Bilder und Dokumente, s. 106-108).

107 Günther Rittau, Special Effects in "Metropolis", [w:] Fritz Lang's "Metropolis": Cinematic Visions of Technology and Fear, s. 79 (prwdr.: G. Rittau, Trickaufnahmen in "Metropolis", s. 6).

108 Ibidem, s. 80.

109 H. Bachmann, op. cit., s. 18. 
Langa nie mogło być - dla wiarygodnego wrażenia realności fantastycznego świata przedstawionego - realizowanych przy użyciu tricków Schüfftanowskich, animacji klatka po klatce, "wyzwolonej kamery” czy innych jeszcze specjalnych technik. Woda w scenie powodzi musiała być woda, ogień stosu ogniem, a ekstatyczne czy zbuntowane tłumy - tłumami. Stąd zresztą tak oszałamiające dane liczbowe, które biuletyn Ufy, a za nim rozmaici recenzenci filmu z lubością lub zgrozą przytaczali. Jak wiemy, wszystko to i tak nie opłaciło się ekonomicznie - film był spektakularną klęską finansową. Ale czy przynajmniej opłaciło się artystycznie, czy supermetropolia przyszłości uzyskała istotnie wiarygodny i porażający widza realizmem ekranowy kształt?

Otóż, jak sądzę, i w tym aspekcie Metropolis ponosi klęskę. Nie sposób, rzecz jasna, nie podziwiać naprawdę imponującej scenografii Miasta Robotników, głównej ulicy, maszynowni czy katedry, nie dać się porwać ekspresywnej choreografii mas podczas zmiany szycht, $w$ trakcie buntu, w Yoshiwara czy w sekwencji Wieży Babel. Rzecz jednak w tym, że w swej koncepcji miasto z filmu Langa wcale nie wydaje się - mimo imponujących planów ogólnych - supermetropolią. Brakuje w nim życia obrazowanego z perspektywy ulicy, z widocznymi na niej tłumami przechodniów, pojazdami, lokalami czy sklepami (nie załatwia tu sprawy krótkie ujęcie z Frederem tuż przed jego wtargnięciem do domu Rotwanga czy scenki z robotnikem nr 11 811, gdy podczas jazdy samochodem Federa migają mu przed oczami pokusy Yoshiwary - choć dają one pojęcie, jaki ten film mógłby być, gdyby takich scen i ujęć było znacznie więcej). Nie mamy pojęcia, kto mieszka i żyje w górnym mieście, jak jest ono zorganizowane, jak działają jego służby, policja (jeśli w ogóle jest), komunikacja itd. Wskutek tej niewiedzy plany ogólne metropolii, włącznie z opisywaną przez Kettelhuta, tak pieczołowicie przygotowywana, ogólną panoramą głównej ulicy, wydają się trochę kwiatkiem do kożucha - niezbyt atrakcyjnego kożucha, którym jest niedorzeczna opowieść Thei von Harbou. Rozgrywa się ona w kilku miejscach z zupełnie innej bajki niż nowoczesna metropolia przyszłości (Wieczne Ogrody, Miasto Robotników, dom Rotwanga, katakumby, pseudokatedra), które w dodatku wszystkie wydają się znajdować tuż koło siebie, a postacie błyskawicznie przemieszczają się pomiędzy nimi pieszo, po schodach, ewentualnie windami. Ciasnota horyzontu Thei von Harbou sprawia, iż mimo wspaniałej wizualnej wyobraźni Langa, jego genialnych operatorów i scenografów, to niby-Megapolis przeraźliwie zacieśnia się do faktycznego Mikropolis o charakterze pseudogotyckiego getta, w roku 2026 czy też 3000 niewątpliwie mocno anachronicznego. 



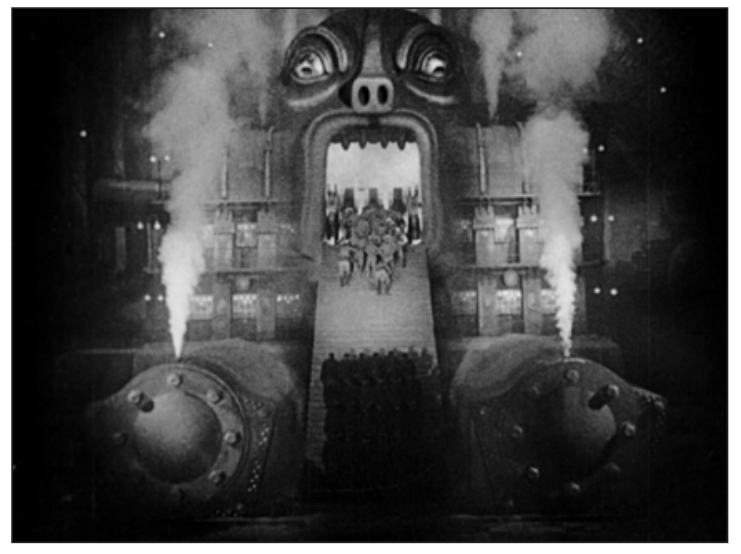

1. Metropolis (1926, reż. Fritz Lang). Wizja Fredera - przemiana maszynowni w Molocha

2. Metropolis (1926, reż. Fritz Lang). „Ukrzyżowanie” Fredera na zegarze - „Ojcze! Ojcze! Czy te dziesięć godzin nigdy się nie skończy?!”
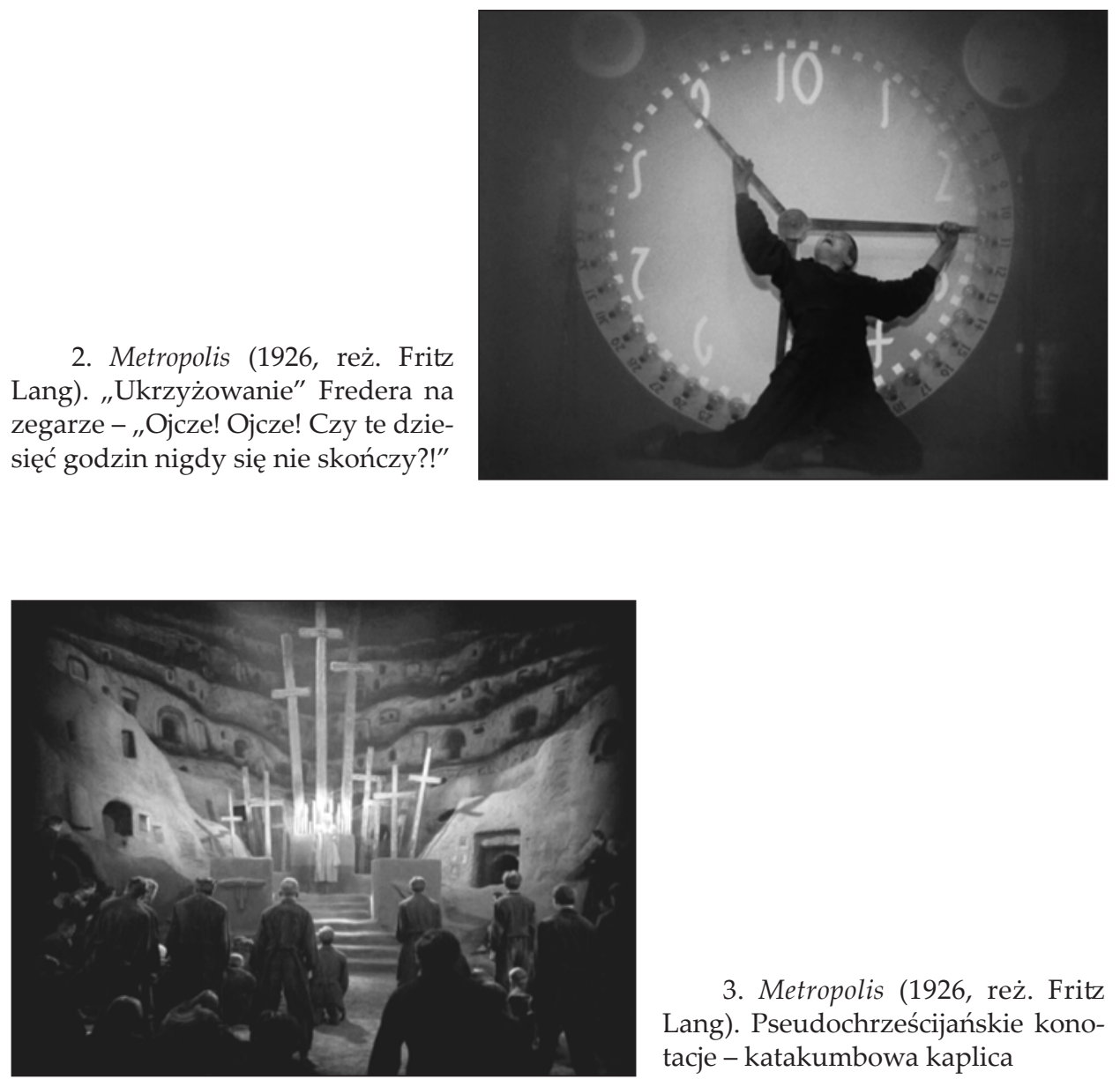

3. Metropolis (1926, reż. Fritz Lang). Pseudochrześcijańskie konotacje - katakumbowa kaplica 


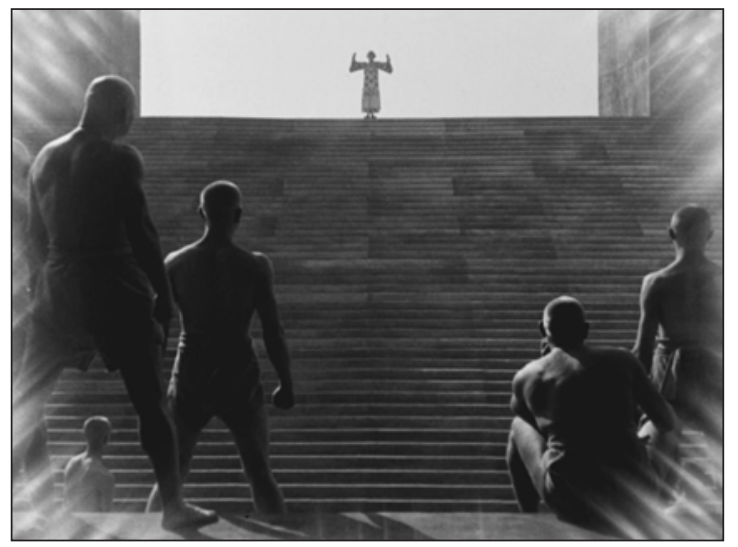

4. Metropolis (1926, reż. Fritz Lang). Legenda o Wieży Babel „mózg" i zbuntowane „ręce"

5. Metropolis (1926, reż. Fritz Lang). Jedno $\mathrm{z}$ nielicznych ujęć ukazujących górne miasto z poziomu ulicy
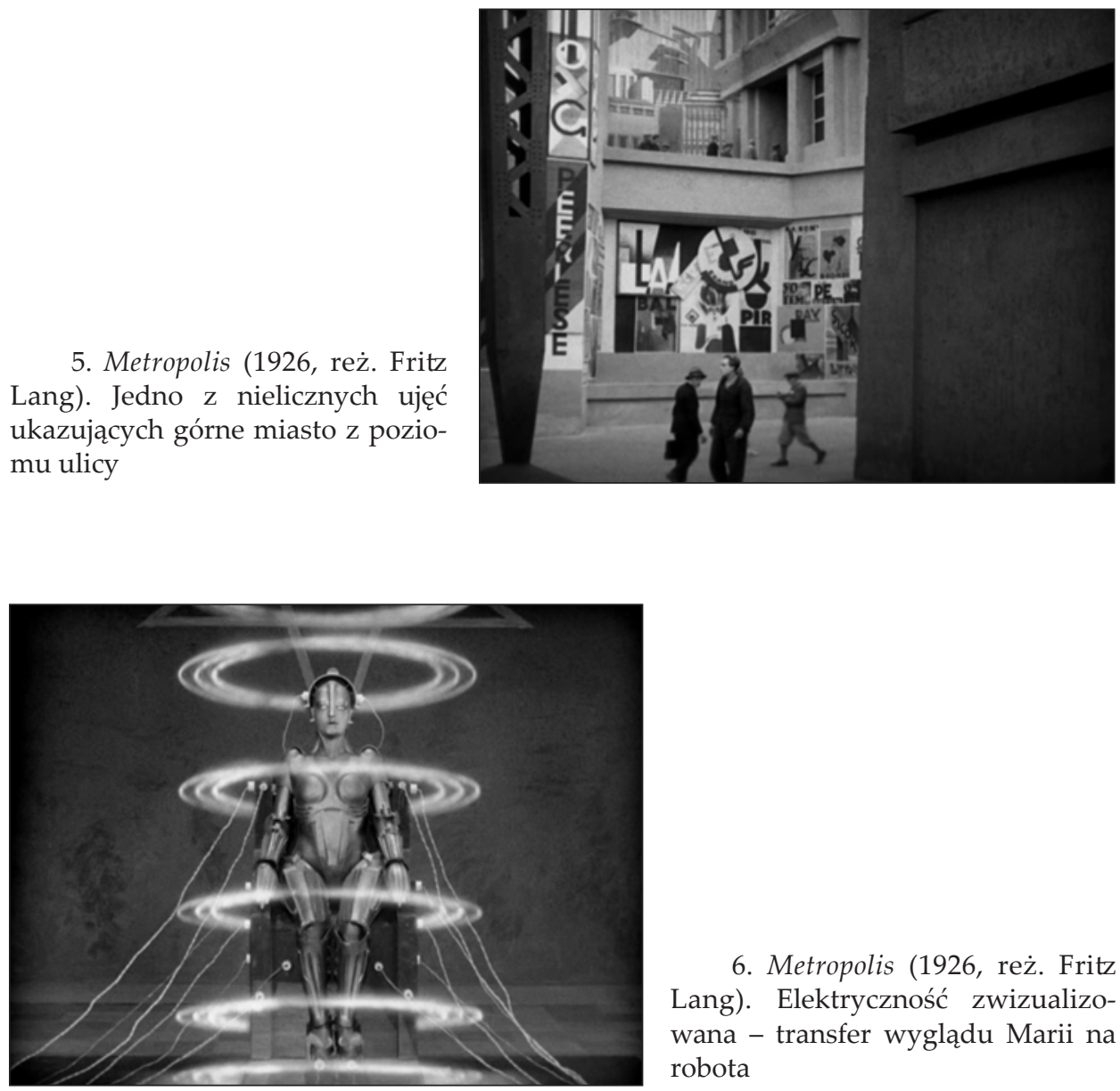

6. Metropolis (1926, reż. Fritz Lang). Elektryczność zwizualizowana - transfer wyglądu Marii na robota 


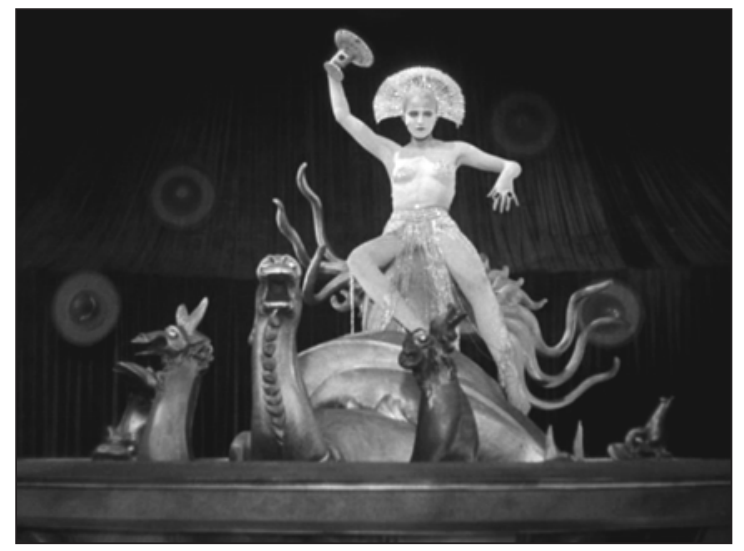

7. Metropolis (1926, reż. Fritz Lang). Fałszywa Maria - babilońska nierządnica

8. Metropolis (1926, reż. Fritz Lang). „Kazanie” fałszywej Marii do robotników w kolażowym kadrze o awangardowej stylistyce
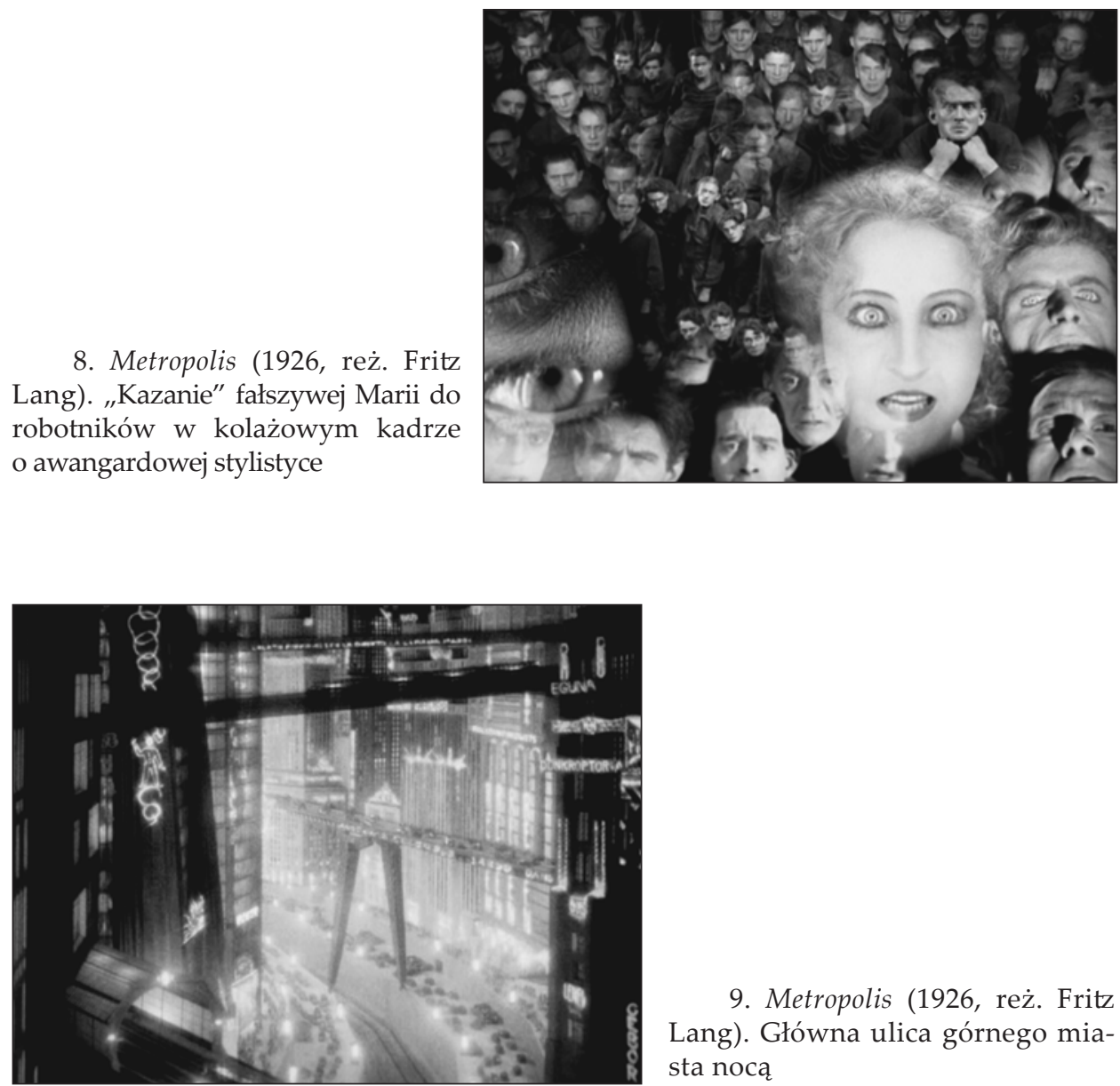

9. Metropolis (1926, reż. Fritz Lang). Główna ulica górnego miasta nocą 


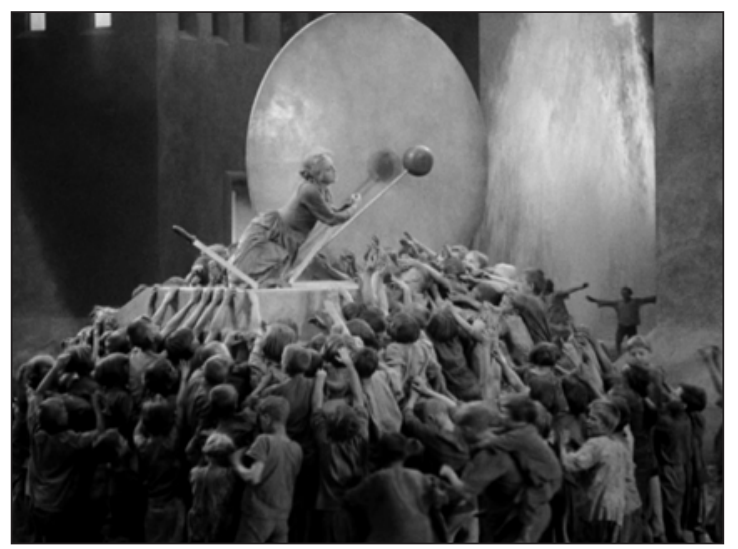

10. Metropolis (1926, reż. Fritz Lang). Dzieci z zatapianego Miasta Robotników skupiają się przy Marii

11. Metropolis (1926, reż. Fritz Lang). Apokaliptyczny paroksyzm „Patrzmy, jak świat idzie do diabła!"
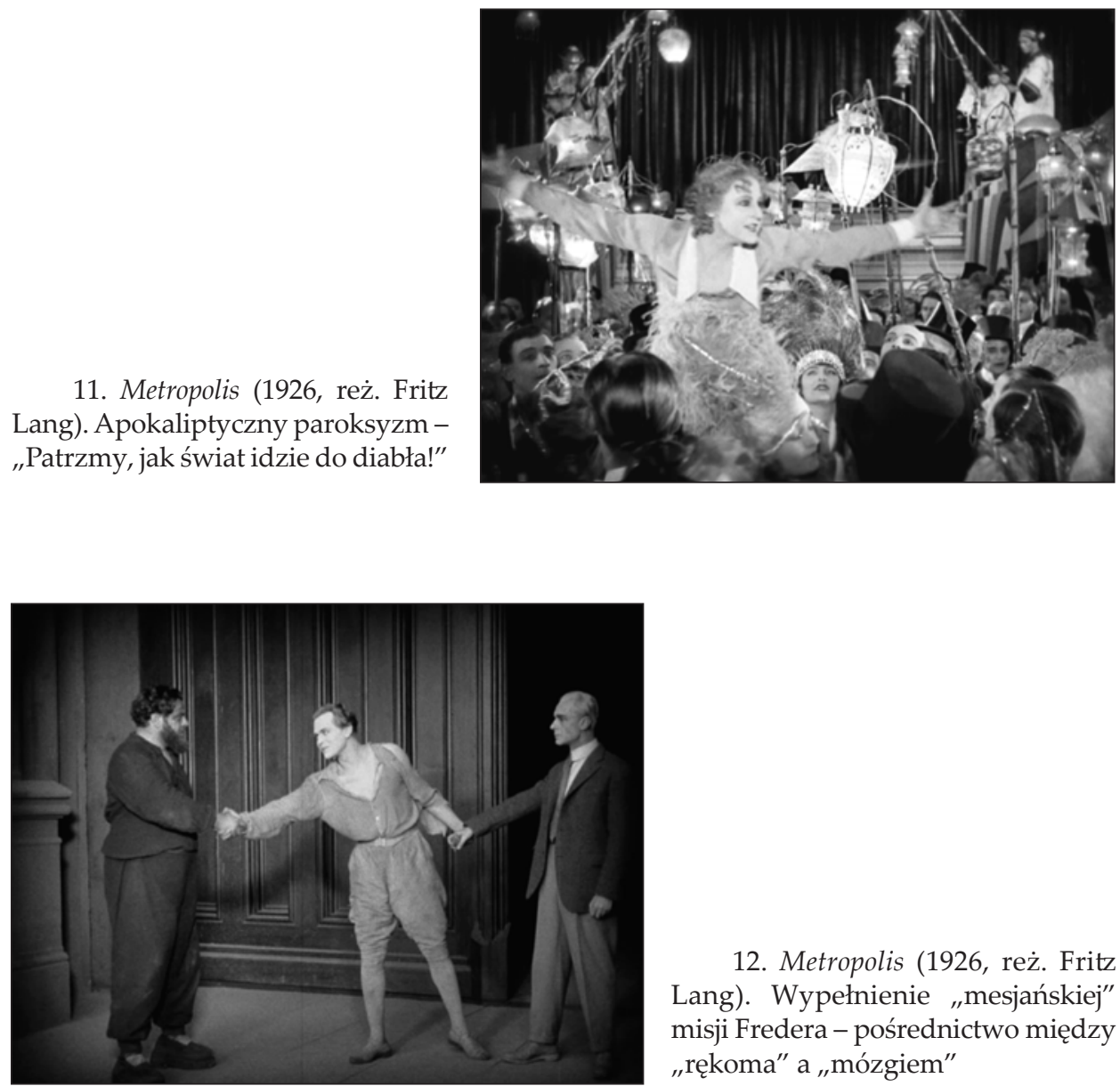

12. Metropolis (1926, reż. Fritz Lang). Wypełnienie „mesjańskiej” misji Fredera - pośrednictwo między „rękoma” a „mózgiem” 


\section{Rozdział 6}

\section{NA ZŁOTYM GLOBIE: KOBIETA NA KSIĘŻYCU}

Tarcza księżycowa lśniła nieskazitelnym blaskiem. Promienie jej, których nie przyćmiewała teraz pełna oparów atmosfera ziemska, przenikały swobodnie przez szybę, nasycając powietrze $\mathrm{w}$ pocisku srebrzystymi refleksami. Czarna zasłona firmamentu uwydatniała jeszcze bardziej blask satelity, który nie rozpraszając się w próżni eteru nie przyćmiewał sąsiednich gwiazd. Niebo oglądane $\mathrm{w}$ ten sposób, przedstawiało niezwykły widok, który był prawdziwą niespodzianką dla ludzkiego oka.

Łatwo sobie wyobrazić, z jakim zaciekawieniem trzej śmiałkowie przypatrywali się Księżycowi, który był ostatecznym celem wyprawy. Góry jego, równiny, cała rzeźba terenu, nie uwydatniały się wyraźniej, niż gdyby je oglądali z jakiegokolwiek punktu na Ziemi, lecz jego światło, biegnąc przez próżnię, lśniło niezwykle intensywnie. Tarcza promieniała niczym platynowe zwierciadło. O Ziemi, która uciekała $w$ dal pod ich nogami, podróżnicy zapomnieli w tej chwili zupełnie ${ }^{1}$.

Jules Verne, Wokót Księżyca

\section{Pożegnanie z Ufą i z filmem niemym}

Drugi film niezależnej spółki produkcyjnej Fritz Lang Film GmbH okazał się jej ostatnim przedsięwzięciem. Oznaczał też zarazem kres współpracy reżysera z Ufa, która była dystrybutorem dla Fritz Lang Film. Związki reżysera z najpotężniejszą niemiecką kompanią filmowa, i tak już mocno rozluźnione po finansowej katastrofie Metropolis, tym razem uległy ostatecznemu zerwaniu. Logo Ufy, widniejące przed czołówkami Doktora Mabuse, gracza, Nibelungów, Metropolis i Szpiegów - być może najwybitniejszych

${ }^{1}$ Jules Verne, Wokót Księżyca, przeł. Ludmiła Duninowska, Nasza Księgarnia, Warszawa 1958, s. 191. 
artystycznie, a w każdym razie najsugestywniejszych wizualnie i najbardziej frapujących znaczeniowo filmów reżysera - po Kobiecie na Księżycu nie pojawi się już w filmach Langa nigdy więcej.

Lang, rozzuchwalony powodzeniem Szpiegów (filmu o dość skromnym budżecie), zamierzył Kobiete na Księżycu jako jeszcze jeden „super-film", o rozmachu porónywalnym z wystawnością Nibelungów czy Metropolis, nie żałując środków na to, co miało być clou spektaklu: projekt rakiety i sekwencję jej startu ${ }^{2}$. Ostateczny koszt realizacji wyniósł 2 miliony marek $^{3}$ - i to nowych, nieinflacyjnych, silnych Reichsmarek, wprowadzonych w 1924 r. I choć wedle ankiety przeprowadzanej co roku przez „Film-Kurier” pośród właścicieli kin, pytanych o pięć cieszących się największym powodzeniem filmów sezonu, Kobieta na Księżycu zajęła pierwsze miejsce $\mathrm{w}$ sezonie 1929/19304, to ostatecznie sukces ten (w porównaniu z poniesionymi kosztami produkcji i z nakładami na reklamę) okazał się umiarkowany, a rozczarowujące dystrybutora wpływy kasowe przyczyniły się właśnie do ostatecznego zerwania związków Langa z Ufą ${ }^{5}$. W czołówce następnego filmu Langa - M - mordercy - widnieć będzie już wyłącznie logo wytwórni Nero-Film, niezależnej spółki produkcyjnej Seymoura Nebenzahla.

Jak pisze biograf reżysera, „Lang niezmiennie irytował egzekutywę studia swymi naleganiami na wcielanie $\mathrm{w}$ życie jego własnych pomysłów w kampaniach reklamowych. Nieuleczalny promotor samego siebie, Lang pisał okazjonalne artykuły, udzielał nieautoryzowanych wywiadów i żądał promocji Fritz Lang Film GmbH - w osobie Fritza Langa - w każdej autoryzowanej wzmiance o swym dziele" ${ }^{\prime \prime}$. Decydujący dla zerwania był jednak (tak zresztą charakterystyczny dla wielu wybitnych twórców kina niemego) opór Langa wobec dźwięku, a ściślej - wobec udźwiękowienia filmu, zamierzonego i już realizowanego jako film niemy.

Kobieta na Księżycu powstawała w niefortunnym zarówno dla wytwórni, kiniarzy, filmowców, jak i dla poziomu artystycznego filmów, okresie przechodzenia kinematografii na dźwięk. W Niemczech proces ten zapoczątkowało utworzenie w sierpniu 1928 Syndykatu Filmu Dźwiękowego,

2 Por.: Patrick McGilligan, Fritz Lang: The Nature of the Beast, St. Martin's Press, New York 1997, s. 142.

${ }^{3}$ Klaus Kreimeier, The Ufa Story: A History of Germany's Greatest Company, 1918-1945, University of California Press, Berkeley-Los Angeles-London 1999, s. 167.

4 Tymczasem np. Metropolis w sezonie 1927/1928 znalazło się na miejscu czwartym. Por.: Peter S. Fisher, Fantasy and Politics: Visions of the Future in the Weimar Republic, The University of Wisconsin Press, Madison 1991, s. 141.

5 Por.: P. McGilligan, op. cit., s. 145; Paul M. Jensen, The Cinema of Fritz Lang, A. S. Barnes \& Co.-A. Zwemmer Limited, New York-London 1969, s. 80.

${ }^{6}$ P. McGilligan, op. cit., s. 145. 
Tonbild-Syndikat, zwanego w skrócie Tobis. Skupiał on rozmaite patenty dźwiękowe, w tym Tri-Ergon, rodzimy system typu „dźwięk-na-taśmie”. Wkrótce potem powstała druga kompania, Klangfilm, utworzona przez wielkie filmy nagraniowe i elektryczne. Po krótkim okresie ostrej walki o rynek, obie spółki połączyły się w Tobis-Klangfilm, najpotężniejszą kompanię dźwiękową poza USA. W kwietniu 1929, pod wpływem wieści zza oceanu o sukcesie amerykańskiego systemu filmu dźwiękowego Vitaphone, Ufa zdecydowała się na podpisanie z Tobis-Klangfilm kontraktu i rozpoczęła budowę studiów dźwiękowych ${ }^{7}$.

W połowie czerwca 1929 Ufa desygnowała niebagatelną wówczas kwotę 60 tys. Reichsmarek na synchronizację filmu Langa z dźwiękiem ${ }^{8}$. „Dodanie efektów dźwiękowych - zauważa Patrick McGilligan - nie było wcale takim złym pomysłem", ale nieugięty Lang odmówił, argumentując szefom Ufy, iż „postsynchronizowany dźwięk załamałby wewnętrzny rytm filmowego opowiadania" ${ }^{9}$. Lang nie miał tym razem wyczucia chwili i niewłaściwie ocenił atrakcyjność swej najnowszej produkcji. Jak słusznie zauważa Paul M. Jensen, w Kobiecie na Księżycu „opowiadanie wydaje się wlec w nieskończoność, a Lang z jakichś powodów zarzucił płynną technikę Szpiegów, powracając do stylu nielicznych zbliżeń, powolnego montażu, licznych planów ogólnych i średnich oraz obfitości teatralnych scen dialogowych"10. Dość męczące, gdyż mimo wizualnego rozmachu statyczne, kluczowe sceny filmu (start rakiety, jej zderzenie z powierzchnią Księżyca), mogłyby zostać silnie zdynamizowane i uatrakcyjnione stosownymi efektami dźwiękowymi, przed którymi Lang niepotrzebnie się wzbraniał. „W okresie, kiedy film dystrybuowano, każde miasto miało przynajmniej jedno kino przystosowane do wyświetlania filmów dźwiękowych, a choć artyzm pierwszych talkies był wątpliwy, miały one po swej stronie przynajmniej atrakcyjność nowości"11. Jensen konstatuje, iż braku tego aspektu nowości nie mógł zrekompensować przejawiający się w narracyjnej statyczności i dłużyznach wątpliwy artyzm tego filmu. Ja dodałbym również - jego wątpliwa atrakcyjność jako widowiska.

Ufa oczywiście nie spisała z góry filmu na straty i jak zwykle zainwestowała $\mathrm{w}$ kampanię reklamową oraz odpowiednią oprawę premiery,

7 Zob.: Kristin Thompson, David Bordwell, Film History: An Introduction, McGraw-Hill, Inc., New York 1993, s. 220.

${ }^{8}$ Zob.: Fritz Lang. Leben und Werke. Bilder und Dokumente, Red. Rolf Aurich, Wolfgang Jacobsen und Cornelius Schnauber, Filmmmuseum Berlin-Deutsche Kinemathek und jovis Verlag GmbH, Berlin 2001, s. 134.

9 P. McGilligan, op. cit., s. 145.

${ }^{10}$ P. M. Jensen, op. cit., s. 80.

11 Willy Ley, Rockets, Missiles and Space Travel, Viking, New York 1952 (cyt. za: P. M. Jensen, op. cit., s. 80). 
która miała miejsce 15 października 1929 w kinie Ufa-Palast am Zoo, i tradycyjnie już zgromadziła artystyczne, polityczne i intelektualne elity Berlina ${ }^{12}$. Atrakcją premiery była tym razem pierwsza $w$ historii niemieckiego radia transmisja na żywo ${ }^{13}$ oraz wystrój fasady kina. „,Rudi Feld, szef wydziału reklamy Ufy, swą pomysłową manipulacją światła i ruchu przekształcał fasady kin w wielkie ekrany i miejsca pokazu widowiskowych efektów technicznych. Na premierę Kobiety na Księżycu (1929) Fritza Langa udekorował Ufa-Palast am Zoo rozświetloną draperia, przekształcając ją w obraz kosmosu. Nad trzema wejściami regularnie wystrzeliwano z kuli ziemskiej model rakiety, który znikał na sztucznym nocnym niebie"14.

Splendor premiery jednak nie wystarczył, podobnie zresztą jak fakt zajęcia przez Kobietę na Księżycu pierwszego miejsca wśród najpopularniejszych niemieckich filmów sezonu 1929/1930 - sezonu, dodajmy, niedobrego, który zbiegł się ze światowym kryzysem gospodarczym i odpływem z kin zbiedniałej nagle publiczności. Nieusatysfakcjonowana wpływami z eksploatacji, „Ufa odmówiła przedłużenia swego kontraktu z Langiem, rezygnując z inwestowania w przyszłe filmy i wycofując się ze wszystkich zobowiązań reklamowych i dystrybucyjnych. Fritz Lang Film Gmbh nie mogła dalej istnieć bez Ufy. Marzenie Langa - stać na czele swej własnej kompanii i funkcjonować jako producent swych własnych filmów - legło w gruzach"15.

Jak zwykle w wypadku weimarskich filmów Langa opinie krytyki były zróżnicowane. , «Film-Kurier» powitał Kobietę na Księżycu jako film wspaniały, zdumiewający, niezapomniany. «Der Tag» opisał najnowszy epos Langa jako «sensację, wielkie wydarzenie», a jego twórcę jako «największego europejskiego reżysera naszych czasów». Dziennik «Berliner Morgenpost» uznał Kobietę na Księżycu za «kolosalne osiągnięcie reżyserskie»"16.

Z kolei anonimowy recenzent niezależnego lewicowego pisma „Film und Volk" wyraził swój sceptycyzm wobec tak jednogłośnie brzmiących w licznych gazetach pochwał, sugerując, iż wielkie sumy wyłożone przez Ufę na promowanie filmu Langa spowodowały, iż film niejako skazany był na sukces (przynajmniej w recenzjach): „Laik patrzy z podziwem na wielką reklamę i nawet nie rozpoznaje nonsensu, którym raczony jest $\mathrm{w}$ tym «pierwszorzędnym» filmie Ufy. Recenzje w prasie... niemal wszystkie

12 Por. Wstęp do niniejszej książki.

13 Zob.: Fritz Lang. Leben und Werke. Bilder und Dokumente, s. 134.

${ }^{14}$ K. Kreimeier, op. cit., s. 117. Por. także: Fritz Lang. Leben und Werke..., s. 134. Autorem wystroju fasady kina podczas opisanej w poprzednim rozdziale premiery Szpiegów również był Rudi Feld.

${ }^{15}$ P. McGilligan, op. cit., s. 145. Druga z prób Langa powołania własnej niezależnej spółki produkcyjnej, Diana Productions, także załamie się po zaledwie dwóch ukończonych filmach: Scarlet Street (1945) i Secret Beyond the Door (1948).

16 P. McGilligan, op. cit., s. 143. 
są entuzjastyczne. Jak zresztą «obiektywni» recenzenci filmowi mogliby się ośmielić uznać za zły najdroższy film najpotężniejszej kapitalistycznej spółki! Albo nasza entuzjastyczna gazeta należy osobiście do drogiego boga Hugenberga, albo jest jakoś powiązana z jego imperium, choćby tylko poprzez ogłoszenia reklamowe"17. Autor tej recenzji widzi w Kobiecie na Księżycu czysty kicz, nieciekawy ani z kulturowego, ani z technicznego punktu widzenia. Jest on jeszcze jednym przykładem "duchowego bankructwa niemieckiego przemysłu filmowego"18.

W niepowiązanych z Hugenbergiem gazetach ukazały się negatywne recenzje, i to tak poważnych autorów, jak Rudolf Arnheim, Herbert Ihering czy Kurt Pinthus, zresztą zwyczajowo zabierających już głos przy okazji premiery kolejnego filmu Langa.

Arnheim ubolewa, że to właśnie takiemu filmowi, jak Kobieta na Księżycu, przychodzi reprezentować niemiecki przemysł filmowy za granicą. Chwaląc stronę techniczną (szczególnie model rakiety), znany psycholog i filozof sztuki nie szczędzi słów krytyki sensacyjnej fabule ${ }^{19}$.

Herbert Ihering już na wstępie swej recenzji wyraża żal, iż Lang, któremu z racji jego rangi powierza się duże sumy, marnuje je wraz ze swymi talentami na realizacje scenariuszy Thei von Harbou. Trudno orzec, gdzie w Langu kończy się artysta, a zaczyna biznesmen. W Kobiecie na Księżycu sprzeczność polega na tym, iż postacie rodem z minionej epoki obsługują maszyny, które jeszcze nie stały się rzeczywistością dzisiejszej ludzkości. Pedanteria filmu, jeśli chodzi o obraz maszyn i prezentację ich funkcjonowania, zadziwiająco kontrastuje z brakiem wiarygodnego przedstawienia postaci ludzkich. Intryga fabularna roi się od nieprawdopodobieństw, a znakomita strona techniczna i tak idzie na marne, gdyż służy wyrażeniu rzeczy z gruntu fałszywych ${ }^{20}$.

Z kolei zdaniem Kurta Pinthusa, lepiej potraktować Kobietę na Księżycu jako parodię, gdyż Lang zastosował z przesadą wszystkie elementy filmu

17 A. A., Deutsche Spitzenproduktion, „Film und Volk” 1929, Nr. 9-10 (November), s. 13 (cyt. za: P. S. Fisher, op. cit., s. 141). Dr Alfred Hugenberg to powiązany z wielkim przemysłem i kręgami nacjonalistycznymi magnat prasowy i wydawniczy, który od 1927 objął naczelne kierownictwo Ufy. Był właścicielem wydawnictwa Scherl Verlag, które opublikowało powieści Thei von Harbou: Metropolis, Szpiedzy, Kobieta na Księżycu. Szerzej nt. jego postaci i jego roli w Ufie, zob.: K. Kreimeier, op. cit., s. 158-172 (Chapter 14: The General in Civoies: Ufa under Hugenberg).

18 A. A., Deutsche Spitzenproduktion (cyt. za: E. Ann Kaplan, Fritz Lang: A Guide to References and Resources, G. K. Hall \& Co., Boston 1981, s. 159).

19 Rudolf Arnheim, „Die Frau im Mond”, „Die Weltbühne”, 22 Oktober 1929 (referuję za: E. Ann Kaplan, op. cit., s. 159).

${ }^{20}$ Herbert Ihering, „Frau im Mond”, „Berliner Börsen-Courier”, 16 Oktober 1929 (przedruk: Herbert Ihering, Von Reinhardt bis Brecht, vol. 2: Vier Jahrzehnte Theater und Film, Aufbau Verlag, Berlin 1959, s. 577-579; zob. też: E. Ann Kaplan, op. cit., s. 159-160). 
przygodowego. Temat - lot rakiety na Księżyc - jest wprawdzie atrakcyjny, ale gwiazdę filmu, Gerdę Maurus, zmuszono, by wyglądała jak woskowy manekin w oknie salonu fryzjerskiego, śmieszna w swych pumpach. Fabuła jest sentymentalna i łzawa, z czego wynika, że za kolosalnym przedsięwzięciem technicznym kryje się pustka. Nonszalancka Kobieta na Księżycu jest raczej krokiem wstecz w dorobku reżysera, gdy uwzględni się niewątpliwy postęp w ciągu 10 lat jego artystycznej kariery. Niemniej jest to film znakomity technicznie, zwłaszcza w aspekcie montażu i efektów specjalnych ${ }^{21}$.

H. P. stwierdza, iż we współpracy z Theą von Harbou Lang zrealizował zarówno dobre, jak i złe filmy (do tych drugich zaliczyć trzeba Metropolis i poniekąd Szpiegów). Kobieta na Księżycu jest filmem ważnym z racji zdjęć i mistrzowskiej strony technicznej: sekwencja startu rakiety - najlepsza w całym dziele - jest znakomicie zmontowana i choćby tylko dla niej warto, zdaniem H. P., ten film zobaczyć. Fabuła jednak jest dość żałosna w swym zmieszaniu eksploracji kosmosu z trójkątem miłosnym. Recenzent, kryjący się pod tymi inicjałami, chwali aktorstwo, ale wskazuje też niezbyt jasne elementy intrygi i pewne niespójności $\mathrm{w}$ - skądinąd sugestywnych - szczegółach technicznych ${ }^{22}$.

Do Stanów film zawitał dopiero w 1931 r. i nie spotkał się z dobrym przyjęciem. Wpływ na to miały rozmaite czynniki: istotnie słabszy poziom artystyczny Kobiety na Księżycu niż poprzednich filmów Langa; techniczna anachroniczność filmu niemego w kraju, gdzie kino dźwiękowe było już w pełnym rozkwicie; przyzwyczajenie amerykańskiej publiczności do znacznie żywszego tempa narracji (nawet dla europejskiego widza A. D. 2005, który przeszedł lekcję Antonioniego, Wendersa czy Jarmuscha, rozwlekłość i statyczność Kobiety na Księżycu jest trudna do zniesienia); wreszcie - zwyczajowe już kiereszowanie filmów Langa przez dystrybutorów za oceanem. Film ten został na rynek amerykański tak drastycznie skrócony i przemontowany, że nie tylko zupełnie niejasne stały się motywacje fabularne, ale i nie było wcale wiadomo, co w ogóle się zdarzyło w świecie przedstawionym (np. jak zginął profesor Manfeldt). Jak zwykle, zmieniono też tytuł - na By Rocket to the Moon (Rakieta na Księżyc) ${ }^{23}$.

${ }^{21}$ Kurt Pinthus, „Frau im Mond”, „Das Tage-Buch”, 19 Oktober 1929 (referuję za: E. Ann Kaplan, op. cit., s. 160).

${ }^{22}$ H. P., "Frau im Mond”, „Der Bildwart” 1930, Nr. 1 (Januar). Referuję za: E. Ann Kaplan, op. cit., s. 161.

${ }^{23}$ Miałem okazję widzieć amerykańską wersję filmu, gdyż tylko nią dysponowałem (na kasecie VHS), zanim nie ukazała się płyta, opracowana przez Friedrich-Wilhelm-Murnau-Stiftung, prezentująca pełna, zrekonstruowaną oryginalną wersję niemiecką. Wystarczy już porównanie czasu projekcji - ok. 100 minut wersji amerykańskiej wobec ok. 168 minut wersji oryginalnej. W wersji amerykańskiej ginie bardzo ważny wątek 
W każdym razie recenzent jednego z najbardziej opiniotwórczych amerykańskich pism filmowych, "Variety", stwierdził (o tej i tak skróconej o ponad godzinę wersji!), iż film jest „,niemiłosiernie rozwlekły”, a ponadto, iż „podróż rakiety na Księżyc otacza banalna melodramatyczna rama z byle jakim romansem" ${ }^{24}$.

Nie tylko jednak miażdżąca krytyka spotkała film poza granicami Niemiec. We Francji entuzjastyczny tekst (chyba jednak niesponsorowany przez Hugenberga, po rozstaniu Langa z Ufą) napisał recenzent paryskiego miesięcznika "Cinémagazine", Jean Arroy. Jego zdaniem, Kobieta na Księżycu opiewa wyzwalający efekt maszyny, która jest w stanie uwolnić człowieka z wszelkich ograniczeń grawitacji, przestrzeni i czasu, dzięki której można osiągnąć niedostępne dotąd części wszechświata. Nie jest to wcale tak fantastyczny pomysł, gdyż dzięki postępowi nauki ludzie wkrótce będą mogli podróżować w kosmosie, napotykając poważne konsekwencje fizyczne i duchowe takich podróży. Astronauta to nie wymysł wyobraźni, ale zapowiedź tego, co wkrótce się urzeczywistni. Lang, dbały o autentyzm i naukową wiarygodność, zatrudnił jako technicznego konsultanta znanego eksperta w dziedzinie podróży międzyplanetarnych, Hermanna Obertha. Aby widzowie i czytelnicy jego recenzji nie traktowali filmu Langa jako czystej fantazji, Arroy omawia takie zagadnienia, jak prędkość niezbędna do pokonania przez rakietę ziemskiej grawitacji, przeciążenia, jakie podczas startu może znieść ludzkie ciało, czy taki sposób odpalenia rakiety, by rzeczywiście poszybowała w kosmos. Arroy jest pod wrażeniem połączenia w filmie Langa geniuszu naukowego i filmowego. Podziwia księżycowe krajobrazy, których nikt inny nie mógłby sobie wyobrazić w satysfakcjonujący sposób. Lang wiarygodnie przedstawia nam kolejno: konstrukcję rakiety, męczące przygotowania, zapierający dech odlot, fizyczne efekty podróży, pierwszy widok księżycowego krajobrazu, złote góry, rywalizację miłosną, tragiczne zakończenie... Ten pierwszy międzygwiezdny epos otwiera nieoczekiwane horyzonty dla wszystkich innych artystów ${ }^{25}$.

napadu na Heliusa w samochodzie, podczas którego zostaje skradziony rękopis prof. Manfeldta, oraz równoczesnego obrabowania mieszkania Heliusa przez ludzi Turnera. Paul Jensen i Lotte Eisner, gdy pisali swe książki, nie dysponowali wersją oryginalną - toteż wskazują liczne luki i nielogiczności fabuły, brakujące zaś w analizowanej przez nich wersji amerykańskiej partie opowieści opisują nie zawsze adekwatnie. Por.: P. M. Jensen, op. cit., s. 79-92; Lotte H. Eisner, Fritz Lang, Da Capo Press, New York 1986, s. 106-110.

${ }^{24}$ Recenzję z „Variety” cytuję za: P. McGilligan, op. cit., s. 144 (tamże informacje nt. amerykańskiej recepcji Kobiety na Księżycu).

25 Jean Arroy, „La Femme sur la Lune”, „Cinémagazine” 1930, no. 6 (juin), s. 16-21 (referuję za: E. Ann Kaplan, op. cit., s. 160-161). 


\section{Weltraumfahrt}

Lata dwudzieste $X X$ w. to w Europie okres kształtowania wrażliwości estetycznej i formułowania rozmaitych programów artystyczno-ideowych pod wpływem rozwoju techniki, przemian technologicznych, eksplozji nowych mediów i środków komunikacji (w społeczeństwie masowym to szczególnie ważny aspekt), zachłyśnięcia się wielkomiejską cywilizacją. Futuryzm, konstruktywizm, seria utopii i antyutopii w literaturze czy wreszcie powstałe w rozmaitych krajach filmy określane mianem „wielkomiejskich symfonii", są wyrazem tego urzeczenia techniką i cywilizacją techniczną. Trzy „M" z programowego artykułu Tadeusza Peipera Miasto. Masa. Maszyna syntetycznie ujmują Zeitgeist, który w sztukach pięknych, literaturze, filmie czy architekturze tego okresu znajduje różnoraki wyraz. W kontekście ostatniego niemego filmu Langa, którego największą atrakcją i narracyjnym centrum miała być rakieta - a zatem $\mathrm{m}$ a s z y n a - nie od rzeczy będzie przywołanie rozważań Peipera unaoczniających przejście od przerażenia maszyną do jej afirmacji.

„Między epoką narzędzia kamiennego a epoką narzędzia maszynowego pojawiło się zjawisko podziału pracy. Ludzie pracujący nad maszyna, ludzie wytwarzający maszynę, nie zastosowują jej praktycznie, nie biorą udziału w tej części jej życia, w której zaczyna spełniać ona swoje zadanie. Nie widzą więc tego ścisłego związku, jaki istnieje między budową maszyny a jej funkcją. Stąd brak owych ogniw psychologicznych, na podstawie których mogłoby wyróść nowe uczucie estetyczne: brak owego specyficznego zadowolenia, rodzącego się z porównania formy narzędzia z celem, któremu ono ma służyć. [...] a tym mniej forma ta może zamienić się w nim psychicznie na formę piękną.

Stało się nawet coś gorszego. Maszyna wydawała się człowiekowi czymś brzydkim. Przyczyny tego były podobne do przyczyn, które wywoływały estetyczną degradację miasta. Więc przede wszystkim: konflikt z ideami odziedziczonymi. Maszyna była rzeczą nową i tworzyła rzeczy nowe. [...] Następnie: moment natury społecznej. Maszyna... fabryka... fabrykant... proletariusz... nadwartość... wyzysk... uczucie buntu przeciw systemowi społecznemu z mimowolnymi przedłużeniami uczuciowymi skierowanymi przeciwko «środkom produkcji». Wreszcie: moment natury fizjologicznej. Maszyna... fabryka... kłęby dymu nad miastem... hałas $\mathrm{w}$ ulicy... suchoty robotnika... choroby zawodowe... ofiary pracy... degeneracja. W rezultacie: żal do maszyny.

Ten negatywny stosunek do maszyny nie mógł trwać wiecznie. [...] Maszyna raziła człowieka, jak długo wpływami swoimi obejmowała tylko część życia ludzkiego; przestała go razić, kiedy całkowicie 
przekształciła życie ludzkie. Jak długo panowała częściowo, była tolerowanym intruzem; kiedy zapanowała całkowicie, stała się adorowanym suwerenem. Cóż się stało? Trzeba było, ażeby korzyści wniesione w nasze życie przez maszynę, rozlały się tak szeroko, by ukazać się wszystkim. Trzeba było, ażeby maszyna wyczarowała ze siebie nie przewidywane dotąd wyspy wygód i rozkoszy, dostępnych dla wszystkich. Trzeba było, ażeby maszyna (kolej żelazna, tramwaj elektryczny, autobus, telegraf, telefon, światło elektryczne etc.) mogła być konsumowana przez wszystkich i przez wszystkich odczuwana jako dobrodziejstwo. Jeżeli w epokach minionych życzliwy stosunek człowieka do jego narzędzia wyrastał na podłożu produkcji, to dzisiaj pośrednikiem przyjaźni między nimi staje się konsumpcja. Dzięki niej maszyna zdobywa powoli serce człowieka"26.

W dwóch "fantastycznych" filmach Langa, Metropolis i Kobiecie na Księżycu, znalazły wyraz owe dwie opisane przez krakowskiego poetę fazy ewolucji relacji człowieka z maszyną. Metropolis w kostiumie futurystycznej antyutopii unaocznia etap pierwszy: alienacji maszyny, urzeczowienia człowieka w zmechanizowanej cywilizacji przemysłowej, rozziewu między wykonywaną pracą a brakiem rozumienia jej mechanizmu, celu i sensu (vide: przemiana maszynowni w Molocha pożerającego robotników, „ukrzyżowanie” Federa zastępującego robotnika na jego przypominającym zegar stanowisku pracy - pracy niezwykle monotonnej i odmierzanej zegarem o 10-godzinnej tarczy, wreszcie przypowieść o Wieży Babel, w której „ręce” wykonawców nic nie wiedzą o projekcie planującego "mózgu”). W Kobiecie na Księżycu "maszyna” ma efekt wyzwalający, uwalniając człowieka, jak pisał w swej recenzji Jean Arroy, z ograniczeń przestrzeni, czasu i grawitacji, umożliwiając przeniesienie się na inny glob, a także jednocząc ludzkość, dzięki medialnej transmisji (radio, film), poprzez uczestnictwo w doniosłym wydarzeniu. Długie i celebrowane partie tego filmu („film w filmie" demonstrujący piątce "mędrców” bezzałogową rakietę H32, start rakiety "Friede”, sekwencja "Dziennika pokładowego") mają charakter wybitnie opisowy, w zasadzie - afabularny, a ich celem jest unaocznienie piękna „maszyn” i ich funkcjonalności wobec śmiałych projektów człowieka.

Krzysztof Loska, w artykule dotyczącym niemieckich filmów science-fiction z okresu dwudziestolecia międzywojennego, pisze: „Kulturowy klimat Republiki Weimarskiej sprzyjał rozkwitowi sztuki, będącej odzwierciedleniem piękna maszyny, ucieleśnieniem estetyki, którą charakteryzują: rytmiczność, fascynacja powierzchnią i kształtami geo-

26 Tadeusz Peiper, Miasto. Masa. Maszyna, „Zwrotnica”, lipiec 1922 (cyt. za: Tadeusz Peiper, Pisma: Tędy. Nowe usta, Wydawnictwo Literackie, Kraków 1972, s. 44-46). Podkreślenia Peipera. 
metrycznymi, efektywność, doskonałość, jednolitość, cielesność, a przede wszystkim funkcjonalność, którą utożsamiano z pięknem. Wzorem i bohaterem nowej sztuki stał się inżynier, łączący w sobie cechy artysty, rzemieślnika i naukowca, którego pracę wyróżniał obiektywizm, precyzja i chłodna kalkulacja. Podstawą nowej estetyki stały się logika i racjonalność, zaś wytwory artystyczne wyróżniały się regularnością, prostotą oraz matematyczną doskonałością kształtów. Ale z drugiej strony maszynie przypisywano nierzadko wymiar mistyczny, toteż romantyczne i irracjonalne aspekty nowoczesności wysuwały się na plan pierwszy" ${ }^{27}$. Oczywiście, te ostatnie - i to z apokaliptycznymi konotacjami - przeważają w Metropolis, podczas gdy estetyka logiki, racjonalności, matematycznej regularności i prostoty dominuje w Kobiecie na Księżycu. Inżynier-konstruktor Wolf Helius z tego filmu wydaje się wręcz wzorcowo skupiać wskazane przez Loskę atrybuty modelowego bohatera nowej estetyki weimarskiej fantastyki. Trzeba jednak też zauważyć, iż $\mathrm{w}$ równym (a kto, wie, czy nie większym) stopniu, atrybuty te posiada postać tytułowa, „studentka astronomii”, Frieda Velten, dzięki czemu jest zresztą od początku dla widza jasne, iż jej narzeczony, inżynier Hans Windegger, jest dla niej nieodpowiednim partnerem, a „idealną parę" może ona stworzyć tylko z Heliusem. A swoją drogą zadziwiająco to przypomina zarówno nazistowskie, jak i socrealistyczne (znane np. $\mathrm{z}$ „,kołchozowych komedii” Iwana Pyrjewa), koncepcje idealnego „doboru naturalnego" partnerów w miłosnym związku.

„Technika jako temat literacki i filmowy dotyczyła przede wszystkim trzech sfer: poszukiwania nowych źródeł energii, sposobów transportu (samoloty, statki kosmiczne) oraz rewolucji w sferze komunikacyjnej (telewizja)"28. Oczywiście, Kobieta na Księżycu jako film o podróży rakietą na inny glob dotyczy drugiego przypadku (tj. sposobów transportu), który Loska tak dalej charakteryzuje: „W drugim przypadku, będącym przedłużeniem nowoczesnej wiary w postęp naukowy, chodzi o cały zespół urządzeń technicznych tworzących ikonografię filmów science-fiction, a więc łodzie podwodne i statki kosmiczne, sondy i nowoczesne pojazdy mechaniczne - to wszystko zatem, co pozwala na przemieszczanie się w czasie i przestrzeni. Szczególnego znaczenia nabiera w tym kontekście obraz rakiety jako ucieleśnienia zdolności człowieka do pokonywania przeszkód, sugerujący możliwość poznania odległych światów, będący przy tym symbolem łączącym to, co znane z tym, co nieznane, a zarazem materialnym

${ }^{27}$ Krzysztof Loska, Kultura i technika - niemiecki film fantastycznonaukowy $w$ latach 1918-1939, [w:] Kino niemieckie w dialogu pokoleń i kultur: Studia i szkice, red. Andrzej Gwóźdź, Rabid, Kraków 2004, s. 22-23.

${ }^{28}$ K. Loska, op. cit., s. 23. 
dowodem postępu" ${ }^{29}$. Tę charakterystykę rakiety jako symbolu naukowego postępu i optymizmu poznawczego potwierdza zamieszczone tuż po czołówce i poprzedzające pierwsze ujęcie filmu Langa jego motto: Es gibt für den menschlichen Geist kein "Niemals”, höchstens ein "Noch nicht” („Dla ludzkiego ducha nie istnieje «Nigdy», najwyżej - «Jeszcze nie»").

Podróż kosmiczna, Weltraumfahrt, w Niemczech lat 20. stała się tematem wielce dyskutowanym, zarówno w kręgach naukowców, jak i przez szeroką opinię publiczną. Terminu tego użył po raz pierwszy Hermann Oberth, zamieszkały w Transylwanii Austriak, który jeszcze w latach I wojny światowej naszkicował wstępne plany artylerii rakietowej dla armii austro-węgierskiej. Przełomowa okazała się jego książka z roku 1923, Die Rakete zu den Planetenräumen (Rakieta w przestrzeń międzyplanetarna). W roku 1929 ukazało się jej znacznie rozszerzone wydanie pod zmienionym tytułem Wege zur Raumschiffahrt (Drogi ku podróży kosmicznej); zawierało ono dedykację z podziękowaniami dla Fritza Langa i Thei von Harbou. A miał Oberth za co dziękować filmowemu małżeństwu: od czerwca 1929, kiedy przybył do Berlina z Rumunii, był zatrudniony jako naukowy konsultant $\mathrm{w}$ przygotowaniach do Kobiety na Księżycu w studiach Ufy w Neubabelsbergu. To m.in. na podstawie jego wskazówek skonstruowano wzbudzający wówczas zachwyt swym realizmem krajobraz księżycowy; zbudował też wykorzystany w filmie model rakiety, tylko nieznacznie różny od również przez siebie zaprojektowanej rakiety, faktycznie przeznaczonej do odbycia kosmicznego lotu. Prace konstrukcyjne i eksperymenty związane z tą ostatnią były możliwe dzięki inicjatywie dbałego o publicity Langa, który zdołał skłonić Ufę do ich współfinansowania oraz do użyczenia badaniom Obertha warsztatów i laboratoriów wytwórni w Neubabelsbergu. 9 lipca 1929 Oberth podpisał z Langiem i Ufą umowę, przewidującą kontynuowanie jego już mocno zaawansowanych badań nad rakietą napędzaną płynnym paliwem. I Lang, i Ufa wyłożyli na to $\mathrm{z}$ własnej kieszeni po 5 tys. marek. Połowa ewentualnych zysków z jakiegokolwiek przyszłego "komercyjnego zastosowania” odkryć uczonego miała trafiać do inwestorów aż do 31 grudnia 2020 [sic!]. Badania i eksperymenty Obertha, podczas których uległ zresztą dość groźnemu wypadkowi, rzeczywiście miały poważną rangę naukową a dla Langa, z racji zainteresowania nimi opinii publicznej, miały istotny walor reklamy jego najnowszego filmu. Niemniej koszty badań wzrastały, eksperymenty nie przebiegały tak, jak zaplanowano, i zapowiadany z hukiem na dzień premiery filmu (15 października 1929) start rakiety Obertha trzeba było przesunąć na dość nieokreślony moment „jesieni" ${ }^{30}$.

${ }^{29}$ Ibidem.

${ }^{30}$ Nt. postaci Hermanna Obertha (1894-1989), jego prac oraz umowy z Ufą i Langiem, zob.: P. McGilligan, op. cit., s. 141-143; Fritz Lang. Leben und Werke. Bilder und Dokumente, s. $130,134$. 
Lang kontakt z Oberthem nawiązał dzięki innemu pionierowi badań nad podróżami kosmicznymi, Willemu Leyowi, autorowi książki Die Möglichkeit der Weltraumfahrt (Możliwość podróży kosmicznej, 1926), którą napisał jako dwudziestolatek, opierając się na badaniach Obertha. Ley (1906-1969), berlińczyk, człowiek wówczas bardzo młody, pracował jako wolny strzelec dla rozmaitych gazet i magazynów, w tym dla wychodzącego w latach 1927-1929 pisma "Die Rakete”, będącego organem mającego swą siedzibę we Wrocławiu Towarzystwa Podróży Kosmicznych (Verein für Raumschifffahrt). Lang i Ley poznali się wiosną $1928^{31}$ na pokazie pewnego eksperymentalnego filmu, i to właśnie Ley zasugerował reżyserowi Obertha jako konsultanta filmu (nb. również Oberth był członkiem wrocławskiego Towarzystwa). Znajomość Langa $\mathrm{z}$ młodym naukowcem przerodziła się w długotrwałą przyjaźń, którą utrwaliła zresztą emigracja ich obu za ocean po dojściu nazistów do władzy ${ }^{32}$. I to właśnie w liście Leya do Langa z 4 lipca 1958 znajdują się szczegółowe relacje na temat przygotowań do Kobiety na Księżycu oraz ciekawa informacja, iż atrakcja w postaci statku kosmicznego pierwotnie była zamierzona dla Metropolis, ale ostatecznie uznana została, za „zbyt wielka, by się tam zmieścić" ${ }^{33}$ (prawdopodobnie z racji zarówno kosztów jej kreacji, jak i wielości innych atrakcji w tamtym filmie).

W pracy nad filmem Willy Ley („wielką pomoc” z jego strony Lang będzie po latach mocno podkreślał) i Hermann Oberth, który w czołówce figuruje jako główny konsultant naukowy, mieli nadrzędną pozycję wobec stałych scenografów Langa, Ottona Hunte i Karla Vollbrechta, których znakomita praca przesądziła w dużej mierze o fascynującej stronie wizualnej Doktora Mabuse, Nibelungów, Metropolis czy Szpiegów. „Aby stworzyć księżycowy krajobraz w ograniczonych warunkach studia, zamówiono ciężarówki do przewozu białego piasku z przedmieść Berlina, a potem rozrzucono go na podłodze. Wtedy przystąpili do pracy Hunte i Vollbrecht, formując piasek w sugestywne zawijasy i wydmy (tworząc, wedle słów Paula Rothy, «cudowną świetlistość księżycowego pejzażu»). Kiedy Lang spoglądał wstecz na swe berlińskie lata, z jego pamięci wyłaniały się owe ciężarówki, przewożące biały piasek. Był to szczytowy moment jego kariery, okres, kiedy reżyser miał władzę, by wyczarować swą osobistą podróż do innego świata" ${ }^{34}$.

31 Taką datę podaje najbardziej wiarygodne źródło - tom Fritz Lang. Leben und Werke..., s. 134. Mc Gilligan datuje pierwsze spotkanie Langa i Leya na początek 1927 r. (op. cit., s. 141).

${ }^{32}$ Nt. postaci Leya zob.: P. McGilligan, op. cit., s. 141; Fritz Lang. Leben und Werke..., s. $130,134$.

${ }_{33}$ Zob.: Fritz Lang. Leben und Werke..., s. 134.

34 P. McGilligan, op. cit., s. 142. Zacytowane przez McGilligana słowa Paula Rothy pochodzą z jego książki The Film Till Now: A Survey of the Cinema, New York-London-Toronto 1930. 
Takiej podróży nie udało się uskutecznić Hermannowi Oberthowi: jego rakieta nie wystartowała ani ,jesienią", ani w ogóle nigdy, a "finansowo i moralnie zrujnowany" opuścił Berlin, zostawiając na lodzie swych inwestorów ${ }^{35}$. Choć chyba nie tylko ta porażka była przyczyną odmiennego wyboru politycznego niż ten, którego dokonali Lang i Ley: po 1933 Oberth został w Trzeciej Rzeszy i aktywnie poparł nazistów.

Willy Ley pracował natomiast w Stanach jako ekspert do spraw rakiet ${ }^{36}$. Ale i on nie zaznał smaku satysfakcji z rzeczywistego spełnienia swych uzasadnionych naukowo prognoz, które kiedy w 1926 wydał swą książkę, a w 1929 odbywał z Langiem konsultacje, mogły wydawać się niemal utopią. Frederick W. Ott pisze: „W roku 1969, czterdzieści lat po premierze Kobiety na Księżycu, Lang rozpamiętywał wkład Willego Leya. Pamiętał rozmowę z naukowcem $\mathrm{w}$ roku 1929: «Kiedy siedzieliśmy na tarasie mego domu, z Księżycem w pełni nad nami, na który żartem wskazałem, mówiąc «mój plener» [my location set], zastanawiając się, czy ludzie kiedykolwiek postawią stopę na jego powierzchni, Willy odpowiedział z doskonale niezmienną pewnością i ufnością: «Będziemy tam!» Ale Willy Ley nigdy nie miał ujrzeć lądowania na Księżycu; dwadzieścia siedem dni przed startem Apolla XI, Willy Ley zmarł na atak serca w swym domu w Nowym Jorku"37.

Czy jednak istotnie Langowi udało się bardziej niż jego dwóm konsultantom? Czy faktycznie wyczarował w Kobiecie na Księżycu wiarygodny obraz Weltraumfahrt, podróży na inny glob, czy też w gruncie rzeczy konceptualnie pozostał na Ziemi, nie mogąć oderwać się od własnych, Thei von Harbou czy też wspólnym im obojgu, obsesji?

\section{Niebo gwiaździste i moralny nieład}

Lotte Eisner twierdzi w swej monografii reżysera, iż głównym punktem zainteresowania Langa w realizacji Kobiety na Księżycu była sekwencja startu rakiety, toteż sygnowana jego nazwiskiem wypowiedź w „Deutsche Filmzeitung" pochodzi tak naprawdę albo od speca od reklamy, albo od Thei von Harbou. Brzmi ona jak następuje: „Czterech mężczyzn, kobieta i dziecko - garstka ludzi złączonych przez los. Spiesząc z zawrotną prędkością nigdy niewidzianym pojazdem na nigdy wcześniej niedotknięte stopą człowieka miejsce, w nieskończoną samotność Księżyca, pozostają

35 Por.: P. McGilligan, op. cit., s. 143.

36 Por.: informacja Langa w wywiadzie z 1975 dla Gene D. Phillipsa z „Focus on Film” (1975, Spring, no. 20, s. 43-51), przedruk w: Fritz Lang, Interviews, ed. Barry Keith Grant, University of Mississippi Press, Jackson 2003, s. 181.

37 Frederick W. Ott, The Films of Fritz Lang, The Citadell Press, Seacaucus, NJ, 1979, s. 149. 
jednak przywiązani do swego losu, do prawa swej krwi, do swych namiętności, swego szczęścia i swych tragedii. Wydobyć to na jaw było mym marzeniem" ${ }^{\prime 38}$.

Lotte Eisner podobny ton znajduje w podsumowaniu idei filmu danym przez Theę von Harbou: „Niezrównana sposobność zaszczepienia ludzkich losów na kwiecisty ogród gwiazd, pozwolić im dojść do brzemiennego w skutki rozkwitu w nowym świecie - a potem oglądać ich zagładę, doświadczać ich uśmiechów i ich łez w obliczu ogromnego rozmiaru świata jako czegoś nawet odeń większego..." ${ }^{39}$ Jako komentarz do niniejszego fragmentu, Eisner przytacza broniące tego rodzaju "emocjonalizmu” słowa Langa, który wskazuje, iż nieuchronnie musiał być on związany z filmem niemym, gdzie słowa należało zastąpić ekspresją twarzy, mimiką, gestem, postawą ${ }^{40}$. Rzecz jednak w tym, iż słabością tego filmu, krytykowaną w przywołanych wcześniej recenzjach, jest nie tyle "emocjonalizm” na poziomie stylu (może nawet mniej go tutaj niż w innych filmach Langa, np. w Metropolis czy Szpiegach), ile dość fałszywy s e n t y m e n t a li z m fabuły, sprzężony z d e t e r m in i z m e m losów postaci, nieprzekonującą amplitudą ich doznań (od euforycznej szczęśliwości do histerycznego poczucia tragiczności) i z ich u r z e c z o w i e $\mathrm{n}$ i e $\mathrm{m}$. To ostatnie przejawia się zarówno we „wchłonięciu” bohaterów przez „maszynę” czy ich podporządkowaniu rozmaitym technicznym urządzeniom, jak i w poczuciu widza, że postacie nie są pełnymi ludźmi z krwi i kości, lecz raczej jakimiś symbolicznymi funkcjami w przypowieści o apriorycznej konstrukcji czy łatwymi do podstawienia zmiennymi w jakimś banalnym równaniu. Potwierdza zresztą takie wrażenie widza pretensjonalna retoryka przytoczonej wyżej wypowiedzi scenarzystki. Symptomatyczne zreszta, iż w owym najsłabszym artystycznie filmie spółki Lang - von Harbou jedyny raz właśnie tylko ona figuruje jako autor scenariusza; we wszystkich innych ich wspólnych filmach Lang wymieniany jest w czołówce jako współscenarzysta.

Fatalizm i sentymentalizm zdarzeń fabularnych i koncepcji postaci kłóci się z pedantyczną opisowością scenerii - nie tylko zresztą w sekwencjach rakiety czy Księżyca, ale też w pierwszej, „ziemskiej” części filmu. Czyni to z Frau im Mond jeden z najbardziej "zgrzytliwych" stylistycznie spośród wszystkich niemieckich filmów Langa, może z wyjątkiem Metropolis, w którym jednak stylistyczną niespójność, fabularne nonsensy i nieznośną ideologię kompensowały porywające do dziś atrakcje wizualne i niezrównany rytm. A tych elementów w drugim "fantastycznym” filmie Langa niestety zabrakło.

38 „Deutsche Filmzeitung” 1929, Nr. 42 (cyt. za: L. H. Eisner, Fritz Lang, s. 106).

39 Ibidem.

${ }^{40}$ L. H. Eisner, Fritz Lang, s. 106. 
Fabularnie i kompozycyjnie jest to najmniej skomplikowany z wszystkich weimarskich filmów Langa. Dość prosta - w porównaniu np. ze Szpiegami - wydaje się jego segmentacja, wyznaczona przede wszystkim jednością akcji poszczególnych jednostek dramaturgicznych - wyznaczona na tyle klarownie, że nie burzą wrażenia tej prostoty takie komplikacje, jak retrospekcje (w segmencie 1), symultaniczność akcji (w segmentach 1 , 2 i ostatnim), wtrącona sekwencja o kompozycji szkatułkowej ( $\mathrm{z}$ „filmem w filmie") i o niejasnym statusie zarazem narracji werbalnej, jak i akcji symultanicznej (w segmencie 2$)^{41}$.

Segment 1: Profesor Manfeldt. Inżynier-konstruktor Wolf Helius jest świadkiem, jak profesor Manfeldt, stary, żyjący na poddaszu astronom, zrzuca ze schodów człowieka przedstawiającego się jako Walt Turner z Chicago. Profesora oburzyła propozycja Amerykanina, który wykorzystując biedę uczonego, chciał od niego odkupić rękopis jego książki Hypothetische Darstellung des Goldgehaltes der Mondgebirge (Hipotetyczne przedstawienie złóż złota w górach Księżyca). Z oburzenia urażonego w swej godności Manfeldta, który ostentacyjnie zwraca Heliusowi podrzucone mu podczas poprzedniej wizyty pieniądze na jedzenie, oraz z dyplomatycznego oświadczenia gościa, iż chce spożyć w towarzystwie profesora kolację, orientujemy się, iż inżynier wspomaga głodującego uczonego. Retrospekcja 1a: Rok 1896 - młody profesor Manfeldt zostaje wyśmiany $i$ wygwizdany przez naukowe gremium po prezentacji swych hipotez na temat istnienia na Księżycu wielkich złóż złota i przepowiedni załogowego lotu na Księżyc, by przywieźć stamtąd na Ziemię ów kruszec. Helius obwieszcza profesorowi swe postanowienie - zdecydował się polecieć na Księżyc. „Ale nie beze mnie, Helius, nie beze mnie" - woła profesor, który pyta też, czy poleci z nimi przyjaciel Heliusa, inżynier Hans Windegger. Narracja prezentuje nam akcję symultaniczną: Windegger wręcza Friedzie Velten, pracującej jak i on w zakładach Heliusa studentce astronomii, pierścionek zaręczynowy. Frieda z rozbawieniem konstatuje, iż jest on za duży na każdy z palców, nawet na kciuk, a Hans w tym czasie odbiera kwiaty od Heliusa z bilecikiem, na którym prócz życzeń dla narzeczonych jest prośba o wybaczenie, że nie będzie on na ich wieczorze zaręczynowym. Frieda smutnieje. Manfeldt ostrzega Heliusa, iż już więcej osób niż oni wie o jego planach

41 Chodzi tu o sekwencję 2a, przedstawiającą "pięcioro mędrców”. Zaczyna opowiadać o nich Heliusowi Turner, toteż traktujemy ją jako ekwiwalent narracji werbalnej postaci. Ale kończy się ona słowami jednego z „piątki”, informującego pozostałych członków gremium o właśnie odbywającej się rozmowie Turnera z Heliusem - zatem jest to zarazem wstawka ukazująca akcję symultaniczną. Podobną dwuznaczność statusów narracji jako zarazem opowieści i akcji symultanicznej odnajdujemy w Nibelungach (Krymhilda z pieśni Volkera dowiaduje się o czynach Zygfryda, który „wewnątrz” tej opowieści od leśnego starca dowiaduje się o Krymhildzie). 
podróży i opowiada (Retrospekcja 1b) o próbie kradzieży przed trzema dniami z jego mieszkania rękopisu swej ksiażki. Profesor wręcza na odchodne Heliusowi ów rękopis, sądząc, że u niego będzie on bezpieczniejszy, a po wyjściu gościa resztkami z kolacji karmi mieszkającą z nim myszkę.

Segment 2: Turner. Gdy samochód wracającego od Manfeldta Heliusa grzęźnie w spowodowanym przez jakąś kraksę korku ulicznym, inżynier zaprasza do niego oferującą mu fiołki dziewczynę. Tymczasem gospodyni Heliusa wpuszcza do mieszkania Turnera (w innej charakteryzacji niż u Manfeldta), przedstawiającego rzekomy list polecający od Windeggera; odwraca on jej uwagę od dwóch swych ludzi, włamujących się do mieszkania Heliusa innym wejściem. Gdy samochód Heliusa zajeżdża pod dom, okazuje się, iż inżynier leży nieprzytomny na podłodze. Oprzytomniawszy, Helius stwierdza kradzież rękopisu Manfeldta (został po nim tylko sznurek). Korzystając z nieobecności w mieszkaniu gospodyni, zaalarmowanej o wypadku przez Gustawa, chłopca z sąsiedztwa, ludzie Turnera wymykają się niezauważeni z łupem. Helius bierze od Turnera "list polecający" i usiłuje zadzwonić na policję, a nie mogąc się połączyć, wysyła tam kierowcę. Na dany przez Turnera przez okno znak, jeden z jego ludzi kradnie samochód Heliusa - Gustaw i kierowca ścigają go w szalonym biegu ulicami. Helius z gospodynią odkrywaja, że sejf, w którym inżynier trzymał rzeczy związane z projektem kosmicznej podróży, jest pusty. Od sąsiada z dołu Helius dzwoni do Windeggera, u którego trwa w najlepsze przyjęcie zaręczynowe. Hans nie bardzo ma ochotę przerywać imprezę, ale Frieda, odebrawszy słuchawkę, mówi Heliusowi, iż natychmiast przyjdą. Wracając do swego mieszkania, Helius zastaje przed drzwiami Turnera (w tej postaci, jak u Manfeldta). Turner demonstruje mu swą zdolność metamorfozy (to, że to on był człowiekiem z listem polecającym), informuje, że to on odłączył telefon i że to na jego polecenie skradziono właśnie odstawiony samochód - wszystko po to, by Helius nie informował policji. Turner opowiada Heliusowi o swych mocodawcach: „pięciu najbogatszych i najtęższych głowach, które chcą mieć pod kontrolą złoża złota na Ziemi" - i na Księżycu, po to, by dostały się one (jeśli rzeczywiście istnieją) nie w ręce "fantastów” i „idealistów”, lecz biznesmenów. Wstawka 2a: zebranie piatki "mędrców"; jeden z nich prezentuje pozostałej czwórce film (wstawka 2a) o skonstruowanej przez Heliusa bezzałogowej rakiecie H32, zawierajacy też wykonane przez nia zdjęcia "drugiej strony Księżyca". Prezenter informuje pozostatych, iż właśnie ich przedstawiciel składa w "bardzo konkretnej formie" propozycje Heliusowi. Owe propozycje polegają na szantażu: jeśli Helius nie zgodzi się pracować pod rozkazami mocodawców Turnera, ulegną zniszczeniu jego zakłady, rakieta i wszystkie plany. Inżynier prosi o 24 godziny do namysłu. Turner mija się w drzwiach z Friedą i Hansem. Sekwencja montażowa 2b: Helius opowiada 
Windeggerowi o napadzie w samochodzie i okradzeniu sejfu. Hans uspokaja kolegę, iż ma u siebie duplikaty planów, ale zaniepokojony przez Friedę biegnie do siebie sprawdzić, czy aby ich także nie skradziono. Pod jego nieobecność Frieda czyni wyrzuty Heliusowi, iż zataił przed nią plany swego lotu i nalega na wzięcie z sobą siebie i Hansa. Helius przypomina Friedzie tragiczny los poprzedniej wyprawy w kosmos (wstawka 2c: tablica pamiątkowa ku czci bohaterskich pionierów, którzy nie powrócili z kosmicznego lotu). Roztrzęsiony Hans peroruje po powrocie o kradzieży planów. Frieda informuje narzeczonego, iż lecą razem z Heliusem w kosmos - po czym całują się na oczach patrzącego na to błędnym wzrokiem Heliusa. A w samochodzie Turnera, gdzie są prócz niego dwaj znani nam włamywacze i „dziewczyna z fiołkami”, ta ostatnia przygląda się z satysfakcją pierścionkom na palcach - prawdopodobnie honorarium za udaną akcję.

24 godziny później - w zakładach Heliusa następuje eksplozja. Helius, w obecności Turnera, odbiera telefon informujący o niej. Szantażysta nazywa ją tylko pierwszym ostrzeżeniem. Turner obiecuje inżynierowi zwrot wszystkich skradzionych materiałów po wyrażeniu przezeń zgody na współpracę. Frieda wzrokiem każe Heliusowi zgodzić się na propozycje Amerykanina.

Segment 3: Start. Samolot wypisuje na niebie litery "START $\alpha \beta$ ”. Helius przed mikrofonem udziela ostatniego wywiadu przed startem rakiety „Friede”, który nastąpi o wschodzie Księżyca. Frieda żegna się wylewnie z pracownikami kosmodromu, po czym po drabince sznurowej wchodzi do rakiety, gdzie czeka już na nią profesor Manfeldt. Sprawozdawca radiowy informuje o rozlegających się w tej chwili na całym świecie syrenach i bijących dzwonach, by uczcić pionierów lecących w kosmos. Tłum wokół rakiety zdejmuje czapki i kapelusze, jakby żegnał zmarłych. Zza horyzontu zaczyna wyłaniać się Księżyc. Rakieta po specjalnym torze przesuwa się z hangaru do basenu, z którego wystartuje. Tłum usiłuje przedrzeć się przez kordon policji. W rakiecie Helius ostatni raz prosi Friedę, by się zastanowiła. Frieda jest niezłomna: „Helius, chce pan w ostatniej chwili zawstydzić mnie, kobietę. Oczy całego świata zwrócone są na nas, wszystkie uszy na świecie nas słuchają". Zdanie to powtarza, chcąc sobie dodać przed startem odwagi, przerażony Hans. Rakieta dociera do basenu, a sprawozdawca informuje publiczność: „Ponieważ rakieta jest za lekka, żeby samodzielnie stać, zostaje zatopiona w basenie, w którym będzie w pozycji wyprostowanej". Helius pokazuje załodze prędkościomierz i miernik przyspieszenia, informując o 8 krytycznych minutach, zanim rakieta osiągnie konieczną prędkość $11200 \mathrm{~m} / \mathrm{s}$ : w tym czasie będą musieli zmagać się z gigantycznym przeciążeniem, które będzie zabójcze, jeśli przyspieszenie przekroczy $40 \mathrm{~m} / \mathrm{s}^{2}$. Hans uświadamia sobie jeszcze inne niebezpieczeństwo - jeżeli nie będą w stanie zatrzymać 
prędkości na $11200 \mathrm{~m} / \mathrm{s}$, polecą dalej, bez ratunku straceni w kosmosie. O wpół do dziesiątej rakieta zostaje odpalona ku gwiaździstemu niebu. Miernik przyspieszenia zbliża się do punktu krytycznego. Olbrzymie przeciążenie powoduje, iż wszyscy tracą przytomność - w ostatniej jednak chwili Heliusowi nadludzkim wysiłkiem udaje się zatrzymać dźwignię prędkości dokładnie na $11200 \mathrm{~m} / \mathrm{s}$. Miernik przyspieszenia gwałtownie spada, a rakieta leci na rozgwieżdzonym niebie $\mathrm{z}$ nieprzytomną załogą.

Segment 4: Lot. Sekwencja montażowa, obrazująca nam kilkoma ujęciami pokładowego zegara, jak długo pasażerowie „Friede” byli nieprzytomni (Helius zemdlał jako ostatni, za 20 dziesiąta, 10 minut po starcie; jako pierwszy, 12 po szóstej, po ośmiu i pół godzinie, budzi się Manfeldt). Przebudzony profesor konstatuje, iż towarzysząca mu w locie myszka Josephine ma się dobrze. Potem budzi się Helius, który cuci Friedę, co zauważa tknięty zazdrością przebudzony Hans. Windegger rezygnuje jednak $\mathrm{z}$ ataku na Heliusa, gdy Frieda wyciąga ku niemu ramiona - pada w jej objęcia i tuli głowę na jej łonie. Heliusowi udaje się też - ku rozczarowaniu profesora - ocucić Turnera. Frieda, udając się do ładowni po koniak, odkrywa ukrytego w skafandrze Gustawa. W plecaku chłopaka, który indagowany przez Heliusa mówi, iż "całe życie zajmował się problemem Księżyca”, odnajdują ze śmiechem kosmiczne komiksy, z dzielnym bohaterem Mingo. Frieda, zadumana nad okładką jednego z numerów, pokazującą ziemski glob, pyta melancholijnie: „Ziemia... gdzie jest nasza Ziemia?" Helius otwiera okno, przez które oglądają kulę ziemską z zarysem kontynentów i oceanów niczym na globusie. „Na naszej Ziemi wschodzi Słońce" - komentuje Helius gwałtowny rozbłysk światła nad krawędzią globu. Gdy inni patrzą na Ziemię, Manfeldt wymyka się do teleskopu i kieruje go przez rozgwieżdżone niebo na tarczę Księżyca. W dalszym toku widzimy rękę Heliusa czyniącą zapiski w „Dzienniku pokładowym" i scenki unaoczniające panujący na statku stan nieważkości, gdy w odległości $227000 \mathrm{~km}$ od Ziemi wyłączone zostają silniki i rakieta leci dalej bez siły napędowej (Gustaw, idący do Heliusa z termosem, ląduje pod sufitem, gdy nierozważnie puścił zabezpieczające przed nieważkością uchwyty; Hans z Friedą mają problem z przelaniem do kieliszka koniaku z butelki). Po wkroczeniu rakiety w pole grawitacyjne Księżyca, zostaje ona odwrócona, by maksymalnie złagodzić skutki jej zderzenia z powierzchnią globu. Pasażerowie „Friede” widzą Ziemię zachodzącą za horyzontem coraz większej i coraz bliższej powierzchni Księżyca. Budzi to rozpacz Windeggera i jego agresję wobec Manfeldta, który, jego zdaniem, dla swych ambicji naraża ich życie. Spięcie łagodzi Helius. Manfeldt przywiera do okna, jakby chcąc dotknąć przybliżającej się coraz gwałtowniej powierzchni Księżyca. Helius rozkazuje zamknąć luki okienne, ale 
zamknięte przez Friedę okno otwiera profesor, zafascynowany wyciągając ręce ku coraz bliższemu Księżycowi. Załogę przygniata wzrastające przeciążenie. Rakiecie po gwałtownym zderzeniu udaje się ostatecznie bez eksplozji paliwa zaryć głęboko w księżycowym pyle.

Segment 5: Na Złotym Globie. Hans zamierza naprawić kabel zapłonowy, a profesor aż pali się, by wyruszyć na rekonesans („Księżyc czeka!'); Frieda studzi jednak jego zapał koniecznością pobrania próbek atmosfery. Zdenerwowany Hans mówi narzeczonej, iż marzy tylko o jak najszybszym powrocie na Ziemię. Odkrywają pęknięcie zbiorników z wodą i wyciek jej zapasów. Windegger ma nadzieję, że to zmusi Heliusa do decyzji o natychmiastowym powrocie, a gdy Frieda przypomina, iż może uda się znaleźć na Księżycu wodę za pomocą różdżki, Hans w histerii krzyczy, że znajdą tu tylko śmierć. Opętany Manfeldt wykrada kombinezon i różdżkę, wychodzi na zewnątrz, a zapaliwszy trzy zapałki konstatuje, iż atmosfera nadaje się do oddychania i zrzuca ciężki hełm skafandra. Jakby ciągnięty siłą różdżki, Manfeldt udaje się ku górom. Windegger zabiera się za odkopywanie rakiety, Turner oferuje się Heliusowi szukać jednocześnie profesora i wody, i wyrusza w stronę, w którą podążył Manfeldt, Frieda zaś filmuje księżycowy krajobraz. Gustaw z kolei zastępuje Heliusa w prowadzeniu dziennika. Frieda zauważa zranioną rękę Heliusa - gdy ją bandażuje, padają na nią jej łzy, uświadamiając konstruktorowi, że ich uczucie jest wzajemne. Gustaw pomaga Hansowi w odkopywaniu rakiety, a później podąża z niespokojnym Heliusem na poszukiwanie profesora. Tymczasem Manfeldt, minąwszy dziwną grotę z bulgoczącymi zbiornikami z jakąś cieczą odkrywa wielką żyłę złota. Pieści ogromny samorodek o przypominających kobiecy posąg kształtach. Obciążony swym ogromnym i ciężkim „złotym idolem", wystraszony przez zaskakującego go Turnera, wpada w głęboką rozpadlinę i ginie. Turner napycha sobie kieszenie oderwanymi od skał bryłkami złota, chowa się przed Heliusem i Gustawem, którzy daremnie nawołują profesora, i pospiesznie wraca do rakiety. Gdy Frieda wewnątrz rakiety wywołuje film, Turner ogłusza Hansa i wiąże go. Ten zdołał jednak ostrzec wołającą go Friedę, by nie wpuszczała Turnera na statek. Friedzie udaje się zablokować własną ręką drzwi rakiety przed napierającym na nie Turnerem do czasu nadejścia z odsieczą Heliusa choć przypłaca to omdleniem. Helius stacza z Amerykaninem walkę na piasku nieopodal rakiety. Pokonany Turner strzela do zbiornika z tlenem, a uwolniony przez Gustawa Windegger strzela do Turnera, który umiera na rękach Heliusa. Ponieważ strzał uszkodził zbiornik z tlenem i spowodował wyciek ponad połowy jego zapasów, nie wszyscy mogą wrócić na Ziemię: jeden z pary Helius - Windegger pozostanie na Księżycu. Ciągną z rąk Friedy trzykrotnie zapałki - los decyduje, że przegranym 
jest Windegger. Widząc jego histerię i śmiertelne przerażenie, Helius postanawia się poświęcić dla narzeczonego ukochanej. Wlewa do drinków Friedy i Hansa "na strzemiennego” środek nasenny. Gdy Windegger zasypia, a udająca senność Frieda gdzieś znika, Helius instruuje Gustawa, jak pokierować startem rakiety. Koło uśpionego Hansa zostawia list pożegnalny, wyrażający też nadzieję, że przyjaciel wróci, by go z powrotem zabrać. Helius żegna się z Gustawem, a później obserwuje udany start rakiety. Gdy wydaje mu się, że jest już tylko sam w tym obcym świecie i w rozpaczy opadają mu ręce, na tle obozu z pozostawionymi mu zapasami zjawia się przed nim Frieda, która przejrzała jego zamiar i postanowiła z nim pozostać. Helius wyciąga ręce jak ukrzyżowany. Padają sobie w objęcia.

Fabuła ta nie wymagała raczej lotu w kosmos i księżycowej scenerii: zarówno przetasowanie $\mathrm{w}$ miłosnym trójkącie, jak i historia opętanego swą idée fixe profesora Manfeldta czy machinacje piątki „mędrców” i jej reprezentanta, Turnera, $\mathrm{z}$ równym, albo i lepszym powodzeniem, mogłyby rozegrać się wyłącznie na Ziemi. Tak naprawdę, gdy rozważyć istotne motywacje postaci, cała historia wydaje się nie tyle wyprawą na Księżyc, co zstąpieniem w głąb siebie, w dziedzinę swych na wpół tylko uświadomionych pragnień, w sferę pożądania i obsesji. W zasadzie dla wszystkich jej uczestników - nawet dla małego Gustawa - jest to wyprawa zgubna: realizacja swej idée fixe oznacza dla Manfeldta i Turnera śmierć (niewątpliwą i unaocznioną nam na ekranie); równe w gruncie rzeczy śmierci pozostanie na Księżycu to z kolei cena ostatecznego spełnienia silnego, choć świadomie tłumionego pragnienia Heliusa i Friedy, by być razem; Hansowi Windeggerowi podróż odkrywa własny egotyzm i brak miłości dla Friedy, co przynosi ostatecznie utratę narzeczonej i skazanie na szybowanie samemu we wrogiej pustce kosmosu, bez pomocy opiekuńczego, silnego Heliusa; Gustaw odkrywa, iż martwy, odpychający kosmos nie jest najlepszą scenerią dla ducha przygody, uświadamiając sobie rozziew między rzeczywistością a swymi zrodzonymi z komiksów marzeniami, poznając też przemoc, pożądliwość dóbr, rywalizację erotyczną i śmierć, i płacąc za to poznanie koniecznością podjęcia olbrzymiej odpowiedzialności za los innych.

Niedopasowanie Friedy i Hansa Windeggera jest dla widza oczywiste od pierwszego pojawienia się tej pary na ekranie. Frieda jest spokojna, opanowana, rozsądna (zupełnie jak kochający ją Helius), Hans rozgorączkowany, histeryczny, impulsywny. Symbolicznym wyrazem tego niedobrania narzeczonych jest zbyt duży pierścionek, oferowany Friedzie przez Windeggera. Jest on za wielki nawet na kciuk, nie mówiąc już o innych palcach. Oczywiście, nieodpowiedni pierścionek świadczy 
o niedopasowaniu przede wszystkim seksualnym ${ }^{42}$. Narracja $\mathrm{w}$ dalszym toku podkreśla nam „niemęskość" Hansa w świadczących o jego tchórzostwie histerycznych reakcjach (gdy odkrywa kradzież planów, trzęsie się w panice przed startem, przed lądowaniem na Księżycu obwinia Manfeldta, wykrzykuje Friedzie, iż na Księżycu czeka ich jedynie śmierć, wreszcie, gdy sparaliżowany strachem nie jest $\mathrm{w}$ stanie nawet ciągnąć zapałki w trzeciej turze losowania). Ale ta niemęskość zdaje się też mieć wymiar seksualny: eksponowanym gościem w scenie zaręczynowego przyjęcia jest zwalista postać transwestyty czy transseksualisty $\mathrm{w}$ damskiej sukni. To on(a?) odbiera telefon od Heliusa, niechętnie podając aparat Windeggerowi, który z kolei wcale nie jest skłonny przerywać swego przyjęcia na wezwanie przyjaciela-rywala. $W$ każdym razie ta zagadkowa, hermafrodytyczna, transwestycka czy transseksualna figura, podkreśla, iż „niemęskość" Hansa może mieć wymiar braku nie tylko m ę s t w a w działaniu, ale i męs k ości w aspekcie seksualnym. Z tym brakiem wiąże się też paradygmatyczny w filmach niemieckich lat 20. gest "mężczyzny, który nigdy nie osiągnął dojrzałości": Hans, rezygnując ze swego ataku na Heliusa po nagle obudzonej zazdrości, pada w wyciągnięte ramiona Friedy i tuli głow ę na jej ło n i e ${ }^{43}$. Swiadczy to o jego infantylizmie i o tym, iż raczej niż być dlań kochanką czy narzeczona, silniejsza odeń Frieda pełni wobec niego rolę matki. Temu infantylizmowi towarzyszy też najzwyklejszy w świecie egoizm, troska tylko i wyłącznie o siebie. „Róbcie, co chcecie! Mnie interesuje tylko, jak stąd odlecieć” - mówi Windegger Friedzie i Manfeldtowi, gdy Frieda wspomina o konieczności pobrania próbek atmosfery, zanim spenetrują powierzchnię Księżyca. A gdy Frieda po przegranym przez niego losowaniu wielkodusznie ofiaruje się dotrzymać mu na Księżycu towarzystwa, rozhisteryzowany Hans wykrzykuje: „Mam tylko jedno marzenie: z powrotem na Ziemię!!!”.

Frieda (to dla widza od początku oczywiste) kocha tak naprawdę Heliusa, a nie Windeggera, z którym właściwie nie wiadomo dlaczego się zaręcza. Frieda smutnieje, gdy bilecik w kwiatach obwieszcza, że Wolf nie zjawi się na przyjęciu. I bezzwłocznie gotowa jest je porzucić, by przyjść $\mathrm{mu} \mathrm{z}$ pomoca $-\mathrm{w}$ przeciwieństwie do niezbyt skłonnego do tej pomocy

$42 \mathrm{Nt}$. symboliki pierścionka zaręczynowego jako wyrazu seksualnego dopasowania partnerów, zob.: Bruno Bettelheim, Cudowne i pożyteczne: O znaczeniach i wartościach baśni, przeł. Danuta Danek, Państwowy Instytut Wydawniczy, Warszawa 1985, t. 2, s. 190.

${ }^{43}$ Lejtmotywowe niemal powracanie w filmach niemieckich lat 20. sceny takiej słabości mężczyzny i takiej pociechy, jaką znajduje na łonie silniejszej odeń kobiety, konstatuje - wraz z jej rozmaitymi ideologicznymi implikacjami - Siegfried Kracauer. Por.: idem, Od Caligariego do Hitlera: Z psychologii filmu niemieckiego, przeł. Wanda Wertenstein i Eugenia Skrzywanowa, Filmowa Agencja Wydawnicza, Warszawa 1958, s. 87, 134 (tamże zacytowane w cudzysłowie słowa). 
Hansa. „Przyjdziemy natychmiast, Helius” - mówi, zabrawszy słuchawkę Windeggerowi. Gdy Hans raptownie wybiega do siebie sprawdzić, czy aby na pewno duplikaty planów są u niego bezpieczne, Frieda czyni Heliusowi wyrzuty o zatajenie przed nią planu podróży na Księżyc i zarzuca mu ręce na ramiona, przed czym ten gwałtownie musi się bronić. „O nie, Helius, nie poleci pan na Księżyc bez Windeggera" - przekonuje Wolfa o konieczności jego lojalności wobec narzeczonego. Ale to tylko pretekst - za chwilę Frieda ujawni swój prawdziwy cel: „I beze mnie też nie..." To Frieda wzrokiem da znać Heliusowi, by przystał na propozycję szantażującego go Turnera, dając tym samym tak naprawdę świadectwo nie tyle swej roztropności (co narracja wydaje się sugerować: mądrość Friedy ratuje pionierskie przedsięwzięcie przed katastrofą), ile swego egzaltowanego uczucia do konstruktora. Kiedy zdesperowany Hans obwieszcza, że gdy rakieta z powrotem będzie gotowa do startu, zmusi Heliusa i Manfeldta do powrotu na Ziemię bez względu na ich plany, Frieda pyta narzeczonego: „Masz zamiar zadać cios w plecy Heliusowi?” A choć w jej oporze wobec planów Windeggera można by upatrywać dbałości o naukowy cel wyprawy i silniejszej od lęku ciekawości poznawczej, to sposób zadania tego pytania świadczy jednak, iż podstawową motywacją jest tu uczucie żywione do Heliusa.

Księżyc katalizuje rozpad narzeczeństwa Friedy i Hansa, przyspieszając jej związanie z Heliusem. Po wylądowaniu na Srebrnym Globie (który zgodnie z hipotezami Manfeldta okazuje się Złotym Globem) Frieda wita Hansa bardzo czule. Wkrótce jednak dochodzi do sprzeczki, ujawnia się egotyzm Windeggera i jej zatroskanie o Heliusa. Gdy Frieda kończy już filmowanie lunarnego krajobrazu, patrzy przez chwilę na narzeczonego pracującego z łopatą przy rakiecie, po czym po wahaniu rozchodzą się $\mathrm{w}$ przeciwne strony. Zerwanie narzeczeństwa w zasadzie się dokonało. Przypieczętowaniem natomiast jej miłości do Heliusa stają się łzy, które płyną z jej oczu na jego zranioną rękę. A gdy ruszającego za Manfeldtem Heliusa dogania Gustaw, wręcza mu „wałówkę" ze słowami: „Od panny Friedy, żeby pan nie zgłodniał".

W dramatycznej scenie ciągnienia zapałek, które ma zdecydować, kto z pary Helius - Windegger będzie musiał pozostać na Księżycu, Frieda usytuowana niczym wyrocznia między oboma mężczyznami, trzyma "losy". Frieda wydaje się uosabiać los czy przeznaczenie, a zarazem na los zdawać w swym wyborze. Takie hazardowe postawienie sprawy w rozwiązaniu trójkąta miłosnego podkreśla tabelka stanu "gry" pomiędzy przyjaciółmi-rywalami, prowadzona przez Gustawa. Gustaw kibicuje Heliusowi, który jest jego idolem jako spec od Księżyca i kosmonautyki, a wyrażają to wielkie, wyraziste znaki ",+" i „,-, jeśli losowanie jest pomyślne dla Heliusa, i niewyraźny, ledwo widoczny zapis, gdy los sprzyja 
Windeggerowi. Ciekawy jest jednak fakt, że rubryki określające "graczy” mają w nagłówku, odpowiednio, „H” (Helius) i „W" (Windegger). Gdyby jednak zastosować klucz imion, a nie nazwisk, przyporządkowanie liter byłoby odwrotne: „W" (Wolf) $\mathrm{i}$ „, $\mathrm{H}^{\prime \prime}$ (Hans). Zatem oznaczenia „ $\mathrm{H}^{\prime} \mathrm{i}$ „,W”, przy uwzględnieniu faktu, że obaj mają te same inicjały imienia i nazwiska, tylko w odwrotnej kolejności, czynią to losowanie i zapis jego wyników wielce dwuznacznym, podkreślając w pewnym stopniu ich wzajemną ",substytutywność” w relacji do Friedy. Swiadczy też o tym sekwencja zdarzeń: gdy przegrywa Hans, Frieda nie korzysta z losu, ale z racji poczucia obowiązku (formalnie przecież zaręczyn nie zerwali), oferuje mu swe towarzystwo na Księżycu. Egoizm Windeggera zwalnia ją jednak z jej lojalności wobec niego. A odgadłszy wielkoduszny plan Heliusa, który mimo swego zwycięstwa w losowaniu, decyduje się poświęcić się dla Hansa (i dla niej samej) i samemu pozostać na Złotym Globie, ona sama dokonuje szlachetnego podstępu, nie wypijając środka nasennego i stawiając pogrążonego w rozpaczy Heliusa przed faktem dokonanym: swym dobrowolnym towarzyszeniem mu w kosmicznej pustce.

Finałowy czyn Friedy, mimo znamion caritas, chrześcijańskiego z ducha poświęcenia $\mathrm{w}$ imię miłości, niepokojąco jednak przypomina czyn Dziewczyny z ramowej historii w Zmęczonej Śmierci: Frieda, jak i ona, zamiast wrócić do życia, woli pozostać ze swym ukochanym w zaświatach. Czyn Friedy nie jest co prawda ewidentnym samobójstwem, jak wybór Dziewczyny, ma jednak samobójstwa znamiona, a czystość intencji jej poświęcenia zamąca fakt, iż połączenie z Heliusem było jej długo skrywanym erotycznym pragnieniem; tym samym z tą caritas zmieszany jest jednak silnie eros, niepomny na pozostawienie w pędzącej ku Ziemi rakiecie rozhisteryzowanego (eks-?)narzeczonego i niekompetentnego dziecka. Choć może nie jest ów finał apoteozą wystylizowanego na caritas samobójstwa, jak było w Zmęczonej Smierci, nie jest on jednak wolny od moralnej ambiwalencji - jak cała zresztą postać Friedy, dość bezproblemowo padającej w ramiona jednego mężczyzny i wylewającej czułe łzy nad drugim.

W postaci Heliusa nie ma takiej dwuznaczności: jego finałowe poświęcenie się dla Windeggera jest istotnie caritas, rezygnacją z samego siebie i swej ukochanej, nawet gdy los - zwycięskie losowanie - nadał mu prawo do dalszego życia i do narzeczonej rywala. Helius nie zamierza (jak Dziewczyna w Zmęczonej Śmierci, jak zaraz potem Frieda) „połączyć się z ukochaną osobą w zaświatach", ale rzeczywiście poświęca się za kogoś innego, i to - za rywala. Aspekt caritas w osobie Heliusa podkreślony jest też w scenie I, gdy odkrywamy jego dyskretną pomoc dla głodującego Manfeldta, oraz na Księżycu, gdy niespokojny o profesora, rusza na jego poszukiwanie. Usuwając się na bok, gdy Windegger zaręcza się z Friedą, i planując podróż na Księżyc bez „szczęśliwych narzeczonych”, Helius usuwa 
potencjalne "teatrum” swej zazdrości i unika opisanej przez René Girarda „rywalizacji mimetycznej”"44. Wplątuje go jednak w ten mechanizm Frieda, skłaniając do zabrania w kosmos Windeggera i samej siebie. Ratuje go jednak przed rodzącą przemoc rywalizacją jego profesjonalizm, poświęcenie się sferze zawodowej i poczucie odpowiedzialności za załogę; jako jedyny z pasażerów "Friede” wydaje się panować nad statkiem, czego wyrazem są np. zastopowanie prędkości na pożądanym pułapie $11200 \mathrm{~m} / \mathrm{s}$ (pomimo niemal uniemożliwiającego to zadanie olbrzymiego przeciążenia) czy przytomne komendy podczas przyciągania rakiety przez księżycową grawitację. O dominacji pierwiastka męskiego, racjonalnego, naukowego w jego osobowości świadczy ewokujące Słońce nazwisko inżyniera - Helius. Choć z drugiej strony, ta racjonalność i „słoneczność" jego osoby, która świetnie się sprawdza w dramatycznych chwilach startu i podróży, wydaje się jednak zawodzić w "lunarnym” świecie, w którym wśród jego załogi do głosu dochodzą pierwotne instynkty i nieświadomość.

Helius i Frieda są parą idealna, co narracja sugeruje nam od samego początku - toteż zaręczenie się bohaterki z impulsywnym, histerycznym Windeggerem, wydaje się cokolwiek niezrozumiałe. Razem z Gustawem tworzą też idealną rodzinę, połączoną wspólną pasją poznawczą wzajemnym zrozumieniem w pół słowa, niekłamaną sympatią i gotowością do poświęceń. To właśnie Gustaw jest „spadkobiercą” Heliusa jako ten, który udanie przeprowadzi start rakiety, choć jego jedyną kosmonautyczną edukacją były komiksy rysowane przez "autora Nicka Cartera”. Wydaje się, że takie przygotowanie i pomoc jedynie ze strony zawodzącego w trudnych sytuacjach Windeggera źle wróżą misji Gustawa i raczej nie ułatwiają spoglądania widzowi z optymizmem w przyszłość - zarówno co do perspektywy pomyślnego lądowania „Friede” na Ziemi, jak i losów pozostawionej na Księżycu pary.

Wyprawa Heliusa od początku miała zresztą znamiona wyprawy w "zaświaty" - nie tylko udania się w kosmos, ale i w "krainę śmierci”. Helius, ostrzegając Friedę przed wyprawą, przywołuje śmiałków, którzy nie powrócili z poprzedniej ekspedycji, a narracja unaocznia nam tablicę pamiątkową ku czci tych dzielnych „pionierów lotów kosmicznych”. Gdy sprawozdawca radiowy obwieszcza przed startem rakiety o rozlegających się w tej chwili na całym świecie wyciu syren i biciu dzwonów dla uczczenia naszych śmiałków, tłum wokół rakiety zdejmuje nakrycia głowy, jakby żegnając zmarłych. Windegger w histerii wykrzykuje Friedzie, że jedyne, co znajdą na Księżycu, to śmierć. Uszkodzone zostają zbiorniki

${ }^{44}$ Por. szczególnie: René Girard, Prawda powieściowa i kłamstwo romantyczne, przeł. Karolina Kot, Wydawnictwo KR, Warszawa 2001; René Girard, Szekspir: Teatr zazdrości, przeł. Barbara Mikołajewska, Wydawnictwo KR, Warszawa 1996. 
z wodą i tlenem - życiodajnymi substancjami, bez których nie sposób ani przebywać na Srebrnym Globie, ani wrócić na Ziemię. Ironiczny wydźwięk w kontekście finału - pozostania Heliusa i Friedy na Księżycu - uzyskuje ich pytanie do umierającego Turnera, czy ma on na świecie kogoś, komu można by przekazać jego ostatnie słowa, kiedy powrócą już na Ziemię. W świetle zaistniałej już śmierci Manfeldta i Turnera oraz takich rozproszonych w narracji sygnałów o "tanatologicznym” wymiarze filmu, trudno jednak odczytywać owo na pozór otwarte zakończenie jako optymistyczne - wszyscy bowiem uczestnicy ekspedycji „Friede”, także ci jeszcze żywi, pozostają w „zaświatach"...

Zupełnie nienaukowe, pozostające w sprzeczności z kosmicznym sztafażem filmu, są też wątki profesora Manfeldta oraz Turnera i jego mocodawców. Szczerze mówiąc, trudno się dziwić naukowemu gremium, które wyśmiewa nie wiadomo na jakiej podstawie wysnute hipotezy Manfeldta o obfitych złożach złota na Księżycu. Wizytówka w prologu przedstawia nam wprawdzie Manfeldta jako „profesora astronomii, członka honorowego Organizacji do Fizycznych Badań Kosmosu oraz Francuskiego Towarzystwa Astronomicznego", ale ani w podróży, ani na Księżycu profesor nie daje dowodów swych naukowych kompetencji w dziedzinie astronomii czy kosmonautyki. Wręcz przeciwnie, wyjściem poza rakietę przed sprawdzeniem składu atmosfery, daje on świadectwo swej niekompetencji i nieodpowiedzialności. Manfeldt wydaje się opętany monomania, chorobliwą idée fixe, której na imię „złoto na Księżycu”. Przyciąga go ona jak magnes, prowokując do działań niemal samobójczych - jak wspomniane już przedwczesne wyjście na powierzchnię Złotego Globu czy uporczywe wpatrywanie się przez rozsunięte okno w powierzchnię Księżyca w chwili spadania na nią rakiety, kiedy ze względów bezpieczeństwa luki okienne powinny być zamknięte. Znamienny jest zresztą wcześniejszy moment, kiedy pasażerowie „Friede” stoją jak urzeczeni przed widniejącym za oknem ziemskim globem, dając w ten sposób wyraz swej nostalgii za "stara, dobrą Ziemią”, Manfeldt zaś wymyka się do teleskopu, by nakierować go na widniejący już w całym swym splendorze Księżyc. Znamienne również, że nad posłaniem Manfeldta na jego poddaszu stał wielki globus Księżyca. Jak się jednak okaże już po wylądowaniu rakiety, „lunarne szaleństwo" profesora ma jednak raczej aspekt obsesji złota, pożądania jego gigantycznych złóż, niż naukowej fascynacji satelitą Ziemi.

To właśnie ku złotu, a nie ku wodzie, różdżka ciągnie Manfeldta, który $\mathrm{w}$ jakimś amoku, zupełnie bezrefleksyjnie podąża $\mathrm{w}$ wyznaczonym przez nią kierunku. Jak podaje Lotte Eisner, „pierwotny projekt przewidywał, że szalony profesor znajduje złoty posąg świadczący o praziemskiej kulturze na Księżycu; a skała, do której ostatecznie w ekstazie 
przywiera, nadal nosi ślady jakiejś formy figuralnej”45. Złoty posag, który pociagnie Manfeldta za sobą w czeluść rozpadliny, profesor obdarza gestami ewidentnie erotycznymi, pieszcząc go i całując niczym kobietę. Zrealizowana przez profesora jego idée fixe, okazuje się zarówno substytutem spełnienia erotycznego, jak i kompensatą materialną za lata spędzone w nędzy i samotności - tyle tylko, że jednocześnie przynosi zgubę, jak zresztą wszystkie i d ole opętujące człowieka egoistyczną i chorobliwą monomanią. Manfeldt przypomina w swej konstrukcji jedno z najbardziej sugestywnych $\mathrm{w}$ światowej literaturze przedstawień monomanii, patologicznego wyznaczenia kierunku życia człowieka przez przesłaniającą rzeczywistość chorobliwą idée fixe - Baltazara Claësa, bohatera należącej do Komedii ludzkiej powieści Poszukiwanie absolutu (La Recherche de l'abso$l u)$, zaprzepaszczającego swe szczęście rodzinne i olbrzymi majątek dla wytworzenia bogactwa drogą alchemiczną... ${ }^{46}$ Tyle tylko, że dla zobrazowania takiej monomanii Manfeldt, doprawdy, nie musiał być astronomem ani tym bardziej lecieć na Księżyc.

Turner jako postać wydaje się bladym echem mistrzów metamorfozy w poprzednich filmach Langa - doktora Mabuse i Haghiego. Demonstruje on Heliusowi swą błyskawiczną przemianę (w aspekcie środków wyrazu dokonaną za pomocą "tricku Mélièsowskiego", przez wyłączenie i ponowne włączenie kamery przy jednoczesnej zamianie filmowanego obiektu) z biznesmena zaczesanego na bok, o fryzurze trochę przypominającej Hitlera, w nieśmiałego petenta w okularach, polecanego rzekomo przez Windeggera. Rzeczywiście, zmiany charakteryzacji Turner dokonuje błyskawicznie, po prostu jakby przez chwilę targając swe włosy, bez skomplikowanej toalety przed lustrem, której musieli oddawać się Mabuse i Haghi. Ale też wcielenia ma tylko dwa, a swe nadzwyczajne zdolności wydaje się tracić w kosmosie, gdzie fizycznie wyczerpany wielkimi przeciążeniami, nie ma nawet siły się uczesać. Turner z jednej strony z sukcesem przeprowadza kunsztowną i symultaniczną akcję w trzech miejscach (zamach na Heliusa w samochodzie, obrabowanie sejfu w mieszkaniu Heliusa, kradzież duplikatów planów z mieszkania Windeggera), z drugiej zaś nie potrafi wykraść staremu człowiekowi jego rękopisu, gdy miał go już niemal w ręku, a potem daje się bezceremonialnie zrzucić Manfeldtowi ze schodów. Przy takich słabościach nie może być on magnetyczną, demoniczną osobowościa, jak Mabuse czy Haghi, na co zresztą wpływ ma też obsadzenie $\mathrm{w}$ tej roli nie wielce przekonującego $\mathrm{w}$ rolach charyzmatycznych

${ }^{45}$ L. H. Eisner, Fritz Lang, s. 108.

46 Zob.: Honoriusz Balzac, Poszukiwanie absolutu, przeł. Julian Rogoziński, [w:] Honoriusz Balzac, Komedia ludzka, t. 22, Studia filozoficzne (II), Czytelnik, Warszawa 1964, s. 97-277. 
przestępców Rudolfa Klein-Rogge, ale wyspecjalizowanego w rolach nieprzyjemnych, obleśnych postaci Fritza Raspa (w Szpiegach zagrał pułkownika Jellusicia, a w Metropolis Chudego).

Na wizy tówce naszego czarnego charakteru nie przypadkiem widnieje: „Walt Turner, Chicago”. W fantastycznych utworach literackich Republiki Weimarskiej negatywnymi postaciami często są właśnie Amerykanie jako dysponujący wielkim i skierowanym w dodatku przeciwko Niemcom kapitałem $^{47}$. Jest to echo resentymentów doby inflacji, kiedy amerykański, czy ściślej - żydowsko-amerykański kapitał był przedstawiany jako wykupujący za bezcen dobra kulturalne czy rozmaite inwestycje Niemiec ${ }^{48}$. Zaś o wizerunku w Kobiecie na Księżycu (w powieści, nie w filmie!) Turnera i jego mocodawców, tak pisze Peter Fisher, przytaczający zresztą ciekawe passusy z dzieła Thei von Harbou: „Sportretowanie przez Harbou amerykańskiego szantażysty i stojących za nim finansistów odsłania jej głęboko osadzoną niechęć do Stanów Zjednoczonych, antypatię związaną z jej generalną wrogością wobec Zachodu (wyraźnie ujawnioną w jej utworach przedwojennych i z lat wojny). W Kobiecie na Księżycu antyamerykanizm wyrażony figurą Walta Turnera przybiera odcieni rasistowskich: «Szczwany kundel... Nigdy nie widziałem fizjonomii, na której wymieszałoby się tyle wpływów. Ani Euroazjata, ani Metys, z pewnością nie Mulat, a jednak po trochu każdego z nich $»^{49}$.

«Co to właściwie za typ człowieka?... Jest niesamowity. Jest obcy i zły. Wyobrażam sobie, że nie urodził się jak inni ludzie» ${ }^{50}$.

Helius opiera się złożonej przez Turnera propozycji współpracy i wsparcia swego księżycowego przedsięwzięcia hojnymi funduszami Amerykanów. Odtrąca z godnością ofertę Amerykanów, ponieważ uświadamia sobie, iż interesuje ich tylko weryfikacja teorii Manfeldta o ogromnych złożach złota na Księżycu. Stojący za Turnerem bankierzy obawiają się, że jeśli teorie profesora są prawdziwe, utracą swój żelazny uścisk na światowych rezerwach złota i wpływ na globalną ekonomię" ${ }^{51}$.

Lang w swym filmie nie pokazuje pięciorga „mędrców” w sposób tak jednoznaczny jak w powieści - jako Amerykanów. Wśród czterech mężczyzn jest jeden Japończyk, dwaj dość nieokreśleni co do narodowości i jeden przypominający Churchilla osobnik ",anglikopodobny" (to właśnie on demonstruje pozostałemu towarzystwu film o skonstruowanej

47 Zob.: P. S. Fisher, op. cit., s. 74-78, 81, 138, 145-146, 211.

48 Zob.: Bernd Widdig, Culture and Inflation in Weimar Germany, University of California Press, Berkeley-Los Angeles-London 2001, s. 187-189.

49 Thea von Harbou, Frau im Mond, August Scherl Verlag, Berlin 1929, s. 14.

50 Ibidem. s. 62.

${ }^{51}$ P. S. Fisher, op. cit., s. 138. 
przez Heliusa bezzałogowej rakiecie H32). Wyraźne rysy amerykańskie, i to przedstawione w karykaturalnie groteskowy sposób, ma natomiast jedyna w piątce kobieta, kostycznie chuda, zmaskulinizowana i paląca cygaro. W kontekście takiej „internacjonalizacji” zarządców światowego kapitału, „pięcioro" jawi się w filmie nie tyle jako klika "amerykańska”, co raczej jako swoista antycypacja dbałego o finansową stabilizację świata gremium w rodzaju Międzynarodowego Funduszu Walutowego, o którym zreszta, jak wieść gminna głosi, wiadomo, iż jest zarządzany przez „żydomasonów”...

W każdym razie będący wysłannikiem tak szacownego grona Turner na samym Księżycu nie zachowuje się całkiem logicznie, napychając sobie kieszenie samorodkami złota i usiłując - bez posiadania ku temu odpowiednich kwalifikacji - samemu ukradkiem odlecieć ze Złotego Globu, czym tylko przyspiesza swą zgubę. Nie pierwsza to jednak i nie ostatnia w filmie Langa logiczna niekonsekwencja (ostatnią jest katastrofa spowodowana przestrzeleniem przez Turnera zbiornika z tlenem - skoro atmosfera Księżyca nadaje się do oddychania bez skafandrów, czy nie można było strat spowodowanych wyciekiem łatwo uzupełnić?).

Na tle księżycowego krajobrazu i gwiaździstego nieba rozgrywa się w filmie Langa moralny i sensacyjno-polityczny dramat $\mathrm{z}$ typowo ziemskimi problemami, któremu cały ten kosmiczny sztafaż jest tak naprawdę całkowicie zbędny.

\section{Wrażenie (nie)realności}

Melodramatyczna i sensacyjna akcja, w którą uwikłane są postacie Kobiety na Księżycu domagałaby się, aby być atrakcyjna dla widza, raczej klasycznego stylu narracji, z montażem analitycznym i jego zmiennością planów, szybkim rytmem (wzmacniającym suspens np. w sekwencjach z symultaniczną akcją), emocjonalną identyfikacją widza z postaciami dzięki ich wyrazistej charakterystyce psychologicznej i typowej dla większości filmów fabularnych "postaciocentryczności” narracji. Tymczasem jednak film Langa powstawał głównie z zamiarem wiarygodnego przedstawienia cudu techniki niedalekiej przyszłości: załogowej rakiety międzyplanetarnej, przebiegu jej startu, kosmicznego lotu i lądowania, wreszcie - scenerii najbliższego celu kosmicznej podróży, powierzchni Księżyca (który istotnie, w roku 1969, 40 lat po realizacji filmu Langa, miał zostać przez człowieka osiągnięty).

Nastawienie na prezentację techniki i krajobrazu nieznanego jeszcze wówczas globu jako clou narracji nie musiało spowodować stylistycznego pęknięcia filmu, gdyby akcja fabularna, generowana przez 
działania postaci, w istotny sposób wiązała się z rakietą podróżą kosmiczną, Księżycem. Jak jednak unaocznia poprzedni podrozdział, takiego istotnego związku zdarzeń fabularnych Kobiety na Księżycu z techniką i kosmiczną scenerią nie ma. Rozwiązania tej niespójności mogły być dwa - albo sztafaż fantastycznonaukowy potraktować pretekstowo i dość zdawkowo, realizując klasyczny w stylu film sensacyjny z wątkiem melodramatycznym (czy też melodramat $\mathrm{z}$ wątkiem sensacyjnym), albo pretekstowo potraktować fabułę, nastawiając się przede wszystkim na W zasadzie afabularne - „wrażenie realności świata przedstawionego”, a w związku z nim na raczej opisowy niż akcjocentryczny styl narracji. Lang wybrał drugie rozwiązanie - nie mógł zresztą inaczej, angażując jako ekspertów autorytety w dziedzinie kosmonautyki (Oberth, Ley) i wiążąc w kampanii reklamowej współfinansowane z własnej kieszeni eksperymenty Obertha $\mathrm{z}$ jego konsultanctwem naukowym $\mathrm{w}$ filmie jako elementy właściwie tego samego historycznego przedsięwzięcia.

Opisowy styl narracji generuje jedną z możliwych dominant w filmie fabularnym, którą w swojej poprzedniej książce nazwałem - za Noëlem Burchem - efekte m di e getyczn y m. Efekt ów można by nazwać także, z grubsza, wrażeniem realności świata przedstawi o n e g o. W tradycyjnym filmie fikcji owo wrażenie fundowane jest zazwyczaj na bazie wypadków fabularnych jako rzecz właściwie uboczna; może natomiast stawać się dominantą w pewnych partiach filmu, np. w sekwencjach o w zasadzie zminimalizowanej zdarzeniowości, bardziej opisowych $\mathrm{w}$ charakterze, $\mathrm{w}$ których dominuje raczej tr wan ie świata przedstawionego niż d zi an i e się jakichś zdarzeń ${ }^{52}$ (podobnie też bywa $\mathrm{w}$ utworach literackich - w zamieszczonym jako motto fragmencie powieści Verne'a Wokót Księżyca statyczny, pozbawiony zdarzeniowości opis ewokuje wrażenie realności Księżyca widzianego z Kosmosu, co zresztą wielce przypomina scenę z filmu Langa, kiedy pasażerowie „Friede” podziwiają ziemski glob, Manfeldt zaś wymyka się do teleskopu, by kontemplować właśnie Księżyc). W Kobiecie na Księżycu styl opisowy nie tylko w sposób oczywisty dominuje w pewnych sekwencjach (film o bezzałogowej rakiecie H32 prezentowany podczas spotkania "pięciorga mędrców”, start rakiety „Friede”, ,Dziennik pokładowy”), ale wydaje się na tyle przeważać w całości utworu, iż jego dominantą jawi się nie fabuła (jak zazwyczaj w „tradycyjnym” filmie), a właśnie efekt diegetyczny.

W sekwencji startu - usytuowanej centralnie w filmie i dla wielu recenzentów najbardziej pamiętnej - oczywiste jest, iż jej „bohaterem” jest

52 Zob.: Tomasz Kłys, Film fikcji i jego dominanty, Wydawnictwo Naukowe Semper, Warszawa 1999, s. 96-130; Noël Burch, Narrative/Diegesis - Thresholds, Limits, "Screen" 1982, vol. 23, no. 2, s. 16-33. 
rakieta, a nie Helius, Frieda, Manfeldt, Turner czy Hans. Postacie są nie tyle aktywnymi podmiotami jako pasażerowie czy członkowie załogi rakiety, ile zostają przez nią "wchłonięte” i ubezwłasnowolnione. Rytm narracji podporządkowany jest nie postaciom, które zresztą niespecjalnie mogą wówczas "działać", przygotowując się do unieruchomienia na swych pryczach, a w końcu obezwładnione zupełnie przez olbrzymie przeciążenie, lecz „maszynie”. Narracja w długich ujęciach kontempluje przesuwanie się rakiety po torach $\mathrm{z}$ hangaru do basenu, osadzanie $\mathrm{w}$ basenie, urządzenia pokładowe (zegar, prędkościomierz, miernik przyspieszenia). Moment największego napięcia - odliczanie kolejnych sekund przed startem, final countdown ${ }^{53}$ - po którym następuje kulminacja: odpalenie rakiety, nie wiąże się bezpośrednio z jakimś działaniem człowieka, a z sukcesem bądź zawodem, jaki sprawi „maszyna”. Bohaterowie, przyłłoczeni gigantycznymi siłami przy wzrastającym przyspieszeniu, nie mogą działać: są "działani”, gdyż to na nich oddziałują nieubłagane prawa fizyki, wciskając ich w koje, odbierając im dech, a w końcu pozbawiając ich przytomności. Jedyny suspens związany z aktywnym działaniem człowieka to pytanie, czy niemal zgnieciony przeciążeniem Helius zdobędzie się jeszcze, by zatrzymać dźwignię prędkości rakiety na 11200 m/s - co, rzecz jasna, ostatnim wysiłkiem woli udaje mu się, zanim na dobre straci przytomność.

"Przedmiotocentryczność", a nie zwyczajową „postaciocentryczność" narracji w tym filmie unaocznia wyraziście następująca po scenie startu sekwencja montażowa obrazująca lot rakiety "Friede” z nieprzytomną załogą. Składa się ona z następujących ujęć: 1. Zegar pokładowy w zbliżeniu pokazuje godzinę za dwadzieścia dziesiątą (jest to 10 minut po starcie, który nastąpił o wpół do dziesiątej). 2-3. Ujęcia nieprzytomnych członków załogi na ich kojach. 4. Na zegarze pokładowym prawie dwunasta. 5. Ujęcie nieprzytomnych Turnera i Manfeldta. 6. Ujęcie animowane: gwiaździste niebo z lecącą na nim rakietą. 7. Na zegarze pokładowym za dwadzieścia

53 Jedną z legend i tytułów do chwały tego skądinąd niedobrego filmu Langa jest to, iż właśnie z niego wywodzi się przyjęty później przy startach prawdziwych pojazdów kosmicznych sposób odliczania przed startem - od końca. Willy Ley pisze: „Wracając myślami w przeszłość, ze zdumieniem uświadomiłem sobie, iż odliczania użyto po raz pierwszy w Kobiecie na Księżycu. Był to niemy film i w pewnym momencie słowa «Noch 10 Sekunden» (,Jeszcze 10 sekund") rozbłysły na ekranie, po czym nastąpiły liczby: 6-5-4-32-1-0-START). Wiedząc, że Fritz Lang służył podczas I wojny światowej w armii austriackiej, zapytałem go, czy przyswoił sobie jakiś wojskowy zwyczaj, kiedy użył odliczania. Odpowiedział, że pracując nad filmem wymyślił to dla efektu dramatycznego; z pewnością nikt nie pomyślałby o takim skutku ubocznym!" (Willy Ley, Rockets, Missiles and Men in Space, Viking, New York 1968; cyt. za: P. McGilligan, op. cit., s. 144; ten sam cytat przytacza Lotte H. Eisner, Fritz Lang, s. 106). 
trzy trzecia. 8. Nieprzytomni członkowie załogi. 9. Na zegarze za trzynaście piąta. 10. Rozgwieżdżone niebo z lecącą rakietą. 11. Zegar: dwanaście po szóstej. 12. Manfeldt otwiera oczy, myszka w trzymanej przezeń klatce rusza się.

Nieprzytomni bohaterowie w sposób oczywisty nie mogą być "aktantami", podmiotami generującej zdarzenia akcji. Rakieta zdaje się lecieć sama, a "bohaterem” i zarazem tematem tej sekwencji statycznych, męczących ujęć jest mijający czas, unaoczniany kolejnymi zbliżeniami zegara z coraz to nową godziną. Narracja jest w ten sposób zupełnie "odantropomorfizowana", a świat przedstawiony - wbrew naturalnej dla widza potrzeby identyfikacji z działającymi postaciami - wydaje się całkowicie martwy. Sekwencja mogłaby mimo to osiągnąć pewne szczególne wrażenie realności przygnębiającego świata, w którym tok rzeczy biegnie „,sam”, bez aktywnego udziału człowieka, gdyby nie dość jednak kompromitujące technicznie (i to chyba nie tylko dzisiaj) animowane ujęcia nieba z rakietą. Ich niesatysfakcjonująca technicznie postać niweczy skądinąd starannie zaplanowany w scenografii rakiety i jej urządzeń pokładowych efekt diegetyczny, a do towarzyszącej tej sekwencji nudzie i zmęczeniu widza dołącza - niezamierzony z pewnością - uśmiech politowania. Najbardziej sugestywnym obrazem, powracającym lejtmotywowo w tej sekwencji, jest zegar pokładowy - jeszcze jeden dziwny zegar zrodzony w ",saturnicznej wyobraźni" Langa, z 12-godzinną tarczą o podwójnej numeracji godzin i wskazówką sekundnika zakończoną półksiężycem. A nie zapominajmy, że w bezpośrednio poprzedzającej tę sekwencję scenie startu niepoślednią funkcję dramatyczną jako „nieludzkie” generatory suspensu odgrywały pokazywane kilkakrotnie w zbliżeniach prędkościomierz i miernik przyspieszenia - choć nieodmierzające czasu, to z racji swej formy, kolistej tarczy z liczbami i wskazówka, kwalifikujące się jako jeszcze jedne dziwne Langowskie zegary.

O ile „przedmiotocentryczność" opisanej sekwencji montażowej, czy innej, pokazującej nam w "filmie w filmie" skonstruowaną przez Heliusa rakietę H32, tłumaczy się fabularnie (nieprzytomnością załogi "Friede”; faktem, że H32 jest bezzałogowa i że sekwencja ją ukazująca pełni funkcję informacyjną - tak dla widza, jak i dla piątki „mędrców”), to Lang używa takiego „odantropomorfizowanego", statycznego stylu także w miejscach, kiedy podobnych pretekstów fabularnych brak. Na przykład pod koniec segmentu 1 Manfeldt odprowadza opuszczającego jego poddasze Heliusa. Obaj wychodzą z izby, a widz przez około pół minuty czasu ekranowego, zanim profesor nie powróci do pokoju i w kadr, kontempluje "martwą naturę" w pustym wnętrzu - butelkę i resztki jedzenia na stole, przy którym profesor ze swym gościem spożywali kolację. Tak jak w sekwencji lotu, świat przedstawiony wydaje się trwać bez ludzi. Podobne „martwe 
natury" nierzadkie są np. w filmach Yasujiro Ozu, wywołując u odbiorcy szczególne wrażenie materialności i namacalności świata przedstawionego oraz wyostrzając na detale jego percepcję, co zresztą po zaakceptowaniu takiego stylu jest źródłem niemałej satysfakcji estetycznej. Kobieta na Księżycu miała być jednak efektownym widowiskiem z sensacyjną akcją i atrakcjami technicznymi za grube pieniądze - toteż takie przedłużanie czasu trwania ujęcia bez jakiejkolwiek motywacji w zdarzeniach fabuły czy atrakcjach spektaklu rodzić musi w odbiorcy nieuchronne poczucie niemiłosiernego wleczenia się filmu, na które słusznie narzekali recenzenci, i wynikającej stąd nieuchronnie, a chyba niezamierzonej estetycznie (jak w filmach Antonioniego, Wendersa czy Jarmuscha) n u d y.

Może jeszcze bardziej wyrazista w aspekcie „przedmiotocentryczności" narracji jest krótka sekwencja montażowa w segmencie 2, kiedy - tak wynika z kontekstu fabularnego - Helius opowiada Windeggerowi o napadzie nań w samochodzie i o obrabowaniu swego mieszkania. Ujęcie poprzedzające: Helius żywo peroruje coś Hansowi. Sekwencja streszczająca przebieg wypadków: 1. Zbliżenie: rzekomy list polecający Hansa, który przedstawił gospodyni Turner. 2. (po przenikaniu) Zbliżenie: przewiązany sznurkiem rękopis książki Manfeldta. 3. (po przenikaniu) Zbliżenie: bukiet fiołków. 4. (po przenikaniu) Sznurek po książce na tylnym siedzeniu samochodu. 5. (po przenikaniu) Zamknięty sejf w mieszkaniu Heliusa. 6. (po przenikaniu) Puste półki otwartego sejfu. Kolejne ujęcie, nienależące już do tej „retrospekcji”, pokazuje Friedę, Hansa i Heliusa stojących przy otwartym, pustym sejfie (w planie ogólnym).

Sensacyjne zdarzenia, o których Helius informuje Windeggera, wcześniej też wcale nie zostały unaocznione w kadrze. Owszem, widzieliśmy skutek sprokurowanego zapewne przez ludzi Turnera wypadku, uliczny korek, z którego korzysta "dziewczyna z fiołkami”, by zastawić na Heliusa pułapkę. Ale jak dokładnie przebiegła akcja - np. w jaki sposób Helius stracił przy tomność - możemy się tylko domyślać. Podobnie zresztą nie widzieliśmy akcji otwierania sejfu przez ludzi Turnera, a tylko wynoszenie przez nich łupu klatką schodową. „, Retrospekcja” (inaczej niż np. dzieje się to na ogół w filmie klasycznym) nie pogłębia tu naszej wiedzy, prezentując w kilku "znakowych" ujęciach albo przedmioty uwikłane w akcję (list, rękopis, bukiet fiołków), albo jej skutki (sznurek po skradzionej książce, pusty sejf). Można powiedzieć, że sekwencja ta w swym eliptyczno-metonimiczno-synekdochicznym stylu jest bardzo interesująca artystycznie, zapowiadając zresztą pamiętną sekwencję metonimicznej prezentacji zbrodni na Elsie Beckmann w $M-$ mordercy. Niemniej, przez swój przedmiotocentryczny i odantropomorfizowany styl narracji nie ułatwia ona emocjonalnego zaangażowania widzowi, a co więcej, wzmaga ona jego dystans, poczucie nieuzasadnionej rozwlekłości i nudę. 
Efekt diegetyczny jako dominanta filmu o charakterze superwidowiska, na które wydano miliony, powinien polegać na oszołomieniu widza spektakularnymi atrakcjami. Udało się atrakcje takie Langowi stworzyć i osiągnąć poruszający widza do dziś ów efekt w Metropolis - i to pomimo niespójności świata przedstawionego czy braku fabularnej logiki w tamtym filmie. Trzeba powiedzieć, że Kobieta na Księżycu pod tym względem w znacznej mierze zawodzi. O ile „wrażenie realności rakiety” zostało $\mathrm{w}$ pewnej mierze osiągnięte $\mathrm{w}$ sekwencji przygotowań do startu, dzięki m.in. monumentalnej scenografii i dość zręcznemu, choć bynajmniej nie porywająco szybkiemu montażowi, to technicznie żałosne są animowane ujęcia obu startów (z Ziemi i z Księżyca) czy pędzącej rakiety na tle gwiaździstego nieba (o czym już wspominałem). W trakcie lotu najciekawsza wydaje się sekwencja unaoczniająca opisane w "Dzienniku pokładowym” zjawisko nieważkości - zwłaszcza moment, kiedy Gustaw, który puścił się uchwytów, unosi się przez właz na kolejny poziom (co zamierzył) i (wbrew swym zamiarom) ląduje pod sufitem. Efekt jest rzeczywiście interesujący technicznie, a $\mathrm{z}$ racji połączenia $\mathrm{w}$ tej scence tonacji komediowej z afirmowaną przez Karola Irzykowskiego „widzialnością obcowania człowieka z materia, przyjaznego lub wrogiego" ${ }^{54}$, przypomina najlepsze, niemal poetyckie gagi, rodem z wielkiej amerykańskiej burleski, np. Chaplina czy Keatona. Znajduje w niej zresztą wreszcie usprawiedliwienie wyposażenie wnętrza rakiety w ewokujące tramwaj uchwyty, które wcześniej wydawały się zupełnie nie na miejscu w pojeździe kosmicznym.

Niestety, mimo pracy przy filmie takich mistrzów nad mistrzami w zakresie scenografii, jak Otto Hunte i Karl Vollbrecht, niezbyt wiarygodny i niezbyt widowiskowy okazuje się filmowy Księżyc. Góry piasku, nawiezionego z berlińskich przedmieść, a później rozbielonego i kunsztownie ułożonego przez scenografów w zawijasy i wydmy o "cudownej świetlistości”, którą zachwycał się Paul Rotha, nie wydają się szczególną atrakcją wizualną - podobnie zresztą jak złote góry z papier-mâché i baseniki z bulgoczącą "lawą", przez które bez najmniejszych przeszkód przechodzą Manfeldt i Turner, Helius i Gustaw. Przy wizualnej monotonii i nudzie, którą ma nam do zaoferowania w filmie Złoty (bo przecież nie Srebrny) Glob, być może jedynym wyjściem wydało się Langowi uatrakcyjnienie sekwencji Księżyca sensacyjnymi wypadkami fabularnymi - amokiem profesora i jego śmiercia, podstępną i tragiczną w skutkach (choć nieumotywowaną ani w jej zainicjowaniu, ani w jej tragiczności, skoro na Langowskim Księżycu jest tlen - sic!) akcją Turnera, wreszcie dramatycznym rozwiązaniem trójkąta miłosnego. Jako jednak zasadniczo

54 Por.: Karol Irzykowski, X Muza: Zagadnienia estetyczne kina, Wydawnictwa Artystyczne i Filmowe, Warszawa 1977, s. 83. 
„niekosmiczna” w swym rodowodzie i w charakterze, akcja fabularna nie pogłębia wrażenia realności, lecz po prostu odwraca uwagę od nieciekawej scenerii, rażącej sztucznością i spóźnionym o dobrych parę lat „ekspresjonizmem" swej estetyki. Bo, paradoksalnie, finałowa sekwencja Kobiety na Księżycu, z jej światłocieniami, ze sztucznością umownością znakowością i symbolicznością jej scenografii, z jej emanowanym przez złoża złota, nałożonym na obraz w podwójnej ekspozycji, napisem "GOLD”, jest w latach 20. może najbardziej ekspresjonistycznym fragmentem twórczości Langa. Co zreszta z racji anachroniczności takiej estetyki A. D. 1929, nie jest bynajmniej komplementem.

Na usprawiedliwienie jednak Langa i jego scenografów trzeba powiedzieć, iż cała prawie historia kina - od Podróży na Księżyc Mélièsa po cykl Gwiezdnych wojen - dowodzi, jak bardzo „niefilmową” przestrzenia, wyjątkowo mało podatną na ewokowanie w kinie wiarygodnego efektu diegetycznego, jest kosmos. 


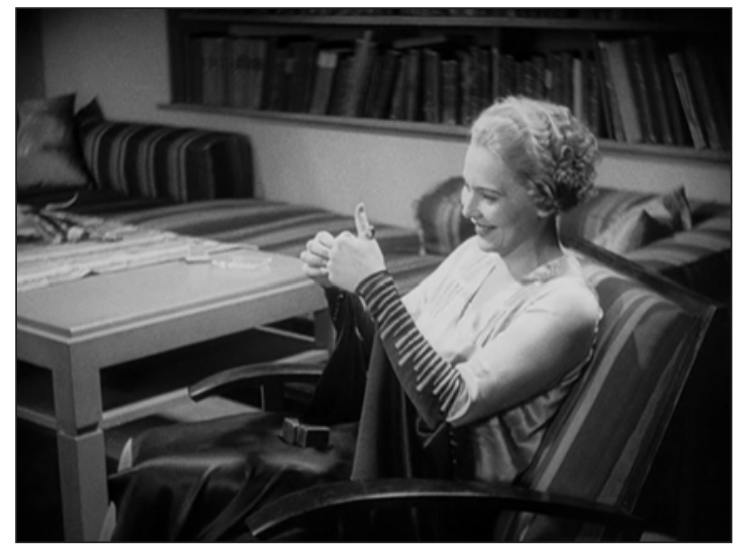

1. Kobieta na Księżycu (1929, reż. Fritz Lang). Oznaka niedopasowania narzeczonych - pierścionek od Hansa zbyt duży nawet na kciuk Friedy

2. Kobieta na Księżycu (1929, reż. Fritz Lang). Uliczne zamieszanie jako potrzask - od roku 1922 obsesyjnie powracający temat Langa
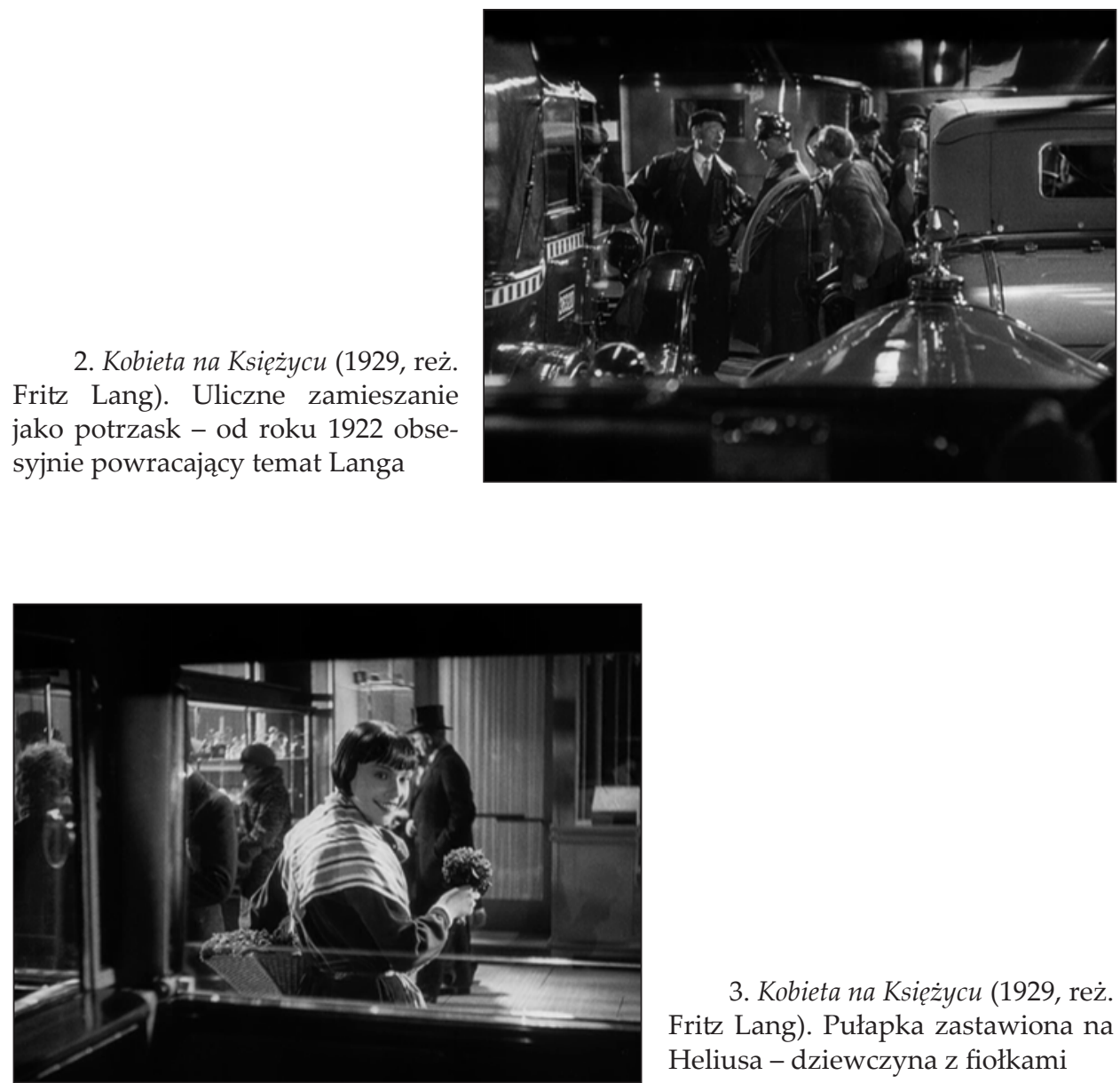

3. Kobieta na Księżycu (1929, reż. Fritz Lang). Pułapka zastawiona na Heliusa - dziewczyna z fiołkami 


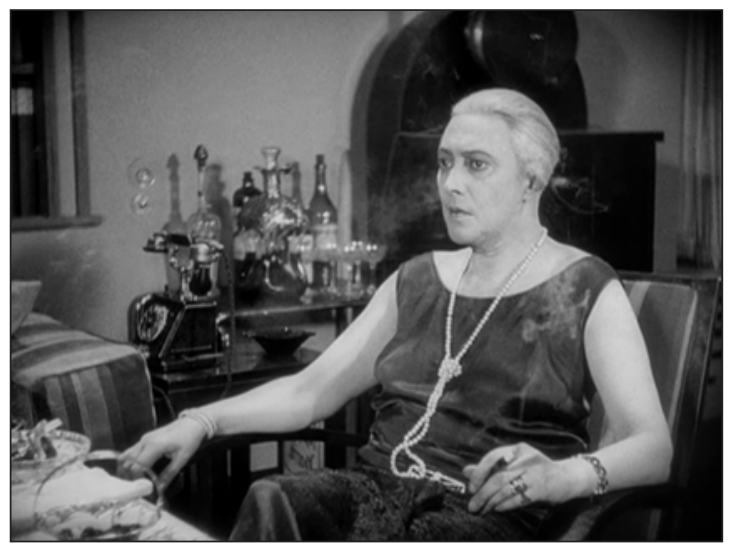

4. Kobieta na Księżycu (1929, reż. Fritz Lang). Zazdrosny o Hansa hermafrodytyczny gość na przyjęciu zaręczynowym

5. Kobieta na Księżycu (1929, reż. Fritz Lang). Pięcioro „mędrców” i model rakiety
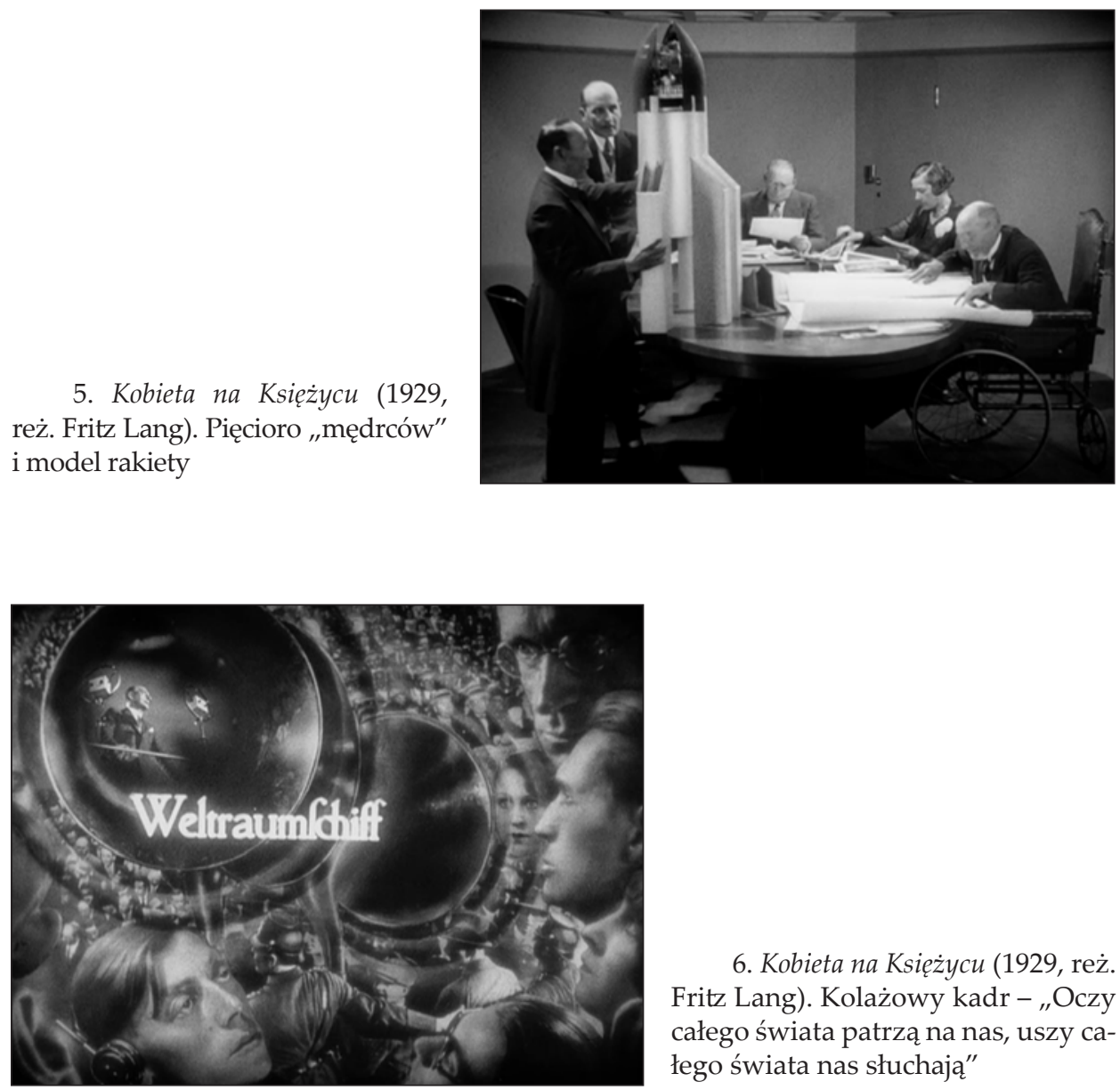

6. Kobieta na Księżycu (1929, reż. Fritz Lang). Kolażowy kadr - „Oczy całego świata patrzą na nas, uszy całego świata nas słuchają" 


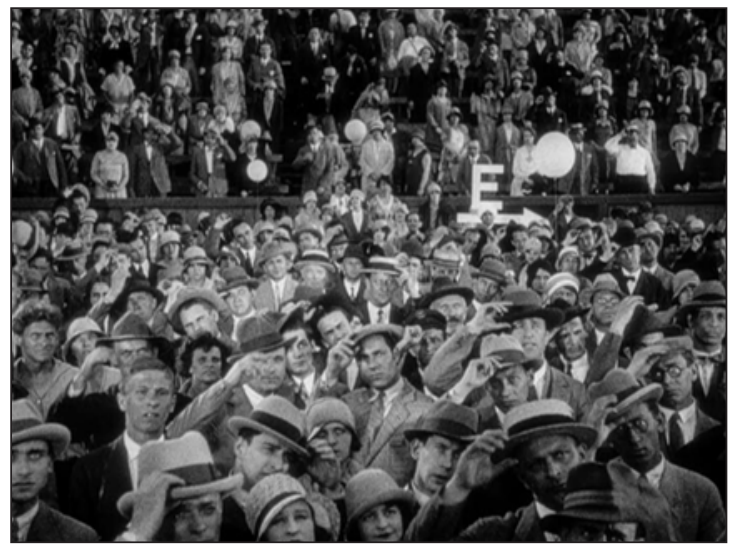

7. Kobieta na Księżycu (1929, reż. Fritz Lang). Tłum żegna bohaterów lecących w kosmos

8. Kobieta na Księżycu (1929, reż. Fritz Lang). „Nad naszą Ziemią wschodzi Słońce" - pasażerowie „Friede" podziwiają Ziemię z kosmosu
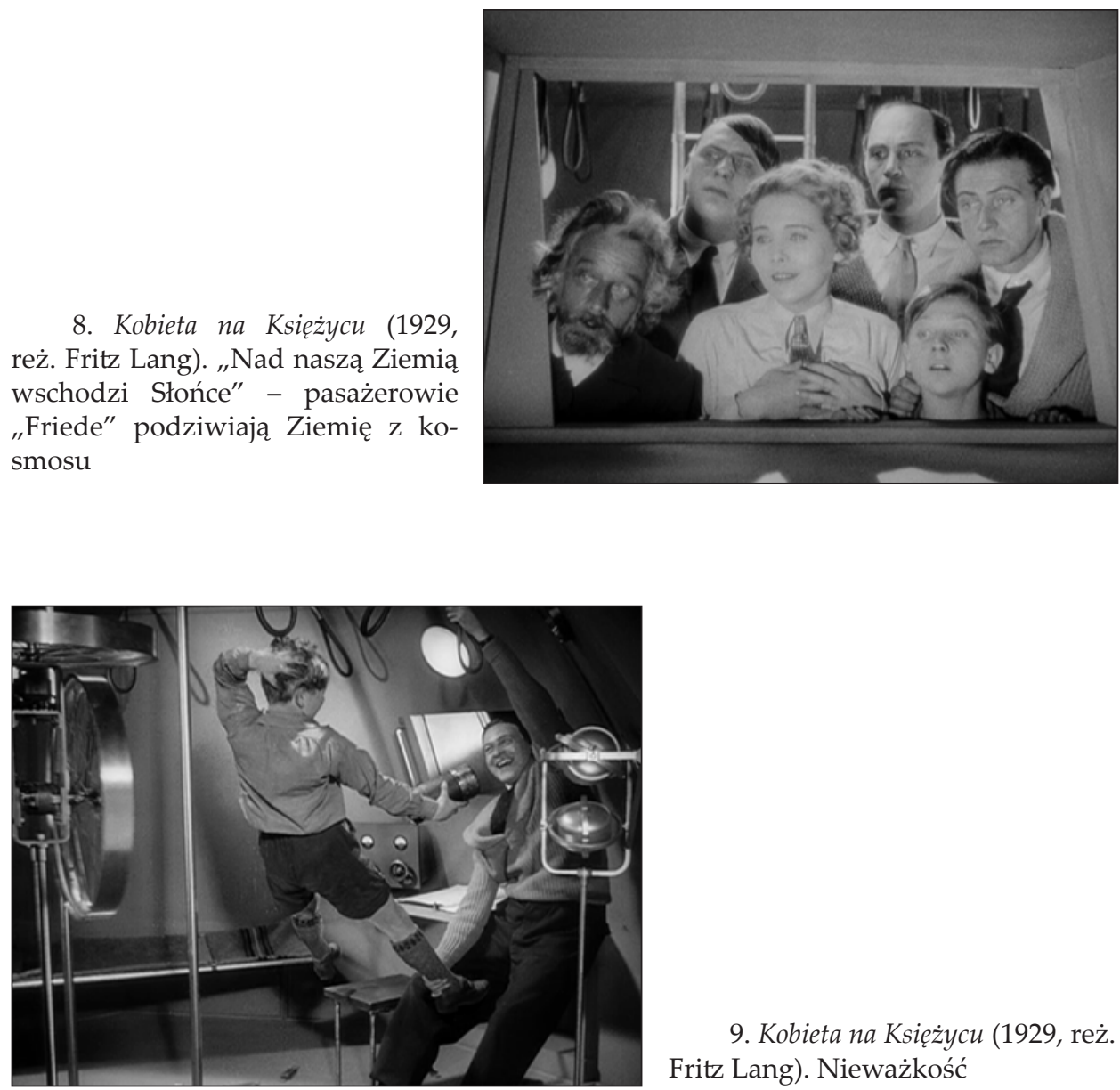

9. Kobieta na Księżycu (1929, reż. Fritz Lang). Nieważkość 


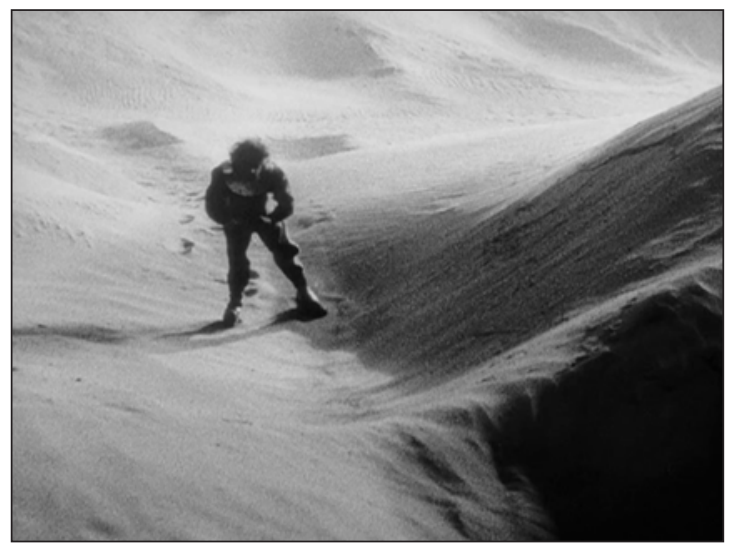

10. Kobieta na Księżycu (1929, reż. Fritz Lang). Lunarny krajobraz

11. Kobieta na Księżycu (1929, reż. Fritz Lang). Manfeldt i księżycowe złoto
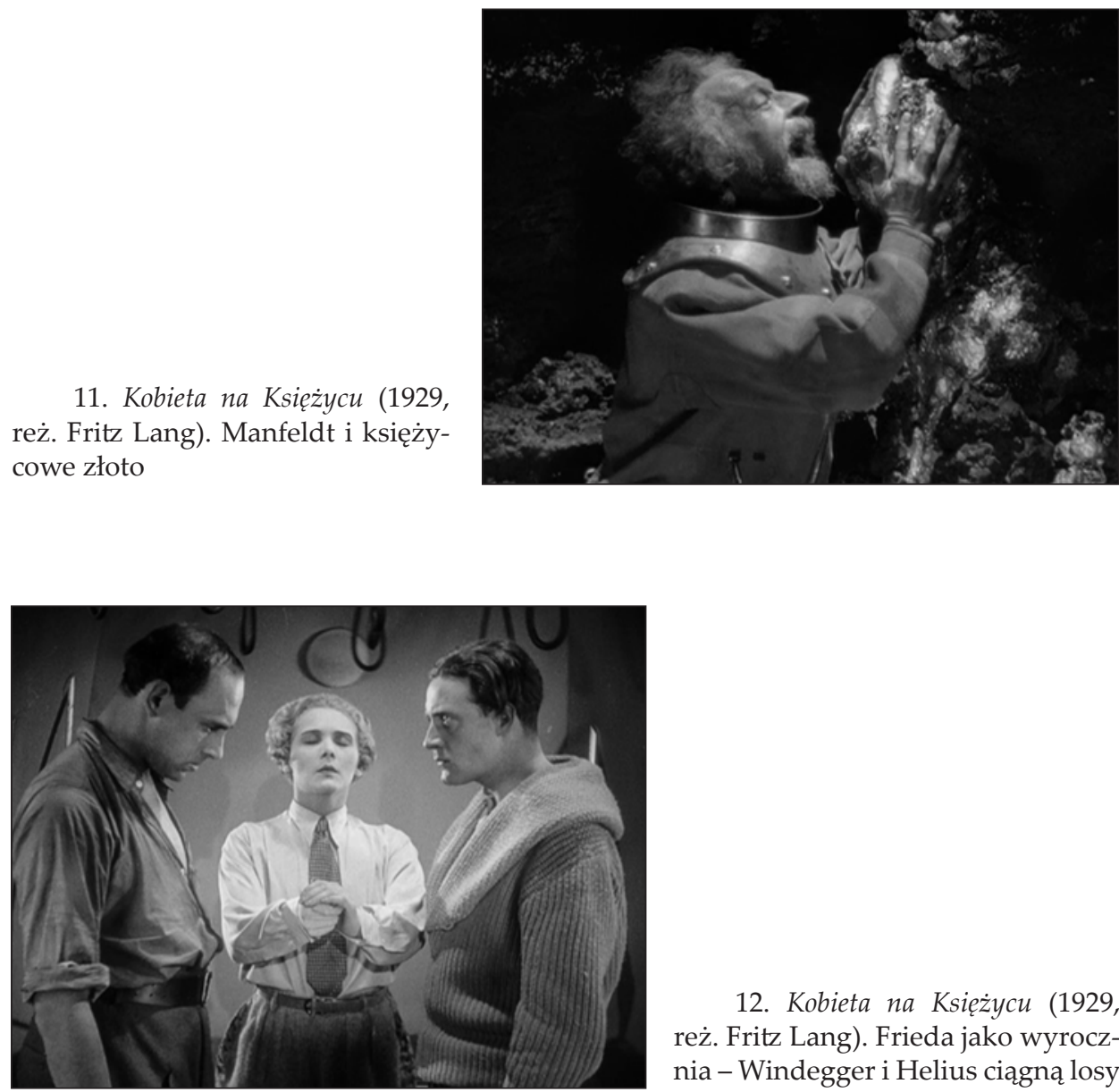

12. Kobieta na Księżycu (1929, reż. Fritz Lang). Frieda jako wyrocznia - Windegger i Helius ciągną losy 
Część 4

KOMISARZ LOHMANN PROWADZI ŚLEDZTWO 



\title{
Rozdział 7
}

\section{CAŁE MIASTO O TYM MÓWI ALBO KRYMINAŁ ZA TRZY GROSZE: $M-M O R D E R C A$}

\author{
A rekiny w oceanie \\ Mają zębów pełen pysk \\ Macheath ma w kieszeni majcher, \\ Lecz kto widział jego błysk \\ Kiedy rekin krwią się splami, \\ Krew w pamięci musi trwać... \\ Mackie nosi rękawiczki, \\ Żeby nic nie było znać. \\ A w Tamizy toń zieloną \\ Wpada nagle ten i ów! \\ Czy to dżuma, czy cholera? \\ Nie, to Mackie krąży znów. \\ A w niedzielny piękny ranek \\ Trup osuwa się na bruk - \\ Mackie Majcher znikł za rogiem, \\ Ale któż go widzieć mógł? [...] \\ Jenny Towler znaleziono \\ Z nożem w piersi, ale cóż? \\ Mackie Majcher spaceruje \\ I nikt nie wie, czyj był nóż. $[\ldots]^{1}$ \\ (Opera za trzy grosze, Prolog)
}

\section{Pochwała pewnego widza}

Choć w świetle dostępnych dziś dokumentów wiadomo, iż wielokrotnie przytaczana $w$ rozmaitych tekstach o historii kina opowieść Fritza Langa o jego spotkaniu z Goebbelsem na przełomie marca i kwietnia 1933 r.,

${ }^{1}$ Bertolt Brecht, Dramaty, t. 1, Państwowy Instytut Wydawniczy, Warszawa 1962, s. 33-34 (przekład Władysława Broniewskiego). 
które jakoby poprzedziło jego „natychmiastową” ucieczkę z Niemiec, najprawdopodobniej jest fikcją jego "wyobrażonym filmem”, to jednak uznanie, jakie Reichspropagandaminister miał dla twórczości Langa nie jest tylko projekcją reżysera. Znajduje ono potwierdzenie w pedantycznie prowadzonym przez Goebbelsa dzienniku, gdzie pod datą 21 maja 1931 r. znajduje się następujący zapisek: „Abends mit Magda Film «M» von Fritz Lang gesehen. Fabelhaft! Gegen die Humanitätsduselei! Für die Todesstrafe! Gut gemacht. Lang wird einmal unser Regisseur"3 („Wieczorem oglądaliśmy z Magdą film Fritza Langa M. Fantastyczne! Przeciwko humanitarnej czułostkowości! Za karą śmierci! Dobrze zrobione. Lang będzie kiedyś naszym reżyserem").

Takie komplementy ze strony przyszłego nazistowskiego ministra propagandy stawiają dzieło Langa w dwuznacznym świetle. Rzecz jasna, wiadomo, iż nie spełniły się nadzieje Goebbelsa. Lang nie tylko nie został „ich” reżyserem, ale w 1933 wyjechał z Niemiec, a za oceanem zrealizował jednoznacznie antynazistowskie filmy: Polowanie na człowieka (Man Hunt, 1941) i Kaci także umieraja (Hangmen Also Die, 1943). Jednak z racji tej kłopotliwej pochwały jednego z najwyżej postawionych ludzi Hitlera, warto bliżej przyjrzeć się $M-$ mordercy, przez wielu - w tym przez samego reżysera - uznawanego za najwybitniejszy film Langa. W samym tekście filmu, a także w jego kontekstach (powstania i recepcji) oraz podtekstach (wymowy) przy bliższym wejrzeniu ujawnia się jakaś fundamentalna ambiwalencja, wobec której pochwała ministra Rzeszy przestaje zaskakiwać. Ambiwalencja ta niepokojąco objawiła się już w wielkich filmach Langa z lat 20:: Zmęczonej Śmierci, Doktorze Mabuse, graczu, Nibelungach i Metropolis.

\section{Mordercy są wśród nas}

Pierwotnie tytuł filmu - ostatecznie sprowadzony do jednej zaledwie litery - miał brzmieć Mörder unter uns, co można przetłumaczyć zarówno jako „Morderca” (w liczbie pojedynczej), jak i „Mordercy” (w liczbie mnogiej) „pośród nas”. „Film-Kurier” z 20 kwietnia 1931 (a więc na 3 tygodnie przed premierą filmu, która odbyła się 11 maja 1931 w berlińskim kinie Ufa-Palast am Zoo ${ }^{4}$ tak uzasadniał zmianę tytułu: „Nie można było użyć

2 Odsyłam do rozdziału wstępnego Wyobrażony film Fritza Langa, s. 151.

3 Die Tagebücher von Joseph Goebbels: Sämtliche Fragmente, vol. 1: 1924-1941, Red. E. Fröhlich, Saur, München 1987 (cyt. za: Fritz Lang. Leben und Werke. Bilder und Dokumente, Red. R. Aurich, W. Jacobsen, C. Schnauber, Filmmuseum Berlin-Deutsche Kinemathek und jovis Verlag, Berlin 2001, s. 169).

${ }^{4}$ Datowanie premiery na podstawie: E. Ann Kaplan, Fritz Lang: A Guide to References and Resources, G. K. Halla \& Co., Boston 1981, s. 61. 
pierwotnego tytułu, Mörder unter uns, ponieważ w paru innych [równolegle realizowanych - dopisek T. K.] filmach w ich tytułach pojawia się słowo «Mörder»; dlatego nowy tytuł filmu będzie pochodził od znaku, który odgrywa ważną rolę $\mathrm{w}$ filmie ${ }^{\prime \prime}$. Zatem zmiana tytułu była spowodowana względami marketingowymi, koniecznością odróżnienia się od innych równoległych produkcji ${ }^{6}$. Choć enigmatyczny, jednoliterowy tytuł wcale nie wydaje się marketingowo atrakcyjniejszy od planowanego - za to z pewnością jest bardziej niejednoznaczny ${ }^{7}$.

Anegdota, którą Lang już na emigracji opowiedział Siegfriedowi Kracauerowi, a która za jego wpływową książką Od Caligariego do Hitlera trafiła, jako „z pierwszej ręki”, do licznych tekstów o historii kina niemieckiego, ma za tło rozmaite problemy, jakich pierwotny tytuł filmu miał jakoby nastręczać Langowi - w postaci listów z pogróżkami czy odmowy wypożyczenia mu hal zdjęciowych w Staaken. " "Ale skąd to całe sprzysiężenie przeciwko filmowi o Kürtenie - mordercy dzieci z Düsseldorfu?» - zapytał w końcu zrozpaczony Lang dyrektora atelier. «Ach, to tak» - powiedział na to dyrektor. Westchnął z ulgą i natychmiast wręczył mu klucze do Staaken. Lang także zrozumiał; podczas sprzeczki z dyrektorem atelier schwycił go za klapę i dostrzegł ukryty znaczek partii hitlerowskiej. «Mordercy są wśród nas»: hitlerowcy bali się kompromitacji"8.

Sceptycyzm wobec tej anegdoty zaleca zarówno monografista $M$, Anton Kaes, jak i monografista Langa, Tom Gunning. Według pierwszego,

${ }^{5}$ Fritz Lang Film ohne Titel, „Film-Kurier”, 20 April 1931 (cyt. za: Anton Kaes, M, BFI Publishing, London 2001, s. 16). Trzeba jednak pamiętać, iż porzucony przez Langa pierwotny tytuł został - w nieznacznie zmodyfikowanej postaci - przejęty przez pierwszy niemiecki film powojenny Die Mörder sind unter uns (Mordercy sa wśród nas, reż. Wolfgang Staudte, 1946). Film ten, zrealizowany dla nowo utworzonej na terenach dawnego studia Ufy w Neubabelsbergu wytwórni DEFA (stanie się ona bazą przyszłej kinematografii NRD), należy do tzw. Trümmerfilme, obrazujących polityczną klęskę narodu i kraj po wojennych zniszczeniach. Por.: Sabine Hake, German National Cinema, Routledge, LondonNew York 2002, s. 88, 90-91.

${ }^{6}$ Kaes wskazuje dwa inne filmy ze słowem Mörder w tytule, które pojawiły się na niemieckich ekranach w roku 1931: Der Mann, der seinen Mörder sucht (Człowiek, który szuka swego mordercy) Roberta Siodmaka i Der Mörder Dimitri Karamazoff (Morderca Dymitr Karamazow) Fiodora Ocepa [zob.: A. Kaes, op. cit., s. 83]. A trzeba by tu też wymienić jeszcze trzeci film z roku 1931 - Człowiek, który popetnił morderstwo (Der Mann, der den Mord beging) w reżyserii Kurta Bernhardta.

7 Polski tytuł: $M$ - morderca na powrót wprowadza słowo, którego producent, dystrybutor czy też sam Lang zdecydowali się w końcu uniknąć. „Uatrakcyjnia” on tytuł oryginalny - ale zarazem ujednoznacznia, choć tytuł ten jednoznaczny nie jest (o czym w dalszej części rozdziału).

${ }^{8}$ Siegfried Kracauer, Od Caligariego do Hitlera: Z psychologii filmu niemieckiego, przeł. W. Wertenstein, E. Skrzywanowa, Filmowa Agencja Wydawnicza, Warszawa 1958, s. 186. 
nic tej opowieści nie podpiera ${ }^{9}$, zdaniem drugiego, jak na prawdziwą wydaje się ona nieco zbyt dramatyczna, a poza tym, dlaczego w owym czasie ktoś miałby ukrywać odznakę partii nazistowskiej? (dodajmy jednej z głównych sił w ówczesnym Reichstagu). Gunning postrzega te historyjkę raczej jako jeszcze jeden „wyobrażony film” Langa, z podobnym suspensem, co anegdota o spotkaniu z Goebbelsem i "ucieczce z Niemiec". Znajduje w niej też wyraz nowy, jakby emblematyczny dla Neue Sachlichkeit, "przedmiotowy” styl Langa, gdzie nieożywione rzeczy (tu: partyjna odznaka) metonimicznie mówią o ludziach, zdarzeniach, ideach ${ }^{10}$. Jak we wcześniejszych, alegorycznych filmach Langa, „objawienie" prowadzi do "konwersji” - dość ironicznie konstatuje Gunning ${ }^{11}$. Potwierdza to pointa opowieści w książce Kracauera: „«Tego dnia - dodał Lang - stałem się pełnoletni politycznie»"12. W anegdocie tej widać podobną strategię, jak w omówionym poprzednio „wyobrażonym filmie” - rzutowania swej obecnej, demokratycznej i antynazistowskiej świadomości politycznej wstecz, w moment sprzed opuszczenia Niemiec, i tym samym ideowego ujednoznacznienia wcale niejednoznacznych poczynań i dzieł z niemieckiego okresu swego życia.

Anton Kaes w swej świetnej monografii $M$ - chociaż sam jest nieufny wobec Langa-narratora - paradoksalnie wymienia powody, dla których w okresie powstawania filmu tytuł Mörder unter uns istotnie mógł być źle rozumiany, tak właśnie, jak miał go zrozumieć dyrektor atelier w Staaken. „Kiedy Lang filmował M w studio Staaken pod Berlinem (byłym hangarze zeppelinów z lat I wojny światowej) od połowy stycznia do końca lutego 1931 r., stolica Niemiec stała się miejscem dzikich strajków, masowych demonstracji i ulicznych walk. M [...] chwyta rozgorączkowaną i wybuchową atmosferę Niemiec na dwa lata przed dojściem Hitlera do władzy. [...] Żądne linczu tłumy i zbrojne bojówki otwarcie polowały na ludzi, zastraszając politycznych przeciwników i szerząc terror wśród ludności. Gazety co dnia pełne były sprawozdań o gwałtownych, często powodujących śmiertelne ofiary, starciach i atakach. Współczesna, nagłośniona w mediach sprawa sądowa przeciwko członkom SA (Oddziałów Szturmowych, czyli «brunatnych koszul») rzuciła cień na realizację $M$, a jej kulminacją był proces, który niósł echa parodystycznego procesu, ukazanego w fil-

${ }^{9}$ A. Kaes, op. cit., s. 16.

10 Por.: Tom Gunning, The Films of Fritz Lang: Allegories of Vision and Modernity, BFI Publishing, London 2000, s. 198-199. Jeśli chodzi o ten nowy, metonimiczno-przedmiotowy styl, pojawił się on już w ostanich dwóch niemych filmach Langa - Szpiegach i Kobiecie na Księżycu.

11 T. Gunning, op. cit., s. 199.

12 S. Kracauer, op. cit., s. 186. 
mie Langa"13. Świadkiem w tym procesie - o zabójstwo przez bojówkarzy SA członka partii komunistycznej - był sam Hitler, który zresztą kategorycznie zaprzeczył, by partia narodowosocjalistyczna dopuszczała się morderstw politycznych. Tydzień po premierze filmu Langa sprawa zakończyła się wydaniem łagodnych wyroków dla morderców... ${ }^{14}$

Lang, owszem, zamierzał zrealizować film, który można by traktować jako Zeitspiegel, zwierciadło epoki, ale nie chodziło mu bynajmniej o polityczne wrzenie u schyłku Republiki Weimarskiej. Miał to być film z genre'u, który Amerykanie nazywają topical film, film podejmujący temat z pierwszych stron gazet [do topical films należały słynne filmy gangsterskie z początku lat 30:: Mały Cezar (Little Caesar, 1931) Melvyna LeRoya, Wróg publiczny (The Public Enemy, 1931) Williama Wellmanna czy Człowiek z blizna (Scarface, 1932) Howarda Hawksa; a także pierwszy amerykański film Langa - Jestem niewinny (Fury, 1936)]. M - morderca z pewnością ma charakterystyczne atrybuty tego genre'u. Wybrany temat był rzeczywiście z pierwszych stron gazet i niesłychanie aktualny - sprawa „wampira z Düsseldorfu”, seryjnego mordercy, Petera Kürtena, terroryzującego Düsseldorf i okolice między lutym 1929 a 24 maja 1930, kiedy to został ujęty. O niesłychanej aktualności projektu Langa świadczy fakt, iż intensywne psychiatryczne i sądowe badania Kürtena - będące zresztą przedmiotem wielkiego zainteresowania prasy i opinii publicznej - miały miejsce od października 1930 do końca stycznia 1931 r., czyli toczyły się równolegle z własnymi przygotowaniami Langa do filmu. Przede wszystkim dzięki przyznaniu się Kürtena do winy i jego wylewności w zeznaniach proces trwał tylko dziesięć dni, od 13 do 22 kwietnia 1931 i zakończył się skazaniem go na karę śmierci za dziewięć morderstw i siedmiokrotną próbę morderstwa (liczba nieudokumentowanych zbrodni, do których się przyznał, była znacznie wyższa). Gdy Lang przedłożył do oceny film urzędowi cenzorskiemu, Filmprüfstelle, w dniu 27 kwietnia 1931, było to zaledwie pięć dni po ogłoszeniu wyroku. Egzekucja Kürtena (poprzez zgilotynowanie) odbyła się w kolońskim więzieniu 2 lipca 1931, niespełna 2 miesiące po premierze filmu (11 maja) ${ }^{15}$.

13 A. Kaes, op. cit., s. 15.

14 Ibidem, s. 15-16.

15 Paralelność w czasie sprawy Kürtena i przygotowań/realizacji/premiery filmu Langa wskazuje A. Kaes w swej monografii filmu $M$ (op. cit., s. 30). Kaes nie poświęca jednak zbyt wiele miejsca samemu „wampirowi z Düsseldorfu”, w dodatku źle datując jego egzekucję (na sierpień 1931). Wiele informacji o samym Kürtenie - a także o innych wzmiankowanych w niniejszym tekście seryjnych mordercach z okresu Republiki Weimarskiej: Grossmannie, Denkem, Haarmannie - można znaleźć na zupełnie rzetelnie zredagowanych i dobrze udokumentowanych stronach internetowych; są one zbyt liczne, by je tu wymieniać (czy zainteresowanie nimi to nie signum temporis także naszej epoki, jak 
Trudno jednak uznać M za "der Kürten-Film”, jak z powodu tej symultaniczności jego realizacji i sprawy „wampira z Düsseldorfu” traktowała go prasa i opinia publiczna. Wbrew temu, co Lang miał powiedzieć dyrektorowi atelier w Staaken i wbrew wizerunkowi Hansa Beckerta, fikcyjnego mordercy z filmu Langa, Kürten nie był wyłącznie dzieciobójcą - jego ofiarami były zarówno dzieci, jak i osoby dorosłe obojga płci. Choć sprawa Kürtena była niewątpliwie bezpośrednim impulsem dla pomysłu Langa i scenariusza Thei von Harbou, jednak jego źródeł należy dopatrywać się także w innych ponurych pierwowzorach, których czyny zaszokowały niemiecką opinię publiczną, oraz w ogólnym klimacie kulturalnym Republiki Weimarskiej. Częstym tematem podejmowanym wówczas z jakąś dwuznaczną fascynacją przez literaturę, teatr, malarstwo i kino byli seryjni mordercy i Lustmord, czyli zbrodnia na tle seksualnym.

Sam Lang - w wywiadzie udzielonym Gero Gandertowi - tak mówił o swych inspiracjach: „Kto uczciwie może powiedzieć, jak dochodzi do tematu? Co miało na niego wpływ? Mógł to być liść spadający z drzewa jesienia, nagłe ustanie wiatru, nagła burza... Kiedy już zawierzę tematowi - «jestem przez niego opętany» - dobrze się do niego przygotowuję. Chcę wiedzieć, ile tylko się da, o każdej znaczącej rzeczy (nic nie jest nieznaczące), aż do najdrobniejszego szczegółu. I skoro w czasie, kiedy już zdecydowałem się na temat $M$, tak liczni seryjni mordercy popełnili już swe odrażające czyny - Haarmann, Grossmann, Kürten, Denke - musiałem oczywiście zadać sobie pytanie: Co skłoniło tych ludzi do ich czynów? Z pewnością nie byli oni współczesnymi «modelami», jak ich pan nazywa, żaden z nich nie był mordercą dzieci. Ale gdzieś w tym czasie we Wrocławiu popełniono na dzieciach straszne zbrodnie, których sprawców nigdy nie złapano. W M przyszło mi zbadać, co skłania kogoś do tak strasznej zbrodni, jak zamordowanie dziecka, a także wytoczyć rozmaite za i przeciw karze śmierci" ${ }^{16}$.

Wymienione przez reżysera nazwiska osławionych zbrodniarzy wskazuja, iż w s e ri i s e r y jn y ch morderców, których sprawy wstrząsnęły Republiką Weimarska, Peter Kürten był numerem którymś z kolei. Pierwszeństwo należy do Georga Karla Grossmanna, rzeźnika z Berlina. On to w latach I wojny światowej i tuż po niej utrzymywał się ze sprzedaży ludzkiego mięsa [sic!]. Zamordował i poćwiartował kilkanaście, a być

u schyłku okresu weimarskiego?). Kompetentnym, acz popularnym źródłem informacji na ten posępny temat jest: Brian Lane, Wilfred Gregg, The Encyclopedia of Serial Killers, Berkley Boulevard 1995.

${ }^{16}$ Gero Gandert, Fritz Lang on "M": An Interview, transl. Barry W. K. Joe, [w:] Fritz Lang, Interviews, ed. Barry Keith Grant, University Press of Mississippi, Jackson 2003, s. 33-34 [prwdr.: Gero Gandert, Fritz Lang über „M": Ein Interview, [w:] „M": Protokoll, Red. Gero Gandert, Ulrich Gregor, Marion von Schröder Verlag, Hamburg 1963]. 
może kilkadziesiąt osób (dokładna liczba ofiar nie jest znana), głównie prostytutek. Ujęto go w sierpniu 1921 r. Śmiał się, gdy odczytano mu wyrok śmierci. Ubiegł jednak wymiar sprawiedliwości i przed wyznaczoną egzekucją sam powiesił się w celi $^{17}$.

Podobnie zakończył swe życie - powiesiwszy się w celi tuż po aresztowaniu - Karl Denke, z miasteczka Münsterberg na Dolnym Śląsku (dziś: Ziębice), ujęty 21 grudnia 1924. Odludek, ale w sumie szanowany obywatel miasta, zamordował co najmniej dwadzieścia osób (tyle ofiar zidentyfikowała policja), a prawdopodobnie dwukrotnie więcej, głównie bezdomnych, włóczęgów i podróżnych. „To, co konstable zobaczyli w jego mieszkaniu i szopie, wprawiło ich $\mathrm{w}$ przerażenie. Znaleziono bowiem liczne naczynia $\mathrm{z}$ zapeklowanym ludzkim mięsem ${ }^{18}$, aparaturę do produkcji mydła, przygotowane do obróbki kości ludzkie. Na ścianach wisiały tuziny pasków, szelek i sznurowadeł z ludzkiej skóry. Szafę zapełniały zakrwawione liczne ubrania, wśród nich jedna spódnica. Na parapecie i stole leżały różne dokumenty i kwity na nazwiska osób zwolnionych z więzień i szpitali"19.

Jeszcze potężniejszy rozgłos zyskała sprawa Fritza Haarmanna, zwanego „rzeźnikiem z Hanoweru”, oskarżonego o zamordowanie pomiędzy 1918 a 1924 r. co najmniej dwudziestu siedmiu młodych mężczyzn i chłopców - choć i w jego przypadku faktyczna liczba zabitych była prawdopodobnie znacznie większa. Podobnie jak Grossmann czy Denke, również handlował mięsem swych ofiar ${ }^{20}$. Nie ubiegł wymiaru sprawiedliwości i, tak jak Kürten, zginął na gilotynie 4 grudnia 1925. Jego sprawa zawładnęła opinią publiczną poprzez relacje prasowe z procesu, a dodatkowy rozgłos zyskała dzięki książce opublikowanej przez dziennikarza i profesora psychologii w jednej osobie, Theodora Lessinga, zatytułowanej Haarmann: Die Geschichte eines Werwolfs (Haarmann: Historia wilkołaka, 1925). Lessing zwrócił uwagę na to, iż potworne czyny Haarmanna nie wzięły się znikąd - zrodził je klimat społeczny ery kryzysu, deprecjacja życia ludzkiego wskutek masowych rzezi podczas I wojny światowej i niewłaściwy

17 Por.: A. Kaes, op. cit., s. 33; Maria Tatar, Lustmord: Sexual Murder in Weimar Germany, Princeton University Press, Princeton, NJ 1995, s. 42. Arcyciekawa książka Marii Tatar, rozważająca z perspektywy feministycznej fenomen seryjnych zbrodniarzy w okresie weimarskim i odbicie tego zjawiska w weimarskiej kulturze, niewolna jest jednak od nieścisłości - i tak np. autorka podaje mylnie imię Grossmanna („Wilhelm” zamiast „Georg Karl”).

${ }_{18} \mathrm{~W}$ dobie kryzysu lat szalejącej inflacji Denke sprzedawał je jako wieprzowinę na targach Wrocławia.

19 Tadeusz Dudź, Ziębicki kanibal, „Gazeta Wrocławska”, 30 lipca 1999. Por. także: map, Kanibal z Ziębic, "Słowo Polskie”, 2 sierpnia 1999; M. Tatar, op. cit., s. 42-44.

${ }^{20}$ Do tego przerażającego aspektu jego postaci nawiązuje piosenka zespołu T. Love Kiełbasy Haarmanna (1992). 
system karny, który pogłębił złe, psychopatyczne skłonności mordercy ${ }^{21}$. Haarmann - a później także Kürten - odsiadywali już wyroki, zanim stali się seryjnymi mordercami. Anton Kaes zwraca uwagę na fakt, iż „sprawa Haarmanna poruszyła zagadnienia, które są obecne $\mathrm{w}$ filmie Langa: pytanie o umysłową poczytalność mordercy, kompulsywny charakter zabijania, kontrowersyjność policyjnych i sądowych procedur"22.

Haarmann tak zawładnął masową wyobraźnia, iż trafił do... popularnej w Republice Weimarskiej dziecięcej wyliczanki. Film Langa rozpoczyna się wyliczanką, a można by ją przełożyć mniej więcej tak: „Strzeż się Czarnego Człowieka/Na kotlety cię posieka/Raz, dwa, trzy/ Odpadasz ty". Jak zwracają uwagę Maria Tatar i Anton Kaes, jest to w zasadzie ta sama wyliczanka, która w dziecięcej wyobraźni rozsławiła „rzeźnika z Hanoweru”, tyle tylko, że nazwisko "Haarmann” zastąpione zostało słowem "Schwarzmann” („Czarny Człowiek”) ${ }^{23}$. W Republice Federalnej Niemiec postać Haarmanna przywoływały wprost trzy filmy: Die Zärtlichkeit der Wölfe (Czułość wilków, 1973, reż. Ulli Lommel), Fritz Haarmann und Theodor Lessing - zwei deutsche Schicksale (Fritz Haarmann $i$ Theodor Lessing - dwa niemieckie losy, 1990, reż. Gisela Marx i Andreas Thiel) oraz frapujący formalnie, wstrząsający, chociaż składający się tylko z "gadających głów” Der Totmacher (Siewca śmierci, 1995, reż. Romuald Karmakar $)^{24}$.

Fascynacja kultury niemieckiej, a zwłaszcza weimarskiej i tuż przedweimarskiej, tematem zbrodni na tle seksualnym i seryjnych morderców, jest w ogóle czymś zastanawiającym i niepokojącym. Pod nożem Kuby Rozpruwacza kończy swą wędrówkę przynosząca nieszczęście mężczyznom Lulu, bohaterka słynnego pre-ekspresjonistycznego dramatu Franka Wedekinda Puszka Pandory (Die Büchse der Pandora, 1904), którego znakomita filmowa adaptacja, dokonana przez Georga Wilhelma Pabsta (1929), jest jednym z arcydzieł weimarskiego kina w okresie Neue

21 Theodor Lessing, Haarmann: The Story of a Werewolf, [w:] Monsters of Weimar, Nemesis Books, London 1993, s. 11-156.

${ }^{22}$ A. Kaes, op. cit., s. 34. Kontrowersyjne procedury, jak wskazuje Kaes, to np. paragraf 51, umożliwiający umieszczenie niepoczytalnego umysłowo zabójcy w szpitalu psychiatrycznym, skąd może wyjść na wolność, by powrócić na drogę zbrodni (tak zresztą stało się w przypadku Haarmanna). Tłum przestępców w $M-$ mordercy w podziemnym procesie wytoczonym Hansowi Beckertowi szydzi z paragrafu 51, żądając śmierci dla seryjnego dzieciobójcy. To stanowisko zdaje się podzielać William Friedkin, twórca szokującego i dającego do myślenia thrillera Rampage (Szaleństwo, 1987).

23 Por.: M. Tatar, op. cit., s. 5; A. Kaes, op. cit., s. 9-10.

${ }^{24}$ Film ten przedstawia serię przesłuchań Haarmanna (w tej roli rewelacyjny Götz George) przez sądowego biegłego, prof. dr. Ernsta Schultze. Pod tytułem Rzeźnik pokazano go w latach 90. w I programie TVP. 
Sachlichkeit. Mizoginiczny zabójca to bohater uchodzącej za pierwszy dramat ekspresjonistyczny sztuki Oskara Kokoschki, prowokacyjnie zatytułowanej Morderca, nadzieja kobiet (Mörder, Hoffnung der Frauen, 1909). Maria Tatar analizuje wnikliwie - choć jej interpretację chyba trochę za bardzo ustawia perspektywa feministyczna - motywy sadystycznego mizoginizmu i zbrodni na tle seksualnym w szokujących obrazach i rysunkach Ottona Dixa i Georga Grosza, a także w powieści Alfreda Döblina Berlin Alexanderplatz (1929), czyli w dziełach artystów dla Neue Sachlichkeit wręcz modelowych ${ }^{25}$. Moosbrugger, seryjny morderca, to jedna z głównych postaci monumentalnej powieści Roberta Musila Człowiek bez właściwości (Der Mann ohne Eigenschaften), której pierwszy tom został opublikowany w roku 1930. Jest to wprawdzie dzieło kultury austriackiej, ale z racji tego samego kręgu językowego i rangi artystycznej, będące też wydarzeniem w Republice Weimarskiej. No i wreszcie temat seryjnego mordercy pojawia się w dziełach inaugurujących i zamykających filmowy ekspresjonizm $^{26}$ - Gabinecie doktora Caligari (Das Cabinet des Dr. Caligari, 1919, reż. Robert Wiene) i Gabinecie figur woskowych (Das Wachsfigurenkabinett, 1924, reż. Paul Leni). Ten ostatni film jest szczególnie interesujący, gdyż paradygmatyczny seryjny morderca - Kuba Rozpruwacz - nie jest osadzony, jak bohaterowie dwóch nowel tego filmu, Harun-al-Raszyd i Iwan Groźny, wewnątrz fikcyjnych opowieści wyraźnie odgrodzonych od „prawdziwej” rzeczywistości, zawartej w otaczającej owe opowieści ramie narracyjnej. Wskutek tego odgraniczenia tamte historie nie emanują jakoś szczególnie groza, wydają się jakoś zneutralizowane, czy jawią się wręcz jako parodia „opowieści z dreszczykiem”. Granica filmowego segmentu z Kubą Rozpruwaczem jest natomiast zatarta, przez co koszmarna rzeczywistość z jego udziałem (gdy ściga parę młodych ludzi w ekspresjonistycznej scenerii wesołego miasteczka) jawi się jako przedłużenie „prawdziwej rzeczywistości" z ramy narracyjnej. Segment z Kubą Rozpruwaczem nie ma, w przeciwieństwie do dwóch pierwszych nowel, jakiejś wyraźnej linii fabularnej, przypominając raczej swą luźną strukturą koszmarny sen, którym ostatecznie szczęśliwie się okazuje. Ale dwuznaczne wrażenie Mörder ist unter uns - pozostaje.

W takim kontekście, tak jak Kürten jawi się jako kolejny przypadek ponurej serii seryjnych morderców, der Kürten-Film, czyli M Langa, jest kolejnym, choć zapewne najsławniejszym i artystycznie najwybitniejszym

${ }^{25}$ M. Tatar, op. cit., s. 67-152.

${ }^{26}$ Jeżeli rozumieć ekspresjonizm - tak jak Barry Salt - bardzo wąsko, sprowadzając go do kilku filmów, reprezentujących „kino malarzy-scenografów”, powstałych między rokiem 1919 a 1924 (zob.: Barry Salt, From Caligari to Who?, „Sight and Sound”, Spring 1992, vol. 48 , no. 2, s. 119-123). 
utworem w serii dzieł Republiki Weimarskiej, dwuznacznie zafascynowanej tym mrocznym tematem. W samym filmie znajduje wyraz jego samoświadomość swego dwuznacznego statusu w kulturze, w której seryjne zbrodnie stają się bodźcem do serializacji sensacji na ich temat ${ }^{27}$. Frau Beckmann, która w pierwszej sekwencji filmu na próżno oczekuje powrotu swej córki ze szkoły (wiemy już, iż małej Elsie zastąpił drogę Hans Beckert, jej morderca), na głos dzwonka otwiera z nadzieją drzwi. Stoi w nich jednak nie córka, lecz znajomy listonosz, Herr Gehrke. Przynosi jej... nowy odcinek sensacyjnej powieści w odcinkach, tak go zachwalając: „przerażający, trzymający w napięciu, sensacyjny”. Jak na ironię (bardzo gorzką ironię), matka Elsie, wręczająca listonoszowi zapłatę za kolejną dawkę sensacji, jakie pochłania, sama stanie się niedługo, jako matka ofiary seryjnego dzieciobójcy, bohaterką sensacji, dawkowanej w odcinkach na pierwszych stronach gazet. Druga sekwencja filmu rozpoczyna się od ujęć ulicy pogrążonej w ciszy, którą nagle rozdziera krzyk gazeciarza: „Extraausgabe!” („Dodatek nadzwyczajny!”). Łapczywie sięgają po niego rozgorączkowani przechodnie. Specjalne wydanie przynosi wiadomość o śmierci Elsie Beckmann, kolejnej ofiary mordercy, który zawładnął wyobraźnią zbiorowości.

\section{Społeczeństwo masowe}

Noël Burch w swej znakomitej tekstualnej analizie filmu Langa dzieli go na dziewięć segmentów powiązanych tematycznie, choć bardzo zróżnicowanych formalnie, o charakterze zbliżającym się bądź to do rozbudowanych, zwartych scen (segment 7: $M$ schwytany w pułapkę i segment 9: Proces), bądź dynamicznych sekwencji montażowych (segment 2: Strach ogarnia miasto i segment 3: Nieskuteczność procedur policyjnych), bądź mieszanym, przeplatającym krótkie lub trochę bardziej rozbudowane sceny w montażu symultanicznym (segment 1: Morderstwo Elsie Beckmann, segmenty 4-6: Równoległe poszukiwania mordercy przez policję i świat podziemia oraz segment 8: Policja wpada na ślad $M)^{28}$. Progresja filmu - gdy wokół Hansa Beckerta coraz bardziej zacieśniają się kręgi równoległych poszukiwań policji i przestępców - polega na klaustrofobicznym zacieśnianiu przestrzeni (biurowiec, w którym przestępcy znajdują Beckerta, a zwłaszcza

${ }^{27}$ Na temat serializacji sensacji w kulturze weimarskiej zob.: A. Kaes, op. cit., s. 26-38.

28 Por.: Noël Burch, Fritz Lang: German Period, transl. Tom Milne, [w:] Cinema: A Critical Dictionary. The Major Film-Makers, ed. Richard Roud, vol. 2: Kinugasa to Zanussi, Martin Secker \& Warburg Ltd., London 1980, s. 593-599. Pozwoliłem sobie tu na pewne prezentacyjne uproszczenie poprzez skondensowanie segmentacji Burcha i trochę inne nagłówki poszczególnych segmentów. 
zagracone poddasze, gdzie się ukrył; piwnice zrujnowanej wytwórni alkoholu, w którym świat podziemia odbywa nad nim sąd), a zarazem na coraz większym „rozciąganiu” czasowym scen, przez co spada tempo filmu, zawrotne szczególnie w segmentach 2-6. Segmenty 2-6 obrazują gwałtowność tempa zdarzeń i obiegu informacji w społeczeństwie masowym.

W społeczeństwie masowym istotną rolę odgrywają media. Lang już w swych wcześniejszych filmach poruszał temat mediów, a ściślej mówiąc, technicznych możliwości inwigilacji i kontroli obiegu informacji, dzięki którym można uzyskać potężną władzę nad społeczeństwem. „Medialna pajęczyna" - jeden z fabularnych aspektów w Doktorze Mabuse, graczu (Dr. Mabuse, der Spieler, 1922), Metropolis (1926) i Kobiecie na Księżycu (Frau im Mond, 1929) - jest centralnym tematem znakomitych Szpiegów (Spione, 1928). W M - mordercy media: generują zbiorową psychozę, kumulującą się w mechanizmie "kozła ofiarnego"; kreują "jaźń odzwierciedloną" seryjnego zabójcy; umożliwiają inwentaryzację, porównywanie i szybki przepływ danych, dając władzy narzędzia kontrolne.

Przyjrzyjmy się segmentowi 2: Strach ogarnia miasto. Ujęcie kamerą z wysoka pokazuje ulicę, gdzie wokół gazeciarza reklamującego wydanie nadzwyczajne zgromadził się tłum ciekawskich. „Wer ist der Mörder?” „Kim jest morderca?" - woła gazeciarz, a wszechwiedząca narracja filmu od razu udziela odpowiedzi wid zow i (ale też tylko jemu), ukazując Beckerta, jak przy parapecie w swym mieszkaniu pisze list do gazety. Po niej następuje ujęcie ulicznego afisza z napisem: „10 $000 \mathrm{Mk}$ Belohnung. Wer ist der Mörder?". Z pytaniem wracającym w mieście i w filmie jak refren powiązana jest informacja o 10 tysiącach marek nagrody za wskazanie sprawcy. Przed afiszem zgromadził się spory tłum. Ci z końca żądaja, by czytać na głos tekst. Kamera oddala się od słupa ogłoszeniowego, ukazując nam rozmiar tłumu, a w ścieżce dźwiękowej słyszymy czytany podniesionym głosem tekst. Czytający jest niezlokalizowany, bo kamera oddaliła się tak, że tłum zasłania nam to, co dzieje się bezpośrednio wokół słupa, ale mamy wrażenie, iż to „ktoś z przodu” czyta obwieszczenie. Przekonanie to jest jednak mylne. „Cięcie do wnętrza baru, gdzie jakiś starszy mężczyzna czyta na głos zgromadzonym przy stoliku z piwem pięciu kompanom tekst z gazety. To jego głos słyszeliśmy. Głos ten, wpierw pozbawiony ciała, łatwo mógł pochodzić z radia, przenosząc wiadomości wszędzie, nie zważając na granice pomiędzy wnętrzem a zewnętrzem, sferą publiczną a prywatną. Gdy miejsca się zmieniaja, dźwięk jest ciągły, łącząc rozmaite przestrzenie i ustanawiając miasto jako złożoną całość, zjednoczoną nieprzerwanym przepływem informacji" ${ }^{29}$. Informacje te przekazuje zarówno prasa, plakaty na mieście, jak i trochę podświadomie sugerowane tu

${ }^{29}$ A. Kaes, op. cit., s. 39. 
radio, być może najważniejsze medium $\mathrm{w}$ Niemczech początku lat trzydziestych XX w. ${ }^{30}$

Co nam mówi ten „intermedialny” tekst? Stawia pytania i sugeruje, wytwarzając zbiorową psychozę. "Jak wygląda morderca? Gdzie się ukrywa? Nie wiadomo. A jednak jest on jednym z nas. Twój sąsiad może być mordercą". Skutki takiego przekazu obrazuje dalszy ciąg segmentu 2. Jeden $z$ mężczyzn $w$ barze podejrzliwie patrzy na drugiego i rzuca nań oskarżenie, że to pewnie on, skoro ugania się za małymi dziewczynkami. Posądzony woła „oszczerca!", a słowo to służy jako most dźwiękowy do następnej scenki. W niej policjant (jak się dalej okazuje, podwładny komisarza Lohmanna z Wydziału Zabójstw) usprawiedliwia się przed człowiekiem, w którego mieszkaniu przeprowadził rewizję, naprowadzony obywatelskim donosem („oszczerstwem”, stwierdza pomówiony): „Policja musi badać każdy ślad... Każdy na ulicy [...] może być winnym”. To stwierdzenie przenosi nas - na zasadzie kolejnego dźwiękowego mostu - na ulicę, gdzie podniecony tłum dwukrotnie jest o krok od samosądu. Za pierwszym razem - czyniąc oskarżycielską wrzawę wokół niepozornego starszego pana, którego dziewczynka na hulajnodze zapytała o godzinę, a ten nieopatrznie, prócz udzielenia jej odpowiedzi, zapytał ją z troską gdzie mieszka. Za drugim razem - rzuciwszy się na złodzieja kieszonkowego, którego eskortował policjant wezwany dla zatrzymania rzekomego "mordercy”. Złodziej broni się, krzycząc, iż zamiast zajmować się zatrzymywaniem takich płotek jak on, policja raczej powinna się zabrać za poszukiwania mordercy dzieci (Kindermörder). Tłum, podchwyciwszy ostatnie słowo i myśląc, że to pod takim właśnie zarzutem został zatrzymany złodziej, rzuca się na niego...

Wydarzenia segmentu 2 obrazują narodziny zbiorowej psychozy strachu, histerii podsycanej dodatkowo przez media, ujawniającej się we wzajemnej podejrzliwości, która, gdyby nie tragizm wydarzeń, jakie do niej doprowadziły (i potencjalny tragizm wydarzeń, które mogą być jej rezultatem), mogłaby się wydawać nawet zabawna (scenki w barze i ze starszym panem mają charakter komediowy, a raczej - tragikomiczny). Psychoza ta unaocznia, iż przedstawione społeczeństwo - jeśli zastosować tu kategorie proponowane przez René Girarda ${ }^{31}$ - znajduje się w stanie

30 Sugestia zapośredniczenia głosu przez radio jest tak silna w tej sekwencji - choć faktycznie nie ma tu transmisji radiowej - iż nawet tak wytrawny analityk, jak Burch, mylnie je wskazuje (N. Burch, op. cit., s. 595). Kaes słusznie uważa, iż to tylko sugestia, podczas gdy Gunning tłumaczy się, iż mimo usilnego wsłuchiwania się nie mógł doszukać się zapośredniczenia głosu przez radio, wskazywanego przez Burcha i innych autorów (T. Gunning, op. cit., s. 176).

31 Po polsku ukazało się już sporo prac Girarda, ale nadal najlepszym wprowadzeniem do jego koncepcji „przemocy mimetycznej” i mechanizmu „kozła ofiarnego” 
„kryzysu niezróżnicowania”, będącego zachwianiem Kolejności, hierarchii wartości, stabilnych odniesień moralnych i poznawczych. Seryjny zbrodniarz jest tylko jednym z przejawów tego kryzysu, który - jak się wydaje - może zostać przezwyciężony jedynie przez znalezienie „winnego" (stosuję tu cudzysłów, gdyż w odniesieniu do społecznego kryzysu aksjologicznego, wina faktycznego mordercy jest jedynie „metonimiczna” czy też "synekdochiczna"). Stąd - gdy nie ma prawdziwego winowajcy - zachodzi mechanizm czynienia z podejrzanych "kozła ofiarnego", jednoczącego społeczność w realnej i symbolicznej przemocy poprzez przywrócenie „sprawiedliwości”. Uliczny lincz ma charakter sądu ad hoc, dlatego zaciera się nieco jego rytualno-prawny charakter, a zaznacza przede wszystkim przemoc. Nieprzypadkowo też świat przestępczy, złapawszy Beckerta, inscenizuje proces. Nadaje to zamierzonej z góry egzekucji „kozła ofiarnego" formę rytualnego zjednoczenia społeczności i - pozorne, nie faktyczne - przezwyciężenie stanu zamętu i chaosu przez wskazanie i usunięci e zła ${ }^{32}$.

Lang do tematu zbiorowej psychozy i realizacji mechanizmu „kozła ofiarnego" poprzez lincz powróci w swym pierwszym amerykańskim filmie Jestem niewinny (Fury). Powód tej paniki jest podobny jak w $M-$ prasowe doniesienia o kidnapingu (prawdziwej amerykańskiej pladze początku lat 30.) i skojarzenia przez małomiasteczkową społeczność zaginięcia dziewczynki z obecnością obcego. Pierwszy amerykański film Langa - prawdziwe arcydzieło gatunku topical film - pokazuje, iż nawet pozornie stabilne, $\mathrm{w}$ pełni demokratyczne społeczeństwo, jest podatne na opisane przez Girarda mechanizmy mimetycznej przemocy - zwłaszcza, jeśli podsycają je media ${ }^{33}$.

W mediach odnajduje swą „jaźń odzwierciedloną" sam morderca. Pisze do prasy list, żądając jego publikacji, a gazeta nie tylko zamieszcza go na pierwszej stronie, ale reprodukuje jego faksymile. Ten szczegół nie

u podłoża rozmaitych kultur, wydaje mi się monograficzny numer „Literatury na Świecie” (1983, nr 12), a zwłaszcza zamieszczone tam obszerne fragmenty jednego z jego głównych dzieł - Rzeczy ukryte od założenia świata (w przekładzie Mirosławy Goszczyńskiej).

32 Czy nie ten sam (Girardowski, w gruncie rzeczy) mechanizm nie zadziałał np. w nazistowskim prześladowaniu Żydów? Przyczyn w przyzwoleniu Niemców na ich masową eliminację Elias Canetti, w sugestywnym wywodzie, upatruje w obciążeniu Żydów za hiperinflację z początku lat 20., której rezultatem była katastrofa wszelkich wartości - nie tylko ekonomicznych. Por.: Elias Canetti, Masa $i$ wtadza, przeł. Eliza Borg, Maria Przybyłowska, Czytelnik, Warszawa 1996, s. 212-214.

33 Znakomitą analizę Fury przedstawia Elżbieta Durys w artykule Zjednoczenie społeczności w milczeniu o zbrodni: "Jestem niewinny" Fritza Langa, [w:] Lustra i krzywe zwierciadła: społeczne konteksty kina i telewizji, red. Konrad Klejsa, Grzegorz Skonieczko, Rabid, Kraków 2002, s. 23-33. 
jest pomysłem scenariusza Langa i Thei von Harbou, ale jednym $\mathrm{z}$ wymownych faktów w sprawie „wampira z Düsseldorfu”. „Kürten napisał do policji anonimowy list, szczegółowo określając, gdzie pochował jedną ze swych ofiar. Kiedy policja zignorowała list, 14 listopada 1929 wysłał jego kopię do komunistycznej gazety Mittag, która opublikowała faksymile. Zreprodukowany we wszystkich głównych gazetach Niemiec, spowodował dalszą panikę i zalew fałszywych listów od ludzi, którzy twierdzili, iż są mordercami" ${ }^{34}$.

Z jednej strony zatem, morderca „zapośrednicza” swe zbrodnie poprzez informacje o nich w środkach przekazu, co alienuje odeń i „obiektywizuje" sprawcę, zapewniając mu sławę (gdy on sam pozostaje anonimowy) i umożliwiając przy lekturze prasy czy obwieszczeń delektowanie się nią. Beckert spotyka Elsie Beckmann przy słupie z ogłoszeniami, na którym widniał afisz informujący o jego zbrodniach i o 10 tys. marek nagrody za wskazanie mordercy. Jak sam później przyznaje przed podziemnym "sądem”, czytał takie obwieszczenia pełen jednak niewiary i zdumienia, że on sam wszystko to rzeczywiście popełnił. A w tej niewierze i zdumieniu przerażenie własnymi czynami i duma ze swej sławy musiały się niejasno ze sobą mieszać w jakiejś przerażającej dialektyce.

Z drugiej strony, „jaźni odzwierciedlonej” w prasie, jego sławy, zazdroszczą mordercy jego naśladowcy. Nie jego czynów (na szczęście) ale listów i wyznań. Około dwieście osób przypisywało sobie zbrodnie Kürtena, przyznając się do niepopełnionych win, dzwoniąc i pisząc do prasy czy na policję. Jeden z tych rzekomych sprawców, niejaki Johann Stausberg, był nawet sądzony w sierpniu 1929, ale rychło okazało się, że to psychicznie chory mitoman ${ }^{35}$. Zaginiona dziś sekwencja filmu Langa, której scenariusz w monografii filmu wydanej przez BFI, opublikowany został na podstawie tzw. Zensurkarten (zapisów cenzury, której przedstawiano film do aprobaty), ukazuje kłopot komisarza Lohmanna z rozmaitymi rzekomymi sprawcami dzwoniącymi na berlińską policję, a to z Hamburga, a to z Drezna, i kierującymi się najdziwniejszymi motywami - „sprawca” z Drezna chciał, by policja zafundowała mu bilet do Berlina ${ }^{36}$. Zresztą efemeryczną sławę z pierwszych stron gazet zdobyć chcieli nie tylko "sprawcy”, ale i rzekomi ",świadkowie”. Kaes wspomina o 12 tys. rozmaitych wskazówek, śladów czy poszlak, wskazywanych policji i prasie przez opinię publiczną w sprawie Kürtena ${ }^{37}$. Na podobny nadmiar fałszywych tropów skarży się w 3 segmencie filmu Langa komendant główny

\footnotetext{
${ }^{34}$ A. Kaes, op. cit., s. 31.

35 Por.: ibidem, s. 31-32.

${ }^{36}$ Opublikowany scenariusz zaginionej sceny w: A. Kaes, op. cit., s. 82.

37 Ibidem, s. 32.
} 
policji w rozmowie z ministrem spraw wewnętrznych. Jeden z przykładów, które podaje, a które narracja filmu unaocznia nam w rozbudowanej scence, to zeznanie nr 1478 w sprawie Elsie Beckmann. Dwóch świadków zażarcie kłóci się o kolor czapki, w której ofiara feralnego dnia wracała ze szkoły. "Czerwona" - twierdzi stanowczo jeden świadek, „zielona” upiera się drugi. Ironia sytuacji polega na tym, iż - jak to dobrze pamięta widz - Elsie feralnego dnia nie miała żadnego nakrycia głowy.

Media i technika, choć mogą policji dezorganizować pracę, dają zarazem narzędzia kontroli społecznej czy inwigilacji. System alarmowy w biurowcu, sprzężony z policyjnym rejestratorem i gigantyczną kartoteka, umożliwia policji dotarcie do biurowca, w którym osaczono Beckerta na tyle szybko, by nie wszyscy uczestniczący w akcji przestępcy zdążyli się ewakuować. Prawdziwą rewolucję w ustalaniu tożsamości wniosła stosunkowo niedawno wprowadzona w Niemczech daktyloskopia - policjant na tle rzutowanego na ekran ogromnego obrazu odcisku palca to jeden z najsłynniejszych i emblematycznych kadrów tego filmu. Policja dysponuje ogromnymi archiwami, kartotekami, bazami danych, na podstawie których nie jest co prawda w stanie wskazać sprawców konkretnego przestępstwa, ale znacznie zacieśnić krąg podejrzanych. Komisarz Lohmann, słusznie rozumując, iż sprawca tak drastycznych zbrodni, jak dzieciobójstwa musiał mieć już w jakiś sposób do czynienia z prawem czy instytucjami dla osób psychicznie chorych, każe swym pracownikom przeszukać odpowiednie archiwa. Taką drogą „dedukcyjną" znacznie zawęża zakres możliwych sprawców i dzięki niej wpada na trop Beckerta w zasadzie równocześnie ze ścigającymi go przestępcami (chociaż ci zdołają go jednak ubiec w fizycznym ujęciu mordercy). Archiwa i kartoteki - wspomagane coraz to doskonalszą techniką - osaczają społeczeństwo masowe ogromnymi zbiorami informacji. W takim świecie człowiek zatraca swą podmiotowość, fizyczność, staje się numerem w aktach, przypadkiem, adresem, przedmiotem, który po nim pozostał, jeśli zginął lub zostawił ślad, które metonimicznie określają jego tożsamość. Ciekawe zreszta, iż świat przestępców posługuje się w zasadzie takimi samymi metodami, jak legalne państwo - prowadząc kartoteki, inwentaryzując łupy we własnych ",archiwach" i wykorzystując coraz to doskonalszą technikę. Organizacja żebraków, prowadząc "giełdę" produktów żywnościowych, naśladuje jedną z najważniejszych legalnych instytucji ekonomicznych. Ten akurat aspekt chyba nie jest zbyt serio i wydaje się parodią zarówno sceny giełdy z własnego filmu Langa sprzed 9 lat Doktor Mabuse, gracz (1922), jak i Brechtowskiej Opery za trzy grosze (Die Dreigroschenoper, 1928), która zresztą wyraźnie inspirowała Langa w zobrazowaniu przestępczego „alternatywnego państwa”.

„Odpersonalizowanie” człowieka w społeczeństwie masowym odzwierciedla się w metonimiczno-przedmiotowym stylu narracji niektórych 
sekwencji tego filmu, w których przedmioty i miejsca wydają się trwać bez ludzi. Puste nakrycie przy stole w jej domu, pusta otchłań klatki schodowej kamienicy, w której mieszkała, pusty strych, na którym suszy się jej bielizna, są - w dziwnych, irytująco statycznych ujęciach - oznaką nieobecności Elsie Beckmann. Podobnie zresztą jak jej tocząca się w krzaki piłka i zaplątany w przewody telefoniczne, kupiony jej przez Beckerta, balonik odlatujący w końcu gdzieś ku niebu, metonimicznie (czy też synekdochicznie) mówią o jej śmierci. Gdy Lohmann czyta raport o włamaniu do biurowca, podsunięty mu przez komisarza Gröbera, jego ponadkadrowemu głosowi (voice over) towarzyszą statyczne obrazy pokazujące rozmaite miejsca tego budynku po akcji przestępców, bez żadnych ludzi w kadrze - unaoczniają tylko dziwaczne skutki włamania, np. przewiercony sufit i nienaruszony sejf ${ }^{38}$. Również morderca zostawia przedmiotowe ślady - metonimie jego związku ze zbrodnią: pudełko po papierosach Ariston, ślad czerwonej kredki, którą pisał list do prasy, zadrapania na drewnianym parapecie. Metonimią jego osoby i związku z zamordowaną jest gwizdany przezeń motyw muzyczny $W$ grocie Króla Gór ze suity Edvarda Griega Peer Gynt, który zdradzi go przed niewidomym sprzedawcą baloników dobrze pamiętającym dzień śmierci Elsie.

\section{"M"}

Co właściwie oznacza ten enigmatyczny znak? „Zdefiniowanie” litery "M" w polskim tytule zubaża ją semantycznie, podczas gdy, jak wskazuje Anton Kaes, ,jest to signifiant z licznymi możliwymi znaczeniami: Mörder (morderca), Mensch (człowiek), Mutter (matka), Mann (mężczyzna), Mabuse, Metropolis. Znak kondensuje poprzednie znaczenia i stygmatyzuje Beckerta w naszych oczach"39. Ale, oczywiście, „M" to p r z e d e w s zy stki m "morderca”. Wiemy o nim niewiele, choć w sumie dość szybko poznajemy tożsamość człowieka, który terroryzuje czteromilionowe miasto. Nie ma tu zatem zagadki tożsamości mordercy, jak w kryminałach bardziej tradycyjnych. Doprawdy, pod względem atrakcyjności dramaturgicznej dla odbiorców sensacji „standardowej” film Langa to kryminał „za trzy grosze”. Pomimo tego, że nie ma zagadki tożsamości,

${ }^{38} \mathrm{~W}$ podobnej stylistyce, w zupełnie odantropomorfizowanych ujęciach samych rzeczy i miejsc, które metonimicznie mówiły o zdarzeniu, została zrealizowana sekwencja opowieści Heliusa o kradzieży rękopisu Manfeldta w Kobiecie na Księżycu.

39 A. Kaes, op. cit., s. 63. Jak Kaes i Eric Rentschler zauważają w rozmowie, służącej jako audiokomentarz w edycji filmu Langa dla Criterion Collection (2004), dla tytułu filmu inspiracją mogło być nazywanie Wydziału Zabójstw berlińskiej policji, powołanego w 1926 przez komisarza Ernsta Gennata, M-Division. 
Beckert pozostaje niedookreślony. Rozbudowana scena finałowa, w której ma on głos przed sądem podziemia, mówiąc o swej wewnętrznej udręce i o przymusie zabijania, tak naprawdę nic nam nie mówi o przyczynach jego potwornych czynów, nie daje żadnej wykładni jego choroby psychicznej. Wiemy tylko, że został zwolniony z kliniki psychiatrycznej, a przestępcy chcą go zgładzić z obawy, by wyrokiem legalnego sądu, na mocy paragrafu 51, ponownie tam nie trafił.

Beckert, choć bardzo szybko zostaje „dany” w sjużecie widzowi, to bardzo długo pozostaje niedookreślony fizycznie - niczym istny "człowiek bez właściwości". Podczas jego pierwszego pojawienia się w filmie, gdy spotyka na swej drodze Elsie Beckmann, widzimy tylko jego demoniczny cień rzucony na afisz informujący o jego zbrodniach i słyszymy dobiegający spoza kadru jego wysoki, mało męski głos, którym mówi do Elsie: "Jaką śliczną masz piłeczkę. Jak się nazywasz?". Kiedy kupuje Elsie balonik, jest odwrócony plecami do kamery. W kolejnym jego pojawieniu się (w segmencie 2) kamera pokazuje go znad pleców, piszącego przy parapecie list do gazety. Chociaż nie za bardzo jeszcze wiemy, jak wygląda, nie mamy wątpliwości, że to on. Znakiem rozpoznawczym jest melodia Griega, którą gwiżdże i którą gwizdał, kupując ofierze balonik, sama treść listu i miejsce w strukturze filmu - usytuowaniem tej sceny wszechwiedząca narracja odpowiada na pytanie gazeciarza: „Wer ist der Mörder?”. Jego trzecim „wejściem” w sjużecie (w segmencie 3) narracja zdaje się potwierdzać ekspertyzę grafologa, iż charakter pisma „świadczy o patologicznej seksualności, objawiającej się na zewnątrz jako indolencja, czy nawet letargia, a przedstawiona próbka pisma zdradza nieomylne objawy szaleństwa". Beckert, jakby chcąc potwierdzić tę diagnozę, niesłyszaną przecież przez niego, stroi do lustra dziwne, przerażające miny, a wygląd jego twarzy, choć widzianej teraz przez widza w pełni swej dziwności i brzydoty, jest zapośredniczony przez lustrzane odbicie. Wreszcie w segmencie 5 ledwo zauważamy, jak Beckert opuszcza kadr po wyjściu z kamienicy, w której mieszka. Czyni to chwilę przed tym, jak do jego mieszkania trafi podwładny Lohmannowi policjant, który według alfabetycznej listy sprawdza eks-pacjentów szpitali psychiatrycznych. Morderca „wsiąka" w miasto, wtapia się w tłum uliczny niczym anonimowy przechodzień.

Bo też wielkie miasto, metropolia, jest jego naturalnym środowiskiem. Francuski filmoznawca, Michel Marie, dopatrzył się w Beckercie figury flâneura ${ }^{40}$. Trop ten podjęli w swoich analizach filmu także Tom Gunning ${ }^{41}$

40 Zob.: Michel Marie, M, le Maudit: Fritz Lang etude critique, Nathan, Paris 1993, s. 52.

41 T. Gunning, op. cit., s. 188-192. 
i Janet Ward ${ }^{42}$, wskazując nie tylko na włóczenie się Beckerta po ulicach (o tej kompulsywnej potrzebie Beckert mówi podczas "procesu”), ale i na kontemplowanie przezeń wystaw sklepowych, charakterystycznego atrybutu metropolii. Janet Ward analizuje w swej książce ważny aspekt wielkomiejskiego wystroju w okresie weimarskim - Schaufenster, okno wystawowe. Schaufenster swym rozmaitym wystrojem, oświetleniem, wizualnymi atrakcjami tworzyło fantasmagorię sprzedawania i kupowania, niesłychanie rozbudzając konsumpcyjne pragnienia mas. Te zaś musiały ulec frustracji u schyłku Republiki Weimarskiej, w dobie gospodarczego kryzysu. Autorka konkluduje: „Film ten zręcznie sugeruje, iż weimarska «kultura powierzchni» wytworzyła, wskutek bankructwa ostatnich lat Republiki, podobne sennym marzeniom obrazy dla mas w Schaufenster, ale także agresywny popęd konsumpcji za wszelką cenę: tutaj-mordercy, który jest zarazem ofiarą konsumenckich struktur fantazji, jak i napastnikiem na niczego nie podejrzewających konsumentów (uosobionych przez dziewiczą niewinność małych dziewczynek). W ostatnich podrygach weimarskiej kultury powierzchni, wystawanie przy oknach sklepów stało się rzeczą niebezpieczną"43.

Beckert nieustannie daje wyraz swemu popędowi konsumpcji - czy to kupując jabłko na straganie i natychmiast je zjadając, czy zamawiając w kawiarni dwa koniaki pod rząd i łapczywie je wypijając. Zaspokaja go także obdarowywaniem swych małych "przyjaciółek”. Elsie Beckmann kupuje balonik, niedoszłej ofierze - pomarańcze, a wiemy też, że niedaleko miejsca, gdzie znaleziono jedną z poprzednich ofiar, policja odkryła torebkę po słodyczach. Niezależnie od morderczych intencji i faktu, że owe prezenty można traktować jak przynętę, Beckertowi zdaje się sprawiać radość - radość potencjalnej ofiary. I jemu, i dzieciom wspólna jest szczęśliwość z natychmiastowego zaspokojenia pragnienia czy pobudzanie tych pragnień przez kontemplację fantasmagorycznych okien wystawowych. A ta wspólnota - jak słusznie zauważa Gunning - jest jedną z najbardziej skandalicznych, zbijających z tropu rzeczy w tym filmie ${ }^{44}$.

Sekwencja trzech okien wystawowych, przed którymi stają Beckert i dwie jego niedoszłe ofiary, jest arcyciekawa formalnie i znaczeniowo. W filmie Langa Schaufenster trzykrotnie obrazuje zestawienie w jednej przestrzeni naiwnego, rozmarzonego konsumpcjonizmu dziecka ze

42 Janet Ward, Weimar Surfaces: Urban Visual Culture in 1920s Germany, University of California Press, Berkeley-Los Angeles-London 2001, s. 233-239.

${ }^{43}$ Ibidem, s. 239.

44 T. Gunning, op. cit., s. 172. Gunning zwraca uwagę, iż dzieci na początku filmu swą wyliczanką poniekąd przyzywają Schwarzmanna - raczej je fascynuje niż budzi grozę, niczym jakiś baśniowy potwór. 
zbrodniczym popędem Beckerta do natychmiastowej gratyfikacji pożądania za wszelką cenę. Znaczące jest to, iż morderca i dziewczynki przyglądają się nie tylko rzeczom eksponowanym na wystawie, ale i sobie samym odbitym w szybach - sobie samym pośród rzeczy pożądanych lub choćby tylko fascynujących. Po podziwianiu przez zabójcę swych grymasów w lustrze, pisaniu do gazety czy czytaniu na ulicznych afiszach relacji o swych zbrodniach, to kolejny dowód, iż Beckert żyje swą „jaźnią odzwierciedloną".

W pierwszym oknie - eksponującym sztućce w rozmaitych układach - odbicia noży w szybie tworzą wokół twarzy mordercy fascynującą swą geometrią i połyskliwością ramę. Za chwilę w "ramie z noży” pojawi się twarz dziewczynki, a w Beckercie obudzi się zbrodnicze pożądanie, czego oznaką będą półprzymknięte oczy, spazmatyczny oddech i pogwizdywanie melodii Griega ${ }^{45}$. Wkrótce znika ona Beckertowi i widzowi z oczu. Pojawia się przy drugim oknie wystawowym, tym razem antykwariatu, w którym jej uwagę przykuwa „(falliczna/kontrolowana) pionowa strzałka, poruszająca się rytmicznie w górę i w dół, a na prawo od niej (waginalna/chaotyczna) tarcza, wirująca z namalowaną na niej zwróconą dośrodkowo spirala, dwie popularne mechaniczne atrakcje optyczne w weimarskich oknach wystawowych. Symbole stają się aż nadmiernie klarowne, gdy kamera podąża za dziewczynką na prawo i dostrzegamy cień strzałki poruszający się nieustannie w górę i w dół nad hipnotyczną spiralą. Jako widzowie nie wiemy jeszcze, gdzie stoi $M$, ale kamera zdaje się implikować nasze usytuowanie zgodnie z jego polem widzenia, skoro śledzimy dziewczynkę jak ofiarę"46. Ofiarą jednak dziewczynka się nie staje, gdyż za chwilę spotyka swą matkę i zbrodnicze pożądanie Beckerta nie znajdzie upustu.

Morderca wkrótce „zaprzyjaźnia się" z następną dziewczynką. Po zakupieniu pomarańczy i obraniu jednej z nich przystają oboje przed oknem wystawowym sklepu z zabawkami, uśmiechnięci i chyba szczęśliwi. W idylliczny, piękny kadr kunsztownie, choć na krawędzi percepcji, niemal w sposób podświadomy, został wkomponowany - i to dwukrotnie - złowrogi znak „M”, którym parę chwil wcześniej Beckert został już

${ }^{45}$ Maria Tatar (op. cit., s. 158) zwraca uwagę, iż W grocie Króla Gór jest fragmentem suity Griega, fabularnie odpowiadającym temu fragmentowi dramatu Henryka Ibsena Peer Gynt, kiedy bohaterowi na dworze trolli, przed małżeństwem z córką trolla samemu grozi przemiana w potwora poprzez wyrośnięcie ogona (niedwuznacznie seksualne konotacje). Por.: Henryk Ibsen, Peer Gynt: Poemat dramatyczny, przeł. Zbigniew Krawczykowski, Biblioteka Narodowa, seria II, nr 152, Ossolineum, Wrocław-Warszawa-Kraków 1967, s. 78-81. Lang chyba nieprzypadkowo dobrał motyw muzyczny, sugerując poprzez niego przemianę Beckerta w "potwora”.

${ }^{46}$ J. Ward, op. cit., s. 238. 
naznaczony przez świat podziemia: „Nogi skaczącego pajacyka, gdy szeroko rozstawione, tworzą $M$ ponad głową Beckerta, a co więcej, można dostrzec inne, niewyraźne białe $\mathrm{M}$, odbicie $\mathrm{w}$ oknie, gdy nogi są rozstawione $^{\prime \prime 4}$. To, co powinno trafić do podświadomości Beckerta, stanie się dlań oczywiste za chwilę, kiedy niedoszła ofiara zwróci uwagę „wujkowi", iż się ubrudził. W lustrze - znowu w lustrze - z przerażeniem dojrzy na plecach swego palta kredowe, białe "M".

Polisemantyczność tego znaku wykracza poza przywołane już niemieckie słowa rozpoczynające się tą literą i związane $z$ tematem filmu. Heinrich, chłopak, który kredowym „M" oznacza Beckerta, by nie stracić go z oczu, czyni to przy pomocy pokrytych kredą zasadniczych linii papilarnych rozpostartej dłoni. Znak ",M" jest zatem przyrodzony nam wszystkim jako ludziom po prostu. Tytuł filmu znaczy zatem $M$ als Mörder w równym stopniu, co $M$ als Mensch - a w takim zrównaniu Lang już po raz kolejny w swej twórczości wykazuje się głęboko Girardowską intuicją o przemocy kryjącej się u podstaw ludzkiej natury i kultury - przemocy zrodzonej z pożądania i rywalizacji mimetycznej, prowadzących do kryzysu, którego rozwiązaniem jest kozioł ofiarny ${ }^{48}$.

Tu ujawnia się kolejny skandal tego filmu - jak można współczuć mordercy, seryjnemu dzieciobójcy, co więcej - jak można w s p ół c z u ć z n i m? A przecież do tego skłania nas choćby suspens i narracyjne centrum emocjonalnej identyfikacji w sekwencji ukrywania się Beckerta w biurowcu i gorączkowych poszukiwań go przez przestępców. Znajdą go czy nie znajdą? Kibicujemy raczej zwierzynie łownej niż myśliwym, mimo że w tym przypadku i jeden, i drudzy są wyjątkowo odstręczający $i$ antypatyczni. Strach Beckerta czyni go jednak bardzo ludzkim, przeraża zaś chłód i bezwzględność przywódcy przestępców, Kasiarza (Schränker), o którym wiemy, iż ma też na sumieniu ludzkie życie, a swymi gestami, manierami, tonem i skórzanym płaszczem przypomina gestapowca [gra go Gustaf Gründgens, jeden z prominentnych aktorów Trzeciej Rzeszy, będący pierwowzorem bohatera powieści Klausa Manna Mefisto (Mephisto) i nagrodzonej Oscarem jej ekranizacji w reżyserii Istvána Szabó (1981)]. Maria Tatar konstatuje, że łatwo nam powziąć współczucie i coś w rodzaju sympatii dla Beckerta, gdyż ani razu nie widzimy jego ofiar. Zbrodnia na Elsie pokazana jest metonimicznie, a pozostałe miały miejsce w przedakcji filmu. Co więcej, dla widzów późniejszych napiętnowanie Beckerta kredowym znakiem może nasuwać skojarzenia z oznaczaniem gwiazdą Dawida Żydów przez nazistów [przychodzi mi też do głowy kredowy

47 T. Gunning, op. cit., s. 191.

48 Odsyłam tu do swej analizy Girardowskiej wymowy Nibelungów. Mechanizm kozła ofiarnego dość wyraźnie obrazuje też spalenie przez tłum fałszywej Marii w Metropolis. 
znak, jakim przygotowujący Noc św. Bartłomieja znaczyli domostwa hugenotów w Nietolerancji (Intolerance, 1916) Davida Warka Griffitha].

To odbieranie mordercy jako ofiary przestałoby być skandalem, gdyby dalszy ciąg filmu - już po złapaniu Beckerta - można było uznać za „głos przeciwko karze śmierci", niezależnie od tego, za jaką zbrodnię odpowiadałby oskarżony. Tak jednak nie jest. W scenie „procesu” niespodziewana wolta "obrońcy", wskazującego, iż człowiek niepoczytalny - a takim jest Beckert - nie może odpowiadać za swe czyny, wydaje się jakoś mniej przekonująca retorycznie i emocjonalnie niż argumenty kobiet o bólu matek ofiar oraz argumenty Kasiarza o niebezpieczeństwach związanych z paragrafem 51, dzięki któremu psychicznie chory morderca wkrótce może ponownie znaleźć się na wolności... W dodatku w scenie "procesu” Beckert budzi - inaczej niż w sekwencji obławy - raczej obrzydzenie niż litość. O ile napiętnowanie kredą można odczytać - zwłaszcza w świetle późniejszych wydarzeń historycznych - jako "anytycypującą demaskację” mechanizmów zinstytucjonalizowanego antysemityzmu, to portret mordercy $\mathrm{w}$ finale jawi się raczej jako kulminacja nieświadomego antysemityzmu w samej koncepcji jego postaci. Do roli szerzącego terror w metropolii seryjnego zabójcy Lang wybrał bowiem Petera Lorre, z pochodzenia węgierskiego Żyda (prawdziwe nazwisko - László Löwenstein), mówiącego wyraźnie obcym, austriackim akcentem, szczególnie odmiennym od berlińskiego dialektu większości obsady. Fizyczność Beckerta - jego raczej niski wzrost, korpulentność, wyłupiaste oczy, wysoki, niemęski głos, nerwowość ruchów, histeryczna ekspresja, pewien rys zniewieściałości czy androgyniczności - od razu piętnowały go jako "obcego", „nienormalnego", „psychopatę". W roku 1940 obszerny fragment filmu Langa, w którym przed "sądem” Beckert czyni swe konwulsyjne wyznanie, porażające zarówno dla wewnatrzdiegetycznych, jak i ekstradiegetycznych widzów, został wykorzystany w jednym z najbardziej odrażających filmów nazistowskiej propagandy, osławionym antysemickim filmie montażowym Fritza Hipplera Der ewige Jude (Wieczny Żyd). „Identyfikując aktora z rola, film twierdził, iż «Żyd Lorre» uczynił z mordercy dzieci kogoś w rodzaju godnej współczucia ofiary, tak wywracając do góry nogami jakiekolwiek poczucie prawa i porządku. [...] Nie-niemiecka/nie-nordycka skłonność Beckerta do Südfrüchte (owoców południowych), jak i implikowane wzajemne powiązanie seksualnej perwersji, szaleństwa i zbrodni, łatwo konotowało «żydowskość» dla tych z góry skłonnych do antysemickich stereotypów już w roku 1931"49. Z jednej strony w takim kontekście pochwała filmu przez Goebbelsa przestaje budzić zdziwienie. Choć, z drugiej, tenże Goebbels w roku 1934 zakaże rozpowszechniania M. Powodem tej decyzji

49 A. Kaes, op. cit., s. 71. 
wydaje się jednak raczej wyjazd Langa z Trzeciej Rzeszy (i być może odkrycie jego żydowskiego pochodzenia) niż przekonanie, jakie o wymowie filmu żywił minister propagandy.

Hans Beckert umknął podziemnemu wymiarowi sprawiedliwości: dzięki dedukcji i sprytowi komisarza Lohmanna, reprezentanta porządku demokratycznego państwa, wyrok w jego sprawie wydał normalny, państwowy sąd. Dwie ostatnie, króciutkie sceny przedstawiają sędziów, którzy za chwilę obwieszczą wyrok, oraz trzy matki ofiar w żałobie. Jedną $\mathrm{z}$ nich jest Frau Beckmann, która z błędnym wzrokiem, pełnym żałości głosem mówi: „to nie wróci nam naszych dzieci”. „Co?” - chcielibyśmy zapytać. Zapewne wyrok, którego narracja ostentacyjnie wzbrania nam poznać. Ale może to i lepiej. Przez to nieprzyjemny, dwuznaczny, budzący skrajnie sprzeczne odczucia i sądy, choć formalnie niewątpliwie mistrzowski film Langa, tym bardziej daje do myślenia. 


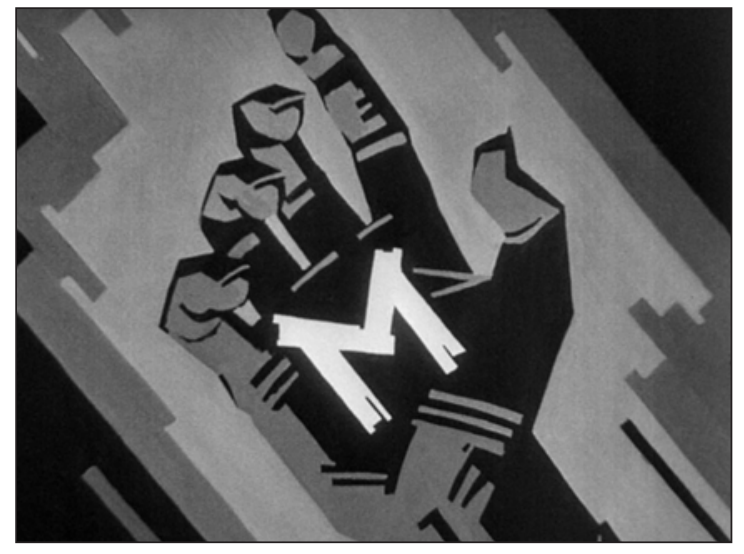

1. $M$ - morderca (1931, reż. Fritz Lang). Plansza tytułowa filmu. Znak ", $\mathrm{M}^{\prime \prime}$ tworzą linie papilarne wpółotwartej dłoni u niemal każdego człowieka

2. $M$ - morderca (1931, reż. Fritz Lang). Dziecięca wyliczanka „,Strzeż się Czarnego Człowieka, / na kotlety cię posieka. / Raz, dwa, trzy, / odpadasz ty!"
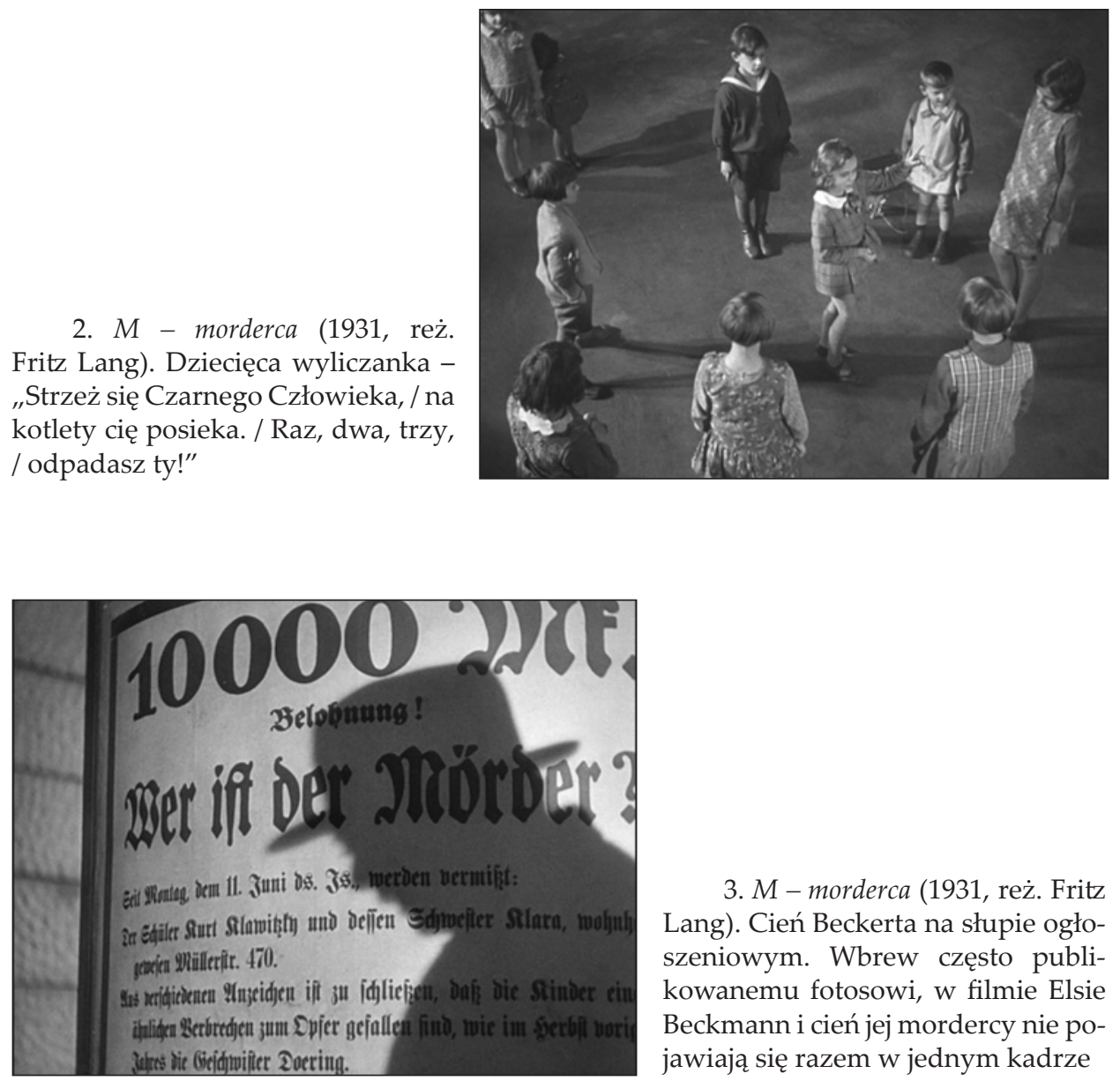

3. $M$ - morderca (1931, reż. Fritz Lang). Cień Beckerta na słupie ogłoszeniowym. Wbrew często publikowanemu fotosowi, w filmie Elsie Beckmann i cień jej mordercy nie pojawiają się razem w jednym kadrze 


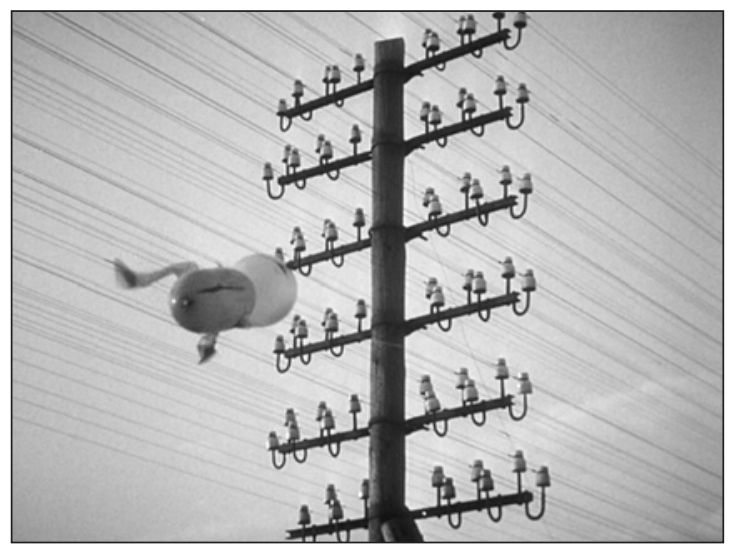

4. $M$ - morderca (1931, reż. Fritz Lang). Metonimia zbrodni - zaplątany $\mathrm{w}$ przewody balonik ofiary

5. M- morderca (1931, reż. Fritz Lang). Daktyloskopia - nowa technika $\mathrm{w}$ kryminalistyce
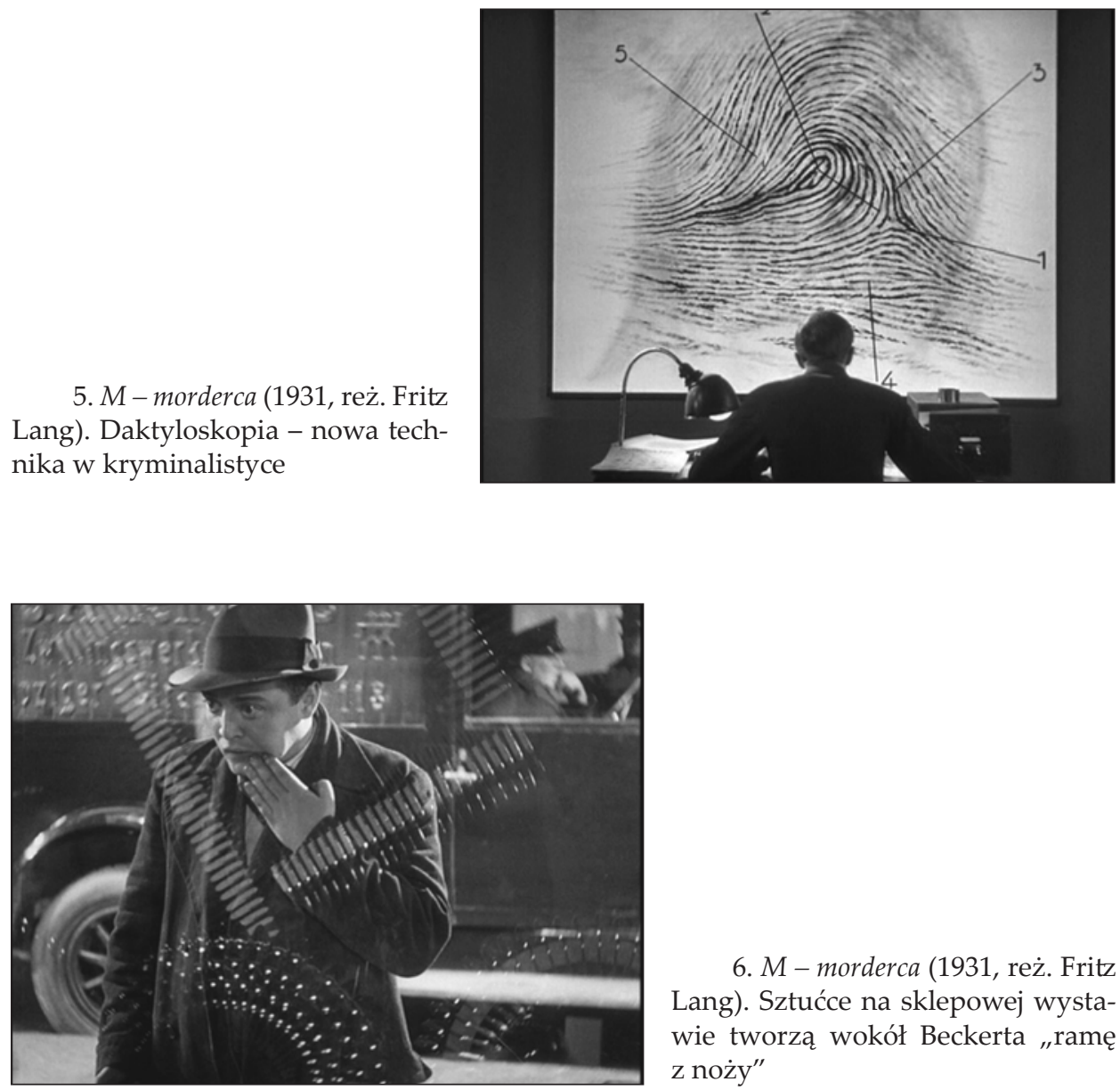

6. M-morderca (1931, reż. Fritz Lang). Sztućce na sklepowej wystawie tworzą wokół Beckerta „ramę z noży" 


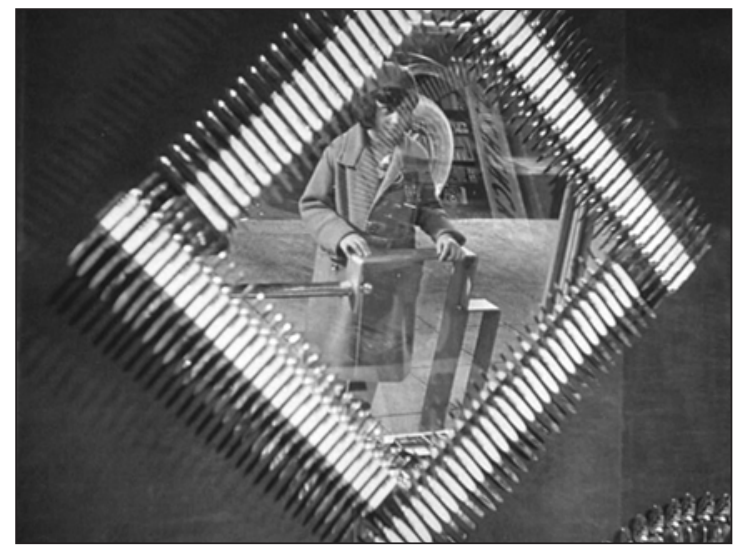

7. $M$ - morderca (1931, reż. Fritz Lang). W „ramie z noży” potencjalna ofiara - punkt widzenia ( $P O V$ shot) Beckerta

8. M-morderca (1931, reż. Fritz Lang). Beckert i niedoszła ofiara przed wystawą sklepu z zabawkami. Ruchome nogi pajacyka nad nimi tworzą litere „" $\mathrm{M}^{\prime \prime}$

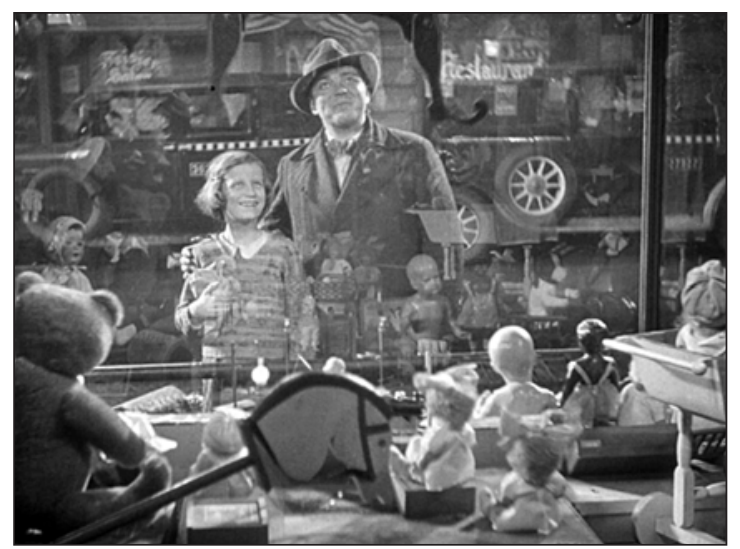

9. $M$ - morderca (1931, reż. Fritz Lang). Napiętnowany Beckert pojmuje, że go namierzono 


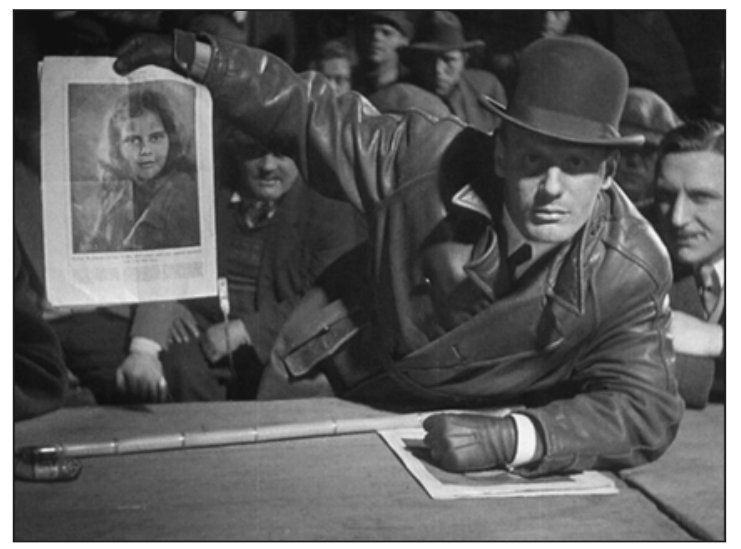

10. $M$ - morderca (1931, reż. Fritz Lang). Sąd podziemia. Kasiarz jako oskarżyciel demonstruje Beckertowi zdjęcia ofiar

11. $M$ - morderca (1931, reż. Fritz Lang). Bezbronny Beckert przed "ludową sprawiedliwością" półświatka
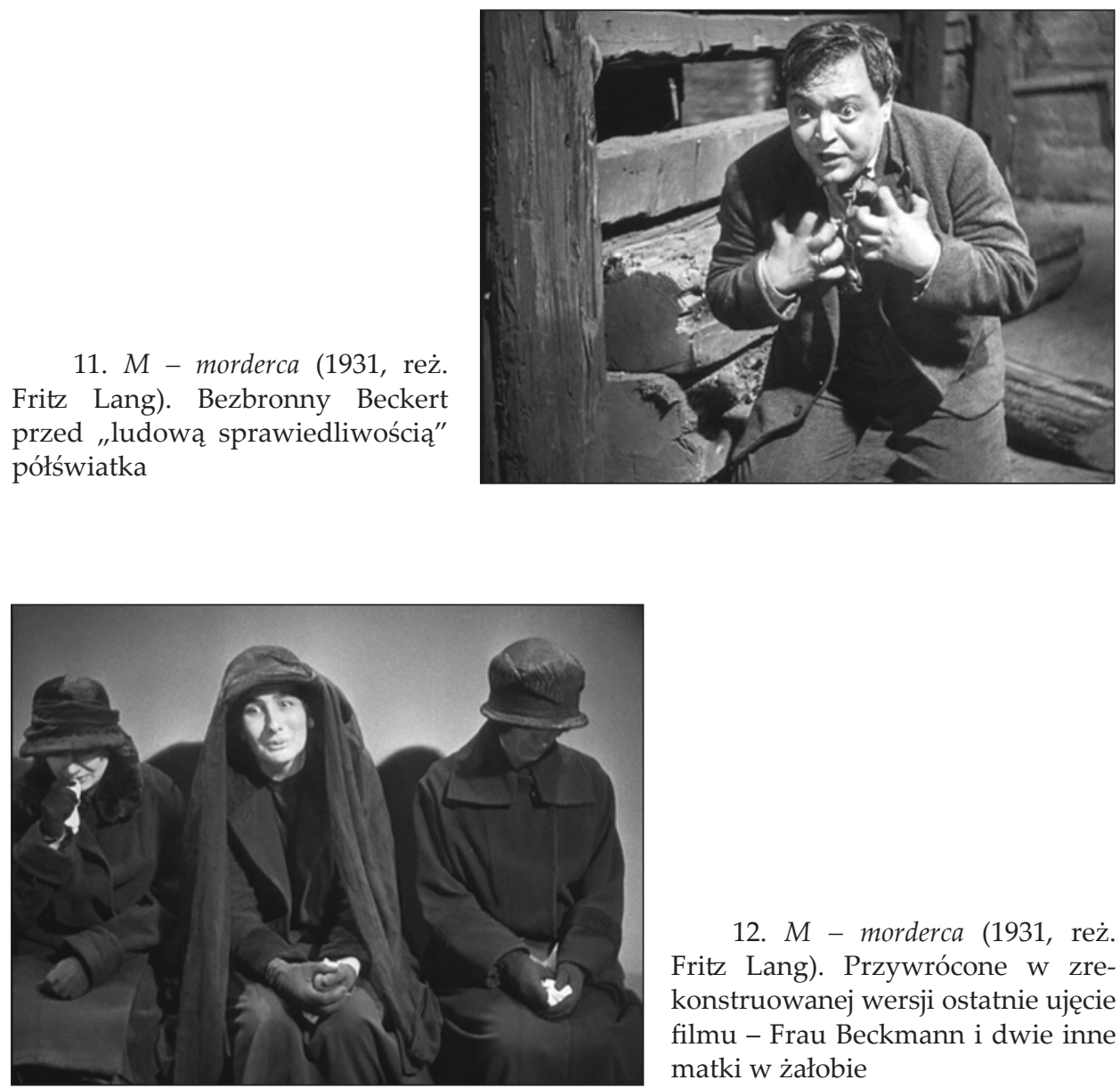

12. $M$ - morderca (1931, reż. Fritz Lang). Przywrócone w zrekonstruowanej wersji ostatnie ujęcie filmu - Frau Beckmann i dwie inne matki w żałobie 


\title{
Rozdział 8
}

\section{SZEPCZĄCE ŚCIANY ALBO AWATAR: TESTAMENT DOKTORA MABUSE}

\begin{abstract}
Starość urzeczywistnia marzenia młodości; widzimy to na przykładzie Swifta: w młodości budował dom dla wariatów, na starość sam tam poszedłํ.
\end{abstract}

Søren Kierkegaard, $\Delta \iota \alpha \psi \alpha \lambda \mu \alpha \tau \alpha$

\section{Historia z mrocznej epoki, gdy rządzili naziści/Żydzi (niepotrzebne skreślić)}

Jak wiele filmów europejskich z początku lat trzydziestych XX w., ostatni weimarski film Fritza Langa, Testament doktora Mabuse (Das Testament des Dr. Mabuse, 1933), to multilingual film, posiadający więcej niż jedną wersję językową - w tym przypadku, prócz niemieckiej także francuską. Producent filmu, Seymour Nebenzahl, właściciel małej spółki Nero Film, w której zrealizowano również $M$ - mordercę, wyprodukował wcześniej niemiecką i francuską wersję filmowej adaptacji Brechtowskiej Opery za trzy grosze (Die 3-Groschen-Oper/L'Opéra de quat'sous, 1931), obie w reżyserii Georga Wilhelma Pabsta. Zapewne zachęcony rezultatem, skłonił Langa, by ten wyreżyserował równolegle obie wersje nowego filmu o Mabusem - w tym samym studio, $\mathrm{w}$ tej samej scenografii, $\mathrm{z}$ tym samym operatorem (Fritz Arno Wagner $)^{2}$. Wersje te różniły się, rzecz jasna, obsadą, choć dwie ważne

1 Søren Kierkegaard, Albo - albo, przeł. Jarosław Iwaszkiewicz, t. 1, Państwowe Wydawnictwo Naukowe, Warszawa 1976, s. 21.

${ }^{2}$ Le Testament $d u$ Dr. Mabuse, bo taki tytuł nosi wersja francuska, to zatem i w pełni autorski film Langa, i multilingual film sensu stricto. Inaczej rzecz się ma w przypadku $M-$ mordercy $(M, 1931)$ : wersje francusko- i angielskojęzyczna tego filmu powstały w rok po premierze niemieckiego oryginału i są interesującymi jako dokument epoki przełomu dźwiękowego, ale bardzo niespójnymi zarówno warsztatowo, jak i artystycznie, hybrydami. Zawierają one oryginalny materiał nakręcony przez Langa, ale przemontowany i zdubbingowany na francuski bądź angielski, a także partie nakręcone na nowo, z udziałem francuskich/angielskich aktorów oraz Petera Lorre, grającego po francusku/angielsku 
role powierzono tym samym aktorom - $\mathrm{w}$ obu $\mathrm{w}$ postać tytułową wcielił się Rudolf Klein-Rogge, odtwórca roli doktora Mabuse w dyptyku z roku 1922, zaś eks-policjanta Hofmeistra zagrał mówiący płynnie i po niemiecku, i po francusku Karl Meixner. Kiedy Lang ciągle jeszcze pracował nad wersją niemiecka, gotowy materiał filmowy wersji francuskojęzycznej wysłano do Paryża, gdzie jego montażem, wedle ścisłych wskazówek Langa, zajął się Lothar Wolff. Była to więc wersja w pełni przez reżysera autoryzowana, ale, co ciekawe, jest ona około 30 minut krótsza od trwającej 121 minut wersji niemieckiej, której montaż nadzorował sam Lang ${ }^{3}$. Oczywiście, pierwotną wersję niemiecką jako $\mathrm{w}$ pełni będącą (w dzisiejszej nomenklaturze) directo$r^{\prime}$ s cut trzeba uznać - co też czyni niniejszy rozdział - za podstawę wszelkiej analizy tekstualnej. Faktycznie, jej nieco wolniejszy rytm, z ujęciami trwającymi trochę "zbyt długo" niż pozwalały na to standardy sensacyjnego kina około roku 1930, bliższy jest stylowi Langa z jego poprzednich filmów niż bardziej konwencjonalne tempo wersji francuskiej. Rzecz jasna, skoro ze względu na inną obsadę powtórzone było filmowanie poszczególnych ujęć i scen, obie wersje różnią się nieznacznie, lecz wyraźnie, ustawieniami kamery, kadrowaniem, czasową rozpiętością ujęcia (na ogół krótszą w wersji francuskiej). Zasadnicza jednak rozbieżność między nimi to znaczna redukcja w wersji francuskiej romansowego wątku Lilli i Toma Kenta - ona też w dużej mierze przyczynia się do tego, że wersja francuska jest aż o pół godziny krótsza ${ }^{4}$.

Do zapowiedzianej na 24 marca 1933 r. niemieckiej premiery filmu w berlińskim kinie Ufa-Palast am Zoo, gdzie zazwyczaj inaugurowały swój żywot ekranowy poprzednie filmy Langa, jak wiadomo, nie doszło.

\footnotetext{
(aktor władał oboma tymi językami). Z pewnością wersje te nie należą do Langowskiego kanonu - trzeba przypisać je producentom, którym Seymour Nebenzahl odsprzedał prawa autorskie: Bernardowi Natanowi (wersja francuska) i Ericowi Hakimowi (wersja angielska), oraz reżyserom-,,adaptatorom”, którzy nakręcili nowy materiał: Rogerowi Goupillières i Charlesowi Barnettowi. Mało znaną w historii kina kwestię $M-$ mordercy jako filmu "wielojęzycznego" referuje drobiazgowo Robert Fischer w artykule Mörder meurtrier - murderer: The Multi-lingual Versions of Fritz Lang's "M". Jest on zamieszczony w książeczce (s. 28-38) dołączonej do edycji filmu Langa w serii "Masters of Cinema” (Eureka Entertainment, London 2010). Zawiera ona odrestaurowaną oryginalną niemiecką wersję w reżyserii Langa i niedawno odkrytą wersję angielską.

${ }_{3}$ Zob.: David Kalat, The Strange Case of Dr. Mabuse: A Study of the Twelve Films and Five Novels, McFarland \& Company, Inc., Publishers, Jefferson (North Carolina)-London 2001, s. 70.

${ }^{4}$ Obie wersje można porównać dzięki amerykańskiej edycji The Testament of Dr. Mabuse (The Criterion Collection, New York 2004). Zawiera ona odrestaurowaną pierwotną wersję niemiecką oraz wersję francuska, której transfer cyfrowy oparto o kopię $16 \mathrm{~mm}$ znajdującą się w Cinémathèque de Luxembourg. Holenderskie napisy zdają się świadczyć, iż była to kopia eksploatacyjna na rynek krajów Beneluksu.
} 
Utworzonemu niespełna dwa tygodnie wcześniej (11 marca 1933) ministerstwu Goebbelsa (Reichsministerium für Volksaufklärung und Propaganda), któremu trzeba było przedłożyć film do aprobaty (choć formalnie o dopuszczeniu lub niedopuszczeniu filmu do eksploatacji decydował urząd cenzorski proweniencji jeszcze weimarskiej), wersja niemiecka nie mogła być pokazana przed 23 marca, gdyż trwały nad nią ostatnie prace. Dnia 24 marca, po wstępnej ocenie filmu przez urząd Goebbelsa, wydano komunikat, iż premiera zostaje przełożona na inny termin „z powodów technicznych" ${ }^{\prime 5}$. Zaś 29 marca 1933 r. niemiecki urząd cenzury filmowej, Filmprüfstelle, któremu przewodniczył niejaki radca Zimmermann, zakazał rozpowszechniania filmu, uzasadniając, iż stanowi on „groźbę dla prawa oraz bezpieczeństwa i porządku publicznego"6.

Lang później wielokrotnie, w coraz to nowych wersjach i z coraz to innymi szczegółami, opowiadał o swym spotkaniu z Goebbelsem, o złożonej przez ministra „propozycji nie do odrzucenia” i „natychmiastowej” po tej rozmowie swej ucieczce za granicę. Dziś już wiemy, że historia ta zapewne jest wymysłem Langa, jego „wyobrażonym filmem”" Jak już nadmieniałem we wstępie, po raz pierwszy pojawiła się ona w roku 1943 w materiałach promujących wejście na ekrany dwóch filmów Langa: zrealizowanego w Hollywood antynazistowskiego dramatu wojennego Kaci także umieraja (Hangmen Also Die) oraz francuskiej wersji Testamentu doktora Mabuse. Kontekst taki, po pierwsze, legitymizował Langa jako antynazistę i ułatwił mu rzutowanie swej ówczesnej (A. D. 1943) świadomości politycznej na rok 1933, po drugie zaś - w połączeniu z fortunnym dla politycznej reputacji Langa zatrzymaniem w Trzeciej Rzeszy Testamentu doktora Mabuse - sugerował, iż jego ostatni weimarski film jest filmem antyhitlerowskim. Przygotowując zresztą do amerykańskiej premiery Le Testament du Dr. Mabuse, który pod tytułem The Last Will of Dr. Mabuse miał być wyświetlany $\mathrm{w}$ kinach $\mathrm{z}$ angielskimi napisami, Lang poczynił pewne kroki, by naprowadzić widzów na takie właśnie odczytanie jego wymowy. Tak o tym pisze David Kalat: „Napisy sporządzono po części na podstawie scenariusza Thei von Harbou, lecz nie przełożono ich wprost. Zamiast tego dystrybutor wziął pod uwagę to, o czym Lang mówit, iż znajduje się w filmie, i tak wyprodukował przekazywany napisami dialog, znacznie wyraziściej eksponujący polityczne stanowisko niż można to rzec o oryginale"s.

${ }^{5}$ D. Kalat, op. cit., s. 70-72.

6 Datę 29 marca 1933 podaję za: Gösta Werner, Fritz Lang and Goebbels: Myth and Facts, „Film Quarterly" 1990, Spring, s. 25. D. Kalat (op. cit., s. 72) zakaz datuje na 30 marca.

7 Por. Wstęp. Wyobrażony film Fritza Langa w niniejszej publikacji, s. 151.

8 D. Kalat, op. cit., s. 74-75. 
To jednak nie wszystko - przed nowojorską premierą filmu Lang obwieścił: „Film ten miał ukazać metody hitlerowskiego terroru poprzez parabolę. Slogany i wyznania wiary w Trzecią Rzeszę wypowiadane są ustami przestępców. Takim sposobem miałem nadzieję zdemaskować doktryny, za którymi czaił się zamiar zniszczenia wszystkiego, co ludziom drogie" .

Kulminacją przypisywania ostatniemu weimarskiemu filmowi Langa antynazistowskiej wymowy była obróbka, jakiej poddano niemiecką wersję filmu w roku 1952 przed wprowadzeniem jej na amerykańskie ekrany pod tytułem The Crimes of Dr. Mabuse. Film zdubbingowano na angielski, a tłumacz niemieckich dialogów, Leo Katcher, oparł się raczej na już poniekąd utrwalonej renomie reżysera jako antynazisty i filmu jako antyhitlerowskiego niż na tym, co te dialogi mówiły wprost. Co więcej, film The Crimes of Dr. Mabuse zawierał dodaną na użytek amerykańskiej publiczności „objaśniającą” sekwencję początkowa, która expressis verbis sytuowała zdarzenia między rokiem 1932 a 1939, w zenicie okresu nazistowskiego, gdy Niemcami rządzili „,hitlerowscy przestępcy”"10.

David Kalat zauważa, że gdy 40 lat po powstaniu filmu, w roku 1973 pojawiła się w amerykańskich kinach bez żadnych „opracowań" oryginalna wersja niemiecka, to powszechna opinia o Testamencie doktora Mabuse jako intencjonalnej antynazistowskiej alegorii była tak mocno utrwalona, że mało komu przyszłaby do głowy inna interpretacja ${ }^{11}$. Powodem tego był też zapewne fakt, iż Lang wciąż żył i cieszył się niekwestionowanym autorytetem, więc nikt nie ośmielił się ani podważyć jego „wyobrażonego filmu", ani baczniej przyjrzeć się wymowie Testamentu doktora Mabuse. Wyłom w recepcji „wyobrażonego filmu” i początek nieufności historyków kina wobec rozmaitych wypowiedzi Langa nastąpił po opublikowaniu na łamach „Film Quarterly” wiosną 1990 r. (niecałe 14 lat po śmierci reżysera) przywoływanego już artykułu Gösty Wernera Fritz Lang and Goebbels: Myth and Facts. To po nim nastąpił wysyp kolejnych tekstów, rewizjonistycznych zarówno wobec osoby, jak i dzieł Fritza Langa, wśród których prawdopodobnie najbardziej niechętną mu praca, aczkolwiek świetnie udokumentowana, jest biograficzna książka Patricka McGilligana Fritz Lang: The Nature of the Beast ${ }^{12}$.

${ }^{9}$ Cyt. za: ibidem, s. 74.

10 Ibidem, s. 75, 90.

${ }^{11}$ Ibidem, s. 75. Ale zdarzały się też wyjątki - Kalat wymienia jeden z nich, Bosleya Crowthera, który recenzując w roku 1943 The Last Will of Dr. Mabuse dla „The New York Times", wyraził wątpliwość, czy aby istotnie dr Mabuse jest, jak twierdzi Lang, filmową alegorią Adolfa Hitlera (zob. ibidem, s. 91).

12 Patrick McGilligan, Fritz Lang: The Nature of the Beast, St. Martin's Press, New York 1977. 
A jednak chyba nie trzeba było czekać aż do śmierci Langa w roku 1976, przekazania przez wdowę berlińskiej filmotece jego paszportu i zinterpretowania zamieszczonych $\mathrm{w}$ nim danych przez Göstę Wernera jako podstawy do uznania opowieści o spotkaniu z Goebbelsem za konfabulację. Jednym $\mathrm{z}$ istotnych elementów tej historii - przynajmniej w niektórych jej wariantach - jest usprawiedliwiające się wyłuszczanie przez Goebbelsa powodów zatrzymania filmu. Winne miało być zakończenie, grożące wywróceniem na opak porządku publicznego, bo ani przestępca $\mathrm{w}$ finale nie zostaje przykładnie ukarany przez prawo, ani nie pojawia się niczym deus ex machina Führer, pokonujący czy demaskujący Mabusego, i przywracający "prawdziwe ideały”. Jeżeli Lang nawet w swym „wyobrażonym filmie" nie włożył w usta ministra propagandy uzasadnienia zatrzymania filmu odczytaniem jego wymowy jako skierowanej przeciw władzy nazistów, to pomimo rozmaitych zabiegów z "opracowaniami" amerykańskich wersji filmu mimowolnie ujawnił prawdę o tej wymowie - Testament doktora Mabuse nie był intencjonalnie przeciw nazistom skierowany. Potwierdzają to zresztą następujące okoliczności - po pierwsze, współscenarzystka filmu, Thea von Harbou, wykazywała pronazistowskie sympatie jeszcze przed objęciem władzy przez Hitlera i rozwodem z Langiem, w roku 1933 wstąpiła do NSDAP, a w zreorganizowanej przez Goebbelsa kinematografii stała na czele organizacji scenarzystów. Po drugie, zakaz cenzury z 29 marca 1933 dotyczył tylko terytorium Niemiec - niemiecka wersja filmu była sprzedawana na rynki ościennych państw, mających tradycyjnie silną więź z niemieckim rynkiem filmowym (np. na Węgry - premiera w Budapeszcie 21 IV 1933, czy do Austrii - premiera w Wiedniu 12 V 1933); gdyby w odczuciu nazistów film ich szkalował, raczej uniemożliwiliby jego dystrybucję na zewnątrz kraju, a z pewnością nie zezwoliliby na doniesienia o jego zagranicznej recepcji w rodzimej prasie filmowej! ${ }^{13}$ Po trzecie, o czym mało wiedzą nawet wytrawni znawcy historii kina, pozostający jednak pod wpływem „wyobrażonego filmu”, zakaz rozpowszechniania filmu w Trzeciej Rzeszy wkrótce (choć nie na długo) został zniesiony przez samego Goebbelsa. Dokręcono nową

13 Berliński magazyn „Der Kinematograph” z 16 maja 1933 donosił niemieckim kinomanom: „Film Fritza Langa Testament doktora Mabuse wywołał wielkie zainteresowanie w Wiedniu podczas swego premierowego pokazu w Stafa Kino z racji popularności pierwszego filmu o Mabusem i sensacji spowodowanej zakazem filmu w Niemczech. Od strony warsztatowej i reżyserskiej film jest nadzwyczajny. Nie można tego samego rzec o scenariuszu Thei von Harbou, który w hipnotycznych scenach filmu przechodzi w kicz. Scenariusz żąda też od publiczności zbytniej łatwowierności; w dodatku film przedstawia wiele paskudnych spraw, które mogłyby niejako działać na widzów demoralizująco, co tłumaczyłoby zakaz rozpowszechniania filmu w Niemczech". Cyt. za: Frederic W. Ott, The Films of Fritz Lang, The Citadell Press, Seacaucus (New Jersey) 1979, s. 167. 
sekwencję o charakterze "ramy narracyjnej” (to częsty i popularny chwyt w kinie niemieckim), w której Otto Wernicke jako komisarz Lohmann wyjaśnia, iż przedstawione $\mathrm{w}$ filmie zdarzenia miały miejsce $\mathrm{w}$ owej niedawnej, mrocznej epoce, kiedy krajem rządzili Żydzi... ${ }^{14}$

Możliwość, poprzez stosunkowo drobne zabiegi manipulacyjne, wpisania w fabułę Testamentu doktora Mabuse tak rozbieżnych interpretacji (film jest proroczą wizją zbrodniczej władzy Trzeciej Rzeszy - film jest retrospektywnym podsumowaniem „żydowskich rządów” w Republice Weimarskiej) zdaje się świadczyć, iż wymyślony niegdyś przez Norberta Jacques'a, lecz zawłaszczony przez duet Lang - von Harbou superprzestępca, pozostał w roku 1933 (podobnie jak w 1922) "pustym miejscem”, które można było „naznaczyć” odmiennymi politycznymi i kulturowymi konotacjami, zawsze jednak związanymi z władza, przemoca, zbrodnia, finansowymi matactwami i zakulisową manipulacją.

\section{Komisarz Lohmann kontra awatar doktora Mabuse}

W ostatnim weimarskim filmie Langa występują dwie postacie, które były bohaterami dwóch dzieł, należących do jego największych osiągnięć: Mabuse, doktor psychoanalizy i superprzestępca w jednej osobie, z przebojowego dyptyku z roku 1922, oraz komisarz Lohmann z Wydziału Zabójstw w Kwaterze Głównej Policji, który w dwa lata wcześniejszym $M$ - mordercy (1931) doprowadził do schwytania i skazania przez prawo Hansa Beckerta, terroryzującego Berlin seryjnego dzieciobójcy. Fabuły Doktora Mabuse, gracza i $M$ - mordercy nie miały ze sobą żadnych punktów wspólnych. Poprzez umieszczenie ich bohaterów razem w kolejnym filmie Lang stworzył ze swych dzieł - przynajmniej tych trzech - rodzaj artystycznego kosmosu, w którym, niczym w Komedii ludzkiej Balzaka, postacie przechodzą z utworu do utworu. Oczywiście, chwyt taki ułatwia traktowanie tych „współczesnych” filmów Langa jako rodzaju Zeitspiegel czy Bild der Zeit - zwierciadeł czy obrazów znanej współczesnej kinowym widzom owych filmów rzeczywistości.

Co ciekawe, Mabuse i Lohmann nie spotykają się jednak w świecie przedstawionym tego filmu. Mabuse, milczący, fizycznie „wyłączony” ze

${ }^{14}$ D. Kalat, op. cit., s. 90. A swoją drogą, Otto Wernicke, grający Lohmanna, i Wera Liessem, filmowa Lilli, zaraz po ukończeniu Testamentu doktora Mabuse zagrali w pierwszym z trzech „brunatnych eposów heroicznych”, jakie pojawiły się na niemieckich ekranach w roku 1933 - w filmie Franza Seitza SA-Mann Brand. Trudno uzasadnić występ tych samych aktorów w filmie jawnie prohitlerowskim niemal natychmiast po filmie jakoby intencjonalnie antynazistowskim - co jest jeszcze jednym argumentem przeciwko przypisywaniu antynazizmu filmowi Langa. 
świata przez szaleństwo, w którym się pogrążył, kompulsywnie zapisujący niezrozumiałymi zrazu zapiskami niezliczone kartki, jest czystą obecnością - nie odgrywa, przynajmniej na planie fizycznym, żadnej aktywnej roli w akcji fabularnej. Umiera zresztą gdzieś w połowie filmu i Lohmann przybywa do kliniki profesora Bauma, której Mabuse był pacjentem, tylko po to, by zobaczyć w kostnicy jego zwłoki. Lohmann z kolei, podobnie jak w $M-$ mordercy, jest pełnym energii, niezmordowanym policjantem, ale tym razem śledztwo, które prowadzi, wiedzie donikąd, a rozwiązanie zagadki, jakie w finale poznaje, niczego nie wyjaśnia.

Warto zatem prześledzić sjużet tego filmu. Być może pozwoli to unaocznić pozorność zagadek, pustkę odpowiedzi i jałowy bieg akcji, na pierwszy rzut oka sensacyjnej i wartkiej, ale tak naprawdę wiodącej donikąd. Komentarze autorskie do poszczególnych sekwencji zostały zapisane kursywą.

1. W jakimś tajemniczym pomieszczeniu, pełnym ogłuszającego hałasu wydawanego przez niewidzialne maszyny, nerwowy mężczyzna z rewolwerem w dłoni śledzi z ukrycia krzątających się tam ludzi - zapewne przestępców. Ci zauważają jego obecność, ale pozwalają mu wymknąć się na zewnątrz. Na ulicy o mało nie zabija go spadający tuż przed nim kawał gzymsu oraz eksplodująca tuż koło niego beczka z łatwopalnym materiałem, spuszczona przez zbirów z oddalającej się szybko ciężarówki.

2. Kwatera Główna Policji, Wydział Zabójstw. Komisarz Lohmann nie zdąży wymknąć się do opery na Walkirię Wagnera. Zatrzymuje go telefon eks-policjanta Hofmeistra (to człowiek z 1 sekwencji filmu), który rozpaczliwie żąda rozmowy z komisarzem. Informuje on Lohmanna, iż jest na tropie niebezpiecznego gangu trudniącego się m.in. fałszowaniem pieniędzy i może wyjawić nazwisko jego szefa (w montażu symultanicznym przechodzimy od biura komisarza do pokoju, skąd dzwoni Hofmeister). Kiedy eks-policjant ma już podać nazwisko herszta, wydaje nagły okrzyk, ekran ściemnia się, słyszymy huki wystrzałów i widzimy niemal podprogowo ich błyski. Komisarz, wciąż na drugim krańcu linii trzymający słuchawkę telefonu, nie może nawiązać kontaktu z Hofmeistrem. Słysząc jego nonsensowny śpiew, dochodzi do wniosku, że przerażony czymś Hofmeister prawdopodobnie oszalał.

3. Aula, w której profesor Baum, psychiatra, wygłasza wykład dla studentów medycyny o skutkach, jakie może wywołać u człowieka wielki wstrząs. Podaje przykład pacjenta swej kliniki, psychoanalityka doktora Mabuse, który oszalał, gdy przed laty policja przybyła go aresztować za jego liczne i poważne przestępstwa. Profesor opowiada, jak jego pacjent po fazie katatonicznego odrętwienia, w jakie wpadł w więzieniu, zaczął później pokrywać dziwnymi zapiskami niezliczone kartki papieru. Z zapisków tych, zrazu chaotycznych i na pozór bezsensownych, stopniowo 
zaczęły się wyłaniać opisy wielkich przestępstw, na skalę dezorganizacji życia społecznego. Baum nie kryje wobec studentów swej fascynacji "geniuszem" Mabusego, a jego słowa o paranormalnych zdolnościach pacjenta zdają się potwierdzać - gdy na ekranie pojawia się fotografia Mabusego, wszyscy słuchacze jak rażeni gromem momentalnie przyjmują pozycję niemal "na baczność".

4. Znani nam, w większości z sekwencji 1, przestępcy w znanej też już scenerii (to prawdopodobnie drukarnia fałszywych pieniędzy, o której Hofmeister wspominał Lohmannowi). Jeden z „drukarzy" zastanawia się nad skutkami ucieczki "szpicla" - raczej nie będą one poważne, skoro Sekcja 2-B, przewidziana na takie sytuacje, zapewne unieszkodliwiła potencjalnego donosiciela. Co zreszta potwierdza niebawem telefon, informujący też, że już 20 minut po „załatwieniu” Hofmeistra pojawił się u niego sam Lohmann (jak wiemy z $M-$ mordercy - w świecie przestępczym otoczony złowrogą sławą).

5. W pokoju, z którego dzwonił Hofmeister, komisarz Lohmann usiłuje zrekonstruować, co się tam właściwie zdarzyło. Wnioskuje, iż eks-policjant, cofając się przed czymś, co śmiertelnie go przeraziło, musiał oprzeć się o okno. Badając szybę, odkrywa na niej zadrapania, będące prawdopodobnie zapisem informacji, jaką chciał zostawić komisarzowi przyparty do okna Hofmeister. Lohmann rozkazuje swym ludziom zabrać szybę do analizy.

6. Klinika psychiatryczna. Na szpitalnym łóżku z jakimś desperackim zapamiętaniem i „wyłączony” z rzeczywistości Mabuse zapisuje kolejne kartki. Spadają one na podłogę, skąd skrupulatnie zbiera je pielęgniarz i wręcza Baumowi. Gdy profesor ujmuje rękę pacjenta, by zbadać jego puls, doznaje krótkiej wizji: „widmo” Mabusego (podwójna ekspozycja) wychodzi z jego ciała i staje naprzeciw Bauma. Jakby zafrasowany profesor, wychodząc, zleca pielęgniarzowi „mieć oko” na Mabusego i dać mu zastrzyk.

7. Tom Kent i zakochana w nim Lilli spotykają się $\mathrm{w}$ kawiarni. Retrospekcja (7a) przypomina, jak rok wcześniej bezrobotny Tom zwrócił jej uwagę, gdy w desperacji wywołał awanturę w urzędzie pracy. Lilli pomogła mu wtedy, pożyczając 20 marek, od czego datuje się ich znajomość. W Kencie rozpoznajemy jednego z ludzi gangu Mabusego (scena 4) - tego, który sprzeciwił się zabijaniu ludzi podczas akcji, choć sam, jak wyznał członkom gangu, ma na sumieniu życie dwóch osób.

8. Klinika psychiatryczna. Dr Kramm, kolega Bauma, pod nieobecność profesora wchodzi do jego gabinetu i strąca na podłogę leżące na biurku zapiski Mabusego. Zbierając je, zaczyna czytać i odkrywa niezwykłe podobieństwo obmyślonego tam planu napadu rabunkowego ze znajdującym się w codziennej gazecie opisem skoku na jubilera, który faktycznie miał miejsce. Gdy Baum przychodzi, rozemocjonowany Kramm usiłuje 
go przekonać, iż ktoś zahipnotyzowany przez jego niebezpiecznego pacjenta mógł popełnić to przestępstwo. Profesor bagatelizuje podejrzenia kolegi, ale ten, odchodząc, zapowiada, iż natychmiast powiadomi policję o tej dziwnej koincydencji.

9. Sekcja 2-B w gangu Mabusego (do spraw „likwidacij”) otrzymuje telefonicznie namiar na skrzyżowanie, gdzie prawdopodobnie niedługo znajdzie się samochód Kramma, a także jego numery rejestracyjne (nie wiemy, kto dzwonił - profesor? podsłuchujący pod drzwiami jego asystent Winkler?). Ruchliwe skrzyżowanie. Samochód doktora Kramma razem ze sznurem innych wozów utknął przed przejściem dla pieszych. Hardy, zabójca z Sekcji 2-B, który zdążył już namierzyć swą ofiarę, inauguruje „ponaglający” klakson. Inni kierowcy, w tym i Kramm, ochoczo podejmują trąbienie. $W$ ogłuszającym hałasie nie słychać strzału. Po zmianie sygnalizacji jeden samochód wciąż stoi w miejscu. Gdy kierujący ruchem policjant podbiega do stojącego wozu, by ponaglić kierowcę, odkrywa w nim zwłoki Kramma i przestrzeloną kulą szybę. Z auta wypada niezauważona gazeta, donosząca na pierwszej stronie o napadzie na jubilera, podczas którego łupem padły kosztowności za ćwierć miliona marek.

10. Kryjówka ludzi Mabusego - „ekspert” od klejnotów szacuje łupy ze sklepu jubilerskiego na prawie ćwierć miliona. Jego kolega, Karetzky, zastanawia się nad sensem takiej akcji, skoro "szefowi” nie chodzi o obłowienie się, ale o przeznaczenie zysku z łupów na narkotyki (kokainę, heroinę, morfinę, opium) później „bezinteresownie” rozprowadzane w społeczeństwie. Nie jest on odosobniony w swych wątpliwościach wspomina innego członka gangu (retrospekcja 10a) niepojmującego, po co wszystkie te szantaże i morderstwa, jeśli nie chodzi o to, by na nich zarobić. "Jubiler" przestrzega Karetzky'ego przed zbytnią ciekawością - jeden ciekawy, co jest w "pokoju za kotarą", w którym urzęduje boss, został znaleziony przed tą kotarą martwy (retrospekcja 10b). A przecież - argumentuje ,jubiler" - szef zapewnia im zawsze dobre alibi i w razie czego najlepszych adwokatów.

11. Kent, zamyślony, przy oknie u siebie w mieszkaniu, na jego biurku niedokończony list do Lilli, w którym próbuje jej wyznać - choć nie ma odwagi dokończyć - kim jest i dlaczego nie mogą się więcej spotykać. Dzwonek do drzwi. Przygnębiony Kent odczytuje odebrany telegram: „Dziś w nocy o pierwszej. Dr Mabuse” i drze niedokończony list.

12. W swym biurze Lohmann równocześnie zajmuje się zniknięciem Hofmeistra i zabójstwem Kramma. W pierwszej sprawie wysłuchuje raportów swych ludzi o daremności dotychczasowych poszukiwań eks-policjanta i dzwoni do policyjnego technika Webera z zapytaniem o wynik analizy szyby. W drugiej - wysłuchuje sprawozdania eksperta o rodzaju broni i okolicznościach oddania strzału oraz rozkazuje rozlepić na mieście 
afisze $\mathrm{z}$ obwieszczeniem o nagrodzie za wskazanie zabójcy i udzielenie informacji o dwóch ostatnich godzinach życia Kramma, między godziną 6 a 8 wieczorem. Elektryzuje go telefon, iż Hofmeister odnalazł się w komisariacie na Schöneberger Ufer.

13. Rzeczony komisariat - Hofmeistrowi, kompulsywnie odgrywającemu daremne próby nawiązania połączenia z Lohmannem, wchodzący do jego celi Lohmann z policyjnym lekarzem, w jego subiektywnej wizji (ekspresjonistyczny design scenografii plus podwójna ekspozycja) jawią się jako idący ku niemu zabójcy z Sekcji 2-B. Przed tworami swej wyobraźni zrodzonymi traumatycznym wspomnieniem eks-policjant broni się ucieczką w wyśpiewywanie bezsensownej piosenki. Lohmann jeszcze małym podstępem, udając, iż Hofmeistrowi udało się z nim połączyć, próbuje wydobyć od niego informację, którą ten rozpaczliwie chce mu przekazać, ale bezskutecznie, gdyż po chwili eks-policjant ponownie „ucieka” w szaleństwo. Policyjny lekarz mówi komisarzowi na odchodne, iż „biedaka" trzeba odesłać do szpitala dla psychicznie chorych.

14. Pielęgniarza z kliniki Bauma niepokoi stan Mabusego, który zaprzestał pisania i tylko gapi się przed siebie przerażającym, przeszywającym na wskroś spojrzeniem. O stanie pacjenta próbują z Winklerem powiadomić profesora, ale po zapukaniu i naciśnięciu klamki jego gabinetu słyszą stanowczy głos: „Jestem zajęty, proszę mi nie przeszkadzać”.

15. Zbliżenie rąk w rękawiczkach otwierających zaszyfrowany zamek. To ludzie z gangu Mabusego wkraczają do „pokoju przed kotarą” na umówione na pierwszą spotkanie. Głos bossa zza kotary udziela nagany drukarni za spartaczenie sprawy Hofmeistra i pochwały Sekcji 2-B za sprawne jej „naprawienie”. Kent otrzymuje ostrzeżenie (pierwsze i ostatnie), że kwestionowanie przezeń rozkazów nie będzie tolerowane - organizacja wymaga bezwzględnego posłuszeństwa. Na ulicy Kent i zbesztany przez bossa "drukarz” mijają afisz z obwieszczeniem o nagrodzie za informacje w sprawie zabójstwa Kramma. W Tomie wzbudza on raz jeszcze protest przeciwko zabijaniu, a "drukarza” skłania do przyjacielskiej rady, by nie sprzeciwiać się organizacji.

16. Kent w mieszkaniu kończy tym razem pożegnalny list do Lilli: ona musi o nim zapomnieć, lecz on z pewnością nie zapomni jej nigdy.

17. Kwatera Główna Policji. Technik Weber rozszyfrowuje, iż zadrapania na szybie pozostawione przez Hofmeistra układają się $\mathrm{w}$ napis "Mabuse”. W policyjnym archiwum Lohmann dostaje gruby plik akt z nagłówkiem „Dr. Mabuse, der Spieler” (takim samym, jak tytuł filmu Langa z 1922 r.). Telefon z kliniki Bauma, gdzie komisarz rozkazał zadzwonić swemu asystentowi, informuje, iż Mabuse właśnie umarł. Potwierdza to o chwilę wcześniejsza, krótka przebitka pokazująca kartkę z nazwiskiem „Mabuse" doczepioną do nóg denata. 
18. Zasępiony Kent kontempluje kartkę z wiadomością: „Dziś o północy - dr Mabuse”. „Drukarz” obwieszcza, iż szykuje się nocą grubsza akcja (wezwane zostały Wydziały 5 i 9 oraz Sekcja 2-B) i stara się wyperswadować Kentowi, że sprzeciw jest daremny - doktor jest potężniejszy.

19. W kostnicy Baum odsłania Lohmannowi zwłoki Mabusego.Profesor zdradza się przed komisarzem swym podziwem dla "geniuszu" zmarłego, choć raczej trudno się go dopatrzeć w zrodzonych z mizantropii projektach zniszczenia ludzkości. Rozentuzjazmowany apologią Mabusego Baum mimowolnie wyjawia komisarzowi istnienie swego rodzaju "testamentu" zmarłego w postaci jego zapisków. Lohmann, ku niezadowoleniu profesora, wyraża zainteresowanie nimi; pyta też o Hofmeistra, który jest najświeższym pacjentem kliniki. Baum „dla dobra pacjenta”, kompulsywnie wciąż odtwarzającego traumatyczną scenę przerwanej rozmowy telefonicznej, odmawia policjantowi kontaktu z nim. Z rozmowy pielęgniarzy dowiadujemy się, iż na polecenie profesora Hofmeister trafił do celi przez 10 lat zajmowanej przez Mabusego.

20. Szczególna sekwencja, która w montażu symultanicznym przeplata ze soba dwa miejsca oddalone od siebie przestrzennie, a powiazane akcja w sposób nie do końca oczywisty. Przechodzenie od jednej przestrzeni do drugiej, w obrębie jednak tej samej dramaturgicznie (czy rzeczywiście?) sekwencji, sygnalizuja oznaczenia literowe z liczba wskazująca, które to z kolei odwołanie do tej samej przestrzeni.

20 A1. Poczekalnia przed „pokojem z kotarą”. Ludzie gangu Mabusego zgromadzeni $w$ większej liczbie niż do tej pory. Głos wzywa do szefa Wydział 5.

20 B1. Zbliżenie pliku kartek z maszynowym nagłówkiem: „Zapiski doktora Mabuse, 15 lutego-31 marca". W swym gabinecie profesor Baum szykuje się do ich lektury. Czaszki w gablocie, upiorne egzotyczne maski z gabinetowej kolekcji i demoniczne postacie z ekspresjonistycznego obrazu na ścianie zdają się osaczać go swymi „spojrzeniami”. Uwagę profesora skupia kartka z nagłówkiem Panowanie przestępczości (Herrschaft des Verbrechens), inaugurująca jakby „rozdział”, który zaczyna głośno odczytywać: „Dusza ludzka musi być wstrzaśnięta do samej głębi, przerażona nieprzeniknionymi i na pozór bezsensownymi zbrodniami, z których nikt nie czerpie korzyści, których jedynym celem jest wzbudzenie strachu i terror". Dalszy ciąg tego "manifestu zła”, wypowiadany demonicznym szeptem, zrazu wydaje się dochodzić ze ścian, ale Baum zauważa siedzące naprzeciw niego, z drugiej strony biurka, widmo Mabusego. Jest przeraźliwie zdeformowane, ohydne wyłupiaste oczy niemal wychodzą mu z orbit, a pozbawiona sklepienia czaszka odsłania materię mózgu (jego widmowy status zaznaczony jest niematerialnością i przejrzystością osiągniętym dzięki podwójnej ekspozycji). Potworna zjawa kontynuuje: „Gdyż 
ostatecznym celem zbrodni jest ustanowienie nieograniczonego panowania przestępczości, stan całkowitego poczucia braku bezpieczeństwa i anarchii, ufundowany na skażonych ideałach świata skazanego na zagładę. Kiedy ludzkość ujarzmiona przez terror zbrodni popadnie w szalenstwo wskutek strachu i grozy, i kiedy chaos stanie się nadrzędnym prawem, wtedy nadejdzie czas na PANOWANIE PRZESTĘPCZOŚCI". Widmo Mabusego, dokończywszy tekst, rozdwaja się - jedno nadal siedzi naprzeciw Bauma, drugie wstaje z fotela i znalazłszy się za plecami profesora, podsuwa mu papiery. Baum przejmuje je, a niematerialne widmo siada $\mathrm{w}$ jego fotelu, stapiając się $\mathrm{z}$ masywną postacią psychiatry. Następuje zbliżenie kolejnej kartki zapisków z napisem jakby inaugurującym kolejny rozdział: Ataki na linie kolejowe, zbiorniki z gazem, zaktady chemiczne.

20 A2. Pokój przed kotarą. Wydział 5 wysłuchuje głosu szefa dającego wytyczne do akcji wywołania pożaru w zakładach chemicznych. Ogień swym zasięgiem ma objąć także magazyny i bocznicę z cysternami, i musi być niemożliwy do ugaszenia, gdy przyjedzie straż pożarna. Szef wzywa do siebie Wydział 3 i doktora Hausera.

20 B2. Kartka z zapisków Mabusego z nagłówkiem: Akcje przeciwko bankom $i$ walucie.

20 A3. Pokój przed kotarą. Dr Hauser referuje niewidzialnemu szefowi przebieg działań przeciwko Bankowi Zamorskiemu - obciążające ów bank papiery nie były mu wydane, nawet gdy oferował wielkie sumy, dopóki nie przystał całkowicie na żądania organizacji. Organizacja jest teraz w posiadaniu duplikatów kluczy do skarbca banku, kombinacji do wszystkich jego sejfów i planów systemów alarmowych. Bank otrzyma kompromitujące papiery tylko wtedy, kiedy akcja organizacji zakończy się sukcesem. Hauser po zreferowaniu spraw i przekazaniu „drukarzowi” z Wydziału 3 jakichś pakietów wychodzi. Głos szefa udziela „drukarzowi" i Kentowi instrukcji - mają punktualnie o godzinie 11 włamać się do banku i podrobione banknoty z pieczęciami podłożyć na miejsce zdeponowanych tam dotąd pieniędzy, a bank później sam będzie rozprowadzał fałszywe banknoty. Gdy Kent wzdryga się na rozkaz, iż strażników należy zabić, głos szefa z naciskiem podkreśla raz jeszcze: „Zabić!”. Nie powinno być najmniejszej wskazówki, iż sejfy zostały otwarte. Po zakończeniu akcji, zgodnie z planem, należy uruchomić system alarmowy, aby stworzyć wrażenie, iż była próba włamania, ale została udaremniona.

21. Pomimo otrzymania pożegnalnego listu Lilli czeka na Toma na klatce schodowej jego domu. Zaskoczony jej obecnością Kent zaprasza ją do siebie i wyjaśnia swą kryminalną przeszłość: zabił przyjaciela i swą dziewczynę, która go z nim zdradziła, a z więzienia został zwolniony za dobre sprawowanie. Dziś nie jest bezrobotny, ma pieniądze i mieszkanie tylko dlatego, że pracuje dla szajki przestępczej przy fałszowaniu pieniędzy 
(retrospekcja 21a pokazuje bezwzględność organizacji Mabusego poprzez dyrektywy, jakich głos szefa w pokoju przed kotarą udziela Sekcji 2-B: „Wraz ze zniszczeniem plonów trzeba zatruć zapasy wody. Epidemie wszelkich możliwych chorób maja złamać opór ludności. Ostrzeżenie dla elementów chwiejnych nie będzie ponawiane. Najmniejsza oznaka zdrady będzie natychmiast karana śmierciq"; trochę nielogicznie retrospekcja ta ma status opowieści Toma dla Lilli). Niezrażona niczym Lilli odpowiada, iż ma nadzieję, że swą miłością wyrwie go z rozpaczy i przywróci mu wiarę w siebie. Padają sobie w ramiona.

22. Wydział $3 \mathrm{w}$ wytwórni fałszywych pieniędzy starannie obwiązuje banderolami paczuszki podrobionych banknotów, które mają być podrzucone do banku. „Drukarz", skoro Kent nie stawił się do roboty, a czekał nań do ostatniej chwili, powiadamia telefonicznie Sekcję 2-B o tej niesubordynacji.

Od sceny 23 do sceny 40 sjużet przeplata w montażu symultanicznym dwie osobne linie akcji, które spotkaja się za jakiś czas (jedna - to watek Kenta i Lilli, druga - Lohmanna i jego akcji przeciw ludziom Mabusego). Trudno w tym wypadku o bezdyskusyjna segmentacje sjużetu na jednostki dramaturgiczne. Przeskoki rozbijaja jedność scen, ale też, jak to zazwyczaj bywa w montażu symultanicznym, ułatwiaja pomijanie mniej interesujacych partii czasu poprzez elipsy.

23. W mieszkaniu Kenta. Lilli radzi Tomowi, by udać się po pomoc do Lohmanna, niegdyś przychylnego mu w jego opresji.

24. Pogrążonego w swym biurze w głębokiej drzemce Lohmanna budzą jego ludzie z wieścią iż namierzyli „brylantową Annę”, gdy paradowała w prawdziwych, bardzo drogich perłach. To kochanka znanego nam już ,jubilera” z gangu Mabusego, co unaocznia krótka przebitka na przestępczą parę w ich mieszkaniu-kryjówce (24a).

25. Uzbrojony w rewolwer jednonogi żebrak i Hardy z Sekcji 2-B zgarniają Toma i Lilli na ulicy przed domem Kenta, a następnie pod bronią ładują do samochodu.

26. Lohmann wysyła swych dwóch policjantów na akcję przeciwko grupie ,jubilera" i radzi, by byli ostrożni.

27. Ludzie z Sekcji 2-B dostarczają Toma i Lilli do „pokoju przed kotarą". Za niesubordynację głos szefa skazuje Kenta na śmierć, zginąć ma także Lilli. Tom w desperacji strzela do sylwetki „człowieka za kotarą", ale gdy wraz z Lilli wdzierają się za kotarę, ich oczom ukazuje się, iż był to wycięty z tektury kontur postaci (obecnie podziurawiony kulami). $\mathrm{Na}$ stole, za którym „siedział” kontur, znajduje się mikrofon i głośnik. Ten ostatni, choć też przeszyty pociskiem, nadal transmituje głos znajdującego się gd zi eś in d zi ej szefa, który obwieszcza, iż nie opuszczą już pokoju, w którym się znaleźli, a pozostały im jeszcze trzy godziny życia. Od tej chwili para skazanych słyszy dobiegające skądś, niemożliwe do 
zlokalizowania, tykanie odmierzającej czas ich życia bomby (to kolejny, szczególny zreszta, Langowski zegar).

28. Dźwięk tykającej bomby niepostrzeżenie przechodzi w odgłos stukania łyżeczką w skorupkę jajka, które przenosi nas do kryjówki „brylantowej Anny", gdzie "jubiler" akurat spożywa śniadanie. Są tam też Karetzky oraz znani nam dwaj ludzie z Sekcji 2-B: Hardy, zabójca Kramma i jego kierowca. Dzwonek do drzwi przebranego za inkasenta człowieka Lohmanna inicjuje akcję policji przeciw gangowi. Hardy rani kulą jednego z policjantów i postanawia ostrzeliwać się przy zabarykadowanych drzwiach mieszkania, podczas gdy reszcie gangu rozkazuje próbować znaleźć drogę ucieczki przez sufit.

29. Uwięzieni Kent i Lilli daremnie szukają sposobu wydostania się z pokoju-pułapki. W ścieżce dźwiękowej wciąż słychać tykającą bombę.

30. Gdy członkowie gangu zniechęceni niemożnością przekucia sufitu chcą się poddać, Hardy zaprowadza w oblężonym mieszkaniu terror swemu kierowcy każe „słabeuszy” trzymać na muszce, a sam dalej desperacko ostrzeliwuje klatkę schodową z zabarykadowanych drzwi.

31. Kolejny wysiłek Toma i Lilli okazuje się daremny - za ceglaną ściana, którą usiłowali rozbić, znajduje się stalowa płyta. Oboje wydają się zrezygnowani.

32. Hardy zostaje ranny podczas ostrzału. Członkowie gangu odnoszą go w głąb mieszkania, a klatkę schodową dalej ostrzeliwuje kierowca. Pomimo ostrzału Lohmann z szaleńczą odwagą dostaje się pod drzwi oblężonego pomieszczenia i osobiście stawia gangowi ultimatum. Pozbawieni ducha (i terroru) Hardy'ego gangsterzy rzucają broń i z podniesionymi rękoma wychodzą. Z mieszkania dochodzi strzał - Hardy popełnił samobójstwo. Pistolet, który wypadł z jego martwej dłoni, podnosi komisarz, przypominając sobie, iż z takiej właśnie broni zastrzelono Kramma. Dalszy ciąg (32a) ma już miejsce w biurze Lohmanna. Przesłuchiwany kierowca z Sekcji 2-B nie chce przyznać się do zabójstwa lekarza.

33. Zdesperowany Kent postanawia przebić rurę wodociągową by woda zalewająca pokój-pułapkę zamortyzowała wybuch bomby.

34. Lohmann zastawia pułapkę na kierowcę, demonstruje mu, iż kula, z której zabito Kramma, i kula, którą wyjęto z pistoletu jego martwego wspólnika, są identyczne. Gangster pasuje, zdradza Lohmannowi istnienie „szefa”, ale zastrzega, iż nic nie wie o jego tożsamości.

35. Pokój-pułapka z uwięzionymi w nim Tomem i Lilli, pełen wciąż wzbierającej wody.

36. Przyciśnięty przez Lohmanna kierowca zeznaje o akcji zabójstwa Kramma na rogu Körnerstraße i Grüner Winkel. Tknięty tym adresem komisarz konstatuje, iż nieopodal znajduje się klinika Bauma i że to 
prawdopodobnie tam denat spędził ostatnie godziny życia. Dzwoni do archiwum policji, czy nie mają czegoś w papierach na profesora.

37. Krótka przebitka na Lilli i Kenta uczepionych kotary, gdy woda na znaczną już wysokość zalewa pokój-pułapkę.

38. Skoro archiwum nie ma o Baumie żadnych danych, Lohmann dzwoni do profesora (przebitka 38a: Baum nad zapiskami Mabusego) i pod fałszywym pretekstem konfrontacji z kimś, kto podaje się za eks-pacjenta jego kliniki, prosi, by przybył na policję.

39. Woda w niemal po sufit zalanym pokoju istotnie amortyzuje wybuch bomby. Lej po eksplozji, którym wycieka woda, wskazuje Kentowi i Lilli drogę ucieczki.

40. Konfrontacja na policji nic nie daje - ani członkowie gangu Mabusego nie rozpoznają Bauma, ani on nie przyznaje się, iż zna kierowcę z Sekcji 2-B, który miał być rzekomo jego pacjentem. Gdy Baum wczytuje się w afisz z obwieszczeniem o śmierci Kramma, Lohmann czyni mu wyrzut, iż nie zgłosił policji, że to właśnie w jego klinice zmarły kolega spędził ostatnie chwile przed swą tragiczną śmiercią. Profesor tłumaczy się zapracowaniem i brakiem czasu na czytanie obwieszczeń. Do Lohmanna przybywają ocaleni ze śmiertelnej pułapki Kent i Lilli. Baum mimowoli zdradza się przed Lohmannem, iż zna Kenta, kiedy zaskoczony faktem, że Tom żyje, powtarza na głos jego nazwisko - ale oczywiście zaprzecza, iż go zna. Już po odejściu profesora indagowany przez Lohmanna Tom twierdzi, że go nie zna. Opowiada za to komisarzowi, iż szefem gangu jest dr Mabuse. Lohmann w pierwszej chwili uznaje to za absurd, skoro Mabuse umarl, ale po zastanowieniu dochodzi do wniosku, iż ktoś może po prostu posługiwać się tym nazwiskiem. Pod koniec sceny krótka przebitka (40a) na klinikę Bauma - profesor, wchodząc do swego gabinetu, mówi Winklerowi, że nie ma go dla nikogo i by pod żadnym pozorem nie przeszkadzano mu w pracy.

41. Kiedy Lohmann z Kentem chcą wejść do gabinetu Bauma, zza drzwi rozlega się: „Jestem zajęty, proszę mi nie przeszkadzać”. Tom rozpoznaje teraz ten głos jako należący do szefa. Włamują się do gabinetu, ale nikogo w nim nie ma. Lohmann odkrywa za to mechanizm uruchamiający płytę z nagranym przez profesora zakazem przeszkadzania $\mathrm{mu}$, gdy nacisnęło się klamkę drzwi od gabinetu. Uwagę komisarza zwraca rozłożony na biurku plan północnej części miasta z zaznaczonymi na nim zakładami chemicznymi „Löhr und Stegerwald”, aktualną datą 15 października i godziną 20:30 (a jest już 21:10). Z leżących obok planu Zapisków doktora Mabuse przerażony komisarz konkluduje, iż chodzi o trwającą już jakiś czas akcję terrorystyczną. Znaleziony przez Lohmanna tekst głosi m.in.: „Pożaru tak wywołanego w magazynach zakładów chemicznych nie moga ugasić strażacy. Zbiorniki eksplodujące pod 
wpływem temperatury szybko uwolnia ogromne ilości trującego gazu na tereny otaczajace miasto".

42. Przenikanie przenosi nas z zapisków Mabusego pod płonące zakłady chemiczne. W ogłuszającym huku pożaru i eksplozji oraz wyjących syren strażackich walą się wielkie kominy fabryki, płoną i wybuchają beczki z łatwopalnymi materiałami na bocznicy kolejowej, strażacy ewakuują zagrożony pociąg z cysternami. Lohmann i Kent przybywaja, kiedy rozpętane piekło trwa już na dobre. Tom zauważa w świetle pożaru Bauma przyglądającego się zza krzaków dziełu zniszczenia. Wywiązuje się pościg samochodowy, w którym mimo szaleńczej prędkości komisarz i Tom nie zdołają dogonić wozu profesora - auto Lohmanna łapie gumę. Baum, kierowany przez widmo Mabusego, pędzi na oślep do... swej kliniki. Widmo otwiera mu bramę, wręcza plik kartek z zapiskami Mabusego i prowadzi do celi niegdyś zajmowanej przez Mabusego, a obecnie okupowanej przez Hofmeistra. Baum, wchodząc tam, wita Hofmeistra słowami: „Pan pozwoli, że się przedstawię. Nazywam się Mabuse... Doktor Mabuse”. Pielęgniarzy dobiegają wrzask Hofmeistra: „Mabuse!” i odgłosy walki. Gdy Lohmann i Kent przybywają wreszcie do kliniki, prowadzony przez pielęgniarzy, znienacka wyzdrowiały i przytomny Hofmeister kończy wreszcie swą przerwaną niegdyś wiadomość: „Panie komisarzu, ów człowiek nazywa się Mabuse". Tymczasem w celi oszalały Baum, siedząc na łóżku, drze na strzępy zapiski swego eks-pacjenta (rozrzuconymi kartkami usiana jest cała podłoga wokół niego). Lohmann, obserwujący z progu to smutne widowisko, mówi Kentowi, iż policjant do spraw kryminalnych nie ma tu już nic więcej do roboty.

\section{Niby-kryminał o narracji pełnej „rymów”}

Testament doktora Mabuse jest w twórczości Langa kolejnym, po Doktorze Mabuse, graczu (1922) i Szpiegach (Spione, 1928), filmem o superprzestępcy. Nic dziwnego zatem, że pełno w nim repetycji - zarówno w zakresie narracji, która jednak powiela wypracowane wcześniej, zwłaszcza w Szpiegach, tryb montażu i stylistykę kadru, jak i w sferze motywów wizualnych czy fabularnych tematów ${ }^{15}$. Wizualnie dominuje tu, podobnie jak w Szpiegach,

15 Powraca predylekcja Langa do częstych zbliżeń rozmaitych detali, w sposób metonimiczny czy synekdochiczny sygnalizujących jakąś akcję (np. bliski plan dłoni otwierających szyfrowany zamek na początku segmentu 15, czy zbliżenie dłoni z pistoletem jako metonimii samobójstwa w segmencie 32, to niemal powtórki bardzo podobnych ujęć ze Szpiegów). W finale filmu - podobnie jak na zakończenie Zmęczonej Śmierci, Nibelungów i Metropolis - znów mamy do czynienia z apokaliptycznym pożarem. Zabójstwo doktora Kramma w korku samochodowym to kolejny, czwarty już (i nieostatni w filmach 
Kobiecie na Księżycu i $M$ - mordercy, chłodny, dość ascetyczny styl Nowej Rzeczowości, choć jak i w tamtych filmach zdarzają się niewielkie wtręty rodem z ekspresjonizmu. Do malarstwa tego nurtu czy do stylistyki filmów Roberta Wiene (Gabinet doktora Caligari, Genuine) nawiązuje design celi na komisariacie, gdzie w chwili przyjścia Lohmanna Hofmeister aktualizuje traumatyczne wspomnienie: idących ku niemu zabójców z Sekcji 2-B. Odczucie tego kadru jako ekspresjonistycznego ułatwia zresztą podwójna ekspozycja, nakładająca na wchodzących do celi Lohmanna i lekarza obraz pary zbirów. Innym takim wtrętem jest zrealizowana w niskim kluczu i eksponująca kubistyczno-ekspresjonistyczny design egzotycznych masek oraz obrazu na ścianie gabinetu scena 20 B1, kiedy widmo upiornie zmienionego po śmierci Mabusego (też zresztą bardzo ekspresjonistyczne) „wciela” się w Bauma, „namaszczając” go jako kolejną swą inkarnację. Niewątpliwie ekspresjonistyczne są też eksponowane w zbliżeniach rysunki na niektórych kartkach z zapiskami Mabusego oraz sam graficzny układ na nich liter i cyfr.

Testament to drugi film dźwiękowy Langa i, podobnie jak dwa lata wcześniejszy $M$ - morderca, pełen pomysłowych rozwiązań w zakresie zarówno estetycznie autotelicznego, jak i dramaturgicznie funkcjonalnego wykorzystania dźwięku. Pamiętna jest rozegrana bez słów, za to pełna ogłuszającego, rytmicznego huku jakichś niewidzialnych maszyn (drukujących fałszywe banknoty?) początkowa scena, kiedy ludzie z Wydziału 3 gangu Mabusego-Bauma nakrywają szpiegującego Hofmeistra. Huk - percepcyjnie trudny do zniesienia - wzmaga niewątpliwie suspens i nadaje początkowi filmu niesamowitej, infernalnej aury. Taką niepokojącą aurę sekwencji 20 B1 prócz wspomnianego wyżej niskiego klucza oraz ekspresjonistycznego designu obrazu i masek nadaje także demoniczny szept widma, wypełniający niemal całą przestrzeń gabinetu Bauma, wydający się zrazu rozchodzić ze ścian i niemal rozsadzający czaszkę profesora. Niewątpliwie suspensotwórcze jest ciche, ale nieubłagane w swej jednostajności tykanie bomby w pokoju-pułapce, z uwięzionymi w nim

\footnotetext{
Langa) wariant „zbrodni na ulicy”, której okoliczności przypominają zabójstwo Walthera Rathenaua (poprzednie to zabójstwo Pescha w Doktorze Mabuse, graczu, zabójstwo ministra handlu w prologu Szpiegów, obrabowanie Heliusa w Kobiecie na Księżycu). Tom Gunning (The Films of Fritz Lang: Allegories of Vision and Modernity, BFI Publishing, London 2000, s. 141) zwraca też uwagę na obecny w Testamencie wizualny motyw "pisania palcem w powietrzu", gdy postać intensywnie myśli nad jakimś zaprzątającym ją problemem. Lohmann, bo to jego gest, oczywiście zachowuje się w drugim z filmów ze swym udziałem podobnie jak w $M$ - mordercy, ale taki gest wykonywała też Sonia Barranikowa w Szpiegach. W Testamencie także szalony Mabuse pisze palcem w powietrzu, dopóki nie zostaną mu dostarczone kartki do jego zapisków. Mówiąc o tym studentom podczas wykładu, gest ten powtarza także Baum.
} 
Tomem i Lilli. Jednak chyba najciekawszy dramaturgicznie aspekt dźwięku to fakt, iż głos Bauma słyszanego na żywo Kent uznaje za należący do nieznanej mu osoby, natomiast natychmiast rozpoznaje go, kiedy usłyszał głos technicznie zapośredniczony nagraniem na płycie i emisją przez głośnik; tak bowiem zmediatyzowany, zmieniony przez mikrofon, transmisję i głośnik, docierał dotąd do niego głos szefa. Ten moment wydaje się też swego rodzaju autotematyczną refleksją na temat statusu głosu i w ogóle dźwięku w filmie.

Pewna skaza wcześniejszych scenariuszy Langa i Thei von Harbou - skłonność do przesłodzonego melodramatyzmu w wątku miłosnym i do "barokowych" rozwiązań dramaturgicznych w wątku sensacyjnym - w tym filmie ujawnia się z całą jaskrawościa, przesłaniając kiczem i absurdem to, co faktycznie jest interesujące i nowatorskie. A najciekawsze są chyba sprzeczności w zakresie logiki fabularnej i spójności przestrzennej, które podobnie jak we wcześniejszych filmach (np. w Zmęczonej Śmierci, Nibelungach czy Szpiegach) kreują intrygująca, ambiwalentna, modernistyczną z ducha narrację, chociaż w Testamencie - porównywalnie zresztą do Metropolis - mogą też wydawać się po prostu potknięciami dramaturgii czy błędami w konstrukcji.

Tryb narracji w ostatnim weimarskim filmie Langa najbardziej chyba przy pomina Szpiegów. Sjużet składa się z około 40 scen (dokładna ich liczba to rzecz dość dyskusyjna), przeplatających się w ten sposób, iż mamy wrażenie symultaniczności rozmaitych linii akcji. Upływ czasu w obrębie każdej ze scen powoduje, że gdy przechodzimy montażowo do kolejnej sceny, rozgrywającej się „gdzieś indziej”, ale niby-to "równocześnie”, to faktycznie przechodzimy do akcji rozgrywającej się jednak ni e co późn iej niż ta, którą śledziliśmy w dopiero co obejrzanej scenie. Przeskoki w montażu symultanicznym ze sceny do sceny i zjednej przestrzeni do drugiejułatwiają narracji faktyczne maskowanie przed widzem elips - czyli pomijania w sjużecie pewnych partii czasu. Symultaniczność oczywiście najbardziej zwraca na siebie uwagę, gdy w scenach między 23 a 40 sjużet przeplata linię akcji związaną z działaniami komisarza Lohmanna przeciwko gangowi Mabusego/Bauma z wątkiem Kenta i Lilli uwięzionych w pokoju-pułapce. Oczywiście, przeplatanie dwóch linii akcji fabularnej z sugestią ich symultaniczności jest znane w kinie niemal od samych początków (vide: filmy Brightończyków czy Edwina Portera), ale kanoniczną postać uzyskało ono w sekwencjach pościgów i last-minute-rescues w filmach Davida Warka Griffitha. Warto zauważyć, iż w sekwencjach pościgowych dwie (przynajmniej) linie akcji są od siebie wzajemnie zależne, kreując suspens: ścigający złapią czy nie złapią przestępców? dążący na ratunek zdążą czy nie zdążą ocalić znajdujących się w niebezpieczeństwie? Wskutek takiego powiązania, jak to wykazał David Bordwell, analizując sławetną 
sekwencję jazdy Ku-Klux-Klanu na ratunek Elsie Stoneman i oblężonych Cameronów w Narodzinach narodu (The Birth of a Nation, 1915), czas w każdej z linii akcji płynie nieco inaczej: w jednej szybciej (np. skracanie czasu i przestrzeni do przebycia jadącym na ratunek), w drugiej wolniej (np. przedłużanie nadziei na ratunek znajdującym się $\mathrm{w}$ niebezpieczeństwie, które jest od nich tuż-tuż ${ }^{16}$. W narracji Testamentu doktora Mabuse na ogół brak takich dialektycznych relacji: owszem, w scenie 40 (wedle powyższej segmentacji) biegnące równolegle w sjużecie wątki Lohmanna oraz Kenta i Lilli spotykają się, jednak brak było między nimi dramaturgicznej zależności. Nie od komisarza zależy, czy Tom i Lilli wydostaną się ze śmiertelnej pułapki. Ale, oczywiście, przeskok do drugiej linii akcji maskuje elipsę: gdy od akcji ludzi Lohmanna przeciwko gangowi (scena 28) wracamy do pokoju-pułapki (scena 29), widzimy częściowo wyrwane z podłogi deski czy ślady na ścianach, świadczące o desperackich próbach wydostania się pary z opresji. A kiedy po tej scenie znowu przenosimy się do mieszkania oblężonych przez ludzi Lohmanna gangsterów (scena 30), dostrzegamy rezultat zapewne dłuższej i nieskutecznej akcji przebicia się na wyższe piętro w postaci niewielkiej tylko dziury w suficie i sporej ilości tynku na stole i podłodze pod nią. Niezbyt chyba atrakcyjne dla widza w tym wypadku (wbrew sławetnej definicji Karola Irzykowskiego ${ }^{17}$ ) zmaganie się człowieka z materią zostało w sjużecie pominięte - dzięki przeskokom montażowym widzimy rezultaty „nudnych” działań bohaterów (rezultaty konieczne dla rozumienia akcji) bez konieczności nudzenia się podczas patrzenia, jak Tom próbuje podważyć i wyrwać deski podłogowe czy Karetzky wywiercić dziurę w suficie.

W sekwencji 42, którą wyodrębniłem jako jedną jednostkę sjużetu ze względu na ciągłość dramaturgiczna, w jej środkowej części mamy do czynienia z dwiema przeplatającymi się liniami symultanicznej akcji - ale nic w tym dziwnego, bo jest to przykład sekwencji pościgowej: Baum ucieka swym autem przed Lohmannem i Kentem goniącymi go samochodem policyjnym. Ten fragment filmu wydaje się kreować typowy dla filmowych pościgów suspens: czy komisarz dogoni Bauma, o którym już wie, iż jest szefem zbrodniczego "gangu Mabusego"? Suspens zdaje się wzmagać przez coraz większą prędkość jazdy, przeszkody trafiające się na drodze (zamykany przejazd kolejowy, wóz, który Baum płynnie mija, a który samochodowi policyjnemu zagradza drogę). Ostatecznie profesor wydaje

\footnotetext{
16 Por. David Bordwell, Narration in the Fiction Film, University of Wisconsin Press, Madison 1985, s. 84.

17 „Kino jest widzialnością obcowania człowieka z materią” - Karol Irzykowski, X Muza: Zagadnienia estetyczne kina, Wydawnictwa Artystyczne i Filmowe, Warszawa 1977, s. 26.
} 
się być góra, gdyż auto komisarza łapie gumę. I po tych chwilowych emocjach, zupełnie one pryskaja, a suspens okazuje się pozorny, gdy dowiadujemy się, iż Baum donikąd przed komisarzem nie uciekał, ale „opętany duchem Mabusego" (co unaocznia wizualizacja widma w podwójnej ekspozycji) po prostu wracał do swojej kliniki, by zająć w niej dawne miejsce swego „mistrza” i eks-pacjenta w jednej osobie. Suspens pościgu okazał się jedynie "suspensem percepcyjnym” - dramaturgicznie właściwie go nie było, a raczej był udawany. Podobnie zresztą cały film swym sztafażem (komisarz policji, śledztwo, morderstwo, przygotowywane akcje terrorystyczne) udaje film kryminalny, choć kluczowy dla „rozwiązania zagadki” (o ile w ogóle o takiej można tu mówić) motyw „wcielenia się" zbrodniczej jaźni Mabusego w osobę zajmującego się nim psychiatry przenosi nas z wykluczającego metafizyczne uzasadnienie kryminału w dziedzinę fantastyki.

Wrażenie, iż narracja niemal całego filmu opiera się przede wszystkim o montaż symultaniczny, budowane jest przez permanentny chwyt - łączenie poszczególnych segmentów dramaturgicznych w sposób, który Noël Burch nazywa „ry mowanie m” ${ }^{18}$. Jest to właściwie bardzo bliskie temu, co analizowane już było przy okazji filmu Szpiedzy jako montaż e rotetyczny (udzielanie natychmiastowej odpowiedzi przez następujące po pytaniu ujęcie) oraz montaż o charakterze i r o n i c z nego kontrapunktu. Burch pisze: „Oczywiście, w Testamencie doktora Mabuse można znaleźć artykulacje tego samego typu - przez pytanie i odpowiedź, przez myślowe skojarzenie lub po prostu przez przyczynę i skutek - ale znajdzie się też wiele innych nieredukowalnych w taki sposób do materii fabularnej, takich, które równocześnie odsłaniaja, poprzez bliski związek, jaki mają z artykulacjami «fabularnymi» - istnienie znacznie ogólniejszej kategorii artykulacji między ujęciami zupełnie nieciągłymi przestrzennie (innymi słowy, między sekwencjami [podkr. - T. K.]). Tę kategorię nazywam «ry m e m». A w Testamencie Lang poddał rym procesowi wariacji co najmniej równie bogatemu, jak ten, któremu podlegała elipsa w Szpiegach"19.

Poręcznie będzie mi się tu posłużyć wywodem Toma Gunninga, który wykorzystał Burchowską kategorię „rymu” między sekwencjami w swym opisie wiązań montażowych między pierwszymi pięcioma segmentami dramaturgicznymi Testamentu doktora Mabuse. „Sekwencja pierwsza, próba ucieczki Hofmeistra przed gangiem Mabusego - pisze Gunning - kończy

18 Por. Noël Burch, Fritz Lang: German Period, [w:] Cinema: A Critical Dictionary. The Major Film-Makers, ed. Richard Roud, vol. 2: Kinugasa to Zanussi, Secker \& Warburg, London 1980, s. 591-593.

19 Ibidem, s. 592. 
się eksplozją beczki z łatwopalną substancją która wypełnia kadr płomieniami. Gdy ujęcie się ściemnia, słyszymy głos Lohmanna z następnej sceny, wykrzykujący: «Feuerzauber!»(«magiczne ognie»). Może się wydawać, że głos ten komentuje płomienie, które widzimy, ale gdy rozjaśnienie przenosi nas do następnej sceny w Kwaterze Głównej Policji, odkrywamy, iż Lohmann omawia muzyczny motyw z Walkirii Wagnera. Sekwencja kończy się wyśpiewywaniem przez oszalałego Hofmeistra do telefonu i reakcją Lohmanna: «Musiał ze strachu postradać zmysły». Lang tnie bezpośrednio do półzbliżenia profesora Bauma zwróconego do kamery i obwieszczającego, że «nie są niczym niezwykłym przypadki», że nagły strach czy przerażenie może spowodować utratę rozumu. Zakładamy, że mówi on o Hofmeistrze, ale w rzeczywistości to początek jego wykładu dla studentów o doktorze Mabuse. Wykład kończy się opisem planów przestępstw przygotowanych przez Mabusego, przestępstw dopracowanych do najdrobniejszych szczegółów. Lang tnie z sali wykładowej do ogólnego planu zebrania członków gangu, słuchających «drukarza», który wyjaśnia, iż jeśli tylko będą realizować «plan doktora», nic nie może pójść źle. Scena kończy się widokiem «drukarza», jak z niedowierzaniem mówi do telefonu: «Lohmann we własnej osobie?» Lang tnie do Lohmanna, badającego scenerię przerwanej rozmowy telefonicznej Hofmeistra" ${ }^{20}$.

Takich międzysekwencyjnych wiązań jest w filmie oczywiście więcej. Przywołajmy tu choćby nagłówek z pierwszej strony gazety informujący o kradzieży kosztowności za 250 tys. marek (ostatni obraz sekwencji 9) i wycenę łupu na takąż kwotę przez ,jubilera” z gangu Mabusego (początek segmentu 10). Gdy w tym przykładzie wiązanie jest, by tak rzec, „,wprost”, to już np. „rymy” między pointą segmentu 17 i początkiem segmentu 18 oraz między segmentami 18 i 19, są raczej à rebours, tworząc, jak w omawianych wcześniej przykładach ze Szpiegów, rodzaj i ronicznego kontra punktu. Odkrycie przez Lohmanna, iż Mabuse umarł (unaocznione chwilę wcześniej przebitką z synekdochicznym obrazem jego zwłok), kontrastuje z odczytywanym przez Kenta, wypełnionym maszynowym pismem, wezwaniem: „Dziś o północy - doktor Mabuse”, którego zbliżenie inauguruje następną, krótką zreszta, scenę filmu. W przypadku „rymu” między segmentem 18 i 19 wektor ironii skierowany jest w przeciwną stronę - przekonanie gangstera o potędze "doktora" kontrapunktowane jest obrazem martwego ciała Mabusego, które w kostnicy Baum odsłania Lohmannowi.

Jawnie ironiczny charakter ma też „zrymowanie się" tykania bomby z odgłosem stukania łyżeczką w skorupkę jajka (sceny 27/28) - przy okazji warto odnotować tu nowatorskie zastosowanie dźwięku w postaci „gagu

20 T. Gunning, op. cit., s. 144-145. 
dźwiękowego”. Może nie akurat „rymem” w ściśle Burchowskim rozumieniu tej kategorii, ale zabawnym pa ra leli zme m między dwoma liniami symultanicznych akcji (ujawniającym zarazem pod obieńs two, jak i przeciwieństwo rozwiązania) jest zestawienie nieudanej ucieczki gangsterówprzez dziurę w suficiez udaną ucieczką Toma i Lilli przez dziurę w podłodze. Jako przykład takiej ironii wypada też potraktować montażowe zestawienie zeznania skruszonego kierowcy z Sekcji 2-B, który mówi zirytowanemu Lohmannowi o istnieniu potężnego i tajemniczego szefa gangu (scena 34), z obrazem przestrzelonego przez Kenta konturu "szefa”, do połowy już zatopionego w zalewanym przez wodę „pokoju z kotarą".

"Rym” może także kamuflować elipsę przez graficzne podobieństwo kadrów i/albo tożsamość przedmiotu w kadrze. W segmencie 32 widzimy w zbliżeniu wypadający z ręki martwego Hardy'ego pistolet, który za chwilę unosi jakaś inna dłoń. Ten sam pistolet w tej samej dłoni, po ledwie zauważalnym cięciu, okazuje się jednak znajdować już w całkiem innej przestrzeni - Lohmann, który w kryjówce gangsterów zainteresował się bronią samobójcy, w ujęciu drugim ukazany jest w swoim biurze podczas oględzin pistoletu, z którego, jak trafnie odgadł, zastrzelono doktora Kramma. A swoją droga, kadr ze zbliżeniem broni jako synekdocha samobójstwa to niemal znak rozpoznawczy Langa - obraz taki napotkamy zarówno we wcześniejszych filmach reżysera (Metropolis, Szpiedzy), jak i w późniejszym od Testamentu o dwadzieścia lat Bannionie (The Big Heat, 1953).

W rozpisaniu sjużetu segment 20 wyodrębiłem jako jedną całostkę dramaturgiczna, ale po wahaniach, czego świadectwem jest zresztą rozbicie go na aż pięć podsegmentów. Oczywiście, skoro akcja w podsegmentach oznaczonych literą $A$ ma miejsce $w$ innej przestrzeni niż akcja $\mathrm{w}$ podsegmentach oznaczonych B, można by też uznać całą sekwencję 20 za pięć segmentów przeplatających się symultanicznie, podobnie jak segmenty 23-40. Wówczas przejścia B1/A2 i B2/A3 (z nagłówków stosownych „rozdziałów" w zapiskach Mabusego do odpraw w "pokoju przed kotarą", odpowiednio, Wydziału 5 i Wydziału 3, czyli "chemicznej” i „finansowej” sekcji gangu) byłyby jeszcze jednymi „rymami” międzysekwencyjnymi. Sprawa jest jednak bardziej zawiła, zarówno w aspekcie logiki fabuły, jak i fizykalnej spójności przestrzeni świata przedstawionego.

Przejścia te zdają się nadawać podsegmentom segmentu 20 je d n o ść a kcji fabula rn ej-Baum zainspirowany lekturą zapisków Mabusego (B1, B2) wydaje odpowiednim oddziałom swego (?) gangu rozkaz przygotowania akcji ",chemicznego terroryzmu” przez podpalenie chemicznych zakładów (A2) i „finansowego chaosu” przez rozprowadzenie fałszywego pieniądza (A3). Unaocznienie nam w podsegmencie B1 „wcielenia się" 
w Bauma widma Mabusego i przekazania przez nie profesorowi papierów odbieramy jako ostateczną kropkę nad ,i": Mabuse po swej fizycznej śmierci definitywnie zawładnął osobą psychiatry, który odtąd będzie posłusznie realizował jego plany (na to byliśmy już wcześniej przygotowani - vide: entuzjazm, z jakim Baum mówi o "geniuszu” swego pacjenta podczas wykładu dla studentów i w rozmowie z komisarzem, czy moment w scenie 6, kiedy profesor jakby doznał „przywidzenia”, dostrzegłszy stojące naprzeciw siebie widmo Mabusego w chwili, kiedy sam żywemu jeszcze Mabusemu badał puls). Ale w aspekcie logiki fabularnej coś tu nie $\mathrm{g} \mathrm{r}$ a: Baum nie mógł zostać przez ducha swego zmarłego pacjenta dopiero teraz, w podsegmencie 20 B1 namaszczony jako szef gangu, jako nowy a w a t a r superprzestępcy, bo przecież "gang Mabusego-Bauma" działał wcześniej, o czym świadczą: sekwencja 1, akcja przeciw Hofmeistrowi, zabójstwo Kramma czy wyznanie Kenta dla Lilli (21a). Co więcej, jak dowodzą segmenty 18 i 20 A1 czy sprawozdanie doktora Hausera o skuteczności szantażu wobec Banku Zamorskiego, zwołanie sekcji „,chemicznej” $\mathrm{i}$ „finansowej” gangu na tę konkretną, unaocznioną w sjużecie noc, było zaplanowane znacznie wcześniej, a rozkazy dla nich były uprzednio starannie przemyślane i wynikały z wcześniejszych działań gangu. Ta nieodparta logika kolejności zdarzeń stoi w ewidentnej sprzeczności ze stylem narracji, która poprzez symultaniczny montaż „na rymach” zdaje się sugerować, iż inspiracja dla rozkazów dla gangu zrodziła się tej nocy pod wpływem lektury przez Bauma zapisków Mabusego i „namaszczenia” profesora przez ducha zmarłego na "następcę”. Oczywiście, można by też uznać, że zdarzenia ciągu B (lektura i ceremonia „namaszczenia”) wbrew naprzemienności w sjużecie wcale nie są symultaniczne do ciągu A (odprawa w „pokoju z kotarą"). Mogłoby to wprawdzie jakoś wyjaśnić innego typu sprzeczności - związane z przestrzenią ale czyniłoby narrację Testamentu doktora Mabuse aż nazbyt awangardową w swej zwodniczości, a nie wydaje się ona taką podczas normalnego odbioru filmu.

Niespójność czy zagadkowość przestrzeni w segmencie 20, ale i w całym filmie, ujawnia się zwłaszcza wtedy, kiedy zaczynamy się zastanawiać, gdzie fizycznie znajduje się Baum (bo przecież jednak nie Mabuse), gdy mają miejsce odprawy gangu w "pokoju z kotarą" oraz gdy zapada wyrok na Toma i Lilli. Kent, strzelając do sylwetki człowieka za kotara, demaskuje, iż był on jedynie czymś w rodzaju „stracha na wróble”, tandetną sugestią obecności groźnego szefa, który podczas odpraw był istotnie obecny, ale gdzie indziej niż za kotarą i w inny sposób. Gdzie zatem i jak?

Głos Bauma dochodzi do „pokoju z kotarą” poprzez umieszczony na stole przed atrapą szefa głośnik. Ale s ką d Baum nadaje? Mechanizm uruchamiający płytę z głosem profesora przez naciśnięcie klamki jego 
gabinetu miał działać wtedy właśnie, gdy był on "zajęty" - nie tyle pracą naukowa, co przekazywaniem rozkazów gangowi. Czyżby centrum dowodzenia mieściło się $\mathrm{w}$ klinice, $\mathrm{w}$ gabinecie profesora? Jednak Lohmann po włamaniu się tam, choć demaskuje mechanizm przy drzwiach, nie odkrywa żadnego "studia nadawczego" czy "centrum dyspozycyjnego". Montaż symultaniczny w segmencie 20 sugeruje nam jednak równoczesność obecności profesora w swym gabinecie i wydawania przezeń dyspozycji dla gangu. Z wrażeniem tym kłóci się z kolei poczucie bezpośredniej fizycznej obecności szefa w "pokoju z kotarą": Kent nie wypowiada na głos żadnego słowa sprzeciwu wobec rozkazu zabicia strażników banku, ale szef, ergo Baum, zdaje się wi d zi eć fizyczne wzburzenie Toma, gdyż poirytowany z naciskiem powtarza słowo „zabić!”. Przestrzelenie przez Kenta głośnika w scenie 27 nie przerywa, ku jego zdumieniu, transmisji głosu szefa, który nadal, niewidzialny niczym Bóg, zdaje się śledzić każde posunięcie swego niedoszłego "zabójcy”. Jednak już po obwieszczeniu wyroku śmierci na Toma i Lilli, jakby pewien, że nie mogą się oni wydostać z pokoju-pułapki, szef zdaje się rezygnować z obserwowania pary i mogą oni całkiem bezkarnie wykorzystać pozostały im czas na poszukiwanie sposobów ocalenia.

Jedynym racjonalnym wytłumaczeniem tych sprzeczności wydaje się dysponowanie przez Bauma te le w i z ją - kamery i mikrofony zainstalowane g d zi i ś w „pokoju z kotarą" (mikrofon radiowy zresztą widzimy na stole obok głośnika) mogłyby przekazywać mu obraz i dźwięk stamtąd do jego ukrytego g dzieś "studia”, skąd z kolei transmitowałby jedynie swój głos osobom obecnym przed kotarą. Wdarcie się Kenta z a kotarę nie tylko odkrywa fizyczną nieobecność szefa, ale poprzez ujawnienie mikrofonu i głośnika, technicznych narzędzi rejestracji i transmisji (co prawda tylko dźwięku, ale to wydaje się drugorzędne) obnaża mechanizm medialnego zapośredniczenia rzeczywistości i medialnej nad nią kontroli. Jest to zatem, po pierwsze, moment a u t o te mat y c z n y: ujawnienie w początkach filmu dźwiękowego mikrofonu i głośnika jako rejestratora i transmitera głosu nieobecnej fizycznie "tu i teraz" osoby, głosu, który może zresztą należeć do kogoś innego niż wydaje się widzowi, porównać można chyba w samozwrotnej funkcji do obnażania obecności kamery i/lub ekranu filmowego w niemych filmach Dzigi Wiertowa i Bustera Keatona ${ }^{21}$. Po drugie, jest to kolejny już w filmach Langa, choć tu jedynie raczej impli-

${ }^{21}$ Moment wtargnięcia Kenta za kotarę w kategoriach doniosłego strukturalnie chwytu autotematycznego rozpatruje Michel Chion. Jego analiza głosu i ścieżki dźwiękowej w Testamencie doktora Mabuse jest bardzo interesująca, choć, jak na mój gust, zbyt wymyślna terminologicznie i pokrętna retorycznie. Zob. Michel Chion, The Voice in Cinema, transl. Claudia Gorbman, Columbia University Press, New York 1999, s. 17-47. 
kowany niż spektakularnie unaoczniony, obraz wła d zy medialnej, panoptycznej i "panakustycznej” zarazem, sprawowanej przez kogoś, kto ze swego "centrum obserwacyjno-dyspozycyjnego" podgląda i podsłuchuje świat, co umożliwia kontrolę i wyprzedzające posunięcia wobec przeciwnika i/lub „poddanych”. Taką władza, opartą nie o technikę, lecz wynikającą z transcendentnego statusu wobec świata, dysponowała Śmierć w Zmęczonej Śmierci. Przywołajmy jednak gabinet Joh Fredersena z Metropolis na szczycie Nowej Wieży Babel, z jego wideofonem i roztaczającą się wokół, widzianą z góry panoramą miasta u stóp jego władcy, czy też klatkę schodową i na jej szczycie gabinet $\mathrm{z}$ „medialnym biurkiem" w kwaterze głównej Haghiego w Szpiegach - to przecież, o czym już była mowa, warianty rozsławionego przez Michela Foucaulta w Nadzorować i karać Benthamowskiego Panopticonu. Film $M-$ morderca przynosił z kolei obraz „panopticonu rozproszonego”, oplecenia człowieka w społeczeństwie masowym pajęczyną zarówno mediów i obserwatorów, jak i zasobów informacji w postaci archiwów i kartotek.

I choć to "telewizyjne studio" profesora Bauma jest w Testamencie doktora Mabuse centrum akcji, to jednak jest c e n tru m n i e o b e c n y m, przestrzenią jedynie implikowana, którą trzeba postulować, by nie zarzucić filmowi braku fabularnej logiki i czasoprzestrzennej niespójności. Mimo wszystko wydaje się, iż istnienie tego studia jest postulatem zasadnym. Po pierwsze, w marcu 1935 r. ruszyły w Niemczech publiczne transmisje telewizyjne. Na przełomie 1932 i 1933 r., kiedy powstawał film, wieści o zaawansowaniu prac nad telewizją raczej nie mogły nie dotrzeć do zainteresowanego techniką Langa, tym bardziej, że przecież już w roku 1926 w Metropolis zobrazował to medium. Telewizja w Testamencie jest więc dialektycznie obecna i nieobecna zarazem, podobnie jak A. D. 1932 jest ona jeszcze nieobecna w niemieckiej przestrzeni publicznej, choć oswojone z radiem społeczeństwo ju ż w znakomitej większości oczekuje pojawienia się wynalazku transmitującego nie tylko fale dźwiękowe, ale i obraz. Po drugie, gdy po wojnie Lang w swym ostatnim w ogóle filmie powróci do doktora Mabuse, to władza kolejnej inkarnacji superprzestępcy, Corneliusa/Jordana, opierać się będzie o szpiegowski monitoring $\mathrm{w}$ naszpikowanym mikrofonami i kamerami telewizyjnymi Hotelu Luxor. Usytuowane gdzieś w hotelu tajne studio jest pełne telewizyjnych monitorów, dzięki którym „Mabuse nr 3" może podglądać i podsłuchiwać hotelowych gości: zdobywa w ten sposób informacje ułatwiające mu odgrywanie niewidomego jasnowidza (sic!) i realizację swych rozmaitych niecnych celów. Ciekawe zresztą, że Lang w Tysiacu oczu doktora Mabuse (Die 1000 Augen des Dr. Mabuse, 1960), gdzie ukazując telewizję jako medium manipulacji i kontroli, postawił kropkę nad "i” niepostawioną w Testamencie, zrezygnował z metafizyki na rzecz wyjaśnienia 
racjonalnego - Cornelius nie ma nadnaturalnych zdolności parapsychicznych, tylko udaje jasnowidza. W Testamencie "prawdziwy" Mabuse, choć zdaje się żałosnym wrakiem człowieka, pogrążonym w malignie wariatem zamknętym w szpitalu dla psychicznie chorych, nie tylko zachował swe paranormalne zdolności telepatii i hipnozy znane nam z Doktora Mabuse, gracza, ale też po śmierci, jako "duch”, „wciela się" w Bauma. Ta dość tandetna metafizyka ostatecznie niszczy w tym filmie poetykę kryminału i niepotrzebnie odwraca uwage od tego, co jest jednak chyba najbardziej intrygującym aspektem fabuły: telewizji jako narzędzia kontroli i władzy.

Gatunek kryminału zostaje w tym filmie zepsuty na inne jeszcze sposoby, np. przez faktyczne unieważnienie suspensu sekwencji pościgu Lohmanna i Kenta za Baumem, ale przede wszystkim przez pozorność zagadek ja w n y ch, gdyż prawdziwie frapująca fabularna zagadka (jak i skąd profesor komunikuje się z gangiem?) nie została wykesponowana w narracji. Rzekomość „zagadek” napędzających akcję, czyli śledztwo Lohmanna, powoduje iż akcja filmu toczy się na jałowym biegu, po prostu donikąd. Pierwszą taką zagadką jest nazwisko szefa gangu, którego Hofmeister nie zdążył przekazać komisarzowi w przerwanej wtargnięciem Sekcji 2-B rozmowie telefonicznej. Hofmeister, po odzyskaniu $\mathrm{w}$ finale świadomości, triumfalnie obwieszcza Lohmannowi nazwisko "Mabuse", ale ani dla komisarza, ani tym bardziej dla widza nie jest to żadna rewelacja - tym bardziej, iż informacja to cokolwiek spóźniona. Zagadką druga, wyjaśnioną zresztą znacznie wcześniej, jest odcyfrowanie wydrapanego przez Hofmeistra napisu na szybie. Jej rozwiązanie, „Mabuse”, prócz tego, że i tak definitywnie przesądza, iż nie trzeba wcale czekać na rozwiązanie zagadki numer jeden, to w chwili, gdy się pojawia, niewiele wnosi w postęp akcji kryminalnej: Lohmann zaraz po poznaniu rozwiązania dowiaduje się, iż Mabuse nie żyje, a widz i tak od jakiegoś czasu ma świadomość, że to n i e Mabus e, przynajmniej jako osoba fizyczna, jest obecnie szefem gangu, który drukuje fałszywe banknoty i zabija doktora Kramma.

Lohmann równolegle zajmuje się trzema sprawami, które, o czym doskonale wie widz, a czego nie wie jeszcze komisarz, są rozmaitymi elementami tej samej sprawy "gangu doktora Mabuse". Chodzi o zniknięcie Hofmeistra i jego nieprzekazaną wiadomość, zabójstwo doktora Kramma i napad na jubilera. Oczywiście, przewaga informacyjna widza nad prowadzącym śledztwo policjantem może być źródłem odbiorczej przyjemności (w oparciu o tę przewagę skonstruowane są odcinki lubianego przez widzów serialu Columbo). W Testamencie widz ma jednak raczej poczucie, iż sensowne skonstruowanie kryminalnej akcji z policyjnym śledztwem nie bardzo się Langowi udało, a odkrywanie jak poniewczasie Lohmann 
wpada na to, co widz już wie od dawna, nie sprawia w tym filmie żadnej przyjemności, wydaje się raczej pleonastycznym powtórzeniem, co tym bardziej każe widzieć akcję filmu jako toczącą się na jałowym biegu.

Temu, by uznać Testament doktora Mabuse za udany film kryminalny, nie służy też nadmiar „barokowych” rozwiązań dramaturgicznych, sprzecznych ze zdrowym rozsądkiem... przestępców (i widza). Gangsterzy z Wydziału 3 zamiast od razu "załatwić" na miejscu w drukarni zauważonego przez nich Hofmeistra dokonują nań nieudanych, acz spektakularnych zamachów na ulicy (spadający gzyms, wybuchająca beczka). A gdy odpowiedzialna za likwidację Sekcja 2-B odwiedza Hofmeistra w jego mieszkaniu, to zamiast go po prostu zabić, w jakiś niewytłumaczalny sposób w jednej chwili „odbiera mu rozum” i uznaje to za wystarczające unieszkodliwienie potencjalnie niebezpiecznego informatora policji. Nie bardzo chce się wierzyć w pochwałę, jakiej po tej akcji udzielił Hardy'emu i jego kompanowi szef, skoro jednocześnie uznał za karygodne niedbalstwo równie nieskuteczne, a jednak na oko bardziej zdeterminowane $\mathrm{w}$ dążeniu do likwidacji przeciwnika poczynania "drukarzy”. Zupełnym absurdem „barokowej” dramaturgii jest rodzaj egzekucji przygotowany przez Bauma dla Toma i Lilli. Hardy z uzbrojonym żebrakiem mogli ich po prosu zastrzelić na ulicy pod domem Kenta, i byłoby to najprostsze i najskuteczniejsze rozwiązanie. Ostatecznie egzekucja mogłaby się odbyć ",przed kotarą” zaraz po usłyszeniu przez nich wyroku (tak zapewne zginął ciekawski, o którym ",jubiler" mówi Karetzky'emu). Tymczasem Kentowi nie zabrano nawet broni, dzięki czemu mógł on strzelić do rzekomego szefa i odkryć tajemnicę „pokoju z kotarą”. Baum odwleka wybuch bomby o trzy godziny (daje to skazańcom wystarczająco dużo czasu na znalezienie sposobu ocalenia) i zupełnie przestaje się interesować tym, co oni porabiają w ,pokoju-pułapce”, , ,wyłączając transmisję". Zaplanowane zniszczenie tego miejsca przez eksplozję wydaje się, z punktu widzenia interesów profesora, zupełnie bezcelowe i bezsensowne: było zakonspirowane (szyfrowany zamek u drzwi wejściowych), wyposażone $\mathrm{w}$ kosztowną technikę (co najmniej w aparaturę do transmisji i odbioru dźwięku, a zapewne też w kamery telewizyjne), służyło jako bezpieczne i wygodne miejsce dla "bezcielesnego" spotykania się szefa z gangiem. Jak już jednak pokazały podobnie "barokowe” i podobnie nieskuteczne pułapki zastawiane przez superprzestępców w poprzednich filmach Langa (telepatyczne kierowanie prokuratora von Wenka do urwiska Melior w Doktorze Mabuse, graczu czy katastrofa kolejowa, jaką w Szpiegach organizuje Haghi dla usunięcia Agenta 326), reżyser nie mógł sobie darować wymyślnych intryg i efektów rodem z popularnych seriali sensacyjnych à la Fantomas, obrazujących superprzestępców raczej jako metteurs-en-scène niż organizatorów logicznej akcji. Toteż Testament 
doktora Mabuse to raczej rozgrywająca się przy pozorach realizmu gdzieś w abstrakcyjnym i wydumanym świecie pulp fiction, nie zaś wiarygodnie osadzony w społecznych realiach topical film, jak zrealizowany dwa lata wcześniej $M$ - morderca. Bo też udział w fabułach obu filmów komisarza Lohmanna nie ma tu nic do rzeczy.

\section{Od gabinetu doktora Caligari do kliniki profesora Bauma}

Analiza oryginalnej niemieckiej wersji filmu z roku 1933, pozbawionej wszelakich „opracowań" (jak niezbyt wierne napisy z roku 1943 czy stosowny dubbing i dokrętka z roku 1952) musi utwierdzić w przekonaniu, że dość uporczywe w historii kina traktowanie Testamentu doktora Mabuse jako filmu antyhitlerowskiego jest jednak bezzasadne. Co więcej, gdy się zastanowić, zlecona przez Goebbelsa dokrętka, sugerująca, iż gang Mabusego/ Bauma był „żydowską bandą”, wydaje się mieć więcej uzasadnienia niż dopatrywanie się w nim alegorycznego przedstawienia nazistów. O działalności gangu wiemy z eliptycznego i w wielu miejscach niedopowiedzianego sjużetu stosunkowo niewiele. Poznajemy jego cztery „wydziały”, choć z numeracji wynika, iż musi ich być więcej. Najistotniejszy w intrydze filmu jest Wydział 3 („finansowy”). Współpracujący z nim ekonomiczny ekspert, dr Hauser, skutecznym szantażem wobec potężnego banku („Banku Zamorskiego”) przygotował grunt pod jedną z najważniejszych akcji Mabusego/Bauma - rozprowadzenie przez legalną instytucję finansową fałszywego pieniądza, co ma wywołać ekonomiczny chaos. W analizie pierwszego filmu o doktorze Mabuse uznałem, inspirowany zresztą znakomitymi interpretacjami Toma Gunninga ${ }^{22}$ i Bernda Widdiga ${ }^{23}$, że jest on alegorią inflacji, która była traumatycznym doświadczeniem społeczeństwa niemieckiego po I wojnie światowej. Badanie rozmaitych wcieleń doktora Mabuse unaoczniło, iż większość z nich (giełdowy spekulant, psychoanalityk, komunista, wędrowny przekupień, rzekomy jasnowidz z kabaretu) wiąże się z ż y d o w s k o ś c i ą. Elias Canetti i Bernd Widdig dowodza, iż za inflację obwiniani byli przede wszystkim Żydzi. Narodowy socjalizm - twierdzi Canetti - w szczególnym psychologicznym rewanżu „zdewaluował" Żydów, tak jak oni swymi zakulisowymi manipulacjami jakoby zdewaluowali na początku lat 20. niemiecką walutę, odbierając jej posiadaczom godność poprzez klasową i materialną degradację do stanu nędzarzy; dotyczyło to ludzi wszystkich klas społecznych i prowadziło

22 T. Gunning, op. cit., s. 87-116.

${ }^{23}$ Bernd Widdig, Culture and Inflation in Weimar Germany, University of California Press, Berkeley-Los Angeles-London 2001, s. 113-133. 
do „zrównania klas”, nie w sensie demokracji, lecz poniżającego zglajchszaltowania. Oczywiście, domagało się to zarówno symbolicznego, jak i realnego odwetu Niemców ${ }^{24}$. Lang - twierdzi z kolei Widdig o Doktorze Mabuse, graczu - choć nie stworzył filmu expressis verbis antysemickiego, odwołał się w nim jednak do antysemickiej nieświadomości, której wyrazem są żydowskie konotacje superprzestępcy ${ }^{25}$.

Testament doktora Mabuse konotacje te ponownie ożywia. Gang Mabusego, podobnie jak w filmie o 11 lat wcześniejszym, znowu produkuje fałszywe pieniądze i dokonuje manipulacji finansowej na wielką skalę, o czym świadczy raport, jaki zdaje szefowi dr Hauser. Godna uwagi jest pokazana w zbliżeniu kartka z zapisków Mabusego (jednoujęciowy podsegment 20 B2), otwierająca ich rozdział o ekonomicznych działaniach gangu. Nagłówek w ekspresjonistycznym liternictwie obwieszcza tytuł „Aktionen gegen Banken und Währung" (Dziatania przeciwko bankom i walucie); pod nim dwukrotnie widnieje napis "INFLATION", a powtarzające się na stronie długie szeregi kółek wydają się z a r a z e m monetami i zerami w pamiętnych z okresu inflacji astronomicznych nominałach. Trzeba pamiętać, iż ostatni weimarski film Langa powstawał w okresie kryzysu gospodarczego, który dotknął Niemcy szczególnie mocno, co zapewne musiało ożywiać traumatyczne wspomnienie inflacji, poskromionej przed zaledwie niespełna dekadą. Kontekst taki musiał więc sprzyjać ożywieniu czy wzmożeniu resentymentów skierowanych przeciwko winnym (wedle szemranej opinii publicznej podsycanej przez nazistowską propagandę) zapewne nie tylko inflacji, ale i bieżącemu kryzysowi (wybuchł on w Ameryce, a amerykańscy potentaci finansowi to, jak przecież „,wiadomo”, Żydzi...). Na takim tle reminiscencja inflacji $\mathrm{w}$ filmie Langa, $\mathrm{z}$ jej astronomicznymi nominałami, nie jest doprawdy niewinna. Stworzyła zresztą świetny pretekst do explicite antysemickiej dokrętki, z którą film nie miał już innych przeszkód do wyświetlania w Trzeciej Rzeszy, jak tylko żydowskie pochodzenie reżysera.

Fragmenty zapisków Mabusego, czytane przez Bauma w noc „namaszczenia" go przez ducha (podsegment 20 B1) oraz odczytane przez Lohmanna w noc ataku na zakłady chemiczne (segment 41), a także dyspozycje dawane gangowi w segmentach 20 A2 i 21a, świadcza, iż gang Mabusego/Bauma to nie naziści, lecz t e r r o r y ści. Działania dążące do panowania przestęp czości, wywołania w społeczeństwie stanu anarchii i braku poczucia bezpieczeństwa jako charakterystyka poczynań narodowych socjalistów wydają się nietrafione, natomiast znakomicie pasują do opisu współczesnego nam międzynarodowego terroryzmu (Lang

24 Elias Canetti, Masa i władza, przeł. Eliza Borg, Maria Przybyłowska, Czytelnik, Warszawa 1996, s. 212-214.

25 B. Widdig, op. cit., s. 121-122. 
proroczo antycypuje zjawisko, które stanie się jednym z największych zagrożeń dla świata w początkach XXI wieku). To, co Mabuse/Baum planuje - zniszczenie plonów, zatrucie ujęć wody, wywołanie rozmaitych epidemii i skierowanie na miasto chmury trującego gazu - stanowi „modelowe” projekty terroryzmu. Trudniej uznać za takowe przeznaczanie pieniędzy z przestępczych łupów (zrabowanych ze sklepu jubilerskiego kosztowności o wartości ćwierć miliona marek) na zakup narkotyków, by potem „bezinteresownie” (tj. bez zysku) rozprowadzać je w społeczeństwie (o takich działaniach szefa dowiadujemy się z rozmowy Karetzky'ego z , jubilerem" w segmencie 10). To raczej ideologiczny projekt a n a r c h i z m u, zrodzonego, podobnie jak i plany akcji terrorystycznych, z bezgranicznej mizantropii. Tych dążących do chaosu i społecznego rozkładu projektów z całą pewnością nie można jednak utożsamiać z narodowym socjalizmem, ideologia, która w okresie swych rządów szczycić się będzie (przynajmniej w okresie przedwojennym) zaprowadzeniem w społeczeństwie porządku i ładu, uzdrowieniem gospodarki, wzrostem konsumpcjonizmu czy przeprowadzeniem szeroko zakrojonej technologicznej modernizacji.

A może lepiej niż doszukiwać się w projekcie Testamentu doktora Mabuse inspiracji politycznych, zwrócić uwagę na jego afiliacje filmowe? David Kalat, monografista całej serii filmów o Mabusem, zapoczątkowanej przez Langa i później kontynuowanej przez pochodzącego z Łodzi berlińskiego producenta Artura Braunera, zwrócił uwagę, że istotnych korzeni tego filmu być może należy szukać jeszcze przed Doktorem Mabuse, graczem, w innym wielkim klasyku kina weimarskiego, a mianowicie w Gabinecie doktora Caligari (Das Cabinet des Dr. Caligari, 1919), paradygmatycznym dla niemieckiego ekspresjonizmu filmie Roberta Wiene. Pokrewieństwo nie dotyczyłoby jednak stylu wizualnego, lecz struktury fabularnej. „Oba filmy - pisze Kalat - opowiadają historię o tajemniczych zbrodniach, skupionych wokół szpitala dla umysłowo chorych, w którym psychiatra zatracił rozróżnienie między tożsamością własną a przedmiotu swych badań, dopuszczając do tego, iż zniewolenie przez obsesję przekształca go w szalonego przestępcę. W obu filmach tożsamość mordercy jest prawie dana - podejrzenie wcześnie kieruje się na Cezara, podopiecznego Caligariego, i Mabusego, pacjenta Bauma, lecz prawdziwym pytaniem jest nie tyle «kto jest sprawcą?», co raczej «jak to zrobił?». Jeżeli Cezar i Mabuse są bezpiecznie zamknięci i pod stałą obserwacja, to jak się dzieje, iż równocześnie mogą być na wolności i czynić zamęt?"26

Lang w udzielonych wywiadach, m.in. w rozmowie z Gretchen Berg podczas sławetnej „wiedeńskiej nocy” w roku $1965^{27}$ i w wywiadzie, któ-

${ }^{26}$ D. Kalat, op. cit., s. 81.

27 Gretchen Berg, The Viennese Night: A Fritz Lang Confession, [w:] Fritz Lang, Interviews, ed. Barry Keith Grant, University of Mississippi Press, Jackson 2003, s. 58. 
ry Gene D. Phillips przeprowadził z nim rok przed śmiercia, w roku $1975^{28}$, wyznał, iż to właśnie on, a nie Wiene, miał początkowo reżyserować Gabinet doktora Caligari, lecz musiał z tego zrezygnować, gdyż Erich Pommer, jego producent, zlecił mu realizację drugiej części serialu Pająi (Die Spinnen, 1919), zatytułowanej Brylantowy statek (Das Brillantenschiff). Gotowy film Roberta Wiene zawdzięcza jednak Langowi (w każdym razie on sam tak twierdzi) ramę narracyjną. Lang miał ją zaproponować Pommerowi jako swego rodzaju racjonalistyczne uzasadnienie szalonego stylu plastycznego filmu, który jego zdaniem był zbyt trudny dla publiczności do zaakceptowania - chyba że umotywuje go status przedstawionej historii jako „opowieści wariata”.

W tym, co Lang mówił w wywiadach, zwraca uwagę, w jak płaski i przyziemny sposób uzasadniał swą propozycję. Gdyby rama w Caligarim istotnie miała pełnić tylko taką funkcję, z pewnością nie byłaby (a jest!) bodaj najbardziej artystycznie frapującym rozwiązaniem tego filmu i nie stałaby się (a stała się!) tak powszechnie później stosowanym w kinie weimarskim zabiegiem kompozycyjnym. Pomysł Langa - jeśli to istotnie jego pomysł - zaowocował niepokojącym wzajemnym podważaniem się statusu ontycznego ramy i historii obramowanej, zatarł granicę między wariactwem a normalnościa, między pacjentem i medycznym autorytetem, między byciem ofiarą a sprawcą. Musiało to oczywiście, już po II wojnie światowej, sprowokować Siegfrieda Kracauera do symptomatycznej, w duchu psychoanalizy społecznej, lektury tego filmu i dopatrywania się w jego ambiwalencji prefiguracji nazizmu ${ }^{29}$.

Sam Lang, choć świadomie i eksplicytnie nawiązał do Doktora Mabuse, gracza i $M$ - mordercy, tak naprawdę skonstruował Testament doktora Mabuse jako dramaturgiczną (wyjąwszy może "globalną" ramę narracyjną) powtórkę Gabinetu doktora Caligari. Być może to właśnie tłumaczy rozmaite, wskazane wyżej, nielogiczności, niedopowiedzenia czy dwuznaczności tego filmu. Próg i kres kina weimarskiego znaczą zatem dwa filmy o zbrodniczych psychiatrach, którzy sami popadają w szaleństwo i ostatecznie zostają pacjentami kierowanych przez siebie „domów wariatów”. Historia kina weimarskiego wiedzie w przedziwny sposób od gabinetu doktora Caligari do kliniki profesora Bauma, od Pommera do Goebbelsa, od jednej opowieści Langa (być może prawdziwej) do drugiej, będącej jedynie jego „wyobrażonym filmem”.

28 Gene D. Phillips, Fritz Lang Remembers, [w:] F. Lang, Interviews, s. 177.

29 Siegfried Kracauer, Od Caligariego do Hitlera: Z psychologii filmu niemieckiego, przeł. Wanda Wertenstein, Eugenia Skrzywanowa, Filmowa Agencja Wydawnicza, Warszawa 1958, s. 56-69. 



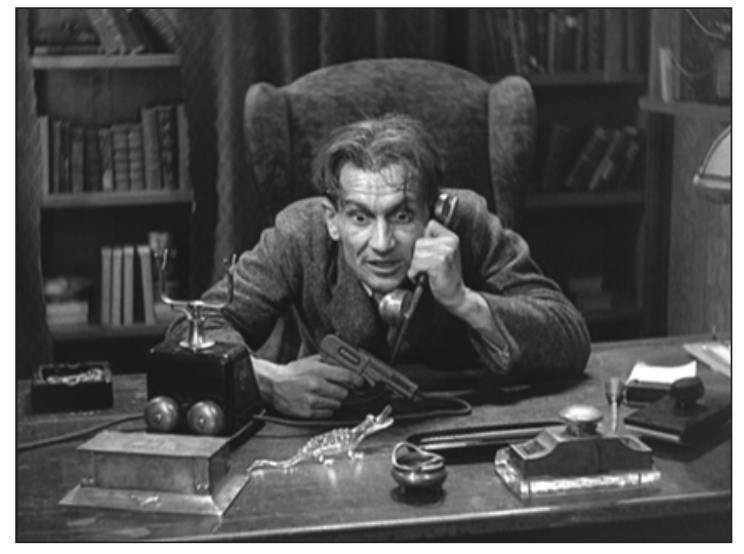

1. Testament doktora Mabuse (1933, reż. Fritz Lang). Hofmeister w przerwanej rozmowie telefonicznej z Lohmannem

2. Testament doktora Mabuse (1933, reż. Fritz Lang). Zbrodnia w ulicznym korku - Hardy doktora Kramma ma już na muszce
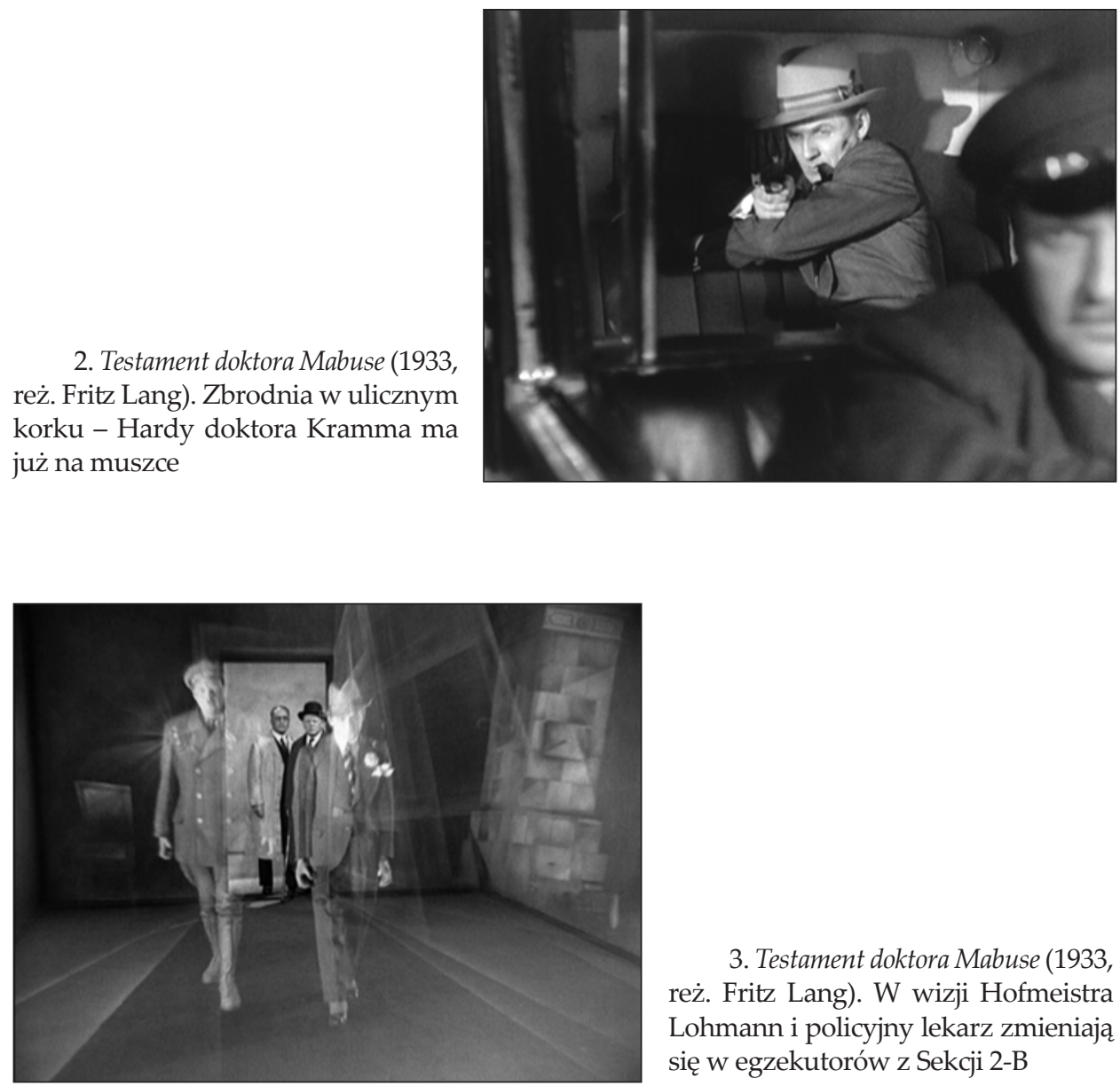

3. Testament doktora Mabuse (1933, reż. Fritz Lang). W wizji Hofmeistra Lohmann i policyjny lekarz zmieniają się w egzekutorów z Sekcji 2-B 


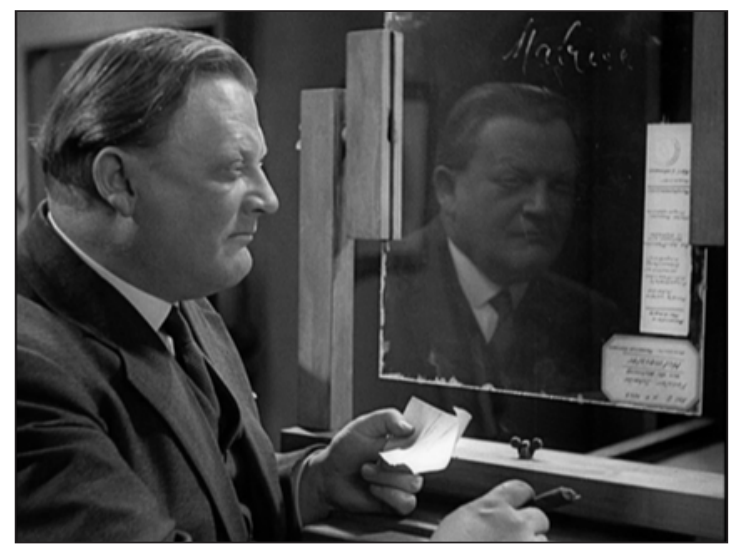

4. Testament doktora Mabuse (1933, reż. Fritz Lang). Komisarz Lohmann z rozwiązaniem zagadki napisu na szybie

5. Testament doktora Mabuse (1933, reż. Fritz Lang). Lohmann i Baum nad zwłokami Mabusego
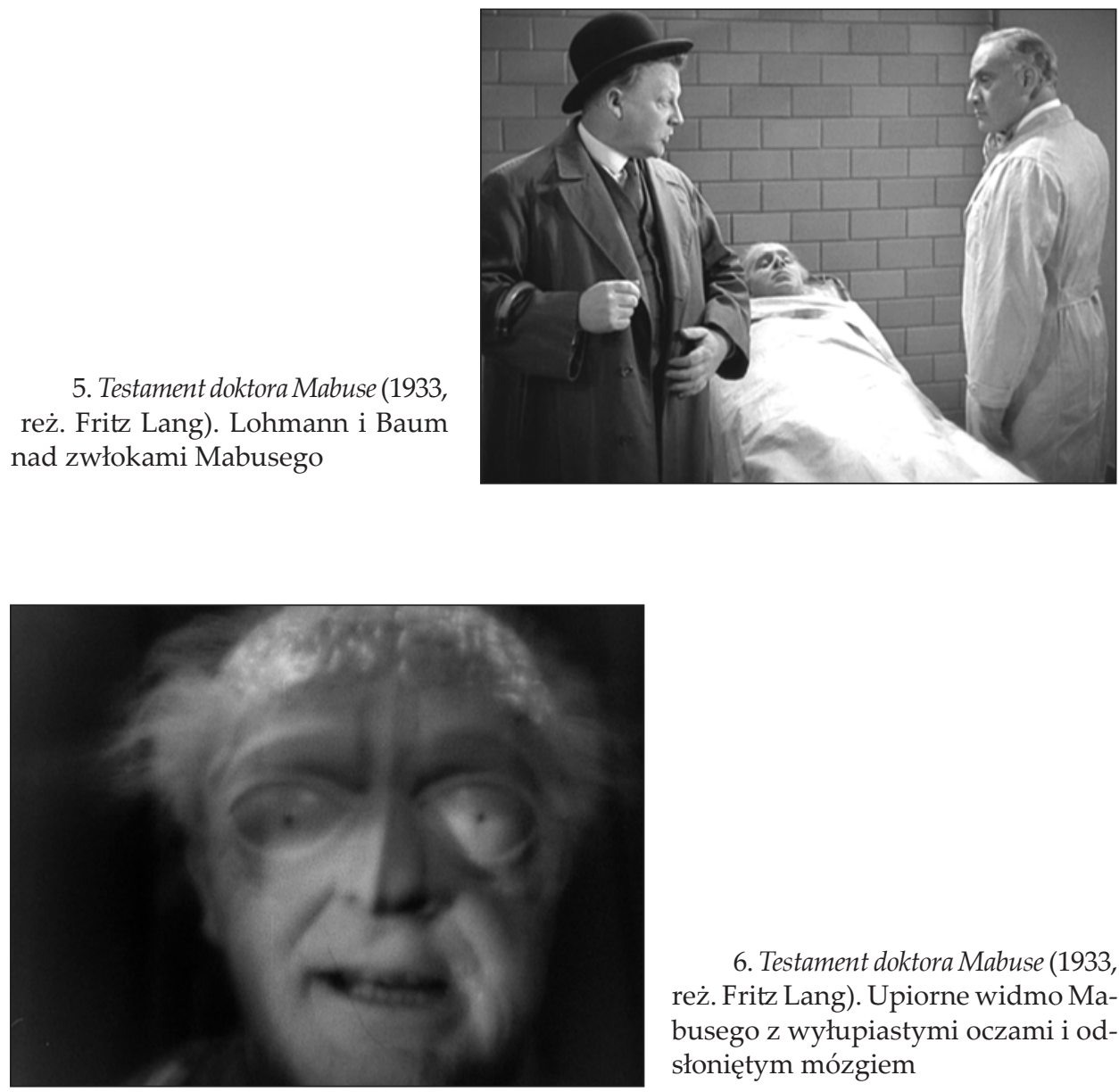

6. Testament doktora Mabuse (1933, reż. Fritz Lang). Upiorne widmo Mabusego z wyłupiastymi oczami i odsłoniętym mózgiem 


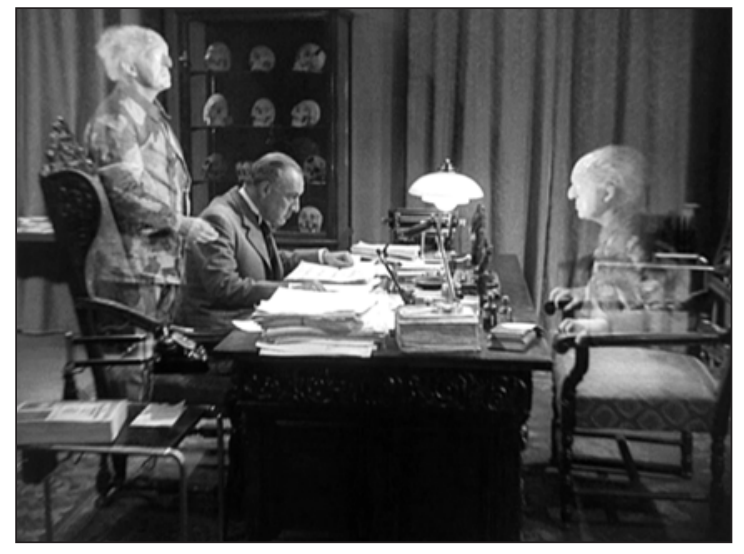

7. Testament doktora Mabuse (1933, reż. Fritz Lang). Duch zmarłego Mabusego „wciela się" W profesora Bauma

8. Testament doktora Mabuse (1933, reż. Fritz Lang). Zapiski Mabusego - nagłówek rozdziału o działaniach skierowanych przeciwko bankom
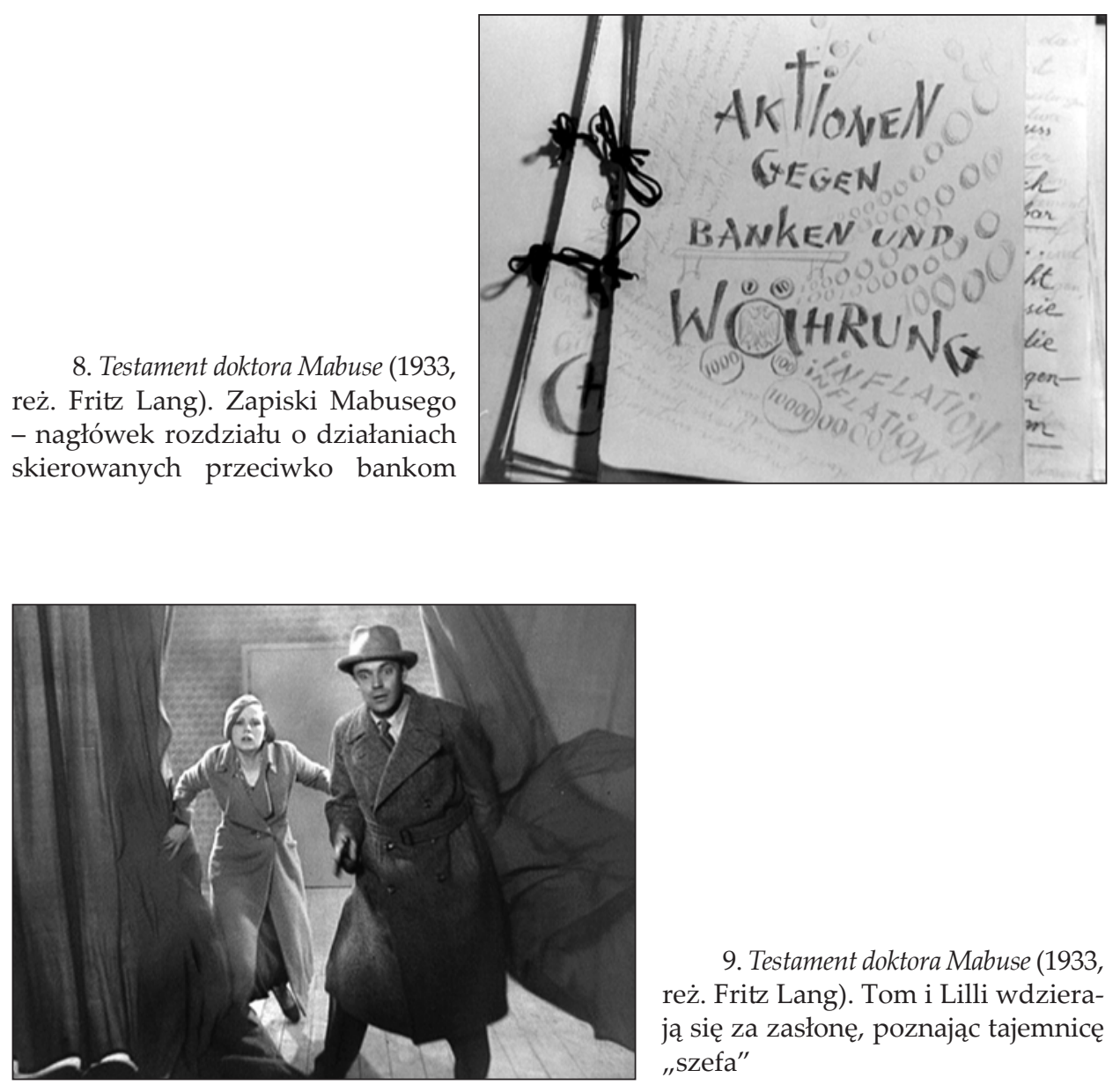

9. Testament doktora Mabuse (1933, reż. Fritz Lang). Tom i Lilli wdzierają się za zasłonę, poznając tajemnicę "szefa" 


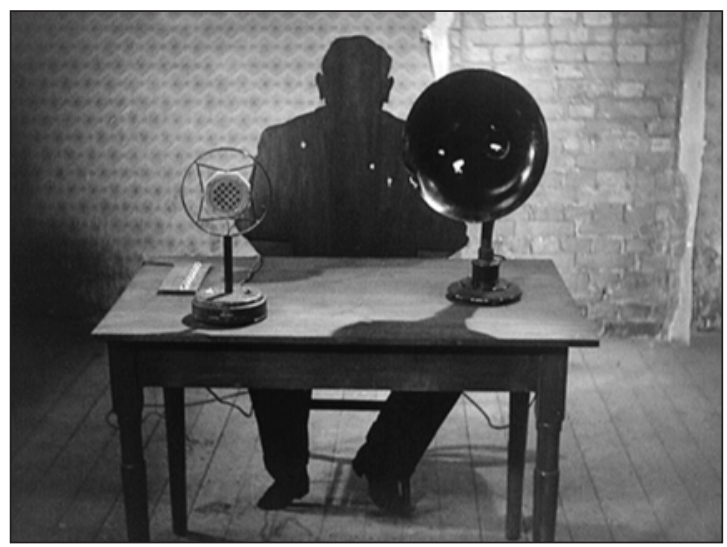

10. Testament doktora Mabuse (1933, reż. Fritz Lang). Za kotarą - mikrofon, głośnik i atrapa szefa. Jeszcze jedno "medialne biurko" w filmach Langa

11. Testament doktora Mabuse (1933, reż. Fritz Lang). Widmo Mabusego kieruje Bauma prosto do jego kliniki
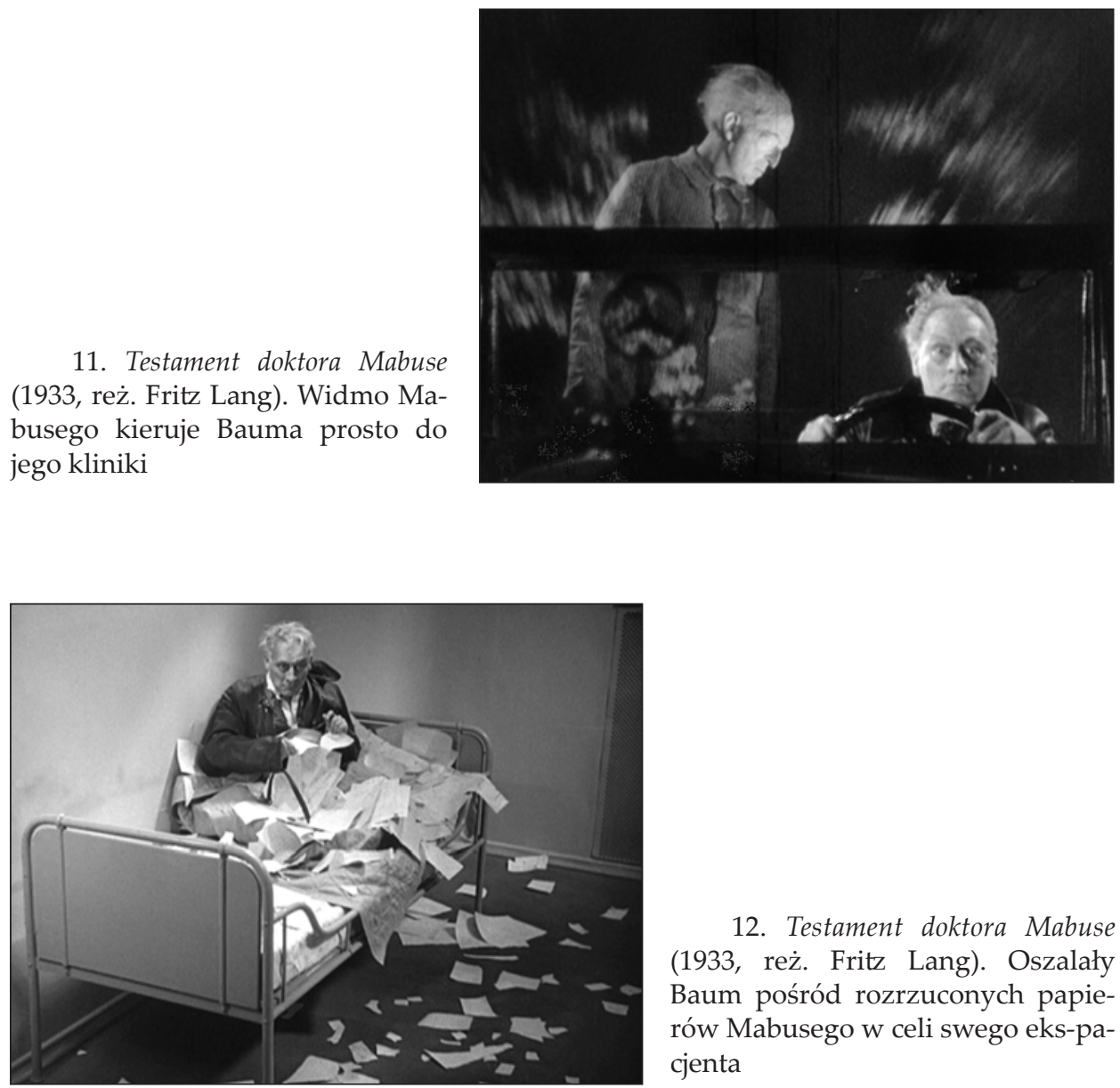

12. Testament doktora Mabuse (1933, reż. Fritz Lang). Oszalały Baum pośród rozrzuconych papierów Mabusego w celi swego eks-pacjenta 


\section{Podsumowanie}

\section{WEIMARSKIE FILMY FRITZA LANGA}

Lata 1921-1933 to apogeum twórczości Fritza Langa. Omówionych w tej książce osiem filmów zrealizowanych przez Langa w tym czasie - chciałoby się powiedzieć: zaledwie osiem - ma swoje trwałe miejsce w historii kina. Pięć z nich: Zmęczona Śmierć, Doktor Mabuse, gracz, Nibelungi, Szpiedzy i $M-$ morderca, to bezdyskusyjne arcydzieła, pozostałe trzy: Metropolis, Kobieta na Księżycu i Testament doktora Mabuse, są filmami, w których razi dysonans między klasą realizacji i ich stroną wizualną $\mathrm{z}$ jednej strony a pretensjonalnością i ckliwym melodramatyzmem z drugiej. Pomimo to jednak właśnie Metropolis ma dziś status filmu "kultowego" i kto wie, czy nie tylko nie jest najpowszechniej dziś znanym klasykiem kina niemieckiego, ale i najpopularniejszym z wszystkich niemych filmów. Oba zresztą fantastyczne filmy Langa, choć poniżej oczekiwań, rozbudzonych wspaniałym poziomem jego pozostałych dzieł z lat 20., w swoim gatun$\mathrm{ku}$, science-fiction, należą do osiągnięć wybitnych i niekwestionowanych. Pionierskość zaś Testamentu doktora Mabuse pośród filmów sensacyjnych oraz nowatorstwo i oryginalność zastosowania w tym filmie dźwięku są jego niekwestionowanymi atutami.

Sześć omawianych niemych filmów - nawet nieco skromniejszych Szpiegów - cechuje niebywały w kinie europejskim tamtych lat rozmach produkcyjny, w wypadku Nibelungów i Metropolis budzący podziw i zdumienie nawet dzisiaj. Oczywiście, rozmach ten wynika ze związków Langa z najpotężniejszą europejską kompanią filmową - Ufą. Co prawda, produkcji wyłącznie Ufy jest tylko jeden film - za to paradygmatyczny dla megalomanii tej wytwórni: Metropolis. Spółka Decla-Bioscop, gdzie powstały Zmęczona Śmierć, Mabuse i Nibelungi, została jednak de facto przez Ufę, potężnego partnera, wchłonięta, toteż począwszy od Doktora Mabuse w filmach Langa widnieje już logo Ufy, a rozmach tych filmów nie byłby możliwy bez finansowania przez nią i korzystania z technicznego zaplecza tego giganta. Nawet po rozstaniu Langa z Ufa, logo jej widniało w czołówkach dwóch filmów samodzielnej spółki Fritz Lang Film, gdyż była ich dystrybutorem. I to na tyle szczodrym oraz pokładającym $\mathrm{w}$ reżyserze zaufanie, iż nie szczędziła na reklamę, public relations i kosztowną 
oprawę premier niemałych środków. W ogóle organizowane przez Ufę premiery filmów Langa $\mathrm{w}$ reprezentacyjnym kinie kompanii Ufa-Palast am Zoo, z udziałem niezliczonych dygnitarzy oraz znakomitości świata artystycznego i intelektualnego Berlina, przeszły do legendy oraz historii filmowej recepcji jako wielkie wydarzenia. Producentem pierwszych czterech filmów (od Zmęczonej Śmierci po Metropolis), powstałych w latach 1921-1926, był Erich Pommer, darzący Langa niemal nieograniczonym kredytem zaufania, ponieważ wiedział, jak atrakcyjnego filmu i zarazem jak wysokiej klasy artystycznej można po nim się spodziewać. Toteż Lang mógł pozwalać sobie na przekraczanie i tak niebywałych budżetów, żądając jakichś nieprawdopodobnych rzesz statystów, niezwykle kosztownych dekoracji, niezliczonych dubli. Po odejściu z Ufy Pommera Lang próbował przedłużyć swą niezależność artystyczną jaką faktycznie cieszył się dotąd, powołując własną niezależną spółkę Fritz Lang Film GmbH. Impetu i zaufania kredytodawców starczyło na jeden znakomity film (Szpiedzy) i na jedna, za to dość nieudana, superprodukcję (Kobieta na Księżycu). Pożegnanie z filmem niemym, którego Lang był jednym z największych mistrzów (a w Europie, kto wie czy nie największym), okazało się także definitywną utratą przez Langa pozycji filmowca, który praktycznie mógł zdobyć każde środki na wszystko, cokolwiek sobie zamarzył. Było to też definitywne rozstanie $\mathrm{z}$ finansowo rozczarowana, a i żeglującą coraz bardziej ku nazizmowi Ufa, nigdy więcej już nawet nie dystrybuującą filmów Langa.

Ostatnie dwa weimarskie filmy reżysera, już dźwiękowe, wyprodukuje - przy udziale znacznie skromniejszych środków - niezależny producent Seymour Nebenzahl. Jak i inni żydowscy producenci filmowi, opuści on Niemcy po dojściu do władzy nazistów w roku 1933.

Robert Herlth, jeden ze znakomitych scenografów Langa (współpracował z nim przy Zmęczonej Śmierci), tak oto wspomina reżysera w jego zenicie, w szalonych latach 20.: „Kiedy Lang przybywał rano na plan trze m a samochodami, reszta jego ekipy - technicy, charakteryzatorzy i projektanci kostiumów - już tam była; i nawet jeszcze zanim wysiadł z samochodu, wszyscy poddawaliśmy się czarowi jego autorytetu. Choć był dyktatorem, wciąż musiał osobiście wszystko nadzorować. Samemu czynił ostatnie poprawki w charakteryzacji aktora, pracował nad trudnymi scenami trickowymi i nawet wypuszczał płonące strzały w Nibelungach. Podczas montażu, który w tamtych dniach należał do samego reżysera, czasem całymi tygodniami nie opuszczał terenu studia. Spał tuż obok montażowni, ponieważ zdarzało mu się wstawać w środku nocy, by kontynuować montaż. Był ekstrawagancki jak figura renesansowa. Podobnie jak Cellini nie znał miłosierdzia ani dla siebie, ani dla współpracowników. Choć traktował ich surowo, zawsze stawał po ich 
stronie z chłopięcą lojalnością, a tajemnicą jego sukcesu było to, iż jego przykład zarażał innych"1.

Prócz produkcyjnego rozmachu filmów, związku z Ufą, niekwestionowanej władzy, jaką miał wówczas podczas realizacji, i autorytetu, którym powszechnie się cieszył, dwie jeszcze sprawy mogą wydawać się istotne przy omawianiu dzieła Langa w latach weimarskich: kwestia ekspresjonizmu i współpraca z drugą żona, Theą von Harbou. Nie chcę tu nad nimi się zatrzymywać ani też nie poświęciłem im zbyt wiele miejsca w książce, gdyż przyznam szczerze, iż szczegółowsze roztrząsanie każdej z nich wydaje mi się jałowe poznawczo. Sądzę, iż w kwestii ekspresjonizmu tym razem należy zawierzyć Langowi, który w rozmaitych swych wypowiedziach odżegnywał się od etykietowania go jako ekspresjonisty. Przewodnicząc okragłostołowej dyskusji na temat ekspresjonizmu na festiwalu weneckim w roku 1960, zapytał: „Co to jest ekspresjonizm? Ani Brecht, ani ja nigdy nie byliśmy ekspresjonistami" ${ }^{2}$. Przypomina to dystans, z jakim Mabuse odpowiada hrabiemu Toldowi, namiętnemu kolekcjonerowi dzieł sztuki nowoczesnej, głównie ekspresjonistycznych: „Expressionismus ist Spielerei. Aber warum auch nicht? Alles ist heute Spielerei-!" Zgodnie z tą cyniczną odpowiedzia, w Doktorze Mabuse, graczu, najbardziej „ekspresjonistycznym" z omawianych filmów, Lang po prostu strawestował czy sparodiował ekspresjonizm, ujmując go $\mathrm{w}$ rozmaite cudzysłowy. $\mathrm{W}$ innych filmach stylistyka, którą można by nazwać ekspresjonistyczną pojawia się wyraziście w pewnych partiach - w weneckiej noweli Zmęczonej Śmierci, w epizodach Metropolis rozgrywających się w katakumbach i Mieście Robotników, w wizji dr. Matsumoto w Szpiegach, w księżycowej części Frau im Mond czy w scenie z Testamentu doktora Mabuse, gdy "duch” zmarłego superprzestępcy wciela się w profesora Bauma. Ale równie ważne wydaje się wskazane przez Thomasa Elsaessera dziedzictwo wiedeńskiej i monachijskiej s e c e s j i (Jugendstil), z którego właśnie - a nie z ekspresjonizmu - wywodzi się wtapianie postaci jako ornamentu w tło (arabska i chińska nowela Zmęczonej Śmierci, lokale w Doktorze Mabuse, dwór Burgundów w Nibelungach, urzeczowienie postaci we wnętrzu rakiety w Kobiecie na Księżycu), s ow i e ckiej szkoły montażu (początek Metropolis, synekdochiczno-eliptyczny styl Szpiegów), i przede wszystkim estetyka N e u e S a chli ch keit (obecna już w Metropolis, dość istotna w „ziemskiej” sekwencji Kobiety na Księżycu, ale dominująca w Szpiegach i obu filmach dźwiękowych). Zastrzegam jednak, iż podpisuję się tu pod wąskim i dość precyzyjnym rozumieniem ekspresjonizmu, które zaproponował Barry Salt. W szerokim rozumieniu - dla którego Salt sensownie,

1 Cyt. za: Lotte H. Eisner, Fritz Lang, Da Capo Press, New York 1986, s. 147.

2 Cyt. za: ibidem, s. 141. 
jak sądzę, proponuje, nazwę eks presywizm u - omawiane filmy Langa są ekspresjonistyczne, a raczej: ekspresywistyczne.

Jeśli chodzi o zagadnienie wkładu Thei von Harbou - jak dalece to ona właśnie odpowiedzialna jest za niedobry sentymentalizm, niepokojącą wymowę ideową z prenazistowskimi bądź antysemickimi podtekstami, czy też za dość żałosną pseudochrześcijańską stylizację, będącą tak naprawdę niedopuszczalnym zawłaszczaniem religijnych konotacji w Zmęczonej Śmierci i Metropolis - to wydaje się ono dziś nie do rozstrzygnięcia. Jest faktem, iż po rozstaniu Langa z Harbou na długo (aż do „indyjskiego" dyptyku) znika z jego filmów przesłodzony, sentymentalny ton Metropolis i Kobiety na Księżycu, ulatnia się niepokojąca dwuznaczność politycznej wymowy, za to w większym wymiarze pojawia się niejednoznaczność moralna postaci i jakaś konfundująca identyfikacja z cynizmem ich postępowania (np. Kobieta w oknie, Scarlet Street, The Big Heat, Beyond Reasonable Doubt). Nie można jednak wskutek tego definitywnie przypisać kiczu i „pretotalitarnych” inklinacji wyłącznie żonie-scenarzystce. Zdemaskowanie dzięki ujawnionym dokumentom „wyobrażonego filmu” Langa o jego „ucieczce z Niemiec” w 1933 jako jedynie konfabulacji świadczy o dwuznaczności ideowej postawy samego Langa; w świetle tej demaskacji niepokojące czy kompromitujące aspekty ideowe jego filmów weimarskich obciążają oczywiście również i jego.

W ośmiu omawianych w tej książce filmach - niezależnie od ich poziomu artystycznego - znajduje wyraz pokrętny, uwikłany w sprzeczności i ideologiczne antynomie, trafnie rozpoznający niebezpieczeństwo, ale w dwuznaczny sposób nim zafascynowany i wobec niego przedziwnie uległy, „duch” Republiki Weimarskiej, Zeitgeist. Oczywiście, tylko cztery współczesne filmy - Doktor Mabuse, Szpiedzy, M i Testament doktora Mabuse - tematyzują go explicite, podczas gdy pozostałe alegorycznie przebierają go w kostium historii i tradycji (Zmęczona Śmierć, Nibelungi) lub też przyszłości (Metropolis, Kobieta na Księżycu). Wyznam, iż rozbiór tego „ducha”, oczywiście przy pomocy rozmaitych autorów piszących o Langu i nie tylko o Langu, w przedstawionych tu analizach filmów i ich kontekstów, był niełatwą, ale fascynującą przygodą intelektualną. 


\section{Bibliografia}

\section{OD MABUSEGO DO GOEBBELSA: WEIMARSKIE FILMY FRITZA LANGA}

A. A., Deutsche Spitzenproduktion, „Film und Volk” 1929, Nr. 9-10 (November).

A Companion to the "Nibelungenlied", ed. Winder McConnell, Camden House, Columbia (S.C.) 1998.

A 11 a i n Marcel, S o u v e s t r e Pierre, Fantomas, William Morrow, New York 1986.

A 1 t m a n Rick, "The Lonely Villa" and Griffith's Paradigmatic Style, "Quarterly Review of Film Studies" 1981, vol. 6, no. 2.

A n d e r s e n Hans Christian, Opowiadanie o matce, [w:] idem, Baśnie, przeł. Stefania Beylin, Jarosław Iwaszkiewicz, Państwowy Instytut Wydawniczy, Warszawa 1959, t. 1, s. $418-423$.

A n o $n$ i m, How "Siegfried" Was Produced, „New York Times”, 6 September 1925.

A n o n i m, "Metropolis", „Kinematograph”, 16 Januar 1927; przedruk [w:] Fritz Lang's "Metropolis": Cinematic Visions of Technology and Fear, eds. Michael Minden, Holger Bachmann, Camden House, Rochester-Woodbridge 2000, s. 82-83.

A n o n i m, „Spione”, „Filmkritische Rundschau” 1929, Nr. 10 (Oktober).

A r m o u r Robert A., Fritz Lang, Twayne Publishers, Boston 1978.

A r n h e i m Rudolf, "Die Frau im Mond”, "Die Weltbühne”, 22 Oktober 1929.

A r n h e i m Rudolf, "Metropolis", „Das Stachelschwein”, 1 Februar 1927.

A r $n$ h e i m Rudolf, „Spione”, „Das Stachelschwein” 1928, Nr. 5 (Mai).

A r r o y Jean, „La Femme sur la Lune”, „Cinémagazine” 1930, no. 6 (juin).

B a chmann Holger, "The Production and Contemporary Reception of Metropolis",

[w:] Fritz Lang's "Metropolis": Cinematic Visions of Technology and Fear, eds. Michael Minden, Holger Bachmann, Camden House, Rochester-Woodbridge 2000.

B a lz a c Honoriusz, Poszukiwanie absolutu, przeł. Julian Rogoziński, [w:] H. Balzac, Komedia ludzka, t. 22, Studia filozoficzne (II), Czytelnik, Warszawa 1964.

B a r 1 o w John D., German Expressionist Film, Twayne, Boston 1982.

B a r ry Iris, The Cinema: "Metropolis", [w:] Fritz Lang's "Metropolis": Cinematic Visions of Technology and Fear, eds. Michael Minden, Holger Bachmann, Camden House, Rochester-Woodbridge 2000, s. 104-105 [prwdr.: „The Spectator”, 26 March 1927].

B a r r y Iris, "The Nibelungs”, „The Spectator”, 14 June 1924.

B a r tle tt Randolph, German Film Revision Upheld as Needed Here, [w:] Fritz Lang's "Metropolis": Cinematic Visions of Technology and Fear, eds. Michael Minden, Holger Bachmann, Camden House, Rochester-Woodbridge 2000, s. 89-90 [prwdr.: „The New York Times", 13 March 1927].

B e d n a re k Bogusław, Śmiercia naznaczon i stawa: Notatki o "Niedoli Nibelungów", [w:] Niedola Nibelungów, reprint jubileuszowy, przeł. Ludomił German, Wydawnictwo Wacław Bagiński i Synowie, Wrocław 1994. 
B e n e t F e r r a n d o Vincente J., Symbole, metaphore et stabilité narrative dans "Der müde Tod", [w:] Fritz Lang: La mise en scène, ed. Bernard Eisenschitz, Paolo Beretto, Cinémathèque Française, Paris 1993.

B e $\mathrm{n}$ j a m i n Walter, Dramat tragiczny i tragedia, przeł. Małgorzata Sugiera, „Literatura na Świecie" 1995, nr 3 (284).

B e n j a m in Walter, The Origin of German Tragic Drama, transl. John Osborne, Verso, London-New York 2003.

B e r g Gretchen, The Viennese Night: A Fritz Lang Confession, [w:] Fritz Lang, Interviews, ed. Barry Keith Grant, University of Mississippi Press, Jackson 2003.

B e r te 11 in i Giorgio, Restoration, Genealogy and Palimpsests: On Some Historiographical Questions, [w:] Fritz Lang's "Metropolis": Cinematic Visions of Technology and Fear, eds. Michael Minden, Holger Bachmann, Camden House, Rochester-Woodbridge 2000 [prwdr.: „Film History” 1995, vol. 7, no. 3 (Autumn)].

B e t t el he im Bruno, Cudowne i pożyteczne: O znaczeniach $i$ wartościach baśni, przeł. Danuta Danek, Państwowy Instytut Wydawniczy, Warszawa 1985.

B i r n b a u m Daniel, Ols s on Anders, Czarna żótć. Melancholia klasyczna, przeł. Jan Balbierz, „Literatura na Świecie” 1995, nr 3 (284).

B o g d a n o v i c h Peter, Fritz Lang in America, Studio Vista, London 1967.

B o r d w e 11 David, Making Meaning: Inference and Rhetoric in the Interpretation of Cinema, Harvard University Press, Cambridge (Mass.)-London 1989.

B o r d w e 11 David, Narration in the Fiction Film, University of Wisconsin Press, Madison 1985.

B r e c h t Bertolt, Opera za trzy grosze, przeł. Bruno Winawer, Barbara Witek-Swinarska, Władysław Broniewski, Witold Wirpsza, [w:] B. Brecht, Dramaty, t. 1, Państwowy Instytut Wydawniczy, Warszawa 1962, s. 31-144.

B r e $\mathrm{n}$ e z Nicole, Symptome, exhibition, angoisse: réprésentation de la terreur dans l'œuvre allemande de Fritz Lang, "Cinémathèque” 1993, no. 3 (Printemps/Été).

B r o d n a x Mary M., Man a Machine: The Shift from Soul to Identity in Lang's "Metropolis and Ruttmann's "Berlin”, [w:] Peripheral Visions: The Hidden Stages of Weimar Cinema, ed. Kenneth S. Calhoon, Wayne State University Press, Detroit 2001.

B u ñu el Luis, "Metropolis", transl. Carol O'Sullivan, [w:] Fritz Lang's "Metropolis": Cinematic Visions of Technology and Fear, eds. Michael Minden, Holger Bachmann, Camden House, Rochester-Woodbridge 2000, s. 106-108 [prwdr.: „Gazeta Literaria de Madrid" 1927].

B u r c h Noël, Fritz Lang: German Period, transl. Tom Milne, [w:] Cinema: A Critical Dictionary. The Major Film-Makers, ed. Richard Roud, vol. 2: Kinugasa to Zanussi, Martin Secker \& Warburg Ltd., London 1980.

B u r c h Noël, Narrative/Diegesis - Thresholds, Limits, „Screen” 1982, vol. 23, no. 2.

B u r c h Noël, Notes on Fritz Lang's First Mabuse, "Ciné-Tracts” 1981, vol. 4, no. 1 (Spring).

c. c., "Spione”, „Reichsfilmblatt” 1928, Nr. 12 (24 März).

C a n e t $\mathrm{i}$ Elias, Auto da fé, przeł. E. Sicińska, Czytelnik, Warszawa 2004.

C a n e t t i Elias, Masa i władza, przeł. Eliza Borg, Maria Przybyłowska, Czytelnik, Warszawa 1996.

C h e v a 1 i e r Jean, G h e e r b r a n t Alain, A Dictionary of Symbols, transl. John Buchanan-Brown, Penguin Books, London-New York 1996.

$\mathrm{C}$ h i o $\mathrm{n}$ Michel, The Voice in Cinema, transl. Claudia Gorbman, Columbia University Press, New York 1999.

C i e u t a Brigitte, Fritz Lang z-MORODER-nizowany, czyli o sztuce sprzeniewierzenia: „Metropolis", przeł. Ireneusz Dembowski, „Film na Świecie” 1985, nr 318-319 (czerwiec-lipiec). 
C o a t e s Paul, Maria, mit i Inny: obraz, kult $i$ tabu, przeł. Teresa Rutkowska, „Kwartalnik Filmowy" 2003, nr 41-42 (wiosna-lato).

C o d e 11 i Lorenzo, Wywiad z Enno Patalasem, konserwatorem Filmoteki Monachijskiej (o "Metropolis" i kilku innych filmach Fritza Langa), przeł. Ireneusz Dembowski, „Film na Świecie" 1985, nr 318-319 (czerwiec-lipiec).

C o n a n D o y le, The Final Problem, [w:] Sir Arthur Conan Doyle, The Memoirs of Sherlock Holmes, Penguin Books, Harmondsworth 1950.

C o o k e Paul, German Expressionist Film, Pocket Essentials, Harpenden 2002.

C o u r t a d e Francis, Fritz Lang, Le Terrain Vague, Paris 1963.

Ć w i k i e 1 Agnieszka, "Metropolis", albo z archiwum filmowej ikonografii, [w:] Kino niemieckie w dialogu pokoleń i kultur, red. Andrzej Gwóźdź, Rabid, Kraków 2004.

D., „Spione”, „Vorwärts”, 23 März 1928, Nr. 142.

D a d o u n Roger, „Metropolis": Mother City - «Mittler» - Hitler, „Camera Obscura” 1986, vol. 15, (Autumn).

D e y Martin, Nibelungenbuch und Nibelungenfilm: Betrachtungen eines Laien, Rufus, Dortmund 1924.

D o v e r Julia, The Imitation Game: Paralysis and Response in Fritz Lang's "Metropolis" and Contemporary Critiques of Technology, [w:] Fritz Lang's "Metropolis": Cinematic Visions of Technology and Fear, eds. Michael Minden, Holger Bachmann, Camden House, Rochester-Woodbridge 2000.

Dr. Mabuse: Roman - Film - Dokumente, red. Günter Scholdt, Werner J. Röhrig Verlag, St. Ingbert 1987.

D r u m m o n d Ann, Fritz Lang's „Metropolis" (niepublikowana praca doktorska), University of Edinburgh 1982.

D u d ź Tadeusz, Ziębicki kanibal, „Gazeta Wrocławska”, 30 lipca 1999.

D u r y s Elżbieta, Zjednoczenie społeczności w milczeniu o zbrodni: „Jestem niewinny" Fritza Langa, [w:] Lustra i krzywe zwierciadła: społeczne konteksty kina i telewizji, red. Konrad Klejsa, Grzegorz Skonieczko, Rabid, Kraków 2002, s. 23-33.

Edda poetycka, przeł. i oprac. Apolonia Załuska-Stromberg, BN, seria II, nr 214, Ossolineum, Wrocław 1986.

E g g e b r e c h t Axel, „Metropolis", „Die Weltbühne” 1927, Nr. 3.

E h r i s m a n n Otfrid, "Nibelungenlied": Epoche - Werk - Wirkung, Beck, München 1987.

E is e n s ch itz Bernard, "Metropolis", UFA and le cinéma allemand, [w:] "Metropolis": Images d'un tournage, Cinémathèque Française, Paris 1985.

E i s e n s t e i n Siergiej, Nieobojętna przyroda, przeł. Mieczysław Kumorek, Wydawnictwa Artystyczne i Filmowe, Warszawa 1975.

E i s n e r Lotte H., Ekran demoniczny, przeł. Konrad Eberhardt, Wydawnictwa Artystyczne i Filmowe, Warszawa 1974.

E i s n e r Lotte H., Fritz Lang, Da Capo Press, New York 1986.

E i s $n$ e r Lotte H., The Haunted Screen: Expressionism in the German Cinema and the Influence of Max Reinhardt, transl. Robert Greaves, University of California Press, Berkeley-Los Angeles 1973.

E 1 s a e s s e r Thomas, „Metropolis”, BFI Publishing, London 2003.

E 1 s a e s s e r Thomas, "Metropolis”, przeł. Lech Niedzielski, „Film na Świecie” 1985, nr 318-319 (czerwiec-lipiec).

E $1 \mathrm{~s}$ a e s s e r Thomas, Niewinność przywrócona, przeł. Lech Niedzielski, „Film na Świecie” 1985, nr 318-319 (czerwiec-lipiec).

E $1 \mathrm{~s}$ a e s s e r Thomas, Weimar Cinema and After: Germany's Historical Imaginary, Routledge, London-New York 2000. 
E $1 \mathrm{~s}$ a e s s e r Thomas, Weimar Cinema, Mobile Selves and Anxious Males: Kracauer and Eisner Revisited, [w:] Expressionist Cinema: New Perspectives, ed. Dietrich Scheunemmann, Camden House, Rochester-Woodbridge 2003.

E u r y p i d e s, Alkestis, [w:] idem, Tragedie, t. 1, przeł. Jerzy Łanowski, Państwowy Instytut Wydawniczy, Warszawa 1967.

Expressionist Films: New Perspectives, ed. Dietrich Scheunemann, Camden House, RochesterWoodbridge 2003.

Expressionist Utopias: Paradise, Metropolis, Architectural Fantasy, ed. Timothy O. Benson, Los Angeles County Museum of Art-University of California Press, Berkeley-Los Angeles-London 2001.

F a r i n Michael, S c h o $1 \mathrm{~d}$ t Günter, Dr. Mabuse, Medium des Bösen, Rogner und Bernhard, $\mathrm{GmbH}$, Hamburg 1994.

F e 1 d Hans, „Spione”, „Film Kurier”, 23 März 1928, Nr. 72.

F e ld m a n Gerald D., The Great Disorder: Politics, Economy and Society in the German Inflation 1914-1924, Oxford University Press, Oxford 1997.

F i s c h e r Robert, Mörder - meurtrier - murderer: The Multi-lingual Versions of Fritz Lang's „M" - artykuł zamieszczony w książeczce (s. 28-38) dołączonej do edycji płyty DVD: Fritz Lang, M, seria „Masters of Cinema”, Eureka Entertainment, London 2010.

F is he r Peter S., Fantasy and Politics: Visions of the Future in the Weimar Republic, The University of Wisconsin Press, Madison 1991.

F o r d Henry, My Life and Work, Doubleday, Page, Garden City (N.Y.) 1922.

F o u c a u 1 t Michel, Panoptyzm, przeł. Tadeusz Komendant, „Literatura na Świecie” 1988, nr 6 (203).

F r a z e r James George, Złota gałą́, przeł. Henryk Krzeczkowski, Państwowy Instytut Wydawniczy, Warszawa 1978.

F r e u d Sigmund, Niesamowite, przeł. Robert Reszke, [w:] idem, Dzieła, tom III: Pisma psychologiczne, Wydawnictwo KR, Warszawa 1997.

F r e u d Zygmunt, Poza zasada przyjemności, [w:] idem, Poza zasada przyjemności, przeł. Jerzy Prokopiuk, Państwowe Wydawnictwo Naukowe, Warszawa 1975.

F r e u d Zygmunt, Psychologia zbiorowości i analiza ego, [w:] idem, Poza zasada przyjemności, przeł. Jerzy Prokopiuk, Państwowe Wydawnictwo Naukowe, Warszawa 1975.

F r e u d Zygmunt, Żałoba i melancholia, przeł. Barbara Kocowska, [w:] Kazimierz Pospiszyl, Zygmunt Freud - człowiek i dzieło, Ossolineum, Wrocław-Warszawa-Kraków 1991.

Fritz Lang, red. Renata Prokurat, Grażyna M. Grabowska, Filmoteka Narodowa-Goethe Institut, Warszawa 1993.

Fritz Lang Film ohne Titel, „Film-Kurier”, 20 April 1931.

Fritz Lang. Leben und Werke. Bilder und Dokumente, Red. Rolf Aurich, Wolfgang Jacobsen, Cornelius Schnauber, Filmmuseum Berlin-Deutsche Kinemathek und jovis Verlag, Berlin 2001.

Fritz Lang: Die Stimme von Metropolis, Red. Fred Gehler, Ullrich Kasten, Henschel Verlag, Berlin 1990.

Fritz Lang: Filmbilder, Vorbilder, Red. Heide Schönemann, Hentrich Verlag, Berlin 1992.

Fritz Lang: La mise en scène, ed. Bernard Eisenschitz et Paolo Bertetto, Cinémathèque Française, Paris 1993.

Fritz Lang: The Image and the Look, ed. Stephen Jenkins, BFI Publishing, London 1981.

Fritz Lang's "Metropolis": Cinematic Visions of Technology and Fear, ed. Michael Minden, Holger Bachmann, Camden House, Rochester-Woodbridge 2000.

F r o m m Erich, Ucieczka od wolności, przeł. Olga i Andrzej Ziemilscy, Czytelnik, Warszawa 1978. 
G a n d e r t Gero, Fritz Lang on "M": An Interview, transl. Barry W. K. Joe, [w:] Fritz Lang, Interviews, ed. Barry Keith Grant, University Press of Mississippi, Jackson 2003 [prwdr.: Gero Gandert, Fritz Lang über „M": Ein Interview, [w:] „M": Protokoll, Red. Gero Gandert, Ulrich Gregor, Marion von Schröder Verlag, Hamburg 1963].

G a r b i c z Adam, K 1 i n o w s k i Jacek, Kino, wehikuł magiczny: Przewodnik osiagnięć filmu fabularnego. Podróż pierwsza 1913-1949, Wydawnictwo Literackie, Kraków 1981.

G a y Peter, Weimar Culture: The Outsider as Insider, W. W. Norton \& Company, New YorkLondon 2001.

Gentry Francis G., Key Concepts in the "Nibelungenlied", [w:] A Companion to the "Nibelungenlied", ed. Winder McConnel, Camden House, Columbia (S.C.) 1998.

German Film and Literature: Adaptations and Transformations, ed. Eric Rentschler, Methuen, London-New York 1986.

G i r a r d René [blok monograficzny], „Literatura na Świecie” 1983, nr 12 (149).

G i r a r d René, Kozioł ofiarny, przeł. Mirosława Goszczyńska, Wydawnictwo Łódzkie, Łódź 1987.

Gi r a r d René, Prawda powieściowa i kłamstwo romantyczne, przeł. Karolina Kot, Wydawnictwo KR, Warszawa 2001.

G i r a r d René, Szekspir: Teatr zazdrości, przeł. Barbara Mikołajewska, Wydawnictwo KR, Warszawa 1996.

G i r a r d René, Widziałem szatana spadajacego z nieba jak błyskawica, przeł. Ewa Burska, Instytut Wydawniczy Pax, Warszawa 2002.

G o e th e Johann Wolfgang, Göłz von Berlichingen Żelaznoręki, przeł. Włodzimierz Lewik, [w:] idem, Dramaty wybrane, t. 1, Państwowy Instytut Wydawniczy, Warszawa 1984.

G r a f e Frieda, Fritz Lang, przeł. Maria Dehn, „Film na Świecie” 1978, nr 6 (238).

Grafe Frieda, P at a las Enno, Prinzle r Hans Helmut, Fritz Lang, Carl Hanser Verlag, München-Wien 1976.

G r i m m bracia, Kuma Śmierć, [w:] Baśnie domowe i dziecięce, zebrane przez braci Grimm, przeł. Emilia Bielicka, Marceli Tarnowski, Ludowa Spółdzielnia Wydawnicza, Warszawa 1987, t. 1, s. 209-213.

Gr o b Norbert, "Bringing the Ghostly to Life”: Fritz Lang and His Early Dr. Mabuse Films, [w:] Expressionist Films: New Perspectives, ed. Dietrich Scheunemmann, Camden House, Rochester-Woodbridge 2003.

G u n n ing Tom, The Films of Fritz Lang: Allegories of Vision and Modernity, BFI Publishing, London 2000.

H. Fr., Der Nibelungen-Film, „Lichtbildbühne”, 16 Februar 1924.

H. P., "Frau im Mond”, „Der Bildwart” 1930, Nr. 1 (Januar).

H. P., "Spione”, „Der Bildwart” 1928, Nr. 5 (Mai).

H. W., „Der müde Tod: Ein deutsches Volkslied in 6 Versen”, , Lichtbildbühne”, 8 Oktober 1921.

$\mathrm{H}$ a a s Willy, Two Major Film Premieres, transl. Holger Bachmann, Meg Tait, [w:] Fritz Lang's "Metropolis": Cinematic Visions of Technology and Fear, eds. Michael Minden, Holger Bachmann, Camden House, Rochester-Woodbridge 2000, s. 84-86 [prwdr.: W. H., Zwei große Filmpremieren, „Die Literarische Welt” 1927, Nr. 3 (21 Januar)].

H a k e Sabine, Architectural Hi/stories: Fritz Lang and "The Nibelungs", "Wide Angle" 1990, vol. 12, no. 3 (July).

H a k e Sabine, German National Cinema, Routledge, London-New York 2002.

$\mathrm{H}$ a k e Sabine, The Cinema's Third Machine: Writing on Film in Germany, 1907-1933, University of Nebraska Press, Lincoln-London 1993.

H a 11 Mordaunt, "Siegfried”, „New York Times”, 24 August 1925.

H a r b o u Thea von, Das Nibelungenbuch, Drei Masken Verlag, München 1923. 
$\mathrm{H}$ a r b o u Thea von, Frau im Mond, August Scherl Verlag, Berlin 1929.

$\mathrm{H}$ a $\mathrm{r} \mathrm{b}$ o u Thea von, Metropolis, $75^{\text {th }}$ Anniversary Edition, introduction Forrest J. Ackerman, James A. Rock \& Company, Publishers, Rockville 2002.

$\mathrm{H}$ a r b o u Thea von, Spione, August Scherl Verlag, Berlin 1928.

H a r d t Remy M., Ufa-Palast: "Kriemhilds Rache”, "Der Kritiker”, Mai-Juni 1924.

$\mathrm{H}$ a r tm a n n Siegfried, Metropolis-Technik, "Deutsche Allgemeine Zeitung”, 20 Januar 1927.

Harts ough Denise, Soviet Film Distribution and Exhibition in Germany, 1921-1933, „Historical Journal of Film, Radio and Television” 1986, vol. 5, no. 2.

Hasty Will, "From Battlefields to Bedchambers: Conquest in the Nibelungenlied", [w:] A Companion to the "Nibelungenlied", ed. Winder McConnell, Camden House, Columbia (S.C.) 1998.

He b b e 1 Friedrich, Die Nibelungen: Ein deutsches Trauerspiel in drei Abteilungen, Philipp Reclam Jun. GmbH 7 Co., Stuttgart 1995.

He g e 1 Georg Wilhelm Friedrich, Fenomenologia ducha, t. 1, przeł. Adam Landman, Państwowe Wydawnictwo Naukowe, Warszawa 1963.

H e i b e r Helmut, The Weimar Republic, transl. W. E. Yuill, Blackwell, Oxford-Cambridge (Mass.) 1995.

He in zle Joachim, The Manuscripts of the "Nibelungenlied", [w:] A Companion to the "Nibelungenlied", ed. Winder McConnell, Camden House, Columbia (S.C.) 1998.

He 11 e r Michał, N i e k r i c z Aleksander, Utopia u władzy: Historia Zwiazku Sowieckiego, t. 1, przeł. Andrzej Mietkowski, Polonia Book Fund Ltd., Londyn 1985.

$\mathrm{H}$ e $1 \mathrm{~m}$ a n Alicja, Niemiecki ekspresjonizm filmowy, [w:] Niemiecki ekspresjonizm filmowy, red. Alicja Helman, Alina Madej, Uniwersytet Śląski, Katowice 1985.

H e n d r y k o w s k i Marek, Fritz Lang a problem atrakcyjności kina, [w:] Niemiecki ekspresjonizm filmowy, red. Alicja Helman, Alina Madej, Uniwersytet Śląski, Katowice 1985; lub [w:] Niemiecki ekspresjonizm filmowy, wyd. Peter C. Seel, Bogusław Zmudziński, Akademickie Centrum Kultury „Rotunda”-Goethe Institut, Kraków 1995.

H e r l i n g-G r u d z i ń s k i Gustaw, Dziennik pisany noca 1980-1983, Res Publica, Warszawa 1990.

H i g g i n s Bertram, "Destiny” at the Polytechnic Hall, „The Spectator”, 23 February 1924.

H i l d e b r a n d t Fred, „Metropolis", „Berliner Tageblatt”, 11 Januar 1927.

H i 1 d e b r a n d t Fred, „Spione”, „Berliner Tageblatt”, 23 März 1928, Nr. 142.

$\mathrm{H}$ of $\mathrm{fm}$ a n $\mathrm{n}$ E. T. A., Magnetyzer. Zdarzenie z życia rodzinnego, przeł. Jerzy Ficowski, [w:] E. T. A. Hoffmann, Dzieła wybrane: Opowieści fantastyczne, Czytelnik, Warszawa 1959.

H of $\mathrm{f} m$ a n n E. T. A, Piaskun, przeł. Felicjan Faleński, [w:] E. T. A. Hoffmann, Dzieła wybrane: Opowieści fantastyczne, Czytelnik, Warszawa 1959.

$\mathrm{H}$ of $\mathrm{fm}$ a n $\mathrm{n}$ Werner, The Reception of the "Nibelungenlied" in the Twentieth Century, [w:] A Companion to the "Nibelungenlied", ed. Winder McConnell, Camden House, Columbia (S.C.) 1998.

H o r a k Jan-Christoph, Die Nibelungen, broszura dołączona do edycji dwupłytowego albumu Die Nibelungen, Kino on Video, New York 2002.

$\mathrm{H}$ ö r b i g e r Paul, Ich habe für Euch gespielt, Herbig, München-Berlin 1979.

$\mathrm{H}$ u 11 David Stewart, Film in the Third Reich, University of California Press, Berkeley-Los Angeles-London 1969.

H u m p h ri e s Reynold, Fritz Lang: Genre and Representation in His American Films, The John Hopkins University Press, Baltimore-London 1989.

H u n t e Otto, My Work on "Metropolis", transl. Holger Bachmann, Meg Tait, [w:] Fritz Lang's "Metropolis": Cinematic Visions of Technology and Fear, eds. Michael Minden, Holger Bachmann, Camden House, Rochester-Woodbridge 2000, s. 80-81 [prwdr.: 
O. Hunte, Meine Arbeit bei „Metropolis”, „Berliner Zeitung am Sonntag”, 7 Januar 1927].

H u y s s e n Andreas, The Vamp and the Machine: Fritz Lang's "Metropolis", [w:] Fritz Lang's "Metropolis": Cinematic Visions of Technology and Fear, eds. Michael Minden, Holger

Bachmann, Camden House, Rochester-Woodbridge 2000.

I b s e n Henryk, Peer Gynt: Poemat dramatyczny, przeł. Zbigniew Krawczykowski, Biblioteka

Narodowa, seria II, nr 152, Ossolineum, Wrocław-Warszawa-Kraków 1967.

Ich und die Stadt: Mensch und Großstadt in der deutschen Kunst des 20. Jahrhundert, Red.

Eberhard Roters, Bernhard Schulz, Nicolaische Verlagsbuchhandlung, Berlin 1987.

I c k e s Paul, Kritik der Leinwand: "Metropolis", „Die Filmwoche”, 19 Januar 1927.

I h e r i n g Herbert, „Frau im Mond”, „,Berliner Börsen-Courier”, 16 Oktober 1929.

I h e r i n g Herbert, „Spione”, „Berliner Börsen-Courier”, 23 März 1928.

I h e r i n g Herbert, The "Metropolis"-Film, transl. Holger Bachmann, Meg Tait, [w:] Fritz

Lang's "Metropolis": Cinematic Visions of Technology and Fear, eds. Michael Minden,

Holger Bachmann, Camden House, Rochester-Woodbridge 2000, s. $86-87$ [prwdr.:

Herbert Ihering, Der Metropolis-Film, „Berliner Börsen-Courier”, 11 Januar 1927].

I he r ing Herbert, Von Reinhardt bis Brecht: Vier Jahrzehnte Theater und Film, vol. 1-2,

Aufbau Verlag, Berlin 1959.

I r z y k o w s k i Karol, X Muza: Zagadnienia estetyczne kina, Wydawnictwa Artystyczne

i Filmowe, Warszawa 1977.

J a c q u e s Norbert, Dr. Mabuse, der Spieler, Rogner und Bernhard, GmbH, Hamburg 1994.

J a c qu e s Norbert, Dr. Mabuse, Master of Mystery, transl. Lilian A. Clare, Allen \& Unwin Ltd., London 1923.

J a c qu e s Norbert, Mit Lust gelebt, Hoffmann und Campe, Hamburg 1950.

Jak obs o n Roman, Dwa aspekty języka $i$ dwa typy zakłóceń afatycznych, przeł. Leon

Zawadowski, [w:] R. Jakobson, W poszukiwaniu istoty języka: Wybór pism, red. Maria

Renata Mayenowa, t. 1, Państwowy Instytut Wydawniczy, Warszawa 1989.

J e n s e n Paul M., The Cinema of Fritz Lang, Barnes \& Co.-Zwemmer Ltd., New YorkLondon 1969.

Jo rd a nova Ludmilla, Science, Machine and Gender, [w:] Fritz Lang's "Metropolis": Cinematic Visions of Technology and Fear, eds. Michael Minden, Holger Bachmann, Camden House, Rochester-Woodbridge 2000.

K a e s Anton, Cinema and Modernity: On Fritz Lang's "Metropolis", [w:] High and Low Cultures: German Attempts at Mediation, ed. Reinhold Grimm, Jost Hermand, The University of Wisconsin Press, Madison 1994.

K a e s Anton, M, BFI Publishing, London 2001.

K a e s Anton, Metropolis: City, Cinema, Modernity, [w:] Expressionist Utopias: Paradise, Metropolis, Architectural Fantasy, ed. Timothy O. Benson, Los Angeles Country of Art University of California Press, Berkeley-Los Angeles-London 2001.

$\mathrm{K}$ a 1 a t David, The Strange Case of Dr. Mabuse: A Study of the Twelve Films and Five Novels, McFarland \& Company, Inc., Publishers, Jefferson, NC-London 2001.

K a pla n E. Ann, Fritz Lang and German Expressionism: A Reading of "Dr. Mabuse, der Spieler", [w:] Passion and Rebellion: The Expressionist Heritage, ed. Stephen Eric Bronner, Douglas Kellner, Columbia University Press, New York 1983.

K a p 1 a n E. Ann, Fritz Lang: A Guide to References and Resources, G. K. Hall \& Co., Boston 1981.

K e i n e r Reinhold, Thea von Harbou und der deutsche Film bis 1933, Olms, Hildesheim 1991. $\mathrm{K}$ e $\mathrm{t} \mathrm{t} \mathrm{e} \mathrm{l} \mathrm{h}$ u $\mathrm{t}$ Erich, Errinerungen, materiały niepublikowane, Archiv Filmmuseum Berlin. Ke t t e l h u t Erich, Hauptstraße, [w:] Fritz Lang. Leben und Werke. Bilder und Dokumente,

Red. Rolf Aurich, Wolfgang Jacobsen, Cornelius Schnauber, Filmmuseum Berlin 
- Deutsche Kinemathek und jovis Verlag, Berlin 2001, s. 106-108 [źródło: Erich Kettelhut, Errinerungen, j. w.].

Kettelhut Erich, Moloch, [w:] Fritz Lang. Leben und Werk. Bilder und Dokumente,

Red. Rolf Aurich, Wolfgang Jacobsen, Cornelius Schnauber, Filmmuseum Berlin

- Deutsche Kinemathek und jovis Verlag, Berlin 2001, s. 115-118 [źródło: Erich Kettelhut, Errinerungen, j. w.].

Kę p i ń s k i Antoni, Melancholia, Państwowy Zakład Wydawnictw Lekarskich, Warszawa 1974.

K i e r k e g a a r d Søren, Albo - albo, przeł. Jarosław Iwaszkiewicz, Państwowe Wydawnictwo Naukowe, Warszawa 1976.

Kły s Tomasz, Film fikcji $i$ jego dominanty, Wydawnictwo Naukowe Semper, Warszawa 1999.

K o e r b e r Martin, Notes on the Restoration of "Metropolis", broszura dołączona do edycji Metropolis na DVD, Kino on Video, New York 2002.

K oło d y ń s k i Andrzej, 100 filmów angielskich, Wydawnictwa Artystyczne i Filmowe, Warszawa 1975.

K oło d y ń s k i Andrzej, Dziedzictwo wyobraźni: Historia filmu sf, Wydawnictwa "Alfa”, Warszawa 1989.

K o p a 1 i ń s k i Władysław, Słownik mitów i tradycji kultury, Państwowy Instytut Wydawniczy, Warszawa 1987.

K r a c a u e r Siegfried, From Caligari to Hitler: A Psychological History of the German Film, Revised and Expanded Edition, ed. and introduced by Leonardo Quaresima, Princeton University Press, Princeton-Oxford 2004.

K r a c a u e r Siegfried, Od Caligariego do Hitlera: Z psychologii filmu niemieckiego, przeł. Eugenia Skrzywanowa, Wanda Wertenstein, Filmowa Agencja Wydawnicza, Warszawa 1958.

K r a c a u e r Siegfried, The Mass Ornament: Weimar Essays, transl. and ed. Thomas Y. Levin, Harvard University Press, Cambridge (Mass.)-London 1995.

K r a s z n a-K r a u s z A., "Spione”, "Filmtechnik", 31 März 1928.

K r e i m e i e r Klaus, The Ufa Story: A History of Germany's Greatest Film Company, transl. Robert and Rita Kimber, University of California Press, Berkeley-Los AngelesLondon 1999.

Krymhilda: Opowieść rycerska o Nibelungach, według średniowiecznego eposu napisał [oraz opatrzył posłowiem] Robert Stiller, Nasza Księgarnia, Warszawa 1974.

L a $n$ e Brian, G r e g g Wilfred, The Encyclopedia of Serial Killers, Berkley Boulevard 1995.

L a n g Fritz [blok monograficzny], „Film na Świecie” 1978, nr 6 (238).

L a n g Fritz, Interviews, ed. Barry Keith Grant, University Press of Mississippi, Jackson 2003.

L a n g Fritz, On Benevolent Death, [w:] Lotte H. Eisner, Fritz Lang, Da Capo Press, New York 1986, s. 55-56 [prwdr.: „Berliner Tageblatt”, 1 Januar 1927].

L a n g Fritz, Was ich in Amerika sah, „Film-Kurier”, 11 Dezember 1924.

L a ng Fritz, Worauf es beim Nibelungen-Film ankam, [w:] Fritz Lang: Die Stimme von Metropolis, Red. Fred Gehler, Ullrich Kasten, Henschel Verlag, Berlin 1990.

L a q u e u r Walter, Weimar: A Cultural History 1918-1933, Perigee, New York 1980.

L e b l a n s Anne, Inventing Male Wombs: The Fairy-Tale Logic of "Metropolis", [w:] Peripheral Visions: The Hidden Stages of Weimar Cinema, ed. Kenneth S. Calhoon, Wayne State University Press, Detroit 2001.

L e s s in g Theodor, Haarmann: The Story of a Werewolf, [w:] Monsters of Weimar, Nemesis Books, London 1993, s. 11-156. 
L e v i n David J., Richard Wagner, Fritz Lang and the Nibelungen: The Dramaturgy of Disavowal, Princeton University Press, Princeton 1998.

L e y Willy, Rockets, Missiles and Men in Space, Viking, New York 1968.

L i n d s a y Vachel, The Art of the Moving Picture, Liveright Publishing Company, New York 1970.

L o s k a Krzysztof, Kultura i technika-niemiecki film fantastycznonaukowy w latach 1918-1939, [w:] Kino niemieckie w dialogu pokoleń i kultur, red. Andrzej Gwóźdź, Rabid, Kraków 2004.

„M": Protokoll, Red. Gero Gandert, Ulrich Gregor, Marion von Schröder Verlag, Hamburg 1963.

Mai e r C. S., Between Taylorism and Technocracy: Ideologies and the Vision of Industrial Productivity in the 1920s, "Journal of Contemporary History" 1970, no. 5.

M a n n Tomasz, Nieład i wczesna udręka, [w:] idem, Nowele, przeł. Leopold Staff, Czytelnik, Warszawa 1956.

M a n v e 11 Roger, F r a e n k e 1 Heinrich, The German Cinema, Praeger Publishers, New York-Washington 1971.

map, Kanibal z Ziębic, „Słowo Polskie”, 2 sierpnia 1999.

M a r i e Michel, M, le Maudit: Fritz Lang etude critique, Nathan, Paris 1993.

M c Gi 11 i g a n Patrick, Fritz Lang: The Nature of the Beast, St. Martin's Press, New York 1997.

"Metropolis": Das Schicksal einer Menscheit im Jahre 2000, Parufamet Presse- und Propagandaheft, Berlin 1926.

Metropolis, Sondernummer des Ufa-Magazins, Red. Stefan Lorant, Press Abteilung der Ufa, Berlin 1927.

M i n d e n Michael, The Critical Reception of "Metropolis", [w:] Fritz Lang's "Metropolis": Cinematic Visions of Technology and Fear, eds. Michael Minden, Holger Bachmann, Camden House, Rochester-Woodbridge 2000.

Morga n Ben, "Metropolis" - The Archetypal Version: Sentimentality and Self-Control in the Reception of the Film, [w:] Fritz Lang's "Metropolis": Cinematic Visions of Technology and Fear, eds. Michael Minden, Holger Bachmann, Camden House, RochesterWoodbridge 2000.

M o u 11 e t Luc, Fritz Lang, Seghers, Paris 1963.

M u r d o c h Brian, Politics in the "Nibelungenlied", [w:] A Companion to the "Nibelungenlied", ed. Winder McConnell, Camden House, Columbia (S.C.) 1988.

Niedola Nibelungów, przeł. Ludomił German, nakł. Wilhelma Zukerkandla, Złoczów 1894.

Niemiecki ekspresjonizm filmowy, red. Alicja Helman, Alina Madej, Uniwersytet Śląski, Katowice 1985.

Niemiecki ekspresjonizm filmowy, wyd. Peter C. Seel, Bogusław Zmudziński, Akademickie Centrum Kultury „Rotunda"-Goethe Institut, Kraków 1995.

O 1 i m s k y Fritz, "Spione”, „Berliner Börser-Zeitung”, 24 März 1928.

O t $t$ Frederick W., The Films of Fritz Lang, The Citadell Press, Seacaucus, N. J., 1979.

O w i d i u s z, Przemiany, przeł. Bruno Kiciński, Unia Wydawnicza „Verum”, Warszawa 1995.

P a l c z e w s k i Juliusz K., Wstęp [do:] Herbert George Wells, Wehikut czasu, przeł. Feliks Wermiński, BN, seria II, nr 216, Ossolineum, Wrocław 1985.

Passion and Rebellion: The Expressionist Heritage, ed. Stephen Eric Bronner, Douglas Kellner, Columbia University Press, New York 1983.

P a talas Enno, The City of the Future - A Film of Ruins: On the Work of Munich Film Museum, transl. Holger Bachmann, Meg Tait, [w:] Fritz Lang's "Metropolis": Cinematic 
Visions of Technology and Fear, eds. Michael Minden, Holger Bachmann, Camden House, Rochester-Woodbridge 2000.

P e i p e r Tadeusz, Miasto. Masa. Maszyna, [w:] idem, Pisma: Tędy. Nowe usta, Wydawnictwo Literackie, Kraków 1972 [prwdr.: „Zwrotnica”, lipiec 1922].

Peripheral Visions: The Hidden Stages of Weimar Cinema, ed. Kenneth S. Calhoon, Wayne State University Press, Detroit 2001.

Perriam Annina, Hebbel's Nibelungen: Its Sources, Method and Style, The Macmillan Company, New York 1906.

Peukert Detlev J. K., The Weimar Republic: The Crisis of Classical Modernity, transl. Richard Deveson, Hill and Wang, New York 1993.

P h $\mathrm{i} 11$ i p s Gene D., Fritz Lang Remembers, [w:] F. Lang, Interviews, ed. Barry Keith Grant, University of Mississippi Press, Jackson 2003.

Pieśń o Nibelungach, przełożył, przedmowa, komentarzami i indeksami opatrzył Andrzej Lam, Unia Wydawnicza „Verum”, Warszawa 1995.

P in th u s Kurt, Der Nibelungen-Film, „Das Tagebuch” 1924, Nr. 18 (3 Mai); przedruk [w:] Fritz Lang. Leben und Werk. Bilder und Dokumente, Red. Rolf Aurich, Wolfgang Jacobsen, Cornelius Schnauber, Filmmuseum Berlin - Deutsche Kinemathek und jovis Verlag, Berlin 2001, s. 84-97.

P i n th u s Kurt, Dr. Mabuses Welt, „Das Tage-Buch” 1922, Nr. 18 (6 Mai); przedruk: Fritz Lang. Leben und Werke. Bilder und Dokumente, Red. Rolf Aurich, Wolfgang Jacobsen, Cornelius Schnauber, Filmmuseum Berlin - Deutsche Kinemathek und jovis Verlag, Berlin 2001, s. 74-80.

P i n th u s Kurt, „Frau im Mond”, „Das Tage-Buch”, 19 Oktober 1929.

P i n th u s Kurt, "Spione”, „Das Tagebuch” 1928, Nr. 13 (31 März).

Pismo Święte Starego i Nowego Testamentu w przekładzie W. O. Jakuba Wujka SJ, Wydawnictwo Apostolstwa Modlitwy, Kraków 1962.

Pismo Święte Starego i Nowego Testamentu w przekładzie z języków oryginalnych (Biblia Tysiaclecia, wydanie 3 poprawione), Wydawnictwo Pallotinum, Poznań-Warszawa 1980.

P u r d i e Edna, Friedrich Hebbel: A Study of His Life and Work, Oxford University Press, Oxford 1969.

P y n ch o n Thomas, Tęcza grawitacji, przeł. Robert Sudół, Prószyński i S-ka, Warszawa 2001.

Q u a resim a Leonardo, Ninon, la hermana de Maria: "Metropolis" y sus variantes, „Archivos de la Filmoteca de Valencia”, VI 1994, vol. 17.

Re nt s chle r Eric, The Ministry of Illusion: The Nazi Cinema and Its Afterlife, Harvard University Press, Cambridge (Mass.) 1996.

R h o d e Eric, A History of Cinema from Its Origins to 1970, Penguin Books, London-New York 1978.

R it t a u Günther, Special Effects in "Metropolis", transl. Holger Bachmann, Meg Tait, [w:] Fritz Lang's Metropolis: Cinematic Visions of Technology and Fear, eds. Michael Minden, Holger Bachmann, Camden House, Rochester-Woodbridge 2000, s. 78-80 [prwdr.: G. Rittau, Trickaufnahmen in "Metropolis", „Mein Film” 1927, Nr. 60].

Rudolf Arnheim: Kritiken und Aufsätze zum Film, Red. Helmut H. Diederichs, Fischer Verlag, München 1976.

R u t s ky R. L., The Mediation of Technology and Gender: "Metropolis", Nazism, Modernism, [w:] Fritz Lang's "Metropolis": Cinematic Visions of Technology and Fear, eds. Michael Minden, Holger Bachmann, Camden House, Rochester-Woodbridge 2000 [prwdr.: „New German Critique” 1993, no. 60 (Fall)]. 
S a 1 t Barry, From Caligari to Who?, „Sight \& Sound”, Spring 1992, vol. 48, no. 2.

$\mathrm{S}$ a $1 \mathrm{t}$ Barry, Styl $i$ technologia filmu: Historia $i$ analiza, t. 2, przeł. Alicja Helman, PWSFTviT, Łódź 2003.

S a u nders Thomas J., Hollywood in Berlin: American Cinema and Weimar Germany, University of California Press, Berkeley-Los Angeles-London 1994.

S c h a c h t Roland, Der Metropolisfilm der Ufa, "Der Kunstwart” 1927, Nr. 5.

S c h a c h t Roland, "Spione”, „B. Z. am Mittag”, 23 März 1928.

$\mathrm{S}$ ch e u n e m a n n Dietrich, Activating the Differences: Expressionist Film and Early Weimar Cinema, [w:] Expressionist Film: New Perspectives, ed. Dietrich Scheunemann, Camden House, Rochester-Woodbridge 2003.

S i e m s e n Hans, Eine Filmkritik, wie sie sein soll, „Die Weltbühne” 1927, Nr. 24 (14 Juli).

Sloterdijk Peter, Critique of Cynical Reason, transl. Michael Eldred, University of Minnesota Press, Minneapolis-London 2001.

S t u r m Georges, Die Circe, der Pfau und das Halbblut: Die Filme von Fritz Lang, 1916-1921, Wissenschaftliche Verlag Trier, Trier 2004.

T a t a r Maria, Lustmord: Sexual Murder in Weimar Germany, Princeton University Press, Princeton, NJ 1995.

T a y 1 o r Frederic Winslow, The Principles of Scientific Management, Harper, New York 1911. The Nibelungen Tradition: An Encyclopedia, ed. Francis G. Gentry, Winder McConnell, Ulrich Müller, Werner Wunderlich, Routledge, New York-London 2002.

The Weimar Republic Sourcebook, ed. Anton Kaes, Martin Jay, Edward Dimendberg, University of California Press, Berkeley-Los Angeles-London 1995.

T h o m p s o n Kristin, Narodziny i schyłek "filmowej Europy", przeł. Tomasz Kłys, [w:] Kino Europy, red. Piotr Sitarski, Rabid, Kraków 2001.

Th o m p s o n Kristin, B o r d w e 11 David, Film History: An Introduction, McGraw-Hill, Inc., New York 1993.

T o e plit z Jerzy, Portret Fritza Langa, [w:] Fritz Lang, red. Renata Prokurat, Grażyna M. Grabowska, Filmoteka Narodowa-Goethe Institut, Warszawa 1993.

T r a s k C. Hooper, Some New German Films, „New York Times”, 20 May 1928.

Ty bje rg Caspar, Red Satan: Carl Theodor Dreyer and the Bolshevik Threat, [w:] Nordic Explorations: Film Before 1930, ed. John Fullerton, Jan Olsson, John Libbey \& Company Pty Ltd., Sydney 1999.

U l i t z s c h Ernst, "Die Nibelungen": Uraufführung des ersten Teilen "Siegfried" am Ufa-Palast am Zoo, „Der Kinematograph” (Düsseldorf), 17 Februar 1924.

V e r n e Jules, Wokół Księżyca, przeł. Ludmiła Duninowska, Nasza Księgarnia, Warszawa 1958.

V o g e l e r Erich, Der Nibelungenfilm: 1. Teil: „Siegfried”, „Berliner Tageblatt” 1924, Nr. 79 (15 Februar).

Wagner's "Ring of the Nibelung": A Companion, The full German text with the acclaimed English translation by Stewart Spencer, Thames \& Hudson, New York 2000.

W a r d Janet, Weimar Surfaces: Urban Visual Culture in 1920s Germany, University of California Press, Berkeley-Los Angeles-London 2001.

W e b b e r Andrew, Canning the Uncanny: The Construction of Visual Desire in "Metropolis", [w:] Fritz Lang's "Metropolis": Cinematic Visions of Technology and Fear, eds. Michael Minden, Holger Bachmann, Camden House, Rochester-Woodbridge 2000.

W e $11 \mathrm{~s}$ Herbert George, Mr. Wells Reviews a Current Film, [w:] Fritz Lang's "Metropolis": Cinematic Visions of Technology and Fear, eds. Michael Minden, Holger Bachmann, Camden House, Rochester-Woodbridge 2000, s. 94-100 [prwdr.: „The New York Times Magazine", 17 April 1927]. 
W e r n e r Gösta, Fritz Lang and Goebbels: Myth and Facts, „Film Quarterly” 1990, Spring.

W i d d i g Bernd, Culture and Inflation in Weimar Germany, University of California Press, Berkeley-Los Angeles-London 2001.

W i 11 e t t John, Art and Politics in the Weimar Period: The New Sobriety 1917-1933, Pantheon Books, New York 1978.

W i 11 e t t John, Ekspresjonizm, przeł. Maria Kluk, Wydawnictwa Artystyczne i Filmowe, Warszawa 1976.

W i 11 i a m s Alan, Structures of Narrativity in Fritz Lang's "Metropolis", [w:] Fritz Lang's "Metropolis": Cinematic Visions of Technology and Fear, eds. Michael Minden, Holger Bachmann, Camden House, Rochester-Woodbridge 2000 [prwdr.: „Film Quarterly” 1974, vol. 27, no. 4 (Summer)].

W itkiew ic z Stanisław Ignacy, Dzieła zebrane: Nienasycenie, Państwowy Instytut Wydawniczy, Warszawa 1992.

W i t k i e w i c z Stanisław Ignacy, Dzieła zebrane: Pożegnanie jesieni, Państwowy Instytut Wydawniczy, Warszawa 1992.

Y b a r r a T. R., "Die Nibelungen" Meets Disaster in Berlin: First Showing of Nationalist Propaganda Film Interrupted on Account of Protests, „New York Times”, 29 April 1924. 


\section{FILMOGRAFIA}

\section{Filmy Fritza Langa}

\section{(ur. 5.12.1890, Wiedeń - zm. 2.08.1976, Los Angeles)}

1919 - Halbblut (Skaza krwi) [film zaginiony]

Der Herr der Liebe (Władca miłości) [film zaginiony]

Die Spinnen. Erster Teil: Der Goldene See (Pająki. Część I: Złote jezioro)

Harakiri [film w posiadaniu F. W. Murnau-Stiftung; premiera DVD: listopad 2012]

Die Spinnen. Zweiter Teil: Das Brillantenschiff (Pająki. Część II: Brylantowy statek) 1920 - Das wandernde Bild (Wędrujacy obraz) [film w posiadaniu F. W. Murnau-Stiftung; premiera DVD: listopad 2012]

Kämpfende Herzen (Walcząe serca) [film rozpowszechniany także pod tytułem Die Vier um die Frau (Ich czterech, ona jedna); w posiadaniu F. W. Murnau-Stiftung; premiera DVD: listopad 2012]

1921 - Der müde Tod (Zmęczona Śmierć)

1922 - Dr. Mabuse, der Spieler. Erster Teil: Der große Spieler - ein Bild der Zeit. Zweiter Teil: Inferno - ein Spiel von Menschen unserer Zeit (Doktor Mabuse, gracz. Część I: Wielki gracz - obraz epoki. Część II: Inferno - film o ludziach naszych czasów)

1924 - Die Nibelungen. Der erste Teil: Siegfried. Der zweite Teil: Kriemhilds Rache

(Nibelungi. Część I: Zygfryd. Część II: Zemsta Krymhildy)

1926 - Metropolis

1928 - Spione (Szpiedzy)

1929 - Frau im Mond (Kobieta na Księżycu)

1931 - M (M- morderca)

1933 - Das Testament des Dr. Mabuse/Le Testament du Dr. Mabuse (Testament doktora Mabuse)

1934 - Liliom (Człowiek jest grzeszny)

1936 - Fury (Jestem niewinny) You Only Live Once (Za cenę życia)

1938 - You and Me (Ten, którego ukochałam)

1940 - The Return of Frank James (Powrót Franka Jamesa)

1941 - Western Union Man Hunt (Polowanie na człowieka)

1943 - Hangmen Also Die (Kaci także umieraja)

1944 - Ministry of Fear (Ministerstwo strachu)

The Woman in the Window (Kobieta w oknie) 


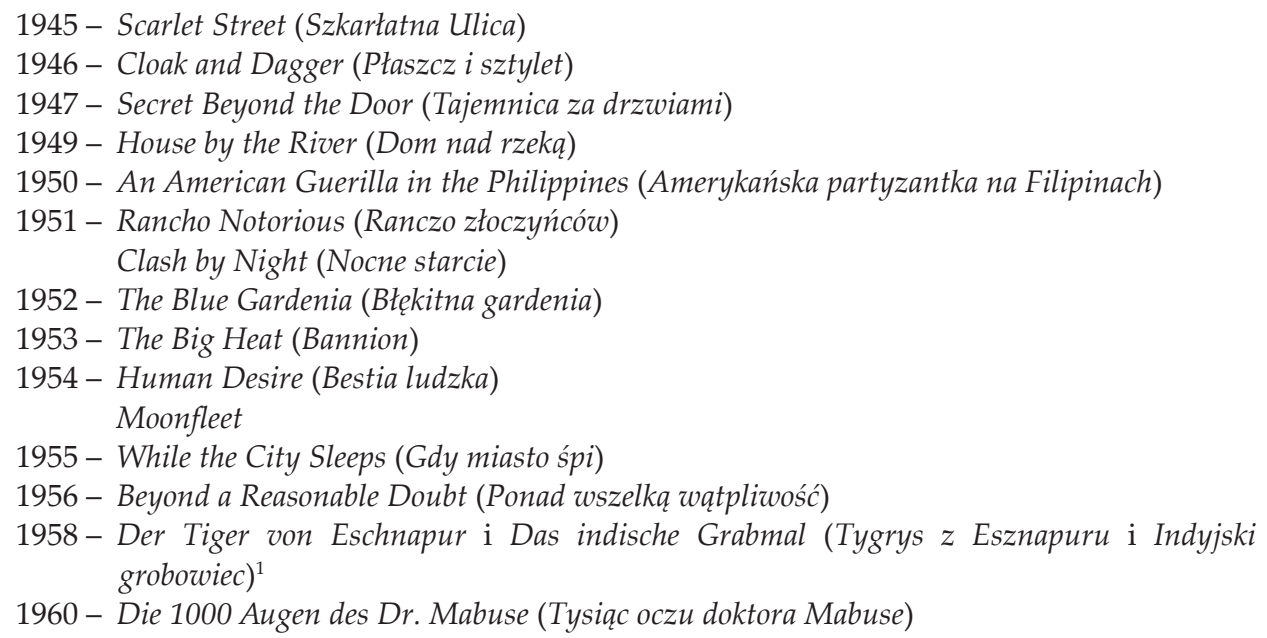

\section{Metryki analizowanych filmów}

\section{ZMĘCZONA ŚMIERĆ (DER MÜDE TOD)}

Produkcja: Decla-Bioscop 1921

Reżyseria: Fritz Lang

Scenariusz: Fritz Lang, Thea von Harbou

Zdjęcia: Erich Nitzschmann, Hermann Saalfrank, Fritz Arno Wagner

Oswietlenie: Robert Hegerwald

Scenografia: Walter Röhrig, Hermann Warm, Robert Herlth

Kostiumy (w epizodzie arabskim i chińskim): Heinrich Umlauff, kustosz Volksmuseum Hamburg

Obsada: Lil Dagover (Dziewczyna, Zobaida, Fiametta, Tiao Tsien), Bernhard Goetzke (Śmierć, El Mot, cesarski łucznik), Walter Janssen (Chłopiec, Frankończyk, Giovanfrancesco, Liang), Rudolf Klein-Rogge (derwisz, Girolamo), Karl Platen (aptekarz), Lydia Potechina (oberżystka), Georg John (żebrak), Eduard von Winterstein (kalif), Max Adalbert (notariusz, cesarski minister skarbu), Paul Biensfeldt (A Hai), Karl Huszar-Puffy (cesarz), Erika Unruh (Ayesha), Lewis Brody (Maur), Lothar Müthel (posłaniec Fiametty), Lina Paulsen (niania Fiametty), Paul Neumann (kat cesarza), Hans Sternberg (burmistrz), Carl Rückert (pastor), Erich Pabst (nauczyciel), Paul Rehkopf (grabarz), Marie Wismar (staruszka), Grete Berger (matka) i inni

Długość: $2311 \mathrm{~m}$

Premiera: 7 października 1921, Ufa-Theater i Mozartsaal, Berlin

${ }^{1}$ Dyptyk indyjski, którego obie części o ciągłości fabularnej między nimi, stanowią jedną całość, nie jest jednak połączony wspólnym tytułem dla całości, jak np. Nibelungi czy Doktor Mabuse, gracz. 
DOKTOR MABUSE, GRACZ (DR. MABUSE, DER SPIELER)

CZĘŚĆ I: WIELKI GRACZ - OBRAZ EPOKI

(ERSTER TEIL: DER GROßE SPIELER - EIN BILD DER ZEIT)

CZĘŚĆ II: INFERNO - FILM O LUDZIACH NASZYCH CZASÓW

(ZWEITER TEIL: INFERNO - EIN SPIEL VON MENSCHEN UNSERER ZEIT)

Produkcja: Ullstein-Uco Film - Decla-Bioscop - Ufa 1922

Reżyseria: Fritz Lang

Scenariusz: Fritz Lang i Thea von Harbou (na podstawie powieści Norberta Jacques'a)

Zdjęcia: Carl Hoffmann

Scenografia: Otto Hunte, Carl Stahl-Urach oraz Erich Kettelhut, Karl Vollbrecht

Kostiumy: Vally Reinecke

Obsada: Rudolf Klein-Rogge (Mabuse), Bernhard Goetzke (prokurator Norbert von Wenk), Aud Egede Nissen (Cara Carozza), Gertrud Welcker (hrabina Dusy Told), Alfred Abel (hrabia Told), Paul Richter (Edgar Hull), Hans Adalbert von Schlettow (Georg), Robert Forster-Larrinaga (Spoerri), Georg John (Pesch), Grete Berger (Fine), Karl Huszar-Puffy (Hawasch), Julius Falkenstein (Karsten), Lydia Potechina (bogata Rosjanka), Julius Hermann (Schramm), Karl Platen (służący Toldów), Anita Berber („Wenus" z „Folies Bergères") i inni

Długość: $3496+2560 \mathrm{~m}$

Premiera: część I - 27 kwietnia 1922, część II - 26 maja 1922, Ufa-Palast am Zoo, Berlin

NIBELUNGI (DIE NIBELUNGEN)

CZĘŚĆ I: ZYGFRYD (SIEGFRIED)

CZĘŚĆ II: ZEMSTA KRYMHILDY (KRIEMHILDS RACHE)

Produkcja: Decla-Bioscop - Ufa 1924

Reżyseria: Fritz Lang

Scenariusz: Thea von Harbou i Fritz Lang na podstawie eposu Das Nibelungenlied

Zdjęcia: Carl Hoffmann, Günther Rittau oraz Walter Ruttmann (zdjęcia i animacja sekwencji "Sen o sokole")

Scenografia: Otto Hunte oraz Erich Kettelhut, Karl Vollbrecht

Kostiumy: Paul Gerd Guderian, Änne Willkomm oraz Heinrich Umlauff (Hunowie)

Charakteryzacja: Otto Genath

Muzyka: Gottfried Huppertz

Obsada: Margarethe Schön (Krymhilda), Paul Richter (Zygfryd), Theodor Loos (Gunter), Hans Adalbert von Schlettow (Hagen Tronje), Hanna Ralph (Brunhilda),

Rudolf Klein-Rogge (Etzel), Bernhard Goetzke (Volker), Georg John (kowal Mime, Alberyk, Blaodel), Gertrude Arnold (królowa Uta), Rudolf Rittner (Rydygier z Bechlarn), Hans Carl Müller (Gernot), Erwin Biswanger (Giselher), Fritz Alberti (Dytrych z Bern), Hardy von François (Dankwart), Hubert Heinrich (Werbel), Georg Jurowski (ksiądz), Frida Richard (wieszczka Brunhildy), Georg August Koch (Hildebrand), Iris Roberts (paź Krymhildy) i inni

Długość: $3216+3576 \mathrm{~m}$

Premiera: część I - 14 lutego 1924, część II - 26 kwietnia 1924, Ufa-Palast am Zoo, Berlin 


\section{METROPOLIS}

Produkcja: Ufa 1926

Dystrybucja: Parufamet

Reżyseria: Fritz Lang

Scenariusz: Thea von Harbou, Fritz Lang

Zdjęcia: Karl Freund, Günther Rittau

Efekty specjalne: Eugen Schüfftan oraz Helmar Lenski, Konstantin Irmen-Tschet

Scenografia: Otto Hunte, Erich Kettelhut, Karl Vollbrecht

Rzeźby: Walter Schulze-Mittendorf

Kostiumy: Änne Willkomm

Muzyka: Gottfried Huppertz

Obsada: Brigitte Helm (Maria, fałszywa Maria), Gustav Fröhlich (Freder), Alfred Abel (Joh Fredersen), Rudolf Klein-Rogge (Rotwang), Heinrich George (nadzorca Grot), Theodor Loos (Jozafat), Erwin Biswanger (Nr 11 811), Fritz Rasp (Chudy), Heinrich Gotho (mistrz ceremonii), Olaf Storm (Jan), Hanns Leo Reich (Marinus), Max Dietze, Georg John, Walter Kühle, Arthur Reinhard, Erwin Vater (robotnicy), Grete Berger, Olly Böheim, Ellen Frey, Lisa Gray, Rose Liechtenstein, Helene Weigel (żony robotników), Fritz Alberti (Mechaniczny Człowiek), Margarete Lanner, Beatrice Garga, Anny Hintze, Helen von Münchhofen, Hilde Woitscheff (damy z „wiecznych ogrodów") i inni

Długość: wersji autorskiej - 4189 m, drugiej wersji niemieckiej-3241 m

Premiera: 10 stycznia 1927, Ufa-Palast am Zoo, Berlin

Dystrybucja drugiej wersji niemieckiej od 26 sierpnia 1927

\section{SZPIEDZY (SPIONE)}

Produkcja: Fritz Lang Film GmbH 1928

Dystrybucja: Ufa

Reżyseria: Fritz Lang

Scenariusz: Thea von Harbou, Fritz Lang

Zdjęcia: Fritz Arno Wagner

Scenografia: Otto Hunte, Karl Vollbrecht

Obsada: Rudolf Klein-Rogge (Haghi), Gerda Maurus (Sonia Barranikowa), Willy Fritsch (Agent 326), Lupu Pick (dr Matsumoto), Fritz Rasp (płk Jellusić), Lien Deyers (Kitty), Craighall Sherry (Jason), Paul Hörbiger (Franz), Hertha von Walther (Lady Leslane), Louis Ralph (Morrier), Julius Falkenstein (kierownik Hotelu Olympic), Gustl Stark-Gstettenbaur (chłopiec spod Cafe Danielli) i inni

Długość: $4364 \mathrm{~m}$

Premiera: 22 marca 1928, Ufa-Palast am Zoo, Berlin

\section{KOBIETA NA KSIĘŻYCU (FRAU IM MOND)}

Produkcja: Fritz Lang Film GmbH, 1929

Dystrybucja: Ufa

Reżyseria: Fritz Lang

Scenariusz: Thea von Harbou (na podstawie własnej powieści) 
Zdjęcia: Court Courant, Oskar Fischinger, Otto Kanturek

Efekty specjalne: Konstantin Tschetwerikoff

Scenografia: Otto Hunte, Emil Hasler, Karl Vollbrecht

Konsultacja naukowo-techniczna: Hermann Oberth, Willy Ley

Obsada: Gerda Maurus (Frieda Velten), Willy Fritsch (Wolf Helius), Fritz Rasp (Walt Turner), Gustav von Wangenheim (Hans Windegger), Klaus Pohl (profesor Manfeldt), Gustl Stark-Gstettenbaur (Gustaw), Alexa von Porembsky (dziewczyna z fiołkami), Max Maximilian (kierowca Heliusa), Margarete Kupfer (gospodyni Heliusa), Tilla Durieux, Hermann Vallentin, Max Zilzer, Mahmud Terja Bey, Borwin Walth (pięcioro „mędrców”) i inni

Długość: 4356 m

Premiera: 15 października 1929, Ufa-Palast am Zoo, Berlin

\section{$M-M O R D E R C A(M)$}

Produkcja: Nero Film AG, 1931

Reżyseria: Fritz Lang

Scenariusz: Thea von Harbou, Fritz Lang

Zdjęcia: Fritz Arno Wagner

Scenografia: Emil Hasler, Karl Vollbrecht

Montaż: Paul Volkenberg

Dźwięk: Adolf Jansen

Temat ze suity Edvarda Griega Peer Gynt gwizdany przez Fritza Langa

Obsada: Peter Lorre (Hans Beckert), Otto Wernicke (komisarz Lohmann), Gustaf Gründgens (Kasiarz), Gerhard Bienert (policjant z Wydziału Zabójstw), Ellen Widmann (Frau Beckmann), Inge Landgut (Elsie Beckmann), Theodor Loos (komisarz Groeber), Friedrich Gnaß (włamywacz Franz), Paul Kemp (kieszonkowiec), Georg John (sprzedawca baloników), Hertha von Walther (prostytutka), Rudolf Blümmer („obrońca” Beckerta), Franz Stein (minister), Ernst Stahl-Nachbaur (komendant główny policji), Heinrich Gotho (starszy pan) i inni

Długość: 3208 m (wersja premierowa), 2996 m (wersja zrekonstruowana)

Premiera: 11 maja 1931, Ufa-Palast am Zoo, Berlin

\section{TESTAMENT DOKTORA MABUSE (DAS TESTAMENT DES DR. MABUSE)}

Produkcja: Nero Film AG, 1933

Reżyseria: Fritz Lang

Scenariusz: Fritz Lang, Thea von Harbou

Zdjęcia: Fritz Arno Wagner, Karl Vaß

Scenografia: Karl Vollbrecht, Emil Hasler

Kostiumy: Hans Kothe

Muzyka: Hans Erdmann

Dźwięk: Adolf Jansen

Montaż: Conrad von Molo, Lothar Wolff

Obsada: Otto Wernicke (komisarz Lohmann), Oskar Beregi, Sr. (profesor Baum), Rudolf Klein-Rogge (Mabuse), Gustav Diessl (Tom Kent), Wera Liessem (Lilli), Karl Meixner 
(Hofmeister), Theodor Loos (doktor Kramm), Gerhard Bienert (policjant), A. E. Licho (dr Hauser), Theo Lingen (Karetzky), Rudolf Schündler (Hardy), Camilla Spira (Anna), Oskar Höcker (Bredow), Hadrian Maria Netto (,,jubiler"), Klaus Pohl (Müller), Georg John (Winkler), Paul Henckels („,drukarz”) i inni

Długość: 3341 m (wersja premierowa), 3270 m (wersja zrekonstruowana)

Premiera: 21 kwietnia 1933, Budapeszt 


\section{INDEKS OSÓB}

A. A. 445

Abel Alfred 309, 395

Abraham Karl 38

Adams Edward 405

Aecjusz (Aëtius Flavius) 246

Aleksander Wielki (Aleksander III Macedoński) 312,372

Albers Hans 69, 76, 78, 102, 107, 126-127, 138

Allain Marcel 289

Allgeier Sepp 52, 53, 70, 94, 128

Almeida Fabrice d' 147

Altman Rick 205

Amann Betty 40

Andersen Hans Christian 167, 186

Andreu-Rivel (trio) 137

Angst Richard 70

Ant Adam 407

Anton Karl 109

Antonioni Michelangelo 311, 446, 472

Armour Robert A. 156

Arnheim Rudolf 57, 63, 340, 396, 445

Arno Siegfried 69

Arroy Jean 447, 449

Arystoteles 186, 199

Ascheid Antje 147

Asquith Anthony 123

Attyla (Attila) 246

Aurich Rolf 87, 151, 154, 170, 224, 280, 336, 437, 443,478

Baarová Lída 70, 106

Bach Friedemann 117

Bach Johann Sebastian 117

Bachmann Holger 51, 378, 386, 388, 389, 391, 393, $395,397,398,403-406,437,438$

Báky Josef von 69, 102, 127

Balázs Béla 56, 57, 60, 63

Balbierz Jan 198

Balcon Michael 112

Balser Ewald 116

Balzac Honoré de 256, 466, 504

Barlow John D. 33, 328, 329

Barnett Charles 500

Barr Alfred Hamilton, Jr. 379

Barrault Jean-Louis 117

Barry Iris 219, 220, 227, 228, 400-402, 413, 416

Bartlett Randolph 405

Bassermann Albert 14, 68, 85
Batko Zbigniew 146

Baudry Jean-Louis 247, 326

Beauchamp Edmond 125

Becce Giuseppe 165

Bednarek Bogusław 242, 249

Beethoven Ludwig van 117

Benatar Pat 407

Benet Ferrando Vicente José 205, 206

Benjamin Walter 198, 208, 209, 250

Benson Timothy O. 388

Bentham Jeremy 41, 375, 376, 422, 523

Beretto Paolo 205

Berger Ludwig 17, 22, 68, 78, 80, 117, 121, 171

Berlichingen Götz von 320

Berg Gretchen 390, 528

Bergman Ingmar 116, 137, 207, 372

Bergman Ingrid 70

Bergner Elisabeth 68, 82

Bernhardt Kurt 55, 68, 84, 94, 157, 479

Bertellini Giorgio 404, 406

Besson Luc 392, 436

Bettelheim Bruno 461

Beylin Stefania 186

Biegańska Ewa M. 63

Bielicka Emilia 186

Bismarck Otto von 94, 115, 116

Birgel Willy 70, 129

Birnbaum Daniel 198

Blom August 17, 58

Boccaccio Giovanni 167, 175

Böcklin Arnold 267

Boese Carl 17, 29, 47, 59, 69, 80, 81, 119, 120, 124

Bogdanovich Peter 390

Bolváry Géza von 69, 108

Bordwell David 14, 15, 18, 21, 22, 27, 32-35, 42, $74,75,158,200,213,216,220,368,370,393$, $443,516,517$

Borg Eliza 306, 371, 489, 527

Borsody Eduard von 69, 105

Botticelli Sandro 292

Boyer Charles 84

Boyer Jean 78, 125

Brasseur Pierre 79

Braun Eva 145

Braun Harald 117

Brauner Artur 88, 278, 528

Brecht Bertolt 39, 87, 89, 91, 92, 103, 156, 160, 244, $477,491,499,533$ 
Brenez Nicole 343

Breughel Starszy Peter 430

Brockman Stephen 146

Brody Lewis 201

Broniewski Władysław 477

Bronner Stephen Eric 323

Brooks Louise 39, 40

Bruegel de Oude Pieter zob. Breughel Starszy Peter

Brunichilde 246

Brüning Heinrich 73

Bruns Jana Francesca 147

Buch Fritz Peter 108

Buchanan-Brown John 185, 266

Buchowetzki Dimitri zob. Buchowiecki Dymitr

Buchowiecki Dymitr 22, 46, 47, 60

Budd Mike 63

Bülow Bernhard von 252

Buñuel Luis 400, 401

Burch Noël 291, 293, 310, 313, 319, 349, 356, 365, 469, 486-488, 518, 520

Burska Ewa 256

Canetti Elias 306, 307, 371, 489, 526, 527

Canudo Ricciotto 24

Čapek Karel 392, 402

Capone Al 288, 289, 378

Capra Frank 105, 125

Carné Marcel 117

Caspar Horst 116, 118

Cavalcanti Alberto 401

Cellini Benvenuto 532

Chaney Lon 392

Chaplin Charles 96, 120, 137, 205, 312, 421, 425,473

Charell Erik 68, 78, 125

Chaucer Geoffrey 175

Chevalier Jean 185, 191, 207, 266

Chion Michel 522

Chlodwig I 246

Chmara Grigorij 84

Chopin Fryderyk 108, 116

Churchill Winston 144, 467

Cieutat Brigitte 407

Clair René 54, 89, 421, 425

Clare Lilian A. 280

Coates Paul 393

Codelli Lorenzo 404

Comedian Harmonists 79

Conan Doyle Arthur 43, 335, 369

Conrad Joseph 346

Cook David A. 14, 19, 20, 22

Cooke Paul 327-328

Courtade Francis 155

Crowther Bosley 502

Cserépy Arzén von 47, 95

Cummings Doug 53
Curtiz Michael 22

Czajkowski Piotr 77, 116, 125

Czechowa Olga 70, 81, 123

Czeschka Carl Otto 270

Czinner Paul 82

Ćwikiel Agnieszka 51

D. zob. Degner Ernst

D'Annunzio Gabriellino 392

Dadoun Roger 432

Dagover Lil 13, 70, 140, 201

Danek Danuta 461

Dante Alighieri 175

Daven André 79

Davidson Paul 14, 15, 19, 58

Dawes Charles Gates 21

Deburau zob. Debureau Baptiste

Debureau Baptiste (właśc. Deburau Jean Gaspard) 116, 117

Degner Ernst 344

Dehnel Piotr 63

Delluc Louis 24

Dembowski Ireneusz 390, 404, 407

DeMille Cecil Blount 208

Denke Karl 86, 481-483

Deppe Hans 71, 133

Dessau Paul 69

Deutsch Ernst 30, 68

Deveson Richard 283

Dey Martin 223

Deyers Lien 119, 340

Dibbets Karl 15

Dickens Charles 184

Diederichs Helmut H. 396

Diessl Gustav 70, 118

Dieterle Wilhelm 55, 61

Dietrich Marlene 68, 73, 75, 123, 129, 160

Dix Otto 37, 379, 380, 485

Döblin Alfred 37, 91, 392, 485

Dondzik Michał 8

Dostojewski Fiodor 84, 256, 322, 323

Drewniak Bogusław 69, 97, 99, 115, 117, 135, 146

Dreyer Carl Theodor 25, 42, 44, 60, 70, 175, 176, 197

Drössler Stefan 47

Drummond Ann 388

Dudow Slatan (Dudow Zlatan) 39, 68, 90, 91, 380

Dudź Tadeusz 483

Dulac Germaine 208

Duninowska Ludmiła 441

Dupont Ewald André 22, 52, 55, 61, 74, 81, 152

Dürer Albrecht 165

Durys Elżbieta 489

Eberhardt Konrad 12, 62, 158, 171, 270, 328, 339

Edison Thomas Alva 13 
Eggebrecht Axel 57, 396, 398, 399

Eggerth Marta 70

Ehrismann Otfrid 249

Eisler Hanns 91

Eisenschitz Bernard 205, 404

Eisenstein Siergiej 115, 157, 172, 400

Eisner Lotte Henriette 11, 12, 16, 17, 30, 32-34, $62,153,155,158,159,167,168,171,172,177$, $186,194,218-221,254,255,266,267,269-271$, 282-286, 288, 305, 323, 328-331, 338-340, 343, $346,348,349,356,361,363,365,378,386,447$, $453,454,465,466,470,533$

Eldred Michael 159, 186, 333

Eliade Mircea 265

Elsaesser Thomas 12-21, 23, 26, 28, 30, 42, 51, 62, $67,68,147,158-160,171,174-176,185,201-$ 203, 277, 280, 286-288, 325, 329, 331, 333, 356, $388,390-394,404-407,420,433,533$

Elser Johann Georg 142

Emo E. W. (Emo Emerich Wojtek) 117

Engel Erich 69

Engels Erich 109

Ensor James 26

Epstein Jean 208

Ernst Paul 250

Eurypides 167, 191

Ewers Hanns Heinz 14, 15, 102

Fairbanks Douglas 165, 194, 388

Faleński Felicjan 310

Fanck Arnold 52, 53, 61, 62, 69, 92, 93, 128

Farrère Claude 391

Fassbinder Reiner Werner 90

Fejos Paul (właśc. Fejös Pál) 117

Feld Hans 348

Feld Rudi 152, 444

Feldman Gerald D. 283, 304, 310

Feuchtwanger Lion 112

Feuillade Louis 49, 175, 289, 290

Ficowski Jerzy 310

Fischer Robert 500

Fisher Peter S. 50, 442, 445, 467

Ford Henry 371, 424, 425

Forst Willi (Willy) 69, 70, 77, 79, 80, 117, 123, 124, 126, 137

Forster Rudolf 70, 82, 89

Fosse Bob 381

Foucault Michel 41, 375, 376, 523

Fox William 45

Foy Bryan 74

Francen Victor 82

Franco Jesús (Jesús Franco Manera) 278

Fraenkel Heinrich 146, 222

Franciszek Ferdynand, arcyksiążę 348

Franz Ferdinand Habsburg, Erzherzog zob. Franciszek Ferdynand, arcyksiążę

Frazer James George 265
Fregonese Hugo 278

Freud Sigmund 30, 38, 187, 188, 192, 193, 196, 309, $310,312,317-319$

Freund Karl 16, 22, 45, 51, 52, 61, 70, 79, 345, 400, 436, 438

Friedkin William 484

Friedrich II Hohenzollern zob. Fryderyk II Wielki

Fritsch Willy 69, 75, 77-80, 122, 123, 125, 126, 143, $339,345,361$

Fröhlich Elke 154, 478

Fröhlich Gustav 40, 69, 85, 115, 122, 339, 395

Froelich Carl 67-70, 77, 82-84, 86, 95, 110, 116, 120, $125,130,142$

Fromm Erich 11, 319

Fryderyk II Wielki 47, 94, 114, 115

Fullerton John 176

Gad Urban 14

Galeen Henrik 17, 171

Galewska Joanna 146

Gallone Carmine 74

Gance Abel 208

Gandert Gero 288, 482

Garat Henri 78, 79

Garbicz Adam 176

Garbo Greta 22, 39, 61, 129, 157

Gardner Cyril 93

Gärtner Adolf 13

Gay Peter 160, 203

Gebühr Otto 48, 94, 115

Gehler Fred 248

Geibel Emanuel 250

Geller Michaił zob. Heller Michał

Gennat Ernst 492

Gentry Francis G. 230

George Heinrich 69, 92, 103, 112, 113, 116, 118, 130, 133-135, 395

Gerlach Arthur von 17, 33, 42, 60, 171

German Ludomił 212, 230, 242

Gerron Kurt 69, 80

Gheerbrant Alain 185, 191, 207, 266

Gibson Mel 207

Giesen Rolf 147

Girard René 46, 113, 255, 256, 265, 308, 427, 464, $488,489,496$

Gliese Rochus 22, 28, 61, 71, 117

Goebbels Joseph 7, 15, 66, 68, 70, 71, 73, 87, 94-99, 101, 104-106, 109-111, 118, 120, 121, 126, 133, $135,139,141,143-146,152-158,253,268,287$, $320,477,478,480,497,501,503,526,529$

Goebbels Magda 145, 320, 478

Goethe Johann Wolfgang 17, 122, 171, 222, 320

Goetz Curt 69

Goetzke Bernhard 201, 276, 309

Gold Käthe 70, 126

Gombrowicz Witold 44

Gorbman Claudia 522 
Göring Hermann 253

Goszczyńska Mirosława 256, 308, 489

Gottschalk Joachim 70, 143

Goulding Edmund 157

Goupillières Roger 500

Grabbe Christian Dietrich 392

Grabowska Grażyna M. 63, 164

Grafe Frieda 155

Grant Barry Keith 152, 165, 390, 453, 482, 528

Grau Alexander 335

Gregg Wilfred 482

Gregor Ulrich 482

Griebel Otto 37, 379

Grieg Edvard 492, 493, 495

Griffith David Wark 13, 47, 49, 175, 176, 205, 208, 388, 401, 497, 516

Grimm Brüder (Grimm Jacob i Wilhelm) 167, 186, 197, 228

Grimm Reinhold 388

Grossmann Georg Karl 86, 481-483

Grosz Georg 37, 379, 380, 485

Gründgens Gustaf 69, 81, 117, 496

Grünewald Matthias 165

Grune Karl 39, 60, 380

Gunning Tom 13, 50, 51, 154-157, 166, 172, 178, 185-188, 192, 197, 199, 200, 206, 208, 219, 220, $241,242,245-247,263,264,279,287,289,290$, $303,308,310-312,325-327,332,341,343,346$, $349,356,358,362,364,370-373,377,378,386$, 393, 429, 430, 434, 479, 480, 488, 493, 494, 496, $515,518,519,526$

Gwóźdź Andrzej 50, 51, 62, 450

H. Fr. zob. Fraenkel Heinrich

H. P. zob. Pander Hans

H. W. zob. Wollenberg Hans

Haarmann Fritz 86, 481-484

Haas Dolly 80

Haas Willy (W. H.) 56, 57, 396, 397

Hablik Wenzel 267

Hagemann Peter A. 97

Hagen Peter 106-107

Hainisch Leopold 117

Hake Sabine 15, 17, 56, 57, 72, 78, 96, 98, 100-102, $126,146,147,171,479$

Hakim Eric 500

Hall Mordaunt 228, 229

Hameister Willy 70

Hamman Joë 93

Hansen Max 68

Hansen Rolf 68, 69, 77, 105, 130, 140

Harbou Thea von 42, 49, 50, 54, 69, 87, 164, 166, $167,170,175,184,186,192,202,214,222-225$, $248,251-253,278,280,281,311,337,339,340$, $346,360,373,390-392,394,396-398,400,402$, $403,406,418,419,421,428,429,433-436,439$,
$445,446,451,453,454,467,482,490,501,503$, $504,516,533,534$

Hardt Remy M. 223

Harlan Veit 47, 68-71, 77, 92, 98, 99, 108, 112-115, $118,131-134,137,308$

Hartl Karl 69, 80, 93, 108, 117, 123, 126, 127

Hartlaub Gustav 36, 37, 378, 379

Hartmann Paul 70, 115

Hartmann Siegfried 420

Hartsough Denise 342

Harvey Lilian 70, 77-79, 119, 123, 125-126

Hast Willy 258

Hatheyer Heidemarie 70

Hauff Wilhelm 112

Hauptmann Gerhard 14, 17, 25, 134

Hawks Howard 481

Hebbel Friedrich 221, 222, 246, 250-252, 257

Heckel Erich 27

Hegel Georg Wilhelm Friedrich 325

Heine Heinrich 269, 270

Heinzle Joachim 249

Helbig Heinz 111

Heller Michał 347

Hellmund-Waldow E. 339, 349

Helm Brigitte 39, 70, 80, 385, 387, 395

Helman Alicja 29, 32, 62, 281, 329, 330, 340

Hendrykowski Marek 62, 280, 281

Herking Ursula 70

Herling-Grudziński Gustaw 376

Herlth Robert 28, 71, 78, 85, 194, 208, 532

Hermand Jost 388

Heymann Claude 122

Higgins Bertram 165

Hildebrand Hilde 70, 123

Hildebrandt Fred 343, 399

Hildico 246

Himmler Heinrich 142, 145

Hindenburg Paul von 65, 72, 139, 140, 253

Hinkel Hans 96, 144

Hinz Werner 114

Hippler Fritz 101, 113, 144, 497

Hirschbiegel Oliver 320

Hirschfeld Magnus 55

Hitchcock Alfred 214, 286, 350

Hitler Adolf 7, 15, 20, 48, 65, 66, 68, 72, 73, 83, 89, 93-96, 104, 105, 114, 115, 121, 139-145, 153, $157,160,253,255,267,268,276,307,321,377$, $466,478,480,481,502,503$

Hofer Franz 18

Hoffmann Carl 16, 70, 78, 218, 223, 330

Hoffmann Werner 250, 253

Hoffmann Ernst Theodor Amadeus 16, 310, 312,318

Hofmannstahl Hugo von 14, 392

Hogenkamp Bert 15

Holländer Friedrich 69, 75

Homer 167, 175, 183, 249, 372-373 
Hoppe Marianne 70, 137

Horak Jan-Christoph 213

Hörbiger Paul 70, 338

Horney Brigitte 70

Hugenberg Alfred 19, 23, 61, 72, 73, 76, 95, 96, 100, $138,141,391,395,398,445,447$

Hugo Victor 392

Hull David Stewart 314-315

Hunte Otto 28, 70, 76, 216, 222, 223, 330, 400, 452,473

Huppertz Gottfried 213, 220, 221, 229, 252, 393, $394,406,415$

Huppertz Toni 105

Huxley Aldous 419

Huyssen Andreas 378, 396

Ibsen Henrik 134, 495

Ickes Paul 57, 396, 398

Ihering Herbert 57, 223, 224, 338, 349, 396-398, 445

Irzykowski Karol 473, 517

Iwaszkiewicz Jarosław 186, 323, 499

Jacobsen Wolfgang 87, 146, 151, 170, 224, 280, 336, $437,443,478$

Jacoby Georg 69, 80, 117, 124, 143, 392

Jacques Norbert 50, 278-280, 284, 288, 289, 311, $317,391,504$

Jaeger Malte 112

Jakobson Roman 205, 429

Jan Chrzciciel św. 434, 435

Jannings Emil 13, 22, 45, 46, 48, 51, 52, 61, 65, 69, $84,110,114,115,133-135,392$

Janowitz Hans 24

Janssen Walter 117, 201

Jarmusch Jim 446, 472

Jeanne d'Arc zob. Joanna d'Arc

Jenkins Stephen 156

Jensen Paul M. 151, 155, 165, 166, 199, 203, 219, $228,229,251,283,284,309,313,337,341,343$, $346,349,371,372,377,386,390,442,443,447$

Jessner Leopold 33, 42, 59, 60

Jezus Chrystus 76, 176, 196, 197, 255, 257, 436

Joanna d'Arc, św. 110

Joe Barry W. K. 482

Johnson Julian 405

Jordan Wilhelm 250

Jordanova Ludmilla 422-425

Jugo Jenny 70, 123

Jung Karol 63

Jutzi Piel (właśc. Jutzi Phil) 37, 40, 62, 68, 69, 90-92

Kaes Anton 87, 146, 388, 390, 393, 394, 424, 428, 479-481, 483, 484, 486-488, 490, 492, 497

Kaiser Georg 30, 391

Kalat David 50, 152, 154, 277-282, 289, 311, 500$502,504,528$

Kandinsky Wassily 27
Kaplan E. Ann 152, 171, 199, 203, 221-224, 228, $229,281,323,339-341,396,397,399,445-$ 447,478

Kapp Wolfgang 286

Karkowska Magdalena 57

Karmakar Romuald 484

Karol X (Charles X Bourbon) 116

Karlweis Oskar 79

Kasten Ullrich 248

Kästner Erich 85

Katcher Leo 502

Käutner Helmut 69, 71, 120, 127, 136-138

Kayßler Friedrich 70

Keaton Buster 473, 522

Keiner Reinhold 166

Keller Gottfried 120, 137

Kellner Douglas 323

Kemp Paul 77, 125

Kertész Mihály zob. Curtiz Michael

Kettelhut Erich 28, 70, 216, 218, 391, 394, 437-439

Kępiński Antoni 187, 189, 192

Kiciński Bruno 163, 212

Kiepura Jan 70

Kierkegaard Søren 323, 499

Kieślowski Krzysztof 200

Kimber Rita 18, 66, 146, 164, 336, 388

Kimber Robert 18, 66, 146, 164, 336, 388

Kimmich Max W. 110

King George 84

Kirchner Ernst Ludwig 27, 31

Kisch Egon Erwin 36, 348, 379

Klein-Rogge Rudolf 70, 170-171, 275, 276, 309, $339,343,369,370,385,387,395,428,467,500$

Kleist Heinrich von 135

Klejsa Konrad 489

Klimt Gustav 331

Klingler Werner 110, 128, 278

Klinowski Jacek 176

Klitzsch Ludwig 19, 23, 61, 72

Klöpfer Eugen 112

Kluk Maria 63

Kłys Tomasz 63, 83, 169, 336, 363, 408, 469

Kłyszcz Jolanta 62

Knight Esmond 125

Knopf Edwin H. 94

Kobe Hanns 29, 59, 329

Koch Carl 56

Koch Robert 115, 116

Kocowska Barbara 187

Koerber Martin 406

Kokoschka Oskar 27, 31, 58, 485

Kołodyński Andrzej 62, 403

Komendant Tadeusz 376

Kopaliński Władysław 190

Korda Alexander 68, 403

Korda Zoltan 83

Kornblum Hanns Walter 38, 61 
Korngold Erich Wolfgang 69

Kortner Fritz 68, 84

Kot Karolina 464

Kowa Viktor de 70

Kracauer Siegfried 7, 11, 12, 14-16, 23, 24, 34, 36$38,40,42,46,48,50,52,55-57,62,67,75,80$, $83,89,90,92,95,145,158,159,171,177,216$, $219,267,268,277,279,306,308,319,328,329$, 337, 378-380, 390, 433, 461, 479, 480, 529

Kraszna-Krausz Andor 338, 349

Krause Willi 139

Krauss Werner (Krauß Werner) 28, 30, 38, 39, 47, $69,116,124,133$

Krawczykowski Zbigniew 495

Kreimeier Klaus 18-23, 66-69, 73-76, 78, 146, 164, $166,167,279-282,336,388,389,442,444,445$

Krzeczkowski Henryk 265

Kubin Alfred 27

Kumorek Mieczysław 172

Kupfer Margarete 70

Kürten Peter 86, 479, 481-485, 490

Kurtz Rudolf 33, 56, 61

Kurz Iwona 63

L'Herbier Marcel 311, 392

Lam Andrzej 230, 249

Lamprecht Gerhard 55, 69, 85, 126, 127

Land Robert 73

Landman Adam 325

Lane Brian 482

Lang Fritz 7, 8, 17, 19-22, 25, 29, 30, 32, 34, 35, 39, $41,42,46,49-51,59-63,67,68,86-88,103$, $109,126,136,151 \mathrm{nn}$. passim

Lange Konrad 12

Latté Lily 154

Lautensack Heinrich 14

Le Guin Ursula K. 419

Leander Zarah 70, 77, 125, 129-131, 144

Lefèvre René 79

Léger Fernand 392

Legien Carl 427

Leiser Erwin 146

Leni Paul 22, 25, 60, 61, 174, 202, 329, 485

Lenin Władimir 104, 313, 343, 344, 356, 370, 371

LeRoy Melvyn 481

Lessing Gotthold Ephraim 47

Lessing Theodor 483, 484

Levin David J. 220, 245, 247, 248

Levin Thomas Y. 268

Ley Willy 151, 443, 452, 453, 469, 470

Liebeneiner Wolfgang 69, 70, 81, 99, 108, 114, 115, $133,141,144$

Liedtke Harry 54, 70, 73, 74

Liessem Wera 504

Lindau Paul 14, 15

Lindsay Vachel 208

Lingen Theo 70
Liszt Franz von 253

Litvak Anatol 68

Löck Carsta 70

Lommel Ulli 484

Loos Teodor 70

Lorant Stefan 388

Lorre Peter 68, 86, 497, 499

Loska Krzysztof 50, 449, 450

Löwenstein László zob. Lorre Peter

Lubelski Tadeusz 7,8

Lubitsch Ernst 18, 21, 22, 29, 36, 48, 49, 53, 54, 59, $60,68,122,213,227$

Lucas George 392, 436

Ludendorff Erich von 18, 58, 253

Ludwig Otto 392

Lumière August i Louis 12

Łanowski Jerzy 191

Maarek Philippe J. 146

Mack Max 14, 55, 58

Macke August 27

Madej Alina 62, 281, 330

Maggi Luigi 176

Maier Charles S. 422

Maisch Herbert 69, 116

Majewski Tomasz 57, 137

Mann Heinrich 75, 76

Mann Klaus 496

Mann Thomas 278, 307

Mannheim Lucie 68

Manvell Roger 146

Marc Franz 27

Marian Ferdinand 70, 112, 130, 133, 137

Marie Michel 493

Martin Karlheinz 29-31, 33, 59, 329

Martin Paul 77, 79, 123, 125

Marx Gisela 484

Marx Wilhelm 393

Massary Fritzi 68

Massey Raymond 82

Maté Rudolph 69, 70

Matejko Theo 289

Maupassant Guy de 123, 137

Maurus Gerda 338-340, 361, 446

Maury Jacques 79

May Joe 18, 40, 49, 59, 68, 70, 166, 175, 281

May Karl 167

May Mia 49

May Paul 278

Mayenowa Maria Renata 205

Mayer Carl 22, 24, 42-44, 61, 68

McConnell Winder 230, 241

McGilligan Patrick 152, 154, 155, 157, 165, 166, 168-170, 199, 214-222, 228, 252, 268, 281, $288,337,338,360,388,389,391,442-444,447$, $451-453,470,502$ 
Meisel Kurt 118

Meixner Karl 500

Méliès Georges 16, 28, 193-195, 466, 474

Mendes Lothar 112

Menzies William Cameron 403

Mercury Freddie 407

Messter Oskar 13, 14, 18, 19, 57

Metz Christian 326

Metzner Ernö 38, 90

Meyendorff Irene von 132

Meyer Johannes 109, 114

Meyrink Gustav 171

Mietkowski Andrzej 347

Mikołajewska Barbara 464

Milestone Lewis 89

Milne Tom 486

Minden Michael 51, 378, 386, 393

Molier (Molière) 26, 43, 126

Mołotow Wiaczesław 107, 108, 116, 135, 142, 143

Morlay Gaby 82

Moroder Giorgio 393, 407, 418

Moser Hans 70, 80

Motte Fouqué Friedrich de la 250

Moullet Luc 155

Mozart Wolfgang Amadeus 117, 323

Müller Renate 70, 78, 80, 121-123, 126, 141

Müller Traugott 117

Müller Ulrich 230

Munch Edvard 26

Murdoch Brian 241

Murnau Friedrich Wilhelm 17, 19, 22, 25, 29-31, $39,42,44,45,49,54,59-63,108,131,136,171$, $175,176,197,305,336,345$

Murphy Dudley 392

Murray Bruce 91

Musil Robert 485

Musset Alfred de 140

Nagy Käthe von 70, 80, 126

Natan Bernard 500

Naylor Gillian 63

Nebenzahl Seymour 68, 88, 89, 442, 499, 500, 532

Negri Pola 48, 49, 59, 60, 70, 124

Nerlinger Oskar 345

Neumann Hans 38

Niedzielski Lech 146, 407

Niekricz Aleksander 347

Nielsen Asta 14, 17, 39, 52

Nietzsche Friedrich 310, 318, 327, 397

Noa Manfred 39, 46, 47, 60

Nolde Emil 27, 31

Noss Rudolf van der 117

Nowell-Smith Geoffrey 13

O'Brien Mary-Elizabeth 147

O'Sullivan Carol 400

Oberth Hermann 51, 447, 451-453, 469
Ocep Fiodor 68, 84, 91, 479

Oertel Curt 71, 133

Olimsky Fritz 336

Olsson Anders 198

Olsson Jan 176

Ophüls Max 68, 81, 82, 108, 119, 124, 137

Orwell George 41, 342, 375, 417, 419

Osborne John 198, 250

Ostrowska Barbara 63

Oswald Richard 16, 46, 55, 59, 60, 68, 171

Oswalda Ossi 53, 54

Ott Frederick W. 151, 156, 165, 214, 215, 217, 221, 227, 228, 251, 339, 343, 346, 386, 390, 453, 503

Owidiusz (Publius Ovidius Naso) 163, 167, 188, $189,212,256,257$

Ozep Fedor zob. Ocep Fiodor

Ozu Yasujiro 472

Pabst Georg Wilhelm 29, 30, 33, 38, 39, 52, 53, 60$63,68,69,71,82,88-90,92,94,103,116,283$, $307,328,380,484,499$

Palczewski Juliusz K. 419

Pander Hans 340, 446

Panofsky Erwin 35

Papen Franz von 95

Parlo Dita 75

Pasolini Pier Paolo 175

Pastrone Giovanni 326, 333, 392

Patalas Enno 155, 404, 406, 407, 411, 415

Pathé Frères (Charles, Émile, Jacques i Théophile) 13,14

Paul Heinz 89, 105

Paulus Friedrich Wilhelm von 144

Peiper Tadeusz 448, 449

Perls Fritz 170

Peukert Detlev J. K. 63, 283

Phillips Gene D. 453, 529

Pick Lupu 42, 55, 59, 60, 339

Piel Harry 17

Pinthus Kurt 57, 224-226, 252, 284, 285, 349, 445,446

Piranesi Giovanni Battista 376, 380

Piscator Erwin 92

Plaut (Titus Maccius Plautus) 126

Ploquin Raoul 78

Poirier Léon 89

Pollock Channing 404-406, 421

Pommer Erich 18, 21, 22, 44, 59, 61, 68, 75, 76, 78, $164,216,217,228,389,391,529,532$

Porges Raoul 63

Porten Henny 13, 14, 17, 48, 70

Porter Edwin S. 516

Pospiszyl Kazimierz 187

Pötzsch Albin 173, 174

Prager Wilhelm 38, 61

Prawer Siegbert Salomon 55

Préjean Albert 89 
Pressburger Arnold 68

Prinzler Hans Helmut 146, 155

Prokopiuk Jerzy 193, 318

Prokurat Renata 63, 164

Protazanow Jakow 29, 392

Proust Marcel 256

Przybyłowska Maria 306, 371, 489, 527

Puccini Giacomo 126

Puszkin Aleksander 135

Putti Lya de 22, 61

Pynchon Thomas 275-277, 279, 315, 385-386, 387, 420,425

Pyrjew Iwan 450

Quaresima Leonardo 379, 391

Rabinowitsch Gregor 68

Raddatz Carl 70, 132

Radek Karl 312

Raeder Gustav 111

Rafael 76

Ralph Hanna 228

Rapée Ernö 221

Rasp Fritz 70, 85, 89, 348, 467

Rathenau Walther 160, 286, 287, 312, 364, 515

Raupach Ernst 250

Redl Alfred 347-349

Reed Carol 32

Reimann Walter 22, 28, 61, 71

Reinert Robert 29, 55, 59

Reinhardt Max 15, 42, 48, 51, 328

Reiniger Lotte 56, 61

Reinl Harald 278

Renoir Jean 90, 94, 138

Rentschler Eric 66, 98, 138, 147, 308, 492

Reszke Robert 310

Rhode Eric 167, 175

Riazanow Eldar 200

Ribbentrop Joachim von 107, 108, 116, 135, 142,143

Richard Frida 70

Richter Paul 229

Riefenstahl Leni 38, 46, 52, 53, 61, 67, 69, 93, 104, 140-142

Rigaud George 122

Rippert Otto 17, 171

Rittau Günther 16, 51, 70, 76, 218, 219, 437, 438

Ritter Karl 68, 69, 77, 104-106, 109, 126, 133

Rivel Charlie 137

Robison Arthur 25, 60

Rodin Auguste 430

Roethe Gustav 253

Rogers Ginger 124

Rogoziński Julian 466

Röhm Ernst 115, 140

Röhrig Walter 28, 71, 78, 85, 208

Rökk Marika 70, 124, 125, 143
Romm Michaił 105

Roosevelt Franklin Delano 144

Rosenberg Alfred 66, 104

Rosenthal Elisabeth 170

Rosmer Milton 128

Ross Corey 147

Roters Ebehard 379

Rotha Paul 452, 473

Roud Richard 349, 486, 518

Rühmann Heinz 69, 78-81, 85, 119-121, 123, 127,137

Rutkowska Teresa 393

Rutsky R. L. 386, 433

Ruttmann Walter 38, 56, 61, 69, 73, 74, 219, 220, $241,345,380,392,400$

Rye Stellan 15, 58, 171, 312

Sachs Hans 249

Sachs Hanns 38

Sagan Leontine $67,82,83$

Saladyn 47

Salt Barry 11, 29, 31, 32, 85, 329, 330, 340, 485, 533

Sand George 108

Sandrock Adele 70

Sauer Fred 81, 119

Saville Victor 80

Schacht Roland 57, 340, 341, 396, 397

Schad Christian 37, 379

Scheunemann Dietrich 12, 171, 329

Schiele Egon 331

Schiller Friedrich 116, 118

Schlesinger Lang Paula 170

Schlettow Hans Adalbert von 229

Schlichter Rudolf 37, 379, 381

Schlüter Andreas 116

Schmid-Wildy Ludwig 109

Schmidt Kurt 421

Schmitz Sybille 70, 108

Schnauber Cornelius 87, 151, 170, 224, 280, 337, $437,443,478$

Schneeberger Hans 53, 70

Schneider Hannes 52

Schneider Magda 70, 81

Schnitzler Arthur 14, 81

Scholdt Günter 280, 283, 308

Scholl Hans 144

Scholl Sophie 144

Schön Margarethe 229

Schönemann Heide 267, 333, 345, 421

Schröder Marion von 482

Schubert Franz 77, 117, 123

Schüfftan Eugen 51, 69, 436, 437, 439

Schulte-Sasse Linda 147

Schultze Ernst 484

Schulz Bernhard 379

Schulze Hugo O. (Schulze H. O.) 438

Schumann Robert 117 
Schünzel Reinhold 68, 69, 77, 122, 126

Schwarz Hanns 68, 75, 78

Scott Ridley 392

Seeber Guido 16, 38, 70

Seel Peter C. 62

Seitz Franz 102, 504

Selpin Herbert 69, 106, 110, 127, 144

Shakespeare zob. Szekspir William

Shaw George Bernard 74

Shelley Mary 392, 402

Siemsen Hans 56, 402

Sienkiewicz Henryk 392

Sierck Detlef 69, 77, 129, 130

Sigibert (Sigebert) 246

Sima Oskar 77, 125

Siodmak Robert 38, 68, 84, 85, 119, 380, 479

Sirk Douglas zob. Sierck Detlef

Sitarski Piotr 83, 336

Skladanowski Emil 12, 57

Skladanowski Max 12, 57

Skonieczko Grzegorz 489

Skrzywanowa Eugenia 11, 62, 75, 145, 158, 177, 216, 277, 337, 461, 479, 529

Sloterdijk Peter 63, 159, 160, 186, 333

Söderbaum Kristina 70, 112, 115, 118, 131-133

Souvestre Pierre 289

Sowińska Iwona 7

Spencer Stewart 252

Spengler Oswald 46, 272

Spielberg Steven 215

Spoerl Heinrich 121

Staal Viktor 70, 129, 130

Stahl-Urach Carl 330

Stalin Josif 94, 144, 344

Starace Gino 289

Staudte Wolfgang 69, 70, 136, 137, 479

Stauffenberg Claus von 144

Stausberg Johann 490

Steinhoff Hans 40, 69, 71, 92, 99, 102-104, 110, 114-117, 133, 134, 143, 145

Stemmle Robert Adolf 121

Sten Anna 78

Stendhal 44

Sternberg Josef von $67,68,75,76,152$

Stiller Robert 230, 246, 249, 250, 252

Stinnes Hugo 20, 213, 275, 315, 316, 426-428

Stöckel Joe 105

Stoker Bram 25

Storm Theodor 132, 133

Strauss Johann 117, 121

Stresemann Gustav 221

Stroheim Erich von 406

Stuart Maria 110, 130

Sudermann Hermann 108, 131

Sudół Robert 276, 386

Sugiera Małgorzata 198

Sutter John (Suter Johann) 129
Swett Pamela E. 147

Swift Jonathan 417, 499

Syska Rafał 7

Szabó István 347, 496

Szabrański Antoni J. 230

Szekspir William 15, 256, 464

T. Love 483

Tait Meg 397, 398, 404

Tarnowski Marceli 186

Tatar Maria 483-485, 495, 496

Tauber Richard 68, 74

Taylor Frederick Winslow 421-423, 425

Taylor Richard 147

Tedesco Jean 24

Tegel Susan 147

Teodoryk Wielki 246

Thackeray William Makepeace 323

Thiel Andreas 484

Thiele Hertha 70, 82, 83, 135

Thiele Wilhelm 68, 78-80, 119, 121, 125

Thoma Hans 271

Thompson Kristin 14, 15, 18, 21, 22, 27, 32-35, 42, $74,75,83,213,216,220,336,342,443$

Tiller Girls 52, 268

Tiudimer (Thiudimer, Thiudemer, Dietmar, Dytmar) 246

Toeplitz Jerzy $65,71,81,98,115,134,135,137$, 146, 164

Toller Ernst 391

Tomasz Apostoł, św. 197

Toulouse-Lautrec Henri de 26

Tourjansky Viktor zob. Turżański Wiktor

Trask C. Hooper 341

Trenker Luis 52, 53, 69, 70, 93, 94, 127-130, 157

Trocki Lew 313, 343, 344, 370

Tschechowa Olga zob. Czechowa Olga

Turżański Wiktor 69, 108

Tybjerg Casper 176

Tykwer Tom 200

Tyler Bonnie 407

Ucicky Gustav 69, 71, 77, 92, 95, 99, 106-108, 110, $123,127,133-135$

Udet Ernst 93

Uhland Ludwig 250

Ulitzsch Ernst 222, 223

Ullmann Gerhard 406

Ullrich Luise 70

Ulmer Edgar Georg 38, 68

Umlauff Heinrich 271

Valetti Rosa 68

Van de Velde Henry 331

Van Gogh Vincent 26

Vaucorbeil Max de 79 
Veidt Conrad 13, 22, 28, 30, 35, 49, 55, 61, 68, 74, $78,84,112$

Verne Jules 373, 391, 441, 469

Viertel Bertold 38, 61

Vigo Jean 138

Villiers de L'Isle-Adam Auguste 392

Vogeler Erich 224

Volkmer Klaus 406

Vollbrecht Karl 215, 220, 452, 473

Wagner Fritz Arno 16, 70, 87, 110, 499

Wagner Richard 70, 220-222, 224, 228, 229, 237, 246, 250-252, 254, 266, 270, 505, 519

Wagowski Erich 46, 47

Wajda Andrzej 32

Walbrook Anton zob. Wohlbrück Adolf

Walden Herwarth 26, 27, 58

Walker Alexander 154

Wallburg Otto 69

Walsh Raoul 388

Walther Hertha von 339

Walther-Fein Rudolf 74

Ward Janet 494, 495

Warm Hermann 28, 33, 71, 208

Waschneck Erich 69, 110-111, 122

Wasylewski Stanisław 108

Weber Carl Maria von 117

Wechsler Lazar 91

Wedekind Frank 40, 484

Wegener Paul 15-17, 29, 58, 59, 69, 70, 104, 106, $108,118,171,305$

Weill Kurt 89

Weiss Helmut 121

Welch David 66, 95-97, 99-101, 104, 106, 109, 147

Welles Orson 406

Wellmann William A. 481

Wells Herbert George 391, 392, 400, 402, 403, 418421,436

Wenders Wim 446, 472

Wendhausen Fritz 33, 60

Wenzler Franz 15, 102-104

Werckmeister Hans 33, 51, 59

Wergiliusz (Publius Vergilius Maro) 167, 188

Werner Gösta 152, 154, 157, 501-503

Werner Ilse 70, 123, 127, 138

Wernicke Otto 69, 88, 118, 504

Wertenstein Wanda 11, 62, 63, 75, 145, 158, 177, $216,277,337,461,479,529$

Wessel Horst 15, 102, 104

Wessely Paula 70, 123, 124
Wetzel Kraft 97

Widdig Bernd 20, 50, 213, 279, 280, 283, 293-295, $303,304,307-309,315,316,322,323,327$, $426-428,433,467,526,527$

Wieck Dorothea 82, 135

Wieman Mathias 69, 106, 133

Wiene Robert 7, 8, 11, 23, 27, 29, 31, 35, 59, 60, 63, $76,165,175,176,270,305,312,329,332,392$, $485,515,528,529$

Wiertow Dziga 522

Wilbrandt Adolf von 250

Wilde Ernest 62

Wilder Billie (Billy) 68, 85

Wilhelm II 13, 24, 59

Willett John 36, 63, 378, 379

Winkler Max 100, 101, 141

Winsloe Christa 83

Winston Carl 78

Wisbar Frank zob. Wysbar Frank

Witkacy zob. Witkiewicz Stanisław Ignacy

Witkiewicz Stanisław Ignacy 37, 272, 285, 343, 379

Wohlbrück Adolf 70, 123

Wolff Lothar 152, 500

Wollenberg Hans 165

Woringen Paul von 15, 58

Worsley Wallace 392

Wujek Jakub 385

Wunderlich Werner 230

Wynne-Jones Frederick 229

Wysbar Frank 71, 82, 135, 136

Ybarra Thomas Russell 228

Zahorska Stefania 134

Zamiatin Jewgienij 417, 419

Zapolska Gabriela 108

Zawadowski Leon 205

Zeller Magnus 333

Zeller Wolfgang 74

Zelnik Friedrich 68, 94

Zerlett Hans H. 111

Ziemilska Olga 319

Ziemilski Andrzej 319

Zille Heinrich 40, 91, 103

Zimmermann Aljoscha 309

Zimmermann Heinrich 152, 501

Zinowjew Grigorij 346, 347

Zmudziński Bogusław 62

Zöberlein Hans 89, 109 


\section{INDEKS FILMÓW}

À nous la liberté (Niech żyje wolność!) 421

A to cham! (So ein Flegel) 121

Abenteuer des Prinzen Achmed, Die (Przygody księcia Achmeda) 56, 61

Abwege (Kryzys) 39, 103

Abschiedswalzer (Chopin, piewca wolności) 108, 116

Aelita 29, 392

Akrobat schö-ö-ö-n... 136-137

Aleksander Newski (Aleksandr Niewskij) 115

Aleksandr Niewskij (Aleksander Newski) 115

Algol (Algol - Tragödie der Macht) 33, 35, 51, 59

Algol - Tragödie der Macht (Algol) 33, 35, 51, 59

Alkohol 55

All Quiet on the Western Front (Na Zachodzie bez zmian) 89

Allotria 123

alte und der junge König, Der (Stary i młody król) 114-115

Amfitrion (Amphitryon) $\mathbf{1 2 6}$

Amphitryon (Amfitrion) $\mathbf{1 2 6}$

Andere, Der (Inny) 14, 58

Anders als die Andern (Inaczej niż inni) 55, 59

Andreas Schlüter 116

Anna Boleyn 21, 48, 52, 59

Anna i Elżbieta (Anna und Elisabeth) 82, 135-136

Anna Karenina (Love), reż. Edmund Goulding (1927) 157

Anna und Elisabeth (Anna i Elżbieta) 82, 135-136

Argent, L' (Pieniadz), reż. Marcel L'Herbier (1929) 311

Ariana (Ariane) 82

Ariana (Ariane, jeune fille russe), wersja francuska 82

Ariana (The Loves of Ariane), wersja angielska 82

Ariane (Ariana) 82

Ariane, jeune fille russe (Ariana), wersja francuska 82

Asfalt (Asphalt) 40, 52, 62

Asphalt (Asfalt) 40, 52, 62

Atak klonów (Star Wars, Episode II: Attack of the Clones) 436

Atalanta (L'Atalante) 138

Atalante, $L^{\prime}$ (Atalanta) 138

Atlantic 74, 152

Atlantis (Atlantyda) 17, 58
Atlantyda (Atlantis) 17, 58

Auf Wiedersehn, Franziska! (Do widzenia, Franciszko!) 136

Aufforderung zum Tanz (Zaproszenie do tańca) 117

Aufruhr in Damaskus (Awantura w Damaszku) 106

Augen der Mumie Mâ, Die (Oczy mumii Mâ) 48, 59

August der Starke (August Mocny) 108

August Mocny (August der Starke) 108

Aus den Errinerungen eines Frauenarztes (Ze wspomnień ginekologa) 55

Austernprinzessin, Die (Księżniczka ostryg) 54, 59

Awantura w Damaszku (Aufruhr in Damaskus) 106

Balet mechaniczny (Ballet mécanique) 392

Ballet mécanique (Balet mechaniczny) 392

Bannion (The Big Heat) 348, 520, 534

Batman Returns (Powrót Batmana), reż. Tim Burton (1992) 392

Bel Ami 123, 124

Berg des Schicksals, Der (Góra przeznaczenia) 52

Berg ruft, Der (Góra wzywa), reż. Luis Trenker (1937) 128

Berge in Flammen (Góry w płomieniach), reż. Luis Trenker, Karl Hartl 93-94, 128

Bergkatze, Die (Dzika kotka) 35, 36, 48, 59

Berlin Alexanderplatz (Berlin-Alexanderplatz: Die Geschichte Franz Biberkopfs) 37, 67, 87, 90, 91-92

Berlin-Alexanderplatz: Die Geschichte Franz Biberkopfs (Berlin Alexanderplatz) 37, 67, 87, 90, 91-92

Berlin, die Sinfonie der Großstadt (Berlin, symfonia wielkiego miasta) 38, 61, 345, 380

Berlin, symfonia wielkiego miasta (Berlin, die Sinfonie der Großstadt) 38, 61, 345, 380

Besatzung Dora (Załoga "Dory”) 105

Bettelstudent, Der (Student żebrak) 124

Beyond a Reasonable Doubt (Ponad wszelka watpliwość) 534

Biali niewolnicy (Weiße Sklaven) 109

Biate piekto na Piz Palü (Die weiße Hölle vom Piz Palü) 53, 62, 92, 93

Białe szaleństwo (Der weiße Rausch - Neue Wunder des Schneeschuhs) 93, 128 
Biegnij Lola, biegnij (Lola rennt) 200

Big Heat, The (Bannion) 348, 520, 534

Birth of a Nation, The (Narodziny narodu) 388, 517

Bismarck 115

Black Roses (Czarne róże), wersja angielska, reż. Paul Martin (1936) 125

Blade af Satans Bog (Kartki z Księgi Szatana) 25, 175-176

Blade Runner (Łowca androidów) 392

Blaue Engel, Der (Błękitny Anioł) 67, 68, 75-76, 126, 152, 160

blaue Licht, Das (Niebieskie światło) 93

blonder Traum, Ein (Jasnowłosy sen), reż. Paul Martin (1932) 79-80, 123, 125, 126

Blue Angel, The (Błękitny Aniot) wersja angielska 67, 152

Błękitny Anioł (Der Blaue Engel) 67, 68, 75-76, 126, 152,160

Błękitny Anioł (The Blue Angel) wersja angielska 67, 152

Bomben aufMonte Carlo (Bomby na Monte Carlo) 78

Bomby na Monte Carlo (Bomben auf Monte Carlo) 78

Braterstwo (Kameradschaft) 90, 94

Brazil, reż. Terry Gilliam (1985) 392

Brillantenschiff, Das (Brylantowy statek) 163, 529; zob. też Spinnen, Die (Pająki)

Bronienosiec Potiomkin (Pancernik Potiomkin) 157, 172,400

Brylantowy statek (Das Brillantenschiff) 163, 529; zob. też Pająki (Die Spinnen)

Büchse der Pandora, Die (Puszka Pandory) 39, 40, 62,484

Buntownik (The Rebel), wersja angielska, reż. Luis Trenker, Edwin H. Knopf (1933) 94

Buntownik (Der Rebell), reż. Luis Trenker, Kurt Bernhardt (1932) 94, 128, 157

Burgtheater (Teatr Miejski) 124, 137

Burza nad Mont Blanc (Stürme über dem Montblanc) 92-93

Burze namiętności (Stürme der Leidenschaft) 84

Burze namiętności (Tumultes), wersja francuska 84

Byłem Jackiem Mortimerem (Ich war Jack Mortimer) 68

Cabaret (Kabaret) 381

Cabinet des Dr. Caligari, Das (Gabinet doktora Caligari) 7, 8, 11, 23-24, 26-28, 29-35, 39, 41, 42, $59,63,165,175,208,270,305,312,328-330$, $332,386,392,485,515,528,529$

Cabiria 326, 333, 392

Café Elektric 123

Całuję twoja dłoń, madame (Ich küsse ihre Hand, Madame) $73-74$

Capriccio 68, 125-126
Carl Peters 110, 127

Carlos und Elisabeth (Don Carlos i Elżbieta) 46

Carmen 48, 59

Casablanca 22

Challenge, The (Góra wzywa), wersja angielska, reż. Milton Rosmer, Luis Trenker (1938) 128

Chciwość (Greed) 406

Chemin du paradis, Le (Trzej ze stacji benzynowej), wersja francuska, reż. Wihelm Thiele, Max de Vaucorbeil (1930) 79

Chopin, piewca wolności (Abschiedswalzer) 108, 116

Choral von Leuthen, Der (Chorat pod Leuthen) 95

Chorat pod Leuthen (Der Choral von Leuthen) 95

Ciebie tylko kochałem (Dich hab' ich geliebt) 74

Cienie (Schatten) 25, 26, 60

Congrès s'amuse, Le (Kongres tańczy), wersja francuska, reż. Jean Boyer, Erik Charell (1931) 78

Congress Dances, The (Kongres tańczy), wersja angielska, reż. Erik Charell (1932) 78

Crimes of Dr. Mabuse, The, amerykańska wersja dystrybucyjna filmu Das Testament des Dr. Mabuse (reż. Fritz Lang, 1933/1952) w angielskim dubbingu 502

Cud stworzenia (Wunder der Schöpfung) 38, 61

Cud w koszarach (Kasernenzauber) 81

Cuda narciarskich szusów (Das Wunder des Schneeschuhs) 52

Cytadela warszawska (Die Warschauer Zitadelle) 108

Czarne róże (Black Roses), wersja angielska, reż. Paul Martin (1936) 125

Czarne róże (Roses noires), wersja francuska, reż. Jean Boyer, Paul Martin (1935) 125

Czarne róże (Schwarze Rosen), reż. Paul Martin (1935) 125

Człowiek, który był Sherlockiem Holmesem (Der Mann, der Sherlock Holmes war) 127

Człowiek, który popetnit morderstwo (Der Mann, der den Mord beging) 84, 479

Człowiek, który szuka swego mordercy (Der Mann, der seinen Mörder sucht) 85, 119, 479

Człowiek z blizna (Scarface) 481

Czterej muszkieterowie (Die vier Musketiere) 105

Czułość wilków (Die Zärtlichkeit der Wölfe) 484

Danton 46

Dark City (Mroczne miasto), reż. Alex Proyas (1998) 392

Decameron, Il (Dekameron), reż. Pier Paolo Pasolini (1971) 175

Dekameron (Il Decameron), reż. Pier Paolo Pasolini (1971) 175

Dernier miliardaire, Le (Ostatni miliarder) 54

Dich hab' ich geliebt (Ciebie tylko kochatem) 74 
Dirnentragödie (Tragedia ulicznej dziewczyny) 52, 61

Dlaczego walczymy (Why We Fight) 105

Do Niemiec! (Ein Mann will nach Deutschland) 106

Do widzenia, Franciszko! (Auf Wiedersehn, Franziska!) 136

Doktor Mabuse, gracz (Dr. Mabuse, der Spieler) 20, 29, 30, 36, 41, 50, 60, 166, 192, 198, 213, 216, 222, 275-333, 337, 339, 341, 344-346, 349, $356,369,370,372,377,381,391,392,395$, $428,435,441,478,487,491,504,514,515$, 524, 525, 527-529, 531, 533, 534

Dom na Księżycu (Das Haus zum Mond) 33, 59

Don Carlos i Elżbieta (Carlos und Elisabeth) 46

Doomed Batalion (Góry w płomieniach), wersja angielska, reż. Luis Trenker, Karl Hartl oraz Cyril Gardner [angielskojęzyczne dokrętki] (1932), 93

Douaumont - Die Hölle von Verdun (Douaumont piekło pod Verdun) 89

Douaumont - piekło pod Verdun (Douaumont - Die Hölle von Verdun) 89

Dr. M. schlägt zu zob. Zemsta doktora Mabuse

Dr. Mabuse, der Spieler (Doktor Mabuse, gracz) 20, 29, 30, 36, 41, 50, 60, 166, 192, 198, 213, 216, 222, 275-333, 337, 339, 341, 344-346, 349, $356,369,370,372,377,381,391,392,395$, $428,435,441,478,487,491,504,514,515$, $524,525,527-529,531,533,534$

Dreaming Lips (Rozmarzone usta), wersja angielska 82

3-Groschen-Oper, Die (Opera za trzy grosze) 82, 86, 89-90, 499

Drei Mäderl um Schubert (Trzy panny wokót Schuberta) 117

Drei Tage Mittelarrest (Trzy dni paki) 81

Drei von der Kavallerie (Trzej z kawalerii) 81

Drei von der Tankstelle, Die (Trzej ze stacji benzynowej), reż. Wilhelm Thiele (1930) 78-79, 119, 125,126

Dreizehn Mann und eine Kanone (Trzynastu ludzi i jedno działo) 109

Droga do raju zob. Chemin du paradis, Le

Drogi do sity i piękna (Wege zu Kraft und Schönheit - Ein Film über moderne Körperkultur) 37, 38, 61

Duch ziemi (Erdgeist) 33, 42, 60

Duma trzeciej kompanii (Der Stolz der 3. Kompanie) $81,119,120$

Dusze dzieci oskarżaja was (Kinderseelen klagen euch an) 55

Dymisja (Die Entlassung) 99, 115

Dziennik upadłej dziewczyny (Tagebuch einer Verlorenen) $39,40,62$
Dziewczęta w mundurkach (Mädchen in Uniform) $67,70,82-84,135$

Dziewica Joanna (Das Mädchen Johanna) 110

Dzika kotka (Die Bergkatze) 35, 36, 48, 59

Dzisiejsze czasy (Modern Times) 421

Dzwonnik z Notre Dame (The Hunchback of Notre Dame) 392

Eclisse, L'(Zaćmienie) 311

Eine kleine Nachtmusik 117

Emil i detektywi (Emil und die Detektive) 85-86, 87 Emil und die Detektive (Emil i detektywi) 85-86, 87 Enfants du paradis, Les (Komedianci), reż. Marcel Carné (1945) 117

englische Heirat, Die (Małżeństwo po angielsku) 122-123

Entlassung, Die (Dymisja) 99, 115

Erdgeist (Duch ziemi) 33, 42, 60

Es war eine rauschende Ballnacht (Romanse Czajkowskiego) 77, 116, 124-125

Es werde Licht! (Niech się stanie światłość!) 55

Es wird schon wieder besser (Niedtugo znowu będzie lepiej) 80

ewige Jude, Der (Wieczny Żyd) 101, 113, 497

F.P. 1 antwortet nicht (FP 1 nie odpowiada) $\mathbf{1 2 6}$

FP 1 nie odpowiada (F.P. 1 antwortet nicht) $\mathbf{1 2 6}$

Fährmann Maria (Przewoźnik Maria) 71, 136

Fantom (Phantom) 25, 26, 29, 30, 36, 60

Fantomas (Fantômas) 49, 289, 290, 525

Fantômas (Fantomas) 49, 289, 290, 525

Faust (Faust - Eine deutsche Volkssaga) 17, 19, 22, 29, 33, 52, 61, 171, 336

Faust - Eine deutsche Volkssaga (Faust) 17, 19, 22, 29, 33, 52, 61, 171, 336

Feinde (Wrogowie) 108

Feuerzangenbowle, Die (Poncz) 121

Fifth Element, The (Piaty element) 392, 436

Fille de l'eau, La (Panna wodna) 138

Finanse wielkiego księcia (Die Finanzen des Großherzogs) 54, 60

Finanzen des Großherzogs, Die (Finanse wielkiego księcia) 54, 60

fiore delle mille e una notte, Il (Kwiat tysiaca i jednej nocy), reż. Pier Paolo Pasolini (1974) 175

Flötenkonzert von Sanssouci, Das (Koncert na flet $z$ Sans-Souci) 95

Flüchtlinge (Uchodźcy) 106-107, 109, 127

Forsy nie trzeba (Man braucht kein Geld), reż. Carl Boese (1932) 80, 119

Frau am Steuer (Kobieta za kótkiem) 125

Frau im Mond (Kobieta na Księżycu) 35, 51-52, 62, 126, 151, 166, 167, 287, 331, 332, 336, 361, 
371, 422, 431, 441-474, 480, 487, 492, 515, 531-534

Frau meiner Träume, Die (Kobieta moich marzeń) 124

Frauen sind doch bessere Diplomaten (Lepszymi dyplomatami sa jednak kobiety) 124, 143

Freie Liebe (Wolna miłość) 55

fremde Fürst, Der (Obcy ksiażę) 16, 171

Frères Karamazoff, Les (Morderca Dymitr Karamazow), wersja francuska 84

freudlose Gasse, Die (Zatracona uliczka) 30, 39, 61, $103,283,30$

Fridericus 114-115

Fridericus Rex 47

Friedemann Bach 117

Friedrich Schiller: Der Triumph eines Genies (Fryderyk Schiller) 116, 118

Friesennot (Niedola Fryzów) 106, 107, 109

Fritz Haarmann $i$ Theodor Lessing - dwa niemieckie losy (Fritz Haarmann und Theodor Lessing zwei deutsche Schicksale) 484

Fritz Haarmann und Theodor Lessing - zwei deutsche Schicksale (Fritz Haarmann $i$ Theodor Lessing dwa niemieckie losy) 484

Front zachodni 1918 (Westfront 1918) 88-89

Frühlingsstimmen (Wiosenny nastrój) 117

Fryderyk Schiller (Friedrich Schiller: Der Triumph eines Genies) 116, 118

Fuchs von Glenarvon, Der (Lis z Glenarvon) 110

Fury (Jestem niewinny) 217, 481, 489

Gabinet doktora Caligari (Das Cabinet des Dr. Caligari) 7, 8, 11, 23-24, 26-28, 29-35, 39, 41, 42, $59,63,165,175,208,270,305,312,328-330$, $332,386,392,485,515,528,529$

Gabinet figur woskowych (Das Wachsfigurenkabinett) $25,26,29,32,35,36,60,174,202,329,485$

Gaiety George 83

Gasmann, Der (Inkasent) 68, 120-121

Gasparone 124

Geheimnisse einer Seele (Tajemnice duszy) 29, 38, 61 gelbe Flagge, Die (Źótta flaga) 127

Geld auf der Straße (Pieniądz leży na ulicy) 80

Genuine 29, 35, 42, 59, 329, 515

Germanin 110

Geschlecht in Fesseln (Płeć w kajdanach) 55, 61

Giełda miłości zob. Café Elektric

Gläserne Wundertiere (Szklane cud-zwierzaki), reż. Ulrich K. T. Schulz 74

Glückskinder (Szczęściarze) 77, 125, 126

Gold (Złoto) 127

Goldene See, Der (Złote Jezioro) 163; zob. też Spinnen, Die (Pająki)

goldene Spinne, Die (Złoty pają) 109 goldene Stadt, Die (Złote miasto) 117, 131-132

Golem (Der Golem), reż. Henrik Galeen, Paul Wegener (1915) 16, 171

Golem (Der Golem, wie er in die Welt kam), reż. Paul Wegener, Carl Boese (1920) 17, 29, 30, 34, 35, 59, 305

Golem, Der (Golem), reż. Henrik Galeen, Paul Wegener (1915) 16, 171

Golem, wie er in die Welt kam, Der (Golem), reż. Paul Wegener, Carl Boese (1920) 17, 29, 30, 34, 35, 59, 305

Golem i tancerka (Der Golem und die Tänzerin) 16, 171

Golem und die Tänzerin, Der (Golem $i$ tancerka) 16,171

Goraca krew (Heißes Blut) 124

Góra przeznaczenia (Der Berg des Schicksals) 52

Góra wzywa (Der Berg ruft) 128

Góra wzywa (The Challenge), wersja angielska, reż. Milton Rosmer, Luis Trenker (1938) 128

Góry w płomieniach (Berge in Flammen), reż. Luis Trenker, Karl Hartl (1931) 93-94, 128

Góry w płomieniach (Doomed Batalion), wersja angielska, reż. Luis Trenker, Karl Hartl oraz Cyril Gardner [angielskojęzyczne dokrętki] (1932), 93

Góry w płomieniach (Les Monts en flammes), wersja francuska, reż. Luis Trenker, Joë Hamman (1931) 93

GPU 104, 109

Gräfin von Monte Christo, Die (Hrabina Monte Christo) 80

Grande illusion, La (Towarzysze broni) 71, 90, 94

Greed (Chciwość) 406

Große Freiheit Nr. 7 127, 138

große König, Der (Wielki król) 99, 114, 115, 131

große Liebe, Die (Wielka miłość) 77, 105, 130

große Sprung, Der (Wielki skok) 128

G'schichten aus dem Wienerwald (Opowieści Lasku Wiedeńskiego) 117

Guerre des valses, La (Wojna walców), wersja francuska, reż. Ludwig Berger, Raoul Ploquin (1933) 78

Gwiezdne wojny (Star Wars), cykl filmowy 19772005474

Gwiezdne wojny (Star Wars), reż. George Lucas (1977) 392

Halbblut 163

Hallo Janine 124

Hangmen Also Die (Kaci także umieraja) 156, 478,501

Hanneles Himmelfahrt (Hanusia) 166

Hans Westmar: Einer von Vielen (Hans Westmar: jeden $z$ wielu) 15, 91, 102-104, 105 
Hans Westmar: jeden z wielu (Hans Westmar: Einer von Vielen) 15, 91, 102-104, 105

Hanusia (Hanneles Himmelfahrt) 166

Harakiri 164

Haus zum Mond, Das (Dom na Księżycu) 33, 59

heilige Berg, Der (Święta góra) 52, 53, 61, 92, 93, 128 Heimat 69, 77, 130

Heimkehr (Powrót) 99, 106, 107, 108, 113

Heimkehr ins Glück (Szczęśliwy powrót w rodzinne strony) 120

Heißes Blut (Goraca krew) 124

Helena (Helena Trojańska) 47, 60

Helena Trojańska (Helena) 47, 60

Herr der Liebe, Der (Władca miłości) 163

Herrin der Welt, Die (Wtadczyni świata) 49, 59

Herrscher, Der (Władca) 71, 134-135

Herz der Königin, Das (Serce królowej) 77, 110, 130

Hintertreppe, Die (Schody kuchenne) 42-44, 59

Hitlerjunge Quex 40, 86, 91, 102-104

Hoffmanns Erzählungen (Opowieści Hoffmanna) 16,171

Homunculus 17, 171

Horst Wessel 104, 105; zob. Hans Westmar: jeden $z$ wielu

Hrabina Monte Christo (Die Gräfin von Monte Christo) 80

Hunchback of Notre Dame, The (Dzwonnik z Notre Dame) 392

I ty pojedziesz, mój skarbie (Und du, mein Schatz, fährst mit) 124

Ich bei Tag and du bei Nacht (Ja w dzień, a ty noca) 80 Ich für dich - du für mich (Ja tobie, ty mnie) 84, 86

Ich klage an (Oskarżam) 114

Ich küsse ihre Hand, Madame (Całuję twoją dłoń, madame) 73-74

Ich möchte kein Mann sein (Nie chcę być mężczyzna) 53, 54, 122

Ich noce (It Happened One Night) 125

Ich war Jack Mortimer (Byłem Jackiem Mortimerem) 68

Idylle au Caire (Sezon w Kairze), wersja francuska, reż. Claude Heymann, Reinhold Schünzel (1933) 122

Im Glück vergessen (Zapomniana w szczęściu) 14

Im Stahlnetz des Dr. Mabuse (W stalowej sieci doktora Mabuse) 278

Immensee 77, 132-133, 137

Inaczej niż inni (Anders als die Andern) 55, 59

indische Grabmal, Das (Indyjski grobowiec), reż. Fritz Lang (1958) 49, 534

indische Grabmal, Das (Indyjski grobowiec), reż. Joe May (1921) 49, 59, 166, 167, 281
Indyjski grobowiec (Das indische Grabmal), reż. Fritz Lang (1958) 49, 534

Indyjski grobowiec (Das indische Grabmal), reż. Joe May (1921) 49, 59, 166, 167, 281

Inhumaine, L' (Nieludzka) 392

Inkasent (Der Gasmann) 68, 120-121

Inny (Der Andere) 14, 58

Insel der Seligen (Wyspa błogosławionych) 15

Intolerance (Nietolerancja) 49, 175, 176, 388, 497

It Happened One Night (Ich noce) 125

Iwan Groznyj (Iwan Groźny) 115

Iwan Groźny (Iwan Groznyj) 115

Ja tobie, ty mnie (Ich für dich - du für mich) 84, 86

Ja w dzień, a ty noca (Ich bei Tag and du bei Nacht) 80

Jak cię widza, tak cię pisza (Kleider machen Leute) 120, 137

Jasnowłosy sen (Ein blonder Traum), reż. Paul Martin (1932) 79-80, 123, 125, 126

Jasnowłosy sen (Un Rêve blond), wersja francuska, reż. André Daven, Paul Martin (1932) 79

Jaws (Szczęki) 215

Jestem niewinny (Fury) 217, 481, 489

Jew Süss (Żyd Süss), reż. Lothar Mendes (1934) 112

Jeździec na siwym koniu (Der Schimmelreiter) 71, 133-134

Jeźdźcy z Niemieckiej Afryki Wschodniej (Die Reiter von Deutsch-Ostafrika) 106

Jogin (Der Yoghi) 16, 171

Jud Süß (Żyd Süss), reż. Veit Harlan (1940) 47, 68, 92, 112-113, 130, 131, 308

Jungfrukällan (Źródło) 207

Jurassic Park 215

Jutrzenka (Morgenrot) 95

K 13513: Die Abenteuer eines Zehnmarkscheines (Przygody dziesięciomarkowego banknotu) 38,61

Kabaret (Cabaret) 381

Kaci także umieraja (Hangmen Also Die) 156, 478, 501

Kadeci (Kadetten) 109

Kadetten (Kadeci) 109

Kaiser von Kalifornien, Der (Kalifornijski cesarz) 128-129

Kalifornijski cesarz (Der Kaiser von Kalifornien) 128-129

Kameradschaft (Braterstwo) 90, 94

Kamienny jeździec (Der steinerne Reiter) 33, 60

Kämpfende Herzen (Walczące serca) 164, 166, 294, 345

Kapelle Etté spielt den Ramona, Die (Ramona), reż. Walter Ruttmann (1928) 73 
Kartki z Księgi Szatana (Blade af Satans Bog) 25, 175-176

Kasernenzauber (Cud w koszarach) 81

Kinderseelen klagen euch an (Dusze dzieci oskarżaja was) 55

Kleider machen Leute (Jak cię widza, tak cię pisza) 120, 137

Kobieta moich marzeń (Die Frau meiner Träume) 124

Kobieta na Księżycu (Frau im Mond) 35, 51-52, 62, $126,151,166,167,287,331,332,336,361$, 371, 422, 431, 441-474, 480, 487, 492, 515, 531-534

Kobieta w oknie (The Woman in the Window) 534

Kobieta za kółkiem (Frau am Steuer) 125

Kogo bogowie kochaja (Wen die Götter lieben) 117

Kolberg 68, 92, 98, 113, 115, 117-118, 131, 145

Koncert życzeń (Wunschkonzert) 105

Kongres tańczy (The Congress Dances), wersja angielska, reż. Erik Charell (1932) 78

Kongres tańczy (Le Congrès s'amuse), wersja francuska, reż. Jean Boyer, Erik Charell (1931) 78

Kongres tańczy (Der Kongreß tanzt), reż. Erik Charell $(1931)$ 78, 125, 126

Kongreß tanzt, Der (Kongres tańczy), reż. Erik Charell (1931) 78, 125, 126

Königsloge, Die (Loża królewska) 74

Komedianci (Komödianten), reż. Georg Wilhelm Pabst (1941) 69

Komedianci (Les Enfants du paradis), reż. Marcel Carné (1945) 117

Komödianten (Komedianci), reż. Georg Wilhelm Pabst (1941) 69

Koncert na flet z Sans-Souci (Das Flötenkonzert von Sanssouci) 95

Koniec Sankt-Petersburga (Koniec Sankt-Pietierburga) 311

Koniec Sankt-Pietierburga (Koniec Sankt-Petersburga) 311

Kopciuszek (Der verlorene Schuh) 17, 171

Kora Terry 124

Kraina miłości (Land der Liebe) 68

Kręte drogi pięknego Karola (Die Umwege des schönen Karl) 68,120

Kronika z Grieshuus (Zur Chronik von Grieshuus) $17,33,171$

Kryzys (Abwege) 39, 103

Księżniczka ostryg (Die Austernprinzessin) 54, 59

Księżniczka Turandot (Prinzessin Turandot) 126

Ku nowym brzegom (Zu neuen Ufern) 129

Ku wolności (Ritt in die Freiheit) 108, 109

Kuhle Wampe, albo do kogo należy świat? (Kuhle Wampe, oder: Wem gehört die Welt?) 39, 70, 90-91, 103, 380
Kuhle Wampe, oder: Wem gehört die Welt? (Kuhle Wampe, albo do kogo należy świat?) 39, 70, 90-91, 103, 380

Kwiat tysiaca i jednej nocy (Il fiore delle mille e una notte), reż. Pier Paolo Pasolini (1974) 175

\section{La Habanera 69, 129-130}

Lachende Erben (Roześmiani spadkobiercy) 119

Lady Hamilton 46

Lalka (Die Puppe) 29, 36, 53-54, 59

Land der Liebe (Kraina miłości) 68

Land ohne Frauen, Das (Ziemia bez kobiet) 74

Land without Women, The (Ziemia bez kobiet), wersja angielska 74

Landstraße, Die (Wiejska droga) 15, 58

Last Will of Dr. Mabuse, The, amerykańska wersja dystrybucyjna filmu Le Testament $d u$ Dr. Mabuse (reż. Fritz Lang, 1933/1943) z angielskimi napisami 156, 501-502

lebende Leichnam, Der (Żywy trup) 91

Leinen aus Irland (Płótno z Irlandii) 111-112

Leise flehen meine Lieder (Niedokończona symfonia), reż. Willi Forst (1933) 77, 117, 123

Lepszymi dyplomatami sa jednak kobiety (Frauen sind doch bessere Diplomaten) 124, 143

Letzte Lied, Das (Ostatnia pieśń), reż. Frank Clifford (1928) 73

letzte Mann, Der (Portier z hotelu Atlantic) 42-45, $51,60,71,345,438$

Liebe der Jeanne Ney, Die (Miłość Joanny Ney) 39, 52,61

Liebelei (Miłostki) 81-82, 108, 124, 137

Liebesbriefe aus dem Engadin (Listy miłosne z Engadyny), reż. Luis Trenker, Wilhelm Klingler (1938) 128

Liebesleute (Zakochani) 121-122

Liebeswalzer (Walc miłości), reż. Wilhelm Thiele (1930) 78, 125

Lied für dich, Ein (Pieśń dla ciebie) 70

Lis z Glenarvon (Der Fuchs von Glenarvon) 110

Listy miłosne z Engadyny (Liebesbriefe aus dem Engadin), reż. Luis Trenker, Wilhelm Klingler (1938) 128

Little Caesar (Mały Cezar) 481

Lola rennt (Biegnij Lola, biegnij) 200

Lonely Villa, The (Samotna willa) 205

Love (Anna Karenina), reż. Edmund Goulding (1927) 157

Love Waltz, The (Walc miłości), wersja angielska, reż. Carl Winston (1930) 78

Loves of Ariane, The (Ariana), wersja angielska 82 Loża królewska (Die Königsloge / The Royal Box) 74 Lucrezia Borgia (Lukrecja Borgia) 46, 60 
Ludzie w niedziele (Menschen am Sonntag) 38, 380

Lukrecja Borgia (Lucrezia Borgia) 46, 60

Łowca androidów (Blade Runner) 392

$M(M-$ morderca $)$ 7, 86-88, 152, 154, 187, 322, 328, 345, 346, 359, 431, 442, 472, 477-498, 499, 500, 504-506, 515, 523, 526, 529, 531

$M-$ morderca $(M)$ 7, 86-88, 152, 154, 187, 322, 328, $345,346,359,431,442,472,477-498,499$, 500, 504-506, 515, 523, 526, 529, 531

Madame DuBarry 21, 48, 59, 213

Mädchen in Uniform (Dziewczęta w mundurkach) 67, 70, 82-84, 135

Mädchen Johanna, Das (Dziewica Joanna) 110

Magnificent Ambersons, The (Wspaniałość Ambersonów) 406

Maty Cezar (Little Caesar) 481

Małżeństwo po angielsku (Die englische Heirat) 122-123

Man braucht kein Geld (Forsy nie trzeba), reż. Carl Boese (1932) 80, 119

Man Hunt (Polowanie na człowieka) 478

Mann, der den Mord beging, Der (Człowiek, który popetnit morderstwo) $\mathbf{8 4 ,} 479$

Mann, der seinen Mörder sucht, Der (Człowiek, który szuka swego mordercy) 85, 119, 479

Mann, der sich Mabuse nannte, Der zob. Zemsta doktora Mabuse

Mann, der Sherlock Holmes war, Der (Człowiek, który byt Sherlockiem Holmesem) $\mathbf{1 2 7}$

Mann will nach Deutschland, Ein (Do Niemiec!) 106

Marnotrawna córka zob. Heimat

Marzenie (Träumerei) 117

Maskarada (Maskerade) 124, 137

Maskerade (Maskarada) 124, 137

Mazurek (Mazurka) 124

Mazurka (Mazurek) 124

Mefisto (Mephisto) 496

Mein Leben für Irland (Moje życie dla Irlandii) 110

Mélo (Rozmarzone usta), wersja francuska 82

Melodia miłości zob. Romanca w moll

Melodia serc (Melodie des Herzens) 74-75

Melodia świata (Melodie der Welt) 74

Melodie des Herzens (Melodia serc) 74-75

Melodie der Welt (Melodia świata) 74

Men of Tomorrow 83

Menschen am Sonntag (Ludzie w niedziele) 38, 380

Mephisto (Mefisto) 496

Metropolis 19-22, 25, 26, 29, 32, 34, 35, 39, 46, 50, 51, 61, 153, 157, 166-168, 213, 216, 217, 221, $222,229,268,276,281,283,326,328,329$, $331,332,336-338,340,341,345,349,360$, 361, 367, 378, 381, 385-439, 441, 442, 445,
$446,449,450,452,454,467,473,487,492$, 496, 514, 516, 520, 523, 531-534

Męczeństwo Joanny d'Arc (La Passion de Jeanne $\left.d^{\prime} A r c\right) 70$

Michael 42-44, 52, 60, 70

Mijaja godziny (Rien que les heures) 401

Miłostki (Liebelei) 81-82, 108, 124, 137

Miłość Joanny Ney (Die Liebe der Jeanne Ney) 39, 52,61

Młynarz $i$ jego dziecko (Der Müller und sein Kind) 13

Modern Times (Dzisiejsze czasy) 421

Moje życie dla Irlandii (Mein Leben für Irland) 110

Monts en flammes, Les (Góry w płomieniach), wersja francuska, reż. Luis Trenker, Joë Hamman (1931) 93

Mörder Dimitri Karamasoff, Der (Morderca Dymitr Karamazow) 84, 479

Mörder sind unter uns, Die (Mordercy sa wśród nas) 479

Morderca Dymitr Karamazow (Les Frères Karamazoff), wersja francuska 84

Morderca Dymitr Karamazow (Der Mörder Dimitri Karamasoff) 84, 479

Mordercy sa wśród nas (Die Mörder sind unter uns) 479

Morgenrot (Jutrzenka) 95

Mroczne miasto (Dark City), reż. Alex Proyas (1998) 392

müde Tod, Der (Zmęczona Śmierć) 17, 25, 26, 29, 30, 35, 36, 49, 59, 136, 163-209, 216, 217, 223, 226, 227, 241, 247, 262, 276, 277, 313, 314, $317,322,331,332,328,349,357,359-361$, $367,372,373,392,395,400,422,429,432$, $463,478,514,516,523,531-534$

Müller und sein Kind, Der (Młynarz i jego dziecko) 13

Münchhausen 102, 127, 144

Musketier Meier III (Muszkieter Meier III) 105

Muszkieter Meier III (Musketier Meier III) 105

Mutter Krausens Fahrt ins Glück (Podróż Matki Krause do szczęścia) 40, 62, 91, 103

Na Zachodzie bez zmian (All Quiet on the Western Front) 89

Nacht im Mai, Eine (Noc majowa) 124

Narodziny narodu (The Birth of a Nation) 388, 517

Natan Mędrzec (Nathan der Weise) 39, 46-47, 60

Nathan der Weise (Natan Mędrzec) 39, 46-47, 60

Nerven (Nerwy) 29, 36, 59

Nerwy (Nerven) 29, 36, 59

Nibelungen, Die (Nibelungi) 21, 29, 30, 34, 35, 46, $47,50,53,60,153,157,166,167,168,192$, 211-272, 276, 281, 328, 331, 337, 338, 349, 
$358,360,361,367,387,394,395,406,441$, $442,452,455,478,496,514,516,531-534$

Nibelungi (Die Nibelungen) 21, 29, 30, 34, 35, 46, $47,50,53,60,153,157,166,167,168,192$, 211-272, 276, 281, 328, 331, 337, 338, 349, $358,360,361,367,387,394,395,406,441$, 442, 452, 455, 478, 496, 514, 516, 531-534

Nie chcę być mężczyzna (Ich möchte kein Mann sein) 53, 54, 122

Niebieskie światło (Das blaue Licht) 93

Niech się stanie światłość! (Es werde Licht!) 55

Niech żyje wolność! (À nous la liberté) 421

Niedtugo znowu będzie lepiej (Es wird schon wieder besser) 80

Niedokończona symfonia (Leise flehen meine Lieder), reż. Willi Forst (1933) 77, 117, 123

Niedokończona symfonia (Unfinished Symphony), wersja angielska, reż. Anthony Asquith, Willi Forst (1934) 77, 123

Niedola Fryzów (Friesennot) 106, 107, 109

Nieludzka (L'Inhumaine) 392

Nieśmiertelny walc (Unsterblicher Walzer) 117

Nietolerancja (Intolerance) 49, 175, 176, 388, 497

Niewidzialne szpony doktora Mabuse (Die unsichtbaren Krallen des Dr. Mabuse) 278

Noc majowa (Eine Nacht im Mai) 124

Nosferatu, eine Symphonie des Grauens (Nosferatu, symfonia grozy) 25, 26, 31, 35, 41, 60, 136, 305

Nosferatu, symfonia grozy (Nosferatu, eine Symphonie des Grauens) 25, 26, 31, 35, 41, 60, 136,305

O prawa człowieka (Um das Menschenrecht) 109

Obcy książe (Der fremde Fürst) 16, 171

Obyknowiennyj faszyzm (Zwyczajny faszyzm) 105

Oczy mumii Mâ (Die Augen der Mumie Mâ) 48, 59

Od poranka do pótnocy (Von Morgens bis Mitternachts) 29, 30-31, 33, 59, 329

Oddział szturmowy 1917 (Stoßtrupp 1917), reż. Hans Zöberlein, Ludwig Schmid-Wildy (1934) 89

Ohm Krüger (Wuj Krüger) 99, 110, 113, 143

Olimpiada (Olympia) 38, 67, 141-142

Olympia (Olimpiada) 38, 67, 141-142

Opéra de quat'sous, L' (Opera za trzy grosze), wersja francuska 89, 499

Opera za trzy grosze (Die 3-Groschen-Oper) 82, 86, 89-90, 499

Opera za trzy grosze (L'Opéra de quat'sous), wersja francuska 89, 499

Operetka (Operette) 124

Operette (Operetka) 124

Opfergang (Poświęcenie) 132-133, 137

Opium 55, 59
Opowieści Hoffmanna (Hoffmanns Erzählungen) 16, 171

Opowieści kanterberyjskie (I racconti di Canterbury), reż. Pier Paolo Pasolini (1972) 175

Opowieści Lasku Wiedeńskiego (G'schichten aus dem Wienerwald) 117

Oskarżam (Ich klage an) $\mathbf{1 1 4}$

Osobista sekretarka (Die Privatsekretärin), reż. Wilhelm Thiele (1931) 80, 121

Osobista sekretarka (Sunshine Susie), wersja angielska, reż. Victor Saville (1931) 80

Ostatni akord (Schlußakkord) 69, 77

Ostatni miliarder (Le Dernier miliardaire) 54

Ostatnia pieśn (Das letzte Lied), reż. Frank Clifford (1928) 73

Ostatnie tango w Paryżu (Ultimo tango a Parigi), reż. Bernardo Bertolucci (1972) 82

Otello (Othello) 46, 60

Othello (Otello) 46, 60

Pająki (Die Spinnen) 49-50, 59, 163, 164, 175, 529

Pancernik Potiomkin (Bronienosiec Potiomkin) 157, 172,400

Panna wodna (La Fille de l'eau) 138

Paracelsus 69, 71, 116

Pasja (The Passion of the Christ) 207

Passion de Jeanne d'Arc, La (Męczeństwo Joanny d'Arc) 70

Passion of the Christ, The (Pasja) 207

Patrioci (Patrioten) 106

Patrioten (Patrioci) 106

Peter der Große (Piotr Wielki) 46

Petersburger Nächte (Petersburskie noce) 117

Petersburskie noce (Petersburger Nächte) 117

Phantom (Fantom) 25, 26, 29, 30, 36, 60

Piaty element (The Fifth Element) 392, 436

Pieniadz (L'Argent), reż. Marcel L'Herbier (1929) 311

Pieniądz leży na ulicy (Geld auf der Straße) 80

Pieśń dla ciebie (Ein Lied für dich) 70

Piękny zakatek (Das Schöncheitsfleckchen) $\mathbf{1 4 0}$

Piotr Wielki (Peter der Große) 46

Płeć w kajdanach (Geschlecht in Fesseln) 55, 61

Ptótno z Irlandii (Leinen aus Irland) 111-112

Poczmistrz (Der Postmeister) 71, 92, 135

Pod goracym niebem (Unter heißem Himmel) 127

Pod mostami (Unter den Brücken) $\mathbf{1 3 8}$

Podróż Matki Krause do szczęścia (Mutter Krausens Fahrt ins Glück) 40, 62, 91, 103

Podróż do Tylży (Die Reise nach Tilsit) 108, 131

Podróż na Księżyc (Le Voyage dans la Lune) 474

Polowanie na człowieka (Man Hunt) 478

Ponad wszelka watpliwość (Beyond a Reasonable Doubt) 534 
Poncz (Die Feuerzangenbowle) $\mathbf{1 2 1}$

Portier z hotelu Atlantic (Der letzte Mann) 42-45, 51, 60, 71, 345, 438

Postmeister, Der (Poczmistrz) 71, 92, 135

Postrach garnizonu (Der Schrecken der Garnison) 81

Poświęcenie (Opfergang) 132-133, 137

Pour le Mérite 105

Powrót (Heimkehr) 99, 106, 107, 108, 113

Powrót Batmana (Batman Returns), reż. Tim Burton (1992) 392

Prinzessin Turandot (Księżniczka Turandot) $\mathbf{1 2 6}$

Privatsekretärin, Die (Osobista sekretarka), reż. Wilhelm Thiele (1931) 80, 121

Promienie śmierci doktora Mabuse (Die Todesstrahlen des Dr. Mabuse) 278

Przewoźnik Maria (Fährmann Maria) 71, 136

Przygody dziesięciomarkowego banknotu (K 13513: Die Abenteuer eines Zehnmarkscheines) 38, 61

Przygody księcia Achmeda (Die Abenteuer des Prinzen Achmed) 56, 61

Przypadek 199

Public Enemy, The (Wróg publiczny) 481

Pułkownik Redl (Redl ezredes) 347

Puppe, Die (Lalka) 29, 36, 53-54, 59

Puszka Pandory (Die Büchse der Pandora) 39, 40, 62,484

racconti di Canterbury, I (Opowieści kanterberyjskie), reż. Pier Paolo Pasolini (1972) 175

Ramona (Die Kapelle Etté spielt den Ramona), reż. Walter Ruttmann (1928) 73

Rampage (Szaleństwo) 484

Raskolnikow 29, 60, 270, 329

Rattenfänger von Hameln, Der (Szczurołap z Hameln) 16,171

Rebel, The (Buntownik), wersja angielska, reż. Luis Trenker, Edwin H. Knopf (1933) 94

Rebell, Der (Buntownik), reż. Luis Trenker, Kurt Bernhardt (1932) 94, 128, 157

Redl ezredes (Pułkownik Redl) 347

Reifende Jugend (U progu dojrzałości) 84

Reise nach Tilsit, Die (Podróż do Tylży) 108, 131

Reiter von Deutsch-Ostafrika, Die (Jeźdźcy z Niemieckiej Afryki Wschodniej) 106

Rejs 121

Rembrandt 71, 116

Rêve blond, Un (Jasnowłosy sen), wersja francuska, reż. André Daven, Paul Martin (1932) 79

Rien que les heures (Mijaja godziny) 401

Ritt in die Freiheit (Ku wolności) 108, 109

Robert i Bertram (Robert und Bertram) 111

Robert Koch, der Bekämpfer des Todes (Robert Koch, zwycięzca śmierci) 115-116
Robert Koch, zwycięzca śmierci (Robert Koch, der Bekämpfer des Todes) 115-116

Robert und Bertram (Robert i Bertram) 111

Rok 2000 (Things to Come) 403

Romanca w moll (Romanze in Moll) 71, 137

Romanse Czajkowskiego (Es war eine rauschende Ballnacht) 77, 116, 124-125

Romanze in Moll (Romanca w moll) 71, 137

Rosen aus dem Süden (Róże z południa) 117

Roses noires (Czarne róże), wersja francuska, reż. Jean Boyer, Paul Martin (1935) 125

Rothschilds: Aktien auf Waterloo, Die (Rotszyldowie) 110-111

Rotszyldowie (Die Rothschilds: Aktien auf Waterloo) 110-111

Royal Box, The (Loża królewska), wersja angielska 74

Rozbity dzban (Der zerbrochene Krug) 135

Roześmiani spadkobiercy (Lachende Erben) 119

Rozmarzone usta (Dreaming Lips), wersja angielska 82

Rozmarzone usta (Mélo), wersja francuska 82

Rozmarzone usta (Der träumende Mund) 82

Róże z południa (Rosen aus dem Süden) 117

Rübezahls Hochzeit (Wesele króla gór) 16, 171

Rzeźnik zob. Siewca śmierci

SA-Mann Brand 91, 102-103, 504

SOS Eisberg 128

Saison in Kairo (Sezon w Kairze), reż. Reinhold Schünzel (1933) 122, 126

Samotna willa (The Lonely Villa) 205

Satana 176

Satanas 25, 49, 175-176

Scarface (Człowiek z blizna) 481

Scarlet Street 336, 444, 534

Schatten (Cienie) 25, 26, 60

Schatz, Der (Skarb) 33, 35, 60

Schimmelreiter, Der (Jeździec na siwym koniu) 71, 133-134

Scherben (Szyny) 42-44, 59

Schloß Vogelöd: Die Enthüllung eines Geheimnisses (Zamek Vogelöd) 42-43, 59

Schlußakkord (Ostatni akord) 69, 77

Schody kuchenne (Die Hintertreppe) 42-44, 59

Schönheitsfleckchen, Das (Piękny zakątek) 140

Schrecken der Garnison, Der (Postrach garnizonu) 81

Schwarze Rosen (Czarne róże), reż. Paul Martin (1935) 125

Scotland Yard jagt Dr. Mabuse (Scotland Yard kontra doktor Mabuse) 278

Scotland Yard kontra doktor Mabuse (Scotland Yard jagt Dr. Mabuse) 278 
Secret Beyond the Door (Tajemnica za drzwiami) 336, 444

Serce królowej (Das Herz der Königin) 77, 110, 130

Serenada (Serenade) 124

Serenade (Serenada) 124

Sergeant Berry (Sierżant Berry) 127

Seven (Siedem), reż. David Fincher (1995) 392

Sezon w Kairze (Idylle au Caire), wersja francuska, reż. Claude Heymann, Reinhold Schünzel (1933) 122

Sezon w Kairze (Saison in Kairo), reż. Reinhold Schünzel (1933) 122, 126

Sieben Ohrfeigen (Siedmiokrotny policzek) 125

Siedem (Seven), reż. David Fincher (1995) 392

Siedmiokrotny policzek (Sieben Ohrfeigen) 125

Siegfrieds Tod (Śmierć Zygfryda), nazistowskie "opracowanie" filmu Fritza Langa Die Nibelungen, Der erste Teil: Siegfried (Nibelungi, część I: Zygfryd) z muzyką Wagnera (1933) 221, 254

Sierżant Berry (Sergeant Berry) 127

Siewca śmierci (Der Totmacher) 484

Siódma pieczęć (Det sjunde inseglet) 116

sjunde inseglet, Det (Siódma pieczęć) 116

Skarb (Der Schatz) 33, 35, 60

So ein Flegel ( $A$ to cham!) 121

So endete eine Liebe (Tak kończy się mitość) 123

Soldaten-Kameraden (Żotnierze kamraci) 105

Somma (Die Somme) 89

Somme, Die (Somma) 89

Spinnen, Die (Pajaki) 49-50, 59, 163, 164, 175, 529

Spione (Szpiedzy) 41, 50, 61, 103, 109, 126, 167, 198, 287, 305, 313, 331, 332, 335-381, 395, 422, 431, 435, 441-446, 452, 454, 455, 467, 480, $487,514-516,518-520,523,525,531-534$

Spótka czterech (Die vier Gesellen) 70, 84

Spóźniona skrucha (Zu späte Reue!) 13

Star Wars (Gwiezdne wojny), cykl filmowy 19772005474

Star Wars (Gwiezdne wojny), reż. George Lucas (1977) 392

Star Wars, Episode II: Attack of the Clones (Atak klonów) 436

Stary i młody król (Der alte und der junge König) 114-115

steinerne Reiter, Der (Kamienny jeździec) 33, 60

Stolz der 3. Kompanie, Der (Duma trzeciej kompanii) $81,119,120$

Stoßtrupp 1917 (Oddział szturmowy 1917), reż. Hans Zöberlein, Ludwig Schmid-Wildy (1934) 89

Straße, Die (Ulica) 39, 60, 380

Student von Prag, Der (Student z Pragi), reż. Henrik Galeen (1926) 17, 171
Student von Prag, Der (Student $z$ Pragi), reż. Stellan Rye (1913) 15-16, 31, 32, 58, 102, 171, 312

Student z Pragi (Der Student von Prag), reż. reż. Henrik Galeen (1926) 17, 171

Student $z$ Pragi (Der Student von Prag), reż. Stellan Rye (1913) 15-16, 31, 32, 58, 102, 171, 312

Student żebrak (Der Bettelstudent) 124

Stürme der Leidenschaft (Burze namiętności) 84

Stürme über dem Montblanc (Burza nad Mont Blanc) 92-93

Stukas 77,105

Sumurun 48, 59, 227

Sunrise (Wschód słońca) 108, 131

Sunshine Susie (Osobista sekretarka), wersja angielska, reż. Victor Saville (1931) 80

Sylvester (Sylwester) 42-44, 60

Sylwester (Sylvester) 42-44, 60

Syn marnotrawny (Der verlorene Sohn) 128-129

Szaleństwo (Rampage) 484

Szczęki (Jaws) 215

Szczęściarze (Glückskinder) 77, 125, 126

Szczęśliwy powrót $w$ rodzinne strony (Heimkehr ins Glück) 120

Szczurołap z Hameln (Der Rattenfänger von Hameln) 16,171

Szklane cud-zwierzaki (Gläserne Wundertiere), reż. Ulrich K. T. Schulz 74

Szpiedzy (Spione) 41, 50, 61, 103, 109, 126, 167, 198, 287, 305, 313, 331, 332, 335-381, 395, 422, 431, 435, 441-446, 452, 454, 455, 467, 480, 487, 514-516, 518-520, 523, 525, 531-534

Szyny (Scherben) 42-44, 59

Śledztwo (Voruntersuchung) 85

Śmierć Zygfryda (Siegfrieds Tod), nazistowskie "opracowanie" filmu Fritza Langa Nibelungi, część I: Zygfryd (Die Nibelungen, Der erste Teil: Siegfried) z muzyką Wagnera (1933) 221, 254

Święta góra (Der heilige Berg) 52, 53, 61, 92, 93, 128

Świętoszek (Tartüff) 25, 26, 39, 42-43, 61

Tagebuch einer Verlorenen (Dziennik upadłej dziewczyny) $39,40,62$

Tajemnica za drzwiami (Secret Beyond the Door) 336,444

Tajemnice duszy (Geheimnisse einer Seele) 29, 38, 61

Tak kończy się mitość (So endete eine Liebe) 123

Tancerka Barberina (Die Tänzerin Barberina) 47

Tancerka z Sans-Souci (Die Tänzerin von Sanssouci) 94

Taniec na wulkanie (Tanz auf dem Vulkan) 116-117

Tannenberg 89

Tanz auf dem Vulkan (Taniec na wulkanie) 116-117 
Tänzerin Barberina, Die (Tancerka Barberina) 47

Tänzerin von Sanssouci, Die (Tancerka z Sans-Souci) 94

Tartüff (Świętoszek) 25, 26, 39, 42-43, 61

1000 Augen des Dr. Mabuse, Die (Tysiac oczu doktora Mabuse) 88, 198, 278, 287, 345, 375, 422, 523-524

Teatr Miejski (Burgtheater) 124, 137

Terminator 2: Dzień Sądu (Terminator 2: Judgment Day), reż. James Cameron (1991) 392

Terminator 2: Judgment Day (Terminator 2: Dzień Sądu), reż. James Cameron (1991) 392

Testament des Dr. Mabuse, Das (Testament doktora Mabuse), reż. Fritz Lang (1933) 7, 32, 88, 152, 153, 156-158, 217, 278, 287, 322, 345, 346, 361, 422, 499-529, 531, 533, 534

Testament des Dr. Mabuse, Das (Testament doktora Mabuse), reż. Werner Klingler (1961) 278

Testament doktora Mabuse (Das Testament des Dr. Mabuse), reż. Fritz Lang (1933) 7, 32, 88, 152, 153, 156-158, 217, 278, 287, 322, 345, 346, 361, 422, 499-529, 531, 533, 534

Testament doktora Mabuse (Das Testament des Dr. Mabuse), reż. Werner Klingler (1961) 278

Testament doktora Mabuse (Le Testament du Dr. Mabuse), reż. Fritz Lang (1933, wersja francuska) 88, 152, 156, 499-500, 501

Testament du Dr. Mabuse, Le (Testament doktora Mabuse), reż. Fritz Lang (1933, wersja francuska) 88, 152, 156, 499-500, 501

Theresienstadt (Theresienstadt. Ein Dokumentar Film aus dem jüdischen Siedlungsgebiet) 69

Theresienstadt. Ein Dokumentar Film aus dem jüdischen Siedlungsgebiet (Theresienstadt) 69

Thief of Bagdad, The (Złodziej z Bagdadu) 165, 388

Things to Come (Rok 2000) 403

Tiger von Eschnapur, Der (Tygrys z Esznapuru) 49, 534

Todesstrahlen des Dr. Mabuse, Die (Promienie śmierci doktora Mabuse) 278

Torgus (Verlogene Moral) 29, 59, 329

Totmacher, Der (Siewca śmierci) 484

Towarzysze broni (La Grande illusion) 71, 90, 94

Tragedia pewnego strajku (Tragödie eines Streiks) 14

Tragedia ulicznej dziewczyny (Dirnentragödie) 52, 61

Tragödie eines Streiks (Tragedia pewnego strajku) 14

träumende Mund, Der (Rozmarzone usta) 82

Träumerei (Marzenie) 117

Traumulus 68, 84

Triumf woli (Triumph des Willens) 46, 67, 104, 140,268

Triumph des Willens (Triumf woli) 46, 67, 104, 140, 268

Trzej z kawalerii (Drei von der Kavallerie) 81
Trzej ze stacji benzynowej (Le Chemin du paradis), wersja francuska, reż. Wihelm Thiele, Max de Vaucorbeil (1930) 79

Trzej ze stacji benzynowej (Die Drei von der Tankstelle), reż. Wilhelm Thiele (1930) 78-79, 119, 125,126

Trzy dni paki (Drei Tage Mittelarrest) 81

Trzy panny wokół Schuberta (Drei Mäderl um Schubert) 117

Trzynastu ludzi i jedno działo (Dreizehn Mann und eine Kanone) 109

Tumultes (Burze namiętności), wersja francuska 84

Tygrys z Esznapuru (Der Tiger von Eschnapur) 49, 534

Tysiac oczu doktora Mabuse (Die 1000 Augen des Dr. Mabuse) 88, 198, 278, 287, 345, 375, 422, 523-524

U progu dojrzałości (Reifende Jugend) 84

Uchodźcy (Flüchtlinge) 106-107, 109, 127

Ulica (Die Straße) 39, 60, 380

Ultimo tango a Parigi (Ostatnie tango w Paryżu), reż. Bernardo Bertolucci (1972) 82

Um das Menschenrecht (O prawa człowieka) 109

Umwege des schönen Karl, Die (Kręte drogi pięknego Karola) 68, 120

Und du, mein Schatz, fährst mit (I ty pojedziesz, mój skarbie) 124

Unfinished Symphony (Niedokończona symfonia), wersja angielska, reż. Anthony Asquith, Willi Forst (1934) 77, 123

unsichtbaren Krallen des Dr. Mabuse, Die (Niewidzialne szpony doktora Mabuse) 278

Unsterblicher Walzer (Nieśmiertelny walc) 117

Unter den Brücken (Pod mostami) 138

Unter heißem Himmel (Pod goracym niebem) 127

Untergang (Upadek) 320, 321

Upadek (Untergang) 320, 321

Urlaub auf Ehrenwort (Urlop na słowo honoru) 68, 105-106

Urlop na słowo honoru (Urlaub auf Ehrenwort) 68, 105-106

Vampires, Les (Wampiry) 49

Vampyr (Wampir) 70

Vanina 42-44, 52, 60

Variété 52, 61, 81

venezianische Nacht, Eine (Wenecka noc) 15

venganza del Dr. Mabuse, La (Zemsta doktora Mabuse) 278

Verdun, obrazy historii (Verdun, visions d'histoire) 89

Verdun, pamiątki historii (Verdun, souvenirs d'histoire) 89

Verdun, souvenirs d'histoire (Verdun, pamiatki historii) 89 
Verdun, visions d'histoire (Verdun, obrazy historii) 89

Veritas vincit 49

Verlogene Moral (Torgus) 29, 59, 329

verlorene Schuh, Der (Kopciuszek) 17, 171

verlorene Sohn, Der (Syn marnotrawny) 128-129

Verräter (Zdrajca) 109

Verwehte Spuren (Zatarte ślady) 68, 131

vier Gesellen, Die (Spótka czterech) 70, 84

vier Musketiere, Die (Czterej muszkieterowie) 105

Viktor $i$ Viktoria (Viktor und Viktoria) 77, 122, 123

Viktor und Viktoria (Viktor i Viktoria) 77, 122, 123

Volksfeind, Ein (Wróg ludu) 92, 134

Von Morgens bis Mitternachts (Od poranka do pótno-

cy) 29, 30-31, 33, 59, 329

Voruntersuchung (Śledztwo) 85

Voyage dans la Lune, Le (Podróż na Księżyc) 474

W stalowej sieci doktora Mabuse (Im Stahlnetz des Dr. Mabuse) 278

Wachsfigurenkabinett, Das (Gabinet figur woskowych) 25, 26, 29, 32, 35, 36, 60, 174, 202, 329, 485

Walc miłości (Liebeswalzer), reż. Wilhelm Thiele (1930) 78, 125

Walc miłości (The Love Waltz), wersja angielska, reż. Carl Winston (1930) 78

Walczace serca (Kämpfende Herzen) 164, 166, 294,345

Walzerkrieg (Wojna walców), reż. Ludwig Berger (1933) 78, 117, 121, 122, 126

Wampir (Vampyr) 70

Wampiry (Les Vampires) 49

wandernde Bild, Das (Wędrujacy obraz) 164, 166, 345

Warschauer Zitadelle, Die (Cytadela warszawska) 108

Wasser für Canitoga (Woda dla Canitogi) 127

Wege zu Kraft und Schönheit - Ein Film über moderne Körperkultur (Drogi do sity i piękna) 37, 38,61

Weib der Pharao, Das (Żona faraona) 48, 60

weiße Hölle vom Piz Palü, Die (Białe piekło na Piz Palï) 53, 62, 92, 93

weiße Rausch - Neue Wunder des Schneeschuhs, Der (Białe szaleństwo) 93, 128

Weiße Sklaven (Biali niewolnicy) 109

Wen die Götter lieben (Kogo bogowie kochaja) 117

Wenecka noc (Eine venezianische Nacht) 15

Wesele króla gór (Rübezahls Hochzeit) 16, 171

Westfront 1918 (Front zachodni 1918) 88-89

Wędrujacy obraz (Das wandernde Bild) 164, 166, 345

Why We Fight (Dlaczego walczymy) 105

Wieczny Żyd (Der ewige Jude) 101, 113, 497

Wiedeńska krew (Wiener Blut) 117, 124, 126

Wiedeńskie dziewczęta (Wiener Mädeln) 124

Wiejska droga (Die Landstraße) 15, 58
Wielka miłość (Die große Liebe) 77, 105, 130

Wielki król (Der große König) 99, 114, 115, 131

Wielki skok (Der große Sprung) 128

Wiener Blut (Wiedeńska krew) 117, 124, 126

Wiener Mädeln (Wiedeńskie dziewczęta) 124

Wiosenny nastrój (Frühlingsstimmen) 117

Wtadca, (Der Herrscher) 71, 134-135

Władca miłości (Der Herr der Liebe) 163

Władczyni świata (Die Herrin der Welt) 49, 59

Woda dla Canitogi (Wasser für Canitoga) 127

Wojna walców (La Guerre des valses), wersja francuska, reż. Ludwig Berger, Raoul Ploquin (1933) 78

Wojna walców (Walzerkrieg), reż. Ludwig Berger (1933) 78, 117, 121, 122, 126

Wolna miłość (Freie Liebe) 55

Woman in the Window, The (Kobieta w oknie) 534

Wrogowie (Feinde) $\mathbf{1 0 8}$

Wróg ludu (Ein Volksfeind) 92, 134

Wróg publiczny (The Public Enemy) 481

Wschód stońca (Sunrise) 108, 131

Wspaniałość Ambersonów (The Magnificent Ambersons) 406

Wuj Krüger (Ohm Krüger) 99, 110, 113, 143

Wunder des Schneeschuhs, Das (Cuda narciarskich szusów) 52

Wunder der Schöpfung (Cud stworzenia) 38, 61

Wunschkonzert (Koncert życzeń) 105

Wyspa błogosławionych (Insel der Seligen) 15

Yoghi, Der (Jogin) 16, 171

Zabytaja miełodia dlia fliejty (Zapomniana melodia na flet) 200

Zaćmienie (L'Eclisse) 311

Zakochani (Liebesleute) 121-122

Załoga "Dory" (Besatzung Dora) 105

Zamek Vogelöd (Schloß Vogelöd: Die Enthüllung eines Geheimnisses) 42-43, 59

Zapomniana melodia na flet (Zabytaja miełodia dlia fliejty) 200

Zapomniana w szczęściu (Im Glück vergessen) 14

Zaproszenie do tańca (Aufforderung zum Tanz) 117

Zärtlichkeit der Wölfe, Die (Czułość wilków) 484

Zatarte ślady Verwehte Spuren (Verwehte Spuren) 68, 131

Zatracona uliczka (Die freudlose Gasse) 30, 39, 61, 103, 283, 307

Zdrajca (Verräter) 109

Ze wspomnień ginekologa (Aus den Errinerungen eines Frauenarztes) 55

Zemsta doktora Mabuse (La venganza del Dr. Mabuse / Dr. M. schlägt zu) 278

zerbrochene Krug, Der (Rozbity dzban) 135 
Ziemia bez kobiet (Das Land ohne Frauen) $\mathbf{7 4}$

Ziemia bez kobiet (The Land without Women), wersja angielska 74

Złodziej z Bagdadu (The Thief of Bagdad) 165, 388

Złote Jezioro (Der Goldene See) 163; zob. też Pająki (Die Spinnen)

Złote miasto (Die goldene Stadt) 117, 131-132

Złoto (Gold) 127

Złoty pająk (Die goldene Spinne) 109

Zmęczona Śmierć (Der müde Tod) 17, 25, 26, 29, 30, 35, 36, 49, 59, 136, 163-209, 216, 217, 223, $226,227,241,247,262,276,277,313,314$, $317,322,331,332,328,349,357,359-361$, $367,372,373,392,395,400,422,429,432$, $463,478,514,516,523,531-534$
Zu späte Reue! (Spóźniona skrucha) 13

Zur Chronik von Grieshuus (Kronika z Grieshuus) $17,33,171$

Zwyczajny faszyzm (Obyknowiennyj faszyzm) 105

Źródło (Jungfrukällan) 207

Żotnierze kamraci (Soldaten-Kameraden) 105

Żona faraona (Das Weib der Pharao) 48, 60

Żótta flaga (Die gelbe Flagge) 127

Żyd Süss (Jew Süss), reż. Lothar Mendes (1934) 112

Żyd Süss (Jud Süß), reż. Veit Harlan (1940) 47, 68, 92, 112-113, 130, 131, 308

$\dot{Z}$ ywoj trup (Żywy trup) 91

Żywy trup (Der lebende Leichnam / Żywoj trup) 91 